\title{
LA ARQUITECTURA \\ DEL EXPOLIADO PALACIO CONDAL DE OLIVA A TRAVÉS DEL LEGADO GRÁFICO
}

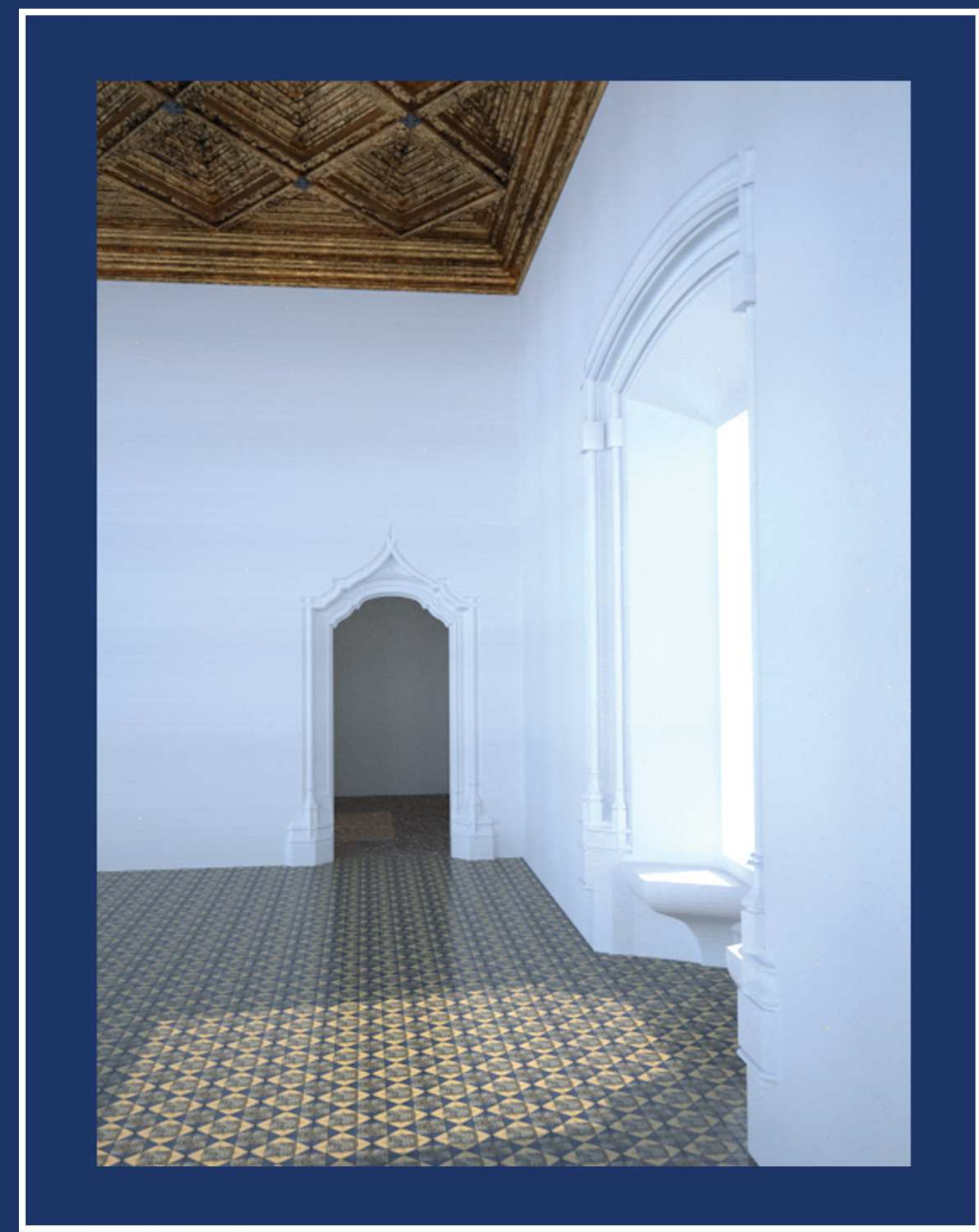

Autor

Joaquín Ángel Martínez Moya

Directoras de tesis

Dra. Alba Soler Estrela y Dra. Ma Jesús Máñez Pitarch

Marzo de 2017

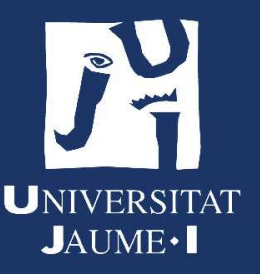




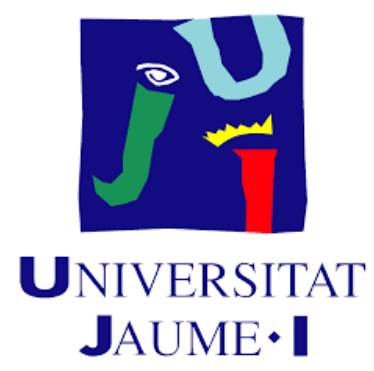

Tesis doctoral

La arquitectura del expoliado Palacio Condal de Oliva a través del legado gráfico

Autor: Joaquín Ángel Martínez Moya

Directoras de tesis: Dra. Alba Soler Estrela y Dra. Mạ Jesús Máñez Pitarch Marzo de 2017 

A los grandes promotores del arte y la cultura, en cuyo espejo se ve reflejado Serafín de Centelles, que siendo un poderoso señor y poseedor de una gran riqueza, supo compatibilizar, como gran hombre del renacimiento que fue, sus facetas de político y guerrero con la protección de las artes y de las ciencias.

A los grandes maestros, como Baldomar, Compte, Corbera, Muñoz, y tantos otros, cuya sabiduría ha llegado hasta nosotros a través de sus grandes obras.

A Egil Fischer a quien, a pesar de su controvertido papel en esta historia, debemos el poder seguir disfrutando de este gran Palacio.

A Vilhelm Lauritzen, quien con gran profesionalidad y meticulosidad dibujó cada moldura de este edificio, dejando una huella imborrable. Su papel ha sido determinante tanto en la documentación del Palacio, como en su recuperación.

A Priscila E. Muller, cuya minuciosa, constante y exquisita labor de investigación transmitida a través de sus textos, supo despertar mi interés por este intrigante Palacio.

A todos aquellos que, de uno u otro modo, han ayudado a mantener vivo este gran monumento a través de sus labores de documentación, estudio, investigación, custodia o amor por este gran legado.

A todos que han creído en mí, apoyándome y alentándome a seguir adelante en lo buenos y los malos momentos.

A Paco, mi compañero de viaje.

A mis padres, Ángel y Nieves, por enseñarme a volar. 



\section{Índice}

\section{CAPITULO I \\ PROPUESTA}

1. INTRODUCCIÓN 13

1.1. El municipio de Oliva 13

1.2. El condado de Oliva 13

1.3. El Palacio Condal de Oliva 15

1.4. Los arquitectos daneses 17

2. INTERVINIENTES 22

2.1. Directoras de tesis 22

2.2. Aspirante a doctor 23

3. OBJETIVO GENERAL 24

4. OBJETIVOS ESPECÍFICOS 24

5. PALABRAS CLAVE 25

6. JUSTIFICACIÓN 25

7. ELECCIÓN DEL TEMA 26

8. EL CONTEXTO DE LA INVESTIGACIÓN 27

9. METODOLOGÍA 28

9.1. Redacción del trabajo $\quad 30$

9.2. Abreviaturas utilizadas 30

9.3. Cuestiones de estilo 31

10. ANTECEDENTES-ESTADO DEL ARTE 31

11. AGRADECIMIENTOS 47

\section{CAPITULO II ANTECEDENTES HISTÓRICOS}

1. INTRODUCCIÓN

1.1. Los Carroz 52

1.2. Los Riu-Sec 54

1.3. Los Centelles Riu-Sec 54

1.3.1. Los Señores de Nules 55

1.3.2. Los Señores de Oliva y Nules 58

1.3.3. Los Condes de Oliva y Señores de Nules 60

2. EL SIGLO XVI 66 
2.1. Contexto histórico y político

2.2. Contexto jurisdiccional y económico 71

2.3. Contexto social y demográfico 73

2.4. Los pesos y medidas valencianas $\quad 77$

\section{CAPITULO III \\ EL CONTEXTO ARQUITECTÓNICO}

1. INTRODUCCIÓN 81

2. EL ÚLTIMO GÓTICO EN EL REINO DE VALENCIA

3. EL PRIMER RENACIMIENTO EN EL REINO DE VALENCIA 85

4. LOS CASTILLO-PALACIOS GÓTICOS VALENCIANOS 88

4.1. Introducción 88

4.2. Los castillo-palacios $\quad 89$

4.3. Características de los palacios góticos 90 valencianos

4.4. Relación de castillos-palacio góticos valencianos 91

\section{CAPITULO IV \\ EL PALACIO}

1. EMPLAZAMIENTO Y LOCALIZACIÓN 95

2. ANTECEDENTES 97

3. DESCRIPCIÓN GENERAL 98

3.1. Los patios 100

3.2. Las torres 101

3.3. Las Plantas 101

3.4. Las fachadas 109

4. DATACIÓN 113

5. ESTADO ACTUAL DEL PALACIO 115

5.1. Elementos in situ $\quad 115$

5.2. Piezas diseminadas 123

5.2.1. Museo Arqueológico de Oliva 124

5.2.2. Colecciones privadas de Oliva 129

5.2.3. Museo de Diseño y de las Artes

Aplicadas de Copenhague

(Dinamarca)

5.2.4. Nørrehald. Femmøller Strand 134

5.2.5. Hispanic Society of America 137 


\section{CAPITULO V \\ EL LEGADO GRÁFICO DE E. FISCHER Y V. LAURITZEN}

1. INTRODUCCIÓN 141

2. NOTEBOOKS 142

2.1. Notebook I 142

2.1.1. Documentación gráfica 143

2.1.2. Textos 144

2.2 Notebook II 145

2.2.1.Documentación gráfica $\quad 145$

2.2.2.Textos 146

3. PLANOS 147

3.1. Portadas 147

3.2. Ventanas 148

3.3. Techos 148

3.4. Varios 148

3.5. Planos Proyecto Pile Allé 149

3.6. Plantas 149

4. FOTOGRAFÍAS 149

4.1. Álbum de Fotos Grande $\quad 150$

4.2. Álbum de Fotos Pequeño 151

5. ESTUDIO Y CLASIFICACIÓN 152

5.1. Plantas 153

5.2. Ventanas 158

5.2.1. Ventanas numeradas 158

5.2.2. Ventanas no numeradas $\quad 175$

5.3. Forjados y artesonados $\quad 184$

5.3.1 Forjados Notebooks $\quad 184$

5.3.2 Forjados y artesonados. Planos $\quad 188$

5.4. Bóvedas 198

5.5. Galería Patio 207

5.6. Galería Torre Grande 209

5.7. Pavimentos y piezas cerámicas 212

5.7.1. Piezas cerámicas 212

5.7.2. Pavimentos 218

6. OTRAS FUENTES DOCUMENTALES 224

6.1. Archivo del IPCE 224

6.2. Archivo General y Fotográfico de la Diputación de Valencia 228

6.3. Danmarks Kunstbibliotek Studiesalen 230

6.4. Kunst Industri Museet 240 


\section{CAPITULO VI \\ LAS PORTADAS}

1. INTRODUCCIÓN 245

2. METODOLOGÍA 245

3. ANÁLISIS GRÁFICO 247

4. TIPOS DE ARCOS 347

4.1. Portadas de arcos uniformes 347

4.2. Portadas de arcos múltiples 354

5. BASAS 362

5.1. Basas de dos columnillas 364

5.2. Basas de una columnilla 366

6. SECCIÓN DE JAMBAS Y ARCOS 367

6.1. Sección de jambas de dos columnillas 370

6.2. Sección de jambas de una columnilla 373

7. CAPITELES 374

8. ORNAMENTACIÓN RENACENTISTA 384

9. MÉTRICA Y PROPORCIONES GEOMÉTRICAS 394

9.1. Métrica 394

9.2. Proporciones geométricas 400

10. OTRAS PORTADAS 406

10.1. Castillo-Palacio de los Aguilar o de las Cuatro Torres (Alaquás) 406

10.2. Palacio de Albalat dels Sorells 407

10.3. Castillo Palacio de Ceyt Abu Ceyt o del Marqués de Monistrol (Argelita) 408

10.4. Castillo de Benisanó 410

10.5. Castillo de Bolbaite 411

10.6. Monasterio de Cotalba 412

10.7. Castillo Palacio de los Duques de Medinaceli (Geldo) 416

10.8. Iglesia del Corpus Christi (Lluxent) 417

10.9. Palacio de Luxent 418

10.10. Castillo de Ortells 420

10.11.Palacio de Sot de Ferrer 421

10.12. Catedral de Valencia 423

10.13.Palacio de los Escrivá (Valencia) 424

10.14.Palacio de la Generalitat (Valencia) 425

10.15. Lonja de Valencia 431

10.16. Monasterio de la Santísima Trinidad (Valencia) 434

10.17. Palacio de Mosén Sorell (Valencia) 435

10.18. Palacio de los Almirantes de Aragón (Valencia) 438 


\section{CAPITULO VII \\ DESARROLLO GRÁFICO}

1. INTRODUCCIÓN 441

2. PLANOS 2D 442

2.1. Croquis 443

2.2. Croquis y fotografía 443

2.3. Lámina a escala 448

2.4. Lámina a escala y fotografía 450

2.5. Ventana calle Palau no 7

3. PIEZAS en 3D 456

3.1. Portadas 457

3.2. Ventanas 462

3.3. Forjados y artesonados 464

3.4. Bóvedas 465

4. RESTITUCIÓN GRÁFICA SALA 12

5. ANAGLIFOS 475

6. MAQUETAS 480

6.1. Maquetas físicas 480

6.2. Maquetas virtuales 483

\section{CAPITULO VIII \\ CONCLUSIONES}

1. EL EDIFICIO

1.1. Enclave 487

1.2. Datación 487

1.3. Magnitud 488

1.4. Tipología constructiva 489

1.5. Sus constructores 490

2. LEGADO GRÁFICO 492

2.1. Datación de los documentos 493

2.2. Autoría de los documentos 494

2.3. El valor de los documentos 496

2.4. Los elementos arquitectónicos 497

2.5. Els studis blanchs $\quad 502$

2.6. Els studis daurats 503

2.7. El proyecto de Pile Allé $\quad 507$

3. LAS PORTADAS 508 
3.1. Clasificación 509

3.2. Las basas $\quad 510$

3.3. Sección de jambas y arcos 512

3.4. Capiteles y ménsulas 515

3.5. La métrica $\quad 515$

3.6. Las proporciones geométricas 516

3.7. Paralelismos con otras portadas 517

4. DESARROLLO GRÁFICO 520

4.1. Planos 2D 520

4.2. Piezas 3D 521

4.3. Restitución gráfica Sala 12

4.4. Anaglifos 521

4.5. Maquetas $\quad 522$

5. SÍNTESIS FINAL

\section{BIBLIOGRAFÍA}

1. LIBROS 525

2. CAPÍTULOS DE LIBROS 527

3. ARTÍCULOS DE REVISTAS 528

4. PRENSA HISTÓRICA 531

5. PRENSA ON LINE 531

6. ACTAS DE CONGRESOS 531

7. NORMAS 533

8. TESIS NO PUBLICADAS Y TRABAJOS ACADÉMICOS 533

9. PROYECTOS TÉCNICOS DE RESTAURACIÓN 533

10. DOCUMENTACIÓN ARCHIVOS 533

11. PÁGINAS WEB 534

12. MUSEOS Y EDIFICIOS HISTÓRICOS VISITADOS 536

13. BIBLIOTECAS CONSULTADAS 537 


\section{RESUMEN}

El Palacio Condal de Oliva, declarado Monumento Nacional en 1920, hoy casi desaparecido, fue un referente de la arquitectura tardogótica valenciana. El objetivo principal del presente trabajo consiste en profundizar en su conocimiento y fomentar su difusión.

Se ha realizado una labor de búsqueda de fuentes documentales para poder contextualizar el edificio, así como a sus promotores y posibles creadores desde un punto de vista histórico, social y estilístico.

Partiendo de la documentación gráfica levantada por los arquitectos daneses Fischer y Lauritzem entre 1917 y 1920 se ha procedido a analizar los elementos arquitectónicos que lo componían, estudiando su trazado, métrica y composición. Se han restituido algunos de sus elementos más singulares siguiendo una rigurosa metodología gráfica, con la finalidad de poder visualizar y entender este espacio arquitectónico.

El resultado final es una exhaustiva restitución gráfica de estos elementos mediante una completa definición geométrica a partir de la cual se puede profundizar en el análisis y comprensión del conjunto arquitectónico, para posteriores estudios, así como la difusión de este monumento de un alto valor histórico y patrimonial.

Palabras clave: Arquitectura, gótico, Renacimiento, tardogótico, Castillo-palacio, Oliva, Centelles, Egil Fischer, Vilhem Lauritzen, portadas.

\section{ABSTRACT}

The Earls' Palace in Oliva, which was declared a National Monument in 1920 but today has almost disappeared, was a point of reference of the Valencian late-Gothic architecture. The aim of this work is to deepen its knowledge and promote its dissemination.

A search has been made to find documentary sources to be able to contextualize the building, as well as its promoters and possible creators from a historical, social and stylistic point of view.

The work started with the graphic information dating from between 1917 and 1920 that was collected by the Danish architects Fischer and Lauritzen, proceeding to analyse the architectural elements that composed it, studying its layout, metrics and composition. Some of its most unique elements have been graphically restored following a rigorous graphic methodology, in order to be able to visualize and understand this architectural space.

The result is a comprehensive graphical restitution of these elements by means of a thorough geometric definition that allows a deeper analysis and understanding of the architectural complex, for use in further studies. At the same time, it also allows this monument of great historical and heritage value to be made known to a wider public.

Key words: Architecture, Gothic, Renaissance, late-Gothic, Castle-palace, Oliva, Centelles, Egil Fischer, Vilhem Lauritzen, portals. 



\section{CAPITULO I}

\section{PROPUESTA}

\section{INTRODUCCIÓN}

\subsection{El municipio de Oliva}

El municipio de Oliva está situado en la comarca de La Safor, al sur de la provincia de Valencia, en la Comunidad Valenciana (España). Geográficamente se encuentra a una latitud de $38^{\circ} 55^{\prime} 10^{\prime \prime} \mathrm{N}$ y a una longitud de $0^{\circ} 07^{\prime} 16^{\prime \prime} \mathrm{W}$. Su término municipal tiene una extensión de 77,2 $\mathrm{Km}^{2}$, limitando por el oeste con los municipios de La Font d'en Carròs, Vilallonga (provincia de Valencia) y L'Atzúvia (provincia de Alicante); por el norte con los términos de L'Alqueria de la Comtessa y Piles; por el este con el Mar Mediterráneo y por el sur con la provincia de Alicante (municipios de Dénia y Pego) ${ }^{1}$. El núcleo urbano está situado a unos 25 metros de altitud y la mayor altitud corresponde al pico Coballetes (365 metros). Parte de su término municipal está integrado dentro del parque natural de la Marjal de Pego-Oliva y dispone de $11,8 \mathrm{~km}$ de costa.

En cuanto a su patrimonio arquitectónico, podemos destacar la Iglesia de Santa María la Mayor (s. XVII-XVIII), las casas de la calle Tamarit no 2-4 y no 6 (s. XVIII), la casa Abadía (s. XV), la Iglesia de San Roc (s. XIX), la capilla del Cristo (s. XVIII), el Castillo de Santa Ana (s. $\mathrm{XVI}$ ), la torre de la antigua muralla (s. XVI) y los restos del Palacio de los Centelles (s. XV y $\mathrm{XVI}$ ), objeto de estudio del presente trabajo.

\subsection{El condado de Oliva}

La familia Centelles se desplazó con Carlomagno al sur de Francia y a Cataluña y, posteriormente, a Valencia tras su reconquista, estableciéndose como señores, primero de Nules y después también de Oliva. ${ }^{2}$

El día 14 de abril del año 1449 Francesc Gilabert de Centelles i de Queralt es nombrado conde de Oliva por el rey Alfonso el Magnánimo por los servicios prestados a la corona tanto por él como por su padre, Bernat de Centelles Riu-Sec i de Cabrera.

Los territorios del condado de Oliva estarán formados, además de por el señorío de Oliva, por el resto de señoríos y posesiones que había acumulado la familia Centelles desde su

\footnotetext{
${ }^{1}$ Cardona Miralles, S. (1988) El medio físico. En Cardona Miralles, S. (Ed.). Iniciación a la Historia de Oliva (2a Ed.). Oliva, Valencia: Publicaciones del Ayuntamiento de Oliva. pp. 37.

2 E. Muller, P. (2013). El Palacio de los Centelles de Oliva: contexto y contextos. En Gavara Prior, Joan J. y E. Muller, Priscilla. El Palacio Condal de Oliva. Catálogo de los planos de Egil Fischer y Vilhelm Lauritzen. Valencia, España: Diputación de Valencia. pp. 35.
} 
asentamiento en tierras valencianas. A continuación detallamos los territorios más importantes adquiridos por dicha familia y su año de compra o segregación ${ }^{3}$ :

\section{Gilabert de Centelles y de Bellpuig}

- 1314: compra del castillo y villa de Nules a Ramón de Montcada.

\section{Gilabert de Centelles y de Montcada}

- 1342: permuta de la potestad y jurisdicción sobre la villa y castillo de Nules y escorrentías de la acequia de Villareal por el castillo de Montornés al rey Pedro II el Ceremonioso.

- 1358: compra de Alfarb al rey Pedro II el Ceremonioso.

\section{Pere de Centelles i Vilabona}

Durante el señorío de Pere de Centelles i Vilabona no se ha datado ninguna adquisición patrimonial relevante.

\section{Gilabert de Centelles i Riu-Sec}

- 1387: recibe en herencia de su tío Ramón de Riu-Sec los señoríos de Oliva y Rebollet.

\section{Bernart de Centelles Riu-Sec i de Cabrera}

- 1420: Alfonso el Magnánimo le concede la jurisdicción de Rocafort de Queralt.

- 1421: recibe de manos del rey los feudos de Monteagudo, Anglona, Osilo, Merguine, Mesolongo, y los condados de Gociano y Barbairas en la isla de Cerdeña.

\section{Francesc Gilabert de Centelles Riu-Sec i de Queralt}

- 1438: Alfonso el Magnánimo le dona el Castro Genovese en la isla de Cerdeña.

- 1453: Alfonso el Magnánimo lo nombra alcaide del castillo Jenuense, Cabo Sácer y Lugudor, en Cerdeña.

- 1454: el Rey le entrega la castellanía de Sácer.

- 1463: compra la villa de Murla.

- 1473: compra la baronía de Pego y sus lugares anejos: Favara, Benumeya y Adsubia.

- 1476: Compra las baronías de Orba y Alaguar.

\section{Serafí de Centelles Riu-Sec i Ximénez de Urrea}

- En 1480 adquiere del rey Fernando las encontradas de Marquine y el castillo de Macomer en Sicilia.

\footnotetext{
${ }^{3}$ Mestre i Pons, F. (1997). Apunts bibliogràfics dels Centelles. En VV.AA. Esteve i Blai, Antoni. El Palau dels Centelles d'Oliva. Recull gràfic y documental. L'Associació Cultural Centelles i Riu-Sec Oliva (pp. 41-75) Oliva, España: Gràfiques Colomar.
} 
Su gran aportación al legado familiar fue el embellecimiento del Palacio Condal de Oliva.

\section{Francesc Gilabert de Centelles Riu-Sec i Fernández de Heredia}

- 1522: hereda de su padre, Querubí de Centelles Riu-Sec, el señorío de la Vall de Ayora.

- 1536: hereda de su tío, Serafí de Centelles i Riu-Sec, los estados de Oliva y Nules.

\section{Pere de Centelles Riu-Sec i Folch de Cardona}

Durante el señorío de Pere de Centelles Riu-Sec no se tiene constancia de ninguna adquisición patrimonial relevante.

\section{Magdalena de Centelles Riu-Sec i Folch de Cardona}

- 1594: hereda de su hermano, Pere de Centelles, el Condado de Oliva con sus baronías valencianas y los señoríos de Cerdeña. La Baronía de Nules pasa a su primo Cristòfor Centelles, y el valle de Ayora a su primo Francesc Centelles.

\section{Carlos Francisco de Borja-Centelles y Velasco}

- 1596: a la muerte de su madre, Magdalena de Centelles, hereda los estados de los Borja y de los Centelles, siendo: VII Duque de Gandía, IV Marques de Llombai, VI Conde de Oliva, Señor y Barón de las Encontradas y baronía de Anglona, Monteagudo, Osilo, Marguine, Comer y Coginet, etc. en el reino de Cerdeña, y de las baronías de Pego, Murla, Orba, y Alahuar, Corbera, Turís, Chella, Albalat de la Ribera, Castelló de Rugat, la Vall de Gallinera, la Vall de'Ebo, el Real, Les Almiones, Benieto, Bellrreguard, Xeresa, Xeraco, Miramar y Alcodar.

\subsection{El Palacio Condal de Oliva}

El Palacio Condal de Oliva corresponde a la tipología del gótico tardío flamígero con elementos mudéjares que se desarrolló en España a mediados del siglo XIV. Asimismo incorpora elementos decorativos del primer renacimiento en España ${ }^{4}$.

La construcción del palacio debió de iniciarse en la segunda mitad del siglo XIV por la familia de los Centelles de Oliva y Nules, y duró hasta mediados del siglo XVI. Con el nombramiento en 1449 de Francesc Gilabert de Centelles Riu-Sec (1408?-1480?) como Conde de Oliva por parte de Alfonso el Magnánimo comienza la época de esplendor del palacio, que continuaría su hijo Serafí de Centelles Riu-Sec (†1536), a quién se le atribuye su embellecimiento. Posteriormente, fue fortificado convirtiéndose en un alcázar $^{5}$.

En el siglo XIX los últimos dueños, la familia Osuna, venden el palacio. Los compradores se llevaron todo lo que pudieron arrancar fácilmente $y$, para poderlo parcelar, abrieron una calle que lo atravesaba.

\footnotetext{
${ }^{4}$ E. Muller, P (1996). El Palacio de Oliva de los Centelles. Architectura 18: Arkitekturhistoriskårsskrift. pp. 129.

${ }^{5}$ E. Muller, P (1996). Óp. cit. pp. 129.
} 
En 1917 el arquitecto danés Egil Fisher (1878-1963), interesado por el arte español, llega a Oliva y compra siete sectores del antiguo palacio con la finalidad de desmontar aquellas piezas que pudieran salvarse y construir un museo español en Dinamarca donde poder incorporarlas ${ }^{6}$.

En 1919 se traslada de nuevo a Oliva acompañado de un equipo de tres personas entre las que se encuentra el joven estudiante de arquitectura, Vilhem Lauritzen (1894-1984). Juntos inician una labor de documentación gráfica del palacio con la finalidad de clasificar y ordenar todos los elementos "aprovechables" del mismo?.

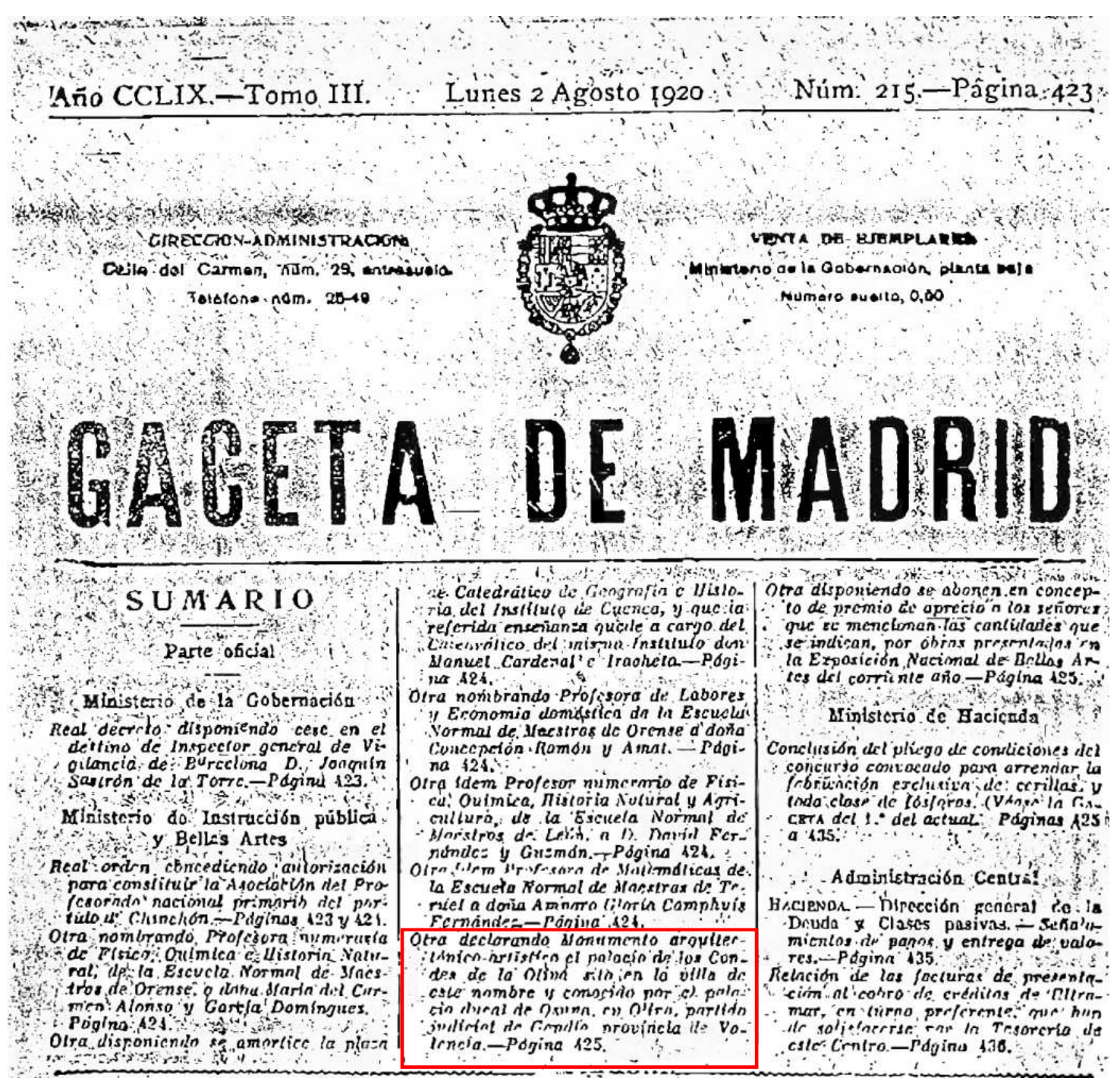

Figura 1: Orden Real declarando el palacio de los condes de Oliva Monumento Arquitectónico Artístico. Gaceta de Madrid. Fuente: BMV.

${ }^{6}$ Lauritzen, V (1997). Relación sobre el Palacio, Oliva, Valencia. En Esteve i Blai, Antoni (Ed.). El Palau dels Centelles d'Oliva. Recull gràfic y documental. Oliva, España: L'Associació Cultural Centelles i RiuSec. pp.141

${ }^{7}$ Lauritzen, V. Óp. cit. pp. 141. 
Las quejas de otros propietarios hicieron que un arquitecto provincial enviara un informe al Ministerio solicitando el cese de las demoliciones y el palacio, finalmente, fue declarado monumento nacional en 1920 (Fig.1).

A partir de ese momento se prohibió la exportación de las piezas que habían sido desmontadas y Fischer, después de muchos intentos por llevarse el material, desiste de su empeño ${ }^{8}$.

Debido a inclemencias meteorológicas y a las consecuencias de la guerra civil el palacio sufrió un gran deterioro. En 1950 los restos que quedaban en pie fueron declarados en estado de ruina y derribados ${ }^{9}$.

En 1980 The Hispanic Society of America (HSA) adquiere en una subasta en Londres dos secciones del friso de la sala de armas, así como otras piezas procedentes del Palacio de Oliva. Así comienza un intenso trabajo de investigación liderado por Priscilla E. Muller, conservadora del Museo de la HSA quien, con la ayuda de Lauritzen, consigue localizar todo el legado gráfico levantado años atrás por Fischer, el cual se encontraba en manos de la viuda de este último, Olga Fischer, quien finalmente donó toda la documentación a la HSA en el año $1986^{10}$.

Finalmente, esta documentación fue cedida al Municipio de Oliva por la HSA en el año 2010. Actualmente se encuentra archivada en el Museo Arqueológico Municipal.

\subsection{Los arquitectos daneses}

El punto de partida de esta tesis es la documentación gráfica levantada por los arquitectos daneses Egil Fischer y Vilhelm Lauritzen entre 1917 y 1920.

Expondremos una breve biografía de estos dos arquitectos, así como su trayectoria profesional para tener un mayor conocimiento de estas dos figuras clave en las tareas de documentación gráfica del palacio.

\section{Egil Fischer (21-10-1878 al 23-04-1963)}

Nació en Copenhague en 1878 y se graduó en Arquitectura en 1897. Entre 1897 y 1904 trabajó con Martin Nyrop y Martin Borch en el Ayuntamiento de Copenhage. En 1912 recibió la beca Stolt Bergske, y en 1922 se convirtió en miembro de la Academia de Arquitectos. Desde el principio de su carrera se interesó por la planificación urbana, y ya antes de la Primera Guerra Mundial hizo una importante contribución en una serie de proyectos. En 1901 obtuvo el segundo premio en un concurso para un plan de desarrollo de

\footnotetext{
${ }^{8}$ Lauritzen, V. Óp. cit. pp. 142.

${ }^{9}$ Lauritzen, V. Óp. cit. pp. 143.

${ }^{10}$ E. Muller, Priscilla. (1999). A la recerca del Palau. Cabdells: revista d'investigació de l'Associació Cultural Centelles i Riu-Sec, Núm. 1. pp. 24.
} 
un barrio en Odense y el segundo premio en el concurso para la solución de las islas Brygge (1907). También participó en el concurso de un plan de desarrollo para Copenhague (1908), mostrando una clara preocupación por los futuros problemas de tráfico de la ciudad. Sugirió que las principales líneas de tráfico se reunieran en un nuevo centro al oeste de la ciudad vieja para preservar los edificios del centro histórico y propuso, también por primera vez, la idea de una expansión de los puertos en la costa este de Amager. Junto con O. K. Nobel y Holger Rasmussen consiguió el primer premio en el concurso para los terrenos junto a la estación de ferrocarril. Fue una de las figuras más importantes en la planificación de la ciudad de Copenhague, siendo pionero en un campo todavía por desarrollar en esa época en Dinamarca e influyendo posteriormente en la planificación de la ciudad danesa. Realizó también numerosos proyectos privados de edificios pequeños, incluyendo villas en la Exposición Nacional de Aarhus en 1909 y su propia casa en Mols ${ }^{11}$. Junto con Olaf Petri construyó los cuarteles de Holbaek en 1913 y con Chr. Christensen el museo Gunnar Sadolins (Casa Sadolins) en Dragør (1933-1934).
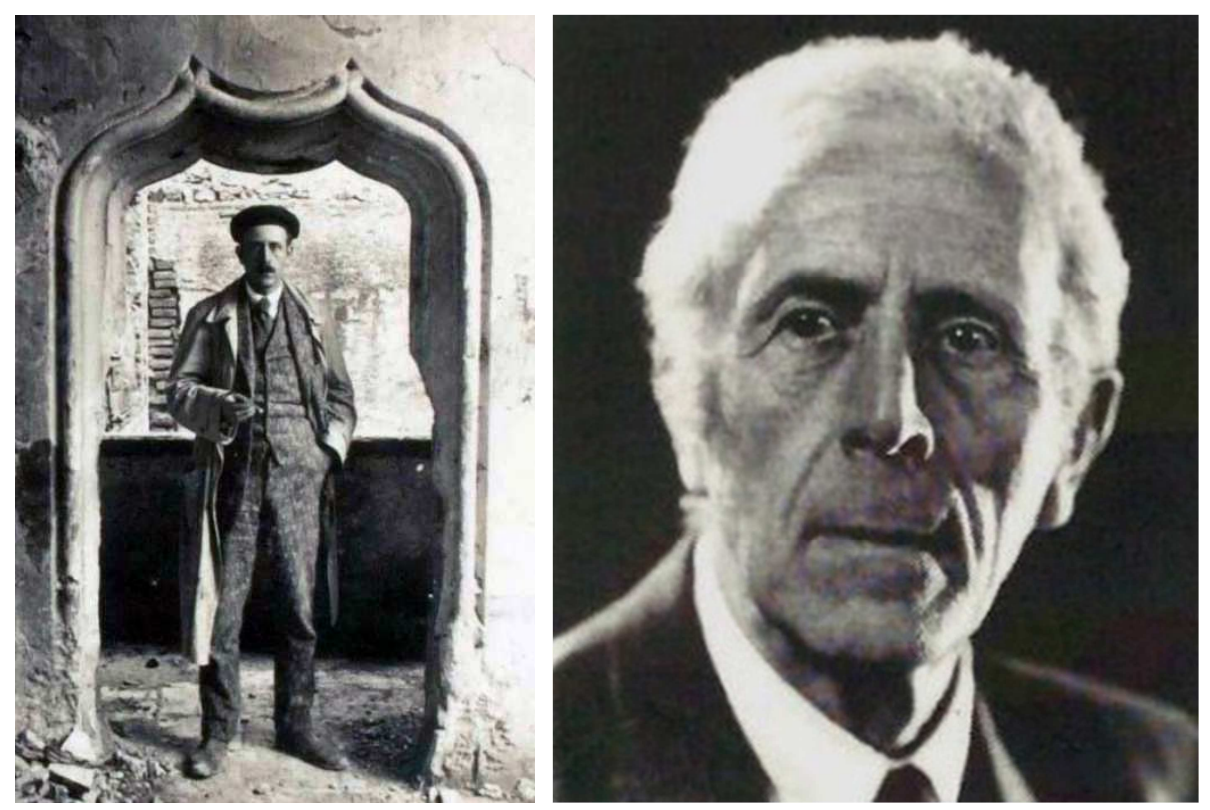

Figura 2: Izquierda: Egil Fischer en el Palacio de Oliva. Fuente: Fot. 73. AFG. MAO. Egil Fischer. Derecha: Fotografía Egil Fischer. Fuente: www.femmoller-strand.dk/egil-fischer.

Viajó con su padre a Alemania e Italia en 1884-85, y entre 1901 y 1905, viajó por Alemania, Italia, Suiza, Francia y España. En 1913 viajó de nuevo a España donde volvería en numerosas ocasiones hasta $1920^{12}$.

En 1917 oyó hablar de la ruinas de un castillo (el Palacio de Oliva). Visitó Oliva y compró 7 sectores del antiguo Palacio. En 1918 comenzó el desmontaje a modo de ensayo y en 1919

\footnotetext{
${ }^{11}$ Femmoller Satrand. Recuperado de: www.femmoller-strand.dk/egil-fischer.

${ }^{12}$ Kultur Ministeriet (Ministerio de Cultura Danés). Recuperado de: www.kulturarv.dk.
} 
se instaló en Oliva junto con el resto de la "Brigada Danesa"13 para para documentar y desmontar los elementos más singulares de este Palacio ${ }^{14}$.

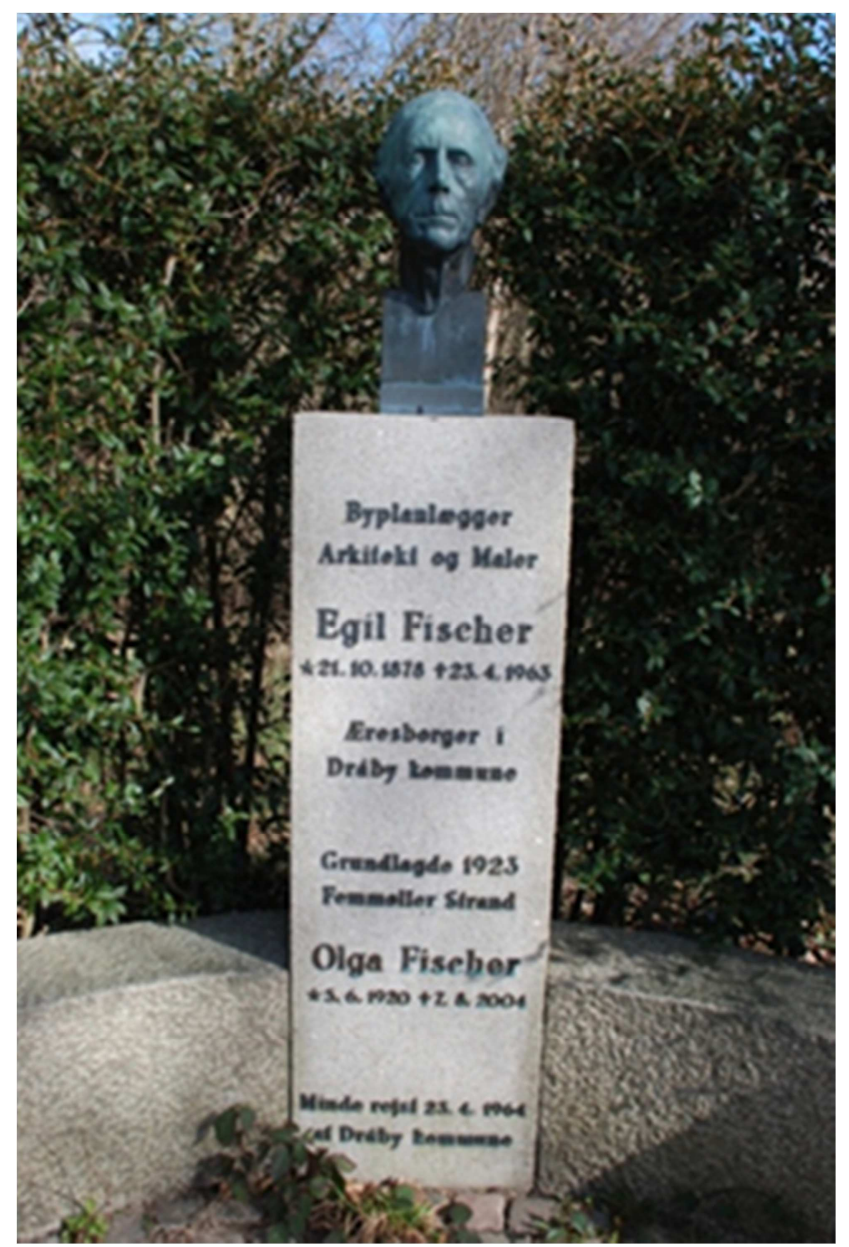

Figura 3. Busto de E. Fischer y monolito de E. Fischer y Olga Fischer en Femmøller Strand. Ebeltoft.

Entre 1929-1931 participó como miembro de la Academia de Arquitectos en un informe sobre legislación y tuvo un papel importante en la redacción la nueva ley de la construcción de Copenhague (1939). En 1922 se inició la construcción de los edificios de la playa de Femmøller. En 1938 reanudó su actividad como arquitecto de planificación urbana llevando a cabo, entre otros, los planes de desarrollo para el núcleo histórico de Aarhus (galardonado con la Medalla Eckersberg en 1939) y los planes para las localidades de

\footnotetext{
${ }^{13}$ Lauritzen, V. Óp. cit. (pp. 141). Este término lo utiliza Lauritzen para referirse al equipo de cuatro personas que en 1919 se desplazó a Oliva para llevar a cabo las labores de documentación y desmontaje de parte del Palacio de Oliva. Estaba formado por Egil Fischer, Mogens Clemmensen (arquitecto del Museo Nacional), Kjartan Fischer (artesano sobrino de E. Fischer) y el propio Vilhelm Lauritzen.

${ }^{14}$ Lauritzen, V. Óp. cit. (pp. 143).
} 
Svendborg y Ebeltoft (1941), el proyecto de planificación para la ciudad de Horsens (1942), junto con O. Gjerløv-Knudsen, y el plan de conservación de Dragør (1949). Sus proyectos y propuestas urbanísticos eran muy avanzados para su tiempo, caracterizándose por poseer un gran respeto por las áreas con edificios antiguos, así como por los valores históricos y la naturaleza. Sin embargo, su falta de flexibilidad en las relaciones profesionales le creó ciertos conflictos con las autoridades locales. En 1941 recibió la medalla de honor de la Asociación de Arquitectos para el embellecimiento de la capital. Fischer cultivó también la pintura y expuso varias veces en Charlottenborg. Se casó dos veces: en 1904 con Magnella Kirstine Djørup Arentz, y con Olga Hersom en 1934. Murió en Ebeltoft, y sus restos descansan en un jardín junto a la playa de Femmøller, en el Parque Nacional de Mols Bjerge, donde hay un monolito en su memoria ${ }^{15}$ (ver Fig. 3).

\section{Vilhelm Lauritzen Theodor (10-09-1894 al 22-12-1984)}

Nació en Slagelse (Dinamarca). Estudió en la Real Academia Danesa de Bellas Artes y finalizó sus estudios de Arquitectura en 1921. Siendo estudiante, viajó a España contratado por el arquitecto Egil Fischer para medir y dibujar los restos del Palacio de Oliva ${ }^{16}$. Realizó una estancia en Grecia desde 1921 hasta 1922, donde fue miembro de l'Ecole Francaise d'Atenas. En 1926 ganó la medalla de oro de la Academia. Fue ayudante de Holger Rasmussen en la construcción de la Logia Masónica en Blegdamsvej (1924-1927). En 1929 fundó su propio estudio de arquitectura creando su estilo particular. Como ejemplos podemos destacar la villa Tuborgvej 79, (1929; y ampliada en 1934) y la casa de retiro, Ordrup Jagtvej, 193 (1934). Desde la década de los 30 se convirtió en un firme defensor de las nuevas ideas funcionalistas, que suponen una ruptura radical con la tradición, donde la funcionalidad y el diseño determinan por completo la forma. Lauritzen encontró una forma de expresión que pareció ajustarse a su temperamento. Así, fue considerado uno de los principales pioneros del funcionalismo y el principal representante de la era moderna. Como ejemplos tenemos su propuesta de un nuevo museo de Zoología en la Universidad de Nørrefælled (1931), la remodelación del teatro Nørrebro (1932), el jardín de los periodistas en Peter Rørdamsvej 2-4 (1936), el Ayuntamiento de Gladsakse (1937) y la escuela Marielyst Gladsaksevej 178-206 (1938).

En 1936 ganó el primer premio en un concurso para un nuevo edificio para la terminal del aeropuerto internacional de Copenhague, que construyó entre 1937 y 1939. Era un nuevo tipo de edificio al que Lauritzen dio un diseño moderno y exclusivo que ayudó en gran medida a dar identidad al funcionalismo. También fue significativo su diseño de la Casa de la Radio en Rosenørns Allé 22, cuyos primeros diseños datan de 1934 y que fue construida finalmente entre 1937 y 1941. Durante muchos años fue el arquitecto de los grandes almacenes Daells, Nørregade, donde trabajó en 1923 y 1928-31 junto con Frits Schlegel. En 1936 y 1950 realizó él solo una remodelación radical del edificio.

${ }^{15}$ Millech, K y Villadsen, V. (1979-1984). Den Store Danske. Enciclopedia Bibliográfica Danesa. Recuperado de:

www.denstoredanske.dk/Dansk_Biografisk_Leksikon/Kunst_og_kultur/Arkitektur/Arkitekt/Egil_Fisch er y Wikipedia. Egil Fischer. Recuperado de: www.da.wikipedia.org/wiki/Egil_Fischer.

${ }^{16}$ Lauritzen, V. Óp. cit. (pp. 143). 


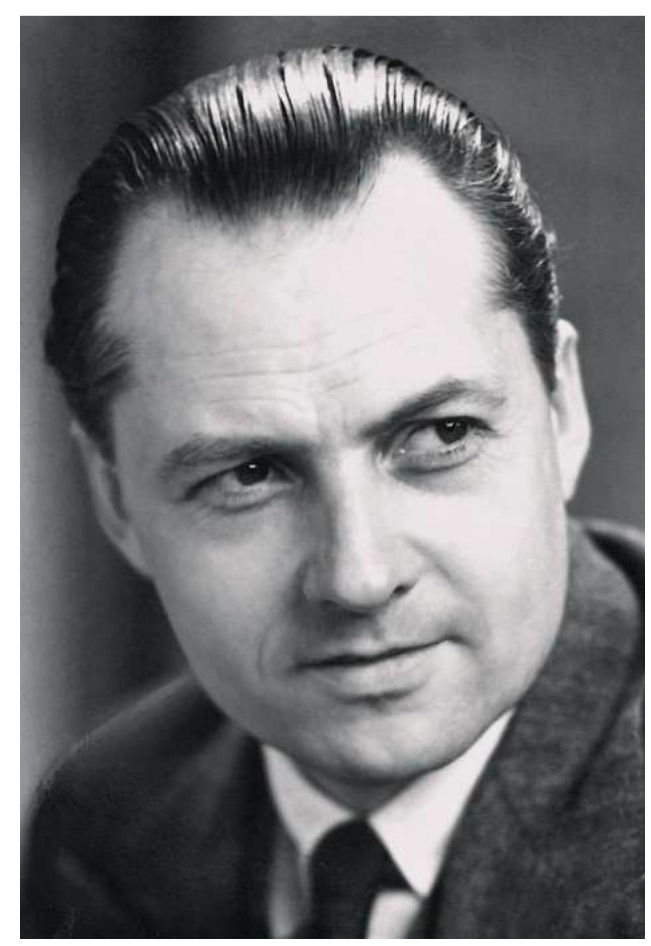

Figura 4: Fotografía Egil Vilhelm Lauritzen. Fuente: www.louispoulsen.com

Después de la II Guerra Mundial Lauritzen tuvo la oportunidad de demostrar una vez más sus capacidades innovadoras con la escuela Stengård en Triumfvej, 1 en Gladsakse (19491952) siendo el primer ejemplo de construcción de una nueva escuela en una sola planta. En 1950 le encargaron la construcción de una serie de grandes edificios públicos y privados en un diseño convencional, menos radical y con nuevas soluciones constructivas que en gran medida llegaron a influir en las futuras prácticas constructivas. Entre 1950-1951 construyó el edificio Shell Houseen Kampmannsgade, 2 para reemplazar el edificio original que fue parcialmente destruido tras unos ataques aéreos británicos en 1945. El nuevo edificio fue construido en una estructura de hormigón armado y fachadas ligeras, convirtiéndose en un modelo de construcción. En 1935-1956 construyó la Casa del Pueblo en Enghavevej, 40. A mediados de la década de 1950 se le asignó la construcción de una nueva terminal para el aeropuerto de Copenhague en Kastrup. El edificio fue diseñado como una gran sala alargada en la que las múltiples funciones se desplegaban en una estructura abierta con un plan racional. En 1959 entregó la obra de los estudios de TV en Gyngemosen. El sistema fue diseñado como un grupo de edificios dispersos separados para diversos fines, construidos con fachadas de piedra dorada y con un perfil de techo característico en forma de cuenco. Además, fue el encargado de diseñar un edificio de apartamentos para la administración y varios edificios técnicos. Lauritzen también trabajó en las artes decorativas, diseñando muebles y lámparas.

Fue asimismo profesor en la Academia de Arte (1926 a 1941), miembro de la Junta Académica del Colegio de Arquitectos (1942-1944), miembro de la Academia desde 1943 y presidente del Instituto de Investigación para la Construcción del Estado en 1947. Recibió la medalla Eckersberg en 1941; la medalla CF Hansen en 1954; y fue miembro de la Academia 
de Arquitectos con medalla de honor de la asociación en 1964 y arquitecto del Instituto Real de Arquitectos en 1946. Se casó con la arquitecta Ingeborg Ziegler en 1922. En 1978 visita Oliva con su hija buscando los restos del viejo Palacio ${ }^{17}$. Murió en 1984 a los 90 años de edad ${ }^{18}$. El estudio de arquitectura fundado por él continúa estando en activo bajo su mismo nombre: Vilhelm Lauritzen Arkitekter ${ }^{19}$.

\section{INTERVINIENTES}

La presente tesis se encuadra dentro del programa de doctorado TIME (Tecnologies Industrials, Materials i Edificació) de la Universidat Jaume I. A su vez está, se encuentra dentro de la línea de investigación "Patrimonio Arquitectónico: Interpretación, Conservación y Desarrollo"; y, dentro de esta línea, en el gótico civil mediterráneo.

Los códigos UNESCO de referencia son los siguientes:

620100-Arquitectura

550601-Historia de la Arquitectura

\subsection{Directoras de tesis}

\section{Directora: ALBA SOLER ESTRELA}

Arquitecta por la Universitat Politècnica de València en el año 2000, con doble especialidad: edificación y urbanismo. Es doctora "cum laude" en el programa "Patrimonio Arquitectónico: Historia, Composición y Estudios Gráficos" de dicha universidad en 2009. Es profesora del área de Expresión Gráfica Arquitectónica en la Universitat Jaume I de Castellón desde 2006 hasta la fecha, impartiendo docencia en el grado en Arquitectura Técnica y en el grado en Ingeniería en Diseño Industrial y Desarrollo de Productos. Ha sido profesora asociada en la Universitat Politècnica de València entre 2002 a 2006. Es coordinadora del grupo de investigación 203 "Arquitectura, Diseño y Patrimonio" de la Universitat Jaume I desde su creación en 2009. Ha sido Investigadora Principal de proyectos concedidos en convocatorias públicas: "Bóvedas aristadas en el gótico valenciano: recreación virtual a partir del estudio geométrico-constructivo para su difusión en las redes de comunicación" (2012-2014) y "Metodologías y técnicas aplicadas a la investigación arquitectónica del Gótico Mediterráneo. Estudio de casos" (2011-2013). Posteriormente, ha formado parte del equipo de investigación del proyecto "Torres de vigía y defensa del litoral valenciano. Generación de metadatos y modelos 3D para su interpretación y efectiva puesta en valor" del Ministerio de Economía y Competitividad. Ha desarrollado, asimismo, una trayectoria en el ámbito de la conservación del patrimonio arquitectónico mediante la

\footnotetext{
${ }^{17}$ Lauritzen, V. Óp. cit. (pp. 144).

${ }^{18}$ Villadsen, V. (1979-1984). Den Store Danske. Enciclopedia Bibliográfica Danesa. Recuperado de: http://denstoredanske.dk/Dansk_Biografisk_Leksikon/Kunst_og_kultur/Arkitektur/Arkitekt/Vilhelm_ Lauritzen.

${ }^{19}$ Vilhelm Lauritzen Arkitekter. Recuperado en: www.vla.dk/projekter.html.
} 
elaboración de proyectos y direcciones de obra, así como trabajos de investigación y propuestas de difusión, con numerosas contribuciones en congresos, libros y revistas especializadas. Es miembro del International Council of Monuments and Sites (ICOMOS) ${ }^{20}$.

\section{Codirectora: Ma JESÚS MÁÑEZ PITARCH}

Es Arquitecta Técnica (1994), Ingeniera de Materiales (2008), Máster Oficial en Edificación (2008) y Doctora (2014) por la Universitat Politècnica de València. Es asimismo profesora del Área de Expresión Gráfica Arquitectónica en la Universitat Jaume I de Castellón desde 2005, impartiendo docencia en el grado en Arquitectura Técnica y en el Grado en Ingeniería Agroalimentaria y del Medio Rural. Fue premio extraordinario de tesis doctoral, en la rama de Arquitectura, en el año 2015. Es miembro del grupo de investigación "Arquitectura, Diseño y Patrimonio" de la Universitat Jaume I y directora del proyecto de investigación "El Renacimiento: impronta arquitectónica en la provincia de Castellón. Huellas, rastros, trazas y vestigios". Ha participado como investigadora en los siguientes proyectos de investigación: "Bóvedas aristadas en el gótico valenciano: recreación virtual a partir del estudio geométrico-constructivo para su difusión en las redes de comunicación" (20122014) y "Metodologías y técnicas aplicadas a la investigación arquitectónica del Gótico Mediterráneo. Estudio de casos" (2011-2013) 21.

\subsection{Aspirante a doctor}

JOAQUÍN ÁNGEL MARTÍNEZ MOYA. Arquitecto Técnico (1992) y Graduado en Ingeniería de la Edificación (2011) por la Universitat Politècnica de València. Master en Energías Renovables por la Universidad San Pablo CEU de Madrid (2012). Profesor de la Universitat Jaume I de Castellón desde 2007, en el Departamento de Ingeniería de Sistemas Industriales y Diseño. Es profesor ayudante en el área de Expresión Gráfica Arquitectónica, impartiendo docencia en el Grado en Arquitectura Técnica y en el Grado en Ingeniería Agroalimentaria y del Medio Rural. Es miembro del grupo de investigación "Arquitectura, Diseño y Patrimonio" de la Universitat Jaume I. Además, ha participado en los siguientes proyectos de investigación: "Bóvedas aristadas en el gótico valenciano: recreación virtual a partir del estudio geométrico-constructivo para su difusión en las redes de comunicación" (2012-2014) y "El Renacimiento: impronta arquitectónica en la provincia de Castellón. Huellas, rastros, trazas y vestigios" (2016-2017). Ha realizado estancias docentes y de investigación en otras universidades nacionales e internacionales y es autor de diversas publicaciones de carácter científico en revistas, libros y actas de congresos nacionales e internacionales relacionados con el levantamiento gráfico y el patrimonio arquitectónico. Posee una amplia experiencia profesional en el campo de la edificación, participando en la construcción de edificios de diversa índole, así como en distintas obras de rehabilitación y consolidación de edificios históricos y patrimoniales (1992-2014).

\footnotetext{
${ }^{20}$ Universitat Jaume I. Recuperado de: www.uji.es.

${ }^{21}$ Universitat Jaume I. Óp. cit.
} 


\section{OBJETIVO GENERAL}

El objetivo general de la presente tesis es el estudio exhaustivo de la documentación gráfica existente del Palacio Condal de Oliva para la definición de los elementos desaparecidos, así como la realización de un análisis desde distintos puntos de vista: constructivo, formal y estilístico, con el fin de contribuir a situar el Palacio en su contexto histórico y arquitectónico y permitir restituir parte de la arquitectura desaparecida para su difusión y su disfrute como elemento cultural.

\section{OBJETIVOS ESPECÍFICOS}

Este objetivo general se desarrolló a través de una serie de objetivos específicos que se listan a continuación; cada uno de ellos se desarrollará más ampliamente al abordar la metodología del trabajo:

a. Recopilar datos bibliográficos, gráficos y archivísticos del edificio.

b. Analizar el contexto urbano, territorial, social, histórico y artístico del edificio.

c. Reconocer la época y tendencias históricas de la construcción del edificio en su contexto.

d. Datar correctamente el Palacio Condal de Oliva.

e. Clasificar y analizar y la documentación gráfica recuperada del Palacio Condal de Oliva.

f. Estudiar las portadas del Palacio Condal de Oliva a través de la documentación gráfica existente.

g. Analizar los aspectos formales, morfológicos, compositivos, geométricos, metrológicos y métricos de las portadas del Palacio Condal de Oliva.

h. Estudiar otras portadas tardogóticas localizadas en la Comunidad Valenciana.

i. Restituir gráficamente algunos elementos del edificio para mejorar su comprensión y percepción.

j. Justificar la importancia del edificio, declarado Monumento Nacional, y fomentar su conocimiento y difusión cultural.

k. Extraer las conclusiones relativas a los diferentes análisis y estudios realizados. 


\section{PALABRAS CLAVE}

Arquitectura, gótico, Renacimiento, tardogótico, Castillo-palacio, Oliva, Centelles, Egil Fischer, Vilhem Lauritzen, portadas.

\section{JUSTIFICACIÓN}

Este trabajo se desarrolla intentando abarcar principalmente tres propuestas:

1․ Por una parte, contribuir al conocimiento y salvaguarda del patrimonio cultural valenciano, mediante un profundo estudio del Palacio Condal de Oliva, ya que dicho Palacio fue declarado Bien de Interés Cultural con categoría de Monumento con fecha 23 de julio de 1920 y publicado en el BOE con fecha 2 de agosto de 1920 (ver Fig. 5). Su código es: (R.I.)-51-0000181-00000. Dicho inmueble figura asimismo en la relación BIC's de la Conselleria d'Educació, Investigació, Cultura i Esport con el código 46.25.181-004. Su clasificación es la siguiente: bienes inmuebles 1a; y su categoría: Monumento y su estado: Declaración singular (ver Fig.6).

\begin{tabular}{|c|l|}
\hline Bien: & Palacio Condal PALACIO DE LOS CONDES DE CENTELLES \\
\hline Comunidad Autónoma: & C. Valenciana \\
\hline Provincia: & Valencia \\
\hline Municipio: & Oliva \\
\hline Categoria: & Monumento \\
\hline Código: & (R.I.) - 51-0000181-00000 \\
\hline Registro: & (R.I.) REGISTRO BIC INMUEBLES: Código definitivo \\
\hline Fecha de Declaración: & $23-07-1920$ \\
\hline Fecha Boletin Declaración: & $02-08-1920$ \\
\hline Matiz: & \\
\hline
\end{tabular}

Figura 5: Ficha BIC's Ministerio de Cultura. Palacio de los Condes de Centelles. Fuente: http://www.mecd.gob.es/23.

\footnotetext{
${ }^{22}$ Ministerio de Cultura: Recuperado de: www.mecd.gob.es.

${ }^{23}$ Ministerio de Cultura: Recuperado de: www.mecd.gob.es.
} 


\begin{tabular}{|c|c|c|}
\hline \multicolumn{2}{|c|}{ FIXXA BIC's / FICHA BIC's } & 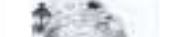 \\
\hline Código: & $48,25,181-004$ & \\
\hline Denominación: & Palacio de los Condes de Oliva & \\
\hline Municipio: & OLIVA & \\
\hline Comarca: & LA SAFOR & \\
\hline Provincia: & WALENCIA & \\
\hline Localización: & $\begin{array}{l}\text { C/ Duque de Osuna, del Palacio y Vicent Aibert. Y calle } \\
\text { Comare }\end{array}$ & \\
\hline Época: & s.XV: s.xv & \\
\hline Uso primitivo: & Residencial & \\
\hline Estilo: & Gótico-Renacimiento & \\
\hline Tipologia: & $\begin{array}{l}\text { Edificios - Edificios residenciales - Casas - Palacios } \\
\text { Edificis - Edificis residencials - Cases - Palaus }\end{array}$ & If: \\
\hline \multicolumn{3}{|l|}{ DATOS JuREDCos } \\
\hline Sección: & Primera & \\
\hline Clasificación: & Bienes inmuebles $1^{2}$ & \\
\hline Categoria: & Monumento & \\
\hline Estado: & Declaración singular & \\
\hline Anotación $\mathrm{M}^{\circ}$ : & R-1-51-0000181 & \\
\hline F. Disposición: & $23 / 7 / 1920$ & \\
\hline Pub. BOE: & $2 / 8 / 1920$ & \\
\hline Tipo delimitación: & Genérico & \\
\hline
\end{tabular}

Figura 6: Ficha BIC's Generalitat Valenciana. Palacio de los Condes de Oliva. Fuente: http://www.cult.gva.es ${ }^{24}$.

20. En segundo lugar, elaborar un documento de recopilación de información, tanto escrita como gráfica sobre el Palacio, que por una parte documente algunos de los elementos más singulares del edificio y, por otra, sirva de base para posteriores estudios o trabajos sobre el edificio.

3․ Por último, poner en valor esta joya arquitectónica, hoy perdida, permitiendo mejorar su visualización y comprensión para otros investigadores interesados en el tema y para el público en general, facilitando su difusión con fines culturales y educativos.

\section{ELECCIÓN DEL TEMA}

Cuando me planteé realizar mi tesis doctoral mantuve varias conversaciones con mi tutora, Alba Soler, con el fin de plantear un tema que pudiera ser interesante, a la vez que inédito en el campo de la Expresión Gráfica. Ella me habló de un palacio gótico-renacentista existente en Oliva, ya desaparecido, y de la abundante documentación gráfica que se había

${ }^{24}$ Consellería de Cultura de la Generalitat Valenciana. Recuperado de: www.cult.gva.es. 
recuperado recientemente, a la que había tenido acceso y que estaba disponible para su estudio. Para introducirme en el tema me facilitó una copia del artículo de Priscila E. Muller, sobre el palacio titulado "El Palau d'Oliva dels Centelles"25. Cuando acabé de leerlo ya no tuve dudas sobre la elección del tema. La historia del Palacio y el largo viaje de su documentación tenían todos los ingredientes clave para sentirme atraído por este, sin duda, fascinante tema: historia, patrimonio, documentación gráfica antigua y un trasfondo internacional, todo ello rodeado por un halo de aventura. El reto era enorme y lo he afrontado con humildad, intentando bucear entre tanta documentación, y buscando realizar una pequeña aportación personal en un tema tan vasto que ofrece, sin duda, la oportunidad de realizar numerosos trabajos de investigación con infinidad de enfoques.

\section{EL CONTEXTO DE LA INVESTIGACIÓN}

Para la ejecución del trabajo se han seguido las pautas imprescindibles a la hora de estudiar el patrimonio arquitectónico: los estudios previos.

Así, en 1972 se aprobó en Italia "La Carta del Restauro" que, en su anejo B, establecía que antes de redactar un proyecto de restauración arquitectónico previamente se debía llevar a cabo un riguroso estudio del monumento. A esta tarea se le conoce con el nombre de "estudios previos".

"La Carta del Restauro" recoge que los estudios previos deben realizarse desde distintos puntos de vista: su localización en el contexto territorial y paisajístico, los aspectos tipológicos, las apariencias y cualidades formales, y los sistemas y métodos constructivos tanto de la fábrica original, como de los posteriores añadidos y modificaciones. Asimismo, especificaba que se deberían recopilar investigaciones bibliográficas, iconográficas y archivísticas previamente, con el fin de documentar todos los datos históricos que fuera posible. Este mismo documento también indicaba que el proyecto de restauración se debía centrar no sólo en un completo levantamiento planimétrico y fotográfico, interpretado también bajo el aspecto metrológico, sino también de los trazados reguladores y de los sistemas proporcionales ${ }^{26}$.

Posteriormente, en 1998, surge también en Italia (con motivo esta vez de la reunión de un grupo de expertos italianos, franceses y españoles) el documento "Carta del levantamiento arquitectónico" ${ }^{27}$. El documento se aprobó en Nápoles un año más tarde, en abril de 1999, difundiéndose su contenido ese mismo año. En mayo de 2000 la versión española del escrito fue aprobada en Barcelona durante el VIII Congreso de Expresión Gráfica Arquitectónica EGA 2000 y, unos meses después, en el Castello de Sant'Angelo de Roma, se

\footnotetext{
${ }^{25}$ VV.AA. Esteve i Blai, A. (1997). El Palau dels Centelles d'Oliva. Recull gràfic y documental. Oliva, Valencia. L'Associació Cultural Centelles i Riu-Sec Oliva. pp. 87-144.

${ }^{26}$ Carta del Restauro 1932. Roma. Recuperado en:

htpp://ipce.mcu.es/pdfs/1972_Carta_Restauro_Roma.pdf.

${ }^{27}$ El documento se redactó a partir de las aportaciones de Cesare Cundari, Antonio Almagro, Gianni Carbonara, Stella Casiello, Secondino Coppo, Gaspare de Fiore, Mario Docci, Mario Fondelli, Tatiana Kirova, Emma Mandelli, Paola Rota, Rossi Doria, Ciro Robotti, Jean Paul Saint-Aubin, Franseco Starace.
} 
aprobó la declaración sobre el levantamiento arquitectónico "Carta del Rilievo", que sintetizaba el documento anterior.

El profesor Antonio Almagro va un paso más allá y escribe: "Precisamente en Italia, el concepto de rilievo se ha ido ampliando hasta abarcar todo lo que supone el conocimiento y la compresión global del edificio. Por ello creemos que en España deberíamos extender también el significado del término levantamiento en el sentido más amplio asumiendo lo que hasta ahora en muchos casos se ha venido en llamar 'estudios previos'", pues creemos que ese tipo de actividad tampoco tiene que ser necesariamente 'previa' a nada, sino que la investigación para el conocimiento de nuestro Patrimonio, y en nuestro caso particular de la arquitectura, debería ser actividad o disciplina autónoma y no necesariamente vinculada a la restauración. Un extenso conocimiento del patrimonio es la base indispensable para la correcta conservación que implica mucho más que la mera restauración, pues ésta debiera considerarse actividad excepcional ${ }^{\prime 28}$.

En resumen, la "Carta del levantamiento arquitectónico" recoge las premisas incluidas en la "Carta del Restauro" y renombra los "estudios previos", incluyendo el levantamiento planimétrico y fotográfico exhaustivo que recomienda la Carta italiana de 1972, y le da el nombre de "Levantamiento arquitectónico".

\section{METODOLOGÍA}

La metodología utilizada en el desarrollo del presente trabajo ha incluido las siguientes actividades:

1. En primer lugar, la búsqueda de información histórica y geográfica de Oliva y su comarca, así como otros casos de estudio coetáneos, con el fin de situar los edificios y elementos arquitectónicos estudiados en su contexto urbano, territorial, social, histórico y artístico.

2. En segundo lugar, se han registrado los datos bibliográficos, gráficos y archivísticos obtenidos sobre el edificio y demás casos analizados.

3. En tercer lugar, se ha procedido a clasificar y analizar toda la documentación gráfica digitalizada con el fin de poder conocer todos los elementos arquitectónicos y, así, proceder a su estudio y posterior representación gráfica de algunos de los elementos más característicos; centrándose este trabajo en las portadas del Palacio Condal de Oliva. Para ello, se han analizado los elementos arquitectónicos y compositivos más característicos de las mismas: basas, molduras de jambas, capiteles y tipos de arcos; así como un estudio de sus proporciones.

4. En cuarto lugar, ha abarcado también la toma de datos in situ de algunos elementos existentes tanto en el Palacio como en otros casos de estudio. Para ello, se han realizado trabajos de campo con el objetivo de captar las características dimensionales, métricas, geométricas y gráficas de estos elementos.

\footnotetext{
${ }^{28}$ Almagro Gorbea, A (2004). Levantamiento arquitectónico. Granada: Universidad de Granada. pp. 14-15.
} 
Para la adquisición de los datos se han utilizado desde sistemas tradicionales consistentes (realización de croquis, reconocimiento táctil de molduras, comprobación de dimensiones mediante elementos manuales tales como flexómetros, peine de arqueólogo, brújula, distanciómetro láser, etc.) hasta instrumentos y aparatos topográficos. Respecto a los instrumentos y aparatos topográficos empleados, estos han sido un láser escáner terrestre 3D basado en pulsos (tiempo de vuelo) y un láser invisible de clase uno de largo alcance, tipo Topcon GLS 1500 y precisión de $4 \mathrm{~mm}$, en un rango de escaneo hasta $150 \mathrm{~m}$ y angular de 6", asociado con una cámara digital integrada de 2.0 megapíxeles.
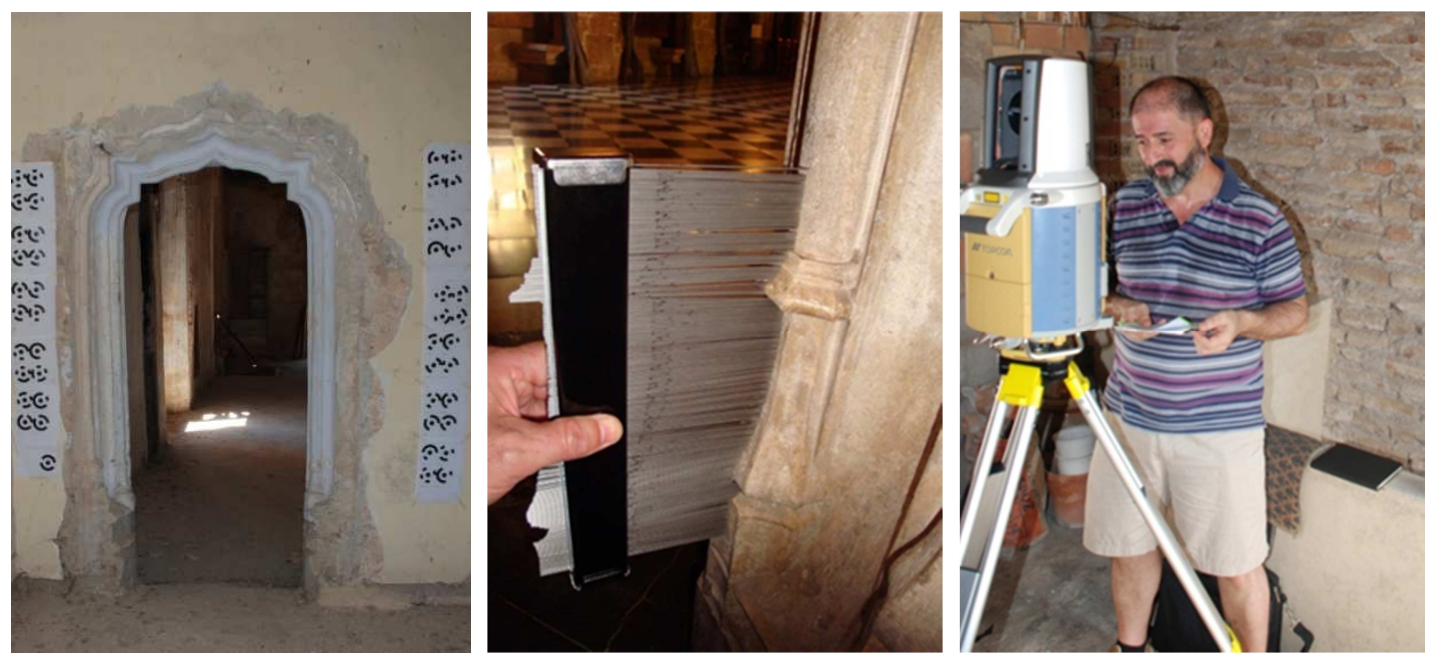

Figura 7: Distintos métodos de captura de datos: fotogrametría, plantillas manuales y escáner 3D.

La toma de datos se ha completado con una cámara fotográfica digital Nikon modelo D-80 de 10,2 megapíxeles, con un objetivo comprendido entre los 18-135 $\mathrm{mm}$ y con apertura focal de f/3.5-5.6.

Posteriormente, la información recogida mediante el escáner 3D se ha procesado y digitalizado en gabinete mediante software específicos para la gestión y el tratamiento de nubes de puntos y mallas espaciales. Se han utilizado asimismo herramientas del entorno CAD para la realización de planos; software de rectificación fotogramétrica para la rectificación de las fotografías y láminas antiguas digitalizadas; software de restitución fotogramétrica structure-frommotion para la generación de imágenes; mallas tridimensionales; herramientas de renderizado para la obtención de imágenes virtuales; y sistemas de configuración mecánica para la creación de maquetas a escala. Se ha completado el trabajo obteniendo anáglifos a partir de las fotografías antiguas digitalizadas, realizados mediante software específico.

La finalidad del trabajo ha sido obtener el mayor número posible de documentos gráficos, tales como planos (alzados, plantas y secciones en sistema diédrico), fotografías o modelos 3D, que representarán objetivamente los elementos 
arquitectónicos. A través de esta representación gráfica ha sido posible analizar las características dimensionales y compositivas en el contexto de la época en que se construyó, así como tratar de encontrar los modelos geométricos y trazas que llevaron a su construcción,

5. En quinto lugar se ha llevado a cabo una revisión continua de los resultados encontrados con la finalidad de realimentar, corregir y actualizar el trabajo desde un punto de vista crítico.

\subsection{Redacción del trabajo}

La redacción del trabajo se ha estructurado en diez partes: propuesta; antecedentes históricos; contexto arquitectónico; edificio; legado gráfico; portadas; desarrollo gráfico; conclusiones; bibliografía; y anexo gráfico.

Los capítulos sobre los antecedentes históricos, el contexto histórico y el edificio se han elaborado a través del estudio del inmueble en su contexto urbano, territorial, social, histórico y artístico a partir de datos bibliográficos, gráficos y archivísticos hallados sobre el edificio.

En el apartado dedicado al legado gráfico se clasifica y analiza la documentación gráfica levantada por los arquitectos daneses Egil Fischer y Vilhelm Lauritzen, así como otros documentos gráficos recuperados del Palacio.

En el capítulo dedicado a las portadas se clasifican, analizan y estudian las portadas documentadas por los arquitectos daneses. Se ha decidido tratarlas en un capítulo independiente dado que es uno de los ejes principales de este trabajo.

En la sección de conclusiones se recogen todos los resultados que se han alcanzado en los distintos apartados.

En el apartado de bibliografía se recopila toda la documentación bibliográfica y archivística consultada, así como una relación de los museos, bibliotecas y edificios históricos visitados para la realización de este trabajo.

En el apéndice gráfico se recopilan los distintos documentos gráficos elaborados para la redacción de este documento, los cuales se incorporan con una escala normalizada.

\subsection{Abreviaturas utilizadas}

ACCR: Associació Cultural Centelles i Riu-Sec

AFG: Álbum Fotográfico Grande

AFP: Álbum Fotográfico Pequeño

AGFDV: Archivo General y Fotográfico de la Diputación de Valencia.

AHN: Archivo Histórico Nacional

AHN. Osuna: Archivo Histórico Nacional. Sección Nobleza. Archivo de los Duques de Osuna

AHNu: Archivo Histórico de Nules

BMV: Biblioteca Municipal de Valencia 
CP Oliva: Colección Privada de Oliva

DRAE: Diccionario Real Academia Española.

HSA: Hispanic Society of America. New York. USA

IPCE: Instituto del Patrimonio Cultural de España

MAO: Museo Arqueológico de Oliva

MECD: Ministerio de Cultura Educación y Deporte

MNAD: Museo Nacional de las Artes Decorativas

MNCASGM: Museo Nacional de Cerámica y Artes Suntuarias González Martí

MPSO: Museo Parroquial de Santa María de Oliva

\subsection{Cuestiones de estilo}

La decisión del formato de esta tesis doctoral se ha establecido a partir de las normas de publicaciones que establece la Universitat Jaume ${ }^{29}$. En la portada de la tesis se han incorporado el escudo de la Universidad, el título del trabajo, el nombre de las directoras de tesis y del autor, y el mes y año de su presentación. El formato de la escritura que se presenta es de $24 \mathrm{~cm} \times 17 \mathrm{~cm}$ impreso sobre un papel de formato normalizado Din-A-4 en posición vertical.

Por su parte, la bibliografía se ha referenciado siguiendo las pautas establecidas por APA ${ }^{30}$, si bien las citaciones se han realizado mediante la inserción de las referencias numeradas en el texto para un mejor seguimiento de las mismas, detallándose a pie de cada página la fuente bibliográfica.

\section{ANTECEDENTES-ESTADO DEL ARTE}

En el presente apartado analizaremos las referencias escritas y gráficas que hemos localizado sobre el Palacio Condal de Oliva, tanto directas como indirectas, que nos han servido de referencia para comprender este complejo monumento, hoy casi desaparecido, así como para intentar encajar el mayor número posible de piezas de este inmenso puzle a través de sus referencias bibliográficas.

\section{Gaspar Escolano}

Escolano, en su Segunda parte de la década primera de la historia de la insigne, y coronada ciudad y Reyno de Valencia nos dice que los vecinos de Oliva tienen por tradición que el rey Jaume I mandó construir dos torres para defenderla, una por mar y otra por tierra, y que a una de ellas la llamó "la Torre Maestra", que quedó incorporada al Palacio que construyeron los Señores de Oliva al construirse a su alrededor. Dice que tiene trescientas casas de cristianos viejos y cuatrocientas de moriscos, con su castillo y su muro ${ }^{31}$. Esta torre que menciona Escolano era sin duda la del homenaje del Palacio de Oliva. Nos habla

\footnotetext{
${ }^{29}$ Univesitat Jaume I. Óp. cit.

${ }^{30}$ Normas APA. Recuperado de: www.normasapa.net.

31 Escolano, Gaspar (1611) Segunda parte de la década primera de la historia de la insigne, y coronada ciudad y Reyno de Valencia. Valencia: Pedro Patricio Mey. pp. 159-160.
} 
también de la familia Centelles, proveniente del Duque de Borgoña, que tomaron el nombre del castillo y Villa de Centelles cuando se asentaron en Cataluña ${ }^{32}$. Nos habla del nombramiento de Gilabert de Centelles como primer conde de Oliva por Alfonso el Magnánimo, y relaciona a todos los condes y llega hasta la unión de esta casa con la de los Borja, así como la separación del Valle de Ayora y el Señorío de Nules del Condado de Oliva.

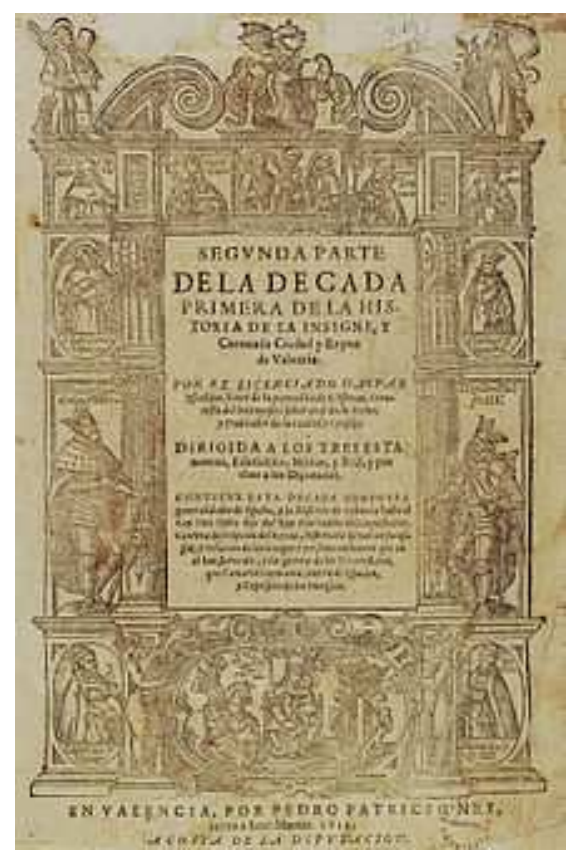

Figura 8: Portada del libro Segunda parte de la década primera de la historia de la insigne, y coronada ciudad y Reyno de Valencia. Fuente: Biblioteca Valenciana Digital.

Los historiadores Sebastián Castellanos, Llorente, González Simancas, Sarthou, Tormo y Vidal vieron el Palacio en pié. Recogemos aquí sus testimonios, ordenados cronológicamente:

\section{Basilio Sebastián Castellanos}

Sebastián Castellanos, cronista y anticuario, redacta entre 1851 y 1852 una memoria sobre las propiedades y títulos de D. Mariano Téllez Girón, Duque de Osuna, por encargo de este último. Para ello llevó a cabo dos viajes recorriendo todas las propiedades del Duque en tierras valencianas. Esta memoria descriptiva fue publicada por Luis Arciniega García en $2001^{33}$ y en ella se transcriben los textos de Sebastián Castellano, entre los que se encuentra una breve reseña histórica del condado de Oliva y una exhaustiva descripción de parte del Palacio. En ella, se detalla a su dueño tanto la singularidad del inmueble y de

32 Escolano, Gaspar Óp. Cit. pp. 166.

33 Arciniega García, L. (2001). La Memoria del ducat de Gandia i els seus títols annexos. Redactada per Basilio Sebastián per al duc d'Osuna (1851-1852). Gandia: CEIC Alfonso el Vell. pp. 216-225. 
algunos de sus elementos arquitectónicos como su estado de conservación. Su texto nos aporta información importante sobre el Palacio, ya que se trata del último testimonio antes de su venta por parte de la casa de Osuna y su posterior desmembración.

\section{Teodoro Llorente}

En 1889 escribe lo siguiente: "Desde cualquier punto que se mire á Oliva, se la ve dominada por el palacio condal, que en la parte alta de la villa se levanta, y aún parecía mayor su imperio señorial cuando se erguía en él la fuertísima torre cuadrada, en nuestros tiempos desmochada. Fueron los condes de Oliva de los señores más poderosos de este reino: su ilustre familia descendía de los duques soberanos de Borgoña, y venida á Cataluña con Carlomagno, según los cronistas de la casa, tomó el nombre del pueblo de Centelles, donde se asentó. Camarlengo del rey Don Alfonso el Magnánimo era D. Francisco Gilabert de Centelles, cuando por premio a sus servicios en las guerras de Nápoles, le dió aquel monarca título de conde en 1449, siendo Oliva la cabeza del condado. Extendíase éste por la sierra y por el llano: en la sierra tenía á Pego, famosos por sus olivares, y a Murla en sitio más agreste; en el llano á Fuente de Encarroz, uno de los mejores pueblos de la Conca, con los lugares de Potries, Hixber, Beniflá, Alquería Nueva y Rafelcofer. La familia condal de Centelles se extinguió pronto: á D. Francisco, el primer conde, sucedió su hijo D. Serafín, que logró fama de espléndido magnate, valeroso caballero y excelente literato; siguiéndole su sobrino D. Francisco, y luego el hijo de éste, D. Pedro, que murió loco y sin sucesión. Recayó entonces el condado de Oliva en una hembra, la condesa Magdalena, que casó, como ya hemos visto, con el duque de Gandía, aumentándose con ello el poderío y la riqueza de la casa Borja.

De la esplendidez y buen gusto de los Centelles dan cumplida razón los restos de su palacio de Oliva. Deleita el ánimo del amante de las artes, y a la vez lo disgusta y lo indigna, la hermosura de aquel alcázar, medio destruido y completamente devastado. Por treintamil reales lo vendió la casa Osuna, destinando esa cantidad á mejoras en la iglesia mayor. Los compradores lo partieron por el medio, abriendo una calle á través del artístico patio claustral, y demoliendo la escalera de honor que, según cuentan era magnífica, toda de piedra, con anchísimos peldaños de una sola pieza y balaustres muy bien labrados. En el interior del edificio arrancaron todo lo que tenía algún valor, con lo cual hicieron buenos negocios los mercaderes de antigüedades. Queda algo, sin embargo, que deteriorado y maltrecho como está, da a conocer la suntuosidad de aquel palacio y ofrece todavía interés artístico. Su arquitectura es ojival, con las novedades y caprichos introducidos en la última época de aquel estilo. Pero la ornamentación pertenece ya al Renacimiento, ofreciendo vivo interés para la historia del arte español. Aún se conservan en sus desmantelados salones artesonados de mucho mérito, molduras primorosamente afiligranadas, e interesante colección de azulejos en el pavimento. Pero la pieza capital, en los conceptos histórico y artístico, es el friso de un gran salón cuadrado, cuyo techo tiene también minuciosa decoración policromada del gusto del Renacimiento. En este friso, sobre fondo azul están dibujadas en blanco y negro muchísimas figuras que representan un ejército en marcha. Letreros en lengua valenciana explican los diferentes grupos de ese séquito militar comenzando por los zapadores, que van abriendo camino y nombrando los jefes con sus pajes y escolta, las diferentes armas que entonces se conocían, las piezas de artillería con su 
denominación especial, los carros de las municiones, etc. Sería interesantísima la copia exacta y publicación de esta obra de arte, que es á la vez un dato para la historia" ${ }^{34}$.

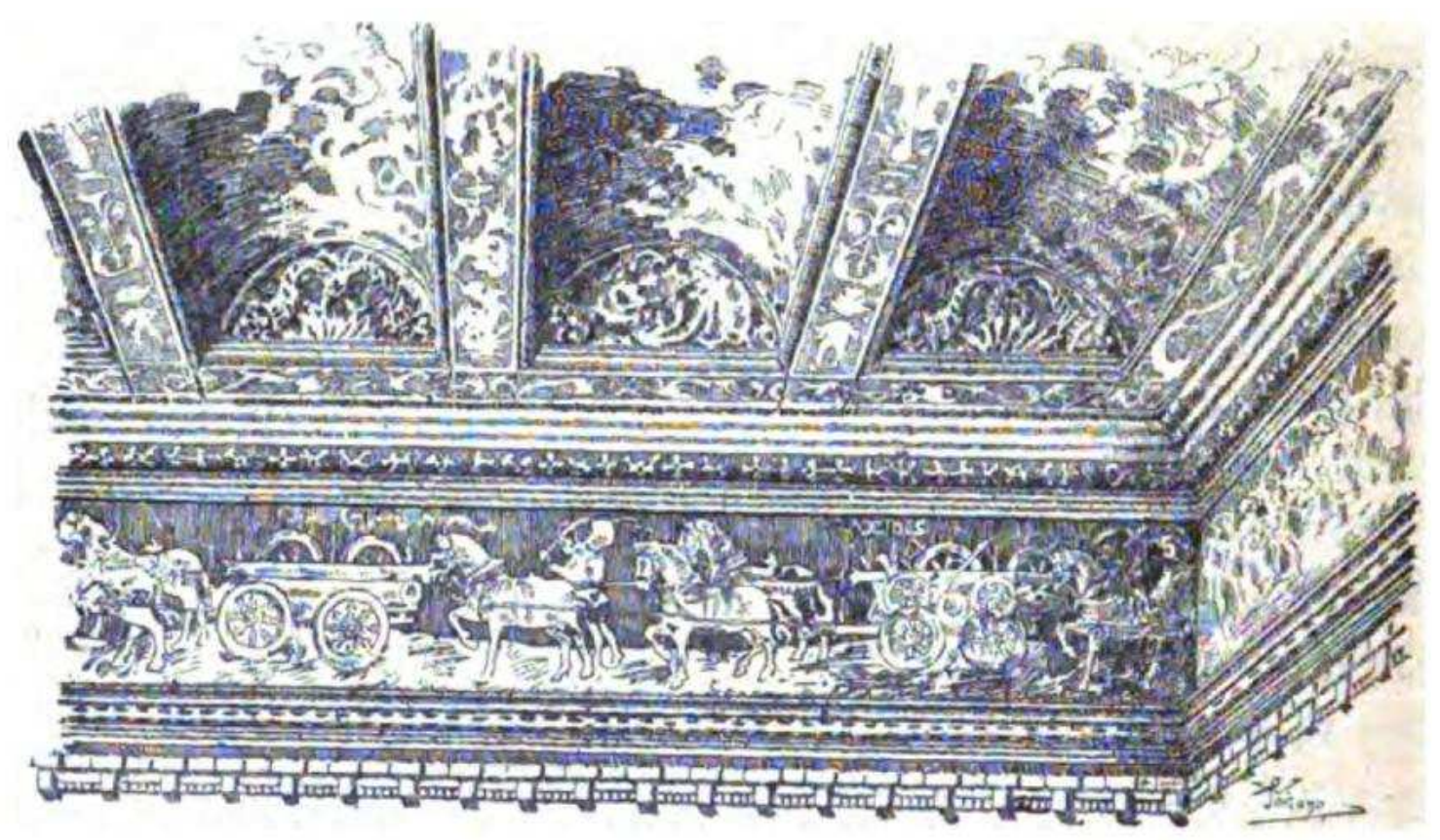

Figura 9: Grabado del Friso y forjado de la Sala de Armas de V. Soriano. Fuente: Llorente Teodoro (1889).

Este texto de Llorente fue copiado íntegramente por Fischer en el Notebook II junto con toda la referencia que hace este autor en su libro sobre la ciudad de Oliva, por lo que sabemos que el arquitecto tuvo acceso a dicha fuente bibliográfica y despertó su interés por la información histórica que aportaba sobre el Palacio y sus antiguos moradores. Esta transcripción no fue realizada por Fischer, en base a la tipografía, que es muy diferente a la suya, tal y como podemos observar en las páginas 12 y 13 de dicho cuaderno. Una hipótesis es que dicha transcripción la realizara Vicente Arnal, amigo de Fischer desde su llegada a Oliva ${ }^{35}$. Cabe destacar que el elemento que más interés causó a Llorente fue, sin duda, el friso de la sala de armas, de la cual propone realizar una copia exacta para su estudio y difusión.

\section{Manuel González Simancas}

En 1916 Simancas escribe lo siguiente: "De la villa medieval no queda nada. Se derrumbó o lo demolieron, un pequeño castillo que había en la cumbre del cerro del Calvario y cayeron las murallas que defendían la población. Ésta, formada por un apiñado caserío de calles

34 Llorente, Teodoro (1889). Valencia. Colección «España: sus monumentos y sus artes - su naturaleza é historia». Barcelona: Editorial de Daniel Cortezo y C. pp. 706-709.

${ }^{35}$ Lauritzen, V. Óp. cit. pp. 140. 
estrechas y pendientes, aparece dominada en toda su extensión por la masa imponente del palacio-fortaleza de los Condes de Oliva, levantado por Don Serafín de Centelles quien dejó la memoria de su obra mandando esculpir sus blasones en mármol blanco con la fecha de 1531 debajo y alrededor de esta inscripción latina: "Ardva cum celsishaec propvgnacvlamuris -Infra annvm comes extrv - xit Seraphinvs ab imo."

Aquel grandioso edificio, vendido en el siglo pasado por la casa de Osuna sucesora de los Centelles, perdió primero la robusta torre del homenaje, y luego los nuevos poseedores siguieron la obra de destrucción abriendo una calle que cortó el patio central; demolieron la escalera de honor; y por último, fueron arrancando en las habitaciones cuanto les pareció de algún valor artístico para venderlo malvendido, por unas cuantas pesetas a los negociantes de antigüedades que allí acudieron como los buitres a carne muerta.

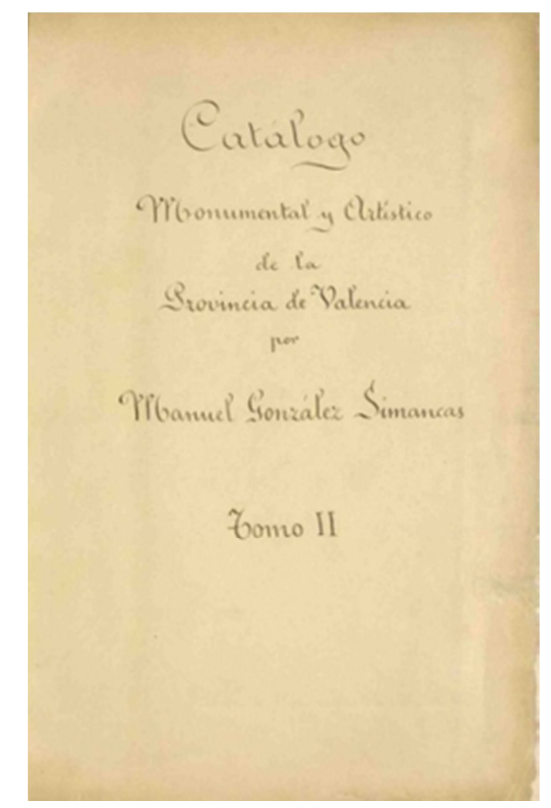

Figura 10. Primera página del manuscrito. Catálogo monumental y artístico de la provincia de Valencia. Tomo II. Fuente: IPCE

Cuando visitamos las construcciones que la piqueta había dejado en pie, aún pudimos ver algunos artesonados de apreciable labor, y entre ellos uno, el del salón principal, de subido valor artístico por las pinturas que lo decoran, o mejor dicho, lo decoraban, pues ignoramos si después de nuestra visita se llegó a destruir. El techo estaba formado por vigas, y, a semejanza de otros que se han conservado en la Aljafería de Zaragoza, tenían las maderas y bovedillas ornamentadas con bella flora y caprichosos adornos policromados del estilo del Renacimiento italiano. Todo el friso estaba colorido de azul y sobre el fondo aparecían dibujadas a blanco y negro las figuras de soldados, caballos y carros de guerra figurando una columna en marcha. Debajo corría esta inscripción: "Açó es exer. --Açó es los cascadors per fer camí. --Gentdarmes. --Gentdarmes. --Capitans de la vanguardia. --Patges. -- Açó les piques. -- Açó les banderes de la gent de peu. --Alabardes. --Espingardes. -- Açó son ballestes. --Los carruatges. -- Açó es falconet. -- Açó la artillería. -- Açó el canó gros de bombardes. -- Açó es munició de scales é rodes pera la guerra. -- Açó es munició de pólvora é de pedres". Estas letras en valenciano parecen indicar el origen del artista que nos dejó 
en su obra un documento de valor histórico útil para el conocimiento de la indumentaria del ejército español a mediados de la décima sexta centuria" ${ }^{136}$.

El texto de Simancas nos aporta varias novedades respecto al de Llorente: la primera de ellas es la referencia a la gran torre del homenaje ya desaparecida; otra es la placa conmemorativa de su construcción fechada en 1531, siendo conde Serafín de Centelles. Al igual que le sucedió a Llorente, el elemento que más impresionó a este historiador fue sin duda la Sala de Armas a la que denominó "salón principal", haciendo una comparación de su forjado de vigas y bovedillas decoradas con los de la Aljafería de Zaragoza (ver Fig. 11) y transcribe, al igual que el primero, los textos en valenciano que hacen referencia al ejército en marcha representado en el friso.

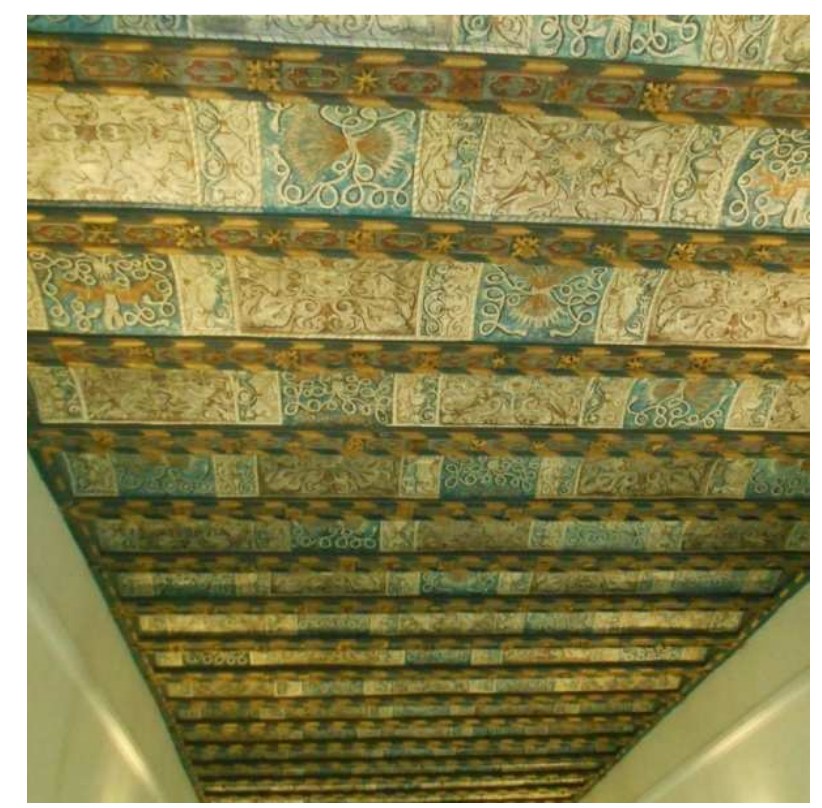

Figura 11: Forjado de revoltones decorado. Aljafería. Zaragoza.

\section{Carlos Sarthou Carrreres}

En 1920, en su Geografía General del Reino de Valencia, Sarthou realiza una descripción del Palacio tal y como lo encontró. Nos habla de cómo este Palacio rivalizó en su día con el de los Borgia en Gandía, siendo símbolo de poder y buen gusto de la familia Centelles. Comenta también cómo destacaba del conjunto su torre del homenaje, ya desmochada por entonces y la singularidad de su estilo gótico de "arquitectura ojival" que incorporaba elementos decorativos renacentistas. Nos habla de su venta por parte de la familia Osuna por 1.500 duros dedicados a reparar la iglesia parroquial y cómo a partir de este momento se inicia su lenta destrucción por parte de sus nuevos dueños que comienza con la

\footnotetext{
${ }^{36}$ González Simancas, M. (1916). Catálogo monumental y artístico de la provincia de Valencia. Tomo /I [Manuscrito]. Madrid. pp. 34-36.
} 
demolición de la escalera de honor "construida de ricos mármoles y caladas balaustradas" para abrir una calle en medio del patio de armas $^{37}$.

Según Sarthou, el uso de los salones principales del Palacio por parte de una sociedad cooperativa católica fundada por P. Vicent ayudó a detener su ruina. Nos describe cómo uno de estos salones tiene un artesonado con ricas bovedillas policromadas y que bajo el mismo se representa un ejército en marcha pintado en tintas blanca y negra sobre fondo azul, y textos en lengua valenciana que explican las figuras representadas. Esta descripción corresponde, sin lugar a dudas, a la Sala de Armas. Nos relata también cómo el Palacio fue vendido a finales del siglo XIX a un anticuario que lo despojó de elementos artísticos tales como cuadros, puertas y azulejos, y cómo a su vez este lo vendió a un señor extranjero; sin duda, al arquitecto danés E. Fischer. Prosigue su relato explicando cómo Fisher fue derribando algunos de sus elementos (galerías, artesonados, frisos, puestas, zócalos, etc.) para enviarlos a su país de origen frente a la indiferencia de las distintas administraciones competentes de la época. Del mismo modo, describe cómo desde lo alto del "desmochado" torreón del homenaje, se podía contemplar la falta de techumbre de algunas salas y cómo otras disponían de una techumbre provisional que cubría salas convertidas en almacenes donde se guardaban muchos de los materiales embalados, listos para ser exportados y "exhibirse donde se aprecia mejor el valor de estas cosas". Sarthou vaticinaba cómo todos los elementos singulares del Palacio sólo podrían ser vistos por las generaciones futuras gracias a las fotografías que acompañaban el libro o viajando fuera de España.

En su texto hace una dura crítica a las labores de desmantelamiento llevadas a cabo por Fischer. Ambos coincidieron cronológicamente en el Palacio, aunque no sabemos si se llegaron a conocer personalmente. Sin embargo, sí queda constatado que compartieron su interés por el inmueble.

En su publicación aparecen un total de diez fotografías del Palacio más una vista general de Oliva desde el este, donde se puede ver la parte exterior del Palacio. De las diez imágenes, cinco corresponden a portadas o parte de portadas interiores, dos a la galería de la planta principal del patio, una al artesonado del "gran salón de las Batallas", otra a una bovedilla decorada y la última al arranque de las nervaduras de una bóveda de crucería con molduras renacentistas. Los clichés están referenciados como pertenecientes a V. Arnal y C. Sarthou. Estas fotografías, salvo la vista general de Oliva (pág. 429 del libro), la vista frontal del lado largo de la galería y la parte superior de la portada 20 (anexo fotográfico), son las mismas que las del archivo de E. Fischer, lo que abre una duda razonable sobre quién las tomó y a quién pertenecían.

A raíz de este hallazgo documental se buscó en el archivo fotográfico de la Diputación de Valencia donde hemos encontrado una serie de fotografías antiguas atribuidas a Carlos Sarthou. En otro apartado analizaremos estos documentos gráficos.

\footnotetext{
${ }^{37}$ Sarthou y Carreres, C. (1920). Geografía General del Reino de Valencia. Provincia de Valencia. Tomo II. Barcelona: Editorial de Alberto Martín .pp. 428-436.
} 


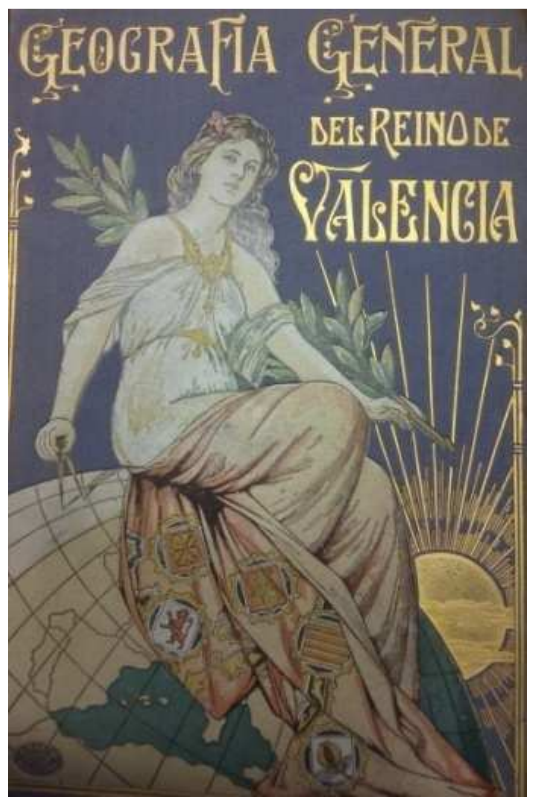

Figura 12: Portada de Geografía General del Reino de Valencia.

\section{Elías Tormo}

Tormo escribió lo siguiente en 1923: "Oliva. A 300 m. de la c., de 9.700 habs., cabeza del condado que tuvieron los Centellas, rivales de los Borjas de Gandía, hasta que se unieron las dos casas (s. XVI). En lo más alto, el que fue muy notable palacio condal, ojival y con notas del Renacimiento, con detalles decorativos en relieve y pintados de muy notable interés, del que se ha ido arrancando y vendiendo (para Dinamarca) todo lo vendible. Subsisten las galerías del patio." ${ }^{38}$

En este breve testimonio Tormo nos confirma que las arcadas del patio central no fueron desmontadas por Fischer, aunque sí fueron dibujadas y numeradas por los arquitectos daneses, sin duda con este propósito.

\section{José Ma Vidal}

Vidal escribe en 1932 un artículo en el número XI del Semanario científico, literario y de información agrícola "Patria Chica" ${ }^{139}$ en el que informa que, en la noche del 19 de enero de 1932, se derrumbaron, a causa de las lluvias los pisos principal y segundo del ala oeste del palacio, habiéndose informado a la administración por tratarse de un monumento arquitectónico y siendo visitado el edificio por el arquitecto de la Diputación provincial D. Luis Albert junto con otros técnicos. Aunque a la fecha de este artículo no se había emitido el informe técnico definitivo, todo apuntaba a que este recomendaría la demolición de las

${ }^{38}$ Tormo, E (1923) España. Levante. Guías Calpe. Madrid: Calpe. pp. 235.

39 Vidal, J.M. (1932) "El Palacio de los Condes de Oliva". Semanario científico, literario y de información agrícola Patria Chica № 11. 
partes que amenazaran ruina dada la imposibilidad de su restauración. En el artículo, además, hacía una crítica a las labores de desmantelamiento y mercadeo del Palacio por parte de sus antiguos dueños y a la falta de interés por la conservación del patrimonio artístico y cultural en ésta época. Asimismo, documenta que el origen del Palacio pudo ser la "Torre Maestral" o "Torre del Homenaje", una imponente torre con una altura de 120 palmos ( $27,6 \mathrm{~m}$.) situada en los solares de las casas número 18 y 20 de la calle Palacio y 10 , 12 y 14 de la calle de las Torres. Esta torre fue derruida en 1882 para abrir la calle Palacio. De acuerdo con el documento, en esta fecha se conservaban en el Palacio, aunque fuera de su emplazamiento original, las dos placas de mármol fechadas en 1545 y 1546 ya citadas por otros autores y que hacen referencia a la fortificación en tiempos de Francesc de Centelles, III Conde de Oliva. Asimismo, el documento relata el interés artístico del Palacio por su estilo de transición entre el gótico y el renacimiento. Otro dato interesante que nos aporta es el nombre de algunas de sus salas, recogidos de algunos documentos históricos: "el Conde Don Pedro hace entrega de su testamento junt a la finestra de la Sala centellada del palau e Castell de Oliva'; Don Francisco recibe al Síndico del Concejo en la 'sala Serafina'; Doña Magdalena se despide de los Jurados y Mustafá en el 'pasadis de $\mathrm{Na}$ Hipólita a partir para un viaje'". No podemos identificar con precisión los nombres de estas salas a partir de las documentadas por Fisher y Lauritzen, si bien la Sala centellada podría ser la Sala de Armas por todas las referencias iconográficas que existen sobre el linaje de los Centelles.

El autor hace referencia, asimismo, al friso de la Sala de armas por tratarse del elemento de mayor relevancia artística.

\section{Egil Fischer}

La documentación que nos aporta Fisher es, sin duda, uno de los dos pilares sobre el que se sustenta este trabajo: el Notebook I, el Notebook II, el Álbum Fotográfico Grande, el Álbum Fotográfico Pequeño y algunos de los planos para el proyecto del Museo Español en Dinamarca $^{40}$, actualmente depositados en el MAO, junto con otros documentos gráficos originales localizados en la Danmarks Kunstbibliotek (Biblioteca Nacional Danesa del Arte), en Copenhague. Se trata, por tanto, de documentación gráfica en su mayoría, pero de un incalculable valor ya que nos permite visualizar gran parte del Palacio tal y como se encontraba a principios del siglo $X X$, y son el punto de partida de este trabajo de investigación. Los textos escritos son escuetos y se limitan a breves anotaciones en los cuadernos de notas y pies de imágenes en los álbumes fotográficos, así como a la rotulación de los planos. Sólo algunos textos se han podido transcribir y traducir.

\footnotetext{
${ }^{40}$ Fischer, E. y Lauritzen V. (1917-1920). Planos. Oliva, Valencia: Museo Municipal de Oliva, Archivo Público Documental, Palacio Condal. y Fischer, E. (1917-1920). Notebook I., Notebook II, Álbum Fotos Grande y Álbum de Fotos Pequeño. Oliva, Valencia: Museo Municipal de Oliva, Archivo Público Documental, Palacio Condal.
} 


\section{Vilhelm Lauritzen}

En cuanto a la documentación aportada por Lauritzen contamos con los planos del Palacio elaborados por encargo de Fischer. Sólo uno de ellos (de planta) aparece firmado por Fischer, por lo que sería necesario un estudio grafológico de los breves textos escritos para determinar la autoría de dichas láminas. Independientemente de quién delineara dichos planos, y sin entrar en cuestiones sobre la propiedad intelectual de los mismos, no cabe la menor duda de que ambos arquitectos fueron coautores de dicho trabajo, ya que Fischer fue quien encargó y dirigió el proyecto y Lauritzen quien, casi con toda certeza, lo elaboró. Sin embargo, Muller, en su Catálogo ${ }^{41}$, atribuye la autoría de la mayoría de láminas originales (salvo las plantas) a Lauritzen, y en el caso de las copias en papel calco deja abierta la autoría a Fischer y/o Lauritzen.

De Lauritzen contamos además con un documento escrito fechado en $1979^{42}$ e incluido como anexo en el artículo de Muller ${ }^{43}$ en el que aporta información muy valiosa sobre la llegada del equipo danés a Oliva.

\section{Alejandro Ferrant}

Arquitecto conservador de monumentos de la 4a Zona del Ministerio de Educación, Ferrant redacta en 1946 el Proyecto de Obras de Conservación de Elementos Decorativos Pertenecientes al Palacio de los Condes de Oliva (Valencia), que se encuentra actualmente en el archivo del IPCE en Madrid. Este breve proyecto consta de una memoria, un presupuesto y un plano de planta de los restos del Palacio en esa época. El objeto del proyecto consistía en la sustitución de la cubierta de la Sala de Armas debido al mal estado de la misma y a la extracción de los elementos decorativos en yeso que quedaban en ella para trasladarlos a algún museo valenciano ${ }^{44}$. Este breve documento aporta una información valiosísima para poder determinar el estado de los restos del Palacio en sus últimos días y verificar las dimensiones de la Sala de Armas y las salas limítrofes.

\section{Priscila E. Muller}

Si tenemos que destacar un investigador entre todos los que han estudiado el Palacio condal de Oliva, esta figura es sin duda la investigadora norteamericana del HSA Priscilla E. Muller, cuyo interés por el Palacio y su meticuloso trabajo de investigación han sido claves para redescubrir esta joya arquitectónica del tardogótico y primer renacimiento en el antiguo Reino de Valencia. Su primer contacto, tal y como ella misma relata en su artículo

\footnotetext{
${ }^{41}$ Gavara Prior, J. y E. Muller, P. (2013). El Palacio Condal de Oliva. Catálogo de los planos de Egil Fischer y Vilhelm Lauritzen. Oliva, Valencia: Ajuntament de Oliva. pp. 65-179.

42 Lauritzen, V (1979). Relación sobre el Palacio. Documentación Palacio de Oliva. FA68 y FA69. Søborg, Dinamarca: Archivo DKS.

43 E. Muller, P. (1996) "El Palacio de Oliva de los Centelles" Architectura 18: Arkitekturhistoriskårsskrift 18.

${ }^{44}$ Ferrant, A. (1946). Proyecto de Obras de Conservación de elementos Decorativos Pertenecientes al Palacio de los Condes de Oliva (Valencia). Archivo IPCE. Madrid.
} 
sobre el Palacio ${ }^{45}$, se produce cuando viaja a Londres para examinar dos secciones del friso y otras piezas que habían salido a subasta. A partir de este momento se produce una intensa relación que la lleva a visitar Dinamarca y España para profundizar en el conocimiento del inmueble y su historia.

Así, su primer trabajo de investigación sobre el Palacio es el artículo publicado en la revista danesa Arkitekturhistorisk Årsskrift 18, en 1996. En la introducción de este artículo Muller ofrece una visión completa sobre su acercamiento al Palacio, así como sobre su localización, antiguos moradores y el papel determinante que jugaron en su historia los arquitectos daneses Fischer y Lauritzen. El objeto principal del artículo es la descripción y catalogación de la Sala de Armas a través de la documentación gráfica elaborada por los arquitectos daneses y de una rigurosa investigación histórica que sitúa dicha sala en su contexto artístico e iconográfico. En su artículo la autora realiza un minucioso análisis de la sala comenzando por su identificación y localización en el Palacio, sus proporciones y el estudio de cada uno de los elementos arquitectónicos que la componen: portadas, ventanas y, sobre todo, el friso, por ser el elemento más singular del cual conserva dos de sus secciones la institución para la que trabajaba la investigadora: el HSA. El trabajo incluye un breve epílogo donde hace referencia al proyecto de Fischer para la construcción del Museo Español de Dinamarca. Además del texto principal, las 63 notas aclaratorias nos aportan una información de valor incalculable tanto del estudio de las piezas originales conservadas en el HSA como de sus investigaciones en Dinamarca, y sus conversaciones con el arquitecto Vilhelm Lauritzen. Este mismo artículo, traducido al castellano, fue incluido como capítulo en el libro El Palau dels Centelles d'Oliva. Recull gràfic y documental, publicado por L'Associació Cultural Centelles i Riu-Sec en $1997^{46}$.

En 1999 Muller publica otro artículo, esta vez en la revista de investigación Capdells, promovida por la Asociación Centelles y Rui-Sec, titulado A la recerca del Palau. En este escrito la investigadora detalla pormenorizadamente todo el proceso de investigación sobre el Palacio desde su primer contacto en 1980 cuando llega a su despacho del Museo de la HSA el catálogo de una subasta de Christie's de Londres, hasta que la HSA reúne todo el legado de los arquitectos daneses sobre el Palacio y la publicación de sus trabajos ${ }^{47}$. Resulta interesante la trazabilidad que realiza de esta labor de investigación y cómo la complementa con un profundo estudio histórico para situar el Palacio en su contexto histórico y artístico.

En 2013 sale a la luz el libro El Palacio Condal de Oliva. Catálogo de los planos de Egil Fischer y Vilhelm Lauritzen, editado por la Diputación de Valencia y que se había elaborado unos años antes. Esta publicación, cuya autoría comparte con el historiador Joan Gavara, tiene dos aportaciones: por un lado, el capítulo El Palacio de los Centelles de Oliva: Contexto y Contextos y el Catálogo. En la introducción de este capítulo Muller trata de datar la construcción del Palacio tanto a partir de los datos históricos disponibles, de las

45 E. Muller, P. (1996) "El Palacio de Oliva de los Centelles" Architectura 18: Arkitekturhistorisk Årsskrift 18.

${ }^{46}$ E. Muller, P. (1997). El Palau d'Oliva dels Centelles. En A. Esteve i Blai, Antoni (Ed.). El Palau dels Centelles d'Oliva. Recull gràfic y documental. Oliva (pp. 87-138) Oliva, España: L'Associació Cultural Centelles i Riu-Sec Oliva.

${ }^{47}$ E. Muller, Priscilla. (1999) A la recerca del Palau. Cabdells: revista d'investigació de l'Associació Cultural Centelles i Riu-Sec, Núm 1. pp. 21-28. 
características estilísticas de sus materiales y tipologías constructivas (azulejos, ventanas, etc.), así como por las monedas encontradas por Fischer durante sus trabajos de desmontaje. A partir de toda esta información llega a la conclusión de que hay constancia de que en tiempos de Gilabert de Centelles i de Castellet (\$1368) y de Gilabert de Centelles y Rui-Sec (†1409) ya existía un Castillo en Oliva y su transformación en Palacio se llevó a cabo durante el señorío de sus descendientes, Bernat de Centelles Riu-Sec i de Cabrera $(+1433$ ?) y de Francesc Gilabert de Centelles y Rui-Sec i de Queralt, primer conde de Oliva (†1480?). Los principales trabajos de construcción y renovación del Palacio, ya en tiempos de Serafín de Centelles i Riu-Sec (146..?-1536?) los data ente 1511 y 1515. Posteriormente, tras la ocupación del inmueble, durante las revueltas de Germanías, este volvería a recuperar su integridad entre 1445-46, en tiempos de su sobrino Francesc Gilabert de Centelles i Riu-Sec (1499-1550?), gracias a las labores llevadas a cabo por ambos para fortalecer y embellecer los muros y torres de este Castillo-Palacio.
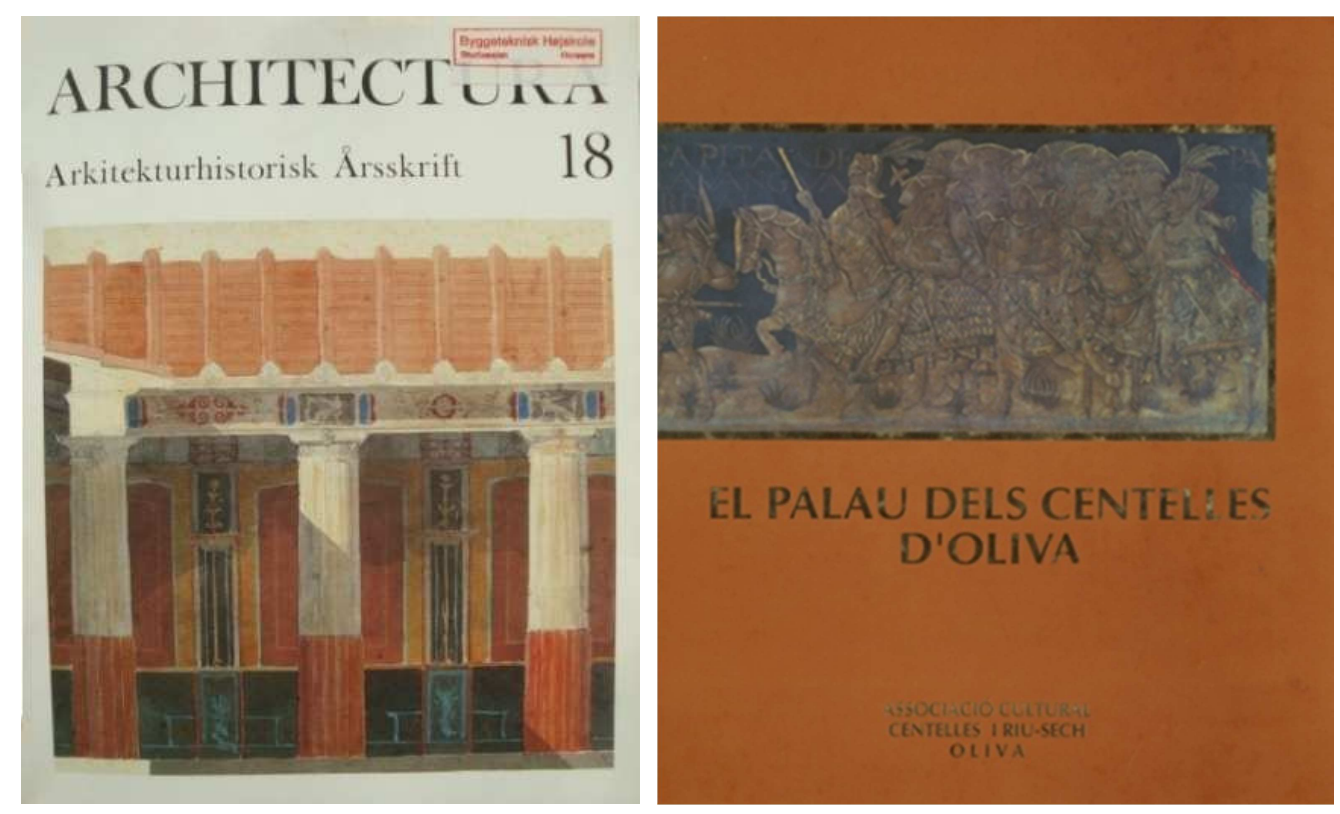

Figura 13: Izquierda: portada del no 18 de la revista Architectura. Arkitekturhistorisk Årsskrift 18. Derecha: Portada de El Palau dels Centelles d'Oliva.

Muller, en su capítulo Contexto y Contextos, se centra en el contenido de las dos grandes áreas del Palacio documentadas por Fischer y Lauritzen, "la Casa de Miguel" y la "Casa de Sanchis", que corresponden a la zona de menos interés de la planta noble. También presta atención a las estancias 11 a 20 de dicha planta noble, donde se encuentran los elementos arquitectónicos más interesantes. Además, dedica un apartado a la descripción y estudio de los pórticos y ventanas más singulares de estas salas, centrándose en aquellas portadas con decoración renacentista, y a la descripción de la Capilla, Gabinete y Vestíbulo, describiendo tanto sus portadas tardogóticas como sus techos abovedados con rica decoración renacentista. El último apartado de este texto lo dedica a la Sala de Armas, centrándose en su decoración pictórica, tanto de su forjado de vigas y revoltones policromados como en el 
friso pintado al fresco que rodea toda la sala y que es el objeto principal de sus estudios ${ }^{48}$ como conservadora de la HSA. Al igual que en el resto de textos de Muller, sus notas bibliográficas nos aportan una valiosísima información añadida y nos muestran el rigor de su trabajo.

Por otra parte, en el Catálogo, firmado también por Muller, se recoge una amplia selección de las láminas elaboradas por Fischer y Lauritzen en las que aparecen los siguientes elementos: plantas del palacio, forjados y artesonados, bóvedas, la galería del Patio, la logia sobre la Sala de Armas, portadas, ventanas y algunos detalles arquitectónicos. En dicho catálogo se enumera el elemento, se atribuye la autoría a uno de los dos arquitectos o se deja abierta la autoría, de detallan las dimensiones y material del soporte y la técnica gráfica utilizada, y se traducen al castellano las breves inscripciones en danés que aparecen rotuladas sobre la lámina, así como la numeración de la misma.

\section{Vicent Felip Sempere}

Sempere publica en 2000 Recull per a una historia de Nules. Una parte de esta publicación es el capítulo titulado "Notas sobre los Centelles en el Reino de Valencia y el inventario de su palacio en Oliva". Este texto, tal y como su título indica, incluye dos partes diferenciadas: la primera se trata de una reseña histórica de cada uno de los miembros de la familia Centelles, desde Gilabert de Centelles i Bellpuig, primer Centelles que llega a tierras valencianas desde Cataluña, en torno a 1308, hasta Pedro de Centelles i Cardona (15371569), así como los litigios por su sucesión que llevaron a unir las casas Borja y Centelles, y a separar definitivamente la Baronía de Nules del Condado de Oliva ${ }^{49}$. Esta reseña se ha referenciado meticulosamente con publicaciones históricas previas y con múltiples documentos del AHN. Osuna; en la segunda parte se cometa y transcribe un documento existente en el AHNu. Se trata del inventario del Palacio de Oliva realizado tras la muerte de Francesc Gilabert de Centelles en 1522, encargado por su viuda, María de Cardona, tutora de su hijo Pedro de Centelles.

El documento es de gran interés ya que en él se mencionan e identifican muchos de los espacios y salas del Palacio, así como su uso y contenido, aportándonos una información muy valiosa para poder entender cómo era y el uso que tenía en una época donde se le daba plena funcionalidad por residir en él los Condes de Oliva, años en los que ya se habían completado prácticamente sus obras de embellecimiento y fortificación.

\footnotetext{
${ }^{48}$ Gavara Prior, J. y E. Muller, P. (2013). El Palacio Condal de Oliva. Catálogo de los planos de Egil Fischer y Vilhelm Lauritzen. Oliva, Valencia: Ajuntament de Oliva. pp.31-64.

${ }^{49}$ Felip Sempere, V. (2001). Recull per a una historia de Nules (Barcelona. 1977 - Nules 2000) Vol. II. Nules: Caixa Rural de Sant Josep de Nules. pp. 301-368.
} 


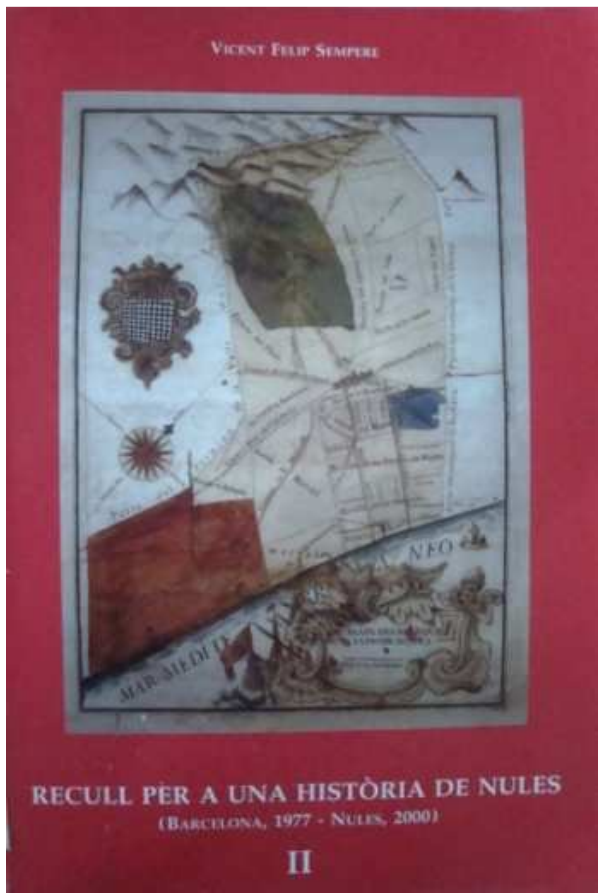

Figura 14: Portada del libro Recull per a una història de Nules II.

\section{Joan J. Gavara Prior}

Gavara es coautor, junto con Priscila E. Muller, de El Palacio condal de Oliva. Catálogo de los planos de Egil Fischer y Vilhelm Lauritzen. En el capítulo desarrollado por Gavara, titulado "El nuevo léxico ‘a la romana' del Palacio Condal de Oliva y sus posibles artífices" el investigador trata de situar el lenguaje renacentista del Palacio en el contexto de otros edificios valencianos emblemáticos de la época que, como éste, han desaparecido en nuestro días como son la capilla de la Generalitat (1514), la capilla de la Casa de la Ciudad (1517) y el palacio del Embajador Vich (1528). En el texto nos habla de la figura de Serafín de Centelles en sus múltiples facetas: militar, política, cortesana y humanista. Como se sabe, bajo su señorío el Palacio de Oliva sufre su gran transformación, adoptando el nuevo estilo "a la romana" que proviene de Italia y que durante un tiempo convive con el último gótico valenciano que incorpora estas nuevas formas decorativas ${ }^{50}$.

${ }^{50}$ Gavara Prior, J. y E. Muller, P. (2013). El Palacio Condal de Oliva. Catálogo de los planos de Egil Fischer y Vilhelm Lauritzen. Oliva, Valencia: Ajuntament de Oliva. pp. 19-29. 


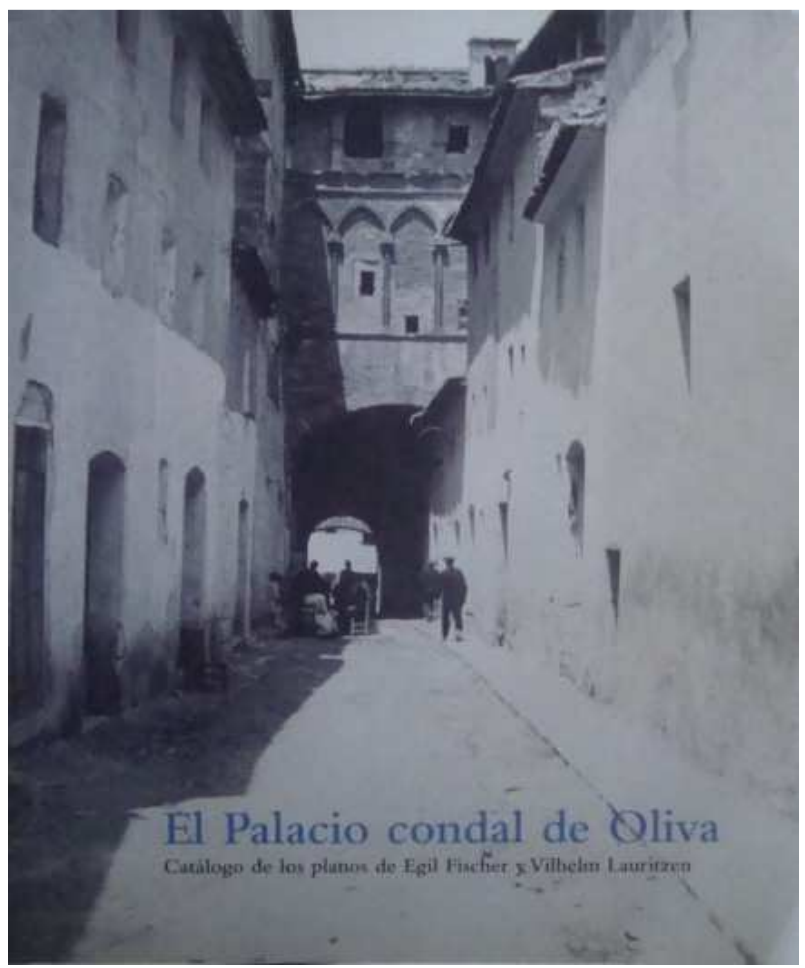

Figura 15: Portada del libro El Palacio Condal de Oliva.

\section{Joaquín Berchez}

Berchez, en su obra Arquitectura Renacentista Valenciana (1500-1570), hace especial referencia al palacio en su primer capítulo, titulado "El encuentro con el lenguaje renacentista" ${ }^{\prime 51}$. Este autor pone el Palacio de Oliva como uno de los referentes en la introducción del nuevo estilo "a la romana", dentro del panorama valenciano durante el primer tercio del siglo XVI, donde se introduce este nuevo lenguaje formal promovido por el segundo conde de Oliva, Serafín de Centelles, quien fue mecenas de artistas y escritores y tuvo un gran interés por el humanismo y gusto por la antigüedad.

De este modo, a través de las fotografías antiguas y los restos conservados, realiza un recorrido estilístico de algunos de sus elementos, describiendo la decoración renacentista como las portadas y forjados, y hace especial mención a la armadura de la Sala de Armas y a la galería del Patio con su galería de columnas de orden compuesto, sus arcos apuntados y su entablamento tripartito donde se entrelazan a la perfección el nuevo gusto por lo clásico con la tradición gótica autóctona.

\footnotetext{
${ }^{51}$ Berchez Gómez, J. y Jarque, F. (1994). Arquitectura Renacentista Valenciana (1500-1570). Valencia: Bancaixa Obra Social. pp. 28-62.
} 


\section{Arturo Zaragozá}

Zaragozá hace referencia a las portadas del Palacio de Oliva en su publicación sobre el gótico valenciano ${ }^{52}$. Esta tipología de portadas que denomina de "cortina o de pabellón" normalmente están enmarcadas por un "guardapolvos dispuesto a modo de alfiz" y en su parte superior por un arco mixtilíneo formado por varias curvas y contracurvas. Según Zaragozá la primera portada de estas características de la que tenemos noticias documentales es la antigua biblioteca de la Catedral de Valencia, cuya decoración en alabastro realiza el escultor Johan de Kassel en 1497. Nos documenta cómo este tipo de portadas fue utilizado tanto en edificios religiosos como en edificios públicos civiles y nos relaciona algunos de ellos (iglesia del Convento de Dominicos de Llombay, iglesia de la Sangre de Cristo de Benigánim, monasterio de San Jerónimo de Cotalba, palacio de la Generalitat y Lonja de Valencia, aunque tuvieron mayor presencia en las casas señoriales, como en los castillos-palacios de Argelita, Benissanó, Sot de Ferrer, Onteniente, Oliva, o el de los Escrivá en Valencia. Zaragozá, además, establece paralelismos entre estas portadas y las realizadas en otros puntos de Europa: las portadas del Hospital Real de Santiago de Compostela (obra de Enrique Egas), las portadas manuelinas de Olivenza, o las ventanas/cortinas del castillo-palacio de Meissen en Sajonia.
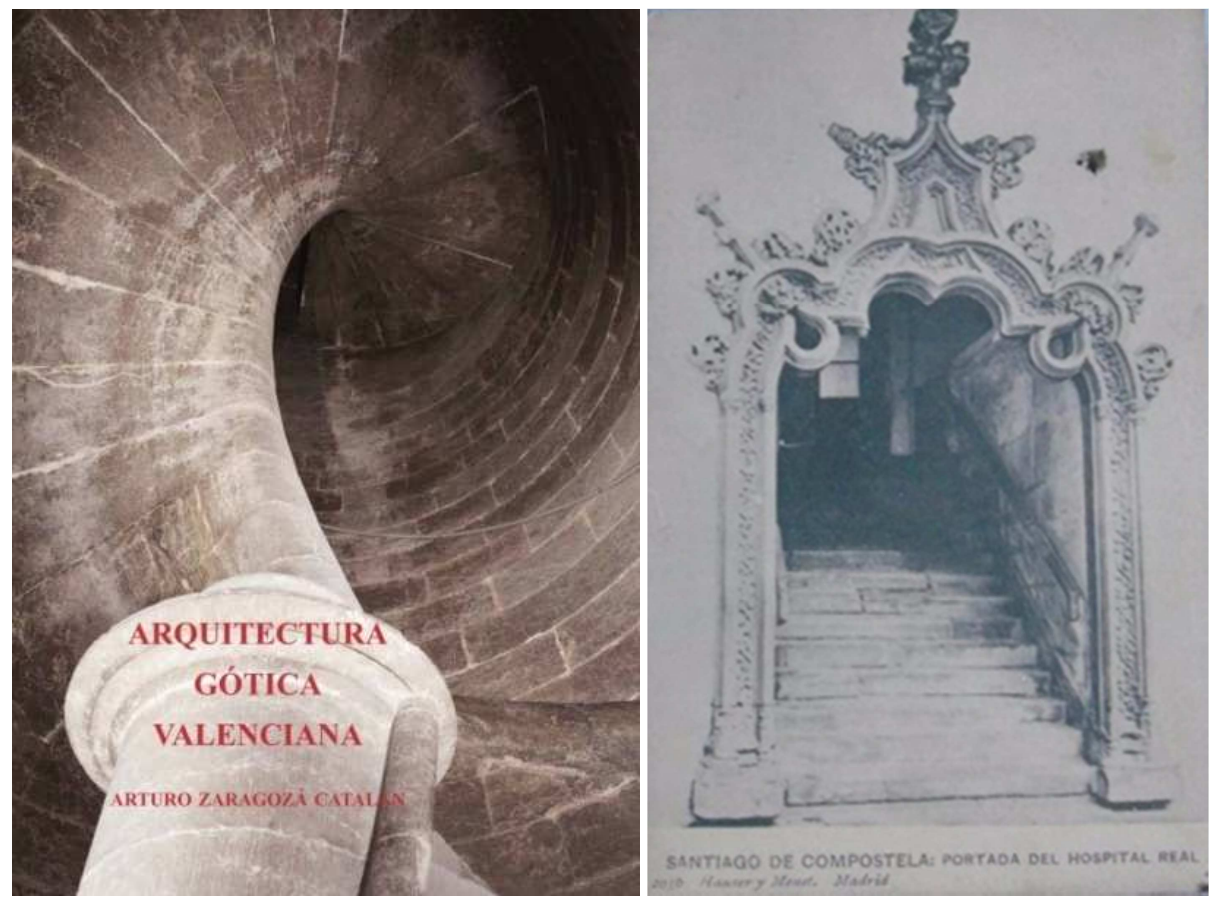

Figura 16. Izquierda: Portada libro Arquitectura Gótica Valenciana, Derecha: Portada del Hospital Real de Santiago de Compostela. Fuente: Hansen y Menet

\footnotetext{
52 Zaragozá Catalán, A. (2000). Arquitectura Gótica Valenciana. Siglos XIII-XV. Valencia: Generalitat Valenciana. Conselleria de Cultura i Educació. pp. 166-188.
} 


\section{Luis Arciniega}

Arciniega en su obra, además de analizar y profundizar en los textos de Sebastián Castellanos, documenta, a través de su investigación en los archivos de la casa de Osuna, algunas intervenciones de obras de menor calado llevadas a cabo en el Palacio desde principios del siglo XVII, lo que evidencia que quedó relegado a un segundo plano tras la incorporación del condado de Oliva al Ducado de Gandía, lo que paradójicamente hizo que se conservaran sus elementos originales ${ }^{53}$.

\section{AGRADECIMIENTOS}

Mi gratitud y reconocimiento a todas las personas que, directa o indirectamente, me han ayudado, me han inspirado y me han motivado a seguir adelante y llevar a término este trabajo.

\section{A mis directoras:}

- A Alba Soler, por haberme descubierto este fascinante palacio y transmitido su pasión por el tema, así como por su constante motivación y asesoramiento.

- A Ma Jesús Máñez, mi eterna compañera a lo largo de mi vida universitaria. Por haberme motivado, aconsejado y ayudado en esta tarea.

\section{A mis compañeros:}

- A Cristina Fabuel, Estela López, Cristian Ferrer y, especialmente, a Alexis Chumillas, por su ayuda en la parte gráfica.

- A Helen Blundell por su ayuda en la corrección de los textos.

- A mi amiga Raquel Møller-Jensen por su ayuda con el danés.

- A mi colega Giuseppe Amoruso por sus sabios consejos e inestimable apoyo.

- A todos mis compañeros del Área de Expresión Gráfica Arquitectónica y, especialmente, a Francisco Felip, Jaume Gual y José Garfella por su inestimable ayuda y consejos.

- A Carlos Vila, mi primer director de Departamento, por toda su ayuda y apoyo durante todos estos años.

- A Roberto Sanchis, director de Departamento, por su ayuda y apoyo durante los últimos años.

\footnotetext{
${ }^{53}$ Arciniega García, L. (2001). La Memoria del Ducat de Gandia i els seus títols annexos. Redactada per Basilio Sebastián per al duc d'Osuna (1851-1852). Gandia: CEIC Alfonso el Vell. pp. 73-81.
} 
- A todos los compañeros que me han alentado a seguir adelante.

\section{A los colaboradores:}

- A Rafael Soler, doctor arquitecto, por haberme ayudado a introducirme en los entresijos de éste palacio y su arquitectura.

- Muy especialmente a Vicent Burguera, arqueólogo municipal de Oliva, por haberme abierto de par en par las "puertas" del palacio y haberme ayudado en todas mis consultas.

A los cooperantes:

- A los propietarios de la vivienda no 7 de la Calle Palacio, por su enorme gentileza al abrirme sus puertas para poder documentar la ventana gótica de su cambra.

- Al hermano Alejandro por abrirme las puertas del Monasterio de Portaceli y mostrarme algunas de las maravillas que alberga.

- A la bibliotecaria de Det Kongelige Danske Kunstakademis Skolerfor Arkitektur, Designog Konservering, que me ayudó a localizar algunas de las piezas de Fischer.

\section{A las instituciones:}

- A la Universitat Jaume I por facilitarme todos los medios técnicos y el apoyo para llevar a cabo este trabajo.

- A los Ayuntamientos de Geldo y Lluxent, que tan gentilmente me abrieron las puertas de sus palacios.

- A la Danmarks Kunstbibliotek (Biblioteca Nacional Danesa del Arte), que tan amablemente localizó y facilitó toda la documentación sobre Fischer y Lauritzen.

\section{A mi familia:}

- A mis padres, que siempre me han apoyado en todas mis decisiones y me han ayudado a conseguir todos mis sueños. Les dedico especialmente a ellos este trabajo, con todo mi cariño, por haberme enseñado a volar y haberme sabido transmitir el valor del esfuerzo.

- A mi hermano y hermanas por creer tanto en mí y estar siempre a mi lado a pesar de la distancia.

- A mis abuelos, que ya no están, y que tan orgullosos estuvieron siempre de mí. 
- A Julián, con quien comencé esta nueva aventura, por su constante y continuo apoyo y aliento.

- A Paco y Alejandro, por todo lo que me han animado y motivado al final d este largo camino. 



\section{CAPITULO II}

\section{ANTECEDENTES HISTÓRICOS}

\section{INTRODUCCIÓN}

La localidad de Oliva y su término municipal ha sido, desde los tiempos antiguos, lugar de asentamiento de los distintos pueblos que se han establecido en la costa mediterránea española. De ello dan testimonio sus numerosos yacimientos arqueológicos, íberos, romanos y musulmanes encontrados en su territorio. Esto es debido sin duda a su posición estratégica, al encontrarse localizada a mitad de camino en la calzada romana que une las ciudades de Xàtiva y Dénia. Durante la dominación islámica, el núcleo principal de Oliva empieza a destacar sobre el resto de poblaciones de la zona y el castillo del Rebollet aseguraba la defensa del flanco sur de la comarca de La Safor. Tras la conquista, el rey Jaume I entrega al caballero Carroz la villa y castillo del Rebollet el 18 de julio de 1240, según el Llibre del Repartiment, en compensación por su lucha contra los moros. Este había sido nombrado caballero en 1229. El rey le encomendó, asimismo, tras su conquista, la guarda de diversas fortalezas en el la zona costera del sur del Reino de Valencia ${ }^{54}$.

Después de la conquista cristiana, los nuevos pobladores de Oliva se establecieron en la parte baja de la montaña de Santa Anna, conocida como "la villa", mientras que los musulmanes ocuparon la parte alta o arrabal. A principios del siglo XV, Oliva se sitúa al frente de la producción de azúcar, producto que en aquel momento dominaba los mercados europeos, llegando a ser la segunda ciudad en rentas del Reino después de Gandía. En 1449 se convierte en la cabeza del Condado de Oliva y a principios del siglo XVI el conde Serafín de Centelles embellece su palacio con motivos renacentistas de acuerdo con las nuevas tendencias artísticas de la época.

En 1609 se produce la expulsión de los moriscos que deja los campos valencianos abandonados y que afecta también al municipio de Oliva, iniciándose un largo periodo de decadencia demográfica y económica ${ }^{55}$, que culminaría a principios del siglo XVIII con la Guerra de Sucesión. El matrimonio de Magdalena de Centelles con Carlos de Borja también afectó sin duda a este declive.

Para contextualizar la obra arquitectónica objeto de estudio, el Palacio de Oliva, debemos tener una información básica de quiénes fueron sus propietarios y moradores durante su periodo de mayor esplendor, la Familia Centelles Riu-Sec, los cuales ostentaron el título de Condes de Oliva durante siglo y medio, y establecieron en él su residencia principal. Por

\footnotetext{
${ }^{54}$ Camarena Mahiques, J. (1988). De la historia de Oliva y Rebollet. En Cardona Miralles, S. (Ed). Iniciación a la Historia de Oliva (2a Ed.). Oliva, Valencia: Publicaciones del Ayuntamiento de Oliva. pp. 140-143.

${ }^{55}$ Camarena Mahiques, J. (1988). Óp. cit. pp. 196-203.
} 
ello, se realizará una breve reseña histórica de los antiguos señores del señorío de Oliva y Rebollet desde su conquista, los Carroz, y el cambio de dinastía a través de los Riu-Sec.

\subsection{Los Carroz}

Según el Llibre del Repartiment, el castillo y la villa de Rebollet fue entregado al señor de Carroz el 18 de julio de 1240. Existen dudas sobre su nombre de pila y nacionalidad de origen; algunos historiadores creen que pudiera ser de origen italiano por su tradición marinera, su devoción por San Nicolás de Bari y por los nombres que dio a sus hijos. Esta donación se realizó con anterioridad a la conquista de esta comarca a los musulmanes. En 1250 se concretaba esta donación y se mencionaba explícitamente Oliva como parte de los territorios pertenecientes al Castillo de Rebollet. El caballero Carroz ayudó en las luchas contra los árabes en el flanco sur del Reino acompañando a Jaume I en 1266 en la campaña de Murcia. Se estima que murió hacia $1276^{56}$.

Los hijos del primer señor de Rebollet fueron Francisco, Arnaldo y Berenguer, existiendo dudas de si Arnaldo fue realmente hijo o nieto. Francisco, que se casó con María Ferrándiz, no sobrevivió a su padre y no se sabe si tuvo descendencia, y de si este hijo fue realmente Arnaldo. Berenguer, por su parte, fue enviado por el padre a reprimir la sublevación mudéjar de Xàtiva en 1275. Posteriormente, mandó la flota que Roberto de Nápoles envió para combatir a los piratas de la isla de Gerba y parece ser que se quedó a vivir en Italia (Cerdeña). Ninguno de estos dos hijos fue Señor de Rebollet, por lo que todo apunta a que el señorío lo asumió Arnaldo, siendo su mujer Sancha Cruilles ${ }^{57}$.

El siguiente señor de Rebollet fue Francisco Carroz y Cruilles, quien luchó junto a Jaume II en el sitio de Almería y, tras la Paz de Agreda con los castellanos, en Italia, donde el monarca centró sus esfuerzos. Fue nombrado almirante de los reinos de Aragón, Valencia, Cerdeña, Córcega y del condado de Barcelona en 1313, quedando bajo su jurisdicción toda la flota. Participó en la expedición a Cerdeña junto con el infante Alfonso en 1323. En 1338 el ya rey Pedro el Ceremonioso le ordena establecerse en Oliva para tener preparadas sus fortalezas por el peligro que suponía la alianza entre los moros benimerines y granadinos. El rey fue recibido por Francisco Carroz en Oliva cuando este inspeccionó las fortalezas de la costa alicantina y, entre ellas, la de Denia. Estos últimos hechos evidencian que en esta época ya existía un castillo o palacio donde moraría Carroz y donde recibía al rey. Se le presuponen dos esposas: Teresa de Entenza, con la que tuvo sus cuatro hijos, y Benita de Arborea. Retornó a Cerdeña en 1342 muriendo al año siguiente por unas fiebres (l'intemperia $)^{58}$. Fue enterrado en la iglesia del castillo del Rebollet, dedicada a San Nicolás de Bari. Su tumba fue trasladada a la iglesia de La Font d'en Carròs tras la destrucción de la primera por un terremoto en $1598^{59}$.

\footnotetext{
${ }^{56}$ Camarena Mahiques, J. (1988). Óp. cit. pp.140-145.

${ }^{57}$ Camarena Mahiques, J. (1988). Óp. cit. pp.145-148.

${ }^{58}$ Camarena Mahiques, J. (1988). Óp. cit. pp.148-151.

${ }^{59}$ Ayuntamiento La Font d'en Carròs. Recuperado en :

http://www.lafontdencarros.es/es/page/historia-monumentos.
} 


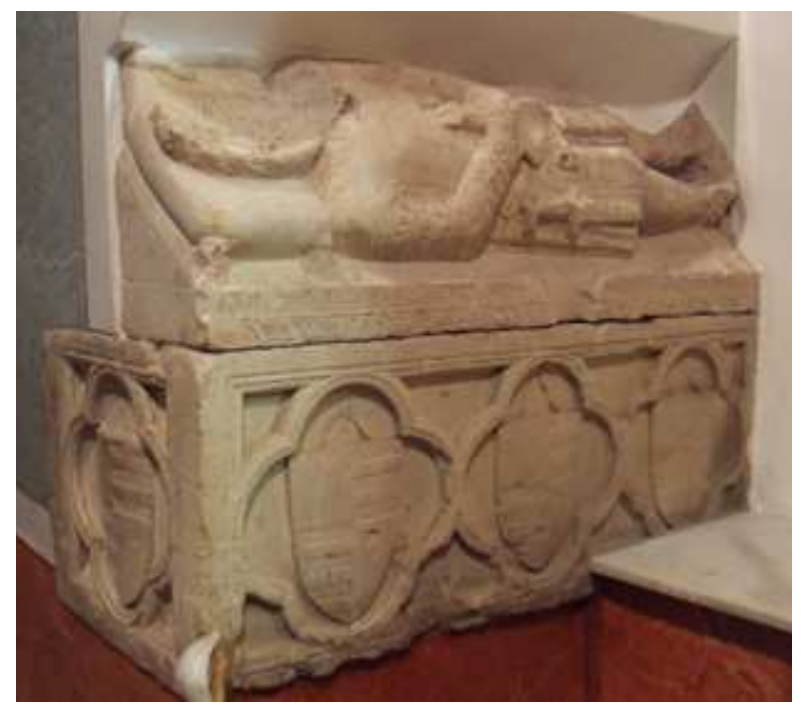

Figura 17. Sepulcro de Francisco Carroz y Cruilles. Iglesia de La Font d'en Carròs. Fuente: www.lafontdencarros.es.

Su hijo primogénito, Francisco, heredó el señorío. Él también fue almirante, aunque sólo de una escuadra, con la que participó en la conquista de Mallorca. Casó con Estefanía (Lauria) en primeras nupcias y Teresa Ximénez de Borriol, en segundas. Sus hijos fueron Esteban, Juana y Francisca. Murió también en Cerdeña, poco después que su padre, también por l'intemperia y fue enterrado junto a él en la Iglesia del Castillo del Rebollet, aunque su tumba no estaba esculpida como la del primero ${ }^{60}$.

Su primogénito fue Esteban Carroz y Lauria. Se casó con una Vilaragut y tuvo dos hijos, Esteban y Ramoneta. Murió muy joven, posiblemente de la peste negra, ya que en las cortes de 1349 actúa como administrador de su hija Ramón Boxados, Señor de Ondara, por lo que su hijo había fallecido también en esa fecha y Ramoneta podría haber heredado los derechos del señorío. Durante este periodo se produjo la guerra de los dos Pedros en Castilla, en la que Pedro el Ceremonioso de Aragón tomó partido, por lo que Pedro el Cruel de Castilla, en su paso de Jumilla a Valencia, saqueó Oliva y dejó el Castillo de Rebollet en estado de ruina. Ramoneta murió sin descendencia pasando el señorío a su prima hermana Alamanda hija de Juana Carroz y Lauria. ${ }^{61}$.

Alamanda contrajo matrimonio con Berenguer de Vilaragut, señor de la Baronía de Onteniente, quien como señor consorte de la Honor del Rebollet, dio la Carta Pobla a la Font d'en Carròs con el fin de repoblarla tras su casi abandono después del saqueo de los castellanos. El matrimonio no tuvo hijos o estos no les sobrevivieron ${ }^{62}$.

${ }^{60}$ Camarena Mahiques, J. (1988). Óp. cit. pp.151-152.

${ }^{61}$ Camarena Mahiques, J. (1988). Óp. cit. pp. 152-154

${ }^{62}$ Camarena Mahiques, J. (1988). Óp. cit. pp.154-155. 


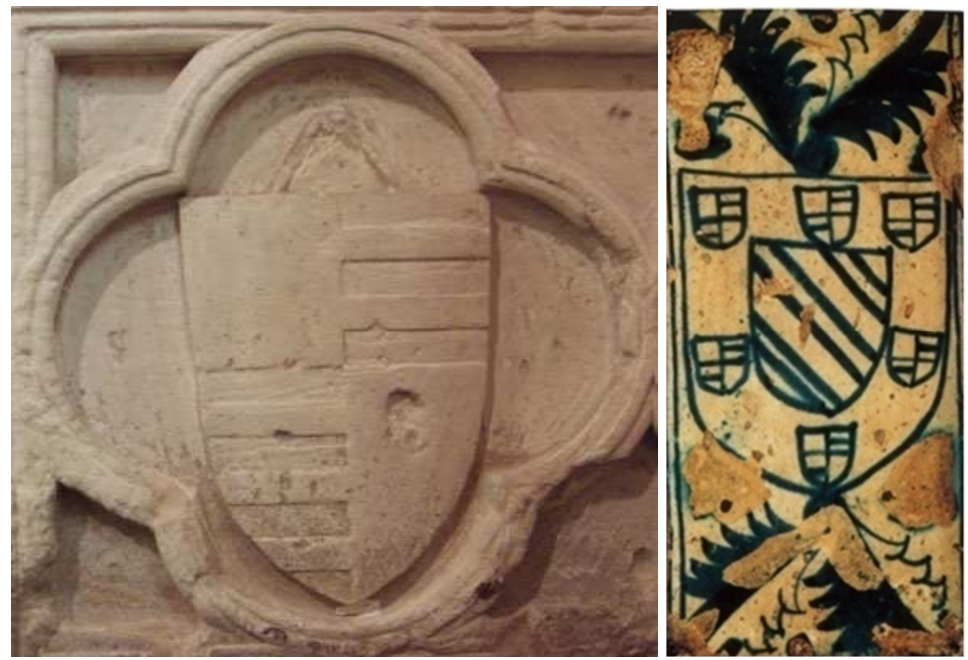

Figura 18. Izquierda: Escudo de armas de los Carroz. Detalle del sepulcro de Francisco Carroz y Cruilles. Iglesia de La Font d'en Carròs. Fuente: www.lafontdencarros.es. Derecha: Azulejo decorado en azul sobre fondo blanco, $11 \times 22 \mathrm{~cm}$. Representa un escudo con las armas de los Carroz, señores de Oliva y El Rebollet. Manises. Siglo XV. (CP. Oliva). Fuente: Salvador Mañó i Fenollar.

\subsection{Los Riu-Sec}

A la muerte de Berenguer de Vilaragut sin descendencia el señorío de Oliva y Rebollet pasa a manos de Ramón de Riu-Sec, a pesar de que Alamanda no había fallecido. Camarenas Mahiques justifica este hecho en que el derecho del señorío pudiera transmitirse por vía materna pero sólo pudiera ser desempeñado por varones. Ramón de Riu-Sec era nieto de Francisca Carroz y Enteza y de Ramón Riu-Sec y Moraira y, por tanto, tenía derechos sobre sobre el señorío, que consiguió tras un pleito con otros pretendientes. Murió en 1387 sin hijos.

A su muerte hereda sus derechos su hermana Ramoneta Riu-Sec, por lo que el señorío pasa de hecho a su sobrino, Gilabert de Centelles i Riu-Sec, uniéndose los señoríos de Nules con el de Oliva-Rebollet.

\subsection{Los Centelles Riu-Sec}

Esta familia aristocrática valenciana tiene sus orígenes en la alta nobleza feudal catalana estando emparentada con los Centelles, los Riu-Sec e incluso los Carroz, familias que intervinieron en la conquista de Mallorca y Valencia.

Los señoríos de Nules y Oliva los obtienen por sus alianzas matrimoniales y, posteriormente, su destacada actividad militar en Sicilia y Cerdeña en apoyo de la corona, les permitirá ampliar sus posesiones en estas tierras. 
La familia Centelles experimenta la transición del Gótico al Renacimiento, siendo Serafín de Centelles "el conde Humanista" el que incorpora en sus Palacios de Oliva y Valencia su gusto por la decoración renacentista o "a la romana".

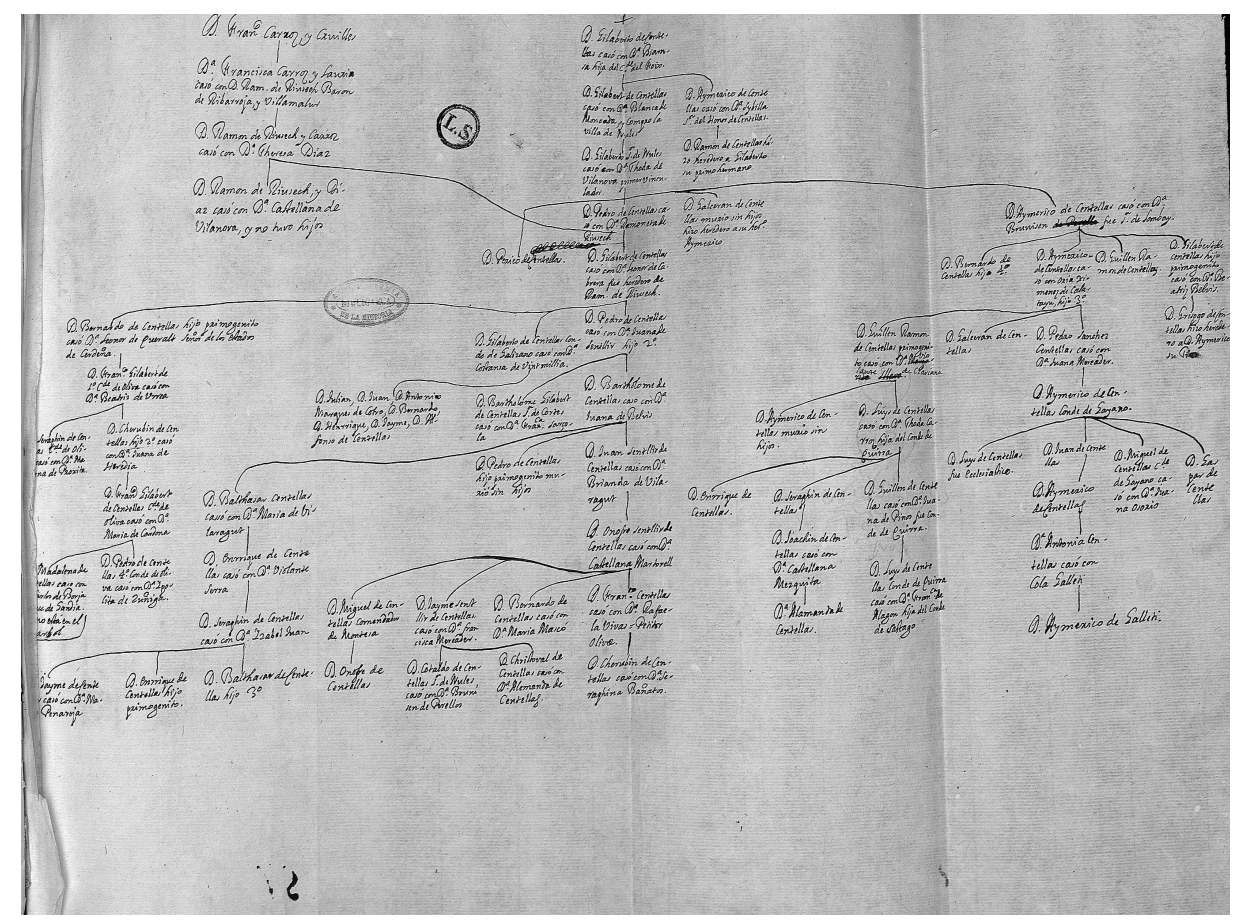

Figura 19. Árbol Genealógico de la Familia Centelles. Fuente: Biblioteca Academia de Historia.

\subsubsection{Los Señores de Nules}

\section{Gilabert de Centelles i Bellpuig, ( $\dot{c}-?$-1319)}

Es el primer miembro de la familia Centelles del que tenemos constancia en el Reino de Valencia. Es hijo del Señor del Castillo y Villa de Centelles, en el principado de Cataluña. El 19 de abril de 1308 prestó homenaje al rey Jaume II en Valencia por el feudo del Castillo de Montornés del Vallés.

El 18 de noviembre de 1314 el Rey autorizó a Ramón de Montcada la venta del castillo de Nules a Gilabert de Centelles, firmándose posteriormente las capitulaciones matrimoniales entre éste y Blanca de Montcada, hija de Ramón de Montcada, pasando así a manos de la Familia Centelles el castillo y la villa de Nules. El 9 de octubre de 1316 Gilabert Centelles prestó homenaje al rey Jaume II en la ciudad de Lleida por dichas posesiones.

Asimismo, fue Embajador del Rey en diversas delegaciones enviadas por este a la península Itálica, y ostentó el cargo de lugarteniente de gobernador en el Reino de Valencia. Poco 
tiempo después de su matrimonio se trasladó a Cerdeña, donde participó en las campañas de conquista de la isla, durante las que murió en el año $1319^{63}$.

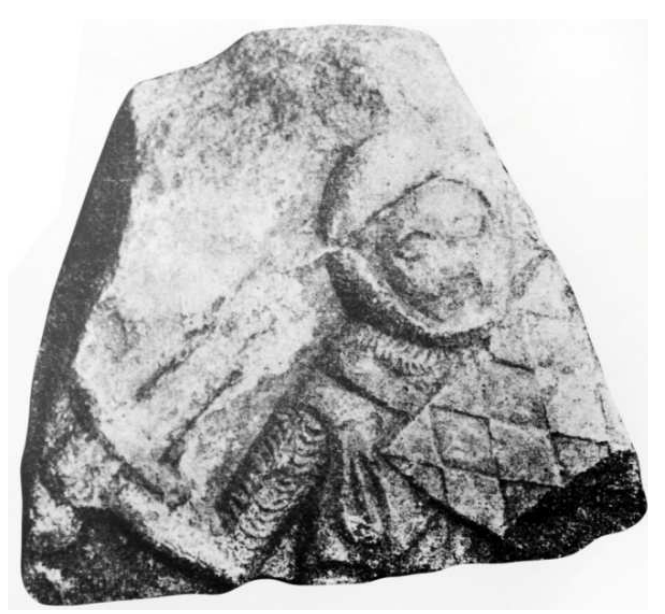

Figura 20. Fragmento del sepulcro de Gilabert de Centelles i Bellpuig, primer señor de Nules. Procedente del Castillo de Nules. Paradero desconocido. Fuente: D. Camarlench, (1914).

\section{Gilabert de Centelles i Montcada ( $\dot{i}-?-1368)$}

A la muerte de su padre, Gilabert de Centelles y Montcada era todavía un niño. El rey Jaume II se encargó de su protección y nombró personalmente a sus tutores: Berenguer de Vilafreser y Bernat Fabrer (a la muerte del primero en 1325), velando para que estos cuidaran los intereses del joven noble y de su madre.

En 1335 pactó su matrimonio con Toda de Vilanova, hija del Comendador de Montblanc. Este pacto fue aprobado por el rey dos años más tarde.

En 1342 Gilabert de Centelles consigue que el Rey Pedro II el Ceremonioso le conceda los privilegios que el rey mantenía sobre el castillo y la villa de Nules, así como el derecho sobre las aguas de la acequia de Villareal, entregándole a cambio el castillo de Montornés. Con esta permuta Gilabert de Centelles se convirtió en el señor de la Baronía de Nules comenzando la influencia de esta familia en la corte de Pedro el Ceremonioso y ostentando en ella diversos cargos relevantes: consejero real en 1347 (encargándole el rey la custodia del castillo de Xàtiva) y gobernador del Reino de Mallorca en 1348, pocos años después de que el Rey recuperara el Reino de Mallorca para la Corona. Desempeñó un papel importante defendiendo los intereses de la corona durante las guerras de la Unión, así como durante la invasión del Reino de Valencia por parte de Pedro el Cruel de Castilla, conteniendo las revueltas en el Reino de Mallorca y derrotando a Jaume III en la batalla de Llucmajor. Participó asimismo en la expedición a Cerdeña conteniendo la rebelión de Mateo Doria.

\footnotetext{
${ }^{63}$ Felip Sempere, V. (2000). Recull per a una història de Nules (Barcelona, 1977-Nules 2000) II. Nules: Caixa Rural de Sant Josep de Nules. pp. 279-280.
} 
Se casó con Toda de Vilanova con la que tuvo 7 hijos: Pedro, Galcerán, Luis, Emeric, Toda, Elvira y Catalina ${ }^{64}$.

Tabla 1. Tabla cronológica de los Señores de Centelles y Reyes de Aragón S. XIV al XVI.

\begin{tabular}{|c|c|c|c|c|c|}
\hline \multicolumn{3}{|c|}{ Reyes de Aragón } & & & \\
\hline Dinastía & Rey & Reinado & \multicolumn{3}{|c|}{ Familia Centelles } \\
\hline \multirow{8}{*}{ 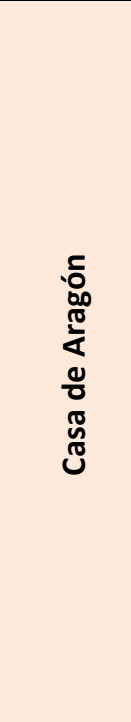 } & & & Periodo & Cabeza de la familia Centelles & Título \\
\hline & $\begin{array}{l}\text { Jaume II EI } \\
\text { Justo }\end{array}$ & $\begin{array}{l}1291- \\
1327\end{array}$ & $\dot{c} ?-1319$ & Gilabert de Centelles i Bellpuig & \multirow{5}{*}{ 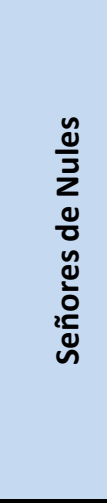 } \\
\hline & $\begin{array}{l}\text { Alfonso IV EI } \\
\text { Benigno }\end{array}$ & $\begin{array}{l}1327- \\
1336\end{array}$ & \multirow[t]{2}{*}{$1319-1368$} & \multirow[t]{2}{*}{ Gilabert de Centelles i Montcada } & \\
\hline & Pedro IV EI & $1336-$ & & & \\
\hline & Ceremonioso & 1387 & \multirow[b]{2}{*}{$1368-1391$} & \multirow[b]{2}{*}{ Pere de Centelles i Vilanova } & \\
\hline & \multirow{2}{*}{$\begin{array}{l}\text { Juan I El } \\
\text { Cazador }\end{array}$} & \multirow{2}{*}{$\begin{array}{l}1387- \\
1396\end{array}$} & & & \\
\hline & & & 1391-1409 & Gilabert de Centelles i Riu-Sec & \multirow{4}{*}{ 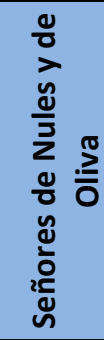 } \\
\hline & $\begin{array}{l}\text { Martín I El } \\
\text { Humano }\end{array}$ & $\begin{array}{l}1396- \\
1410\end{array}$ & $1091-140 Y$ & \multirow{3}{*}{ Bernat de Centelles i Cabrera } & \\
\hline \multirow{6}{*}{ 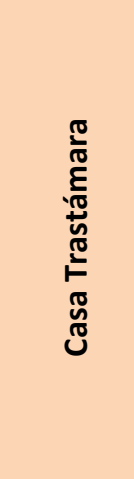 } & $\begin{array}{l}\text { Fernando I El } \\
\text { Benigno }\end{array}$ & $\begin{array}{l}1412- \\
1416\end{array}$ & \multirow[t]{2}{*}{ 1409-1433 } & & \\
\hline & \multirow{2}{*}{$\begin{array}{l}\text { Alfonso V El } \\
\text { Magnánimo }\end{array}$} & \multirow{2}{*}{$\begin{array}{l}1416- \\
1458\end{array}$} & & & \\
\hline & & & \multirow{3}{*}{$1433-1480$} & \multirow{3}{*}{$\begin{array}{l}\text { Francisco Gilabert de Centelles i } \\
\text { Queralt } \\
\text { Nombrado Conde de Oliva el } 14 \text { de } \\
\text { abril de } \mathbf{1 4 4 9}\end{array}$} & \multirow{7}{*}{ 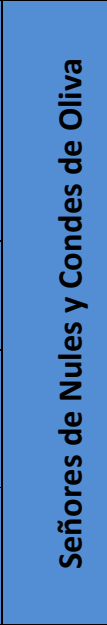 } \\
\hline & $\begin{array}{l}\text { Juan II El } \\
\text { Grande }\end{array}$ & $\begin{array}{l}1458- \\
1479\end{array}$ & & & \\
\hline & \multirow{2}{*}{$\begin{array}{l}\text { Fernando II EI } \\
\text { Católico }\end{array}$} & \multirow{2}{*}{$\begin{array}{l}1479- \\
1516\end{array}$} & & & \\
\hline & & & \multirow[t]{2}{*}{$1480-1536$} & \multirow{2}{*}{$\begin{array}{l}\text { Serafí de Centelles i Ximenez de } \\
\text { Urrea }\end{array}$} & \\
\hline \multirow{3}{*}{ 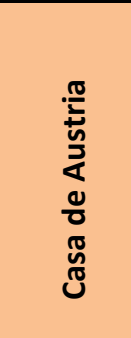 } & \multirow[b]{2}{*}{ Carlos I } & \multirow[b]{2}{*}{$\begin{array}{l}1516- \\
1556\end{array}$} & & & \\
\hline & & & $1536-1550$ & $\begin{array}{l}\text { Francisco Gilabert de Centelles i } \\
\text { Fernández de Heredia }\end{array}$ & \\
\hline & Felipe II & $\begin{array}{l}1556- \\
1598\end{array}$ & $1550-1569$ & Pere de Centelles i Cardona & \\
\hline
\end{tabular}

${ }^{64}$ Felip Sempere, V. Óp. cit. pp. 280-283. 


\section{Pedro de Centelles y de Villabona (i-? -1391)}

Desempeñó un papel importante al lado del rey Pedro II el Ceremonioso durante la invasión castellana por parte de Pedro el Cruel. Ocupó cargos de consejero y camarlengo del rey, así como camarlengo de la reina Sibila.

Se casó con Ramoneta de Riu-Sec, hermana de Ramón de Riu-Sec, Señor de Oliva y El Rebollet. Del matrimonio nacieron Gilabert, Pedro, Ramón, Juan, Jaime, Galcerán, Ramoneta, Blanca, Toda y Elvira ${ }^{65}$.

\subsubsection{Los Señores de Oliva y Nules}

\section{Gilabert de Centelles i Riu-Sec ( $i-?$-1409)}

Ramón de Riu-Sec, al no tener descendencia, testó a favor de su sobrino Gilabert de Centelles a condición de que este adoptara el nombre de Ramón de Riu-Sec y de que en su escudo, sello y bandera portara las armas de este linaje. El 31 de agosto de 1387 Gilabert de Centelles y de Riu-Sec hereda los señoríos de Oliva y Rebollet de su tío Ramón de Riu-Sec y, tres años más tarde, a la muerte de su padre, el señorío de Nules. A partir de este momento la familia Centelles se convierte en una de las más influyentes del Reino de Valencia.

Gilabert de Centelles ocupó cargos de confianza del rey Juan I, participando en la defensa de Cataluña contra las compañías de los Armanyac, donde fue hecho prisionero. En 1392 fue enviado junto con sus hermanos Pedro y Juan de Centelles a Sicilia en servicio del infante D. Martín (futuro rey Martín el Humano).

A su regreso a Valencia participó en luchas entre distintas familias valencianas de nobles (los Centelles, los Soler y los Vilaragut), conocidas como "bandosidades"; fruto de estos enfrentamientos murió su hermano Pedro y este vengó su muerte matando a D. Jaume Soler. Los enfrentamientos continuaron entre los dos bandos produciéndose nuevas muertes. Estos hechos provocaron que los Centelles, a pesar de contar con la protección de la corona, tuvieran enfrentamientos con el Rey, quien llegó a ordenar al Gobernador de Valencia que tomase en su nombre el castillo y la baronía de Nules, restituyéndose esta situación posteriormente al rendir homenaje Gilabert de Centelles al Rey por el feudo de Nules. También en la Baronía de Oliva el Rey ordenó despojar a los Centelles de sus cargos públicos motivado por estas luchas entre nobles.

También fue consejero y camarlengo del rey Martín el Humano y albacea testamentario de la reina María de Luna. Se casó con Leonor de Cabrera y sus hijos fueron Bernardo, Gilabert, Pedro y Margarita ${ }^{66}$.

\footnotetext{
${ }^{65}$ Felip Sempere, V. Óp. cit. pp. 283-284.

${ }^{66}$ Felip Sempere, V. Óp. cit. pp. 284-286.
} 

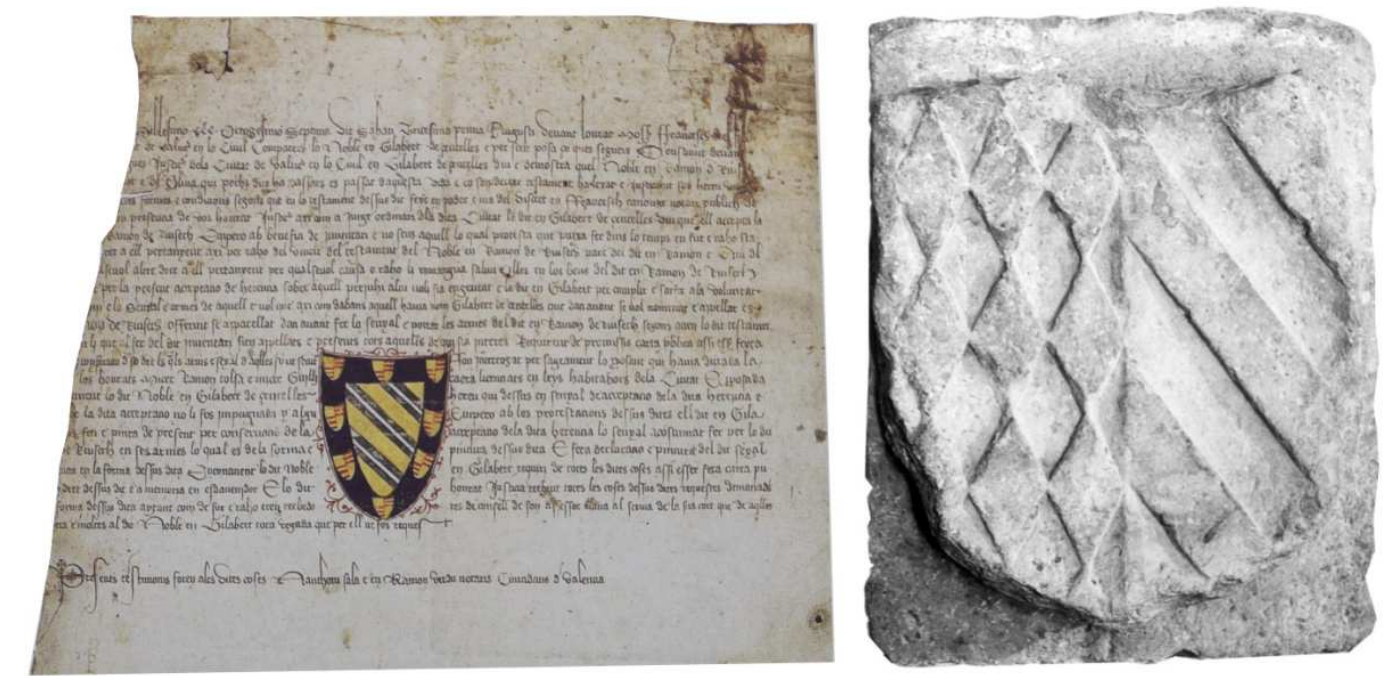

Figura 21. Izquierda: Documento de aceptación de la herencia de Ramón de Riu-Sec. En el centro el escudo de armas de los Riu-Sec. MECD. AHN. Osuna. Carp. 84. doc. 4. Fuente: V. Felip Sempere.

Derecha: Escudo de los Centelles i Riu-Sec. Museo de Historia de Nules. Fuente: V. Felip Sempere.

\section{Bernart de Centelles Riu-Sec i de Cabrera ( $\dot{c}-?-1433)$}

Desde muy joven estuvo en Sicilia al servicio del rey Martín el Joven de Sicilia, del que fue consejero y amigo, acompañándolo con tropas propias en Cerdeña (1408). Heredó de su padre los señoríos de Nules, Oliva y Rebollet, a los que añadió los feudos en la isla de Cerdeña como reconocimiento por sus campañas y las de sus antepasados.

Se casó con Leonor de Queralt y tuvo 3 hijos: Francisco Gilabert, Violante y Catalina.

Al morir el rey Martín I el Humano sin descendencia volvió a Valencia para intervenir en las luchas sucesorias y capitanear el bando de los Centelles, partidarios de Fernando de Castilla, frente al bando de los Vilaragut, partidarios del conde de Urgel. Estas disputas finalizaron con la elección en Caspe de Fernando de Antequera como rey de Aragón.

Este nombramiento supuso un triunfo para los Centelles y Fernando I le recompensó nombrándole Mariscal de la Corona y Condestable de Aragón. Asimismo, Alfonso $\mathrm{V}$ el Magnánimo lo nombró Capitán General de sus ejércitos durante sus campañas en Cerdeña, Córcega y Nápoles, nombrándole Virrey de Cerdeña en 1421.

En 1423 fue hecho prisionero por Francesco Sforza, siendo rescatado tras un trueque de prisioneros realizado por la reina Juana de Nápoles. Ese mismo año participó en la conquista de Iscla y en el saqueo a la ciudad de Marsella, donde su galera rompió la cadena que defendía la entrada del puerto dando la victoria al rey Alfonso, parte de dicha cadena la trajo a Nules como trofeo y actualmente se encuentra en la Capilla del Santo Cáliz de la Catedral de Valencia. 
En su testamento, fechado en 1432, aparece como Señor de las baronías de Nules y Oliva, Mariscal de Aragón y de Sicilia, y virrey y Gobernador del Reino de Cerdeña ${ }^{67}$.

\subsubsection{Los Condes de Oliva y Señores de Nules}

\section{Francesc Gilabert de Centelles Riu-Sec i Queralt (1408-1480)}

Tenía sólo 12 años cuando acompaña a su padre a Italia con la armada, rumbo a Nápoles. Fue consejero y camarlengo y amigo de Alfonso el Magnánimo.

En 1433 regresó al Reino de Valencia a tomar posesiones y baronías que heredó de su padre junto con las de la isla de Cerdeña. Volvió a Italia al servicio del Rey, permaneciendo allí hasta el año 1459, cuando entra en la ciudad de Valencia.

El 14 de abril de 1449 Alfonso el Magnánimo lo nombra Conde de Oliva en el Castellnuovo, Nápoles en reconocimiento por los servicios prestados tanto por él como por su padre a la corona, destacando algunas de las gestas en las que había participado: conquista de Iscla, saqueo de Marsella, guerras con Castilla, campaña en el norte de África, ataque a Génova, defensa de Nápoles y guerra con los florentinos. En 1453 Alfonso el Magnánimo lo nombra alcaide del castillo Jenuense, Cabo Sácer y Lugudor, en Cerdeña y, al año siguiente, le entregaba la castellanía de Sácer. A su regreso a Valencia se le recibe con honores organizándose una cabalgada en su honor y participó como juez en las fiestas organizadas con motivo de la llegada del rey Juan II a Valencia. Incrementa su patrimonio con diversas propiedades: la villa de Murla, la baronía de Pego y sus lugares anejos (Favara, Benumeya y Adsubia) y las baronías de Orba y Alaguar. En 1478 el rey Juan II lo nombra Gobernador General del Reino de Valencia a la muerte de su predecesor, Juan Roig de Corella, conde de Cocentaina.

Testó en Oliva el 21 de enero de 1980 disponiendo ser enterrado en la cripta de la Iglesia Mayor de Nules junto con el resto de sus antepasados.

Se casó con Francesca de Montcada, enviudando sin hijos. De su segundo matrimonio con Beatriz Ximenez de Urrea tuvo 4 hijos: Serafín, Querubín, Beatriz y Estefanía. Su hijo Querubín estuvo prometido con Lucrecia Borgia, hija del papa Alejandro VI.

Fruto de sus relaciones extramatrimoniales tuvo dos hijos reconocidos. El primero fue Ramón Gullén de Centelles, que fue canónigo de la catedral de Valencia, ocupando los cargos de pronotario y tesorero pontificio, siendo legitimado por el papa Alejandro VI. El segundo fue Jordi de Centelles, retor de Oliva y Almenara y canónigo de la catedral de Valencia. Este último fue asimismo nombrado maestro de capilla y consejero real por parte de Fernando el Católico cuando este era Rey de Sicilia. Murió en Cerdeña en $1480^{68}$.

\footnotetext{
${ }^{67}$ Felip Sempere, V. Óp. cit. pp. 286-287.

${ }^{68}$ Felip Sempere, V. Óp. cit. pp. 287-290.
} 

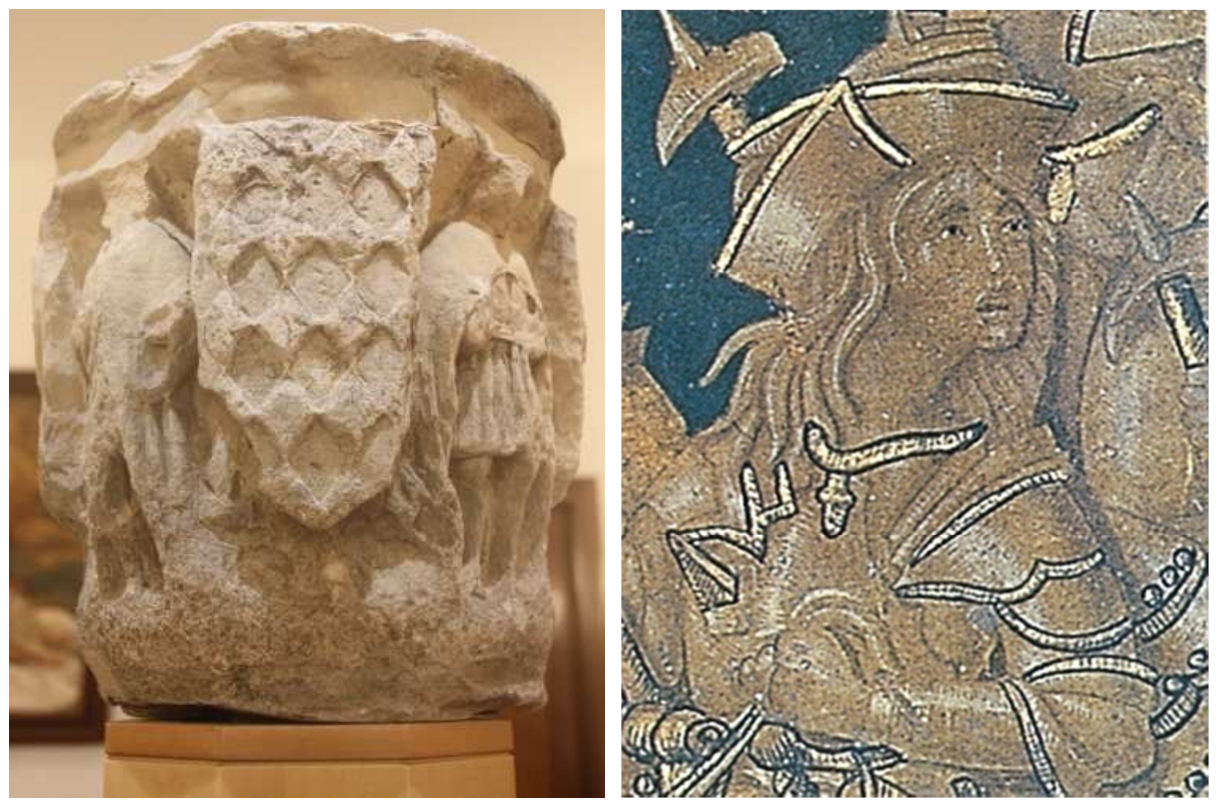

Figura 22. Izquierda: Escudo de armas de los Centelles. A su izquierda escultura de Francesc Gilabert de Centelles i Riu-Sec. Nudo octogonal de un peiró. MAO. Fotografía: Josep A. Gisbert Santonja. Derecha: Retrato de Francesc Gilabert de Centelles i Riu-Sec, I conde de Oliva. Detalle del friso de la Sala de Armas del Palacio Condal de Oliva. (HSA. Nueva York). Fuente: Salvador Mañó i Fenollar.

\section{Serafín de Centelles i Ximenez de Urrea (¿ ? - 1536)}

Tras la muerte de su padre toma posesión de la villa de Oliva, del Castillo del Rebollet y de todas las posesiones del condado de Oliva, el 21 de febrero de 1480, siendo menor de edad. Su madre actuó como tutora. Al año siguiente tomó posesión del castillo y las villas de la baronía de Nules a través de sus procuradores por encontrarse en Italia, donde estuvo largos periodos al servicio de la Corona.

En 1480 adquiere del rey Fernando las encontradas de Marquine y el castillo de Macomer en Sicilia.

En 1482 encargó a Rodrigo de Osona el retablo de la iglesia Mayor de Nules.

Participó en el sitio de Málaga, en las campañas de Fernando II en Nápoles y fue uno de los dirigentes de la represión en las revueltas de Germanías.

Recogió los frutos de todos los señoríos adquiridos y heredados por su padre, siendo sus rentas las segundas mayores del reino en aquella época, provenientes principalmente de la caña de azúcar y de los moriscos.

Tuvo afición por las letras, siendo un ejemplo de noble humanista. Subvencionó la publicación de varias obras, entre ellas, del Cancionero General de Hernando del Castillo, que incluía algunos poemas propios. Fue protector asimismo del humanista Juan Bautista Anyés, al que escogió como preceptor de su sobrino y sucesor, Francisco Gilabert de Centelles y Fernández de Heredia. 
Residió en el Palacio de Oliva y en su palacio valenciano de la calle Caballeros.

A Serafín de Centelles se le atribuye la transformación del castillo de Oliva en un palacio, el cual había sido saqueado por los agermanados a finales de julio de 1521, recibiendo por ello una compensación de 7.000 ducados al finalizar la guerra. Según Berchez (1994), en la segunda década del siglo XVI se descubren en tierras del conde de Oliva unas canteras de mármol de gran calidad y en la tercera década ya existía en el Reino de Valencia una cierta estructura para elaborar capiteles como los de Génova ${ }^{69}$. Estas circunstancias y el interés de Serafín por el Humanismo pudieron favorecer la remodelación del Palacio de Oliva, al introducir el nuevo estilo renacentista o "a la romana".

Participó activamente en la vida social en la capital del Reino de Valencia con un papel relevante en la vida cortesana, política y financiera. Financió la Taula dels Cambis, lo que le ocasionó casi la ruina; asistió a la entrada de la reina Isabel la Católica en la cuidad en 1481, a la de Fernando el Católico con su segunda esposa, Germana de Foix, en Valencia en 1507 y a la toma de posesión de Germana de Foix como virreina de Valencia en 1523. En su palacio de la calle Caballeros se alojó Germana de Foix durante los funerales en Valencia de su segundo marido.

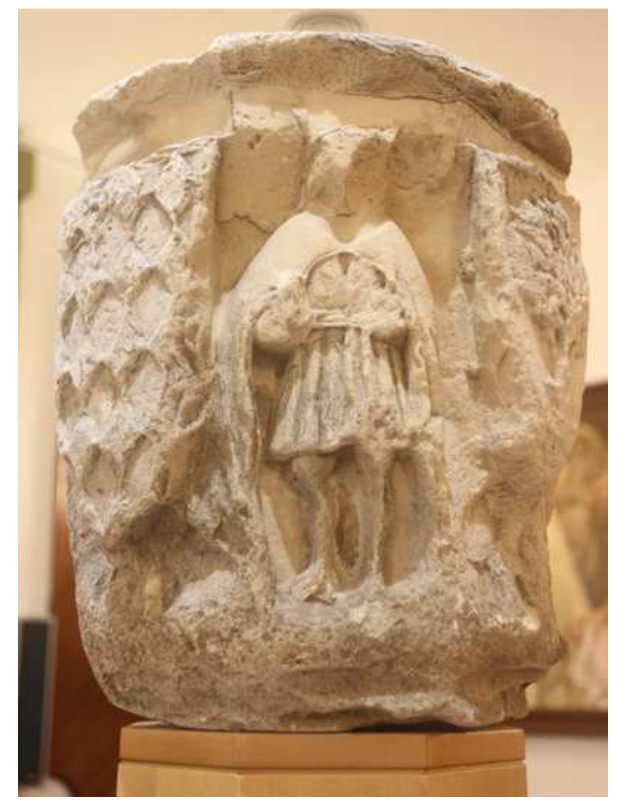

Figura 23. Serafín de Centelles, II conde de Oliva, con indumentaria renacentista y vara, que significa la jurisdicción civil y criminal sobre su condado. Nudo octogonal de un peiró. MAO. Fotografía: Josep A. Gisbert Santonja.

\footnotetext{
${ }^{69}$ Berchez Gómez, J. y Jarque, F. (1994). Arquitectura Renacentista Valenciana (1500-1570). Valencia: Bancaixa Obra Social. pp.46.
} 
Se casó con Magdalena de Próxita, no sobreviviendo ninguno de los hijos del matrimonio, por lo que designo como su heredero a Francisco Gilabert de Centelles y Fernández de Heredia.

Realizó su testamento en la villa de Oliva en 1528, disponiendo ser enterrado en la cripta de la iglesia Mayor de Nules junto con sus antepasados ${ }^{70}$.

\section{Francesc Gilabert de Centelles i Fernández de Heredia (¿’? - 1550)}

Hijo de Querubín Centelles i Ximénez de Urrea. En 1515 heredó de su padre la baronía del Valle de Cofrentes. Viviendo aún su tío fue herido por un enfrentamiento con los moros en el Valle d'Alfondec, estando en peligro de muerte. Su tío Serafín de Centelles se preocupó de su formación encargándole esta tarea al humanista Juan Bautista Agnesio, quien le instruyó en las letras. Publicó algunas poesías, cartas y elegías en las obras de su maestro.

Participó junto a su tío en las fiestas que la ciudad de Valencia y "combatió" con el Emperador Carlos y otros nobles a "las cañas".

A la muerte de su tío heredó todas sus posesiones, siendo conocido como el "conde letrado".

Su tutor le inculcó también fuertes convicciones religiosas, y en 1538 se fue para cristianizar a sus vasallos moriscos del Valle de Cofrentes.

Se casó con María de Cardona, cuyas capitulaciones matrimoniales fueron firmadas el 21 de noviembre de 1525. De este matrimonio nacieron seis hijos: Pere, Magdalena, Ana, Felipa, Juana y María.

En su testamento, realizado el 4 de mayo de 1547, nombró heredero a su único hijo varón, Pere de Centelles i Cardona y a su esposa tutora y administradora hasta que éste alcanzara la mayoría de edad. También nombró como albacea a Miguel de Centelles, señor de Pedralba y a su maestro, Juan Bautista Agnesio.

Murió en Oliva el día 28 de octubre de $1550^{71}$.

\section{Pere de Centelles i Cardona (1537-1569)}

Nació en el Palacio de Oliva el 3 de agosto de 1537.

A la muerte de su padre tenía sólo 13 años, asumiendo su madre los papeles de tutora y administradora, previa realización de escritura de inventario ${ }^{72}$. Antes de cumplir los 16 años fue prometido en matrimonio con Hipóita de Zúñiga y Requenses. A los 19 años enfermó de

\footnotetext{
${ }^{70}$ Felip Sempere, V. Óp. cit. pp. 290-292

${ }^{71}$ Felip Sempere, V. Óp. cit. pp. 292-293.

${ }^{72}$ Felip Sempere, V. Óp. cit. pp. 305-368.
} 
paroxismo y perdió la razón, recluyéndose en los "estudios dorados" y los "estudios blancos" del palacio de Oliva, realizando múltiples actos de locura.

El 17 de mayo de 1558 el emperador Carlos V otorgó un Privilegio Real por el que ordenaba a Carlos Fenollet que administrara y rigiera la casa y estados del Conde junto con su madre María de Cardona.

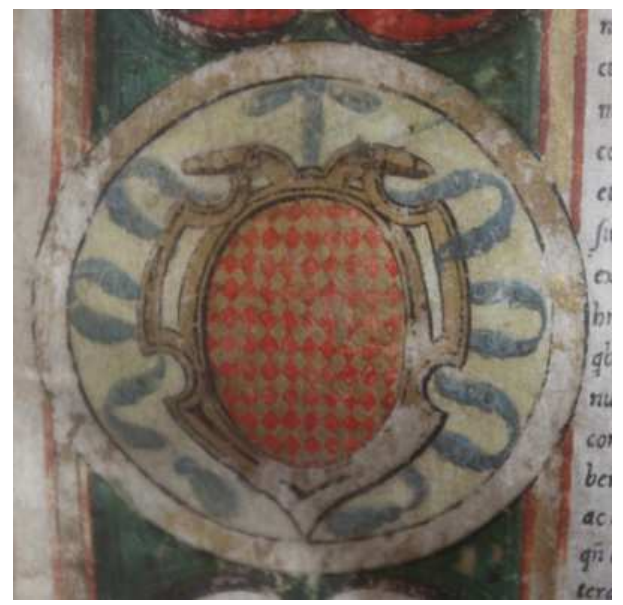

Figura 24. Emblema del señorío en la hoja fundacional de la cofradía de la sangre (1559). Archivo Iglesia Santa María de Oliva. Fuente: Josep A. Gisbert Santonja.

A partir de esa fecha se alternaron etapas de cierta normalidad con otras de locura, llegando a herir de gravedad a su esposa en un altercado. A causa de este hecho Jaime de Centelles lo encerró en una estancia del palacio manteniéndole atado y vigilado para que no se lesionara. Después de esta agresión un nuevo privilegio real nombró a Juan Alapont administrador general de sus bienes y a Serafín Centelles le encargó su cuidado. Su esposa se recluyó en el convento de Santa Clara de Xàtiva, aunque más tarde volvió al palacio a convivir con el Conde.

Pedro de Centelles se hizo rodear de una auténtica corte al estilo renacentista con halconeros, ministriles, maestro de esgrima, pajes, lacayos, maestresala, copero, repostero, etc.

Fue el último Centelles que ostentó los títulos de Conde de Oliva y Señor de Nules y, al no tener descendencia, en el Palacio se llevaron a cabo, como en toda buena corte renacentista, numerosas intrigas protagonizadas por su propia madre, su hermana Magdalena y su esposo Carlos, e incluso por algunos de sus vasallos.

El 17 de enero de 1559 entregó su testamento a su secretario, Pedro Sans de Soria. En dicho testamento ordenaba que le heredase, en caso de no tener descendencia masculina, Jaime de Centelles, Señor de Almedíjar y, a la muerte de éste, sus hermanos y los descendientes masculinos de los mismos. Asimismo otorgaba una renta a sus hermanas Ana y Felipa y no mencionaba a su hermana Magdalena, duquesa de Gandía. El testamento 
se mantuvo en secreto hasta ser desvelado por el propio Conde en uno de sus episodios de locura, causando la ira de su propia madre. El 29 de octubre de 1562 lo revocó y dio conformidad a las capitulaciones matrimoniales concertadas por su padre, Francisco Gilabert de Centelles, y Francisco de Borja para casar a sus hijos, Magdalena de Centelles y Carlos de Borja, según el cual si Pere de Centelles no tenía descendencia masculina heredaría su hermana Magdalena y sus descendientes.

Pere de Centelles murió en el Palacio de Oliva el 3 de mayo de 1569 sin haber tenido descendencia, siendo enterrado probablemente en la iglesia de Oliva. A partir de su muerte la familia Centelles y su linaje entraría en un periodo de decadencia ${ }^{73}$.

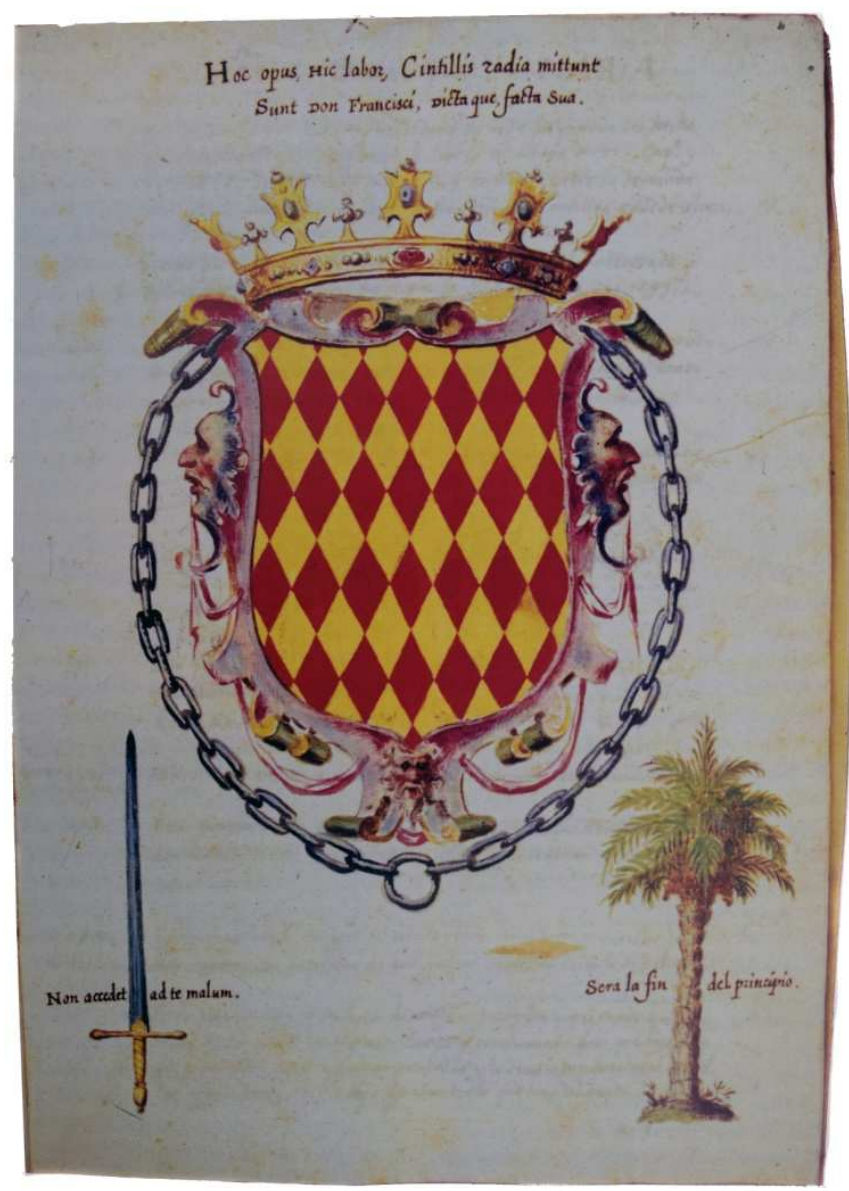

Figura 25. Portada del libro sumario de testimonios del proceso de sucesión de Pere de Centelles i Cardona. Escudo de los Centelles con las cadenas del puerto de Marsella traídas a Nules por Bernardo Centelles. MECD. AHN. Osuna. Leg. 620.8. Fuente: V. Felip Sempere.

\footnotetext{
${ }^{73}$ Felip Sempere, V. Óp. cit. pp. 293-297.
} 


\section{Magdalena de Centelles i Cardona (?- 1596) y Carlos de Borja y Castro (1530-1592)}

A la muerte de Pedro de Centelles en 1569, Jaime de Centelles, Señor de la Baronía de Almedíjar, disputó a Magdalena de Centelles la herencia del Condado de Oliva y demás posesiones del primero, en virtud del testamento que depositó en la Catedral de Valencia y que, posteriormente, sería anulado. Fueron varios los escritos al Virrey y la Real Audiencia de Valencia emitidos por ambas partes y el litigio duró muchos años.

En 1581 se dictó una primera sentencia real por la que la baronía de Nules pasaría a Cotaldo de Centelles, hijo de Jaime de Centelles; y el Valle de Cofrentes a Magdalena de Centelles. El Condado de Oliva y el resto de posesiones quedaron bajo la administración de José Vallés hasta resolverse el pleito.

Finalmente, el 24 de septiembre de 1582 una sentencia real adjudicó el condado Oliva y todas las demás posesiones, salvo la baronía de Nules, a Magadalena, Ana y Felipa de Centelles ${ }^{74}$.

Carlos de Borja y Magdalena de Centelles vivían en el palacio de Gandía, por lo que habían perdido su contacto con Oliva, que se interrumpió cuando Carlos fue nombrado Capitán General de Portugal (1582) en sustitución del Gran Duque de Alba. Retornó a Gandía en 1586 al enfermar de gota, donde recibiría como visitantes a Felipe II, a la infanta Isabel y al príncipe Felipe. Murió el 16 de junio de 1592 en Gandía. A su muerte su hijo Francisco Tomás Borja y Centelles hereda el Ducado.

A la muerte de Carlos, Magdalena se retiró al Palacio de Oliva, dejando probablemente el condado de Oliva en manos de su hijo, donde moriría en $1596^{75}$.

Tras la muerte de la duquesa el palacio deja de ser habitado por sus dueños, sufriendo cierto abandono. Este hecho hace que prácticamente no sufra modificaciones importantes a partir de esta fecha.

\section{EL SIGLO XVI}

Aunque las primeras obras de construcción del Palacio se produjeron a partir del siglo $\mathrm{XIV}^{76}$, la gran remodelación del Palacio Condal de Oliva tuvo lugar en la primera mitad del siglo XVI, por iniciativa del segundo conde de Oliva, Serafín de Centelles i Riu-Sec; el análisis del contexto histórico, político, social, demográfico, jurisdiccional y económico de este siglo nos ayudará a poner en contexto la época en la que el Palacio de Oliva alcanza su esplendor tanto a nivel arquitectónico como político: es el momento en el que se convierte en el centro del poder de los señores de Centelles i Riu-Sec.

\footnotetext{
${ }^{74}$ Felip Sempere, V. Óp. cit. pp. 297-300.

${ }^{75}$ Camarena Mahiques, J. (1988). De la historia de oliva y Rebollet. En Cardona Miralles, S. (Ed.). Iniciación a la Historia de Oliva (2- Ed.). Oliva, Valencia: Publicaciones del Ayuntamiento de Oliva. pp. 192.

${ }^{76}$ Gavara Prior, J. y E. Muller, P. (2013). El Palacio Condal de Oliva. Catálogo de los planos de Egil Fischer y Vilhelm Lauritzen. Oliva, Valencia: Ajuntament de Oliva. pp. 35.
} 


\subsection{Contexto histórico y político}

A comienzos del siglo $\mathrm{XVI}$, la estructura social del Reino de Valencia era piramidal y estamental. La realeza, la nobleza y el clero eran grupos privilegiados. Por debajo se situaban los campesinos, los burgueses y las clases populares de las ciudades. Estas últimas estaban sometidas a un régimen señorial que les obligaba a entregar parte de su producción o cosechas. La agricultura era la principal fuente de riqueza y, por ello, la posesión de tierras otorgaba a los grupos privilegiados rentas y poder. No obstante, la mayoría de las propiedades, del clero, de los nobles o de los consejos (ayuntamientos) estaba amortizada, llamada en "manos muertas", por lo que no se podían comprar ni vender. Uno de los ejemplos era la creación de los mayorazgos, que vinculaban la propiedad de los bienes al título nobiliario, que lo heredaba el primogénito pero no podía dividirlo ni venderlo, sólo administrarlo. Esto impedía el movimiento económico, ya que la principal fuente de recursos estaba inmovilizada. Durante este periodo la mayor parte de la población era pobre y analfabeta ${ }^{77}$.

Fernando II El Católico era el rey de Aragón desde 1479, y por tanto del Reino de Valencia, que se establecía como un reino independiente y disponía de sus propias cortes, leyes-furs, monedas, pesos o medidas que habían sido otorgados por el rey Jaume I tras la reconquista.

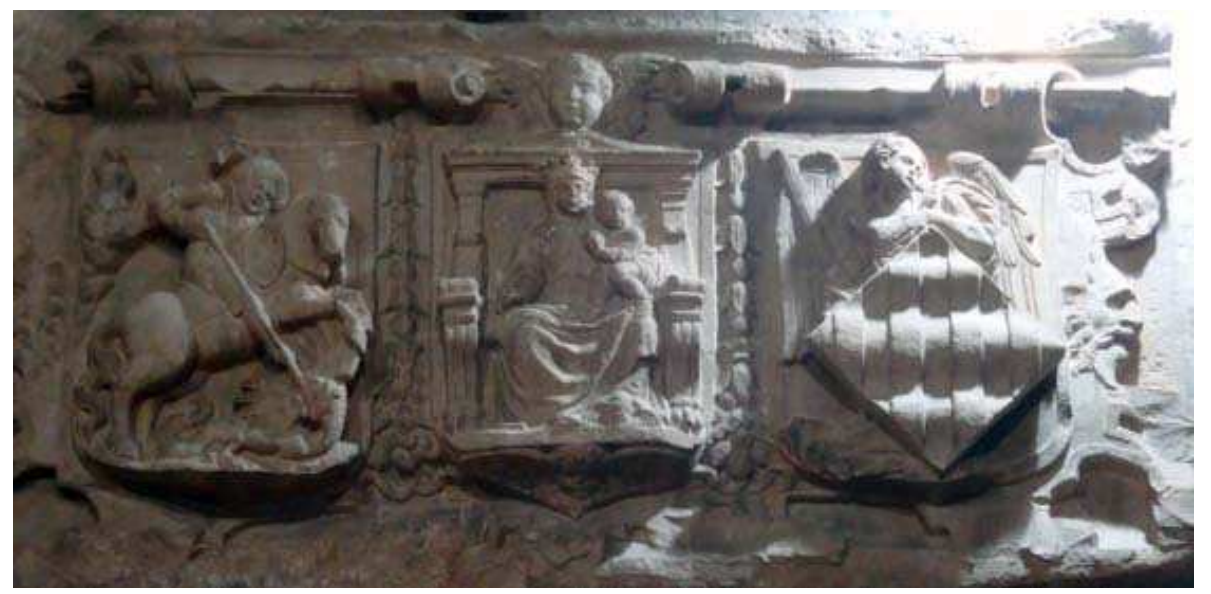

Figura 26. Relieve representando los tres estamentos de Les Corts. Patio del Palau de la Generalitat Valenciana.

Las Cortes Valencianas, creadas por Jaume I en 1261, eran convocadas por el rey para tratar los asuntos de Estado y estaban divididas en tres brazos o estamentos: el brazo eclesiástico (arzobispos, obispos, maestres o lugartenientes de las órdenes, abades, priores, comendadores, etc.), el brazo militar o noble (caballeros y nobles) y el brazo real o popular

\footnotetext{
${ }^{77}$ Máñez Pitarch, M. J. (2014). La Arquitectura religiosa renacentista en tierras del Maestre: la Iglesia de Nuestra Señora de la Asunción de Vistabella del Maestrazgo. (Tesis). Universitat Politècnica de València, Valencia, España. pp. 74.
} 
(representantes de las ciudades o villas de realengo que no pertenecían ni a señoríos ni a órdenes militares). Las funciones principales de las Cortes eran el juramento del rey de los Fueros, privilegios y libertades, y la fidelidad de los estamentos representados en Cortes al rey, así como la financiación del rey y del reino, y la atención a diversas peticiones de los diferentes brazos. Si las peticiones se realizaban por parte de los tres brazos, se aprobaban como leyes universales: fueros (furs) y si sólo lo solicitaba alguno de los brazos o estamentos se denominaban "actos de corte" y sólo obligaban al estamento que lo había presentado $^{78}$. Además, las Cortes debían velar por el cumplimiento de los Fueros.

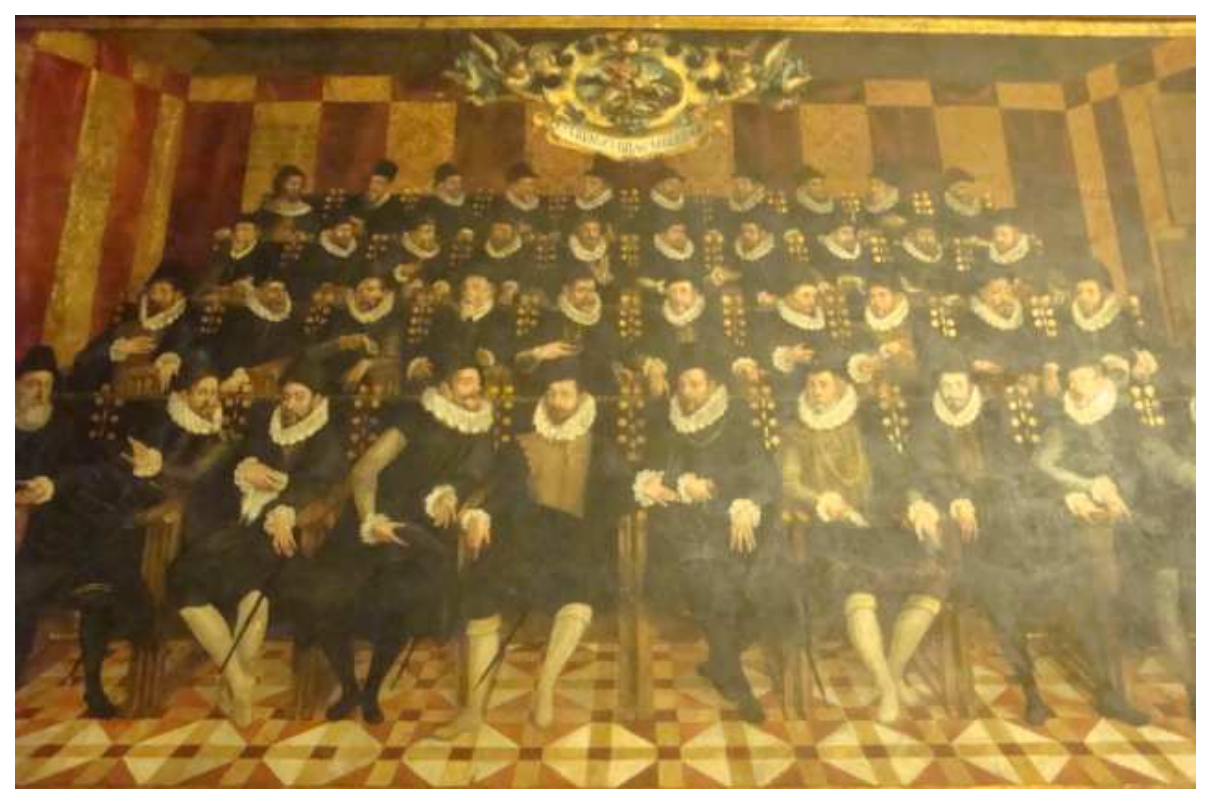

Figura 27. Representantes del Brazo militar en Les Corts. Sala Nova. Palau de la Generalitat Valenciana.

Las peticiones, en la mayoría de los casos, iban encaminadas a mejorar las condiciones de vida de la nobleza y el clero en detrimento de la de sus vasallos. En las Cortes se solicitaba desde el reconocimiento de la nobleza para algunos individuos y grupos eclesiásticos, hasta la autorización real de la distribución de diezmos o primicias o la exención de impuestos ${ }^{79}$. Las convocatorias de Cortes fueron decayendo a lo largo de los años desde su creación en tiempos de Jaume I. En el siglo XVI, por ejemplo, sólo se celebraron nueve reuniones de Corts y todas ellas tuvieron lugar en Monzón (Aragón), a pesar de que los Fueros determinaban que se debían celebrar cada tres años y en territorio valenciano. Así, las Cortes se reunieron una vez en 1510, al final del reinado de Fernando II el Católico, seis

\footnotetext{
${ }^{78}$ Giménez Chomet, V. (1993) La representatividad política en la Valencia foral. Revista Estudis, no18. pp. 7-28.

${ }^{79}$ Carbonell Boria, M.J. (1995).Las Cortes Forales Valencianas. Cortes Valencianas. Corts: Anuario de derecho parlamentario, no1. pp. 61-78.
} 
durante el reinado de Carlos I $(1528,1533,1537,1542,1547$ y 1552$)$ y dos veces durante el reinado de Felipe II (1563 y 1585$)^{80}$.

Por otra parte, en 1418 se creó la Diputació del General del Reino de Valencia como una comisión delegada de les Corts que se encargada de administrar el impuesto aprobado en Cortes denominado "generalitats", de ahí que esta institución fuera conocida también con el nombre de "Generalitat". Se convirtió en un órgano permanente y la integraban seis diputados (dos por cada brazo) ${ }^{81}$ que se elegían cada tres años. A finales del siglo XV Fernando II anuló el sistema de elección y designó oficiales reales para ocupar los diputados reales ${ }^{82}$.

Desde principios del siglo XV, cuando el rey estaba ausente del reino, hecho muy frecuente, la más alta representación de la Corona la ostentaba el lloctinent general (lugarteniente general), que era nombrado por el rey entre los miembros de la familia real y, más tarde, entre los miembros de la alta nobleza ${ }^{83}$.

En 1520, bajo el Reinado de Carlos I, se estableció el virreinato de Valencia, nombrándose virrey a D. Diego Hurtado de Mendoza y Lemos. Se mantuvieron las gobernaciones, pero éstas perdieron gran parte de su peso político. Esta figura sustituía a la de lugarteniente general y dio origen a la Guerra de Germanías, ya que se interpretó como un gesto centralizador de la corona.

Entre 1536 y 1538 el cargo de Virreina de Valencia lo ostentó Germana de Foix, la que había sido esposa de Fernando II el Católico. El Reino de Valencia estaba dividido en dos gobernaciones: Valencia y Orihuela. La Gobernación de Valencia estaba, a su vez, dividida en tres territorios: la Governació dellà Xúquer o de Xàtiva, para la zona comprendida entre Jijona y el río Júcar; la Governació dellà Uixó o Castellón, para el territorio al norte del río Uixó; y el gobernador de Valencia, que tenía jurisdicción entre el Júcar y el Uixó y ejercía la supervisión de sus lugartenientes en Xàtiva y Castellón. El condado de Oliva, por tanto, formaba parte de la gobernación de Xàtiva y estaba representado en las Cortes por el brazo militar, al tratarse de un señorío.

\section{Las Germanías}

Uno de los hechos imprescindibles para conocer el contexto histórico y político del primer tercio del siglo XVI en el Reino de Valencia y, más concretamente, en la Comarca de La Safor fueron las revueltas de Germanías.

Durante el reinado de Fernando el Católico se aprobó la germanía. Se trataba de una asociación armada del pueblo para defenderse de los piratas berberiscos. La huida de los nobles de la ciudad de Valencia debido a una epidemia de peste hizo que los gremios y las

\footnotetext{
${ }^{80}$ Salvador Esteban, E. (1988). Valencia en el siglo XVI. En Manuel Cerdá. Historia del pueblo valenciano. Valencia: Levante. pp. 401.

${ }^{81}$ Furió, A. (1995). Història del País Valencià. Valencia: Edicions Alfons el Magnànim. pp.179.

${ }^{82}$ Furió, A. (1995).Óp. cit. pp. 179.

${ }^{83}$ Furió, A. (1995).Óp. cit. pp. 177.
} 
clases medias se hicieran progresivamente cargo de un representante de cada gremio para regir la capital. Los nobles, en cuya comisión se encontraba Serafín Centelles, pidieron al rey Carlos la anulación de estos privilegios y estaban dispuestos a resistir con armas el levantamiento popular. En la Junta de los Trece se fueron imponiendo los extremistas y no se pudo controlar la situación.

En la comarca de La Safor la situación era de tranquilidad debido al mejor nivel de vida debido a la industria de la cañamiel; hasta que un grupo de veintitantos gandienses se alzaron y Juan de Borja los condenó a morir descuartizados. Los condenados huyeron Valencia y volvieron con refuerzos a Gandía para derrocar a los señores. El duque pidió ayuda a Serafín de Centelles para combatir a los agermanados que estaban creciendo en efectivos a base de moriscos y mercenarios castellanos. El 24 de julio de 1521 hubo una reunión en el palacio de Gandía y los nobles convencieron al virrey para combatirlos a campo abierto y éste puso al Conde de Oliva el mando de las tropas. El 25 de julio se produjo una batalla cerca del Azud de Palma, sobre el río Vernisa, en la que se impusieron los agermanados. Incapaces de defender sus posesiones, los señores pusieron rumbo a Denia donde embarcaron hacia Peñíscola. Tanto el palacio de Gandía como el de Oliva fueron saqueados, destrozando archivos, escudos y todo lo que tuviera que ver con los señores. Posteriormente recorrieron la comarca bautizando a todos los mudéjares.

A pesar de esta derrota, pronto las topas nobiliarias y reales acabaron con la revuelta, produciéndose una gran represión contra los agermanados; algunos fueron ajusticiados y se confiscaron muchas multas y bienes. Serafín de Centelles percibió una compensación de 7.000 ducados, aunque se desconoce cuánta de esta cantidad correspondería pagar a sus súbditos ${ }^{84}$.

\section{La piratería}

Otro de los hechos de suma importancia en el contexto histórico del siglo XVI en el Reino de Valencia fueron los saqueos y ataques de los piratas en las costas mediterráneas que se habían venido produciendo desde antaño. Durante la época cristiana estos piratas eran berberiscos, genoveses e incluso castellanos, en ciertos momentos de discordia entre los reinos. En este momento el principal peligro para las costas valencianas procedía de los puertos granadinos y del norte de África.

La actividad de estos piratas musulmanes consistía en saquear pueblos, robar y quemar cosechas y tomar prisioneros por los que luego pedían un rescate o vendían como esclavos. Otro de los objetivos, a partir de la sublevación de germanías, era e liberar a los moriscos de la presión de los cristianos viejos, ya que perdieron parte de sus libertades y sufrían persecución social y religiosa.

El pirata Lair-Ed-Din, conocido como "Barbarroja”, supuso una gran amenaza para las costas de La Safor; en 1529 desembarcó en las playas de Oliva saqueando y destruyendo todo a su paso y llevándose con él a 200 moriscos de forma voluntaria hacia Argel. Serafín de Centelles, para intentar recuperar esta gran merma de vasallos, contrató los servicios del

${ }^{84}$ Camarena Mahiques, J. (1988). Óp. cit. pp. 173-177. 
Almirante Portuondo quien, al frente de 8 naves, intentó cortar el paso a los piratas. La expedición fue un desastre ya que se hundieron 7 de las naves, muriendo el propio almirante a manos de los piratas. Posteriormente, realizaron otra operación en la playa de Piles, aunque esta fue abortada por Francisco Gilabert.

Barbarroja, ya con base en Túnez, organizó otra gran expedición, esta vez a Cullera, con una escuadra de 17 naves. Acudieron a combatirlo Juan de Borja y Francisco Gilabert de Centelles con sus tropas (y otras venidas de Valencia y de la Valldigna). A pesar de las mermas que causaron sobre los piratas, éstos consiguieron embarcar no menos de 300 moriscos que estaban esperando la visita de Barbarroja. El conde de Oliva fue herido en la cara por una flecha ${ }^{85}$

La conquista de Túnez redujo la actividad de los corsarios, aunque el fracaso de la conquista de Argel incrementó los ataques. En 1550 el corsario Dragut, lugarteniente de Barbarroja, volvió a Cullera llevándose consigo a más moriscos y a cristianos como cautivos. En esta batalla fue herido de muerte Francisco Gilabert. Los sucesivos ataques no disminuyeron hasta la victoria de Lepanto (1571).

Desde el siglo XIV se había creado un sistema de alerta desde Orihuela hasta el Ebro que funcionaba mediante la intercomunicación de las ciudades costeras a partir de señales de fuego, campanadas de campanario a campanario o correos a caballo. Para mejorar este sistema de comunicación se levantó toda una infraestructura de torres vigía a lo largo de la costa. En esta zona se construyó en 1576 la torre de Piles, que servía de enlace entre Oliva y Gandía, así como El Molinell, que servía de enlace entre Oliva y Denia.

Para los mudéjares, la piratería era una oportunidad de liberación ya que muchos de ellos deseaban marcharse ${ }^{86}$.

\subsection{Contexto jurisdiccional y económico}

En la segunda donación realizada por Jaume I al caballero Carroz, fechada en 1250, se especifica que éste le concede la propiedad "libre y franca de toda carga y derecho en lo que a mi respecte para siempre, y la podáis trasmitir a cualquiera, con los mismos derechos, excepto a la Iglesia y personas eclesiásticas". Esta cláusula no tenía obro objeto que evitar la acumulación de bienes en "manos muertas", es decir, exentas del pago de tributos. No se establecen los derechos sobre las tierras y las personas que las pueblan, ni por qué leyes se regirán. Sí, no obstante, se detallan los derechos e impuestos que el Capitán podrá recibir; y, en cuanto a la justicia, le cede el ejercicio de la redención pecuniaria de las penas, pero no el poder establecer o redimirlas. Aunque no se detallan, se da por hecho que la aceptación del señorío implica la aceptación de las obligaciones de hueste y cabalgada, pago de donativos, vasallaje, etc. ${ }^{87}$.

\footnotetext{
${ }^{85}$ Camarena Mahiques, J. (1988). Óp. cit. pp. 177-178.

${ }^{86}$ Camarena Mahiques, J. (1988). Óp. cit. pp. 179-180.

${ }^{87}$ Camarena Mahiques, J. (1988).Óp. cit. pp. 158-160.
} 
Los condes de Oliva nombraban a los batlles de los cristianos en Oliva, La Font d'en Carròs $y$, a través de su batlle general, gobernaban a los mudéjares y nombraban al justicia de las dos villas cristianas. Además, los jurados (el equivalente a los actuales concejales) eran elegidos por los habitantes ${ }^{88}$. Sus ingresos procedían de sus propiedades particulares, del canon de uso que debían pagar sus vasallos por los hornos, molinos y el trapiche, de los censos y partición de las tierras de sus súbditos o de las transmisiones patrimoniales por venta o herencia. Los mudéjares tenían que pagar, además, impuestos especiales para el mantenimiento del culto en la mezquita y poseían también derechos para fijar condiciones a nuevos pobladores y para explotar nuevas tierras ${ }^{89}$.

La agricultura era la base fundamental de la economía de la zona, por lo que el riego fue siempre una preocupación de los gobernantes. El Azud d'En Carròs existía ya a finales del siglo XIV, mandado construir por alguno de los señores de Carròs. La extensa red de acequias que derivaban de las del Rebollet se construyó a principios del siglo XV con la introducción del cultivo de la caña de azúcar, por tratarse de un cultivo de regadío. Este cultivo había sido introducido en la comarca a finales del siglo XIV. Al principio no pagaban impuestos en base a un privilegio de Jaume I que trataba de fomentar este cultivo, pero hubo quejas del obispo de Valencia y en 1438 se produjo una sentencia a favor del cabildo.

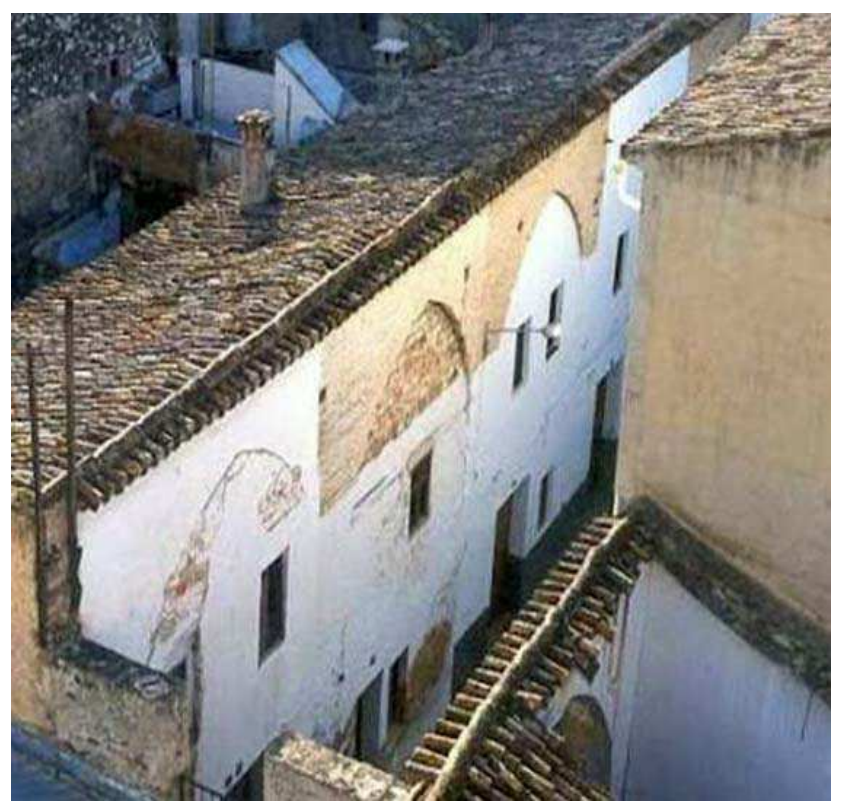

Figura 28. Arcadas del antiguo Ingenio de Oliva en la Calle Enginy, Oliva. Fuente: Borja Arce.

Una de las causas que fomentaron el cultivo del azúcar fueron las conquistas turcas en el este del Mediterráneo, que interrumpieron las rutas comerciales de las especias, así como el clima favorable de la Conca de La Safor, que favorecería su rápido desarrollo. Los

${ }^{88}$ Camarena Mahiques, J. (1988).Óp. cit. pp. 186-187.

${ }^{89}$ Camarena Mahiques, J. (1988).Óp. cit. pp. 160 y 186-187. 
ingresos por este cultivo supusieron unas rentas muy saneadas, lo que les convirtió en una de las familias más poderosas de la economía valenciana ${ }^{90}$.

A finales del siglo XV se inició en esta zona el cultivo de la morera y la cría del gusano de seda, también se desarrolló la industria de los trapiches, la dulcería y la industria de hilados y tejidos de seda, sirviendo de base una actividad comercial con una proyección internacional ${ }^{91}$.

El siglo XVI se caracterizó por ser un periodo de expansión económica en todo el occidente europeo. Este periodo significó para Oliva un periodo de esplendor económico debido a la excelente producción de caña de azúcar, llegando a ser la segunda ciudad en rentas del Reino de Valencia después de Gandía.

En cuanto al comercio, existía una gran actividad por mar entre el puerto de Oliva y el de Valencia, comercializándose principalmente los productos de la huerta. El puerto de Oliva tuvo también un tráfico internacional, aunque para poder exportar ciertos productos, se requería licencia del batlle general y, a través de este registro, sabemos que en el año 1404 el Puerto de Oliva contaba con 8 licencias. A través de su puerto se daba salida a productos locales, principalmente el azúcar que se producía en Oliva, o el jabón y también otros productos de secano del interior, para lo que Oliva se alió con la ciudad de Xàtiva. Existió cierta rivalidad entre los puertos de Oliva y Denia, en el sur del Reino. La actividad de los puertos valencianos se vio disminuida hacia 1530 por los constantes ataques de la piratería berberisca. Durante el siglo XVI, cuando la Corona de Aragón estableció relaciones con el norte de África, tanto Oliva como Denia sirvieron como puerto de escala para los barcos que partían desde Valencia con este destino ${ }^{92}$.

\subsection{Contexto social y demográfico}

El siglo XVI supuso para el occidente europeo una fase de expansión económica. Dentro del Reino de Valencia el ducado de Gandía y el condado de Oliva tuvieron un mayor desarrollo económico debido al excelente rendimiento del cultivo de la caña de azúcar.

La población de Oliva estaba dividida en dos núcleos: la villa y la morería, con una población mixta y una convivencia tolerante entre ambas comunidades que empeoró tras la guerra de Germanías, cuando los agermanados ${ }^{93}$ sometieron a los mudéjares. Tras la conversión de los moriscos cada uno de los núcleos tenía un Consell, que ejercía sus funciones de manera independiente. Esto ocasionó problemas a los condes, ya que los pobladores de la villa

90 Mestre Sanchis, A. (1988). La economía Olivense. En Cardona Miralles, S. (Ed). Iniciación a la Historia de Oliva (2a Ed.). (pp. 273-296). Oliva, Valencia: Publicaciones del Ayuntamiento de Oliva. pp. 274-275.

${ }^{91}$ Camarena Mahiques, J. (1988). Óp. cit. pp. 188-189.

92 Olaso i Sendra, V. (2015). Oliva en "Valencia, puerto mediterráneo en el siglo XV (1410-1525)", de Jaqueline Guiral. Cabdells: Revista d'investigació de l'Associació Cultural Centelles i Riu-Sec, Núm 13. pp. 41-45.

93 Pons Fuster, F. (1988). Estudio demográfico de Oliva. (Siglos XVI-XX). En Cardona Miralles, S. (Ed). Iniciación a la Historia de Oliva (2a Ed.). (pp. 224-272). Oliva, Valencia: Publicaciones del Ayuntamiento de Oliva. pp. 248. 
consideraban que ambas poblaciones, ya cristianas, formaban un todo; estos, por el contrario, preferían contener unidades políticas más reducidas ${ }^{94}$.

Los historiadores afirmarán que en el siglo XVI hubo un aumento progresivo de la población, aunque Lapeyre (1959) mantiene la teoría de que hubo una cierta depresión demográfica en el Reino de Valencia entre 1527 y 1563. En Oliva, en el censo realizado en 1510 con motivo de las Cortes, se establece un censo de 710 casas para Oliva y su morería. A pesar de la huida de 200 moriscos hacia Argel en 1529, la tendencia fue positiva. En 1609 la población aproximada era de 385 casas en la villa y $450^{95}$ en el arrabal, lo que hacía un total de 835 , suponiendo un incremento de 135 casas durante un siglo ${ }^{96}$. Según estos datos, la población de Oliva experimentó un incremento de un 19\% durante todo el siglo XVI, lo que supone un 2 por mil anual. Se trata de un incremento no muy significativo, aunque teniendo en cuenta las huidas de moriscos y la epidemia de peste negra sufrida durante este siglo, hay que interpretarlo como un dato positivo.

\begin{tabular}{|c|c|c|c|c|c|c|c|c|c|c|}
\hline & \multicolumn{10}{|c|}{ OLIVA Y REBOLLET: CENSOS DE POBLACIÓN } \\
\hline & $1490^{\prime}$ & $1510^{2}$ & $1512^{3}$ & $1520^{4}$ & $1527^{\circ}$ & $1563^{\circ}$ & $1572^{\prime}$ & $1602 *$ & $1609^{\circ}$ & $1610^{10}$ \\
\hline \multicolumn{11}{|l|}{ OLIVA } \\
\hline Villa & & & & 510 & 220 & & 267 & & 385 & 300 \\
\hline Moreria & & & & $200^{11}$ & 300 & $186^{12}$ & 200 & 372 & $350^{13}$ & 400 \\
\hline Total & & $710^{14}$ & 702 & 710 & 520 & & 467 & & 735 & 700 \\
\hline \multicolumn{11}{|l|}{ REBOLLET } \\
\hline LA FONT & & & & & 70 & 36 & & 37 & 160 & 160 \\
\hline Villa & & & & & 70 & 30 & & 26 & 160 & 160 \\
\hline Ixber & & & & & & 6 & 1 & 11 & & \\
\hline RAFELCOFER & & & & & & 51 & 69 & 96 & 126 & \\
\hline Rafelcofer & & & & & & 19 & 60 & 48 & 66 & \\
\hline Alcudiola & & & & & 30 & 32 & 9 & 48 & 60 & \\
\hline ALQUERIA & & & & & 40 & 30 & & 61 & 66 & \\
\hline A. Condesa & & & & & 20 & 14 & & 22 & 30 & \\
\hline A. Frailes & & & & & 20 & 16 & & 39 & 36 & \\
\hline POTRIES & & & & & 45 & 38 & 63 & 73 & 108 & \\
\hline BENIFLA & & & & & 20 & 12 & & 18 & 25 & \\
\hline T. Cristianos & & & & & 70 & & & & 160 & 160 \\
\hline T. No Cristianos & & & & & 135 & 167 & & 285 & 325 & \\
\hline Total & & 306 is & 310 & & 205 & & 235 & & 485 & \\
\hline Total CRistianos & & & & & 290 & & & & 545 & 460 \\
\hline TOtal No CRISTIANOS & & & & & 435 & 353 & & 657 & 675 & \\
\hline TOTAL & 822 & 1.016 & 1.012 & & 725 & & 702 & & 1.220 & \\
\hline
\end{tabular}

Figura 29. Datos de población de Oliva y Rebollet desde 1490 a 1610 según datos históricos. Fuente: José Camarena Mahiques ${ }^{97}$.

\footnotetext{
${ }^{94}$ Camarena Mahiques, J. (1988). Óp. cit. pp. 187.

${ }^{95}$ Boronat otorga 350 casas a la morería. Sin embargo, el memorial sobre el reparto de tierras tras la expulsión las cuantifica en 450. Pons Fuster da este segundo dato como más fiable a partir de la evolución de la población en la Parroquia de San Roque.

${ }^{96}$ Pons Fuster, F. (1988). Óp. cit. pp. 248.249.

${ }^{97}$ Camarena Mahiques, J. (1988).Óp. cit. pp. 187 y 240.
} 


\section{Los moriscos}

La población morisca fue muy importante tanto en la población de Oliva como en todo el señorío de Oliva y Rebollet, llegando a suponer dos tercios de la población total. La población cristiana habitaba dentro del perímetro de la muralla y la población morisca en el arrabal.

Sus condiciones dependían de las circunstancias, a veces tenían libertad para emigrar a la Berbería o precisaban un permiso del Batlle General para viajar a Castilla o Granada con fines comerciales. Pagaban más impuestos que los cristianos y estaban protegidos por las leyes contra el robo o la injusticia de sus señores, aunque esto no impedía los saqueos y matanzas en las morerías, aunque luego se hiciera justicia.

Sin embargo, se realizaron esfuerzos para evangelizarles, aunque no se les obligaba a convertirse a la fuerza. Hablaban su propia lengua, el algarabía, y también el valenciano para entenderse con los cristianos. Hubo iniciativas para promover los matrimonios mixtos como la promovida por Fernando el Católico, que concedió a la duquesa de Gandía 1.000 ducados para casar cristianos y cristianas, "lindos" con confesas y confesos. El proceso de fusión fracasó y fue creciendo el odio y los rumores de expulsión que el emperador Carlos $V$ intentó calmar mediante un pregón (1517) desmintiendo dicho rumor y haciendo ver el daño que esto supondría para todo el reino.

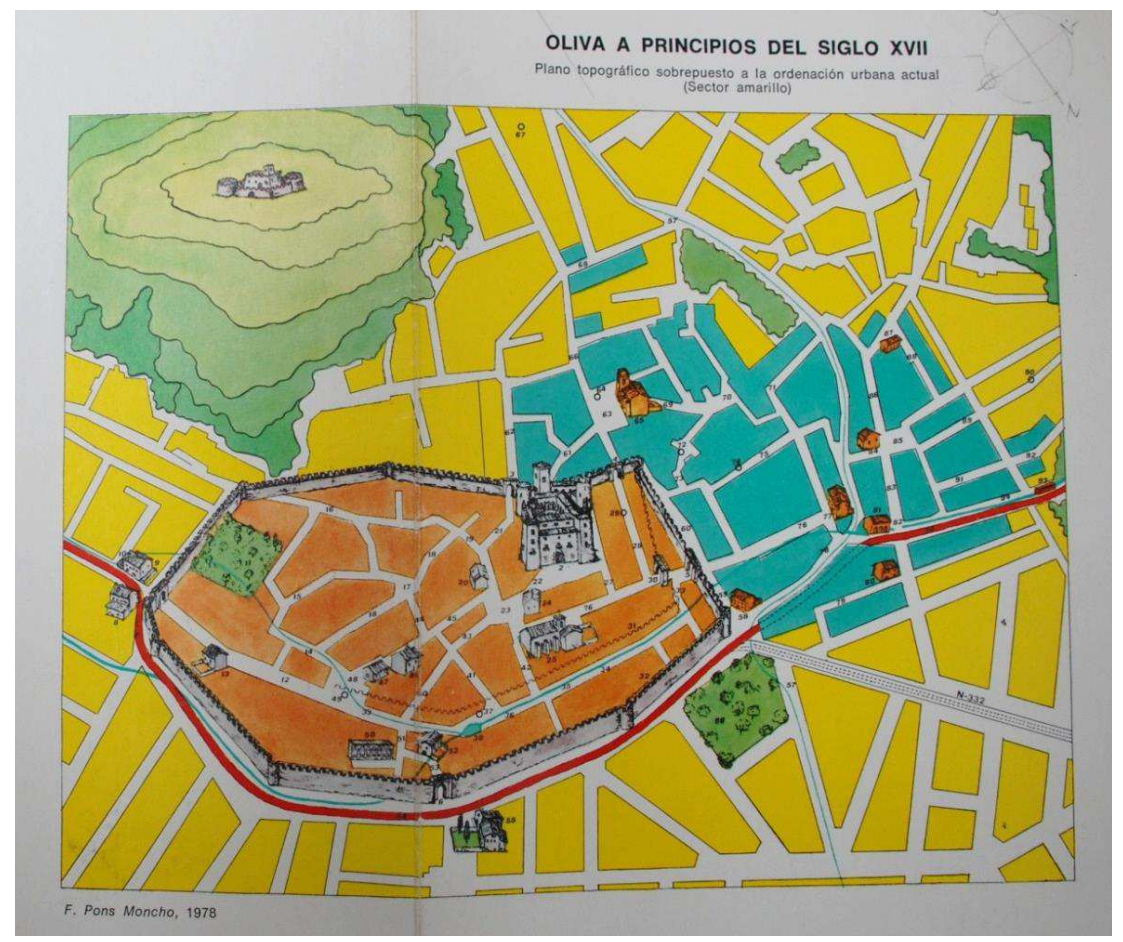

Figura 30. Plano de Oliva (siglo XVII). En naranja la villa y en azul el arrabal. Fuente: F. Pons Moncho $(1978)^{98}$.

\footnotetext{
98 Brines Bañó, F. (1988). El rostro de Oliva. En Cardona Miralles, S. (Ed). Iniciación a la Historia de Oliva (2a Ed.). (pp. 17-32). Oliva, Valencia: Publicaciones del Ayuntamiento de Oliva.
} 
Durante la revuelta de Germanías en la comarca de La Safor fueron bautizados a la fuerza aproximadamente 4.000 moriscos, prácticamente todos ellos. Posteriormente, en 1525, el emperador ordenó la conversión de todos los musulmanes, reprendiendo a Serafín de Centelles por no haber evitado que parte de sus súbditos hubieran huido a la Sierra de Bernia al no aceptar dicha ley. Muchos religiosos se oponían a esta conversión forzada, ya que no tendría un efecto real sobre su fe, y los señores y jurados también se oponían ya que suponía poder cobrarles menos impuestos.

Esto hizo que en las Cortes de 1528 se reconocieran sus derechos y se prohibiera a los mudéjares moverse libremente, lo que favoreció que los nobles promovieran las conversiones, por un lado, y lo que hizo que muchos moriscos huyeran a África con los piratas, por otro. Tras esta teórica conversión, la mezquita de la morería de Oliva se transformó en la iglesia de San Roque, convertida en parroquia en 1534. La morería adquirió el estatus de municipio, lo que no gustó a los vecinos de la Villa ${ }^{99}$.

El rey Felipe III ordenó la expulsión de los moriscos y consiguió la aprobación del Consejo de Estado el 4 de abril de 1609. Esta se llevó a cabo de forma escalonada entre 1609 y 1613. Los primeros expulsados fueron los del Reino de Valencia, cuyo decreto no se hizo público hasta el 22 de septiembre de 1609. El virrey y arzobispo Juan de Ribera reunió en Valencia a todos los señores de los moriscos, entre los que se encontraba Carlos de Borja. Éste se reunió en Gandía el 24 de septiembre con los principales representantes de los moriscos y les comunicó la decisión irrevocable.

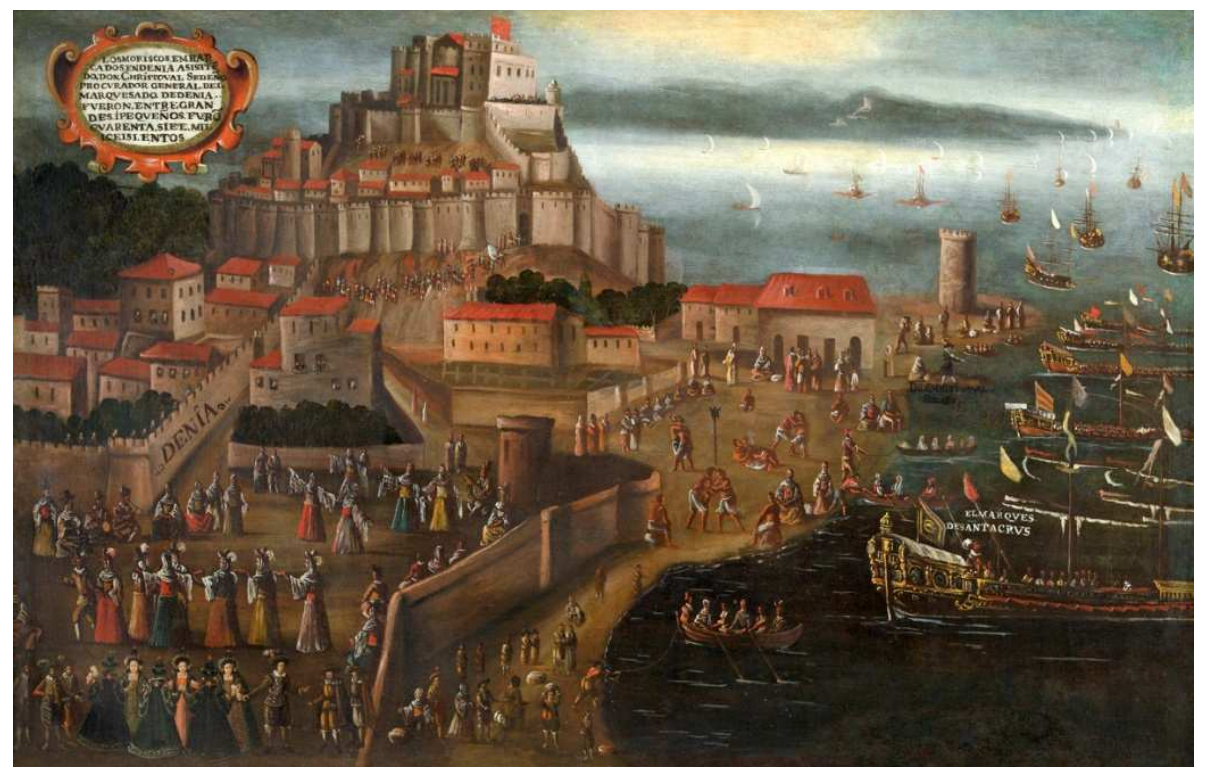

Figura 31. Expulsión de los moriscos en el puerto de Denia. Pintura de Vicente Mostre (1613). Colección Bancaja. Fuente: Alonso de Mendoza.

${ }^{99}$ Camarena Mahiques, J. (1988). Óp. cit. pp. 181-185 y 196-200. 
El día 28 de septiembre de 1609 partieron los moriscos de Oliva hacia el puerto de Denia, acompañados por Carlos de Borja, y el 30 de septiembre y 2 de octubre partieron hacia Orán en 17 galeras napolitanas contratadas para tal fin.

El censo más completo llevado a cabo después de la expulsión cuantifica la población de Oliva (en este caso, no se distingue entre la villa y el arrabal) en 361 casas. Esto supone un decremento de 339 de acuerdo con los datos de Boronat; y de 474, de acuerdo con la teoría de Pons Fuster ${ }^{100}$. Independientemente del baile de cifras podemos afirmar que la población de Oliva tras la expulsión de los moriscos se redujo en un 40 y $48 \%$ de su población anterior. Esto supuso una gran merma de población que afectó a la producción ya que faltaba mano de obra para recoger las cosechas y preparar los cultivos, provocando un ahogo económico para la casa Borja-Centelles, ya que en sus territorios la riqueza se basaba principalmente en el trabajo de éstos, y eran mano de obra especializada en las labores que re requerían. Los gobernantes confiaron en repoblar con cristianos traídos de otros lugares, pero este efecto llamada no resultó fructífero ${ }^{101}$.

\subsection{Los pesos y medidas valencianas}

Como se ha comentado anteriormente, tras la Reconquista, el rey Jaume I otorgó al Reino de Valencia unas leyes propias, los fueros, y con ellas se instauró un sistema de medidas y pesos que debía ser igual en la ciudad de Valencia y en todas las villas, castillos y demás lugares del Reino ${ }^{102}$. Además, en los fueros se establecieron diversas medidas de peso, de volumen, de longitud y de superficie agraria y sus equivalencias, las cuales regían en el Reino de Valencia. La lectura de Los Fueros es difícil de entender, si bien ha sido aclarada en textos posteriores ${ }^{103}$. Las medidas de longitud eran el palmo, la alna o vara, la braza y la cuerda. Las equivalencias eran las siguientes:

- Una alna o vara $=4$ palmos

- Una cuerda $=45$ alnas o varas $=20$ brazas; por tanto: 1 braza $=9$ palmos

Las medidas de superficie eran la fanegada, la cahizada y la yobada. Las equivalencias eran las siguientes:

- Una yobada $=6$ cahizadas $=36$ fanegadas; es decir, 1 cahizada $=6$ fanegadas.

\footnotetext{
${ }^{100}$ Camarena Mahiques, J. (1988). Óp. cit. pp. 187 y 240. Pons Fuster, F. (1988). Óp. cit. pp. 248.249.

${ }^{101}$ Camarena Mahiques, J. (1988). Óp. cit. pp. 181-185 y 201-202.

102 Máñez Pitarch, M. J. (2014). La Arquitectura religiosa renacentista en tierras del Maestre: la Iglesia de Nuestra Señora de la Asunción de Vistabella del Maestrazgo. (Tesis). Universitat Politècnica de València, Valencia, España. pp. 81.

${ }^{103}$ Canga Argüelles, J. (1827). Diccionario de hacienda para el uso de los encargados de la suprema dirección de ella: J L M N O P. Volumen 4. Madrid. pp. 336 y Corachán, J. B. (1719). Arithmetica demostrada theorico-práctica para lo mathematico y mercantil explicanse las monedas, pesos y medidas de los Hebreos, Griegos y Romanos, y de estos Reynos de España, conferidas entre sí. Barcelona.
} 
Por su parte, la relación entre las medidas de longitud y las medidas de superficie eran las siguientes:

- Media fanegada: $10 \times 10$ brazas $=100$ brazas cuadradas

- Una fanegada, por tanto, eran 200 brazas cuadradas, o bien $10 \times 20$ brazas $=200$ brazas cuadradas.

- Una jovada, $3 \times 6$ cuerdas $=60 \times 120$ brazas $=7.200$ brazas cuadradas ${ }^{104}$.

En los fueros valencianos también se establecía el oficio de Mustaçaff, Almudaçaff o Almotacén de la ciudad de Valencia ${ }^{105}$. Su misión era velar por el cumplimiento de los pesos y medidas, la calidad de los productos, la limpieza de la ciudad, y castigar las faltas y engaños. Era un cargo que se ostentaba durante un año, y lo elegían los prohombres y cortes de la ciudad de Valencia en el día de San Miguel de septiembre, jurándose el cargo sobre los Evangelios. Este oficio se extendió a todas las villas, castillos y lugares del Reino. Los reyes de Valencia posteriores a Jaume I (Pedro I, Martín el Humano, Jaume II o Pedro II) matizaron el oficio del Mustaçaff, ordenando que "ni batlles, ni gobernadores pudieran importunar el cargo del Mustaçaf o que los judíos o moros no podían tener un oficial Almotacén propio, siendo éste único para toda la ciudad, villa o lugar"106.

En la ciudad de Valencia la sede del Almotacén estuvo situada tras la iglesia de Santa Catalina, desde 1372 hasta el siglo XVI, donde se custodiaban la vara de hierro y la barcilla de piedra originales de Jaume I. El símbolo del Mustaçaf era un bastón o caña llamado "junc del Mustaçaf" de 6 palmos de longitud. La primera misión tras jurar el cargo era recibir de su antecesor en el puesto los patrones de peso y medidas para su comprobación y afinado, siguiendo un procedimiento reglamentado. Por esto aparece el oficio de afiladores, que eran los encargados de corregir los defectos de los instrumentos de medida. Además y paralelamente, aparecen también los canadors, cuyo trabajo consistía en la medición de terrenos a partir de una unidad llamada cana. Estas medidas de longitud se continuaron utilizando hasta la entrada en vigor del sistema métrico decimal el 29 de julio de 1849 , rubricado por la reina Isabel II. A partir de este momento se publicaron tablas de equivalencias entre el sistema foral antiguo y el nuevo sistema métrico ${ }^{107}$.

Desde entonces se buscó la equivalencia de las medidas antiguas con las nuevas, estableciéndose que el palmo valenciano equivalía a $23^{108}$ centímetros, y a la vara valenciana 91 centímetros; por tanto, la braza equivalía a 207 centímetros y la cuerda a 4.140 centímetros, es decir, 41,40 metros $^{109}$.

\footnotetext{
${ }^{104}$ València (Regne) (1548). Corts. Fori Regni Valentiae. Rúbrica XXXVIII. Folio CCLXI. Valencia.

105 Chalmeta Gendrón, P. (2008). El almotacén a través de los "Ilibre del Mustaçaf". Universidad de Zaragoza, Aragón en la Edad Media. n20, pp. 203-223.

${ }^{106}$ València (Regne). (1548). Corts. Óp. cit. Libro IX. Folio CCXXXVIII.

107 Máñez Pitarch, M. J. (2014). Óp. cit. pp. 83.

108 Esta equivalencia puede variar sensiblemente de acuerdo con los autores (p. ej., Zaragozá lo establece en 22,65 cm). Máñez Pitarch realiza una comprobación de la ermita de Catí con su protocolo notarial y, en este caso, la equivalencia es de 1 palmo $=23 \mathrm{~cm}$.

${ }^{109}$ Máñez Pitarch, M. J. (2014). Óp. cit. pp. 84.
} 
Además, el sistema utilizado era de base duodecimal, principalmente por el alto número de divisiones elementales $2,3,4,6$, evitando el uso de quebrados ${ }^{110}$, utilizándose como submúltiplos las distintas fracciones del palmo en base a dicho sistema: 1/12, 1/6, 1/4 1/3, $2 / 3$ y $3 / 4$; por lo que las equivalencias en el sistema métrico serían las siguientes:

- $1 / 12$ palmo $=1,92 \mathrm{~cm}$

- $1 / 6$ palmo $=3,8 \mathrm{~cm}$

- $1 / 4$ palmo $=5,75 \mathrm{~cm}$

- $1 / 3$ palmo $=7,7 \mathrm{~cm}$

- $1 / 2$ palmo $=11,5 \mathrm{~cm}$

- $2 / 3$ palmo $=15,3 \mathrm{~cm}$

- $3 / 4$ palmo $=17,3 \mathrm{~cm}$

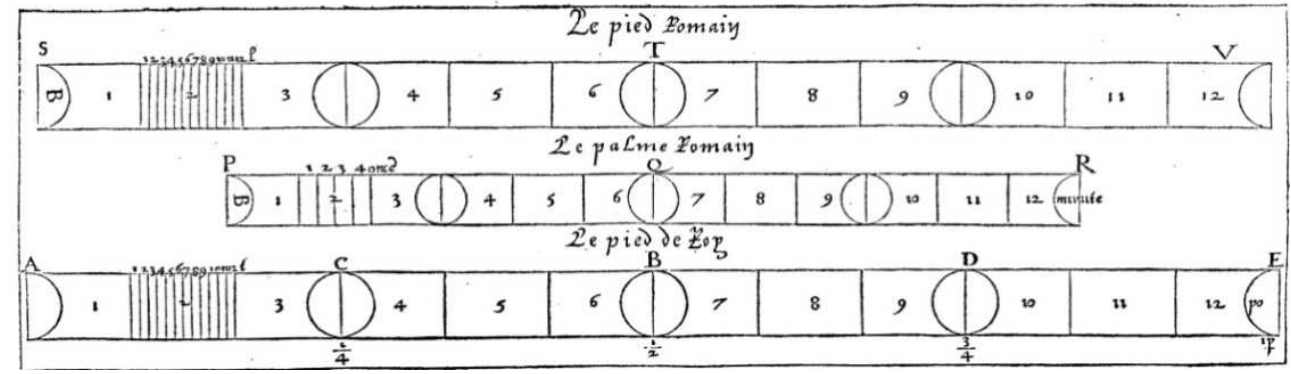

Figura 32. Ejemplo de Sistema Duodecimal. Tratado Philibert De L’Orme. Libro IV. Página 133.

${ }^{110}$ Máñez Pitarch, M. J. (2014). Óp. cit. pp. 222. 



\section{CAPITULO III}

\section{EL CONTEXTO ARQUITECTÓNICO}

\section{INTRODUCCIÓN}

La gran renovación del Palacio Condal de Oliva se produce a principios del siglo XVI. En esta época la arquitectura valenciana ha alcanzado un alto grado de madurez, principalmente a través del arte de la montea o corte de la piedra, desarrollada fundamentalmente por los maestros Francesc Baldomar y Pere Compte.

El primer contacto del nuevo estilo renacentista (originado en Italia) con el Reino de Valencia se produjo con la llegada de los pintores Paolo da San Leocadio y Francesco Pagano en 1472, de la mano del Papa Alejandro VI para pintar los frescos del presbiterio de la Catedral de Valencia. A pesar de la temprana incorporación del nuevo lenguaje renacentista al campo de la pintura, no sucedió lo mismo en los campos de la escultura y la arquitectura. La fuerte inercia de la arquitectura tardogótica mediterránea que se había desarrollado en el sur de Francia y en toda la Corona de Aragón inundó el Reino y, poco a poco, el nuevo gusto "a la romana" fue irrumpiendo en la arquitectura, principalmente en los elementos decorativos, conviviendo con las estructuras y elementos de carácter gótico.

En este capítulo realizaremos una breve introducción al contexto arquitectónico en el que se desarrolló la transformación del Palacio de Oliva, a caballo entre el último gótico y el primer renacimiento.

\section{EL ÚLTIMO GÓTICO EN EL REINO DE VALENCIA}

Durante la segunda mitad del siglo XV se produjo una gran evolución en la arquitectura valenciana que, con grandes obras y maestros en oficios tales como la cantería, la albañilería y la talla del yeso. Pero, sin duda, el campo donde hubo un mayor desarrollo técnico fue en el arte de la estereotomía o corte de la piedra ${ }^{111}$.

Como se ha comentado anteriormente, en el campo de la estereotomía los dos grandes maestros fueron Francesc Baldomar (1425-1463) y su discípulo Pere Compte (1430-1506), quienes llevaron a cabo grandes obras con soluciones muy avanzadas en el arte del corte de la piedra con huecos oblicuos y en esquina, edificios con plantas esviadas y bóvedas

${ }^{111}$ Zaragozá Catalán, A. y Gómez Ferrer, M. (2008) Lenguajes, fábricas y oficios en la arquitectura valenciana del tránsito entre la Edad Media y la Edad Moderna (1450-1550), en Artigrama, núm. 23. pp. 149. 
aristadas, en las que se eliminaron los nervios. El gran avance en estas soluciones se debe a que, para elaborar estos elementos, se pasa de una estereotomía plana, donde los elementos se trazan en dos dimensiones, a una estereotomía tridimensional.

Estas bóvedas de arista las encontramos en diversos edificios valencianos: en la Capilla de Santo Domingo, en la conexión de la Arcada Nova en "el Miguelete" o en las Torres de Quart, obras de Francesc Baldomar. El maestro Compte también utilizaría esta técnica en una de las capillas que unen la Arcada Nova con la Sala Capitular, y en una de las bóvedas de la torre de La Lonja. En la Arcada Nova de la Catedral encontramos aperturas en esviaje y en esquina, obra del maestro Baldomar y de su discípulo, Pere Compte, quien se encargaría de finalizar las obras tras la muerte de su maestro ${ }^{112}$.

Algunas de las soluciones aplicadas por estos maestros fueron recogidas posteriormente en diversos tratados sobre el arte del corte de la piedra, por ejemplo, en el de Vandelvira $(1575-1591)^{113}$ o el de Gelabert $(1653)^{114}$.

Otros de los elementos característicos de la obra de cantería de este periodo fueron las bóvedas aristadas o estrelladas de rampante curvo, las columnas y los nervios entorchados utilizados por Compte en obras como La Lonja de Valencia, la Catedral de Orihuela, la Catedral de Tortosa o la Iglesia de la Cartuja de Portaceli, y las escaleras de caracol de ojo abierto o caracol de Mallorca utilizadas también por ambos maestros ${ }^{115}$.
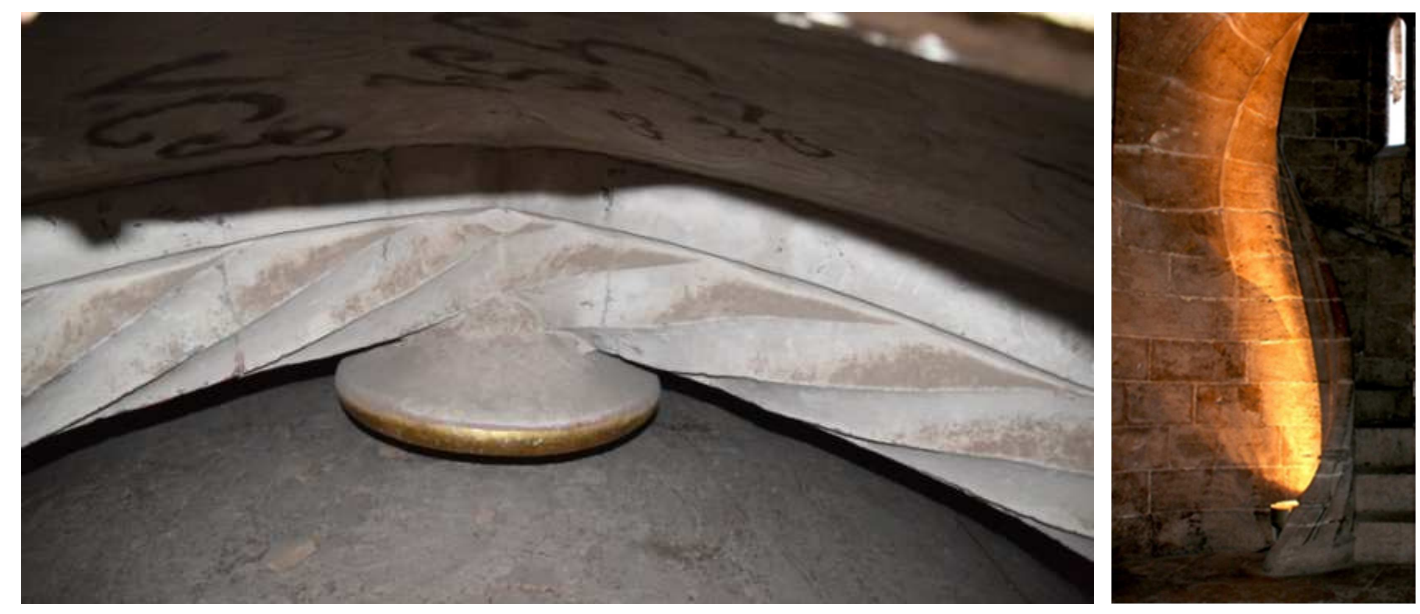

Figura 33. Izquierda: Bóveda de nervios entorchados. Monasterio de Portaceli. Derecha: Arranque escalera caracol. Lonja de Valencia.

\footnotetext{
${ }^{112}$ Zaragozá Catalán, A. y Gómez Ferrer, M. (2008). Óp. cit. pp. 154-165.

${ }^{113}$ Vandelvira, A. (1977). El tratado de arquitectura de Alonso de Vandelvira: reproducción facsímil. Albacete: Caja de Ahorros Provincial de Albacete.

${ }^{114}$ Rabasa Díaz, E. (2011). El manuscrito de cantería de Joseph Gelabert. Palma de Mallorca: Col-legi Oficial d'Arquitectes de les Illes Balears.

${ }^{115}$ Zaragozá Catalán, A. y Gómez Ferrer, M. (2007). Pere Compte Arquitecto. Valencia: Consorci de Museus de la Comunitat Valenciana. pp. 76-130.
} 
Asimismo, Pere Compte y su círculo desarrollan en algunos de sus edificios portadas formadas por arcos conopiales flanqueados por esbeltos pináculos formados por haces de esbeltas cañas prismáticas rematadas por agujas decoradas con cardinas y macolla. Existe similitud entre estas portadas y las dibujadas por el maestro alemán Matthaus Roriczer en su manuscrito Manual del correcto trazado de la rectitud de los pináculos $(1486)^{116}$.

En los capítulos del Gremio de Canteros de 1495 se distingue entre el mestre piquer, que es el que controla la forma, y el menestral, que realiza el trabajo siguiendo las órdenes del mestre. A los menestrals sólo se les permitía contratar por sí mismos elementos aislados (arcos, puertas, ventanas y esquinas de un edificio); mientras que los maestros podían contratar obras mayores y menores (iglesias, capillas, claustros, etc.). En esta época, en Valencia, el círculo de mestres piquers se reducía a Pere Compte, García de Toledo, Antoni Queralt y Johan Corbera. Johan Corbera, discípulo de Compte, le sucedería como maestro en La Lonja y en La $\mathrm{Seo}^{117}$, y participaría muy activamente en las obras de renovación de la Generalitat $^{118}$.

Uno de los referentes arquitectónicos que no podemos dejar de citar es el Palacio de Mosen Sorell. De este magnífico palacio, devastado por un incendio en 1878 y hoy desaparecido, se tienen datadas dos grandes intervenciones: una antes de 1454, en la que se supone que intervino Francesc Baldomar; y otra anterior a 1485, en la que el edificio adquiere su configuración definitiva y que se atribuye al círculo de Pere Comte. Entre la singularidad de su arquitectura sobresalen sus portadas características de arcos carpaneles y conopiales, enmarcadas en pináculos y con decoración de lacería flamígera ${ }^{119}$.

En cuanto a la albañilería, uno de los grandes desarrollos durante la última mitad del siglo $\mathrm{XV}$, que sería utilizada hasta mediados del siglo XVI, fue el de las bóvedas tabicadas. Esta solución, que inicialmente se utilizaba para cubrir la plementería entre los nervios de cantería y para cubrir luces modestas, y cuyo uso supuso un importante ahorro en los costes de las obras, pasa en este periodo a utilizarse en grandes luces y a sustituir los nervios de piedra por otros de yeso con una función simplemente ornamental, como en la Iglesia de Burriana (1471), donde se cubre con esta solución una luz de 15,5 m. Con esta innovación se transfiere la solución de Baldomar de construir bóvedas sin nervios de las obras de cantería a las obras de albañilería realizadas con ladrillo. El gran referente en esta transformación es Francesc Martí Biulaygua y su círculo. Algunas de las obras más significativas realizadas en este periodo son diversas dependencias del Monasterio de la Trinidad, del de Santa María de Valldigna, el claustro de las recordaciones de la Cartuja de Portaceli, algunas dependencias de la Cartuja de Valdecristo, la bóveda del coro de la Iglesia

\footnotetext{
${ }^{116}$ Zaragozá Catalán, A. y Gómez Ferrer, M. (2007). pp. 90-96 y Ruiz de la Rosa, J. A. (1987). Traza y simetría de la Arquitectura. En la Antigüedad y Medievo. Sevilla: Servicio de Publicaciones de la Universidad de Sevilla. pp. 295-299.

117 Zaragozá Catalán, A. y Gómez Ferrer, M. (2008). Lenguajes, fábricas y oficios en la arquitectura valenciana del tránsito entre la Edad Media y la Edad Moderna (1450-1550), en Artigrama, núm. 23. pp. 149-184.

${ }^{118}$ Aldana, S. (1995). El Palau de la Generalitat Valenciana Vol. I. València: Generalitat Valenciana, Consell Valencià de Cultura.

${ }^{119}$ Iborra Bernard, F. y Zaragozá Catalán, A. (2003). El Palacio de Mosén Sorell en Valencia. En Mirá, E. y Zaragozá Catalán, A. (Ed.). Una arquitectura gótica Mediterránea Vol. II. Valencia: Conselleria de Cultura i Educació. pp. 205-213.
} 
del Convento de Luchente y diversas dependencias del Monasterio de San Jerónimo de Cotalba ${ }^{120}$.

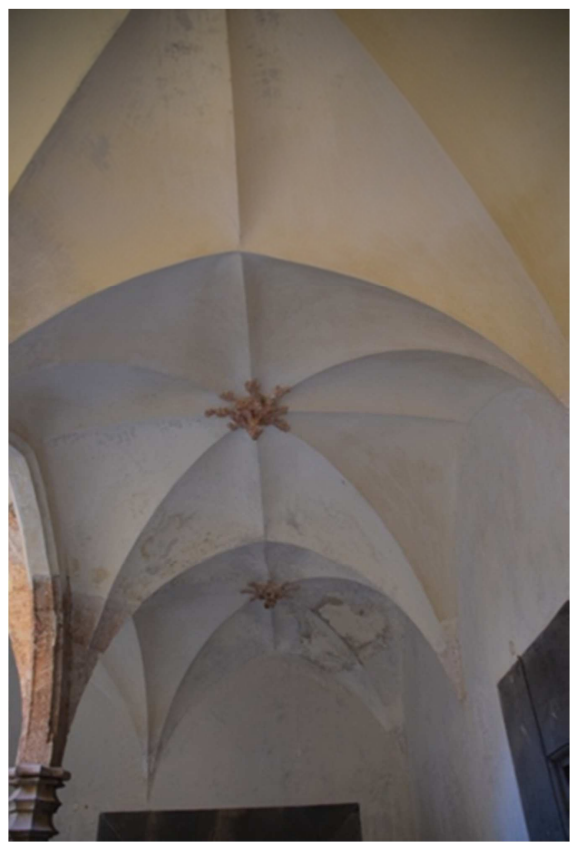

Figura 34. Bóveda aristada del Claustro de las Recordaciones. Monasterio de Portaceli.

Uno de los elementos arquitectónicos que se desarrolló en paralelo a la evolución de las bóvedas tabicadas fue el uso de las portadas llamadas "de cortina" o "pabellón". Estas portadas normalmente se enmarcaban en un guardapolvo a modo de alfiz y estaban formadas por un arco mixtilíneo con varias curvas y contracurvas. La primera constancia documental de estos elementos la tenemos en 1497, cuando el escultor Johan de Kassel esculpió una salutació de alabastro para las enjutas del arco que comunica la Sala Capitular con la Sacristía en la Catedral de Valencia. Estas portadas fueron muy utilizadas en iglesias (Iglesia de Llombay e Iglesia de Benigánim), monasterios (San Jerónimo de Cotalba), edificios públicos (La Lonja y el Palacio de la Generalitat), aunque su mayor presencia se dio en las casas señoriales (castillos-palacios de Alaquás, Argelita, Benissanó, Geldo, Oliva, Sot de Ferrer, el de los Escrivá en Valencia, etc.). El material utilizado para su construcción fue la piedra o el yeso ${ }^{121}$.

Así, la utilización del yeso en elementos arquitectónicos tales como portadas, ventanas, escaleras, nervios de bóvedas de crucería, chimeneas y revoltones fue muy extendido en la arquitectura valenciana a finales del siglo XV y principios del siglo XVI. Su ámbito de aplicación principal fueron las casas señoriales, aunque también fue utilizado en lugares dedicados a la defensa militar (castillos y edificios religiosos). Al igual que ocurre en el caso

${ }^{120}$ Zaragozá Catalán, A. y Gómez Ferrer, M. (2008) Óp. cit. pp. 149-184.

${ }^{121}$ Zaragozá Catalán, A . (2000) Óp. cit. pp. 185-186. 
de la albañilería, su desarrollo se debe a una transferencia de las técnicas alcanzadas en el arte de la estereotomía y su uso estuvo centrado en la ornamentación interior de los edificios, con piezas de gran complejidad técnica y formal que igualan a las desarrolladas en las obras de cantería. Las técnicas utilizadas son el moldeado y el modelado. En la primera de ellas se utiliza un molde para la realización de las piezas, con lo cual estamos ante un proceso de prefabricación; en la segunda se emplea una técnica idéntica a la de la talla y, por ello, se requiere de la destreza del arte de la montea o art de picapedrer. En cuanto a las portadas, todas las mencionadas anteriormente pertenecientes a los castillos-palacios, fueron realizadas con esta técnica. Por su parte, tenemos ejemplos de las escaleras en el colegio Mayor del Arte de la Seda de Valencia, y en el Monasterio de Cotalba. Por último, existen bóvedas construidas con ésta técnica en el Castillo de Geldo y en el Palacio de Oliva. $^{122}$
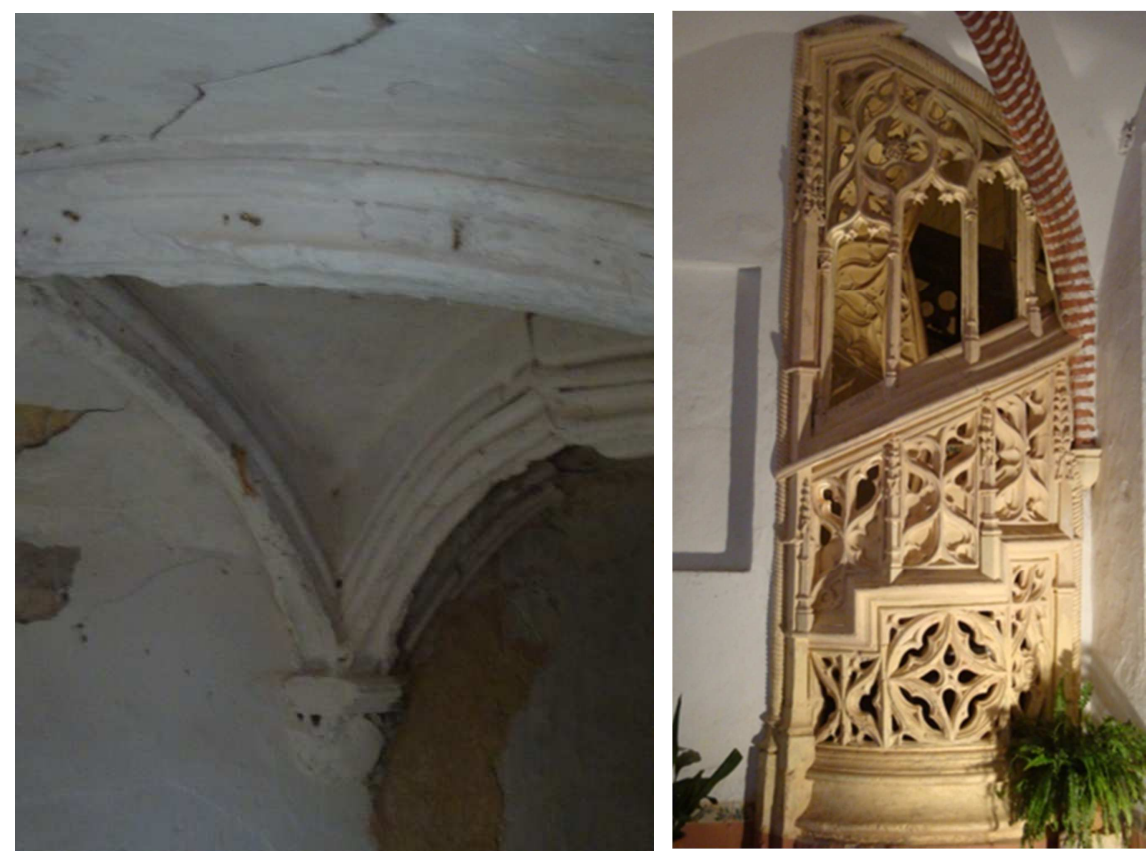

Figura 35. Izquierda: Bóveda con nervios de yeso. Palacio de Geldo. Derecha Escalera Monasterio de Cotalba.

\section{EL PRIMER RENACIMIENTO EN EL REINO DE VALENCIA}

Paralelamente a la construcción de la Arcada Nova, en la Catedral de Valencia se emprendió la modernización del presbiterio con los frescos de Paolo San Leocadio y Francesco Pagano, tras el incendio de 1464, siendo ésta la primera irrupción del nuevo

\footnotetext{
${ }^{122}$ Marín Sánchez, R. (2014). Uso estructural de prefabricados de yeso en la arquitectura levantina de los siglos XV y XVI (Tesis doctoral no publicada). Universitat Politècnica de València. y García Giner, M. I. (2007). El yeso en la arquitectura tardogótica valenciana. En: Actas de Quinto Congreso Nacional de Historia de la Construcción, Instituto Juan de Herrera. pp. 411-422. Burgos, España.
} 
lenguaje renacentista en el entorno valenciano. Esta transferencia de estilos fue promovida tras el nombramiento de Rodrigo de Borja como Papa en 1455, con el nombre de Alejandro VI. Este nuevo gusto por lo romano cobró mayor intensidad tras la muerte del Papa en 1503 y el regreso a Valencia de los nobles y clérigos valencianos que habían formado parte de su corte papal ${ }^{123}$.

En 1506 llegan a Valencia Hernando Yáñez de Almedina y Hernando de los LLanos con el encargo de pintar las puertas del retablo mayor de la catedral; el primero había sido discípulo de Leonardo en Valencia. En sus pinturas introducen fondos arquitectónicos y elementos a candelieri y grutescos sobre fondos azules y rojos. Su actividad no se limitó a la pintura, trabajando entre otros en la caja del órgano de la catedral (1510), donde participaron los tallistas valencianos Jaume Vicent y Lluís Muñoz, quienes asimilarían rápidamente el nuevo repertorio "a la romana" introduciendo grutescos, capiteles corintios, medallones con bustos, armaduras a la romana, putti alados, sirenas vegetalizadas, cornucopias, grifos, mascarones, arpías de cola enroscada, etc. ${ }^{124}$.

La primera serliana y orden con arquitrabe surge también en la Catedral de Valencia, en concreto, en el pórtico de cerramiento de la Capilla de la Resurrección, realizada en torno a 1510 y en la que se combinan el arte del corte de la piedra con una amplia iconografía de carácter renacentista ${ }^{125}$.

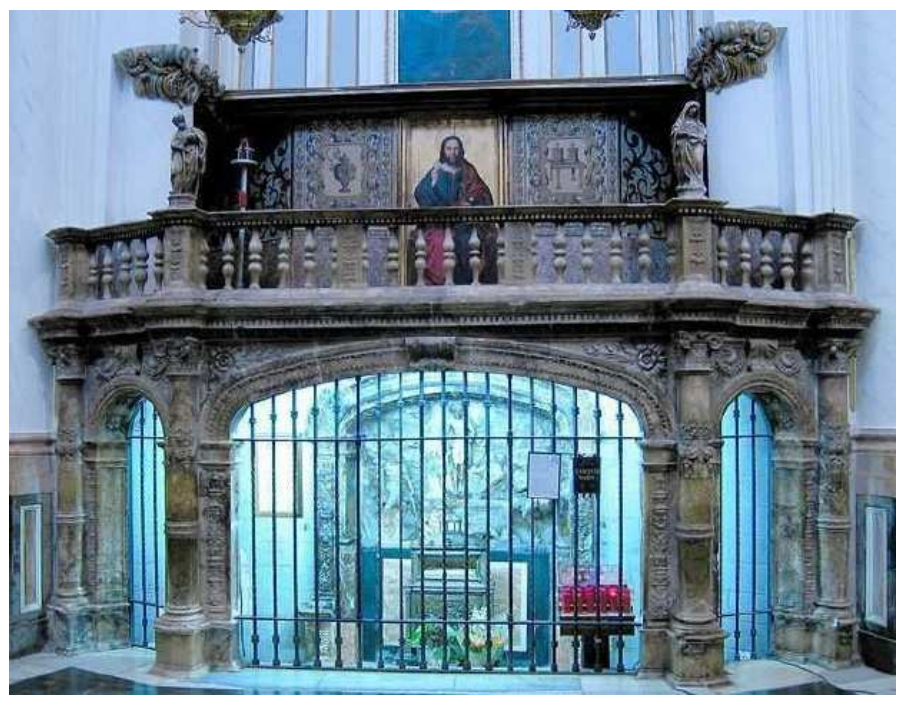

Figura 36. Pórtico de la capilla de la Resurrección. Catedral de Valencia.

123 Berchez Gómez, J. y Jarque, F. (1994). Arquitectura Renacentista Valenciana (1500-1570). Valencia: Bancaixa Obra Social. pp. 32-36 y Gómez-Ferrer, M. (2009). La arquitectura renacentista en Valencia. En Jorge Hermosilla Pla (Ed.). La ciudad de Valencia: historia, geografía y arte de la ciudad de Valencia. Vol. 2. Valencia: Universitat de València. pp. 318.

${ }^{124}$ Berchez Gómez, J. y Jarque, F. (1994). Óp. cit. pp. 34-36 y Gómez-Ferrer, M. (2009). Óp. cit. pp. 318.

${ }^{125}$ Berchez Gómez, J. y Jarque, F. (1994). Óp. cit. pp. 36. 
Durante las primeras décadas del siglo XVI surgen los primeros contratos para la construcción de obras en los que se exigen elementos "a la romana", "a la italiana" o "a la antigua". Esta expresión hacía referencia a una decoración con elementos concretos como eran los grutescos, los motivos de "armería", con escudos y carcajs, o motivos a candelieri $^{126}$.

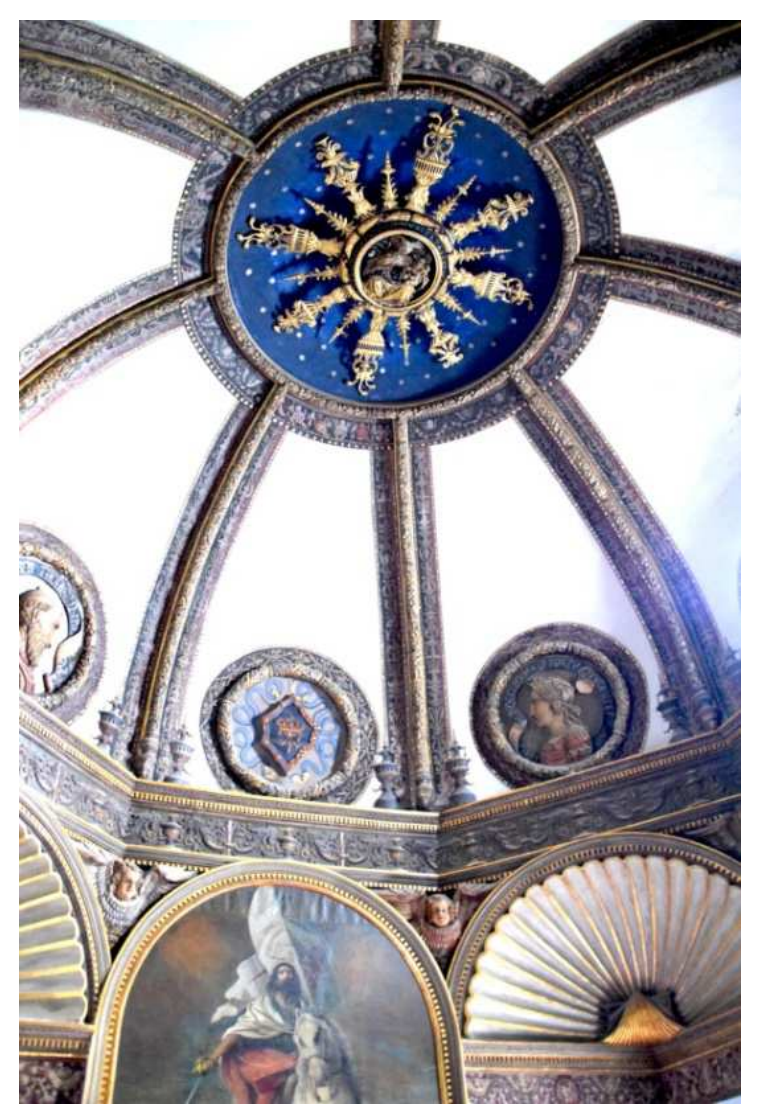

Figura 37. Capilla de Todos los Santos. Monasterio de Portaceli.

Otra de las primeras construcciones realizadas al nuevo gusto "a la romana" fue la Capilla de Todos los Santos, en el Monasterio de Portaceli, iniciada en 1510 y promovida por el prior Alberto Claramunt, de origen noble y presente en Roma entre 1480-1483, con vinculación con el entonces cardenal Rodrigo de Borja . Esta Capilla de planta casi cuadrada $(5 \times 6 \mathrm{~m})$ se cierra con una bóveda claustral de 8 paños con las trompas formadas por 4 veneras a modo de pechinas, y cuatro más simuladas en los tramos rectos. Asimismo, dispone de abundante decoración renacentista: motivos a candelieri, putti, medallones con láureas, elementos en jarra, etc. La Capilla de la Generalitat, realizada por Lluís Muñoz y Johan Mançano y destruida en 1831, guardaba grandes similitudes con esta. Por su parte,

${ }^{126}$ Gómez-Ferrer, M. (2009). Óp. cit. pp. 317 y Zaragozá Catalán, A. y Gómez Ferrer, M. (2008). pp. 176. 
en 1517 se construyó la Capilla de la Casa de la Ciudad, en la que participaron Johan Corbera y Jaume Vicent, y en la que además de elementos decorativos, el lenguaje renacentista se incorporó a la composición arquitectónica con basamentos y capiteles, arcos de medio punto "hecho al estilo romano" y remate con arquitrabe. Otras obras tempranas de decoración renacentista fueron las portadas de la antigua Casa de la Ciudad (1517) y de la escalera del Hospital General (1513), ambas hoy desaparecidas .

En torno a 1510 debieron de iniciarse las obras de renovación del Palacio Condal de Oliva por encargo de Serafín de Centelles, noble protector de humanistas, elogiado por Juan Luis Vives por su erudición y su gusto clásico. Algunas de las portadas y bóvedas de este palacio fueron decoradas con ornamentación renacentista (medallones laureados, grutescos, veneras o ristras a candelieri). Quizás por vez primera en Valencia se utilizaron los "revoltons de algeps e ragola revellats al romà". Esta solución constructiva de armadura de madera y revoltones de ladrillo y yeso, decorados con pinturas policromadas con motivos renacentistas alcanzaron su máxima expresión en el forjado de la Sala de Armas del Palacio. Esta misma solución fue rechazada para uno de los forjados del Palacio de la Generalitat por considerar que los artesonados de madera eran de mucha más durabilidad, calidad y presencia que la obra de revoltones de yeso, por muy dorados y decorados que estos fueran. Otro de los elementos característicos del Palacio es la Galería del Patio Central, donde se entremezclan el nuevo lenguaje "a la romana", con columnas de orden clásico, y un entablamento tripartito con las tradiciones autóctonas de sus arcos apuntados, levemente abocinados ${ }^{127}$.

\section{LOS CASTILLO-PALACIOS GÓTICOS VALENCIANOS}

\subsection{Introducción}

Jaume I, rey cristiano de Aragón, reconquistó el Reino de Valencia a los musulmanes. Después de la Reconquista, el rey donaba villas, castillos o lugares a caballeros y ordenes religioso-militares que le habían ayudado en la Reconquista, otras se las quedaba para él. Así, los dueños y señores de los sitios eran caballeros, ordenes religioso-militares o el propio rey. En este territorio había una gran cantidad de castillos árabes que se habían construido para la defensa de los ataques cristianos. Después de la Reconquista algunos de estos castillos se conservaron, otros se reconstruyeron y adaptaron, y otros se construyeron de nueva planta, para dar cobijo a los nuevos señores.

Al principio, la arquitectura en el nuevo reino cristiano de Valencia fue una arquitectura de necesidad, es decir, se reaprovecharon las construcciones árabes. Así, se utilizaron las mezquitas purificadas o recristianizadas, o bien otros edificios civiles como casas o baños árabes. Pero muy pronto se empezaron a construir edificios de estilo propio. La primera necesidad era edificar nuevas iglesias cristianas. Los primeros templos se construyen con una estructura a base de arcos diafragmas sobre los que se apoya la techumbre inclinada de madera. Este modelo había sido una solución válida desde hacía más de cincuenta años en tierras de Tarragona, Lleida o Huesca. Se trataba, simplemente, de la aplicación del

${ }^{127}$ Berchez Gómez, J. y Jarque, F. (1994). Óp. cit. pp. 40. 
sistema constructivo que las comunidades religiosas y civiles habían utilizado y cuyo funcionamiento había demostrado ser útil. Este sistema constructivo era económico, dado que reducía al mínimo los elementos estructurales y, además, permitía readaptar y reaprovechar el modelo en un futuro e incorporar bóvedas de crucería. Este tipo de arquitectura de necesidad o necesaria se difundió rápidamente en todo el Reino de Valencia, no sólo en los edificios religiosos, sino también en los civiles como bodegas, hospitales, castillos, lonjas u hornos.

De la arquitectura austera a base de arcos diafragmas y techumbres de madera, se pasó a la arquitectura propiamente gótica, a base de arcos apuntados, bóvedas de crucería o ventanas geminadas. Los modelos góticos se desarrollarían en el Reino de Valencia a lo largo de los siglos XIV y XV, alcanzando su fin a mediados del siglo XVI con la finalización de las obras de La Lonja de Valencia ${ }^{128}$. A partir de este hito arquitectónico, las tendencias renacentistas importadas desde Italia iban a romper con la tradición valenciana para imponer, paulatinamente, los modelos "a la romana", pero con fuerte inercia gótica.

\subsection{Los castillo-palacios}

Los musulmanes construían castillos; normalmente en lo alto de las montañas, con la finalidad de defensa de los amplios territorios que formaban los "Hisn". Eran construcciones sencillas (normalmente con una torre atalaya y una muralla exterior) construidas con materiales del terreno y sin sentido decorativo. En el siglo XIII los cristianos se fueron apoderando de estos castillos. Más tarde, ya conquistados los pueblos, algunos de estos viejos castillos se mejoraron, se levantaron altos y gruesos muros, barbacanas, fosos, y las edificaciones se convirtieron en verdaderas fortalezas. Sobre los castillos árabes se construyeron los primeros castillos cristianos. Un gran número de ciudades, villas y pueblos se formaron al amparo de estos castillos. Tras un período de tranquilidad, el rey Pedro el Ceremonioso ordenó la renovación de fortificaciones ante una posible invasión de moros de Granada a principios del siglo XIV. A partir del siglo XV las construcciones bélicas se convirtieron en castillos feudales, casa de los señores, con torre del Homenaje, almenas y murallas. Pero, poco a poco, los castillos perdieron su sentido defensivo y se convirtieron en castillos-palacios. El siglo XV fue la época de esplendor de estas mansiones nobles. La sociedad asumió tanto el dúo señor-castillo, que hasta los palacios construidos en la llanura, conservan el nombre de "castillo", aunque en ocasiones fueran casonas sin pretensión defensiva, pero sí la residencia del señor. No obstante, las continuas guerras y sublevaciones de los moriscos (musulmanes que no terminaban de convertirse al cristianismo), hicieron que algunos de estos castillos-palacios tuvieran que fortificarse, hasta que en el año 1609 Felipe II ordenó la expulsión de los moriscos ${ }^{129}$.

\footnotetext{
${ }^{128}$ José i Pitarch, A (1992). Sobre l'art valencià dels segles XIII-XV. Lluís de Santàngel uno nou home un nou món. Valencia: Presidència de la Generalitat Valenciana.

${ }^{129}$ Beüt Belenguer, E. (1984). Castillos Valencianos. Valencia: José Huguet.
} 


\subsection{Características de los palacios góticos valencianos}

La tipología de las casas señoriales, palacios o castillos-palacios, de la época gótica en el antiguo Reino de Valencia, no son muy diferentes a otros que se encuentran en el Mediterráneo occidental y cristiano. Estos se organizan a partir de un patio central descubierto. Las casas tenían cuatro plantas: la planta baja, el entresuelo, la planta noble y la buhardilla (andana). La escalera de la planta noble se situaba en un ángulo del patio. Estos palacios se construían normalmente aislados de otras construcciones. La fachada principal estaba más cuidada. Éstas poseían las mejores fábricas, ya fueran de sillería o de tapial. En la planta baja se abría únicamente una gran portada, que era el acceso; el entresuelo tenía ventanas rectangulares; y la planta noble solía poseer ventanas ajimezadas, de dos a tres arquillos de medio punto o trilobuladas que descansaban en columnillas. En la andana se abrían una sucesión de arquillos con la función de ventilar. Se remataba con gran alero con vigas labradas. La composición de estas fachadas no seguía ningún tipo de simetría. En el patio solía haber un pozo. La planta baja se destinaba a dependencias de servicio, establos, bodega y leñera. Desde el vestíbulo salía otra escalera que llevaba al entresuelo. La planta noble se abría al patio interior mediante ventanas o galería de arcos. En la planta noble se situaban las estancias de los señores, con techos muy altos. Estos techos estaban formados por alfarjes tallados y policromados. A las golfas o andanas se accedía por escaleras interiores. Allí vivían los criados, se guardaban algunos alimentos o eran almacenes. Detrás de la casa estaba el huerto-jardín ${ }^{130}$. De estos palacios góticos valencianos hay un gran número que se han conservado; otros se encuentran en período de recuperación; y algunos han desaparecido. Pero otros, además de las características mencionadas, disponían de torres defensivas. Algunos con forma cuadrada protegidos con torres en sus esquinas. Este es el caso de los llamados "castillos-palacios" situados en Todolella, Sot de Ferrer y Geldo (ver Fig. 38), en la provincia de Castellón, o Albalat dels Sorrells, Alaquàs, Lluxent y el Palacio de Oliva, en la provincia de Valencia.

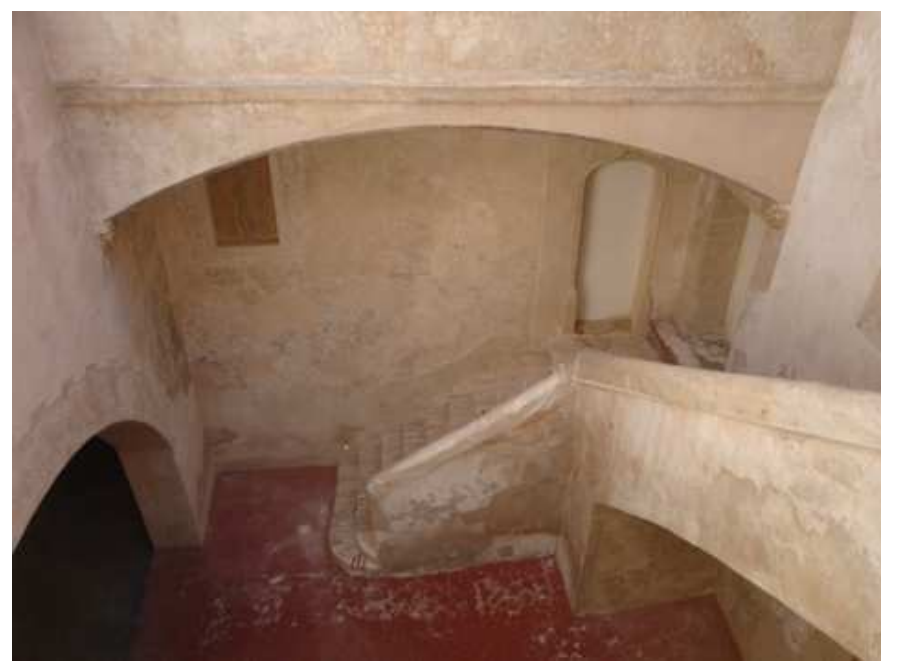

Figura 38. Patio y escalera de honor del Palacio de los Duques de Medinaceli (Geldo).

${ }^{130}$ Zaragozá Catalán, A. (2000). Arquitectura Gótica Valenciana. Siglos XIII-XV Valencia: Generalitat Valenciana. Conselleria de Cultura i Educació. 


\subsection{Relación de castillos-palacio góticos valencianos}

Con el fin de poder elaborar una relación de castillos-palacios góticos valencianos, se han analizado distintos edificios pertenecientes a este periodo para poder determinar su encaje, o no, dentro de esta tipología constructiva. Para ello, se ha partido del Catálogo de Bienes de Interés Cultural (Fichas BIC's) de la Comunitat Valenciana, así como de diversas publicaciones sobre el gótico valenciano ${ }^{131}$. En muchos casos se han visitado los edificios con el fin de poder determinar de primera mano las características arquitectónicas y estilísticas de sus elementos.

Como herramienta de trabajo se ha elaborado una tabla con información básica sobre los edificios y su localización, clasificación, titularidad y estado enlazada mediante hipervínculos a las fichas del catálogo de BIC's y, en algunos casos, a las páginas web municipales o del propio edificio.

Asimismo, se ha incluido la siguiente información básica de los distintos edificios: época de construcción, dimensiones máximas, número de plantas, y la existencia o no de los elementos característicos de esta tipología constructiva que incluye elementos propios de una fortaleza (torres, patio de armas, foso, pozo, bóveda o aspilleras con elementos decorativos propios de un palacio o casa señorial; escalera de honor, galería porticada, logia, ventanas ajimezadas, portadas góticas, alfarjes y artesonados).

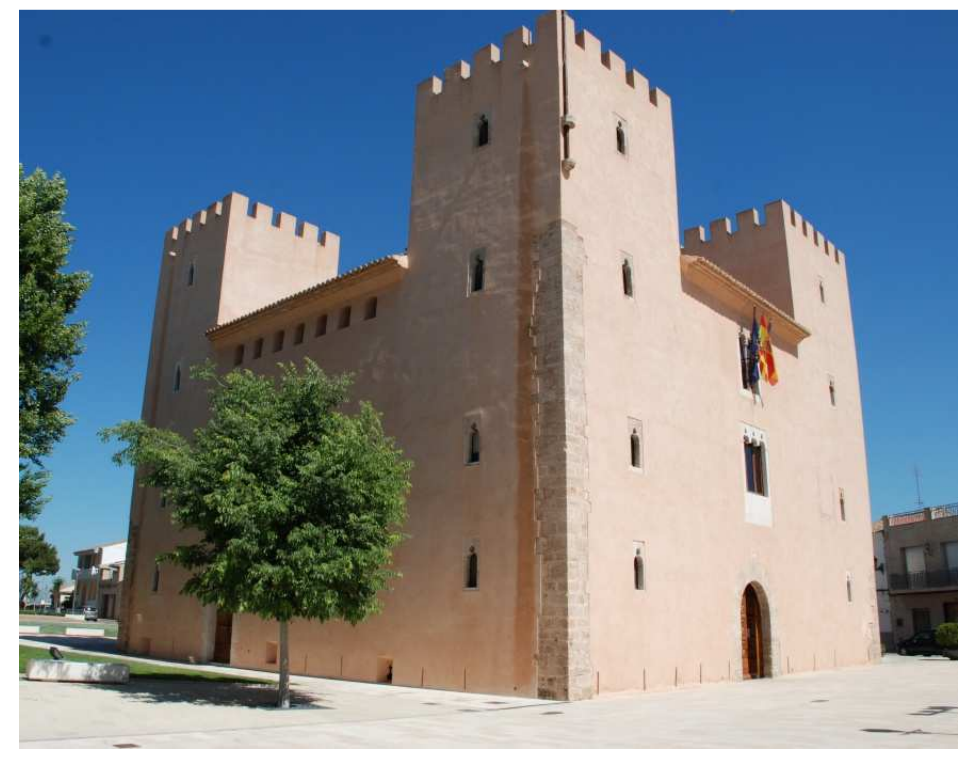

Figura 39. Palacio de Albalat dels Sorells.

\footnotetext{
${ }^{131}$ Berchez Gómez, J. (1983). Catálogo de monumentos y conjuntos de la Comunidad Valenciana I. Valencia: Conselleria de Cultura, Educación y Ciencia de la Generalitat Valenciana; Esteve y Blay, A. et al (1997). El Palau dels Centelles d'Oliva. Oliva: Associació Cultural Centelles i Riu-Sec, Sarthou y Carreres, C. (1920). Geografía General del Reino de Valencia. Provincia de Valencia. Tomo II. Barcelona: Editorial de Alberto Martín y Zaragozá Catalán, A. (2000). Óp. cit.
} 
La combinación de ambas características, junto con su carácter eminentemente gótico, nos determinará la inclusión o no de un castillo o palacio señorial dentro de esta tipología de castillos-palacios góticos.

A partir de los datos obtenidos, procedemos a realizar una relación y descripción (no excluyente) de aquellos castillos-palacio góticos del Antiguo Reino de Valencia, incluyendo todos aquellos edificios históricos que tanto por su tipología constructiva y funcional, como por sus elementos arquitectónicos y época de construcción se pueden incluir dentro de esta tipología.

En la tabla 2 se han enumerado los castillos-palacio englobados en esta clasificación, localizados por provincias y comarcas, e indicando su época de construcción, titularidad pública o privada, visitabilidad y su estado general de conservación. Se han ordenado según su latitud, comenzando por el norte de la provincia de Castellón y finalizando por las comarcas del sur de la provincia de Valencia ${ }^{132}$.

\section{Provincia de Castellón}

En la actual provincia de Castellón encontramos algunos ejemplos claros de esta tipología constructiva en buen estado de conservación. Procedemos a realizar una relación de los mismos que se incluirían en esta ruta:

- Castillo de Todolella

- Palacio del Señor de Sot de Ferrer

- Castillo Palacio de los Duques de Medinaceli (Geldo)

\section{Provincia de Valencia}

En provincia de Valencia encontramos el mayor número de ejemplos de edificios de esta tipología y época. Relacionaremos aquellos más característicos identificados como castillospalacios góticos:

- Castillo Palacio de Albalat dels Tarongers

- Castillo Palacio de Albalat dels Sorells

- Castillo-Palacio de los Aguilar o de las Cuatro Torres (Alaquás)

- Castillo de Benisanó

- Castillo de Bolbaite

- Palau Vell o Palacio de los Próxita (Lluxent)

- Palacio de los Condes de Oliva

- Palacio de la Duquesa de Almodóvar (Ontinyent)

132 Martínez Moya, J.A., Máñez Pitarch, M.J., y Garfella Rubio, J.T. (2015). Valencian Castle-Palace Route. Ruta de los Castillos-Palacio Góticos Valencianos. En: III Congreso Internacional sobre Documentación, Conservación y Reutilización del Patrimonio Arquitectónico. REUSO 2015. (pp. 17081715). Valencia, España. 

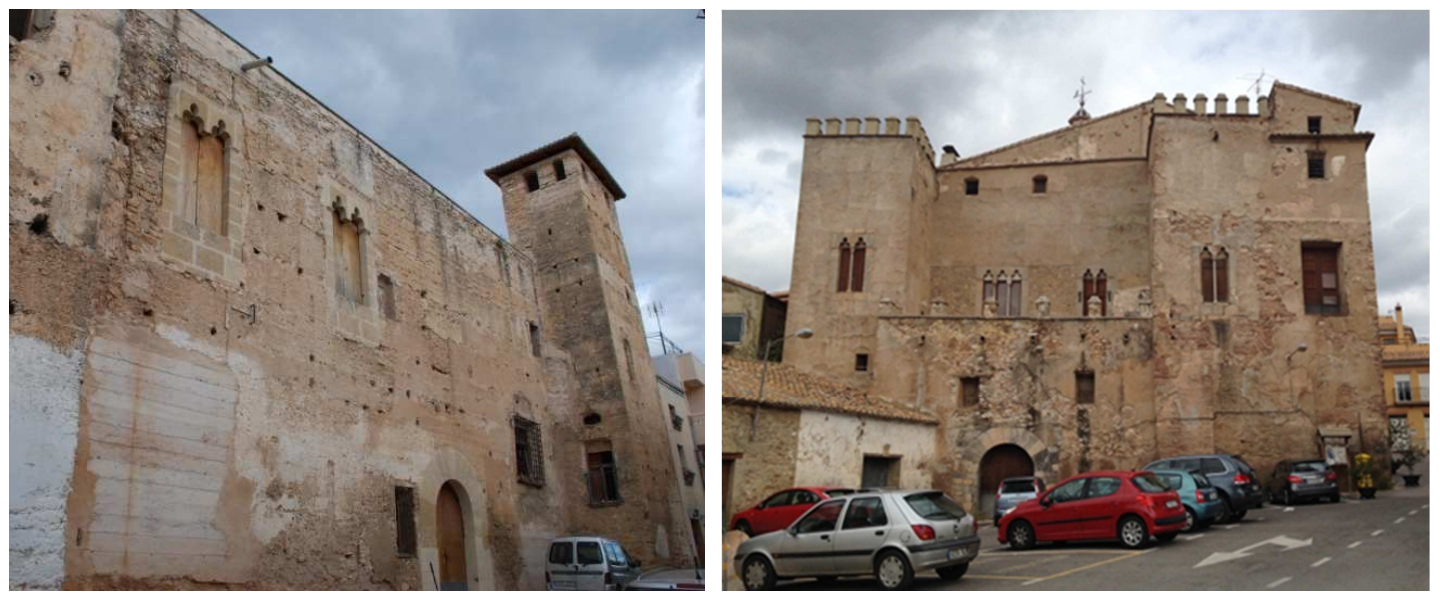

Figura 40. Izquierda: Fachada principal del Palacio de los Próxita (Lluxent). Derecha: Fachada principal del Palacio de Albalat desl Tarongers. Fuente: Alba Soler.

\section{Provincia de Alicante}

En la provincia de Alicante el gótico se introdujo con posterioridad teniendo una menor incidencia en esta área geográfica debido al avance en sentido norte-sur de la Reconquista. $\mathrm{Si}$ bien encontramos claros ejemplos de castillos-palacios en esta zona, como el Palacio Fortaleza del Marqués de Dos Aguas en Onil o el Castillo Palacio de los Milán de Aragón en Albaida, estos se encuadran más en la tipología renacentista, aunque en alguno de ellos como el Palacio de Cocentaina, cuyas obras se iniciaron en el siglo XIV imitando el palacio Real de Valencia ${ }^{133}$, nos encontremos con determinados elementos arquitectónicos góticos como ventanas ajimezadas, al iniciarse sus obras en este estilo arquitectónico.

Tabla 2. Relación de Castillos Palacios Góticos valencianos.

\begin{tabular}{|c|c|c|c|c|c|c|c|c|c|}
\hline Municipio & Comarca & Nombre & Clasificación & Fecha & Identif. & Época & Propiedad & Visitable & $\begin{array}{c}\text { Estado } \\
\text { Conservación }\end{array}$ \\
\hline \multicolumn{10}{|l|}{ Castellón } \\
\hline Todolella & Els Ports & Castillo de Todolella & Monumento & 09/10/1996 & $\begin{array}{c}\text { R-1-51- } \\
0009340\end{array}$ & S. XIV & Privada & NO & Bueno \\
\hline $\begin{array}{l}\text { Sot de } \\
\text { Ferrer }\end{array}$ & Alt Palancia & $\begin{array}{l}\text { Palacio del Señor de Sot } \\
\text { de Ferrer }\end{array}$ & Monumento & $14 / 08 / 2001$ & $\begin{array}{c}\text { RI-51- } \\
0010671\end{array}$ & $\begin{array}{l}\text { S. XIII- } \\
\text { XV }\end{array}$ & Privada & NO & Aceptable \\
\hline Geldo & Alt Palancia & $\begin{array}{l}\text { Castillo Palacio de los } \\
\text { Duques de Medinaceli }\end{array}$ & Monumento & $05 / 10 / 2004$ & $\begin{array}{c}\text { R-I-51- } \\
0011228\end{array}$ & S. XIV & Pública & NO & Mejorable \\
\hline \multicolumn{10}{|l|}{ Valencia } \\
\hline $\begin{array}{l}\text { Albalat dels } \\
\text { Tarongers }\end{array}$ & $\begin{array}{l}\text { Camp de } \\
\text { Morvedre }\end{array}$ & $\begin{array}{l}\text { Castillo Palacio de } \\
\text { Albalat dels Tarongers }\end{array}$ & Monumento & $24 / 04 / 2002$ & $\begin{array}{c}\text { R-I-51- } \\
0010761\end{array}$ & $\begin{array}{c}\text { S. XIV- } \\
\text { XV }\end{array}$ & Privada & No & Mal estado \\
\hline $\begin{array}{l}\text { Albalat dels } \\
\text { Sorells }\end{array}$ & Horta Nord & $\begin{array}{l}\text { Castillo Palacio de Albalat } \\
\text { dels Sorells }\end{array}$ & Monumento & $14 / 12 / 1998$ & $\begin{array}{c}\text { R-I-51- } \\
0010439\end{array}$ & s.Xv & Pública & SI & Bueno \\
\hline Alacuás & Horta Oest & $\begin{array}{l}\text { Castillo-Palacio de los } \\
\text { Aguilar }\end{array}$ & Monumento & $21 / 04 / 1918$ & $\begin{array}{c}\text { R-1-51- } \\
0000153\end{array}$ & S.XVI & Pública & SI & Bueno \\
\hline Benisanó & $\begin{array}{l}\text { El Camp de } \\
\text { Túria }\end{array}$ & Castillo de Benisanó & Monumento & $19 / 10 / 1984$ & $\begin{array}{c}\text { R-I-51- } \\
0008988\end{array}$ & $\begin{array}{l}\text { S.XV- } \\
X X\end{array}$ & Pública & SI & Bueno \\
\hline Bolbaite & $\begin{array}{l}\text { Canal de } \\
\text { Navarrés }\end{array}$ & Castillo de Bolbaite & Monumento & $24 / 04 / 2002$ & $\begin{array}{c}\text { R-1-51- } \\
0010758\end{array}$ & S.XVI & Pública & SI & $\begin{array}{c}\text { Ruina } \\
\text { consolidada }\end{array}$ \\
\hline Oliva & La Safor & $\begin{array}{l}\text { Palacio de los Condes de } \\
\text { Oliva }\end{array}$ & Monumento & $23 / 07 / 1920$ & $\begin{array}{c}\text { R-I-51- } \\
0000181\end{array}$ & $\begin{array}{l}\text { S.XV- } \\
X V I\end{array}$ & $\begin{array}{l}\text { Pública/ } \\
\text { Privada }\end{array}$ & NO & $\begin{array}{c}\text { Malo/ } \\
\text { Desaparecido }\end{array}$ \\
\hline Llutxent & $\begin{array}{l}\text { La Vall } \\
\text { d'Albaida }\end{array}$ & $\begin{array}{l}\text { Palau Vell o Palacio de } \\
\text { los Próxita }\end{array}$ & Monumento & $25 / 07 / 2002$ & $\begin{array}{c}\text { R-I-51- } \\
0010816\end{array}$ & $\begin{array}{l}\text { S. XIV- } \\
\text { XV }\end{array}$ & Pública & NO & Mejorable \\
\hline Ontinyent & $\begin{array}{l}\text { La Vall } \\
\text { d'Albaida }\end{array}$ & $\begin{array}{l}\text { Palacio de la Duquesa de } \\
\text { Almodovar }\end{array}$ & Monumento & $27 / 08 / 2001$ & $\begin{array}{c}\text { R-I-51- } \\
0010677\end{array}$ & S.XV-XX & Pública & SI & Bueno \\
\hline
\end{tabular}

133 Iborra Bernard, F. (2013). Corte y cortesanos: evolución tipológica residencial y ecos del palacio del monarca en el Reino de Valencia. Anales de Historia del Arte. Vol. 23 Núm. especial (II). pp. 479. 



\section{CAPITULO IV}

\section{EL PALACIO}

\section{EMPLAZAMIENTO Y LOCALIZACIÓN}

El Palacio Condal de Oliva se encontraba situado en la parte alta de la villa de Oliva, en la ladera del cerro de santa Ana, junto al Arrabal y frente a la iglesia de Santa María la Mayor. Las coordenadas UTM, Huso 30 en su puerta de acceso eran las siguientes: x 749564; y 4311863, y su altitud 29, $22 \mathrm{~m}$.

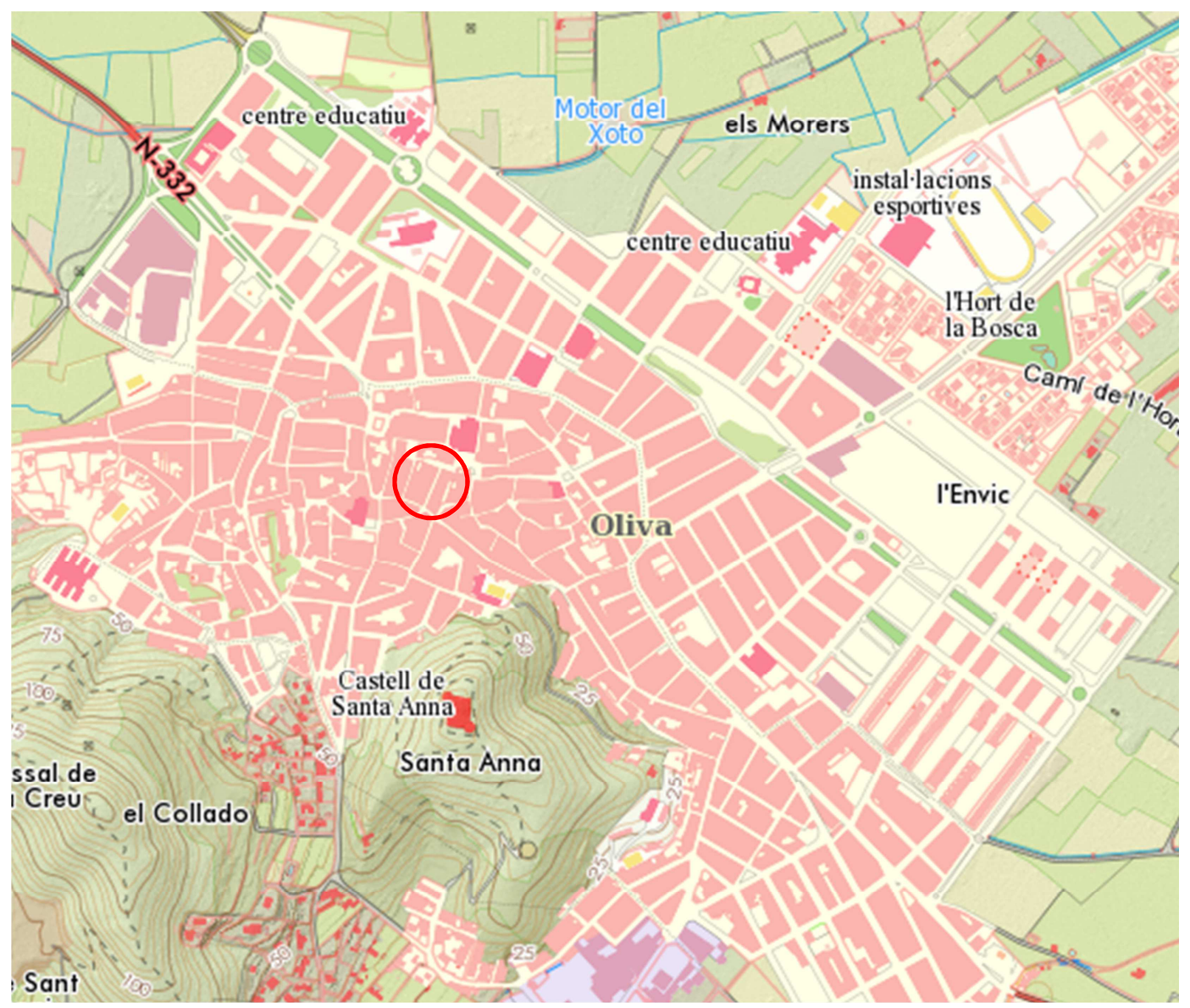

Figura 41. Plano de Emplazamiento del palacio. Fuente: http://cartoweb.cma.gva.es 
El antiguo palacio se asentaba entre las actuales calle de las Torres (NE), calle del Aula (SE), calle del Duque de Osuna (SO) y la calle Vicent Albert, y un solar al que se accede desde dicha calle en la orientación SE (ver Fig. 42). La calle Palacio cruza de norte a sur por el centro de lo que, en su día, fue el patio central del palacio, entroncando en su extremo NE con la calle Duque de Osuna, donde se encontraba la portada de acceso al castillo-palacio.

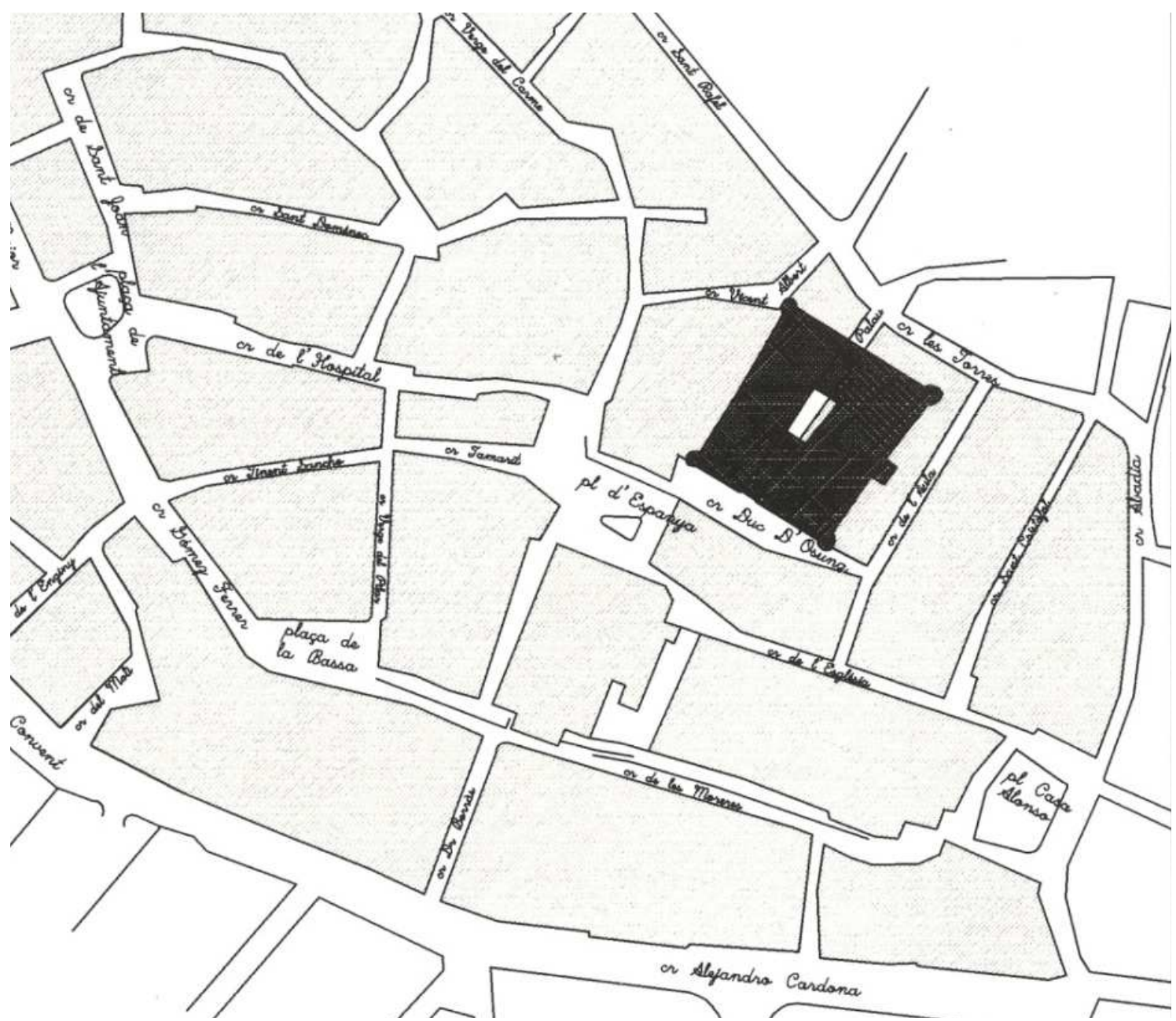

Figura 42. Plano de Localización del Palacio. Fuente: Juan Miguel García y Pérez ${ }^{134}$.

En la actualidad los restos del palacio se encuentran localizados en el interior de las viviendas de dos manzanas del casco histórico de Oliva. Tan sólo los carteles informativos, el nombre de la calle Palacio y la Torre de la Comare, restaurada en el año 1999, nos dan algún indicio de que en este lugar se localizó uno de los mejores palacios góticorenacentistas del Reino de Valencia.

${ }^{134}$ VV.AA. Esteve i Blai, A. (1997). El Palau dels Centelles d'Oliva. Recull gràfic y documental. Oliva, Valencia: L’Associació Cultural Centelles i Riu-Sec. pp. 165. 


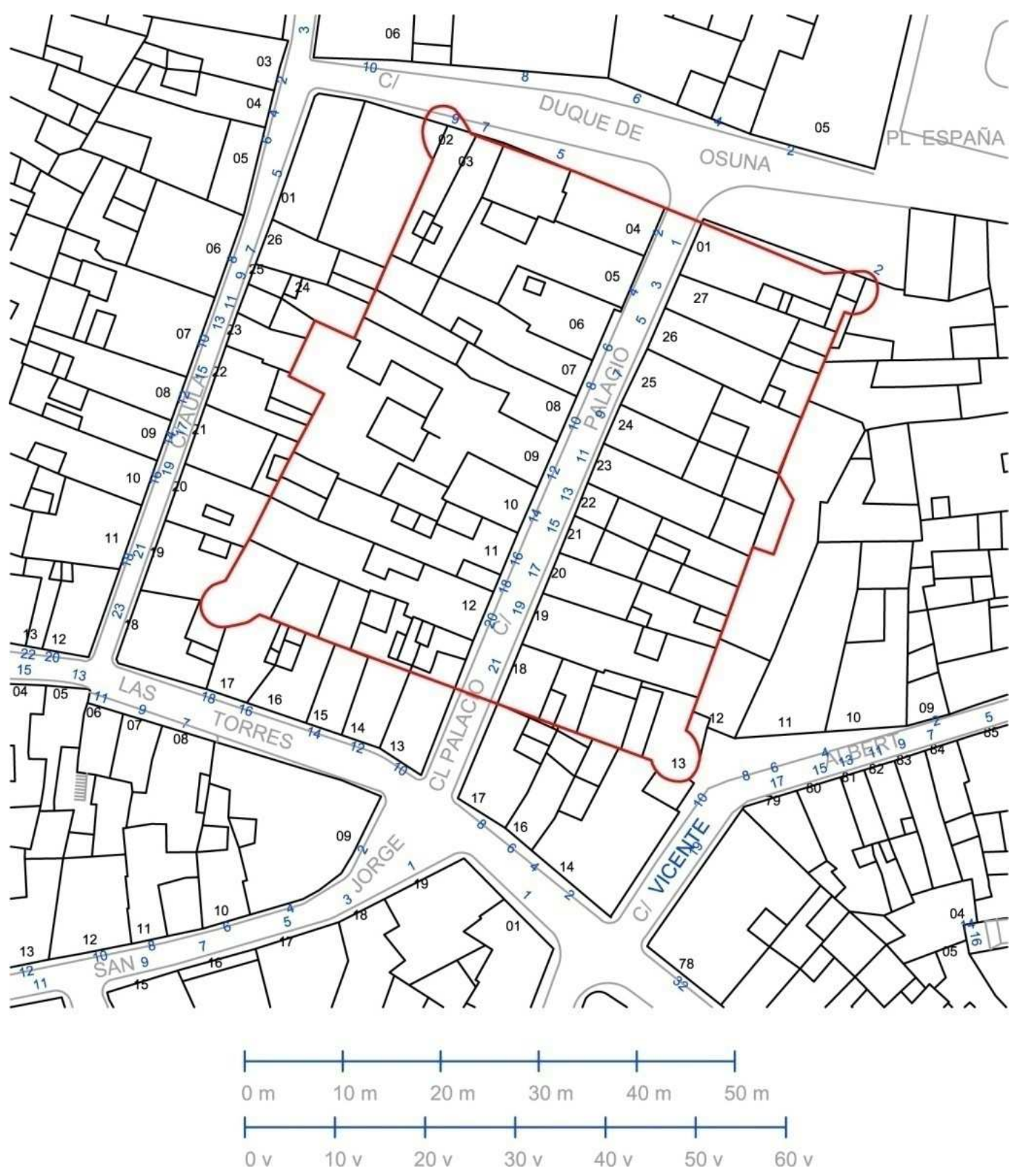

Figura 43. Plano de Localización del palacio sobre cartografía actual. Fuente: Ayuntamiento de Oliva.

\section{ANTECEDENTES}

Tal y como nos indican los documentos históricos, el origen del palacio fue una de las dos torres mandadas construir por Jaume I para proteger esta zona del Reino de los ataques berberiscos por mar y tierra, según nos relata Escolano (1611). Esta "Torre Maestra" pasaría a incorporarse al conjunto del palacio, siendo la más alta de todas las que tuvo ${ }^{135}$. Los primeros señores de Oliva fueron los Carroz, a quienes Jaume I les otorgó estas tierras en 1240 según el Llibre del Repartiment. El señorío incluía las de Oliva y el Castillo de Rebollet. Según Camarena Mahíques (1988), los Carroz fijaron su residencia en Oliva en 1332, en

\footnotetext{
135 Vidal, J.M. (1932) "El Palacio de los Condes de Oliva" Semanario científico, literario y de información agrícola Patria Chica № 11.
} 
tiempos del Almirante Francisco Carroz, cuando Pedro el Ceremonioso le ordenó establecerse en Oliva y preparar sus fortalezas ante la amenaza de ataque por parte de la alianza compuesta por los granadinos y los benimerines ${ }^{136}$.

Debido a la destrucción de los archivos del palacio y de los archivos municipales en las distintas guerras (desde la de Germanías hasta la Guerra Civil Española), se han perdido gran parte de los testimonios escritos que nos permitirían datar y documentar correctamente este monumento hoy casi desaparecido.

\section{DESCRIPCIÓN GENERAL}

"Ciertamente que V. E. habrá visto como yo aun en sus propios Estados de Italia y Bélgica, muchos alcázares castillos, pero no por eso dejaría de alagar su vista, elevando su imaginación, su castillo de Oliva, uno de los más fuertes, magníficos y mejor conservados de su época. Su estado y su importancia es tal que no puedo menos que descubrirle a V. E. arqueológicamente, sintiendo que mi pluma carezca de las artes necesarias para pintarle tan poético edificio con todas las galas y feliz inspiración"

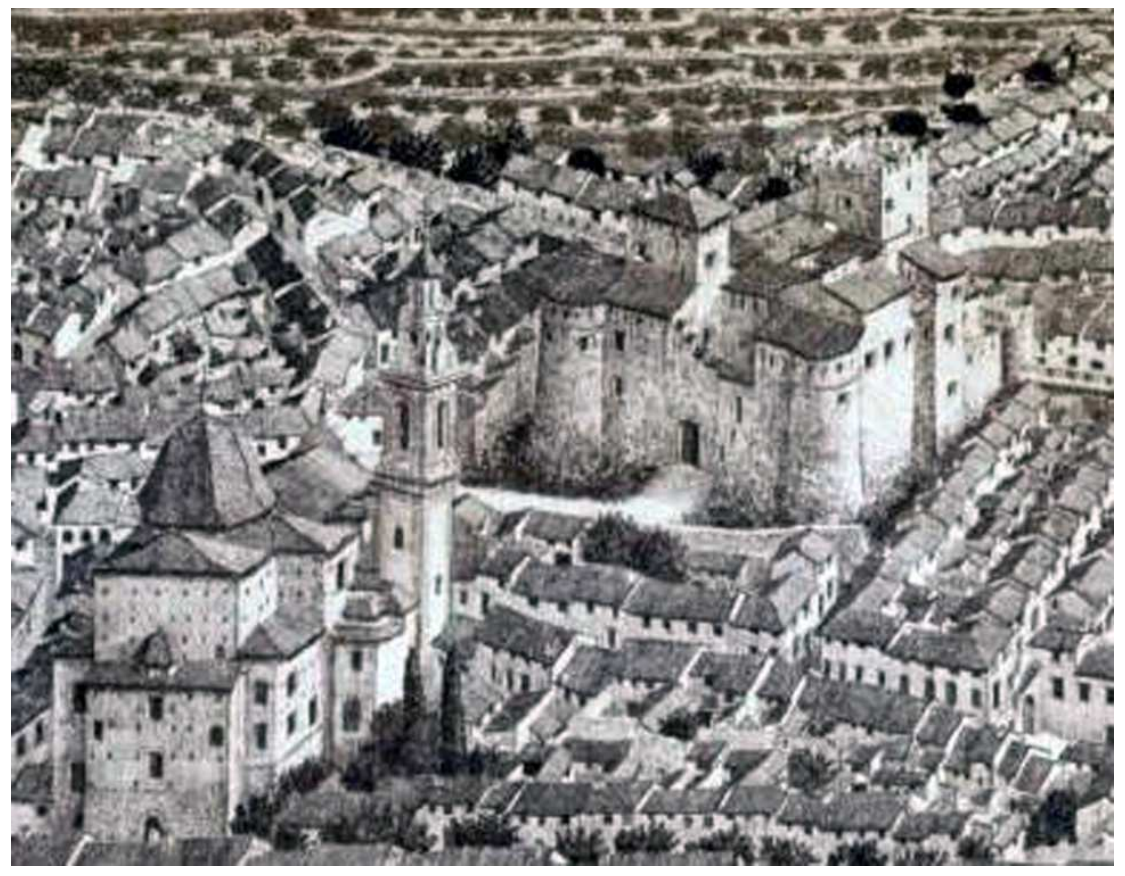

Figura 44. Detalle del Grabado de Oliva sobre 1850. Vista del palacio y de la Iglesia de Sta. María. Autor: Bofí Planes, E. (2002). Fuente: MNCADGM.

Con este párrafo inicia Sebastián Castellanos la descripción que hace del Palacio de Oliva para su dueño el duque de Osuna, D. Mariano Téllez Girón, en 1851-52, cuando el inmueble

${ }^{136}$ Camarena Mahiques, J. (1988). De la historia de Oliva y Rebollet. En Cardona Miralles, S. (Ed.). Iniciación a la Historia de Oliva (2a Ed.). (pp. 125-243). Oliva, Valencia: Publicaciones del Ayuntamiento de Oliva. pp. 150-151. 
se encontraba aún integro ${ }^{137}$. Esta descripción es una fuente documental de gran importancia, al igual que la documentación gráfica de Fischer y Lauritzen, para conocer cómo era el palacio antes de que este fuera parcelado y comenzara su declive. El otro documento escrito de que disponemos es un inventario del lugar, que se conserva en el Archivo Histórico de Nules, bajo la signatura "Varia no 2691". Este inventario se levantó entre los días 20 y 27 de noviembre de 1550, tras la muerte de Francisco Gilabert de Centelles, por orden se su viuda, María de Cardona, quien asumió el papel de tutora de su hijo Pere de Centelles y cuidadora de todos sus bienes ${ }^{138}$. El inventario detalla de manera pormenorizada los bienes muebles del palacio, y si bien enumera muchas de sus salas, por su nombre no es posible identificar dónde se localizaban la mayoría de las dependencias.

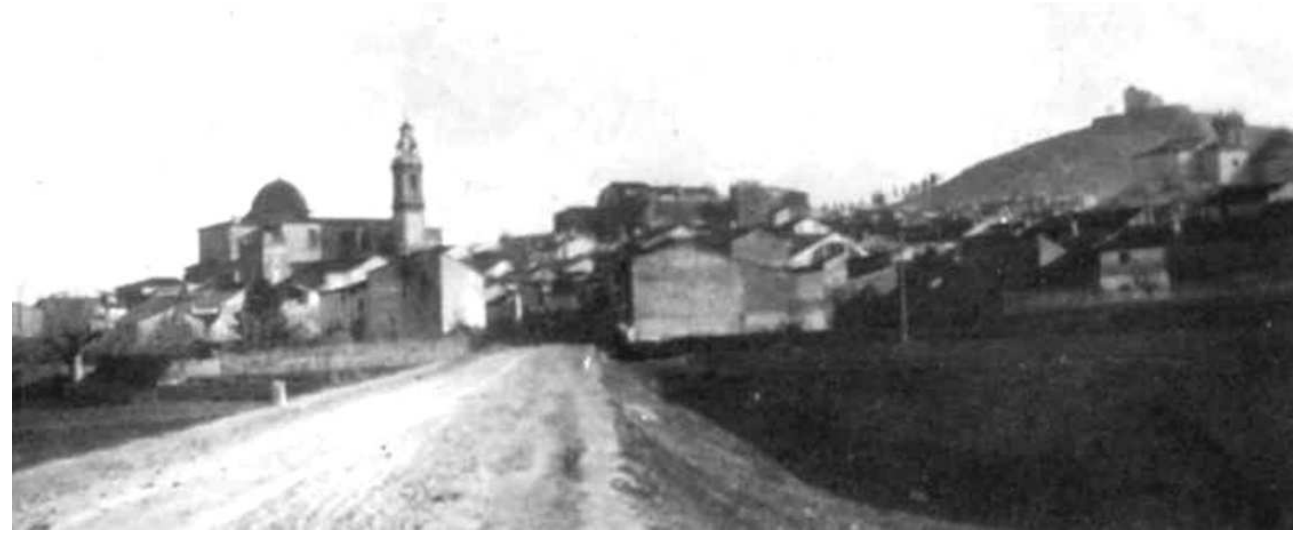

Figura 45. Vista de Oliva desde el camino de Valencia. A la derecha la Iglesia de Santa María; en el centro el palacio y a la derecha el Castillo de Santa Ana. Fot. 3. AFG. Egil Fischer (1917-1920).

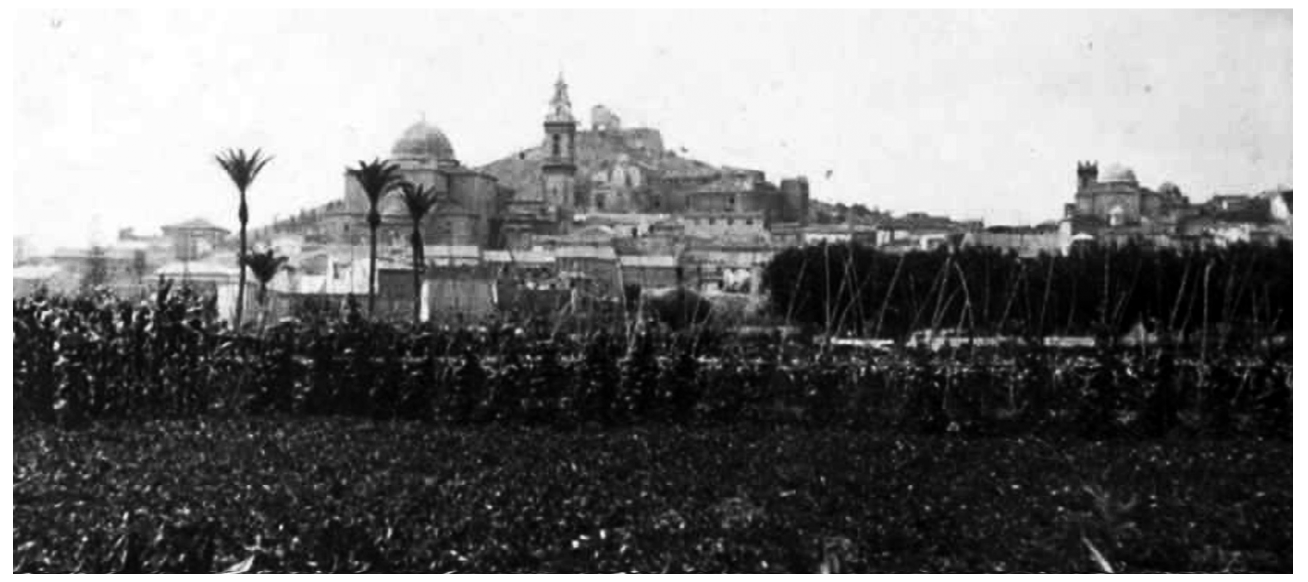

Figura 46. Vista de Oliva desde el ferrocarril. En el centro la Iglesia de Santa María y a la derecha el palacio. Fot. 4. AFG. Egil Fischer (1917-1920).

\footnotetext{
${ }^{137}$ Arciniega García, L. (2001). La Memoria del ducat de Gandia i els seus títols annexos. Redactada per Basilio Sebastián per al duc d'Osuna (1851-1852). Gandia: CEIC Alfonso el Vell. pp. 217-225.

${ }^{138}$ Felip Sempere, V. (2001). Recull per a una historia de Nules (Barcelona. 1977-Nules 2000) Vol. II. Nules, Castellón: Caixa Rural de Sant Josep de Nules. pp. 301-368.
} 


\subsection{Los patios}

El palacio disponía de 6 patios: uno en el acceso, tras el portón de acceso llamado "Pati del Portalet" (Ilamado también "Patio de Armas"); el patio central, llamado "Pati de l'Escala"; y otro junto a la cocina, que daba al lienzo NO del palacio, llamado "Pati del Colomer". Además, entre la cocina y la sala 3 del plano de Fischer, se situaba un patio pequeño donde se encontraba el pozo, denominado "Pati del Pou"; otro que daba al lienzo SE, llamado "Pati del Algutziur"139; y el último, en el extremo SO, junto a la Torre del Homenaje.

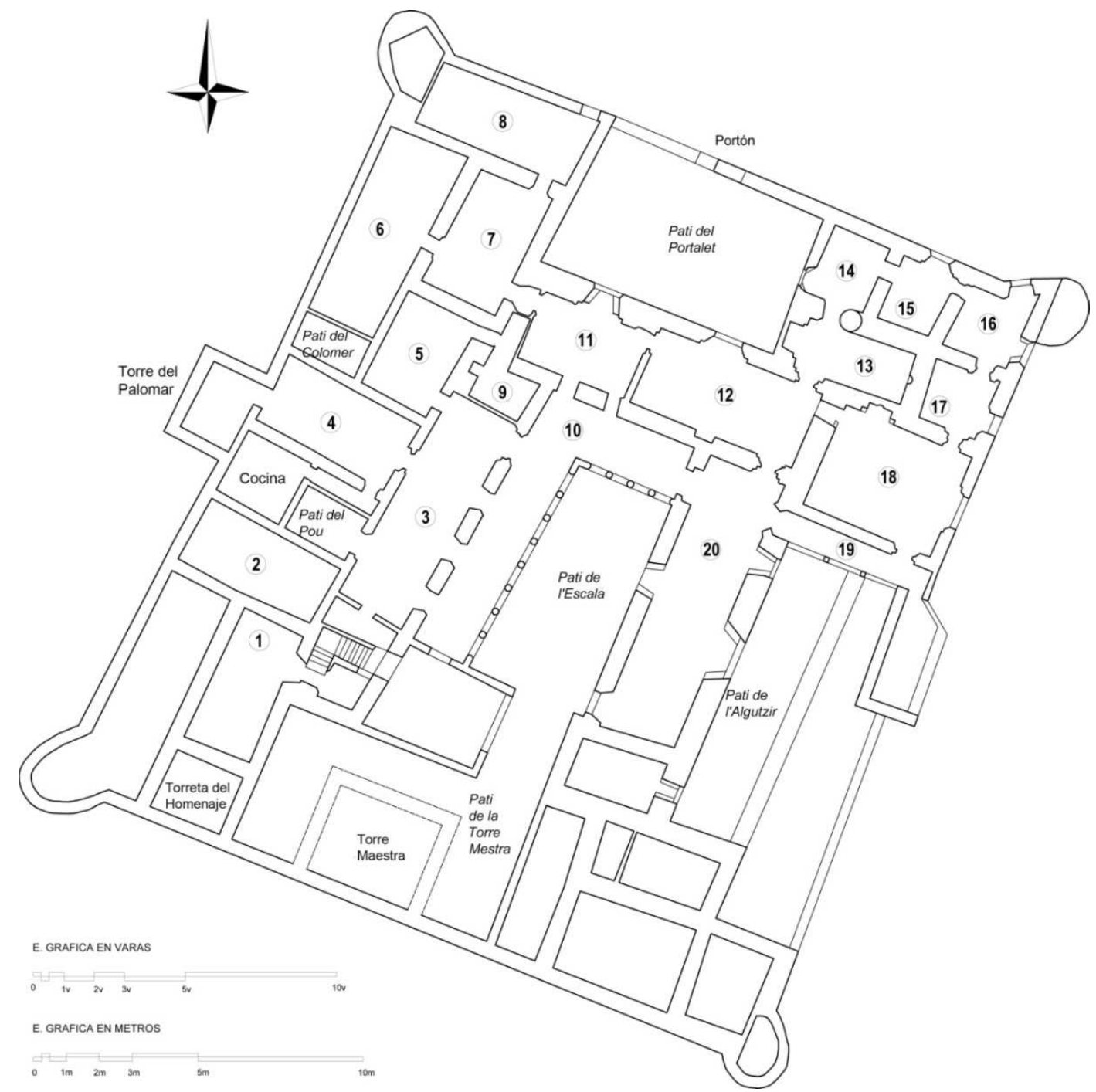

Figura 47. Plano de planta principal del palacio. Numeración de salas según Fischer y Lauritzen, y localización de patios y torres. Fuente: Fischer.

${ }^{139}$ Estas denominaciones las extrae Arcinienaga de un presupuesto realizado con motivo de unas obras de blanqueado y retejado del palacio conservado en el AHN, Osuna, lligall 803, núm. 3(24) (a). Arciniega García, L. (2001). Óp. cit. pp. 78. 


\subsection{Las torres}

El palacio contaba con 8 torres (4 redondeadas en las esquinas, dos rectangulares en el centro de las fachadas NO y SE, la Torre Maestra o del Homenaje y la Torreta del Homenaje $)^{140}$. El inventario de 1550 designa a 7 de estas 8 torres de la siguiente manera ${ }^{141}$ :

- La Torre de l'Almodí.

- La Torre de la galera o de l'Ort del Senyor.

- La Torre de l'Ort de Savall.

- La Torre de la Almàcera de Ferrandiz.

- Lo mig torrejo del camí a la porta (este torreón podría referirse al de la esquina NE, ya que según los planos de Fischer, este no llegaba a la planta principal).

- La Torre de Ferrando.

- La Torre del Colomer (esta torre era rectangular y estaba situada en la fachada NO, denominada así también por Fischer y otros autores).

No aparece en este inventario la Torre Maestra, quizás porque al estar destinada a ser una cárcel, no tuviera ningún objeto digno de ser inventariado. En cualquier caso, estaba situada en el lienzo de la fachada SE, enrasada con el mismo y tenía una altura de 120 palmos ${ }^{142}$. Era maciza en su primer tramo y, en la parte alta, estaban los calabozos con dobles puertas y fuertes cerrojos. Inicialmente estaba almenada, y desde ella se podía contemplar la huerta de Gandía (desde Sueca a Denia) y gran extensión de mar. Asimismo, se divisaban los castillos de Rebollet, Palma y Bayrrén, lo que permitía la comunicación con ellos ${ }^{143}$.

La Torreta del Homenaje de la que habla Gaspar Castellanos debía corresponderse con alguna de las referenciadas aparecidas en el inventario de 1550. Tenía una puerta con arco de medio $y$, en una planta superior, una habitación oscura con una tronera superior $y$, sobre ella, almenas de piedra ${ }^{144}$.

Fischer denomina también "Torre Grande" a la Galería con logia situada sobre la Sala de Armas.

\subsection{Las Plantas}

El palacio tenía una planta cuadrangular con lados algo irregulares, cuatro torres redondeadas en sus extremos y dos torres rectangulares que sobresalían en sus fachadas SE y NO (Torre del Palomar). Las dimensión media en el sentido NE-SO era de 53,5 m (58

\footnotetext{
${ }^{140}$ Esta torre es mencionada en la descripción de Gaspar Escolano y localizada también por Fischer en sus planos del palacio.

${ }^{141}$ Felip Sempere, V. (2001). Óp. cit. pp. 343-344.

${ }^{142}$ Vidal, J.M. (1932). Óp. cit.

${ }^{143}$ Arciniega García, L. (2001). Óp. cit. pp. 219.

${ }^{144}$ Arciniega García, L. (2001). Óp. cit. pp. 219.
} 
varas valencianas), y en el sentido SE-NO de $46,5 \mathrm{~m}$ (50,5 varas). El eje principal del palacio formaba un ángulo $26^{\circ}$ respecto de la orientación NS.

El palacio se componía de planta baja, entresuelo, planta principal o noble y planta alta o galería ${ }^{145}$. El arranque era de mampostería en talud, tal y como se puede ver en los restos del lienzo de la muralla que quedan junto a la Torre de la Comare y en las fotografías tomadas por Fischer. La parte superior era de ladrillo y de tapial, siendo su espesor en la planta noble de 6 pies y $1 / 2(149 \mathrm{~cm})$. Disponía de foso que fue tapado, en parte, para permitir el acuartelamiento de las tropas durante la Guerra de Sucesión ${ }^{146}$.

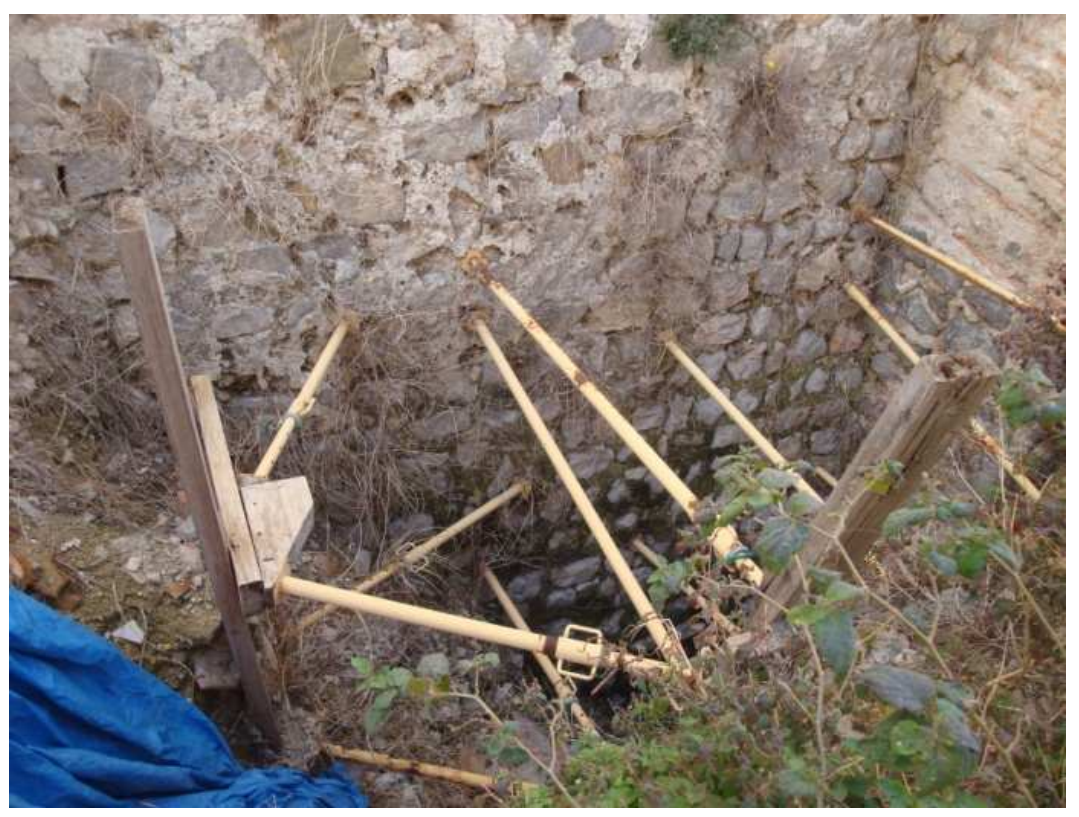

Figura 48. Excavación arqueológica en lienzo muro SE junto torre rectangular. Muro ataluzado de fábrica de mampostería.

Sobre la puerta de entrada se encontraba el escudo de armas de los Centelles y en una banda que lo rodeaba se leía la siguiente inscripción: "Priman Muris Comes Seraphinus Olivam Murus fortior memini 1531". Esta inscripción hace referencia a los trabajos de reconstrucción del palacio por parte de Serafín de Centelles tras la revuelta de Germanías, ya que, como hemos visto en el apartado dedicado a los antecedentes históricos, los agermanados eliminaron todas las referencias a los nobles y sus insignias.

${ }^{145}$ La descripción de las plantas baja, entresuelo y alta las realizaremos basándonos en la descripción hecha por Sebastián Castellanos en su Memoria al duque de Osuna. Arciniega García, L. (2001). Óp. cit. pp. 218-225.

${ }^{146}$ Aguilar, J. V. (1708). Carta al duque de Gandía (Pascual Francisco Borja Centelles Ponce de León). AHN. Osuna. OSUNA,CT.123,D.39. 


\section{Planta baja}

A la derecha del Patio de Armas, en el acceso principal, se localizaban las prisiones antiguas, y a la izquierda el cuerpo de guardia ${ }^{147}$. En el ángulo izquierdo del patio estaba la portada de medio punto con jambas de piedra y hendidura para la gran puerta de hierro. Por su parte, en el zaguán de acceso (bajo la sala $12^{148}$ ) había dos escalerillas que daban acceso al entresuelo mediante dos portadas góticas, similares a las que encontramos en otros palacios como el de los Almirantes de Aragón, el Castillo de Alaquás o el Castillo de Albalat dels Sorells. El forjado era artesonado y pintado ${ }^{149}$. En el Patio Central, frente a la Galería, se encontraba la cuadra abovedada a la que se accedía por dos arcos apuntados (esta zona se situaba bajo la sala 20). En el lado de la galería existían dos habitaciones destinadas a cuarteles y almacenes, así como un paso al patio pequeño, donde se encontraba el pozo y habitaciones para soldados, con salida a la torre almenada (Torre del Palomar) y a la ronda de la muralla (esta zona estaría situada bajo las salas 3 y 4). Al fondo del patio, bajo la escalera gótica, había una pequeña puerta, también gótica, que daba acceso al patio situado a la izquierda de la Torre del Homenaje. En este patio, a derecha e izquierda, se accedía, a partir de dos arcos apuntados, a las cuadras militares o cuerpos de guardia de la Torre $^{150}$.

\section{Entresuelo}

En el lado izquierdo del zaguán de ingreso se accedía, mediante escalerilla, a una sala situada bajo la capilla (sala 13) de idénticas dimensiones que ésta, con forjado en relieve y cornisa labrada. La sala siguiente tenía bóveda de crucería (probablemente bajo la sala 17, con bóveda estrellada) y portadas góticas de piedra. En el lado derecho, a la subida de la escalerilla, estaban las habitaciones que daban al torreón de este lado; tenían portadas sencillas góticas $y$, en la sala cuya ventana daba al foso, había un forjado formado por tirantes labrados y con relieves en estuco: sirenas aladas con canastillos en los medios y cornucopias vertiendo frutos ${ }^{151}$. Por su parte, el pavimento era de azulejos de Manises en blanco y azul (esta zona estaba bajo las salas 7 y 8 ). Al fondo del patio central, subiendo el primer tramo de la escalera, había una puerta de hierro que daba acceso a una habitación con salida al patio de la izquierda de la Torre del Homenaje, a la muralla de esta parte y a la "Torreta del Homenaje", a la que se accedía por un puente de piedra. Por su parte, a la

\footnotetext{
${ }^{147}$ En este patio, el inventario de 1550 habla de una bodega.

${ }^{148}$ Estas referencias se refieren al plano de la planta principal elaborado por E. Fischer y V. Lauritzen.

${ }^{149}$ Este forjado corresponde con el de la Lámina LA1110A. Fischer, E. y Lauritzen V. (1919-1920). Planos. Oliva, Valencia: Museo Municipal de Oliva, Archivo Público Documental, Palacio Condal.

${ }^{150}$ Arciniega García, L. (2001). Óp. cit. pp. 218-219.

${ }^{151}$ Esta descripción se corresponde con el forjado de la Fot. 45. AFG. E. Fischer.
} 
izquierda del patio existía un ala del palacio que había sido destruido por un incendio, en el que había dos habitaciones altas ${ }^{152}$.

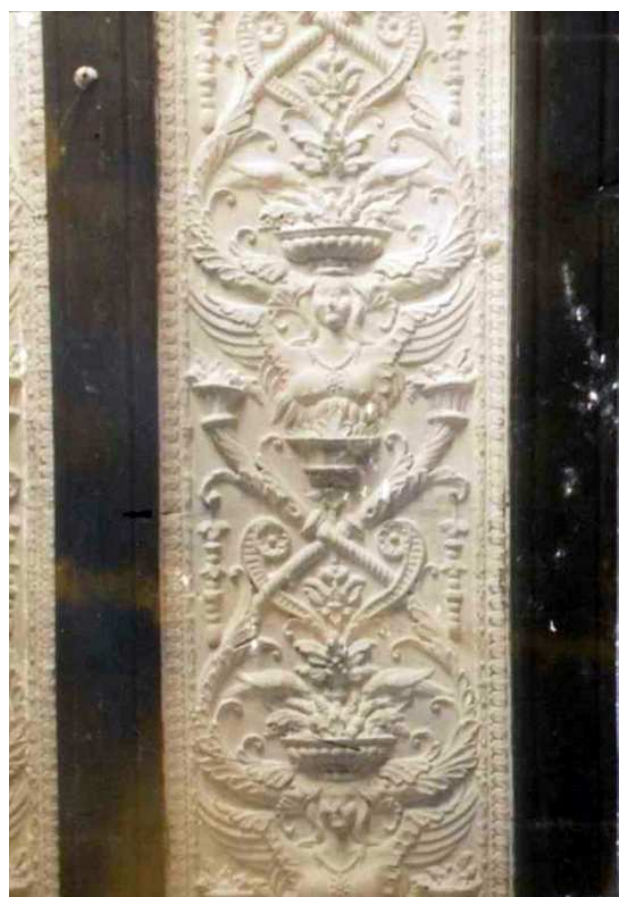

Figura 49. Detalle del forjado de madera con revoltones de yeso decorados: "Sirenas aladas con canastillos en los medios y cornucopias vertiendo frutos". Fot. 45. AFG. E. Fischer.

\section{Planta principal}

En la planta principal se distinguen dos grandes zonas: la zona noble, a la que se accedía por la puerta situada en el ángulo izquierdo, a la subida la escalera gótica; y la zona de servicio, a la que se accedía desde la puerta situada en el ángulo derecho, a la subida de dicha escalera. Las primeras se corresponderían con las salas numeradas de la 10 a la 20 por Fischer, y la segunda con las salas 1 a 9 (y otras estancias que Fischer no numeró). En el inventario de 1550 se habla de los "studis daurats" y los "studis blanchs"153, denominaciones que corresponderían a estas dos grandes zonas.

En la primera área ${ }^{154}$ estaba el acceso a la Torre del Homenaje, el comedor, las cocinas, la repostería y el acceso a los cuartos de los sirvientes. El comedor (sala 3) daba a la galería porticada. La cocina (entre salas 2 y 4 ) era de planta cuadrada y estaba cerrada por una gran cúpula octogonal formada mediante pechinas que terminaba en una linterna abierta para la salida de humos, similar a otras existentes en Sant Mateo y Traiguera (Castellón). ${ }^{155}$

\footnotetext{
${ }^{152}$ Arciniega García, L. (2001). Óp. cit. pp. 218-219.

${ }^{153}$ Felip Sempere, V. (2001). Óp. cit. pp. 301-368.

${ }^{154}$ Esta zona es referenciada por Fischer como área de Sanchis y Miguel en los Notebooks I y II.

155 Soler Estrela, A., Soler Verdú, R. y Cabeza González, M. (11-06-2015). A pyramidal kitchen vault in a Gothic-Renaissance palace. Oliva, Valencia, Spain. En: Heritage and Technology Mind Knowledge Experience (XIII Forum Internationale Le Vie dei Mercanti). pp. 396-403.
} 
La repostería se correspondía con la sala 3 del plano de Fischer. Las salas 5 a 8, por su parte, debían los "studis blanchs" aparecidos en el inventario de 1550.

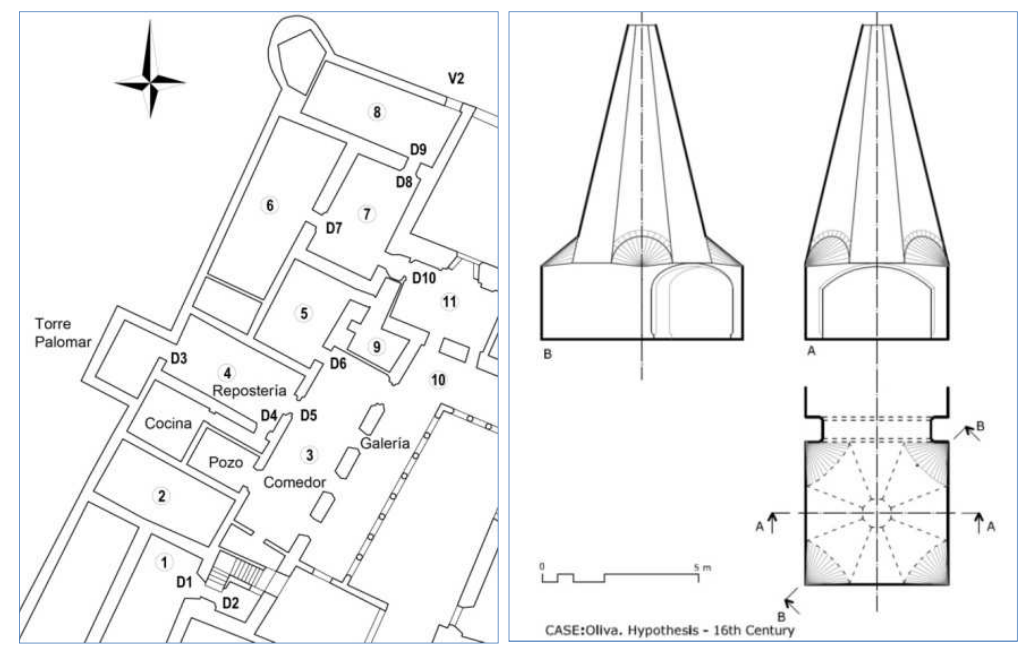

Figura 50. Izquierda: Plano directorio Salas 1-9 Planta principal. Derecha: Hipótesis bóveda de la Cocina del palacio de Oliva. Autora: A. Soler (2015).

- Habitación condal: desde la puerta izquierda, sobre la escalera, se accedía a la antecámara condal o habitación condal (sala 20). Su forjado era de madera labrada y los tirantes apoyaban sobre ménsulas (podría tratarse de las ménsulas de la fotografía 95 del Álbum Fotográfico Grande). Existían además dos grandes ventanas góticas de arcos escarzanos con columnillas y festejadors. La ventana, que recaía en el patio SE o del Algutzir, se corresponde con la de la fotografía 79, en la que se ven en el exterior las 4 piezas de piedra de una ventana cuatrífora. La sala disponía de otra ventana que recaía en el patio SE (LA1181 y Fot.82). Al fondo, en el lienzo frontal, se encontraba la gran portada $27 \mathrm{y}$, a su derecha, la $26^{156}$. La puerta de acceso a la galería estaba situada frente a esta última y era de arco de medio punto. Está dibujada en el mismo plano que la galería ${ }^{157}$.

156 La descripción de las portadas se realiza en el Capítulo VI y la de las ventanas, forjados, artesonados y bóvedas en el Capítulo V. Es este capítulo solamente se enumerarán los elementos arquitectónicos documentados por Fischer y Lauritzen.

${ }^{157}$ Fischer, E. y Lauritzen V. (1919-1920). Planos. Oliva, Valencia: Museo Municipal de Oliva, Archivo Público Documental, Palacio Condal. LA1129. 


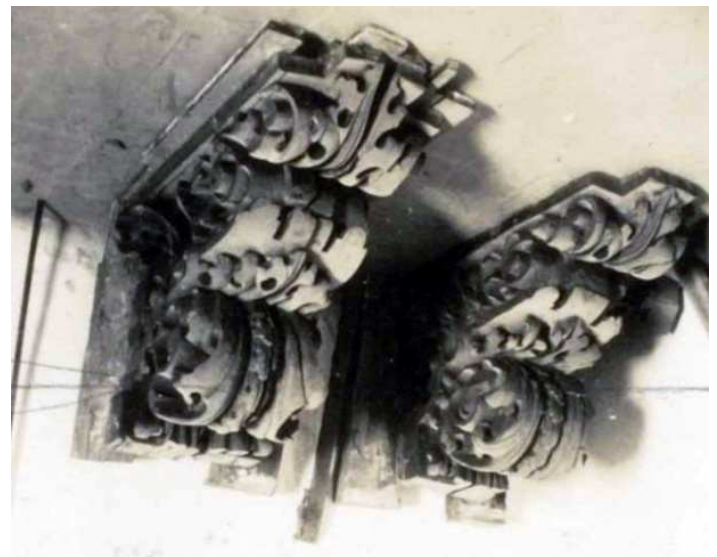

Figura 51. Ménsulas de madera decoradas. Fot. 95. AFG. E. Fischer.

Frente a la puerta de entrada se encontraban dos lápidas incrustadas en la pared, trascritas por Sebastián Castellanos y, posteriormente, por Teodoro Llorente, fuera ya de su lugar original. Después, fueron fotografiadas por Fischer, también fuera de su ubicación primera.

La lápida de la fotografía 87 fue traducida por Teodoro Llorente de la siguiente forma: "Fortificó con muros en otro tiempo Serafín a Oliva, -Su sobrino Francisco fortificó los muros con un alcázar,--aquel en los muros la hizo bella; pero éste -- la hizo formidable al enemigo y la aseguró.--Las torres y murallas fueron erigidas desde los cimientos--el año de Cristo 1545".

En cuanto a la lápida de la fotografía 88 , fue traducida así por Teodoro Llorente la tradujo de la siguiente manera: "La que fuí tierra de los enemigos feroces al ser provista de muros-que crees podré ser estando fortificada con este alcazar?--Son tantos mis muros cuantos mis hijos: no podrás con razón llamarte, Murla, el muro del reino.--Gloria es esta del conde Francisco que me ha fortificado con esta defensa;--pero defensa es él sólo para mí más segura que cualquiera otra.--Año de Cristo 1546".

Ambas hablan de la fortificación que realizó Francisco de Centelles del palacio, sin duda para mejorar sus defensas tras las Germanías, la primera habla también de las obras de embellecimiento que impulsó Serafín de Centelles.

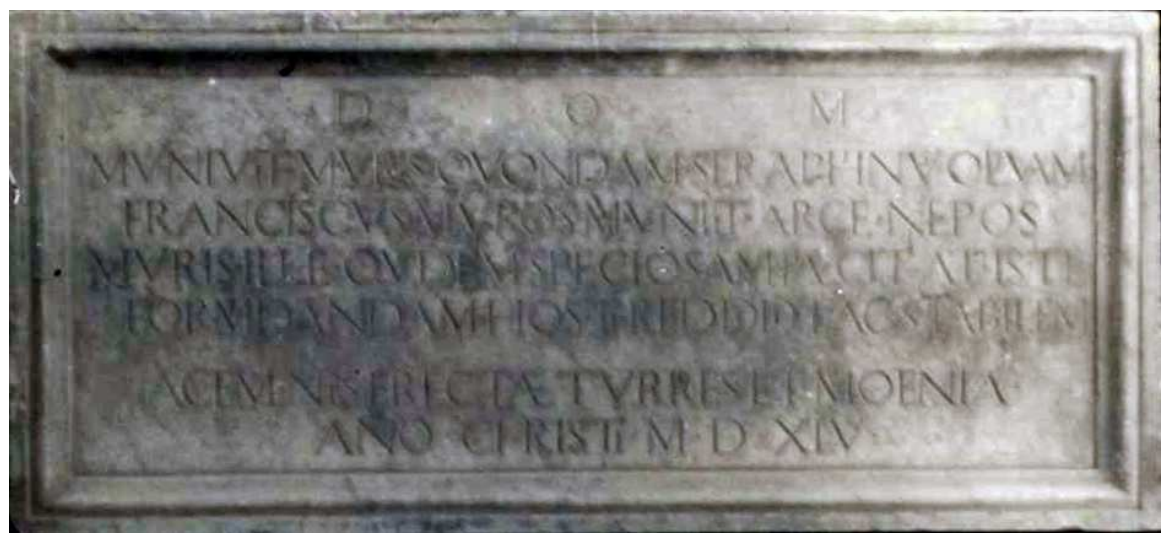

Figura 52. Lápida conmemorativa Palacio Condal de Oliva. Fot. 87. AFG. E. Fischer. 


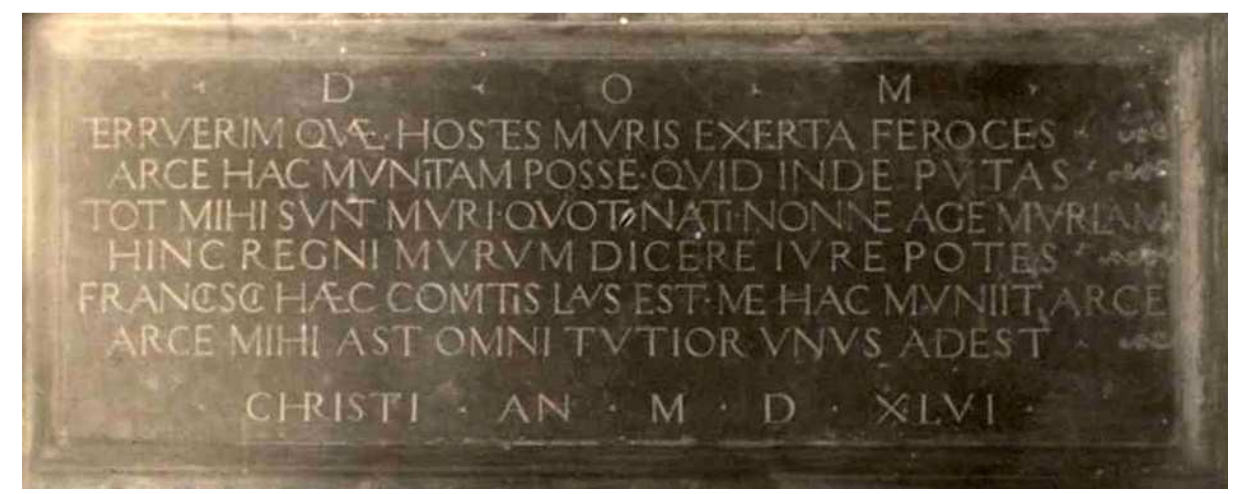

Figura 53. Lápida conmemorativa Palacio Condal de Oliva. Fot. 88. AFG. E. Fischer.

- Salón señorial: Sebastián Castellanos denomina así a la Sala de Armas (Sala 18). En ella se encontraban las portadas D22 y D23 y la gran ventana V10, con vistas a Oliva, al cerro de Santa Ana, y desde la cual se podía divisar hasta Denia. EI pavimento era de azulejos como el resto del palacio. El forjado era decorado y pintado en diversos colores y dorado, "con adornos bellísimos por el estilo de Rafael, con medallones de emperadores romanos"158. Sebastián Castellanos nos trascribe un texto escrito en caracteres semigóticos, localizado en la moldura superior del friso y que pasó desapercibido tanto para Llorente, como para otros historiadores que visitaron el palacio. Este texto, mal trascrito debido a lo enrevesado de sus caracteres, y de difícil traducción, transmitía un mensaje de unidad para mantener el orden, "que es generador de riqueza, la cohesión les hará vencer a toda clase de gente". El texto que transmite un mensaje de unidad hay que contextualizarlo, al igual que el del escudo de la puerta de acceso en los momentos posteriores a la guerra de Germanías, lo que nos ayuda a datar este artesonado. El friso representaba una marcha triunfal y tenía rotulada una inscripción que detallaba lo representado. Este texto fue transcrito, además de por Castellanos, por Llorente ${ }^{159}$ y por González Simancas ${ }^{160}$.

- Gabinete principal: se corresponde con la sala 17. En ella se encontraban las portadas D20 y D21 y la ventana V9. Tenía una bóveda estrellada (Loft 17) con 5 claves o pendolones y escudos de los diferentes señores a los que había pertenecido el palacio. En los lunetos laterales tenía pintados cuatro medallones con los bustos de Julio César, Aníbal, Semiramis la Asiria y Carlo Magno. También están representados bajo los medallones Marco Antonio y el noble romano Mercurio Scévola. En los tímpanos estaba pintado el escudo de la casa de los Centelles .

\footnotetext{
${ }^{158}$ Arciniega García, L. (2001). ÓP. cit. pp. 221-222.

159 Llorente, Teodoro (1889). Valencia. Colección «España: sus monumentos y sus artes-su naturaleza e historia». Barcelona: Editorial de Daniel Cortezo y C. pp. 706-709.

${ }^{160}$ González Simancas, M. (1916). Catálogo monumental y artístico de la provincia de Valencia. Tomo /I [Manuscrito]. Madrid. pp. 34-36.
} 


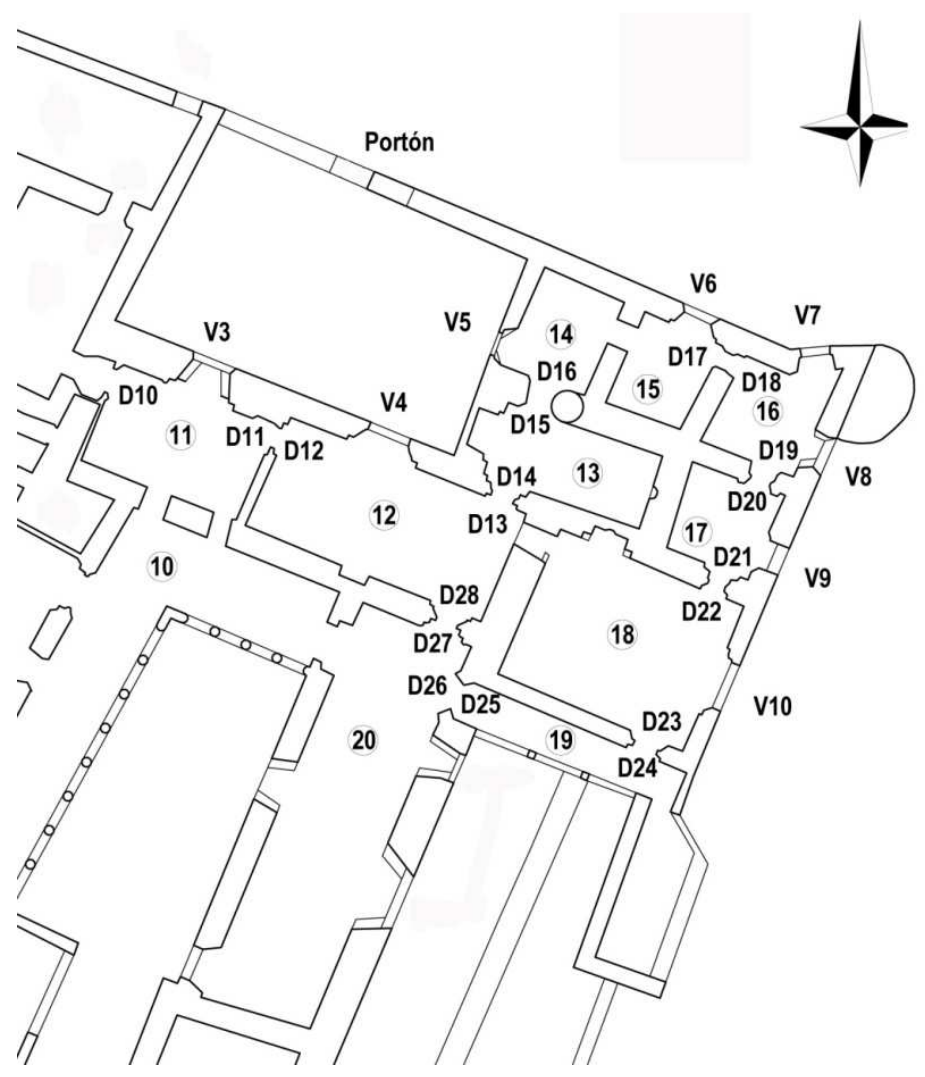

Figura 54. Plano directorio Salas 10-20. Planta principal.

- Piezas de alcoba: se corresponden con las salas 14, 15 y 16 . En la Sala 16 se encontraban las portadas D18 y D19 y las ventanas V7 y V8. El forjado era de vigas de madera y el entrevigado de yeso pintado (Loft 16). En la Sala 15 estaban las portadas D17 y la V6, cubiertas por una bóveda de crucería (Loft 15). Por su parte, en la Sala 14 se encontraba la portada D6, una ventana que Fischer no inventarió y un forjado plano de tirantes; los dos casetones del centro tenían adornos de estuco con medallones y flores ${ }^{161}$. Debió de deteriorarse antes de 1917 ya que es el único de la planta noble que Fischer no detalla. En el plano de Fischer existe asimismo un paso entre las salas 15 y 16, abierto posteriormente a 1851 .

- Oratorio o Capilla: se corresponde con la Sala 13. En ella se encontraban las portadas D14 y D15 y la ventana V5, que daba al Pati del Portalet o Patio de Armas. En el testero, frente a la ventana, tenía una gran venera de arco rebajado en bajorrelieve y, en su otro extremo, un arco apuntado ${ }^{162}$ (tal y como se observa en la fotografía $58^{163}$. La bóveda de escayola rebajada, formada por casetones, (Loft 13) se suspendía de una bóveda de cañón apuntada de fábrica de ladrillo.

- Salón de linajes: Sebastián Castellanos le da esta denominación porque de él colgaron en su día los retratos de los antepasados de la familia como era costumbre

${ }^{161}$ Arciniega García, L. (2001). Óp. cit. pp. 223.

${ }^{162}$ Arciniega García, L. (2001). Óp. cit. pp. 223-224.

${ }^{163}$ Fischer, E. (1917-1920). Álbum Fotos Grande. Fot. 58. pp. 13R. 
en los palacios antiguos de grandes señores. Sebastián Castellanos encontró dieciséis de estos retratos pertenecientes a los Carrós y a los Centelles colgando en una de las salas del Palacio de Gandía. Éste era uno de los salones de mayor dimensión del palacio y se corresponde con la Sala 12 de la numeración de Fischer. En él se encontraban las portadas D12, D13 y D28 y la V4, desde la que se divisaban, por encima del portón de entrada, el Mediterráneo y los pueblos de Piles y Guardamar. Estaba cubierta por un artesonado romboidal (Loft 12), cuya forma emula los blasones de los Centelles ${ }^{164}$. Tenía poleas para colgar tapices, entre otros elementos decorativos.

- Despacho condal: Esta sala corresponde con la Sala 11. En ella se encontraban las portadas D10 y D11 y la ventana V3, exteriormente estaba formada por una ventana ajimezada formada por tres arcos festoneados apuntados. Tenía un artesonado de casetones cuadrados con flores doradas en los encuentros y poleas para colgar tapices como el anterior.

\section{Planta superior}

En la planta superior se situaban las habitaciones humildes destinadas a los sirvientes y las galerías: sobre la galería porticada del patio se encontraba otra galería adintelada llamada por Fischer "Galería Alta", que apoyaba sobre la balaustrada de mármol; sobre la Sala de Armas se encontraba la Galería de la Torre Grande, que estaba abierta con una logia y con 7 arcos góticos en su fachada $\mathrm{SO}^{165}$; sobre la sala 20 había una galería con arcos de medio punto que daban a la fachada SE. En el inventario de 1550 las denomina "cambras" y su uso principal era el almacenamiento de enseres y productos. En 1851 esta planta albergaba la cárcel, los antiguos servidores del palacio y la maestra de Oliva ${ }^{166}$.

\subsection{Las fachadas}

\section{Fachada NE}

En esta fachada estaba situada la puerta de acceso al palacio. La puerta medía 4 varas y estaba formada por un arco rebajado con parmento sobre él almenado. Disponía de un puente levadizo que se echaba sobre el foso mediante un sistema que disponía de una puerta de dos hojas de madera, con un portillo y dos aldabones circulares, y una trampa posterior de hierro que bajaba entre ranuras alojadas en el muro ${ }^{167}$.

La planta noble del palacio recaía sobre esta fachada. De acuerdo con el plano de Fischer, en la sala 8 se encontraba la ventana numerada como V2, y en las salas 14,15 y 16, las V6 y V7, ésta última ya en el lienzo de la propia torre

\footnotetext{
${ }^{164}$ Arciniega García, L. (2001). Óp. cit. pp.224.

${ }^{165}$ Fischer, E. y Lauritzen V. (1919-1920). Planos. LA 1132

${ }^{166}$ Arciniega García, L. (2001). pp. 225. Óp. cit.

${ }^{167}$ Arciniega García, L. (2001). pp. 217-218. Óp. cit.
} 
En las fotografías 6 y 9 tomadas por Fischer podemos ver como se había tapado el foso y habían desaparecido las puertas. Se puede observar además el muro en talud de fábrica de mampostería y el muro superior, que sobre la puerta y en el lateral sur es de tapial con hiladas de ladrillo. El muro sobre el portón está escalonado y rematado con teja árabe, al igual que la cubierta del ala situada a la derecha del portón y de la torre. Las jambas y el arco del portón están realizadas en piezas de sillería. En la fotografía 9 se observa que en el interior del patio de acceso se habían realizado nuevas edificaciones que recaían a la calle Palacio, aunque todavía no se había demolido la puerta del inmueble.
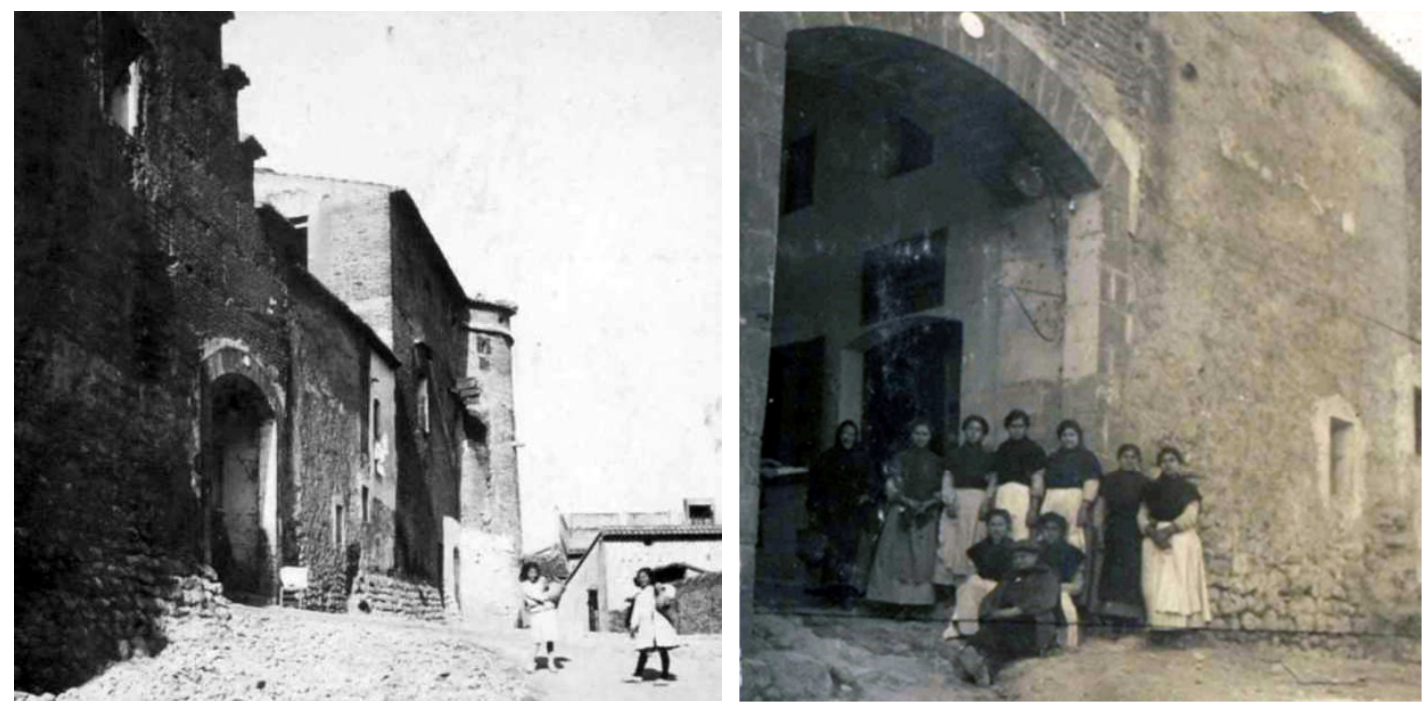

Figura 55. Fachada NE Palacio Condal de Oliva. Fot. 6 y 9 AFG. Egil Fischer (1917-1920).

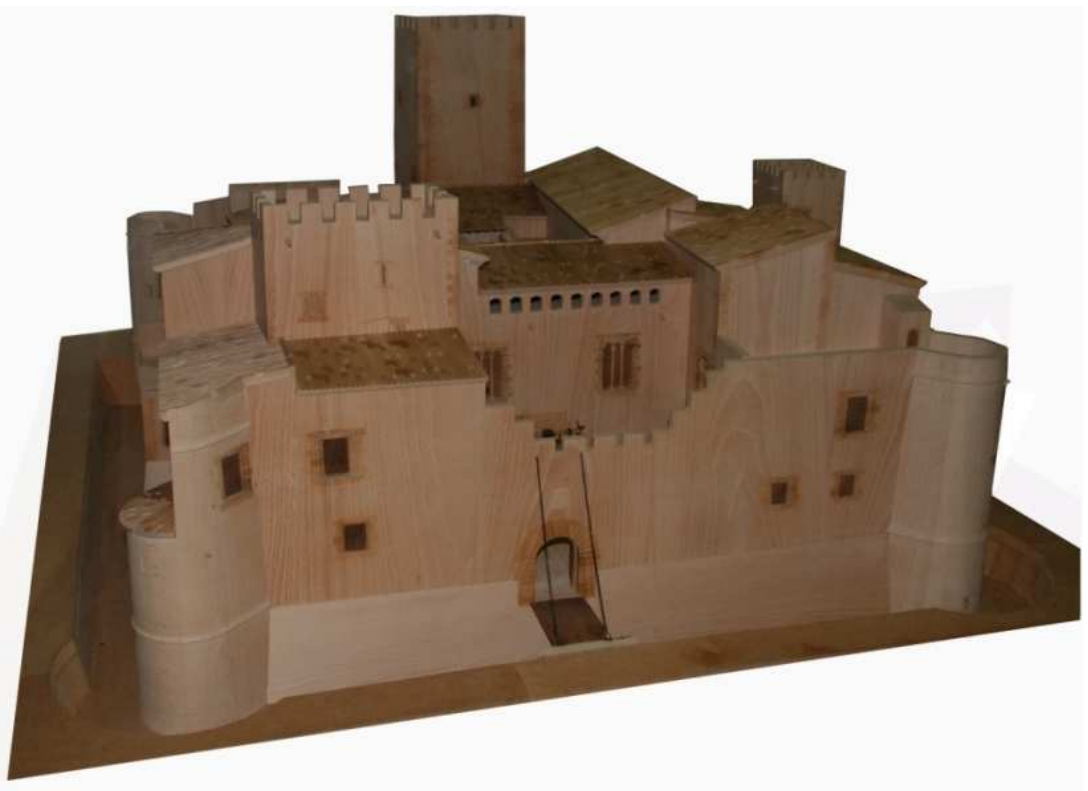

Figura 56. Fachada NE Palacio Condal de Oliva. Maqueta de Carlos Martínez y José García. E: 1/50. 


\section{Fachada SE}

A esta fachada estaban orientadas algunas de las salas más nobles del palacio, como la Sala de Armas, el gabinete y los dormitorios principales. En ellas se encontraban también algunos de los elementos más elevados del inmueble, ya que sobre la Sala de Armas había otra planta de gran altura con una logia, al menos, en dos de sus caras. Este cuerpo tenía cubierta a tres aguas, lo que hace suponer que la logia de arcos góticos rebajados se extendiera también por su cara NE. Sobre la Sala 20 se alzaba otra planta de altura algo inferior a la anterior con arcos de medio punto en su orientación SE y con cubierta a dos aguas.

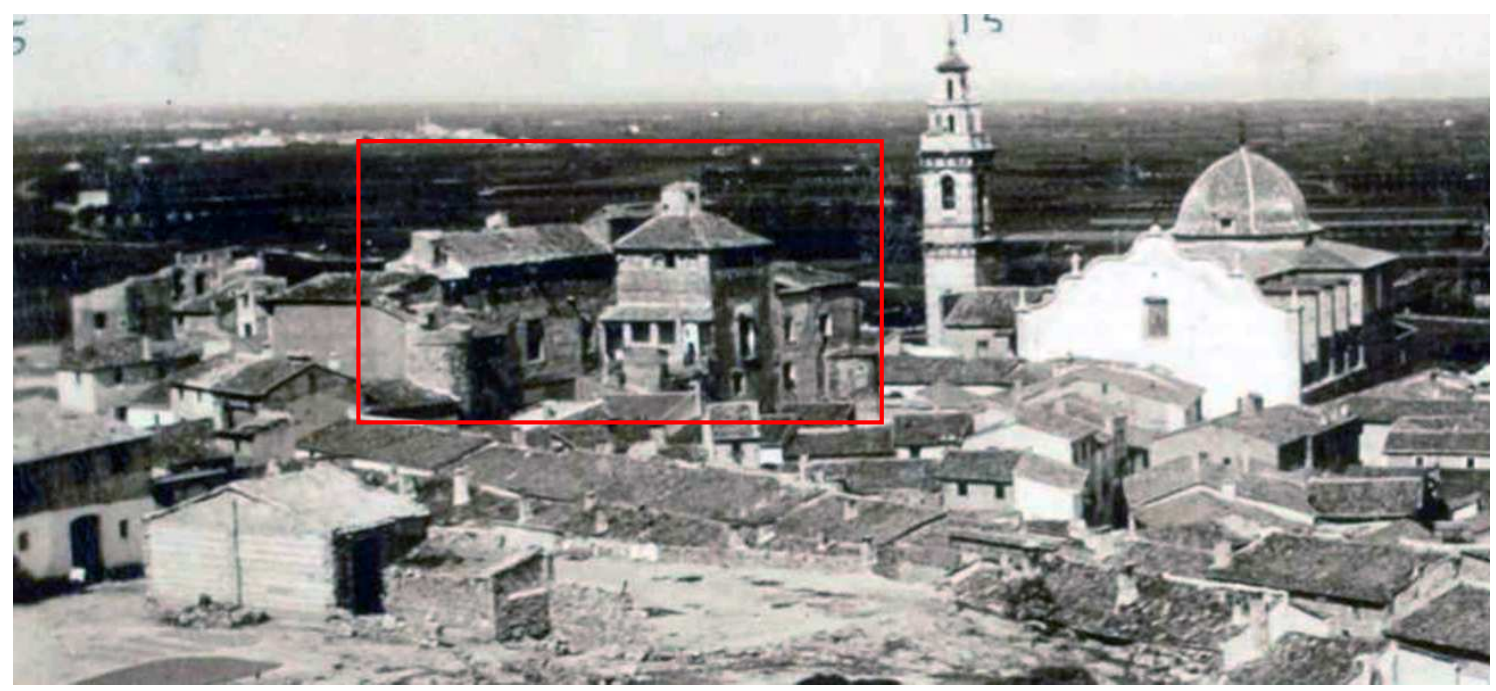

Figura 57. Fachada SE Palacio Condal de Oliva (recuadro). Fot. 5. AFG. Egil Fischer (1917-1920).

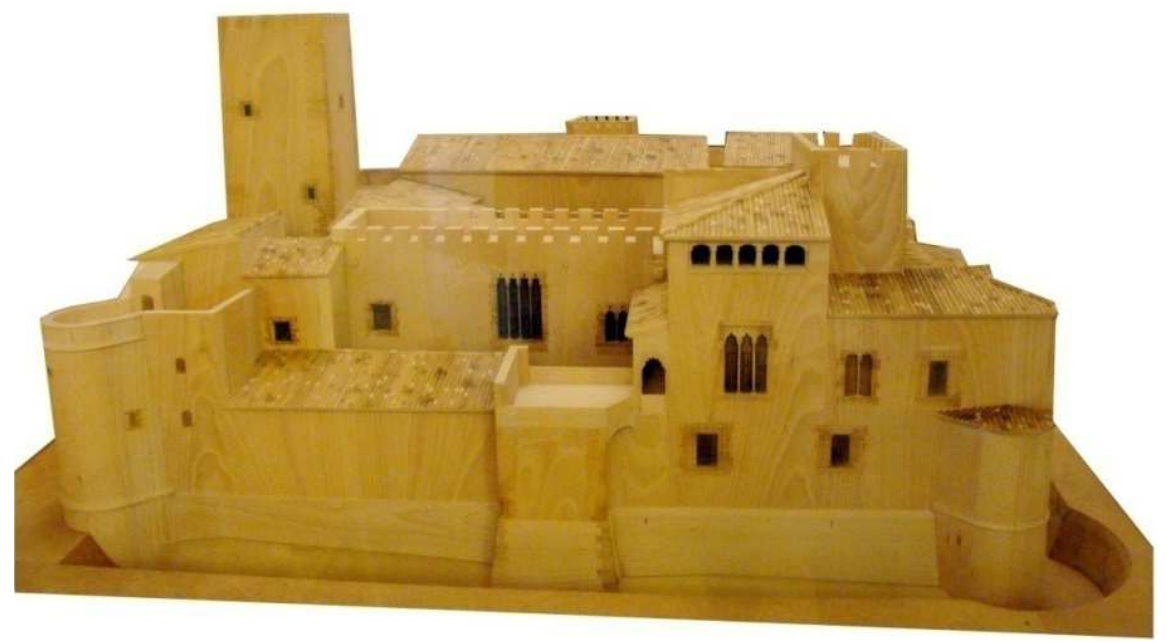

Figura 58. Fachada SE Palacio Condal de Oliva. Maqueta de Carlos Martínez y José García. E: 1/50. 


\section{Fachada SO}

Esta fachada estaba orientada hacia la parte alta o arrabal de Oliva. A ella estaba dirigido el cuerpo situado entre la torre SE y el patio de la Torre Maestra. Este cuerpo es el que se había incendiado antes de 1851. En la fotografía de Fischer se ve reconstruida, sin huecos, y con una comunicación con la torre SE. Enrasada con esta fachada estaba la Torre Maestra y la "Torreta del Homenaje", todavía estaba en pie en 1917. En la siguiente imagen se puede ver que en la planta alta había un hueco de grandes dimensiones orientado hacia ésta fachada SO.

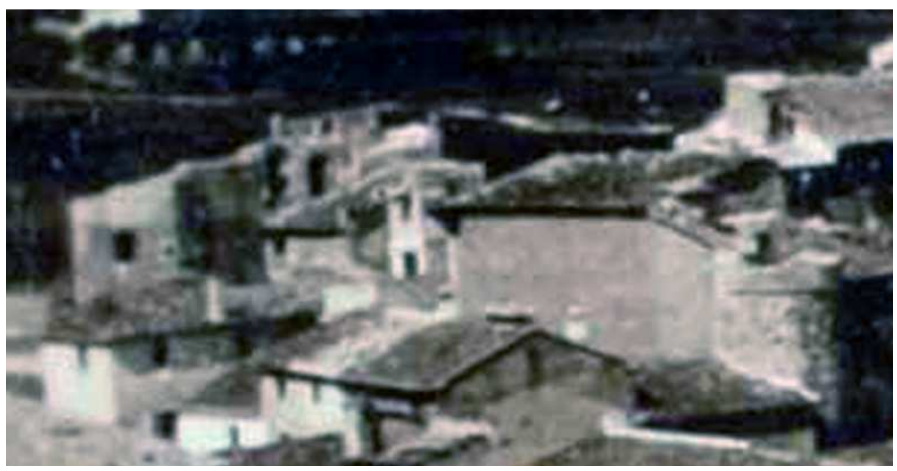

Figura 59. Fachada SO Palacio Condal de Oliva. Fot. 5 (detalle). AFG. Egil Fischer (1917-1920).

\section{Fachada NO}

Esta fachada estaba orientada hacia la entrada de Valencia. Destacaba en ella la torre rectangular llamada "del Palomar", que era el cuerpo más alto; la cocina y las salas 2, 4 y 6 según la numeración de Fischer. Sobre éstas estancias se situaban las habitaciones de los criados. Los huecos eran más modestos que en las fachadas NE y SE. Las ventanas de la Torre del Palomar fueron dibujadas por los arquitectos daneses.

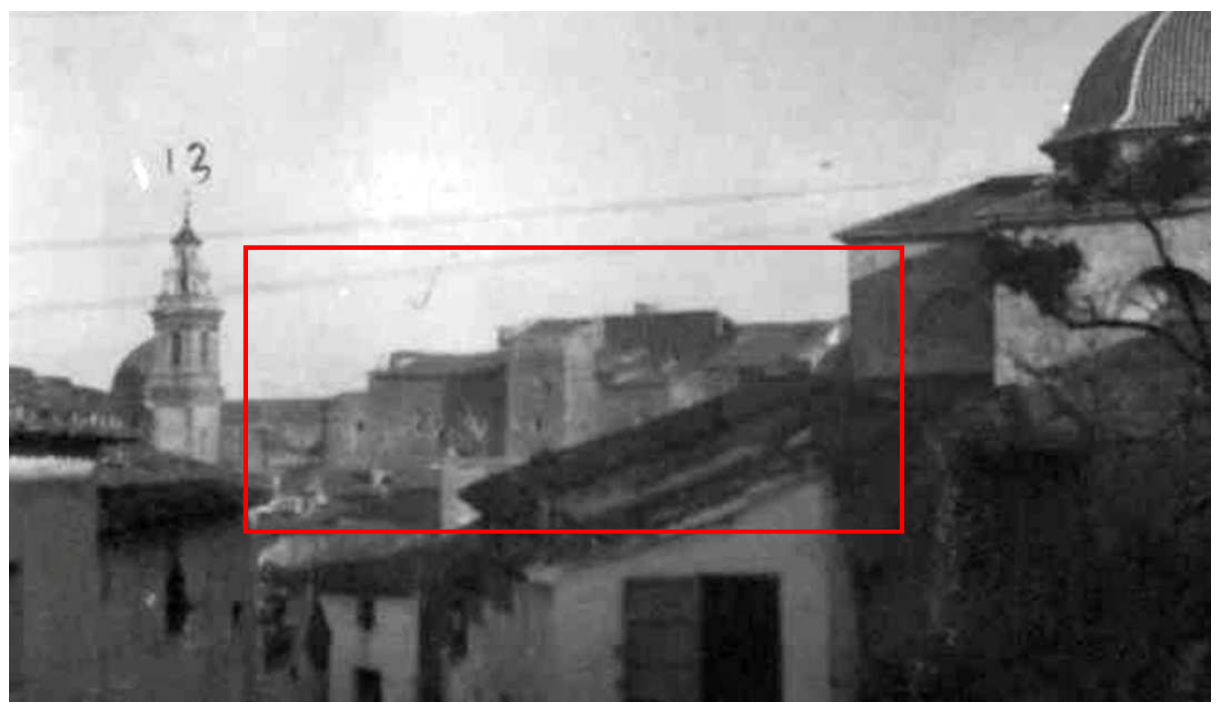

Figura 60. Fachada NO Palacio Condal de Oliva. Fot. 7 (detalle). AFG. Egil Fischer (1917-1920). 
Esta fachada fue dibujada en perspectiva por Egil Fischer en el Notebook $1^{168}$.

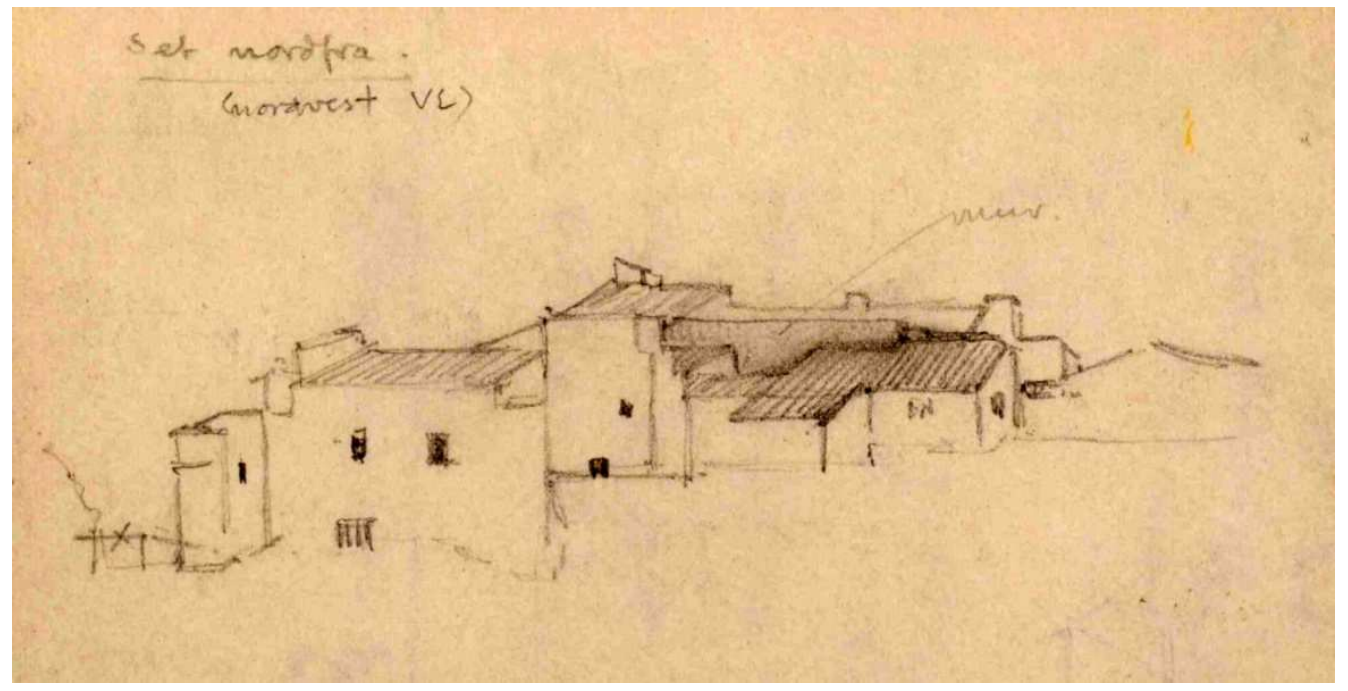

Figura 61. Fachada NO Palacio Condal de Oliva. Croquis Notebook I. Egil Fischer (1917-1920).

\section{DATACIÓN}

La destrucción de los archivos de Oliva durante la Guerra Civil española nos ha privado de muchos documentos históricos imprescindibles para datar correctamente el palacio. Así, el primer elemento del inmueble del que tenemos constancia fue la Torre Maestra, que según la tradición, fue mandada construir por Jaume I tras la Reconquista (mediados del siglo XIII) ${ }^{169}$. Sabemos que el Almirante Francisco Carroz trasladó su residencia del Castillo de Rebollet a Oliva en 1338 por orden del rey Pedro el Ceremonioso, quien le ordenó establecerse en Oliva para preparar sus fortalezas de la amenaza de los musulmanes, por lo que en esa época ya debía de existir una construcción previa ${ }^{170}$. Por su parte, las fases de la edificación definitiva del palacio debieron de llevarse a cabo durante el siglo XIV o principios del $X^{171}$ bajo los señoríos de Gilabert de Centelles i de Castellet ( +1368 ) y Gilabert de Centelles i Riu-Sec († 1409?), señores de Nules y de Oliva. Los trabajos probablemente continuarían durante el señorío de Bernat de Centelles Riu-Sec i de Cabrera († 1433?) y, posteriormente, de su hijo Francesc Gilabert de Centelles Riu-Sec i de Queralt (1408?-1480?), quien se convertiría en el primer Conde de Oliva en $1449^{172}$.

\footnotetext{
${ }^{168}$ Fischer, E. (1917-1920). Notebook I. Oliva, Valencia: Museo Municipal de Oliva, Archivo Público Documental, Palacio Condal. pp. 24A.

${ }^{169}$ Escolano, Gaspar (1611) Segunda parte de la década primera de la historia de la insigne, y coronada ciudad y Reyno de Valencia. Valencia: Pedro Patricio Mey. pp. 159-160.

${ }^{170}$ Camarena Mahiques, J. (1988). Óp. cit. pp. 148-151.

${ }^{171}$ Olga Fischer donó en 1987 a la HSA tres monedas encontradas por su marido durante los trabajos en el palacio de los siglos XIII a XVI, una de ellas de Alfonso V el Magnánimo (1416-1458).

${ }^{172}$ E. Muller, P. (1997). El Palau d'Oliva dels Centelles. En A. Esteve i Blai, Antoni (Ed.). El Palau dels Centelles d'Oliva. Recull gràfic y documental. Oliva (pp. 87-138) Oliva, España: L'Associació Cultural Centelles i Riu-Sec. pp. 93.
} 
Sin embargo, y como se ha venido comentado a lo largo del presente trabajo, quien realmente lo transformó el palacio y lo llevó a su mayor cota de esplendor fue el segundo Conde de Oliva, Serafí de Centelles Riu-Sec i Ximenez de Urrea († 1536). La fecha estimada de esta renovación se sitúa entre 1507-1510, aunque sufrió una remodelación más adelante, tras la ocupación en la guerra de Germanías. En la "Sección de Osuna" del AHN existe numerosa documentación del archivo señorial de Oliva, pero no se dispone del protocolo de construcción del palacio, que tal vez se encontrara entre los desaparecidos protocolos de Dionís Climent, escribano valenciano muy solicitado por Serafí de Centelles junto con Jaume Sendra ${ }^{173}$.

Su sobrino realizó obras de refuerzo de sus muros, tal y como refleja una carta del propio Conde datada en 1544 "y en mi ausencia pararían las obras de las nuevas fortalezas que se hacen en esta villa y en la de Murla, las cuales son muy importantes para la seguridad y la defensión" ${ }^{\prime 174}$. Gracias a las inscripciones encontradas en el palacio sabemos que éstas obras finalizaron en 1546 Las inscripciones fueron transcritas por Sebastián Castellanos y García Simancas y publicadas por Teodoro Llorente ${ }^{175}$.

En el inventario del palacio de 1550 se han encontrado las siguientes anotaciones ${ }^{176}$ :

- "En la caseta que està en dit primer pati, davall los studis daurats, moltes pedres blanques de les nayes".

- "Tretze pedres, per la obra de la naya, de les que portaren de Gènova".

- "En lo graner y en les nayes dels dits graners, foren attobades cinquanta pedres per la obra de dites nayes, entre lanques y blaves, giques y grans, redones y quadrades y planes, caps de pilars y mig peus, ço és, les que se han poguedes contar, com ni haja algunes davall los scalons que sostenen la teulada y per ço no se són pogudes comptar ni posar número".

- "En la stància davall los studis blanchs (...) dos montons de pedres blaves y blanques, les quals per ser molt pesades no se són pogudes comptar per les nayes, y entre elles hi ha dos pilars grososs de pedra blanca y cuatre mig pilars blanchs y partits per mig de dalt a baix y dos pilarets o corrades de la mateixa pedra blanca y més primsa que les altes".

En el inventario aparecen además diversos acopios de vigas de madera para obra de mejora y de "les nayes". Este dato nos revela que las galerías del patio central se ejecutaron posteriormente a la muerte de Francisco Gilabert de Centelles, quizás durante la administración de sus bienes por parte de su viuda, María de Cardona.

\footnotetext{
${ }^{173}$ Gavara Prior, J. y E. Muller, P. (2013). El Palacio Condal de Oliva. Catálogo de los planos de Egil Fischer y Vilhelm Lauritzen. Oliva, Valencia: Ajuntament de Oliva. pp. 22-23.

${ }^{174}$ Arciniega García, L. (2001). La Memoria del ducat de Gandia i els seus títols annexos. Redactada per Basilio Sebastián per al duc d'Osuna (1851-1852). Gandia: CEIC Alfonso el Vell. pp. 120.

175 Llorente, Teodoro (1889). Valencia. Colección «España: sus monumentos y sus artes-su naturaleza e historia». Barcelona: Editorial de Daniel Cortezo y C. pp. 709-710.

${ }^{176}$ Felip Sempere, V. (2001). Recull per a una historia de Nules (Barcelona. 1977-Nules 2000) Vol. II. Nules, Castellón: Caixa Rural de Sant Josep de Nules. pp. 309-310 y 347-348.
} 


\section{ESTADO ACTUAL DEL PALACIO}

El solar que en su día ocupaba el palacio lo conforman actualmente dos manzanas de viviendas unifamiliares separadas por la calle Palacio que lo cruza en sentido NE-SO en la alineación que formaban el antiguo portón de entrada con el patio central del inmueble. En la figura 62 podemos ver en rojo la silueta del antiguo palacio representada sobre una imagen aérea actual.

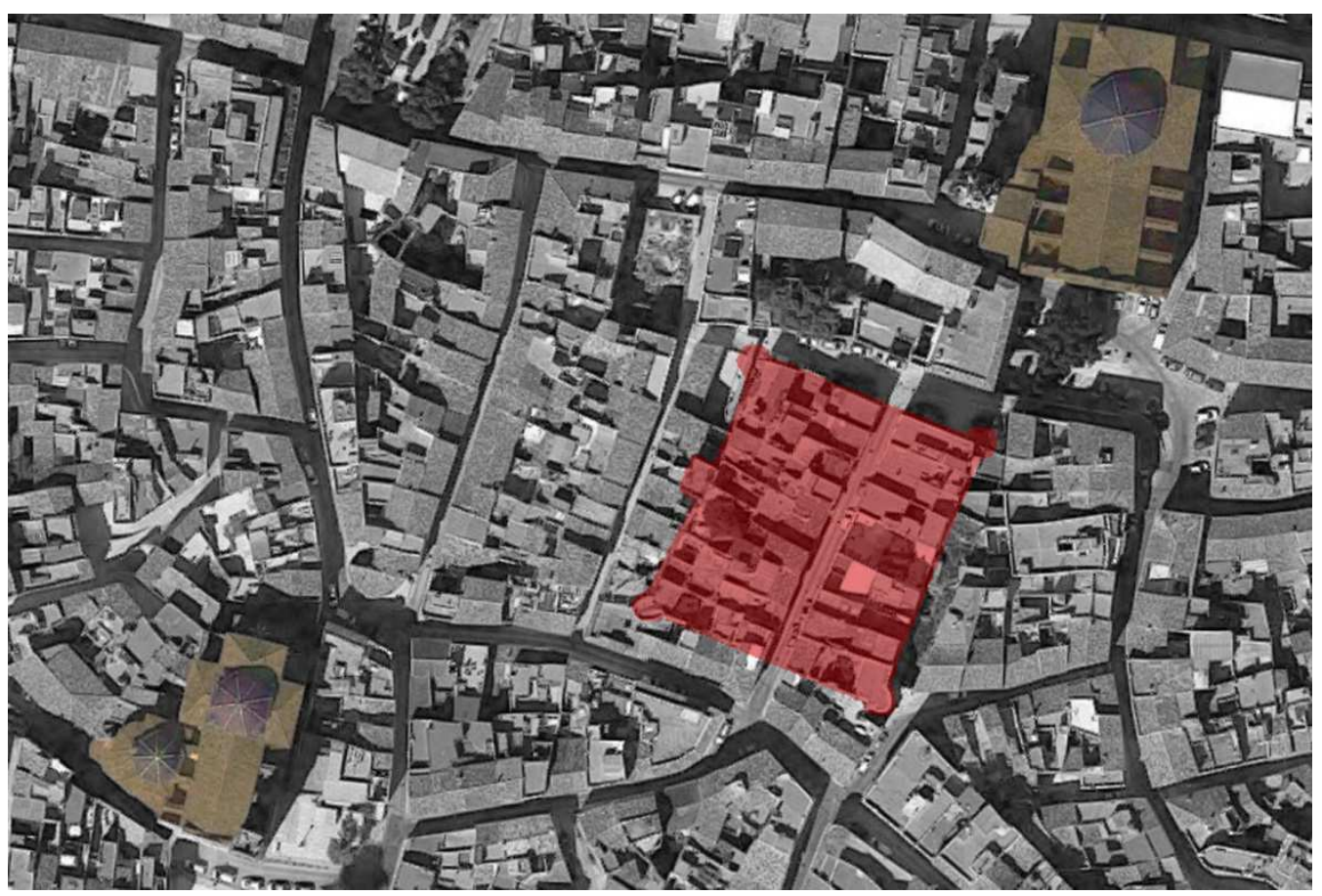

Figura 62. Localización del antiguo palacio sobre imagen aérea actual. Fuente: Googlemaps.

El ayuntamiento de Oliva ha realizado en los últimos años un esfuerzo por adquirir algunas viviendas situadas sobre los restos del antiguo palacio con el fin de poder recuperar y estudiar los restos del mismo que se conservan en su interior.

\subsection{Elementos in situ}

El único elemento restaurado y visitado del palacio es la torre SE, hoy llamada "Torre de la Comare". Por su parte, las viviendas de las que se tiene constancia de existir restos del palacio son las siguientes: calle Palau números $7,9,11,12$ y 14,18 y 20 y calle de las Torres número 14. En el jardín de la Escuela de Gramática se encuentran los restos del arranque de la torre NO.

La mayor parte de estos restos han sido objeto de trabajos profesionales, académicos y de investigación. En este apartado nos limitaremos a referenciar los elementos más significativos: 


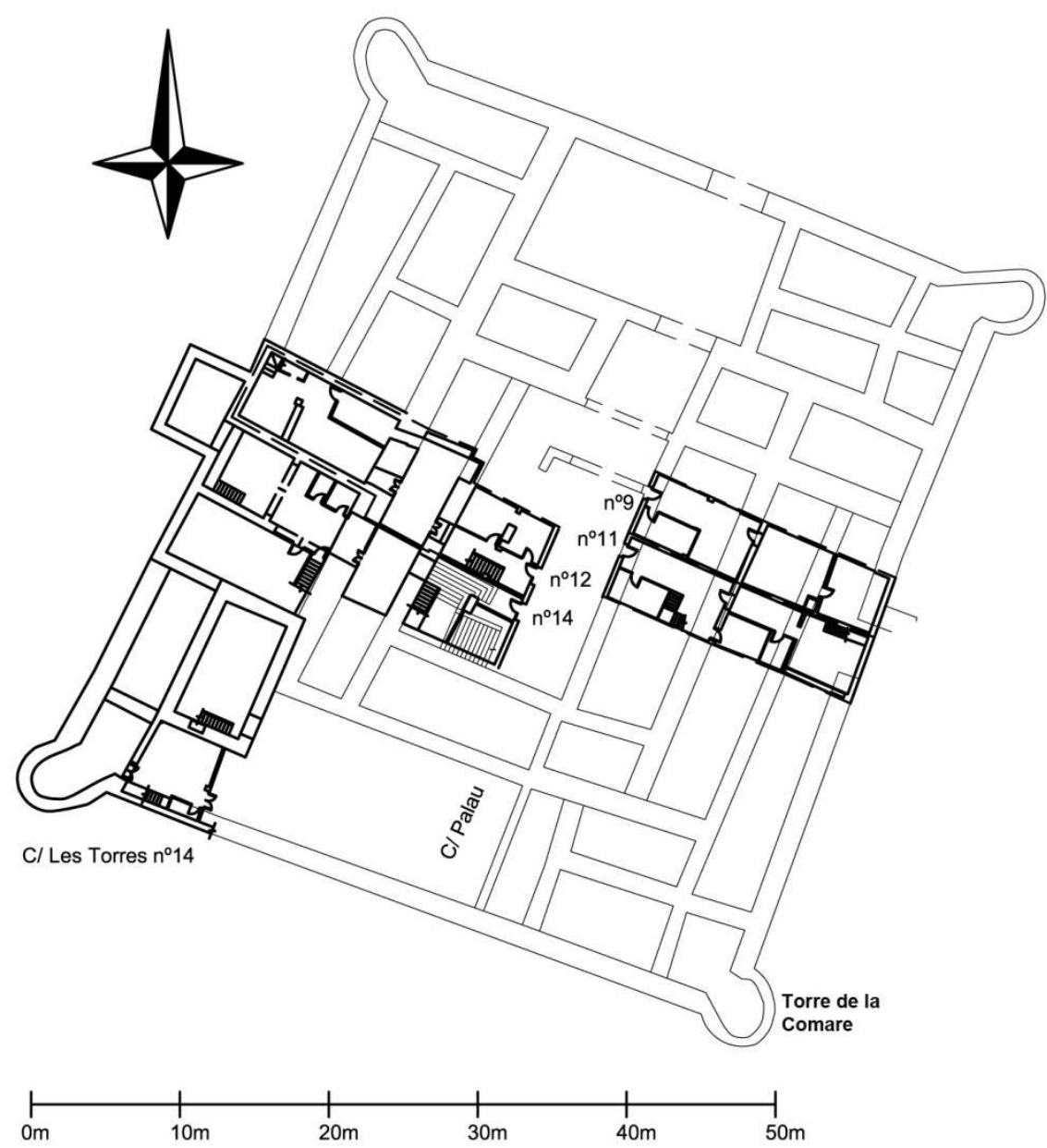

Figura 63. Localización de algunas viviendas con restos en el perímetro del palacio. Fuente: Alba Soler.

\section{Torre de la Comare}

El proyecto fue redactado por el arquitecto Josep Ivars Pérez en el año 1997, y las obras se desarrollaron en 1998, siendo inaugurada como espacio museístico en febrero de 1999. Esta intervención trató de recuperar los restos de esta torre redondeada del antiguo palacio, consolidando sus muros, arcos y bóvedas ${ }^{177}$. Los elementos arquitectónicos más singulares son la bóveda aristada tabicada que cubre la planta baja y la escalera de caracol de bóveda tabicada de ojo abierto.

177 Ivars Pérez, J. (1999). Restauració de la torre del Carrer Comare, Palau dels Centelles (Oliva). Castellón: Direcció General del Patrimoni Artistic, Direcció Territorial de Castelló y Ivars Pérez, J. (2013). Intervenció a la Torre de la Comare: Palau dels Centelles. Cabdells: Revista d'investigació de I'Associació Cultural Centelles i Riu-Sec, Núm. XI. PP. 5-17. 

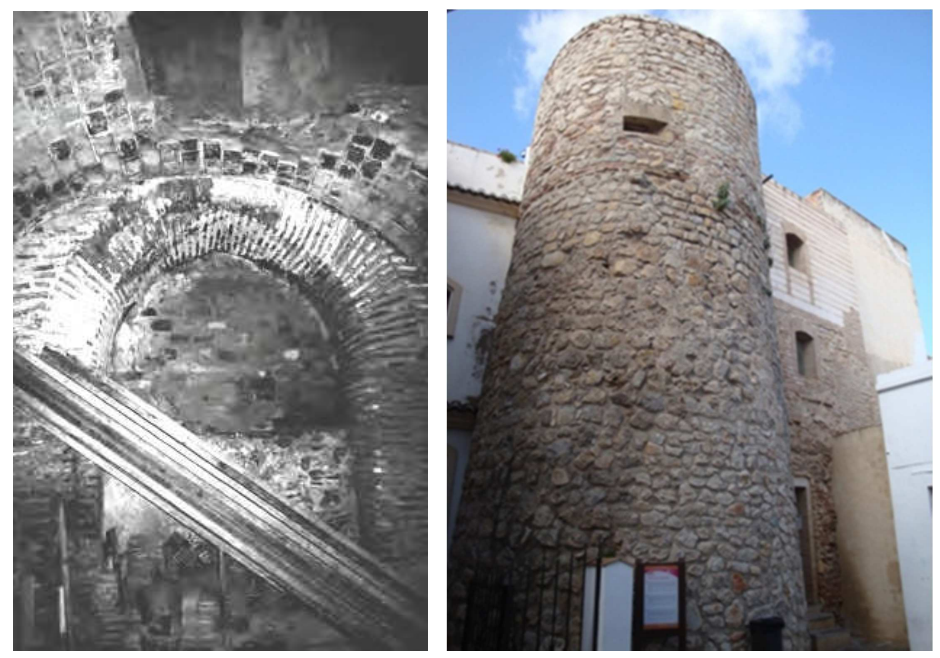

Figura 64. Torre de la Comare. Izq.: Estado previo de la planta baja. Fot: Josep Ivars. Dcha.: Vista exterior. Estado actual.
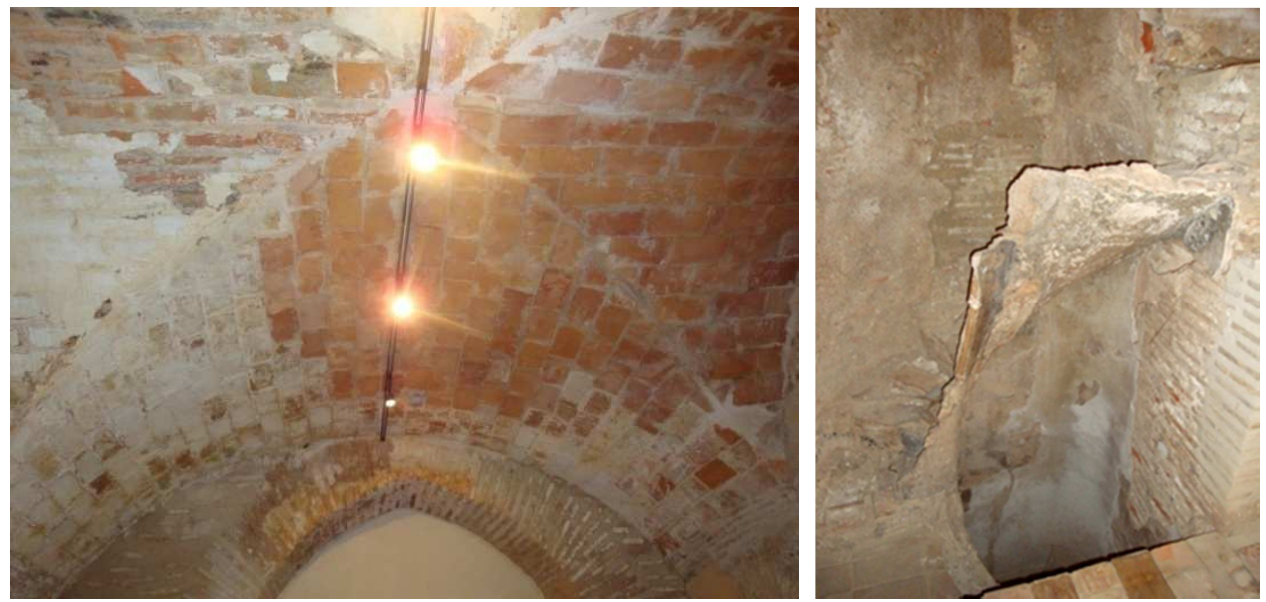

Figura 65. Torre de la Comare. Izq. Bóveda tabicada de arista: Dcha.: Escalera de caracol.

\section{Lienzo de muro sureste}

Este lienzo del palacio, junto a la Torre de la Comare, es el único que se encuentra exento y, aunque ha perdido su altura y elementos decorativos, tiene algunas de las fábricas originales. Los arquitectos Rafael Soler y Alba Soler han realizado una restitución de esta fachada a partir de una ortofo y la documentación existente de los arquitectos daneses ${ }^{178}$ (Ver Fig. 66).

\footnotetext{
${ }^{178}$ Soler Verdú, R. y Soler Estrela, A. (2007). Recuperació de la façana de llevant del Palau dels Centelles d'Oliva. Estudios Previos. Ayuntamiento de Oliva.
} 


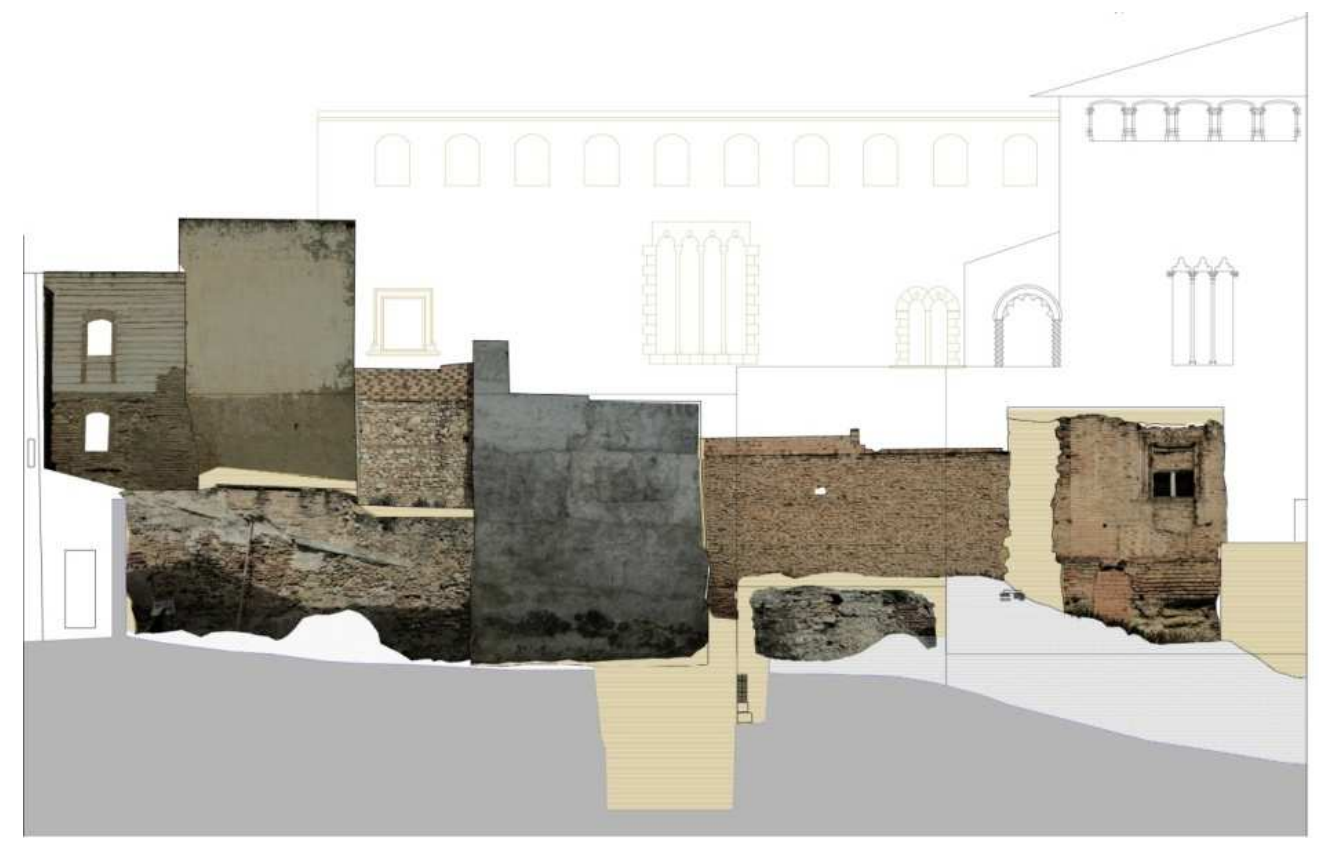

Figura 66. Fachada SE Palacio Condal de Oliva. Restitución aproximada. Fuente: Rafael Soler y Alba Soler

\section{Torre Suroeste}

En la vivienda localizada en la calle de las Torre número 14, actualmente propiedad del Ayuntamiento de Oliva, se encuentra localizada la Torre Suroeste. Esta torre fue levantada por David Perales y Alba Soler ${ }^{179}$ y consta de dos plantas: la primera formada por un forjado y la segunda cerrada por una bóveda de cañón de ladrillo sobre la que se encuentra la terraza plana.
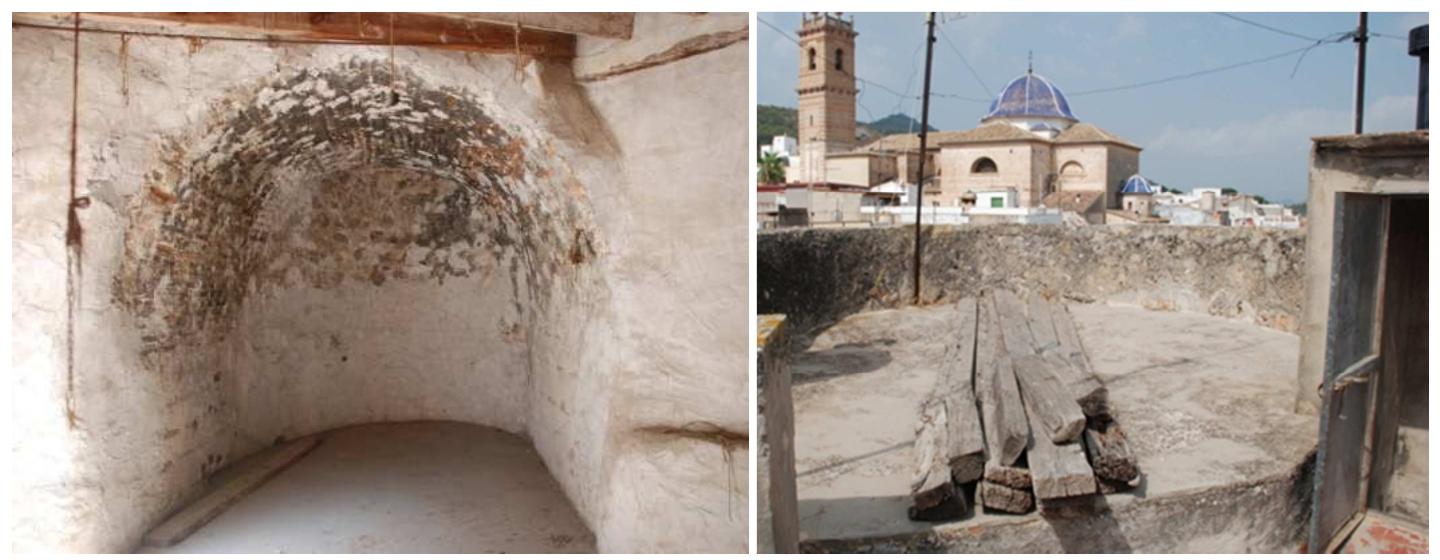

Figura 67. Torre suroeste. Izquierda: bóveda inferior. Derecha: terraza.

${ }^{179}$ Perales Vila, D. (2007). Palau dels Centelles d' Oliva, estudio arquitectónico y constructivo a partir de los restos y fuentes documentales existentes, cerramiento exterior, muros y torres. (Trabajo Final de Carrera. Tutora: Alba Soler Estrela). Universitat Politècnica de València. 


\section{Lienzos de muro fachada suroeste}

En la misma vivienda se encuentran dos muros de fábrica originales, el primero corresponde a la fachada suroeste del palacio y está ejecutado en fábrica de mampostería y rejuntada con mortero de cal.
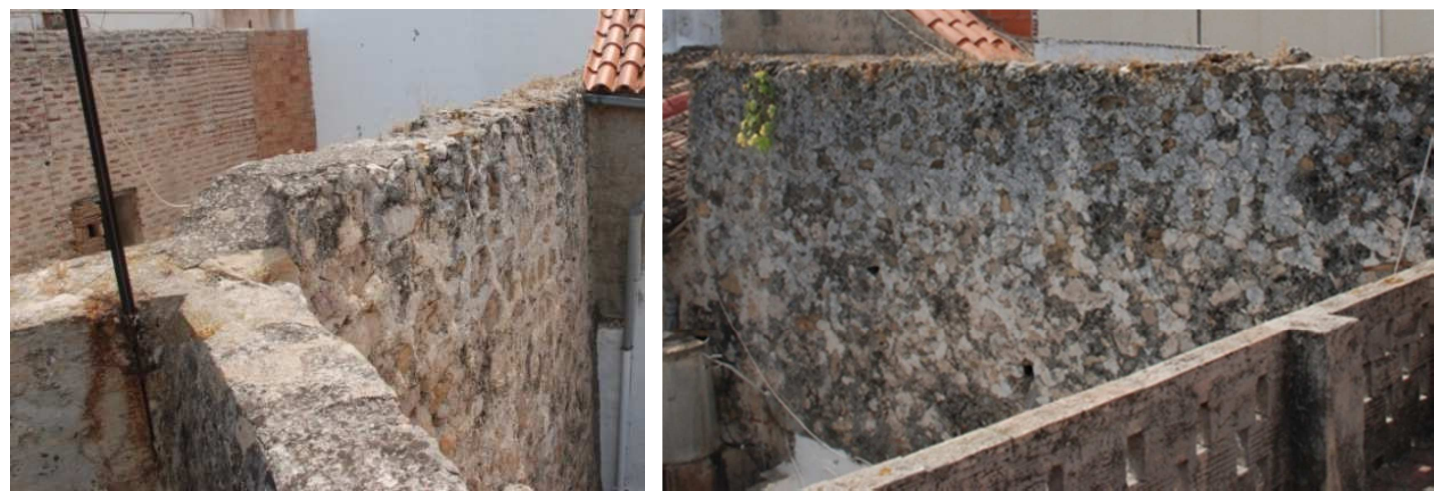

Figura 68. Muro de mampostería fachada SO. Izquierda: cara exterior. Derecha: cara interior.

El segundo muro está realizado con tapial valenciano reforzado con hiladas de ladrillo. Está situado en paralelo al primero y correspondía al cerramiento de la fachada SO de la Sala $1^{180}$ del palacio.

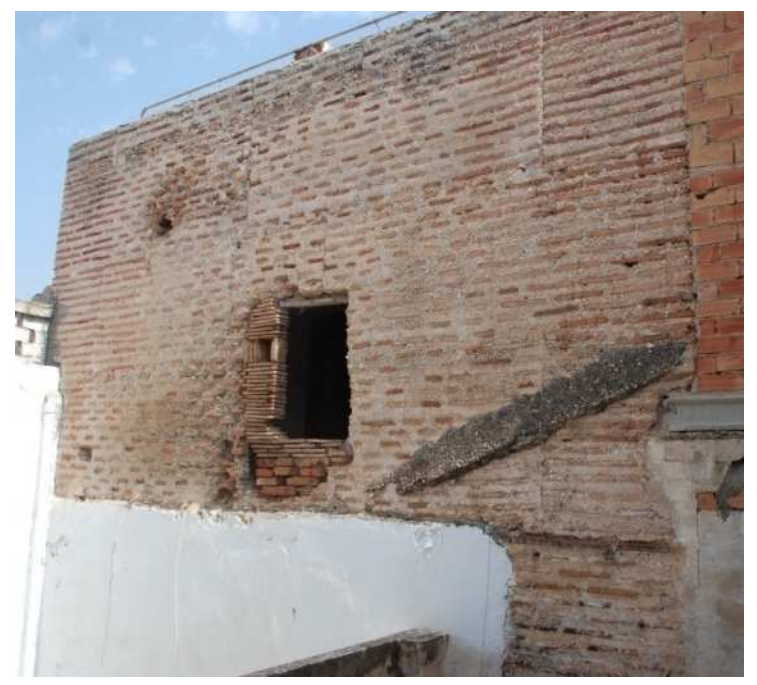

Figura 69. Muro de fábrica de ladrillo. Sala 1. Fachada SO, cara exterior.

${ }^{180}$ Fischer, E. y Lauritzen V. (1919-1920). Planos. Oliva, Valencia: Museo Municipal de Oliva, Archivo Público Documental, Palacio Condal. LA1109. 


\section{Arranque bóveda cocina}

En la vivienda número 14 de la calle Palau se localiza una sala de planta de 4,55 m de luz. En tres de sus muros de fábrica de ladrillo, de doble altura, se encuentran las huellas de un arranque de una bóveda y los restos de una portada sencilla de arco conopial que se encontraba en la planta entresuelo, hoy desaparecida. Esta bóveda estaba situada bajo la gran cocina del palacio y la puerta accedía al interior del cuerpo de la Torre del Palomar. La investigadora Alba Soler ha realizado una hipótesis de restituir dicha bóveda, llegando a la conclusión de que se trataba de una bóveda de arista octopartita de trompas ${ }^{181}$.

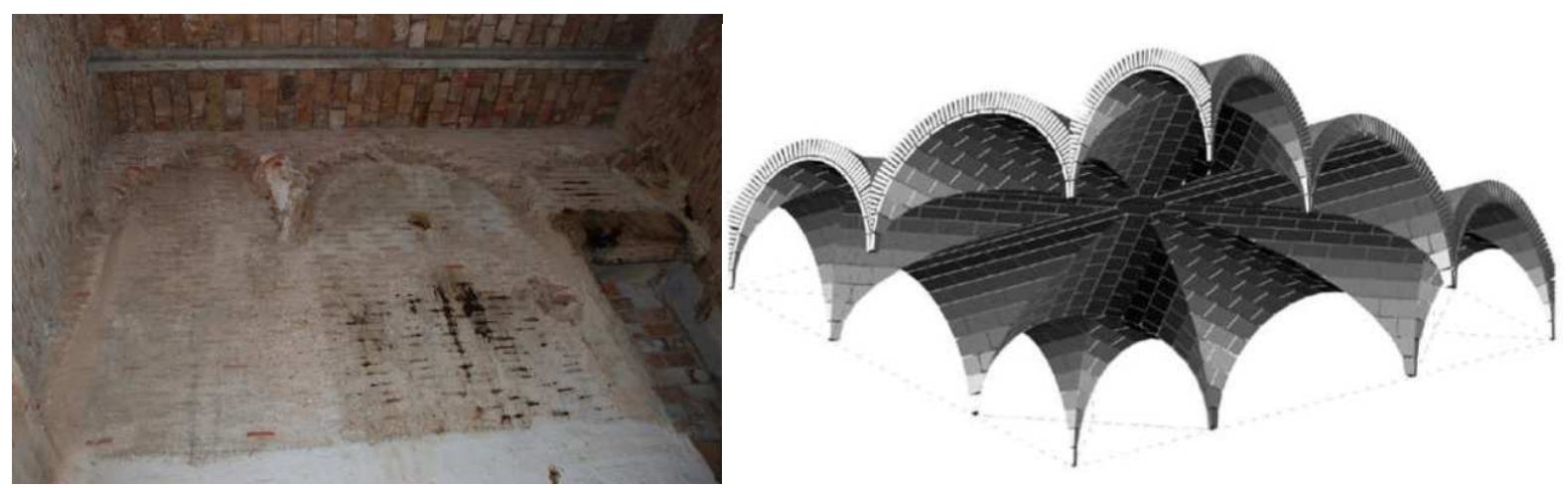

Figura 70. Izquierda: arranques bóveda bajo cocina y portada gótica sencilla. Derecha: hipótesis de restitución de la bóveda de arista octopartita. Fuente: A. Soler, R. Soler y M. Cabeza.

\section{Arcos ojivales}

En la vivienda localizada en la calle Palau número 12, actualmente propiedad del Ayuntamiento de Oliva, existen tres arcos apuntados de fábrica de ladrillo que formaban parte de la estructura de la planta baja del palacio sobre la que se sustentaban las plantas superiores; estaban situados bajo la Sala 4 de acuerdo con la numeración de Fischer. Estos restos fueron documentados por David Perales y Alba Soler ${ }^{182}$.

\footnotetext{
${ }^{181}$ Soler Estrela, A., Soler Verdú, R. y Cabeza González, M. (22-10-2015). Una bóveda desaparecida en el palacio gótico-renacentista de Oliva, Spain. Análisis de los restos y tipología. En: III Congreso Internacional sobre Documentación, Conservación, y Reutilización del Patrimonio Arquitectónico y Paisajístico. Valencia, España. pp. 2315-2322.

182 Perales Vila, D. (2007). Palau dels Centelles d' Oliva, estudio arquitectónico y constructivo a partir de los restos y fuentes documentales existentes, cerramiento exterior, muros y torres. (Trabajo Final de Carrera. Tutora: Alba Soler Estrela). Universitat Politècnica de València.
} 

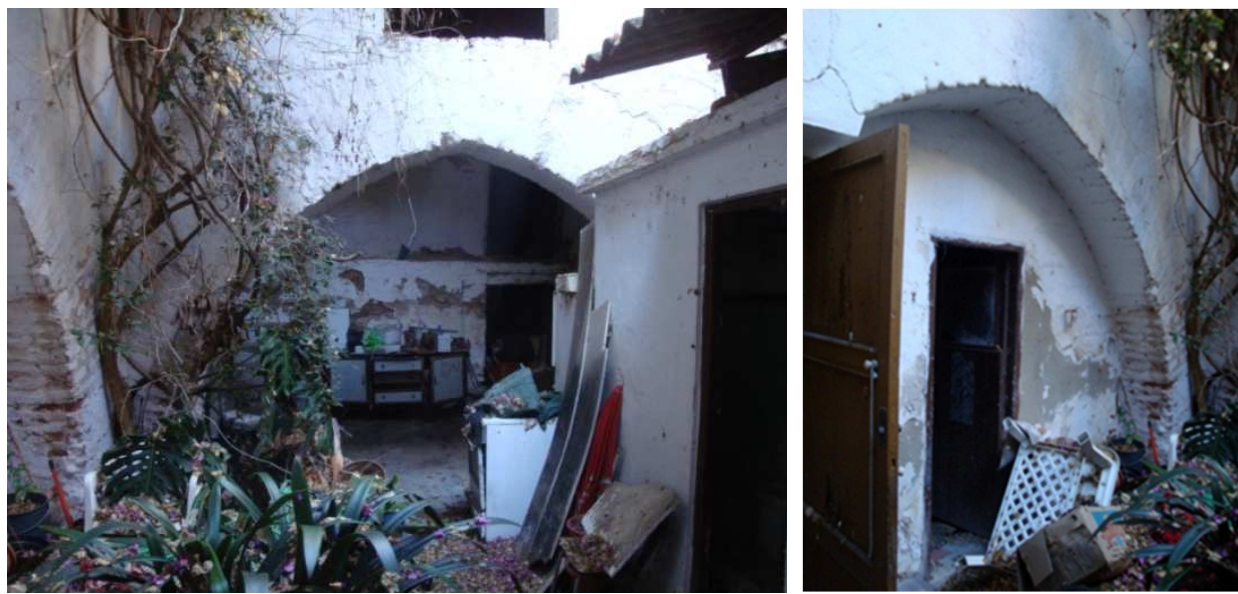

Figura 71. Arcos apuntados de fábrica de ladrillo. Planta Baja vivienda no 12, calle Palau.

\section{Torre del Palomar}

En la vivienda número 14 de la calle Palau se localizan también los restos de la Torre Reratangu, que sobresalía del lienzo del muro NO del palacio, llamada "Torre del Palomar". Quedan en pie la altura equivalente a dos plantas con sus muros originales de mampostería.
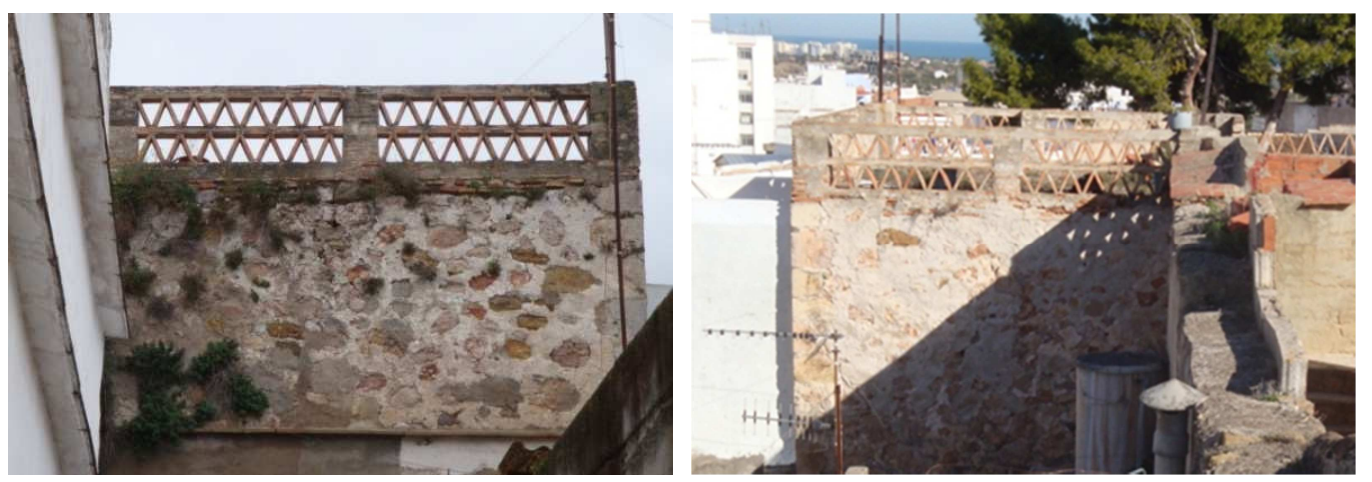

Figura 72. Izquierda: Vista de la Torre del Palomar desde el patio del Aula de Gramática Mayansiana. Derecha: la Torre del Palomar y muro NO visto desde la Torre SO.

\section{Portada calle Palacio}

En la planta primera de la vivienda número 14 de la calle Palau se conserva un hueco de puerta con un trazado de arco conopial contracurvado o variación del flamígero mixtilíneo. Las jambas y el arco no tienen las molduras características de este tipo de portadadas, como las dibujadas por Fischer y Lauritzenm, aunque nos dan una idea de cómo esta tipología de portadas decoraba desde las salas más nobles, a las más humildes del palacio. 


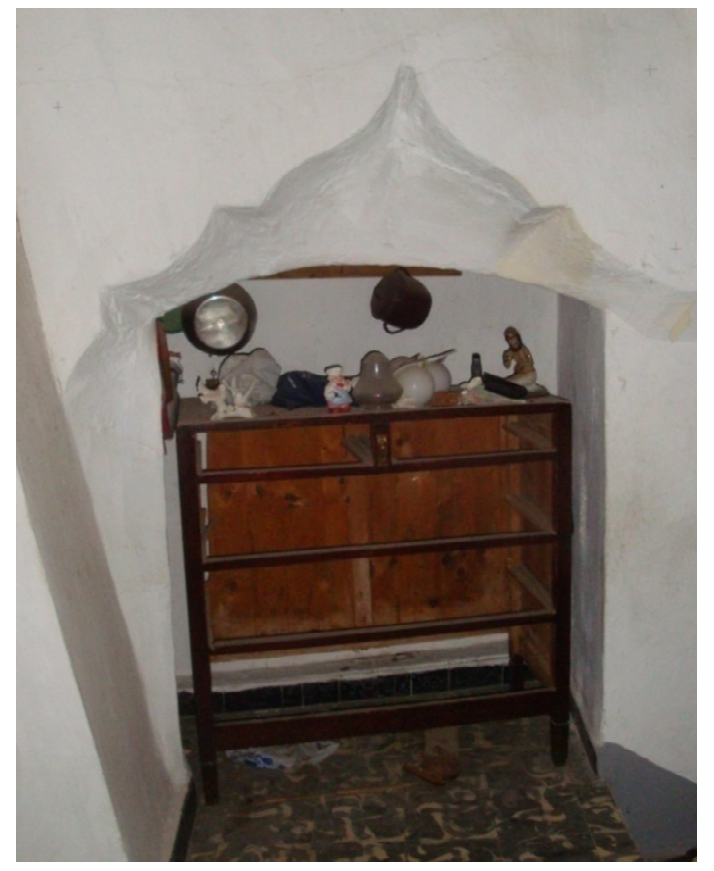

Figura 73. Hueco de puerta con arco conopial en vivienda C/ Palacio № 14.

\section{Pavimento calle Palacio}

En la planta primera de la vivienda número 14 de la calle Palau se conserva un pavimento que combina piezas de cerámica roja de $22 \times 22 \mathrm{~cm}$ con azulejos de $11 \times 11 \mathrm{~cm}$, decorados en blanco y azul. Algunos de los azulejos, aunque muy deteriorados, se identifican con piezas procedentes del palacio.
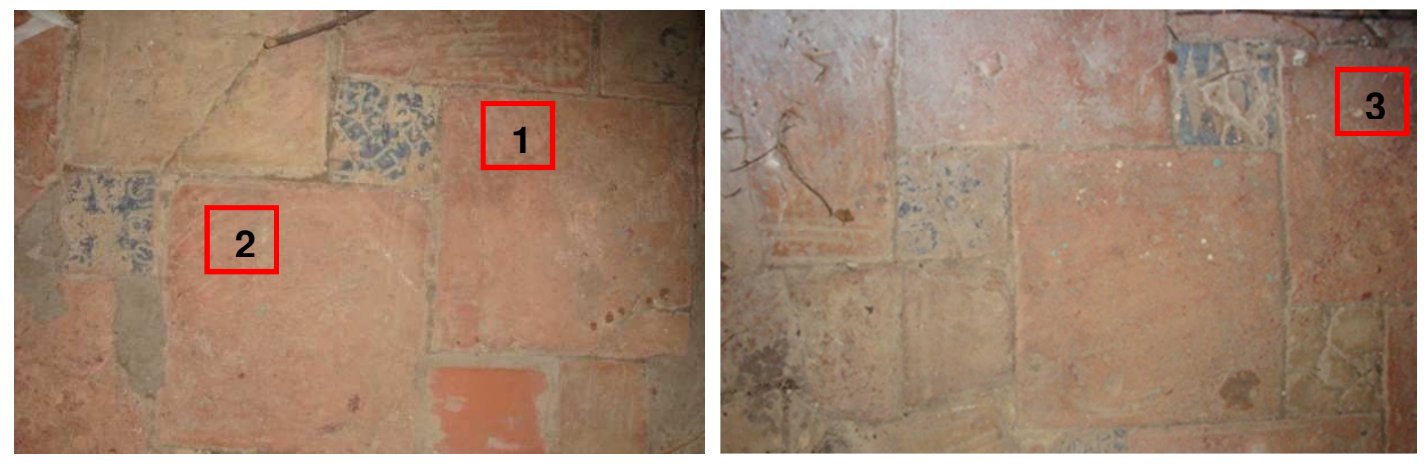

Figura 74. Pavimento original vivienda C/ Palacio no 14. Identificación de piezas.

Las piezas 1 y 2 de la Fig. 74 se identifican con dos de las catalogadas como procedentes del palacio, pertenecientes a colecciones privadas. La pieza es un diseño geométrico en forma de rombos. 


\section{Ventana calle Palacio}

En esta vivienda, en la que actualmente es la cambra de la casa, se conserva una ventana gótica elaborada en yeso de características muy similares a las dibujadas por Fischer y Lauritzen en sus planos, aunque de menores dimensiones. Esta ventana de arco escarzano y jambas formadas por dos columnillas que parten de una basa apoyada en una ménsula, estaba situada en la planta entresuelo del palacio, debajo de la Sala de Armas, en la fachada SE. A pesar de su deficiente estado de conservación, es un vestigio único de lo que en su día fueron las portadas y ventanas góticas del palacio.
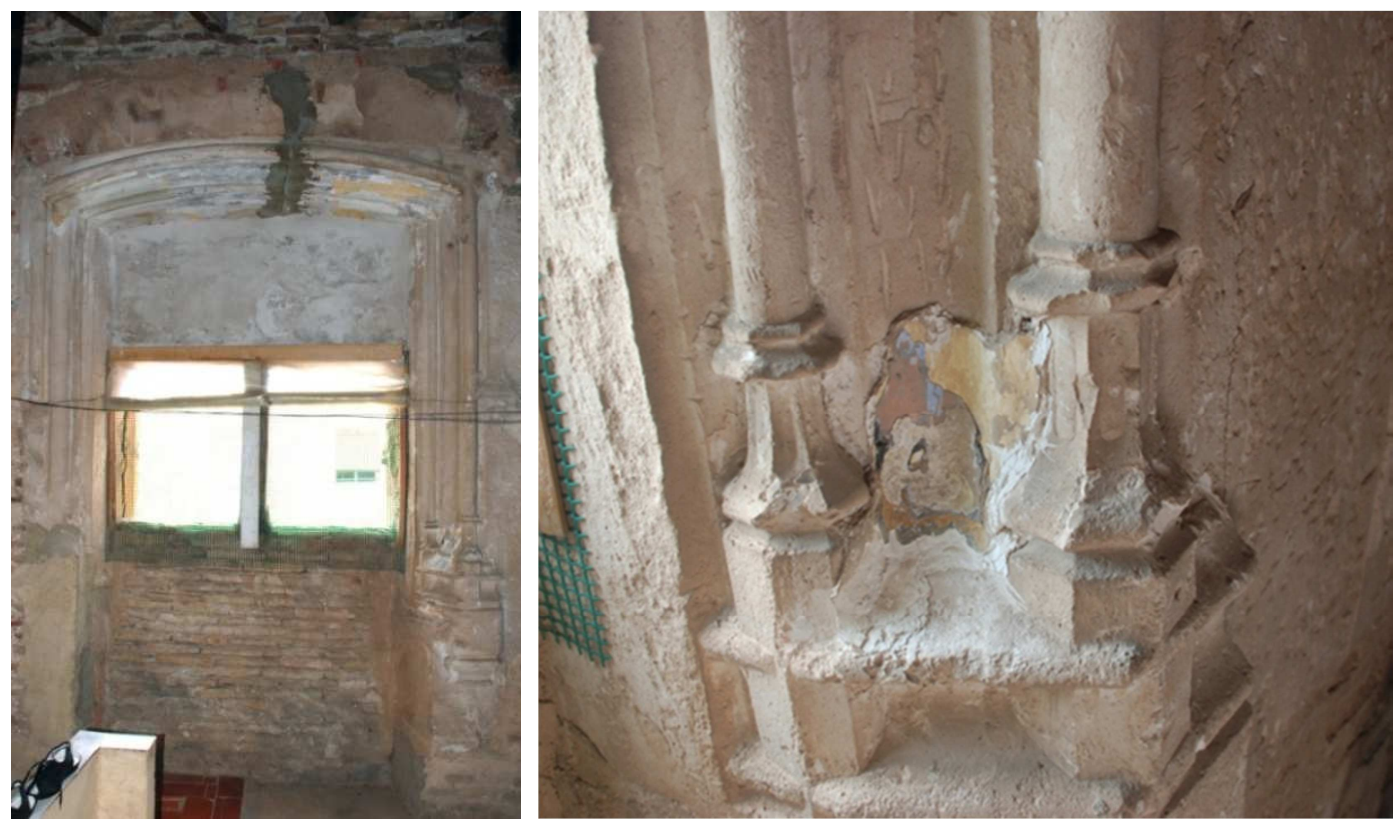

Figura 75. Ventana C/ Palacio, no 7. Vista frontal y detalles de la basa derecha.

\subsection{Piezas diseminadas}

A pesar del gran trabajo de desmontaje y embalado de piezas procedentes del palacio llevadas a cabo por el arquitecto Egil Fischer y su equipo, son pocos los elementos que han llegado hasta nuestros días, al menos de los que tengamos constancia.

En adelante elaboraremos una relación de las piezas de las que tenemos conocimiento de su existencia. No es objetivo de este trabajo investigar el posible destino del resto de piezas desmontadas y hoy desaparecidas, pero sí entendemos que es interesante documentar aquellas de las que tenemos constancia. Para ello, realizaremos una clasificación según el lugar donde se encuentran dichas piezas. 


\subsubsection{Museo Arqueológico de Oliva}

Además del legado gráfico de Fischer y Lauritzen, en el Museo Arqueológico de Oliva se conservan todas las piezas originales del palacio que el Ayuntamiento de la localidad ha ido recuperando mediante compra o donaciones de particulares. Detallaremos las piezas más importantes que se conservan y que están expuestas al público. En los fondos del Museo Arqueológico de Oliva existen otros restos: mármoles, cerámica, etc.

\section{Arcada Galería Patio Central}

El conjunto más importante de piezas que se conserva del palacio es parte de la galería porticada del patio central: en el museo se exhiben 6 columnas completas de mármol blanco, una media columna sin capitel, una cornisa del arquitrabe y mármol blanco, y tres piezas de salmer de donde arrancaban los arcos ojivales, de piedra caliza labrada. Las columnas fueron importadas desde Génova. ${ }^{183}$
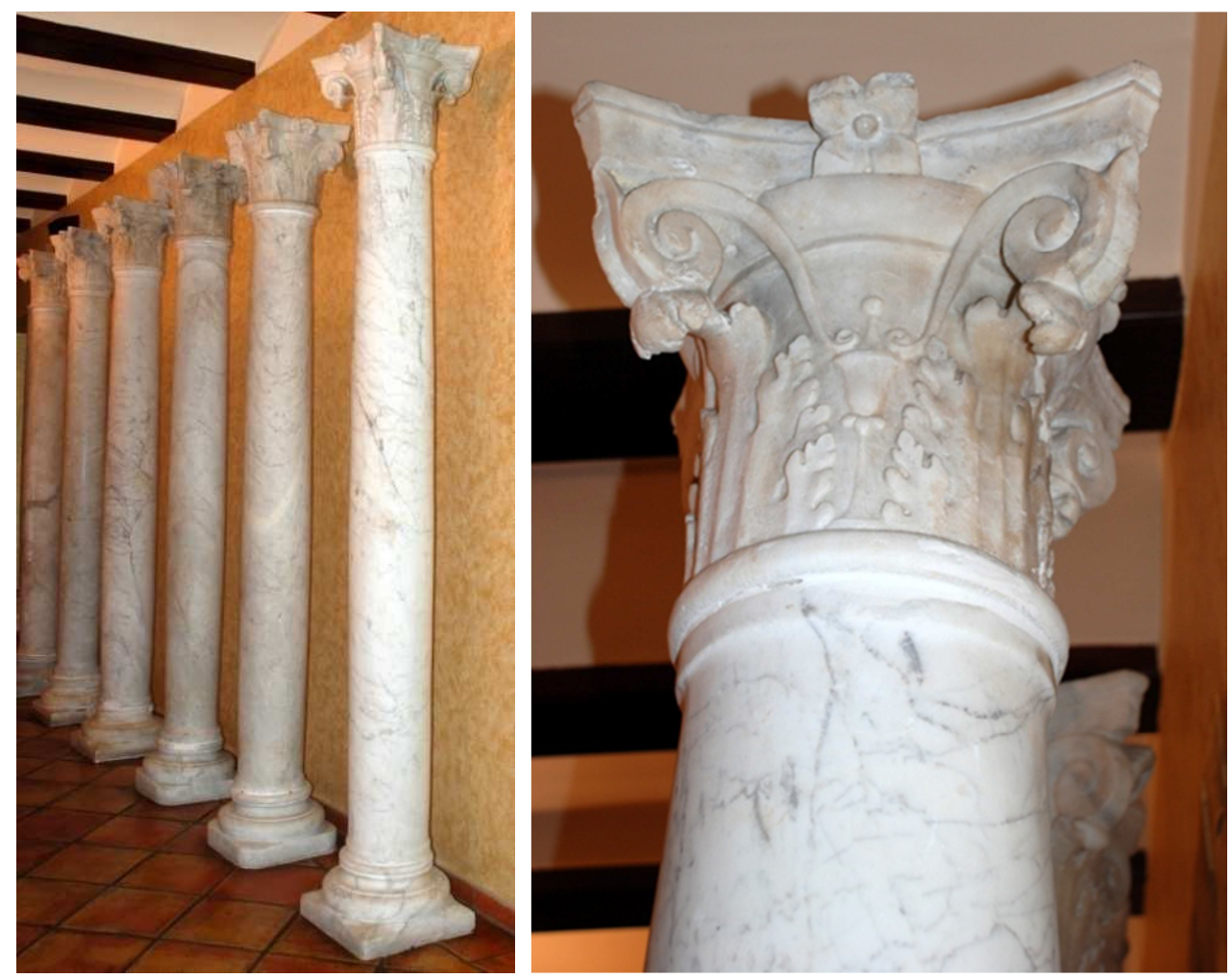

Figura 76. Izquierda: columnas Galería Patio Central. Derecha: Detalle de capitel. MAO.

\footnotetext{
${ }^{183}$ Felip Sempere, V. (2001). Recull per a una historia de Nules (Barcelona. 1977-Nules 2000) Vol. II. Nules, Castellón: Caixa Rural de Sant Josep de Nules. pp. 310.
} 


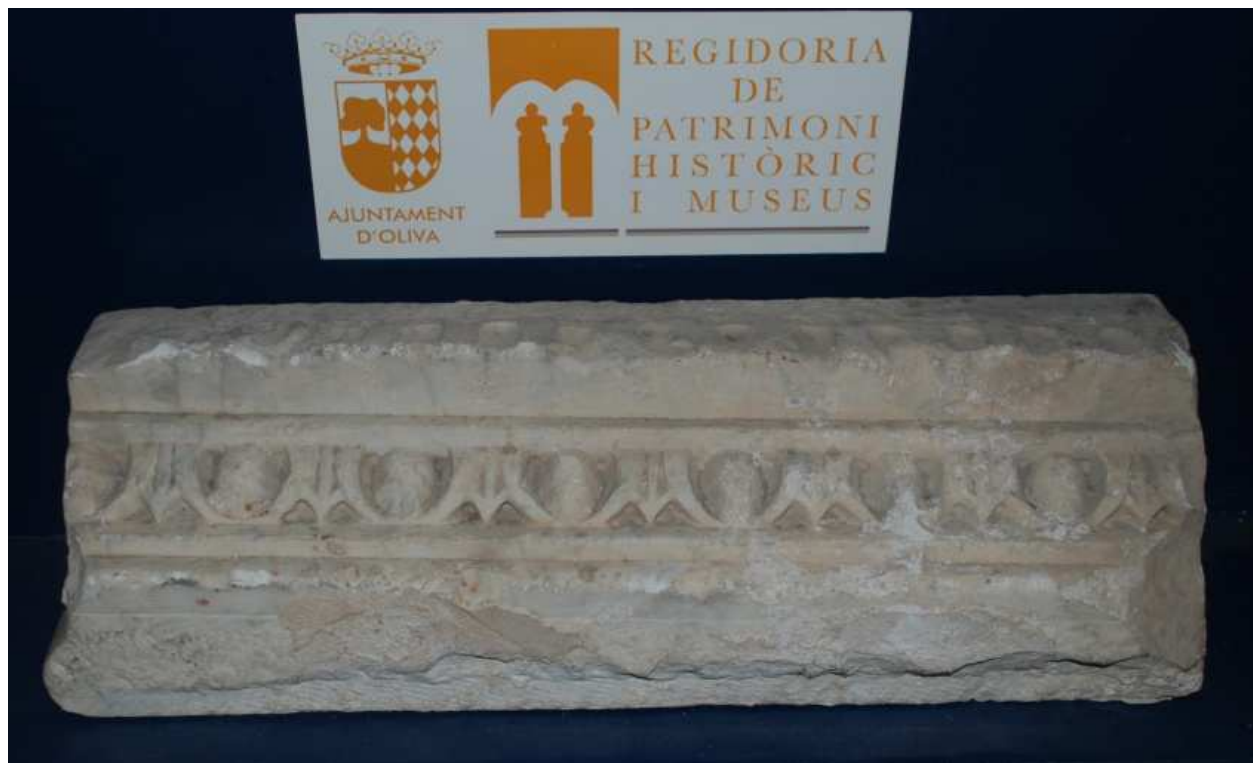

Figura 77. Pieza del arquitrabe de la galería del Patio. MAO.
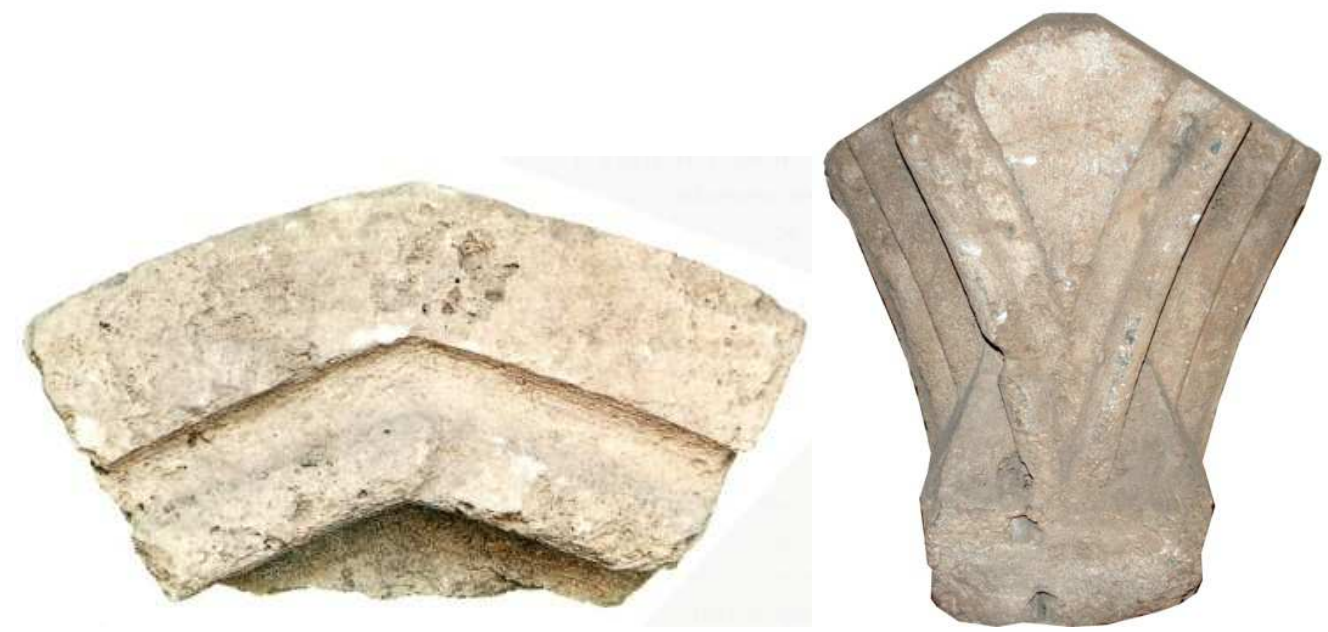

Figura 78. Piezas de la arcada de la Galería del Patio Central. Izquierda: clave. Derecha: salmer o arranque central.

\section{Balaustrada galería superior}

En el museo se conservan también algunas de las piezas de la balaustrada de la galería superior, que formaban conjunto con la columnata de la planta inferior y el arquitrabe que, a su vez, separaba la planta principal de la galería, presumiblemente de la misma procedencia. 

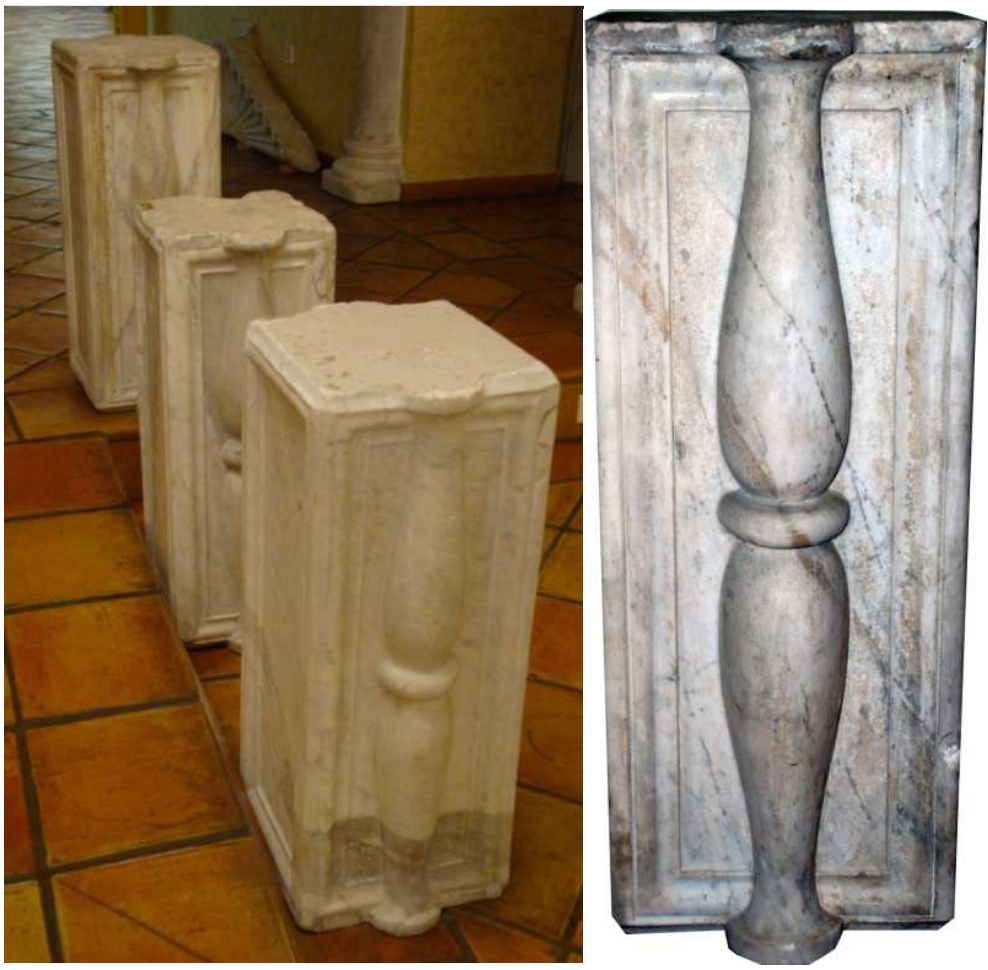

Figura 79. Izquierda: Pilastras centrales de la balaustrada de la galería superior. Patio Derecha: media pilastra balaustrada galería superior MAO. Fuente: Salvador Mañó i Fenollar.

\section{Frontón avenerado}

Asimismo, el museo conserva un frontón avenerado procedente del Palacio Condal que, por sus dimensiones, debía rematar una de las ventanas del inmueble. Su diseño es idéntico a los existentes en las ventanas de la planta principal del Palacio de la Generalitat. Esta pieza no fue documentada por Fischer y Lauritzen.

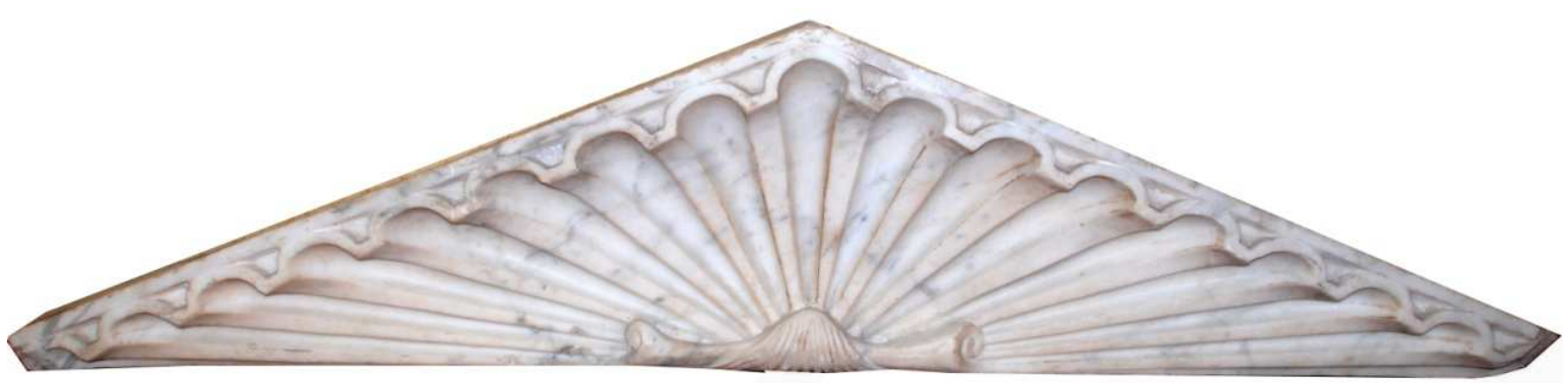

Figura 80. Frontón avenerado. Pieza de mármol blanco, procedente del Palacio de Oliva. MAO. Fuente: Salvador Mañó i Fenollar. 


\section{Guerrero en relieve}

Se trata de la figura en relieve perteneciente a la Portada 23 de la Sala de Armas. Representa un caballero vestido en cota de malla y portando el escudo de los Centelles. Podría representar a Gilabert de Centelles y Riu-Sec ${ }^{184}$.

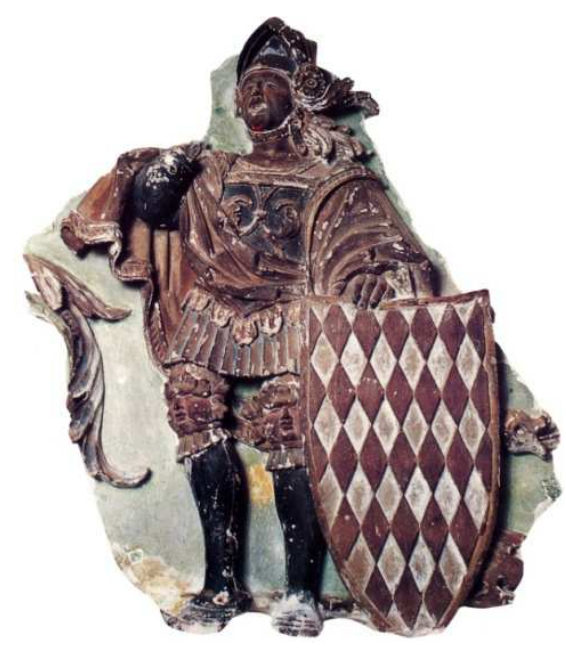

Figura 81. Guerrero con escudo de los Centelles procedente del Palacio de Oliva. MAO. Fuente: Salvador Mañó i Fenollar.

\section{Escudo de los Centelles}

En el museo se conserva asimismo una pieza de mármol blanco, procedente del Palacio de Oliva que se corresponde con parte de un escudo heráldico de la familia Centelles.

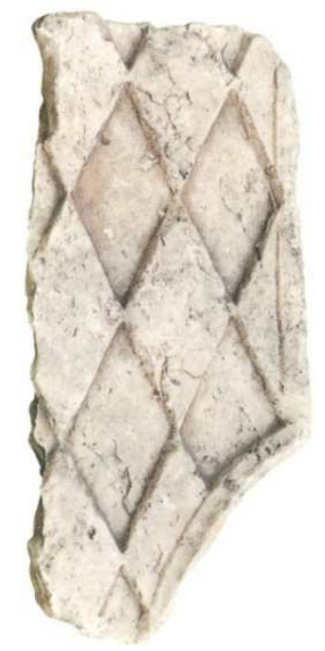

Figura 82. Pieza de mármol blanco, procedente del Palacio de Oliva que corresponde con parte de un escudo heráldico de la familia Centelles, MAO. Fuente: Salvador Mañó i Fenollar.

${ }^{184}$ Gavara Prior, J. y E. Muller, P. (2013). El Palacio Condal de Oliva. Catálogo de los planos de Egil Fischer y Vilhelm Lauritzen. Oliva, Valencia: Ajuntament de Oliva. pp. 42. 


\section{Pavimento Torre de la Comare}

En el museo se exhiben los restos de un pavimento recuperado de la segunda planta de la Torre de la Comare, en blanco y azul de dimensiones aproximadas $12 \times 12 \mathrm{~cm}$, que combina piezas de mocadoret con otras de figuras vegetales estilizadas. Este pavimento es idéntico a otro que se encontraba entre las 183 piezas donadas por la familia Cucart al Ayuntamiento de Oliva en el año $2001^{185}$.

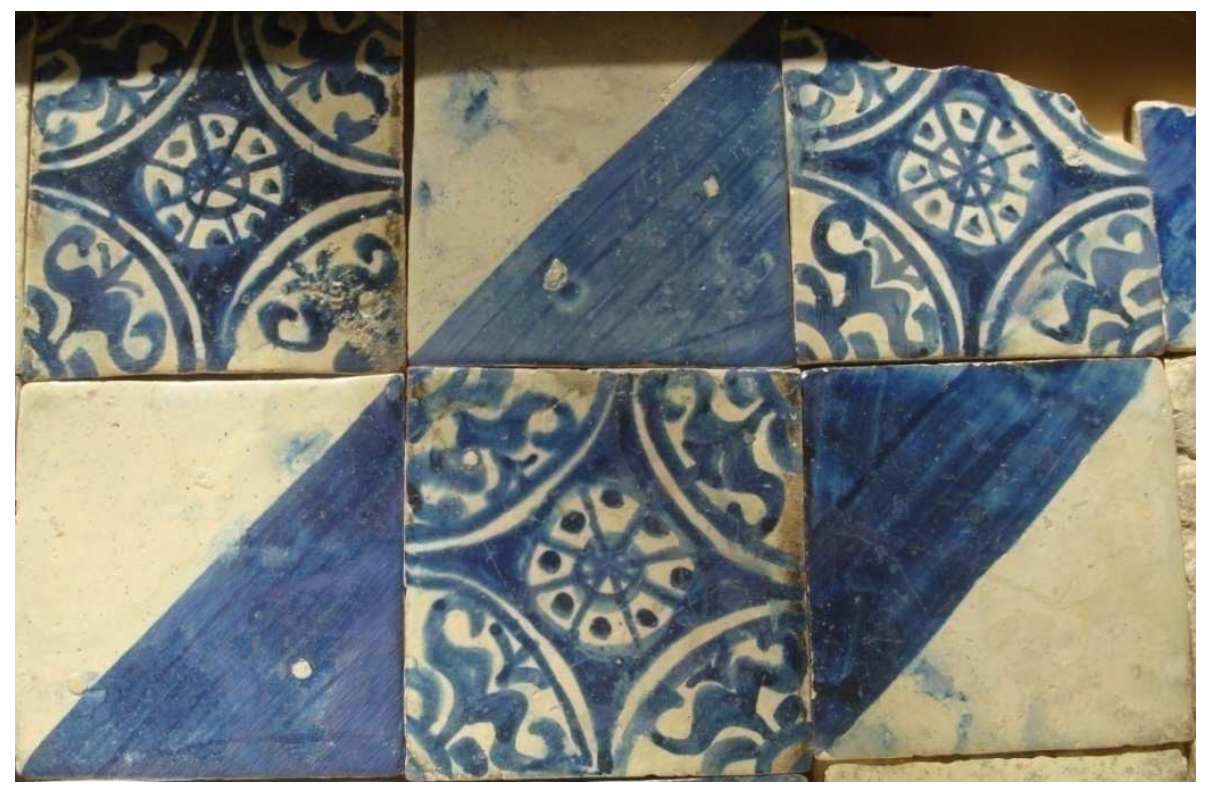

Figura 83. Pavimento de azulejos blancos y azules procedentes de la Torre de la Comare del Palacio Condal. MAO.

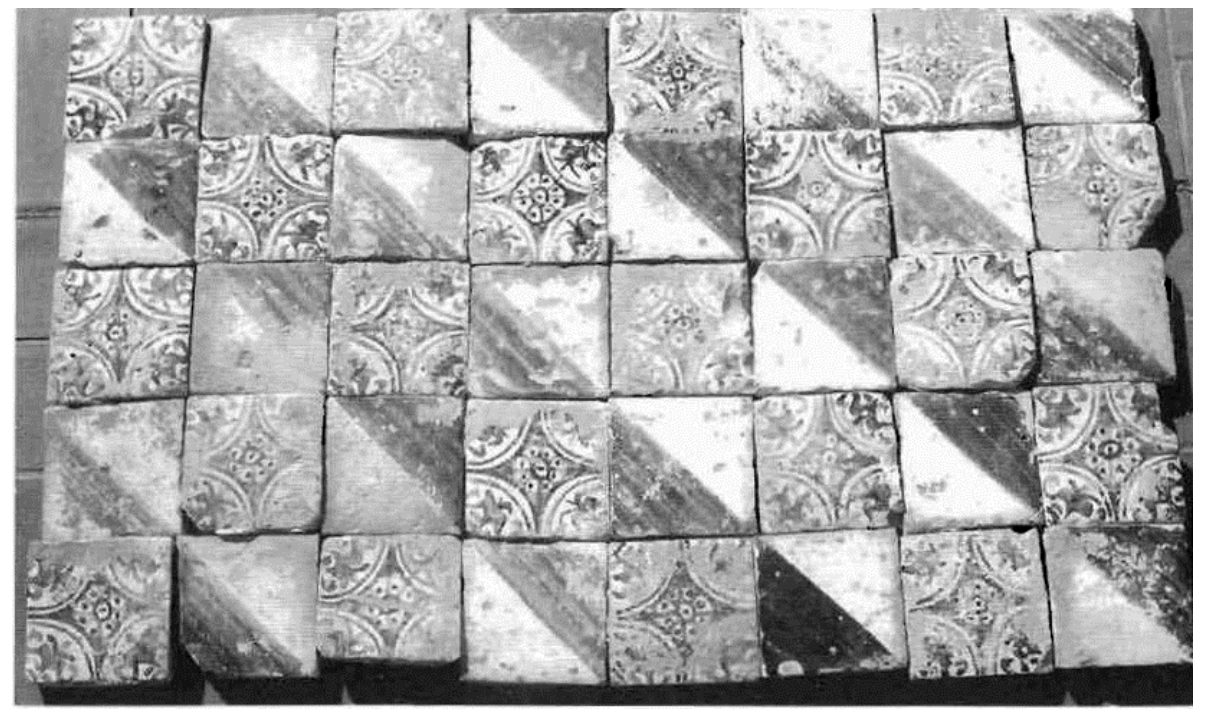

Figura 84. Pavimento de azulejos blancos y azules procedentes del Palacio de Oliva donados por la familia Cucart. MAO. Fotografía (F.M.P.).

${ }^{185}$ Mestre i Pons, F. (2001). Donació de taulletes gòtics del Palau d'Oliva, Núm. 3. pp. 146-151. 


\subsubsection{Colecciones privadas de Oliva}

En algunas viviendas y colecciones privadas de Oliva y de la comarca de La Safor se conservan algunas piezas procedentes del palacio. Algunas de ellas formaron parte de la exposición realizada en 1999 en la cripta de la Iglesia de Santa María con motivo de la conmemoración del 550 aniversario del nombramiento de Francesc Gilabert y Centelles como conde de Oliva en $1449^{186}$. Muchas de estas piezas se utilizaron para ilustrar el libro publicado por la Associació Cultural Centelles y Riu-Sec con motivo de dicho aniversario ${ }^{187}$.

Procederemos a realiza una enumeración de las piezas pertenecientes a estas colecciones:

\section{Cerámica}

Recogemos diversas piezas de cerámica aparecidas en la citada publicación de 1999, si bien en todos los casos no está acreditada su pertenencia al Palacio Condal de Oliva:

- Azulejo decorado en azul sobre fondo blanco, $11 \times 22 \mathrm{~cm}$. Representa uno de los emblema de los Centellesutilizado en la decoración de sus palacios: Cap d'ells ${ }^{188}$.

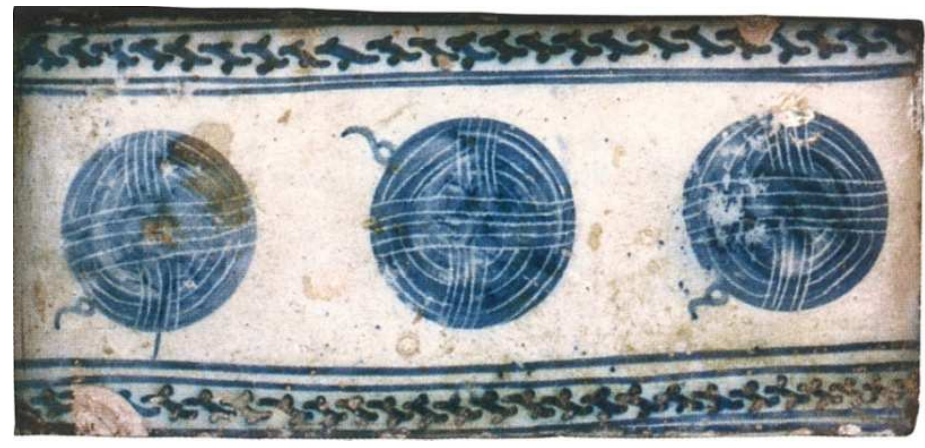

Figura 85. Azulejo decorado en azul sobre fondo blanco, $11 \times 22 \mathrm{~cm}$. Representa uno de los emblemas de los Centelles (Oliva). Fuente: Salvador Mañó i Fenollar.

- Azulejo decorado en azul sobre fondo blanco con dibujos geométricos, 14 x $14 \mathrm{~cm}$. procedente del Palacio Condal de Oliva (Manises, siglo XV). Azulejos idénticos se encuentran, posiblemente recolocados, forrando el peldaño del altar de la Capilla de Todos los Santos. Esta pieza es idéntica a la numerada como (1) en el apartado 5.1 de este capítulo.

\footnotetext{
${ }^{186}$ Batalla, E. (24 febrero, 1999). Oliva recupera la memoria del Palau Comtal en una exposición con motivo de su 550 aniversario. El País. Recuperado de: http://elpais.com/diario/1999/02/24/cvalenciana/919887497_850215.html.

${ }^{187}$ VV.AA. Esteve i Blai, A. (1997). El Palau dels Centelles d'Oliva. Recull gràfic y documental. Oliva, Valencia: L'Associació Cultural Centelles i Riu-Sec Oliva.

188 Los Centelles de Oliva autoproclaman los Cap d'ells (los más importantes entre las ramificaciones de la poderosa familia). Esta referencia se combina con un sugerente juego de palabras-imágenes que nos recuerda que "pel fil traurem lo cabdell" ("por el hilo sacaremos el ovillo") de los interrogantes de nuestro pasado colectivo, extraído de la página de inicio de Cabdells: revista d'investigació de l'Associació Cultural Centelles i Riu-Sec.
} 

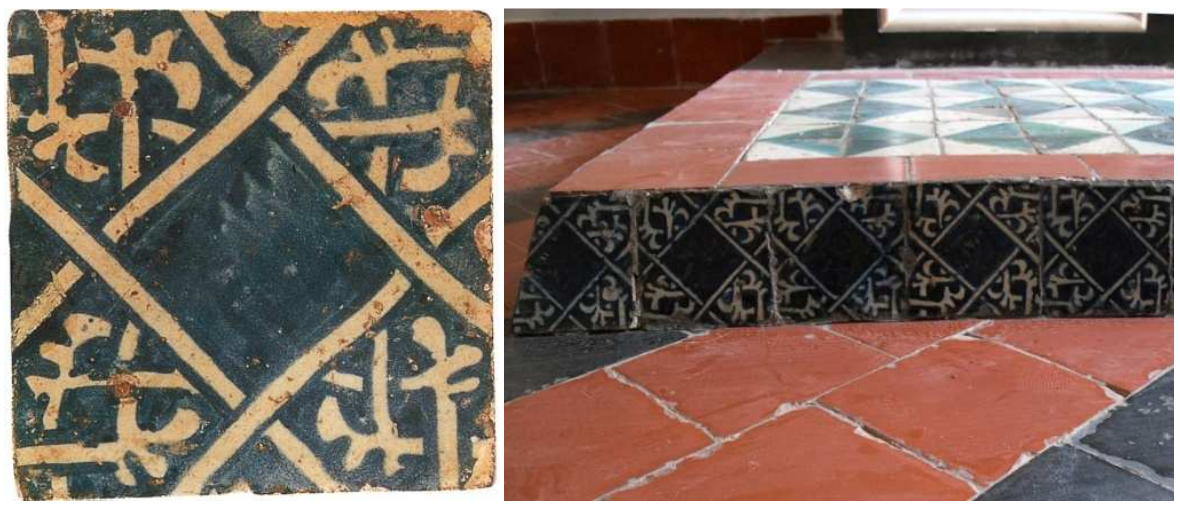

Figura 86. Izquierda: azulejo decorado14x14 cm. procedente del Palacio Condal de Oliva. Manises siglo XV. (Oliva). Fuente: Salvador Mañó i Fenollar. Derecha: Azulejos colocados en el altar de la Capilla de Todos los Santos (Monasterio de Portacoeli).

- Azulejo decorado en azul sobre fondo blanco, 14x14 cm (Manises, siglo XV). Representa un emblema de carácter heráldico: un león rampante. Es uno de los motivos utilizados por la los Centelles en la decoración de sus palacios.

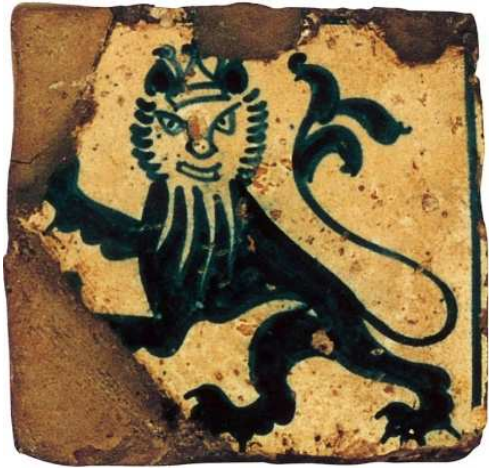

Figura 87. Azulejo decorado en azul sobre fondo blanco, $14 \times 14 \mathrm{~cm}$ (Manises, siglo XV). (CP. Oliva). Fuente: Salvador Mañó i Fenollar.

- Azulejo decorado en azul sobre fondo blanco con dibujos, $14 \times 14 \mathrm{~cm}$ representa un libro de cuentas viejo que se va repasando y, en letras góticas minúsculas, aparece la palabra "Barallanova" ("Baraja nueva") ${ }^{189}$. Es uno de los azulejos utilizados en la decoración de los palacios de los Centelles.

\footnotetext{
${ }^{189}$ La leyenda "baralla nova" hace alusión al viejo refrán: "contes vells, baralla nova", o sea, "cuentas viejas, baraja nueva" ("sacar cuentas a relucir es pelearse de nuevo"). Parece aludir esta leyenda a las luchas que hubo de sostener el conde de Oliva por mantener la primogenitura en el uso delapellido Centelles. Cita de la ficha técnica de otro ejemplar localizado en el Palacio de los Centelles de Nules. Fuente: Museo Arqueológico Nacional. Recuperado de: http://ceres.mcu.es.
} 


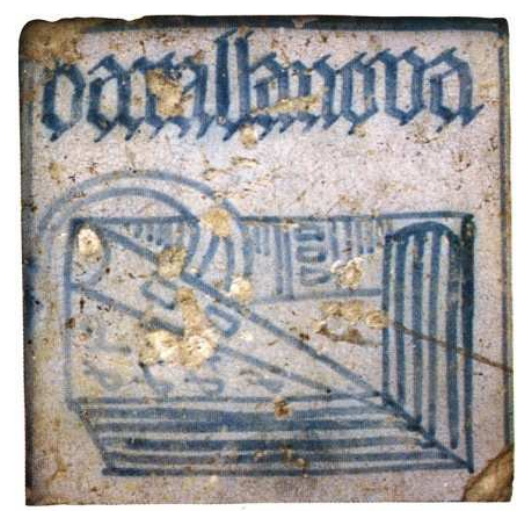

Figura 88. Azulejo decorado en azul sobre fondo blanco con dibujos, $14 \times 14 \mathrm{~cm}$. (CP. Oliva). Fuente: Salvador Mañó i Fenollar.

- Azulejo decorado en azul sobre fondo blanco con motivo floral, $14 \times 14 \mathrm{~cm}$ procedente del Palacio Condal de Oliva (Manises, siglo XV). Esta pieza es idéntica a la numerada como (2) en el apartado 6.1 de este capítulo.

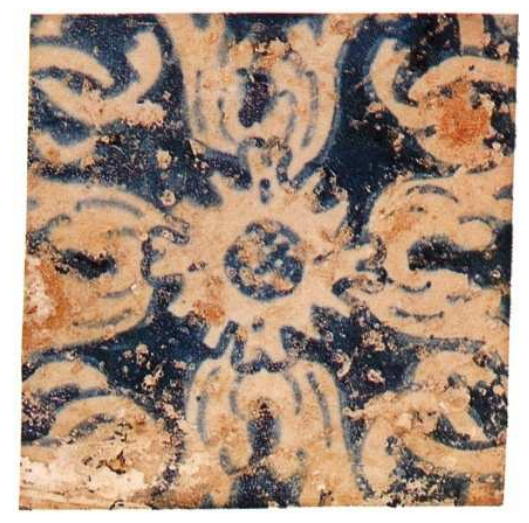

Figura 89. Azulejo $14 \times 14 \mathrm{~cm}$. procedente del Palacio Condal de Oliva (Manises, siglo XV). (CP. Oliva). Fuente: Salvador Mañó i Fenollar.

- Baldosa de barro cocido procedente del Palacio Condal de Oliva con figura floral impresa en relieve.

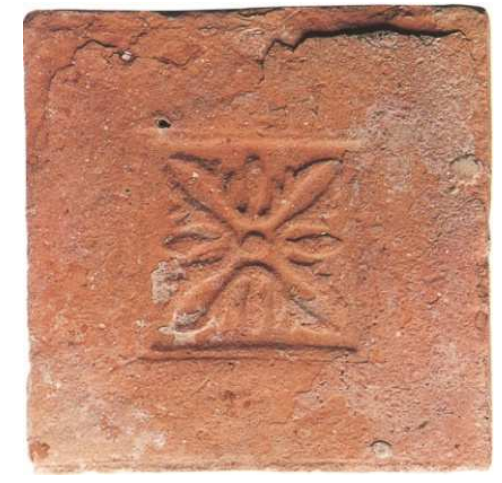

Figura 90. Baldosa de barro cocido procedente del Palacio Condal de Oliva. (CP. Oliva). Fuente: Salvador Mañó i Fenollar. 


\section{Tímpano en relieve}

Otra pieza ornamental procedente del palacio que se encuentran también en colecciones privadas es el tímpano semicircular de altorrelieve trabajado en estuco. Procede del techo de la galería abierta que daba a la Sala de Armas del palacio. Se trata de la decoración existente bajo uno de los arcos formeros de la bóveda estrellada numerada como Loft 19. Corresponde con la que aparece en la Fot. 55 de Fischer.

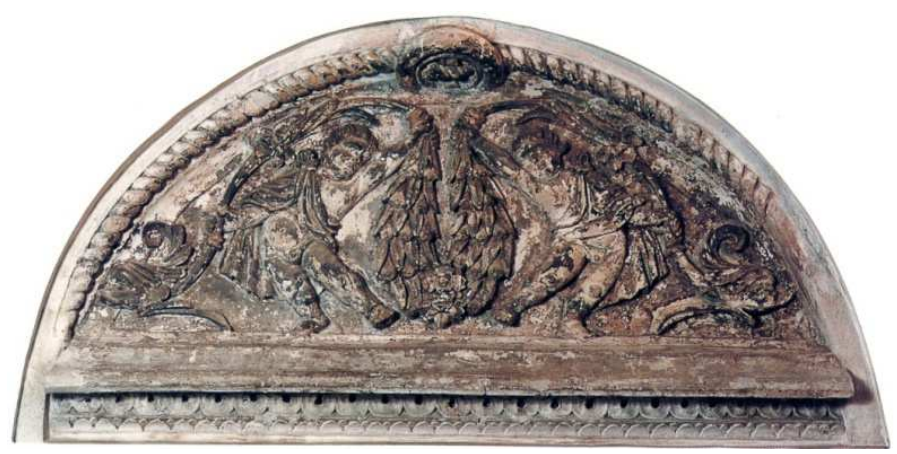

Figura 91.Tímpano semicircular de altorrelieve trabajado en estuco procedente del palacio (CP. Oliva). Fuente: Salvador Mañó i Fenollar.

\section{Ménsula decorada}

Otra pieza que también se encuentra en una colección privada es una de las ménsulas de las portadas y ventanas. Sobre una base geométrica de trazado gótico se representa un dragón alado. Está construida en yeso y policromada. Se ha identificado con la ménsula izquierda de la ventana $\mathrm{V} 10^{190}$, localizada en la Sala de Armas.

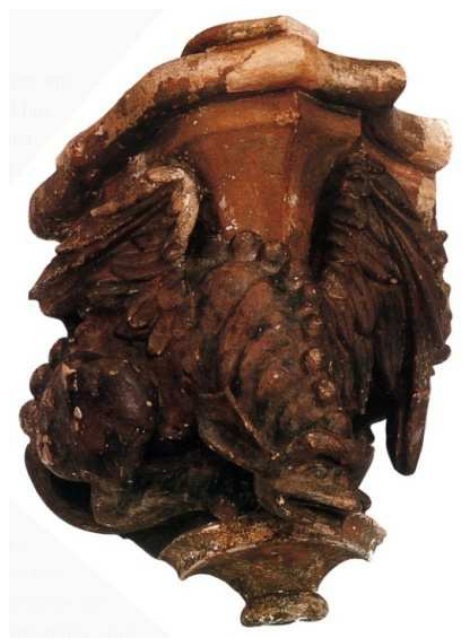

Figura 92. Ménsula decorada izquierda V10 (CP. Oliva). Fuente: Salvador Mañó i Fenollar.

${ }^{190}$ Fischer, E. (1917-1920). AFG. Fot. 27. pp. 7R. 


\section{Forjado de yeso decorado}

En el edificio de la calle Tamarit, no 6 de Oliva, actualmente Biblioteca Municipal, se encuentra un forjado de escayola decorado cuyas piezas proceden del Palacio Condal de Oliva. Corresponde con el forjado fotografiado por Fischer (Fot. 45) y que Sebastián Castellanos describió como la "Planta entresuelo", a la derecha del acceso al palacio.

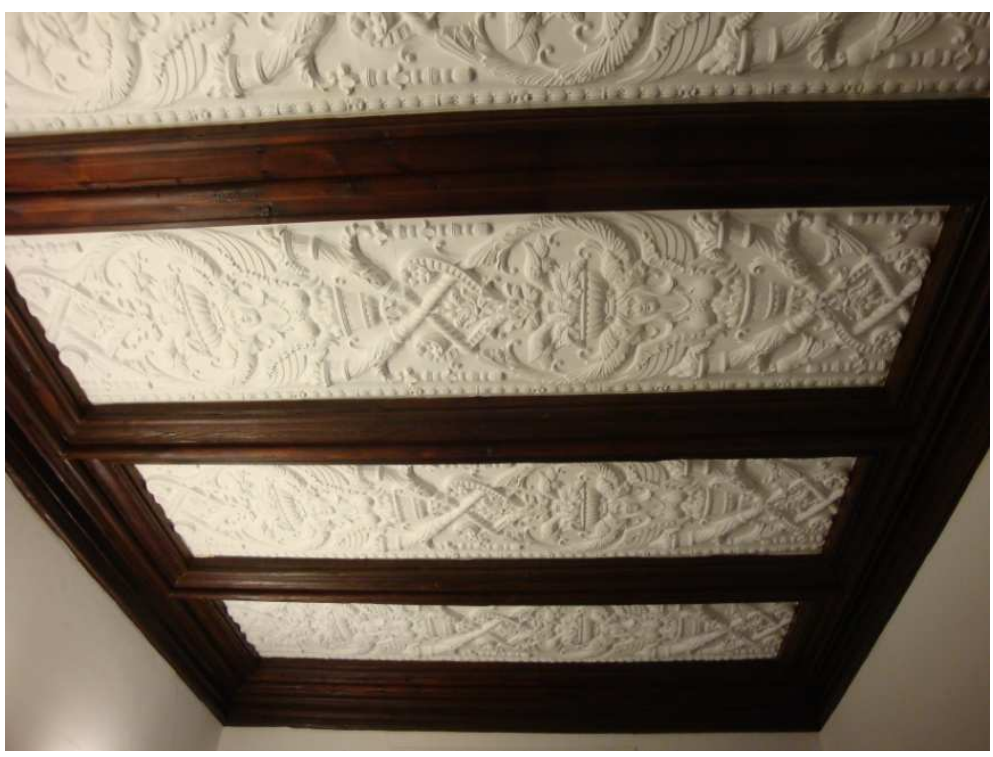

Figura 93. Forjado en Casa calle Tamarit no 6. Oliva.

\subsubsection{Museo de Diseño y de las Artes Aplicadas de Copenhague (Dinamarca)}

Según la información que nos aporta Lauritzen, las piezas que Fischer envió a Dinamarca procedentes de sus viajes por España y otros países europeos se encuentran en museos daneses y en la Escuela de Arquitectura de la Academia Real, si bien parece referirse a los viajes realizados entre 1904 y $1913^{191}$.

Por ejemplo, en la biblioteca del Museo de las Artes Decorativas de Dinamarca se ha localizado una importante cantidad de piezas, algunas de las cuales, presumiblemente, proceden del Palacio de Oliva: en especial sus azulejos y elementos escultóricos de características similares a las de las portadas y ventanas del Palacio de Oliva. Todas estas piezas podrían proceder del envío realizado por Fischer a Dinamarca antes de que fuera paralizada la exportación del palacio hacia Dinamarca. Según la información contenida en la página web de Grundejer Foreningen Femmøller Beach ${ }^{192}$, Fischer envió a su país de origen 6 camiones con material procedente de España. Se trata de una información no contrastada documentalmente, por lo que no podemos afirmar con exactitud la fecha ni cantidad de

${ }^{191}$ Lauritzen, V (1997). Relación sobre el Palacio, Oliva, Valencia. En Esteve i Blai, Antoni (Ed.). El Palau dels Centelles d'Oliva. Recull gràfic y documental. Oliva, España: L'Associació Cultural Centelles i Riu-Sec. pp. 139.

${ }^{192}$ Grundejer Foreningen Femmøller Beach. Recuperado en: http://www.gffs.dk/gffs/Historie. 
piezas enviadas. Sin embargo, en el capítulo $V$ se expone la información recopilada y examinada, ya que sólo se ha podido manejar material documental, y no las piezas, físicamente.

\subsubsection{Nørrehald. Femmøller Strand}

Tras su fracaso al intentar construir el Museo Español en Dinamarca, en 1923 Egil Fischer se instaló en Femmøller Strand (Ebeltoft) y desarrolló un plan urbanístico para construir una ciudad de vacaciones en las inmediaciones del parque natural de Mols Bjerge, a unos 50 kilómetros al oeste de Arhus, en la Península de Jutlandia.

Egil Fischer, junto con Ellen Dahl, compraron terrenos próximos a la costa y en las colinas cercanas declaradas como parque natural ${ }^{193}$. Mediante el desarrollo del plan urbanístico, conservó las características naturales del entorno y construyó una casa suficientemente grande como para albergar su colección de antigüedades. Esta vivienda la denominó "Nørrehald". Cuando ya estaba casi finalizada, el matrimonio Fischer se estableció en ella, aunque poco tiempo después tuvieron que venderla por problemas financieros y se construyeron otra casa más pequeña donde viviría el matrimonio y, posteriormente, su viuda, Olga Fischer.

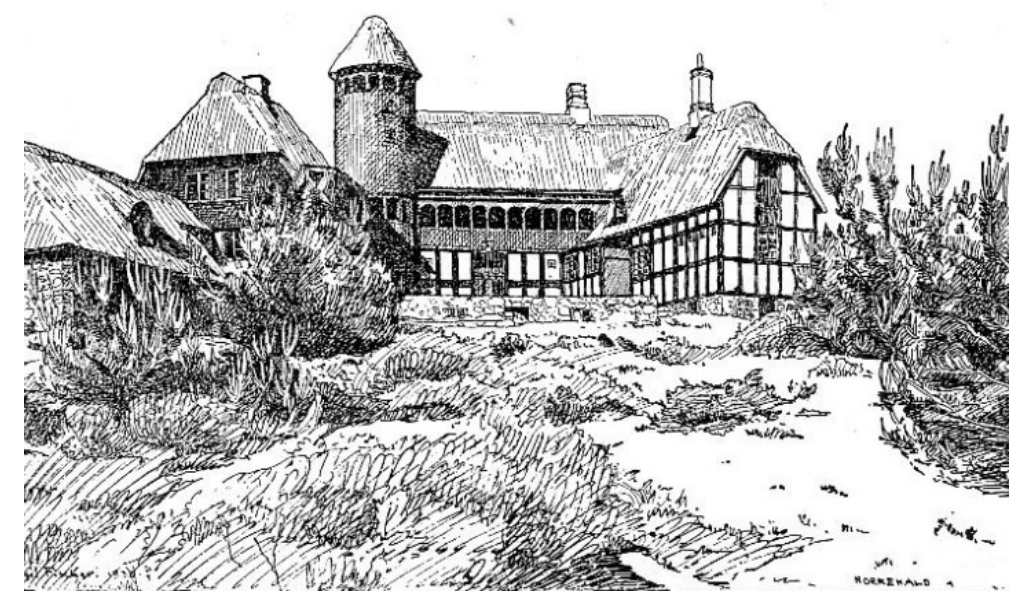

Figura 94. Dibujo de Nørrehald realizado por Fischer en 1938. Fuente: www.femmoller-strand.dk

En estas dos casas se conservaron algunas piezas, al menos hasta 1979, tal y como nos relata Lauritzen ${ }^{194}$. Entre ellas se encontraban dos piezas del friso de la Sala de Armas, algunas del ornamento y diversas rejas incorporadas en la propia construcción.

Entre la documentación encontrada en el archivo de la Danmarks Kunstbibliotek Studiesalen (Biblioteca Nacional Danesa del Arte. Sala de estudio) existe un inventario de las piezas procedentes de Oliva, incorporándose fotografías de ellas, que procedemos a enumerar:

\footnotetext{
${ }^{193}$ Grundejer Foreningen Femmøller Beach. Óp. cit.

${ }^{194}$ Lauritzen, V. (1997). Óp. cit. pp. 144.
} 


\section{Piezas de artesonado}

De acuerdo con la ficha del inventario, se trata de un total de 40 piezas, definidas como piezas de artesonado de dimensiones $44 \times 36 \times 3 \mathrm{~cm}$ pintadas al temple. Representan unas figuras vegetales estilizadas con una gran flor en el centro, enmarcada en un cuadrado, y elementos vegetales en espiral a su alrededor. Aunque no indica el material del que estaban hechas, debe de tratarse de piezas de fábrica revestidas de yeso. Tienen impreso un sello con una figura geométrica que parece ser la marca del artesano (similar a las marcas de cantería). Estas piezas no fueron fotografiadas in situ en el palacio, ni tenemos constancia de ellas ni en los planos ni en los cuadernos de notas. Están incorporadas a la construcción de la chimenea del salón principal de Nørrehald.

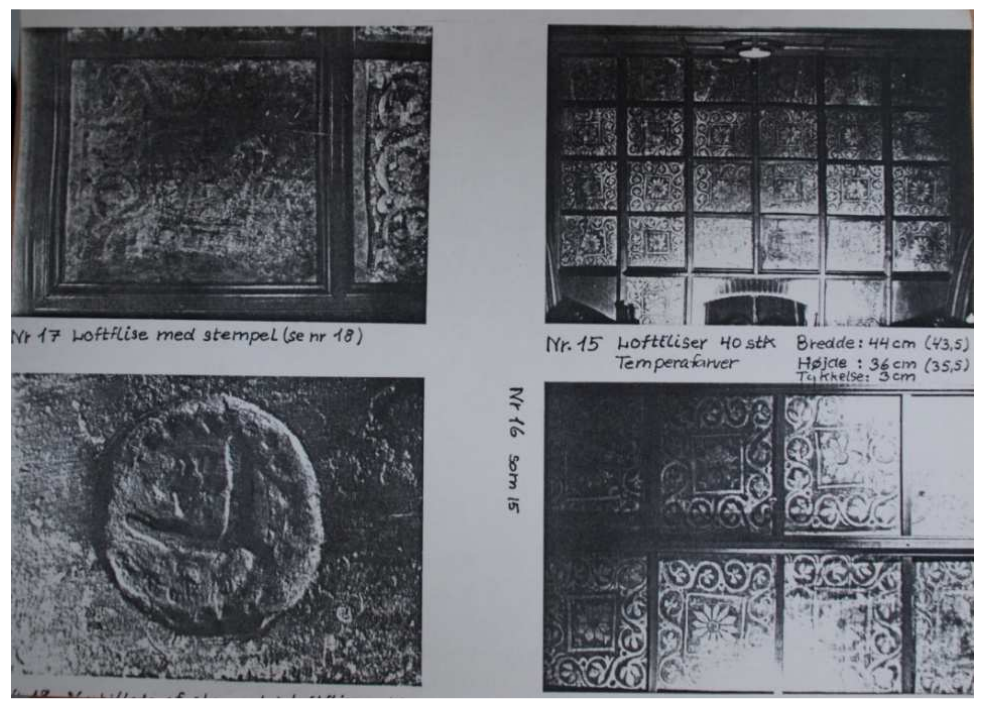

Figura 95. Ficha fotográfica de las piezas de artesonado localizadas en Nørrehald. Fuente: DKS.

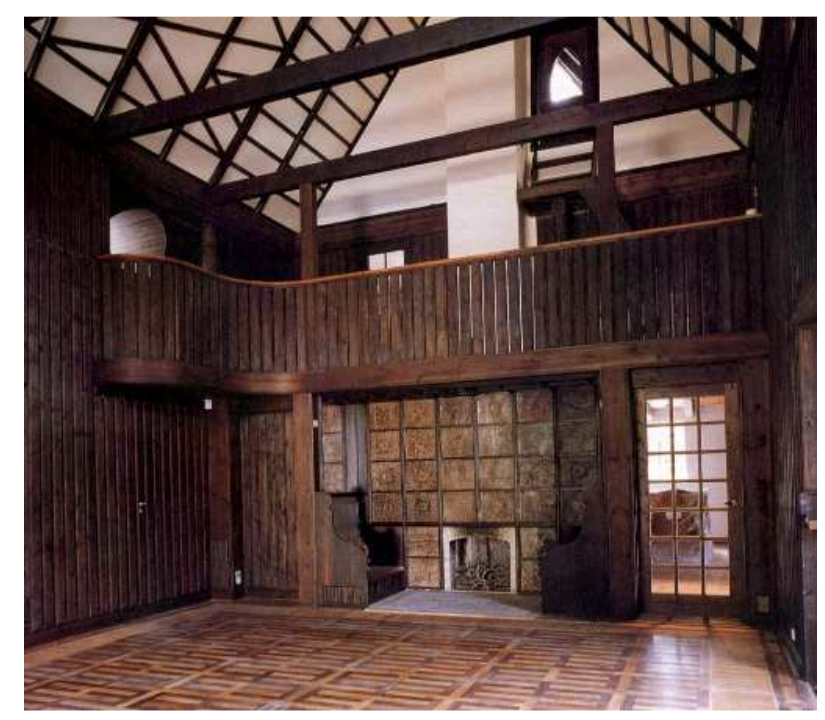

Figura 96. Salón principal Nørrehald. Fuente: www.femmoller-strand.dk 


\section{Rejas}

De acuerdo con la ficha del inventario, existen 3 rejas de forja procedentes del palacio: una de dimensiones $130 \times 170 \mathrm{~cm}$ rematada en cruz, otra de $135 \times 160 \mathrm{~cm}$ con corazones invertidos y una de pequeña formada por tres barrotes. Se encuentran incorporadas a las ventanas como elementos decorativos.

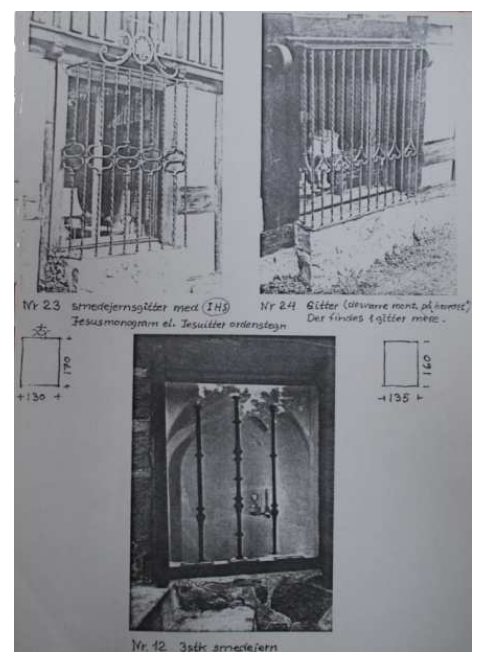

Figura 97. Ficha fotográfica de las rejas localizadas en Nørrehald. Fuente: DKS.

\section{Piezas Forjado Sala de Armas}

De acuerdo con la ficha del inventario, existían 3 piezas procedentes del forjado de la Sala de Armas; dos de ellas eran dos lunetos de dimensiones máximas $76 \times 26 \mathrm{~cm}$ y $76 \times 23 \mathrm{~cm}$. Se trata de piezas en relieve, en estuco policromado, y correspondían a la decoración de los lunetos laterales del forjado. La ficha incluye también una tabla de madera policromada y dorada de dimensiones $80 \times 26 \times 6,2 \mathrm{~cm}$, que correspondía al forro de madera colocado bajo los lunetos, en los testeros del forjado a modo de falsa viga.

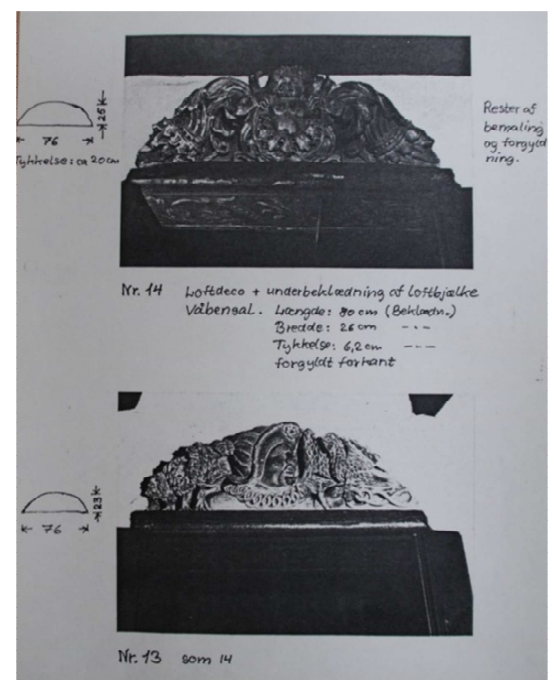

Figura 98. Ficha fotográfica de las piezas del forjado de la Sala de Armas localizados en Nørrehald. Fuente: DKS 


\section{Friso Sala de Armas}

De acuerdo con la ficha del inventario, existían 2 piezas con una dimensión total de $200 \mathrm{x}$ $68 \mathrm{~cm}$ que pertenecían al friso de la Sala de Armas y estaban colgadas en un pasillo del sótano de Nørrehald.

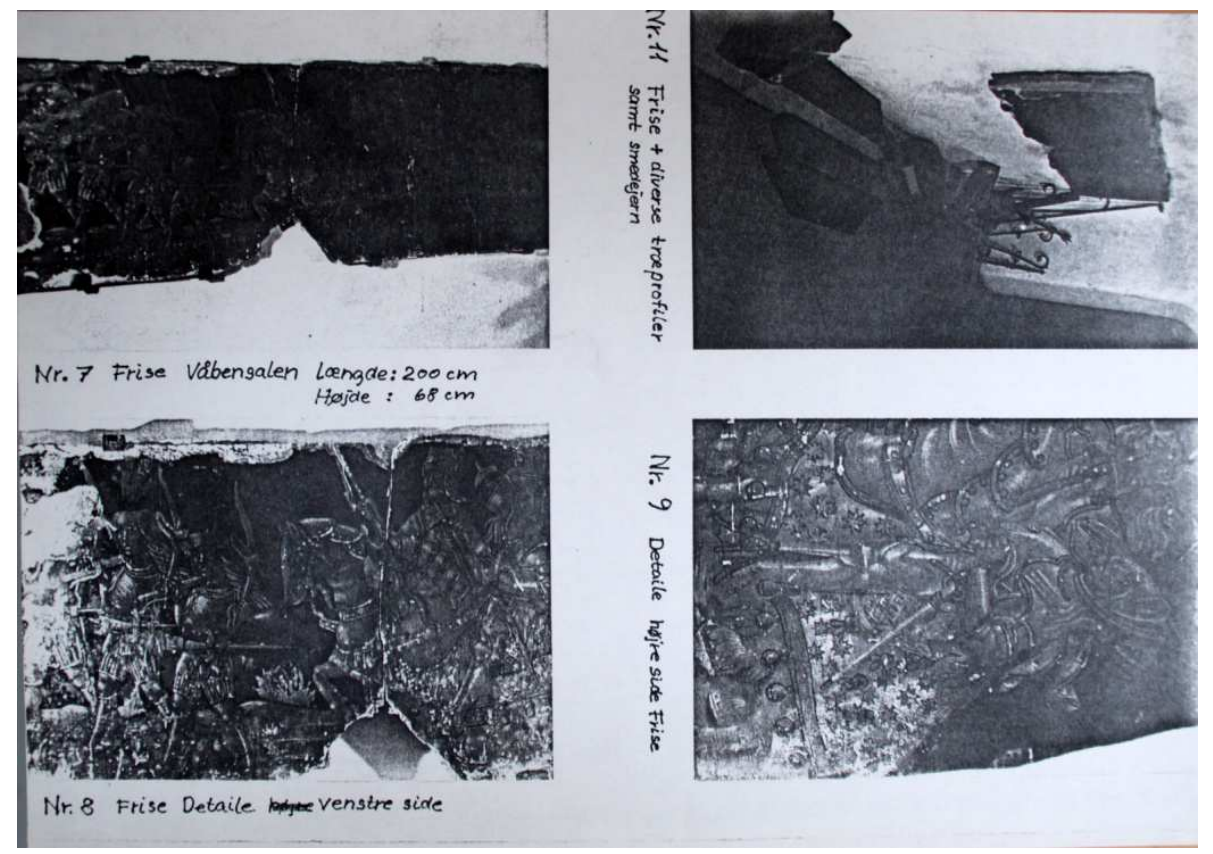

Figura 99. Ficha fotográfica del friso de la Sala de Armas localizado en Nørrehald. Fuente: DKS.

\subsubsection{Hispanic Society of America}

En 1980 salieron a subasta dos piezas del friso de la Sala de Armas y otras piezas pertenecientes al Forjado de la Sala de Armas del Palacio Condal de Oliva. Estas piezas fueron subastadas en Londres en 1980 y adquiridas por la HSA. Por parte de España acudió a la subasta Joaquín Serra Velda, de Valencia, pero no llegó a tiempo para pujar. En la actualidad forman parte de la colección del museo neoyorkino, ya que esta institución las consideró de gran interés para su colección por su singularidad ${ }^{195}$. Se trata de las piezas descritas en el apartado anterior, inventariadas en Nørrehald, y que no formaban parte del edificio propiamente. La HSA envió a Priscila, E. Muller, conservadora del museo a dicha subasta. Después, Muller inició una profunda y rigurosa investigación sobre las piezas y el palacio que las había albergado. Los frutos de dicha investigación han sido fundamentales en la recuperación de la memoria del palacio.

195 E. Muller, Priscilla. (1999). A la recerca del Palau. Cabdells: Revista d'investigació de l'Associació Cultural Centelles i Riu-Sec, Núm. 1. PP. 21-22. 


\section{Friso Sala de Armas}

El friso representa un ejército triunfal en marcha dirigido por los Centelles para conmemorar sus batallas. Está pintado en color grisalla con toques de oro sobre un fondo azul oscuro. Los textos en valencianos sobre las figuras describen cada uno de los cuerpos que formaban este ejército. A través de las guardapas de sus caballos se han podido identificar a miembros de las familias de los Perellós, Centelles, Aguiló y Rojas ${ }^{196}$. El friso fue restaurado por la HSA y está formado por una base de ladrillos cóncavos revestidos con una gruesa capa de yeso sobre la que fue pintado al temple con diversos pigmentos. En la cara inferior presenta una capa gruesa de mortero de cal, y en los bordes superior e inferior quedan restos del molde de madera sobre el que se construyó ${ }^{197}$.

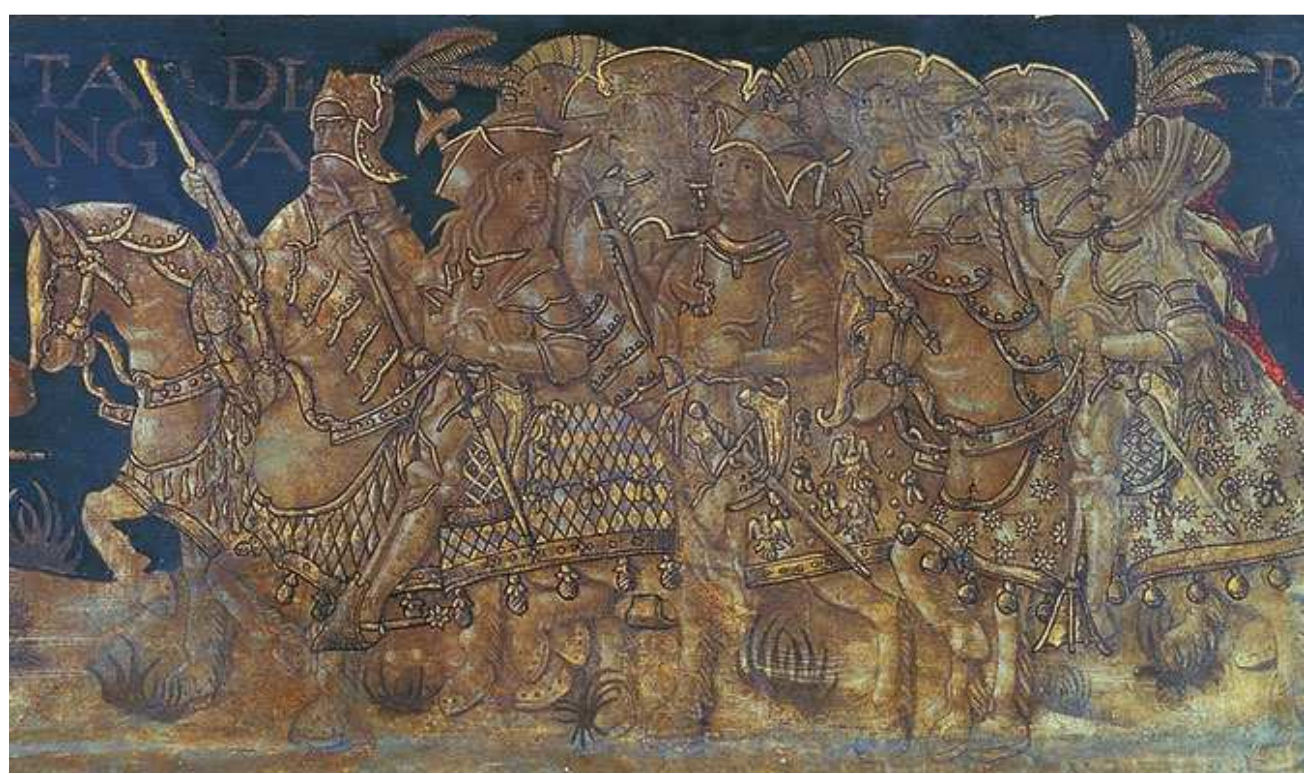

Figura 100. Detalle sección derecha del friso de la Sala de Armas. Fuente: HSA. Fuente: Salvador Mañó i Fenollar.

\section{Piezas forjado Sala de Armas}

Dos de las piezas son altorrelieves de forma semicircular que decoraban los testeros del forjado. Están trabajados en estuco y policromados. Uno de ellos representa una sirena que emerge entre elementos vegetales y está flanqueada por dos columnas torsas inclinadas y rematadas con la corona real. Está decorada en oro sobre fondo azul y las columnas en rojo y oro al modo de la bandera valenciana. El segundo representa un caballero con casco que porta un halcón en su mano izquierda, lugar en el que también se observan árboles representando un bosque.

${ }^{196}$ E. Muller, P. (1997). El Palau d'Oliva dels Centelles. En A. Esteve i Blai, Antoni (Ed.). El Palau dels Centelles d'Oliva. Recull gràfic y documental. Oliva (pp. 87-138) Oliva, España: L'Associació Cultural Centelles i Riu-Sec. pp. 120-128.

${ }^{197}$ E. Muller, P. (1997). óp. Cit. pp.137. 


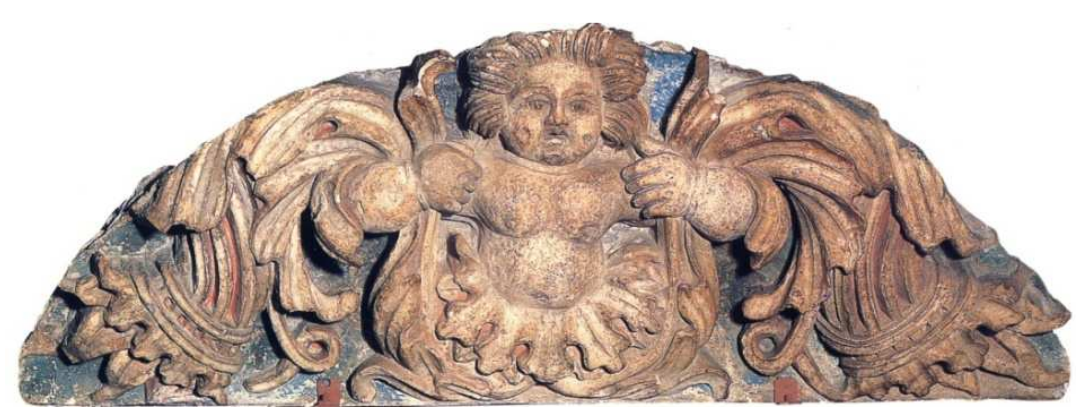

Figura 101. Sirena. Altorrelieve semicircular trabajado en estuco y policromado. Original perteneciente al techo de la Sala de Armas del Palacio Condal de Oliva. Fuente: Salvador Mañó i Fenollar.

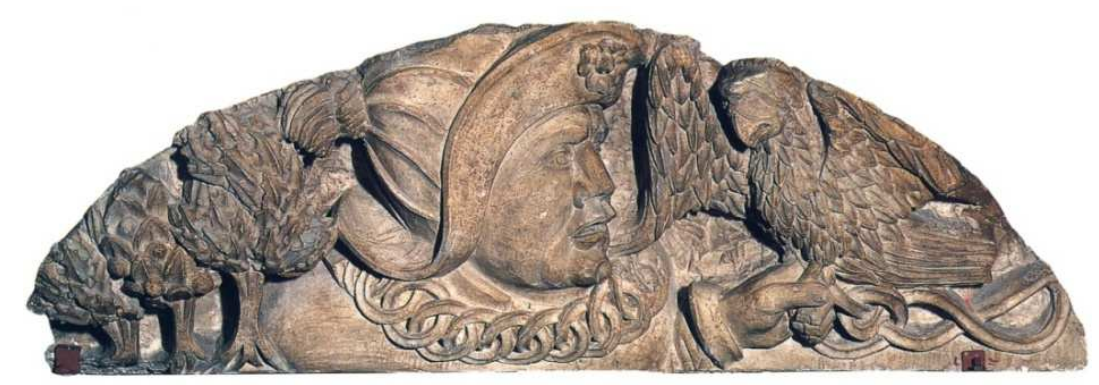

Figura 102. Halconero. Altorrelieve semicircular trabajado en estuco y policromado. Original perteneciente al techo de la Sala de Armas del Palacio Condal de Oliva. Fuente: HSA. Nueva York. Fuente: Salvador Mañó i Fenollar.

La tercera pieza es una madera que remataba el forjado en el testero del forjado. Se trata de una pieza de pino de dimensiones $86,4 \times 27 \times 6 \mathrm{~cm}$. Está pintada a témpera sobre imprimación ${ }^{198}$.

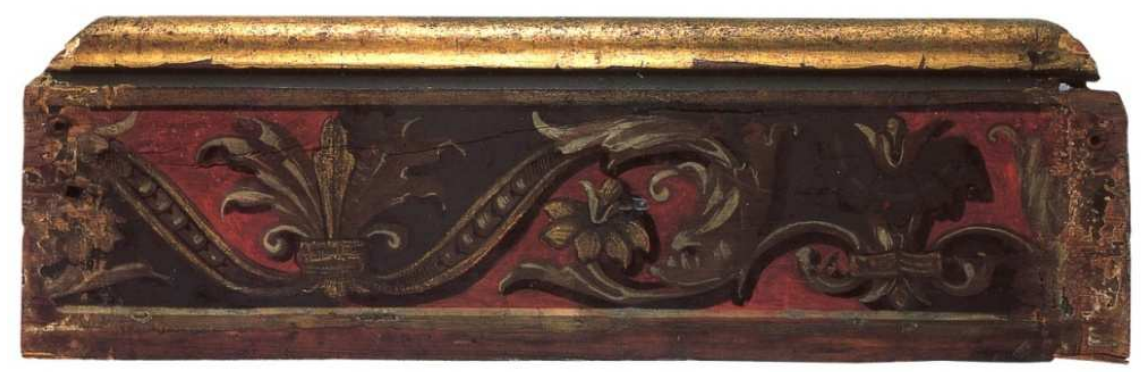

Figura 103. Fragmento original perteneciente al techo de la Sala de Armas. HSA. Nueva York. Fuente: Salvador Mañó i Fenollar.

${ }^{198}$ E. Muller, P. (1997). Óp. cit. pp. 137. 



\section{CAPITULO V}

\section{EL LEGADO GRÁFICO DE E. FISCHER Y V. LAURITZEN}

\section{INTRODUCCIÓN}

En este apartado se realizará una clasificación del material gráfico recuperado que, actualmente, se encuentra en el Archivo de Patrimonio Documental (APD) del Museo Arqueológico de Oliva (MAO), en una estancia de acceso restringido con control de humedad y temperatura para garantizar su conservación. Dichas condiciones fueron solicitadas por la Hispanic Society of America (HSA) en su acuerdo de cesión del material gráfico al Ayuntamiento de Oliva.

El MAO ha realizado la importante labor de ordenar, codificar y escanear dicha documentación, creando una versión digital que permite desarrollar toda una metodología de investigación con los medios tecnológicos actuales. El responsable técnico del MAO y, por tanto, de la documentación gráfica es el arqueólogo municipal Vicent Burguera i Sales.

La primera clasificación del material gráfico se ha realizado según su tipo de soporte físico:

- Notebooks

- Planos

- Álbumes fotográficos

Todos los documentos se encuentran digitalizados, lo que permite una mayor accesibilidad y facilita tanto las labores de clasificación como las de posterior análisis y estudio. Los documentos han sido fotografiados con una escala geométrica y otra cromática de referencia, lo que ayuda a su posterior escalado. Asimismo, contienen un código de referencia, expresado por las letras LA y seguido de un código numérico de 4 cifras ( LAXXXX), salvo en los planos a escala del proyecto de Pile Allé que, en este caso, están numerados como LA E, seguidos de un dígito (LA EX). Esta información, incluida en las imágenes, nos permitirá su posterior escalado y referenciación (ver Fig. 104).

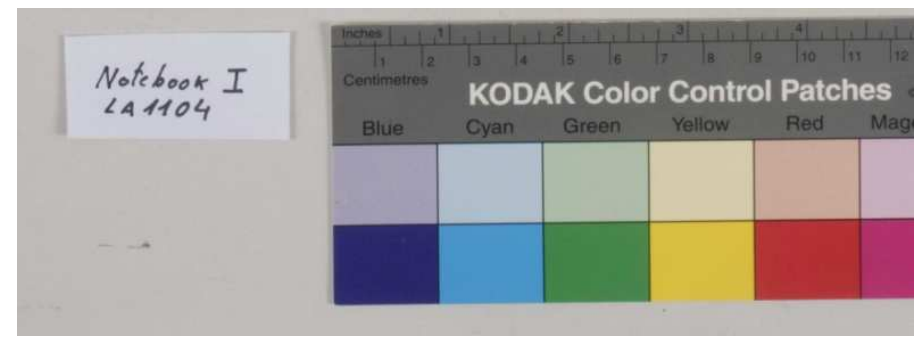

Figura 104. Escala geométrica y cromàtica, y código de referencia. Fuente: MAO, APD. 


\section{NOTEBOOKS}

Una de las tres piezas clave para el estudio y comprensión del Palacio, tal y como lo encontraron Fischer y Lauritzen en 1919, son los Notebooks o cuadernos de notas.

Se trata de dos cuadernos de dimensiones $11 \times 17 \mathrm{~cm}$ con tapas duras de cartón de color azul. Por su parte, la encuadernación del lomo está realizada con tela de color azul marino y las hojas interiores tienen una microperforación en su margen izquierdo para permitir ser cortadas de los cuadernos. El contenido de los cuadernos son notas manuscritas y dibujos a lápiz donde encontramos croquis de elementos arquitectónicos: portadas, arcos, bóvedas, vigas, artesonados, escaleras, carpinterías, pavimentos, molduras, etc. Estos croquis van acompañados de anotaciones en danés. Asimismo, aparecen hojas con mediciones, relación de materiales, direcciones, citas bibliográficas, e incluso un recibí por el pago del alquiler de una de las casas.

Para abordar el presente trabajo realizaremos una primera clasificación del contenido de cada uno de los cuadernos de notas según si predomina la documentación gráfica o la escrita. Con la documentación gráfica realizaremos una clasificación según los elementos constructivos que se describen y, con los textos, una clasificación según su contenido.

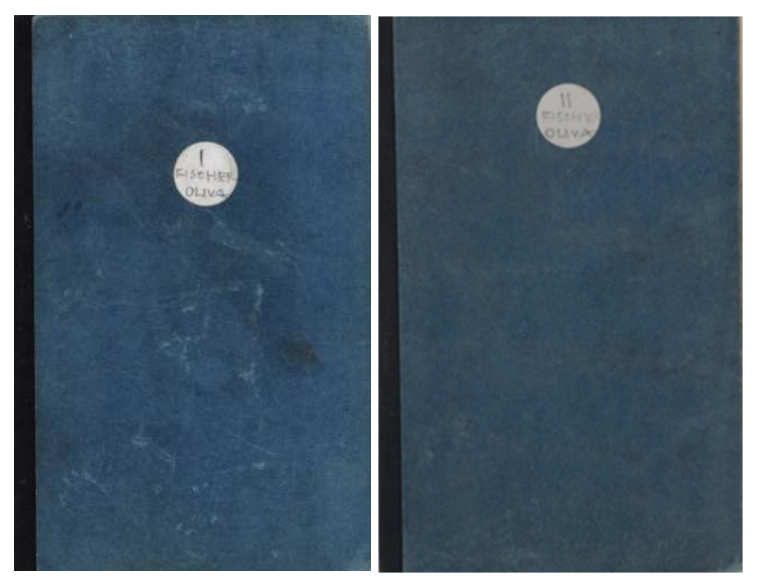

Figura 105. Portada Notebook I y Notebook II. Fuente: E. Fischer, MAO.

\subsection{Notebook I}

Su código de numeración es el siguiente: MAO. APD. Egil Fischer. Notebook I. LA1104. En la portada se encuentra pegado un círculo de papel blanco donde está rotulado a mano "I FISCHER OLIVA". A su vez, las páginas interiores están numeradas manualmente a lápiz en la esquina superior izquierda del número 1 al 77 . Cabe destacar que las páginas 18, 19, 40, $56,57,69,70,72$ y 75 no existen físicamente en el cuaderno. Hay, asimismo, dos hojas sueltas que se encuentran dentro de él: una de $9,3 \times 16 \mathrm{~cm}$ y otra de $12,6 \times 19 \mathrm{~cm}$. En la contraportada hay también anotaciones manuscritas. 


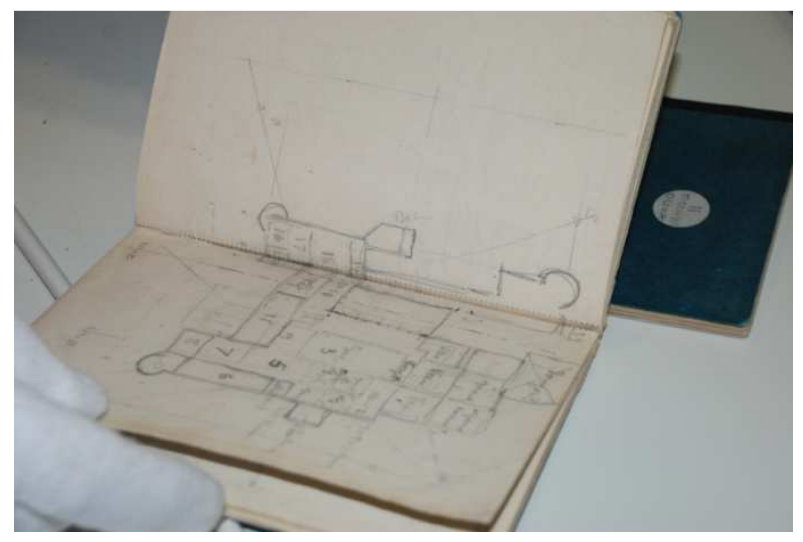

Figura 106. Notebook I. MAO.

\subsubsection{Documentación gráfica}

La mayor parte de las anotaciones de este cuaderno son gráficas; croquis realizados de manera rápida en algunos casos y con mayor detalle en otros. En su mayoría contienen cotas y textos descriptivos en danés, de difícil transcripción casi todos ellos. En este trabajo realizaremos una clasificación de los mismos según los elementos arquitectónicos que representan, con el mismo orden con el que aparece el primer elemento de cada tipología en el cuaderno:

- Carpintería y cerrajería: dentro de este subgrupo estás las dos hojas sueltas adjuntas al cuaderno que contienen alzados y secciones de sendas rejas; así como las páginas 20 y 21 , que contienen el alzado y algunos detalles de una puerta de madera.

- Galería superior: corresponden a este subgrupo las páginas 1 y 2, que contienen una sección de la galería con detalles del forjado inclinado de madera de cubrición, tejas y canalón, y la sección de un pilar con zócalo moldurado, respectivamente.

- Forjados y artesonados de madera: a esta tipología corresponden las páginas 3, 4, $5,16,34,53,54$ y 55 . Existen croquis de plantas cenitales de algunas salas acotadas con la disposición de las vigas de madera, secciones constructivas de algunos de ellos con la forma de las vigas y entrevigados, detalles de las molduras perimetrales de madera y detalles de la ornamentación en yeso se algunos elementos de entrevigado.

- Materiales cerámicos: en esta tipología se incluyen la página 6, donde se dibuja una teja plana y su sistema de unión, y las páginas $10,11,35,36$ y 37 , donde se dibujan y acotan baldosas y azulejos cerámicos, y su diseño de colocación.

- Chimeneas: encontramos 4 páginas con documentación gráfica sobre las chimeneas existentes en el Palacio. Corresponden a las páginas 7, 12, 14 y 49. 


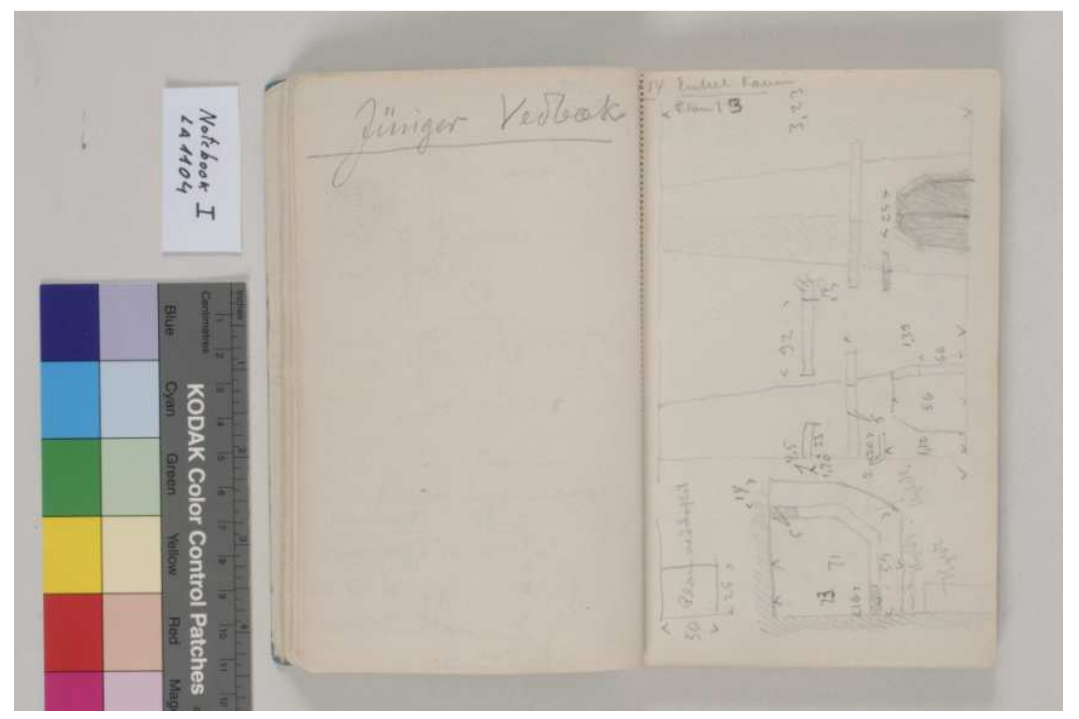

Figura 107. Detalle de una chimenea. Notebook I. Pág. 14. Fuente: Egil Fischer, MAO.

- Salas: en este subgrupo se incluyen los croquis de planta de varias salas, acotados y con la disposición de huecos en las mismas (páginas 13 y 17).

- Galería inferior: Se trata de la galería porticada de la planta primera o principal. Hay una amplia documentación de este singular elemento arquitectónico, del cual existe representación gráfica en las páginas 15, 22 a 33 y 42 a 47. También disponemos de detalles de las columnas, los arcos, el antepecho, el friso superior y las pilastras. Las columnas se encuentran numeradas, y las dovelas de los arcos y piezas de plementería entre los mismos sigladas.

- Planos generales: en esta tipología incluiremos las páginas 39, 61 y 74. Las primeras corresponden a una planta general de la planta $1^{\text {a }}$ del Palacio, con la numeración de las salas y la orientación; la segunda a una planta parcial de la planta primera con rotulación de algunas de las dependencias; y la tercera a una volumetría a mano alzada del Palacio, vista desde el norte-noreste. Tanto la planta general, como la volumetría son, sin duda, los documentos gráficos de mayor valor de los Notebooks, puesto que aportan una visión global del Palacio y nos transmiten su grandiosidad a través de un sencillo trazado.

\subsubsection{Textos}

En este apartado se realizará una clasificación de las páginas donde predominan los textos de este cuaderno de notas según su contenido:

- Datos sobre el Palacio: las páginas 8 y 9 contienen una relación de sus diversas salas. La página 38 , por su parte, contiene las alturas de los distintos elementos constructivos de la "Sala Gótica". Esta sala se corresponde con la Sala de Armas. La página 41 contiene las dimensiones de una portada. 
- Inventarios: las páginas 48 y 50 contienen el inventario de las piezas del antepecho de la Galería. Las páginas 58 a 60, a su vez, muestran un inventario numerado de puertas "para vender", y otro de ventanas y rejas del Palacio.

- Precio de materiales: la página 51 contiene el precio de compra del revoltón nuevo y la 62 una tarifa de precios de distintos tipos de ladrillos.

- Citas bibliográficas: la página 52 contiene una cita bibliográfica del libro de Monseñor Baudrillart, "Cartas del Duque de Borgoña al Rey Felipe V".

\subsection{Notebook II}

Su código de numeración es MMO. APD. PC. Egil Fischer. Notebook II. LA1105. Al igual que en el anterior cuaderno, en la portada se encuentra pegado un círculo de papel blanco donde está rotulado a mano "II FISCHER OLIVA". En este cuaderno las páginas no están numeradas, por lo que la numeración utilizada es la del orden de páginas. Está compuesto por 35 páginas más la contraportada: 17 de ellas son texto, 18 documentación gráfica, y en una de ellas hay un detalle constructivo en la página y texto en la página opuesta, por lo que podemos afirmar que este cuaderno de notas está compuesto por textos y documentación gráfica a partes iguales.

\subsection{1 .Documentación gráfica}

Al igual que en el Notebook I, realizaremos una clasificación de la documentación gráfica según los elementos arquitectónicos que representan y por el mismo orden:

- Escalera: las páginas 11 y 12 contienen la planta, el alzado y los detalles de la barandilla y el pasamanos del arranque del primer tramo de una escalera.

- Portadas: uno de los elementos arquitectónicos más singulares y característicos de este cuaderno de notas es, sin duda, sus portadas. En esta tipología englobaremos la página 7 (detalle de una jamba de puerta y las páginas 13 y 14 a 22, que corresponden a las portadas de la 1 a la 9). Se trata de alzados de las portadas de arcos góticos con sección de las jambas en su mayoría, sección por la basa en algún caso y con cotas generales en casi todas. Aunque son croquis sencillos, nos aportan una información imprescindible para poder documentar estas primeras 9 portadas ya que no disponemos de planos de ellas y sólo en algunos casos de fotografías ( 3 , $4,5,7$ y 8$)$.

- Cocina: la página 23 contiene la planta y sección de la cocina formada por una chimenea en forma de tronco de pirámide de base octogonal que ocupa toda la planta de la estancia. La transición de la planta cuadrada de la cocina al arranque octogonal de la chimenea se realiza mediante cuatro lunetos situados en las esquinas.

- Bóvedas: las páginas 26, 27 y 28 contienen documentación de las salas 15, 13 y 17, cubiertas con bóvedas de arista, cañón y crucería, respectivamente grafiadas en planta y sección (y acotadas). Las bóvedas y las portadas son los documentos de mayor valor de este cuaderno, ya que nos permiten reconstruir gráficamente estos singulares elementos arquitectónicos del Palacio. 
- Salas: las páginas 30 y 31 disponen de croquis acotados de las salas 16 y 18 (Sala de Armas) con disposición de huecos. En la sala 16 se encuentra representada la distribución de vigas del forjado. La página 25, por su parte, representa un esquema de la estructura de madera que forma la cubierta de la Sala de Armas.

\subsubsection{Textos}

En esta ocasión realizaremos la clasificación de los textos que aparecen en el cuaderno de notas según su tipología:

- Cita bibliográfica: las páginas 1 a 10 y las opuestas (con excepción de la página opuesta a la 8 que se encuentra en blanco y la página 7 en la que figura el croquis ya descrito) contienen una copia manuscrita del capítulo dedicado a Oliva del libro de Teodoro Llorente, "Valencia Tomo II"199.

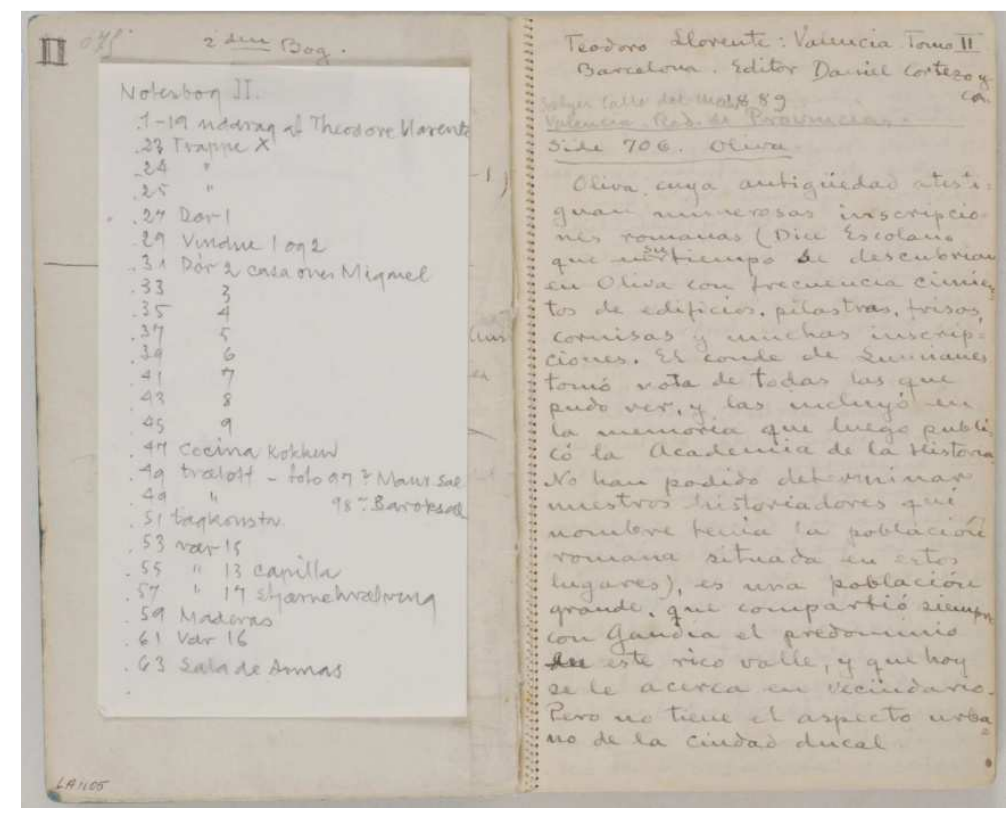

Figura 108. Notebook II. Pág. 1. Relación de contenido y cita de Teodoro Llorente. Fuente: Egil Fischer. MAO.

- Datos del Palacio: en la página 14 hay una anotación sobre la situación de las ventanas 1 y 2 . La página 24 , a su vez, contiene anotaciones con medidas generales de los techos de diversas salas.

- Inventarios: en la página 29 hay un inventario de vigas de madera con su situación y posición. La contraportada contiene un listado de dimensiones de largo alto y ancho, y la suma del volumen. En el texto se indica "Tarragona. Capiteles".

- Anotaciones de contactos y listados de precios: las páginas 32 a 35 contienen diversos contactos con su dirección; listados de precios de materiales de

199 Llorente, Teodoro (1889). Valencia. Colección «España: sus monumentos y sus artes-su naturaleza e historia». Barcelona: Editorial de Daniel Cortezo y C. 
construcción; un inventario de antigüedades; y otras anotaciones, algunas de ellas tachadas.

\section{PLANOS}

En cuanto a los planos, suponen 112 láminas dibujadas a lápiz en su mayoría (y algunas a tinta), más los 8 planos dibujados a tinta de los proyectos de construcción del Museo de Arte Español en Dinamarca. Cada una de ellos está numerado mediante el siguiente código: MMO. APD. Egil Fischer y Vilhelm Lauritzen. LAXXXX. En los planos se encuentran grafiadas la planta principal, el plano de cubiertas del Palacio, así como los artesonados, las bóvedas, los arcos, las portadas, las ventanas y otros elementos arquitectónicos singulares de las plantas nobles del Palacio. El plano de cubiertas incorpora escala gráfica, y en el resto de las láminas encontramos algunas con cotas y otras que carecen de ellas. En la mayoría de los planos de las portadas, ventanas y arcos podemos ver una lámina principal con mayor detalle y otra en papel vegetal que aparenta ser un calco de la primera. En ella se detalla el despiece previsto del elemento arquitectónico para su desmontaje y posterior montaje.

La clasificación se ha realizado según la tipología de los elementos constructivos en los siguientes bloques, ordenados según el número total de planos: portadas, ventanas, techos, varios, planos Proyecto Pile Allé y plantas.

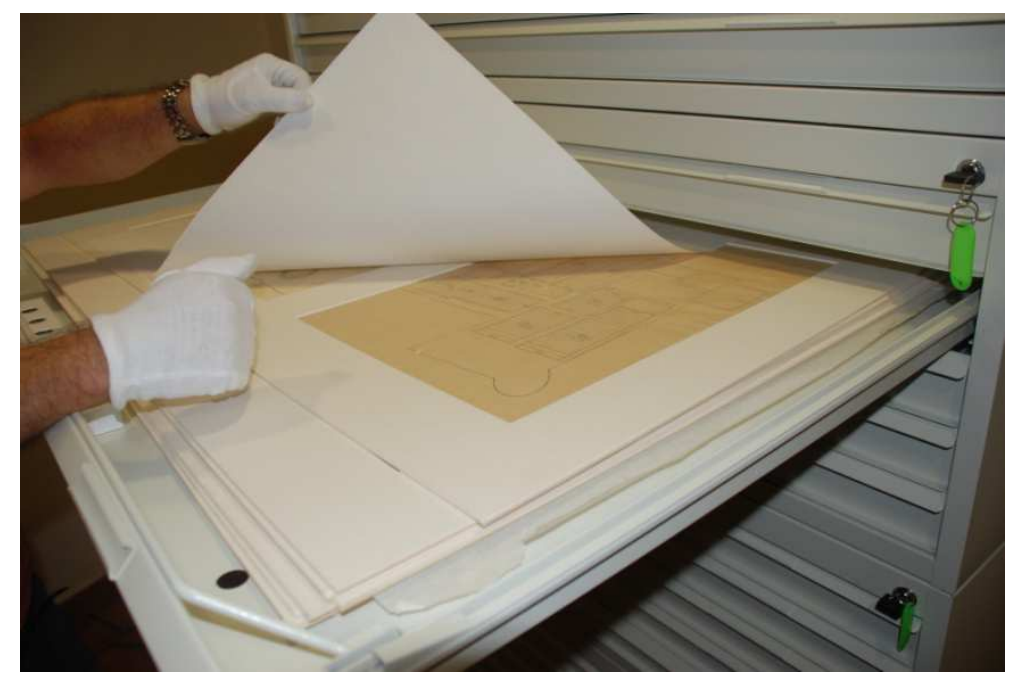

Figura 109. Archivo de planos. MAO.

\subsection{Portadas}

Son el bloque de planos más numeroso. Lo componen un total de 46: LA1122-bis, LA1124, LA1136 a LA1177 (excepto LA1172 y LA1174, que no existen), LA1182, LA 1191 y LA1192. En ellos se encuentran representadas las portadas Dör 8 y Dör 10 a Dör 28. Además, uno de ellos representa un detalle de la portada Dör 7 (LA1182), y las láminas LA1176, LA1177, LA1191 y LA1192 otras cuatro portadas no rotuladas ni identificadas. Dentro de las 
portadas podemos establecer asimismo distintas clasificaciones según la ornamentación, tipo de arco, número de columnas que conforman las jambas, etc.

\subsection{Ventanas}

Este conjunto de planos está formado por 27 láminas: LA1179, LA1183 a LA1187 y LA1193 a LA1213. En ellas se definen las 8 ventanas numeradas: vindue 3 a 10, y 5 ventanas más sin numerar, así como las dimensiones de los huecos y su ornamentación arquitectónica (arcos, jambas, molduras, festejadors ${ }^{200}$, etc.).

\subsection{Techos}

Este grupo lo engloban las láminas LA1110 A, LA1110R, LA1111 a LA1123, LA1124-bis, LA1125 y LA1126; 18 en total. Todas ellas poseen un identificado del número de sala a la que pertenece el techo, excepto las láminas LA1110 A y LA1110R. Dentro de este grupo podemos establecer 3 subgrupos según su tipología: forjados, artesonados y bóvedas.

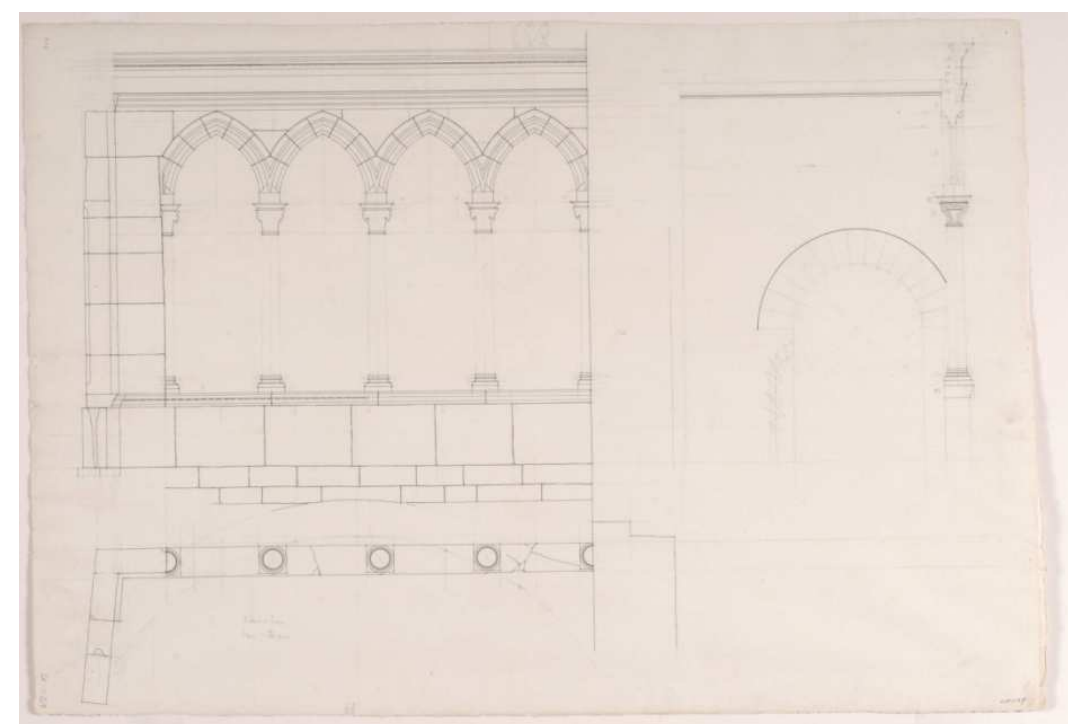

Figura 110. Plano LA1129. Alzados, planta y sección de la Galería del Patio. Fuente: Egil Fischer y/o Vilhelm Lauritzen, MAO.

\subsection{Varios}

En este grupo heterogéneo hemos englobado todas aquellas láminas que no encajaban en el resto de grupos. Está compuesto también por 17 láminas: LA1110-bis, LA1127 a LA 1135, LA1178, LA1180, LA1181, LA1188 a LA1190 y LA1214. Dentro de este grupo podemos

\footnotetext{
200 Festejadors: (valenciano) asientos dispuestos en cada una de las jambas, en la parte interior de una ventana, destinados a la charlar o realizar trabajos que necesiten luz.
} 
establecer, a su vez, 3 grupos diferenciados: Galería Torre Grande, Arcos Galería Patio de Armas y Varios.

\subsection{Planos Proyecto Pile Allé}

Está compuesto por 8 planos a escala grafiados a tinta que contienen las plantas, alzados y secciones de dos propuestas para el Museo Español de Copenhague.

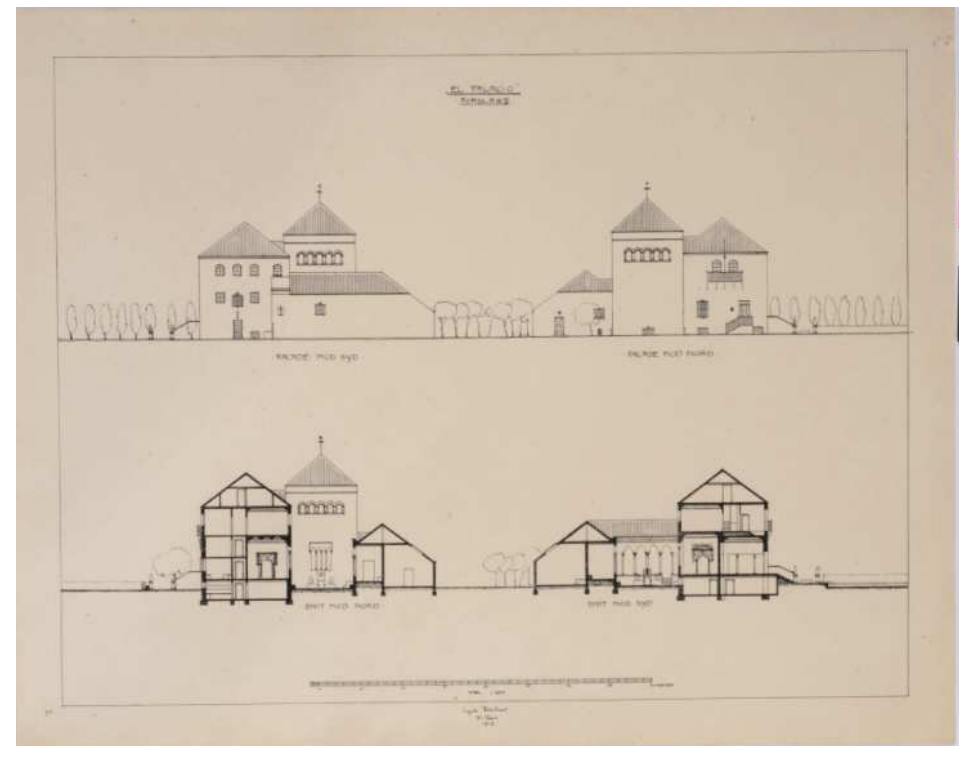

Figura 111. Plano LA E7. Alzados y Secciones. Proyecto Pile Allé. Egil Fischer. Fuente: MAO.

\subsection{Plantas}

Este grupo está formado por un total de 4 láminas a lápiz (LA1106, LA1108, LA1109 y LA 1109-bis) que representan la planta principal del Palacio con la numeración de muchas de sus salas, portadas y ventanas; dos planos de plantas de cubiertas del Palacio y un plano que contiene dos plantas de la distribución de un edificio en el que incorpora muchas de las portadas y ventanas del Palacio, aparentemente otra propuesta para el Museo Español de Copenhague.

\section{FOTOGRAFÍAS}

Dentro de la documentación gráfica recuperada del Palacio y depositada en el MAO existen dos álbumes de fotografías: el Álbum de Fotos Grande y el Álbum de Fotos Pequeño. En ellos encontramos fotografías generales de Oliva y del Palacio, fotografías de elementos arquitectónicos singulares del Palacio, fotografías de otros edificios de referencia y fotografías de los terrenos en Dinamarca donde Egil Fischer pretendía construir su Museo de Arte Español e incorporar las piezas desmontadas del Palacio. Estas fotografías van acompañadas de textos en danés. Toda esta documentación fotográfica resulta de incalculable valor a la hora de entender y poder analizar cómo era el edificio. 


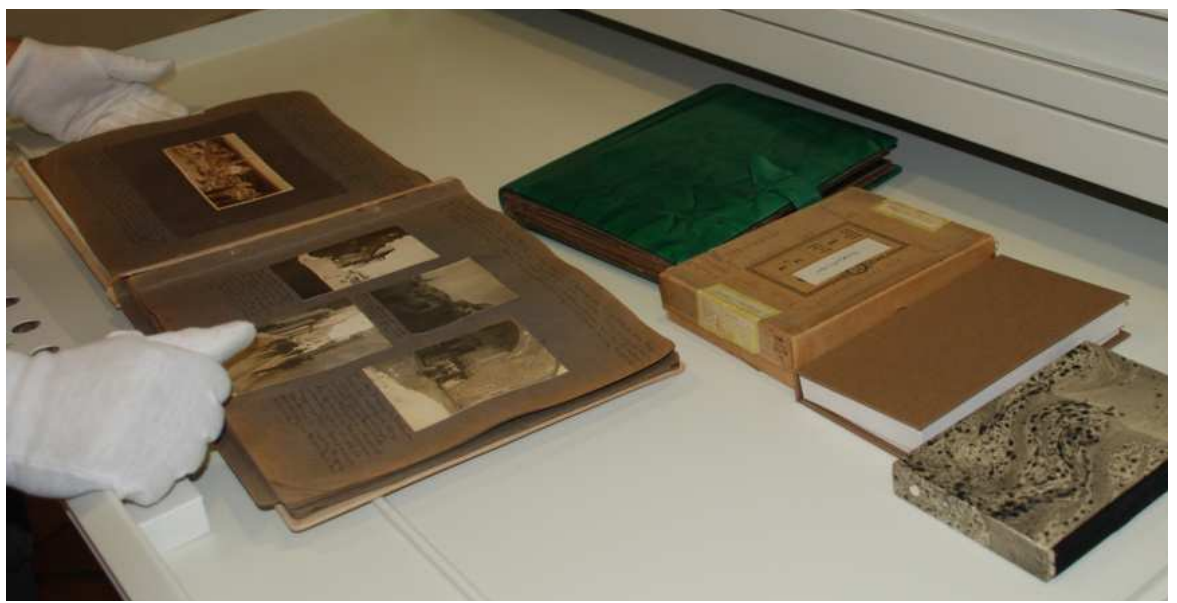

Figura 112. Álbum Fot. Grande. MAO.

En adelante realizaremos una clasificación de los álbumes fotográficos según el contenido de las fotografías de cada uno de ellos.

\section{1. Álbum de Fotos Grande}

Su código de numeración es MMO. APD. Egil Fischer. Álbum de Fotos Grande. Se trata de un álbum apaisado de dimensiones $30 \times 38 \mathrm{~cm}$ de tapas duras y encuadernado mediante dos tornillos roscados. El color de sus tapas es marrón claro. Las hojas interiores son de cartulina gris marengo, y se encuentran reforzadas con una tira de cartulina color marrón claro pegada en el anverso, en la zona de la encuadernación. Contiene un total de 24 páginas. Sobre estas hojas se encuentran pegadas las fotografías, numeradas de la 1 a la 108 a pluma sobre la cartulina. Asimismo, existen notas escritas a pluma como pie de las fotografías y textos explicativos en en danés en algunas páginas. Establecemos los siguientes grupos según los elementos que representan:

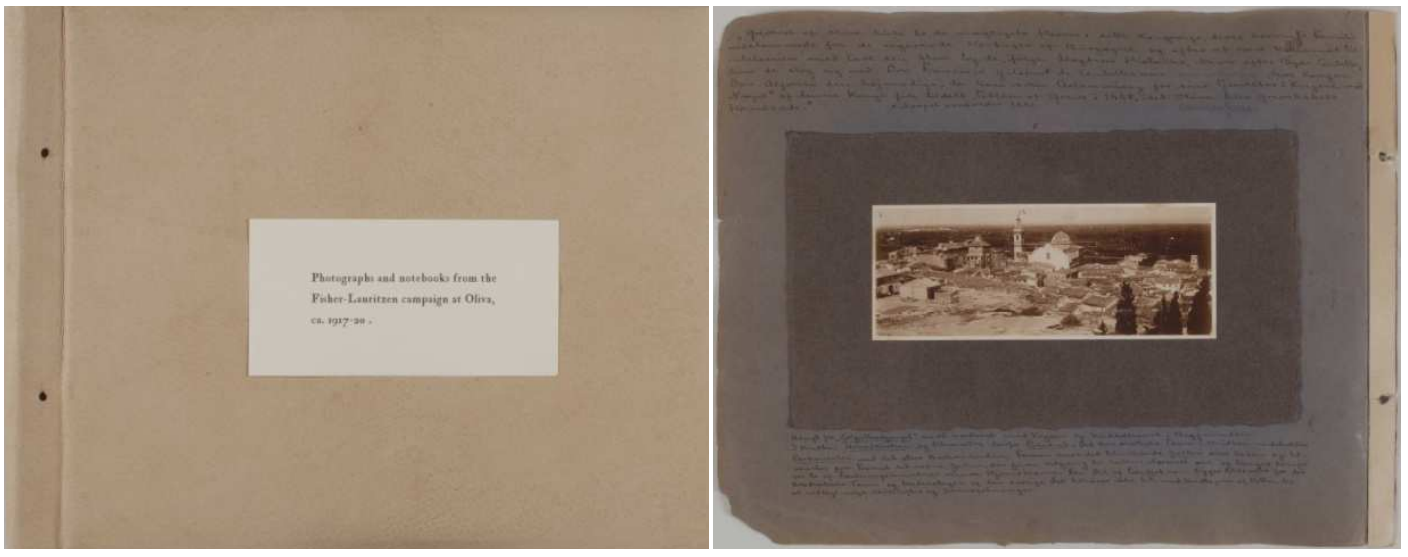

Figura 113. Izquierda: portada. Derecha: pág. 1R. Vista de Oliva desde el SE. Álbum Fot. Grande MAO. 
- Fotografías de Oliva: se trata de fotografías generales de Oliva y sus alrededores. Son un total de 8 fotografías: 1 a 4 y 90 a 93; éstas últimas son fotografías de Oliva tomadas desde el Palacio.

- Fotografías exteriores del Palacio: en este grupo englobamos tanto las fotografías generales como las vistas parciales de fachadas exteriores del Palacio. Está formado por un total de 10 fotografías: 5 a 9, 11, 13, 81, 85 y 89 .

- Fotografías de portadas: es el grupo más numeroso formado por un total de 24 fotografías: 28 a 35, 39, 40, 52, 53, 61, 63 a 69, 72, 73, 75 y 77.

- Fotografías de techos: agrupamos aquí las fotografías que representan forjados, artesonados y bóvedas: en total, 12 fotografías con la siguiente numeración: 25, 26, $43,45,46,48$ a $51,54,56$ y 57.

- Fotografías de galerías y Patio: en este grupo se incluyen todas las fotografías tanto de la galería principal como de la galería superior del Patio. Está compuesto por 7 fotografías: 10,12 y 14 a 18 .

- Fotografías de ventanas: en este grupo englobamos tanto las fotografías de parciales de ventanas tomadas desde el interior como las tomadas desde el interior. Se repiten 3 fotografías del grupo de las portadas por contener documentación gráfica de ambos elementos arquitectónicos. Se trata en total de 10 fotografías con la siguiente numeración: 71, 74 a 77, 79, 80, 82, 84 y 94 .

- Friso Sala de Armas: debido a su importancia ornamental y al gran número de fotografías de este singular elemento constructivo hemos creído oportuno realizar un grupo que englobe las 7 fotografías de este elemento tomadas en su ubicación original. Corresponden a los números 19 a 24 y 27.

- Piezas desmontadas: en este grupo englobamos todas las piezas que han sido desmontadas de su posición original: friso, capiteles, entrevigado, azulejos, etc. Son un total de 20 fotografías: 26 a 38, 41, 42, 44, 47, 55, 58 a 60, 62, y 70.

- Otros edificios: corresponden a este último grupo las últimas 8 fotografías del grupo (101 a 108) que representan otros edificios y elementos que guardan similitudes formales con el Palacio de los Duques de Oliva.

\section{2. Álbum de Fotos Pequeño}

Su código de numeración es MMO. APD. Egil Fischer. Álbum de Fotos Pequeño. Se trata de un álbum de dimensiones $22 \times 26 \mathrm{~cm}$ de tapa dura de color marrón y encuadernación mediante dos tornillos roscados. Las hojas interiores son duras, de idéntico material y color al de las tapas y con una hoja de papel negro adherida en cada una de sus caras. Contiene un total de 12 hojas más la portada y contraportada. Sobre estas hojas se encuentran pegadas las fotografías. Existen asimismo dos fotografías sueltas dentro de este álbum. Sobre los márgenes de las propias fotografías hay textos explicativos en danés. La mayoría de las fotografías se encuentran repetidas respecto al Álbum de Fotos Grande y conservan la numeración de aquel. En otros casos no se hallan numeradas; la numeración está escrita a pluma sobre las propias fotografías o sobre un círculo de papel pegado sobre las mismas. Hay un total de 15 fotografías no repetidas en el Álbum Grande más dos fotografías de dos 
de los planos del Palacio. Procederemos a clasificar solamente estas 17 fotografías según los elementos que representan:

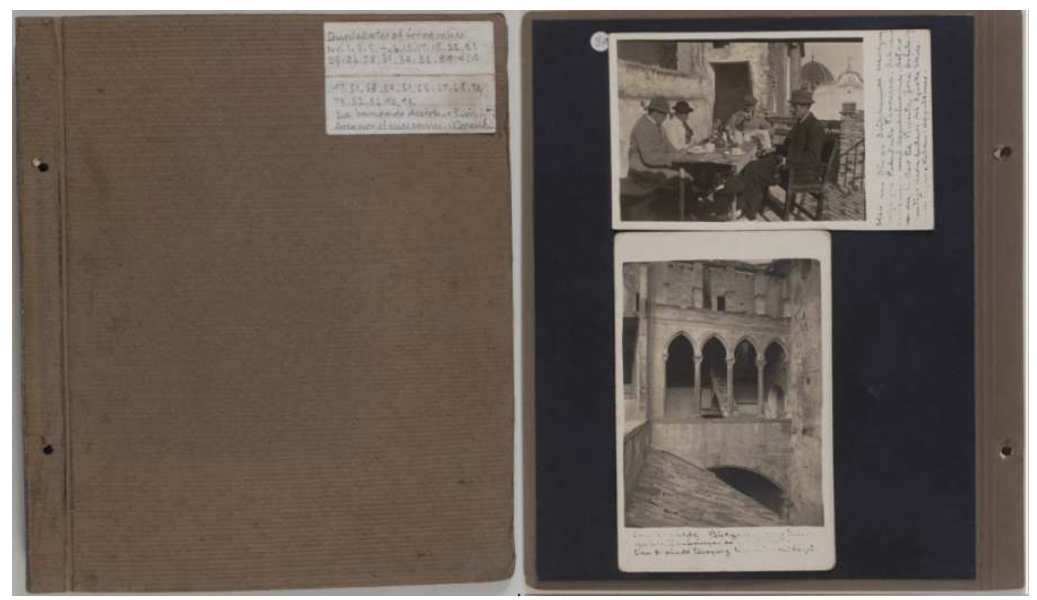

Figura 114. Izquierda: portada. Derecha: pág. 2R. Fot. 80. La "Brigada Danesa" tomando café en la terraza de la torre SE, bajo galería patio central. Álbum Fot. Pequeño. Fuente: MAO.

- Planos: dos fotografías sin numerar de las láminas LA 1113 y LA116 en página 2A, que representan el artesonado de la Sala 12.

- Fotografías de Oliva: fot. F, página 3R.

- Fotografías exteriores del Palacio: fot. sin numerar pág. 3A, fot. 6.1 pág. 4A, fot. 3.1 pág. 5A y fot. sin numerar pág. 13A.

- Fotografías de portadas: fot. 29.1 pág. 6A y fot. 28.1 pág. 7A.

- Fotografías de friso de Sala de Armas: fot. 23.2 pág. 6R y fot. sin numerar pág. 7A.

- Fotografías de techos: fot. 45.1, página 8R.

- Fotografías de Ventanas: fot. sin numerar, página 12A.

- Fotografías piezas desmontadas: fot. sin numeración 4R y fot. 23.2, página 6R. Ambas corresponden a piezas del friso de la Sala de Armas. En la segunda de ellas las piezas se encuentran montadas en una vivienda como elemento decorativo.

- Fotografías Dinamarca: fot. sin numerar pág. 14A y fot. sin numerar pág. 14R. Corresponden a dos fotografías de unos terrenos en Pille Allé, Frederiksberg, donde Fischer quería construir su edificio con las piezas del Palacio.

- Fotografía sin clasificar: fot. A pág. 3R. Elemento decorativo sin relación aparente con el Palacio.

\section{ESTUDIO Y CLASIFICACIÓN}

En el siguiente apartado realizaremos una clasificación de los elementos arquitectónicos más representativos del Palacio documentados por Fischer y Lauritzen en base al tipo de elemento y un estudio de sus características formales. Los grupos que se han establecido son los siguientes:

- Plantas 
- Portadas

- Ventanas

- Forjados y artesonados

- Bóvedas

- Galería

- Logia

- Pavimentos

En el presente capítulo analizaremos todos los grupos salvo las portadas, que por la gran abundancia de documentación y por ser el principal objeto de estudio de este trabajo se tratarán de manera independiente en el capítulo VI. Asimismo, se han dejado fuera de esta clasificación algunos elementos, bien por ser de menor importancia, bien por tratarse de elementos aislados; entre ellos están las chimeneas, las carpinterías, los elementos de cerrajería o la escalera. Tampoco se ha incluido el estudio de los planos de las dos propuestas de proyecto del Museo Español de Copenhague de Fischer en Pile Allé, que podrán desarrollarse en un futuro trabajo de investigación.

\subsection{Plantas}

Disponemos de los siguientes planos de Planta del Palacio: Planos LA1106, LA1107 y LA1109 y croquis de las páginas 39 y 61 del Notebook $I$.

- Plano LA1109201: corresponde a un plano de la planta principal del Palacio. Aunque no está grafiada la escala, se trata de un plano a escala 1:100 por comprobaciones realizadas respecto a otros planos escalados. Está dibujado a grafito y tinta sobre papel sin marca de dimensiones $690 \times 640 \mathrm{~mm}$. En él se representa casi la totalidad de la planta del Palacio, si bien la zona más detallada corresponde a las zonas noroeste y noreste. La zona noroeste es la "casa de Miguel", y en ella Fischer numero las salas de la 1 a la 10. Esta zona del Palacio fue inventariada por Fischer en sus cuadernos de notas (Notebook I y Notebook II). En ella aparecen referenciadas las portadas D1 a D9 y las ventanas V1 y V2. La zona noreste, por su parte, corresponde a las salas numeradas de la 11 a la 20. En esta zona se encontraban las piezas más importantes que Fischer pretendía desmontar, y asignó su dibujo a Lauritzen ${ }^{202}$. En esta zona, además, aparecen identificadas las portadas D10 a D28 y las ventanas V3 a V10. Esta área del Palacio se encuentra perfectamente delineada y dibujada a tinta, identificándose con nitidez las líneas de contorno de los muros, así como las líneas de las ventanas con sus festejadors. En el resto de zonas las líneas están realizadas a grafito y son mucho más tenues. Por su parte, los huecos disponen de un grafismo de cruz en diagonal característico. Asimismo, hay grafiada una escalera en la estancia 2. La zona junto a la Torre Suroeste no se encuentra dibujada, entendemos que Fischer no tuvo acceso a esta zona del Palacio o no la consideró de su interés. Además, junto al lienzo sur del Palacio aparece grafiado un rectángulo con el rótulo "Torre Maestro" en su interior, junto con otro texto en danés, que no ha sido posible transcribir (ver Fig. 115).

\footnotetext{
${ }^{201}$ Fischer, E. y Lauritzen, V. (1919-1920). Planos. Oliva, Valencia: Museo Municipal de Oliva, Archivo Público Documental, Palacio Condal. LA1109.

${ }^{202}$ Gavara Prior, J. y E. Muller, P. (2013). Óp.cit. pp.37.
} 


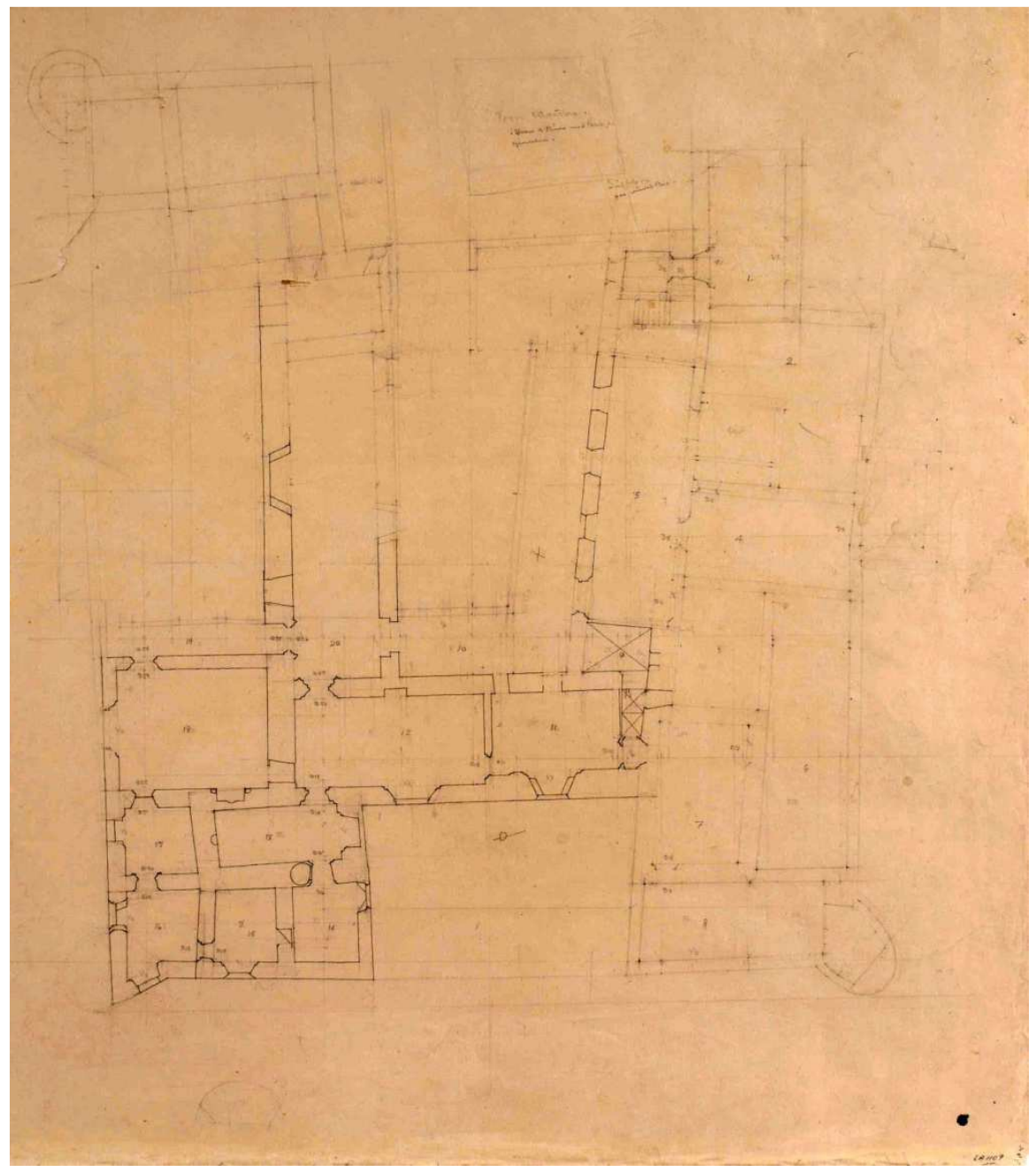

Figura 115. Plano de Planta Principal. LA1109. Fuente: E. Fischer y Vilhelm Lauritzen

- Plano LA1106 ${ }^{203}$ : corresponde a un plano de cubiertas del Palacio. Está dibujado a escala 1:100 y dispone de una escala gráfica en metros. Está dibujado a tinta negra sobre papel de calco de dimensiones $460 \times 589 \mathrm{~mm}$. En él se representa las áreas noreste y noroeste. Están grafiadas las líneas de sección de los muros a una altura que no secciona los huecos y su trazado está relleno con una trama de líneas a $45^{\circ}$ para remarcar la zona seccionada, diferenciando los muros de las galerías abiertas que no disponen de dicho grafismo. En el plano están numeradas las salas de la 2 a la 20 y están rotuladas en castellano algunas otras salas y elementos del Palacio: corral, cocina, torre, foso, calle, tejado, puerta, casas nuevas. En su parte superior derecha aparece rotulado el título del plano "TEJADOS DEL PALACIO" y una leyenda explicativa. El plano se ha realizado haciendo una copia sobre papel traslúcido del plano LA1109, lo que nos permite deducir la escala del primero.

${ }^{203}$ Fischer, E. Y Lauritzen, V. (1919-1920). Óp. cit. LA1106. 


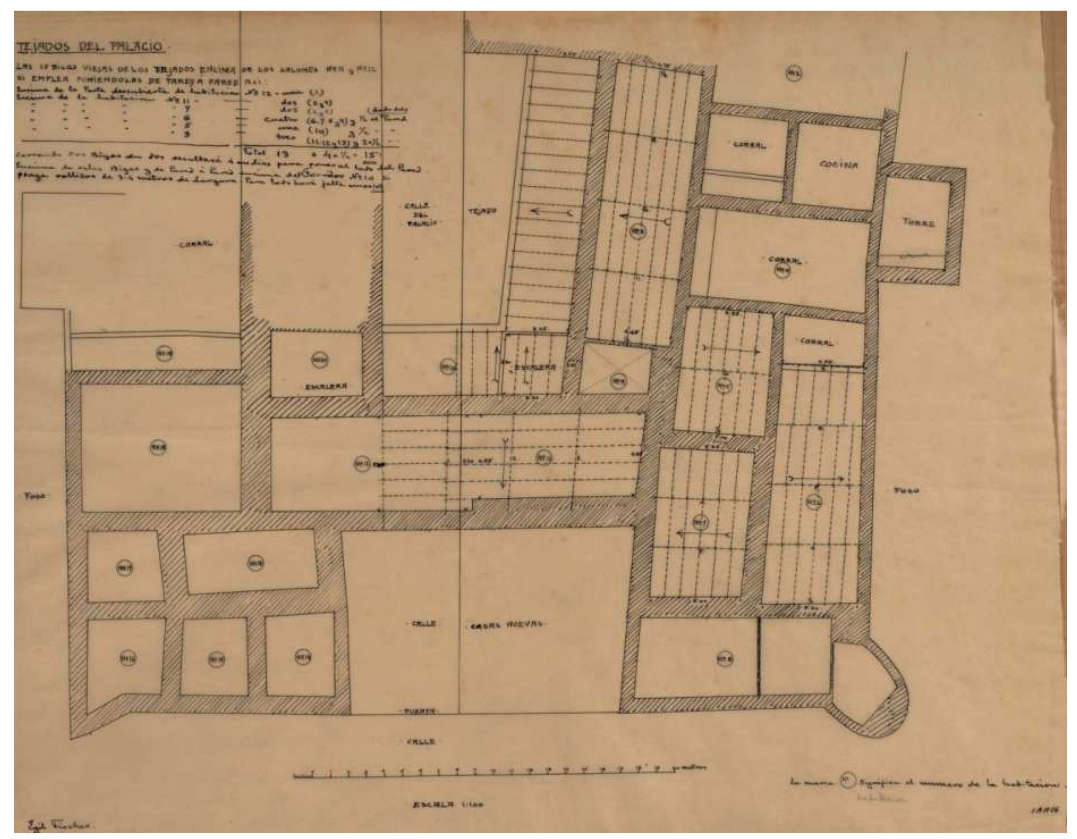

Figura 116. Plano de Planta de Cubiertas. LA1106. Fuente: E. Fischer

De acuerdo con la leyenda explicativa del plano, se trataba de un proyecto para cubrir las salas $3,5,6,7,10,11$ y 12 utilizando para ello vigas provenientes del derribo del Palacio y rollizos de madera. Sabemos por cartas que las autoridades obligaron a Fischer a cubrir el Palacio para evitar su derrumbe ${ }^{204}$.

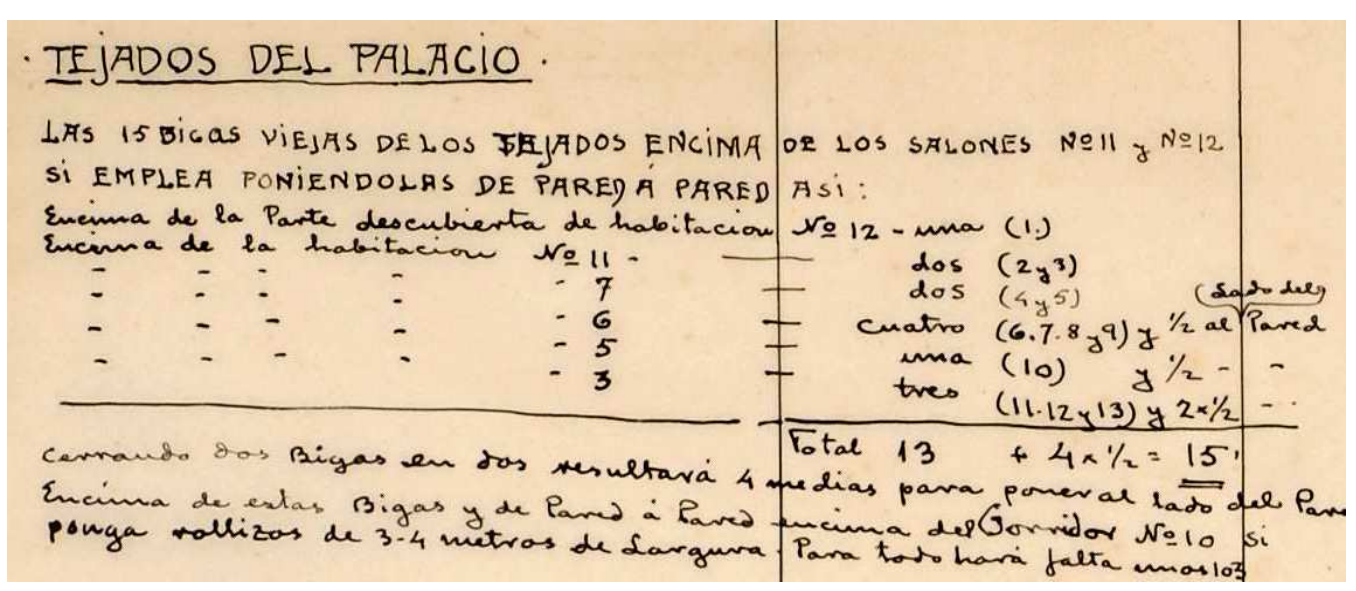

Figura 117. Leyenda Plano de Cubiertas. LA1106. Fuente: E. Fischer.

El plano está firmado por Egil Fischer, si bien sus rótulos en castellano evidencian que fue delineado o, al menos rotulado, por otra persona.

- Plano LA $1107^{205}$ : corresponde a un plano de cubiertas del Palacio. Está dibujado a escala 1:100, a tinta negra y sobre papel de calco de dimensiones $503 \times 425 \mathrm{~mm}$. En él

204 Fischer, E. y Vilhelm L. (1919-1982). Documentación Palacio de Oliva. FA68 y FA69. Søborg, Dinamarca: Archivo DKS.

${ }^{205}$ Fischer, E. y Lauritzen V. (1919-1920). Óp. cit. LA1106. 
se representan las áreas noreste y noroeste del Palacio. Se trata de un plano de un proyecto para cubrir las salas $3,5,6,7,10,11$ y 12 , aunque en este caso con una solución diferente a la del plano LA1106, en el que las vigas se apoyan de muro a muro, evitando vigas intermedias y con una disposición diferente de los pares de cubiertas; da la impresión de ser un boceto anterior al plano definitivo LA1106. En cada una de las salas que se pretende cubrir están rotulados el número de vigas necesarias para cubrir la totalidad de la superficie y la longitud de las mismas (ver Fig. 118).

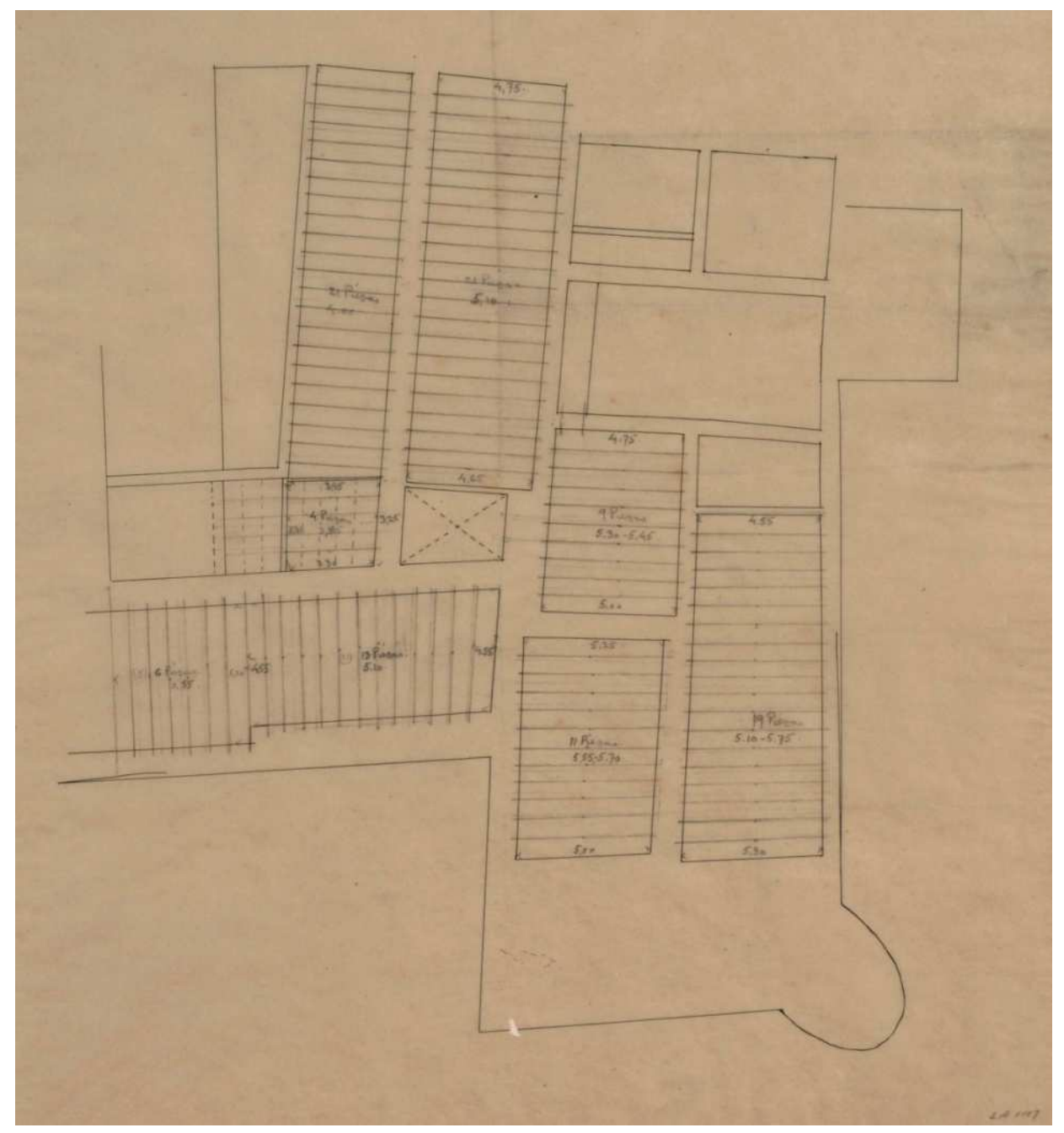

Figura 118. Plano de Cubiertas. LA1107. Fuente: E. Fischer.

- Croquis página 39 del Notebook $2^{206}$ : se trata de un croquis de la planta principal del Palacio donde se han numerado las salas de la 1 a la 19. En algunas de ellas están rotuladas en danés de manera abreviada algunas estancias del Palacio: gaard, tårn, vær, Sal, Rüm... (corral, torre, habitación, sala, espacio, etc.). En este plano se encuentran indicados los puntos cardinales: $N$ (nord), $N N \varnothing$ (nord-nordøst), $\varnothing$ (øst), $S$

${ }^{206}$ Fischer, E. (1917-1920). Notebook I. Oliva, Valencia: Museo Municipal de Oliva, Archivo Público Documental, Palacio Condal. Notebook I (LA1104). pp. 39. 
(syd), V (vest); (norte, norte-noreste, este, sur, oeste). Está grafiado el eje de la calle que atravesaba el Palacio con una línea trazo-punto (ver Fig. 119). Sin duda este croquis es un apunte previo para la elaboración del plano LA1109.

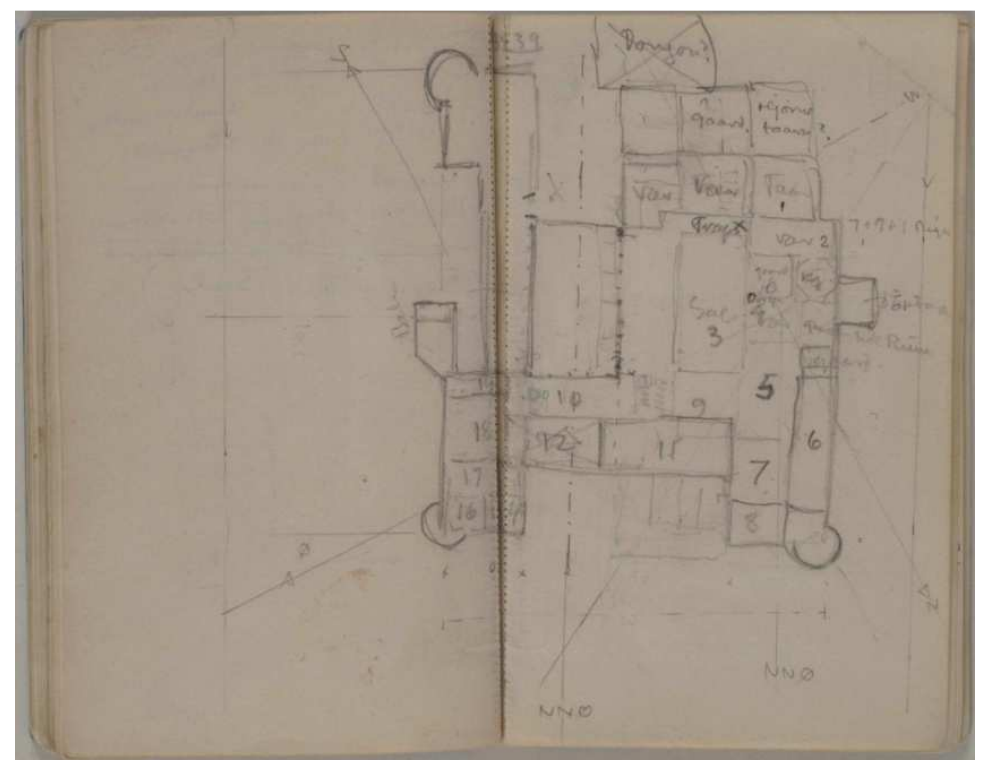

Figura 119. Croquis página 39. Notebook I. Fuente: E. Fischer.

- Croquis (pág. 61 del Notebook ${ }^{207}$ ): se trata de un croquis de una zona de la planta principal del Palacio que corresponde a la zona central de la fachada noroeste. En él se marcan con doble línea gruesa los muros y se grafían con líneas más finas escaleras y otras líneas de elementos no seccionados. Algunas estancias se encuentran rotuladas en castellano: cocina, torre, patio, pozo, bóveda, galería (ver Fig. 120).

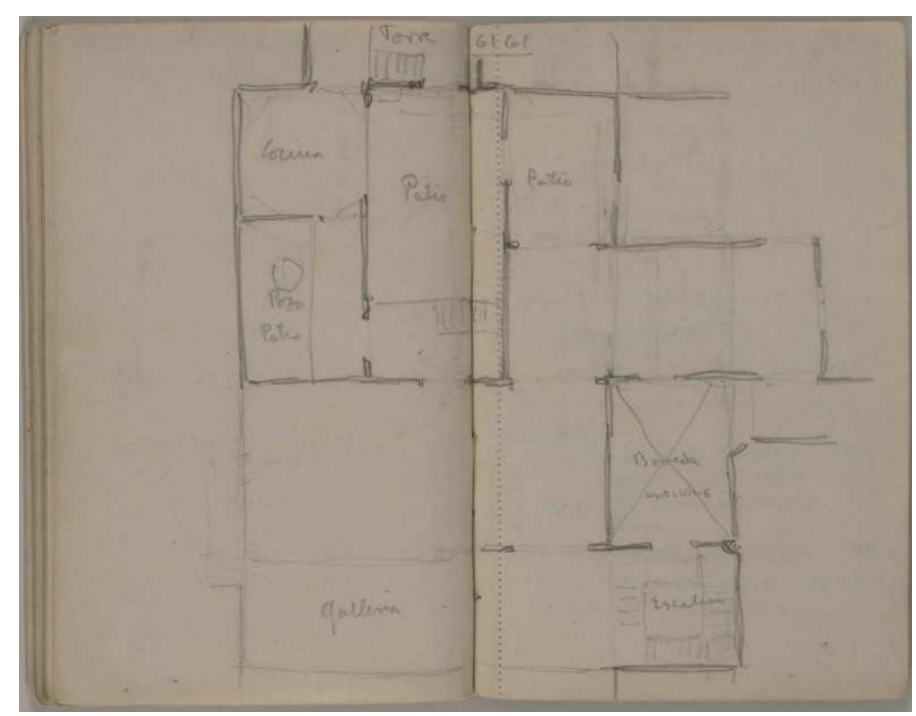

Figura 120. Croquis pág. 61. Notebook I. Fuente: E. Fischer.

${ }^{207}$ Fischer, E. (1919-1920). Óp. cit. pp. 61. 


\subsection{Ventanas}

En la documentación gráfica levantada por los arquitectos daneses disponemos de un total de 28 planos, algunos de ellos, como sucede con las portadas, son copias en papel traslucido de otro plano donde se detalla el despiece a realizar de las ventanas para su desmontaje. En estos planos encontramos información de 8 ventanas numeradas y localizadas en el plano de planta del Palacio, numeradas de la ventana 3 (Vindue 3) a la ventana 10 (Vindue 10), así como información sobre otras 5 ventanas, no numeradas ni localizadas en el Palacio. Además de los planos encontramos información fotográfica de algunas ventanas que, en algunos casos, coincide con la representada en los planos. La mayor parte de las fotografías están tomadas desde el exterior del edificio. Las ventanas V1 y V2 se encuentran grafiadas en el plano de planta ${ }^{208}$, al igual que las V3 a V10; la primera de ellas (V1) en la sala sin numerar contigua a la Sala 2 de la fachada NO y la V2 en la Sala 8, fachada NE, pero no existen planos de detalle de las mismas.

Procedemos a detallar cada una de las ventanas, así como los documentos que disponemos de las mismas y su estudio.

\subsubsection{Ventanas numeradas}

\section{Ventana 3}

La información de que disponemos sobre la ventana 3 equivale a los planos LA1183, LA1194 y LA-1195 y las fotografías 74 y 75 del Álbum fotográfico Grande. Esta ventana se encontraba localizada en la Sala 11 de la planta noble del Palacio, una de las salas más importantes junto con la Sala 12 y la 16 (o Sala de Armas), cuya fachada se encontraba en el patio NE donde, a su vez, se encontraba la puerta de acceso al Palacio. Se trata del único hueco para iluminación de dicha sala, de dimensiones considerables $(1,32 \times 2,69 \mathrm{~m}$ de hueco de carpintería y 3,70 × 4,54 m de dimensiones máximas). Además, sus características son claramente góticas. En el plano se encuentra grafiada solamente la obra de fábrica interior, es decir, desde la carpintería hacia el interior. No disponemos, por tanto, de información sobre la carpintería ni sobre la obra de fábrica exterior, aunque por las características es muy probable que originalmente fuese una ventana ajimezada con una columnilla central.

- Plano $L A 1195^{209}$ : Se trata de una puesta a escala dibujada a grafito sobre una lámina de papel de dimensiones $680 \times 470 \mathrm{~mm}$ donde está representado el alzado de la ventana, una sección horizontal a nivel de las jambas. Las vistas tienen correspondencia diédrica, la disposición del dibujo en la lámina es en vertical y existen líneas auxiliares de dibujo. El plano no dispone de cotas y la escala de representación es 1:10, como en la mayoría de láminas, aunque esta no está grafiada. La ventana está formada por un arco rebajado y jambas molduradas similares a las de las portadas, que arrancan sobre basas sustentadas sobre pequeñas ménsulas que nacen del lienzo del muro. La ventana

\footnotetext{
${ }^{208}$ Fischer, E. y Lauritzen V. (1919-1920). Óp. cit. LA1109.

${ }^{209}$ Lauritzen, V. y Lauritzen, V. (1919-1920). Óp. cit. LA1195.
} 
tiene dos capiteles góticos de planta heptagonal con ornamentación vegetal y zooforme en cada una de sus jambas. Las basas están formadas por dos columnillas de basa heptagonal. Por su parte, las molduras de la jamba desde el extradós al intradós son las siguientes: caveto, filete, baqueta o columnilla, filete, caveto semicircular, filete, baqueta o columnilla, dos cavetos y jamba abocinada curva. En la parte superior izquierda se encuentra rotulado el nombre de la ventana y su ubicación: "Vindue No. 3 Rum No. 11", y en la parte inferior derecha la numeración de la lámina: LA1195. Además, en la parte superior derecha, sobre una línea está rotulado en danés "Underkant Gesims" ("borde inferior de cornisa"), y en el centro del borde derecho "Yderkant af den lille Hjørnedor" (borde exterior de la pequeña puerta del horno) (ver Fig. 121 izq.). Tanto las jambas como el arco están abocinados realizando una transición al hueco rectangular de la ventana. El hueco de la carpintería no está centrado con el arco y las jambas de la ventana se encuentran desplazadas hacia la derecha, por lo que las jambas curvas son asimétricas, realizando esta transición entre el hueco interior y el exterior. Desde las jambas curvas vuelan a cada lado asientos de fábrica o festejadors, característicos de este tipo de ventanas.

- Plano LA1194 ${ }^{210}$ : Se trata de una lámina de papel transparente de dimensiones $673 \mathrm{x}$ $470 \mathrm{~mm}$. La disposición de la lámina es vertical. En ella está grafiada una copia del alzado de la ventana 3, correspondiente al plano LA1195. En la esquina superior izquierda está rotulado el número de la ventana y su localización "Vindue No. 3. (Rum No. 11)" y en la parte inferior derecha la numeración de la lámina: LA1194. La ventana está dividida en 21 secciones numeradas para su desmontaje, comenzando por la basa izquierda y siguiendo un orden antihorario hasta finalizar en la basa derecha (ver Fig. 121 der.).

- Fotografía $74^{211}$ : Dimensiones 7 × $10 \mathrm{~cm}$. En ella se pueden observar los capiteles de la jamba izquierda y el arranque del arco de la ventana $\mathrm{V} 3$.

- Fotografía $75^{212}$ : Dimensiones $7 \times 10 \mathrm{~cm}$. Vista desde el lateral izquierdo y observando la jamba derecha con la basa y los capiteles y el arranque del arco en este lado se ve parcialmente el festejador, que se encuentra oculto tras diverso material apilado (ver Fig. 122 der.).

Los medios fotográficos y de iluminación de que dispuso Fischer no le permitieron tomar buenas fotografías frontales de las ventanas, como en el caso de las portadas, ya que al tener que tomar las fotografías con luz natural, esta le deslumbraba, por lo que las fotografías de las ventanas son vistas parciales y muy oblicuas. Así, en muchos casos disponemos de imágenes de ellas indirectamente, ya que el objeto principal eran las portadas contiguas; y como en el caso de la Fotografía 75, la parte de la ventana está muy sobreexpuesta, no pudiéndose apreciar bien los detalles de la basa.

\footnotetext{
${ }^{210}$ Fischer, E. y Lauritzen, V. (1919-1920). Óp. cit. LA1194.

${ }^{211}$ Fischer, E. (1917-1920). Álbum Fotos Grande. Oliva, Valencia: Museo Municipal de Oliva, Archivo Público Documental, Palacio Condal. pp.16R.

${ }^{212}$ Fischer, E. (1917-1920). Óp. cit. pp. 16R.
} 

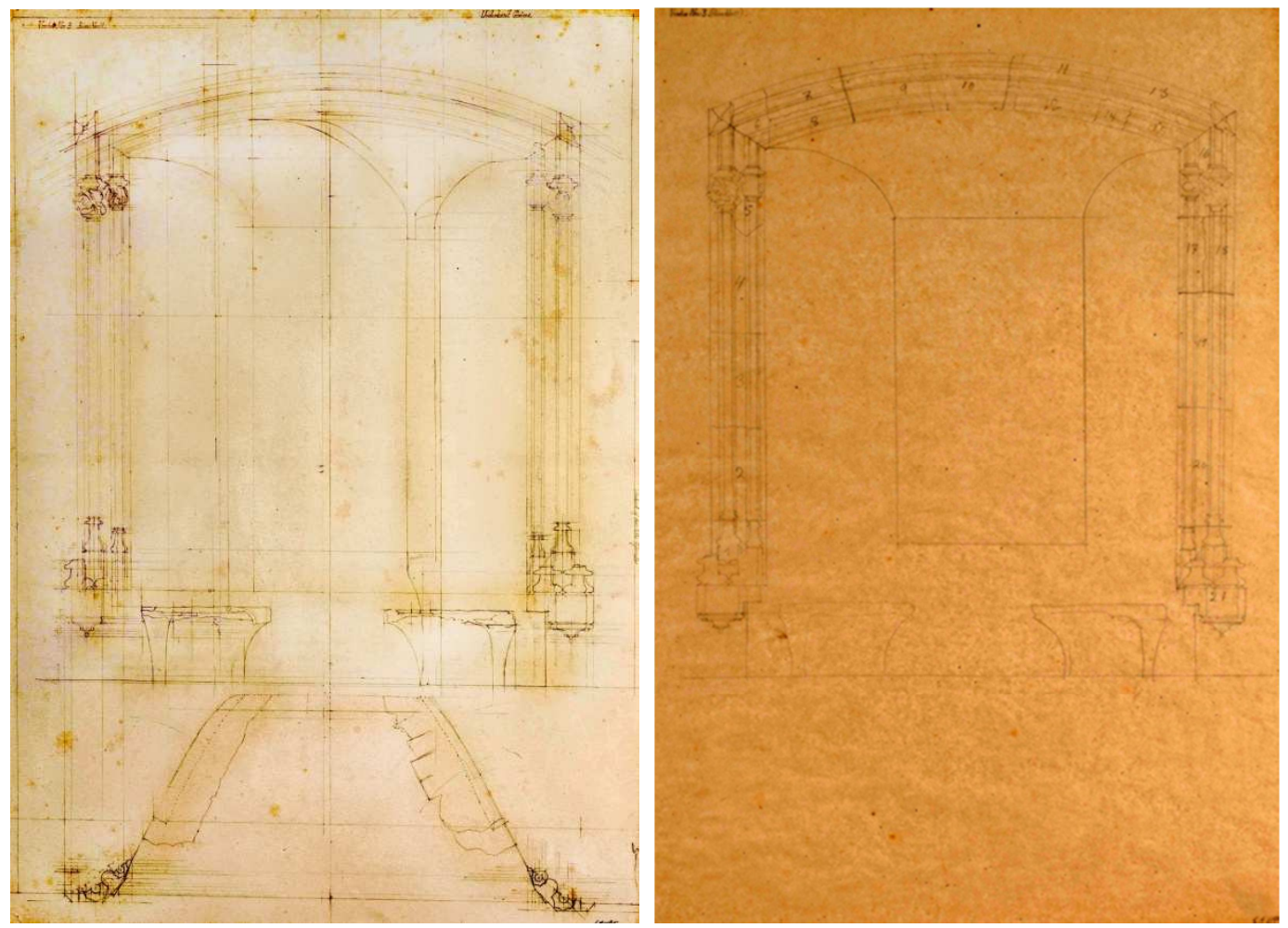

Figura 121. Izquierda: Plano Ventana 3. LA1195. Derecha: Plano de siglado de piezas. V3. LA1194. Fuente: V. Lauritzen y/o E. Fischer.
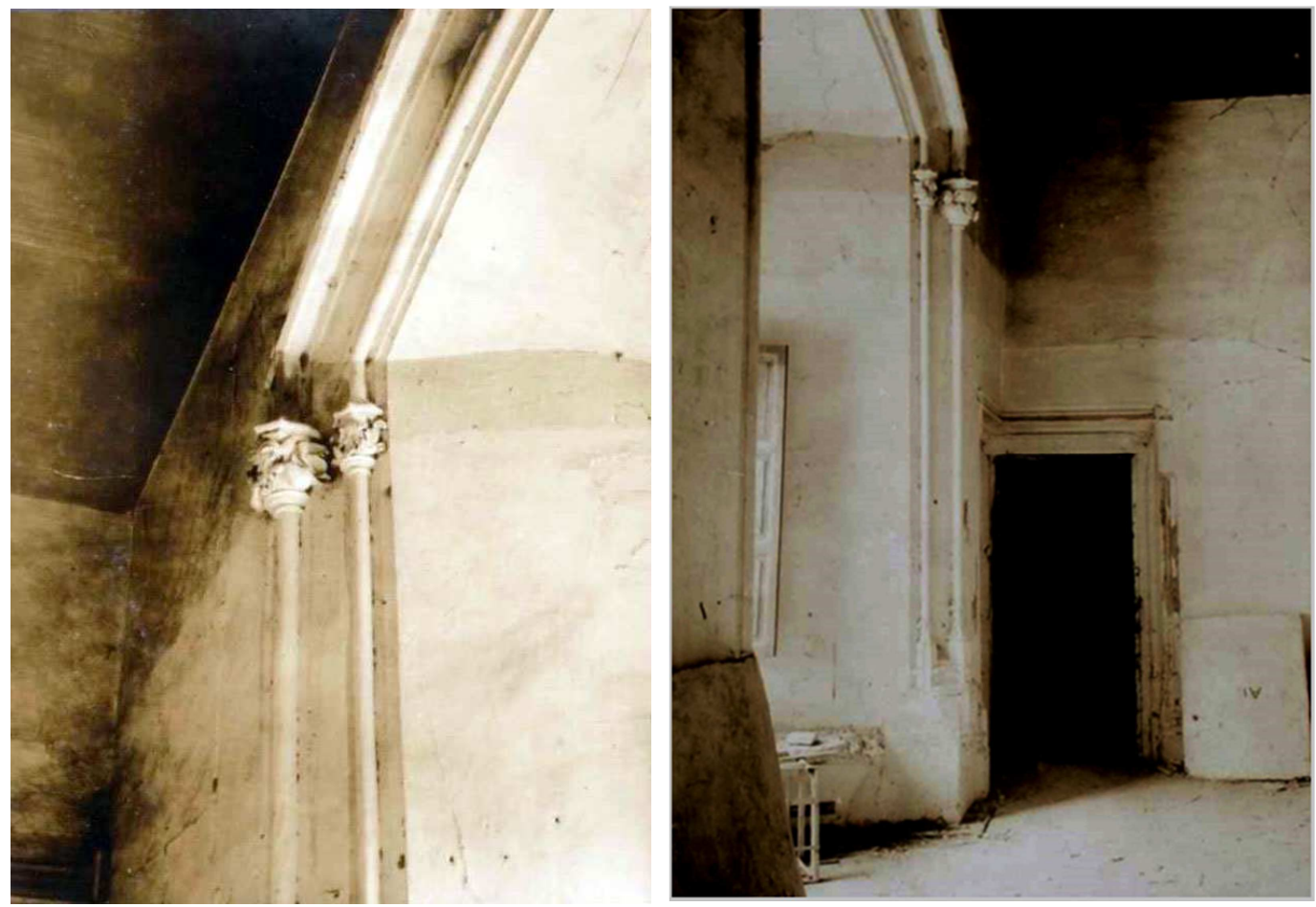

Figura 122. Izquierda: Fot. 74. Ventana 3. Vista capiteles izquierdos. Derecha: Fot. 75. Ventana 3. Vista jamba derecha. Fuente: E. Fischer. 


\section{Ventana 4}

De esta ventana disponemos de 2 planos (LA-1196 y LA-1197) y de las fotografías 76, 77 y 78 del Álbum Fotográfico Grande. Se encontraba localizada en la Sala 12 de la planta noble del Palacio, sin duda la segunda sala más importante del Palacio junto con la Sala de Armas por sus dimensiones y elementos arquitectónicos (portadas, ventana y artesonado). Se trataba del único hueco para iluminación de dicha sala, de ahí sus grandes dimensiones (1,98 x 2,89 m de hueco de carpintería y 3,34 x 4,25 m de dimensiones máximas). En el plano se encuentra grafiada solamente la obra de fábrica interior, es decir, desde la carpintería hacia el interior. No disponemos, por tanto, de información sobre la carpintería ni de la obra de fábrica exterior, aunque por las características es muy probable que originalmente fuese una ventana ajimezada con dos columnillas centrales.

- Plano LA1197 213 : se trata de una puesta a escala dibujada a grafito sobre una lámina de papel de dimensiones $680 \times 470 \mathrm{~mm}$ donde está representado el alzado de la ventana, una sección horizontal a nivel de las jambas y una sección vertical por el eje de simetría representada sobre el propio alzado. Las vistas tienen correspondencia diédrica, la disposición del dibujo en la lámina es en vertical y existen líneas auxiliares de dibujo. El plano no dispone de cotas y la escala de representación es 1:10. Se representan las patologías de la fábrica (deformaciones, grietas y roturas). La ventana está formada por un arco rebajado y jambas molduradas similares a las de las portadas, y arrancan sobre basas sustentadas sobre pequeñas ménsulas que nacen del lienzo del muro. La ventana tiene dos capiteles góticos con ornamentación vegetal y zooforme en cada una de sus jambas. Las basas están formadas por dos columnillas de basa heptagonal. Por su parte, las molduras de la jamba desde el extradós al intradós son las siguientes: caveto, filete, baqueta o columnilla, filete, caveto semicircular, filete, baqueta o columnilla, dos cavetos y jamba abocinada prácticamente recta. En la parte superior izquierda se encuentra rotulado el nombre de la ventana y su ubicación: "Vindue 4 Rum 12", y en la parte inferior derecha, la numeración de la lámina: LA1197. En la parte exterior del lado izquierdo de la planta se encuentra rotulado en danés "Sten fra ældre vindue" (Piedra de ventana más antigua) (ver Fig. 123 izq.), lo que evidencia que esta sala tuvo una ventana anterior que posteriormente fue modificada, presumiblemente durante la transformación estilística que tuvo lugar en el Palacio a manos de Serafín de Centelles. Tanto las jambas como el arco están abocinados, realizando una transición al hueco rectangular de la ventana. Desde las jambas vuelan a cada lado asientos de fábrica o festejadors, que se encontraban muy deteriorados según se ha podido comprobar en su grafismo.

- Plano LA1196 214 : se trata de una lámina de papel transparente de dimensiones $673 \mathrm{x}$ $470 \mathrm{~mm}$ y disposición vertical. En ella está grafiada una copia del alzado de la ventana 4, correspondiente al plano LA1196. En la esquina superior izquierda está rotulado el número de la ventana y su localización "Vindue 4. (Rum 12)" y en la parte inferior derecha la numeración de la lámina: LA1194. Sólo se encuentran sigladas 6 piezas: la 1 corresponde a la basa izquierda, la $2 \mathrm{a}$ a los capiteles izquierdos y la $2 \mathrm{~b}$ al arranque izquierdo del arco, la $3 \mathrm{a}$ corresponde al arranque derecho del arco, la $3 \mathrm{~b}$ a los capiteles

${ }^{213}$ Fischer, E. y Lauritzen, V. (1919-1920). Óp. cit. LA1197.
${ }^{214}$ Fischer, E. y Lauritzen, V. (1919-1920). Óp. cit. LA1196. 
derechos y la 4 a la basa derecha; no están sigladas ni las jambas ni el resto del arco (ver Fig. 123 der.).

- Fotografía $77^{215}$ : tiene unas dimensiones de $7 \times 10 \mathrm{~cm}$. Se trata de una fotografía tomada desde el lateral derecho donde se puede observar el arco de la ventana 3 con sus capiteles y la jamba izquierda, su basa y el festejador. Al fondo se ve la portada 12 y en la parte superior, aunque muy oscuro, el artesonado romboidal de la sala 12. Existe, asimismo, numeroso material acopiado, presumiblemente del desmontaje de otras piezas (ver Fig. 124).

- Fotografías 76 y $78^{216}$ : tienen unas dimensiones de $8 \times 6 \mathrm{~cm}$ con orientación horizontal. En ellas se pueden ver los capiteles izquierdo y derecho, respectivamente, correspondientes a la ventana $\mathrm{V} 3$ una vez desmontados, que podrían representar las piezas sigladas como $2 \mathrm{a}$ y $3 \mathrm{~b}$ en la lámina LA1196. En ellas se pueden observar las formas y decoración de los capiteles con elementos vegetales en macolla (en el caso del capitel pequeño) y formas zoomórficas (en el caso de los capiteles mayores). En el izquierdo se puede ver un dragón comiendo de una cesta de frutos y en el derecho dos dragones enfrentados en actitud de lucha (ver Fig. 125).
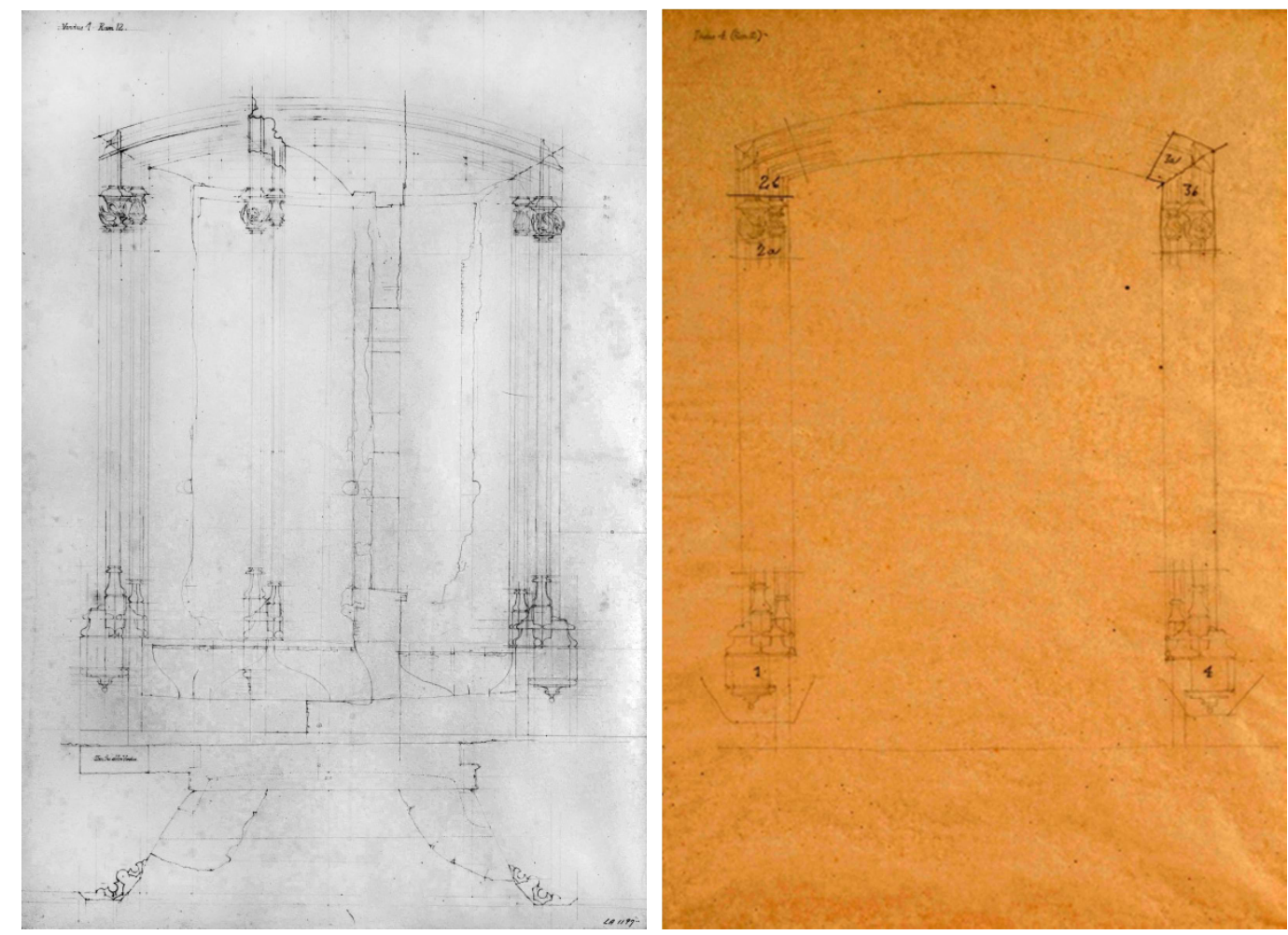

Figura 123. Izquierda: Plano Ventana 4. LA1197. Derecha: Plano siglado de piezas V4. LA1196. Fuente: V. Lauritzen y/o E. Fischer.

${ }^{215}$ Fischer, E. (1917-1920). Óp. cit. pp. 17A.

${ }^{216}$ Fischer, E. (1917-1920). Óp. cit. pp. 17A. 


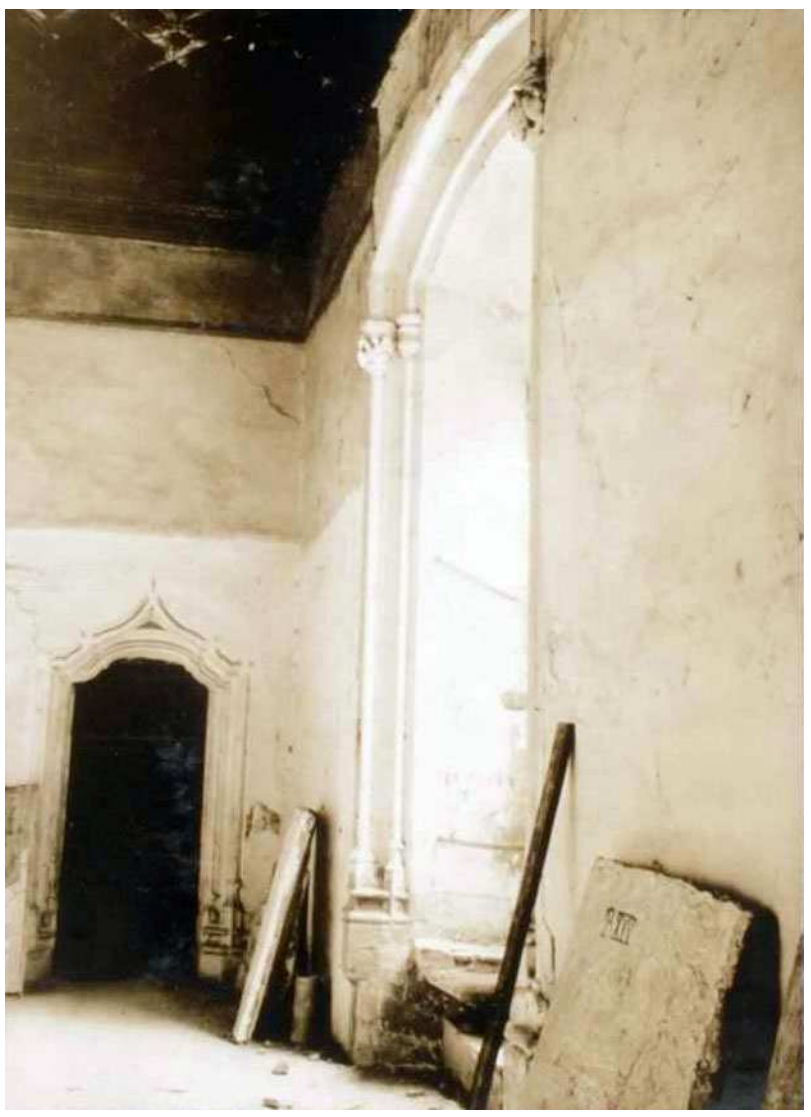

Figura 124. Fot. 77. Ventana 4. Vista lateral. Fuente: E. Fischer.
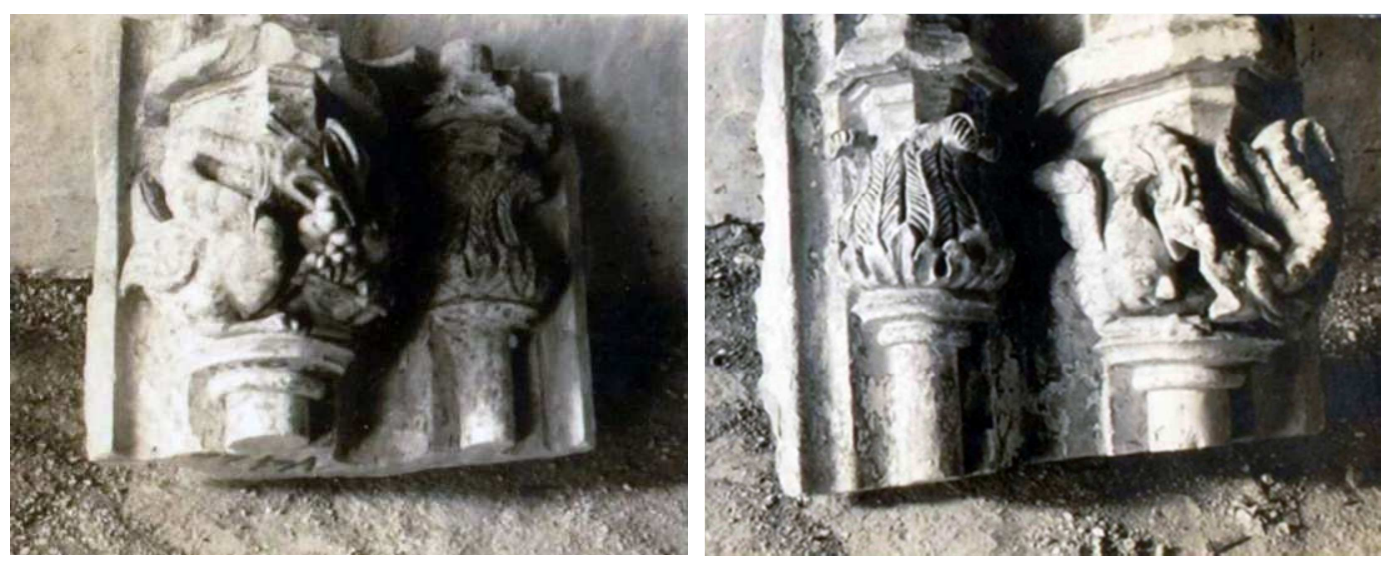

Figura 125. Izquierda: Fot. 76. Capiteles izquierdos V4 desmontados. Derecha: Fot. 78. Capiteles derechos desmontados. Fuente: E. Fischer.

\section{Ventana 5}

De esta ventana carecemos de fotografía; sólo disponemos de los planos LA-1198 y LA1199. Esta ventana se encontraba localizada en la Sala 13 o Capilla del Palacio. De acuerdo 
con el plano de planta del Palacio ${ }^{217}$, la ventana se encontraba cegada en esta época. Sus dimensiones eran de 1,38 $\mathrm{m}$ de ancho de hueco de carpintería y 2,39 $\mathrm{m}$ de ancho máximo, al no estar representado el arco (presumiblemente por no existir en ese momento). No disponemos de datos sobre su altura.

- Plano LA1199218: se trata de una puesta a escala dibujada a grafito sobre una lámina de papel de dimensiones 680 × $470 \mathrm{~mm}$ donde está representado el alzado de la ventana (salvo el arco) y una sección horizontal a nivel de las jambas. Las vistas tienen correspondencia diédrica, la disposición del dibujo en la lámina es vertical y existen líneas auxiliares de dibujo y cotas generales tanto de anchura como de altura. La escala de representación es 1:10. Las ventana debieron tener un arco escarzado como el resto, tal y como se intuye en el arranque dibujado sobre la jamba izquierda. Las jambas son molduradas como las del resto de ventanas documentadas, es decir, arrancan sobre basas apoyadas en pequeñas ménsulas que parten del lienzo del muro. La ventana tiene dos capiteles góticos en cada una de sus jambas (en la jamba derecha se ha perdido el capitel pequeño). Las basas están formadas por dos columnillas, aunque no están representadas las poligonales de las columnillas. Po $r$ su parte, las molduras de la jamba desde el extradós al intradós son las siguientes: caveto, filete, baqueta o columnilla, filete, caveto semicircular, filete, baqueta o columnilla, dos cavetos y jamba abocinada con perfil ligeramente curvo. En la parte superior izquierda se encuentra rotulada la ubicación de la ventana y su numeración: "Rum 13 - Vindue 5", y en la parte inferior derecha la numeración de la lámina: LA1199. Sobre el capitel izquierdo se puede leer en danés "De to Smaa Kapiteler ens" (Uno de los dos capiteles pequeños) (ver Fig. 126 izq.), lo que parece indicar, tal y como se observa en la lámina, que sólo existe uno de los dos capiteles pequeños, ya que en la jamba derecha únicamente aparece grafiado el capitel grande. Tampoco están grafiados los festejadors, bien por no haber existido en esta ventana, bien por haber desaparecido debido a su deterioro.

- Plano LA1198 ${ }^{219}$ : se trata de una lámina en disposición vertical de papel transparente y con unas dimensiones de $660 \times 470 \mathrm{~mm}$. En ella está grafiada una copia del alzado de la ventana 5 correspondiente al plano LA1199. En la esquina superior izquierda está rotulado el número de la ventana "Vindue 5" y, en la parte inferior derecha, la numeración de la lámina: LA1198. Sólo se encuentran sigladas 4 piezas: la 1, correspondiente a la basa izquierda; la 2, a los capiteles izquierdos; la 3, al capitel derecho; y la 4, a la basa derecha. No están sigladas las jambas (ver Fig. 126 der.).

${ }^{217}$ Fischer, E. y Lauritzen, V. (1919-1920). Óp. cit. LA1109.

${ }^{218}$ Fischer, E. y Lauritzen, V. (1919-1920). Óp. cit. LA1199.

${ }^{219}$ Fischer, E. y Lauritzen, V. (1919-1920). Óp. cit. LA1198. 

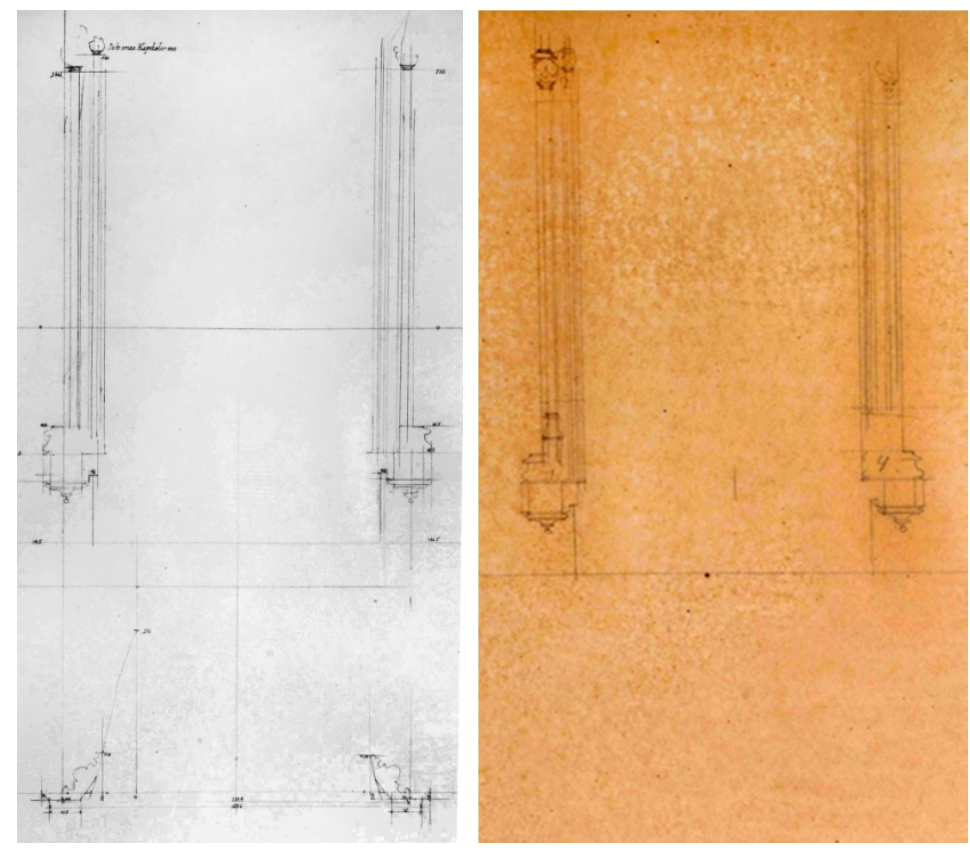

Figura 126. Izquierda: Plano Ventana 5. LA1199. Derecha: Plano alzado V5. LA1198. Fuente: V. Lauritzen y/o E. Fischer.

\section{Ventana 6}

De la V6 existen los planos LA-1200 y LA-1201 y tampoco en esta ocasión se disponen de fotografías. Estaba localizada en la Sala 15 de acuerdo con el plano de planta del Palacio ${ }^{220}$. Sus dimensiones eran las siguientes: 1,34 x 1,91 m de hueco de carpintería y 2,20 × 3,04 m de dimensiones máximas. Disponía de carpintería, aunque por sus características y dimensiones inferiores a las del hueco, no se trataba de la carpintería original.

- Plano LA1201221: se trata de una puesta a escala dibujada a grafito sobre una lámina de papel de dimensiones 680 × $470 \mathrm{~mm}$ que representa el alzado de la ventana (sección horizontal a nivel de las jambas y sección vertical completa por el eje de la ventana mirando hacia la jamba izquierda). Las vistas tienen correspondencia diédrica. La planta sigue el sistema europeo de vistas, mientras que la sección está representada según el sistema americano. La disposición del dibujo en la lámina es vertical y existen líneas auxiliares de dibujo. No existen cotas y la escala de representación es 1:10. El arco de la portada es escarzano. Asimismo, aparece grafiada una grieta a $1 / 3$ del arranque derecho con una anchura máxima de $3 \mathrm{~cm}$. Las jambas son molduradas como las del resto de ventanas documentadas y arrancan sobre basas apoyadas en pequeñas ménsulas que parten del lienzo del muro. La ventana no tiene capiteles. Las basas están formadas por dos columnillas de basa heptagonal. Las molduras de la jamba desde el extradós al intradós son las siguientes: caveto, filete, baqueta o columnilla, filete, caveto semicircular, filete, baqueta o columnilla, dos cavetos y jamba abocinada con perfil

\footnotetext{
${ }^{220}$ Fischer, E. y Lauritzen, V. (1919-1920). Óp. cit. LA1109.

${ }^{221}$ Fischer, E. y Lauritzen, V. (1919-1920). Óp. cit. LA1201.
} 
ligeramente curvo. En la parte superior izquierda se encuentra rotulada la numeración de la ventana y su ubicación: "Vindue 6 - Rum 15", y en la parte inferior derecha, el número de la lámina: LA1201 (ver Fig. 127 izq.). Los festejadors no están grafiados en planta, aunque en el alzado sí está dibujado el arranque de los mismos, por lo que se interpreta que habían existido, quedando solamente sus indicios.

- Plano LA1200222: se trata de una lámina en disposición vertical, de papel transparente y con unas dimensiones de $680 \times 445 \mathrm{~mm}$. En ella está grafiada una copia del alzado de la ventana 6 correspondiente al plano LA1201. En la esquina superior izquierda está rotulado el número de la ventana y su localización "Vindue, (Rum 15)", y en la parte inferior derecha, el número de la lámina: LA1200. No se encuentran sigladas las piezas, lo que nos da a entender que no fue desmontada por Fischer (ver Fig. 127 der.).
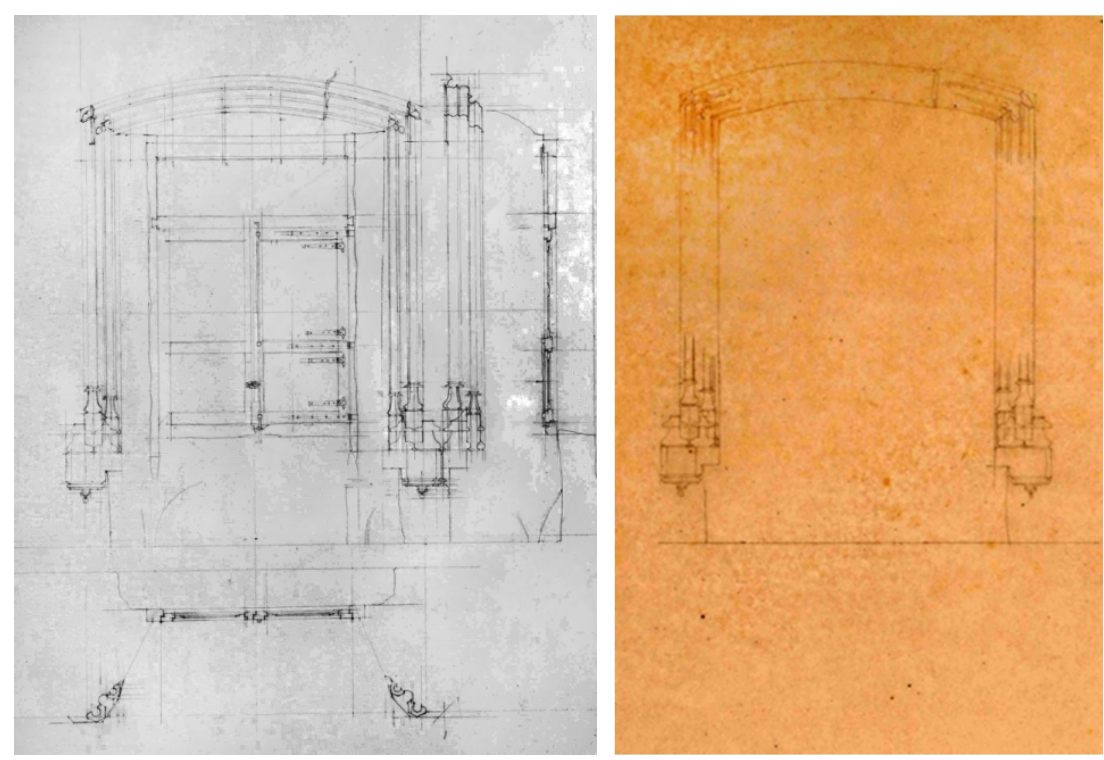

Figura 127. Izquierda: Plano Ventana 6. LA1201. Derecha: Plano alzado V6. LA1200. Fuente: V. Lauritzen y/o E. Fischer.

\section{Ventana 7}

Disponemos de dos láminas de la ventana V7: LA-1202 y LA-1203 y no de fotografías. Se encontraba localizada en la Sala 16, de acuerdo con el plano de planta del Palacio ${ }^{223}$, en la fachada NE. Sus dimensiones eran las siguientes: 1,33 x 1,93 m de hueco de carpintería y 1,96 × 3,18 m de dimensiones máximas. Está representado el marco de la carpintería, que por su posición podía ser el original, aunque no sus hojas.

- Plano LA1203 224 : se trata de una puesta a escala dibujada a grafito sobre una lámina de papel de dimensiones $680 \times 470 \mathrm{~mm}$ donde está representado el alzado de la

\footnotetext{
${ }^{222}$ Fischer, E. y Lauritzen, V. (1919-1920). Óp. cit. LA1200.

${ }^{223}$ Fischer, E. y Lauritzen, V. (1919-1920). Óp. cit. LA1109.

${ }^{224}$ Fischer, E. y Lauritzen, V. (1919-1920). Óp. cit. LA1203.
} 
ventana y la sección horizontal a nivel de las jambas. Las vistas tienen correspondencia diédrica. La disposición del dibujo en la lámina es en vertical y existen líneas auxiliares de dibujo; tiene cotas generales tanto de anchuras como de altura (en este caso, referenciadas a una cota 0 grafiada a media altura de la ventana). La escala de representación es 1:10 y el arco de la portada es escarzano. Las jambas son molduradas como las del resto de ventanas documentadas; arrancan sobre basas apoyadas sobre los bancos o festejadors, que sobresalen del lienzo del muro. Tiene, asimismo, un capitel decorado en cada jamba. Las basas están formadas por una sola columnilla, que aunque no está representada en la sección, entendemos que podría ser de basa heptagonal como en el resto de casos. Las molduras de la jamba desde el extradós al intradós son las siguientes: filete, baqueta o columnilla, filete, caveto semicircular, caveto y jambas con perfil recto. Las jambas son totalmente asimétricas: la izquierda es abocinada y la derecha es casi ortogonal al lienzo del muro. La posición de la carpintería no es paralela al lienzo, formando un ángulo de $3^{\circ}$ respecto a éste. En la parte superior izquierda se encuentra rotulada la numeración de la ventana y su ubicación: "Vindue 7-Rum 16", y en la parte inferior derecha, el número de la lámina: LA1203 (ver Fig. 128). Los festejadors están perfectamente grafiados en planta y en el alzado, siendo paralelos a ambas jambas.

- Plano LA1202 ${ }^{225}$ : se trata de una lámina en disposición vertical y de papel transparente con unas dimensiones de $680 \times 445 \mathrm{~mm}$. En ella está grafiada una copia del alzado de la ventana 7 correspondiente al plano LA1203. En la esquina superior izquierda está rotulado el número de la ventana y su localización "Vindue 7, (Rum 16)" y en la parte inferior derecha, el número de la lámina: LA1202. No se encuentran sigladas las piezas, lo que nos da a entender que no fue desmontada por Fischer (ver Fig. 128).

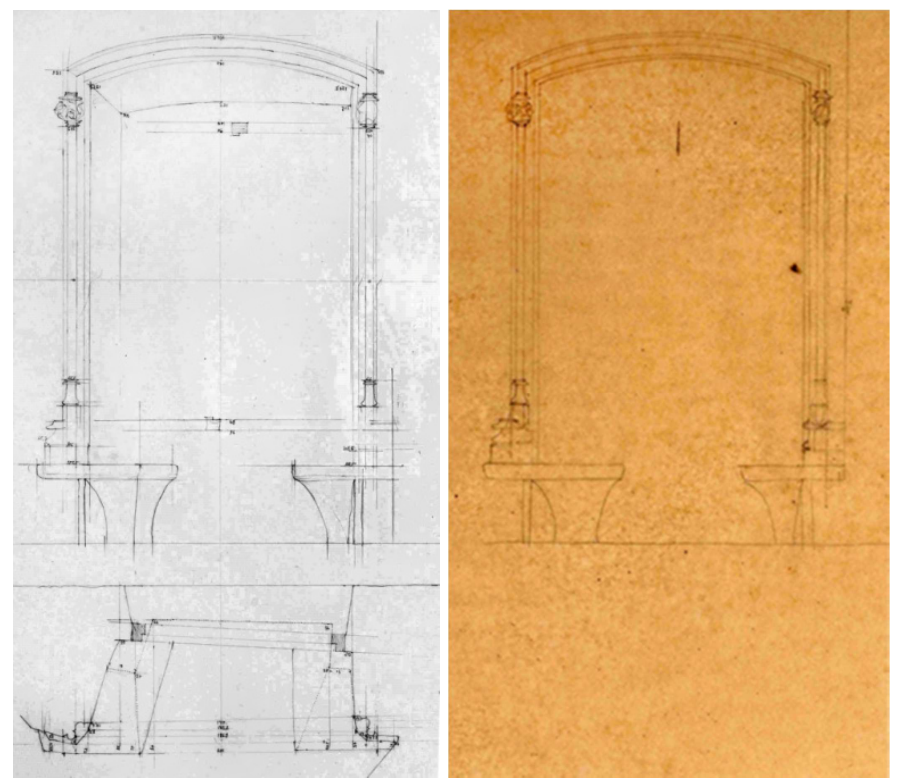

Figura 128. Izquierda: Plano Ventana 7. LA1203. Derecha: Plano alzado V7. LA1202. Fuente: V. Lauritzen y/o E. Fischer.

${ }^{225}$ Fischer, E. y Lauritzen, V. (1919-1920). Óp. cit. LA1202. 


\section{Ventana 8}

De la ventana 8 se dispone de dos láminas (LA-1204 y LA-1205) y de ninguna fotografía. Se encontraba localizada en la Sala 16 , de acuerdo con el plano de planta del Palacio ${ }^{226}$, en la fachada NE y formando ángulo con la V6. Sus dimensiones eran las siguientes: 1,33 x 1,93 m de hueco de carpintería y 1,96 x 3,18 m de dimensiones máximas. No se dispone de información sobre la carpintería.

- Plano LA1205 ${ }^{227}$ : se trata de una puesta a escala dibujada a grafito sobre una lámina de papel de dimensiones $680 \times 470 \mathrm{~mm}$ donde está representado el alzado de la ventana y la sección horizontal a nivel de las jambas. Las vistas tienen correspondencia diédrica. La disposición del dibujo en la lámina es vertical y existen líneas auxiliares de dibujo. Asimismo, contiene cotas generales tanto de anchuras como de altura referenciadas a una cota 0 situada a media altura. La escala de representación es 1:10. El arco de la portada es escarzano y está enmarcado, a su vez, con una baqueta recta tangente al arco, formando dos pirámides invertidas sobre el arco. Las jambas son molduradas como las del resto de ventanas documentadas y arrancan sobre basas apoyadas en los bancos o festejadors, como en la V7, que sobresalen del lienzo del muro. Tiene un capitel decorado en cada jamba. Las basas están formadas por una sola columnilla que, aunque no está representada en la sección, entendemos que podría ser de basa heptagonal como el resto. Las molduras de la jamba desde el extradós al intradós son las siguientes: caveto, baqueta o columnilla, filete, caveto semicircular, caveto y jambas con perfil recto, totalmente asimétricas: la derecha es abocinada y la izquierda es casi ortogonal al lienzo del muro (formando cierta simetría con la V7). En la parte superior izquierda se encuentra rotulada la numeración de la ventana y su ubicación: "Vindue 8 - Rum 16", y en la parte inferior derecha el número de la lámina: LA1205 (ver Fig. 129). Dentro de la ventana, sobre una línea de puntos, está rotulado "Saalbaenk højde vdv. 75" (altura del alfeizar aprox. 75), interpretándose que el alfeizar ya no existía, pero quedaba algún vestigio que indicaba dicha altura. Los festejadors están perfectamente grafiados en planta y en el alzado, siendo paralelos a ambas jambas. En este caso, con línea discontinua, se han representado perfectamente la base y aristas ocultas en la planta, o sección horizontal de la ventana, indicando que se encontraban en perfecto estado.

- Plano LA1204 ${ }^{228}$ : Se trata de una lámina en disposición vertical y de papel transparente con unas dimensiones de $680 \times 476 \mathrm{~mm}$. En ella está grafiada una copia del alzado de la ventana 8 correspondiente al plano LA1205. En la esquina superior izquierda está rotulado el número de la ventana y su localización "Vindue 8, (Rum 16)" y en la parte inferior derecha, el número de la lámina: LA1204 (ver Fig. 129).

\footnotetext{
${ }^{226}$ Fischer, E. y Lauritzen, V. (1919-1920). Óp. cit. LA1109.

${ }^{227}$ Fischer, E. y Lauritzen, V. (1919-1920). Óp. cit. LA1205.

${ }^{228}$ Fischer, E. y Lauritzen, V. (1919-1920). Óp. cit. LA1204.
} 


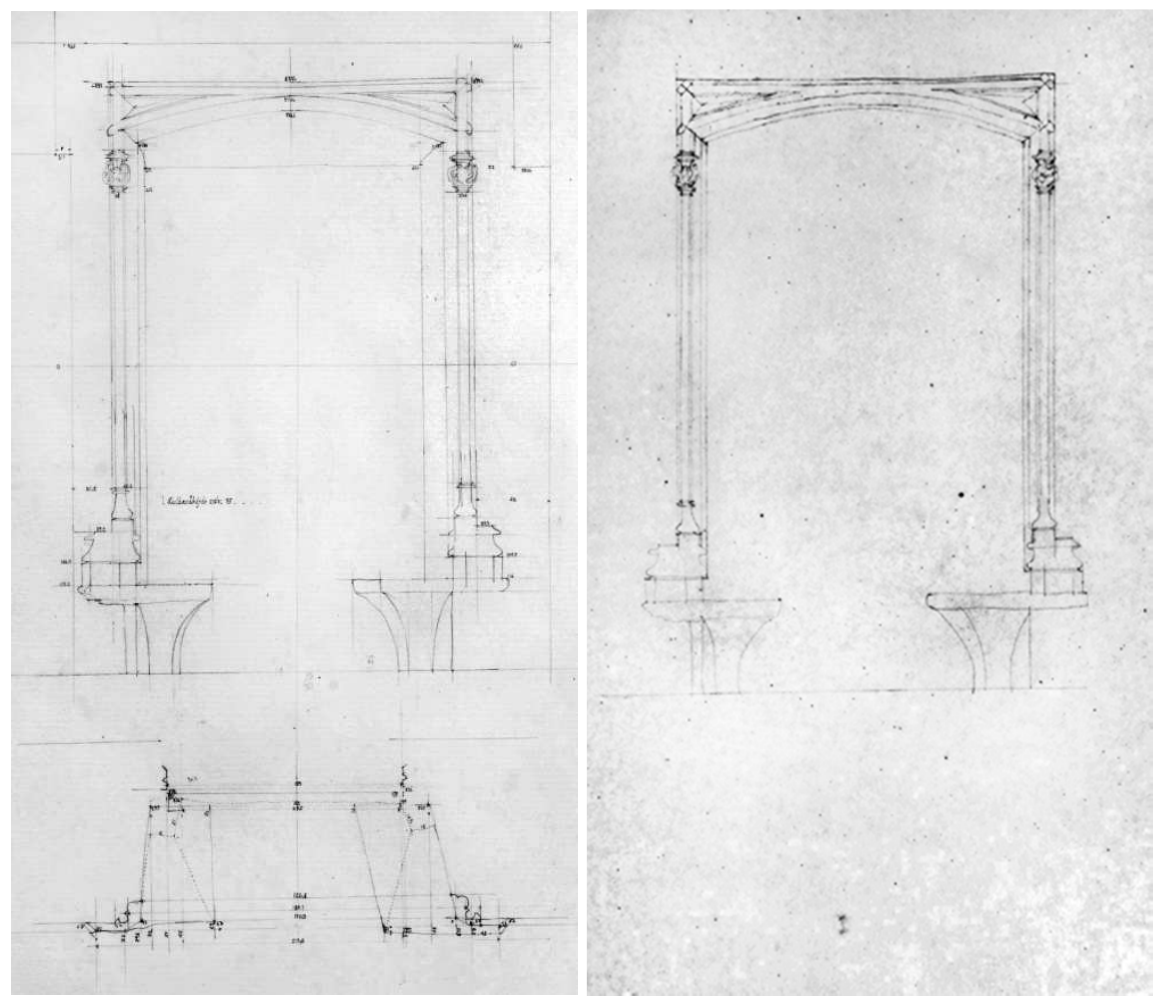

Figura 129.Izquierda: Plano Ventana 8. LA1205. Derecha: Plano alzado V8. LA1204. Fuente: V. Lauritzen y/o E. Fischer.

\section{Ventana 9}

De la ventana V9 se disponen de las láminas LA-1206 y LA-1207. Esta ventaba estaba localizada en la Sala 17, en la fachada NE del Palacio. Su anchura máxima era de 2,00 m y el ancho interior de las molduras de 1,63 m. No disponemos de información sobre el arco, las jambas abocinadas ni la carpintería, entendemos que por haber desaparecido antes de la llegada de Fischer y Lauritzen a Oliva.

- Plano LA1207 ${ }^{229}$ : se trata de una puesta a escala dibujada a grafito sobre una lámina de papel de dimensiones $680 \times 470 \mathrm{~mm}$ donde está representado el alzado de la ventana y la sección horizontal a nivel de las jambas. Las vistas tienen correspondencia diédrica. La disposición del dibujo en la lámina es vertical y existen líneas auxiliares. Tiene cotas generales tanto de anchuras como de altura referenciadas a una cota 0 situada a media altura. La escala de representación es 1:10. El arco de la portada no está representado, posiblemente por no existir. Las jambas son molduradas como las del resto de ventanas documentadas y arrancan sobre basas prismáticas que aparentemente nacen desde el nivel del pavimento. Sobre la jamba derecha se observa el arranque de un capitel; el resto, al parecer, ha desaparecido como el capitel izquierdo. Las basas están formadas por una sola columnilla, que aunque no está representada en la sección, sería heptagonal como el resto. Las molduras de la jamba desde el extradós al intradós son las siguientes: caveto, baqueta o columnilla, caveto, caveto semicircular, y caveto. Además, sólo se representa el arranque de las jambas abocinadas, por lo que se interpreta que

${ }^{229}$ Fischer, E. y Lauritzen, V. (1919-1920). Óp. cit. LA1207. 
esta ventana estaba en muy mal estado. En su parte superior izquierda se encuentra rotulada su numeración y ubicación: "Vindue 9-Rum 17", y en la parte inferior derecha el número de la lámina: LA1207 (ver Fig. 130).

- Plano LA1206 ${ }^{230}$ : se trata de una lámina en disposición vertical, de papel transparente y de dimensiones 680 x $470 \mathrm{~mm}$. En ella está grafiada una copia del alzado de la ventana 9, correspondiente al plano LA1207. La esquina superior izquierda de la lámina se ha desprendido, por lo que ha desaparecido también la identificación de la ventana. En la parte inferior derecha está rotulado el número de la lámina: LA1206 (ver Fig. 130).

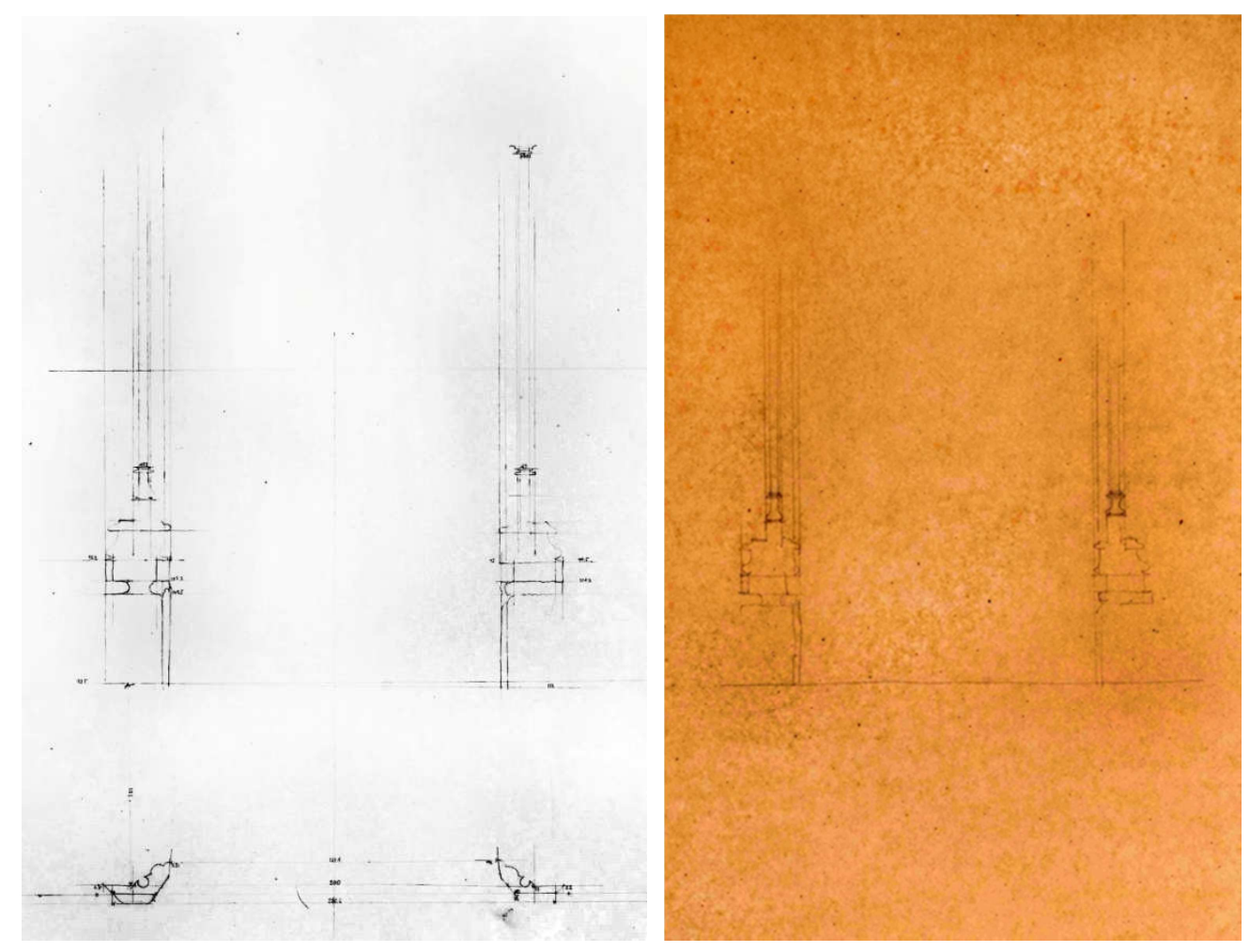

Figura 130.Izquierda: Plano Ventana 9. LA1207. Derecha: Plano alzado V9. LA1206. Fuente: V. Lauritzen y/o E. Fischer.

\section{Ventana 10}

De la ventana V10 existen un total de 7 las láminas: LA-1208, LA-1209, LA1210, LA1211, LA1212A, LA1212R, LA1213, LA1184A y LA1184R y las fotografías 27 y 94 . Se encontraba localizada en la Sala 18 o Sala de Armas, en la fachada NE del Palacio. Sus dimensiones eran de 2,36 x 3,92 de hueco de carpintería, y 3,35 x 5,20 m. Se trataba de una ventana balconera, por lo que el hueco llega hasta el nivel del pavimento. Se trata de la ventana de mayores dimensiones y mayor riqueza ornamental de todas las documentadas, como corresponde a su localización en la sala más noble del Palacio.

- Plano LA1209 231 : se trata de una puesta a escala dibujada a grafito sobre una lámina de papel de dimensiones 680 × 470 mm donde está representado el alzado

${ }^{230}$ Fischer, E. y Lauritzen, V. (1919-1920). Óp. cit. LA1206.

${ }^{231}$ Fischer, E. y Lauritzen, V. (1919-1920). Óp. cit. LA1209. 
de la portada y la sección horizontal a nivel de las jambas. Las vistas tienen correspondencia diédrica. La disposición del dibujo en la lámina es vertical y existen líneas auxiliares de dibujo. Tiene, asimismo, cotas generales tanto de anchuras como de altura referenciadas a una cota 0 sobre la cara superior de la columnilla derecha de mayor tamaño y su escala de representación es 1:10. Las vistas ocupan la práctica totalidad de la lámina dadas las grandes dimensiones de la ventana.

El arco es carpanel como en el resto de las ventanas. Las jambas son molduradas y parten de basas prismáticas que se apoyan en el pavimento. Cada jamba tiene 3 capiteles, uno sobre cada columnilla y un tercero que parte del muro apoyado en una pequeña ménsula. Aunque de dimensiones diferentes, todos están enrasados en su cara superior. Las basas están formadas por dos columnillas, y aunque no está representada en la sección, su base podría tener planta heptagonal como el resto. Las molduras de la jamba desde el extradós al intradós son las siguientes: caveto, baqueta o columnilla, filete, caveto semicircular, filete, baqueta o columnilla, filete y caveto. Las jambas son abocinadas, de perfil prácticamente recto. En la parte superior izquierda se encuentra rotulada la numeración de la ventana y su ubicación: "Vindue 10-Rum 18", y en la parte inferior derecha el número de la lámina: LA1209 (ver Fig. 131).

- Plano LA1208 ${ }^{232}$ : se trata de una lámina de papel transparente de dimensiones 673 x $470 \mathrm{~mm}$ y con una disposición vertical. En ella está grafiada una copia del alzado de la ventana 10 correspondiente al plano LA1209. En la esquina superior izquierda de la lámina está rotulado el número de la ventana y su localización "Vindue 10 (Rum 18)" y en la parte inferior derecha el número de la lámina: LA1204 (ver Fig. 131).
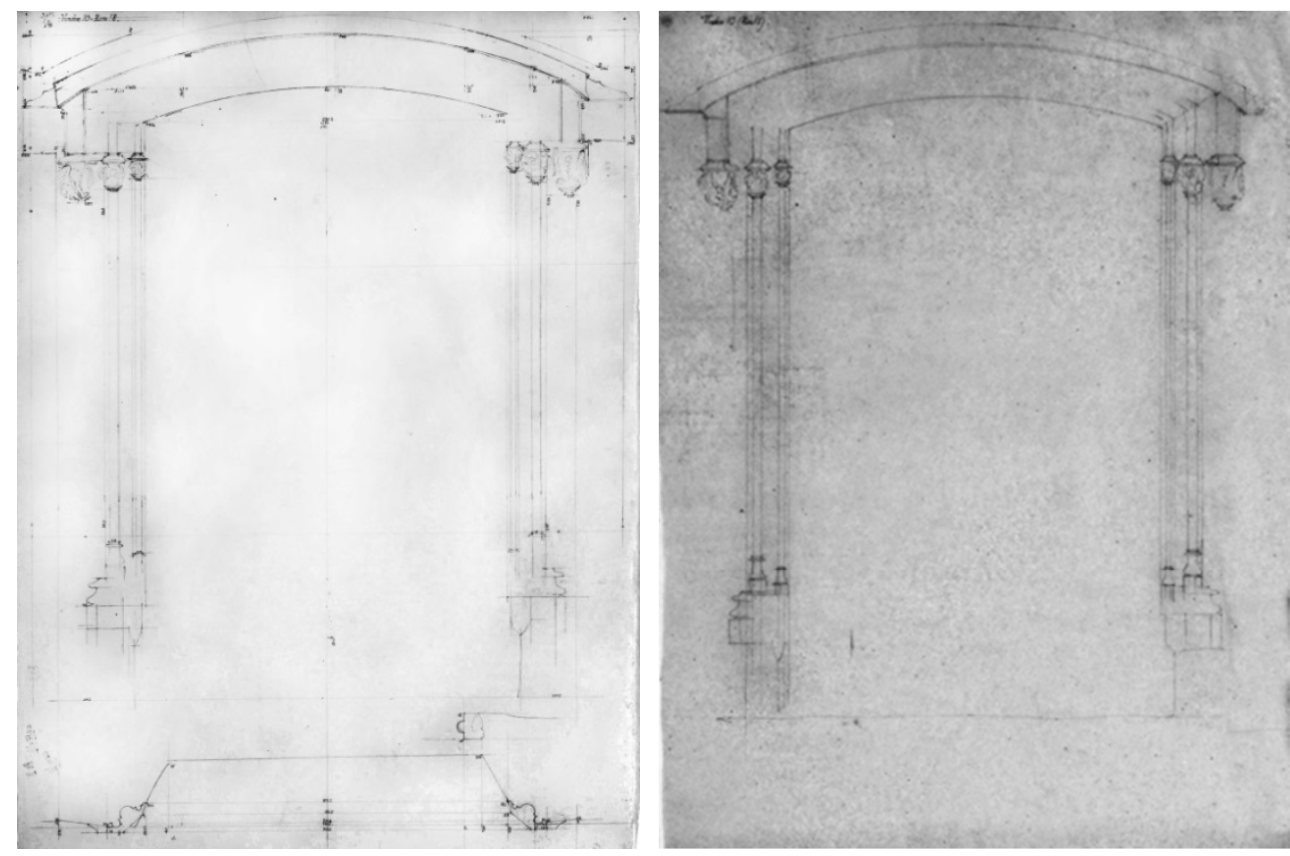

Figura 131.Izquierda: Plano Ventana 10. LA1209. Derecha: plano de alzado V10. LA1208. Fuente: V. Lauritzen y/o E. Fischer.

${ }^{232}$ Fischer, E. y Lauritzen, V. (1919-1920). Óp. cit. LA1208. 
- Plano LA1211 233 : Se trata de una puesta a escala dibujada a grafito sobre una lámina de papel de dimensiones $470 \times 680 \mathrm{~mm}$ con una disposición horizontal. En ella está dibujado el alzado de la tracería calada de la ventana 10. Esta tracería la encontró Fischer oculta en el cerramiento interior del hueco de la ventana V10, sobre el dintel de la ventana actual, tras un revestimiento de yeso ${ }^{234}$. Este plano nos demuestra que se trataba de una ventana ajimezada formada por tres arcos trilobulados cuyo arco central era apuntado. Las molduras del arco se prolongaban para formar tres tímpanos invertidos con ornamentación en relieve. Existen cotas longitudinales parciales de cada uno de los módulos que forman el conjunto y la cota con el ancho total de la tracería. La escala de representación es 1:10. En la parte central superior se encuentra rotulada la numeración de la ventana y su ubicación: "Vindue 10. Rum 18", y en la parte superior derecha, en vertical, el número de la lámina: LA1211 (ver Fig. 132).

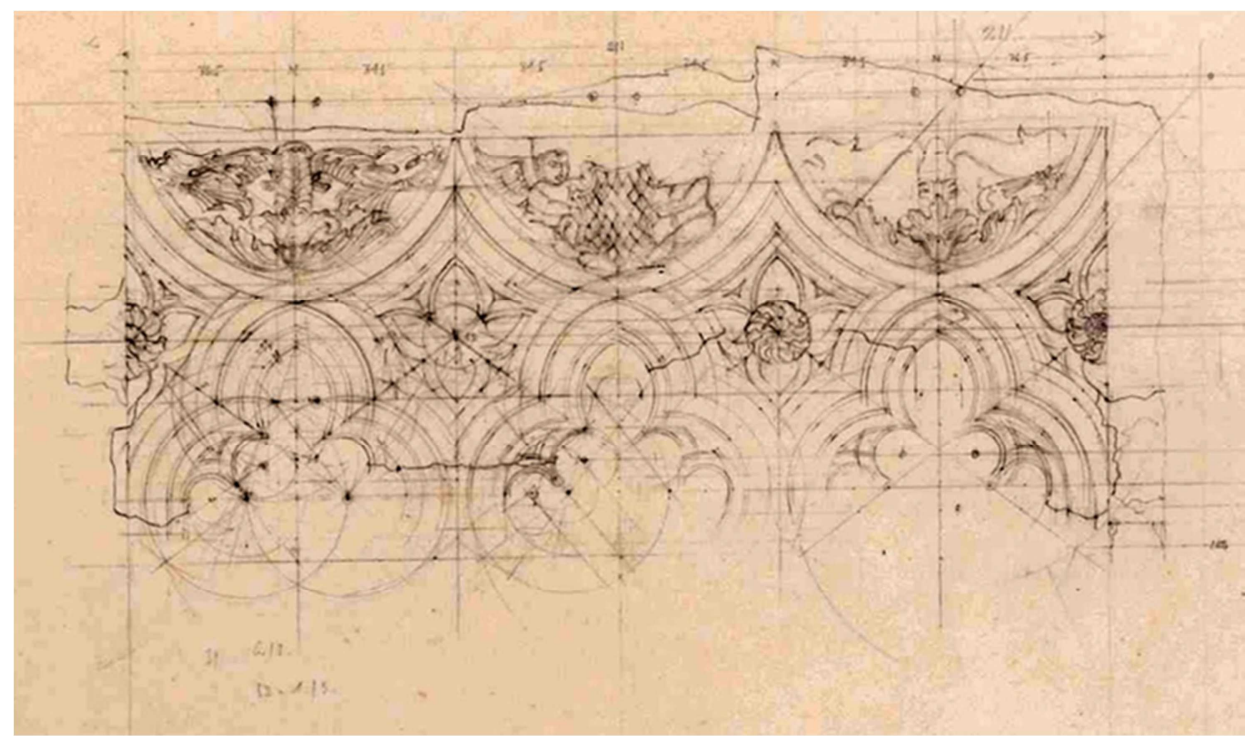

Figura 132. Plano Ventana 10. LA1211. Fuente: V. Lauritzen y/o E. Fischer.

- Plano LA1210 235 : se trata de una puesta a escala dibujada a grafito y tinta negra sobre una lámina de papel de calco de dimensiones $305 \times 514$ mm y en disposición horizontal. Se trata de una copia del plano LA1211 a partir del cual se han dibujado y numerado las 10 piezas recuperadas de la tracería de la ventana que, a su vez, sirvieron para realizar el Plano LA 1210. La escala de representación es 1:10. En la parte superior izquierda se encuentra rotulada la numeración de la ventana y su ubicación: "Vindue 10-Rum 18", y en la parte inferior derecha, el número de la lámina: LA1210 (ver Fig. 133).

\footnotetext{
${ }^{233}$ Fischer, E. y Lauritzen, V. (1919-1920). Óp. cit. LA1211.

${ }^{234}$ E. Muller, P. (1997). El Palau d'Oliva dels Centelles. En A. Esteve i Blai, Antoni (Ed). El Palau dels Centelles d'Oliva. Recull gràfic y documental. Oliva (pp. 87-138) Oliva, España: L'Associació Cultural Centelles i Riu-Sec. pp. 114-116.

${ }^{235}$ Fischer, E. y Lauritzen, V. (1919-1920). Óp. cit. LA1210.
} 


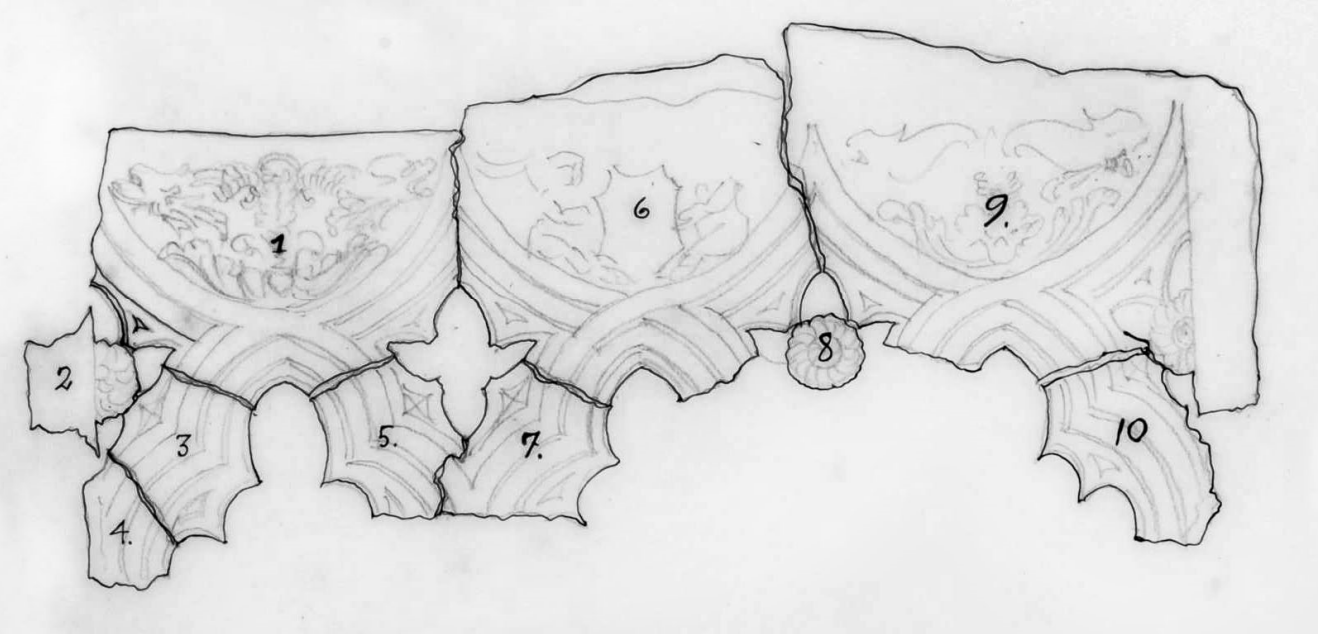

Figura 133. Plano Ventana 10. Siglado. LA1210. Fuente: V. Lauritzen y/o E. Fischer.

- Plano LA1212 Anverso ${ }^{236}$ : se trata de un trazado geométrico a grafito y regla, realizado con instrumentos de dibujo sobre una lámina de papel sin marca de dimensiones $470 \times 680 \mathrm{~mm}$ y en disposición horizontal. Este trazado geométrico es sin duda un boceto anterior del plano que sirvió para realizar el Plano LA 1210. La escala de representación es 1:5. En la parte superior central se encuentra rotulada la numeración de la ventana y su ubicación: "Vindue 10. Rum 18", y en la parte superior derecha, en vertical, el número de la lámina: LA1212 (ver Fig. 134).

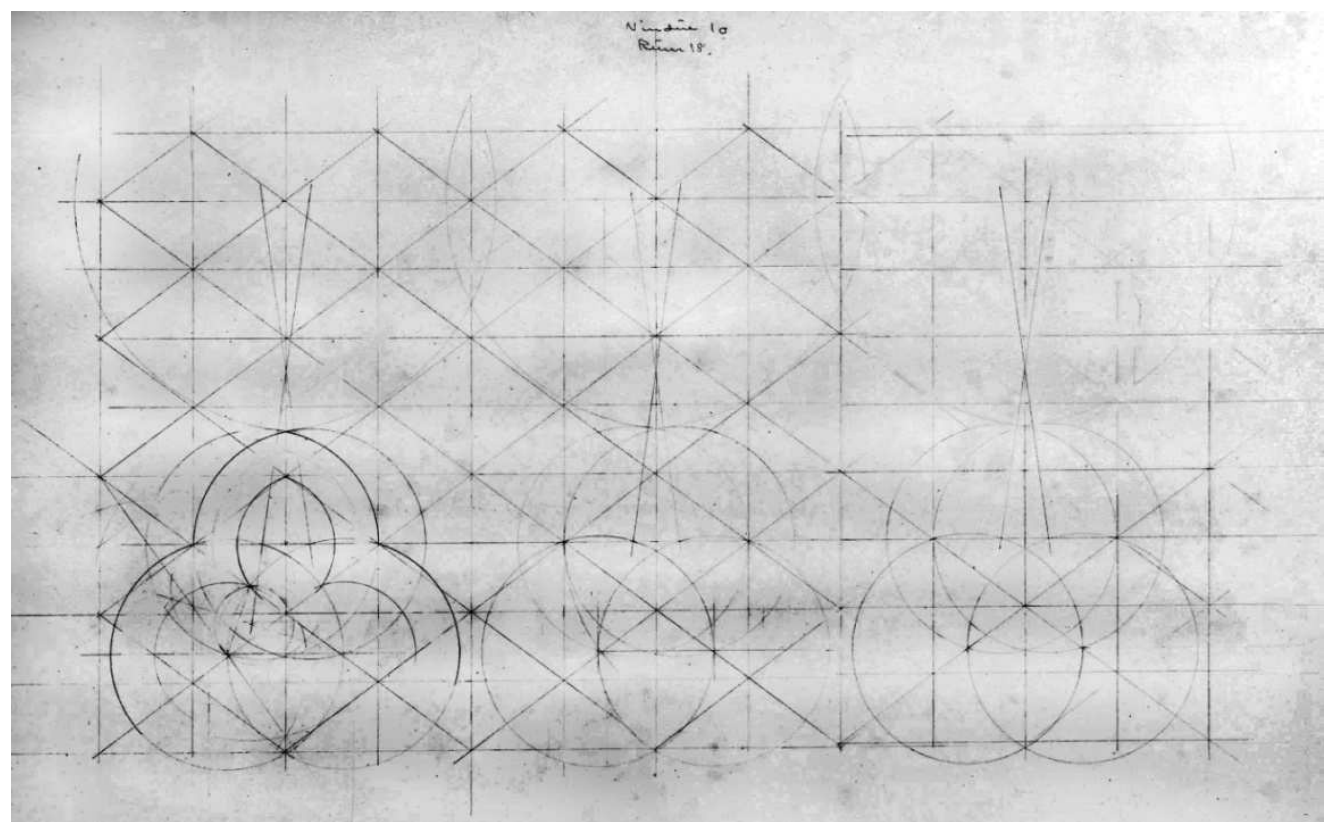

Figura 134. Plano Ventana 10. Trazado. LA1212 Anverso. Fuente: V. Lauritzen y/o E. Fischer.

${ }^{236}$ Fischer, E. y Lauritzen, V. (1919-1920). Óp. cit. LA1212A. 
- Plano LA1212 Reverso ${ }^{237}$ : se trata de otro plano con un borrador del trazado geométrico de la tracería de la ventana 10. La escala es 1:5. En el margen derecho de la lámina hay numerosos cálculos que sin duda sirvieron de apoyo para poder realizar el trazado geométrico de esta lámina (ver Fig. 135).

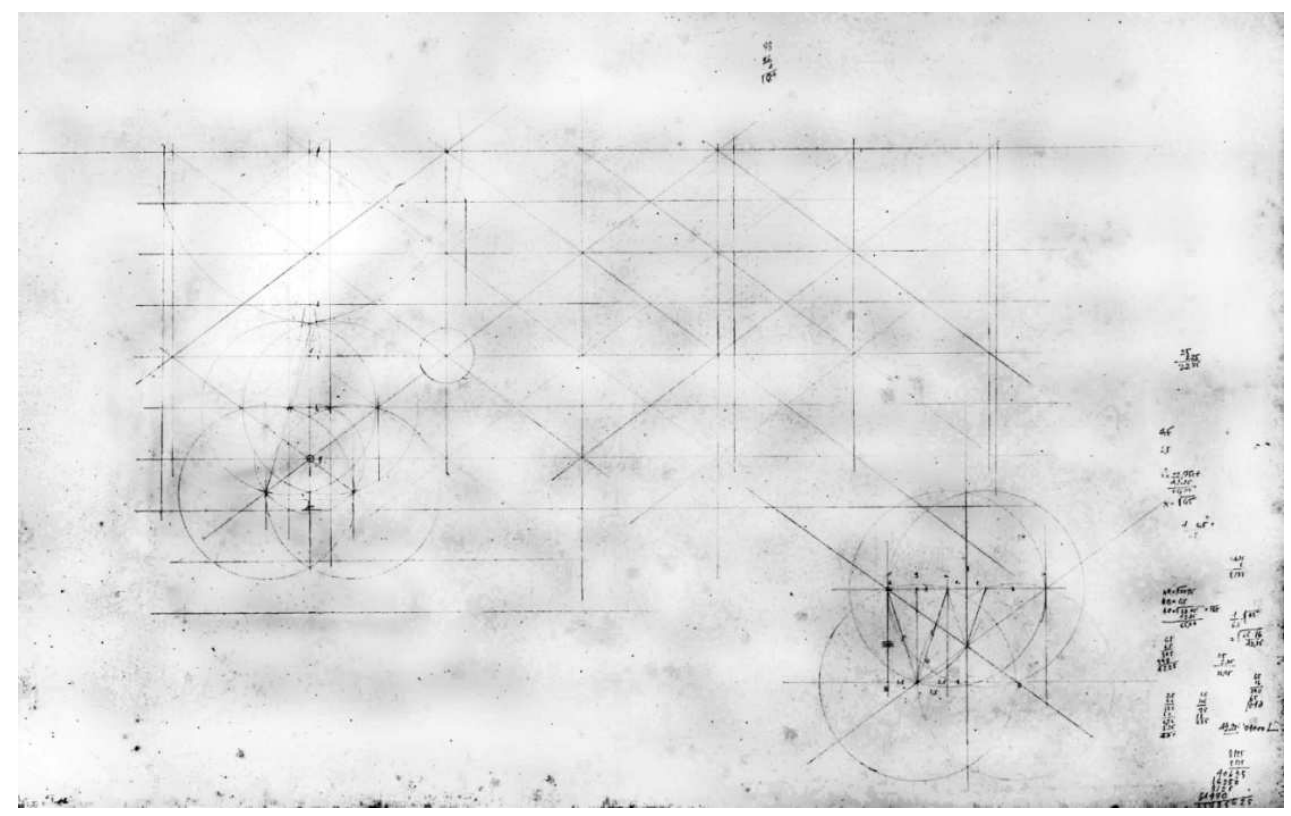

Figura 135. Plano Ventana 10. Trazado. LA1212 Reverso. Fuente: V. Lauritzen y/o E. Fischer.

- Plano LA1213 238 : se trata de otro plano con un borrador del trazado geométrico de la tracería de la ventana 10. La escala es 1:5. La lámina es un papel sin marca de dimensiones $470 \times 680 \mathrm{~mm}$ y disposición horizontal. En ella se encuentran rotulados el número de la ventana, su localización y la numeración de la lámina.

- Plano LA1184 Anverso ${ }^{239}$ : se trata de otro plano correspondiente a la V10. La lámina es un papel sin marca de dimensiones 470 × $680 \mathrm{~mm}$ y disposición vertical. En la lámina se representan dos elementos. En la parte superior está rotulado el título de la misma: Søndre Halvsøjle til store Vindue i Våbensalen (Media columna sur de la ventana grande de la Sala de Armas). Bajo este rótulo se representa la sección y alzado de la media columna de la ventana de la sala de Armas localizada en la jamba, más al sur. Se trataba de una columna entorchada (helicoidal). En la parte izquierda se encuentra representada la sección de una pieza que no podemos interpretar, aunque parece indicar el perfil del dintel exterior de la ventana. En el lateral izquierdo, en vertical, junto a este dibujo, está rotulado: Glat Púds paa ydervægb (Yeso liso en la pared exterior). La escala de ambos detalles es 1:1, aunque no está grafiada (ver Fig. 136).

${ }^{237}$ Fischer, E. y Lauritzen, V. (1919-1920). Óp. cit. LA1212R.

${ }^{238}$ Fischer, E. y Lauritzen, V. (1919-1920). Óp. cit. LA1213.

${ }^{239}$ Fischer, E. y Lauritzen, V. (1919-1920). Óp. cit. LA1184A. 


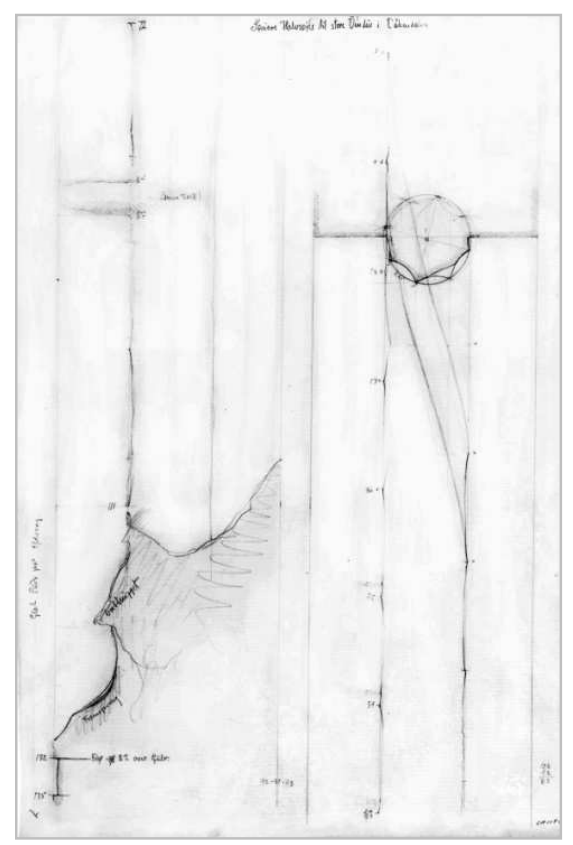

Figura 136. Plano Ventana 10. Columna helicoidal y moldura. LA1184 Anverso. Fuente: V. Lauritzen y/o E. Fischer

- Plano LA1184 Reverso ${ }^{240}$ : en el reverso de la lámina anterior está dibujado a escala 1:1 la sección del arco interior de la ventana con todas sus molduras (ver Fig. 137).

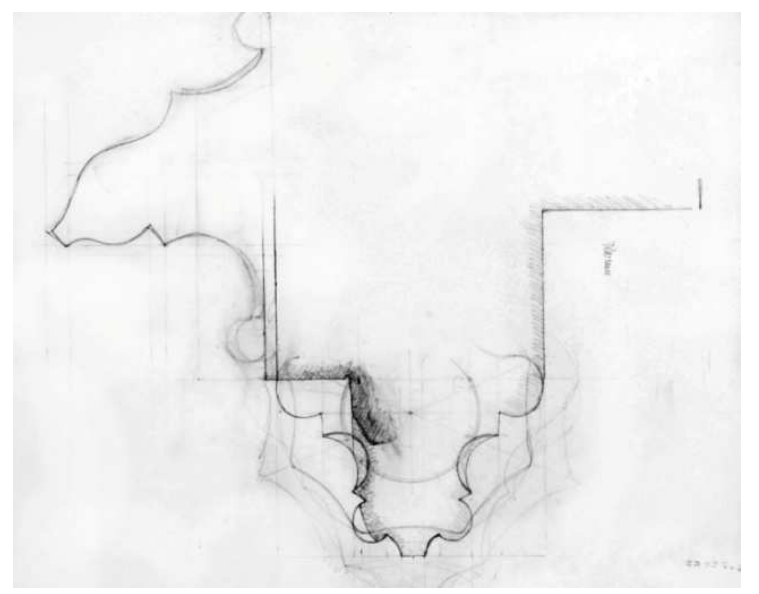

Figura 137. Plano Ventana 10. Sección dintel. LA1184 Reverso. Fuente: V. Lauritzen y/o E. Fischer.

\subsubsection{Ventanas no numeradas}

En este apartado analizaremos la documentación gráfica de otras ventanas grafiadas o fotografiadas por Fischer y Lauritzen, pero que no se encuentran numeradas ni localizadas de una manera clara en el plano de referencia ${ }^{241}$. Se analizará la documentación de las

${ }^{240}$ Fischer, E. y Lauritzen, V. (1919-1920). Óp. cit. LA1184A.

${ }^{241}$ Fischer, E. y Lauritzen, V. (1919-1920). Óp. cit. LA1109. 
mismas y se intentará identificar su localización en el Palacio a través de sus textos y otras referencias. Las identificaremos con el número de la lámina en el caso de disponer de un plano o con el número de la fotografía en el caso de tratarse de un documento fotográfico. En el caso de disponer de ambos documentos, daremos prioridad al número del plano.

\section{Ventana LA1193}

Se trata de una puesta a escala dibujada a grafito sobre una lámina de papel de dimensiones 470 × $680 \mathrm{~mm}$, la disposición es horizontal y la escala de representación es 1:10. En la parte superior derecha está rotulado: Det Nordgate vindue i ødriden? No 3 indvendig? Rum N? (Ventana de la Puerta norte en ¿ं? № 3 ¿interior? Sala № ?); y en la parte superior derecha, en vertical, el código, $\mathrm{LA} 1183^{242}$. En ella está representada la planta y una sección vertical. Existe correspondencia diédrica entre las vistas, y la sección está representada según el sistema americano, a la izquierda del alzado. De la planta sólo está dibujado el esquema de la base de una de las columnillas. La ventana es adintelada y tanto las jambas como el dintel presentan diversas molduras en el exterior de la ventana. Las jambas se apoyan en una basas de las que parten dos columnillas que, a su vez, tienen una pequeña basa, característica de las portadas góticas, en este caso de planta octogonal, tal y como se observa en su detalle en planta. Dispone de dos pares de capiteles de trazado geométrico con decoración floral y su carpintería no está grafiada. Las dimensiones máximas del hueco en el exterior son 1,47 x 1,85 m y el hueco de carpintería 1,28 x 1,62 m (ver Fig. 138).

Aunque en la rotulación aparece como número 3 entre interrogantes, esta ventana no corresponde a dicha numeración en el plano de planta del Palacio, ya que existe otra ventana con dicha numeración que se ajusta al ancho en planta de este hueco, por lo que esta ventana no está localizada en el plano, aunque sí sabemos que estaba en la zona de la puerta de acceso al Palacio. También se desconoce si se trataba de una ventana interior o exterior.

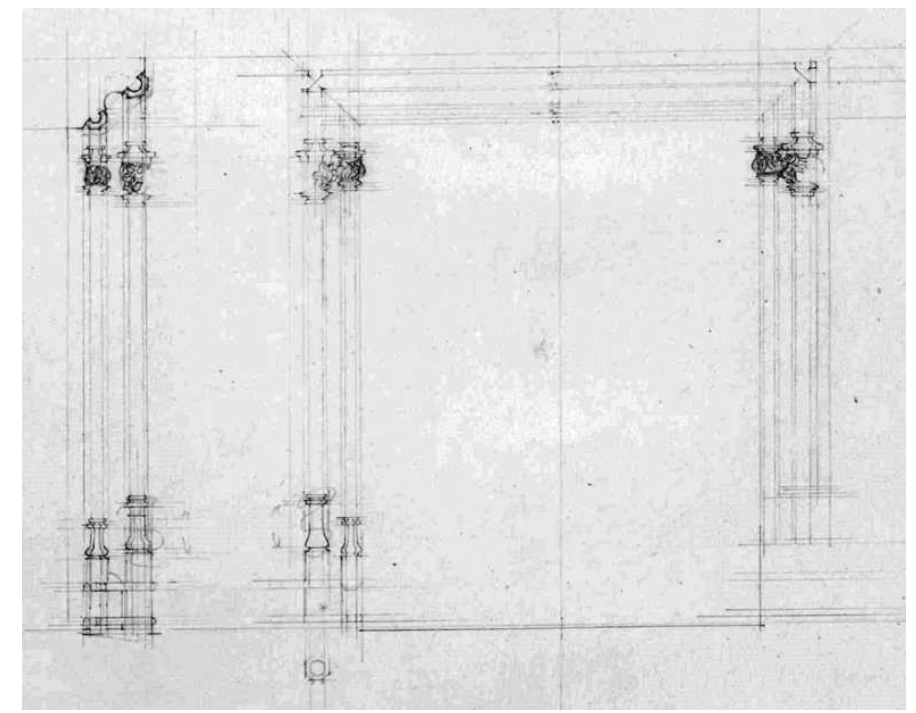

Figura 138. Plano Ventana Puerta Norte. LA1183. Fuente: V. Lauritzen y/o E. Fischer.

${ }^{242}$ Fischer, E. y Lauritzen, V. (1919-1920). Óp. cit. LA1183. 


\section{Ventana LA1179}

Se trata de una puesta a escala dibujada a grafito sobre una lámina en disposición horizontal de papel de dimensiones $470 \times 680 \mathrm{~mm}$ donde sólo está representado el alzado de la ventana y su escala de representación es 1:10. La ventana es adintelada y tanto las jambas como el dintel presentan diversas molduras. El código de la lámina está rotulado en el extremo superior derecho en vertical: LA1179 ${ }^{243}$. En la jamba izquierda está dibujada una basa con una columnilla, que en la parte superior de la jamba tiene un pequeño capitel. A la misma altura de coronación de este capitel existe otro que parte del lienzo del muro. En la jamba derecha se intuyen otro par de ellos. Las molduras superiores forman una especie de cornisa. La falta de referencias no nos permite identificar su posición en el Palacio y si se trataba de una ventana interior o exterior. Sin embargo, podemos señalar que no parece pertenecer a la zona más noble del Palacio (ver Fig. 139).

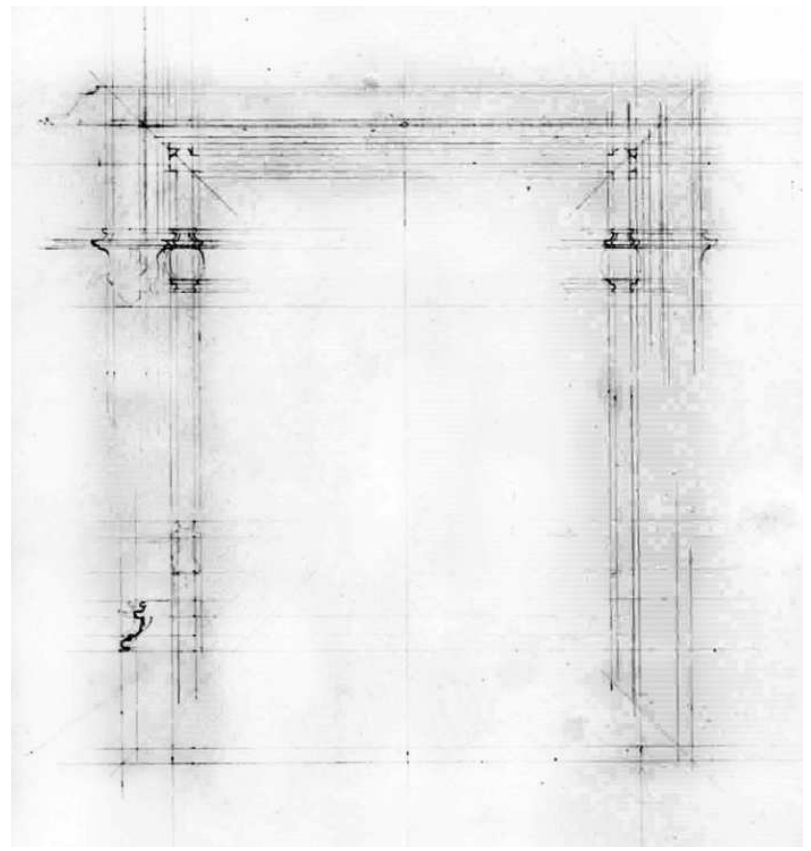

Figura 139. Plano Ventana sin identificar. LA1179. Fuente: V. Lauritzen y/o E. Fischer.

\section{Ventana Torre del Palomar. LA1185}

Se trata de una puesta a escala dibujada a grafito sobre una lámina de papel de dimensiones $470 \times 680 \mathrm{~mm}$ en posición vertical. En el extremo superior izquierdo está rotulado el título de la lámina "Vindue i Duetaarnet" (Ventana en la Torre del Palomar) y en el extremo inferior derecho la numeración de la lámina: LA1185 ${ }^{244}$. Se representa el alzado exterior en la parte superior, la planta o sección horizontal en el centro y el alzado interior en la parte inferior. La ventana tiene una dimensión exterior de $0,99 \times 1,24 \mathrm{~m}(4 \times 5$ palmos, aproximadamente) y unas medidas máximas interiores de $1,29 \times 1,60 \mathrm{~m}(5 \times 6$ palmos, aproximadamente). La escala de representación es 1:10. Asimismo, la ventana está construida con sillares de distinta altura en obra de fábrica. En el exterior es adintelada y en

${ }^{243}$ Fischer, E. y Lauritzen, V. (1919-1920). Óp. cit. LA1179.

${ }^{244}$ Fischer, E. y Lauritzen, V. (1919-1920). Óp. cit. LA1185. 
el interior está cerrada por un arco rebajado. Tanto las jambas como el arco están abocinados; el interior estaba revestido de yeso de acuerdo con la leyenda "pudsen stik" (pared de yeso). En el exterior, bajo el alfeizar de la ventana, está grafiada una textura de mampostería y en la planta la carpintería de madera. Se trata de una ventana de dimensiones modestas sin elementos decorativos (ver Fig. 140).

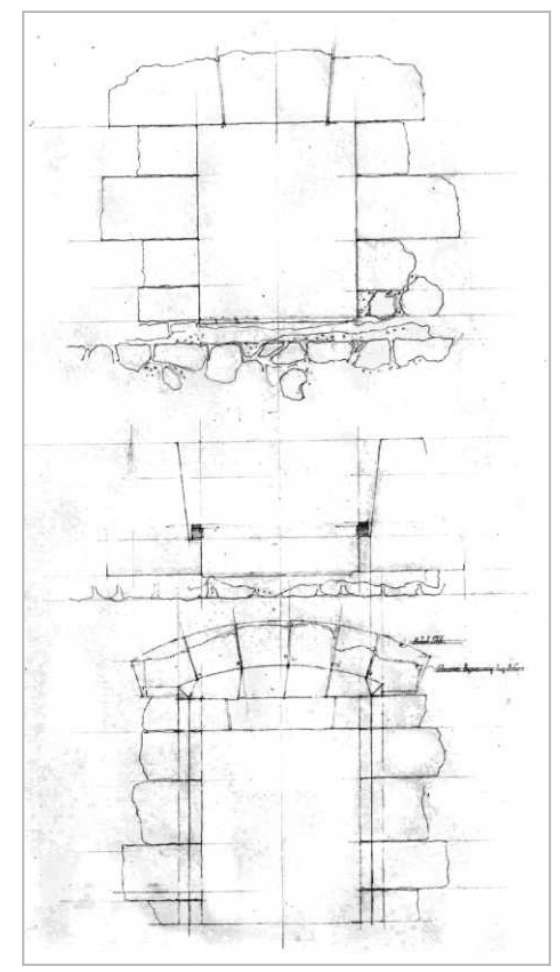

Figura 140. Plano Ventana Torre Palomar. LA1185. Fuente: V. Lauritzen y/o E. Fischer.

\section{Ventanas del Palomar. LA1186}

Se trata de una puesta a escala dibujada a grafito sobre una lámina de papel de dimensiones $470 \times 680 \mathrm{~mm}$ en posición vertical. En el extremo superior izquierdo está rotulado el título de la lámina "Fra Duetaarnet" (Del Palomar) y en el extremo inferior derecho la numeración de la lámina, LA1186 ${ }^{245}$. Su escala es de 1.100. En el plano se representan dos huecos. En la parte superior está dibujada la planta y alzado interior de una aspillera formada por bloques de piedra numerados. Las dimensiones exteriores del hueco son de $18 \times 32 \mathrm{~cm}$. En la parte inferior de la lámina están representados la planta, el alzado interior, el alzado exterior y la sección vertical de una ventana de pequeñas dimensiones ( $56 \times 75 \mathrm{~cm}$ en el exterior y 0,67 ×0,75 cm en el interior). El hueco es prácticamente recto, estando ligeramente abocinada la jamba derecha. La ventana es adintelada y está formada por tres bloques de piedra en el exterior (jambas y dintel) y 4 en el interior (jambas, dintel y alfeizar) colocados en un muro de mampostería. El hueco exterior está desplazado hacia la derecha, no coincidiendo exactamente con el interior (ver Fig. 141). Se trata de una ventana de pequeñas dimensiones con unas funciones defensivas, al igual que la aspillera representada en esta misma lámina.

${ }^{245}$ Fischer, E. y Lauritzen, V. (1919-1920). Óp. cit. LA1186. 


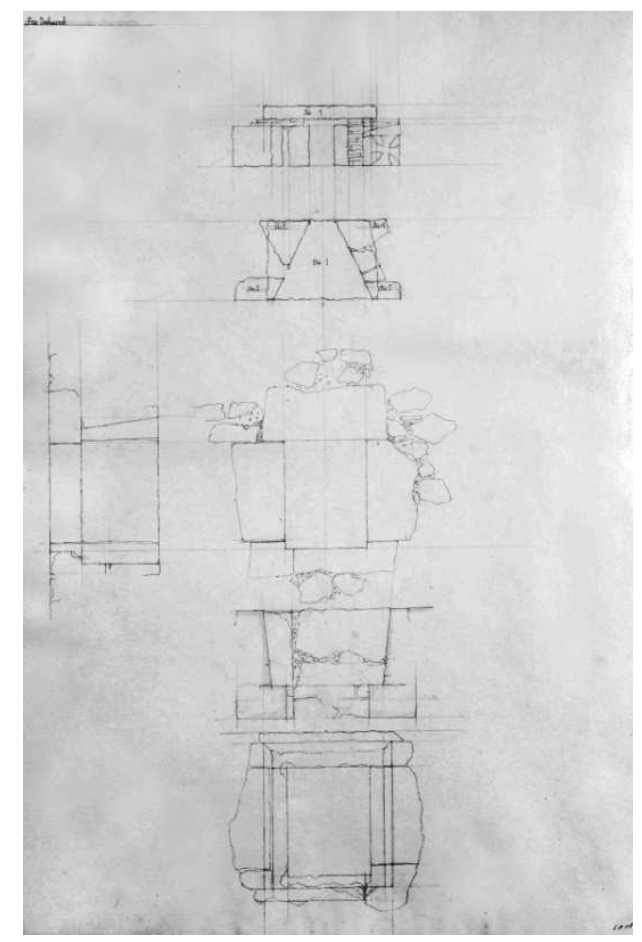

Figura 141. Plano Ventana Torre Palomar. Fuente: LA1186. V. Lauritzen y/o E. Fischer.

\section{Ventana Bífora LA1187}

Se trata de una puesta a escala dibujada a grafito sobre una lámina de papel de dimensiones $470 \times 680 \mathrm{~mm}$ en posición vertical. La lámina no tiene ninguna leyenda identificativa y en su extremo inferior derecho está rotulada la numeración LA1186 ${ }^{246}$. La escala es 1.100. Está dibujada la planta, el alzado exterior y la sección vertical de una ventana ajimezada bífora. Las dimensiones interiores del hueco son $191,5 \times 219 \mathrm{~cm}$ en el interior y las dimensiones máximas exteriores $132 \times 0,75 \mathrm{~cm}$. La ventana en el exterior está formada por sillares de distintas medidas colocados en un muro de fábrica de ladrillo. La cierran dos arcos apuntados formados por 5 dovelas con una dovela central común. La clave tiene una perforación en forma de flama y en las jambas, bajo el arranque de los arcos, hay unas molduras labradas que sobresalen del paramento, características de estos arcos de factura gótica, aunque no tienen labrada ninguna decoración en relieve. El alfeizar, también de piedra, sobresale formando un goterón que se prolonga bajo las jambas y bajo el mismo hay dos hiladas más de mampostería que parecen indicar que arrancan desde el nivel del forjado (ver Fig. 142 izq.).

De esta ventana disponemos también de la fotografía $82^{247}$ (ver Fig. 142 dcha.), lo que nos permite localizar esta ventana en la Sala 20 del Palacio, a la derecha de la portada 26. En la fotografía se aprecia que no tenía la carpintería original y que claramente se había sustraído la columnilla central característica de esta tipología de ventanas.

\footnotetext{
${ }^{246}$ Fischer, E. y Lauritzen, V. (1919-1920). Óp. cit. LA1186.

${ }^{247}$ Fischer, E. (1917-1920). Álbum Fotos Grande. Oliva, Valencia: Museo Municipal de Oliva, Archivo Público Documental, Palacio Condal. p 18A.
} 

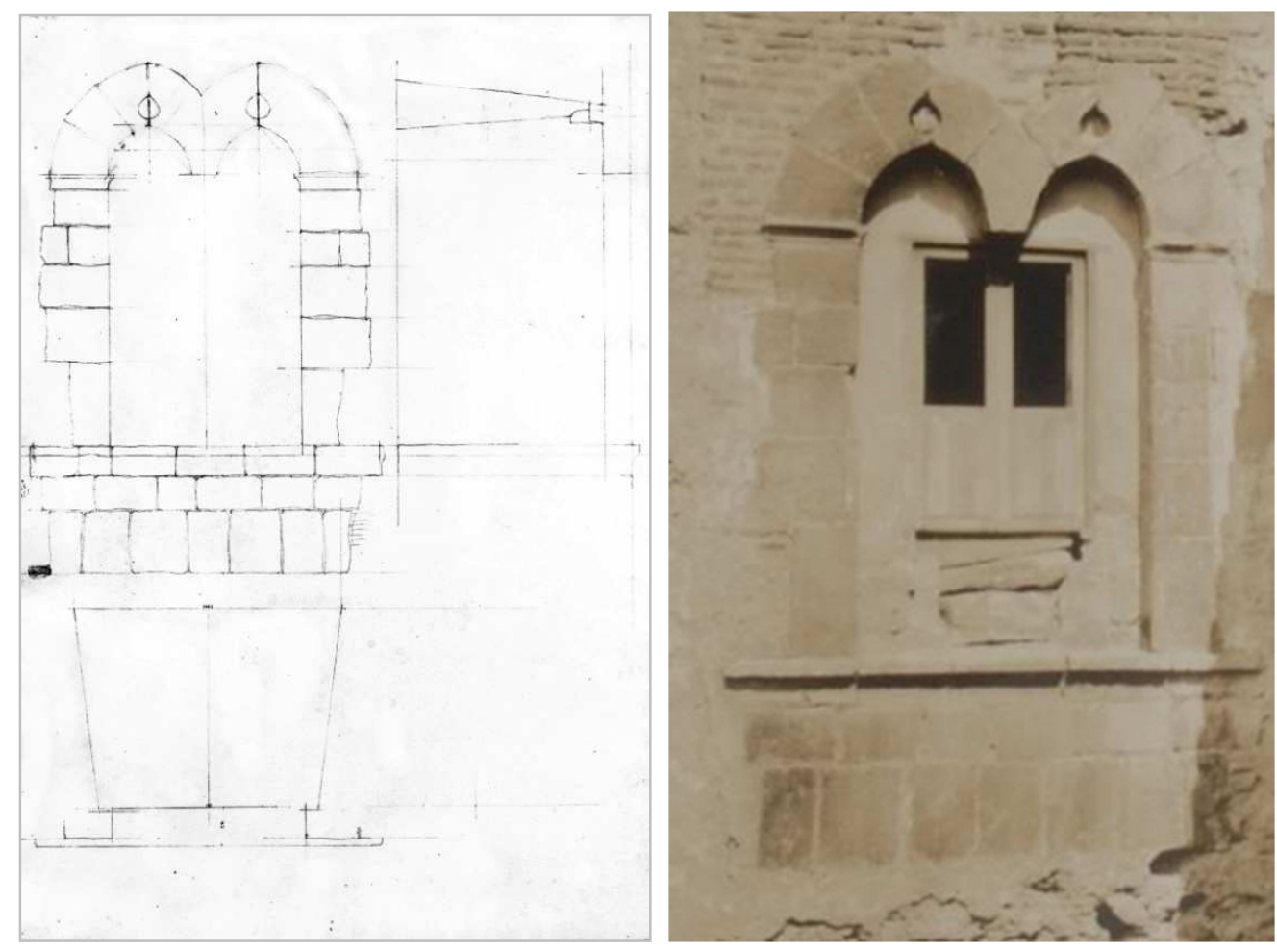

Figura 142. Ventana Ajimezada. Izquierda: Plano LA1187. Derecha: Fot.82. Fuente: V. Lauritzen y/o E. Fischer.

\section{Ventana LA1193}

Se trata de una puesta a escala dibujada a grafito sobre una lámina en disposición horizontal de papel de dimensiones $470 \times 680 \mathrm{~mm}$. La escala de representación es 1:10. En ella está representada la planta, el alzado exterior y una sección vertical. Existe correspondencia diédrica entre las vistas y la sección está representada según el sistema americano, a la izquierda del alzado. La ventana es adintelada y tanto las jambas como el dintel presentan diversas molduras en el exterior de la ventana. Las jambas se apoyan en basas de las que parten dos columnillas que, a su vez, tienen una pequeña basa, característica de las portadas góticas, en este caso de planta octangular. No dispone de capiteles. El hueco interior está abocinado tanto en sus jambas como en el dintel, que por el grafismo se interpreta su transición a un arco rebajado. En el interior no existen molduras, aunque si festejadors en ambas jambas. Lo que queda de la carpintería, que parece ser la original, está grafiada. La forman seis cuarterones con decoración en rombos en el centro de cada uno de ellos. Las dimensiones máximas del hueco en el exterior son $1,29 \times 1,51 \mathrm{~m}$ y el hueco de carpintería $0,83 \times 1,29 \mathrm{~m}$. La altura del alfeizar desde el nivel interior de pavimento es de $0,86 \mathrm{~cm}$. En la parte superior está grafiado el alero de la cubierta y en la parte superior derecha está rotulado "vindue i oldte?" (Ventana en ¿ं?). Por su parte, en la parte superior derecha, en vertical, aparece el código LA1193 ${ }^{248}$ (ver Fig. 143).

${ }^{248}$ Fischer, E. y Lauritzen, V. (1919-1920). Óp. cit. LA1193. 


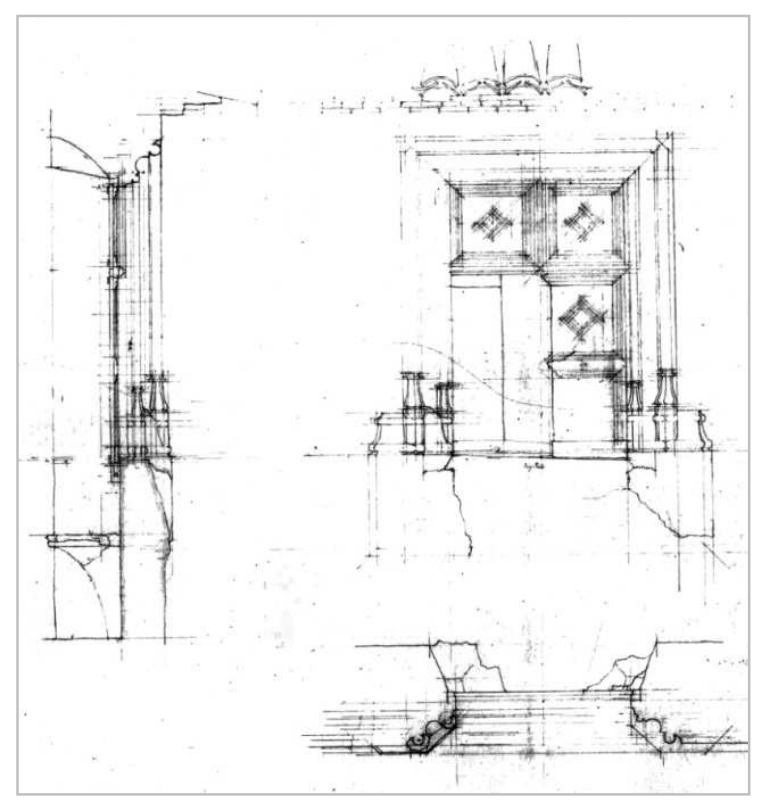

Figura 143. Plano Ventana sin identificar. LA1193. Fuente: V. Lauritzen y/o E. Fischer.

De esta ventana disponemos asimismo de una fotografía (Fot. 80 del Álbum de Fot. Grande $^{249}$ ) del exterior y en ella podemos visualizar los mismos elementos ornamentales detallados en el plano. Aparentemente se trata de una ventana realizada en yeso como las interiores debido a la textura y la ausencia de juntas de corte de piedra. La falta de referencias no nos permite identificar su posición en el Palacio, si bien sabemos que estaba en una sala cerrada con una cubierta inclinada (ver Fig. 144).

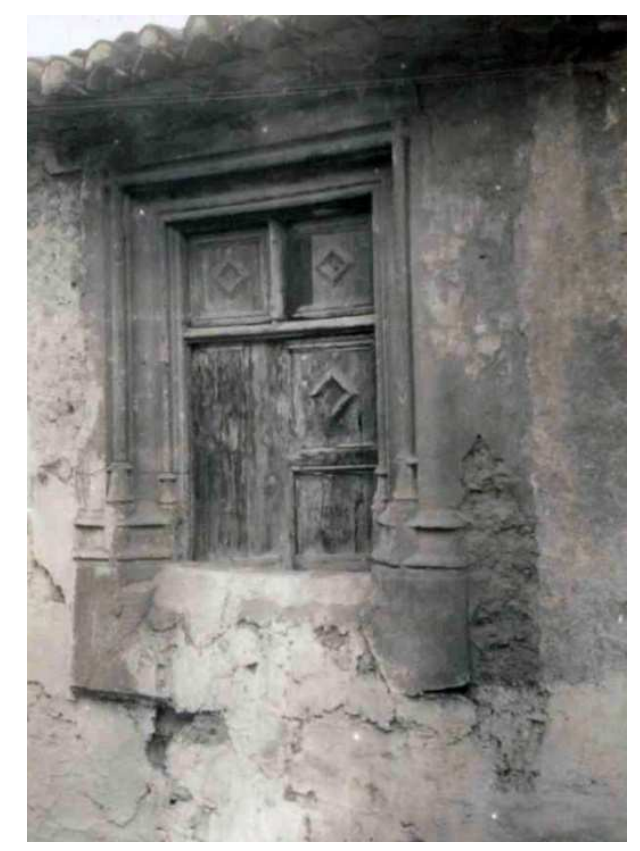

Figura 144. Fot 80. Ventana sin identificar. LA1193. Fuente: E. Fischer.

${ }^{249}$ Fischer, E. (1917-1920). Álbum Fotos Grande. Oliva, Valencia: Museo Municipal de Oliva, Archivo Público Documental, Palacio Condal. pp. 17R 


\section{Ventana cuatrífora. Fot. 79}

De esta ventana no disponemos de planos, tan sólo de la fotografía $79^{250}$. En ella se puede observar el exterior de los restos de una ventana ajimezada cuatrífora. Las jambas, alfeizar y dintel son de cantería. Cada uno de los arquillos que forman el dintel son de una única pieza, recta en su cara superior y formando un arco trilobulado en su cara inferior. Se puede ver un dintel de madera flechado que sustenta todas las piezas, que en su día se apoyarían sobre tres esbeltas columnillas propias de esta tipología de ventanas características del gótico mediterraneo (ver Fig. 145 Izq.). En el MAO existen dos piezas de piedra caliza tallada que formarían parte de una ventana ajimezada similar a la de la Fot. 80 , aunque por su diseño y dimensiones no corresponde exactamente a esta ventana (ver Fig. 145 dcha.).
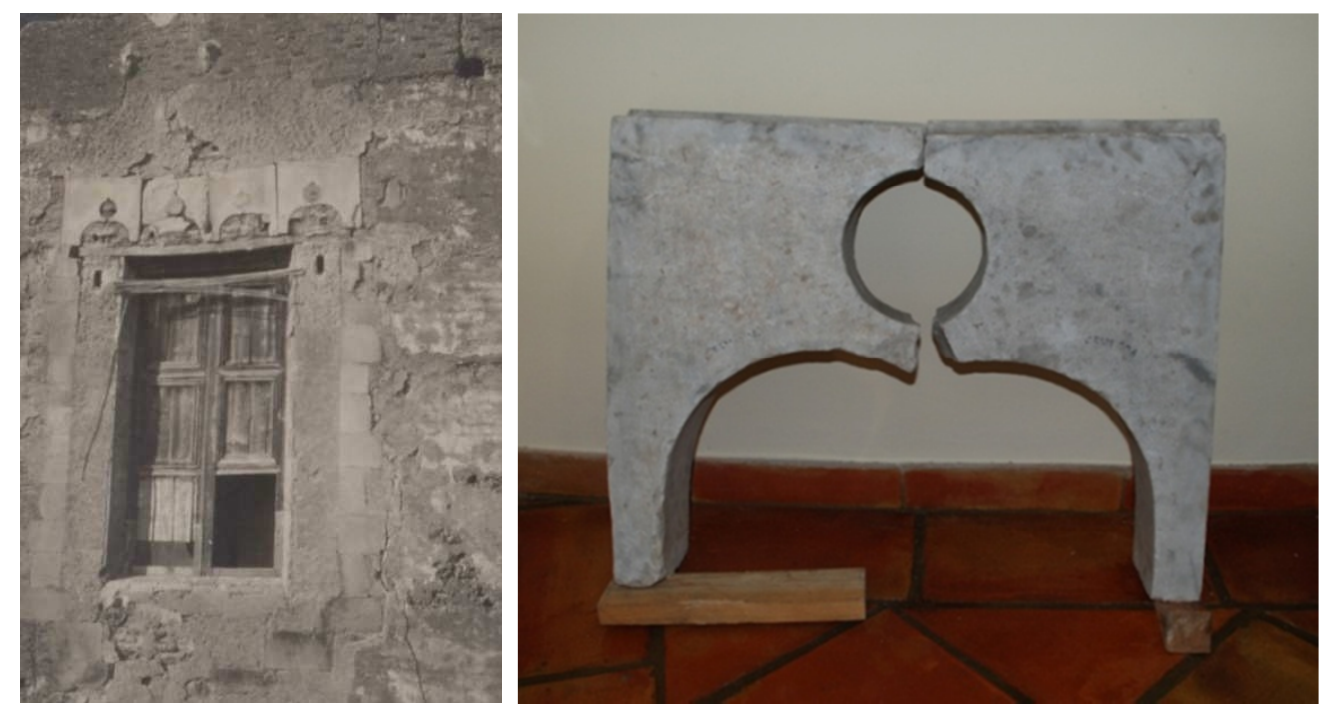

Figura 145. Izquierda: Fot. 79 Ventana cuatrífora. E. Fischer. Derecha: Pieza ventana ajimezada. MAO. Palacio Condal de Oliva.

\section{Ventana Bífora. Fot. 84}

De esta ventana no disponemos de planos, tan sólo de la fotografía $84^{251}$. En ella se observa el exterior de una ventana ajimezada bífora formada por dos arcos trilobulados. Las jambas y arcos son de fábrica de ladrillo de un pie. En las jambas, bajo el arranque de los arcos, hay unas pequeñas ménsulas de piedra talladas y en el centro una columnilla de piedra como parteluz (ver Fig. 146 izq.). Estas columnillas se producían seriadas, principalmente en Gerona, para este tipo de ventanes, muy utilizadas en toda la Corona de Aragón ${ }^{252}$. En el edificio de la calle Virgen del Carmen no 7 de Oliva existe una ventana idéntica a la de la

${ }^{250}$ Fischer, E. (1917-1920). Álbum Fotos Grande. Oliva, Valencia: Museo Municipal de Oliva, Archivo Público Documental, Palacio Condal. pp. 17R.

${ }^{251}$ Fischer, E. (1917-1920). Álbum Fotos Grande. Oliva, Valencia: Museo Municipal de Oliva, Archivo Público Documental, Palacio Condal. pp. 18R.

252 Zaragozá, A. (2003) Arquitecturas del Gótico Mediterráneo. En Mirá E. y Zaragozá, A. (Ed). Una arquitectura gótica mediterránea, Volum 2. Valencia: Generalitat Valenciana. pp. 162. 
Fot. 84 que se dice perteneció al Palacio. Si bien la fotográfia de Fischer es de muy mala calidad, vistas las semejanzas, se puede afirmar que esta ventana, trasladada de su localización original, se corresponde con la ventana del Palacio documentada en dicha fotografía (ver Fig. 146 dcha.). Por su parte, en la Fot. 83 de Fischer aparece fotografiada una moldura de una jamba de ventana ajimezada similar a la de esta ventana, si bien no se trata de la misma, ya que en este caso la ornamentación de cada una de las caras es un rosetón y un escudo, en lugar de dos rosetones. Sin embargo, se trata sin duda de una pieza de una ventana similar (ver Fig. 147).
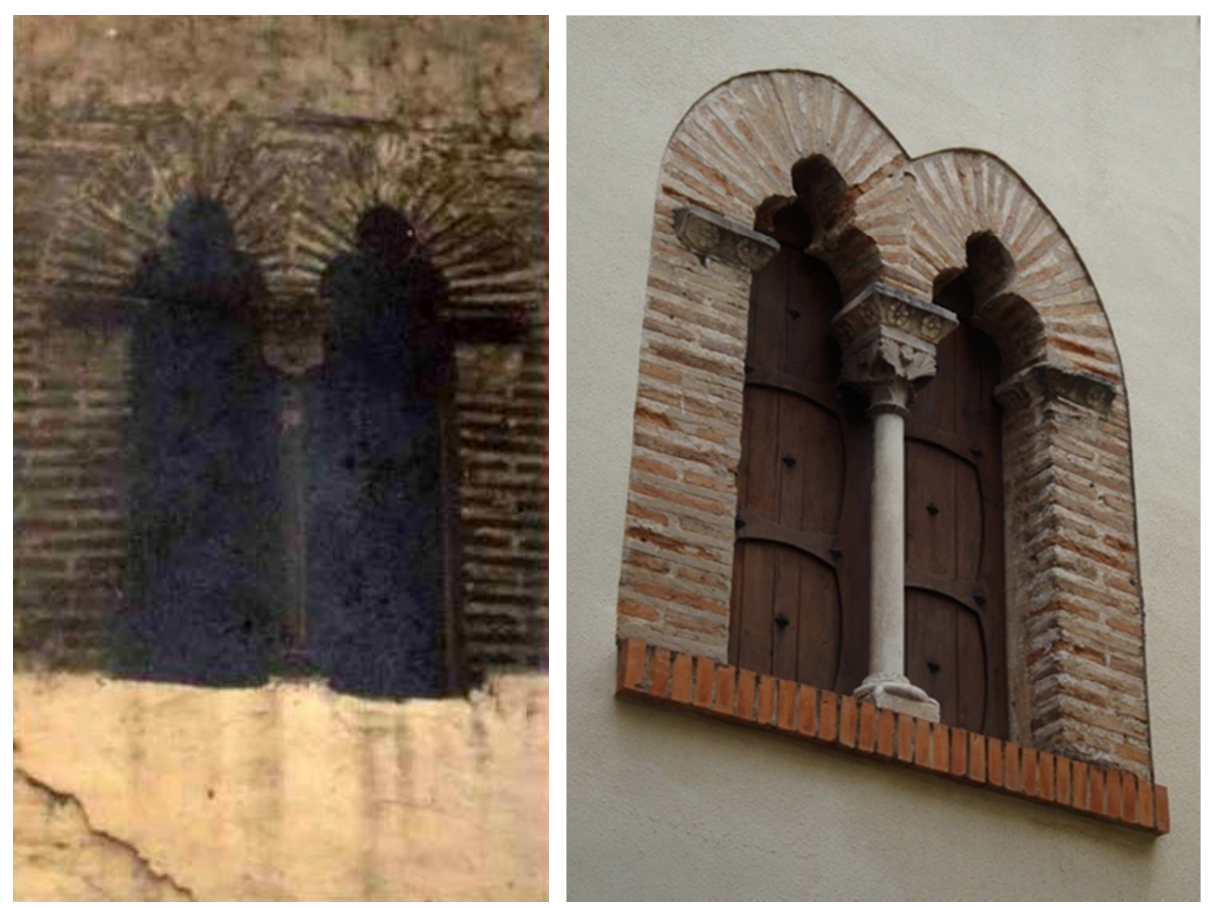

Figura 146. Izquierda: Fot. 84. Ventana Bífora. E. Fischer. Derecha: Fot. Ventana Ajimezada C/ Virgen del Carmen no 7, Oliva.

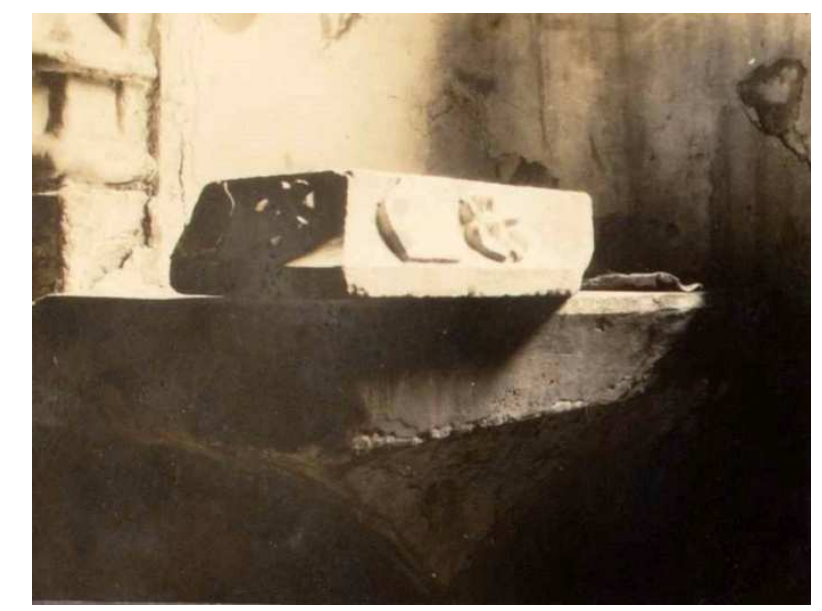

Figura 147. Fot. 83. Capitel ventana desmontado. E. Fischer. 


\subsection{Forjados y artesonados}

En la documentación gráfica nos encontramos documentados varios forjados y artesonados de madera tanto en los planos como en los croquis de los cuadernos de notas. Asimismo, se disponen de algunas fotografías que nos muestran parte de estos elementos constructivos y decorativos del Palacio. Los clasificaremos según el tipo de documento en el que aparezcan.

\subsubsection{Forjados Notebooks}

\section{Artesonado I}

El Artesonado I se encuentra grafiado en el Notebook I, páginas 3, 3R, 4 y $5^{253}$. Aunque Fischer lo denomina "Artesonado", en realidad se trata de un forjado de madera de 3,70 m de anchura por 4,07 m de longitud formado por cuatro vigas de madera molduradas, dos de ellas centrales y otras dos adosadas a los muros, todas de $30 \mathrm{~cm}$ de ancho. Dispone de una moldura perimetral de madera enrasada con la cara inferior de las vigas y que circunda toda la sala de $20 \mathrm{~cm}$ de ancho por $16 \mathrm{~cm}$ de altura (ver Fig. 148 izqda., 149 y 150). En los testeros se forma una falsa viga formada por dos tablas de madera con idénticas molduras a las de las vigas, de manera que, junto con las vigas laterales y las molduras, enmarcan todo el perimetro del techo. Las piezas de entrevigado son de escayola decorada con motivos renacentistas (ver Fig. 148 dcha.). Cada tramo de entrevigado está formado por tres piezas idénticas de $83 \mathrm{~cm}$ de ancho por 1,15 cm de largo.
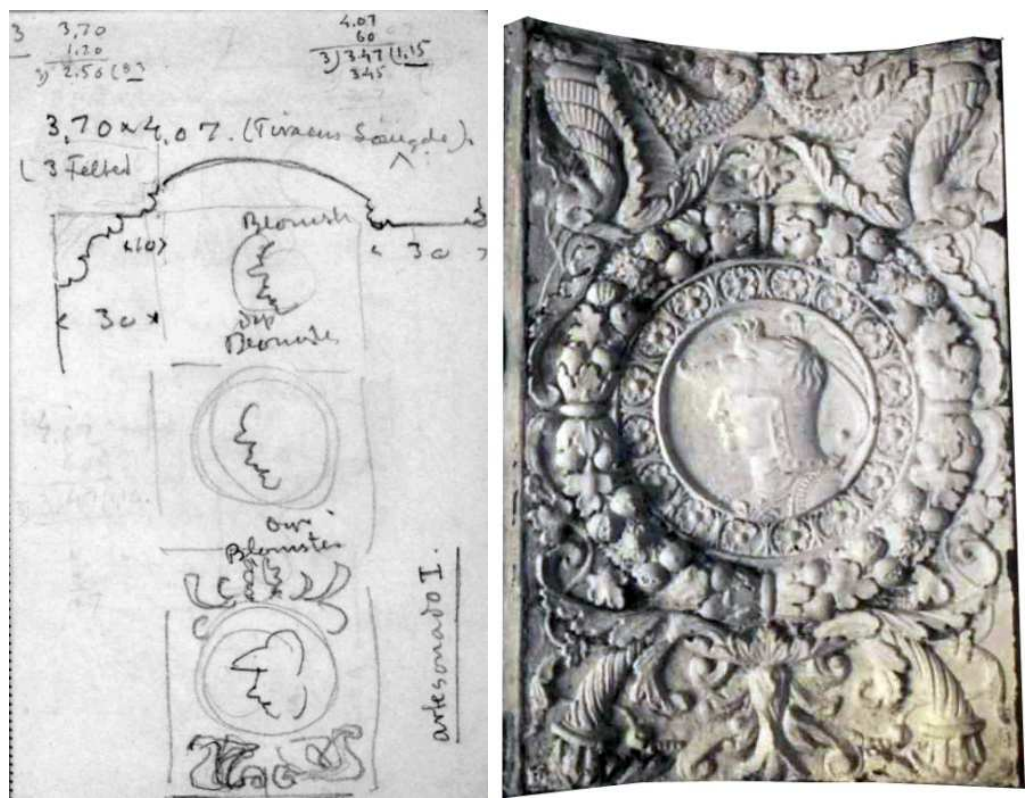

Figura 148.Izquierda: Sección transversal Artesonado I Pág 3.Notebook I. Derecha Fot. 47. Álbum Fot. Grande. Fuente: Egil Fischer.

\footnotetext{
${ }^{253}$ Fischer, E. (1919-1920). Notebook I. Oliva, Valencia: Museo Municipal de Oliva, Archivo Público Documental, Palacio Condal. pp. 3, 3R, 4 y 5.
} 


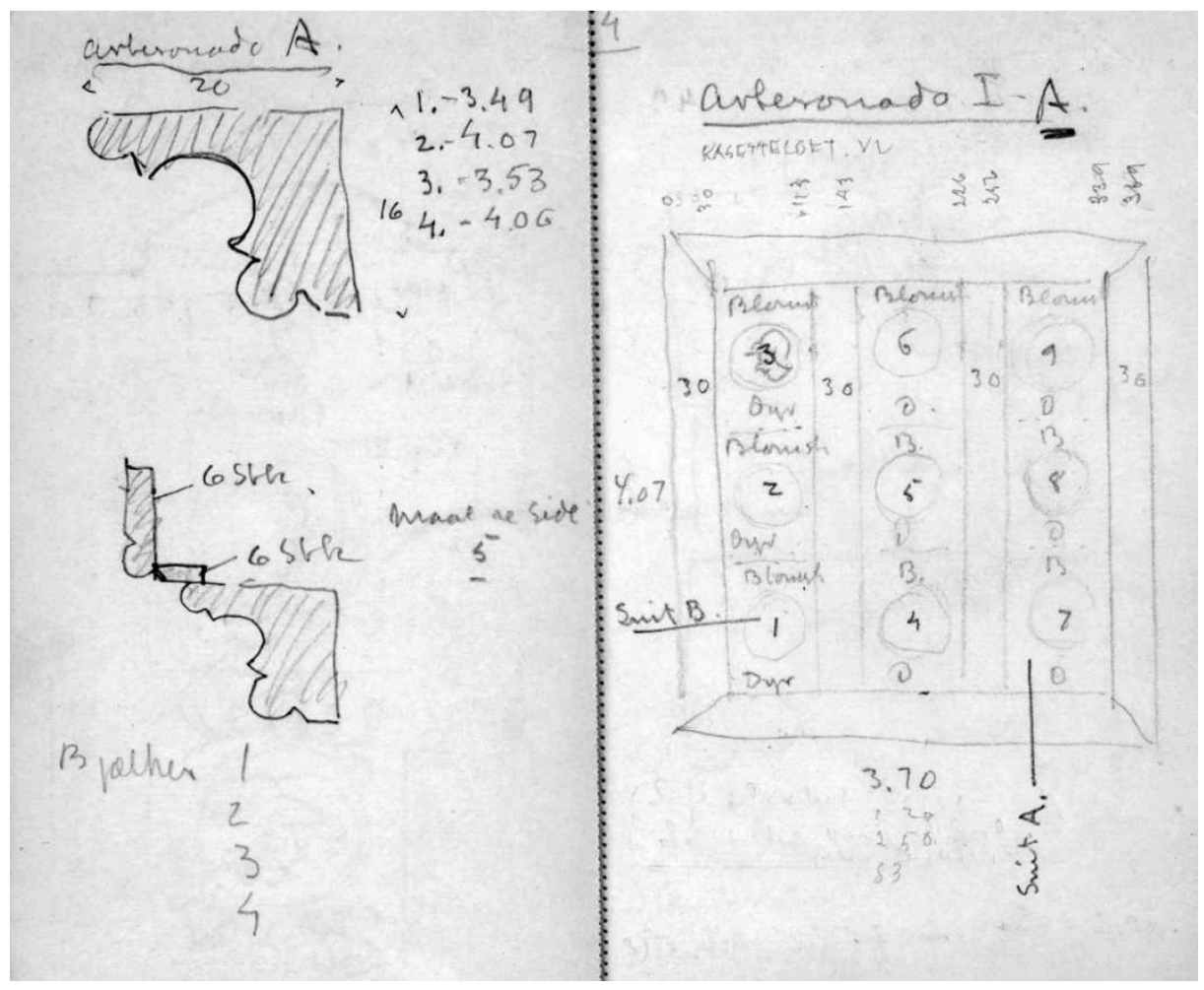

Figura 149. Detalle sección longitudinal y planta cenital Artesonado I Pág 4. Notebook I. Fuente: Egil Fischer.

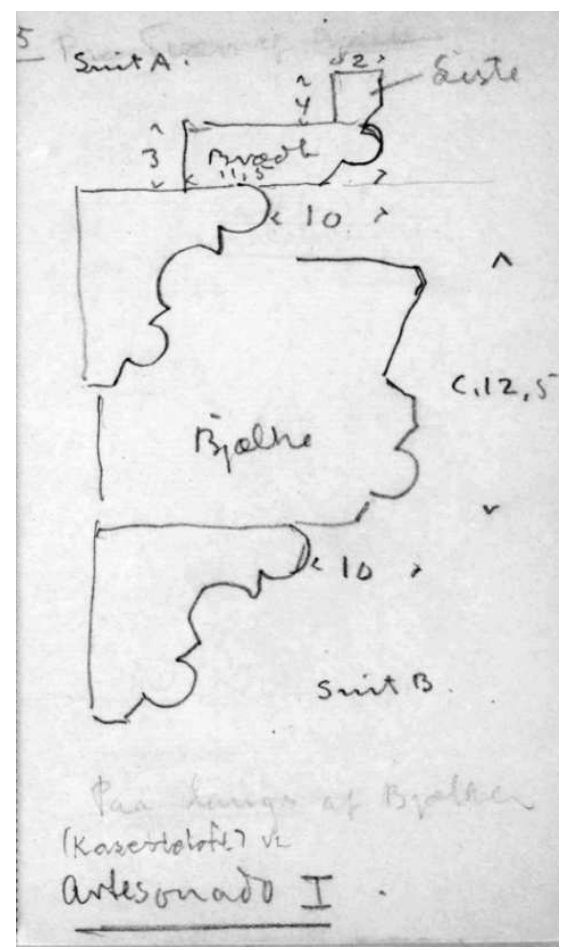

Figura 150. Detalle Secciones A y B. Notebook I, Pág. 5. Fuente: Egil Fischer. 


\section{Forjado B}

El Forjado se encuentra grafiado en el Notebook I, páginas $13,53,53 R$ y $54^{254}$. En la parte inferior de la página 13 hay un pequeño esquema de la planta que se detalla de manera más clara en la página 53. Está rotulado como "Loft B. Over Sanchis to ostligate stuer" (Forjado B. De Sanchis dos $\dot{¿}$ ? salas de estar). Se trata de un forjado de unidireccional de 4,42 - 4,67 m de anchura por 5,74-5,89 $\mathrm{m}$ de longitud formado por seis vigas de madera de madera molduradas, cuatro de ellas centrales más otras dosmedias adosadas a los muros laterales, las centrales de sección $26 \times 28 \mathrm{~cm}$. Dispone de una moldura perimetral de madera enrasada con la cara inferior de las vigas y que circunda toda la sala de $22 \mathrm{~cm}$ de ancho por 16,5 cm de altura (ver Fig. 151 y 152). En los testeros se forma una falsa viga formada por dos tablas de madera con identicas molduras a las de las vigas, de manera que junto con las vigas laterales y las molduras enmarcan el todo el perimetro del techo. Las piezas de entrevigado son de escayola con perfil curvo (ver Fig. 152). Cada tramo de entrevigado está formado por tres piezas de igual medida. Están numeradas de la 1 a la 15 en el plano de planta. Aunque no se ha podido transcribir la leyenda de estas piezas, entendemos que estaban decoradas y de ahí su interés por numerarlas y recuperarlas.

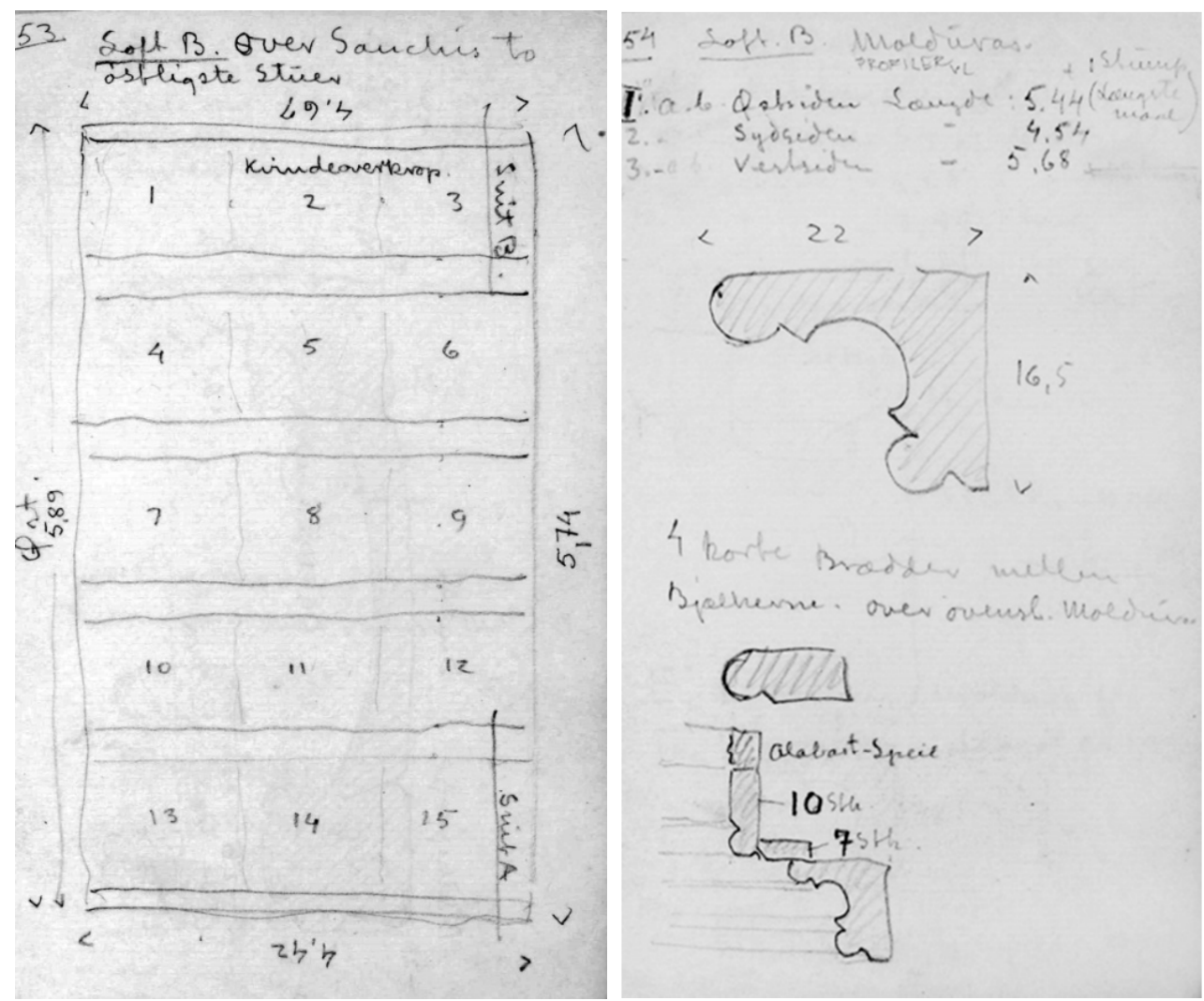

Figura 151. Izquierda: Panta Forjado B. Pág. 53. Derecha: Detalles molduras testeros Forjado b. Pág 54. Notebook I. Fuente: Egil Fischer.

\footnotetext{
${ }^{254}$ Fischer, E. (1919-1920). Óp. cit. pp. 13, 53, 53R y 54.
} 


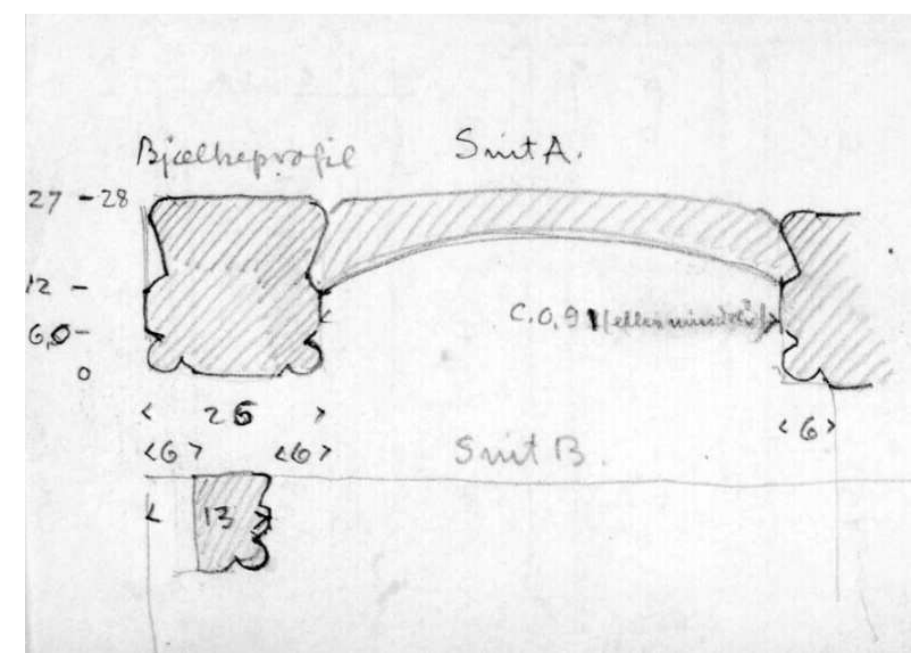

Figura 152. Secciones A y B. Forjado B. Notebook I. Pág. 53R. Fuente: Egil Fischer.

\section{Forjado o Techo C}

Se encuentra grafiado en el Notebook I, página $19^{255}$. Está rotulado como "Loft C.Maal paa molduras langs væggen under loftet i parentes" (Forjado C. Molduras a lo largo de la pared bajo las vigas del techo). Por su parte, en el lateral en vertical está rotulado "Sanchis bageste stuer" (Cuartos traseros de Miguel). En realidad en el croquis sólo se representa la planta de una sala rectancular con las coras de los cuatro lados y, bajo estas, otra medida entre paréntesis algo menor en algunos casos, que se entiende corresponde a la longitud existente de moldura a moldura (ver Fig. 153). En nuestra opinión, el objetivo de este croquis era el de inventariar la moldura existente en el perímetro de la sala bajo el forjado, ya que no hay información alguna sobre el mismo.

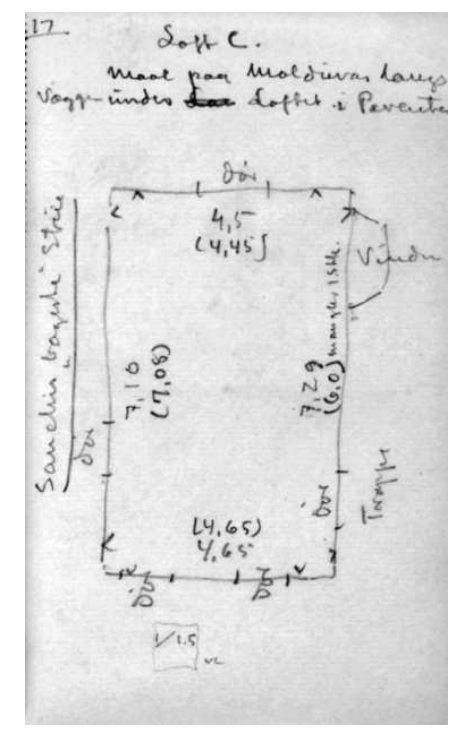

Figura 153. Croquis Forjado C. Pág 19. Notebook I. Fuente: Egil Fischer.

${ }^{255}$ Fischer, E. (1919-1920). Óp. cit. pp. 53. 


\section{Forjado D}

Se encuentra grafiado en el Notebook I, página $55^{256}$, rotulado como "Molduras fra loftet $D$. Sanchis bageste stuer" (Molduras del forjado D. Cuartos traseros de Sanchis) (ver Fig. 154). Detalla unas molduras perimetrales de un forjado similares a las del forjado $B$, aunque con distintas secciones. Están indicadas las longitudes de cada una de las piezas $(6,68 \mathrm{~m}, 3,95 \mathrm{~m}$ y $1,21 \mathrm{~m}$ ) del conjunto de tres piezas y una de $1,93 \mathrm{~m}$ de la moldura inferior. Sin duda se trataba de piezas sueltas recuperadas de un forjado incompleto, ya que no se detallan el resto de piezas que componían el forjado.

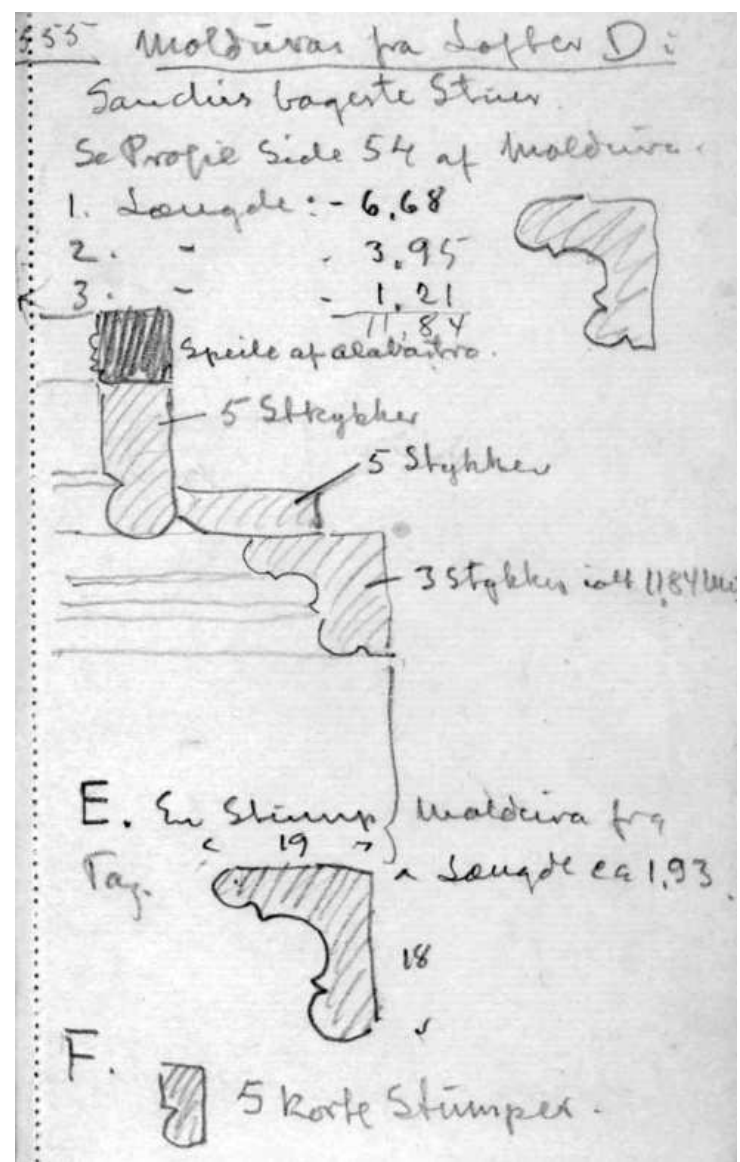

Figura 154. Croquis forjado D. Pág. 55 Notebook I. Fuente: E. Fischer.

\subsubsection{Forjados y artesonados. Planos}

\section{Forjado bajo Puerta}

Se encuentra grafiado en la Lámima LA $1110^{257}$. Se trata de una puesta a escala dibujada a grafito sobre una lámina de papel de dimensiones 470 × $680 \mathrm{~mm}$ en disposición vertical. Su

\footnotetext{
${ }^{256}$ Fischer, E. (1919-1920). Óp. cit. pp. 55.

${ }^{257}$ Fischer, E y/o Vilhelm, L. (1919-1920). Óp. cit. LA1110.
} 
escala de representación es 1:20. Está rotulado como "Loftet over porten" (Forjado sobre la puerta). En él se representa la planta cenital de un forjado unidireccional formado por 8 vigas transversales de ancho $34 \mathrm{~cm}$ y medias vigas en los testeros con una moldura inferior perimetral similar a la de los forjados A y B (ver fig. 155). Las dimensiones de la sala son $4,78 \times 10,74 \mathrm{~m}$. Por su referencia, podría tratarse del forjado inferior de la Sala 12 , situada sobre la puerta de acceso al Palacio.

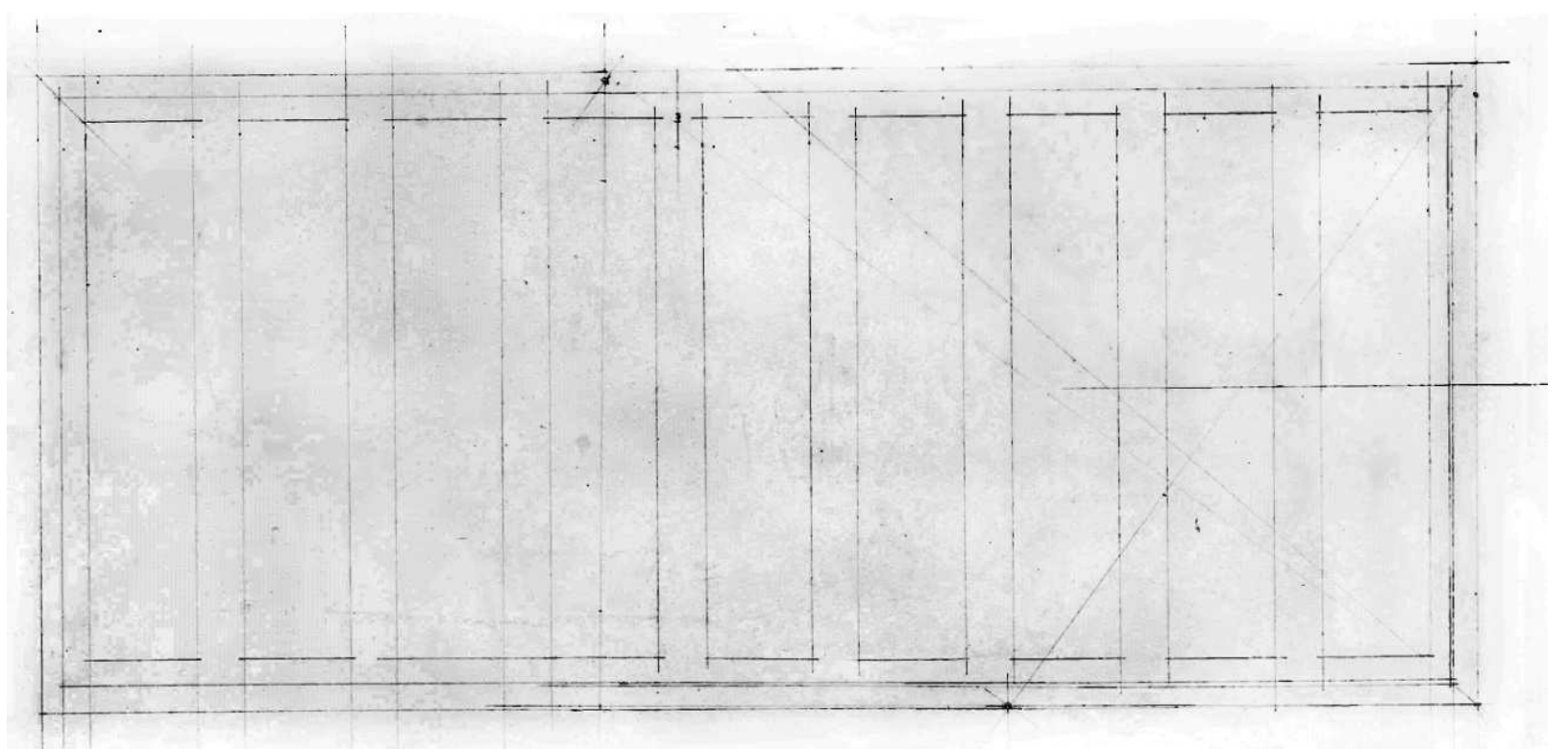

Figura 155. Plano Forjado bajo Puerta. LA1110. Fuente: Egil Fischer y/o E. Fischer

\section{Artesonado E}

Este artesonado corresponde a la Sala 11 de acuerdo con la numeración de Egil Fischer. Se trata de una de las salas nobles del Palacio, situada entre la sala 7, la galería del Patio, la sala 12 y recayente al patio Noreste del Palacio. Las dimensiones de la sala son 7,20 x 4,46 $\mathrm{m}$.

Disponemos de dos planos del artesonado (LA1113 y LA112 ${ }^{258}$ ) en los que aparecen rotulados el número de la sala, el nombre del artesonado y la escala: "Rum: 11. Loft E. Mall: 1:20". El primero de ellos es un plano a escala donde se representa una planta cenital, y una sección longitudinal y otra transversal de la sala. Está realizado a lápiz sobre papel sin marca. El segundo está dibujado a tinta sobre papel de calco. En él se representan las mismas vistas que en el primero, siendo sin duda una copia del mismo. Además, en el plano se enumeran todas y cada una de las piezas que forman el artesonado, sin duda con el objetivo de desmontarlo y volverlo a montar.

Por su parte, el artesonado está formado por 18 casetones cuadrados en retícula de $6 \times 3$. La estructura portante está formada por 7 vigas de sección cuadrada de $28 \times 28 \mathrm{~cm}$,

\footnotetext{
${ }^{258}$ Fischer, E. y Lauritzen V. (1917-1920). Planos. Oliva, Valencia: Museo Municipal de Oliva, Archivo Público Documental, Palacio Condal. LA 1112 y LA1113.
} 
numeradas de la I a la VII (ver Fig. 157) y apoyadas en los muros de mayor dimensión, tal y como podemos observar en el plano realizado por los arquitectos daneses.

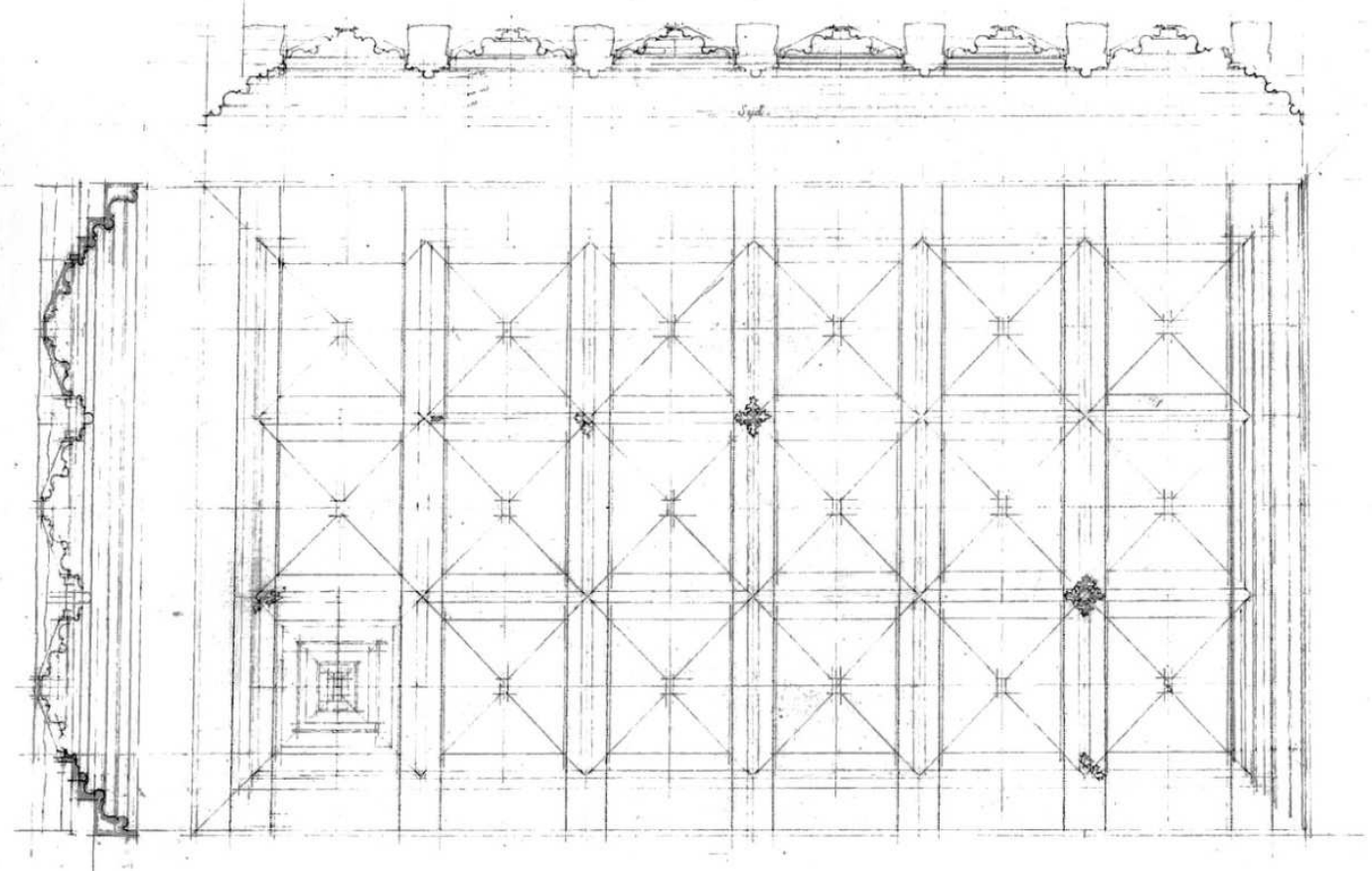

Figura 156. Artesonado E. Sala 11.Planta Cenital y secciones. LA1113. Fuente: Egil Fischer y Vilhelm Lauritzen.

Estas vigas se encuentran revestidas con una tabla decorada de sección $31 \times 8 \mathrm{~cm}$ que, junto con las colocadas perpendicularmente, forman la retícula inferior del artesonado. Estas piezas están cortadas a doble inglete en cada uno de sus extremos, interseccionando con el resto de piezas tanto longitudinal como transversalmente (numeradas de la E-1 a la E-45). Sobre esta retícula se apoyan los 18 casetones que forman el artesonado. Cada uno de ellos está formado, a su vez, por 9 piezas: 4 listones perimetrales de sección $5 \times 5 \mathrm{~cm}$ apoyados sobre la base, 4 tableros inclinados de sección $36 \times 10 \mathrm{~cm}$ que forman un tronco de pirámide y una pequeña pieza horizontal que cierra el tronco de pirámide. Cada una de las piezas está numerada con el siguiente criterio: E-1-I a E-1-V E. El primer número corresponde al número del casetón, numerados del 1 al 18 de abajo a arriba y de derecha a izquierda. Por su parte, el número romano corresponde a la pieza, siendo el I la pieza central, el II la orientada hacia el oeste. Además, y siguiendo el sentido de las agujas del reloj, la tabla trapezoidal y el listón contiguo comparten numeración ya que son piezas con diferente forma, fácilmente distinguibles. Por debajo de la cara inferior del artesonado, en el perímetro de la sala, se sitúan tres piezas que forman su moldura perimetral. De abajo a arriba está formado por un listón recto de apoyo de $4 \times 6 \mathrm{~cm}$, una primera pieza moldurada de $32 \times 21 \mathrm{~cm}$ de sección y, por último, una pieza moldurada de $20 \times 10 \mathrm{~cm}$. Sobre esta última pieza se apoyan las horizontales, que forman la base del artesonado. Cada una de estas molduras es de una sola pieza y están numeradas como E-101, E-201 y E-301, de arriba abajo las del lado oeste. El último dígito va cambiando en cada uno de los lados siguiendo el sentido de las agujas del reloj. En el encuentro de las piezas horizontales colgaba una pieza ornamental en forma de rosetón, tal y como apreciamos en el plano LA1113 (ver Fig. 156) sólo dos de ellas permanecían completas en el momento del levantamiento gráfico y tres de ellas parcialmente. 


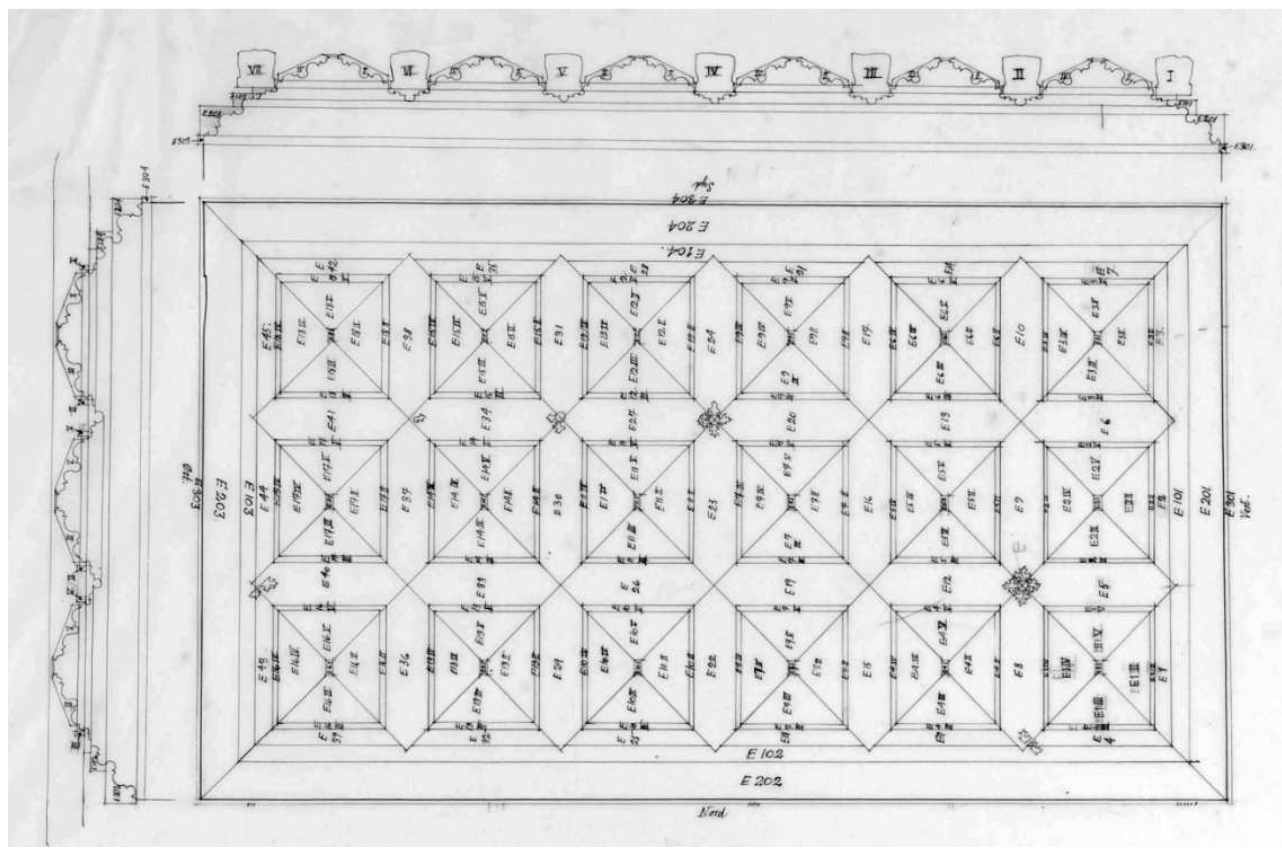

Figura 157. Artesonado E. Sala 11. Siglado de piezas. LA1112. Fuente: Egil Fischer y Vilhelm Lauritzen.

\section{Artesonado Sala 12}

Este artesonado corresponde a la Sala 12 de acuerdo con la numeración de Egil Fischer. En este caso no se le asigna una letra para identificarla. Se trata de una de las salas nobles del Palacio situada entre la sala 12 , la galería del Patio, la Sala de Armas y recayente al patio Noreste del Palacio. Las dimensiones de la sala son $12,04 \times 5,46 \mathrm{~m}$, siendo por sus dimensiones una de las más importantes del Palacio.

Disponemos de cuatro planos del artesonado (LA1114, LA1115, LA1116 y LA117 ${ }^{259}$ ) en los que aparecen rotulados el número de la sala. En uno de los planos se la denomina "Sal med Rhombeloft" (Sala con techo de rombos). En el LA1116 están representadas la planta cenital del artesonado y una sección longitudinal. La lámina está dibujada a grafito sobre papel sin marca. Por su parte, en el plano LA1114, realizado a tinta sobre papel de calco, se representan las mismas vistas que en el LA1116, siendo una copia del mismo. En él se enumeran todas y cada una de las piezas que forman el artesonado. En ambas láminas se puede observar como parte del artesonado ya había sido desmontado antes del levantamiento gráfico realizado por Fischer y Lauritzen.

Por último, la lámina LA1117 representa un plano para un posible montaje del artesonado en una sala de menor dimensión, ya que en ella aparecen las vigas grafiadas en el plano LA1114, eliminando el hueco entre la viga $\mathrm{V}$ y VI y colocando la viga VII en la posición de la $\checkmark$ (ver Fig. 158). Esta propuesta parece pretender diseñar un nuevo artesonado en el que se aprovecharían las piezas existentes para cubrir una sala sin necesidad de tenerse que fabricar las piezas que faltaban. En la LA1115 se representa, simplemente, el contorno de esta nueva sala con su geometría exacta formada por un rectángulo irregular y la posición de la ventana.

\footnotetext{
${ }^{259}$ Fischer, E. y Lauritzen V. (1917-1920). Planos. Oliva, Valencia: Museo Municipal de Oliva, Archivo Público Documental, Palacio Condal. LA 1114, LA1115.
} 


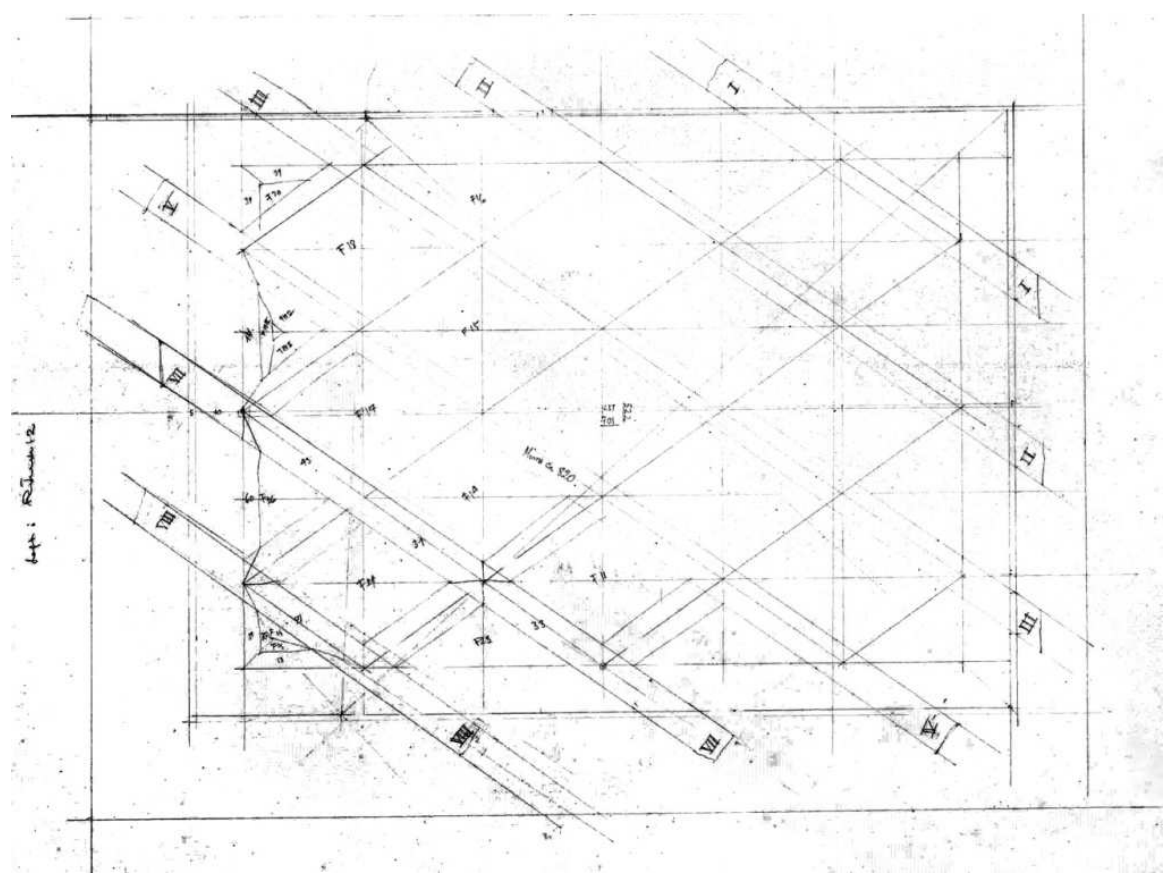

Figura 158. Artesonado Sala 12. Propuesta de montaje. LA1117. Fuente: Egil Fischer y Vilhelm Lauritzen.

El artesonado estaba formado originalmente por 23 casetones romboidales, 8 medios casetones triangulares (rombos cortados en sentido longitudinal), 4 triangulares (rombos cortados en sentido transversal) y 4 triangulares situados en las esquinas (corresponden con un cuarto del rombo). En los planos de Fischer se evidencia la falta de parte del artesonado cuando ellos lo documentan, quedando tan sólo 15 casetones romboidales, 6 medios triangulares longitudinales, 3 medios triangulares transversales y 3 triangulares de esquina. La estructura portante está formada por 8 vigas de sección cuadrada de $30 \times 30$ cm, numeradas de la I a la VIII (ver Fig. 160).

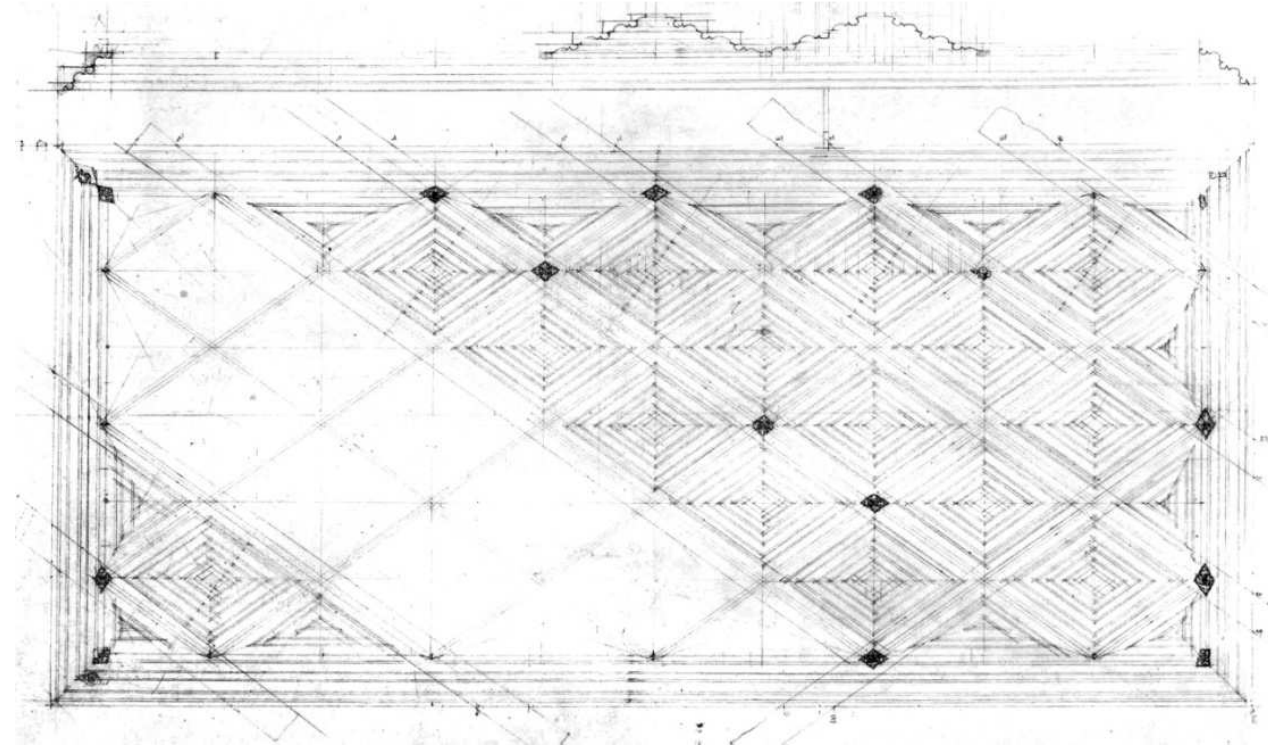

Figura 159. Artesonado Sala 12. Planta cenital y sección longitudinal. LA1116. Fuente: Egil Fischer y Vilhelm Lauritzen. 
Estas vigas se encuentran revestidas con una tabla decorada de sección $22 \times 15 \mathrm{~cm}$ en el caso de las piezas centrales, que junto con las colocadas en diagonal, forman la retícula inferior del artesonado. Estas piezas están cortadas a doble inglete en cada uno de sus extremos interseccionando con el resto de piezas tanto longitudinal como transversalmente (están numeradas de la 1 a la 60). Sobre esta retícula se apoyan los casetones que forman el artesonado. Cada uno de ellos está formado por 13 piezas: 12 tablas de sección $32 \times 7 \mathrm{~cm}$ y largo variable que van montando en horizontal en tres niveles formando un tronco de pirámide y una pequeña pieza horizontal que cierra en pirámide. Cada una de las piezas está numerada con el siguiente criterio: F1l a F26V. El primer número corresponde al número del casetón (numerados del 1 al 26 de abajo a arriba y de izquierda a derecha, según el Plano LA1115, saltando los casetones que faltan); el número romano al de la pieza (siendo el I la pieza central, el II la inferior izquierda de acuerdo con el plano, y el resto siguiendo el sentido de las agujas del reloj). Las tres tablas de un mismo lado tienen la misma numeración ya que son piezas con diferente largo fácilmente distinguibles. Por debajo de la cara inferior del artesonado en el perímetro de la sala se sitúan tres piezas que forman la moldura perimetral del artesonado. De abajo a arriba está formado por un listón moldurado de apoyo de $7 \times 3,5 \mathrm{~cm}$, una primera pieza moldurada de $17 \times 7,4 \mathrm{~cm}$ de sección y, por último, una pieza moldurada de $12 \times 6,7 \mathrm{~cm}$. Precisamente sobre esta pieza se apoyan las piezas horizontales que forman la base del artesonado. Cada una de estas molduras es de una sola pieza en el lado corto y dos piezas en el lado largo, empalmadas en pico de flauta, y están numeradas como 101 a 106, 201 a 206 y 301 a 306. El primer dígito corresponde al nivel comenzando de arriba a abajo y el último al orden de acuerdo con el numerado en el plano LA1115. En el encuentro de las piezas horizontales colgaban unas piezas ornamentales en forma de rosetón, tal y como apreciamos en el plano LA1116 (ver fig. 159). 12 de ellas permanecían completas en el momento del levantamiento gráfico.

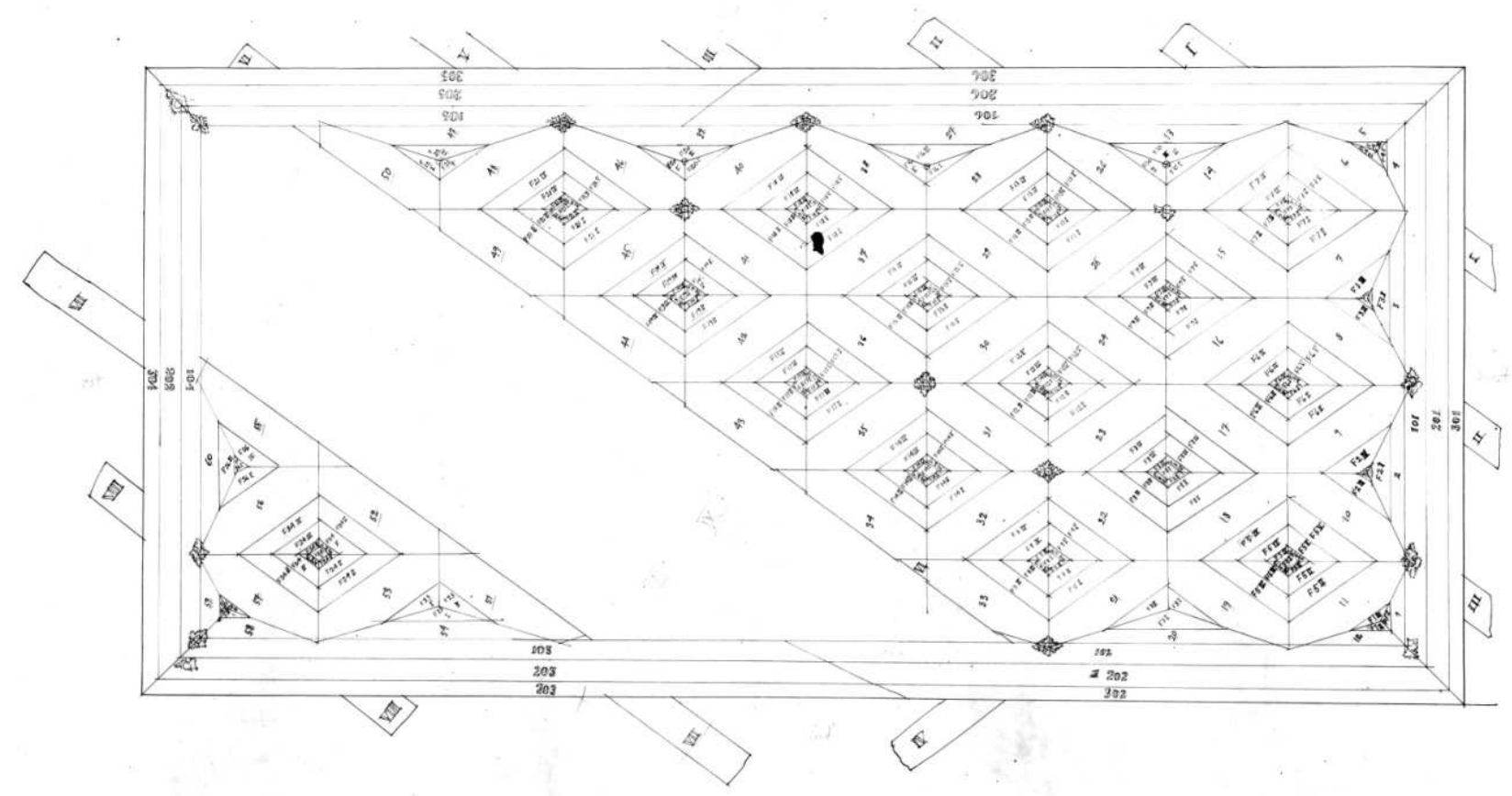

Figura 160. Artesonado Sala 12. Planta cenital y sección longitudinal. LA1115. Fuente: Egil Fischer y Vilhelm Lauritzen. 


\section{Forjado Sala 16}

La Sala 16 se encuentra situada en la esquina Este del Palacio. Junto a una de las torres semicirculares, limita con las fachadas noreste y sureste del Palacio y con las salas 15 y 17. Es una sala de planta trapezoidal de dimensiones 4,32 $\mathrm{m}$ de ancho y largo variable de 4,25 a $5,25 \mathrm{~m}$. Por su parte, la documentación gráfica disponible son los planos LA1121 y LA1122, y el croquis de la página 30 del Notebook II. La LA1121 representa un plano cenital del forjado, una sección longitudinal y dos transversales. Está dibujado a grafito sobre papel sin marca de dimensiones 680 × $470 \mathrm{~mm}$. La escala de representación es 1:20 y el texto que aparece es el siguiente: "Rum 16. Loft" (Sala 16. Techo). La LA1121 es una copia dela anterior. Está dibujada a grafito sobre papel de calco y tiene unas dimensiones máximas de 660 x $460 \mathrm{~mm}$. La lámina se encuentra rasgada y falta una parte. El texto es el mismo que el de la lámina anterior.

La página 30 del Notebook I contiene un croquis acotado del forjado con la distribución de vigas y los siguientes textos: "Værelse 16. Vefiht? male loft. Højde tilbjælkeender4,68. Vindue siddeplads (Kabinet loft)". Sala 16. ¿'? (Techo pintado. Altura hasta la cara de la viga 4,68. Ventana con asiento ${ }^{260}$ (Techo del gabinete).

Se trata de un forjado de viguetas de madera apoyadas en dos de los muros. Son lisas en su cara inferior y presentan una moldura redondeada o baqueta en sus esquinas. El ancho de las viguetas es de $20 \mathrm{~cm}$, y el entrevigado es de revoltón y tiene una anchura de $70 \mathrm{~cm}$. Perimetralmente la sala posee una moldura por debajo de la cara de las viguetas de $18 \mathrm{~cm}$ de ancho y $11 \mathrm{~cm}$ de alto, aunque no tenemos documentación que lo avale. Por el diseño parece ser de madera como las viguetas (ver fig. 161).

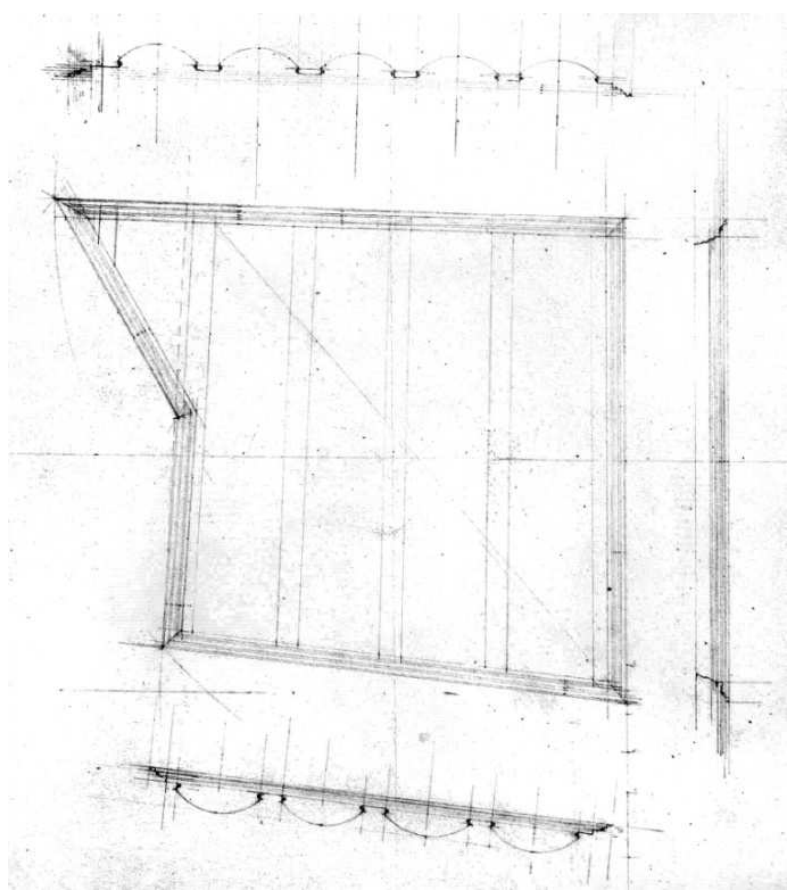

Figura 161. Forjado Sala 16. Planta cenital y secciones. LA1122. Fuente: Egil Fischer y Vilhelm Lauritzen.

\footnotetext{
${ }^{260}$ El término Vindue siddeplads (ventana con asientos) nos indica que se trata de una ventana con festejaors, tal y como se evidencia en el plano de la ventana 8 a la cual corresponde esta leyenda.
} 
Tal y como nos indica el texto que acompaña el croquis, el forjado se encontraba pintado. En base a esta información y a la disposición de las viguetas podemos deducir que el forjado de la fotografía 46 se corresponde con el forjado de la sala 16 (ver fig. 162).
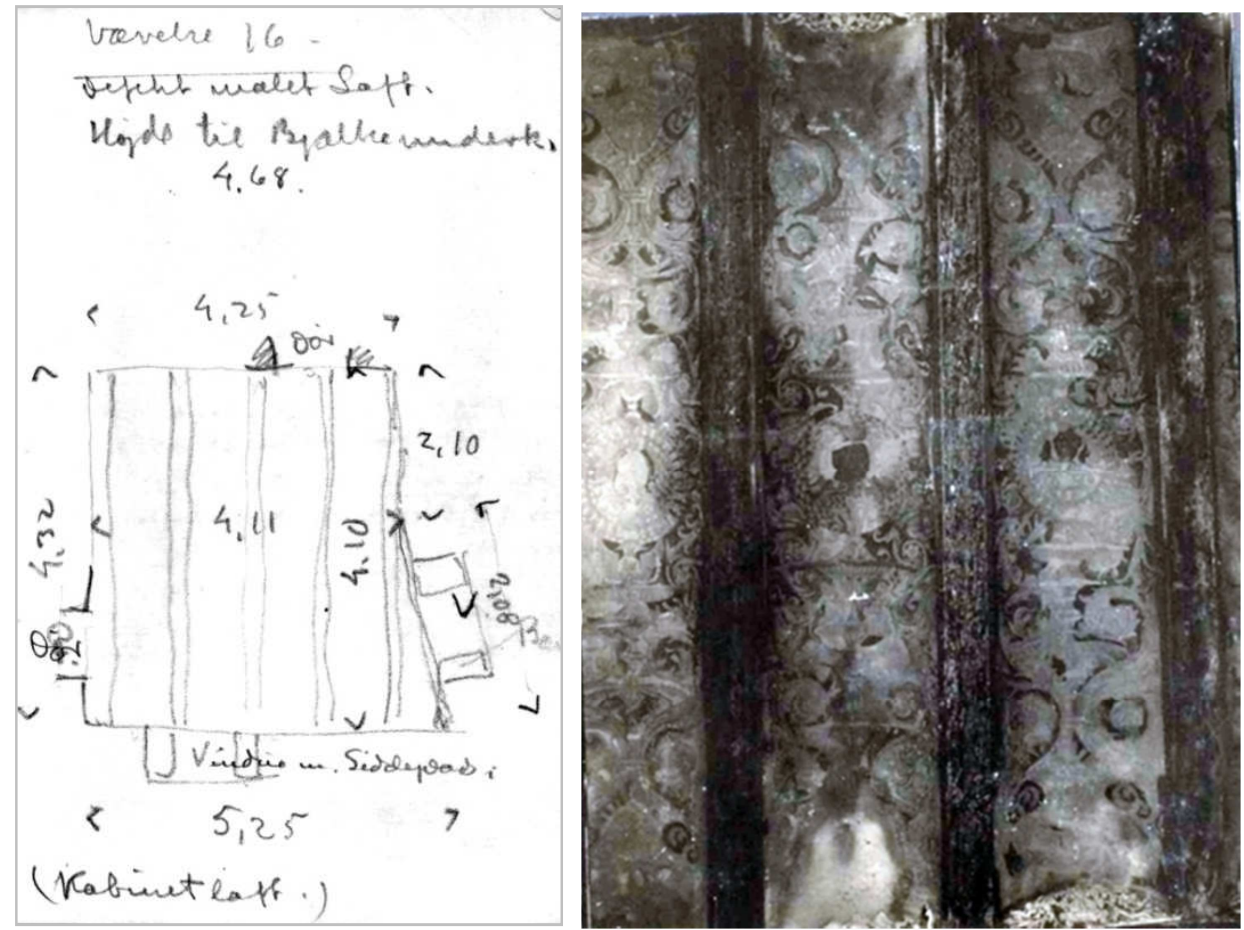

Figura 162.Izquierda: croquis forjado Sala 16. Pág. 30 Notebook II. Derecha: fotografía 46. Álbum Fot. Grande. Fuente: Egil Fischer.

\section{Forjado Sala 18}

La Sala 18 o Sala de Armas se encontraba situada entre las salas 13 y 7 en su lado norte, la Sala 12 en su lado oeste, la galería 19 en su cara sur y la fachada este del Palacio. Es una sala de planta rectangular de dimensiones 7,05 y $7,15 \mathrm{~m}$ de ancho y 8,75 y $8,87 \mathrm{~m}$ de largo (ver Fig. 163). La documentación gráfica disponible de la sala es el plano LA1111, el croquis de la página 31 del Notebook II y las fotografías 19, 20, 21, 22, 26 y 27 del Álbum Fotográfico Grande. Algunas de estas fotografías se encuentran también en el Álbum Fotográfico Pequeño.

La LA1111 representa una vista cenital del forjado. Está dibujada a grafito sobre papel sin marca y posee unas dimensiones $680 \times 470 \mathrm{~mm}$. La escala de representación es 1:20 y el texto reza lo siguiente: "Loft $i$ Vaabensalen. Rum 18"261 (Techo en Sala de Armas Sala 18).

La página 31 del Notebook // contiene un croquis acotado del forjado de la planta de la sala y la posición de huecos en la misma y los siguientes textos: "Sala de Armas. 18. Skab. Den gotihc? (sic, gothic) Sal." (Sala de Armas. 18. Armario. Sala gótica). Además, los cuatro lados de la sala y las diagonales están acotados.

261 "Loft i Vaabensalen" está rotulado entre líneas, probablemente por Lauritzen. "Rum 1" parece escrito por Fischer a posteriori. 

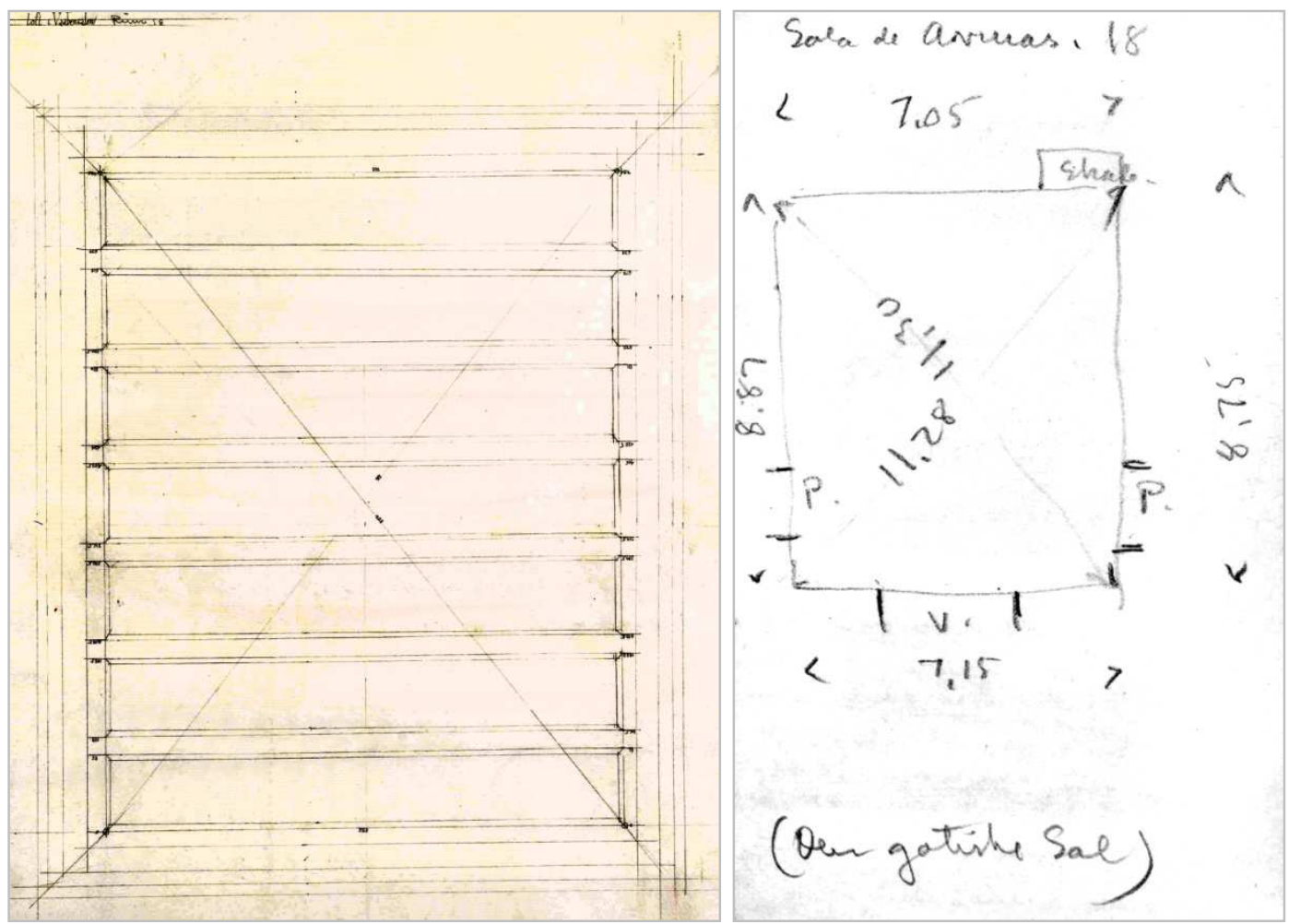

Figura 163. Izquierda: Plano forjado 18. LA1111. E. Fischer y V. Lauritzen. Derecha: croquis Sala 18. Notebook II. Pág. 31. Fuente: Egil Fischer.

Las fotografías 19, 20, 21, 22, 26 y 27 del Álbum Fotográfico Grande nos muestran diversas vistas del forjado de la Sala de Armas y su friso (ver Fig. 164, 165 y 166).

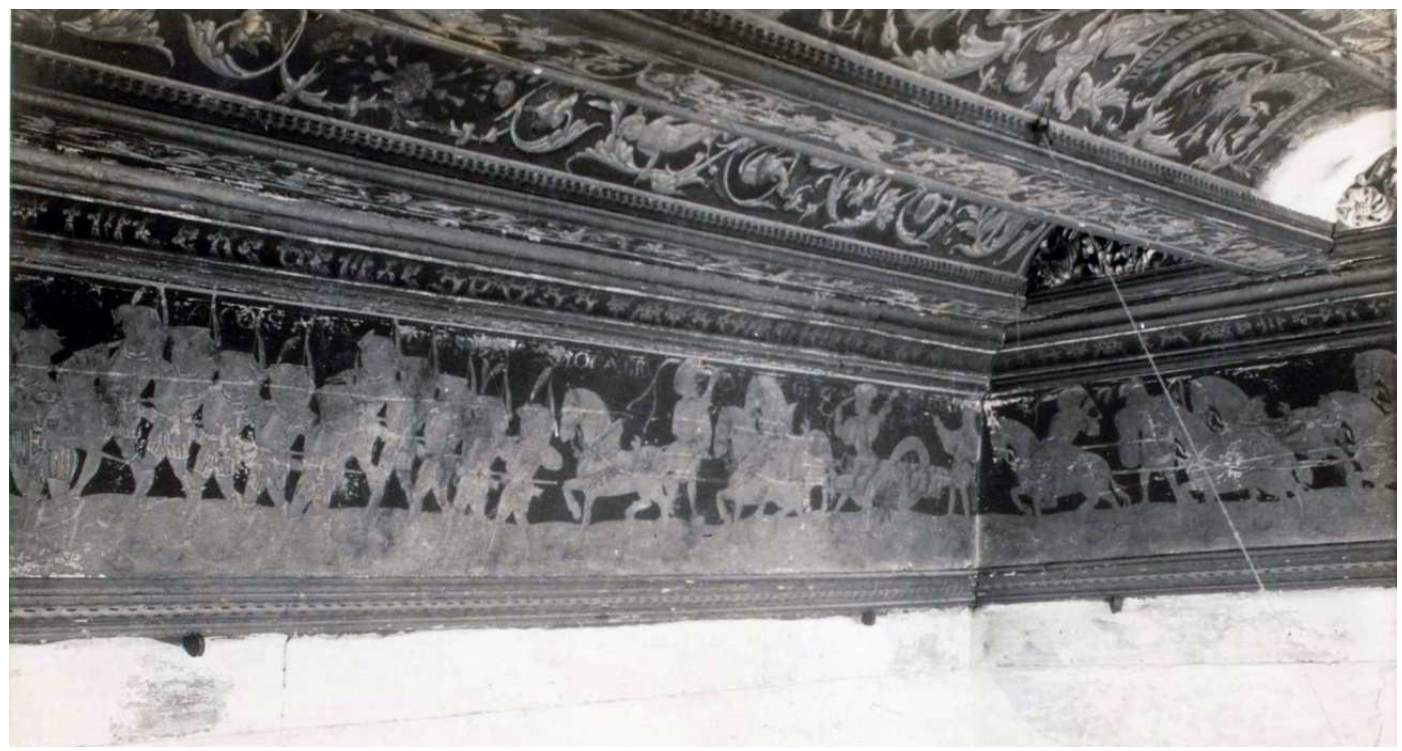

Figura 164. Fotografía 19. Vista de del forjado y friso de la Sala de Armas. Álbum Fot. Grande. Fuente: Egil Fischer. 


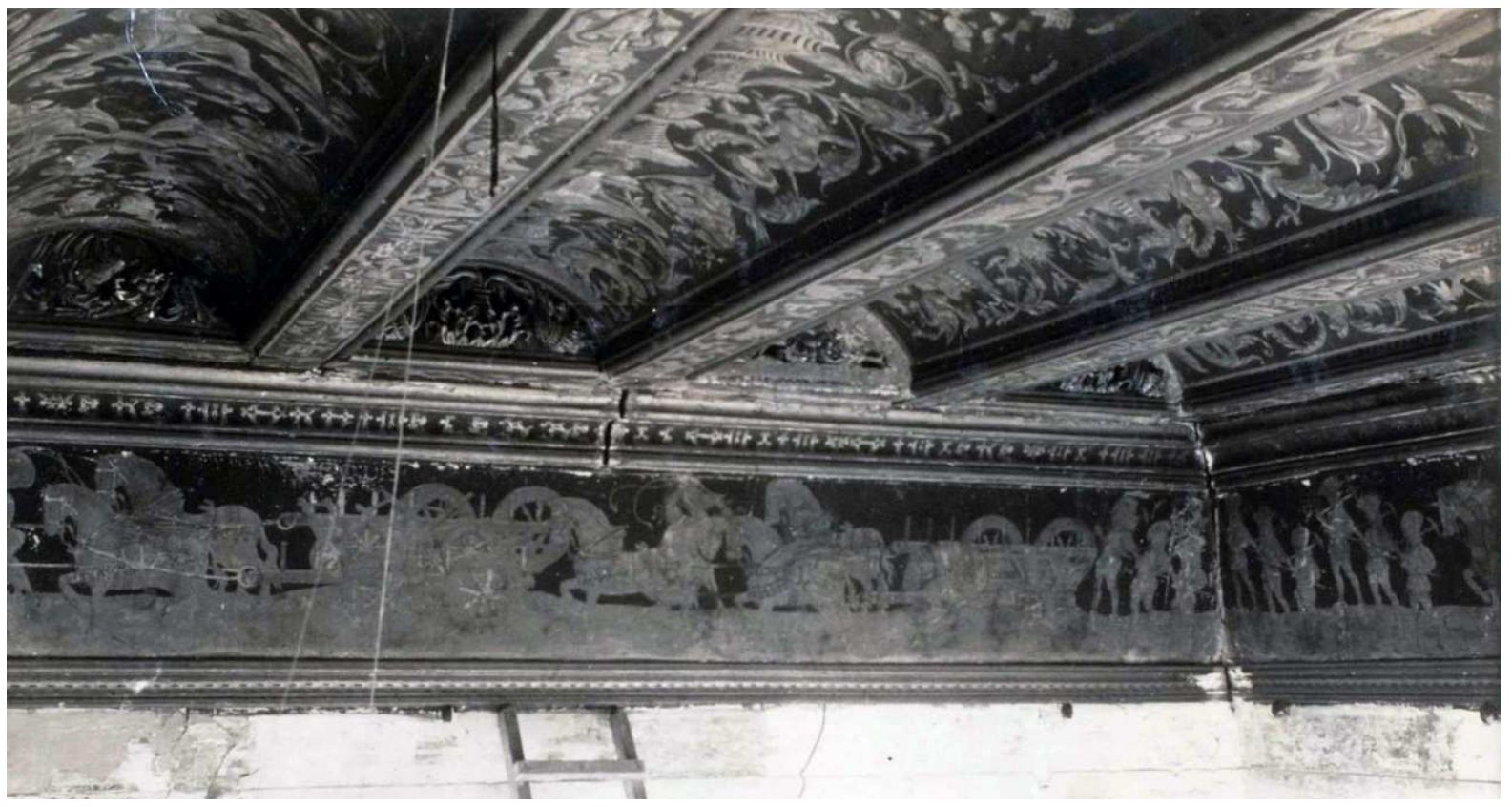

Figura 165. Fotografía 20. Vista del forjado y friso de la Sala de Armas. Álbum Fot. Grande. Fuente: Egil Fischer.

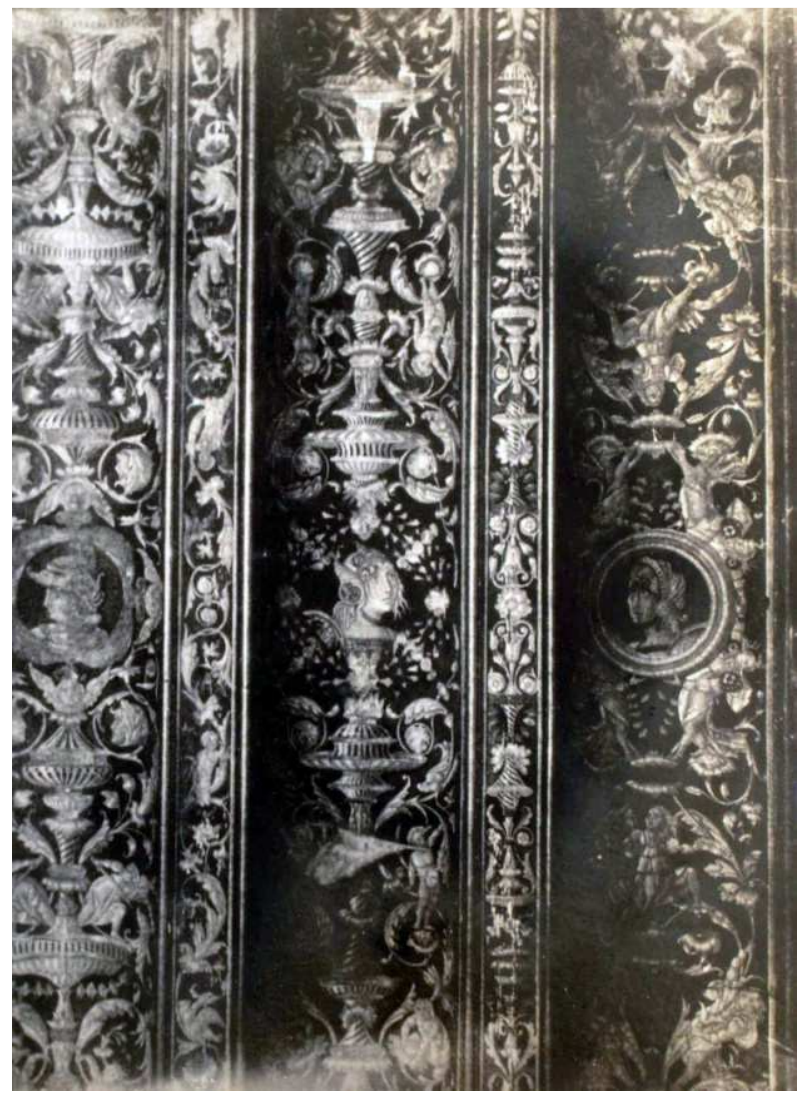

Figura 166. Fotografía 26. Vista cenital del forjado de la Sala de Armas. Álbum Fot. Grande. Fuente: Egil Fischer. 
El forjado de la Sala de Armas era, por su riqueza ornamental, el elemento más singular del Palacio, tal y como atestiguan todos los testimonios que tenemos de las personas que visitaron el Palacio cuando este aún estaba en pie. El forjado estaba formado por 8 vigas de $32 \mathrm{~cm}$, lisas, con extremos con moldura curva o baqueta y policromadas con motivos florales renacentistas. El entrevigado, por su parte, estaba formado por 7 revoltones lisos de $80 \mathrm{~cm}$ de anchura, policromados con rica ornamentación renacentista: elementos en jarra, medallones con figuras de guerreros, puttis y ornamentación vegetal. En los extremos de los revoltones se situaban tablas de $27 \mathrm{~cm}$ de anchura formando un marco perimetral junto con las dos vigas extremas. Cerrando los lunetos, entre estas tablas horizontales y los revoltones, se situaban placas de escayola en relieve decoradas. Bajo las vigas y piezas laterales se localizaba una moldura perimetral de $22 \mathrm{~cm}$ de ancho que podía ser de madera o escayola y que, al igual que el resto del forjado, se encontraba policromada y decorada. Por debajo de esta moldura se estaba el friso decorado de $70 \mathrm{~cm}$ de altura y apoyado sobre una moldura inferior.

\subsection{Bóvedas}

Entre la documentación gráfica elaborada por los arquitectos daneses encontramos cuatro bóvedas que cubrían cuatro de las salas de la planta noble del Palacio, con unas características geométricas y compositivas muy diferentes entre sí.

\section{Bóveda Sala 13. Capilla}

La sala 13 o Capilla se encontraba situada entre las salas 14 y 15 en su lado norte, la sala 17 en su lado este, las salas 12 y 18 en su cara sur, y la fachada el patio norte del Palacio en su lado oeste. Es una sala de planta rectangular de dimensiones 2,25 y 3,30 $\mathrm{m}$ de ancho y 7,14 y 7,20 m de largo (ver Fig. 168).

La documentación gráfica disponible de esta sala son el plano LA1118, el croquis de la página 27 del Notebook II y las fotografías 56, 57, 58 y 59 del Álbum de Fotos Grande. La LA1118 representa una vista cenital de la bóveda, una sección transversal, el alzado de las molduras longitudinales y dos detalles de los casetones que forman la bóveda. Está dibujada a grafito sobre papel sin marca de dimensiones $680 \times 470 \mathrm{~mm}$. Su escala de representación es 1:20 y el texto que aparece es el siguiente: "Rum 13 Loft" ${ }^{262}$ (Sala 13. Techo) (ver Fig. 167). Por su parte, la página 27 del Notebook I/ contiene un croquis acotado de la planta cenital de la bóveda y la posición de huecos en la misma, así como una sección vertical con los siguientes textos: "Værelse 13. Capilla. meget defekt (Trapperium? el Bàd?). cassetteloft" (Sala 13. Capilla. Muy deteriorado (Hueco de escalera? el baño?) artesonado).

Las fotografías $56,57,58$ y 59 contienen imágenes de la bóveda y detalles de la misma tanto en su posición original como una vez desmontados.

\footnotetext{
262 "Loft i Vaabensalen" está rotulado entre líneas, probablemente por Lauritzen. "Rum 1" parece escrito por Fischer a posteriori.
} 


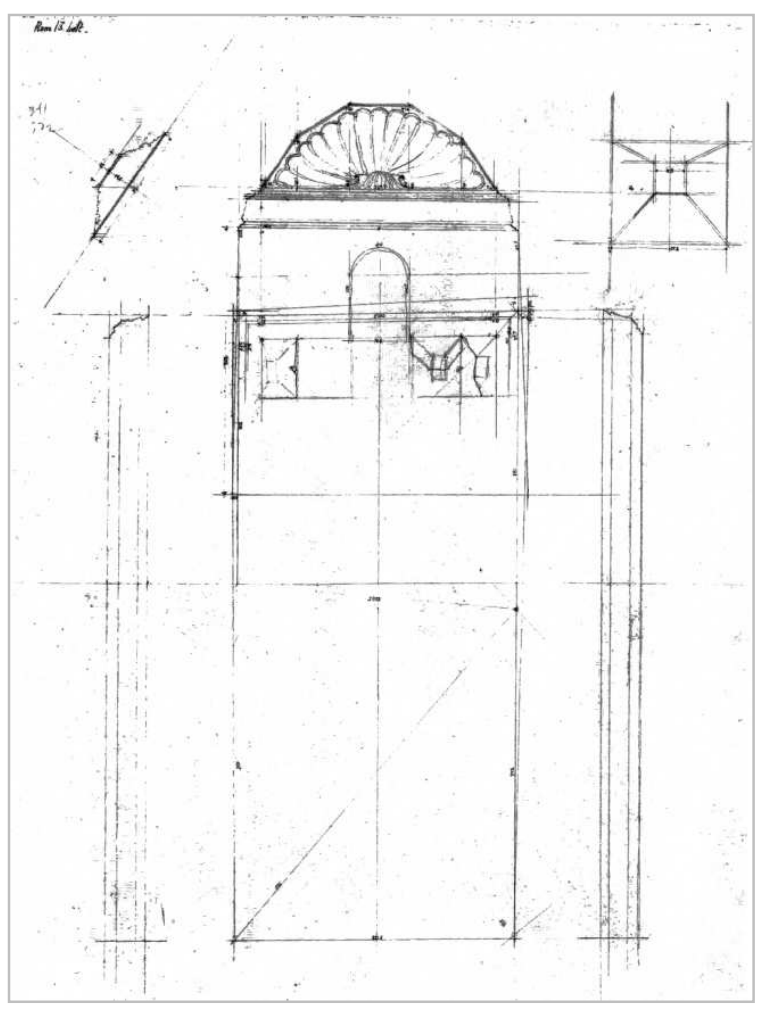

Figura 167. Plano Bóveda Sala 13. Planta sección y detalles. LA1118. Fuente: E. Fischer y V. Lauritzen.

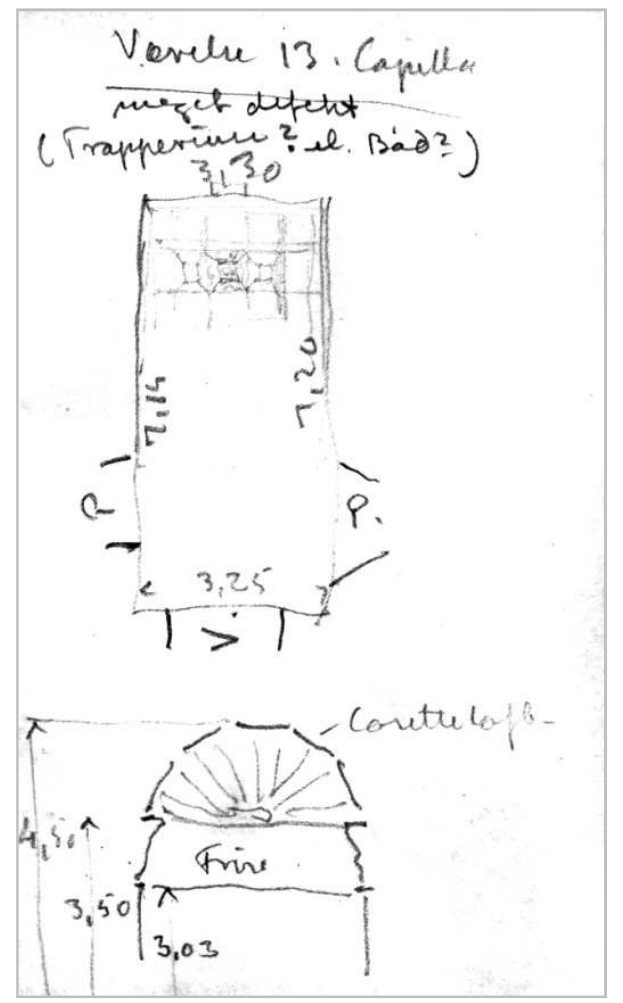

Figura 168. Croquis bóveda Sala 13. Pág. 27. Notebook II. Fuente: Egil Fischer. 
La bóveda de la sala 13 o Capilla es de cañón con decoración renacentista. Tal y como recogen las fotografías y los dibujos de Fischer y Lauritzen se encontraba en muy mal estado en el momento en que documentaron el Palacio, quedando sólo algunos elementos in situ. La estructura de la bóveda, tal y como podemos observar en la Fot. 58 (ver Fig. 169), estaba formada por una bóveda de cañón apuntada realizada con fábrica de ladrillo colocados verticalmente como dovelas. Bajo esta bóveda estructural se sustentaba colgada de la misma una bóveda rebajada poligonal formada transversalmente por cinco casetones en tronco de pirámide realizados con placas de escayola en relieve con motivos renacentistas. Cada casetón estaba formado por una pieza cuadrada tangente a la directriz de la bóveda y cuatro trapecios iguales. La Fot. 58 y el plano correspondiente (ver Fig. 169) ponen de manifiesto que sólo uno de los casetones se encontraba completo y dos más incompletos. Asimismo, en los testeros de la bóveda aparece un frontón de escayola con forma de concha (al parecer sólo se encontraba in situ el del testero norte de la bóveda). En el perímetro de la sala y bajo la bóveda aparece un friso en relieve moldeado en escayola con motivos renacentistas, tal y como podemos observar en las fotografías 56 y 58 (ver fig. 169) con un medallón central con el busto de un guerrero flanqueado por dos esfinges aladas con cuerpo de animal y cabeza humana y, a sus lados, hojas de acanto y elementos florales que creaban simetría con la pieza contigua. La pieza central del friso tenía una altura de $22 \mathrm{~cm}$ y se completaba con una moldura inferior y otra superior con una altura total del friso de $47 \mathrm{~cm}$.
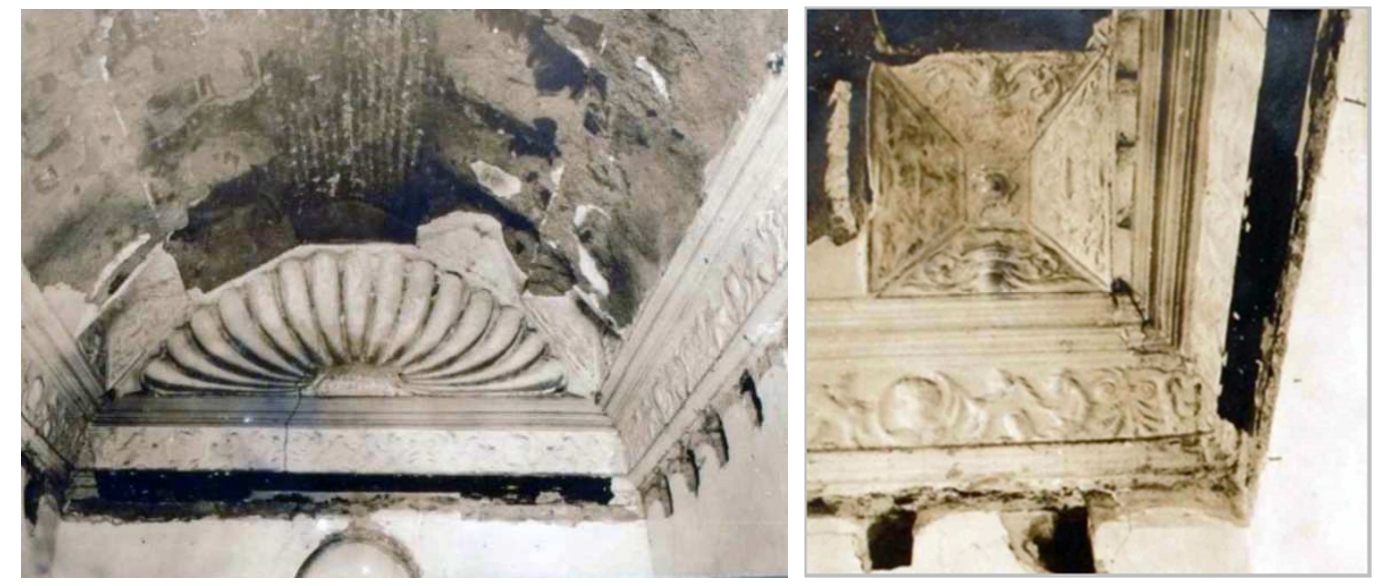

Figura 169. Fotografías bóveda sala 13. Izquierda: Fot. 58. Vista general. Derecha: Fot. 56. Detalle casetón. Álbum Fot. Grande. Fuente: Egil Fischer.

\section{Bóveda Sala 15}

La sala 15 o Capilla se encontraba situada entre la fachada norte del Palacio, la sala 16 en su lado este, la sala 13 en su cara sur y la sala 14 en su lado oeste. Es una sala de planta casi cuadrangular de lados irregulares y de dimensiones 3,50 y 3,75 $\mathrm{m}$ de ancho y 4,35 y 4,17 m de largo (ver Fig. 170). La documentación gráfica disponible de la sala son los planos LA1118 y LA1120, el croquis de la página 28 del Notebook Il y las fotografía 51 del Álbum de Fotos Grande.

La LA1120 representa una planta cenital de la bóveda, una sección transversal, cortando por la clave, y el alzado de los otros arcos perpiaños que no se visualizan en la sección. Está dibujada a grafito sobre papel sin marca y posee unas dimensiones de $680 \times 470 \mathrm{~mm}$, en 
disposición vertical. Su escala de representación es 1:20 y el texto "Rum 15 Loft" (Sala 17. Techo) (ver Fig. 171) Están acotadas tanto en planta como en altura todas las piezas que forman los arcos, formeros y cruceros. En el centro está dibujada la gran clave central con el escudo de armas de los Centelles.

La lámina LA1119 es una copia de la LA1120. Está dibujada a grafito sobre papel de calco de dimensiones $873 \times 470 \mathrm{~mm}$, en disposición vertical. En ella están sigladas con letras las piezas de la cornisa, de la "a" a la " $\mathrm{t}$ " (en uno de los lados sólo está siglada una pieza, la " $\mathrm{t}$ "). Las piezas de los arcos formeros también están numeradas de la 1 a la 20; en este caso están numeradas todas las piezas, y la regularidad de su tamaño indica que cada una de ellas se corresponde con una dovela real. No están siglados los arcos cruceros, ni las ménsulas de arranque de los mismos ni la clave (ver Fig. 171).

Por su parte, la página 26 del Notebook I/ contiene un croquis acotado del forjado de la planta cenital de la bóveda y la posición de huecos en la misma, así como una sección vertical con los siguientes textos: "Værelse 15 medhvælving (Værelse paa i Sal) ornamenter paa i graterne" (Sala 15 con bóveda (Sala en el piso) ornamento en los nervios) (ver Fig. 170).

La fotografía 60 contiene una vista del arranque de uno de los nervios centrales de la bóveda y dos de los nervios laterales desde una ménsula en esquina que arranca del muro (ver Fig. 172). Los nervios que formaban los arcos estaban decorados en forma de guirnaldas. Bajo la ménsula de arranque de los nervios se observa la moldura perimetral que contorneaba la estancia.

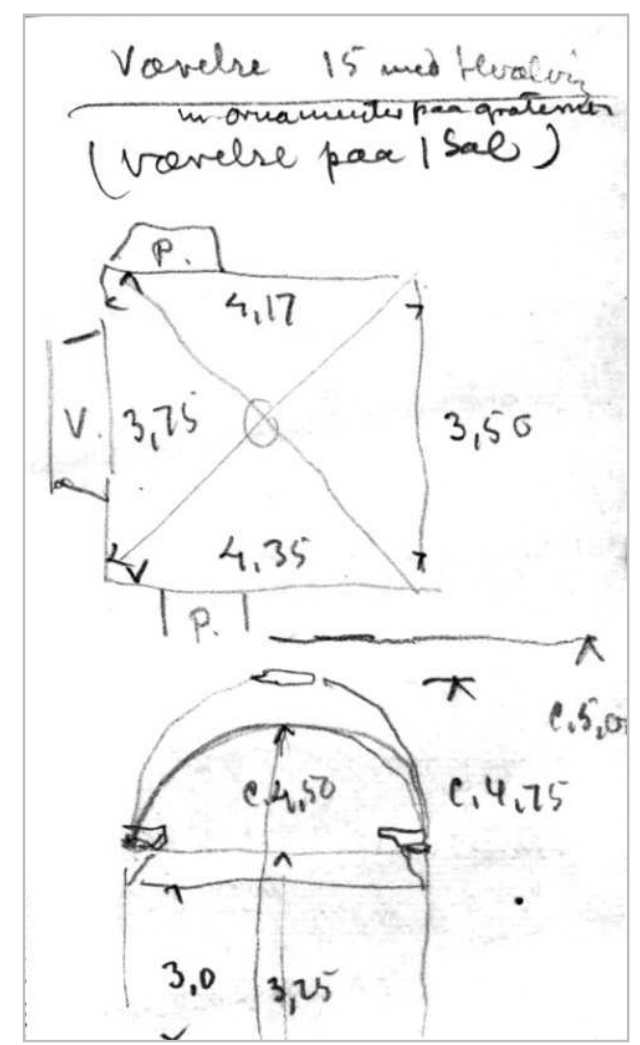

Figura 170. Croquis bóveda sala 15. Pág. 26. Notebook II. Fuente: Egil Fischer. 

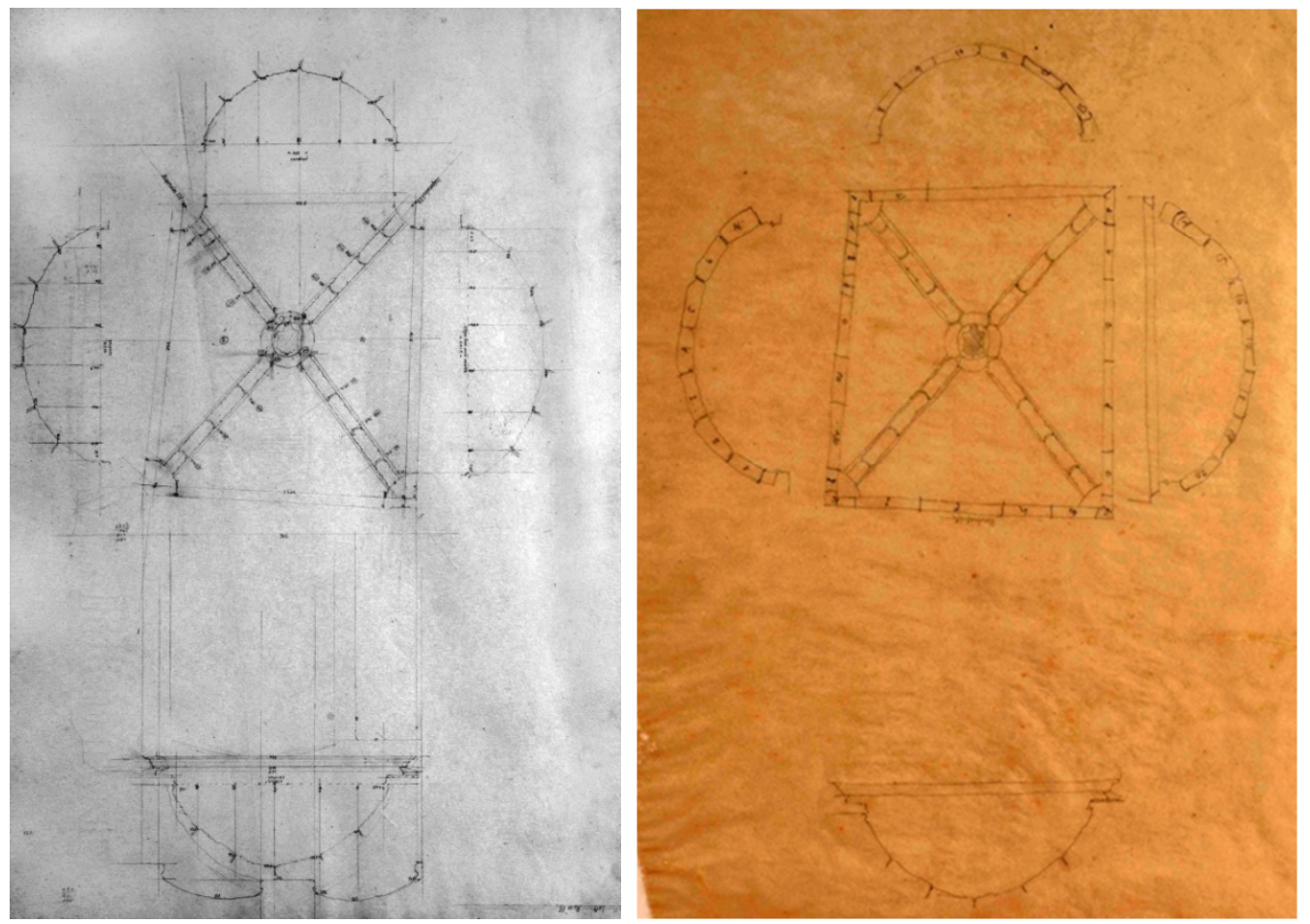

Figura 171. Planos Bóveda sala 15. Izquierda: LA1120. Derecha: LA1119. Fuente: E. Fischer y/o V. Lauritzen.

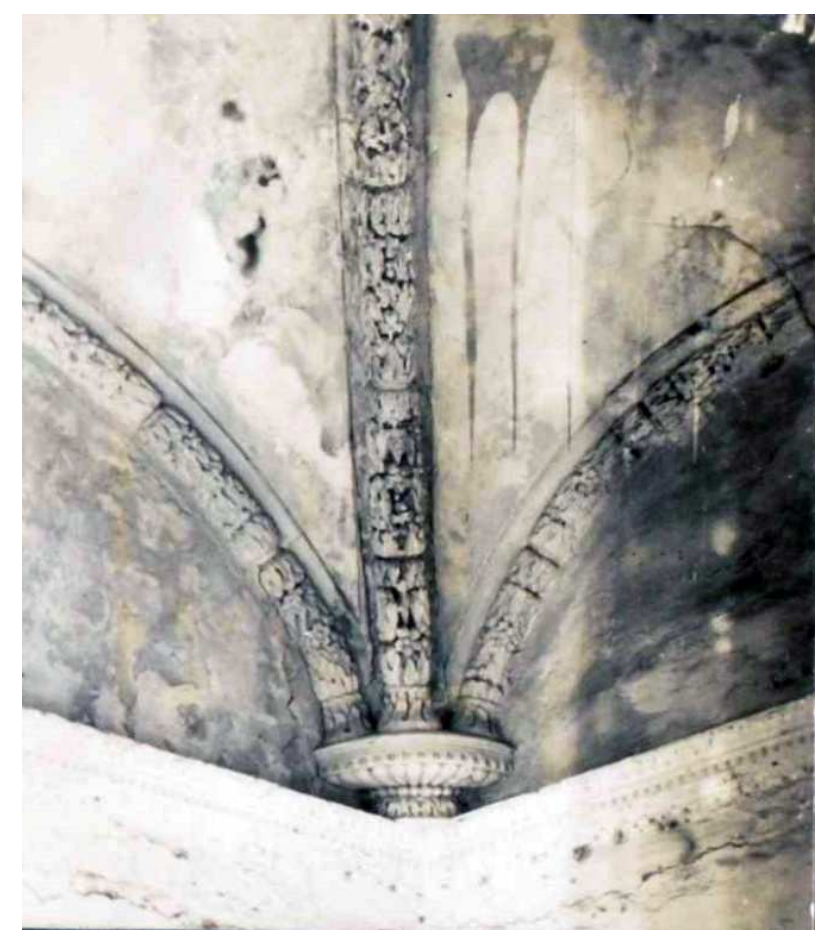

Figura 172. Arranque de los nervios de la bóveda de la Sala 15. Fot. 51. Álbum Fot. Grande. Fuente: Egil Fischer. 


\section{Bóveda Sala 17}

La sala 17 se encontraba situada entre la sala 16 en su lado norte, la fachada este del Palacio, la sala 18 en su lado sur, y la sala 13 su lado oeste. Es una sala de planta cuadrangular irregular de dimensiones 3,93 y $4,00 \mathrm{~m}$ en un sentido y 3,80 y $4,25 \mathrm{~m}$ en el otro. La documentación gráfica disponible de la sala son los planos LA1123 y LA1124, el croquis de la página 28 del Notebook II y las fotografías 49 y 50 del Álbum de Fotos Grande.

La LA1124 representa una planta cenital de la bóveda, dos secciones transversales en cada uno de los sentidos, el alzado de los arcos perpiaños y el trazado del arco crucero. Está dibujada a grafito sobre papel sin marca y posee unas dimensiones de $680 \times 470 \mathrm{~mm}$. La escala de representación es 1:20 y el texto "Rum 17 Loft" (Sala 17. Techo) (ver Fig. 175). Por su parte, la LA1123 es una copia del plano anterior y está dibujada a grafito sobre papel de calco de dimensiones $660 \times 460 \mathrm{~mm}$ con bordes irregulares y se ha perdido un fragmento.

La página 28 del Notebook // contiene un croquis acotado del forjado de la planta cenital de la bóveda y la posición de huecos en la sala y una sección vertical con las alturas de la cornisa y del arco formero y aparece el siguiente texto: "Værelse 17:Stjerneklar hvælving og pendel vipmalade overhalhed. (Loft til i Sal)" (Sala 17: Bóveda estrellada e inclinación del techo pintada ¿?. Techo de la sala) (Ver Fig. 173).

Las fotografías 49 y 50 no contienen una vista cenital de la bóveda ni el arranque de los nervios de la bóveda desde una de sus esquinas, respectivamente. Podemos observar las claves decoradas con un escudo. De las cinco claves de la bóveda, dos se encuentran completas, dos se encuentran incompletas (entre ellas la clave central) y una ha desaparecido. La bóveda se encontraba decorada, aunque la pintura estaba en mal estado y no se puede apreciar bien su decoración (ver Fig. 174).

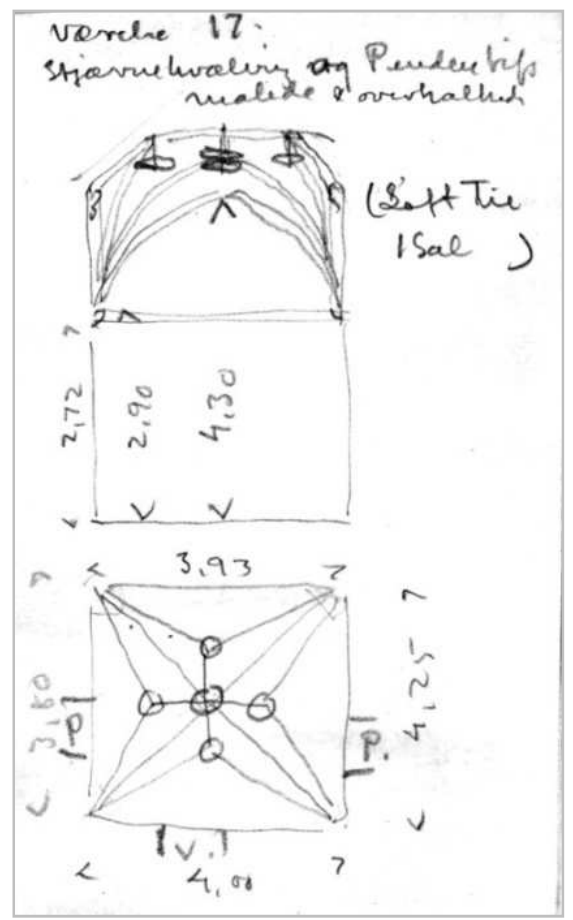

Figura 173. Croquis bóveda sala 17. Pág. 28. Notebook II. Fuente: Egil Fischer. 

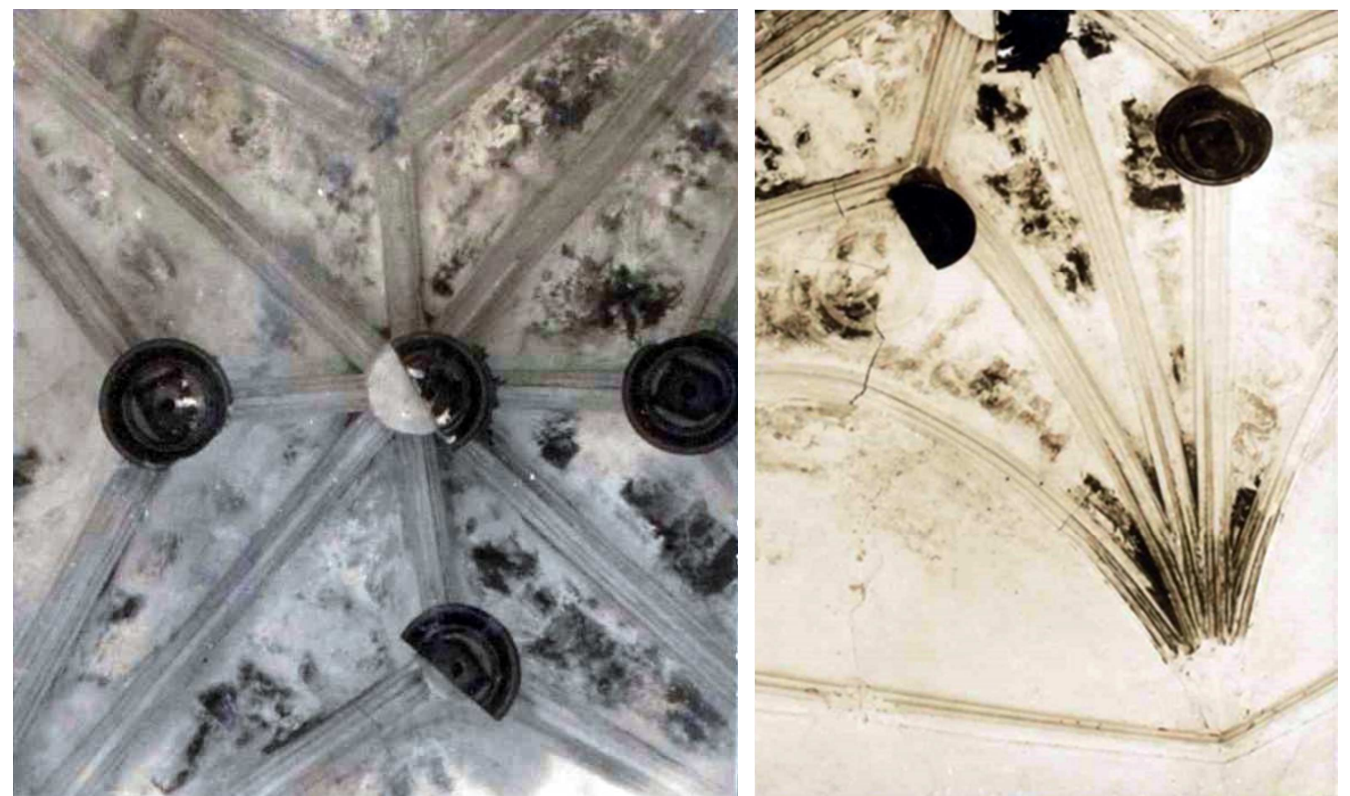

Figura 174. Izquierda: Fot. 49. Vista cenital. Derecha: Fot. 50. Vista del arranque de nervios de una de las esquinas. Bóveda Sala 17. Álbum Fot. Grande. Fuente: Egil Fischer.

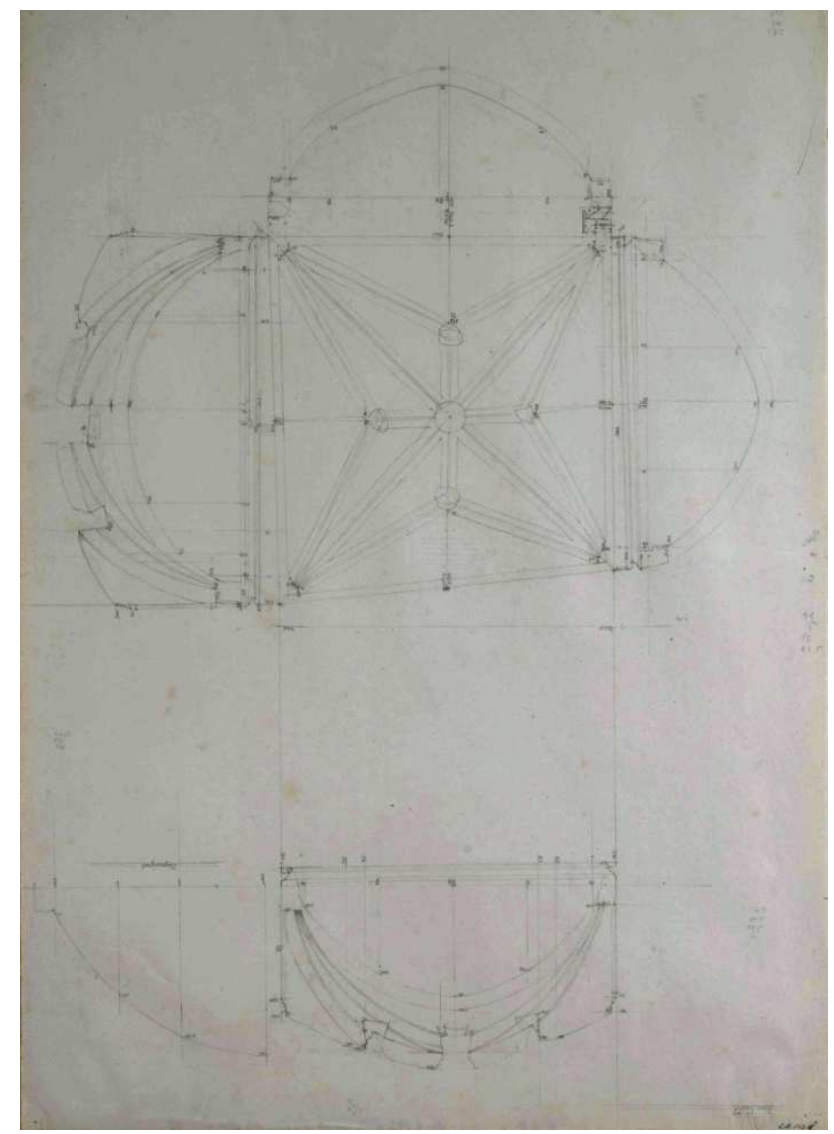

Figura 175. Plano Bóveda sala 17. Planta y secciones. LA1124. Fuente: E. Fischer y V. Lauritzen. 


\section{Bóveda Sala 19}

La sala 19 o Galería se encontraba situada a la salida de la sala 18 , con la que limitaba en su lado norte, la fachada este del Palacio, el patio este del Palacio en su lado sur, y la sala 20 en su lado oeste, desde la cual tenía acceso. Se trata de una sala de planta rectangular con una bóveda de dimensiones 166,3 × 165,5 cm de largo por 124,8 x $157 \mathrm{~cm}$ de ancho. Se encontraba en uno de los extremos de la galería (junto a la sala 20). La documentación gráfica disponible de la bóveda son los planos LA1125 y LA1126, las fotografías 54 y 55 del Álbum de Fotos Grande y la fotografía 54.1 del Álbum de Fotos Pequeño.

La LA1126 representa una planta cenital de la bóveda, una sección longitudinal y el alzado de los dos arcos perpiaños laterales. Está dibujada a grafito sobre papel sin marca y posee unas dimensiones de $680 \times 470 \mathrm{~mm}$. La escala de representación es 1:20 y el texto "Rum 19 Loft" (Sala 19. Techo) (ver Fig. 176).

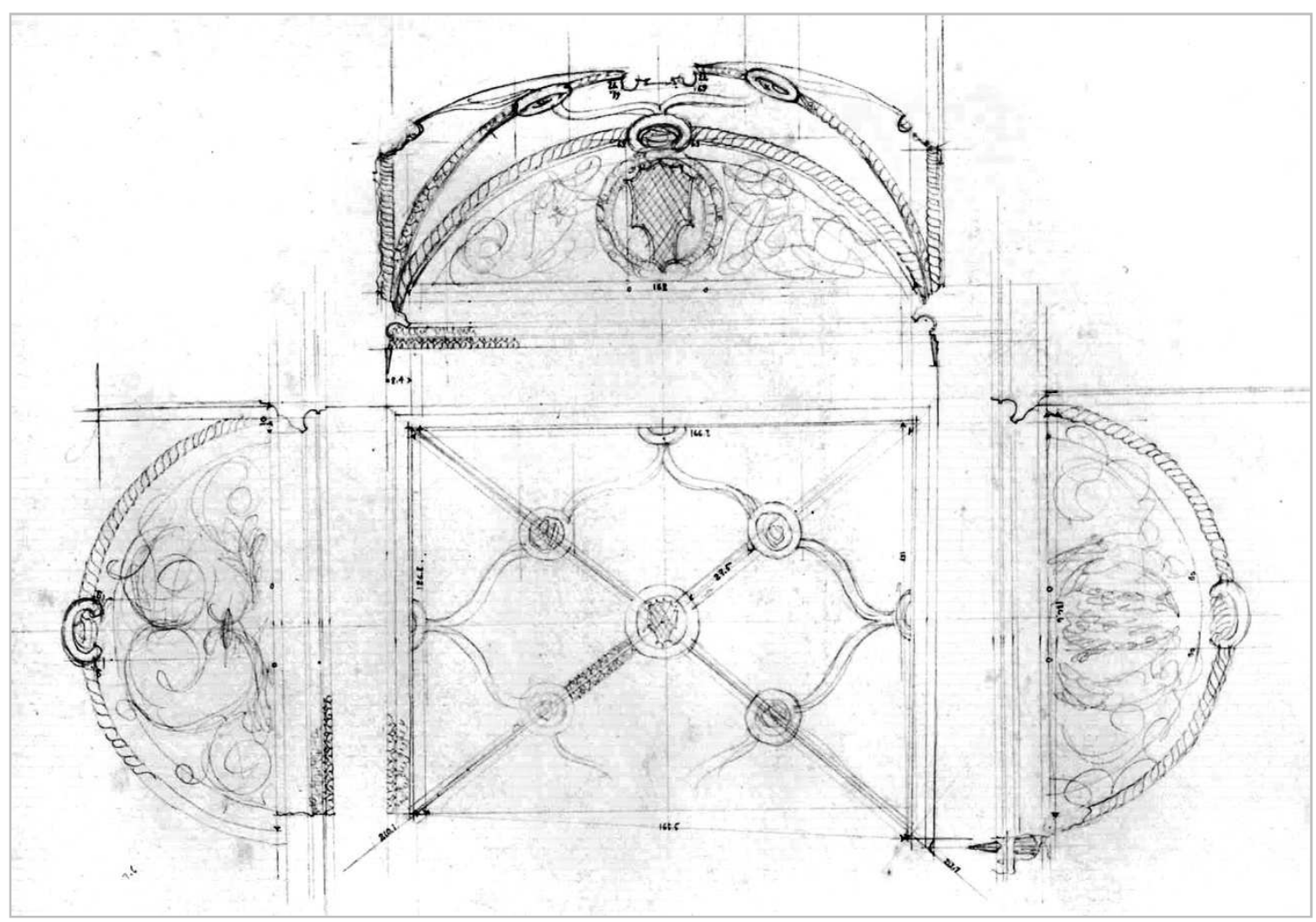

Figura 176. Plano Bóveda sala 19. Planta, sección y alzado. LA1126. Fuente: E. Fischer y V. Lauritzen.

La lámina LA1125 es una copia del plano anterior y está dibujada a grafito sobre papel de calco de dimensiones 663 × $480 \mathrm{~mm}$. Sobre la planta, sección y alzados se encuentran sigladas las piezas irregulares desmontadas de dicha bóveda: las piezas 1 y 2 corresponden al friso bajo el tímpano derecho, las piezas 4, 5 y 6 corresponden al tímpano frontal, la pieza 7 corresponde al frontal derecho y las piezas 8 a 13 corresponden a parte de la bóveda. De acuerdo con este despiece, parte de la bóveda no puedo recuperarse o ya no existía en el momento de su desmontaje (ver Fig. 177). 


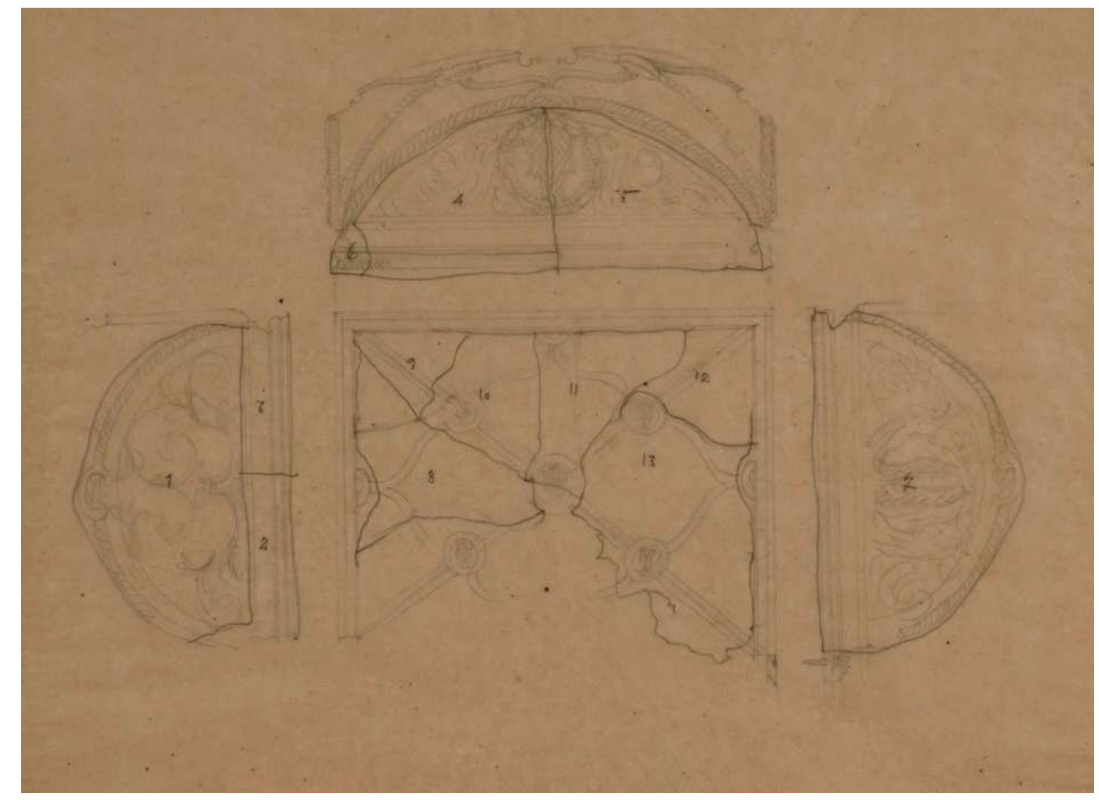

Figura 177. Plano Bóveda sala 19. Siglado de piezas. LA1125. Fuente: E. Fischer y V. Lauritzen.

La fotografía 54 nos muestra una vista cenital de la bóveda donde podemos observar su trazado, el diseño de sus nervios y claves, y la decoración en bajorrelieve de la plementería. En la fotografía se puede observar también en uno de los tímpanos el escudo de los Centelles sustentado por dos ángeles (ver Fig. 178). En la fotografía 55 se observa uno de los tímpanos laterales, ya desmontado, en el que están esculpidos en relieve dos querubines con túnicas situados simétricamente y sustentando dos grandes macollas. En la parte inferior se ven los restos de la cornisa decorada con elementos geométricos y, contorneando el tímpano, el arco formero con una directriz sogueada (ver Fig. 179).

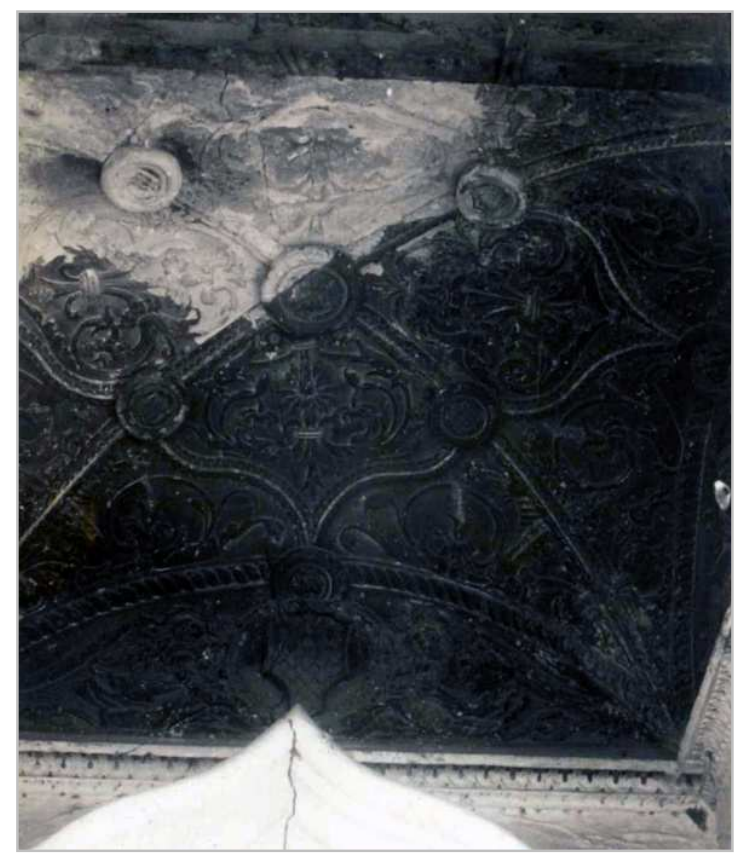

Figura 178. Fot. 54. Vista cenital bóveda Sala 19. Álbum Fot. Grande. Fuente: Egil Fischer. 


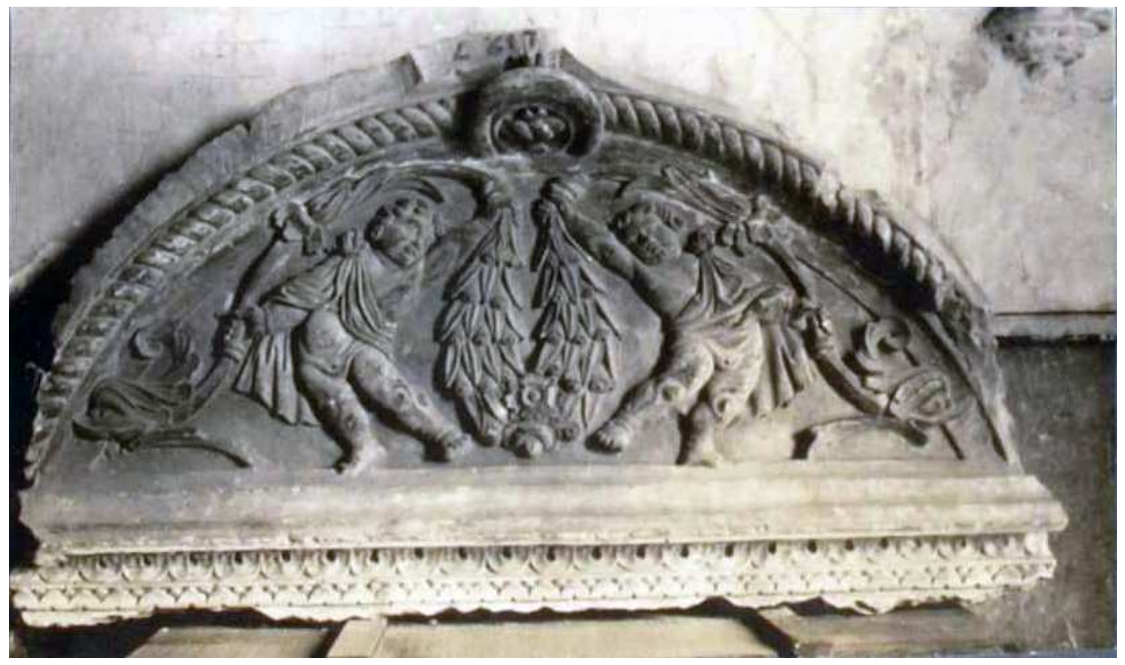

Figura 179. Fot. 55. Tímpano derecho bóveda Sala 19. Álbum Fot. Grande. Fuente: Egil Fischer.

\subsection{Galería Patio}

Otro de los elementos arquitectónicos mejor documentados del Palacio es la Galería del Patio. Esta Galería en forma de $L$ se encontraba en el piso principal del patio central del Palacio y estaba formada por una serie de arcos ojivales sobre columnas de mármol blanco. Sobre dicha Galería se encontraba otra, adintelada y apoyada sobre una balaustrada de mármol blanco. La documentación de que disponemos al respecto es la siguiente: planos LA1128 y LA1129, fotografías 10 a 18 del Álbum Fotográfico Grande, fotografías 14 , 15, $16.1,17,17.1,18$ y 18.1 del Álbum Fotográfico Pequeño y páginas 1, 2, 15, 20, 22 a 33, 42 a 48 y 50 del Notebook $l$.

- Plano LA1129: en él está grafiado el alzado, la planta y la sección vertical de la arcada norte de la Galería del Patio. Está a escala 1:20 y dibujado con tinta negra y grafito sobre papel sin marca. Sus dimensiones son 467 x $676 \mathrm{~mm}$ (ver Fig. 180).

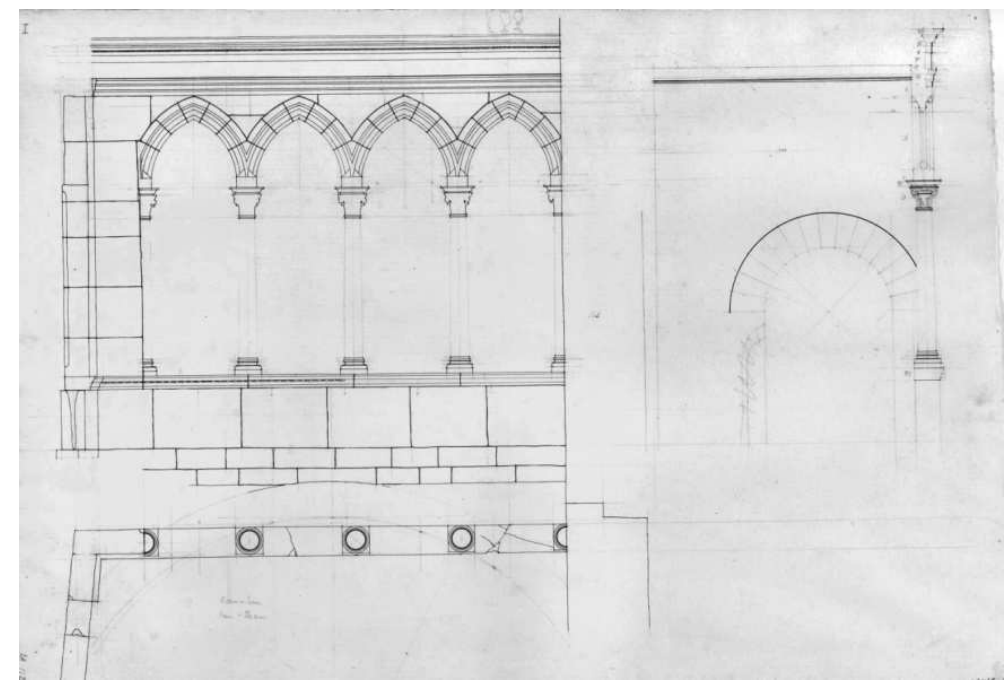

Figura 180. Plano Arcada Norte Galería Patio. LA1129. Fuente: E. Fischer y V. Lauritzen. 
- Plano LA1128: se trata de una copia del plano LA1129 y está realizado con tinta negra y grafito sobre papel de calco de dimensiones $495 \times 673 \mathrm{~mm}$. Sobre este plano se han numerado cada uno de los sillares y las columnas que forman el conjunto (ver Fig. 181).

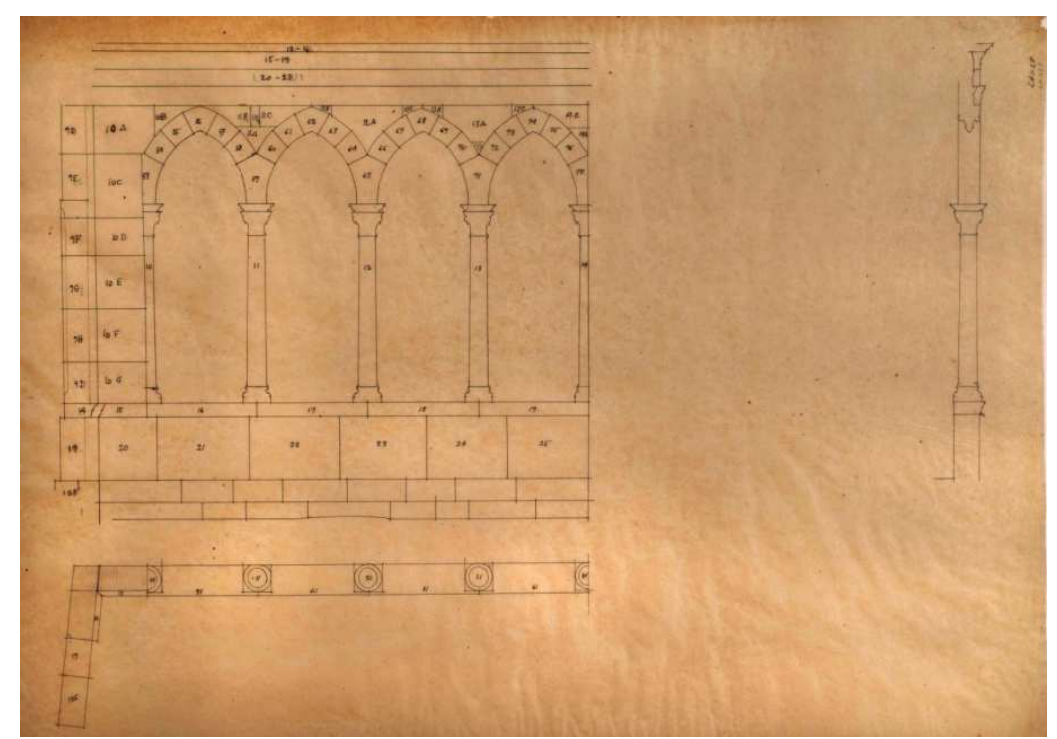

Figura 181. Despiece Arcada Norte Galería Patio. LA1129.

Fuente: E. Fischer y V. Lauritzen.

Las fotografías 10 a 18 del Álbum Fotográfico Grande y las fotografías 14 , 15, 16.1, 17, 17.1, 18 y 18.1 del Álbum Fotográfico Pequeño nos muestran las dos galerías del Patio del Palacio tanto desde el interior como desde el exterior (ver Fig. 182 y 183). Las fotografías han sido tomadas en diversos momentos del proceso de "deconstrucción" del Palacio, por lo que en algunas se puede observar la cubierta de la galería superior ya desmontada o cómo se han desmontado los cerramientos que cegaban parte de la arcada.
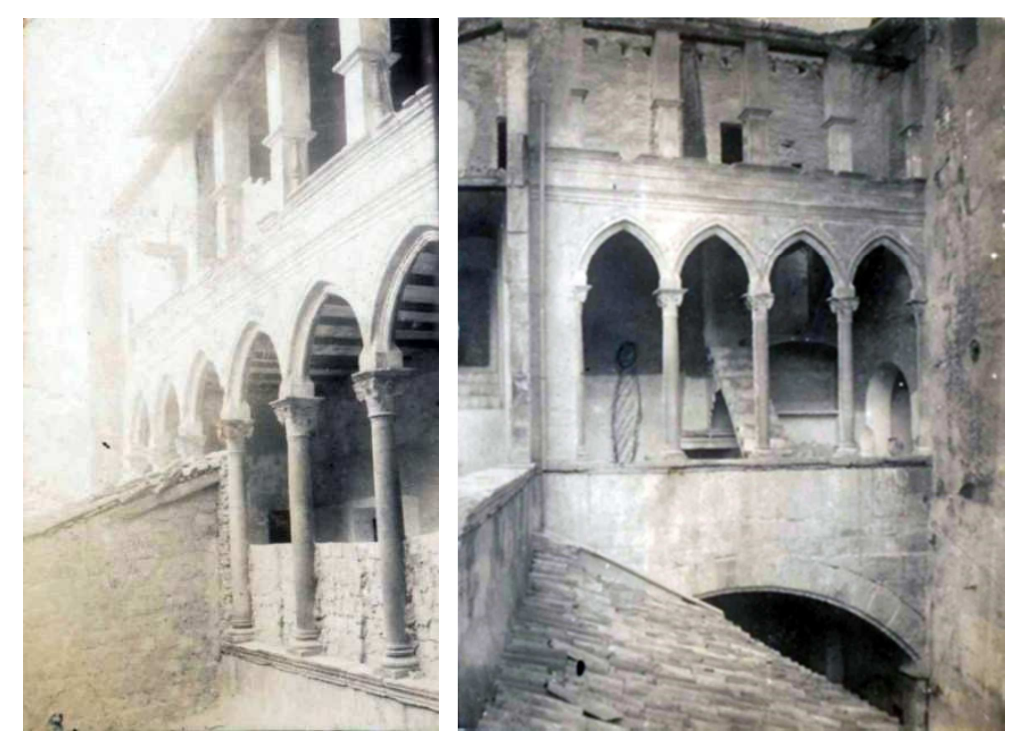

Figura 182. Izquierda: Fot. 10. Galería Oeste Patio. Derecha: Fot. 14. Galería Norte Patio Álbum Fot. Grande. Fuente: Egil Fischer. 

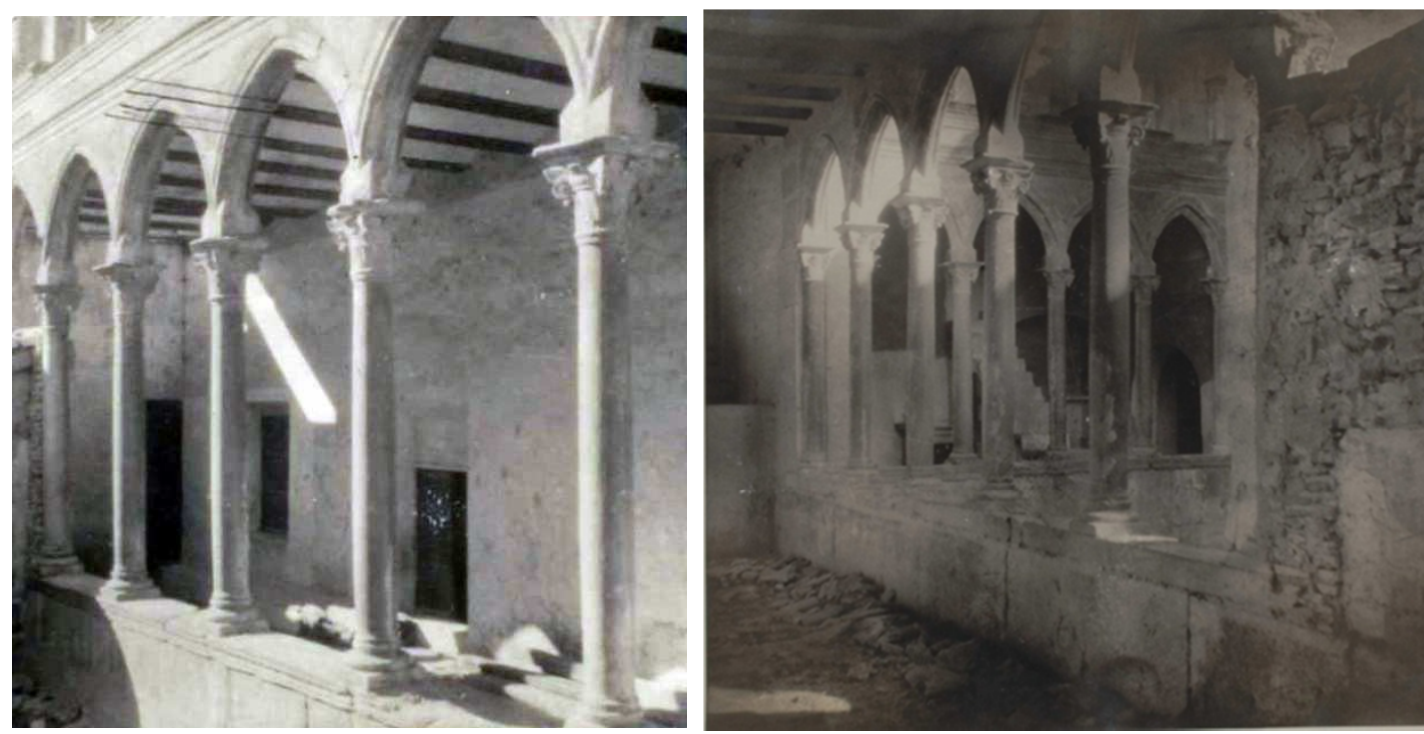

Figura 183. Izquierda: Fot. 16. Arcada Galería Oeste Patio. Derecha: Fot. 18. Arcada Galería Oeste Patio. Vista desde el interior. Álbum Fot. Grande. Fuente: Egil Fischer.

\subsection{Galería Torre Grande}

Es otro de los elementos arquitectónicos singulares del Palacio y también está documentado por parte de los arquitectos daneses. Se trata de una logia que se encontraba situada en la planta superior de la Sala de Armas. Fischer la llamó "Galleri Store Tårn" (Galería Torre Grande). La documentación gráfica existente es la siguiente: Planos LA1127 y LA1130 a LA1135 ${ }^{263}$.

- Plano LA1127: está dibujado a grafito sobre papel sin marca con unas dimensiones de 680 x $470 \mathrm{~mm}$. La escala de representación es 1:10 y el texto reza lo siguiente: "Galleri Store Taarn" (Galería Torre Grande). En él se representan el alzado, la sección horizontal y la sección vertical de un arco de la galería situada sobre la Sala de Armas. Las vistas tienen correspondencia diédrica y en ellas se detallan las pilastras de planta octogonal con lados cóncavos que arrancan con basas de planta octogonal y perfil moldurado, similar al de las basas de las columnillas de las ventanas y portadas. El fuste de las pilastras es recto y remata en un capitel moldurado, también de planta octogonal. Sobre esta pieza arranca el arco rebajado, cuya sección es medio octógono de lados cóncavos. Se representa también el alfeizar con un perfil moldurado y la cornisa formada por tres ladrillos volados sobre los que apoya la teja (ver Fig. 184).

${ }^{263}$ Fischer, E. y Lauritzen V. (1917-1920). Planos. Oliva, Valencia: Museo Municipal de Oliva, Archivo Público Documental, Palacio Condal. LA1127 y LA1130 a LA1135. 


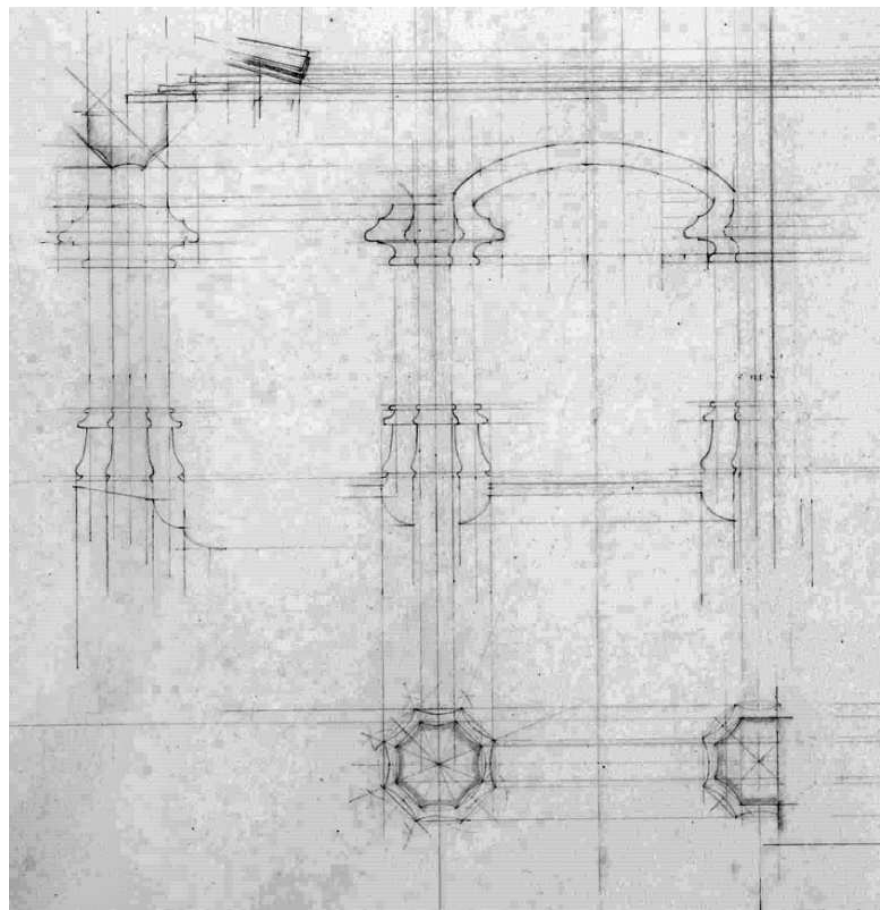

Figura 184. Arco Galería Gran Torre. LA1127. Fuente: E. Fischer y/o V. Lauritzen.

- Plano LA1132: está dibujado a grafito sobre papel sin marca y posee unas dimensiones de $680 \times 470 \mathrm{~mm}$. La escala de representación es 1:100 y su disposición es vertical. En la parte superior izquierda está rotulado el título de la lámina: "Galleri Store Taarn" (Galería Torre Grande) y, en la parte inferior, "Nedre galleri" (Galería inferior). A su vez, en la parte inferior derecha se puede ver su numeración, LA1132. En él se representan el alzado y sección vertical de la galería, que se componía de 7 arcos idénticos, formando una logia, elemento característico de los grandes Palacios valencianos de la época. En la parte inferior de la sección está representado un arco de medio punto rotulado como galería inferior, apoyado sobre dos columnas coriolíticas. Los restos de una de estas columnas lo podemos ver en la fotografía 85 (ver Fig. 185).

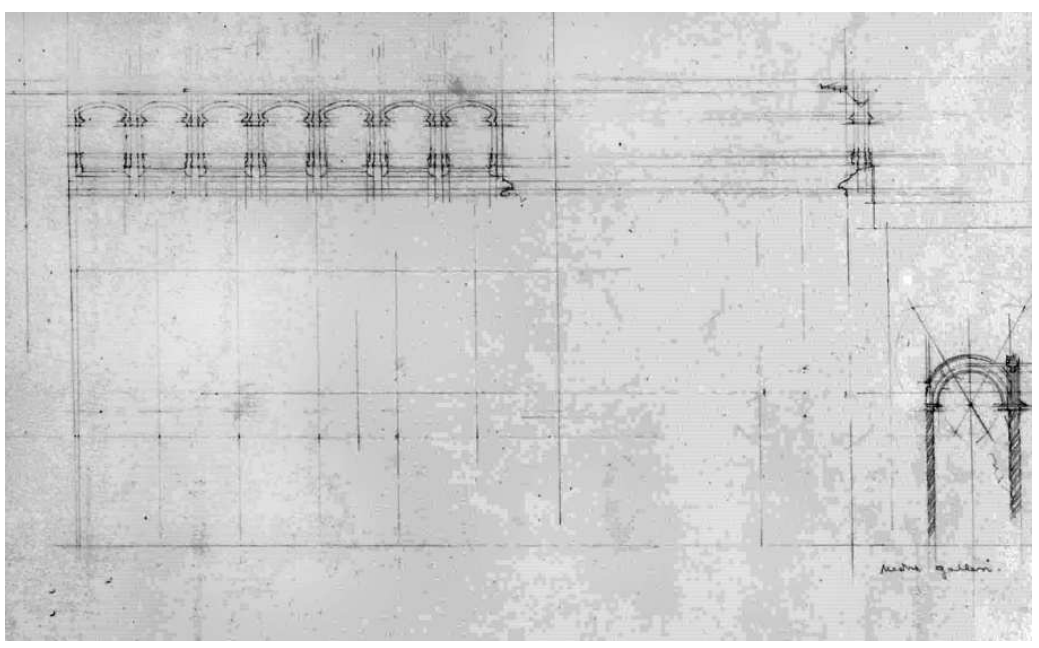

Figura 185. Plano Galería Gran Torre. LA1132. Fuente: E. Fischer y/o V. Lauritzen. 
- Los planos LA1130, LA1131, y LA1133 a LA1135 están referenciados también como Galería Torre Grande. En ellos se detallan a escala 1:1 diversas molduras y detalles de esta Galería: LA1130, detalle del arranque del arco y sección del alero de cubierta; LA1131, trazado geométrico de la planta de la columna; LA1133, detalle de molduras del capitel; LA1134, sección moldura entre capiteles; y LA1135, trazado geométrico de las molduras de las basas. Todos ellos son de un gran interés ya que contienen detalles de elementos y molduras a escala real con trazados realizados con gran precisión y que nos ayudan a interpretar estas mismas formas en otros elementos de características similares del Palacio. Cabe destacar el plano LA1135 (ver Fig. 186) en el que, a partir de la planta de la columna, se trazan las molduras verticales de las basas vistas en proyección diédrica en todas sus aristas.

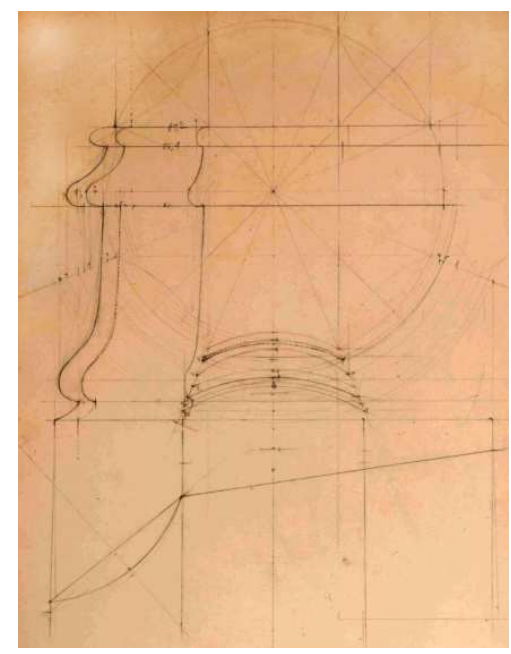

Figura 186. Plano Galería Gran Torre. LA1135. Fuente: E. Fischer y/o V. Lauritzen.

El encontrarse la galería en alto y poderse ver sólo desde el exterior, no se pudieron realizar fotografías de calidad con los medios técnicos de la época. La única instantánea en la que se puede ver parcialmente la galería es la Fot. 81 , en la que se observan los tres primeros arcos de la galería cegados con fábrica (ver Fig.187).
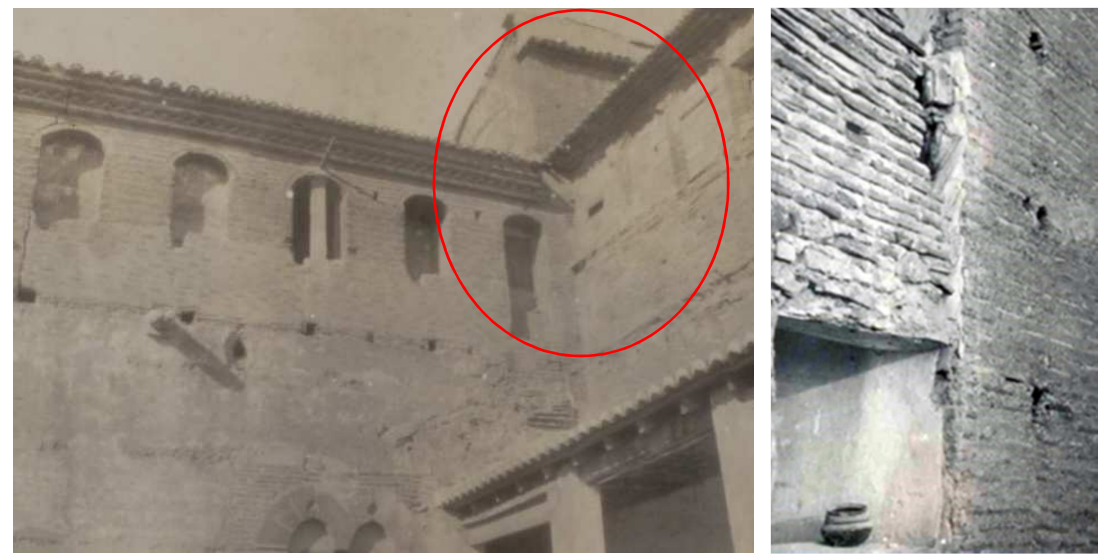

Figura 187. Izquierda: Fot 81. En un círculo vista parcial Galería Gran Torre. Derecha: Fot. 85. Columna coriolítica Galería Inferior. Fuente: E. Fischer 


\subsection{Pavimentos y piezas cerámicas}

En el Notebook I aparecen varias hojas con detalles de colocación de pavimentos e inventarios de piezas cerámicas con un croquis de los mismos, dimensiones y colores ${ }^{264}$. Otra información que recoge este cuaderno de notas es un inventario del número de piezas de cada tipo que se han recuperado del Palacio, numerando las cajas donde se han empaquetado y el número de piezas que contiene cada una de ellas. Asimismo, en el Álbum de Fotografías Grande, se encuentra la fotografía $84^{265}$ (ver Fig. 188), en la que aparecen fotografiadas una serie de piezas cerámicas, colocadas unas junto a otras a modo de muestrario.

A partir de dicha fotografía y de los croquis del Notebook I realizaremos un inventario de los distintos pavimentos y piezas cerámicas del Palacio documentadas por Fischer.

\subsubsection{Piezas cerámicas}

En primer lugar analizaremos las piezas cerámicas recogidas en la documentación gráfica recopilada por Fischer y las compararemos con otras piezas de la época recogidas en el catálogo digital CERES del Ministerio de Cultura ${ }^{266}$ que contiene piezas de los distintos museos nacionales españoles.

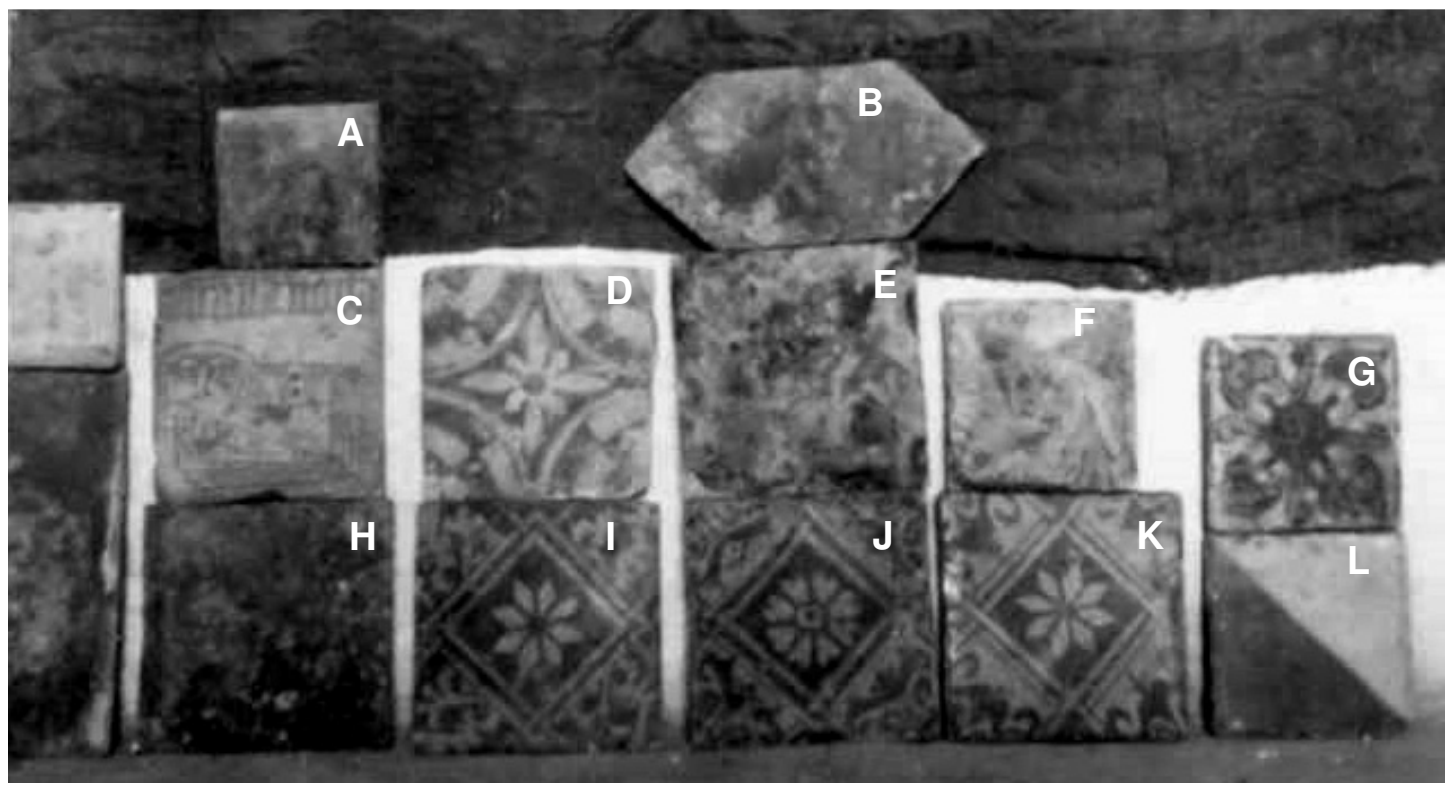

Figura 188. Fotografía 84 con las piezas clasificadas por letras. Álbum Fot. Grande. Fuente: Egil Fischer.

\footnotetext{
${ }^{264}$ Fischer, E. (1917-1920). Notebook I. Oliva, Valencia: Museo Municipal de Oliva, Archivo Público Documental, Palacio Condal. pp. 10, 11, 35, 36, 37, 63, 65, 71 y 73.

${ }^{265}$ Fischer, E. (1917-1920). Álbum Fotos Grande. Oliva, Valencia: Museo Municipal de Oliva, Archivo Público Documental, Palacio Condal. pp. 19A.

${ }^{266}$ CERES. Colecciones en Red. www.http://ceres.mcu.es.
} 


\section{Pieza A}

De acuerdo con la fotografía, aparenta ser una pieza cerámica sin decoración, probablemente en color rojo. La podemos identificar con la baldosa cuadrada del pavimento $x$ croquizado por Fischer y localizado en la Sala 5 del Palacio. Las dimensiones aproximadas de la pieza son $11 \times 11 \mathrm{~cm}$. Se puede identificar como perteneciente a uno de los pavimentos detallado por Fischer ${ }^{267}$.

\section{Pieza B}

Al igual que la anterior, aparenta una baldosa cerámica de color rojo. Se puede identificar con la baldosa de forma de hexágono irregular del pavimento localizado en la Sala 5 del Palacio $^{268}$. Las dimensiones máximas aproximadas de la pieza son $11 \times 26,5 \mathrm{~cm}$.

\section{Pieza C}

Esta pieza se corresponde con un azulejo de fondo blanco decorado en azul. Representa un libro de cuentas viejo que se va repasando y en letras góticas minúsculas aparece la palabra "Barallanova" (Baraja nueva). Sus dimensiones son $14 \times 14 \mathrm{~cm}$. No se encuentra documentada en el Notebook I, aunque sí existe una pieza en una colección privada de Oliva catalogada como proveniente del Palacio (ver Fig. 189). Es uno de los azulejos utilizados en la decoración de los Palacios de los Centelles, y hemos podido documentar parte de un azulejo en el lienzo de las murallas de Mascarell.
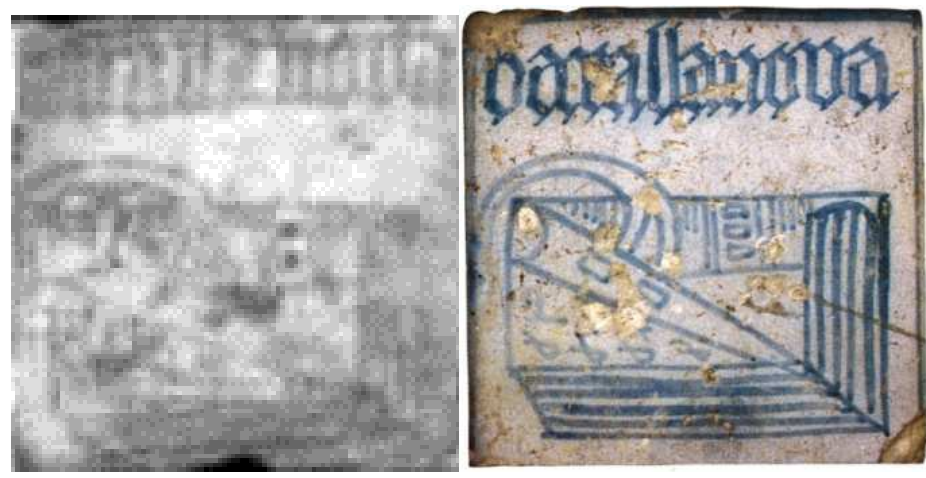

Figura 189.Izquierda: detalle de. Pieza C. Fotografía 84. Álbum Fot. Grande. Derecha: Pieza en colección privada (CP. Oliva).Fuente: Salvador Mañó i Fenollar.

\section{Pieza D}

Se trata de un azulejo cuadrado de fondo blanco en azul, como el resto de las piezas documentadas que está decorado con motivos vegetales y geométricos. Posee cuartos de

\footnotetext{
${ }^{267}$ Fischer, E. (1917-1920). Notebook I. Oliva, Valencia: Museo Municipal de Oliva, Archivo Público Documental, Palacio Condal. pp. 36.

${ }^{268}$ Fischer, E. Óp. cit. pp. 36.
} 
círculo ajedrezado en cada uno de sus lados y, en el centro, aparece el dibujo de una palmeta. No se encuentra documentado en el Notebook $I$.

Se ha referenciado con la piezaCE07439 perteneciente al MNAD. El lugar de producción es Manises y data de 1476-1525. Sus dimensiones son 13,5 x 13,5 cm (ver Fig. 190).

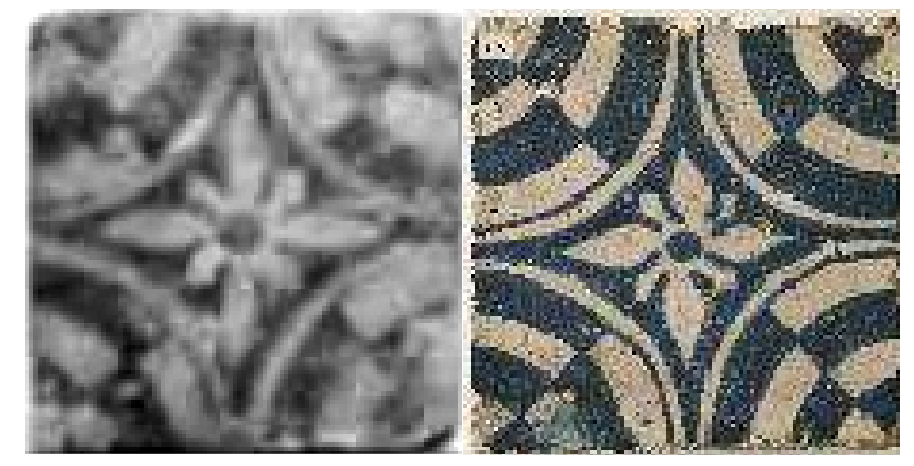

Figura 190. Izquierda:detalle Pieza C. Fotografía 84. Álbum Fot. Grande. Derecha: pieza CE07439. MNAD.

\section{Pieza E}

La mala calidad de la imagen no permite visualizarla correctamente. En apariencia se trata de una baldosa de barro cocido con una figura geométrica en forma de estrella grabada en el centro, similar a otras piezas documentadas del Palacio de Oliva (ver Fig. 191). Sus dimensiones aproximadas son $15 \times 15 \mathrm{~cm}$.
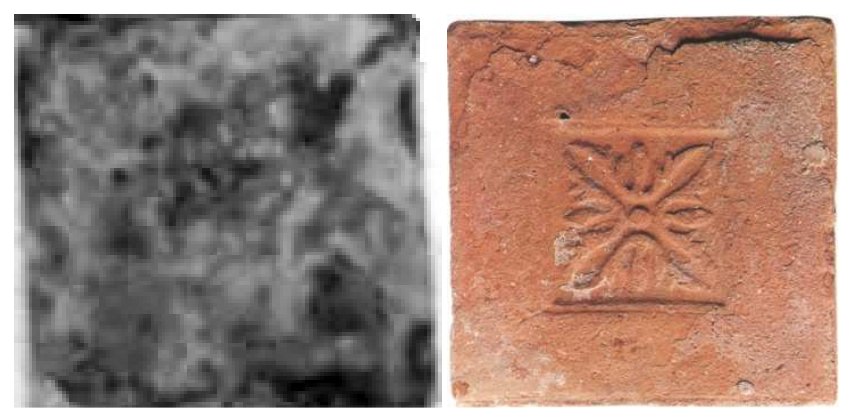

Figura 191. Izquierda: detalle Pieza E. Fotografía 84. Álbum Fot. Grande. Derecha: Baldosa de barro cocido con relieve (CP. Oliva).

\section{Pieza F}

Al igual que la anterior pieza, la mala calidad de la imagen no permite visualizarla correctamente, aunque nos ayuda a identificar el diseño con el del azulejo documentado por Fischer en la página 35 del Notebook I. También se ha podido constatar su parecido con otras piezas catalogadas por el Museo Nacional de Cerámica y Artes Suntuarias González Martí. Se las señala como pertenecientes al siglo XV y procedentes de Manises ( $\mathrm{n}$ - de referencia CE1/03915). Esta pieza tiene un formato de $10 \times 10 \mathrm{~cm}$. (ver Fig. 192). 

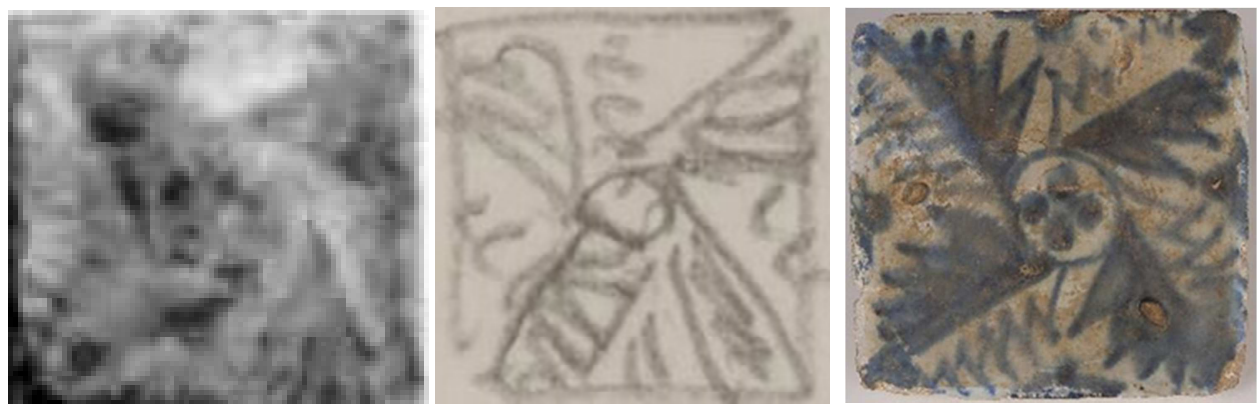

Figura 192. Izquierda: detalle Pieza F. Fotografía 84. Álbum Fot. Grande. Centro: Azulejo fondo blanco con decoración en azul. Pag. 35 Notebook I. Derecha: azulejo CE1/03915. MNCASGM.

\section{Pieza G}

Aunque la calidad de la imagen no nos permite verla con detalle, por el diseño podemos identificar aproximadamente sus dimensiones: $11 x 11 \mathrm{~cm}$ (ver Fig. 193). Esta pieza no se ha podido identificar con un diseño similar coetáneo.

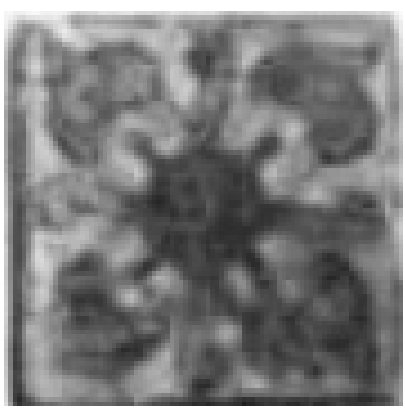

Figura 193. Detalle Pieza G. Fotografía 84. Álbum Fot. Grande.

\section{Pieza H}

Una vez más, la mala calidad de la imagen no permite visualizarla correctamente. Sin embargo, podemos aseverar que, aparentemente, se trata de una baldosa de barro cocido sin decoración (ver Fig. 194) inventariada como Klasse 4 en el cuaderno de Fischer. Sus dimensiones son $13,5 \times 13,5 \times 2 \mathrm{~cm}$.

De esta baldosa se empaquetaron un total de 44 cajas (66 a 97 y 145 a 156) que contenían entre 26 y 31 piezas, lo que representaba un total de 1.254 baldosas.
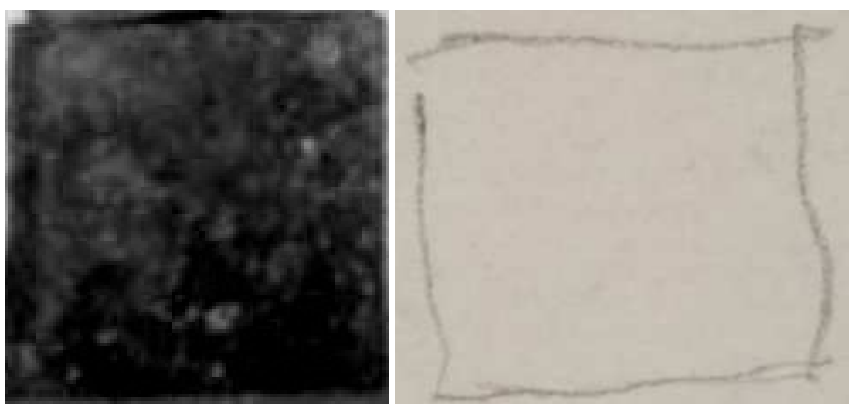

Figura 194. Izquierda: detalle Pieza H. Fotografía 84. Álbum Fot. Grande. Derecha: baldosa roja de 15 x $15 \mathrm{~cm}$. Pag. 35 Notebook I. 


\section{Pieza I}

Se trata de un azulejo cuadrado de fondo blanco decorado en azul. Representa una flor de ocho pétalos con forma geométrica enmarcada en un rombo en el centro y, en cada uno de los ángulos, dos hojas de ataurique esquemáticas contrapeadas. Indudablemente, se trata de un trazado con influencia árabe. El diseño se corresponde con el azulejo representado en la página 21 del Notebook I como "Klasse 3". Sus dimensiones son 13,5 x 13,5 × $2 \mathrm{~cm}$ (ver Fig. 195).

Esta pieza se encuentra entre las inventariadas por Fischer para su traslado a Dinamarca. De acuerdo con las notas que aparecen en el cuaderno, se empaquetaron un total de 26 cajas (cajas 35 a 55 y 61 a 65) que contenían entre 24 y 27 piezas; un total de 665 unidades. En la página 77R relaciona otras dos cajas con azulejos "Klasse 3", aunque en este caso no se indican las unidades.
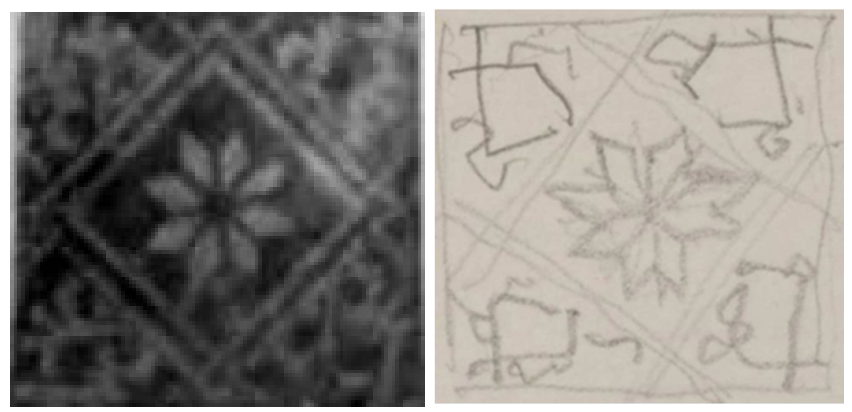

Figura 195. Izquierda: detalle Pieza I. Fotografía 84. Álbum Fot. Grande. Derecha: croquis azulejo Klasse 3 fondo blanco con decoración en azul. Pag. 71 Notebook I.

El diseño es similar al de otra pieza catalogada como procedente del Palacio y que se encuentra en una colección privada, aunque en este caso no aparece la flor central. Este diseño es idéntico al de la pieza CE07438 del MNAD, datado entre 1451-1500 (ver Fig. 196).
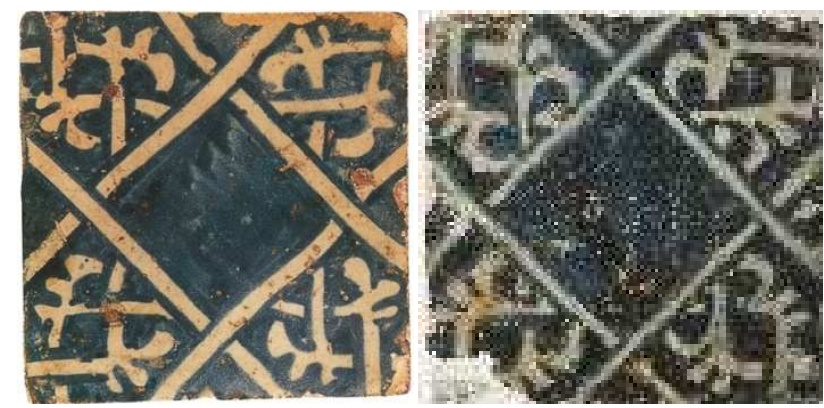

Figura 196. Izquierda: azulejo decorado en azul sobre fondo blanco con dibujos geométricos, $14 \times 14$ $\mathrm{cm}$. procedente del Palacio condal de Oliva. Manises S. XV. (CP. Oliva). Fuente: Salvador Mañó i Fenollar. Derecha: azulejo CE07438 del MNAD. 


\section{Pieza J}

Se trata de un azulejo de fondo blanco con decoración pintada en azul; en reserva de roseta en el centro y con pétalos en forma de corazón incluidos dentro de un rombo compuesto por varias cintas paralelas. En los ángulos se puede observar parte de un motivo vegetal de hojas o similar, que se completa en los azulejos contiguos. El diseño se corresponde con el azulejo representado en la página 21 del Notebook I como "Klasse 2". Las dimensiones son $13,5 \times 13,5 \times 2 \mathrm{~cm}$ (ver Fig. 197).

Cabe señalar que el diseño es similar al de la pieza CE07437 del MAD, datada entre 14761525, aunque en este caso los pétalos son sencillos y el trazado más tosco (ver Fig. 197).

Esta pieza se encuentra entre las inventariadas por Fischer para su traslado a Dinamarca. De acuerdo con las notas que aparecen en el cuaderno, se empaquetaron un total de 16 cajas (cajas 22 a 34 y 58 a 60) que contenían entre 26 y 27 piezas; un total de 412 unidades.
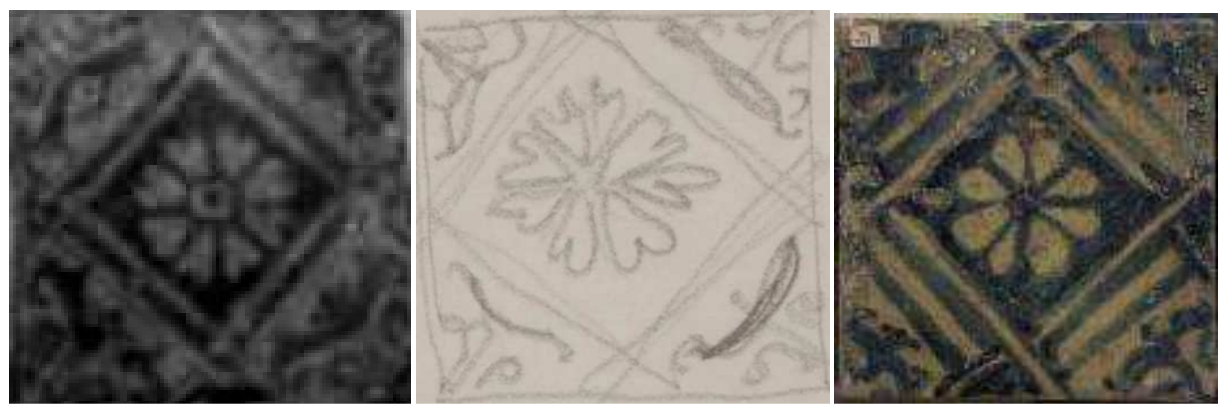

Figura 197. Izquierda: detalle Pieza I. Fotografía 84. Álbum Fot. Grande. Centro: croquis azulejo Klasse2, fondo blanco con decoración en azul. Pág. 21 Notebook I. Derecha: azulejo CE07437. MNAD.

\section{Pieza K}

Como en anteriores ocasiones, se trata de un azulejo de fondo blanco decorado en azul con la decoración pintada en reserva de estrella en el centro, dentro de un rombo compuesto por varias cintas paralelas. En los ángulos aparece un motivo vegetal de hojas (o similar) que se completa en los azulejos contiguos. El diseño corresponde con el azulejo representado en la página 63 del Notebook I como "Klasse 1". Sus dimensiones son 13,5 x $13,5 \times 2 \mathrm{~cm}$ (ver Fig. 198).

El diseño es similar a la pieza CE07435, fechada entre 1476 y 1525 y perteneciente al MNAD, aunque en este caso el trazado es más tosco (ver Fig. 198).

Esta pieza también se encuentra entre las inventariadas por Fischer para su traslado a Dinamarca. De acuerdo con las notas, se empaquetaron 23 cajas ( 1 a 21, 56 y 57), que contenían entre 25 y 27 piezas; un total de 602 unidades. 

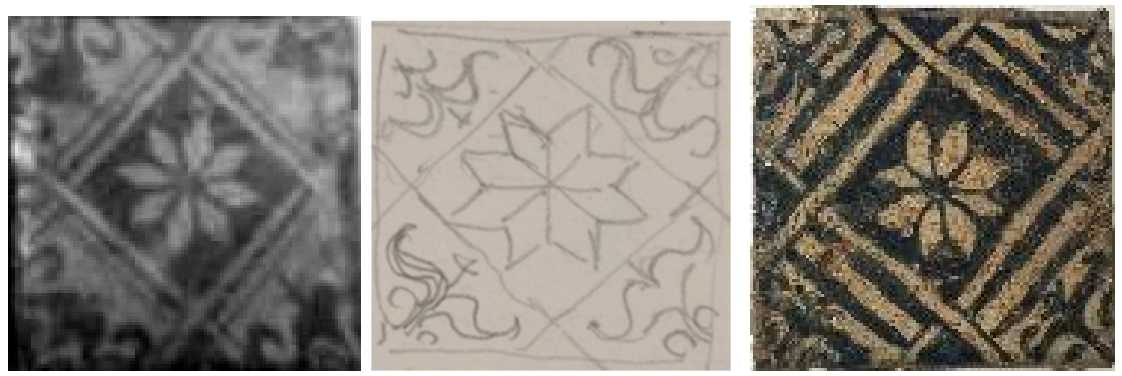

Figura 198. Izquierda: detalle Pieza I. Fotografía 84. Álbum Fot. Grande. Centro: croquis azulejo Klasse 1, fondo blanco con decoración en azul. Pag. 63 Notebook I. Derecha: azulejo CE07435.

MNAD.

\section{Pieza L}

Se trata de un azulejo cuadrado de fondo blanco y decoración en azul o azulejo "de mitad" (mocadoret o pañuelo) que se caracteriza por estar dividido diagonalmente en dos mitades (ver Fig. 199). Las dimensiones son $12 \times 12 \mathrm{~cm}$.
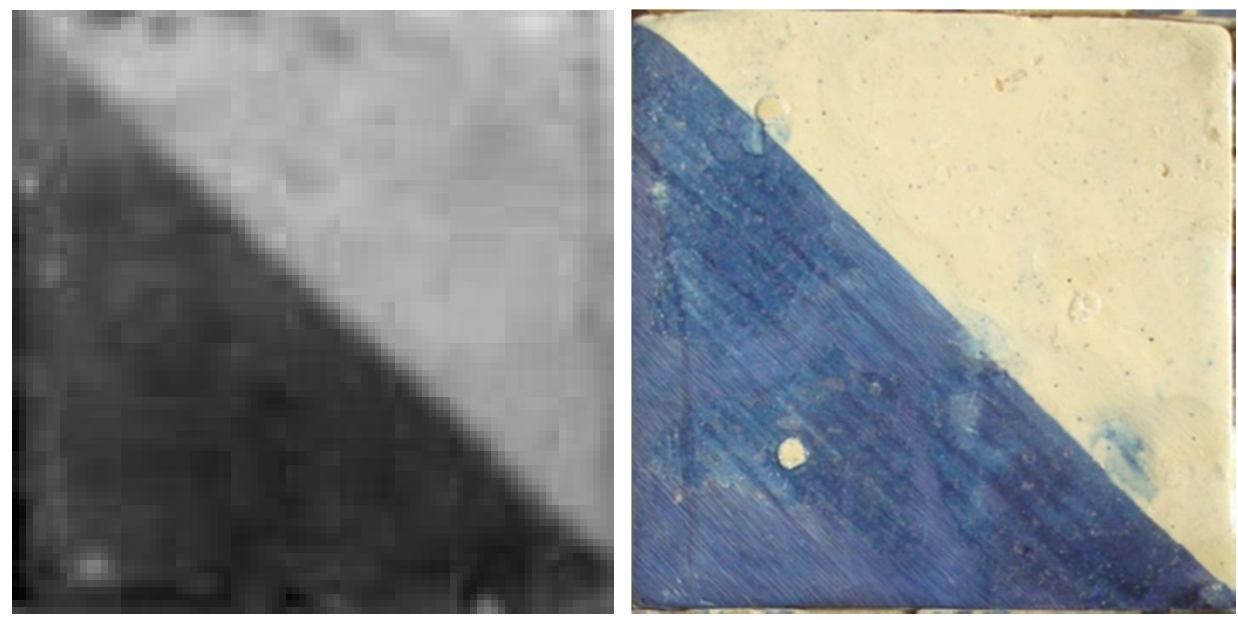

Figura 199. Izquierda detalle Pieza I. Fotografía 84. Álbum Fot. Grande. Azulejo de mocadoret sobre fondo blanco, $12 \times 12 \mathrm{~cm}$. Derecha: azulejo procedente del Palacio de Oliva. Fuente: MAO.

\subsubsection{Pavimentos}

En el Notebook / Fischer documenta varios pavimentos del Palacio mediante croquis ${ }^{269}$. A continuación se estudiará dicha documentación y se tratará de identificar su localización en el Palacio y las piezas que lo componen.

${ }^{269}$ Fischer, E. (1917-1920). Notebook I. Oliva, Valencia: Museo Municipal de Oliva, Archivo Público Documental, Palacio Condal. pp. 10, 10R, 11, 35, 36 y 37. 


\section{Pavimento 1}

El pavimento 1 , grafiado en la página 10 del Notebook $I$, se encuentra en una sala abovedada que no podemos identificar. Sin duda debía ser una sala noble del Palacio por el diseño de su pavimento en un formato de $20 \times 20 \mathrm{~cm}$, alternando baldosas de barro con azulejos decorados en blanco y azul. En el centro, a modo de cruz, se disponían 12 baldosas que, por el grafismo representado, debían ser del tipo mocaoret (ver Fig. 200).

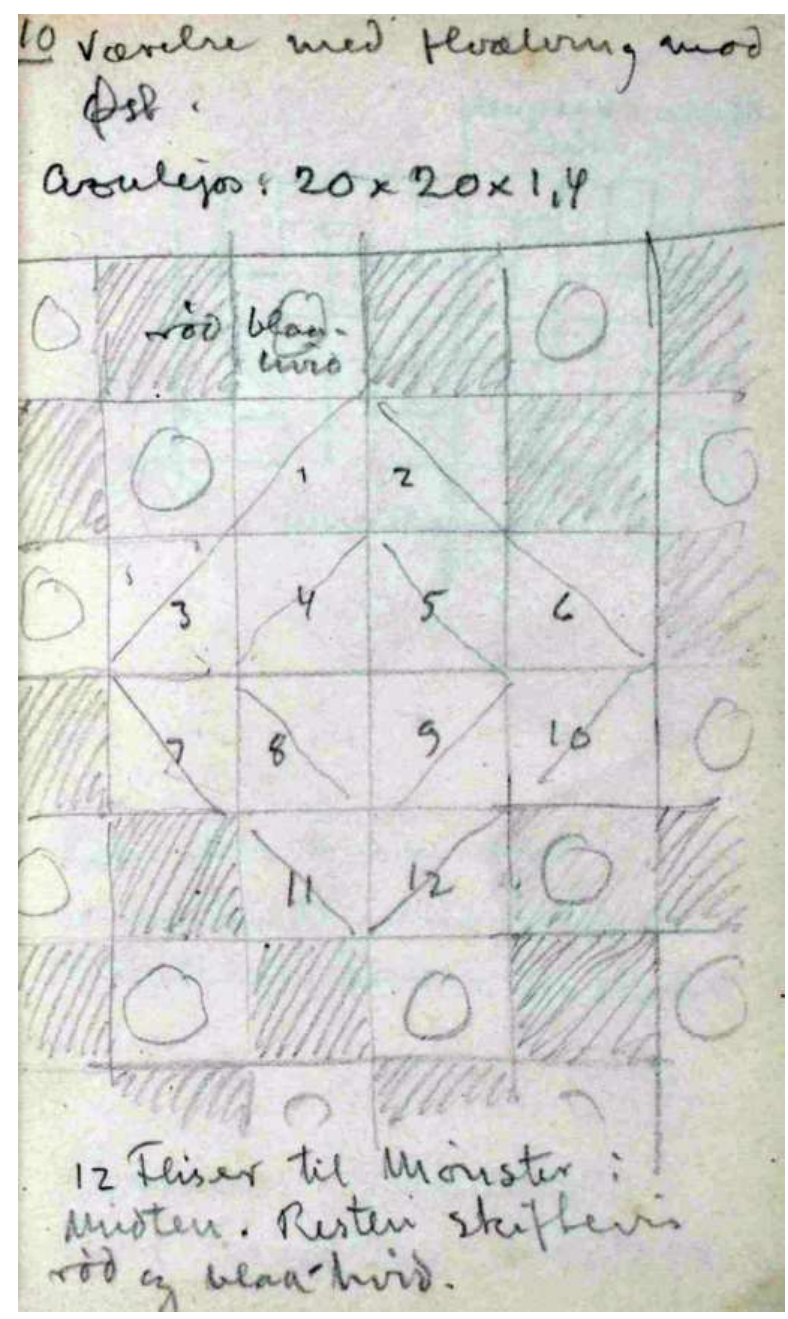

Figura 200. Croquis despiece de pavimento Pág. 10. Notebook I. Fuente: Egil Fischer.

Textos:

"Værelse med hvælving mod ¿?" (Sala con bóveda contra el ¿?)

azulejos: $20 \times 20 \times 1,4$

"rød / blau-hvid" (rojo/blanco-azul)

"12 Fliser til Mønster Midten" (Diseño de los 12 azulejos del centro.)

"Resten skiftevis rød og blau-hvid" (El resto alternos rojo y blanco-azul.) 


\section{Pavimento 2}

El pavimento grafiado en la página 10 (reverso) es rectangular y, posiblemente, está realizado en barro cocido. Sus piezas se disponen de tres en tres, formando una $T$ en el centro. Este conjunto de piezas va girando $180^{\circ}$ formándose, a su vez, una especie de juego de damas. No se indica la medida de las piezas, si bien podrían tener un formato de $12 \times 24$ $\mathrm{cm}$, aproximadamente. Se trata de un pavimento sencillo que no correspondería a una sala noble del Palacio(ver Fig. 201).

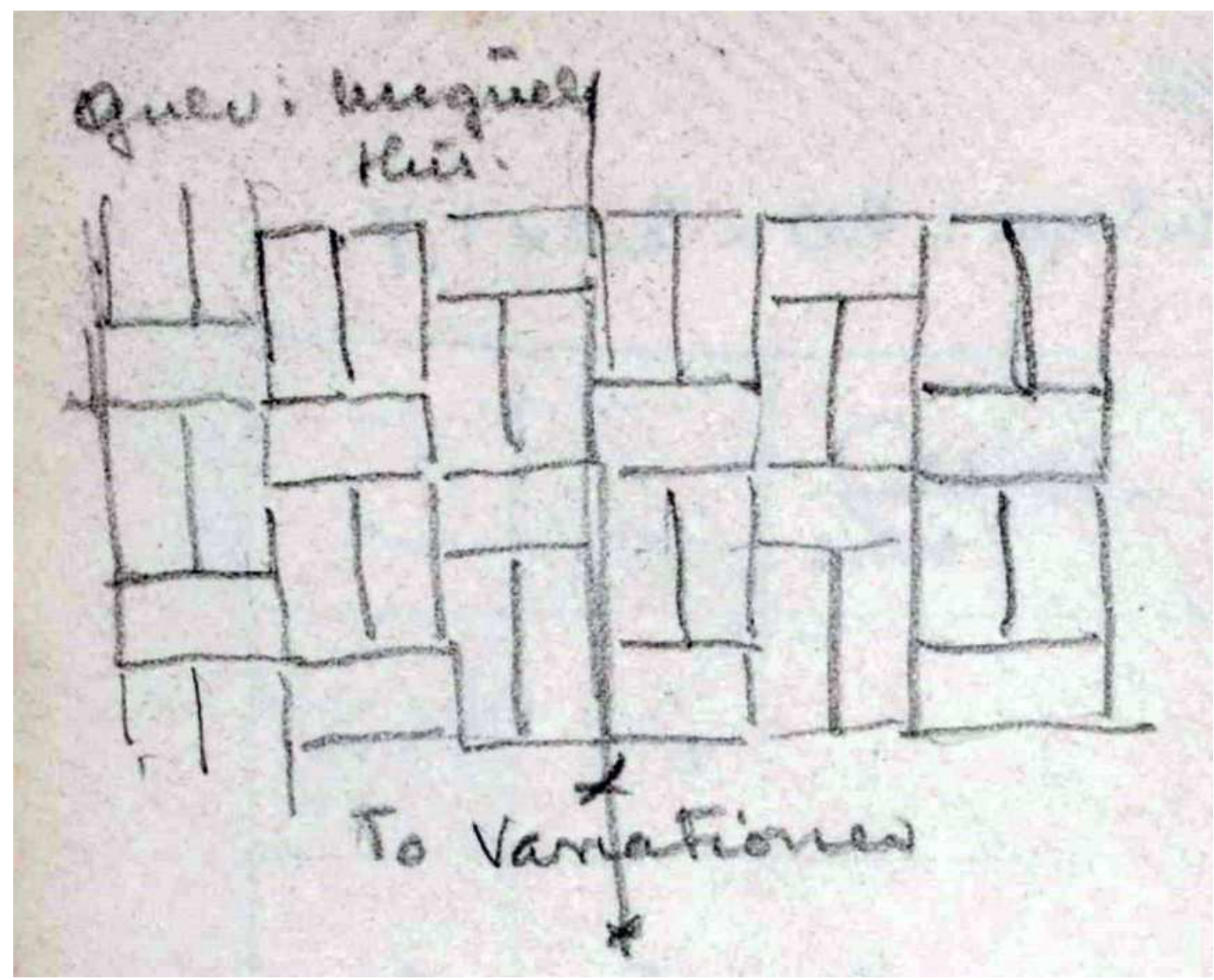

Figura 201. Croquis despiece de Pavimento 2 Pág. 10R. Notebook I. Fuente: Egil Fischer.

Textos:

"Gulv: Miguel Hus" (Pavimento: Casa de Miguel).

"To variationen" (Dos variaciones).

\section{Pavimento 3}

El pavimento 3 estaba localizado en una sala sobre la casa de Sanchis. Se trata de la sala croquizada en la página 13 del Notebook I. Por sus dimensiones $(4,45 \times 6,26 \mathrm{~m})$ y por los elementos decorativos que contiene (forjado de madera, ventana, portada y chimenea) debía ser una sala importante del Palacio, si bien no se encuentra en la zona más noble del mismo. Se disponen en forma de espina de pez baldosas de barro cocido de dimensiones 29 
x 29 × 3 con azulejos blancos decorados en azul y de dimensiones $11 \times 11 \times 1,4 \mathrm{~cm}$ intercalados. La disposición del pavimento es a $45^{\circ}$.

Textos:

"Rød sorte fliser med smaa hvide med Mønster forskellige" (Baldosas grandes de color rojo con pequeñas de color blanco con diferentes diseños).

"Azulejos gulv over Casa Sanchis. Se side 13" (Azulejos pavimento sobre la casa de Miguel. Ver pág. 13).

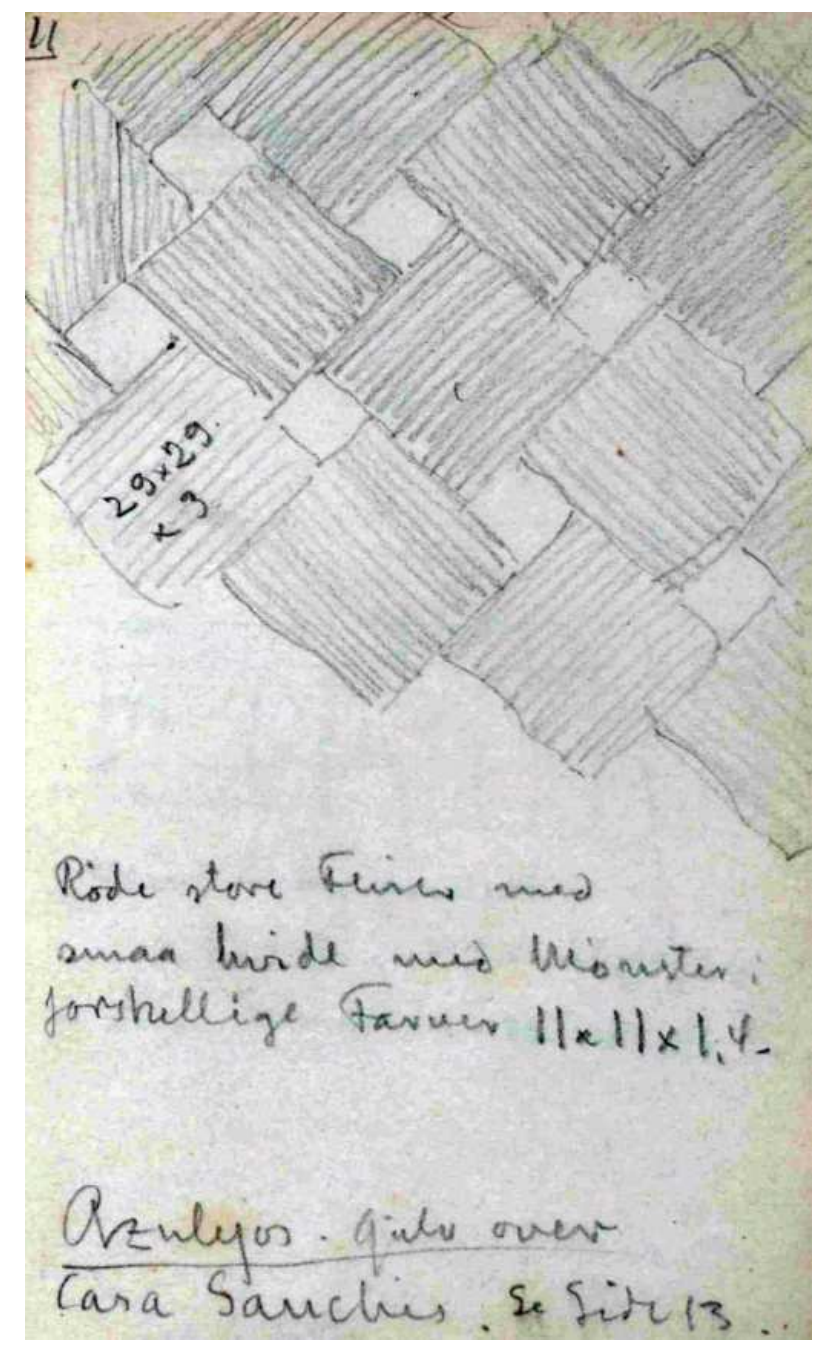

Figura 202. Croquis despiece de Pavimento 3 Pág. 11. Notebook I. Fuente: Egil Fischer.

\section{Pavimento 4}

En la página 35 del Notebook I se detallan dos pavimentos que combinan baldosas rojas de barro rectangulares con azulejos decorados con figuras zoomórficas. Los pavimentos se disponen a $45^{\circ}$; en el primero las baldosas están alineadas intercalando un azulejo ente dos 
baldosas de barro; y en el segundo la disposición es a espina de pez, intercalando los dos tipos de piezas. No aparecen acotadas las piezas, aunque deducimos que las que están decoradas son de $11 \times 11 \mathrm{~cm}$, al igual que las del Pavimento 3 y las baldosas de barro, por tanto, serían de $11 \times 22 \mathrm{~cm}$.

Textos:

"Gulv med smaa gotic azul i nordvest værelse 1,2 3" (Pavimento con pequeños (azulejos?) góticos azules en salas 1,2, 3.)

"Rum aptaaes? til Miguel" (Sala ¿'? de Miguel.)

Andet mønster med samme slags fliser" (Otros diseños con el mismo tipo de azulejos).

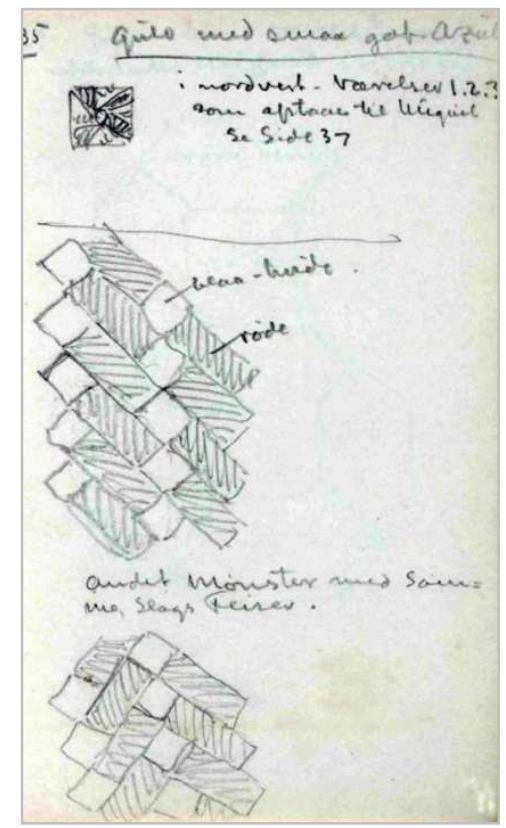

Figura 203. Croquis despiece de Pavimento 4 Pág. 35. Notebook I. Fuente: Egil Fischer.

\section{Pavimento 5}

En la página se representa un pavimento compuesto por piezas de barro cocido, combinando piezas cuadradas con piezas hexagonales y formando octógonos que intersectan entre sí. Las baldosas corresponderían con los las tipologías A y B descritas anteriormente en el apartado de piezas.

Textos:

"Gulv: nord værelse 5 rum aptaaes? til Miguel. (Se side 37)" (Pavimento sala 5 zona norte ¿'? de Miguel) (ver pág. 37).

"Rød fliser. Rød fl". (Baldosa roja. Bald. roja). 


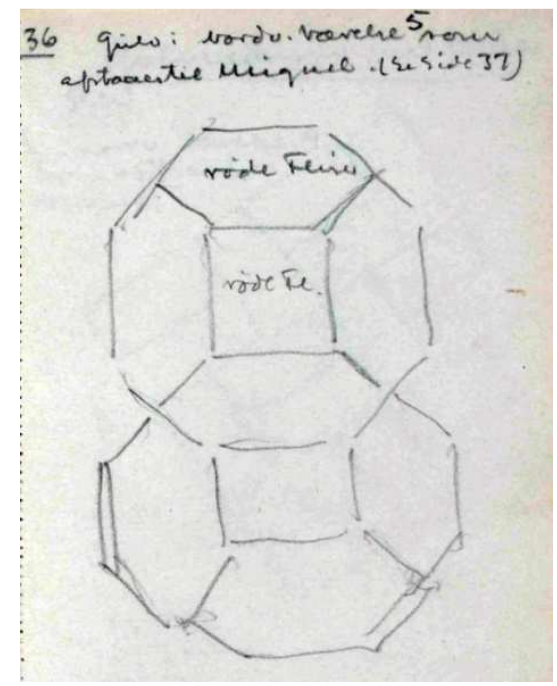

Figura 204. Croquis despiece de Pavimento 5 Pág. 36. Notebook I. Fuente: Egil Fischer.

\section{Pavimento 6}

El pavimento 6 está formado por baldosas rectangulares colocadas con el mismo diseño que el pavimento 2 , pero en este caso dispuestas a $45^{\circ}$. En la parte inferior de la página hay un pequeño croquis en el que se numeran las salas 1 a 5 , donde se encuentran algunos de los diseños de pavimentos grafiados (ver Fig. 205).

Textos:

"Gulv mønster med Mursten" (Diseño de pavimento con ladrillos).

"i nord værelse 4rum aptaaes? til Miguel" (en el norte Sala 4 zona ¿’? de Miguel).

"Trappe" (Escalera).

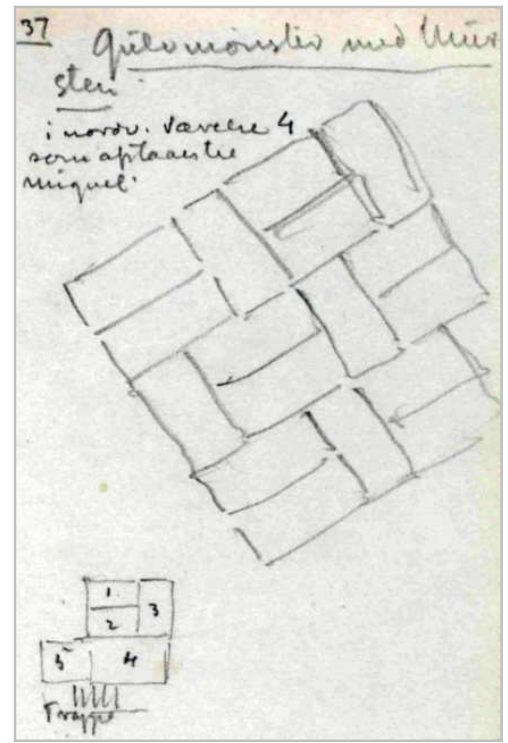

Figura 205. Croquis despiece de Pavimento 6 Pág. 37. Notebook I. Fuente: Egil Fischer. 


\section{OTRAS FUENTES DOCUMENTALES}

Además de la amplia documentación gráfica de los arquitectos daneses conservada en el $\mathrm{MAO}$, se han localizado otros documentos gráficos y escritos correspondientes al Palacio Condal de Oliva en diversos archivos de España y Dinamarca. En este apartado se procede a relacionar y estudiar los documentos gráficos localizados.

\subsection{Archivo del IPCE}

En el archivo digital del IPCE se ha localizado un plano de parte de la planta noble del Palacio, concretamente la esquina situada junto a la torre noreste. Dicho plano corresponde a un proyecto de consolidación de los restos que quedaban del Palacio fechado el 7 de agosto de 1946, y firmado por el arquitecto conservador de monumentos de la 4a zona, Alejandro Ferrant ${ }^{270}$ (ver Fig. 206).

En el plano se representan las salas de la planta noble que se mantenían en pie en esa fecha, tal y como indica el cajetín del plano: "Planta de la parte que aún se conserva después del despojo". El plano está realizado a escala 1:100 y delineado a tinta utilizando dos gruesos de línea, distinguiéndose las líneas de sección y de proyección. Los elementos seccionados están grafiados con una trama en cuadrícula a $45^{\circ}$. Los textos están mecanografiados sobre el plano, donde se numeran 7 salas más el vestíbulo y galería. La planta se ha representado con los muros totalmente ortogonales, lo que denota que se realizó un levantamiento aproximado del inmueble, pero identifica perfectamente las fábricas existentes así como los huecos y carpinterías y su estado de conservación. Los muros exteriores se han representado con un espesor de $1,00 \mathrm{~m}$. y los interiores con 0,80 m. A continuación describiremos las distintas salas representadas en este plano.

Sala № 1. Sala de las Batallas. Se corresponde con la sala 18 o Sala de Armas de acuerdo con la numeración de Fischer. Aparece la siguiente leyenda: "Cubierta con artesonado Renacimiento. Vigas y bovedillas policromadas de las que se conservan seis. La armadura y el tejado en malas condiciones. Han de reconstruirse. Carece de solería". Las dimensiones interiores de la sala, de acuerdo con este plano, son 8,95 x 7,30 m., difiriendo ligeramente con las recogidas por Fischer en el croquis de dicha sala ${ }^{271}(8,75 \mathrm{~m}$. y 8,87 m. de largo por $7,05 \mathrm{~m}$. y 7,15 m de ancho). Las dimensiones de Fischer son mucho más exactas, ya que además de acortar el largo y ancho variable de la sala acotó las dos diagonales (11,28 m. y $11,30 \mathrm{~m}$ ). La sala tenía originalmente 8 vigas contando las adosadas a los muros, por lo que en esta fecha se habían desmontado dos de las vigas originales de la sala, o bien no contempla las dos adosadas a los muros.

\footnotetext{
${ }^{270}$ Ferrant, A. (1946). Proyecto de Obras de Conservación de elementos Decorativos Pertenecientes al Palacio de los Condes de Oliva (Valencia). Archivo IPCE. Madrid.

${ }^{271}$ Fischer, E. (1917-1920). Notebook II. Oliva, Valencia: Museo Municipal de Oliva, Archivo Público Documental, Palacio Condal. pp. 31.
} 


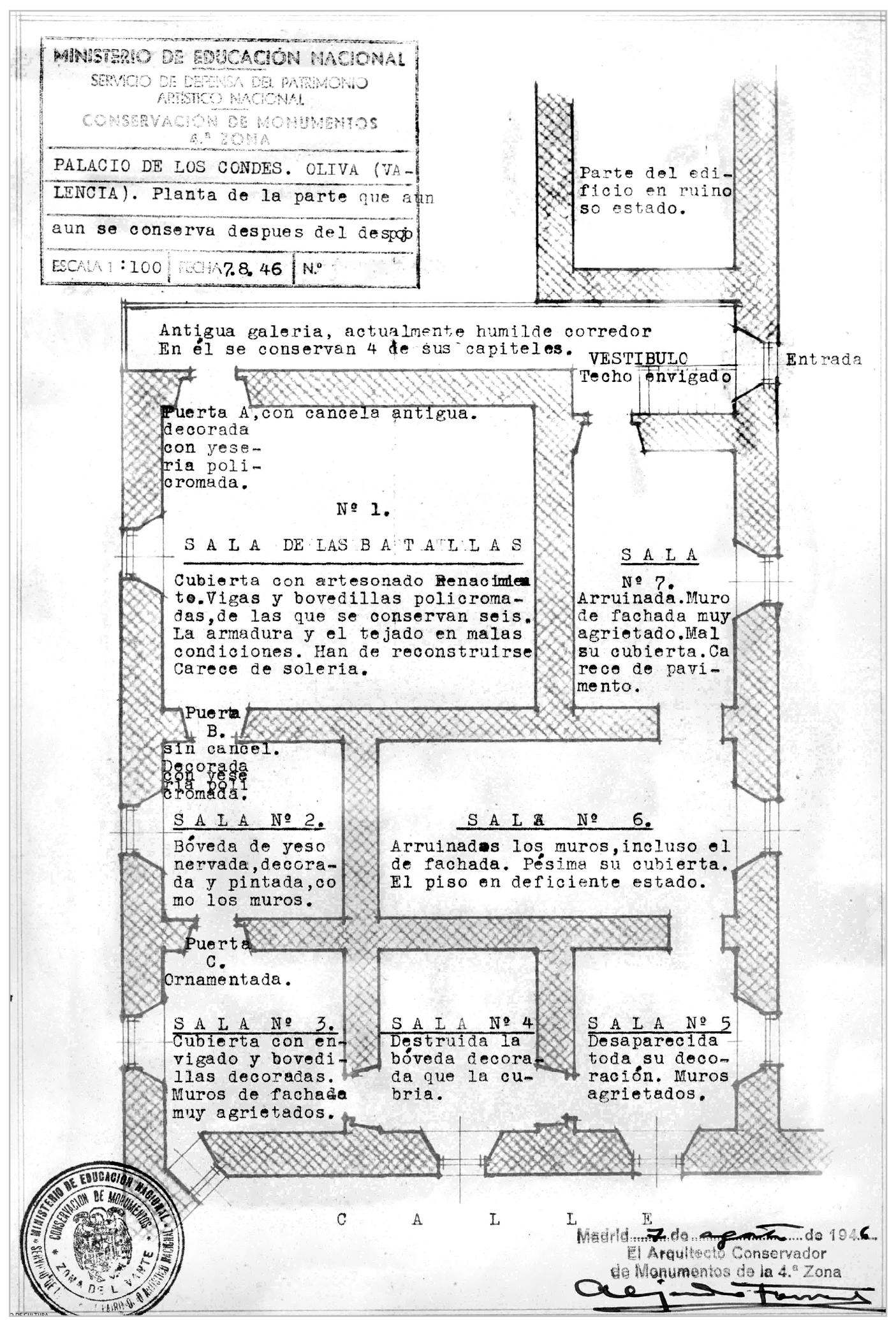

Figura 206. Plano de planta Palacio de Oliva. Proyecto de conservación de 1946. Fuente: Alejandro Ferrant, IPCE. 
Dentro de la sala se identifican dos portadas: la Puerta A "con cancela antigua. Decorada con yesería y policromada" y la Puerta B "Sin cancela. Decorada con yesería policromada". Si bien el plano de Ferrant identifica la puerta en su conjunto y no cada una de sus caras, tal y como hizo Fischer, se entiende que la Puerta A se corresponde con la portada D23 del plano de este último, dado que la indicación se encuentra en el interior de la sala y habla de "policromada". La Puerta B se refiere, del mismo modo, a la portada D22 de Fischer. Por lo tanto, entendemos que Fischer no llegó a desmontar los elementos decorativos de la sala de armas al menos en su totalidad, a pesar de que estos aparecen en la lista de fragmentos desmontados del edificio ${ }^{272}$. En cuanto al forjado, aparece con el número 7 en el inventario y las portadas como "Jambajes" (números 24 al 27). No se hace referencia alguna al Friso, por lo que este debió de ser desmontado en su totalidad, bien por Fischer, bien posteriormente; en el inventario aparece con el número 8.

El proyecto de intervención de Ferrant se centraba exclusivamente en esta sala y su objeto era el desmontaje de la cubierta existente y sustitución por una nueva y, el desmontaje del forjado y las portadas para su posterior montaje en un museo de Valencia.

Sala № 2. Se corresponde con la Sala 17 según la numeración de Fischer. El texto dice: "bóveda de yeso nervada decorada y pintada, como los muros". Las dimensiones de la sala según el plano son 4,36 m x 4,24 m. En esta sala se encontraba la bóveda estrellada documentada por Ficher y Lauritzen y numerada como "Rum 17. Loft"273, y que según este documento no fue desmontada, a pesar de encontrarse también incluida en el inventario de Fischer. La puerta C, cuya cara más noble (D20 de acuerdo con la numeración de Ficher) recaía sobre dicha sala la describe como "Ornamentada", por lo que entendemos que la Portada 20 permanecía en su ubicación original.

Sala № 3. Se corresponde con la Sala 16 según la numeración de Fischer. El texto dice: "Cubierta con entrevigado y bovedillas decoradas. Muros de fachada muy agrietados". Las dimensiones de la sala según el plano son 4,36 m. x 4,37 m. En esta sala se encontraba el forjado identificado por Fischer y Lairitzen como "Rum 16. Loft" ${ }^{\text {"274 }}$, y que según este documento, no fue desmontada. En el inventario figura con el número 10. No se hace referencia a la portada D18 por lo que esta podía no estar en su localización original o no estar documentada en el plano dado que era una portada más sencilla que las anteriores.

Sala № 4. Se corresponde con la Sala 15 según la numeración de Fischer. El texto dice: "Destruida la bóveda decorada que la cubría". Las dimensiones de la sala según el plano son 3,77 m. x 4,37 m. En esta sala se encontraba la bóveda de arista identificada por Fischer y Lauritzen como Rum 15. Loft ${ }^{275}$. En el inventario figura con el número 16. No se hace referencia a la portada D17 que originalmente se encontraba en esta sala.

Sala № 5. Se corresponde con la Sala 14 según la numeración de Fischer. El texto dice: "Desaparecida toda la decoración. Muros agrietados". Las dimensiones de la sala según el

\footnotetext{
272 Fischer, E. (1440). Lista de fragmentos del Palacio de los Condes de Oliva. Søborg, Dinamarca: Danmarks Kunstbibliotek Studiesalen.

${ }^{273}$ Fischer, E. y Lauritzen V. (1919-1920). Planos. Oliva, Valencia: Museo Municipal de Oliva, Archivo Público Documental, Palacio Condal. LA1123 y LA 1124bis.

${ }^{274}$ Fischer, E. y Lauritzen V. (1919-1920). Óp. cit. LA1121 y LA1122.

${ }^{275}$ Fischer, E. y Lauritzen V. (1919-1920). Óp. cit. LA1119 y LA1120.
} 
plano son 3,88 m. x 4,37 m. En esta sala Fischer y Lauritzen tan sólo documentaron la portada D16 que, por otra parte, era una portada bastante sencilla ${ }^{276}$.

Sala № 6. Se corresponde con la Sala 13 según la numeración de Fischer, es decir, con la antigua capilla. El texto dice: "Arruinados los muros, incluso el de fachada. Pésima su cubierta. El piso en deficiente estado". Las dimensiones de la sala según el plano eran 8,56 m. x 4,24 m. En esta sala Fischer y Lauritzen documentaron la bóveda de cañón como "Rum 13. Loft" (número 17 del inventario) ${ }^{277}$ y las portadas D14 y D15 ${ }^{278}$. La descripción deja muy claro que toda la decoración había desaparecido y el estado de ruina en que se encontraban los restos del Palacio.

Sala № 7. Se corresponde con parte de la Sala 12 según la numeración de Fischer. El texto dice: "Arruinada. Muro de fachada muy agrietado. Mal su cubierta. Carece de pavimento". Las dimensiones de la sala según el plano eran 3,93 m. x 6,19 m. En esta sala Fischer y Lauritzen documentaron su artesonado romboidal "Rum 12. Loft" (número 6 del inventario) $)^{279}$ y las portadas D13 y D28 ${ }^{280}$ recayentes en esta área (parte de la Sala 12). El muro recayente a la calle Palacio no es el original, ya que no aparece en los planos de Fischer. No hay referencia a las portadas, por lo que estas debieron ser desmontadas.

Vestíbulo. Corresponde a parte de la Sala 20 del plano de Fischer. El texto dice: "Techo envigado". Las dimensiones de la sala según el plano eran 3,93 m. x 2,69 m. En esta parte de la sala Fischer y Lauritzen documentaron las portadas D26 y D $27^{281}$. En el plano no se hace referencia alguna a estas portadas.

Galería. Se corresponde con el espacio numerado como 19 por Fischer. El texto describe "Antigua galería, actualmente humilde corredor. En él se conservan aún capiteles". Las dimensiones de la sala según el plano eran 10,73 m. x 1,52 m. En la sala galería Fischer y Lauritzen documentaron las portadas D24 y D25 $5^{282}$ y la bóveda estrellada (Rum 19. Loft) ${ }^{283}$. En el inventario la portada 24 se corresponde con el número 25 . La portada 25, más sencilla, se encontraba en el grupo $28 / 48$ "varias entradas más sencillas y enjambres". En el plano no se hace referencia alguna a estos elementos. Asimismo, en el inventario se hace cita una columna entorchada numerada como 4 procedente de esta galería. Esta columna se corresponde con la fotografía 85 (ver Fig. 207 dcha.). Los capiteles a los que hace referencia el plano no fueron identificados por Fischer, y en las fotografías 81 y 82 tomadas por él podemos observar que la galería estaba sustentada por unas pilastras rectangulares de fábrica (ver Fig. 207 izqda.). Podemos establecer dos hipótesis al respecto: bien que estas pilastras fueran colocadas a posteriori, cosa que parece improbable, bien que aparecieran en las pilastras o el muro de la galería al eliminarse o perderse el revestimiento.

\footnotetext{
${ }^{276}$ Fischer, E. y Lauritzen V. (1919-1920). Óp. cit. LA1151 y LA1152.

${ }^{277}$ Fischer, E. y Lauritzen V. (1919-1920). Óp. cit. LA1118.

${ }^{278}$ Fischer, E. y Lauritzen V. (1919-1920). Óp. cit. LA1118.LA1147, LA1148, LA1149 y LA1150.

${ }^{279}$ Fischer, E. y Lauritzen V. (1919-1920). Óp. cit. LA1118.

${ }^{280}$ Fischer, E. y Lauritzen V. (1919-1920). Óp. cit. LA1118. LA1147 a LA1150.

${ }^{281}$ Fischer, E. y Lauritzen V. (1919-1920). Óp. cit. LA1172 a LA1175.

${ }^{282}$ Fischer, E. y Lauritzen V. (1919-1920). Óp. cit. LA1167 a LA1171.

${ }^{283}$ Fischer, E. y Lauritzen V. (1919-1920). Óp. cit. LA1125 a LA1126.
} 


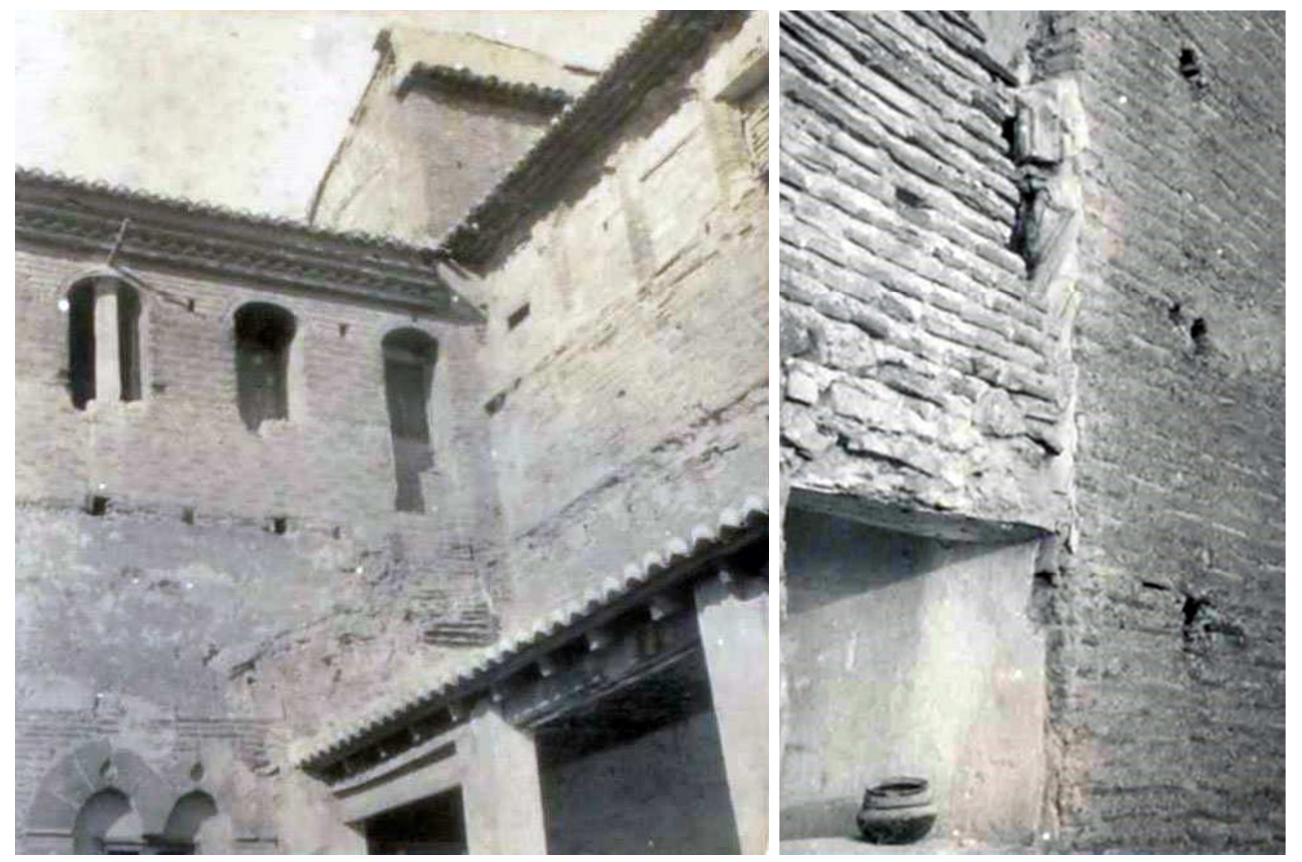

Figura 207. Izquierda. Fot. 81. Vista parcial Galería. Derecha. Fot. 85. Columna entorchada Galería.

\subsection{Archivo General y Fotográfico de la Diputación de Valencia}

Algunas de las imágenes del Palacio de Oliva encontradas en los álbumes fotográficos de Fischer fueron publicadas por Sarthou en $1920^{284}$. Para determinar la verdadera autoría de las fotografías se localizaron las fotografías atribuidas a Carlos Sarthou en el Archivo General y Fotográfico de la Diputación de Valencia. De todos los fondos atribuidos a este fotógrafo e historiador, se localizaron un total de 32 fotografías que se correspondían con el Palacio de Oliva y con las referencias 1639, 1642 a 1644 y 1670 a 1698. Estas imágenes estaban digitalizadas a partir de las copias en papel del fondo fotográfico de Sarthou, pero el archivo no dispone de los negativos de las mismas. Las fotografías están digitalizadas en formato tif y fueron tomadas con una cámara Nikon SRL, modelo D200 y con un objetivo Nikkor $18-135 \mathrm{~mm}$ f/3.5-5.66. Al analizarlas se pudo comprobar que las tomas coincidían exactamente con las de Fischer en su mayoría, si bien debido al proceso de revelado de cada una de ellas hay diferencias en la exposición de las imágenes. En la Tabla 3 se ha realizado un inventario con todas las fotografías del Palacio de Oliva localizadas en el AGFDV y las homónimas de los Álbumes fotográficos de Fischer ${ }^{285}$. Esta tabla se incorpora en el Capítulo IX, Anexo Gráfico de este documento donde se incluye una comparativa visual de las fotografías.

${ }^{284}$ Sarthou y Carreres, C. (1920). Geografía General del Reino de Valencia. Provincia de Valencia. Tomo II. Barcelona: Editorial de Alberto Martín. pp. 428-436.

${ }^{285}$ Fischer, E. (1917-1920). Álbum Fotos Grande y Álbum de Fotos Pequeño. Oliva, Valencia: MMO, Archivo Público Documental, Palacio Condal. 
Tabla 3. Relación fotografías AGFDV y comparativa con fotografías de Fischer.

\begin{tabular}{|c|c|c|}
\hline Ref. AGFDV & Fot. Fischer & Descripción \\
\hline 1639 & Fot. 5 & Vista General SE \\
\hline 1642 & Fot. 11 & Calle Palacio \\
\hline 1643 & Fot. 50 & Bóveda Sala 17 \\
\hline 1644 & Fot. 53 & Portada Escalera Honor \\
\hline 1670 & No existe & Vista de Iglesia S. María desde el Palacio \\
\hline 1671 & Fot. 48 & Artesonado Sala 12 \\
\hline 1672 & Fot. 54 & Bóveda Sala 19 \\
\hline 1673 & Fot. 56 & Casetón Bóveda Sala 13 \\
\hline 1674 & Fot. 75 & Sala 11 \\
\hline 1675 & Fot. 77 & Sala 12 \\
\hline 1676 & Fot. 58 & Bóveda Sala 13 \\
\hline 1677 & Fot. 82 & Ventana Ajimezada Patio SE \\
\hline 1678 & Fot. 64 & Portada 28 \\
\hline 1679 & Fot. 31 & Portada 23 \\
\hline 1680 & $\begin{array}{c}\text { Fot. } 19 \\
\text { (Diferente) }\end{array}$ & Forjado Sala de Armas \\
\hline 1681 & $\begin{array}{c}\text { Fot. } 26 \\
\text { (Diferente) }\end{array}$ & Forjado Sala de Armas \\
\hline 1682 & Fot. 47 & Revoltón Forjado ?? \\
\hline 1683 & Fot. 28.1 & Portada 22 \\
\hline 1684 & Fot. 39 & Portada 26 \\
\hline 1685 & Fot. 28 & Portada 22 \\
\hline 1686 & Fot.14 & Galería Patio Armas \\
\hline 1687 & Fot. 33 & Portada 27 \\
\hline 1688 & Fot. 40 & Portada 26 \\
\hline 1689 & Fot. 35 & Portada 27 \\
\hline 1690 & Fot. 65 & Portada 15 \\
\hline 1691 & Fot. 68 & Portada 8 \\
\hline 1692 & Fot. 63 & Portada 13 \\
\hline 1693 & Fot. 74 & Ventana 4 \\
\hline 1694 & Fot. 32 & Portada 20 \\
\hline 1695 & No existe & Detalle Portada 20 \\
\hline 1696 & Fot. 27 & Sala de Armas \\
\hline 1697 & Fot. 61 & Portada 15 \\
\hline 1698 & Fot. 17 & Galería Patio Armas \\
\hline
\end{tabular}


Una vez comparadas las 32 fotografías atribuidas a Sarthou que se conservan en el AGFDV con las contenidas en los Álbumes de Fischer podemos afirmar que se trata de las mismas fotografías, si bien en el AGFDV existen un total de 4 fotografías que no se encuentran en los álbumes de Fischer. Como se ha comentado anteriormente, no se han localizado los negativos de dichas fotografías. Tal y como se desprende de la descripción de Sarthou sobre el Palacio de Oliva, él lo visitó durante las labores de desmontaje llevadas a cabo por Fischer ${ }^{286}$. En su libro, Sarthou atribuye las imágenes del Palacio dos autorías: clisés de C. Sarthou y clisés de V. Arnal; aunque como hemos podido observar muchas de las imágenes son coincidentes con las de Fischer. Una hipótesis sería que Fischer hubiera hecho un encargo para realizar un reportaje fotográfico de calidad a estos dos fotógrafos y que, a su vez, tomara fotografías de menor calidad con su propia cámara; ya que como se observa en algunas imágenes, estas se han tomado en diferentes momentos del proceso de "deconstrucción" del Palacio.

\subsection{Danmarks Kunstbibliotek Studiesalen}

Por su parte, en el Archivo de la Biblioteca Nacional Danesa del Arte se ha localizado numerosa documentación gráfica y escrita atribuida a los arquitectos Egil Fischer y Vilhelm Lauritzen. Esta documentación se encuentra en el archivo de la biblioteca, denominado Studiensalen (Sala de estudio) y localizado en la localidad de Søborg, cercana a Copenhague, donde se ha podido consultar toda la documentación contenida en dos cajas con diversos documentos y tres carpetas de planos (ver Fig. 208).

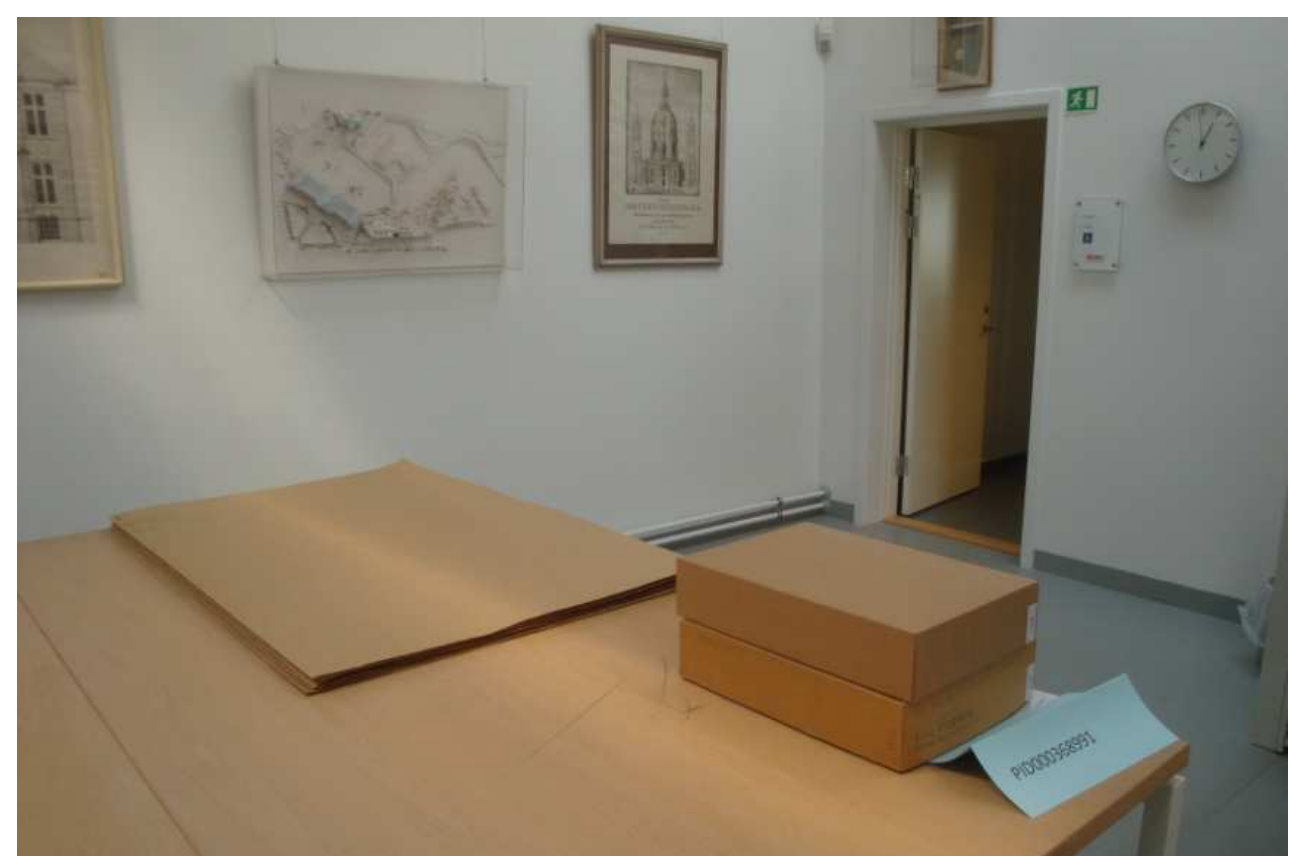

Figura 208. Documentación del arquitecto Egil Fischer. Sala de Estudio. Fuente: Archivo DKS.

${ }^{286}$ Sarthou y Carreres, C. (1920). Geografía General del Reino de Valencia. Provincia de Valencia. Tomo II. Barcelona: Editorial de Alberto Martín. pp. 57. 
Las dos cajas cuyo contenido está titulado "Foreningsarkiv" (Archivo de la sociedad) están codificadas como FA68 y $\mathrm{FA}_{69^{287}}$ y contienen numerosas carpetas que, a su vez, guardan documentos como cartas y escritos relacionados con el Palacio de Oliva; fotografías del Palacio y de las piezas trasladadas a Nørrehald (Femmøller Strand); y algunos planos y dibujos originales.

Las tres carpetas de planos están codificadas como 502 Map 7, 502 Map 8 y 502 Map 9. La carpeta 502 Map $7^{288}$, titulada "El Palacio" contiene los planos con las dos propuestas que Fischer elaboró para el proyecto del Museo Español en Dinamarca. Las otras dos carpetas contienen planos de diversos proyectos de Fischer, tanto de arquitectura como de urbanismo, y entre ellos se encuentran los planos de la planificación urbana de Femmøller Strand, los de numerosas casas unifamiliares, así como los del Hotel Mols, construido en esta urbanización.

Todas las fotografías localizadas en esta documentación referentes al Palacio se encontraban en los álbumes fotográficos de Fischer, igual que con los planos del Museo de España en Dinamarca (salvo el del emplazamiento). Por ello, en este apartado nos limitaremos a analizar los planos y croquis de elementos del Palacio que no se encuentran en la documentación del MAO, así como la "Lista de fragmentos de edificio del Palacio de los Condes de Oliva" en la que se relacionaban todos los elementos que Fischer desmontó o tenía intención de desmontar del Palacio.

\section{Planos}

- Plano pág. 39 y 61 Notebook I. Es una lámina formato folio de papel de calco en disposición vertical. Está dibujado a grafito e indica escala 1:500. En la parte superior se ha copiado el plano de planta del Palacio contenida en la página 39 del Notebook I. Está dibujado a mano libre. En la parte inferior está dibujado el detalle de la planta del Palacio contenido en la página 39 del Notebook I, en este caso con la ayuda de material de dibujo. Están asimismo dibujados los puntos cardinales, acotadas algunas medidas y numeradas las salas 1 a 20. Otras salas y elementos del Palacio (gallleri, køkk. (køkken), gard, tårn, vær. (værsale), etc. (galería, cocina, patio, torre, sala, etc.) también aparecen. El texto en danés hace referencia al croquis del Palacio donde se representa la volumetría de la fachada. Este plano no aporta gran información nueva respecto al contenido en el Notebook I, aunque sí permite identificar algunos rótulos y aporta algunas medidas (ver Fig. 209).

\footnotetext{
${ }^{287}$ Fischer, E. y Lauritzen, V. (1919-1982). Documentación Palacio de Oliva. FA68 y FA69. Søborg, Dinamarca: Archivo DKS.

${ }^{288}$ Fischer, E. (1919-1920). Planos "El Palacio". 502 Map7. Søborg, Dinamarca: Archivo DKS.
} 


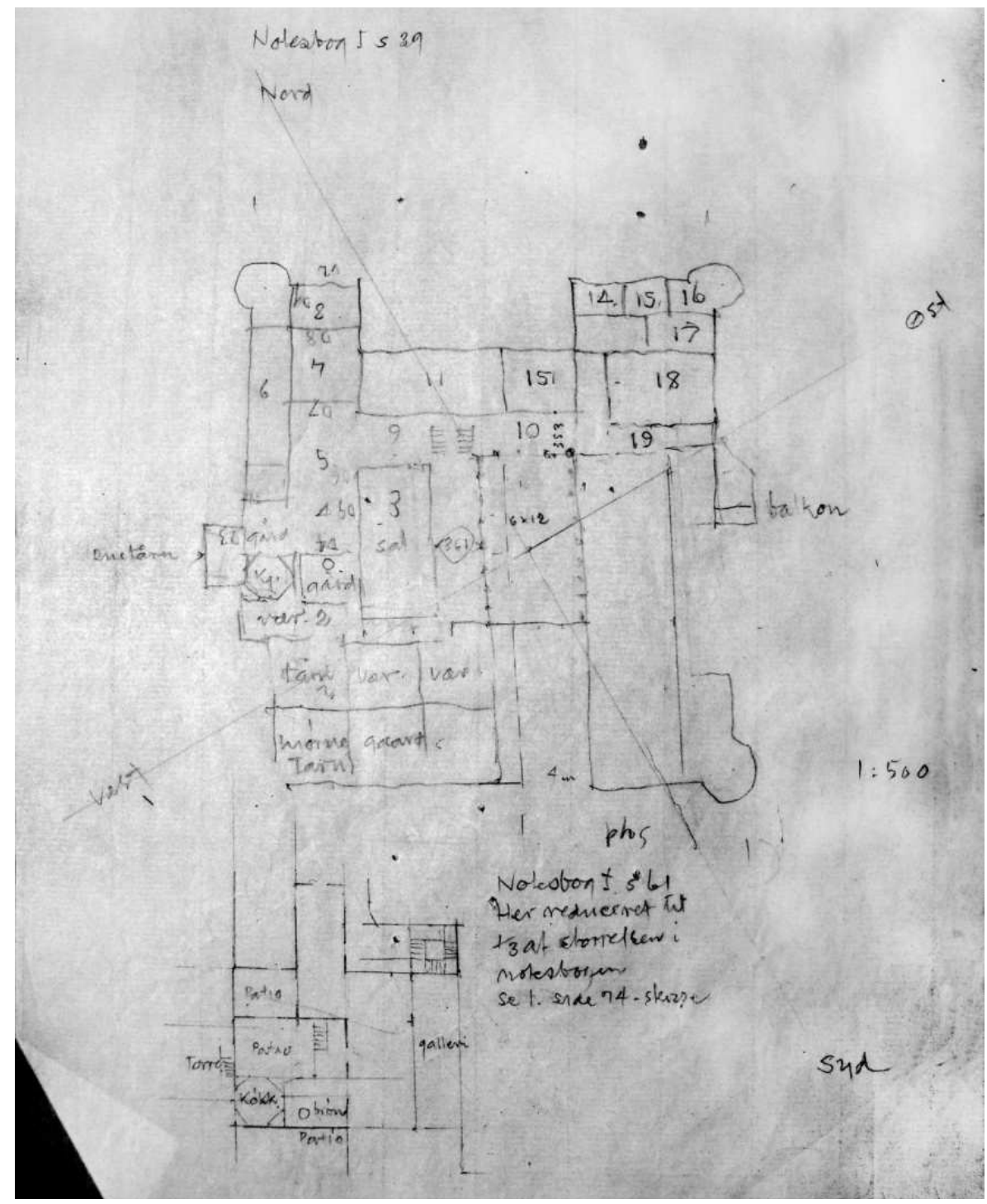

Figura 209. Plano a mano alzada de la planta del Palacio. Egil Fischer. Fuente: Archivo. DKS. E. Fischer.

- Plano pág. 39 Notebook I (Escala). Es una lámina formato folio de papel de calco en disposición vertical dibujada a tinta. No está rotulada la escala, aunque esta es 1:500, como en la lámina anterior. Está dibujada a tinta con la ayuda de herramientas de dibujo y en ella aparecen los puntos cardinales. Asimismo, están acotadas algunas medidas, numeradas las salas 1 a 20 y rotuladas otras salas y elementos del Palacio: S. Armas, balkon, kj. (køkken), gard, tårn, Duetårn, vær. (værsale), etc. (Sala de Armas, balcón, cocina, patio, torre, torre del palomar, sala, etc.) Hay una flecha que nos remite a las páginas 22 a 25 del Notebook II (ver Fig. 210). 


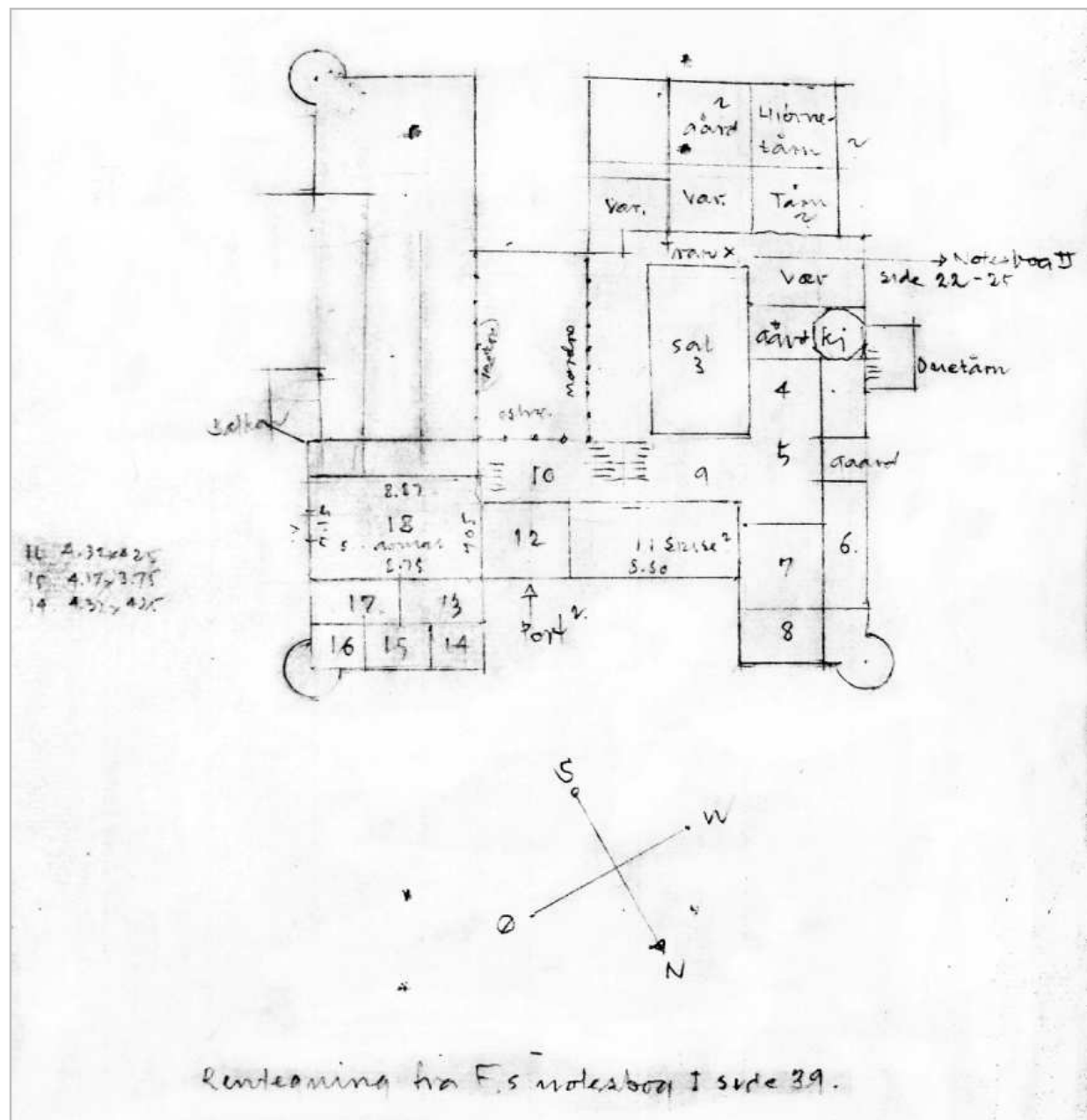

Figura 210. Plano a tinta de la planta de Palacio. Egil Fischer. Archivo DKS. E. Fischer.

- Overste Galleri (Galería Superior). Es una lámina formato folio de papel cuadriculado con perforaciones en disposición vertical dibujada a lápiz con herramientas de dibujo. Está rotulada la escala de representación (1:50). Además, aparece una sección transversal del Patio donde se ve la arcada del lado corto de la galería, la balaustrada de la planta superior y el arco rebajado de la planta baja sobre el que se sustenta la galería, en verdadera magnitud. La arcada del lado largo de la galería y su balaustrada superior se ven en sección. Existen algunas cotas de altura y hace referencia a las páginas del Notebook I que contienen información sobre los distintos elementos que componen la galería y la balaustrada, así como las molduras intermedias (pág. 2, 15, 23 a 34 y 45 a 47). En los planos LA1128 y LA1129 está representado a escala un alzado y sección del lado corto de la galería, pero en ella no aparece la balaustrada superior ni el arco inferior, por lo que este plano nos aporta información adicional (ver Fig. 211). 


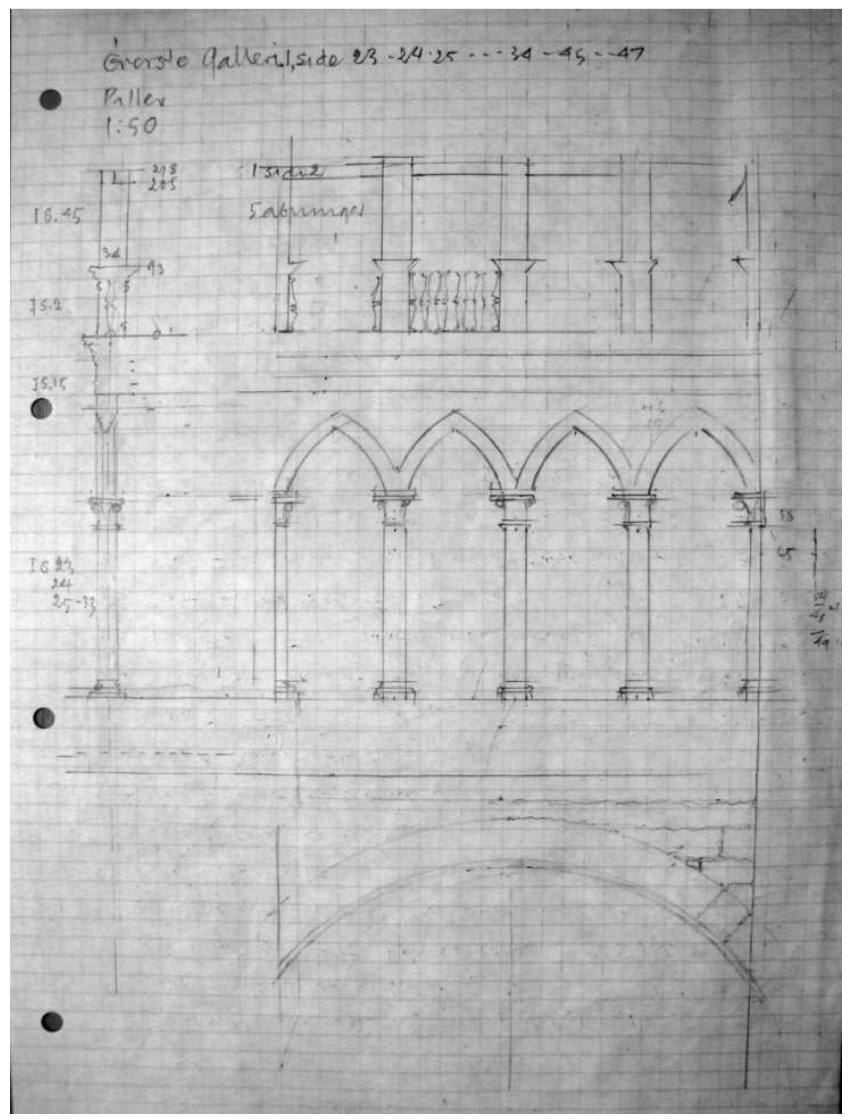

Figura 211. Plano de sección de la galería del Patio. Egil Fischer. Fuente: Archivo DKS. E. Fischer.

- Varios. Notebook I y Notebook II. Es una lámina formato folio de papel de calco en disposición vertical dibujada a lápiz con herramientas de dibujo. Está rotulada la escala de representación: 1:200. En esta lámina aparecen de manera esquemática diversos elementos arquitectónicos cuyos croquis se encuentran grafiados el los cuadernos de notas Notebook I y Notebook II. En los planos aparecen las cotas generales. Procedemos a relacionarlos:

- Planta Sala 15 (bóveda de arista). Pág.28 Notebook II.

- Planta Sala 13. Capilla. Pág.29 Notebook II.

- Planta Sala 16 (forjado). Pág.32 Notebook II.

- Planta Sala 17 (bóveda estrellada). Pág.30 Notebook II.

- Planta cocina. Pág.25 Notebook II.

- Planta Sala Techo B. Sobre Casa Miguel. Pág.13 Notebook I. Están representadas tanto la planta aérea como la cenital de esta sala.

Planta Sala de Armas (Sala 18). Pág.33 Notebook II.

Planta Sala de Artesonado I-A. Pág.3 Notebook I.

Planta Sala Techo C. Casa Miguel.Pág.3 Notebook I.

Chimenea. Pág. 7 Notebook I.

Escalera. Pág. 24 y 25 Notebook I.

Portada 1. Casa Miguel. Pág.15 Notebook II.

Portada 2. Sobre Casa Miguel. Pág.17 Notebook II. 
- Portada 4. Casa Miguel. Pág.19 Notebook II.

Este plano no nos aporta información adicional a la contenida en los croquis de los cuadernos de notas, si bien puede ayudar a transcribir algunas de las anotaciones (ver Fig. 212).

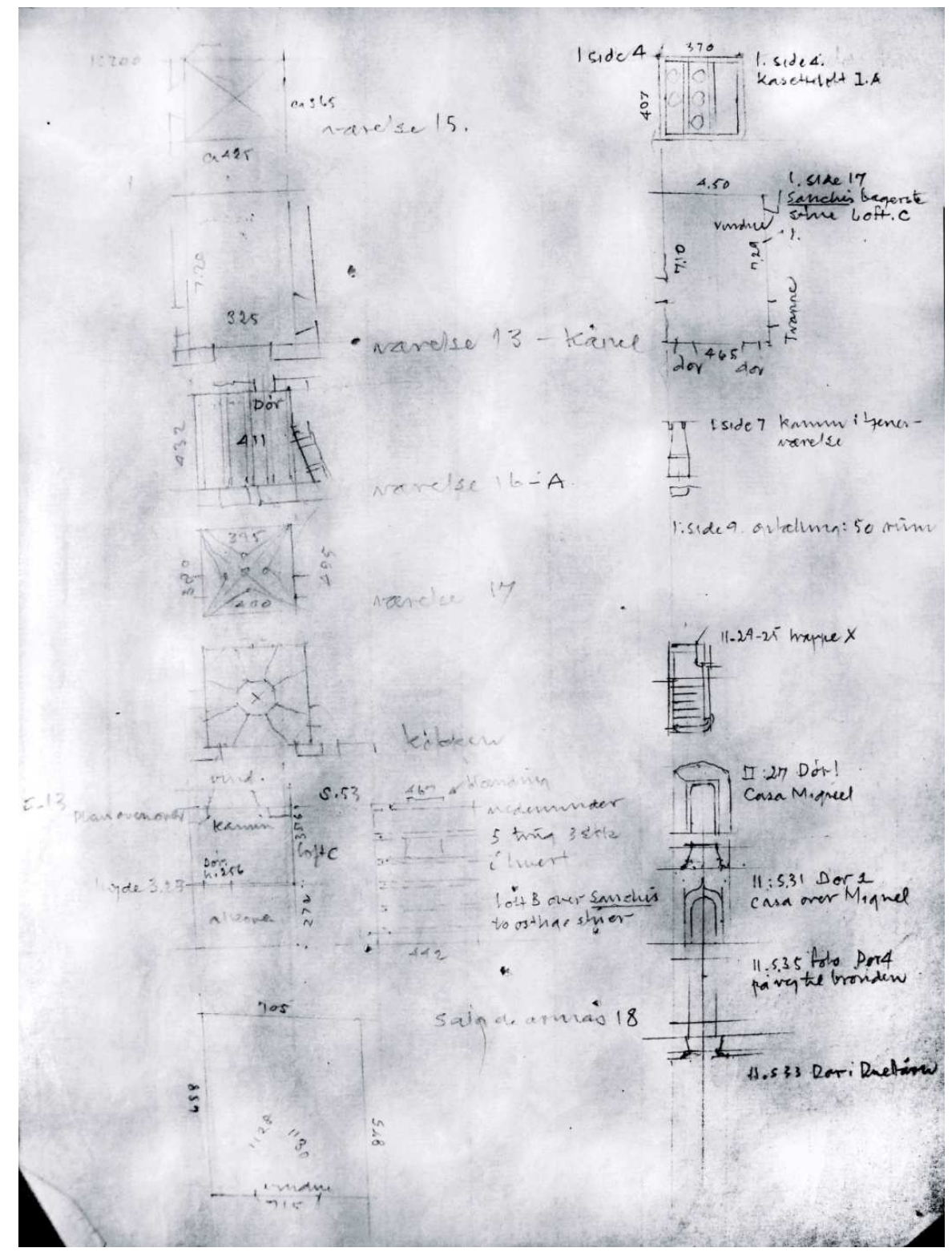

Figura 212. Plano elementos varios. Notebook I y Notebook II. Fuente: Egil Fischer. Archivo DKS.

- Escalera Notebook II. Se trata de una lámina formato folio de papel de calco en disposición vertical dibujada a lápiz con herramientas de dibujo. La escala de representación está rotulada: 1:100. En esta lámina está dibujada la planta y sección longitudinal de la escalera de las páginas 13 y 14 del Notebook II. No aporta información adicional (ver Fig. 213). 


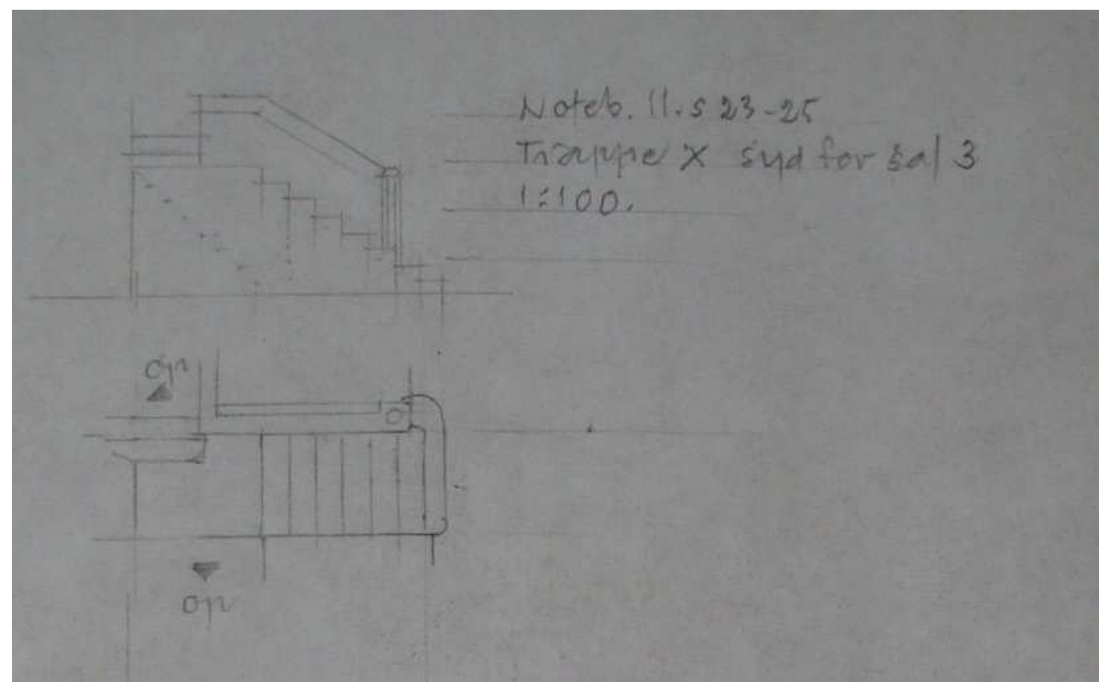

Figura 213. Escalera Notebook II. Fuente: Archivo DKS. E. Fischer.

- Portada, Escalera de Honor y planta Sala de Armas. Se trata de una lámina formato folio de papel de calco en disposición vertical dibujada a lápiz con herramientas de dibujo. No está rotulada la escala de representación, aunque esta es 1:100. En esta lámina están dibujados en la parte superior un alzado esquemático de la portada de la Escalera de Honor situada en el Patio del Palacio (hace referencia a las fotografías 52 y 53 del Álbum Fotográfico Grande y la planta de la Sala de Armas con las cotas de sus 4 lados y la posición de la ventana) (ver Fig. 214).

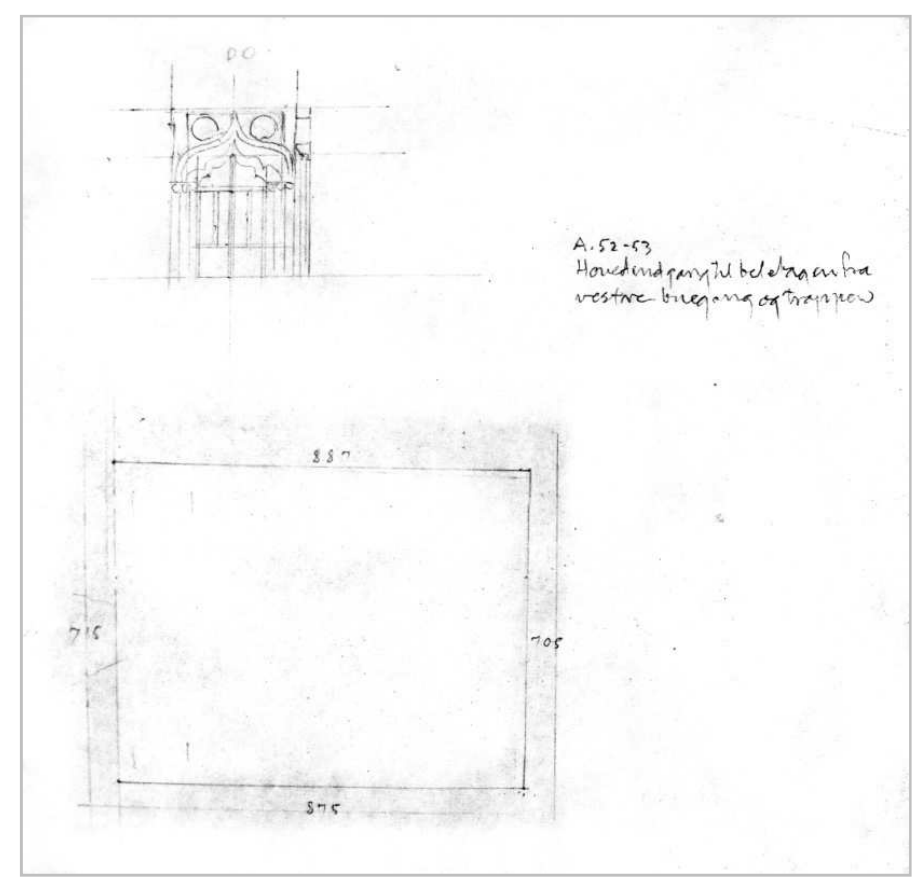

Figura 214. Portada Escalera de Honor y planta Sala de Armas. Fuente: Archivo DKS. E. Fischer. 


\section{Listado de piezas del Palacio}

Uno de los documentos escritos más importantes para comprender las labores de documentación gráfica llevada a cabo por los arquitectos daneses es, sin duda, el "Listado de fragmentos del edificio del Palacio de los Condes de Oliva"289. Este documento se encuentra mecanografiado en castellano en tres folios numerados como 116.C1, 116.C2 y 116.C3 y datados, manualmente, el 4 de abril de 1940. Algunas palabras están traducidas al danés y escritas a mano bajo o sobre el texto original. Existe una copia manuscrita de este documento en danés. Todo hace indicar que se trata de una traducción del listado anterior escrita por Vilhelm Lauritzen. Este listado se ha transcrito en las tablas 4,5 y 6 , donde se han tratado de identificar los elementos recogidos en la documentación gráfica y su localización en el Palacio.

Tabla 4. Listado de fragmentos del Palacio de los Condes de Oliva. 1. Fuente: Archivo DKS. E. Fischer.

\begin{tabular}{|c|c|c|c|}
\hline Numeración & Descripción & Elemento & Localización \\
\hline (1) & $\begin{array}{l}\text { Arcada larga de } 6,40 \text { metros con } 4 \text { arcos. Arcada larga } \\
\text { de 14,80 metros con } 8 \text { arcos. Altura de 5,60 metros. } \\
\text { Material: piedra caliza gris con columnas y perfiles de } \\
\text { mármol blanco y pizarra negra. }\end{array}$ & Arcada & $\begin{array}{l}\text { Patio de } \\
\text { Armas }\end{array}$ \\
\hline$(2)$ & $\begin{array}{l}\text { Balaustrada encima de dicha arcada compuesta de } 8 \\
\text { piezas de mármol enteras y } 3 \text { medias con medias } \\
\text { balaustradas. Falta el resto. }\end{array}$ & Balaustrada & $\begin{array}{l}\text { Patio de } \\
\text { Armas }\end{array}$ \\
\hline (3) & La galería en la torre grande (encima sala de armas ) & Arcada & $\begin{array}{c}\text { Sala sobre } \\
\text { Sala de Armas }\end{array}$ \\
\hline \multirow[t]{2}{*}{ (4) } & $\begin{array}{l}\text { Columna salomónica (corolítica) de alabastro de la } \\
\text { galería de la Sala de Armas. Quitada por supuesto. }\end{array}$ & Columna & $\begin{array}{l}\text { Galería Sala } \\
\text { de Armas }\end{array}$ \\
\hline & Techos & & \\
\hline (5) & $\begin{array}{l}\text { Techos de madera con artesonados (kasetter) } \\
\text { cuadrados. Medidas 7,5 por } 4,6 \mathrm{~m}\end{array}$ & Artesonado & Sala 11 \\
\hline (6) & $\begin{array}{l}\text { Techos de madera con artesonados (kasetter) } \\
\text { "rombales". Medidas 7,0 por 5,2m }\end{array}$ & Artesonado & Sala 12 \\
\hline (7) & $\begin{array}{l}\text { Techo Sala de Armas. Medidas } 8,7 \text { por } 7,0 \text { m capas de } \\
\text { fábrica sobre vigas de madera. Decoración } \\
\text { policromada. }\end{array}$ & $\begin{array}{l}\text { Forjado } \\
\text { policromado }\end{array}$ & $\begin{array}{l}\text { Sala 18. Sala } \\
\text { de Armas }\end{array}$ \\
\hline (8) & $\begin{array}{l}\text { El friso histórico debajo del techo no } 7 \text {. Unos } 2 \mathrm{~m} \text { con } \\
\text { su marco habían sido quitados antes de comprar yo el } \\
\text { Palacio. }\end{array}$ & $\begin{array}{l}\text { Friso } \\
\text { policromado }\end{array}$ & $\begin{array}{l}\text { Sala 18. Sala } \\
\text { de Armas }\end{array}$ \\
\hline (9) & $\begin{array}{l}\text { Relieves semicirculares entre el friso } 8 \text { y el techo } 7 . \\
\text { Varios pedazos quitados antes de la compra. }\end{array}$ & $\begin{array}{l}\text { Lunetos } \\
\text { Forjado }\end{array}$ & $\begin{array}{l}\text { Sala 18. Sala } \\
\text { de Armas }\end{array}$ \\
\hline (10) & $\begin{array}{l}\text { Techo en una pieza al lado de la Sala de Armas de } \\
\text { unos 4,00 m por 4,00 m. Compónese de bóvedas } \\
\text { estrelladas con decoración policromada y escudos de } \\
\text { madera con sus blasones pintados. }\end{array}$ & $\begin{array}{l}\text { Bóveda } \\
\text { estrellada }\end{array}$ & Sala 17 \\
\hline$(11)$ & $\begin{array}{l}\text { En la pieza contigua a no } 10 \text { un techo igual al de la } \\
\text { Sala de Armas, pero más pequeño. Medidas } 4,25 \text { por } \\
4,75 \mathrm{~m} \text {. Bastante deteriorado. }\end{array}$ & $\begin{array}{l}\text { Forjado } \\
\text { policromado }\end{array}$ & Sala 16 \\
\hline
\end{tabular}

\footnotetext{
${ }^{289}$ Fischer, E. (1440). Lista de fragmentos del Palacio de los Condes de Oliva. Søborg, Dinamarca: Danmarks Kunstbibliotek Studiesalen. pp. 116. C1, 116.C2 y 116.C3.
} 
Tabla 5. Listado de fragmentos del Palacio de los Condes de Oliva. 2. Fuente: Archivo DKS. E. Fischer.

\begin{tabular}{|c|c|c|c|}
\hline Numeración & Descripción & Elemento & Localización \\
\hline$(12)$ & $\begin{array}{l}\text { El friso debajo del techo calcado sobre lienzo. } \\
\text { Depositado en el Palacio }\end{array}$ & Friso & Sala 15 \\
\hline (13) & $\begin{array}{l}\text { Techo con camisas de alabastro en relieve entre vigas } \\
\text { de madera. Medidas 3,70 por } 4,07 \text { m. Compuesto de } \\
3 \text { por } 3 \text { bóvedas con cabezas de guerrero en } \\
\text { guirnaldas con frutos. }\end{array}$ & Artesonado I-A & Sin localizar \\
\hline (14) & $\begin{array}{l}\text { Ídem, ídem. Medidas 5,74 por 4,67m con } 5 \text { camisas } \\
\text { con sendas } 3 \text { piezas de bóvedas. Decorado con } \\
\text { esfinges y cornucopias. }\end{array}$ & Forjado B & $\begin{array}{l}\text { Casa Sanchis. } \\
\text { Sin localizar }\end{array}$ \\
\hline (15) & $\begin{array}{l}\text { Ídem, ídem como no } 13 \text { con } 4 \text { piezas de bóvedas, } \\
\text { dudoso, uno con } 15 \text { piezas de bóvedas y otro dudoso } \\
\text { con } 12 \text { piezas de bóvedas. Encuéntrase por ejemplo } \\
\text { sobre las puertas y en la "Academia de la música". }\end{array}$ & $\begin{array}{l}\text { ¿Forjado C? } \\
\text { ¿Forjado D? } \\
\text { Forjado sobre } \\
\text { puerta norte? }\end{array}$ & Sin identificar \\
\hline$(16)$ & $\begin{array}{l}\text { Bóveda en arista de unos } 3,60 \text { por } 4,25 \mathrm{~m} \text { con aristas } \\
\text { de alabastro en forma de guirnaldas. }\end{array}$ & Bóveda arista & Sala 15 \\
\hline (17) & $\begin{array}{l}\text { Bóveda de medio cañón en la "capilla". Medidas unos } \\
7,20 \text { por } 3,30 \mathrm{~m} \text { con artesones, concha en la } \\
\text { extremidad y friso por debajo, todo en relieve de } \\
\text { alabastro. }\end{array}$ & Bóveda Cañón & Sala 13 \\
\hline \multirow[t]{2}{*}{ (18) } & $\begin{array}{l}\text { Bóveda pequeña de unos 2,00 por 1,50 m de } \\
\text { alabastro en la galería entre escalera y la Sala de } \\
\text { Armas (en el lugar donde antes estaba la "Puerta de } \\
\text { los Borja", no22) en la parte quitada. }\end{array}$ & $\begin{array}{l}\text { Bóveda } \\
\text { estrellada }\end{array}$ & $\begin{array}{l}\text { Sala } \\
\text { 19.Galería } \\
\text { Sala de Armas }\end{array}$ \\
\hline & $\begin{array}{l}\text { Jambajes, entre los no } 19 \text { a } 27 \text { presentan adornos } \\
\text { ricos }\end{array}$ & & \\
\hline (19) & Entradas exteriores en piedra caliza con medallones. & $\begin{array}{c}\text { Portada } \\
\text { Escalera Armas }\end{array}$ & $\begin{array}{l}\text { Patio de } \\
\text { Armas }\end{array}$ \\
\hline (20) & $\begin{array}{l}\text { Entrada de alabastro de la escalera para el piso } \\
\text { donde estaba el techo } n \text { o } 6 \text {. }\end{array}$ & Portada 27 & Sala 20 \\
\hline$(21)$ & $\begin{array}{l}\text { Puerta de madera desde dicha puerta entrada con } \\
\text { artesones de octogonales }\end{array}$ & Puerta 27 & Sala 20 \\
\hline$(22)$ & $\begin{array}{l}\text { Entrada desde la escalera hacia la galería con los } \\
\text { escudos de los Borja y Centella. }\end{array}$ & Portada 26 & Sala 20 \\
\hline (23) & $\begin{array}{l}\text { Entrada desde galería hasta la sala de armas. Quitada } \\
\text { por supuesto. }\end{array}$ & Portada 24 & $\begin{array}{l}\text { Sala } 19 . \\
\text { Galería Sala } \\
\text { de Armas }\end{array}$ \\
\hline$(24)$ & $\begin{array}{l}\text { Entrada en la sala de armas hacia la galería con } \\
\text { escudero y escudo de los Centella. Pintura } \\
\text { policromada. Quitada por supuesto. }\end{array}$ & Portada 23 & $\begin{array}{l}\text { Sala } 18 . \text { Sala } \\
\text { de Armas }\end{array}$ \\
\hline$(25)$ & $\begin{array}{l}\text { Puerta de madera tallada de los no } 23 \text { y } 24 \text { con } \\
\text { artesones. Quitada por supuesto. }\end{array}$ & Puerta 24 & $\begin{array}{l}\text { Sala } 19 . \\
\text { Galería Sala } \\
\text { de Armas }\end{array}$ \\
\hline (26) & $\begin{array}{l}\text { Entrada desde la Sala de Armas a la pieza con techo } \\
\text { no } 10 \text {. Con figuras policromadas. }\end{array}$ & Puerta 22 & $\begin{array}{l}\text { Sala } 19 . \\
\text { Galería Sala } \\
\text { de Armas }\end{array}$ \\
\hline
\end{tabular}


Tabla 6. Listado de fragmentos del Palacio de los Condes de Oliva. 3. Fuente: Archivo DKS. E. Fischer.

\begin{tabular}{|c|c|c|c|}
\hline Numeración & Descripción & Elemento & Localización \\
\hline (27) & $\begin{array}{l}\text { Entrada desde la pieza no10 al lado de la Sala } \\
\text { de Armas con flores y figuras. }\end{array}$ & Puerta 20 & Sala 17 \\
\hline \multirow[t]{2}{*}{ (28/48) } & $\begin{array}{l}\text { Varias entradas más sencillas y enjambres, } \\
\text { entre los que algunos al lado de la Sala de } \\
\text { Armas parecen no haber sido quitados. }\end{array}$ & 21 Portadas & $\begin{array}{l}\text { Salas } 1 \text { a } 20 \\
\text { y otras }\end{array}$ \\
\hline & Marcos de ventana & & \\
\hline (49) & $\begin{array}{l}\text { Marco de ventana ricamente adornado de la } \\
\text { Sala de Armas. }\end{array}$ & Ventana 10 & $\begin{array}{c}\text { Sala } 19 . \\
\text { Galería Sala } \\
\text { de Armas }\end{array}$ \\
\hline \multirow[t]{2}{*}{$(50 / 58)$} & $\begin{array}{l}\text { Varios marcos de ventana de más sencillos } \\
\text { cuyos capiteles y zócalos en parte han sido } \\
\text { quitados. En uno de ellos una bóveda } \\
\text { esculpida. }\end{array}$ & $\begin{array}{l}9 \text { Ventanas. V3 a } \\
\text { V9 y otras }\end{array}$ & $\begin{array}{l}\text { Salas } 11 \text { a } \\
17 \text { y otras }\end{array}$ \\
\hline & Varios objetos & & \\
\hline (59) & Rejilla de hierro forjado en un balcón. & Reja o barandilla & Sin localizar \\
\hline (60) & Rejilla más sencilla en la sala de armas. & Barandilla & $\begin{array}{c}\text { Sala } 19 . \\
\text { Galería Sala } \\
\text { de Armas }\end{array}$ \\
\hline$(61 / 62)$ & Dos grandes lapidas con inscripción. & & \\
\hline (63) & $\begin{array}{l}\text { Unas } 4.000 \text { baldosas de mediados del siglo } \\
\mathrm{XVI} \text {, en parte encarnadas. }\end{array}$ & $\begin{array}{l}\text { Baldosas Clases } \\
1,2,3 \text { y } 4\end{array}$ & Sin localizar \\
\hline (64) & Dos medallones ricamente esculpidos. & $\begin{array}{c}\text { ¿Lápidas } \\
\text { conmemorativa? }\end{array}$ & Sin localizar \\
\hline \multirow[t]{2}{*}{ (65) } & Lápida en capitel. & $\begin{array}{l}\text { Capitel ventana } \\
\text { ajimezada }\end{array}$ & Sin localizar \\
\hline & En "La Música" & & \\
\hline (66) & $\begin{array}{l}\text { Rejilla de hierro forjado ante una ventana, } \\
\text { ancha } 2,15 \mathrm{~m} \text {, alta de } 2,78 \mathrm{~m} \text {. }\end{array}$ & Reja & Sin localizar \\
\hline$(67 / 71)$ & 5 entradas. & 5 portadas & Sin localizar \\
\hline (72) & $\begin{array}{l}\text { Una ventana con banco de piedra y marco con } \\
\text { capiteles. }\end{array}$ & $\begin{array}{l}\text { Ventana gótica } \\
\text { con festejador }\end{array}$ & Sin localizar \\
\hline (73) & Baldosas. & Baldosas varias & Sin localizar \\
\hline (74) & Techos como no 14. & Forjados & Sin localizar \\
\hline (75) & $\begin{array}{l}\text { Además rejilla al lado de "Los Amigos de las } \\
\text { Palomas", ancha } 2,10 \mathrm{~m} \text {, alta } 2,75 \mathrm{~m} .\end{array}$ & Reja & Sin localizar \\
\hline (76) & $\begin{array}{l}\text { Buena cantidad de vigas perfiladas para techos } \\
\text { con paño de bóvedas }\end{array}$ & Vigas madera & Sin localizar \\
\hline
\end{tabular}


Este listado es un auténtico inventario de todas las piezas que Fischer y Lauritzen desmontaron (o pretendían desmontar) con el objetivo de trasladarlas a Dinamarca. Esta misma información se encuentra documentada tanto en los Notebooks, como en los Álbumes de Fotografías y Planos realizados por ambos arquitectos y que nos dan una idea del gran trabajo llevado a cabo tanto en las labores de documentación y catalogación como de desmontaje y embalaje para su posterior transporte.

\subsection{Kunst Industri Museet}

En la Biblioteca del Museo Danés del Arte y el Diseño de localizaron numerosas fichas del material que había sido adquirido por el arquitecto Egil Fischer, tal y como figuraba en su inventario. Se trataba principalmente de azulejos decorados datados en los siglos XIV, XV y $\mathrm{XVI}$; piezas decorativas en piedra, datadas en los siglos XII a XIV; y piezas de madera, datadas en los siglos XIV, XV y XVI. Sabemos que una de las actividades de Fischer durante una época de su vida fue la de anticuario, adquiriendo antigüedades de España y otros países del sur de Europa que importaría después a Dinamarca. A pesar de distintos intentos no ha sido posible visualizar y fotografiar las piezas originales, pero sabemos que Fischer realizó un envío de piezas del Palacio, y según la información contenida en las fichas, existe la hipótesis de que algunas de ellas puedan pertenecer al Palacio de Oliva. Procederemos a identificar dichas piezas.

\section{Azulejos}

Dentro de esta documentación se encontró una gran cantidad de azulejos que habían llegado al Museo por medio de Fischer. Están datados entre 1400 y 1500 con origen Valencia.

En concreto, existe un conjunto de azulejos de fondo blanco decorados en azul adquiridos a Fischer en 1920 y catalogados como A20/1920 a A59/1920, A77/1920 y 78/1920 datados en el siglo XV y producidos en Valencia. Desconocemos si todos o parte de los azulejos podían proceder del Palacio de Oliva, pero la fecha de adquisición cuadra con el retorno de Fischer de su campaña en Oliva. No obstante, sí hemos localizado una pieza, la A51/1920 de dimensiones $12 \times 12 \mathrm{~cm}$. que tiene idéntico diseño a otras piezas procedentes de la Torre de la Comare del Palacio Condal de Oliva ${ }^{290}$ y actualmente expuestas en el MAO (ver Fig. 215).
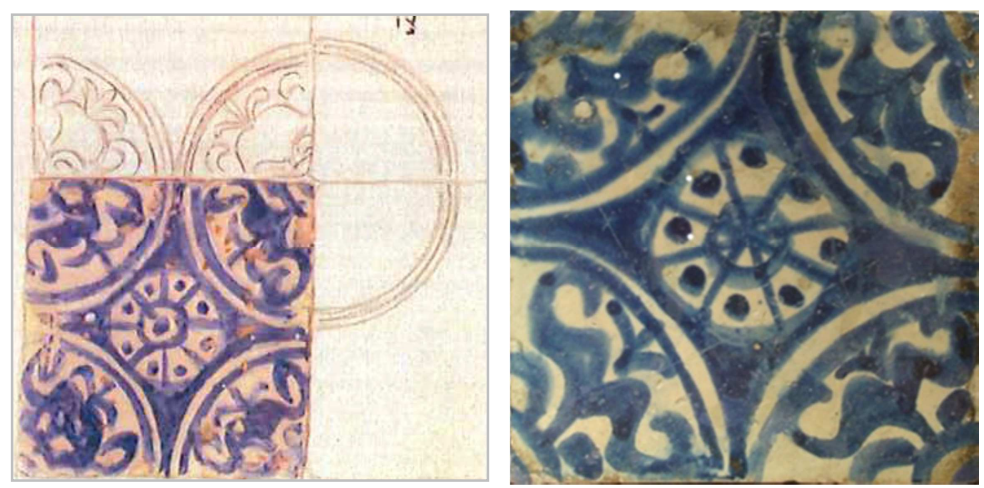

Figura 215. Izquierda: Azulejo 12 x 12 cm. Ref. A51/1920. KIM. Derecha: Azulejo 12 x 12 cm. Fuente: MAO.

\footnotetext{
${ }^{290}$ Mestre i Pons, F. (2001). Donació de les taulletes gòtics del Palau d'Oliva. Revista d'investigació de I'Associació Cultural Centelles i Riu-Sec. Núm. 3. pp. 146-151.
} 


\section{Basas y capiteles}

Otras de las piezas donde existen dudas razonables sobre su pertenencia al Palacio de Oliva son las basas y capiteles. Al respecto, existen dos lotes de piezas adquiridas a Fischer en 1921. El primero de ellos está compuesto por las piezas A68/2 y A/72/1921 a A74/1921, datadas entre los siglos XII-XIV. El material se identifica como piedra caliza y su origen "Toledo?". Asimismo, disponemos de las fichas de las piezas A72/1921 y A74/1921, que más adelante detallaremos. Cada ficha contiene, además de las características físicas, las dimensiones, la datación, el posible origen y la forma de adquisición, así como un dibujo realista coloreado de la pieza que nos muestra su forma aproximada y decoración.

- A72/1921: se trata de un capitel de dimensiones $22 \mathrm{~cm}$ de ancho por $27 \mathrm{~cm}$ de alto. Su parte inferior es lobulada y la parte superior circular, su decoración es vegetal con hojas de acanto y pequeños frutos. La ficha lo define como "Capitel con guirnalda de hojas de parra y racimos. De portada o ventana gótica" (Ver Fig. 216 izqda.).

- A74/1921: se trata de un capitel de dimensiones $27 \mathrm{~cm}$ de ancho, $28 \mathrm{~cm}$ de profundo y $35 \mathrm{~cm}$ de alto. Su parte inferior es circular y la parte superior poligonal. Su decoración es vegetal con hojas de lirio. La ficha lo define como "Basa decorada con guirnalda de hojas de tres hojas grandes", aunque por su forma se trata claramente de un capitel (ver Fig. 216 dcha.).
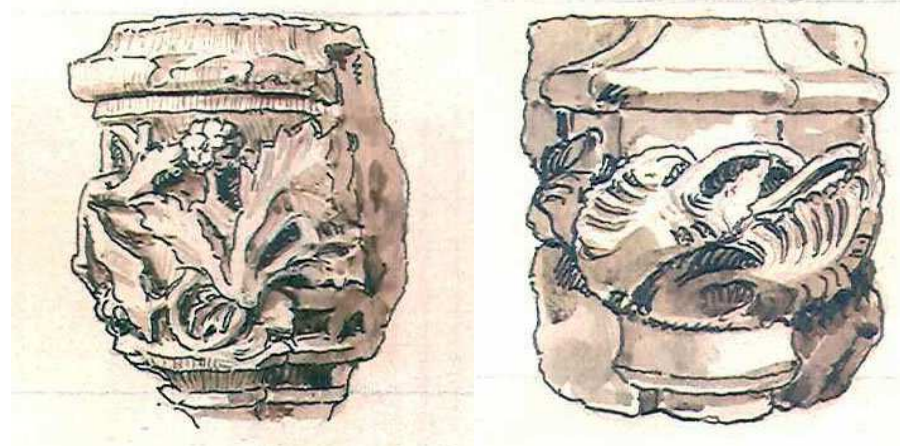

Figura 216. Capiteles góticos adquiridos a E. Fischer. Izquierda: A72/1921. Derecha: A74/1921. KIM.

El segundo lote está compuesto por las piezas A/76/1921 a A79/1921, datadas entre los siglos XII-XIV. El material se identifica como piedra arenisca y su origen "Reus $i$ Catalonien?". Disponemos de todas las fichas que contienen la información anteriormente descrita. Detallaremos la información de estas cuatro piezas.

- A76/1921: se trata de un capitel de dimensiones $38 \mathrm{~cm}$ de ancho, $25 \mathrm{~cm}$ de profundo y $37 \mathrm{~cm}$ de alto. Tanto su sección inferior como la superior tienen un contorno complejo formado por cavetos, baquetas y filetes, adaptándose a las distintas molduras que componían la jamba. Su decoración es vegetal con hojas de acanto. La ficha lo define como "Capitel decorado con guirnaldas, de una portada o ventana gótica" (Ver Fig. 217 izqda.). 
- A77/1921: se trata de una basa de dimensiones $29 \mathrm{~cm}$ de ancho, $48 \mathrm{~cm}$ de profundo y $31 \mathrm{~cm}$ de alto. En su arranque está formada por un prisma de base octogonal u otro rectangular y molduras cóncavas entre ellos. En la parte superior estos prismas transforman su perfil vertical con diversas molduras cóncavas y convexas (cavetos y baquetas) características del estilo gótico. La ficha lo define como "Basa" (Ver Fig. 217 dcha.).
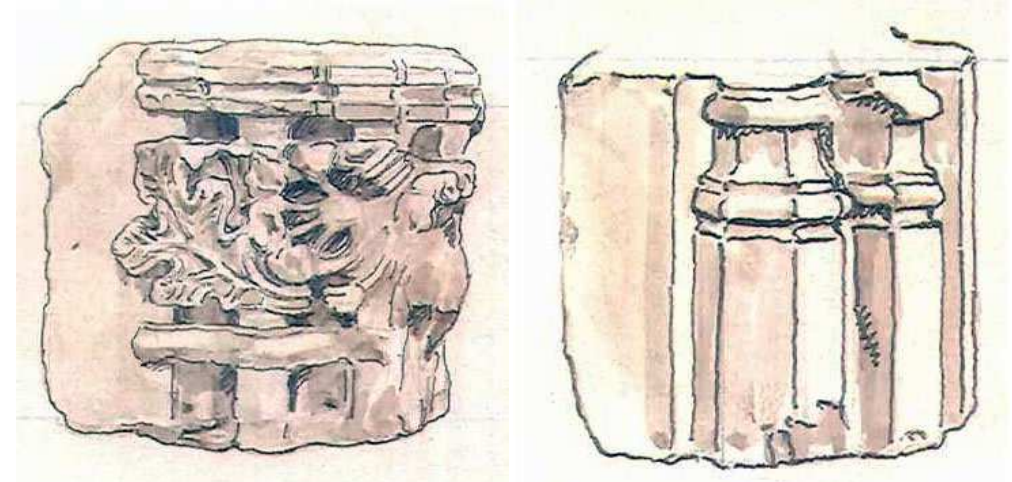

Figura 217. Capiteles góticos adquiridos a E. Fischer. Izquierda: A76/1921. Derecha: A77/1921. KIM.

- A78/1921: Se trata de una basa de dimensiones $33 \mathrm{~cm}$ de ancho, $74 \mathrm{~cm}$ de profundo y $38 \mathrm{~cm}$ de alto. Tanto su base como su coronación tienen un perfil complejo compuesto por cavetos, baquetas y filetes con una forma gótica característica, tiene decoración de hojas de acanto. La ficha lo define como "Capitel decorado con follaje, de una portada gótica" (Ver Fig. 218 izqda.).

- A79/1921: se trata de una basa de dimensiones $31 \mathrm{~cm}$ de ancho, $50 \mathrm{~cm}$ de profundo y $28 \mathrm{~cm}$ de alto. Su base como su coronación tienen un perfil complejo compuesto por cavetos, baquetas y filetes con una forma gótica característica, y su cara superior parece circular rematada en dos cavetos laterales que entregan sobre los dos paramentos rectos de la jamba. Tiene decoración de hojas de acanto. La ficha lo define como "Capitel decorado con hojas de acanto" (Ver Fig. 218 dcha.).
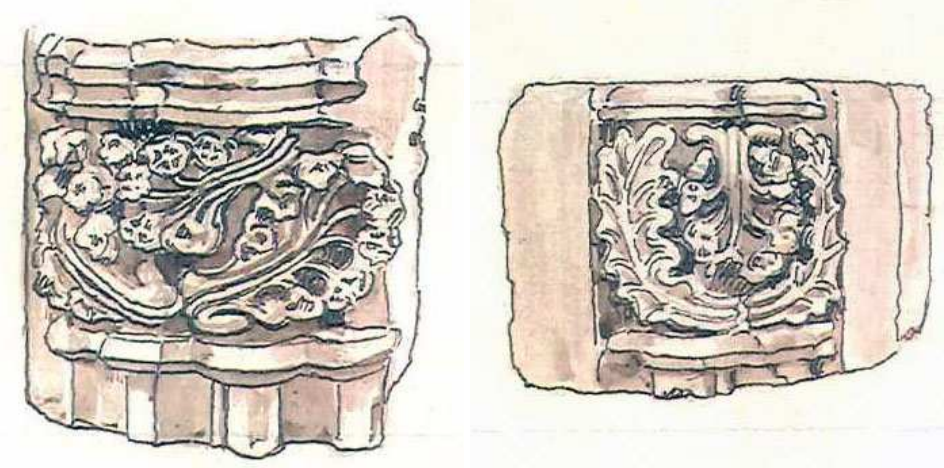

Figura 218. Capiteles góticos adquiridos a E. Fischer. Izquierda: A78/1921. Derecha: A79/1921. KIM. 
Por el tipo de piezas, sus características y su fecha de adquisición, hay muchas posibilidades de que pudieran pertenecer al Palacio de Oliva. Como datos contradictorios tenemos el material y el lugar de procedencia. En cuanto al material, un lote lo identifica como piedra caliza y el otro como piedra arenisca, existiendo una contradicción entre ambas identificaciones, si bien las piezas parecen pertenecer al mismo edificio. Sabemos que las portadas interiores del Palacio eran de yeso y las exteriores de piedra, probablemente caliza. Sería necesario poder analizar las piezas para poder determinar exactamente el tipo de material y su origen. En cuanto al lugar de procedencia, la ficha indica "Reus i Catalonien?", aunque lo ponen en interrogante, por lo que no deja de ser una hipótesis. En la página 36 del Notebook $11^{291}$ encontramos una anotación cuyo título es Tarragona. Kapitæls (Tarragona. Capiteles), donde se detalla una serie de medidas tridimensionales y la cubicación total $\left(2,804 \mathrm{~m}^{3}\right)$ (ver Fig. 219). Todo apunta a que se trata de la cubicación de un envío de cajas que partieron del puerto de Tarragona. La mercancía que llevaban las citadas cajas podrían ser los capiteles. Sería, pues, una prueba que podría vincular los capiteles depositados en el Museo Danés del Arte y el Diseño con los empaquetados por Fischer entre 1919 y 1920.

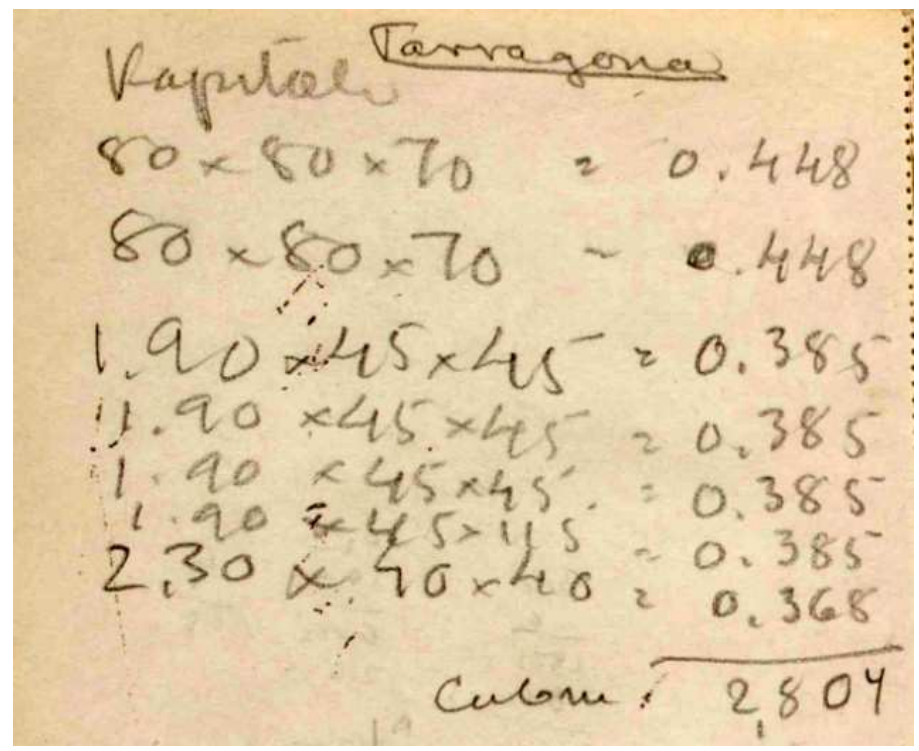

Figura 219. Anotación página 36. Notebook II. Fuente: E. Fischer.

\footnotetext{
${ }^{291}$ Fischer, E. (1919-1920.). Notebook II. Oliva, Valencia: Museo Municipal de Oliva, Archivo Público Documental, Palacio Condal. pp. 36.
} 



\section{CAPITULO VI}

\section{LAS PORTADAS}

\section{INTRODUCCIÓN}

Uno de los elementos arquitectónicos más singulares del Palacio Condal de Oliva, y por tanto, el mejor documentado por Fischer y Lauritzen, son sus portadas tardogóticas. Así, disponemos de 33 fotografías, 10 páginas en los Notebooks que representan o hacen referencia a las mismas y un total de 45 planos con alzados, plantas y despieces en los que aparecen 28 portadas numeradas y ubicadas en el Palacio, más otras 5 dibujadas, pero no localizadas. Todas ellas tienen un lenguaje compositivo común: su trazado y composición tardogóticos, si bien existen elementos diferenciadores entre ellas que hacen que no existan dos portadas idénticas entre todas las grafiadas por Fischer y Lauritzen.

\section{METODOLOGÍA}

Para poder analizar y estudiar las portadas del palacio se ha comenzado por elaborar una base de datos que incluya toda la documentación gráfica correspondiente a las portadas. Para ello, se ha realizado una hoja de cálculo donde se ha incluido toda la documentación existente de las mismas en cada uno de los documentos: Notebook I, Notebook II, Álbum de Fotografías Grande, Álbum de Fotografías Pequeño y planos, enlazando las imágenes jpg de documentación gráfica escaneada a la hoja de cálculo mediante hipervínculos.

Las imágenes jpg de planos y croquis se han insertado en un archivo de CAD y, una vez rectificada su orientación vertical, se ha procedido a redibujar los trazados geométricos de los mismos buscando sus simetrías, trazados rectos, trazados curvos, puntos de corte, intersección y tangencia.

Una vez dibujados dichos trazados se han analizado formalmente e introducido los datos (tramos rectos, tramos curvos y número de centros) y tipo de arco en la hoja de cálculo con el fin de elaborar una tabla dinámica con toda la información de los arcos que componen las portadas para una mejor gestión de la documentación gráfica existente. 
Tabla 7. Relación de portadas y documentación existente.

\begin{tabular}{|c|c|c|c|c|c|c|}
\hline Portada / Dör & Sala / Rüm & Plan & Notebook II & Álbum Grande & Álbum Pequeño & №. Fotogr. \\
\hline Dör 1 & 1 & NO & 5 tgun & No & No & NO \\
\hline Dör 2 & Escalera & NO & Pág.15A & No & No & NO \\
\hline Dör 3 & ¿Torreón? & NO & Pág.16A & Pág.16A & Pág.11A & $\underline{72}$ \\
\hline Dör 4 & 4 & NO & Pág.17A & Pág.16A & Pág.12R & $\underline{73}$ \\
\hline Dör 5 & 3 & NO & Pág.18A & Pág.16A & Pág.11A & $\underline{72}$ \\
\hline Dör 6 & 3 & NO & Pág.19A & No & No & NO \\
\hline \multirow{2}{*}{ Dör 7} & \multirow{2}{*}{7} & \multirow{2}{*}{ LA 1182} & \multirow{2}{*}{ Pág.20A } & \multirow{2}{*}{ Pág.15R } & \multirow{2}{*}{ Pág.9R } & $\underline{61}$ \\
\hline & & & & & & $\underline{69}$ \\
\hline Dör 8 & 7 & NO & Pág.21A & Pág. 15A & Pág.11A & $\underline{68}$ \\
\hline Dör 9 & 8 & NO & Pág.22A & No & No & NO \\
\hline \multirow{3}{*}{ Dör 10} & \multirow{3}{*}{11} & $\underline{\text { LA } 1140}$ & \multirow{3}{*}{ NO } & \multirow{3}{*}{ Pág.15A } & \multirow{3}{*}{ Pág.11R } & \multirow{3}{*}{$\underline{66}$} \\
\hline & & LA 1141 & & & & \\
\hline & & LA 1142 & & & & \\
\hline \multirow{2}{*}{ Dör 11} & \multirow{2}{*}{11} & LA 1137 & \multirow{2}{*}{ NO } & \multirow{2}{*}{ Pág.16R } & P & \\
\hline & & $\underline{\text { LA1138 }}$ & & & NO & $\underline{13}$ \\
\hline Dör 12 & 12 & $\underline{\text { LA } 1138}$ & NO & Pág 17A & NO & 77 \\
\hline Dor 12 & 12 & $\underline{\text { LA } 1139}$ & INO & Pag.1/A & NO & I1 \\
\hline & & $\underline{\mathrm{LA}} 1145$ & & & & \\
\hline Dor 13 & 12 & $\underline{\text { LA } 1146}$ & INO & $\mathrm{rdg} \cdot 14 \mathrm{~K}$ & NO & $\underline{03}$ \\
\hline Dör 14 & 13 & LA 1147 & NO & Pág 14A & $\mathrm{NO}$ & 61 \\
\hline Dor 14 & 13 & LA 1148 & INO & Pag.14A & NO & $\underline{01}$ \\
\hline Dör 15 & 12 & LA 1149 & NO & Pód 14R & No & 65 \\
\hline Dor 13 & 13 & $\underline{\text { LA } 1150}$ & INO & dg. $14 \mathrm{~K}$ & NO & $\underline{05}$ \\
\hline Dör 16 & 14 & LA 1151 & $\mathrm{NO}$ & $\mathrm{NO}$ & $\mathrm{NO}$ & $\mathrm{NO}$ \\
\hline Dor 10 & 14 & LA 1152 & INO & NO & INO & INO \\
\hline & 15 & LA 1153 & NO & $\mathrm{NO}$ & NO & NO \\
\hline Dor 17 & 15 & La 1154 & INO & INO & INO & INO \\
\hline Dör 18 & 16 & LA 1155 & NO & Pág 15A & Pág 11R & 67 \\
\hline DOT 10 & 10 & $\underline{\text { LA } 1156}$ & INO & rdg.1JA & pdg. IIn & $\underline{01}$ \\
\hline & & LA 1157 & & & & \\
\hline Dor 19 & 16 & $\underline{\text { LA } 1158}$ & NO & NO & NO & NO \\
\hline Dör 20 & 17 & $\underline{\text { LA } 1159}$ & NO & Pág 9A & & 32 \\
\hline & & LA 1160 & & & & $\underline{\partial 2}$ \\
\hline Dör 21 & 17 & LA 1161 & م & $\mathrm{N}$ & N & No \\
\hline DOT 21 & 17 & LA 1162 & INO & NO & No & INO \\
\hline Dör 22 & 18 & LA 1163 & NO & Pág 8A & Pág 7A & $\underline{28}$ \\
\hline & & $\underline{\text { LA } 1164}$ & & & & $\underline{28.1}$ \\
\hline Dör 23 & 18 & LA 1165 & م: & Pá 8R & Páđ 7R & 31 \\
\hline DOT 23 & 10 & LA 1166 & INO & dg.on & dg. $/ n$ & $\underline{21}$ \\
\hline Dör 24 & 19 & LA 1167 & NO & Pág 8R & Pág 6A & 29291 \\
\hline & & LA 1168 & & dg.on & $\mathrm{cdg} .0 \mathrm{~A}$ & $29,29.1$ \\
\hline & & LA 1169 & & & & \\
\hline Dör 25 & 19 & $\underline{\text { LA } 1170}$ & NO & NO & NO & NO \\
\hline & & $\underline{\text { LA } 1171}$ & & & & \\
\hline & & $\underline{\text { LA } 1173}$ & & & Pág.4R & $\underline{\underline{39}}$ \\
\hline Dor 26 & 20 & LA 1122 bis & NO & Pag.IUR & Pág.8A & $\underline{40}$ \\
\hline & & $\underline{\text { LA } 1175}$ & & & & $\underline{33}$ \\
\hline Dör 27 & 20 & LA 1124 & NO & Pág.9R & Pág.6A & 34 \\
\hline & & & & & & $\underline{35}$ \\
\hline & & LA 1143 & & & & \\
\hline Dor 28 & 12 & LA 1144 & NO & Pag.14R & NO & $\underline{64}$ \\
\hline Sin Identif. & Sin Identif. & $\underline{\text { LA } 1136}$ & NO & NO & NO & NO \\
\hline Sin Identif. & Sin Identif. & LA 1176 & NO & NO & NO & NO \\
\hline Sin Identif. & Sin Identif. & $\underline{\text { LA } 1177}$ & NO & NO & NO & NO \\
\hline Sin Identif. & Sin Identif. & LA 1191 & NO & NO & NO & NO \\
\hline Sin Identif. & Sin Identif. & $\underline{\text { LA } 1192}$ & NO & NO & NO & NO \\
\hline Escalera Honor & Patio Honor & NO & $\mathrm{NO}$ & Pág 12R & Pág 9R & $\underline{52}$ \\
\hline Escalerd nonor & Patio nomor & INO & INO & Pdg. $12 \mathrm{~K}$ & pdg. $9 \mathrm{~K}$ & $\underline{\underline{53}}$ \\
\hline
\end{tabular}




\section{ANÁLISIS GRÁFICO}

\section{Portada 1}

Se procede a enumerar y analizar la documentación gráfica existente de la Portada 1 (Dör 1), situada en la Sala 1 (Rüm 1) de acuerdo con el plano de la planta noble del Palacio ${ }^{292}$ :

- Notebook II: la Portada 1 está croquizada a lápiz sobre la página $13 A^{293}$. El croquis representa el alzado de la portada y una sección horizontal de la jamba izquierda. Es esquemático y el objetivo, aparentemente, es indicar el despiece para su desmontaje y posterior montaje. Aparecen recuadradas un total de 4 piezas: D1.v, D1.v.a, D1.v.b y Dh. El criterio de numeración de las piezas es el siguiente: D1 identifica que la pieza corresponde a la Portada 1 (Dör 1), la primera letra $(\mathrm{v}, \mathrm{h})$ identifica si corresponde al lado izquierdo o derecho de la portada (venstre y højre en danés) y la siguiente letra (a, $b$, etc.) indica la numeración de la pieza en el sentido de las agujas del reloj (la primera de ellas carece de esta letra). La pieza D1v corresponde a la basa izquierda de la portada, la D1v.a la parte superior de la jamba izquierda en su encuentro con el arco, la D1v.b al arranque izquierdo del arco y la D1h comprende tanto la parte superior como la jamba derecha y el arranque del arco. El hecho de que sólo se hayan numerado estas piezas puede deberse al mal estado del resto del arco o a la intención de utilizarlas como moldes para la realización de plantillas para la posterior restitución del arco. En cualquier caso la no numeración de la basa derecha evidencia la no existencia de ésta en el momento del levantamiento gráfico, ya que esta basa es simétrica a la izquierda y, dada su complejidad formal, sólo se podría obtener mediante tallado o modelado. En cuanto a las cotas, aparecen grafiadas el ancho interior o luz (1,10 m.), el exterior (2,36 $\mathrm{m}$.), así como otros anchos intermedios, la profundidad $(0,90 \mathrm{~m})$, la altura del intradós en el eje $(2,30 \mathrm{~m})$, la altura máxima $(3,01 \mathrm{~m})$, la altura del arco en el intradós $(2,33 \mathrm{~m})$ y extradós $(2,62 \mathrm{~m})$, así como otras alturas intermedias. La sección de la jamba izquierda detalla todas las molduras que la componen, pero no existent cotas de cada una de las molduras. En la parte superior del croquis se encuentra rotulado el siguiente texto "Dör D1 Venstre Sokkel 2 òverste "rejarm". (Casa over Miguel)". "Puerta D1 Basa Izquierda. 2 "rejarm" superior (Sobre Casa de Miguel)" (ver Fig. 220).

\footnotetext{
292 Fischer, E. y Lauritzen V. (1919-1920). Planos. Oliva, Valencia: Museo Municipal de Oliva, Archivo Público Documental, Palacio Condal (LA 1109).

${ }^{293}$ Fischer, E. (1919-1920). Notebook I. Oliva, Valencia: Museo Municipal de Oliva, Archivo Público Documental, Palacio Condal. (LA 1104 pp. 13A).
} 


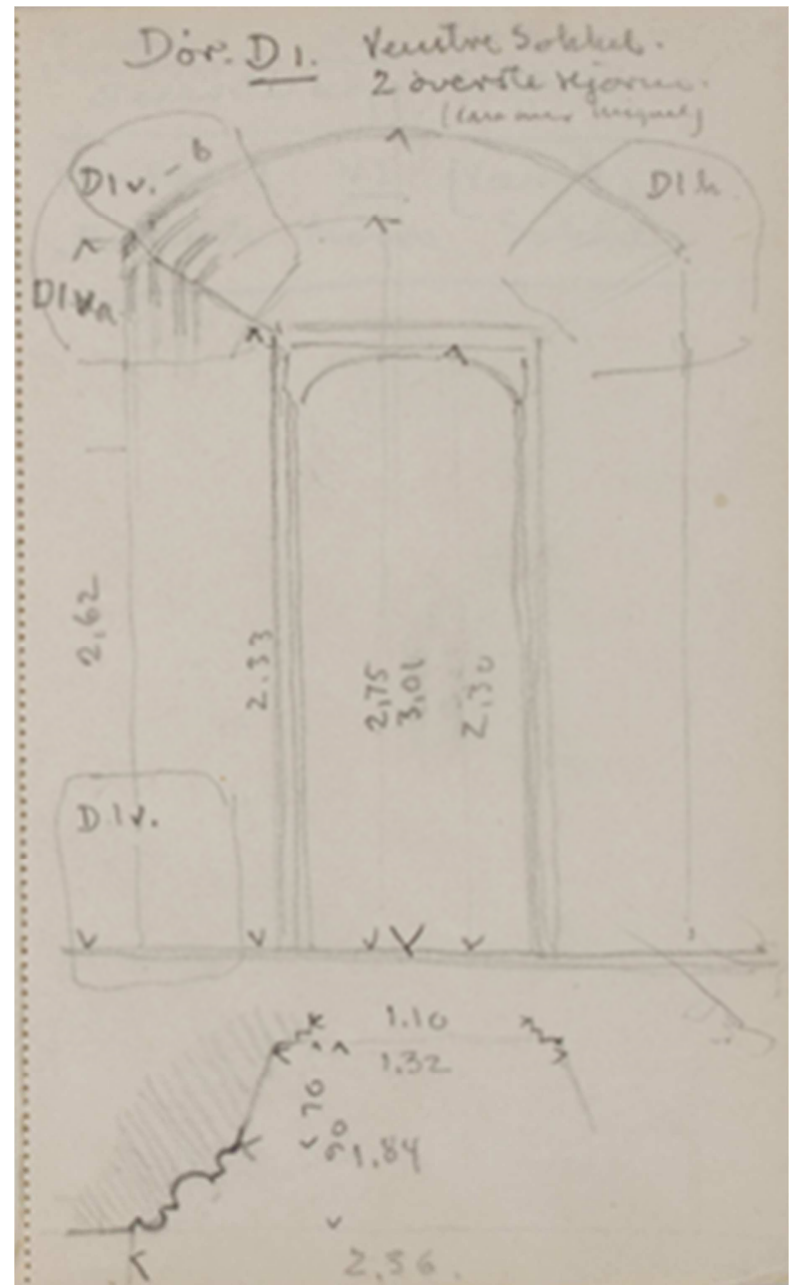

Figura 220. Croquis Portada 1. Notebook II. LA1105. Pág. 13A.

\section{E. Fischer}


Tabla 8. Ficha Portada $1^{294}$.

\begin{tabular}{|c|c|c|}
\hline Ficha 1 & Portada 1 (Dör 1) & \\
\hline Localización & Sala 1 (Rüm 1) & \\
\hline \multirow[t]{4}{*}{$\begin{array}{l}\text { Documentación } \\
\text { existente }\end{array}$} & Notebook I & Pág. 13a \\
\hline & Note Book II & NO \\
\hline & Álbum Fotográfico Grande & NO \\
\hline & Álbum Fotográfico Pequeño & NO \\
\hline \multirow[t]{5}{*}{ Arco Intradós ${ }^{295}$} & Tipo de arco & Carpanel \\
\hline & № Trazados curvos & 3 \\
\hline & № Trazados rectos & 0 \\
\hline & Luz & $1,84 \mathrm{~m}$ \\
\hline & Altura libre & $2,75 \mathrm{~m}$ \\
\hline \multirow[t]{5}{*}{ Arco Extradós } & Tipo de arco & Escarzano \\
\hline & № Trazados curvos & 1 \\
\hline & № Trazados rectos & 0 \\
\hline & Luz & $2,36 \mathrm{~m}$ \\
\hline & Altura total & $3,01 \mathrm{~m}$ \\
\hline Basas & No grafiadas. Sin información & \\
\hline \multirow[t]{9}{*}{ Jamba } & $\begin{array}{c}\text { Molduras del extradós a } \\
\text { intradós: }\end{array}$ & Radio \\
\hline & Caveto & $2 \mathrm{~cm}$ \\
\hline & Baqueta o columnilla & $3 \mathrm{~cm}$ \\
\hline & Caveto & $4 \mathrm{~cm}$ \\
\hline & Caveto (semicircular) & $6 \mathrm{~cm}$ \\
\hline & Filete ¿Falta columnilla? & $4 \mathrm{~cm}$ \\
\hline & Caveto (semicircular) & $3 \mathrm{~cm}$ \\
\hline & Jamba abocinada & $75 \mathrm{~cm}$ \\
\hline & Ángulo jamba & $30^{0}$ \\
\hline Capiteles & NO & \\
\hline
\end{tabular}

294 En las portadas 1 a 9 los datos en negro se han obtenido directamente de los croquis del Notebook I. Por su parte, los datos en rojo se han conseguido a partir de una hipótesis de restitución gráfica a partir de los datos de los croquis y fotografías.

295 En las portadas con arcos abocinados la medida del intradós que se considera es la del arco interior, no la del hueco de puerta adintelado. 


\section{Portada 2}

Procedemos a enumerar y analizar la documentación gráfica existente de la Portada 2 (Dör2), situada en caja de la escalera de acuerdo con el plano de planta del Palacio:

- Notebook II: la Portada 2 está croquizada a lápiz sobre la página $15 a^{296}$. El croquis representa el alzado de la portada y una sección horizontal de la jamba izquierda. Sobre el alzado aparecen recuadradas un total de 7 piezas: D2.v, D2.v.a, D2.v.b, D2.h, D2.h.a, D2.h.b y D2m. Las piezas D2.v y D2.h corresponde a la basas izquierda y derecha, respectivamente, las piezas D2.v.a y D2.h.b corresponden a la parte superior de las jambas, las piezas D2.v.b y D2.h a los arranques del arco y la pieza D2.m. a la clave del arco (la letra " $\mathrm{m}$ " es la abreviatura de midler, medio en danés). En cuanto a las cotas, sólo figuran el ancho interior o luz (1,08 m.), el exterior (1,66 m.), la altura máxima del arco en el intradós $(2,33 \mathrm{~m})$ y en el extradós $(2,94 \mathrm{~m})$, así como otras alturas intermedias. La sección de la jamba izquierda detalla todas las molduras que la componen, pero no existen cotas de cada una de las molduras ni de la profundidad total de la jamba. En la parte superior del croquis se encuentra rotulado el siguiente texto "Dör D2 (Casa over Miguel)". "Portada D1 (Sobre Casa de Miguel)" (ver Fig. 221).

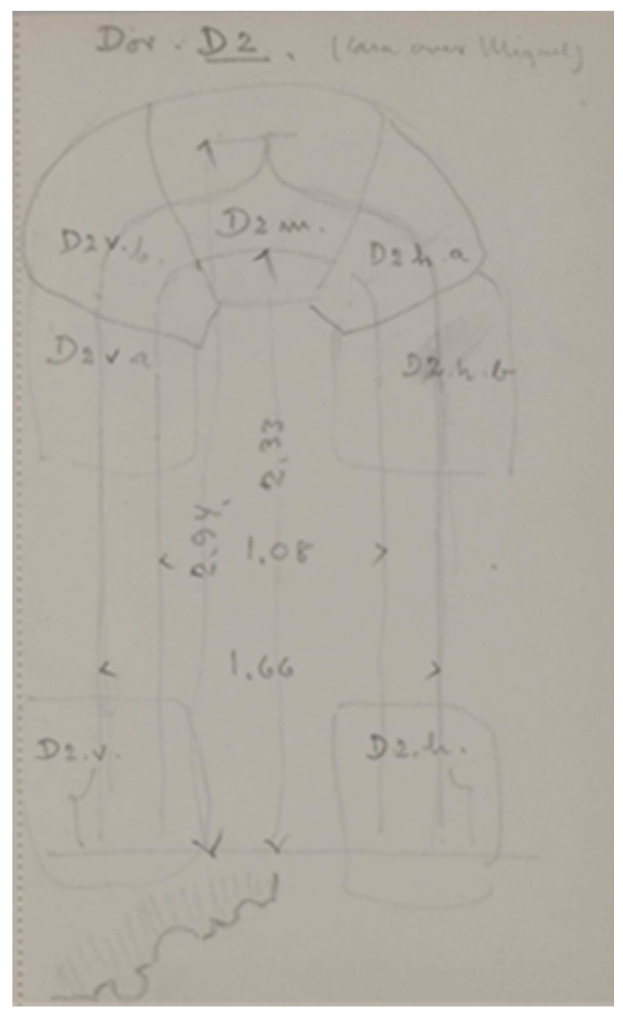

Figura 221. Croquis Portada 2. Notebook II. LA1105. Pág. 15A. E. Fischer

${ }^{296}$ Fischer, E. (1919-1920) Notebook I. Oliva, Valencia: Museo Municipal de Oliva, Archivo Público Documental, Palacio Condal. (LA 1105, pp. 15A). 
Tabla 9: Ficha Portada 2.

\begin{tabular}{|c|c|c|}
\hline Ficha 2 & Portada 2 (Dör 2) & \\
\hline Localización & Sala 1 (Rüm 1) & \\
\hline \multirow{4}{*}{$\begin{array}{l}\text { Documentación } \\
\text { existente }\end{array}$} & Noteboook I & Pág. 15a \\
\hline & Notebook II & NO \\
\hline & Álbum Fotográfico Grande & NO \\
\hline & Álbum Fotográfico Pequeño & NO \\
\hline \multirow[t]{5}{*}{ Arco Intradós } & Tipo de arco & Carpanel \\
\hline & № Trazados curvos & 3 \\
\hline & № Trazados rectos & 0 \\
\hline & Luz & $1,08 \mathrm{~m}$ \\
\hline & Altura libre & $2,33 \mathrm{~m}$ \\
\hline \multirow[t]{5}{*}{ Arco Extradós } & Tipo de arco & $\begin{array}{l}\text { Flamígero } \\
\text { Aquillado }\end{array}$ \\
\hline & № Trazados curvos & 4 \\
\hline & № Trazados rectos & 0 \\
\hline & Luz & $1,66 \mathrm{~m}$ \\
\hline & Altura máxima & $2,94 \mathrm{~m}$ \\
\hline Basas & No grafiada. Sin información & \\
\hline \multirow[t]{12}{*}{ Jamba } & $\begin{array}{l}\text { Molduras del extradós a } \\
\text { intradós: }\end{array}$ & Radio \\
\hline & Caveto & $3 \mathrm{~cm}$ \\
\hline & Baqueta o columnilla & $3 \mathrm{~cm}$ \\
\hline & Caveto & $5 \mathrm{~cm}$ \\
\hline & Caveto (semicircular) & $4 \mathrm{~cm}$ \\
\hline & Filete & $2 \mathrm{~cm}$ \\
\hline & Filete & $2 \mathrm{~cm}$ \\
\hline & Caveto & $5 \mathrm{~cm}$ \\
\hline & Filete & $2 \mathrm{~cm}$ \\
\hline & Caveto (semicircular) & $2 \mathrm{~cm}$ \\
\hline & Caveto & $2 \mathrm{~cm}$ \\
\hline & Ángulo jamba & $32^{\circ}$ \\
\hline Capiteles & NO & \\
\hline
\end{tabular}




\section{Portada 3}

La documentación gráfica existente de la Portada 3 (Dör3), situada en el Torreón de acuerdo con el plano de planta del Palacio es la siguiente:

- Notebook II: la Dör 3 está croquizada a lápiz sobre la página $16 a^{297}$. El croquis representa solamente parte del alzado de la portada (arco), sin existir en este caso información sobre la sección del arco y/o jamba. Sobre el alzado aparecen recuadradas un total de 4 piezas: D3.v.a, D3.v.b, D3.h.a y D3.h.b. Las piezas D3.v.a y D3.h.b. corresponden a los arranques del arco y las piezas D3.v.b yD3.h.a. a la clave del arco. No aparece ninguna cota. En la parte superior del croquis se encuentra rotulado el siguiente texto "Dör 3 Fotografía n 72 Duetaarnet". "Portada 3 Fotografía no 72 Torreón" (ver Fig. 223).

- Álbum de Fotos Grande: la portada 3 aparece en la Fot. $72^{298}$; tiene unas dimensiones de $8 \times 11 \mathrm{~cm}$. Se trata, en realidad, de una fotografía de la Portada 5 . A través del hueco de la puerta podemos ver la Portada 3 muy deteriorada, apreciándose que las molduras de las jambas prácticamente han desaparecido, conservándose solamente en el dintel (ver Fig. 222).

- Álbum de Fotos Pequeño: se trata de la misma fotografía $72^{299}$, en este caso existe un texto inferior manuscrito en danés que nos identifica de qué portada se trata, la Dör 5 y que la portada que podemos visualizar al fondo es la Dör 3 (ver Fig. 223).

${ }^{297}$ Fischer, E. (1919-1920) Notebook I. Oliva, Valencia: Museo Municipal de Oliva, Archivo Público Documental, Palacio Condal. (LA 1104, pp. 16A).

${ }^{298}$ Fischer, E. (1917-1920) Álbum Fotos Grande. Oliva, Valencia: Museo Municipal de Oliva, Archivo Público Documental, Palacio Condal. (pp. 16A).

${ }^{299}$ Fischer, E. (1917-1920) Álbum Fotos Pequeño. Oliva, Valencia: Museo Municipal de Oliva, Archivo Público Documental, Palacio Condal. (pp. 11A). 


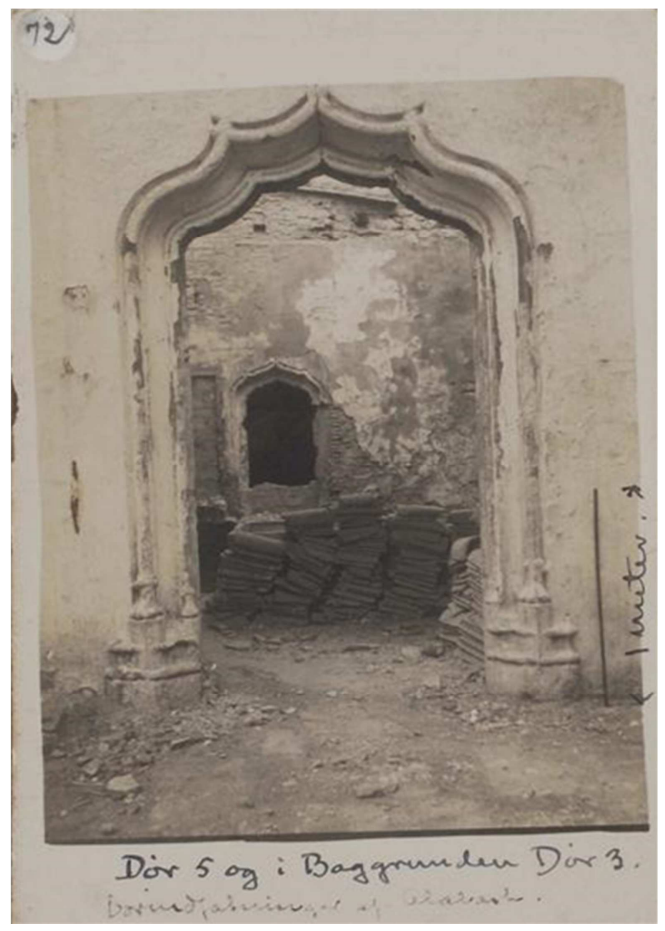

Figura 222. Fot. 72 .Portada 3. Álbum Fotogr. Grande. Hoja 16A. E. Fischer.

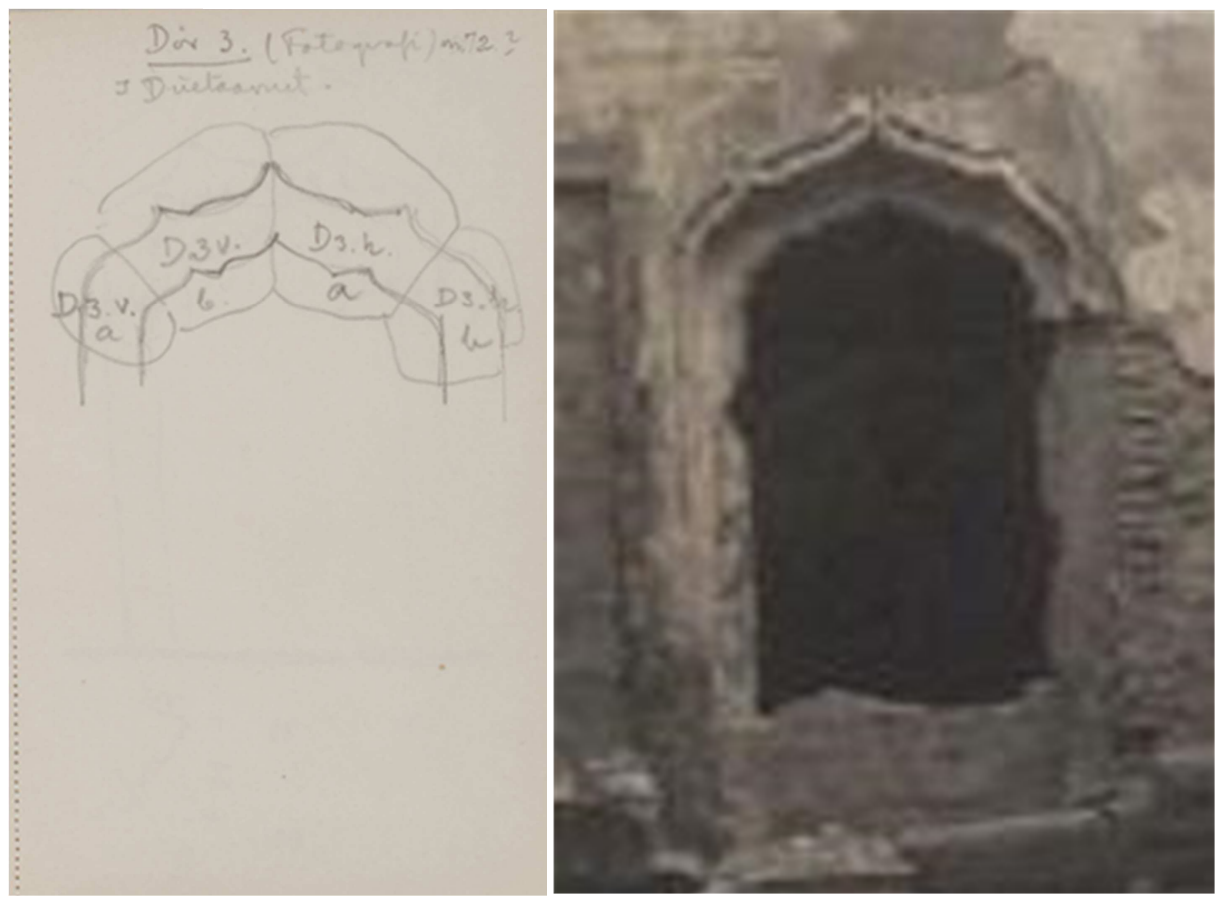

Figura 223. Izquierda: croquis Portada 3. Notebook II. LA1105. Pág. 16A. Derecha: ampliación Portada 5. Álbum Fotogr. Pequeño. Hoja 11A. E. Fischer. 
Tabla 10: Ficha portada 3.

\begin{tabular}{|c|c|c|}
\hline Ficha 3 & Portada 3 (Dör 3) & \\
\hline Localización & Torreón (Duetaarnet) & \\
\hline \multirow{4}{*}{$\begin{array}{l}\text { Documentación } \\
\text { existente }\end{array}$} & Notebook I & Pág. 16a \\
\hline & Notebook II & NO \\
\hline & Álbum Fotográfico Grande & $16 \mathrm{~A}$ \\
\hline & Álbum Fotográfico Pequeño & $11 \mathrm{~A}$ \\
\hline \multirow[t]{5}{*}{ Arco Intradós } & Tipo de arco & $\begin{array}{c}\text { Mixtilíneo/Variación del } \\
\text { flamígero }\end{array}$ \\
\hline & № Trazados curvos & 8 \\
\hline & № Trazados rectos & 2 \\
\hline & Luz & $1,29 \mathrm{~m}$ \\
\hline & Altura libre & $2,55 \mathrm{~m}$ \\
\hline \multirow[t]{5}{*}{ Arco Extradós } & Tipo de arco & $\begin{array}{c}\text { Mixtilíneo/Variación del } \\
\text { flamígero }\end{array}$ \\
\hline & № Trazados curvos & 8 \\
\hline & № Trazados rectos & 2 \\
\hline & Luz & $1,82 \mathrm{~m}$ \\
\hline & Altura máxima & $2,95 \mathrm{~m}$ \\
\hline Basas & No grafiadas & Sin información \\
\hline \multirow[t]{11}{*}{ Jamba } & $\begin{array}{l}\text { Molduras del extradós a } \\
\text { intradós: }\end{array}$ & Radio \\
\hline & Caveto & $6 \mathrm{~cm}$ \\
\hline & Baqueta o columnilla & $3 \mathrm{~cm}$ \\
\hline & Caveto & $6 \mathrm{~cm}$ \\
\hline & Caveto (semicircular) & $5 \mathrm{~cm}$ \\
\hline & Caveto & $5 \mathrm{~cm}$ \\
\hline & Baqueta o columnilla & $2,5 \mathrm{~cm}$ \\
\hline & Caveto & $2,5 \mathrm{~cm}$ \\
\hline & Filete & $1,5 \mathrm{~cm}$ \\
\hline & Profundidad jamba & $23 \mathrm{~cm}$ \\
\hline & Ángulo jamba & $37^{\circ}$ \\
\hline Capiteles & NO & \\
\hline
\end{tabular}




\section{Portada 4}

La documentación gráfica existente de la Portada 4 (Dör 4), situada en la Sala 4 según el plano de planta del Palacio es la siguiente:

- Notebook II: la Dör 4 está croquizada a lápiz sobre la página $17 a^{300}$. El croquis representa el alzado de la portada (arco) y la sección de las dos jambas. Sobre el alzado aparecen recuadradas un total de 4 piezas: D4.v.a, D4.v.b, D4.h.a y D4.h.b. Las piezas D4.v.a y D4.h.b. corresponden a los arranques del arco y las piezas D4.v.b y D4.h.a. a la clave del arco. Las molduras que forman las jambas se encuentran detalladas. Asimismo están acotadas en la sección el ancho de paso de la portada $(0,95 \mathrm{~m})$ y el ancho total de la portada $(1,39 \mathrm{~m})$, así como su profundidad $(0,24 \mathrm{~m})$. No aparece ninguna cota de altura. En la parte superior del croquis se encuentra rotulado el siguiente texto "Dör 4 (Fotografía) Paavejtie "porsindem"" (Dör 4 (Fotografía) Paavejtie "porsindem") (ver Fig. 224).

- Álbum de Fotos Grande: hoja 16 anverso (Fot. 73) 301 . La fotografía tiene unas dimensiones de $8 \times 11 \mathrm{~cm}$. En ella aparece representada la Portada 4. En el hueco de la portada, de pie, se puede ver al arquitecto Egil Fischer. En la fotografía podemos apreciar que las basas han desaparecido casi por completo, así como la parte inferior de las basas (ver Fig. 224).

- Álbum de Fotos Pequeño: hoja 12 reverso (Fot. 73$)^{302}$. Se trata de la misma fotografía. Escrito al pie de la fotografía hay un texto ilegible en danés.
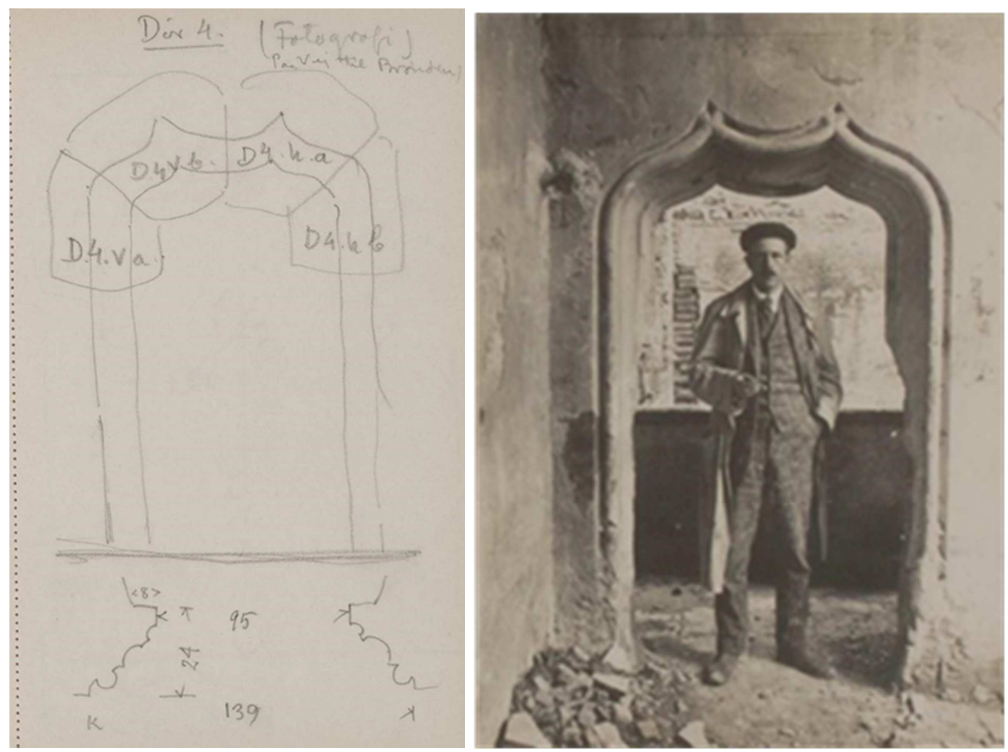

Figura 224. Izquierda: Croquis Portada 4. Notebook II. LA1105. Pág. 17A. Derecha: Fot. 73. Portada 4 con Egil Fischer. Álbum Fotogr. Grande. Hoja 16A. E. Fischer.

\footnotetext{
${ }^{300}$ Fischer, E. (1919-1920) Notebook I. Oliva, Valencia: Museo Municipal de Oliva, Archivo Público Documental, Palacio Condal. LA 1104, pp. 17A.

${ }^{301}$ Fischer, E. (1917-1920) Álbum Fotos Grande. Oliva, Valencia: Museo Municipal de Oliva, Archivo Público Documental, Palacio Condal. pp. 16A.

${ }^{302}$ Fischer, E. (1917-1920). Álbum Fotos Pequeño. Oliva, Valencia: Museo Municipal de Oliva, Archivo Público Documental, Palacio Condal. pp. 12R.
} 
Tabla 11. Ficha Portada 4.

\begin{tabular}{|c|c|c|}
\hline Ficha 4 & \multicolumn{2}{|l|}{ Portada 4 (Dör 4) } \\
\hline Localización & \multicolumn{2}{|l|}{ Sala 4 (Rüm 4) } \\
\hline \multirow{4}{*}{$\begin{array}{l}\text { Documentación } \\
\text { existente }\end{array}$} & Notebook I & Pág. 17A \\
\hline & Note Book II & NO \\
\hline & Álbum Fotográfico Grande & Fot. 73.16A \\
\hline & Álbum Fotográfico Pequeño & Fot. $73.12 \mathrm{R}$ \\
\hline \multirow[t]{5}{*}{ Arco Intradós } & Tipo de arco & Inflexo en talón roto \\
\hline & № Trazados curvos & 5 \\
\hline & № Trazados rectos & 0 \\
\hline & Luz & $0,95 \mathrm{~m}$ \\
\hline & Altura libre & $1,97 \mathrm{~m}$ \\
\hline \multirow[t]{5}{*}{ Arco Extradós } & Tipo de arco & Inflexo en talón roto \\
\hline & № Trazados curvos & 5 \\
\hline & № Trazados rectos & 0 \\
\hline & Luz & $1,39 \mathrm{~m}$ \\
\hline & Altura máxima & $2,19 \mathrm{~m}$ \\
\hline Basas & No grafiadas & Sin información \\
\hline \multirow[t]{10}{*}{ Jamba } & $\begin{array}{l}\text { Molduras del extradós a } \\
\text { intradós: }\end{array}$ & Radio \\
\hline & Caveto & $5 \mathrm{~cm}$ \\
\hline & Baqueta o columnilla & $3 \mathrm{~cm}$ \\
\hline & Caveto & $2,5 \mathrm{~cm}$ \\
\hline & Caveto (semicircular) & $4,5 \mathrm{~cm}$ \\
\hline & Caveto (¿falta columnilla? & $2,5 \mathrm{~cm}$ \\
\hline & Caveto & $2,5 \mathrm{~cm}$ \\
\hline & Filete & $5 \mathrm{~cm}$ \\
\hline & Profundidad jamba & $24 \mathrm{~cm}$ \\
\hline & Ángulo jamba & $39^{\circ}$ \\
\hline Capiteles & NO & \\
\hline
\end{tabular}




\section{Portada 5}

La documentación gráfica existente de la Portada 5 (Dör 5), situada en la Sala 3 según el plano de planta del Palacio es la siguiente:

- Notebook II: la Portada 4 está croquizada a lápiz sobre la página $18 \mathrm{~A}^{303}$. El croquis representa el alzado (arco) y la sección de la jamba izquierda. Sobre el alzado aparecen recuadradas un total de 6 piezas: D5.v, D5.v.a, D5.v.b, D5.h.a, D5.h.b y D5.h. Las piezas D5.v y D5.h corresponden a las bases, las D5.v.a y D5.h.b. a los arranques del arco y las piezas D5.v.b y D5.h.a. a la clave del arco. Las molduras que forman la jamba se encuentran detalladas. Están acotadas en la sección el ancho de paso de la portada $(1,29 \mathrm{~m})$ y el ancho total de la portada $(1,82 \mathrm{~m})$, así como la altura del intradós $(2,55 \mathrm{~m})$, la profundidad de la jamba $(0,27 \mathrm{~m})$ y su anchura $(0,28 \mathrm{~m})$. En la parte superior del croquis se encuentra rotulado el siguiente texto: "Dör 5 (Fotografía) (Mellem 5 al 3 og corral (gard)"." Portada 5 (Fotografía) (Entre la 3 y la 5 (salas) y el corral" (ver Fig. 225 izq.).

- Álbum de Fotos Grande: hoja 16 anverso (Fot. 72) ) $^{304}$. La fotografía tiene unas dimensiones de $8 \times 11 \mathrm{~cm}$. En ella aparece representada la Portada 5. En la fotografía podemos apreciar que la portada se conserva en buen estado, salvo algunos desconchados en las jambas, conservando completas las dos basas. Junto a la jamba derecha aparece fotografiada una especie de vara. Detrás de la portada podemos observar un acopio de teja árabe y al fondo otra portada en mucho peor estado.

- Álbum de Fotos Pequeño: hoja 11 anexo (Fot. 72$)^{305}$. Se trata de la misma fotografía. Escrito al pie hay un texto en danés: "Dör 5 og i Baggrumden Dör 3". (Portada 5 y en el fondo Portada 3). En una segunda línea aparece otro texto en danés que no hemos podido transcribir. Sobre la vara fotografiada se puede ver el siguiente texto "1 meter" (1 metro), lo que nos hace entender que se trataba de una galga o unidad de medida para medir elementos in-situ (ver Fig. 225 derecha).

\footnotetext{
${ }^{303}$ Fischer, E. (1919-1920). Notebook I. Oliva, Valencia: Museo Municipal de Oliva, Archivo Público Documental, Palacio Condal. (LA 1104, pp. 18A).

${ }^{304}$ Fischer, E. (1917-1920). Álbum Fotos Grande. Oliva, Valencia: Museo Municipal de Oliva, Archivo Público Documental, Palacio Condal. (pp. 16A).

${ }^{305}$ Fischer, E. (1917-1920). Álbum Fotos Pequeño. Oliva, Valencia: Museo Municipal de Oliva, Archivo Público Documental, Palacio Condal. (pp. 11A).
} 

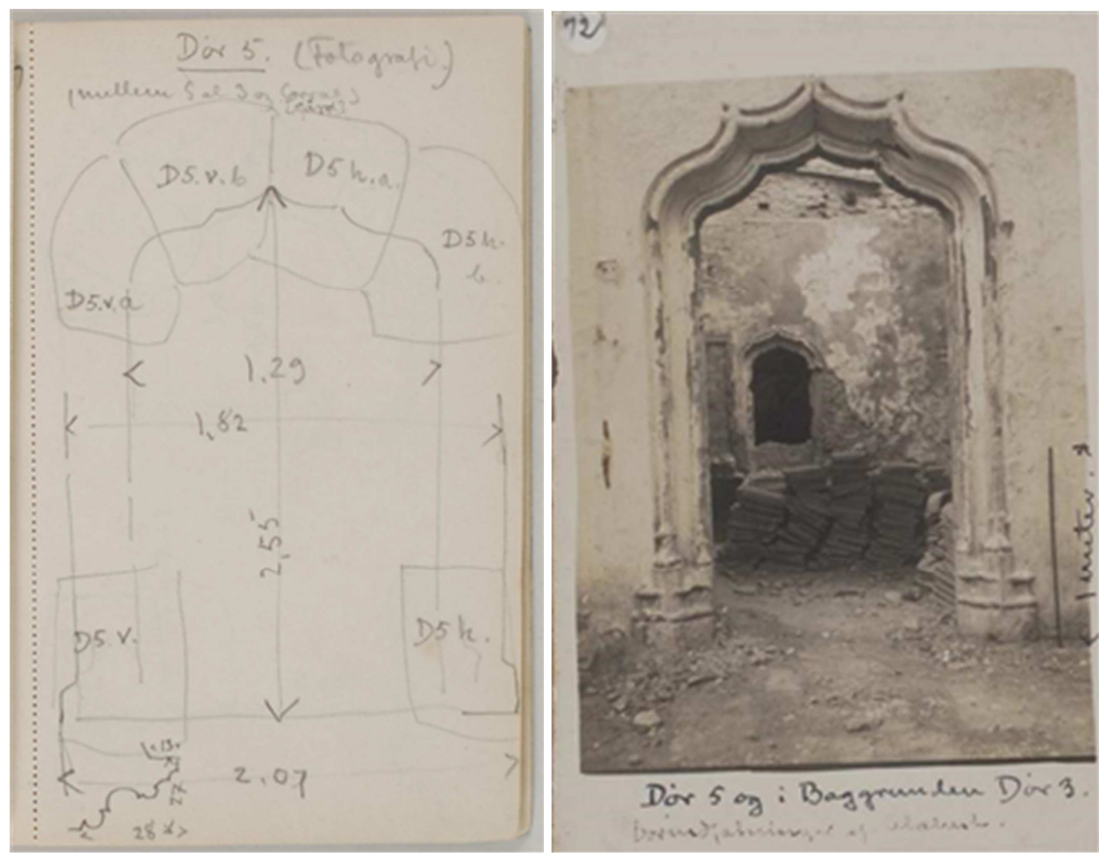

Figura 225. Izquierda: croquis Portada 5. Notebook II. LA1105. Pág. 18A. Derecha: Fot. 72. Portada 4. Bajo ella Egil Fischer. Álbum Fotogr. Pequeño. Hoja 11A. E. Fischer. 
Tabla 12. Ficha Portada 5.

\begin{tabular}{|c|c|c|}
\hline Ficha 5 & Portada 5 (Dör 5) & \\
\hline Localización & Sala 3 (Rüm 3) & \\
\hline \multirow{4}{*}{$\begin{array}{l}\text { Documentación } \\
\text { existente }\end{array}$} & Noteboook I & Pág. 18A \\
\hline & Notebook II & NO \\
\hline & Álbum Fotográfico Grande & Fot. $72.16 \mathrm{~A}$ \\
\hline & Álbum Fotográfico Pequeño & Fot. 72.11A \\
\hline \multirow[t]{5}{*}{ Arco Intradós } & Tipo de arco & Variación del Flamígero \\
\hline & № Trazados curvos & 6 \\
\hline & № Trazados rectos & 0 \\
\hline & Luz & $1,29 \mathrm{~m}$ \\
\hline & Altura paso & $2,55 \mathrm{~m}$ \\
\hline \multirow[t]{5}{*}{ Arco Extradós } & Tipo de arco & Variación del Flamígero \\
\hline & № Trazados curvos & 6 \\
\hline & № Trazados rectos & 0 \\
\hline & Luz & $1,82 \mathrm{~m}$ \\
\hline & Altura total & $2,95 \mathrm{~m}$ \\
\hline Basas & Ver fotografía 72 & 2 basas $^{306}$ ¿heptagonales? \\
\hline \multirow[t]{11}{*}{ Jamba } & $\begin{array}{l}\text { Molduras del extradós a } \\
\text { intradós: }\end{array}$ & Radio \\
\hline & Caveto & $6 \mathrm{~cm}$ \\
\hline & Baqueta o columnilla & $3 \mathrm{~cm}$ \\
\hline & Caveto & $6 \mathrm{~cm}$ \\
\hline & Caveto (semicircular) & $5 \mathrm{~cm}$ \\
\hline & Caveto & $5 \mathrm{~cm}$ \\
\hline & Baqueta o columnilla & $2,3 \mathrm{~cm}$ \\
\hline & Caveto & $2,5 \mathrm{~cm}$ \\
\hline & Filete & $1,5 \mathrm{~cm}$ \\
\hline & Profundidad jamba & $27 \mathrm{~cm}$ \\
\hline & Ángulo jamba & $37^{\circ}$ \\
\hline Capiteles & NO & \\
\hline
\end{tabular}

\footnotetext{
${ }^{306}$ Se refiere a las basas menores de planta poliédrica de las que arrancan las columnillas o baquetas. El número está relacionado con el que contiene cada una de las bases principales.
} 


\section{Portada 6}

La documentación gráfica existente de la Portada 6 (Dör 6), situada en la Sala 3 según el plano de planta del Palacio es la siguiente:

- Notebook II: la Dör 4 está croquizada a lápiz sobre la página $19 \mathrm{~A}^{307}$. El croquis representa el alzado de la portada (arco), la sección de la jamba izquierda y la sección de la basa derecha a nivel del suelo. Sobre el alzado hay recuadradas un total de 9 piezas, numeradas las cuatro de la izquierda como D6.v. y las 5 de la derecha como D.6.H. Seis de estas piezas corresponden a la totalidad del arco, dos de ellas a las bases derecha e izquierda y la otra al primer tramo de la jamba derecha, justo sobre la base. Las molduras que forman la jamba se encuentran detalladas, así como la forma geométrica del arranque de la basa, aunque sólo se dispone de cotas generales de la jamba. Se encuentran acotadas en la sección el ancho de paso de la portada $(1,18 \mathrm{~m})$ y el ancho total de la portada $(1,80 \mathrm{~m})$, así como la altura del intradós $(2,50 \mathrm{~m})$, la altura total del extradós $(3,03 \mathrm{~m})$, la profundidad de la jamba $(0,28 \mathrm{~m})$ y su anchura $(0,30 \mathrm{~m})$. En la parte superior del croquis está rotulado el siguiente texto: "Dör 6 Mellem Sal 3 og 5". "Portada 5 entre las salas 3 y 5 " (ver Fig. 226).

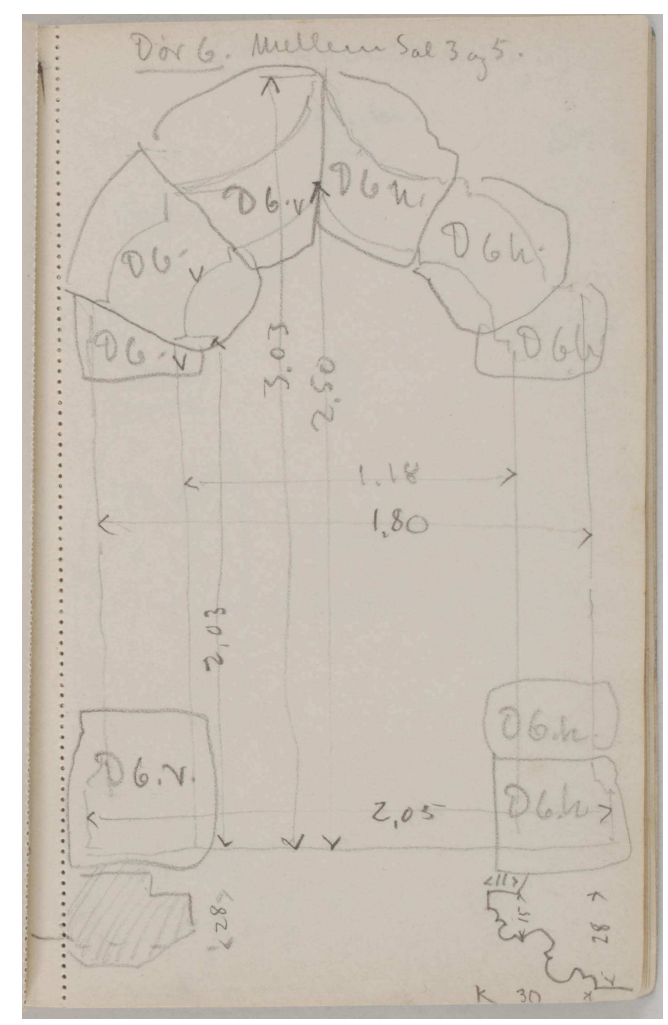

Figura 226. Croquis Portada 6. Notebook II. LA1105. Pág. 19A. E. Fischer.

${ }^{307}$ Fischer, E. (1919-1920). Notebook I. Oliva, Valencia: Museo Municipal de Oliva, Archivo Público Documental, Palacio Condal. (LA 1104, pp. 19A). 
Tabla 13.Ficha Portada 6

\begin{tabular}{|c|c|c|}
\hline Ficha 6 & \multicolumn{2}{|l|}{ Portada 6 (Dör 6) } \\
\hline Localización & \multicolumn{2}{|l|}{ Sala 3 (Rüm 3) } \\
\hline \multirow{4}{*}{$\begin{array}{l}\text { Documentación } \\
\text { existente }\end{array}$} & Notebook I & Pág. 19A \\
\hline & Notebook II & NO \\
\hline & Álbum Fotográfico Grande & NO \\
\hline & Álbum Fotográfico Pequeño & NO \\
\hline \multirow[t]{5}{*}{ Arco Intradós } & Tipo de arco & $\begin{array}{c}\text { Mixtilíneo/Variación del } \\
\text { Flamígero }\end{array}$ \\
\hline & № Trazados curvos & 4 \\
\hline & № Trazados rectos & 2 \\
\hline & Luz & $1,18 \mathrm{~m}$ \\
\hline & Atura paso & $2,50 \mathrm{~m}$ \\
\hline \multirow[t]{5}{*}{ Arco Extradós } & Tipo de arco & $\begin{array}{c}\text { Mixtilíneo/Variación del } \\
\text { Flamígero }\end{array}$ \\
\hline & № Trazados curvos & 4 \\
\hline & № Trazados rectos & 4 \\
\hline & Luz & $1,80 \mathrm{~m}$ \\
\hline & Altura total & $3,03 \mathrm{~m}$ \\
\hline Basa & No grafiadas & Sin información \\
\hline \multirow[t]{12}{*}{ Jamba } & $\begin{array}{l}\text { Molduras del extradós a } \\
\text { intradós: }\end{array}$ & Radio \\
\hline & Caveto & $2 \mathrm{~cm}$ \\
\hline & Caveto & $2,5 \mathrm{~cm}$ \\
\hline & Baqueta o columnilla & $3,8 \mathrm{~cm}$ \\
\hline & Filete & $2,5 \mathrm{~cm}$ \\
\hline & Caveto (semicircular) & $4 \mathrm{~cm}$ \\
\hline & Filete & $2,5 \mathrm{~cm}$ \\
\hline & Baqueta o columnilla & $2,2 \mathrm{~cm}$ \\
\hline & Caveto & $1,7 \mathrm{~cm}$ \\
\hline & Caveto & $2,2 \mathrm{~cm}$ \\
\hline & Profundidad jamba & $27 \mathrm{~cm}$ \\
\hline & Ángulo jamba & $35^{\circ}$ \\
\hline Capiteles & NO & \\
\hline
\end{tabular}




\section{Portada 7}

La documentación gráfica existente de la Portada 7 (Dör 7), situada en la Sala 7 según el plano de planta del Palacio es la siguiente:

- Notebook II: la Portada 7 está croquizada a lápiz sobre la página $20 \mathrm{~A}^{308}$. El croquis representa el alzado de la portada con tímpano sobre dintel y la sección de la jamba izquierda. Es la única portada que tiene una ornamentación claramente renacentista. Sobre el alzado aparecen numeradas un total de 13 piezas: 6 de ellas con la denominación D.7.v correspondientes a la parte izquierda que representan, de abajo a arriba, a la basa, las pilastras, el capitel, la cornisa horizontal, la cornisa sobre tímpano y la decoración superior con elementos en jarra ${ }^{309}$. Las 6 piezas del lado derecho están numeradas como D.7.v y corresponden a las simétricas del lado izquierdo, y la pieza D.7.m. corresponde al elemento en jarra situado sobre el tímpano. Se encuentran acotadas en el alzado el ancho de la cara interior de las pilastras $(1,50 \mathrm{~m})$, el ancho total de la portada $(1,77 \mathrm{~m})$, así como las altura inferior de la cornisa en el centro del tímpano $(2,58 \mathrm{~m})$, la profundidad de la jamba $(0,27 \mathrm{~m})$ y su anchura $(0,23 \mathrm{~m})$. En la sección de la jamba aparecen grafiadas, además de las pilastras, molduras góticas similares al resto de las portadas formadas por cavetos, baquetas o columnillas y filetes. En la parte superior del croquis está rotulado el siguiente texto: "Dör 7 (Mellem $70 g$ 6)". "Portada 7 (Entre la 7 y la 6)" (ver Fig. 227 izq.).

- Álbum de Fotos Grande: aparecen dos fotografías correspondientes a esta portada: Fot. 69 y Fot. $70^{310}$. La fotografía 69 tiene unas dimensiones de $8 \times 11 \mathrm{~cm}$. En ella aparece representada la Portada 7. En la fotografía podemos apreciar que se conserva en buen estado, salvo la cornisa horizontal izquierda, que ha desaparecido, y el elemento en jarra izquierdo, que se encuentra bastante deteriorado. Delante del tímpano y sobre las jambas se ha sobre dibujado el trazado de un arco de características góticas. Junto a la pilastra izquierda podemos observar una baqueta o columnilla. Asimismo, en ambas basas, además de la ornamentación renacentista, podemos observar formas y molduras correspondientes a una portada gótica ${ }^{311}$, lo que nos lleva a pensar que la portada 7 era, en origen, una portada gótica a la que se sobrepuso ornamentación renacentista de una manera un tanto tosca (ver Fig. 227 dcha.). La fotografía 70, de dimensiones $8 x$ $7 \mathrm{~cm}$, corresponde a algunas de las piezas numeradas en el croquis del Notebook // una vez desmontadas y acopiadas en el suelo (ver Fig. 228 izq.).

- Álbum de Fotos Pequeño: en él encontramos la fotografía $69^{312}$ Se trata de la misma fotografía 69 del Álbum Grande, pero con unas dimensiones de $9 \times 12 \mathrm{~cm}$ y $\sin$ el

\footnotetext{
${ }^{308}$ Fischer, E. (1919-1920). Notebook II. Oliva, Valencia: Museo Municipal de Oliva, Archivo Público Documental, Palacio Condal. LA1105, pp. 20 A.

${ }^{309}$ Muller, P. (2013). El Palacio de los Centelles de Oliva: contexto y contextos. En Gavara Prior, Joan J. y E. Muller, Priscilla. El Palacio Condal de Oliva (pp. 39).

${ }^{310}$ Fischer, E. (1917-1920). Álbum Fotos Grande. Oliva, Valencia: Museo Municipal de Oliva, Archivo Público Documental, Palacio Condal.pp. 15R.

${ }^{311}$ Muller, P. Óp. Cit. pp. 39.

312 Fischer, E. (1917-1920). Álbum de Fotos Pequeño. Oliva, Valencia: Museo Municipal de Oliva, Archivo Público Documental, Palacio Condal. pp. 9R.
} 
grafismo sobrepuesto de la portada gótica. Escrito al pie de la fotografía hay un texto en danés: "Alabast portal. Dör 7". (Portada de alabastro. Portada 7).

- Planos: en la colección de planos encontramos la lámina LA1182 $2^{313}$. En ella está grafiado un detalle de la sección de la jamba gótica encontrada al desmontar la portada renacentista y un detalle del alzado del arco donde se observa cómo se entrelazan las molduras en la arista que forman dos trazados curvos. La escala de este detalle es 1:1. Este dato se ha comprobado una vez escalada la lámina con la escala de referencia utilizada para su digitalización y comprobadas las cotas que aparecen en la lámina, cotas que se deduce están expresadas en milímetros. Las molduras que aparecen en la jamba son el caveto, la baqueta o columnilla, el filete, el caveto semicircular y la jamba recta (ver Fig. 228 dcha.).
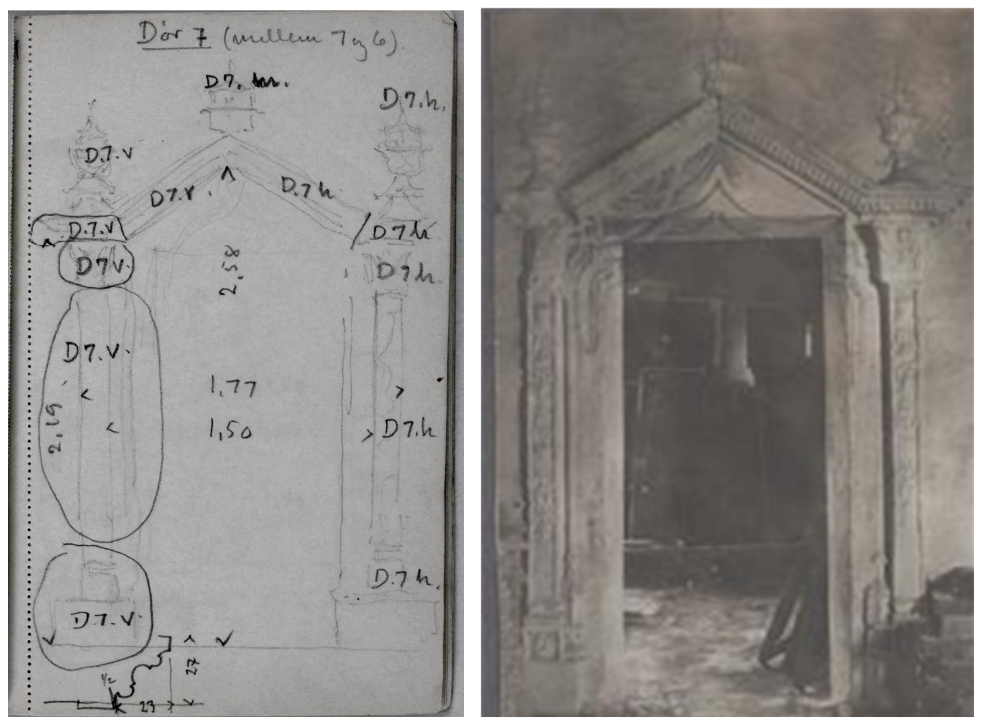

Figura 227. Izquierda: croquis Portada 7. Notebook II. LA1105. Pág. 20A. Derecha: Fot. 69. Portada 7. Álbum Fotogr. Grande. Hoja 15R. E. Fischer.
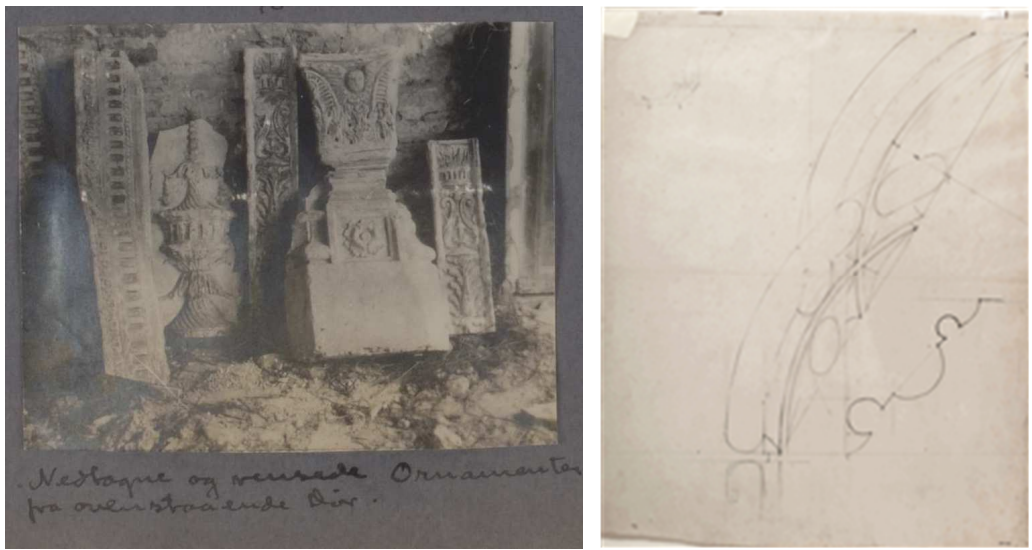

Figura 228. Izquierda: Piezas desmontadas Portada 7. Fot. 61. Álbum Fotogr. Grande. E. Fischer. Hoja 15R. Derecha: Detalle molduras góticas Portada 7. LA 1182. V. Lauritzen.

${ }^{313}$ Fischer, E. y Lauritzen V. (1919-1920). Planos. Oliva, Valencia: Museo Municipal de Oliva, Archivo Público Documental, Palacio Condal. (LA 1182). 
Tabla 14. Ficha 7A. Portada 7 Renacentista.

\begin{tabular}{|c|c|c|}
\hline Ficha $7 \mathrm{~A}$ & \multicolumn{2}{|c|}{ Portada 7 (Dör7) (Portada Renacentista) } \\
\hline Localización & \multicolumn{2}{|l|}{ Sala 7 (Rüm7) } \\
\hline Texto & & \\
\hline \multirow{4}{*}{$\begin{array}{l}\text { Documentación } \\
\text { existente }\end{array}$} & Noteboook II & Pág. 20A \\
\hline & Planos & LA 1182 \\
\hline & Álbum Fotográfico Grande & 69 y 70 \\
\hline & Álbum Fotográfico Pequeño & 69 \\
\hline \multirow[t]{3}{*}{ Intradós } & Tipo & Adintelado \\
\hline & Anchura exterior pilastras & $1,50 \mathrm{~m}$ \\
\hline & Altura hueco paso & -- \\
\hline \multirow[t]{3}{*}{ Extradós } & Tipo & Tímpano \\
\hline & Anchura exterior pilastras & $1,77 \mathrm{~m}$ \\
\hline & Atura tímpano (cara inferior) & $2,58 \mathrm{~m}$ \\
\hline Basas & Cuadradas & Decoración floral \\
\hline \multirow[t]{2}{*}{ Pilastras } & Rectangulares & Decoración vegetal \\
\hline & Acho & $13,5 \mathrm{~cm}$ \\
\hline Capiteles & Tronco pirámide invertido & $\begin{array}{c}\text { Ornamentación vegetal } \\
\text { y putti alado }\end{array}$ \\
\hline Cornisa & En forma de tímpano & Dentada \\
\hline $\begin{array}{l}\text { Ornamentación } \\
\text { superior }\end{array}$ & $\mathrm{Si}$ & En jarra \\
\hline
\end{tabular}


Tabla 15. Ficha 7B. Portada 7 gótica.

\begin{tabular}{|c|c|c|}
\hline Ficha 7 B & \multicolumn{2}{|c|}{ Portada 7 (Dör 7) (Portada Gótica oculta) } \\
\hline Localización & \multicolumn{2}{|l|}{ Sala 7 (Rüm7) } \\
\hline \multirow{4}{*}{$\begin{array}{l}\text { Documentación } \\
\text { existente }\end{array}$} & Notebook II & Pág. 20A \\
\hline & Planos & LA 1182 \\
\hline & Álbum Fotográfico Grande & 69 y 70 \\
\hline & $\begin{array}{ll}\text { Álbum } & \text { Fotográfico } \\
\text { Pequeño } & \end{array}$ & 69 \\
\hline \multirow[t]{5}{*}{ Arco Intradós } & Tipo & $\begin{array}{c}\text { Mixtilíneo/Cortinado/Variación } \\
\text { del flamígero }\end{array}$ \\
\hline & № Trazados curvos & 6 \\
\hline & № Trazados rectos & 2 \\
\hline & Luz & -- \\
\hline & Flecha & -- \\
\hline \multirow[t]{5}{*}{ Arco Extradós } & Tipo de arco & $\begin{array}{c}\text { Mixtilíneo/Cortinado/Variación } \\
\text { del flamígero }\end{array}$ \\
\hline & № Trazados curvos & 6 \\
\hline & № Trazados rectos & 2 \\
\hline & Luz & -- \\
\hline & Flecha & -- \\
\hline Basas & No grafiadas & Sin información \\
\hline \multirow[t]{12}{*}{ Jamba } & $\begin{array}{l}\text { Molduras del extradós a } \\
\text { intradós: }\end{array}$ & Radio /Longitud \\
\hline & Caveto & $4,7 \mathrm{~cm}$ \\
\hline & Baqueta o columnilla & $2,8 \mathrm{~cm}$ \\
\hline & Filete (longitud) & $2,9 \mathrm{~cm}$ \\
\hline & Caveto (semicircular) & $5,3 \mathrm{~cm}$ \\
\hline & Filete (longitud) & $1,8 \mathrm{~cm}$ \\
\hline & Baqueta o columnilla & $1,8 \mathrm{~cm}$ \\
\hline & Caveto & $4,5 \mathrm{~cm}$ \\
\hline & Jamba recta (longitud) & -- \\
\hline & Profundidad jamba & $27 \mathrm{~cm}$ \\
\hline & Ancho & $29 \mathrm{~cm}$ \\
\hline & Ángulo jamba & $43^{\circ}$ \\
\hline Capiteles & NO & \\
\hline
\end{tabular}




\section{Portada 8}

La documentación gráfica existente de la Portada 8 (Dör 8), situada en la Sala 7 según el plano de planta del Palacio es la siguiente:

- Notebook II: la Portada 8 está croquizada a lápiz sobre la página $21 \mathrm{~A}^{314}$. El croquis representa el alzado, la sección de la basa derecha a nivel del arranque y la sección de la jamba izquierda. El tipo de arco es mixtilíneo, cortinado, variación del flamígero. Sobre el alzado aparecen numeradas un total de 8 piezas: 4 de ellas con la denominación D.8.v, correspondientes a la parte izquierda, y que representan, de abajo a arriba, a la basa, la jamba inferior, la jamba superior y el arco. Las 4 piezas del lado derecho están numeradas como D.8.v y corresponden a las simétricas del lado izquierdo. Aparecen acotados la luz del arco $(1,04 \mathrm{~m})$, el ancho del extradós de la portada $(1,58 \mathrm{~m})$ y el ancho total de las basas $(1,90 \mathrm{~m})$, así como la flecha $(2,20$ $\mathrm{m})$, la altura total $(82,70 \mathrm{~m})$, la profundidad de la jamba $(0,28 \mathrm{~m})$ y su anchura $(0,28$ m). En la parte superior del croquis se encuentra rotulado el siguiente texto: "Dör 8 (Mellem 7 og 8) Fotografi". "Portada 8 (Entre la 7 y la 8) Fotografía" (ver Fig. 229 izq.).

- Álbum de Fotos Grande: aparece una fotografía correspondiente a esta portada $\left(\right.$ Fot. 68) ${ }^{315}$. Tiene unas dimensiones de $8 \times 11 \mathrm{~cm}$. En ella aparece representada una vista frontal de la portada 8 . Sobre la fotografía está rotulado a mano el número de la fotografía 68. En la fotografía podemos apreciar que la portada se conserva en buen estado. La basa derecha de encuentra seccionada por un muro perpendicular al lienzo, donde se encuentra la portada. Se observa que el forjado de la sala 8 está desmontando, viéndose vigas de madera apoyadas delante de la portada y en el hueco del forjado. Al fondo a la derecha de la sala 8 se observa una chimenea en esquina a través del hueco de la portada.

- Álbum de Fotos Pequeño: en él encontramos también la fotografía $68^{316}$. Se trata de idéntica fotografía a la 68 del Álbum Grande, pero con unas dimensiones de $8 \mathrm{x}$ $11 \mathrm{~cm}$ más un recuadro blanco en el perímetro de $2 \mathrm{~mm}$. En la parte inferior el recuadro blanco es de $2,5 \mathrm{~cm}$ y contiene un pie de fotografía manuscrito en danés que no hemos podido transcribir. En la parte inferior está manuscrito el número de la portada: "Dör 8". En la esquina superior izquierda aparece superpuesto un círculo de papel pon la numeración de la fotografía: 68 (ver Fig. 229 dcha.).

\footnotetext{
${ }^{314}$ Fischer, E. (1919-1920) Notebook II. LA1105. Oliva, Valencia: Museo Municipal de Oliva, Archivo Público Documental, Palacio Condal. pp. 21A.

${ }^{315}$ Fischer, E. (1917-1920) Álbum Fotos Grande. Oliva, Valencia: Museo Municipal de Oliva, Archivo Público Documental, Palacio Condal. pp. 15A.

${ }^{316}$ Fischer, E. (1917-1920) Álbum de Fotos Pequeño. Oliva, Valencia: Museo Municipal de Oliva, Archivo Público Documental, Palacio Condal. pp. 11A.
} 

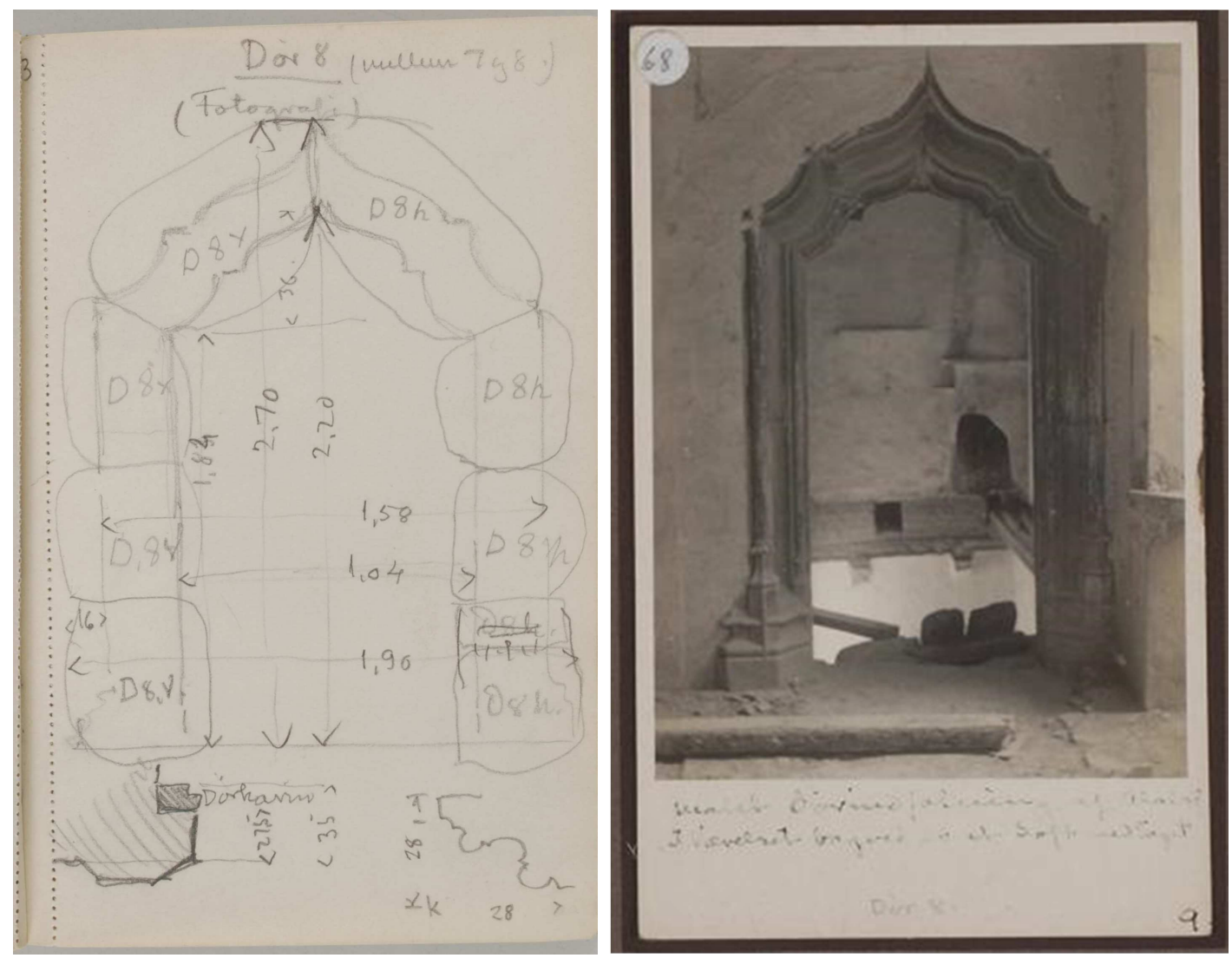

Figura 229.Izquierda: croquis Portada 8. Notebook II. LA1105. Pág. 21A. Derecha: Fot. 68. Portada 8. Álbum Fotogr. Pequeño. Hoja 11A. E. Fischer. 
Tabla 16. Ficha Portada 8.

\begin{tabular}{|c|c|c|}
\hline Ficha 8 & \multicolumn{2}{|l|}{ Portada 8 (Dör8) } \\
\hline Localización & \multicolumn{2}{|l|}{ Sala 7 (Rüm7) } \\
\hline \multirow{3}{*}{$\begin{array}{l}\text { Documentación } \\
\text { existente }\end{array}$} & Notebook II & Pág. 21A \\
\hline & Álbum Fotográfico Grande & 68 \\
\hline & $\begin{array}{l}\text { Álbum } \quad \text { Fotográfico } \\
\text { Pequeño }\end{array}$ & 68 \\
\hline \multirow[t]{5}{*}{ Arco Intradós } & Tipo & $\begin{array}{c}\text { Mixtilíneo/Cortinado/Variación } \\
\text { del flamígero }\end{array}$ \\
\hline & № Trazados curvos & 6 \\
\hline & № Trazados rectos & 2 \\
\hline & Luz & 1,04 \\
\hline & Altura libre & 2,20 \\
\hline \multirow[t]{5}{*}{ Arco Extradós } & Tipo de arco & $\begin{array}{c}\text { Mixtilíneo/Cortinado/Variación } \\
\text { del flamígero }\end{array}$ \\
\hline & № Trazados curvos & 6 \\
\hline & № Trazados rectos & 2 \\
\hline & Luz & 1,58 \\
\hline & Altura máxima & 2,70 \\
\hline Basas & $\mathrm{Si}$ & 2 columnillas ¿heptagonales? \\
\hline \multirow[t]{13}{*}{ Jamba } & $\begin{array}{l}\text { Molduras del extradós a } \\
\text { intradós: }\end{array}$ & Radio /Longitud \\
\hline & Caveto & $8,5 \mathrm{~cm}$ \\
\hline & Baqueta o columnilla & $4,3 \mathrm{~cm}$ \\
\hline & Filete (longitud) & $3,7 \mathrm{~cm}$ \\
\hline & Caveto (semicircular) & $5,0 \mathrm{~cm}$ \\
\hline & Caveto & $3,7 \mathrm{~cm}$ \\
\hline & Baqueta o columnilla & $2,2 \mathrm{~cm}$ \\
\hline & Caveto & $2,7 \mathrm{~cm}$ \\
\hline & Caveto & $2,2 \mathrm{~cm}$ \\
\hline & Jamba recta (longitud) & $4,4 \mathrm{~cm}$ \\
\hline & Profundidad jamba & $28 \mathrm{~cm}$ \\
\hline & Ancho & $28 \mathrm{~cm}$ \\
\hline & Ángulo jamba & $37^{\circ}$ \\
\hline Capiteles & NO & \\
\hline
\end{tabular}




\section{Portada 9}

La documentación gráfica existente que disponible de la Portada 9 (Dör 9), situada en la Sala 8, según el plano de planta del Palacio es la siguiente:

- Notebook II: la Portada 9 está croquizada a lápiz sobre la página $22 \mathrm{~A}^{317}$. El croquis representa el alzado de la portada. El tipo de arco es escarzano. Sobre el alzado aparecen numeradas 2 piezas: la basa izquierda como D9.v. y la basa derecha como D9.h. También aparecen acotados la luz del arco es $(1,40 \mathrm{~m})$, el ancho del extradós de la portada $(1,91 \mathrm{~m})$, el ancho total por las basas $(1,90 \mathrm{~m})$, la flecha $(2,40 \mathrm{~m})$, la altura de la línea de impostas $(2,28 \mathrm{~m})$ y la altura total $(2,70 \mathrm{~m})$. En la parte superior del croquis se encuentra rotulado el siguiente texto: "Dör 9 ( vær $\left.^{318} 8\right)^{\prime \prime}$. "Portada 8 (Sala 8)". Sobre la clave del arco está rotulada la palabra "liso", haciendo referencia, sin duda, a la textura del muro a partir de este punto (ver Fig. 230).

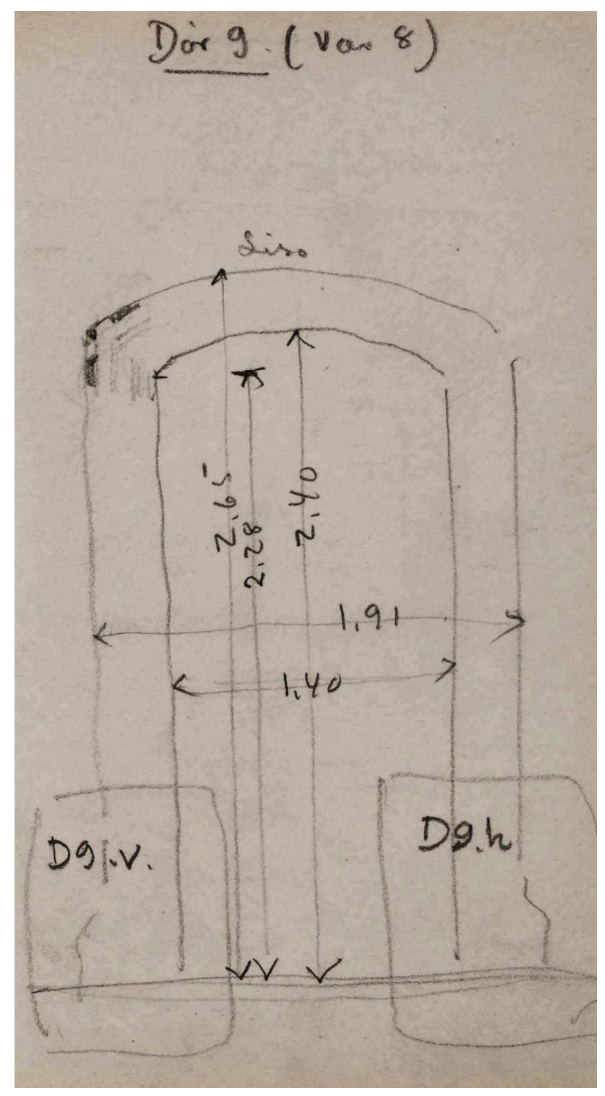

Figura 230. Croquis Portada 9. Notebook II. LA1105. Pág. 22A.E. Fischer.

${ }^{317}$ Fischer, E. (1919-1920). Notebook II. LA1105. Oliva, Valencia: Museo Municipal de Oliva, Archivo Público Documental, Palacio Condal. pp. 21A.

${ }^{318}$ Abreviatura de værelse ("habitación"). 
Tabla 17. Ficha Portada 9.

\begin{tabular}{|c|c|c|}
\hline Ficha 9 & \multicolumn{2}{|l|}{ Portada 9 (Dör9) } \\
\hline Localización & \multicolumn{2}{|l|}{ Sala 8 (Rüm8) } \\
\hline \multirow{3}{*}{$\begin{array}{l}\text { Documentación } \\
\text { existente }\end{array}$} & Notebook II & Pág. 22A \\
\hline & Álbum Fotográfico Grande & NO \\
\hline & $\begin{array}{ll}\text { Álbum } & \text { Fotográfico } \\
\text { Pequeño } & \end{array}$ & NO \\
\hline \multirow[t]{5}{*}{ Arco Intradós } & Tipo & $\begin{array}{c}\text { Mixtilíneo/Cortinado/Variación } \\
\text { del flamígero }\end{array}$ \\
\hline & № Trazados curvos & 1 \\
\hline & № Trazados rectos & 0 \\
\hline & Luz & 1,40 \\
\hline & Altura libre & 2,40 \\
\hline \multirow[t]{5}{*}{ Arco Extradós } & Tipo de arco & $\begin{array}{c}\text { Mixtilíneo/Cortinado/Variación } \\
\text { del flamígero }\end{array}$ \\
\hline & № Trazados curvos & 1 \\
\hline & № Trazados rectos & 0 \\
\hline & Luz & 1,91 \\
\hline & Altura máxima & 2,65 \\
\hline Basas & Sin datos & \\
\hline \multirow[t]{5}{*}{ Jamba } & $\begin{array}{l}\text { Molduras del extradós a } \\
\text { intradós: }\end{array}$ & Radio /Longitud \\
\hline & Sin datos & \\
\hline & Profundidad jamba & -- \\
\hline & Ancho & $25,5 \mathrm{~cm}$ \\
\hline & Ángulo jamba & -- \\
\hline Capiteles & NO & \\
\hline
\end{tabular}




\section{Portada 10}

La documentación gráfica existente de la Portada 10 (Dör 10), situada en la Sala 11 según el plano de planta del Palacio es la siguiente:

- Plano LA1140 ${ }^{319}$ : se trata de una puesta a escala dibujada a grafito sobre una lámina de papel de dimensiones $680 \times 470 \mathrm{~mm}$ donde está representado el alzado de la portada y una sección horizontal de las jambas. La disposición del dibujo es en vertical. No dispone de cotas. La escala de representación es 1:10 como en el resto de las portadas. Esto se deduce al comprobar su tamaño con la escala de referencia utilizada para la digitalización de los planos y con la vara de medir fotografiada junto a la portada que es la misma fotografiada en la 8 y acotada como "1 meter. El tipo de arco es una variación del flamígero en su intradós, si bien las molduras exteriores se prolongan por encima de él formando un arco adintelado o cornisa. La portada no dispone de capiteles. Las basas están formadas por tres columnillas a la izquierda y dos a la derecha, ya que aunque la portada es simétrica, parte de sus molduras se pierden al intersectar con un muro ortogonal al lienzo de la portada. En cuanto a las molduras de la jamba desde el extradós al intradós son (consideramos la jamba izquierda) las siguientes: baqueta o columnilla, filete, 2 cavetos, baqueta o columnilla, filete, caveto semicircular, filete, baqueta 0 columnilla y filete. En la parte superior izquierda se encuentra rotulado el nombre de la portada y su ubicación: "Dör 10. Rum 11", y en la parte inferior derecha la numeración de la lámina: LA1140 (ver Fig. 231 izq.).

- Plano LA1142 ${ }^{320}$ : se trata de una lámina de papel de dimensiones 680 x $460 \mathrm{~mm}$ donde está representada la planta de la Sala 11ạ (distribuidor). Hay dos secciones de la misma, una longitudinal y otra transversal. Las tres vistas están en correspondencia diédrica. La disposición del dibujo en la lámina es vertical. No dispone de cotas. La escala de representación es 1:10, como en el resto de las portadas. La sala 11a es un pequeño distribuidor que comunica la sala 11 con la sala 7 y al que se accede a través de la portada 10. La portada que accede desde la sala 11a a la sala 7 está formada por un arco carpanel y las jambas por dos columnillas de idéntico diámetro unidas por una jamba abocinada y rematadas con sendos cavetos. Sobre el lienzo del muro aparece otra portada ciega formada por un arco carpanel. En la parte superior izquierda se encuentra rotulado el nombre de la sala: "Aposento. Rum 11a (Dör 10)", y en la parte inferior derecha la numeración de la lámina: LA1142 (ver Fig. 232 izq.).

- Plano LA1141 ${ }^{321}$ : se trata de una lámina de papel transparente de dimensiones 680 x $500 \mathrm{~mm}$ donde se ha copiado la información del plano LA1142, y en el hueco entre las tres vistas de este plano el alzado principal de la portada representado en el plano LA1140. En la parte superior izquierda está rotulado el nombre de la sala y de la portada: "Rum 11a og Dör 11", y en la parte inferior derecha la numeración de

\footnotetext{
319 Lauritzen, V. (1919-1920). Planos. Oliva, Valencia: Museo Municipal de Oliva, Archivo Público Documental, Palacio Condal. (LA1140).

${ }^{320}$ Lauritzen, V. (1919-1920). Planos. Oliva, Valencia: Museo Municipal de Oliva, Archivo Público Documental, Palacio Condal. (LA1142).

${ }^{321}$ Lauritzen, V. (1919-1920). Planos. Oliva, Valencia: Museo Municipal de Oliva, Archivo Público Documental, Palacio Condal. (LA1141).
} 
la lámina: LA1141. Tanto las tres portadas como la bóveda que forman el conjunto se encuentran divididas en diversas piezas y numeradas tanto con números como con letras. Sobre la planta de la sala 11a se encuentran rotulados los cuatro puntos cardinales en danés (nor, syd, det, vest) indicando la orientación de las piezas (ver Fig. 232 der.).

- Álbum de Fotos Grande: aparece una fotografía correspondiente a esta portada: Fot. $66^{322}$, con unas dimensiones de $7 \times 10 \mathrm{~cm}$. En ella se representa una vista frontal de la portada 10 . Sobre la fotografía aparece rotulado a mano el número de la fotografía (66). En la imagen podemos apreciar que la portada se conserva en buen estado. La basa derecha de encuentra seccionada por un muro perpendicular al lienzo donde está la portada. Apoyada junto a la jamba izquierda se encuentra la vara de medir que encontramos fotografiada junto a otras portadas y acotada en la fotografía 72. A través del hueco podemos ver la portada 7, que se encuentra alineada con esta al fondo de la sala 7 (ver Fig. 231 dcha.).

- Álbum de Fotos Pequeño: en él encontramos también la fotografía $66^{323}$. Se trata de una fotografía idéntica a la 66 del Álbum Grande, pero con unas dimensiones de $8 \times 11 \mathrm{~cm}$ más un recuadro blanco en el perímetro de $2 \mathrm{~mm}$. En la parte inferior el recuadro blanco es de $2,5 \mathrm{~cm}$ y contiene un pie de foto manuscrito en danés: "alabasterportal" (portada de alabastro). En la esquina inferior aparece superpuesto un círculo de papel pon la numeración de la fotografía: 66.

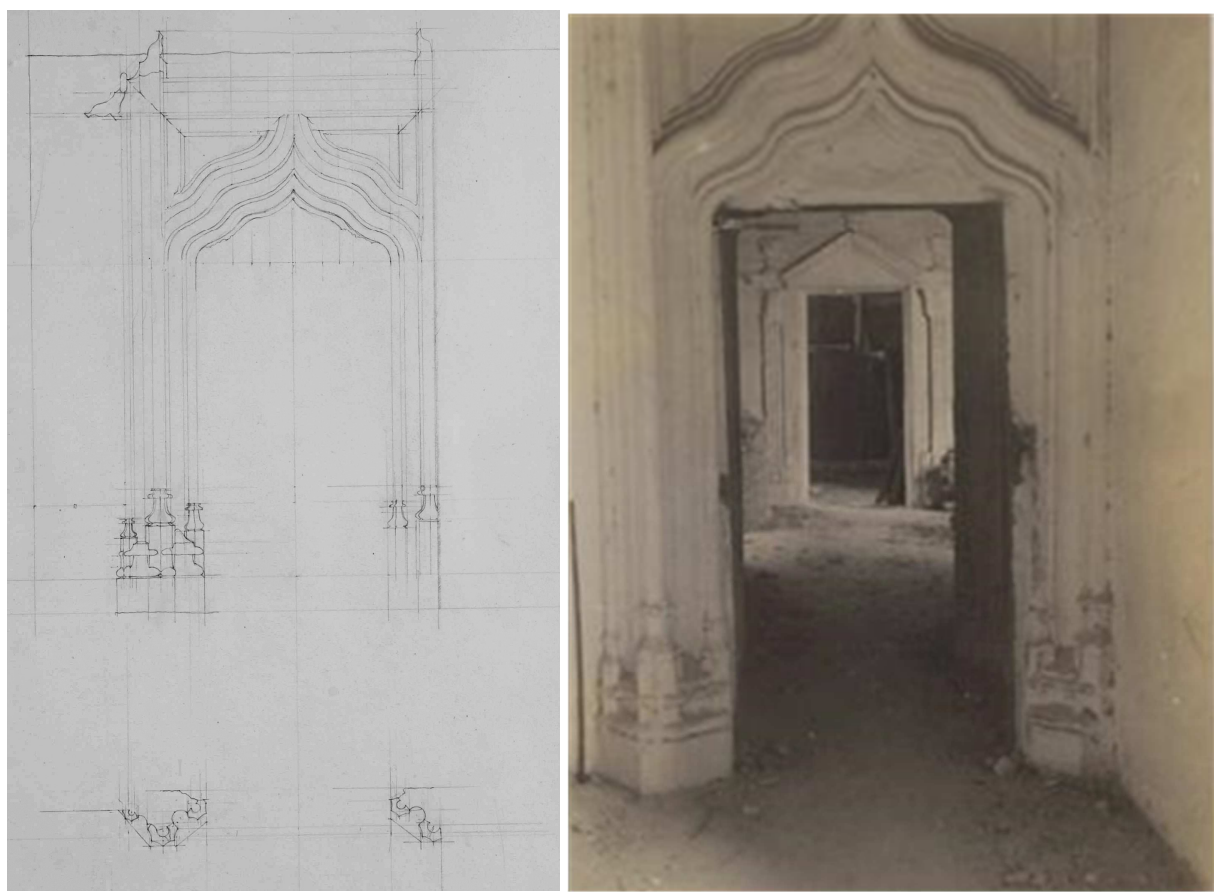

Figura 231. Izquierda: Plano Portada 10. LA1140. V. Lauritzen. Derecha: Fotogr. 66. Portada 10. Álbum Fotográfico Pequeño Pág. 11R.E. Fischer.

\footnotetext{
${ }^{322}$ Fischer, E. (1917-1920). Álbum Fotos Grande. Oliva, Valencia: Museo Municipal de Oliva, Archivo Público Documental, Palacio Condal pp. 15A.

${ }^{323}$ Fischer, E. (1917-1920). Álbum de Fotos Pequeño. Oliva, Valencia: Museo Municipal de Oliva, Archivo Público Documental, Palacio Condal. pp. 11R.
} 

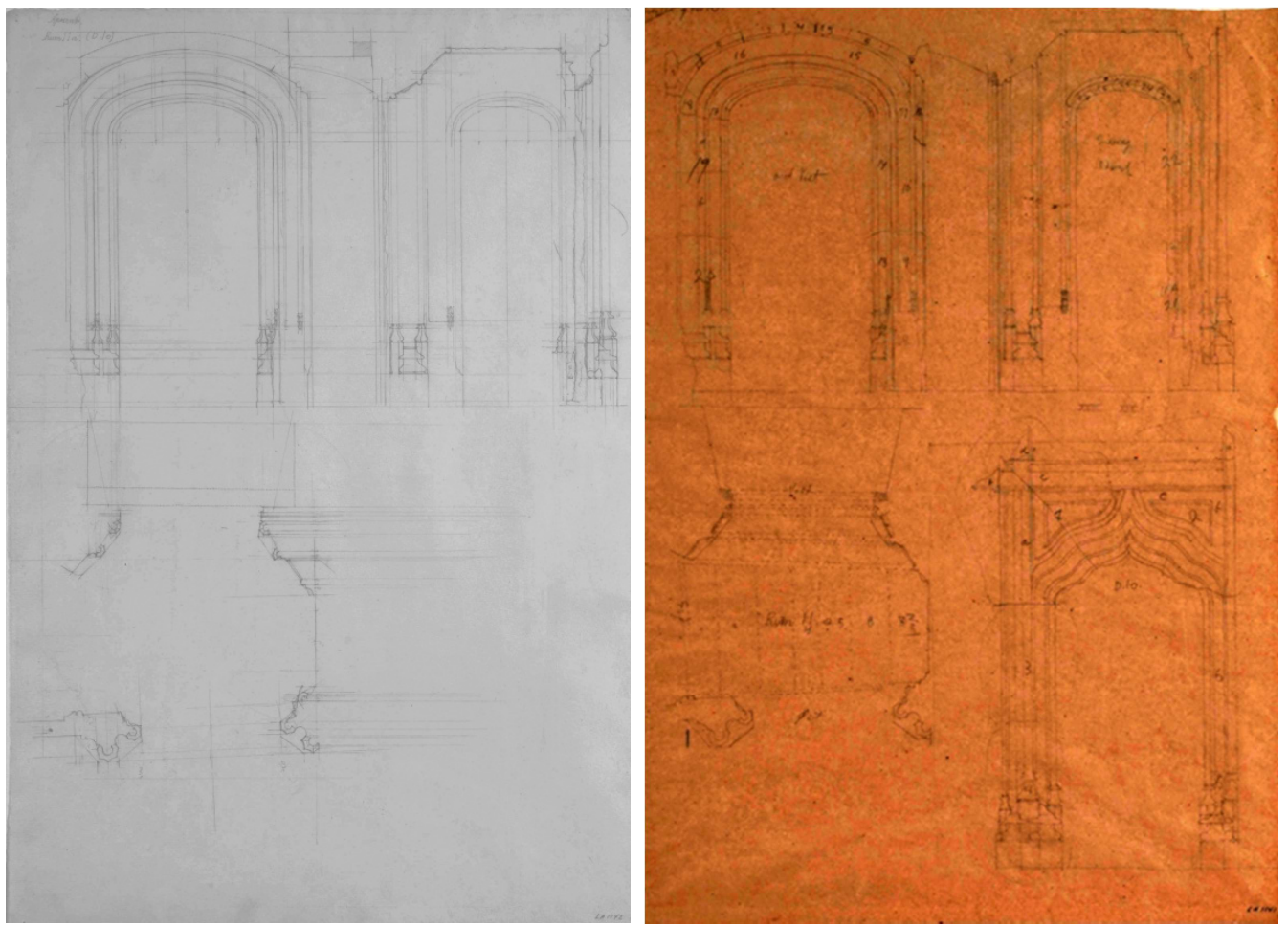

Figura 232. Izquierda: Plano Portada 10. LA1142. V. Lauritzen. Derecha: Plano Portada 10, siglado. LA1141. V. Lauritzen y/o E. Fischer. 
Tabla 18. Ficha Portada 10. (*Estas molduras no existen la jamba derecha).

\begin{tabular}{|c|c|c|}
\hline Ficha 10 & Portada 10 (Dör10) & \\
\hline Localización & Sala 11 (Rüm11) & \\
\hline \multirow[t]{3}{*}{$\begin{array}{l}\text { Documentación } \\
\text { existente }\end{array}$} & Planos & LA1140, LA1141 y LA1142 \\
\hline & Álbum Fotográfico Grande & Fot. 66. Pág. 15A \\
\hline & Álbum Fotográfico Pequeño & Fot. 66. Pág. 11R \\
\hline \multirow[t]{5}{*}{ Arco Intradós } & Tipo & Variación del flamígero \\
\hline & № Trazados curvos & 8 \\
\hline & № Trazados rectos & 0 \\
\hline & Luz & 1,07 \\
\hline & Altura libre & 2,29 \\
\hline \multirow[t]{5}{*}{ Arco Extradós } & Tipo & Adintelado \\
\hline & № Trazados curvos & 0 \\
\hline & № Trazados rectos & 1 \\
\hline & Luz & 1,73 \\
\hline & Altura máxima & 3,22 \\
\hline Basas & $\mathrm{SI}$ & 3 basas heptagonales \\
\hline \multirow[t]{16}{*}{ Jamba } & $\begin{array}{l}\text { Molduras del extradós a } \\
\text { intradós: }\end{array}$ & Radio / Longitud \\
\hline & Baqueta o columnilla* & $1,75 \mathrm{~cm}$ \\
\hline & Filete* & $2,0 \mathrm{~cm}$ \\
\hline & Caveto* & $4,3 \mathrm{~cm}$ \\
\hline & Caveto & $5,5 \mathrm{~cm}$ \\
\hline & Baqueta o columnilla & $3,3 \mathrm{~cm}$ \\
\hline & Filete & $4,2 \mathrm{~cm}$ \\
\hline & Caveto semicircular & $4,8 \mathrm{~cm}$ \\
\hline & Filete & $3,3 \mathrm{~cm}$ \\
\hline & Baqueta o columnilla & $2,5 \mathrm{~cm}$ \\
\hline & Filete & 2,6 \\
\hline & Ancho total jamba Izq. & $42,1 \mathrm{~cm}$ \\
\hline & Profundidad jamba (intradós) & $20,4 \mathrm{~cm}$ \\
\hline & Profundidad jamba Izq. (extradós) & $15,1 \mathrm{~cm}$ \\
\hline & Ángulo jamba Izq. (intradós) & $35^{\circ}$ \\
\hline & Ángulo jamba Izq. (extradós) & $32^{\circ}$ \\
\hline Capiteles & NO & \\
\hline
\end{tabular}




\section{Portada 11}

La documentación gráfica existente de la Portada 11(Dör 11) situada en la Sala 11 según el plano de planta del Palacio es la siguiente:

- Plano LA1137 $7^{324}$ : se trata de una puesta a escala dibujada a grafito sobre una lámina de papel de dimensiones $680 \times 470 \mathrm{~mm}$ donde está representado el alzado de la portada y una sección horizontal a nivel de las jambas. La disposición del dibujo es en vertical. Se encuentran representados los dos alzados de la portada desplegados y una sección horizontal por la jamba en correspondencia diédrica con el alzado derecho. Sobre el dintel de las portadas está dibujada la sección vertical. El plano no dispone de cotas. La escala de representación es 1:10, como en el resto de las portadas. Se trata de una portada adintelada en ángulo recto con ángulo de simetría a $45^{\circ}$; la parte derecha contiene el hueco que comunica la sala 11 con la 12, y la parte izquierda es ciega, formando una especie de hornacina ciega. La portada no dispone de capiteles. Por su parte, las basas están formadas por una columnilla con basa heptagonal. En cuanto a las molduras de la jamba desde el extradós al intradós son las siguientes: 2 cavetos, baqueta o columnilla, 2 cavetos, filete, caveto y jamba recta. En la parte superior izquierda se encuentra rotulado el nombre de la portada y su ubicación: "Dör No 11. Rum No 11", y en la parte inferior derecha la numeración de la lámina: LA1137 (ver Fig. 233 izq.).

- Plano LA1138 $8^{325}$ : se trata de una lámina de papel transparente de dimensiones 680 x $500 \mathrm{~mm}$ donde se ha copiado la del plano LA1137 en la parte inferior y la del LA1139 en la parte inferior. Sobre el alzado izquierdo está rotulado en danés: "D 11 væggen" (Portada 11 Muro) y sobre el alzado derecho: "D 11 Dørhullet" (Portada 11 Hueco de puerta). El alzado de la portada se encuentra dividido en 7 piezas: la 1 corresponde a la basa izquierda, la 2 y 3 a la jamba izquierda, la 4 al dintel izquierdo, la 5 al dintel derecho y la parte superior de la jamba derecha, la 6 al resto de la jamba derecha y la 7 a la basa derecha. En la parte inferior derecha se encuentra rotulada la numeración de la lámina: LA1138 (ver Fig. 234).

- Álbum de Fotos Grande: aparece una fotografía correspondiente a esta portada, la Fot. $75^{326}$. Tiene unas dimensiones de $7 \times 10 \mathrm{~cm}$. En ella se puede visualizar un ángulo de la Sala 11. Al fondo de observa una vista frontal del alzado de la portada 11 , que contiene el hueco de la puerta que comunica con la sala $12 \mathrm{y}$, en el lateral izquierdo, la ventana V3. Sobre la fotografía está rotulado a mano el número de la fotografía (75). En ella, aunque con dificultades, podemos apreciar que la portada se conserva en buen estado (ver Fig. 233 der.).

\footnotetext{
${ }^{324}$ Lauritzen, V. (1919-1920) Planos. Oliva, Valencia: Museo Municipal de Oliva, Archivo Público Documental, Palacio Condal. (LA1137).

${ }^{325}$ Lauritzen, V. (1919-1920) Planos. Oliva, Valencia: Museo Municipal de Oliva, Archivo Público Documental, Palacio Condal. (LA1138).

${ }^{326}$ Fischer, E. (1917-1920). Álbum Fotos Grande. Oliva, Valencia: Museo Municipal de Oliva, Archivo Público Documental, Palacio Condal. pp. 16R.
} 


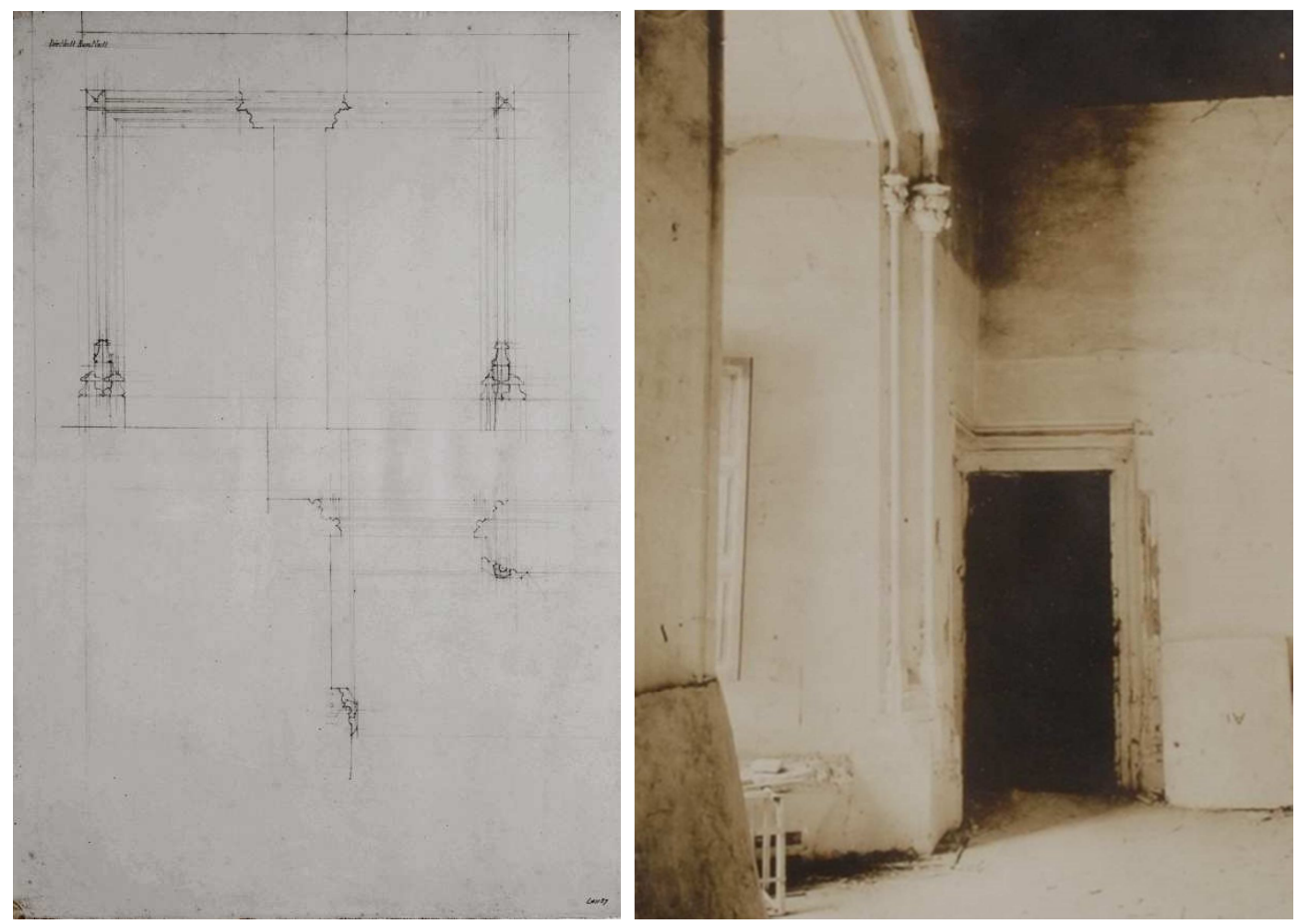

Figura 233. Izquierda: Plano Portada 11. LA1137. V. Lauritzen. Derecha: Fot. 75. Portada 11 al fondo. Álbum Fot. Grande. Pág. 16R.E. Fischer.

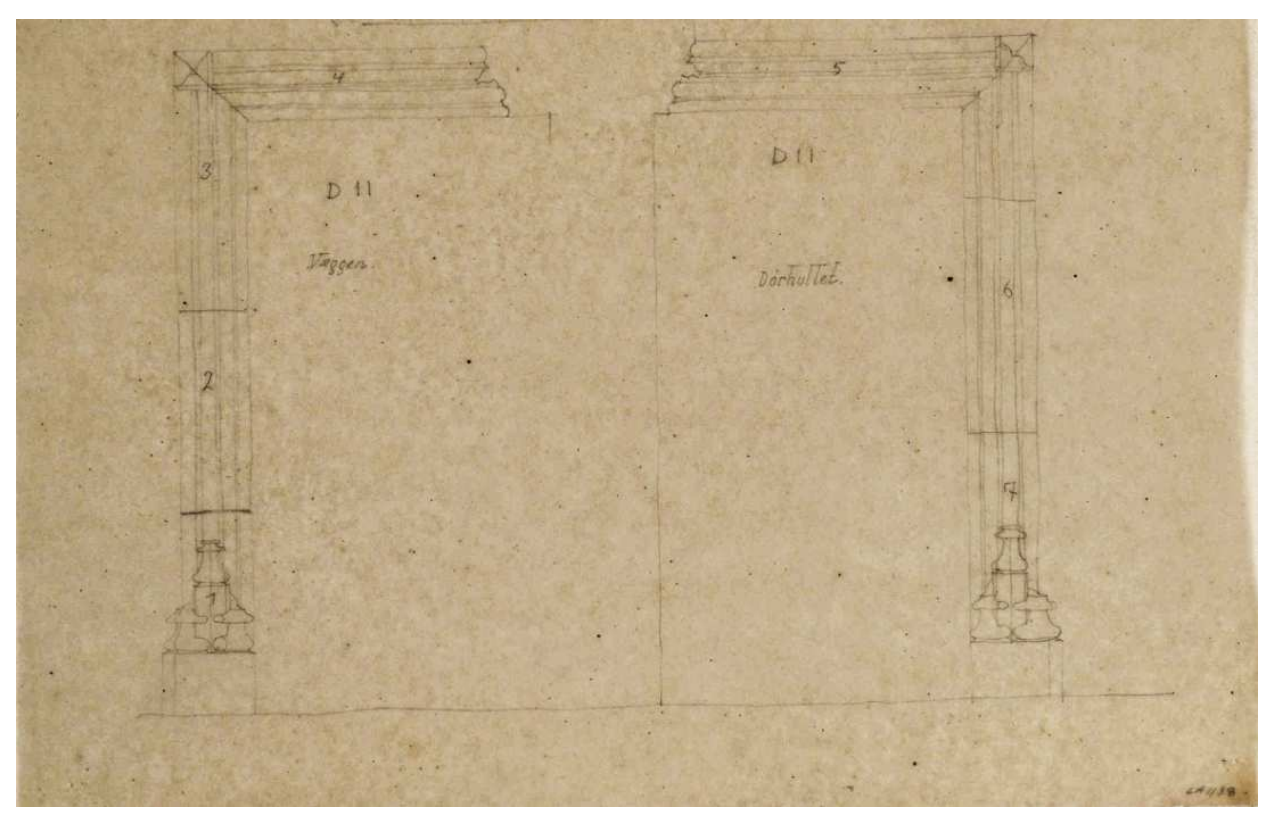

Figura 234. Plano Portada 11, siglado. LA1138. V. Lauritzen y/o E. Fischer. 
Tabla 19. Ficha Portada 11.

\begin{tabular}{|c|c|c|}
\hline Ficha 11 & Portada 11(Dör 11) & \\
\hline Localización & Sala 11 (Rüm11) & \\
\hline \multirow{3}{*}{$\begin{array}{l}\text { Documentación } \\
\text { existente }\end{array}$} & Planos & LA1137 y LA1138 \\
\hline & Álbum Fotográfico Grande & Fot. 75 Pág. 16R \\
\hline & Álbum Fotográfico Pequeño & NO \\
\hline \multirow[t]{5}{*}{ Arco Intradós } & Tipo & Adintelado \\
\hline & № Trazados curvos & 0 \\
\hline & № Trazados rectos & 1 \\
\hline & Luz & 1,14 \\
\hline & Altura libre & 2,23 \\
\hline \multirow[t]{5}{*}{ Arco Extradós } & Tipo & Adintelado \\
\hline & № Trazados curvos & 0 \\
\hline & № Trazados rectos & 1 \\
\hline & Luz & 1,38 \\
\hline & Altura máxima & 2,51 \\
\hline Basas & $\mathrm{SI}$ & 1 basa heptagonal \\
\hline \multirow[t]{12}{*}{ Jamba } & $\begin{array}{l}\text { Molduras del extradós a } \\
\text { intradós: }\end{array}$ & Radio /Longitud \\
\hline & Caveto & $3,2 \mathrm{~cm}$ \\
\hline & Caveto & $2,5 \mathrm{~cm}$ \\
\hline & Baqueta o columnilla & $2,8 \mathrm{~cm}$ \\
\hline & Caveto & $2,4 \mathrm{~cm}$ \\
\hline & Caveto & $3,1 \mathrm{~cm}$ \\
\hline & Filete & $1,4 \mathrm{~cm}$ \\
\hline & Caveto & $2,8 \mathrm{~cm}$ \\
\hline & Jamba recta & $15,7 \mathrm{~cm}$ \\
\hline & Ancho jamba & $25,8 \mathrm{~cm}$ \\
\hline & Profundidad jamba & $26,2 \mathrm{~cm}$ \\
\hline & Ángulo jamba & $23^{\circ}$ \\
\hline Capiteles & NO & \\
\hline
\end{tabular}




\section{Portada 12}

La documentación gráfica existente de la Portada 12 (Dör 12) situada en la Sala 12 según el plano de planta del Palacio es la siguiente:

- Plano LA1139 ${ }^{327}$ : se trata de una puesta a escala dibujada a grafito sobre una lámina de papel de dimensiones $680 \times 470 \mathrm{~mm}$ donde está representado el alzado de la portada y una sección horizontal a nivel del arranque de las jambas. La disposición del dibujo es vertical. Existen líneas auxiliares de dibujo y no dispone de cotas. La escala de representación es 1:10, como en el resto de las portadas. Se trata de una portada formada por un arco mixtilíneo/carpanel en su intradós que se transforma en un arco mixtilíneo/variación del flamígero en su extradós. La portada no dispone de capiteles. Las basas están formadas por dos columnillas de basa heptagonal. Las molduras de la jamba desde el extradós al intradós son las siguientes: caveto, baqueta o columnilla, filete, caveto semicircular, filete, baqueta o columnilla, dos cavetos y jamba recta. En la parte superior izquierda se encuentra rotulado el nombre de la portada y su ubicación: "Dör No 12. RumNo12", y en la parte inferior derecha la numeración de la lámina: LA1139 (ver Fig. 235 izq.).

- Plano LA1138 $8^{328}$ : se trata de una lámina de papel transparente de dimensiones 680 x $500 \mathrm{~mm}$. Su disposición es vertical. En ella se ha copiado el alzado de la portada 12 del plano LA1139 en la parte superior. En el centro del alzado aparece rotulado el número de la portada "D 12"y, en la parte inferior derecha, la numeración de la lámina: LA138. La portada se encuentra dividida en 9 secciones numeradas para su desmontaje: la 1 corresponde a la basa izquierda, la 2 y 3 a la jamba izquierda, la 4 al arranque izquierdo del arco, la 5 a la clave del arco, la 6 al arranque derecho del arco, la 7 a la jamba derecha y la 9 a la basa derecha (ver Fig. 236).

- Álbum de Fotos Grande: en la página 17A de este álbum encontramos la Fot. $77^{329}$. Tiene unas dimensiones de $7 \times 10 \mathrm{~cm}$. En ella aparece representada una vista frontal de la portada 12 al fondo, y a la derecha una vista lateral de la venta V3. Sobre la fotografía aparece rotulado a mano el número de la fotografía (77). En la fotografía podemos apreciar que la portada se conserva en buen estado. Sobre las paredes de la sala 12 se observa material acopiado (ver Fig. 235 dcha.).

\footnotetext{
${ }^{327}$ Lauritzen, V. (1919-1920). Planos. Oliva, Valencia: Museo Municipal de Oliva, Archivo Público Documental, Palacio Condal. (LA1139).

${ }^{328}$ Lauritzen, V. (1919-1920). Planos. Oliva, Valencia: Museo Municipal de Oliva, Archivo Público Documental, Palacio Condal. (LA1138).

${ }^{329}$ Fischer, E. (1917-1920). Álbum Fotos Grande. Oliva, Valencia: Museo Municipal de Oliva, Archivo Público Documental, Palacio Condal pp. 17A.
} 

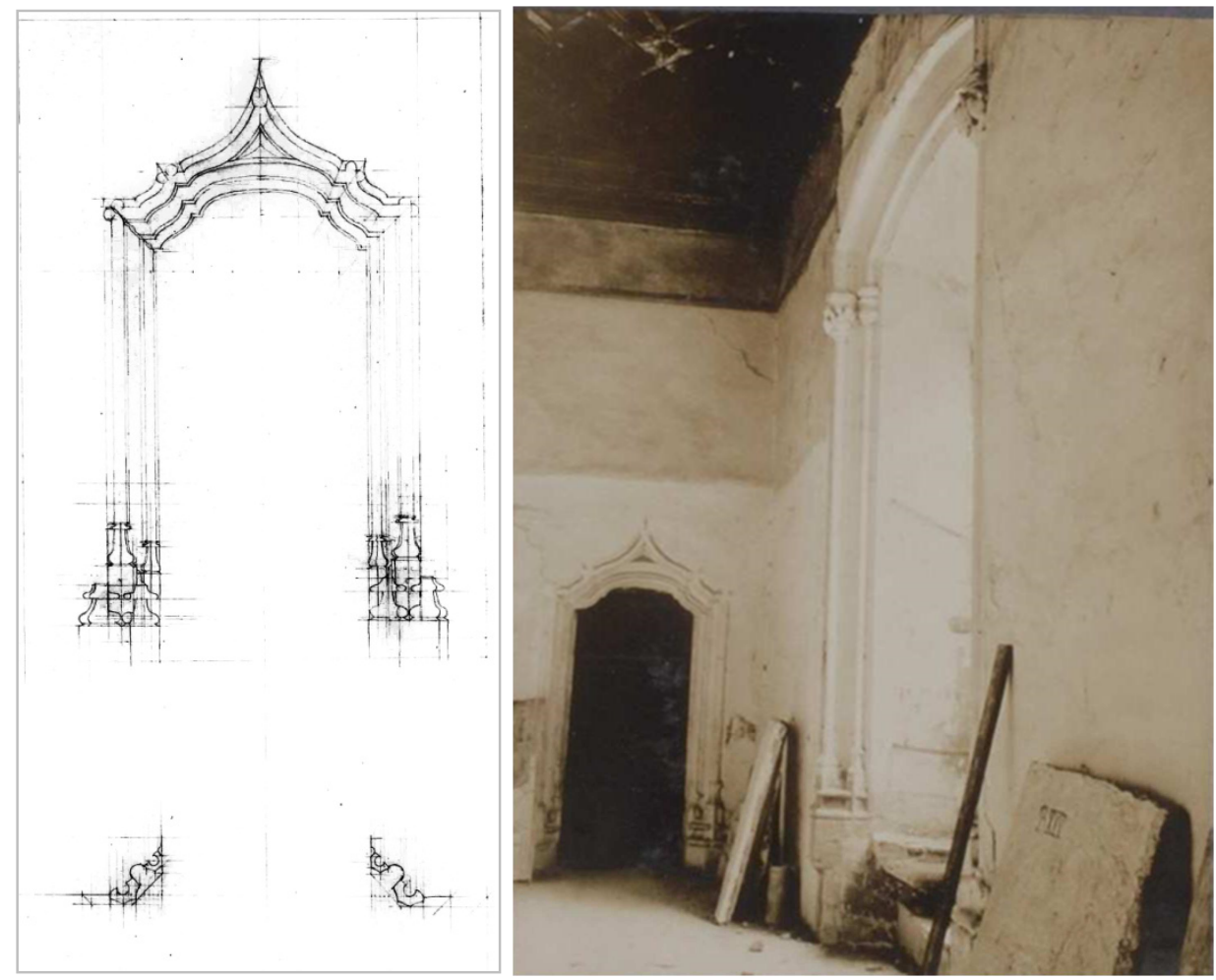

Figura 235. Izquierda: Plano Portada 12. LA1139. V. Lauritzen. Derecha: Fot. 77. Portada 12 al fondo. Álbum Fot. Grande. Pág. 17A.E. Fischer.

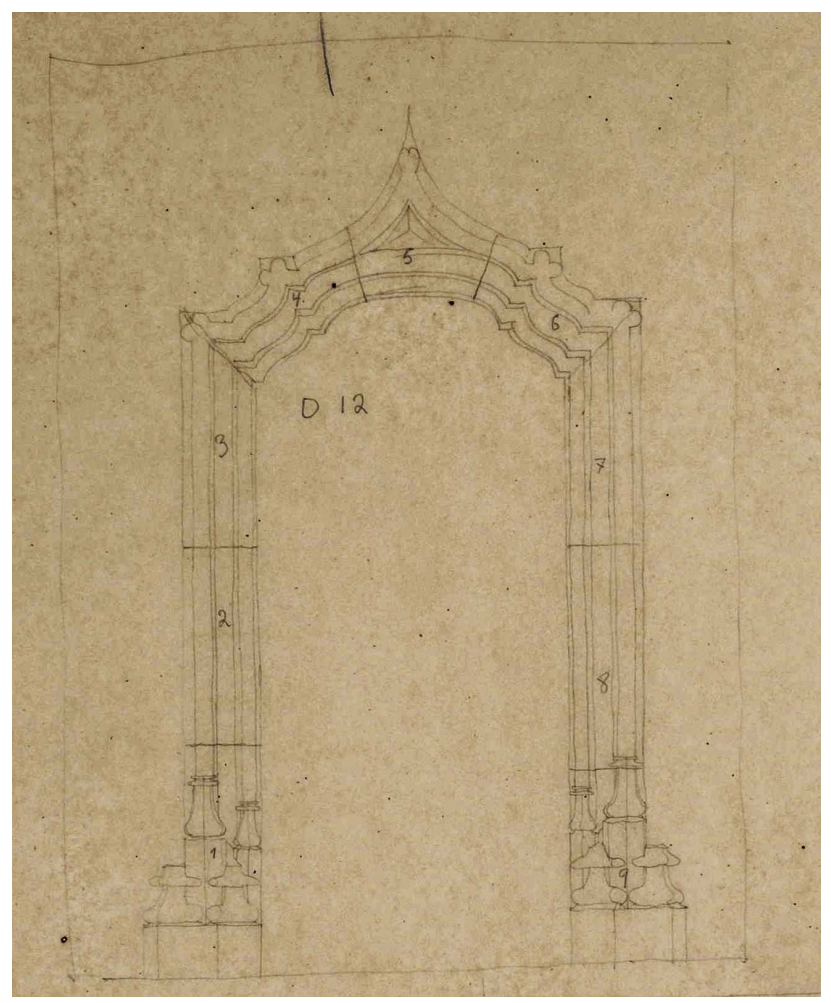

Figura 236. Plano Portada 12, siglado. LA1138. V. Lauritzen y/o E. Fischer. 
Tabla 20. Ficha Portada 12.

\begin{tabular}{|c|c|c|}
\hline Ficha 12 & \multicolumn{2}{|l|}{ Portada 12(Dör 12) } \\
\hline Localización & \multicolumn{2}{|l|}{ Sala 12 (Rüm12) } \\
\hline \multirow{3}{*}{$\begin{array}{l}\text { Documentación } \\
\text { existente }\end{array}$} & Planos & LA1138 y LA1139 \\
\hline & Álbum Fotográfico Grande & Fot. 77 Pág. 17A \\
\hline & Álbum Fotográfico Pequeño & NO \\
\hline \multirow[t]{5}{*}{ Arco Intradós } & Tipo & Mixtilíneo/Carpanel \\
\hline & № Trazados curvos & 7 \\
\hline & № Trazados rectos & 4 \\
\hline & Luz & 1,05 \\
\hline & Altura libre & 2,36 \\
\hline \multirow[t]{5}{*}{ Arco Extradós } & Tipo & $\begin{array}{c}\text { Mixtilíneo/Variación del } \\
\text { flamígero }\end{array}$ \\
\hline & № Trazados curvos & 8 \\
\hline & № Trazados rectos & 4 \\
\hline & Luz & 1,59 \\
\hline & Altura máxima & 3,02 \\
\hline Basas & $\mathrm{SI}$ & 2 basas heptagonales \\
\hline \multirow[t]{13}{*}{ Jamba } & $\begin{array}{l}\text { Molduras del extradós a } \\
\text { intradós: }\end{array}$ & Radio / Longitud \\
\hline & Caveto & $6,3 \mathrm{~cm}$ \\
\hline & Baqueta o columnilla & $3,1 \mathrm{~cm}$ \\
\hline & Filete & $4,2 \mathrm{~cm}$ \\
\hline & Caveto semicircular & $4,2 \mathrm{~cm}$ \\
\hline & Filete & $2,7 \mathrm{~cm}$ \\
\hline & Baqueta o columnilla & $2,6 \mathrm{~cm}$ \\
\hline & Caveto & $7,4 \mathrm{~cm}$ \\
\hline & Caveto & $2,9 \mathrm{~cm}$ \\
\hline & Jamba recta & $4,2 \mathrm{~cm}$ \\
\hline & Ancho jamba & $26,8 \mathrm{~cm}$ \\
\hline & Profundidad jamba & $24,5 \mathrm{~cm}$ \\
\hline & Ángulo jamba & $44^{\circ}$ \\
\hline Capiteles & NO & \\
\hline
\end{tabular}




\section{Portada 13}

La documentación gráfica existente de la Portada 13 (Dör 13) situada en la Sala 12 según el plano de planta del Palacio es la siguiente:

- Plano LA1146 ${ }^{330}$ : se trata de una puesta a escala dibujada a grafito sobre una lámina de papel de dimensiones $680 \times 470 \mathrm{~mm}$ donde está representado el alzado de la portada y una sección horizontal por las jambas. La disposición del dibujo es vertical. Existen líneas auxiliares de dibujo y dispone de algunas cotas; las cotas en altura toman como origen una línea de referencia auxiliar horizontal. La escala de representación es 1:10, como en el resto de las portadas. Se trata de una portada formada por un arco Trilobulado/Rebajado tanto en su intradós como en su trasdós... La portada no dispone de capiteles. Las basas están formadas por dos columnillas de basa heptagonal, siendo este la tipo el más extendido entre las portadas del palacio. Las molduras de la jamba desde el extradós al intradós son las siguientes: caveto, baqueta o columnilla, caveto, caveto semicircular, caveto, baqueta o columnilla, dos cavetos y jamba recta. En la parte superior izquierda se encuentra rotulado el nombre de la portada y su ubicación: "Dör 13 -Rum12", y en la parte inferior derecha, la numeración de la lámina: LA1146 (ver Fig. 237 izq.).

- Plano LA1145 ${ }^{331}$ : se trata de una lámina de papel transparente de dimensiones 667 x $457 \mathrm{~mm}$. La disposición de la lámina es vertical. En ella está grafiada una copia del alzado de la portada 13 del plano LA1146. En la esquina superior izquierda está rotulado el número de la portada y su localización "D 13 (Rum 12)" y en la parte inferior derecha la numeración de la lámina: LA145. La portada se encuentra dividida en 7 secciones numeradas para su desmontaje: la 1 corresponde a la basa izquierda, la 2 a la parte inferior la jamba izquierda, la 3 a la parte superior y arranque izquierdo del arco, la 4 a la clave del arco, la 5 al arranque derecho del arco y parte superior de la jamba, la 6 a la parte inferior de la jamba derecha y la 7 a la basa derecha (ver Fig. 238).

- Álbum de Fotos Grande: en la página 14R de este álbum encontramos la Fot. $63^{332}$. Tiene unas dimensiones de $7 \times 10 \mathrm{~cm}$. En ella aparece representada una vista frontal de la portada 13. A través del hueco podemos visualizar la portada 15 alineada con la primera y, al fondo, la sala 13 o capilla. En la fotografía se puede apreciar que la portada se conserva en buen estado. Sobre las paredes de la salas 12, 13 y 14 (al fondo) se ve material acopiado (ver Fig. 237 dcha.).

\footnotetext{
${ }^{330}$ Lauritzen, V. (1919-1920) Planos. Oliva, Valencia: Museo Municipal de Oliva, Archivo Público Documental, Palacio Condal. (LA1146).

${ }^{331}$ Lauritzen, V. (1919-1920) Planos. Oliva, Valencia: Museo Municipal de Oliva, Archivo Público Documental, Palacio Condal. (LA1145).

${ }^{332}$ Fischer, E. (1917-1920). Álbum Fotos Grande. Oliva, Valencia: Museo Municipal de Oliva, Archivo Público Documental, Palacio Condal pp. 14R.
} 

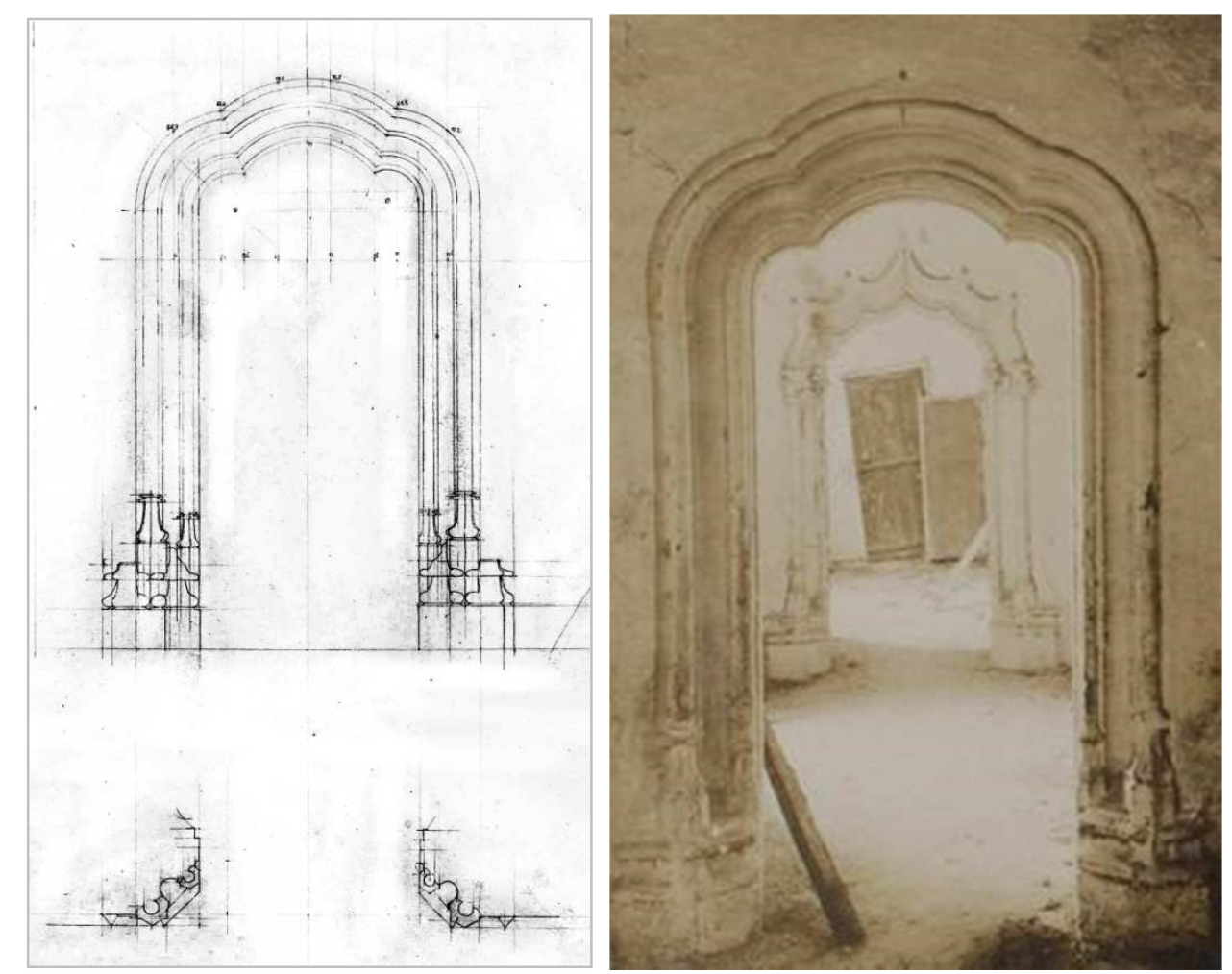

Figura 237. Izquierda: Plano Portada 13. LA1146. V. Lauritzen. Derecha: Fot. 63. Portada 13 en primer plano. Álbum Fot. Grande. Pág. 14R.E. Fischer.

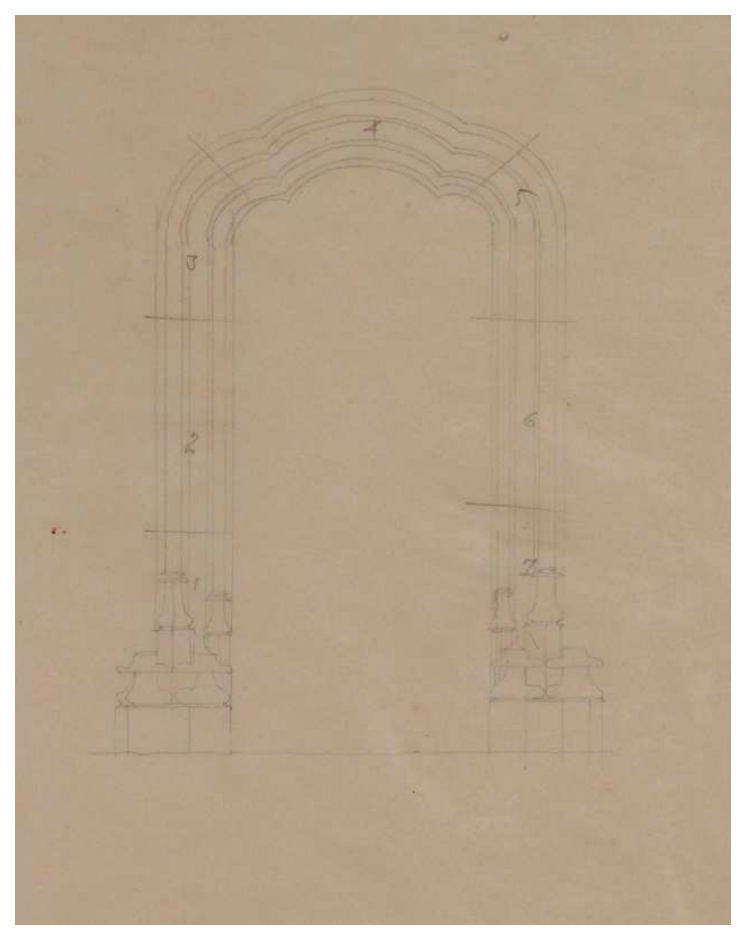

Figura 238. Plano Portada 13, siglado. LA1145. V. Lauritzen y/o E. Fischer. 
Tabla 21. Ficha Portada 13.

\begin{tabular}{|c|c|c|}
\hline Ficha 13 & Portada 13(Dör 13) & \\
\hline Localización & Sala 12 (Rüm12) & \\
\hline \multirow{3}{*}{$\begin{array}{l}\text { Documentación } \\
\text { existente }\end{array}$} & Planos & LA1145 y LA1146 \\
\hline & Álbum Fotográfico Grande & Fot. 63 Pág. 14R \\
\hline & Álbum Fotográfico Pequeño & NO \\
\hline \multirow[t]{5}{*}{ Arco Intradós } & Tipo & Trilobulado/Rebajado \\
\hline & № Trazados curvos & 3 \\
\hline & № Trazados rectos & 0 \\
\hline & Luz & 0,91 \\
\hline & Altura libre & 2,20 \\
\hline \multirow[t]{5}{*}{ Arco Extradós } & Tipo & Trilobulado/Rebajado \\
\hline & № Trazados curvos & 3 \\
\hline & № Trazados rectos & 0 \\
\hline & Luz & 1,45 \\
\hline & Altura máxima & 2,45 \\
\hline Basas & SI & 2 basas heptagonales \\
\hline \multirow[t]{13}{*}{ Jamba } & $\begin{array}{l}\text { Molduras del extradós a } \\
\text { intradós: }\end{array}$ & Radio /Longitud \\
\hline & Caveto & $4,9 \mathrm{~cm}$ \\
\hline & Baqueta o columnilla & $3,1 \mathrm{~cm}$ \\
\hline & Caveto & $7,2 \mathrm{~cm}$ \\
\hline & Caveto semicircular & $4,4 \mathrm{~cm}$ \\
\hline & Caveto & $4,5 \mathrm{~cm}$ \\
\hline & Baqueta o columnilla & $2,3 \mathrm{~cm}$ \\
\hline & Caveto & $2,2 \mathrm{~cm}$ \\
\hline & Caveto & $2,6 \mathrm{~cm}$ \\
\hline & Jamba recta & $10,0 \mathrm{~cm}$ \\
\hline & Ancho jamba & $27,0 \mathrm{~cm}$ \\
\hline & Profundidad jamba & $22,8 \mathrm{~cm}$ \\
\hline & Ángulo jamba & $39^{\circ}$ \\
\hline Capiteles & NO & \\
\hline
\end{tabular}




\section{Portada 14}

La documentación gráfica existente de la Portada 14 (Dör 14) situada en la Sala 13 según el plano de planta del Palacio es la siguiente:

- Plano LA1148 ${ }^{333}$ : se trata de una puesta a escala dibujada a grafito sobre una lámina de papel de dimensiones $680 \times 470 \mathrm{~mm}$ donde está representado el alzado de la portada, una sección horizontal a nivel del arranque de las basas y una sección vertical por el eje de la portada; esta última vista no se encuentra finalizada. Las tres vistas tienen correspondencia diédrica. La disposición del dibujo en la lámina es vertical y existen líneas auxiliares de dibujo. El plano no dispone de cotas y la escala de representación es 1:10, como en el resto de las portadas. Se trata de una portada con un dintel moldurado en su intradós. Tanto las jambas como el arco están abocinados mediante un perfil curvo. El arco exterior es carpanel. La portada tiene dos capiteles góticos de planta heptagonal con ornamentación vegetal y zooforme. Por su parte, las basas están formadas por dos columnillas de basa heptagonal. Las molduras de la jamba desde el extradós al intradós son las siguientes: caveto, baqueta o columnilla, caveto, caveto semicircular, caveto, baqueta o columnilla, dos cavetos y jamba abocinada curva. En la parte superior izquierda se encuentra rotulado el nombre de la portada y su ubicación: "Dör 14 Rum 13", y en la parte inferior derecha, la numeración de la lámina: LA1148. Tangente a la clave del arco aparece una línea horizontal y, sobre ella, está rotulado en danés "Underkantaf Frisen" (Borde inferior del friso) (ver Fig. 239 izq).

- Plano LA1147 $7^{334}$ : se trata de una lámina de papel transparente de dimensiones $660 \mathrm{x}$ $473 \mathrm{~mm}$. Su disposición es vertical. En ella está grafiada una copia del alzado de la portada 14, correspondiente al plano LA1148. En la esquina superior izquierda está rotulado el número de la portada, "Dör 14", y en la parte inferior derecha la numeración de la lámina: LA147. La portada se encuentra dividida en 9 secciones numeradas para su desmontaje: la 1 corresponde a la basa izquierda, la 2 a la parte inferior de la jamba izquierda, la 3 a la parte superior de la jamba izquierda, la 4 a los capiteles arranque del arco del lado izquierdo, la 5 al capitel pequeño derecho, la 6 al capitel grande derecho, la 7 a la basa derecha, la 8 a la mitad izquierda del dintel y la 9 a la mitad derecha del mismo (ver Fig. 239 dcha.).

- Álbum de Fotos Grande: en la página 14R de este álbum encontramos las fotografías 60,61 y $62^{335}$. Tienen unas dimensiones de $7 \times 10 \mathrm{~cm}$. En la fotografía 61 se observa una vista frontal parcial de la portada 14 (en 8 se ven sólo parcialmente las basas y la jamba derecha); a través del hueco podemos visualizar la portada 28, alineada con la primera al fondo de la sala 12. En la fotografía podemos apreciar que la portada se conserva en buen estado, salvo el arco que aparece recubierto por un mortero irregular, a modo de pelladas. Sobre el arco se puede observar una cornisa moldurada con ornamentación vegetal y puttis alados, de estilo claramente renacentista. Las fotografías 60 y 61 corresponden, respectivamente, al capitel grande izquierdo y a los capiteles derechos

\footnotetext{
333 Lauritzen, V. (1919-1920). Planos. Oliva, Valencia: Museo Municipal de Oliva, Archivo Público Documental, Palacio Condal. (LA1148).

334 Lauritzen, V. (1919-1920). Planos. Oliva, Valencia: Museo Municipal de Oliva, Archivo Público Documental, Palacio Condal. (LA1147).

${ }^{335}$ Fischer, E. (1917-1920). Álbum Fotos Grande. Oliva, Valencia: Museo Municipal de Oliva, Archivo Público Documental, Palacio Condal. pp. 14R.
} 
(se ven parcialmente), una vez desmontados por EF y su equipo para su traslado a Dinamarca (ver Fig. 240).
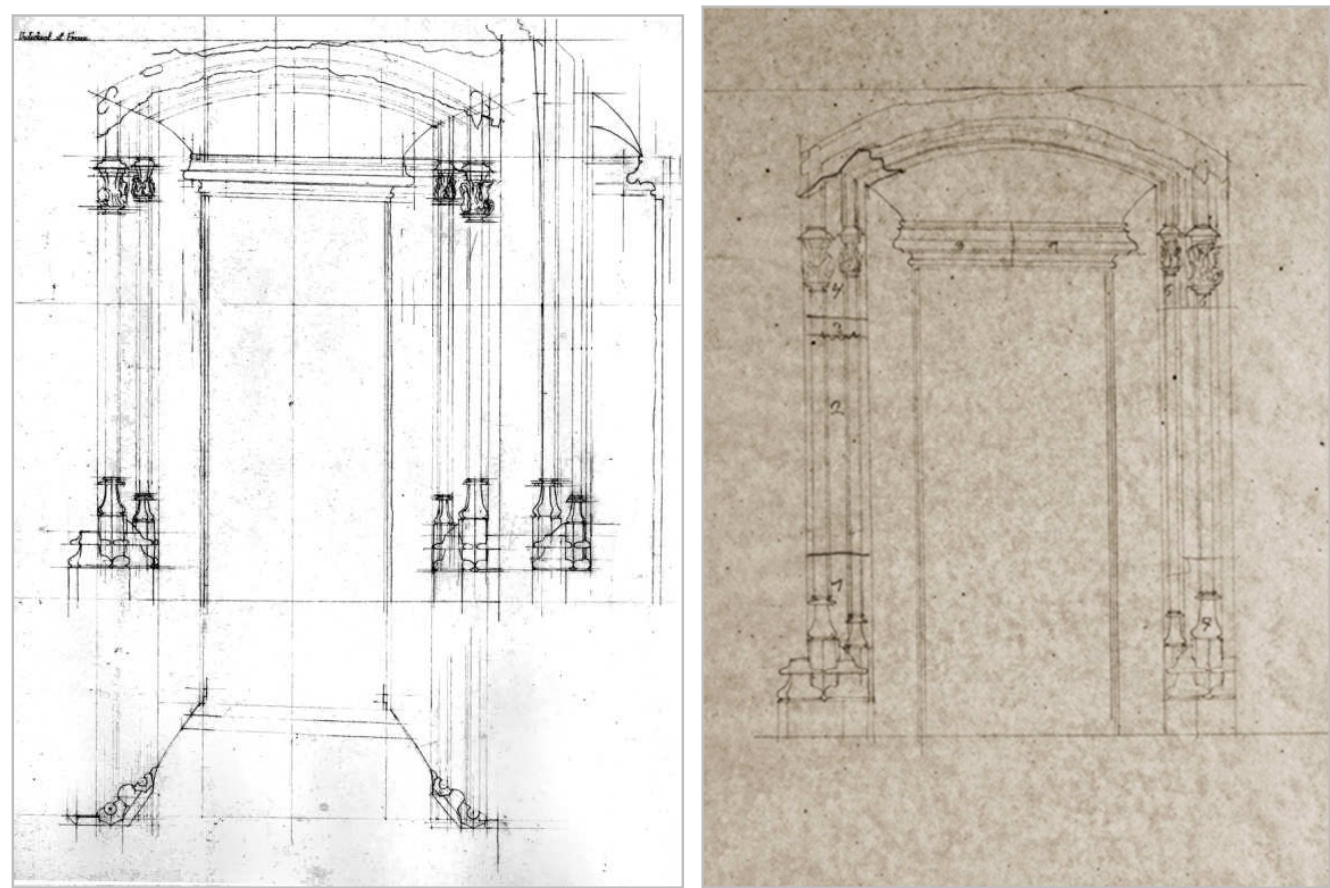

Figura 239. Izquierda: Plano Portada 14. LA1148. V. Lauritzen. Derecha: Plano Portada 14. LA1147. V. Lauritzen y/o E. Fischer.

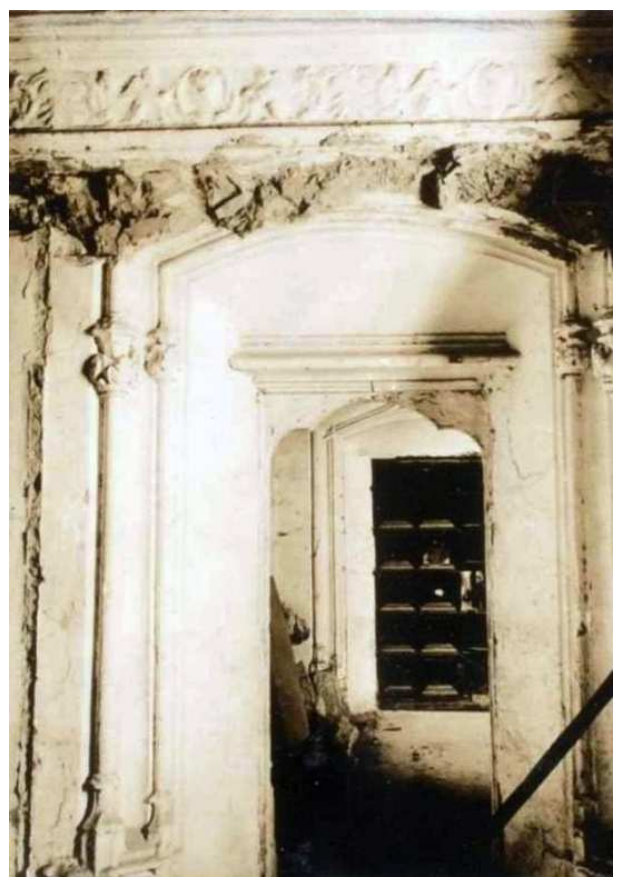

Figura 240. Fot. 61. Portada 14. Álbum Fotgr. Grande. Pág. 14A.E. Fischer. 
Tabla 22. Ficha Portada 14.

\begin{tabular}{|c|c|c|}
\hline Ficha 14 & Portada 14 (Dör 14) & \\
\hline Localización & Sala 13 (Rum13) & \\
\hline \multirow{3}{*}{$\begin{array}{l}\text { Documentación } \\
\text { existente }\end{array}$} & Planos & LA1147 y LA1148 \\
\hline & Álbum Fotográfico Grande & Fot. 61Pág. 14A \\
\hline & Álbum Fotográfico Pequeño & NO \\
\hline \multirow[t]{5}{*}{ Arco Intradós } & Tipo & Adintelado \\
\hline & № Trazados curvos & 0 \\
\hline & № Trazados rectos & 1 \\
\hline & Luz & 0,96 \\
\hline & Altura libre & 2,18 \\
\hline \multirow[t]{5}{*}{ Arco extradós } & Tipo & Escarzano \\
\hline & № Trazados curvos & 1 \\
\hline & № Trazados rectos & 0 \\
\hline & Luz & 2,12 \\
\hline & Altura máxima & 3,03 \\
\hline Basas & $\mathrm{SI}$ & 2 basas heptagonales \\
\hline \multirow[t]{13}{*}{ Jamba } & $\begin{array}{l}\text { Molduras del extradós a } \\
\text { intradós: }\end{array}$ & Radio /Longitud \\
\hline & Caveto & $6,0 \mathrm{~cm}$ \\
\hline & Baqueta o columnilla & $3,2 \mathrm{~cm}$ \\
\hline & Caveto & $1,4 \mathrm{~cm}$ \\
\hline & Caveto semicircular & $6,0 \mathrm{~cm}$ \\
\hline & Caveto & $8,8 \mathrm{~cm}$ \\
\hline & Baqueta o columnilla & $2,4 \mathrm{~cm}$ \\
\hline & Caveto & $4,1 \mathrm{~cm}$ \\
\hline & Caveto & $3,1 \mathrm{~cm}$ \\
\hline & $\begin{array}{l}\text { Ancho jamba } \\
\text { (sin abocinamiento) }\end{array}$ & $33,3 \mathrm{~cm}$ \\
\hline & $\begin{array}{l}\text { Profundidad jamba } \\
\text { (sin abocinamiento) }\end{array}$ & $26,7 \mathrm{~cm}$ \\
\hline & Jamba abocinada curva (cuerda) & $40,0 \mathrm{~cm}$ \\
\hline & Ángulo jamba & $40^{\circ}$ \\
\hline Capiteles & $\mathrm{SI}$ & 2 Góticos $^{336}$ \\
\hline
\end{tabular}

\footnotetext{
${ }^{336}$ El número de capiteles se refiere a cada unidad de jamba. Los capiteles de trazado gótico se encuentran rematando las columnillas, justo por debajo de la línea de impostas.
} 


\section{Portada 15}

La documentación gráfica existente de la Portada 15 (Dör 15) situada en la Sala 13 según el plano de planta del Palacio es la siguiente:

- Plano LA1150 ${ }^{337}$ : se trata de una puesta a escala dibujada a grafito sobre una lámina de papel de dimensiones $680 \times 470 \mathrm{~mm}$ donde está representado el alzado de la portada y una sección horizontal a nivel del arranque de las basas. Las vistas tienen correspondencia diédrica, la disposición del dibujo en la lámina es vertical y existen líneas auxiliares de dibujo. El plano no dispone de cotas y su escala de representación es 1:10. Se trata de una portada con un arco complejo de tipo mixtilíneo/variación del flamígero. El tipo de arco mantiene su trazado desde el intradós al extradós, si bien la mayoría de sus trazados curvos se transforman de uno a dos o tres centros en el extradós. La portada tiene dos capiteles góticos de planta heptagonal con ornamentación vegetal y zooforme. Las basas están formadas por dos columnillas de basa heptagonal y las molduras de la jamba desde el extradós al intradós son las siguientes: 2 cavetos, baqueta o columnilla, filete, caveto semicircular, filete, baqueta o columnilla, dos cavetos y jamba recta. En la parte superior izquierda se encuentra rotulado el nombre de la portada y su ubicación: "Dör 15Rum 13", y en la parte inferior derecha la numeración de la lámina: LA1150 (ver Fig. 241 izq.).

- Plano LA1149 ${ }^{338}$ : se trata de una lámina de papel transparente de dimensiones 660 x $476 \mathrm{~mm}$, con disposición en vertical. En ella está grafiada una copia del alzado de la portada 15 (correspondiente al plano LA1148). En la esquina superior izquierda está rotulado el número de la portada y su localización "Dör 15 (Rum 13)" y en la parte inferior derecha, la numeración de la lámina LA149. La portada se encuentra dividida en 9 secciones numeradas para su desmontaje: la 1 corresponde a la basa izquierda, la 2 a la jamba izquierda, la 3 a la parte superior de la jamba, capiteles y arranque izquierdo del arco, la 4 al resto del lado izquierdo del arco y a los capiteles arranque del arco hasta la línea de simetría, la 5 es la simétrica a la 4, la 6 corresponde a los capiteles del derecho, incluyendo el arranque del arco y la parte superior de la jamba, la 7 y la 8 corresponden a la jamba derecha, que está dividida en dos piezas con un corte diagonal que parece corresponder a una fractura por una grieta y, por último, la 8 corresponde a la basa derecha (ver Fig. 242).

- Álbum de Fotos Grande: en la página 14R encontramos la fotografía $65^{339}$, correspondiente a la portada 15 . Tiene unas dimensiones de $7 \times 10 \mathrm{~cm}$. En la fotografía se puede ver una vista frontal, parte de la portada. El estado de conservación de la portada es bueno, aunque junto a la basa y sobre la jamba derecha podemos observar grietas diagonales que podrían deberse a movimientos

\footnotetext{
337 Lauritzen, V. (1919-1920). Planos. Oliva, Valencia: Museo Municipal de Oliva, Archivo Público Documental, Palacio Condal. (LA1150).

${ }^{338}$ Lauritzen, V. y/o Fischer, E. (1919-1920). Planos. Oliva, Valencia: Museo Municipal de Oliva, Archivo Público Documental, Palacio Condal. (LA1149).

${ }^{339}$ Fischer, E. (1917-1920). Álbum Fotos Grande. Oliva, Valencia: Museo Municipal de Oliva, Archivo Público Documental, Palacio Condal pp. 14R.
} 
en el edificio. A través del hueco de paso se observa la sala 14 iluminada desde el lateral izquierdo por una ventana situada en dicho lado. En el centro de la sala se encuentra Fischer sosteniendo en sus manos una especie de palo que bien podría ser una vara de medir. Al fondo se ven varias hojas de carpintería desmontada, apoyada sobre las paredes de la sala (ver Fig. 241 dcha.).
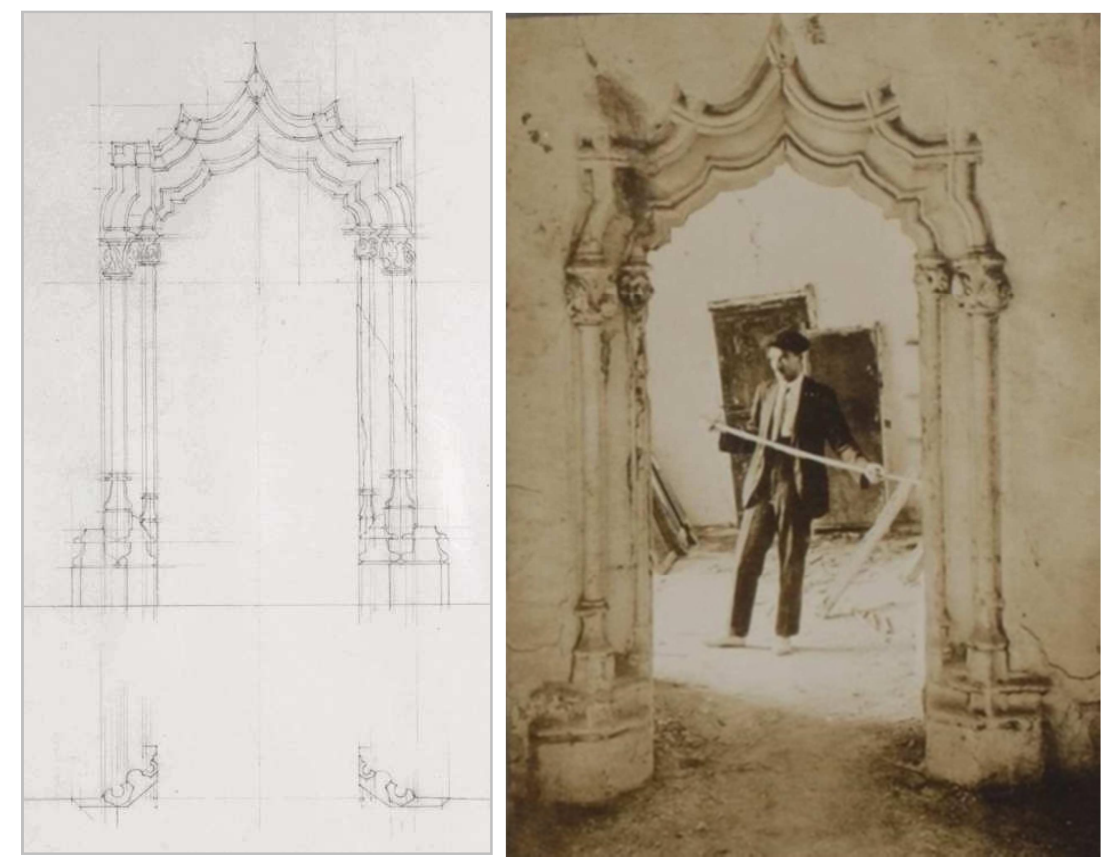

Figura 241. Izquierda: Plano Portada 15. LA11450. V. Lauritzen. Derecha: Fot. 65. Álbum Fot. Grande. E. Fischer.

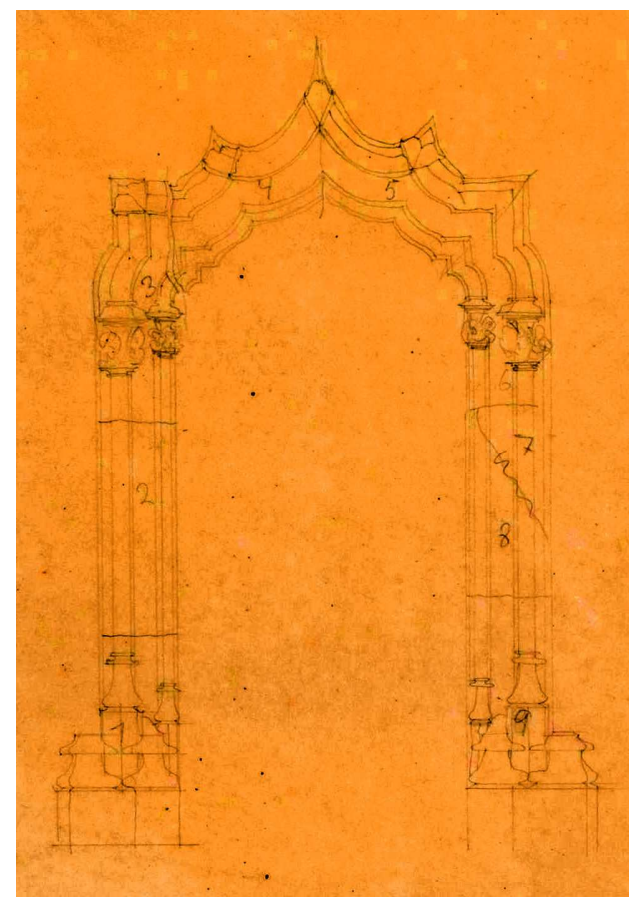

Figura 242. Portada 15. Siglado. LA1149. V. Lauritzen y/o E. Fischer. 
Tabla 23. Ficha Portada 15.

\begin{tabular}{|c|c|c|}
\hline Ficha 15 & Portada 15(Dör 15) & \\
\hline Localización & Sala 13 (Rum13) & \\
\hline \multirow{3}{*}{$\begin{array}{l}\text { Documentación } \\
\text { existente }\end{array}$} & Planos & LA1149 y LA1150 \\
\hline & Álbum Fotográfico Grande & Fot. 65 Pág. 14R \\
\hline & Álbum Fotográfico Pequeño & NO \\
\hline \multirow[t]{5}{*}{ Arco Intradós } & Tipo & $\begin{array}{c}\text { Mixtilíneo/Variación del } \\
\text { Flamígero }\end{array}$ \\
\hline & № Trazados curvos & 10 \\
\hline & № Trazados rectos & 4 \\
\hline & Luz & 1,06 \\
\hline & Altura libre & 2,39 \\
\hline \multirow[t]{5}{*}{ Arco extradós } & Tipo & $\begin{array}{c}\text { Mixtilíneo/Variación del } \\
\text { Flamígero }\end{array}$ \\
\hline & № Trazados curvos & 16 \\
\hline & № Trazados rectos & 4 \\
\hline & Luz & 1,65 \\
\hline & Altura máxima & 2,96 \\
\hline Basas & $\mathrm{SI}$ & 2 basas heptagonales \\
\hline \multirow[t]{14}{*}{ Jamba } & $\begin{array}{l}\text { Molduras del extradós a } \\
\text { intradós: }\end{array}$ & Radio / Longitud \\
\hline & Caveto & $2,8 \mathrm{~cm}$ \\
\hline & Caveto & $3,0 \mathrm{~cm}$ \\
\hline & Baqueta o columnilla & $3,3 \mathrm{~cm}$ \\
\hline & Filete & $1,4 \mathrm{~cm}$ \\
\hline & Caveto semicircular & $6,0 \mathrm{~cm}$ \\
\hline & Filete & $8,8 \mathrm{~cm}$ \\
\hline & Baqueta o columnilla & $2,4 \mathrm{~cm}$ \\
\hline & Caveto & $4,1 \mathrm{~cm}$ \\
\hline & Caveto & $3,1 \mathrm{~cm}$ \\
\hline & Ancho de jamba & $29,4 \mathrm{~cm}$ \\
\hline & Profundidad jamba & $22,9 \mathrm{~cm}$ \\
\hline & Jamba recta & $4,4 \mathrm{~cm}$ \\
\hline & Ángulo jamba & 360 \\
\hline Capiteles & $\mathrm{SI}$ & 2Góticos \\
\hline
\end{tabular}




\section{Portada 16}

La documentación gráfica existente de la Portada 16 (Dör 16) situada en la sala 14 según el plano de planta del Palacio es la siguiente:

- Plano LA1152 $2^{340}:$ se trata de una puesta a escala dibujada a grafito sobre una lámina de papel de dimensiones $680 \times 470 \mathrm{~mm}$ donde está representado el alzado de la portada y una sección horizontal a nivel del arranque de las basas. Las vistas tienen correspondencia diédrica, y la disposición del dibujo en la lámina es vertical. Además, existen líneas auxiliares de dibujo. El plano no dispone de cotas y su escala de representación es 1:10. Se trata de una portada adintelada que se transforma en un arco de tipo escarzano a través del abocinamiento del hueco. La portada no tiene capiteles. En el arranque derecho del arco hay grafiada una grieta que secciona totalmente el arco. Cada una de las basas están formadas por una columnilla de basa heptagonal. Las molduras de la jamba desde el extradós al intradós son las siguientes: caveto, baqueta o columnilla, filete, caveto semicircular, filete, caveto y jamba abocinada recta. Las jambas abocinadas son asimétricas, teniendo distinta longitud y ángulo respecto al lienzo del muro, de manera que el hueco de la puerta no es paralelo al lienzo del muro, formando un ángulo de 30 . En la parte superior izquierda se encuentra rotulado el nombre de la portada y su ubicación: "Dör 16 Rum 14", y en la parte inferior derecha, la numeración de la lámina: LA1152 (ver Fig. 243 izq.).

- Plano LA1151 $1^{341}$ : se trata de una lámina de papel transparente de dimensiones 667 x $468 \mathrm{~mm}$. La disposición de la lámina es vertical. En ella está grafiada una copia del alzado de la portada 16, correspondiente al plano LA1152. En la esquina superior izquierda está rotulado el número de la portada y su localización "Dör 16 (Rum 14)" y en la parte inferior derecha la numeración de la lámina: LA1451. Sobre el alzado de la portada están marcadas con líneas y numeradas 4 piezas: la 1 corresponde a la basa izquierda, la 2 a la esquina izquierda (que forman el encuentro de la jamba y el arranque del arco), la 3 es la simétrica a la anterior, estando limitada esta pieza por una línea de corte imaginaria en su encuentro con la jamba y por la fisura existente en el lado del arco. La pieza 4 corresponde a la basa derecha (ver Fig. 243 dcha.).

340 Lauritzen, V. (1919-1920). Planos. Oliva, Valencia: Museo Municipal de Oliva, Archivo Público Documental, Palacio Condal. (LA1152).

${ }^{341}$ Lauritzen, V. y/o Lauritzen, V. (1919-1920). Planos. Oliva, Valencia: Museo Municipal de Oliva, Archivo Público Documental, Palacio Condal. (LA1151). 

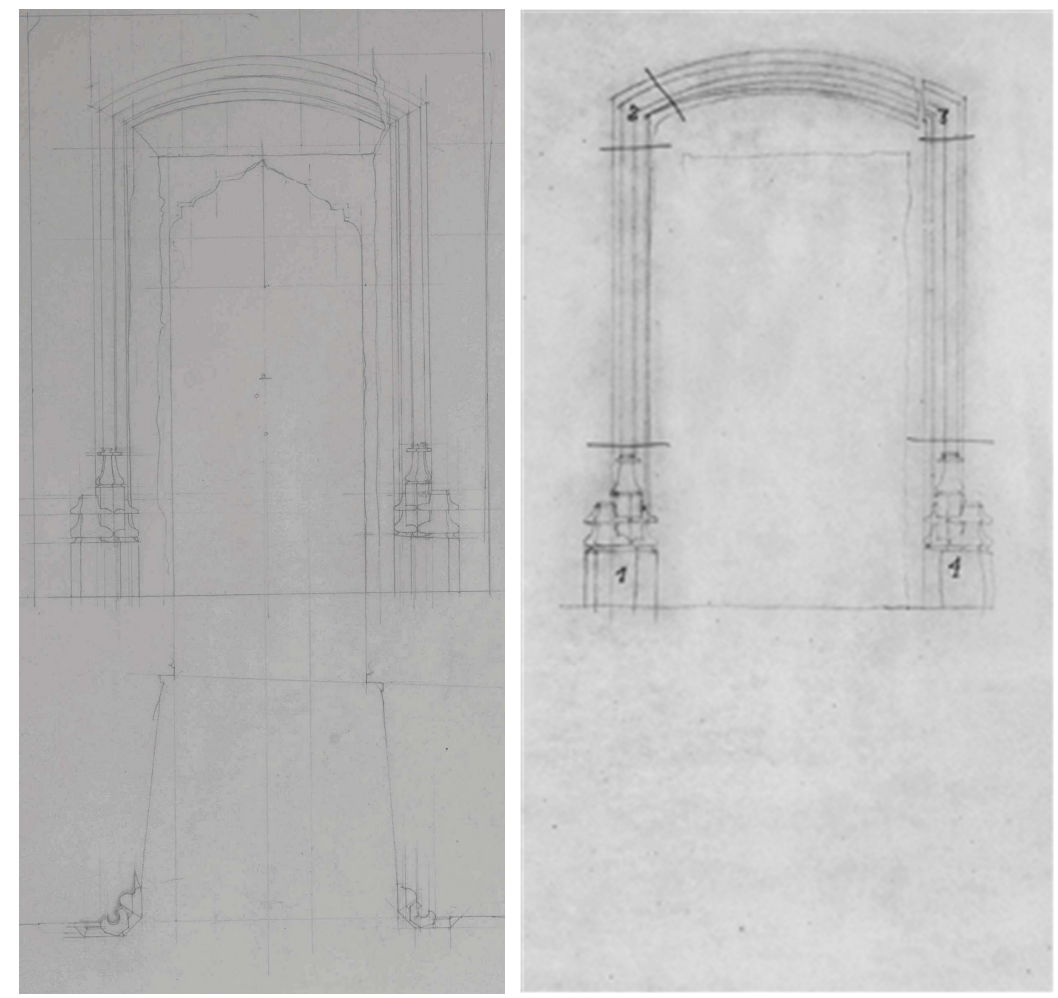

Figura 243. Izquierda: Plano Portada 16. LA1152. V. Lauritzen. Derecha: Izquierda: Plano de despiece Portada 16. LA1151, siglado. V. Lauritzen y/o E. Fischer. 
Tabla 24. Ficha Portada 16.

\begin{tabular}{|c|c|c|}
\hline Ficha 16 & Portada 16 (Dör 16) & \\
\hline Localización & Sala 14 (Rum14) & \\
\hline \multirow[t]{3}{*}{$\begin{array}{l}\text { Documentación } \\
\text { existente }\end{array}$} & Planos & LA1151 y LA1152 \\
\hline & Álbum Fotográfico Grande & NO \\
\hline & Álbum Fotográfico Pequeño & NO \\
\hline \multirow[t]{5}{*}{ Arco Intradós ${ }^{342}$} & Tipo & Escarzano \\
\hline & № Trazados curvos & 1 \\
\hline & № Trazados rectos & 0 \\
\hline & Luz & 1,29 \\
\hline & Altura libre & 2,48 \\
\hline \multirow[t]{5}{*}{ Arco Extradós } & Tipo & Escarzano \\
\hline & № Trazados curvos & 1 \\
\hline & № Trazados rectos & 0 \\
\hline & Luz & 1,70 \\
\hline & Altura máxima & 2,67 \\
\hline Basas & SI & 1 basa heptagonal \\
\hline \multirow[t]{12}{*}{ Jamba } & $\begin{array}{l}\text { Molduras del extradós a } \\
\text { intradós: }\end{array}$ & Radio / Longitud \\
\hline & Caveto & $3,8 \mathrm{~cm}$ \\
\hline & Baqueta o columnilla & $3,0 \mathrm{~cm}$ \\
\hline & Filete & $3,8 \mathrm{~cm}$ \\
\hline & Caveto semicircular & $4,1 \mathrm{~cm}$ \\
\hline & Filete & $1,5 \mathrm{~cm}$ \\
\hline & Caveto & $2,3 \mathrm{~cm}$ \\
\hline & Ancho de jamba & $20,6 \mathrm{~cm}$ \\
\hline & Profundidad jamba & $17,3 \mathrm{~cm}$ \\
\hline & Jamba abocinada recta (izq.) & $102,3 \mathrm{~cm}$ \\
\hline & Jamba abocinada recta (der.) & $95,7 \mathrm{~cm}$ \\
\hline & Ángulo jamba & $44^{\circ}$ \\
\hline Capiteles & NO & \\
\hline
\end{tabular}

${ }^{342}$ Se considera el contorno interior de las jambas y el arco, no el hueco abocinado. 


\section{Portada 17}

La documentación gráfica de la Portada 17 (Dör 17) situada en la Sala 15 según el plano de planta del Palacio es la siguiente:

- Plano LA1154 ${ }^{343}$ : se trata de una puesta a escala dibujada a grafito sobre una lámina de papel de dimensiones $680 \times 470 \mathrm{~mm}$ donde está representado el alzado de la portada y una sección horizontal a nivel del arranque de las basas. Las vistas tienen correspondencia diédrica y la disposición del dibujo en la lámina es en vertical. Existen líneas auxiliares de dibujo. El plano no dispone de cotas y su escala de representación es 1:10. Se trata de una portada adintelada que se transforma en un arco de tipo escarzano a través del abocinamiento del hueco. La portada no tiene capiteles. Cada una de las basas están formadas por una columnilla de basa heptagonal. Las molduras de la jamba desde el extradós al intradós son las siguientes: caveto, baqueta o columnilla, filete, caveto semicircular, filete, 2 cavetos y jamba abocinada recta. Las jambas abocinadas son asimétricas, teniendo distinta longitud y ángulo respecto al lienzo del muro. La jamba izquierda no contiene todas las molduras de su simétrica al seccionar con un muro perpendicular, donde se encuentra la portada. Del mismo modo, la basa izquierda queda seccionada por dicho muro. En la parte superior izquierda se encuentra rotulado el nombre de la portada y su ubicación, "Dör 17- Rum 15", y en la parte inferior derecha la numeración de la lámina: LA1154 (ver Fig. 244 izq.).
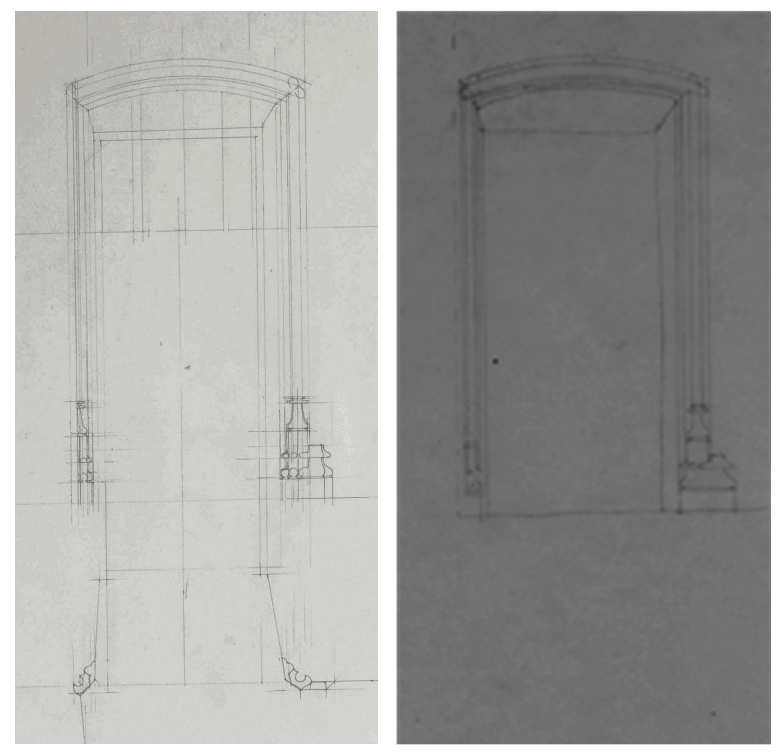

Figura 244. Izquierda: Plano Portada 17. LA1154. V. Lauritzen. Derecha: Plano de Portada 17 en papel traslúcido. LA1153. V. Lauritzen y/o E. Fischer.

${ }^{343}$ Lauritzen, V. (1919-1920). Planos. Oliva, Valencia: Museo Municipal de Oliva, Archivo Público Documental, Palacio Condal. (LA1154). 
- Plano LA1153 ${ }^{344}$ : se trata de una lámina de papel transparente de dimensiones 667 x $466 \mathrm{~mm}$. La disposición de la lámina es vertical. En ella está grafiada una copia del alzado de la portada 17 correspondiente al plano LA1154. En la esquina superior izquierda está rotulado el número de la portada y su localización "Dör 17 (Rum 15)" y en la parte inferior derecha, la numeración de la lámina: LA1453. En ella, a diferencia del resto de láminas, en papel transparente no se ha marcado el despiece de la portada ${ }^{345}$ (ver Fig. 244 dcha.).

Tabla 25. Ficha Portada 17.

\begin{tabular}{|c|c|c|}
\hline Ficha 17 & Portada 17(Dör 17) & \\
\hline Localización & Sala 15 (Rum15) & \\
\hline \multirow[t]{3}{*}{$\begin{array}{l}\text { Documentación } \\
\text { existente }\end{array}$} & Planos & LA1153 y LA1154 \\
\hline & Álbum Fotográfico Grande & NO \\
\hline & Álbum Fotográfico Pequeño & NO \\
\hline \multirow[t]{5}{*}{ Arco Intradós ${ }^{346}$} & Tipo & Adintelado \\
\hline & № Trazados curvos & 0 \\
\hline & № Trazados rectos & 1 \\
\hline & Luz & 1,00 \\
\hline & Altura libre & 1,95 \\
\hline \multirow[t]{5}{*}{ Arco extradós } & Tipo & Escarzano \\
\hline & № Trazados curvos & 1 \\
\hline & № Trazados rectos & 0 \\
\hline & Luz & 1,24 \\
\hline & Altura máxima & 2,38 \\
\hline Basas & $\mathrm{SI}$ & 1 basa heptagonal \\
\hline \multirow[t]{12}{*}{ Jamba } & Molduras del extradós a intradós: & Radio / Longitud \\
\hline & Caveto & $4,7 \mathrm{~cm}$ \\
\hline & Baqueta o columnilla & $2,8 \mathrm{~cm}$ \\
\hline & Filete & $2,9 \mathrm{~cm}$ \\
\hline & Caveto semicircular & $5,3 \mathrm{~cm}$ \\
\hline & Filete & $1,8 \mathrm{~cm}$ \\
\hline & Caveto & $4,5 \mathrm{~cm}$ \\
\hline & Ancho de jamba (der.) & $15,7 \mathrm{~cm}$ \\
\hline & Profundidad jamba (der.) & $12,8 \mathrm{~cm}$ \\
\hline & Jamba abocinada recta (izq.) & $43,5 \mathrm{~cm}$ \\
\hline & Jamba abocinada recta (der.) & $45,4 \mathrm{~cm}$ \\
\hline & Ángulo jamba & $29^{\circ}$ \\
\hline Capiteles & NO & \\
\hline
\end{tabular}

344 Lauritzen, V. y/o Fischer, E. (1919-1920). Planos. Oliva, Valencia: Museo Municipal de Oliva, Archivo Público Documental, Palacio Condal. (LA1153).

${ }^{345}$ Es posible que, dada la sencillez de la portada y su falta de simetría, se decidiera no desmontarla finalmente.

${ }^{346}$ Se considera el contorno interior de las jambas y el arco, no el hueco abocinado. 


\section{Portada 18}

La documentación gráfica existente de la Portada 18 (Dör 18) situada en la Sala 16 según el plano de planta del Palacio es la siguiente:

- Plano LA1156 ${ }^{347}$ : se trata de una puesta a escala dibujada a grafito sobre una lámina de papel de dimensiones $680 \times 470 \mathrm{~mm}$ donde está representado el alzado de la portada y una sección horizontal a nivel del arranque de las basas. Las vistas tienen correspondencia diédrica y la disposición del dibujo en la lámina es vertical. Existen líneas auxiliares de dibujo. El plano dispone de numerosas cotas, tanto de anchura como de altura, y la escala de representación, como en el resto de las portadas, es 1:10. Se trata de una portada formada por un arco flamígero aquillado/mixtilíneo que mantiene su trazado en todas sus molduras. La portada no tiene capiteles. Cada una de las basas están formadas por dos columnillas; no está grafiada la planta de estas columnillas y su trazado en el alzado es esquemático. Las molduras de la jamba desde el extradós al intradós son las siguientes: dos cavetos, baqueta o columnilla, filete, caveto semicircular, filete, baqueta o columnilla y dos cavetos. La jamba derecha no contiene todas las molduras de su simétrica al seccionar con un muro perpendicular el lienzo donde se encuentra la portada; del mismo modo la basa derecha queda seccionada por dicho muro. En la parte superior izquierda se encuentra rotulado el nombre de la portada y su ubicación ("Dör 18- Rum 16"), y en la parte inferior derecha, la numeración de la lámina: LA1156 (ver Fig. 245 izq.).

- Plano LA1155 ${ }^{348}$ : se trata de una lámina de papel transparente de dimensiones 667 x $468 \mathrm{~mm}$, y su disposición es vertical. En ella está grafiada una copia del alzado de la portada 18 correspondiente al plano LA1156. En la esquina superior izquierda está rotulado el número de la portada y su localización "Dör 17 (Rum 15)" y en la parte inferior derecha, la numeración de la lámina: LA1455. No aparecen marcas de despiece como en la mayoría de láminas en papel transparente (ver Fig. 245 derecha).

- Álbum de Fotos Pequeño: en la página 11R encontramos la misma fotografía $67^{349}$, correspondiente a la portada 18 . Tiene unas dimensiones de $7,8 \times 8 \mathrm{~cm}$. La fotografía tiene unos márgenes de 7,6 $\mathrm{mm}$ en el margen derecho y $2 \mathrm{~mm}$ en el resto. Sobre el margen derecho está rotulado en danés: "Alabasportal Dör 18" (Portada de alabastro Portada 18) y en la parte superior derecha hay adherido un pequeño círculo con el número de la fotografía (67). En la esquina inferior derecha está rotulado "9." (ver Fig. 246).

\footnotetext{
${ }^{347}$ Lauritzen, V. (1919-1920). Planos. Oliva, Valencia: Museo Municipal de Oliva, Archivo Público Documental, Palacio Condal. (LA1156).

${ }^{348}$ Lauritzen, V. y/o Fischer, E. (1919-1920). Planos. Oliva, Valencia: Museo Municipal de Oliva, Archivo Público Documental, Palacio Condal. (LA1155).

${ }^{349}$ Fischer, E. (1917-1920). Álbum Fotos Pequeño. Oliva, Valencia: Museo Municipal de Oliva, Archivo Público Documental, Palacio Condal. pp. 11R.
} 

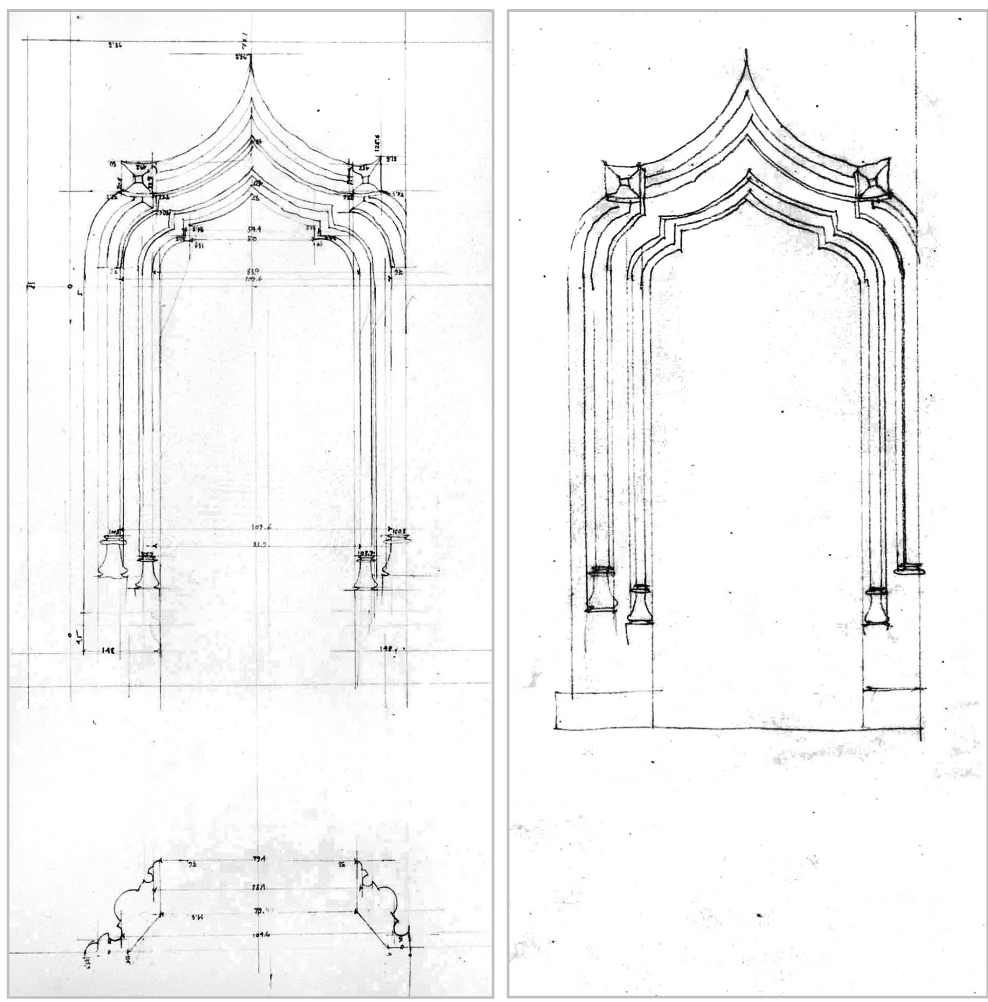

Figura 245. Izquierda: Plano Portada 18. LA1156. V. Lauritzen. Derecha: Plano de Portada 15 en papel traslúcido. LA1155. V. Lauritzen y/o E. Fischer.

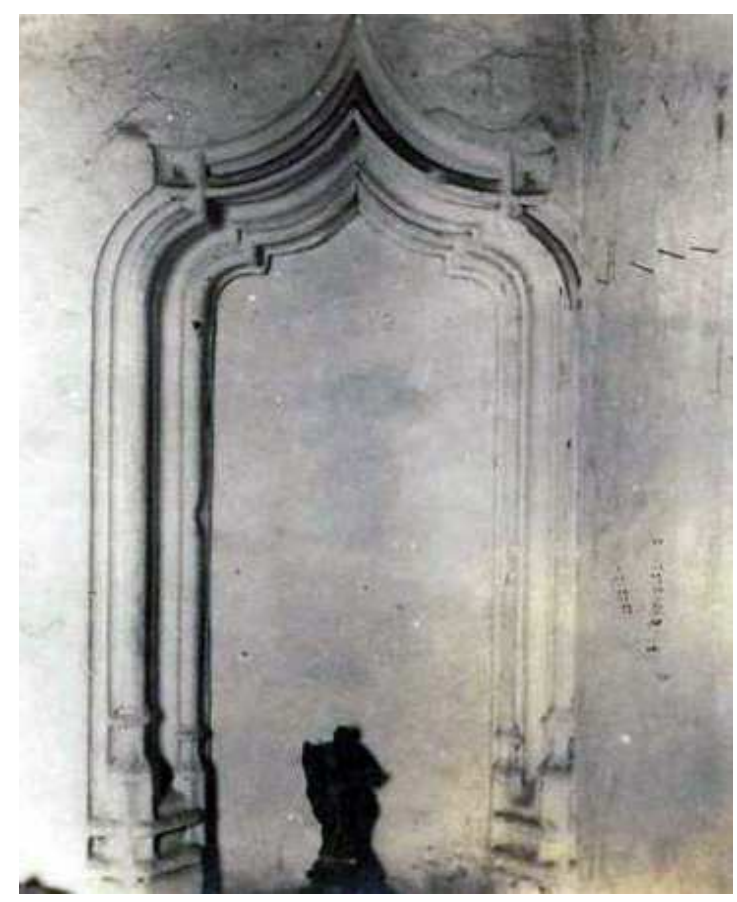

Figura 246. Fot. 67. Portada 18. Álbum Fotogr. Pequeño. Pág. 11R. E. Fischer. 
Tabla 26. Ficha Portada 18.

\begin{tabular}{|c|c|c|}
\hline Ficha 18 & Portada 18 (Dör 18) & \\
\hline Localización & Sala 16 (Rum16) & \\
\hline \multirow{3}{*}{$\begin{array}{l}\text { Documentación } \\
\text { existente }\end{array}$} & Planos & LA1155 y LA1156 \\
\hline & Álbum Fotográfico Grande & Fot. 67 Pág. 15A \\
\hline & Álbum Fotográfico Pequeño & Fot. 67 Pág. 11R \\
\hline \multirow[t]{5}{*}{ Arco Intradós } & Tipo & $\begin{array}{c}\text { Flamígero } \\
\text { aquillado/Mixtilíneo }\end{array}$ \\
\hline & № Trazados curvos & 4 \\
\hline & № Trazados rectos & 2 \\
\hline & Luz & 0,79 \\
\hline & Altura libre & 1,98 \\
\hline \multirow[t]{5}{*}{ Arco extradós } & Tipo & $\begin{array}{c}\text { Flamígero } \\
\text { aquillado/Mixtilíneo }\end{array}$ \\
\hline & № Trazados curvos & 4 \\
\hline & № Trazados rectos & 2 \\
\hline & Luz & 1,29 \\
\hline & Altura máxima & 2,54 \\
\hline Basas & $\mathrm{SI}$ & 2 basas ¿heptagonales? \\
\hline \multirow[t]{13}{*}{ Jamba } & $\begin{array}{l}\text { Molduras del extradós a } \\
\text { intradós: }\end{array}$ & Radio / Longitud \\
\hline & Caveto & $8,2 \mathrm{~cm}$ \\
\hline & Caveto & $5,2 \mathrm{~cm}$ \\
\hline & Baqueta o columnilla & $2,9 \mathrm{~cm}$ \\
\hline & Filete & $2,3 \mathrm{~cm}$ \\
\hline & Caveto semicircular & $7,5 \mathrm{~cm}$ \\
\hline & Filete & $4,5 \mathrm{~cm}$ \\
\hline & Baqueta o columnilla & $2,0 \mathrm{~cm}$ \\
\hline & Caveto & $2,6 \mathrm{~cm}$ \\
\hline & Caveto & $2,3 \mathrm{~cm}$ \\
\hline & Ancho de jamba & $29,9 \mathrm{~cm}$ \\
\hline & Profundidad de jamba & $37,3 \mathrm{~cm}$ \\
\hline & Ángulo jamba & $59^{\circ}$ \\
\hline Capiteles & NO & \\
\hline
\end{tabular}




\section{Portada 19}

La documentación gráfica existente de la Portada 19 (Dör 19) situada en la Sala 16 según el plano de planta del Palacio es la siguiente:

- Plano LA1158 ${ }^{350}$ : se trata de una puesta a escala dibujada a grafito sobre una lámina de papel de dimensiones $668 \times 462 \mathrm{~mm}$ donde está representado el alzado de la portada y una sección horizontal a nivel del arranque de las basas. Las vistas tienen correspondencia diédrica y la disposición del dibujo en la lámina es vertical. Existen líneas auxiliares de dibujo. El plano dispone de numerosas cotas tanto de anchura como de altura y está dibujado a escala 1:10. Se trata de una portada formada por un arco escarzano que mantiene su trazado en todas sus molduras. Las jambas son abocinadas y, en este abocinamiento, el arco se transforma en un dintel recto en la posición de la carpintería. Cada una de las basas está formada por una columnilla. Las molduras de la jamba desde el extradós al intradós son las siguientes: caveto, baqueta o columnilla, caveto, caveto semicircular y caveto. A partir de esta moldura arranca una jamba abocinada con un trazado recto que finaliza con uno curvilíneo en la posición de la carpintería. La portada dispone de un capitel sobre cada una de las columnillas. En la parte superior izquierda se encuentra rotulado el nombre de la portada y su ubicación: "Dör19-Rum 16", y en la parte inferior derecha, la numeración de la lámina: LA1158 (ver Fig. 247 izq.).

- Plano LA1157 $7^{351}$ : se trata de una lámina de papel transparente de dimensiones 650 x $458 \mathrm{~mm}$ y de disposición vertical. En ella está grafiada una copia del alzado de la portada 19, correspondiente al plano LA1158. En la esquina superior izquierda está rotulado el número de la portada y su localización "Dör 19(Rum 16)" y en la parte inferior derecha, la numeración de la lámina: LA1157. No aparecen marcas de despiece como en la mayoría de láminas en papel transparente (ver Fig. 247 derecha).

\footnotetext{
${ }^{350}$ Lauritzen, V. (1919-1920) Planos. Oliva, Valencia: Museo Municipal de Oliva, Archivo Público Documental, Palacio Condal. (LA1158).

${ }^{351}$ Lauritzen, V. y/o Fischer, E. (1919-1920) Planos. Oliva, Valencia: Museo Municipal de Oliva, Archivo Público Documental, Palacio Condal. (LA1157).
} 


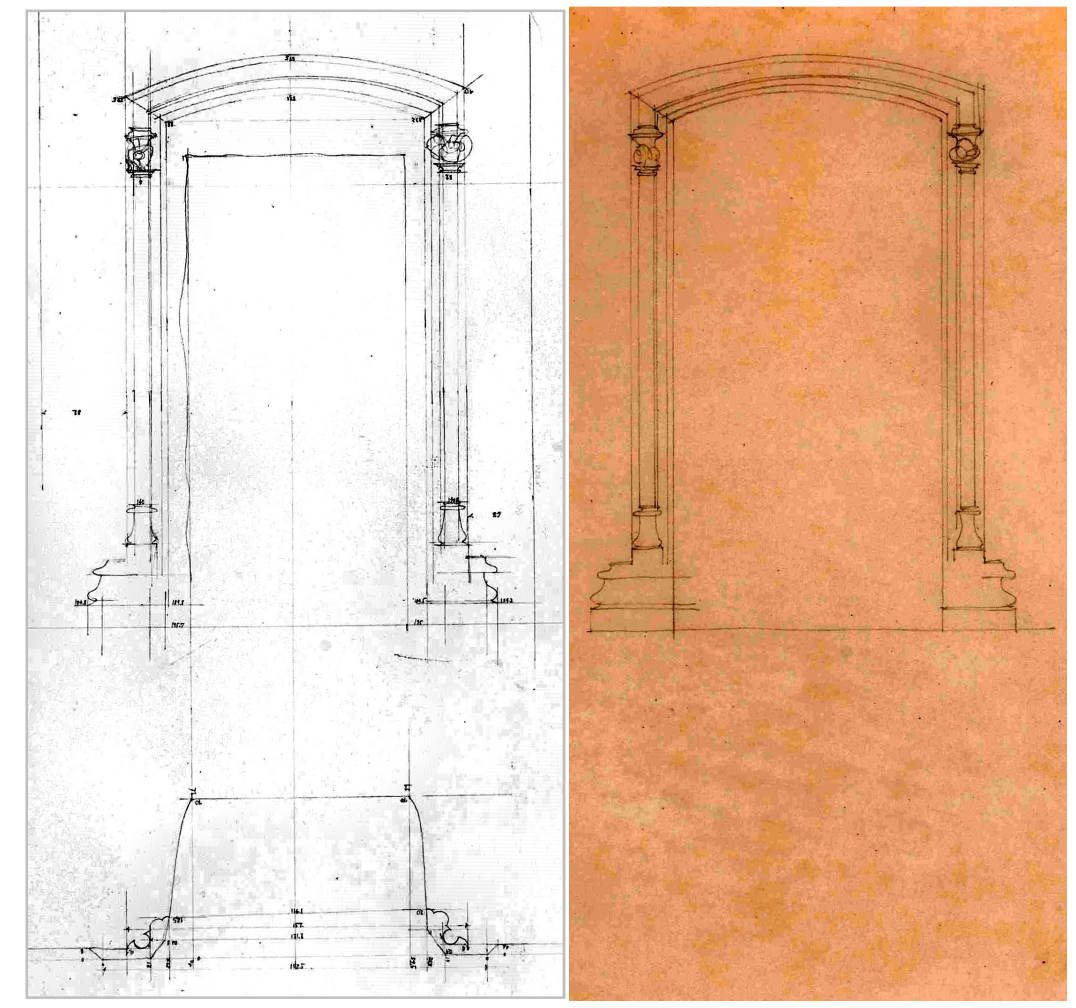

Figura 247. Izquierda: Plano Portada 19. LA1158. V. Lauritzen. Derecha: Plano de Portada 19 en papel traslúcido. LA1157. V. Lauritzen y/o E. Fischer. 
Tabla 27. Ficha Portada 19.

\begin{tabular}{|c|c|c|}
\hline Ficha 19 & \multicolumn{2}{|l|}{ Portada 19 (Dör 19) } \\
\hline Localización & \multicolumn{2}{|l|}{ Sala 16 (Rum16) } \\
\hline \multirow{3}{*}{$\begin{array}{l}\text { Documentación } \\
\text { existente }\end{array}$} & Planos & LA1157 y LA1158 \\
\hline & Álbum Fotográfico Grande & NO \\
\hline & Álbum Fotográfico Pequeño & NO \\
\hline \multirow[t]{5}{*}{ Arco Intradós $^{352}$} & Tipo & Escarzano \\
\hline & № Trazados curvos & 1 \\
\hline & № Trazados rectos & 0 \\
\hline & Luz & 1,2 \\
\hline & Altura máxima & 2,39 \\
\hline \multirow[t]{5}{*}{ Arco Extradós } & Tipo & Escarzano \\
\hline & № Trazados curvos & 1 \\
\hline & № Trazados rectos & 0 \\
\hline & Luz & 1,55 \\
\hline & Altura libre & 2,58 \\
\hline Basas & $\mathrm{SI}$ & 1 basa ¿heptagonal? \\
\hline \multirow[t]{10}{*}{ Jamba } & Molduras del extradós a intradós: & Radio / Longitud \\
\hline & Caveto & $5,5 \mathrm{~cm}$ \\
\hline & Baqueta o columnilla & $3,5 \mathrm{~cm}$ \\
\hline & Caveto & $6,0 \mathrm{~cm}$ \\
\hline & Caveto semicircular & $4,0 \mathrm{~cm}$ \\
\hline & Caveto & $2,5 \mathrm{~cm}$ \\
\hline & Ancho de jamba & $19,5 \mathrm{~cm}$ \\
\hline & Profundidad de jamba & $13,9 \mathrm{~cm}$ \\
\hline & Jamba abocinada curva (cuerda) & $54,0 \mathrm{~cm}$ \\
\hline & Ángulo jamba & $35^{\circ}$ \\
\hline Capiteles & sí & 1 por jamba. Gótico \\
\hline
\end{tabular}

${ }^{352}$ Se considera el contorno interior de las jambas y el arco, no el hueco abocinado. 


\section{Portada 20}

La documentación gráfica de la Portada 20 (Dör 20) situada en la Sala 17 según el plano de planta del Palacio es la siguiente:

- Plano LA1160: la Portada 20 está dibujada a grafito sobre papel sin marca en la lámina LA1160 ${ }^{353}$ de dimensiones $667 \times 466 \mathrm{~mm}$. Se trata de una puesta a escala donde está representado la alzada de la portada y una sección horizontal por las jambas. El plano dispone de diversas cotas tanto de anchura como de altura de puntos singulares de la portada. La escala del plano es 1:100. El tipo de arco es flamígero/aquillado en todo el trazado del arco. La sección está formada por tres pares de columnillas: dos de ellas circulares y una tercera planta compleja mixtilínea, formada por dos baquetas circulares colocadas sobre los lados de un cuadrado de lados cóncavos girado $45^{\circ}$ sobre la línea del muro. Las dos columnillas interiores tienen capiteles. En la parte superior del croquis se encuentra rotulado el siguiente texto: "Dör 20 (Rum 17)". "Portada 20 (Sala 17)" y, sobre la cornisa derecha de la portada, la palabra Underkant Gesims (borde bajo de la cornisa). Esta anotación hace referencia a la posición de la portada respecto a la cornisa perimetral de la sala (ver Fig. 248 izq.).

- Plano LA1159 ${ }^{354}$ : se trata de una lámina de papel transparente de dimensiones 650 x $458 \mathrm{~mm}$ y con disposición vertical. En ella está grafiada una copia del alzado de la portada 19, correspondiente al plano LA1158. En la esquina superior izquierda está rotulado el número de la portada y su localización "Dör 19 (Rum 16)" y en la parte inferior derecha la numeración de la lámina: LA1157. No aparecen marcas de despiece como en la mayoría de láminas en papel transparente (ver Fig. 248 dcha.).

- Álbum de Fotos Grande: la fotografía $32^{355}$, correspondiente a la portada 20, se encuentra en la página $9 \mathrm{~A}$. Tiene unas dimensiones de $17 \times 24 \mathrm{~cm}$. y unos márgenes en blanco de $2 \mathrm{~mm}$. En ella aparece una vista frontal de la portada (ver Fig. 249).

\footnotetext{
353 Lauritzen V. (1919-1920). Planos. Oliva, Valencia: Museo Municipal de Oliva, Archivo Público Documental, Palacio Condal. (LA1160).

354 Lauritzen, V. y/o Fischer, E. (1919-1920). Planos. Oliva, Valencia: Museo Municipal de Oliva, Archivo Público Documental, Palacio Condal. (LA1159).

${ }^{355}$ Fischer, E. (1917-1920). Álbum Fotos Grande. Oliva, Valencia: Museo Municipal de Oliva, Archivo Público Documental, Palacio Condal' pp. 9A.
} 

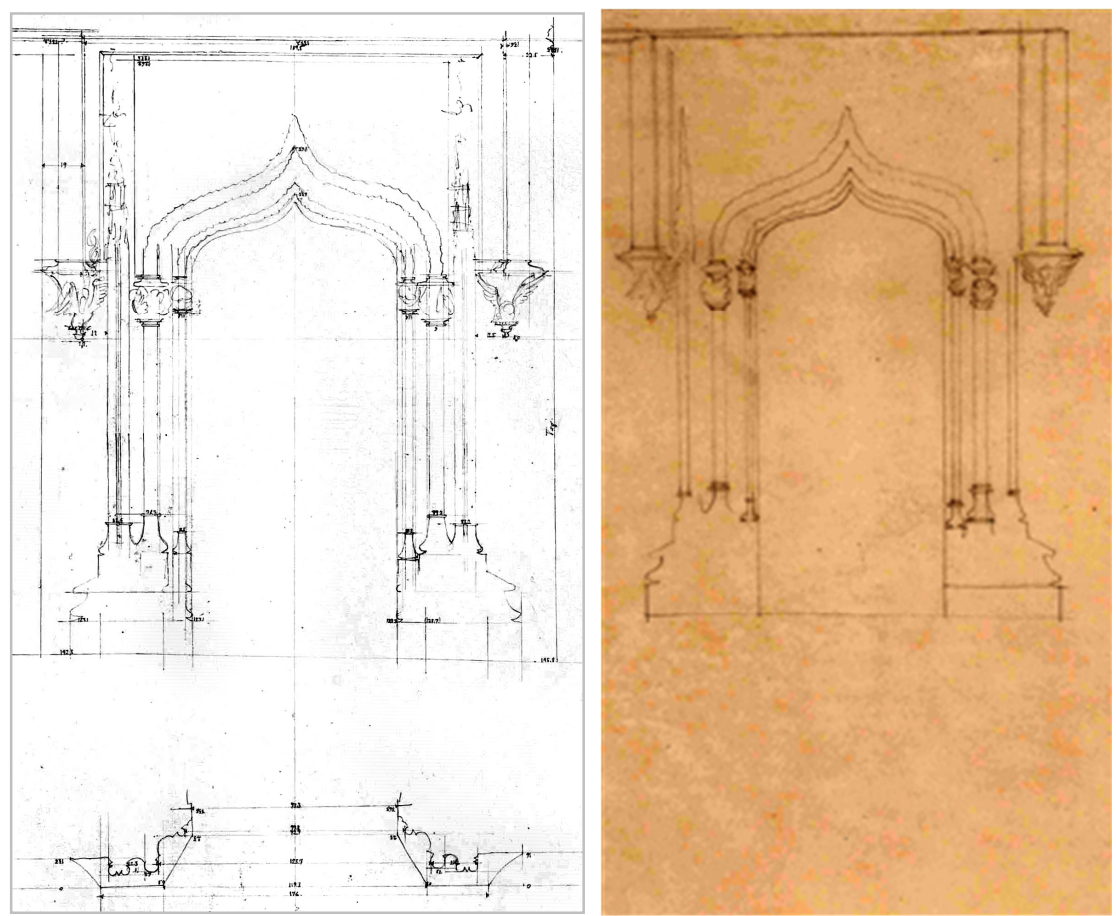

Figura 248. Izquierda: Plano Portada 20. LA1160. V. Lauritzen. Derecha: Plano de Portada 20 en papel traslúcido. LA1159. V. Lauritzen y/o E. Fischer.

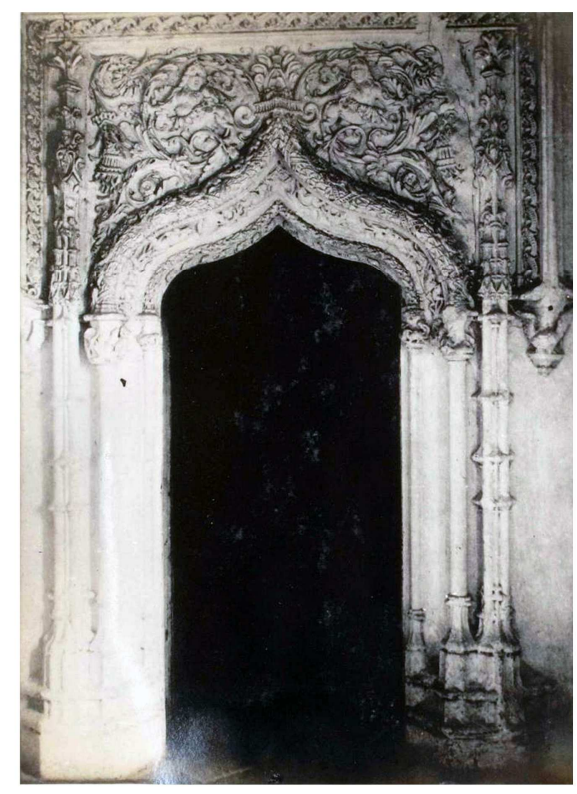

Figura 249. Portada 20. Fot. 33. Álbum Grande. E. Fisher. 
Tabla 28. Ficha Portada 20.

\begin{tabular}{|c|c|c|}
\hline Ficha 20 & Portada 20 (Dör20) & \\
\hline Localización & Sala 17 (Rüm17) & \\
\hline \multirow{3}{*}{$\begin{array}{l}\text { Documentación } \\
\text { existente }\end{array}$} & Planos & LA1159 y LA1160 \\
\hline & Álbum Fotográfico Grande & Fot. 32 Pág. 9A \\
\hline & Álbum Fotográfico Pequeño & NO \\
\hline \multirow[t]{5}{*}{ Arco Intradós } & Tipo & Flamígero aquillado \\
\hline & № Trazados curvos & 6 \\
\hline & № Trazados rectos & 0 \\
\hline & Luz & 0,95 \\
\hline & Altura libre & 2,07 \\
\hline \multirow[t]{5}{*}{ Arco Extradós } & Tipo de arco & Flamígero aquillado \\
\hline & № Trazados curvos & 6 \\
\hline & № Trazados rectos & 0 \\
\hline & Luz & 1,71 \\
\hline & Altura máxima & 2,48 \\
\hline Basa & Sin datos & \\
\hline \multirow[t]{12}{*}{ Jamba } & $\begin{array}{l}\text { Molduras del extradós a } \\
\text { intradós: }\end{array}$ & Radio /Longitud \\
\hline & Columnilla mixtilínea & $\mathrm{L}=9,6 \mathrm{~cm}, \mathrm{R}=1,9 \mathrm{~cm}$ \\
\hline & Caveto & $4,95 \mathrm{~cm}$ \\
\hline & Baqueta o columnilla & $3,3 \mathrm{~cm}$ \\
\hline & Filete & $3,0 \mathrm{~cm}$ \\
\hline & Caveto semicircular & $5,2 \mathrm{~cm}$ \\
\hline & Filete & $3,0 \mathrm{~cm}$ \\
\hline & Baqueta o columnilla & $1,8 \mathrm{~cm}$ \\
\hline & Caveto & $2,7 \mathrm{~cm}$ \\
\hline & Caveto & $6,35 \mathrm{~cm}$ \\
\hline & Jamba recta & $6,7 \mathrm{~cm}$ \\
\hline & Ángulo jamba & $48^{\circ}$ \\
\hline Capiteles & sí & 2 Góticos + 1 Renacentista ${ }^{356}$ \\
\hline
\end{tabular}

${ }^{356}$ Los capiteles renacentistas, a diferencia de los de trazado gótico, arrancan del lienzo de la pared, no de una columnilla de la jamba, y a partir de ellas, arrancan arcos o molduras con decoración de características renacentistas. 


\section{Portada 21}

La documentación gráfica existente de la Portada 21 (Dör21) situada en la Sala 17 según el plano de planta del Palacio es la siguiente:

- Plano LA1162 357 : se trata de una puesta a escala dibujada a grafito sobre una lámina de papel de dimensiones $680 \times 470 \mathrm{~mm}$ donde está representado el alzado de la portada y una sección horizontal a nivel del arranque de las basas. Las vistas tienen correspondencia diédrica, la disposición del dibujo en la lámina es vertical y existen líneas auxiliares de dibujo. El plano dispone de numerosas cotas, tanto de anchura como de altura. La escala de representación es 1:10. Se trata de una portada adintelada en su intradós que se transforma en un arco escarzano a través de un arco abocinado, manteniendo su trazado en todas sus molduras. La portada no tiene grafiados capiteles, aunque sí la moldura que indica el arranque de los mismos. No están grafiadas las bases de las columnillas ni en la planta ni en el alzado, aunque unas líneas en el alzado sobre las columnillas parecen indicar el arranque de las mismas sobre sus bases, por lo que suponemos que disponían de basas heptagonales como el resto de las portadas. Las molduras de la jamba desde el extradós al intradós son las siguientes: caveto, baqueta o columnilla, filete, caveto semicircular, caveto y jamba abocinada de trazado curvo. El plano se encuentra inacabado, ya que no están grafiadas ni las bases de las columnillas ni los capiteles. En la parte superior izquierda se encuentra rotulado el nombre de la portada y su ubicación: "Dör 21. Rum 17", y en la parte inferior derecha, la numeración de la lámina: LA1162 (ver Fig. 250 izq.).

- Plano LA1161 ${ }^{358}$ : se trata de una lámina de papel transparente de dimensiones 660 x $464 \mathrm{~mm}$ en disposición vertical. En ella está grafiada una copia del alzado de la portada 21 correspondiente al plano LA1162, aunque a diferencia de esta, aparecen grafiados los capiteles de manera esquemática insinuando formas orgánicas. En la esquina superior izquierda está rotulado el número de la portada y su localización "Dör 21 (Rum 17)" y en la parte inferior derecha la numeración de la lámina: LA1161. No aparecen marcas de despiece como en la mayoría de láminas en papel transparente (ver Fig. 250 dcha.).

\footnotetext{
357 Lauritzen, V. (1919-1920). Planos. Oliva, Valencia: Museo Municipal de Oliva, Archivo Público Documental, Palacio Condal. (LA1162).

358 Lauritzen, V. (1919-1920). Planos. Oliva, Valencia: Museo Municipal de Oliva, Archivo Público Documental, Palacio Condal. (LA1161).
} 


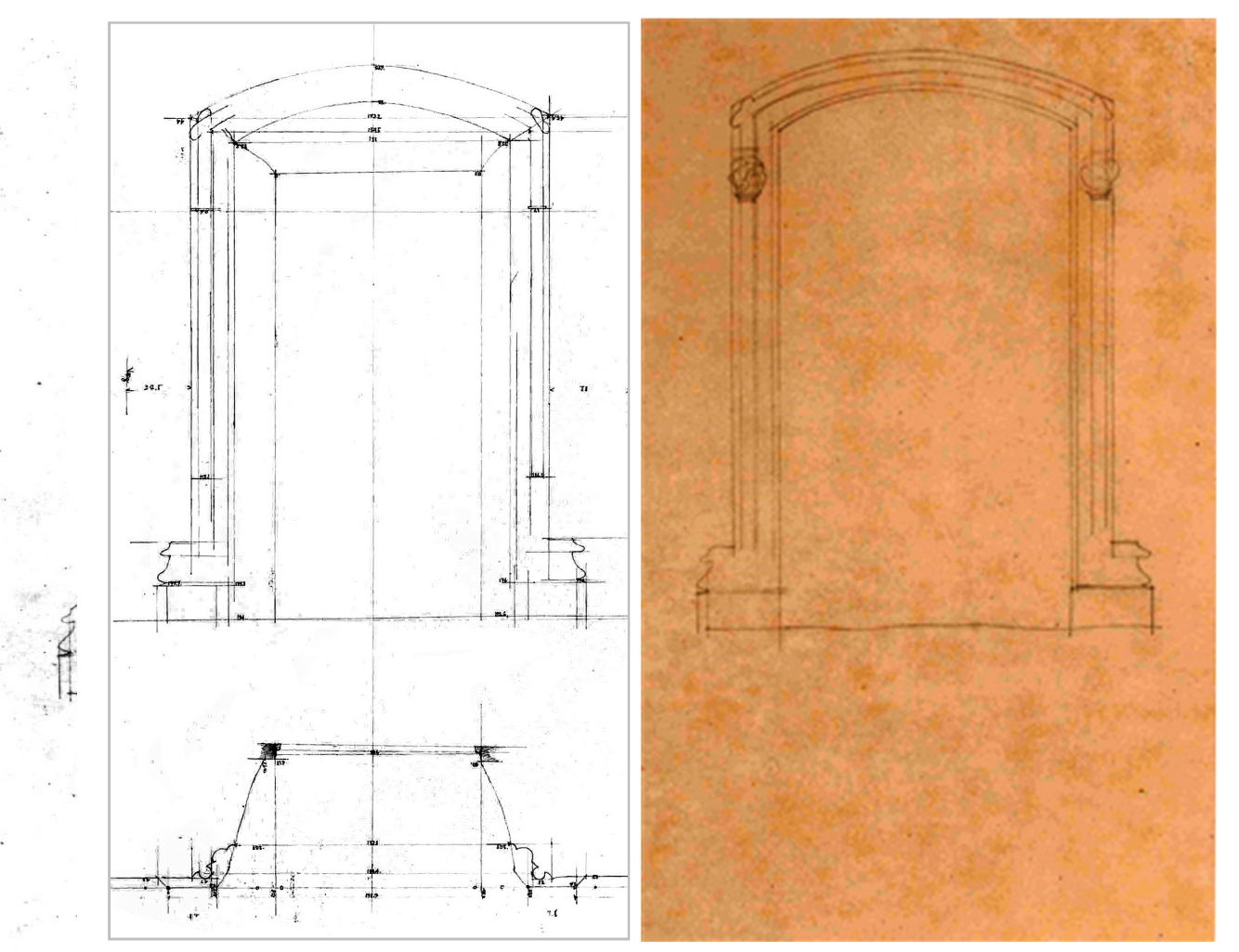

Figura 250. Izquierda: Plano Portada 21. LA1162. V. Lauritzen. Derecha: Plano de Portada 21 en papel traslúcido. LA1161. V. Lauritzen y/o E. Fischer. 
Tabla 29. Ficha Portada 21.

\begin{tabular}{|c|c|c|}
\hline Ficha 21 & Portada 21 (Dör 21) & \\
\hline Localización & Sala 17 (Rum17) & \\
\hline \multirow{3}{*}{$\begin{array}{l}\text { Documentación } \\
\text { existente }\end{array}$} & Planos & LA1161 y LA1162 \\
\hline & Álbum Fotográfico Grande & NO \\
\hline & Álbum Fotográfico Pequeño & NO \\
\hline \multirow[t]{5}{*}{ Arco Intradós ${ }^{359}$} & Tipo & Escarzado \\
\hline & № Trazados curvos & 1 \\
\hline & № Trazados rectos & 0 \\
\hline & Luz & $1,32 \mathrm{~m}$ \\
\hline & Altura libre & $2,48 m$ \\
\hline \multirow[t]{5}{*}{ Arco extradós } & Tipo & Escarzano \\
\hline & № Trazados curvos & 1 \\
\hline & № Trazados rectos & 0 \\
\hline & Luz & $1,73 \mathrm{~m}$ \\
\hline & Altura máxima & $2,69 \mathrm{~m}$ \\
\hline Basas & $\mathrm{SI}$ & 1 basa ¿heptagonal? \\
\hline \multirow[t]{10}{*}{ Jamba } & $\begin{array}{l}\text { Molduras del extradós a } \\
\text { intradós: }\end{array}$ & Radio / Longitud \\
\hline & Caveto & $4,4 \mathrm{~cm}$ \\
\hline & Baqueta o columnilla & $3,0 \mathrm{~cm}$ \\
\hline & Filete & $4,0 \mathrm{~cm}$ \\
\hline & Caveto semicircular & $4,0 \mathrm{~cm}$ \\
\hline & Caveto & $2,2 \mathrm{~cm}$ \\
\hline & Profundidad jamba & $16,0 \mathrm{~cm}$ \\
\hline & Ancho jamba & $19,9 \mathrm{~cm}$ \\
\hline & Jamba abocinada curva (cuerda) & $43,0 \mathrm{~cm}$ \\
\hline & Ángulo jamba & $38^{\circ}$ \\
\hline Capiteles & $\mathrm{SI}$ & 1Gótico \\
\hline
\end{tabular}

${ }^{359}$ Se considera el contorno interior de las jambas y el arco, no el hueco abocinado. 


\section{Portada 22}

La documentación gráfica existente que disponible de la Portada 22 (Dör22), situada en la Sala 18 (Sala de armas), según el plano de planta del Palacio es la siguiente:

- Plano LA1164 ${ }^{360}$ : se trata de una puesta a escala dibujada a grafito sobre una lámina de papel de dimensiones $680 \times 470 \mathrm{~mm}$ donde está representado el alzado de la portada y una sección horizontal por las jambas, ambas incompletas. Las vistas tienen correspondencia diédrica y la disposición del dibujo en la lámina es vertical. Existen asimismo líneas auxiliares de dibujo. El plano dispone de numerosas cotas, tanto de anchura como de altura; algunas de estas cotas son lineales, mientras que otras se establecen a partir de líneas de referencia marcadas con un "0" como origen de acotación. Encontramos varios ejes de acotación, tanto en vertical como en horizontal; uno de ellos coincide con la línea de impostas. La escala de representación es 1:10 como en el resto de las portadas. Se trata de una portada con arco tipo variación del flamígero. Sobre el arco principal que forma el hueco de paso de la portada existe abundante ornamentación renacentista con formas vegetales y antropomórficas. Asimismo aparece un tímpano formado por una cornisa moldurada y un arco rebajado sobre el que se representan dos figuras aladas y más ornamentación vegetal de carácter claramente renacentista. La portada dispone de cuatro pares de capiteles; dos de ellos sobre las columnillas que forman las jambas y dos más que arrancan del lienzo del muro a través de ménsulas (del tercer par sólo aparece grafiada la ménsula). No están grafiadas las bases de las columnillas ni en la planta ni en el alzado, solamente la moldura superior de las mismas en el alzado, por lo que suponemos que disponían de basas heptagonales como en el resto de las portadas. Las molduras de la jamba desde el extradós al intradós son las siguientes: caveto, baqueta o columnilla, filete, caveto semicircular, caveto, baqueta o columnilla, dos cavetos y jamba recta. El plano se encuentra inacabado, ya que no están grafiadas ni las bases de las columnillas ni algunos de los capiteles; la parte ornamental está dibujada de manera esquemática. En la parte superior izquierda se encuentra rotulado el nombre de la portada y su ubicación: "Dör 22 - Rum 18", y en la parte inferior derecha, la numeración de la lámina: LA1164 (ver Fig. 251 izq.).

- Plano LA1163 ${ }^{361}$ : se trata de una lámina de papel transparente de dimensiones $667 \mathrm{x}$ $470 \mathrm{~mm}$ realizada a grafito sobre papel de calco $^{362}$. La disposición de la lámina es vertical. En ella está grafiada una copia del alzado de la portada 22, correspondiente al plano LA1164, aunque a diferencia de esta, aparecen grafiados la tercera pareja de capiteles de manera muy esquemática En la esquina superior izquierda está rotulado el número de la portada y su localización "Dör 22 (Rum 18)" y en la parte inferior derecha, la numeración de la lámina: LA1163. No aparecen marcas de despiece como en la mayoría de láminas en papel transparente (ver Fig. 251 dcha.)

\footnotetext{
${ }^{360}$ Lauritzen, V. (1919-1920). Planos. Oliva, Valencia: Museo Municipal de Oliva, Archivo Público Documental, Palacio Condal. (LA1164).

${ }^{361}$ Lauritzen, V. (1919-1920). Planos. Oliva, Valencia: Museo Municipal de Oliva, Archivo Público Documental, Palacio Condal. (LA1163).

${ }^{362}$ Gavara Prior, Joan J. y E. Muller, Priscilla. (2013). "El Palacio Condal de Oliva. Catálogo de los planos de Egil Fischer y Vilhelm Lauritzen", Valencia: Ajuntament d' Oliva.
} 
- Álbum de Fotos Grande: en la página 8A se encuentra la fotografía $28^{363}$, correspondiente a la portada 22 . Tiene unas dimensiones de $17,5 \times 24 \mathrm{~cm}$. La fotografía tiene unos márgenes de $2 \mathrm{~mm}$. En la parte superior, centrado, está rotulado el número de la imagen (28). Se trata de una fotografía casi frontal de la portada: a la derecha se puede observar parcialmente la jamba de la ventana V10 situada en la misma sala 18. Tiene una calidad aceptable y podemos observar con bastante detalle la portada y, sobre todo, la decoración renacentista de la parte superior. En la fotografía aparece cerrada la carpintería de dos hojas de la portada y observamos asimismo un zócalo pintado en color oscuro en la parte inferior del muro, rematado con dos líneas más oscuras horizontales. El muro está pintado de color blanco y la decoración presenta policromía, aunque no se pueden distinguir los colores al tratarse de una fotografía en blanco y negro (ver Fig. 252 izq.).

- Álbum de Fotos Pequeño: en la página 7A se encuentran las fotografías $28 . P$ y $28.1^{364}$ correspondientes a la portada 22. La primera tiene unas dimensiones de $8 \times 10 \mathrm{~cm}$. En la esquina superior izquierda está rotulado el número de la fotografía (68.P) sobre un círculo adhesivo. Se trata de una imagen casi frontal de la portada, más oscura que la fotografía 28 , y en ella las hojas de la carpintería están abiertas, intuyéndose a través del hueco la portada 20 alineada con la portada 22 al fondo de la sala 17. La segunda tiene unas dimensiones de $8,5 \times 11,5 \mathrm{~cm}$, y en la parte inferior tiene un margen blanco donde aparece rotulado el número 5 subrayado. En la esquina superior izquierda está rotulado el número de la fotografía (68.1) sobre un círculo adhesivo. Se trata de una imagen casi frontal de la portada; el punto de vista es prácticamente idéntico a la fotografía 28.P, aunque esta es más clara que la anterior y en ella las hojas de la carpintería están cerradas. La fotografía presenta dos líneas en diagonal que evidencian que el negativo se encontraba cortado y doblado. En el intradós del arco, sobre la clave hay rotulada una "x" con tinta (ver Fig. 252 centro y dcha.).

\footnotetext{
${ }^{363}$ Fischer, E. (1917-1920). Álbum Fotos Grande. Oliva, Valencia: Museo Municipal de Oliva, Archivo Público Documental, Palacio Condal. pp. 8A.

${ }^{364}$ Fischer, E. (1917-1920). Álbum Fotos Pequeño. Oliva, Valencia: Museo Municipal de Oliva, Archivo Público Documental, Palacio Condal. pp. 7A.
} 


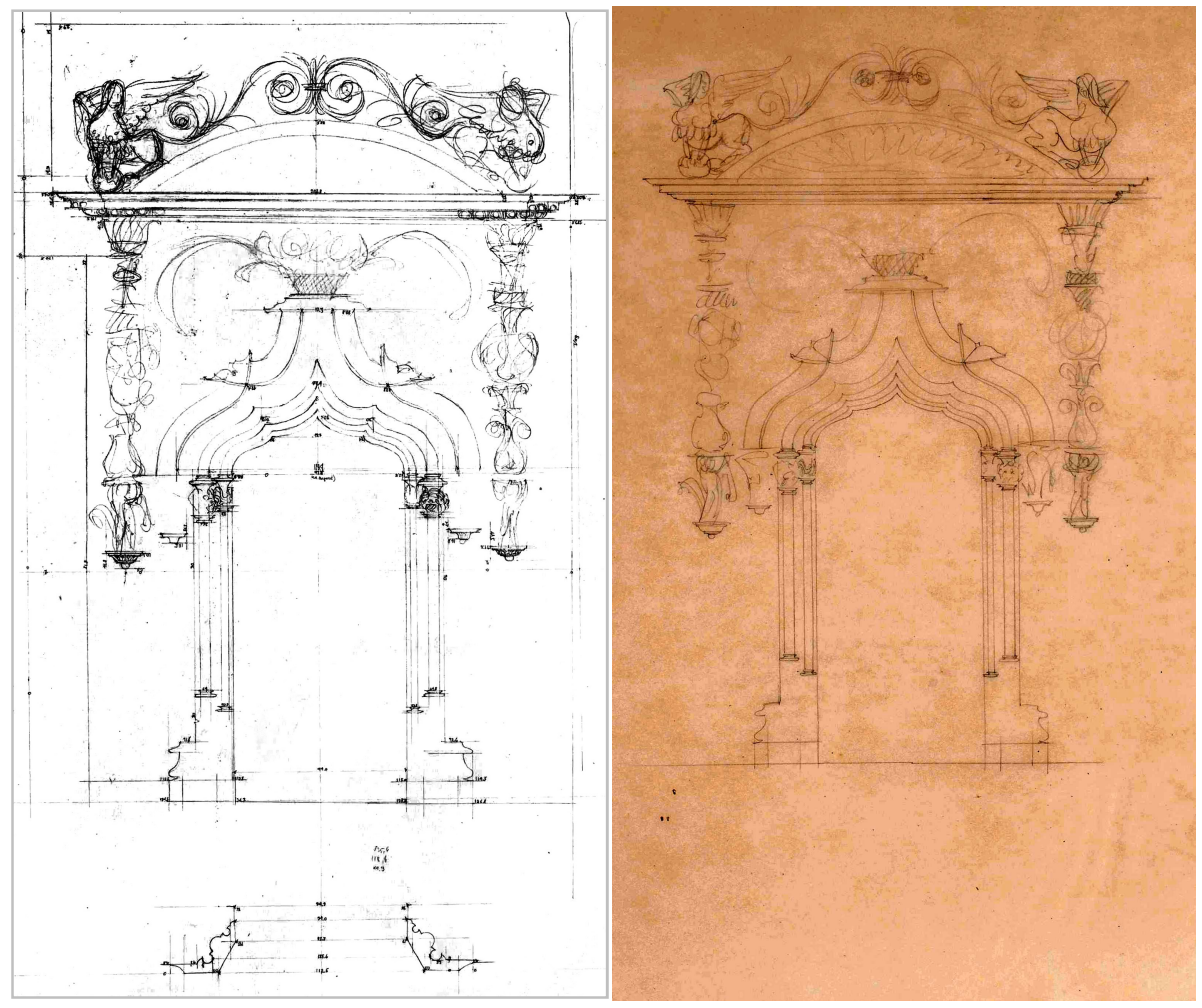

Figura 251. Izquierda: Plano Portada 22. LA1164. V. Lauritzen. Derecha: Plano de Portada 22 en papel de calco. LA1163. V. Lauritzen y/o E. Fischer.
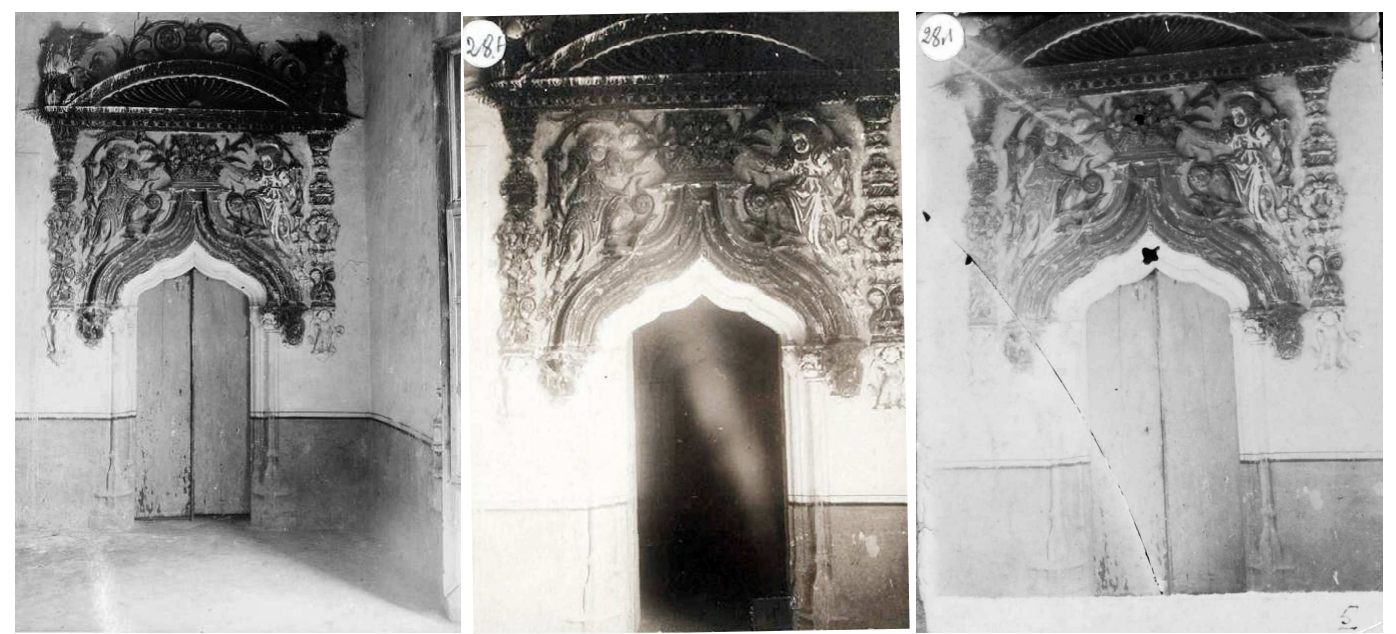

Figura 252. Fotografías Portada 22. Izq.: Fot. 28. Álbum Fotogr. Grande. Pág. 8A. Centro y derecha: Fot. 28.P y Fot. 28.1. Álbum Fotgr. Pequeño. Pág. 7A. E. Fischer. 
Tabla 30. Ficha Portada 22.

\begin{tabular}{|c|c|c|}
\hline Ficha 22 & Portada 22 (Dör 22) & \\
\hline Localización & Sala 18 (Rum18) & \\
\hline \multirow{3}{*}{$\begin{array}{l}\text { Documentación } \\
\text { existente }\end{array}$} & Planos & LA1163 y LA1164 \\
\hline & Álbum Fotográfico Grande & Fot. 28 Pág. 8A \\
\hline & Álbum Fotográfico Pequeño & Fot. 28.P y 28.1 Pág 7A \\
\hline \multirow[t]{5}{*}{ Arco Intradós } & Tipo & Variación del Flamígero \\
\hline & № Trazados curvos & 6 \\
\hline & № Trazados rectos & 0 \\
\hline & Luz & $0,94 \mathrm{~m}$ \\
\hline & Altura libre & $1,98 \mathrm{~m}$ \\
\hline \multirow[t]{5}{*}{ Arco extradós $^{365}$} & Tipo & Variación del Flamígero \\
\hline & № Trazados curvos & 6 \\
\hline & № Trazados rectos & 0 \\
\hline & Luz & $1,27 \mathrm{~m}$ \\
\hline & Altura máxima & $2,28 m$ \\
\hline Basas & $\mathrm{SI}$ & 2 basas ¿heptagonales? \\
\hline \multirow[t]{12}{*}{ Jamba } & $\begin{array}{l}\text { Molduras del extradós a } \\
\text { intradós: }\end{array}$ & Radio / Longitud \\
\hline & Caveto & $4,9 \mathrm{~cm}$ \\
\hline & Baqueta o columnilla & $2,5 \mathrm{~cm}$ \\
\hline & Filete & $1,8 \mathrm{~cm}$ \\
\hline & Caveto semicircular & $4,3 \mathrm{~cm}$ \\
\hline & Caveto & $2,7 \mathrm{~cm}$ \\
\hline & Baqueta o columnilla & $1,9 \mathrm{~cm}$ \\
\hline & Caveto & $2,5 \mathrm{~cm}$ \\
\hline & Caveto & $2,0 \mathrm{~cm}$ \\
\hline & Profundidad jamba & $21,2 \mathrm{~cm}$ \\
\hline & Jamba recta & $46,6 \mathrm{~cm}$ \\
\hline & Ángulo jamba & $53^{\circ}$ \\
\hline Capiteles & SI & 2 Góticos y 2 Renacentistas \\
\hline
\end{tabular}

${ }^{365}$ No se considera la ornamentación renacentista en los datos del extradós. 


\section{Portada 23}

La documentación gráfica de la Portada 23 (Dör23) situada en la Sala 18 (Sala de Armas) según el plano de planta del Palacio es la siguiente:

- Plano LA1166 ${ }^{366}$ : se trata de una puesta a escala dibujada a grafito sobre una lámina de papel de dimensiones $680 \times 470 \mathrm{~mm}$ donde está representado el alzado de la portada y una sección horizontal por la jamba, aunque incompleta, ya que sólo aparece grafiada la posición de la baqueta o columnilla. Las vistas tienen correspondencia diédrica y la disposición del dibujo en la lámina es vertical. Existen líneas auxiliares de dibujo. El plano dispone de numerosas cotas, tanto de anchura como de altura; las cotas en anchura suelen ser lineales o bien referenciadas al eje de simetría, mientras que las verticales se establecen a partir de líneas de referencia marcadas con un "0" como origen de acotación. El eje principal de acotación vertical se encuentra situado por debajo del arranque de los capiteles, aunque es una línea horizontal arbitraria que suponemos fue trazada sobre el muro con el fin de poder acotar los principales puntos singulares de la portada en altura. La escala de representación es 1:10 como en el resto de las portadas. Se trata de una portada con arco escarzano en su intradós que se transforma en un arco angrelado en su extradós. La portada dispone de dos pares de capiteles, uno de ellos sobre las columnillas que forman las jambas y los otros dos arrancan del lienzo del muro a través de ménsulas (del tercer par sólo aparece grafiada la ménsula). Las bases de las columnillas no están grafiadas en la planta, pero sí en el alzado en la jamba derecha. Las molduras que forman la jamba no pueden identificarse en este plano al estar incompleto, tan sólo podemos afirmar que esta portada dispone de una sola baqueta o columnilla en su jamba. En la parte superior izquierda se encuentra rotulada la ubicación de la portada y su numeración: "Rum 18 - Dör 23", y en la parte inferior derecha, la numeración de la lámina: LA1166 (ver Fig. 253).

- Plano LA1165 ${ }^{367}$ : se trata de una lámina de papel transparente de dimensiones 667 x $466 \mathrm{~mm}$ realizada a grafito sobre papel de calco y en disposición vertical. En ella está grafiada una copia del alzado de la portada 23 correspondiente al plano LA1166. En la esquina superior izquierda está rotulado el número de la portada y su localización "Dör 23 (Rum 18)" y en la parte inferior derecha, la numeración de la lámina: LA1165. No aparecen marcas de despiece como en la mayoría de láminas en papel transparente (ver Fig. 253 izq.).

- Álbum de Fotos Grande: en la página 8R se encuentra la fotografía $31^{368}$ correspondiente a la portada 23. Tiene unas dimensiones de $15,5 \times 24 \mathrm{~cm}$ y unos márgenes de $2 \mathrm{~mm}$. En la parte superior, centrado, está rotulado el número de la fotografía (31). Se trata de una imagen casi frontal de la portada. La fotografía tiene

\footnotetext{
${ }^{366}$ Lauritzen, V. (1919-1920). Planos. Oliva, Valencia: Museo Municipal de Oliva, Archivo Público Documental, Palacio Condal. (LA1166).

367 Lauritzen, V. (1919-1920). Planos. Oliva, Valencia: Museo Municipal de Oliva, Archivo Público Documental, Palacio Condal. (LA1165).

${ }^{368}$ Fischer, E. (1917-1920). Álbum de Fotos Grande. Oliva, Valencia: Museo Municipal de Oliva, Archivo Público Documental, Palacio Condal. pp. 8R.
} 
una calidad aceptable y podemos observar con bastante detalle la portada y la decoración renacentista existente en el tímpano formado entre los dos arcos, donde aparece en relieve un guerrero apoyado en el escudo de armas de los Centelles rodeado de espirales de ornamentación vegetal. El muro se encuentra pintado en color blanco con un zócalo pintado en color y rematado con dos líneas finas en color más intenso; la decoración y molduras de los arcos presentan policromía, aunque no se pueden distinguir los colores al tratarse de una fotografía en blanco y negro. En esta misma página se encuentra la fotografía 30, de dimensiones 7,5 $\times 8 \mathrm{~cm}$, que corresponde a la parte superior de la carpintería de madera de la portada 23 . Se trata de una puerta de una hoja de cuarterones. La madera está labrada con motivos ornamentales vegétales, y en el centro del travesaño intermedio aparece labrado el escudo de armas de la familia Centelles (ver Fig. 254).

- Álbum de Fotos Pequeño: en la página 7R se encuentra la fotografía $31^{369}$ correspondiente a la portada 23. Se trata de la misma toma que aparece en el Álbum de Fotografías Grande. La primera tiene unas dimensiones de $8 \times 11 \mathrm{~cm}$. En la esquina superior izquierda está rotulado el número de la fotografía (31) sobre un círculo adhesivo. En esta página encontramos la misma fotografía 30 del álbum grande de dimensiones $8 \times 8,5 \mathrm{~cm}$ y con un margen perimetral de $2 \mathrm{~mm}$, aunque en este caso aparece rotulada con un círculo adhesivo sobre su esquina superior derecha, con la misma numeración que la portada.

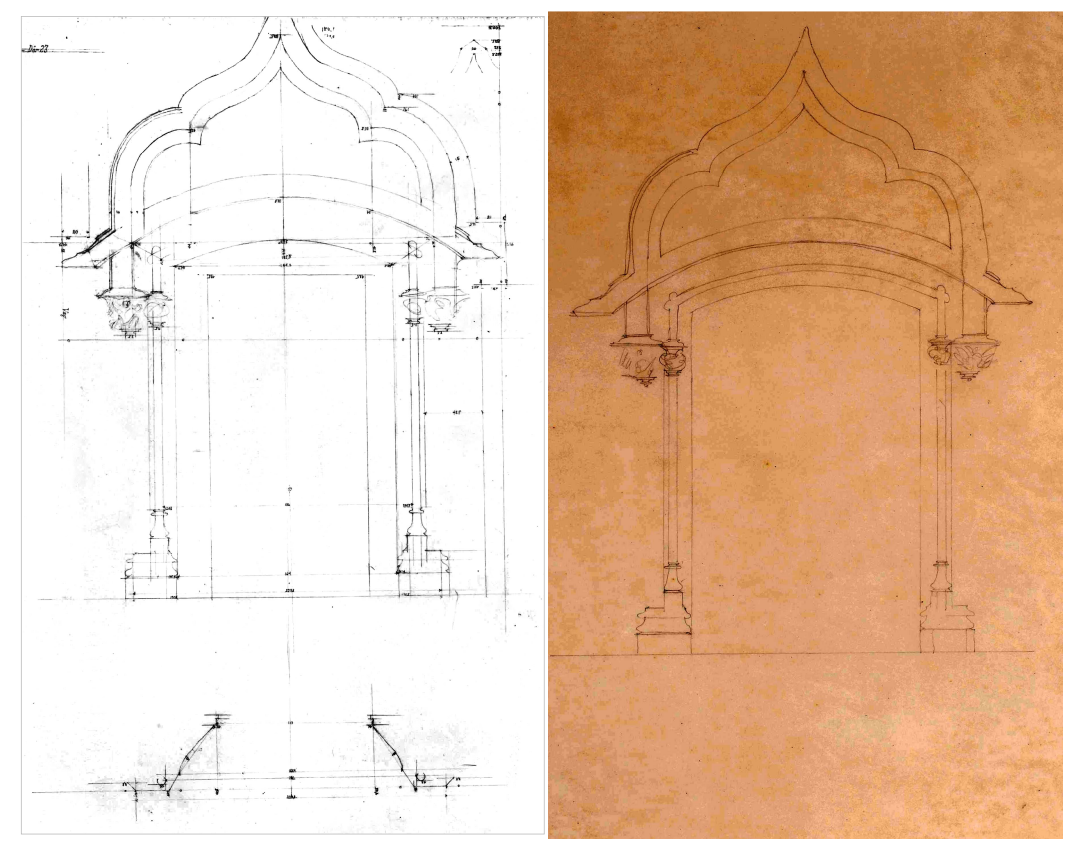

Figura 253. Izquierda: Plano Portada 23. LA1166. V. Lauritzen. Derecha: Izquierda: Plano de Portada 23 en papel de calco. LA1165. V. Lauritzen y/o E. Fischer.

${ }^{369}$ Fischer, E. (1917-1920). Álbum de Fotos Pequeño. Oliva, Valencia: Museo Municipal de Oliva, Archivo Público Documental, Palacio Condal. pp. 7R. 


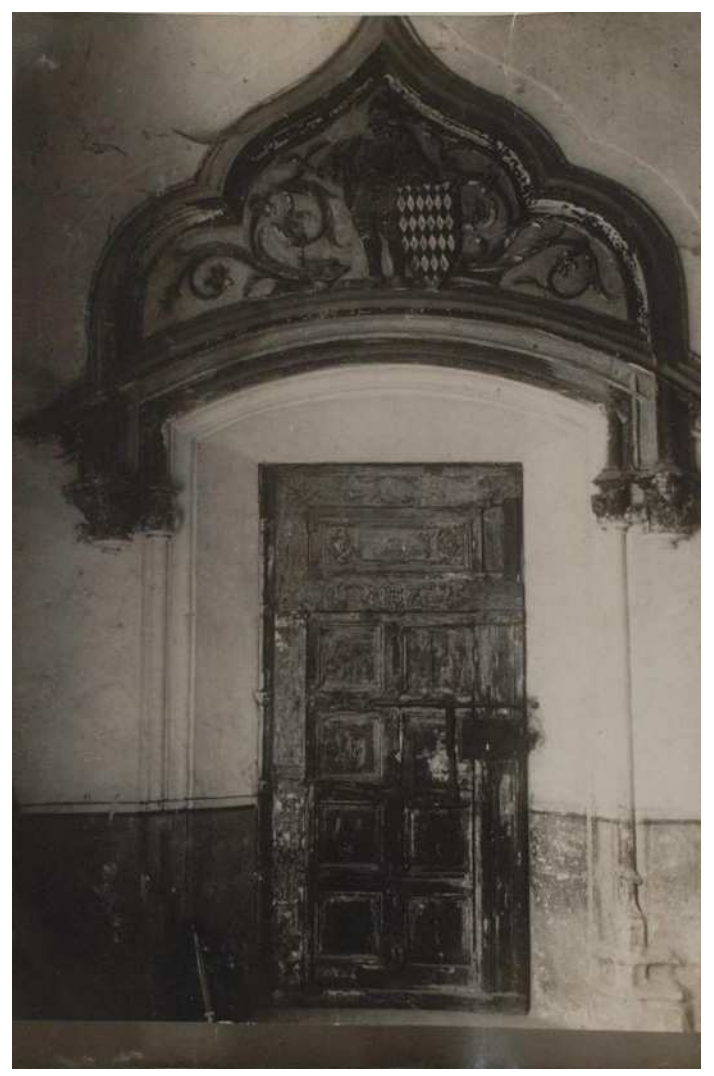

Figura 254. Portada 23. Fot. 31. Álbum Fot. Grande. E. Fischer. 
Tabla 31. Ficha Portada 23.

\begin{tabular}{|c|c|c|}
\hline Ficha 23 & Portada 23 (Dör 23) & \\
\hline Localización & Sala 18 (Rum18) & \\
\hline \multirow{3}{*}{$\begin{array}{l}\text { Documentación } \\
\text { existente }\end{array}$} & Planos & LA1165 y LA1166 \\
\hline & Álbum Fotográfico Grande & Fot. 30 y 31 Pág. $8 R$ \\
\hline & Álbum Fotográfico Pequeño & Fot. 31 y31 Pág 7R \\
\hline \multirow[t]{5}{*}{ Arco Intradós } & Tipo & Escarzano \\
\hline & № Trazados curvos & 1 \\
\hline & № Trazados rectos & 0 \\
\hline & Luz & $1,64 \mathrm{~m}$ \\
\hline & Altura libre & $2,67 \mathrm{~m}$ \\
\hline \multirow[t]{5}{*}{ Arco extradós } & Tipo & Angrelado \\
\hline & № Trazados curvos & 6 \\
\hline & № Trazados rectos & 0 \\
\hline & Luz & $2,06 \mathrm{~m}$ \\
\hline & Altura máxima & $2,85 \mathrm{~m}$ \\
\hline Basas & $\mathrm{SI}$ & 1 basa ¿heptagonal? \\
\hline \multirow[t]{10}{*}{ Jamba } & Molduras del extradós a intradós: & Radio / Longitud \\
\hline & Caveto & -- \\
\hline & Baqueta o columnilla & $3,0 \mathrm{~cm}$ \\
\hline & ¿Filete? & $2,0 \mathrm{~cm}$ \\
\hline & Caveto semicircular & -- \\
\hline & ¿Caveto? & -- \\
\hline & ¿Caveto? & -- \\
\hline & Profundidad jamba & $5,5 \mathrm{~cm}$ \\
\hline & Jamba curva & $44 \mathrm{~cm}$ \\
\hline & Ángulo jamba & -- \\
\hline Capiteles & sí & 1 Gótica y 1 Renacentista \\
\hline
\end{tabular}




\section{Portada 24}

La documentación gráfica de la Portada 24 (Dör24) situada en la Sala 19 (Galería exterior de la Sala de Armas) según el plano de planta del Palacio es la siguiente:

- Plano LA1168 ${ }^{370}$ : se trata de una puesta a escala dibujada a grafito sobre una lámina de papel de dimensiones $680 \times 470 \mathrm{~mm}$ donde está representado el alzado de la portada y una sección horizontal por la basa. Las vistas tienen correspondencia diédrica y la disposición del dibujo en la lámina es vertical. Existen líneas auxiliares de dibujo. El plano dispone de numerosas cotas, tanto de anchura como de altura; las cotas en anchura son lineales, mientras que las verticales se establecen a partir de líneas de referencia marcadas con un "0" como origen de acotación. El eje principal de acotación vertical se encuentra situado enrasado con la parte inferior arranque de los capiteles más bajos (los más exteriores). La escala de representación es 1:10, como en el resto de las portadas. Se trata de una portada con arco trilobulado carpanel mixtilíneo en su intradós que se transforma en un arco angrelado mixtilíneo en su extradós. La portada dispone de tres pares de capiteles: dos de ellos sobre las columnillas que forman las jambas y los otros dos arrancan del lienzo del muro a través de ménsulas. Las bases de las columnillas no están grafiadas en la planta ni en el alzado. Las molduras que forman la jamba no pueden identificarse en este plano al estar incompleto. Dispone de dos baquetas o columnillas en cada jamba. En la parte superior izquierda se encuentra rotulada la ubicación de la portada y su numeración: "Rum 19 - Dör 24", y en la parte inferior derecha, la numeración de la lámina: LA1168 (ver Fig. 255 izq.).

- Plano LA1167 $7^{371}$ : se trata de una lámina de papel transparente de dimensiones 667 $x 470 \mathrm{~mm}$ realizada a grafito sobre papel de calco y con una disposición vertical. En ella está grafiada una copia del alzado de la portada 24, correspondiente al plano LA1168. En la esquina superior izquierda está rotulado el número de la portada y su localización "Dör 24 (Rum 19)" y en la parte inferior derecha la numeración de la lámina: LA1167. No aparecen marcas de despiece como en la mayoría de láminas en papel transparente (ver Fig. 255 dcha.).

- Álbum de Fotos Grande: en la página $8 R$ se encuentra la fotografía $29^{372}$, correspondiente a la portada 24 . Tiene unas dimensiones de $16 \times 24 \mathrm{~cm}$ y unos márgenes de $2 \mathrm{~mm}$. En la parte superior, centrado, está rotulado el número de la fotografía (29). Se trata de una imagen en ángulo tomada desde el lateral derecho de la portada. La fotografía tiene una calidad aceptable y podemos observar con bastante detalle la jamba derecha, las bases de las columnillas, el arco y los capiteles, aunque su ángulo no nos permite tener una visión completa del conjunto.

\footnotetext{
${ }^{370}$ Lauritzen, V. (1919-1920). Planos. Oliva, Valencia: Museo Municipal de Oliva, Archivo Público Documental, Palacio Condal. (LA1168).

${ }^{371}$ Lauritzen, V. (1919-1920). Planos. Oliva, Valencia: Museo Municipal de Oliva, Archivo Público Documental, Palacio Condal. (LA1167).

${ }^{372}$ Fischer, E. (1917-1920). Álbum de Fotos Grande. Oliva, Valencia: Museo Municipal de Oliva, Archivo Público Documental, Palacio Condal. pp. 8R.
} 
La portada dispone de carpintería y está formada por cuarterones cuadrados a $45^{\circ}$ con rosetones en el centro de cada cuarterón. En la parte superior la puerta tiene relieve con ornamentación vegetal y el escudo de los Centelles en el centro (ver Fig. 256 izq.).

- Álbum de Fotos Pequeño: en la página 6A se encuentra la fotografía $29.1^{373}$, correspondiente a la portada 24. Las dimensiones son $8,8 \times 13 \mathrm{~mm}$, con un margen inferior de $13 \mathrm{~mm}$ y el resto irregular entre 1 y $2 \mathrm{~mm}$. Está tomada desde un punto de vista similar a la fotografía 29 , ya que al encontrarse en el lateral de la galería exterior de la Sala de Armas (sala 19), no era factible tomar otra vista con la tecnología de la época. En esta imagen aparecen fotografiados delante de la portada un grupo formado por 3 mujeres, 2 hombres y dos niños. La fotografía se encuentra rota en dos mitades por el centro (ver Fig. 256 dcha.).
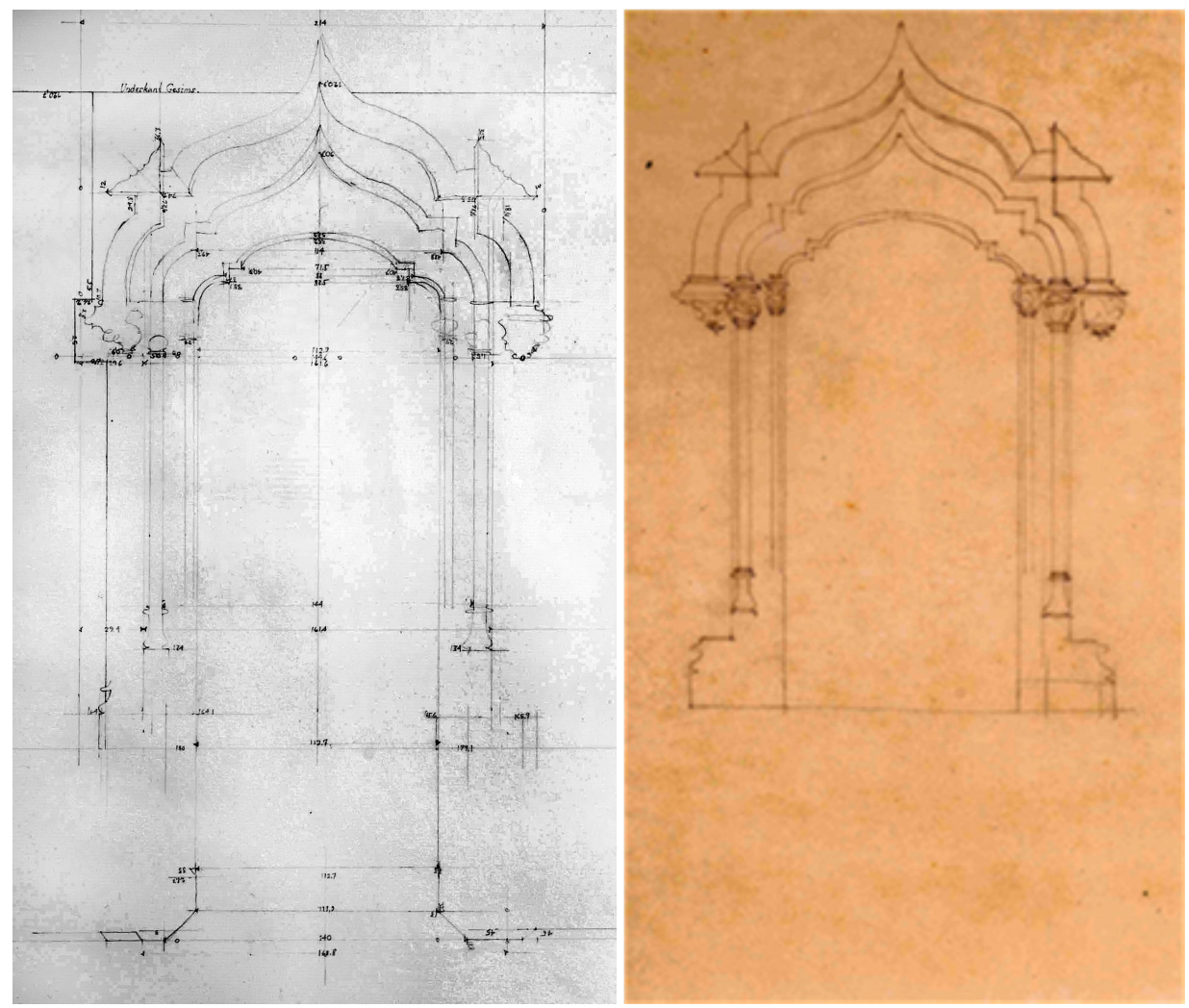

Figura 255. Izquierda: Plano Portada 24. LA1168. V. Lauritzen. Derecha: Plano de Portada 24 en papel de calco. LA1167. V. Lauritzen y/o E. Fischer.

\footnotetext{
${ }^{373}$ Fischer, E. (1917-1920). Álbum Fotos Pequeño. Oliva, Valencia: Museo Municipal de Oliva, Archivo Público Documental, Palacio Condal. pp. 7R.
} 

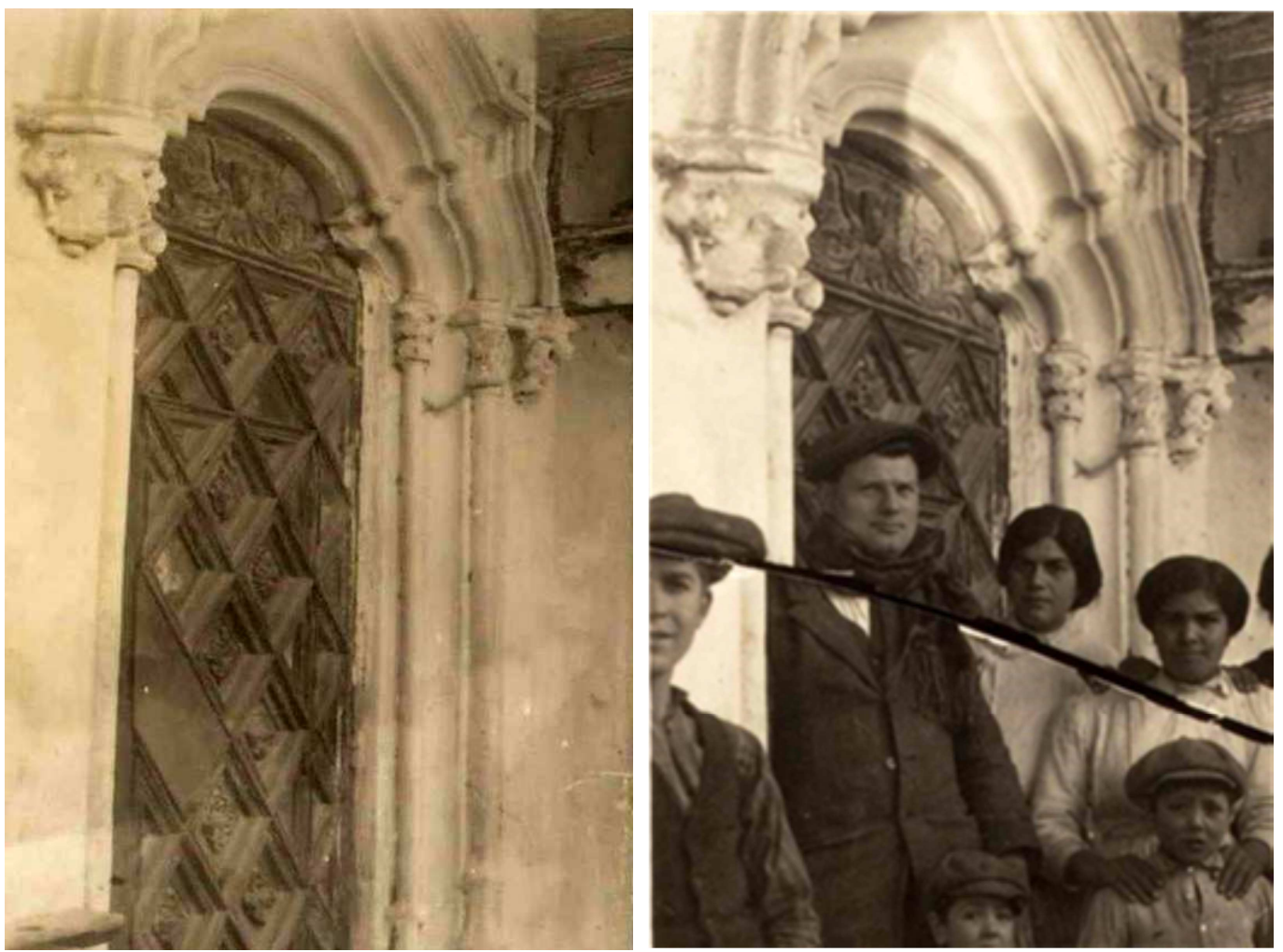

Figura 256. Izquierda: Fot. 29. Portada 24. Álbum Fot. Grande. Derecha: Fot. 29.1. Álbum Fot. Pequeño. E. Fischer. 
Tabla 32. Ficha Portada 24.

\begin{tabular}{|c|c|c|}
\hline Ficha 24 & \multicolumn{2}{|l|}{ Portada 24(Dör 24) } \\
\hline Localización & \multicolumn{2}{|l|}{ Sala 19 (Rum19) } \\
\hline \multirow{3}{*}{$\begin{array}{l}\text { Documentación } \\
\text { existente }\end{array}$} & Planos & LA1167 y LA1168 \\
\hline & Álbum Fotográfico Grande & Fot. 29 Pág. 8R \\
\hline & Álbum Fotográfico Pequeño & Fot. 29.1 Pág 8R \\
\hline \multirow[t]{5}{*}{ Arco Intradós } & Tipo & Angrelado/Mixtilíneo \\
\hline & № Trazados curvos & 5 \\
\hline & № Trazados rectos & 4 \\
\hline & Luz & $1,13 \mathrm{~m}$ \\
\hline & Altura libre & $2,38 \mathrm{~m}$ \\
\hline \multirow[t]{5}{*}{ Arco extradós ${ }^{374}$} & Tipo & Trilobulado/Carpanel/mixtilíneo \\
\hline & № Trazados curvos & 6 \\
\hline & № Trazados rectos & 4 \\
\hline & Luz & $1,59 \mathrm{~m}$ \\
\hline & Altura máxima & $2,87 m$ \\
\hline Basa & sí & 2 basas ¿heptagonales? \\
\hline \multirow[t]{12}{*}{ Jamba } & $\begin{array}{l}\text { Molduras del extradós a } \\
\text { intradós: }\end{array}$ & Radio / Longitud \\
\hline & Caveto & Sin dato \\
\hline & Baqueta o columnilla & Sin dato \\
\hline & Filete & Sin dato \\
\hline & Caveto semicircular & Sin dato \\
\hline & Caveto & Sin dato \\
\hline & Baqueta o columnilla & Sin dato \\
\hline & Caveto & Sin dato \\
\hline & Ancho de jamba & $20,9 \mathrm{~cm}$ \\
\hline & Profundidad jamba & $10,0 \mathrm{~cm}$ \\
\hline & Jamba recta & Sin dato \\
\hline & Ángulo jamba & Sin dato \\
\hline Capiteles & sí & 2 Columnillas y 1 ménsula \\
\hline
\end{tabular}

\footnotetext{
${ }^{374}$ No se consideran las molduras que arrancan de la tercera ménsula sobre el lienzo de la pared.
} 


\section{Portada 25}

La documentación gráfica existente que disponible de la Portada 25 (Dör25), situada en la Sala 19 (Galería exterior de la Sala de Armas), según el plano de planta del Palacio es la siguiente:

- Plano LA1171 ${ }^{375}$ : se trata de una puesta a escala dibujada a grafito sobre una lámina de papel de dimensiones $680 \times 470 \mathrm{~mm}$ donde está representado el alzado de la portada y una sección horizontal por la basa. Las vistas tienen correspondencia diédrica y la disposición del dibujo en la lámina es en vertical. Existen líneas auxiliares de dibujo. El plano dispone de numerosas cotas, tanto de anchura como de altura; las cotas en anchura son lineales, mientras que las verticales se establecen a partir de líneas de referencia marcadas con un "0" como origen de acotación. El eje principal de acotación vertical se encuentra situado enrasado con la parte inferior arranque de los capiteles. La escala de representación es 1:10, como en el resto de las portadas. Se trata de una portada con arco angrelado que mantiene su forma en todas las molduras. La portada dispone de un par de capiteles sobre las columnillas que forman las jambas. Las bases de las columnillas están grafiadas y tienen planta octogonal de lado $7 \mathrm{~cm}$. Las molduras que forman la jamba no pueden identificarse en este plano al estar incompleto, aunque podemos interpretar que cada jamba dispone de una baqueta o columnillas y un caveto semicircular, además de otras molduras que no podemos identificar por estar solamente grafiadas en el alzado. Sobre la moldura más interior aparece rotulada la abreviatura "Trav", que no se ha podido interpretar. En la parte superior izquierda se encuentra rotulada la ubicación de la portada y su numeración: "Rum 19 - Dör 25", y en la parte inferior derecha la numeración de la lámina: LA1171 (ver Fig. 257 izq.).

- Plano LA1170 ${ }^{376}$ : se trata de una lámina de papel transparente de dimensiones 660 x $470 \mathrm{~mm}$ realizada a grafito sobre papel de calco y con una disposición vertical. En ella está grafiada una copia del alzado de la portada 25 , correspondiente al plano LA1171. En la esquina superior izquierda está rotulado el número de la portada y su localización "Rum 19. Dör 25" y en la parte inferior derecha la numeración de la lámina: LA11670. Están sigladas las 13 piezas en que se desmontó la portada: la pieza 1 corresponde a la basa izquierda, la 2 y la 3 a la jamba izquierda, la 4 a la parte superior de la jamba izquierda y capitel, la 5 a la parte derecha del arco hasta el eje de simetría, la 6 a la parte derecha del arco, la 7 al arranque del arco en el lado derecho, la 8 al capitel derecho, las $9,10,11$ y 12 a la jamba derecha y la 13 a la basa derecha. Aparece la misma leyenda del plano LA1171 sobre la moldura interior del arco: "Trav" (ver Fig. 257 dcha.).

\footnotetext{
${ }^{375}$ Lauritzen, V. (1919-1920). Planos. Oliva, Valencia: Museo Municipal de Oliva, Archivo Público Documental, Palacio Condal. (LA1171).

376 Lauritzen, V. (1919-1920). Planos. Oliva, Valencia: Museo Municipal de Oliva, Archivo Público Documental, Palacio Condal. (LA1170).
} 


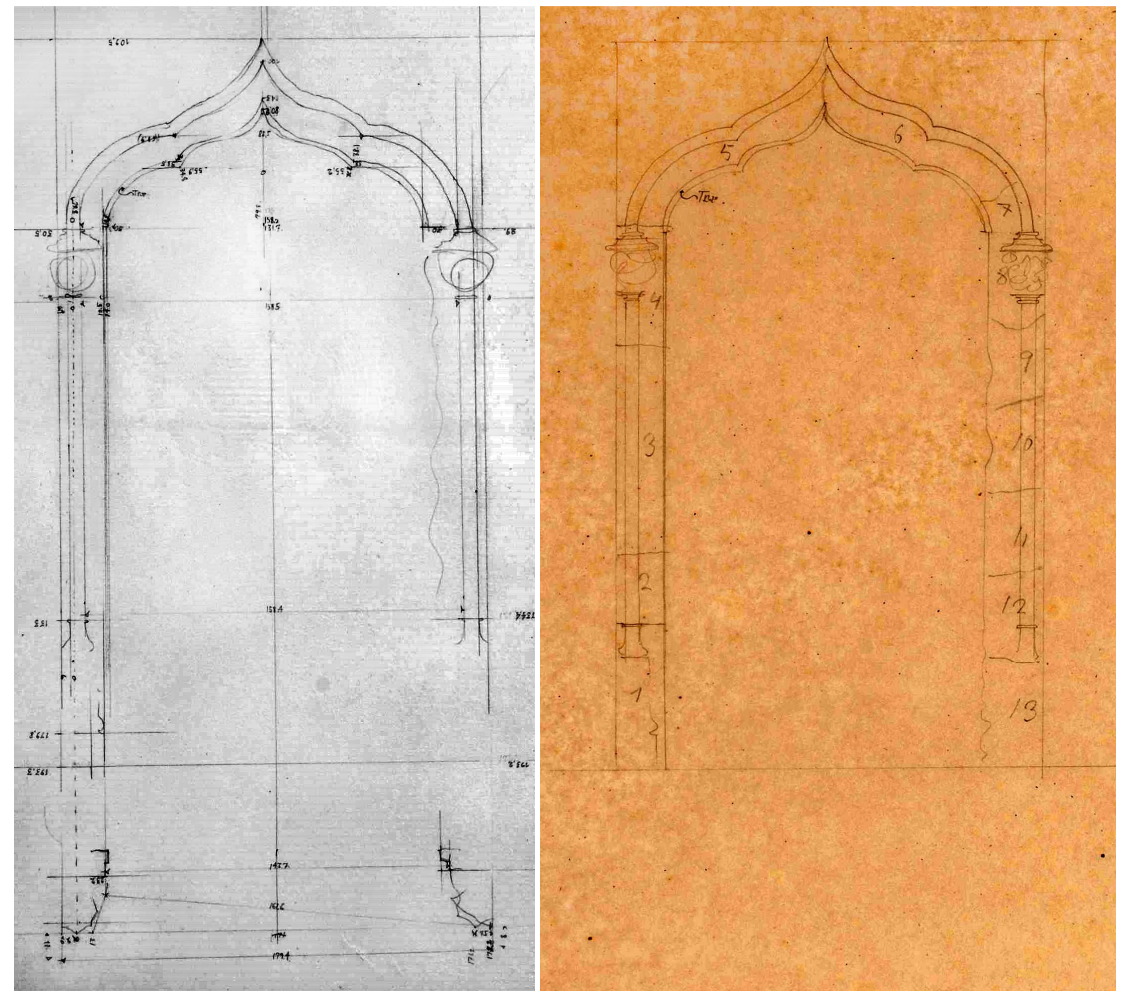

Figura 257. Izquierda: Plano Portada 25. LA1171. V. Lauritzen. Derecha: Plano de Portada 24 en papel de calco. Despiece. LA1170. V. Lauritzen y/o E. Fischer. 
Tabla 33. Ficha Portada 25.

\begin{tabular}{|c|c|c|}
\hline Ficha 25 & Portada 25 (Dör 25) & \\
\hline Localización & Sala 19 (Rum19) & \\
\hline \multirow{3}{*}{$\begin{array}{l}\text { Documentación } \\
\text { existente }\end{array}$} & Planos & LA1169, LA1170 y LA1171 \\
\hline & Álbum Fotográfico Grande & NO \\
\hline & Álbum Fotográfico Pequeño & NO \\
\hline \multirow[t]{5}{*}{ Arco Intradós } & Tipo & Angrelado \\
\hline & № Trazados curvos & 6 \\
\hline & № Trazados rectos & 0 \\
\hline & Luz & $1,44 \mathrm{~m}$ \\
\hline & Altura libre & $2,74 \mathrm{~m}$ \\
\hline \multirow[t]{5}{*}{ Arco extradós } & Tipo & Angrelado \\
\hline & № Trazados curvos & 6 \\
\hline & № Trazados rectos & 0 \\
\hline & Luz & $1,79 \mathrm{~m}$ \\
\hline & Altura máxima & $3,04 m$ \\
\hline Basas & Sí & 1 basa octogonal \\
\hline \multirow[t]{8}{*}{ Jamba } & $\begin{array}{l}\text { Molduras del extradós a } \\
\text { intradós: }\end{array}$ & Radio / Longitud \\
\hline & ¿Caveto? & Sin dato \\
\hline & Baqueta o columnilla & $3,0 \mathrm{~cm}$ \\
\hline & Caveto semicircular & Sin dato \\
\hline & ¿Caveto? & Sin dato \\
\hline & Ancho jamba & \\
\hline & Profundidad jamba & $23,4 \mathrm{~cm}$ \\
\hline & Ángulo jamba & Sin dato \\
\hline Capiteles & sí & 1 Columnilla \\
\hline
\end{tabular}




\section{Portada 26}

La documentación gráfica de la Portada 26 (Dör 26) situada en la Sala 20 según el plano de planta del Palacio es la siguiente:

- Plano LA1173 ${ }^{377}$ : se trata de una puesta a escala dibujada a grafito sobre una lámina de papel de dimensiones $680 \times 470 \mathrm{~mm}$ donde está representado el alzado de la portada y una sección horizontal por la basa. Las vistas tienen correspondencia diédrica y la disposición del dibujo en la lámina es en vertical. Existen líneas auxiliares de dibujo. El plano dispone de numerosas cotas, tanto de anchura como de altura; las cotas en anchura son lineales, mientras que las verticales se establecen a partir de líneas de referencia marcadas con un "0" como origen de acotación. El eje principal de acotación vertical se encuentra situado a dos centímetros de la parte inferior arranque del capitel exterior izquierdo. La escala de representación es 1:10. Se trata de una portada con arco angrelado de 8 centros en todo su trazado. La portada dispone de cuatro pares de capiteles, tres de ellos sobre las columnillas que forman las jambas y el otro arranca del lienzo del muro a través de ménsulas. Las bases de las columnillas no están grafiadas en la planta ni en el alzado. Las molduras que forman la jamba no pueden identificarse en este plano al estar incompleto. Dispone de cuatro columnillas en cada jamba, la más exterior es la de menor diámetro (más que columnilla es un simple caveto ya que no dispone de capitel), la segunda es la de mayor diámetro y tiene un perfil mixto aquillado que finaliza en un listel unido mediante dos cavetos tangentes al baquetón; las dos columnillas interiores están formadas por baquetones sencillos. El arco se encuentra enmarcado en un gran alfiz $y$, entre este y las enjuntas del arco, se localiza el escudo de armas de los Borja y los Centelles rodeados de rica ornamentación renacentista. En la parte superior izquierda se encuentra rotulada la ubicación de la portada y su numeración: "Rum 20 - Dör 26", y en la parte inferior derecha, la numeración de la lámina: LA1173 (ver Fig. 258 izq.).

- Plano LA1172 $2^{378}$ : se trata de una lámina de papel transparente de dimensiones 660 x $470 \mathrm{~mm}$ realizada a grafito sobre papel de calco. Su disposición es vertical. En ella está grafiada una copia del alzado de la portada 26, correspondiente al plano LA1172. En la esquina superior izquierda está rotulado la localización de la portada y su numeración "Rum 20. Dör 26" y en la parte inferior derecha, la numeración de la lámina; en esta, algo ilegible, fue rotulada posteriormente como LA1122. El hecho de que esa numeración pertenezca a otra lámina nos hace pensar que la numeración correcta de la misma debe de ser 1172, siguiendo la secuencia lógica de numeración de las portadas. En esta lámina se detalla el siglado de las piezas en que se ha desmontado la portada. Están numeradas de la 1 a la 34 comenzando por

\footnotetext{
${ }^{377}$ Lauritzen, V. (1919-1920). Planos. Oliva, Valencia: Museo Municipal de Oliva, Archivo Público Documental, Palacio Condal. (LA1173).

378 Lauritzen, V. (1919-1920). Planos. Oliva, Valencia: Museo Municipal de Oliva, Archivo Público Documental, Palacio Condal. (LA1172).
} 
la basa izquierda y finalizando por la derecha. En el despiece está contemplado la totalidad de la portada, incluido el alfiz (ver Fig. 258 dcha.).

- Álbum de Fotos Grande: en la página 10R se encuentran las fotografías 39, 40 y $41^{379}$, correspondientes a la portada 26. La primera tiene unas dimensiones de $17 \mathrm{x}$ $23 \mathrm{~cm}$. La fotografía tiene unos márgenes de $2 \mathrm{~mm} \mathrm{y}$, en la parte superior, centrado, está rotulado el número de la fotografía. Se trata de una imagen frontal de la portada, de buena calidad, donde se la puede ver en su totalidad. La portada dispone de carpintería de dos hojas muy sencilla, lo que pone en duda que se trate de la carpintería original. La parte superior la puerta tiene relieve con ornamentación vegetal y el escudo de los Borja y los Centelles en el centro (ver Fig. 259 izq.). La fotografía 40, de dimensiones $8 \times 10 \mathrm{~cm}$, corresponde a un detalle de los capiteles de la jamba izquierda (ver Fig. 259 dcha.). La fotografía 41, de dimensiones $5 \times 8,5 \mathrm{~cm}$, muestra los capiteles izquierdos una vez desmontados y se correspondería con la pieza 5 de acuerdo con el plano LA1172.

- Álbum de Fotos Pequeño: en la página 8A se encuentra la fotografía $39.1^{380}$, correspondiente a la portada 26. Las dimensiones son $9 \times 14 \mathrm{~cm}$, con márgenes en blanco. Se trata de la misma toma de la fotografía 39 del álbum Fotográfico Grande.

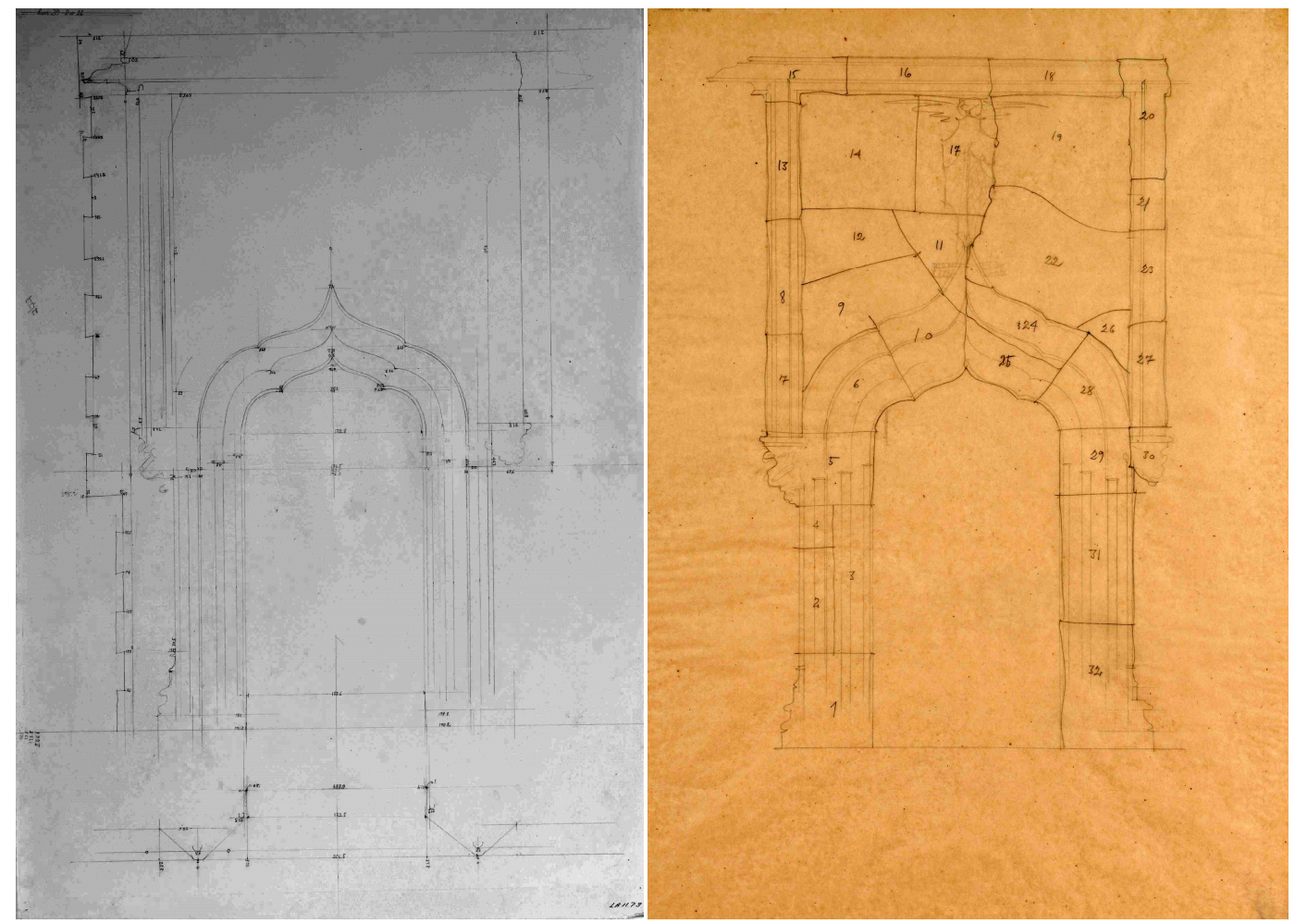

Figura 258. Izquierda: Plano Portada 26. LA1173. V. Lauritzen. Derecha: Plano de Portada 26 en papel de calco. LA1172. V. Lauritzen y/o E. Fischer.

${ }^{379}$ Fischer, E. (1917-1920). Álbum Fotos Grande. Oliva, Valencia: Museo Municipal de Oliva, Archivo Público Documental, Palacio Condal. pp. 10R.

${ }^{380}$ Fischer, E. (1917-1920). Álbum Fotos Pequeño. Oliva, Valencia: Museo Municipal de Oliva, Archivo Público Documental, Palacio Condal. pp. 8A. 


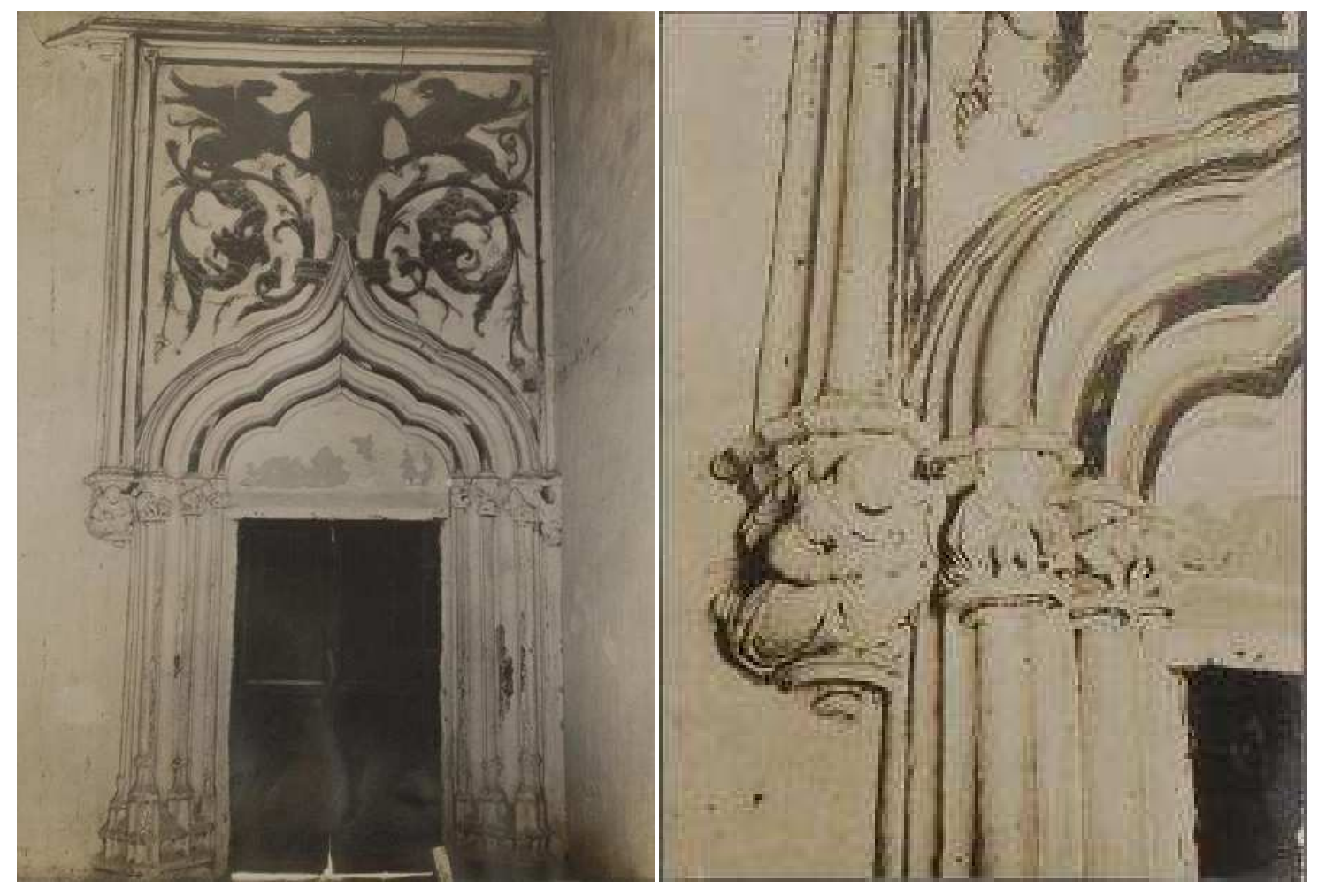

Figura 259. Izquierda: Fot. 39. Derecha: Fot. 40. Álbum Fot. Grande. E. Fischer. 
Tabla 34. Ficha Portada 26.

\begin{tabular}{|c|c|c|}
\hline Ficha 26 & Portada 26 (Dör 26) & \\
\hline Localización & Sala 20 (Rum 20) & \\
\hline \multirow{3}{*}{$\begin{array}{l}\text { Documentación } \\
\text { existente }\end{array}$} & Planos & LA1172 y LA1173 \\
\hline & Álbum Fotográfico Grande & Fot. 39, 40 y 41 Pág. $10 R$ \\
\hline & Álbum Fotográfico Pequeño & Fot. 39.1 Pág 8A \\
\hline \multirow[t]{5}{*}{ Arco Intradós } & Tipo & Angrelado \\
\hline & № Trazados curvos & 8 \\
\hline & № Trazados rectos & 0 \\
\hline & Luz & $1,32 \mathrm{~m}$ \\
\hline & Altura libre & $2,71 \mathrm{~m}$ \\
\hline \multirow[t]{5}{*}{ Arco extradós $^{381}$} & Tipo & Angrelado \\
\hline & № Trazados curvos & 8 \\
\hline & № Trazados rectos & 0 \\
\hline & Luz & $2,39 \mathrm{~m}$ \\
\hline & Altura máxima & $3,56 \mathrm{~m}$ \\
\hline Basa & $\mathrm{SI}$ & 4 basas ¿heptagonales? \\
\hline \multirow[t]{17}{*}{ Jamba } & $\begin{array}{l}\text { Molduras del extradós a } \\
\text { intradós: }\end{array}$ & Radio / Longitud \\
\hline & Baqueta & Sin dato \\
\hline & Filete & Sin dato \\
\hline & Caveto & Sin dato \\
\hline & Caveto & Sin dato \\
\hline & Baquetón aquillado & $3,5 \mathrm{~cm}$ \\
\hline & ¿Caveto? & Sin dato \\
\hline & Caveto semicircular & Sin dato \\
\hline & Filete & Sin dato \\
\hline & Baqueta & Sin dato \\
\hline & Filete & Sin dato \\
\hline & Caveto semicircular & Sin dato \\
\hline & Filete & Sin dato \\
\hline & Baqueta & $2,0 \mathrm{~cm}$ \\
\hline & Filete & Sin dato \\
\hline & Profundidad jamba & $28,0 \mathrm{~cm}$ \\
\hline & Ángulo jamba & $39^{\circ}$ \\
\hline Capiteles & sí & 3 Columnillas y 1 ménsula \\
\hline
\end{tabular}

${ }^{381}$ No se consideran las dimensiones del alfiz que parten de las ménsulas sobre el lienzo de la pared. 


\section{Portada 27}

La documentación gráfica de la Portada 27 (Dör 27) situada en la Sala 20 según el plano de planta del Palacio es la siguiente:

- Plano LA1175 $5^{382}$ : se trata de una puesta a escala dibujada a grafito sobre una lámina de papel de dimensiones $680 \times 470 \mathrm{~mm}$ donde está representado el alzado de la portada y una sección horizontal por la basa. Las vistas tienen correspondencia diédrica y la disposición del dibujo en la lámina es vertical. Existen líneas auxiliares de dibujo. El plano dispone de numerosas cotas, tanto de anchura como de altura; las cotas en anchura son lineales, mientras que las verticales se establecen a partir de líneas de referencia marcadas con un "0" como origen de acotación. El eje principal de acotación vertical se encuentra ubicado en una línea de referencia situada por debajo del arranque de todos los capiteles. La escala de representación es 1:10. Se trata de una portada con arco polilobulado rebajado de 7 centros en su extradós y polilobulado rebajado mixtilíneo de 5 centros en su intradós. La portada dispone de cinco pares de capiteles, todos ellos sobre las columnillas o baquetas que forman las jambas. Las bases de las columnillas no están grafiadas en la planta ni en el alzado. Las molduras que forman la jamba no pueden identificarse en este plano al estar incompleto. Posee cinco columnillas en cada jamba de distinto diámetro y entre ellas se disponen diversas molduras. Al no estar grafiadas, se ha interpretado a partir de las fotografías existentes que una de ellas dispone de ornamentación renacentista a candelieri. Sobre las enjuntas del arco apoyan dos grandes volutas que interseccionan con las molduras del arco y que confluyen en el eje de la portada formando un vértice. En la parte superior izquierda se encuentra rotulada la ubicación de la portada y su numeración: "Rum 20 - Dör 27", y en la parte inferior derecha la numeración de la lámina: LA1175 (ver Fig. 260 izq.).

- Plano LA1174 ${ }^{383}$ : se trata de una lámina de papel transparente de dimensiones 663 x $470 \mathrm{~mm}$ realizada a grafito sobre papel de calco. Su disposición es vertical. En ella está grafiada una copia del alzado de la portada 26, correspondiente al plano LA1172. En la esquina superior izquierda está rotulada la numeración de la portada y su localización "Dör 27 (Rum 20)" y en la parte inferior derecha, la numeración de la lámina, LA1174. En esta lámina se detalla el siglado de las piezas en que se ha desmontado la portada, numeradas de la 1 a la 15 comenzando por la basa izquierda y finalizando por la derecha. En el despiece está contemplado la totalidad de la portada, incluidas las volutas (ver Fig. 260 derecha).

- Álbum de Fotos Grande: en la página 9R se encuentran las fotografías 33, 34 y $35^{384}$, correspondientes a la portada 27 , y en la página $10 \mathrm{~A}$ las fotografías 36,37 y 38 . La

\footnotetext{
382 Lauritzen, V. (1919-1920). Planos. Oliva, Valencia: Museo Municipal de Oliva, Archivo Público Documental, Palacio Condal. (LA1175).

383 Lauritzen, V. (1919-1920). Planos. Oliva, Valencia: Museo Municipal de Oliva, Archivo Público Documental, Palacio Condal. (LA1174).

${ }^{384}$ Fischer, E. (1917-1920). Álbum Fotos Grande. Oliva, Valencia: Museo Municipal de Oliva, Archivo Público Documental, Palacio Condal pp. 10R.
} 
primera tiene unas dimensiones de $17 \times 23 \mathrm{~cm}$ y unos márgenes de $2 \mathrm{~mm}$. En la parte superior, centrado, está rotulado el número de la fotografía. Se trata de una imagen de buena calidad, realizada desde el lateral izquierdo de la portada, donde se la puede ver en su totalidad. Dispone de carpintería de una hoja de cuarterones octogonales, por lo que parece ser original. También se puede ver la portada completa con las volutas superiores (ver Fig. 261). La fotografía 34, de dimensiones $7 \times 7,5 \mathrm{~cm}$, corresponde a una vista más general de la parte superior de la portada. A la derecha vemos parte de la portada 26 (ver Fig. 262 izqda.). La fotografía 35, de dimensiones $7 \times 10$, es una vista frontal parcial de la portada donde se puede ver con mayor detalle la carpintería. Las fotografías 36, 37 y 38, por su parte, corresponden a las piezas 3, 14 y 13, respectivamente, del plano LA1174 una vez desmontadas (ver Fig. 263).

- Álbum de Fotos Pequeño: en la página 8A se encuentra otra copia de la fotografía $36^{385}$, correspondiente a la portada 27 . Las dimensiones son $8 \times 10,5 \mathrm{~cm}$, con márgenes en blanco de $2 \mathrm{~mm}$.

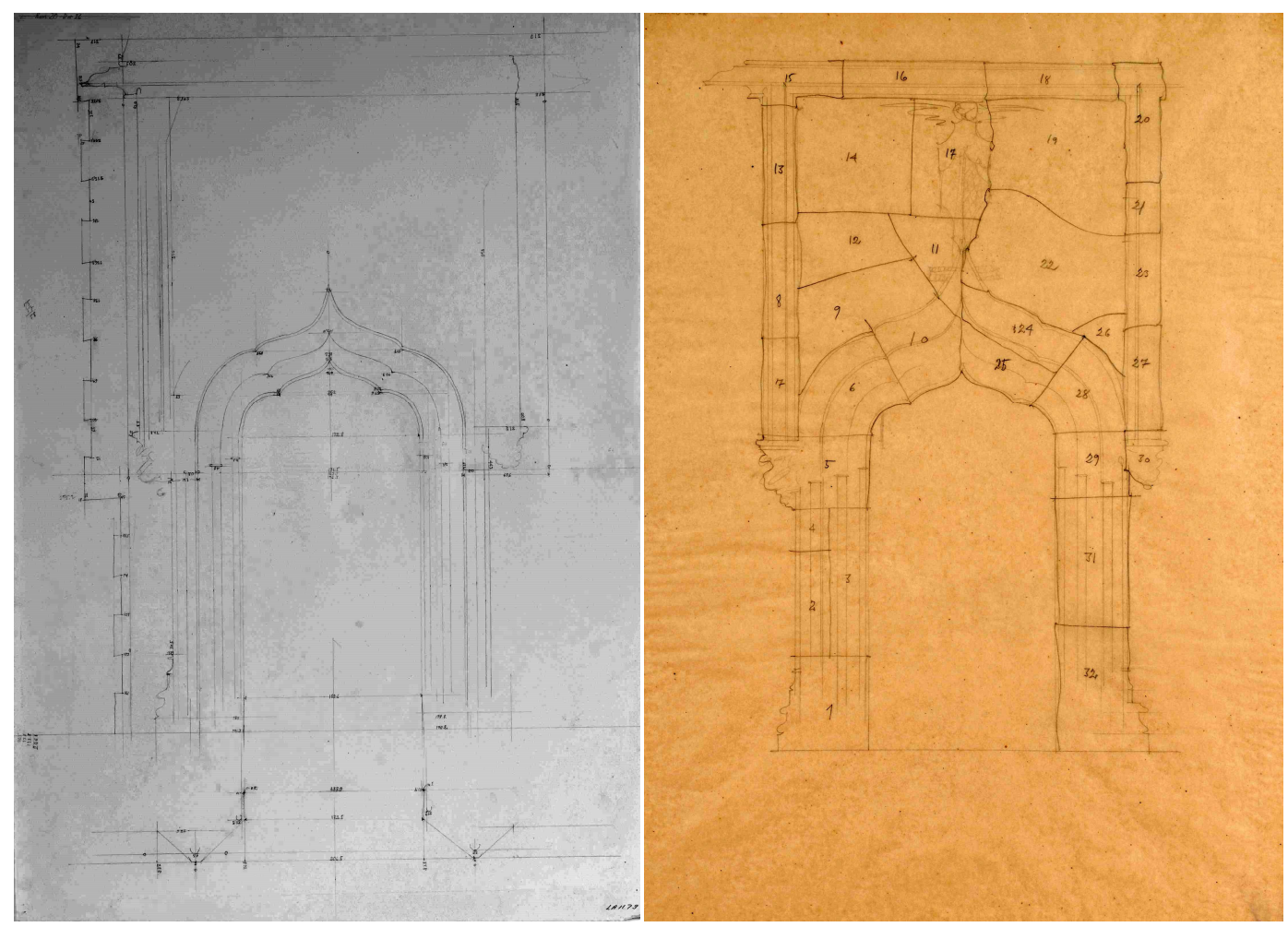

Figura 260. Izquierda: Plano Portada 26. LA1173. V. Lauritzen. Derecha: Plano de Portada 26 en papel de calco. LA1172. V. Lauritzen y/o E. Fischer.

${ }^{385}$ Fischer, E. (1917-1920). Álbum de Fotos Pequeño. Oliva, Valencia: Museo Municipal de Oliva, Archivo Público Documental, Palacio Condal pp. 8A. 

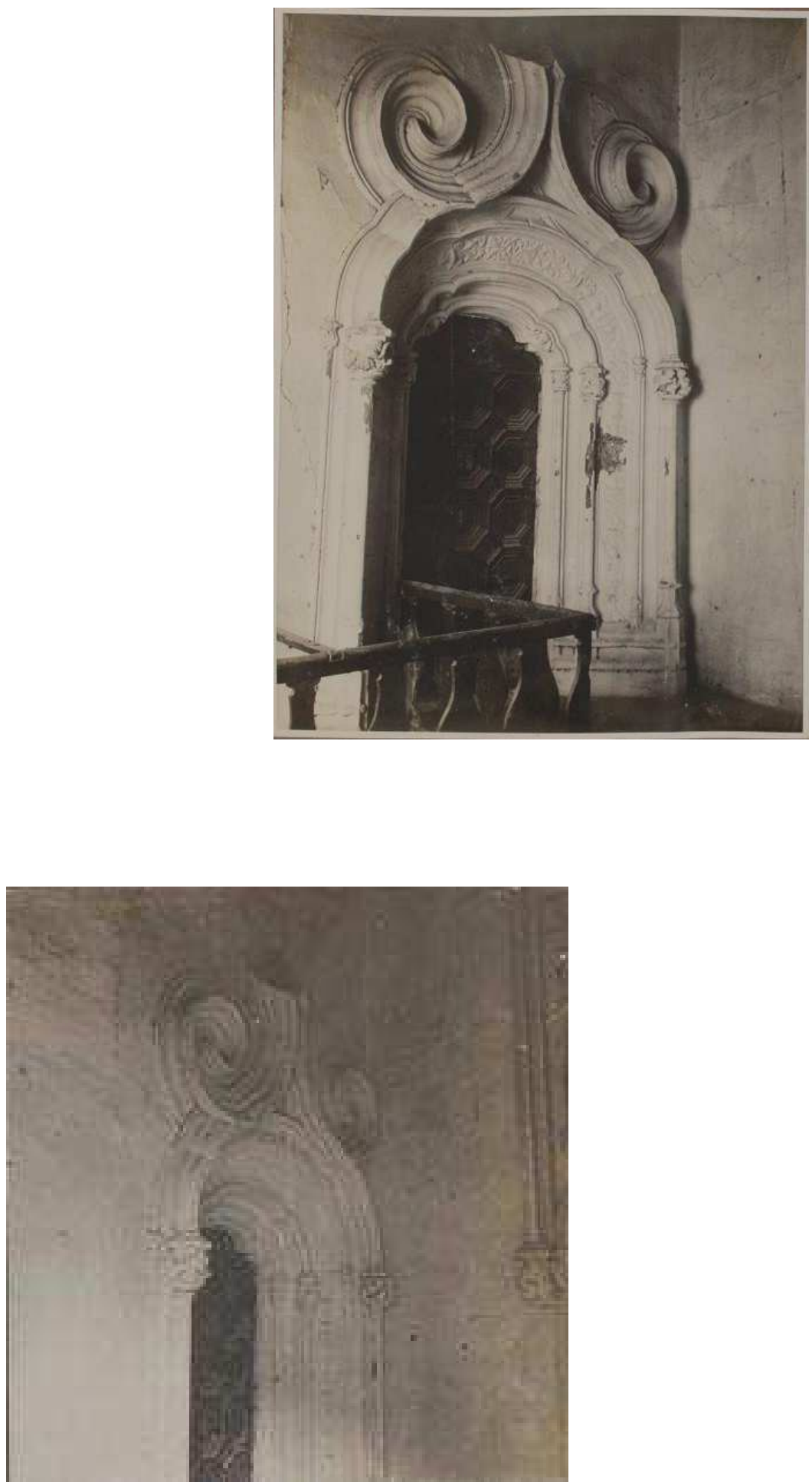


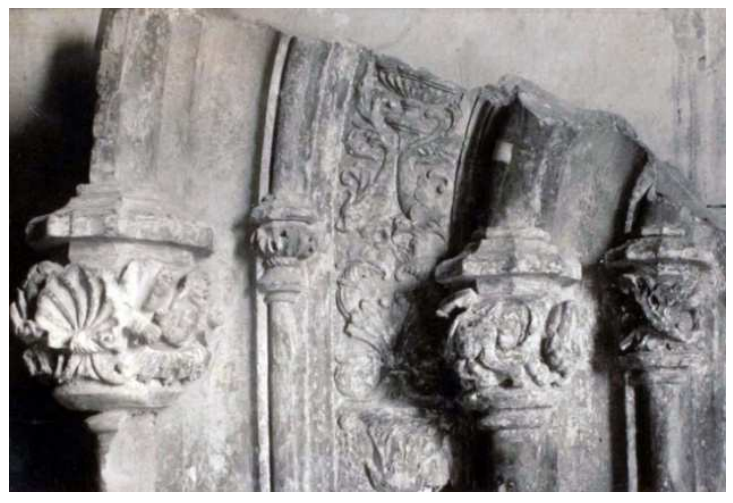


Tabla 35. Ficha Portada 27.

\begin{tabular}{|c|c|c|}
\hline Ficha 27 & Portada 27 (Dör 27) & \\
\hline Localización & Sala 20 (Rum 20) & \\
\hline \multirow[t]{3}{*}{$\begin{array}{l}\text { Documentación } \\
\text { existente }\end{array}$} & Planos & LA1174 y LA1175 \\
\hline & Álbum Fotográfico Grande & Fot. 33 a 38 Pág. 9 R y $10 \mathrm{~A}$ \\
\hline & Álbum Fotográfico Pequeño & Fot. 39.1 Pág 8A \\
\hline \multirow[t]{5}{*}{ Arco Intradós } & Tipo & Angrelado \\
\hline & № Trazados curvos & 5 \\
\hline & № Trazados rectos & 4 \\
\hline & Luz & $1,10 \mathrm{~m}$ \\
\hline & Altura libre & $2,36 \mathrm{~m}$ \\
\hline \multirow[t]{5}{*}{ Arco extradós ${ }^{386}$} & Tipo & Angrelado \\
\hline & № Trazados curvos & 7 \\
\hline & № Trazados rectos & 0 \\
\hline & Luz & $2,23 \mathrm{~m}$ \\
\hline & Altura máxima & $2,98 \mathrm{~m}$ \\
\hline Basa & sí & 5 basas ¿heptagonales? \\
\hline \multirow[t]{24}{*}{ Jamba } & $\begin{array}{l}\text { Molduras del extradós a } \\
\text { intradós: }\end{array}$ & Radio / Longitud \\
\hline & Baqueta & Sin dato \\
\hline & Caveto & Sin dato \\
\hline & Caveto semicircular & Sin dato \\
\hline & Filete & Sin dato \\
\hline & Baqueta & $3,3 \mathrm{~cm}$ \\
\hline & Filete & Sin dato \\
\hline & Caveto semicircular & Sin dato \\
\hline & Filete & Sin dato \\
\hline & Baqueta & $1,6 \mathrm{~cm}$ \\
\hline & Filete & Sin dato \\
\hline & Caveto & Sin dato \\
\hline & Moldura relieve a candeliere & Sin dato \\
\hline & Caveto & Sin dato \\
\hline & Filete & Sin dato \\
\hline & Baqueta & $3,5 \mathrm{~cm}$ \\
\hline & Filete & Sin dato \\
\hline & Caveto semicircular & Sin dato \\
\hline & Filete & Sin dato \\
\hline & Baqueta & $2,0 \mathrm{~cm}$ \\
\hline & Filete & Sin dato \\
\hline & Caveto & Sin dato \\
\hline & Profundidad de jamba & $50,0 \mathrm{~cm}$ \\
\hline & Ángulo jamba & $42^{\circ}$ \\
\hline Capiteles & sí & 5. Sobre columnillas \\
\hline
\end{tabular}

${ }^{386}$ No se consideran las dimensiones de las volutas superiores. 


\section{Portada 28}

La documentación gráfica disponible de la Portada 28 (Dör 28) situada en la Sala 12 según el plano de planta del Palacio es la siguiente:

- Plano LA1144 ${ }^{387}$ : se trata de una puesta a escala dibujada a grafito sobre una lámina de papel de dimensiones $680 \times 470 \mathrm{~mm}$ donde está representado el alzado de la portada y una sección horizontal por las jambas. Las vistas tienen correspondencia diédrica y la disposición del dibujo en la lámina es vertical. Existen líneas auxiliares de dibujo. El plano no dispone de cotas y su escala de representación, como en el resto de las portadas, es 1:10. Se trata de una portada formada por un arco escarzano en su intradós que se transforma en un arco cortinado en su extradós. La portada no tiene capiteles. Cada una de las basas está formada por dos columnillas de planta heptagonal. Las molduras de la jamba desde el extradós al intradós son las siguientes: caveto, baqueta o columnilla, caveto, caveto semicircular, filete, baqueta o columnilla, dos cavetos y jamba curva abocinada. En la parte superior izquierda se encuentra rotulado el nombre de la portada y su ubicación: "Dör 28. Rum 12", y en la parte inferior derecha, la numeración de la lámina: LA1144 (ver Fig. 264 izq.).

- Plano LA1143 ${ }^{388}$ : se trata de una lámina de papel transparente de dimensiones 680 x $490 \mathrm{~mm}$ y disposición vertical. En ella está grafiada una copia del alzado de la portada 28, correspondiente al plano LA1144. En la esquina superior izquierda está rotulado el número de la portada y su localización "Dör 28 (Rum 12)" y en la parte inferior derecha, la numeración de la lámina: LA1143. En este plano están numeradas las piezas en que se desmontó la portadas 28 , de la 1 a la 9 comenzando por la basa izquierda y finalizando por la basa derecha (ver Fig. 264 dcha.).

- Álbum de Fotos Grande: En la página 14R encontramos la misma fotografía $67^{389}$, correspondiente a la portada 28 . Tiene unas dimensiones de $7 \times 10 \mathrm{~cm}$. Sobre la fotografía está rotulado el número de la imagen. No tiene muy buena calidad, pero se puede ver perfectamente la portada en buen estado de conservación. Dispone de carpintería de cuarterones cuadrados (ver Fig. 265).

\footnotetext{
387 Lauritzen, V. (1919-1920). Planos. Oliva, Valencia: Museo Municipal de Oliva, Archivo Público Documental, Palacio Condal. (LA1144).

${ }^{388}$ Lauritzen, V. y/o Fischer, E. (1919-1920). Planos. Oliva, Valencia: Museo Municipal de Oliva, Archivo Público Documental, Palacio Condal. (LA1143).

${ }^{389}$ Fischer, E. (1917-1920). Álbum de Fotos Grande. Oliva, Valencia: Museo Municipal de Oliva, Archivo Público Documental, Palacio Condal. pp. 14R.
} 

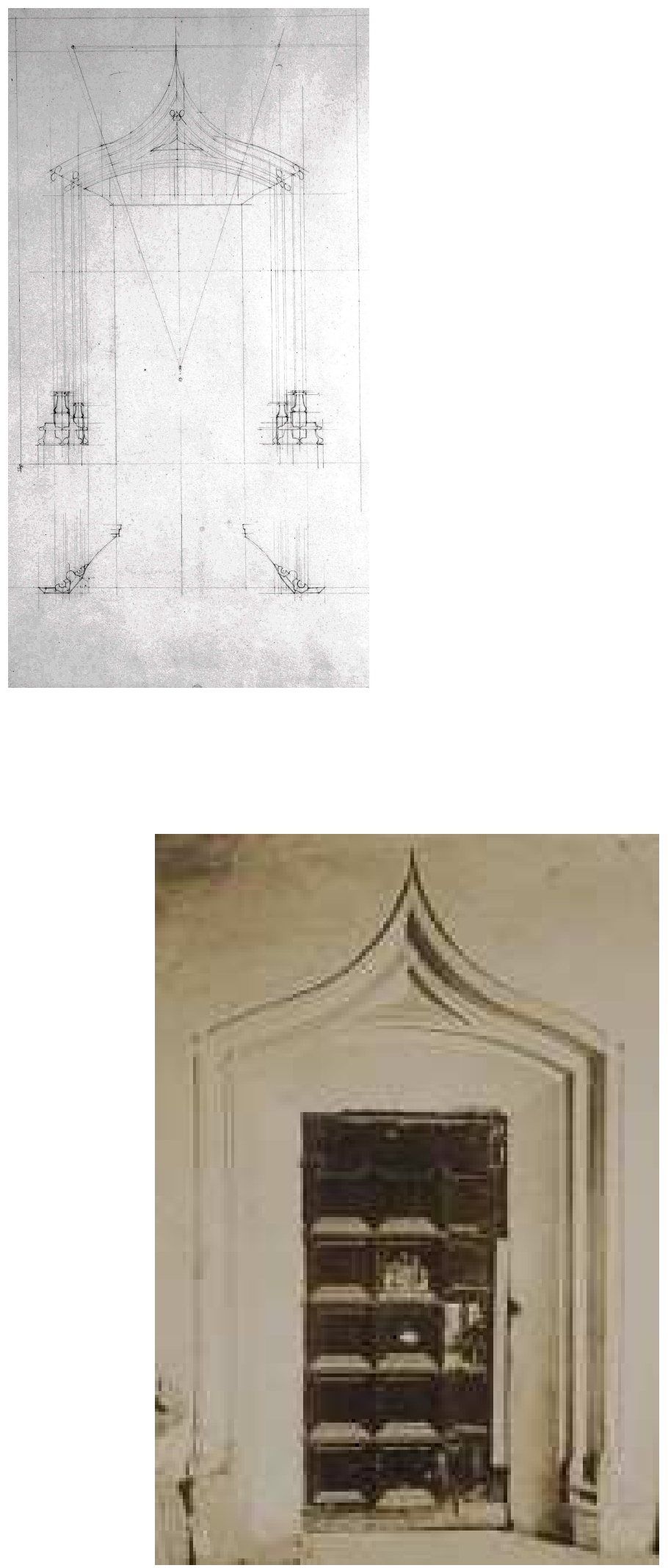
Tabla 36. Ficha Portada 28.

\begin{tabular}{|c|c|c|}
\hline Ficha 28 & \multicolumn{2}{|l|}{ Portada 28 (Dör 28) } \\
\hline Localización & \multicolumn{2}{|l|}{ Sala 12 (Rum12) } \\
\hline \multirow{2}{*}{$\begin{array}{l}\text { Documentación } \\
\text { existente }\end{array}$} & Planos & LA1143 y LA1144 \\
\hline & Álbum Fotográfico Grande & Fot. 64 Pág. 14R \\
\hline \multirow[t]{10}{*}{ Arco Intradós } & Tipo & Escarzano \\
\hline & № Trazados curvos & 1 \\
\hline & № Trazados rectos & 0 \\
\hline & Luz & 1,72 \\
\hline & Altura libre & 2,78 \\
\hline & Tipo & Cortinado escarzano \\
\hline & № Trazados curvos & 3 \\
\hline & № Trazados rectos & 0 \\
\hline & Luz & 2,35 \\
\hline & Altura máxima & 3,91 \\
\hline Basas & sí & 2 basas heptagonales \\
\hline \multirow[t]{13}{*}{ Jamba } & $\begin{array}{l}\text { Molduras del extradós a } \\
\text { intradós: }\end{array}$ & Radio / Longitud \\
\hline & Caveto & $5,0 \mathrm{~cm}$ \\
\hline & Baqueta o columnilla & $3,2 \mathrm{~cm}$ \\
\hline & Caveto & $5,4 \mathrm{~cm}$ \\
\hline & Caveto semicircular & $4,5 \mathrm{~cm}$ \\
\hline & Filete & $2,8 \mathrm{~cm}$ \\
\hline & Baqueta o columnilla & $2,4 \mathrm{~cm}$ \\
\hline & Caveto & $3,8 \mathrm{~cm}$ \\
\hline & Caveto & $3,1 \mathrm{~cm}$ \\
\hline & Profundidad jamba & $21,3 \mathrm{~cm}$ \\
\hline & Ancho jamba & $31,4 \mathrm{~cm}$ \\
\hline & Jamba abocinada (cuerda) & $36,6 \mathrm{~cm}$ \\
\hline & Ángulo jamba & $38^{\circ}$ \\
\hline Capiteles & NO & \\
\hline
\end{tabular}




\section{Portada LA1136}

La documentación gráfica disponible de la Portada LA1136 es la siguiente:

- Planos: Lámina LA1136 $6^{390}$. se trata de una puesta a escala dibujada a grafito sobre una lámina de papel de dimensiones $673 \times 470 \mathrm{~mm}$ donde está representado el alzado de la portada y una sección horizontal a nivel del arranque de las basas. La disposición del dibujo es en vertical. Dispone de diversas cotas tanto de alturas como de anchos de la portada. Las cotas en anchura están representadas mediante cotas lineales y las cortas en altura se representan directamente sobre las líneas del dibujo mediante una cota numérica que indica la altura de esta línea desde el nivel 0 (cota del pavimento donde apoya la portada). La escala de representación es 1:10. El tipo de arco es una variación del inflexo en talón en el intradós y variación del flamígero en el extradós. El grafismo, aunque inacabado nos indica que la portada tenía basas. En cuanto a las molduras, no tenemos información de las mismas, aunque por el grafismo del alzado se deduce que corresponden a un tipo de portada de trazado gótico con dos baquetas de distinto diámetro y caveto semicircular entre ellas, completando la jamba otros cavetos o filetes sin determinar. En la parte superior de la lámina se encuentra rotulada la posible identificación y localización de la portada: "Dör 9? / Rum 8?". Comparando esta lámina con la fotografía 68 correspondiente a la portada 8 comprobamos que no se trata de la misma portada, ya que el arco inferior de la 8 es aquillado en la clave, a diferencia del de la LA1176, y la jamba derecha es tangente a un muro lateral, cosa que no sucede con esta portada, donde el lienzo del muro continúa recto. En la parte inferior derecha se encuentra rotulada la numeración de la lámina en posición horizontal y en posición vertical. También puede verse un texto escrito en danés "Hos fiskerer (sic)", cuya traducción sería "En corrección" (fikserer, no fiskerer) ${ }^{391}$ (ver Fig. 266).

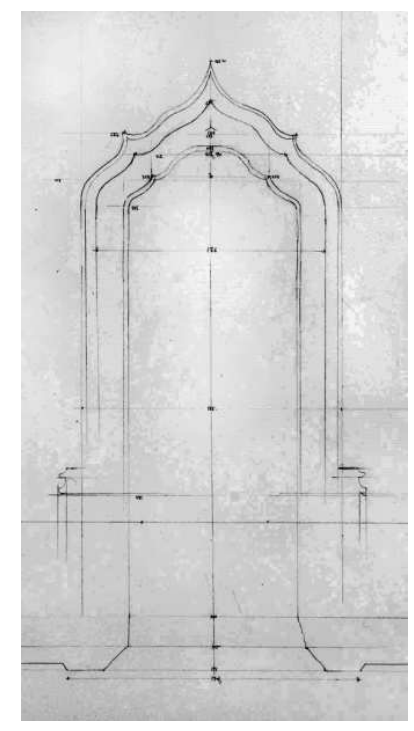

Figura 266. Plano Portada sin numerar LA1136. E. Fischer y/o V. Lauritzen

\footnotetext{
${ }^{390}$ Fischer, E. y Lauritzen V. (1919-1920). Planos. Oliva, Valencia: Museo Municipal de Oliva, Archivo Público Documental, Palacio Condal. (LA1136).

${ }^{391}$ Gavara Prior, Joan J. y E. Muller, Priscilla. El Palacio Condal de Oliva. Catálogo de los planos de Egil Fischer y Vilhelm Lauritzen. Valencia, España: Diputación de Valencia. pp. 99.
} 
Tabla 47. Ficha Portada sin numerar LA1136.

\begin{tabular}{|c|c|c|}
\hline Ficha 29 & \multicolumn{2}{|l|}{ Portada sin numerar (LA1136) } \\
\hline Localización & \multicolumn{2}{|l|}{ Sin identificar } \\
\hline \multirow{3}{*}{$\begin{array}{l}\text { Documentación } \\
\text { existente }\end{array}$} & Planos & LA1136 \\
\hline & Álbum Fotográfico Grande & NO \\
\hline & Álbum Fotográfico Pequeño & NO \\
\hline \multirow[t]{5}{*}{ Arco Intradós } & Tipo & $\begin{array}{c}\text { Variación del inflexo en } \\
\text { talón }\end{array}$ \\
\hline & № Trazados curvos & 9 \\
\hline & № Trazados rectos & 0 \\
\hline & Luz & 0,95 \\
\hline & Altura libre & 2,19 \\
\hline \multirow[t]{5}{*}{ Arco Extradós } & Tipo de arco & Variación del flamígero \\
\hline & № Trazados curvos & 10 \\
\hline & № Trazados rectos & 0 \\
\hline & Luz & 1,44 \\
\hline & Altura máxima & 2,41 \\
\hline Basa & Sin datos & $\begin{array}{l}\text { ¿2 columnillas } \\
\text { Heptagonales? }\end{array}$ \\
\hline \multirow[t]{11}{*}{ Jamba } & $\begin{array}{l}\text { Molduras del extradós a } \\
\text { intradós: }\end{array}$ & Radio /Longitud \\
\hline & ¿Caveto? & -- \\
\hline & Baqueta o columnilla & -- \\
\hline & ¿Filete o caveto? & $3,2 \mathrm{~cm}$ \\
\hline & ¿Caveto semicircular? & -- \\
\hline & ¿Filete o caveto? & -- \\
\hline & Baqueta o columnilla & -- \\
\hline & ¿Caveto? & -- \\
\hline & Profundidad jamba & $10,3 \mathrm{~cm}$ \\
\hline & Ancho jamba & $29,1 \mathrm{~cm}$ \\
\hline & Ángulo jamba & -- \\
\hline Capitel & NO & \\
\hline
\end{tabular}




\section{Portada LA1176}

La documentación gráfica disponible de la Portada LA1176 es la siguiente:

- Planos: Lámina LA1176 ${ }^{392}$. se trata de una puesta a escala dibujada a grafito sobre una lámina de papel de dimensiones $680 \times 470 \mathrm{~mm}$ donde está representado el alzado de la portada y una sección horizontal a nivel del arranque de las basas. La disposición del dibujo es vertical. Dispone de diversas cotas tanto de alturas como de anchos de la portada. Las cotas en anchura están representadas mediante cotas lineales y las cortas en altura se representan directamente sobre las líneas del dibujo mediante una cota numérica que expresa la altura de esta línea desde el nivel 0 (cota del pavimento donde apoya la portada). Aunque no está rotulada, la escala de representación es 1:10. El tipo de arco es inflexo en talón mixtilíneo. El grafismo, aunque inacabado, nos indica que la portada tenía basas. En cuanto a las molduras no tenemos información de las mismas, aunque del grafismo del alzado se deduce que corresponde a un tipo de portada de trazado gótico con dos baquetas de distinto diámetro y caveto semicircular entre ellas, completando la jamba otros cavetos o filetes sin determinar. En la parte inferior derecha se encuentra rotulada la numeración de la lámina en posición horizontal, y en posición vertical aparece el texto en danés "Hosfiskerer (sic)", cuya traducción sería "En corrección" (fikserer, no fiskerer) ${ }^{393}$ (ver Fig. 267).

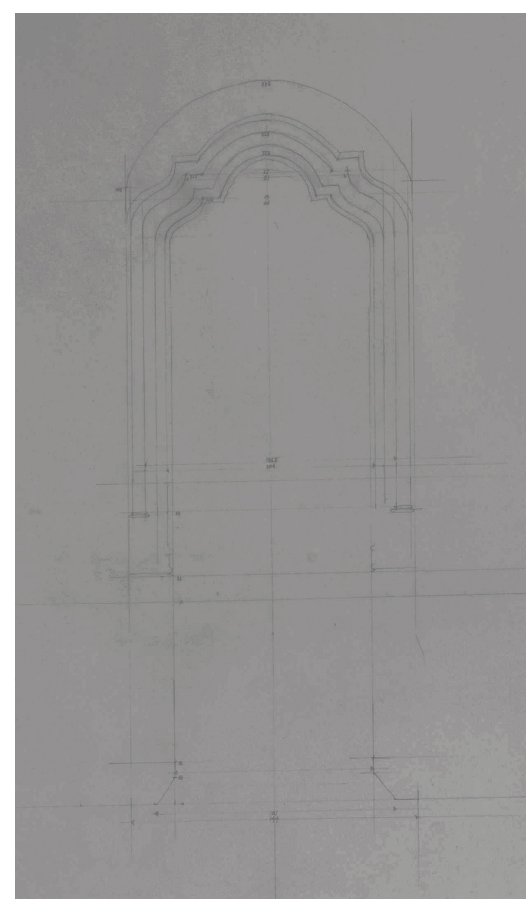

Figura 267. Plano Portada sin numerar LA1176. E. Fischer y/o V. Lauritzen

\footnotetext{
392 Fischer, E. y Lauritzen V. (1919-1920). Planos. Oliva, Valencia: Museo Municipal de Oliva, Archivo Público Documental, Palacio Condal. (LA1176).

${ }^{393}$ Gavara Prior, Joan J. y E. Muller, Priscilla. Óp. cit. pp. 139.
} 
Tabla 38. Ficha Portada sin numerar LA1176.

\begin{tabular}{|c|c|c|}
\hline Ficha 30 & \multicolumn{2}{|l|}{ Portada sin numerar (LA1176) } \\
\hline Localización & \multicolumn{2}{|l|}{ Sin identificar } \\
\hline \multirow{3}{*}{$\begin{array}{l}\text { Documentación } \\
\text { existente }\end{array}$} & Planos & LA1176 \\
\hline & Álbum Fotográfico Grande & NO \\
\hline & Álbum Fotográfico Pequeño & NO \\
\hline \multirow[t]{5}{*}{ Arco Intradós } & Tipo & Inflexo en talón/Mixtilíneo \\
\hline & № Trazados curvos & 5 \\
\hline & № Trazados rectos & 2 \\
\hline & Luz & 0,98 \\
\hline & Altura libre & 2,19 \\
\hline \multirow[t]{5}{*}{ Arco Extradós } & Tipo de arco & Inflexo en talón/Mixtilíneo \\
\hline & № Trazados curvos & 5 \\
\hline & № Trazados rectos & 2 \\
\hline & Luz & 1,44 \\
\hline & Altura máxima & 2,41 \\
\hline Basa & Sin datos & $\begin{array}{c}2 \text { columnillas } \\
\text { ¿Heptagonales? }\end{array}$ \\
\hline \multirow[t]{12}{*}{ Jamba } & $\begin{array}{l}\text { Molduras del extradós a } \\
\text { intradós: }\end{array}$ & Radio /Longitud \\
\hline & ¿Caveto? & -- \\
\hline & Baqueta o columnilla & -- \\
\hline & ¿Filete o caveto? & $3,0 \mathrm{~cm}$ \\
\hline & ¿Caveto semicircular? & -- \\
\hline & ¿Filete o caveto? & -- \\
\hline & Baqueta o columnilla & -- \\
\hline & ¿Caveto? & $2,3 \mathrm{~cm}$ \\
\hline & ¿Caveto? & \\
\hline & Profundidad jamba & -- \\
\hline & Ancho jamba & $22,5 \mathrm{~cm}$ \\
\hline & Ángulo jamba & -- \\
\hline Capitel & NO & \\
\hline
\end{tabular}




\section{Portada LA1177}

La documentación gráfica disponible de la Portada LA1177 es la siguiente:

- Planos: Lámina LA1177 $7^{394}$. se trata de una puesta a escala dibujada a grafito sobre una lámina de papel de dimensiones $680 \times 470 \mathrm{~mm}$ donde está representado el alzado de la portada y una sección horizontal a nivel del arranque de las basas. La disposición del dibujo es vertical. Tiene diversas cotas tanto de alturas como de anchos. Las cotas en anchura están representadas mediante cotas lineales y las cortas en altura se representan directamente sobre las líneas del dibujo mediante una cota numérica que expresa la altura de esta línea desde el nivel 0 (cota del pavimento donde apoya la portada). Aunque no está rotulada, la escala de representación es 1:10. Esto se deduce al comprobar las cotas grafiadas con el tamaño real del dibujo y con la escala de referencia utilizada para la digitalización de los planos. El tipo de arco es angrelado/mixtilíneo. El grafismo, aunque inacabado, nos indica que la portada tenía capiteles y basas. En cuanto a las molduras no tenemos información de las mismas, aunque del grafismo del alzado se deduce que corresponde a una portada de trazado gótico con dos baquetas de distinto diámetro y caveto semicircular entre ellas, completando la jamba otros cavetos o filetes sin determinar. En la parte inferior derecha se encuentra rotulada la numeración de la lámina en posición horizontal, y en posición vertical aparece el texto en danés "Hosfiskerer (sic)", cuya traducción sería "En corrección" (fikserer, no fiskerer) ${ }^{395}$ (Fig. 268).

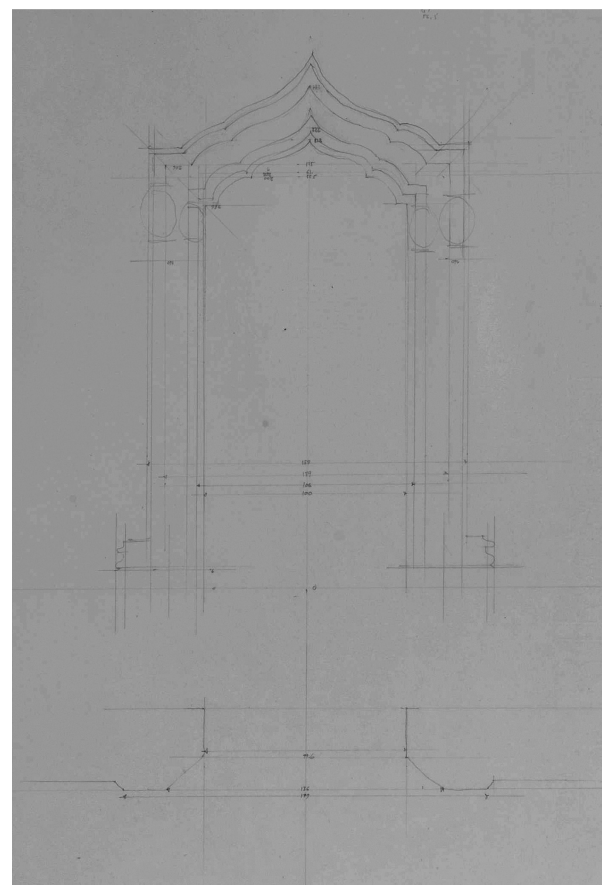

Figura 268. Plano Portada sin numerar LA1177 (detalle). E. Fischer y V. Lauritzen.

${ }^{394}$ Fischer, E. y Lauritzen V. (1917-1920) Planos. Oliva, Valencia: Museo Municipal de Oliva, Archivo Público Documental, Palacio Condal. (LA1177).

${ }^{395}$ Gavara Prior, Joan J. y E. Muller, Priscilla. Óp. Cit. pp. 140. 
Tabla 39. Ficha Portada sin numerar LA1177.

\begin{tabular}{|c|c|c|}
\hline Ficha 31 & Portada sin numerar (LA1177) & \\
\hline Localización & Sin identificar & \\
\hline \multirow{3}{*}{$\begin{array}{l}\text { Documentación } \\
\text { existente }\end{array}$} & Planos & LA1177 \\
\hline & Álbum Fotográfico Grande & NO \\
\hline & Álbum Fotográfico Pequeño & NO \\
\hline \multirow[t]{5}{*}{ Arco Intradós } & Tipo & Angrelado/Mixtilíneo \\
\hline & № Trazados curvos & 6 \\
\hline & № Trazados rectos & 2 \\
\hline & Luz & 1,04 \\
\hline & Altura libre & 2,21 \\
\hline \multirow[t]{5}{*}{ Arco Extradós } & Tipo de arco & Angrelado/Mixtilíneo \\
\hline & № Trazados curvos & 6 \\
\hline & № Trazados rectos & 2 \\
\hline & Luz & 1,62 \\
\hline & Altura máxima & 2,63 \\
\hline Basa & Sin datos & $\begin{array}{c}2 \text { columnillas } \\
\text { ¿heptagonales? }\end{array}$ \\
\hline \multirow[t]{11}{*}{ Jamba } & $\begin{array}{l}\text { Molduras del extradós a } \\
\text { intradós: }\end{array}$ & Radio /Longitud \\
\hline & ¿Caveto? & -- \\
\hline & Baqueta o columnilla & -- \\
\hline & ¿Filete o caveto? & $3,2 \mathrm{~cm}$ \\
\hline & ¿Caveto semicircular? & -- \\
\hline & ¿Filete o caveto? & -- \\
\hline & Baqueta o columnilla & $2,5 \mathrm{~cm}$ \\
\hline & ¿Caveto? & -- \\
\hline & Ancho jamba & $28,6 \mathrm{~cm}$ \\
\hline & Profundidad jamba & $13,3 \mathrm{~cm}$ \\
\hline & Ángulo jamba & -- \\
\hline Capitel & sí & 2 por jamba \\
\hline
\end{tabular}




\section{Portada LA1191}

La documentación gráfica disponible de la Portada LA1191 es la siguiente:

- Planos: Lámina LA1191 ${ }^{396}$. Se trata de una puesta a escala dibujada a grafito sobre una lámina de papel de dimensiones $680 \times 470 \mathrm{~mm}$ donde está representado el alzado de la portada y una sección horizontal a nivel del arranque de las basas. La disposición del dibujo es vertical. Dispone de diversas cotas tanto de alturas como de anchos de la portada. Las cotas en anchura están representadas mediante cotas lineales y las cortas en altura se representan directamente sobre las líneas del dibujo mediante una cota numérica que expresa la altura de esta línea desde el nivel 0 (cota del pavimento donde apoya la portada). Aunque no está rotulada, la escala de representación es 1:10. Esto se deduce al comprobar las cotas grafiadas con el tamaño real del dibujo y con la escala de referencia utilizada para la digitalización de los planos. El tipo de arco es escarzano. El grafismo, aunque inacabado, nos indica que la portada tenía capiteles y basas. En cuanto a las molduras, no tenemos información de las mismas, aunque del grafismo del alzado se deduce que corresponde a una portada de trazado gótico con dos baquetas de distinto diámetro y caveto semicircular entre ellas, completando la jamba otros cavetos o filetes sin determinar. La portada se encuentra localizada en un muro de gran espesor con una jamba abocinada. En la parte inferior derecha se encuentra rotulada la numeración de la lámina en posición horizontal, y en posición vertical aparece el texto en danés "Hosfiskerer (sic)", cuya traducción sería "En corrección" (fikserer, no fiskerer) ${ }^{397}$, (ver fig. 269).

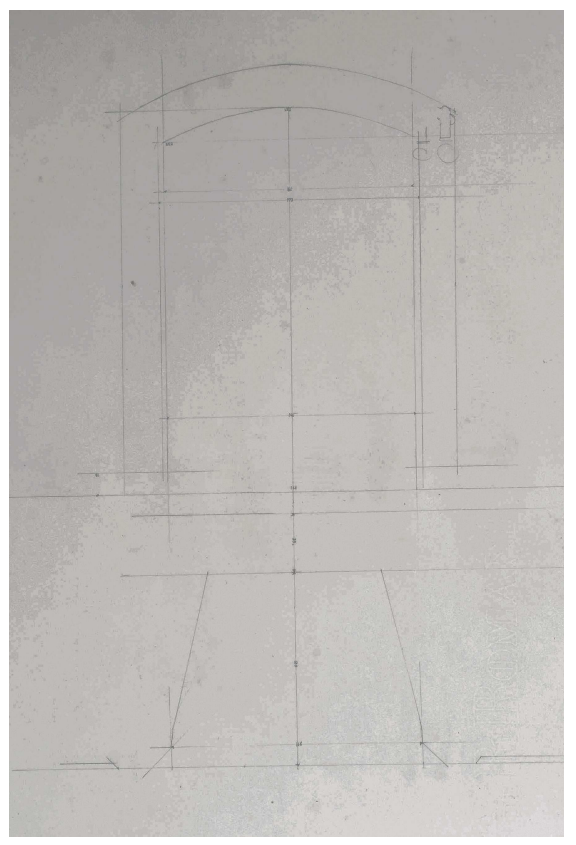

Figura 269. Plano Portada sin numerar.LA1191. E. Fischer y/o V. Lauritzen

\footnotetext{
${ }^{396}$ Fischer, E. y Lauritzen V. (1917-1920). Planos. Oliva, Valencia: Museo Municipal de Oliva, Archivo Público Documental, Palacio Condal. (LA1191).

${ }^{397}$ Gavara Prior, Joan J. y E. Muller, Priscilla. Óp. cit. pp. 155.
} 
Tabla 40. Ficha Portada sin numerar LA1191.

\begin{tabular}{|c|c|c|}
\hline Ficha 32 & Portada sin numerar (LA1191) & \\
\hline Localización & Sin identificar & \\
\hline \multirow{3}{*}{$\begin{array}{l}\text { Documentación } \\
\text { existente }\end{array}$} & Planos & LA1191 \\
\hline & Álbum Fotográfico Grande & NO \\
\hline & Álbum Fotográfico Pequeño & NO \\
\hline \multirow[t]{5}{*}{ Arco Intradós } & Tipo & Escarzano \\
\hline & № Trazados curvos & 1 \\
\hline & № Trazados rectos & 0 \\
\hline & Luz & 1,65 \\
\hline & Altura libre & 2,51 \\
\hline \multirow[t]{5}{*}{ Arco Extradós } & Tipo de arco & Escarzano \\
\hline & № Trazados curvos & 1 \\
\hline & № Trazados rectos & 0 \\
\hline & Luz & 2,20 \\
\hline & Altura máxima & 2,80 \\
\hline Basa & Sin datos & $\begin{array}{l}2 \text { columnillas } \\
\text { (heptagonales) }\end{array}$ \\
\hline \multirow[t]{11}{*}{ Jamba } & $\begin{array}{l}\text { Molduras del extradós a } \\
\text { intradós: }\end{array}$ & Radio /Longitud \\
\hline & ¿Caveto? & -- \\
\hline & Baqueta o columnilla & -- \\
\hline & ¿Filete o caveto? & $3,2 \mathrm{~cm}$ \\
\hline & ¿Caveto semicircular? & -- \\
\hline & ¿Filete o caveto? & -- \\
\hline & Baqueta o columnilla & $2,6 \mathrm{~cm}$ \\
\hline & ¿Caveto? & -- \\
\hline & Profundidad jamba & $9,4 \mathrm{~cm}$ \\
\hline & Ancho jamba & $38 \mathrm{~cm}$ \\
\hline & Ángulo jamba & -- \\
\hline Capitel & sí & 2 por jamba \\
\hline
\end{tabular}




\section{Portada LA1192}

La documentación gráfica disponible de la Portada LA1192 es la siguiente:

- Planos: Lámina LA1192 ${ }^{398}$. se trata de una puesta a escala dibujada a grafito sobre una lámina de papel de dimensiones $680 \times 470 \mathrm{~mm}$ donde está representado el alzado de la portada y una sección horizontal a nivel del arranque de las basas. La disposición del dibujo es vertical. Dispone de diversas cotas tanto de alturas como de anchos de la portada. Las cotas en anchura están representadas mediante cotas lineales y las cortas en altura se representan directamente sobre las líneas del dibujo mediante una cota numérica que expresa la altura de esta línea desde el nivel 0 (cota del pavimento donde apoya la portada). Aunque no está rotulada, la escala de representación es 1:10. Esto se deduce al comprobar las cotas grafiadas con el tamaño real del dibujo y con la escala de referencia utilizada para la digitalización de los planos. El tipo de arco es escarzano. El grafismo, aunque inacabado, nos indica que la portada tenía capiteles y basas. En cuanto a las molduras, no tenemos información de las mismas, aunque del grafismo del alzado se deduce que corresponde a una portada de trazado gótico con dos baquetas de distinto diámetro y caveto semicircular entre ellas, completando la jamba otros cavetos o filetes sin determinar. La portada se encuentra localizada en un muro de gran espesor con una jamba abocinada. En la parte inferior derecha se encuentra rotulada la numeración de la lámina en posición horizontal, y en posición vertical aparece el texto en danés "Hosfiskerer (sic)", cuya traducción sería "En corrección" (fikserer, no fiskerer) ${ }^{399}$, (ver Fig. 270). Se trata de una portada con idénticas características a la LA1191, aunque con distintas medidas.

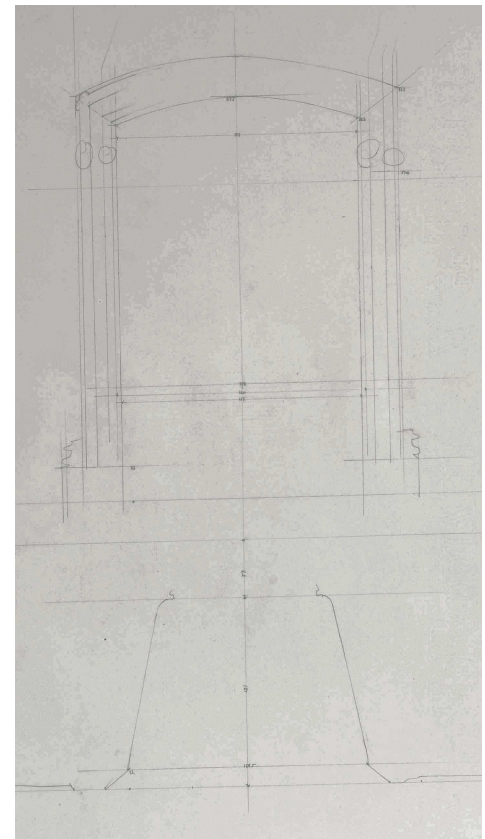

Figura 270. Plano Portada sin numerar. LA1192. E. Fischer y V. Lauritzen

${ }^{398}$ Fischer, E. y Lauritzen V. (1917-1920). Planos. Oliva, Valencia: Museo Municipal de Oliva, Archivo Público Documental, Palacio Condal. (LA1192).

${ }^{399}$ Gavara Prior, Joan J. y E. Muller, Priscilla. Óp. cit. pp. 156. 
Tabla 41. Ficha Portada sin numerar LA1192.

\begin{tabular}{|c|c|c|}
\hline Ficha 33 & \multicolumn{2}{|l|}{ Portada sin numerar (LA1192) } \\
\hline Localización & \multicolumn{2}{|l|}{ Sin identificar } \\
\hline \multirow{3}{*}{$\begin{array}{l}\text { Documentación } \\
\text { existente }\end{array}$} & Planos & LA1192 \\
\hline & Álbum Fotográfico Grande & NO \\
\hline & Álbum Fotográfico Pequeño & NO \\
\hline \multirow[t]{5}{*}{ Arco Intradós } & Tipo & Escarzano \\
\hline & № Trazados curvos & 1 \\
\hline & № Trazados rectos & 0 \\
\hline & Luz & 1,53 \\
\hline & Altura libre & 2,55 \\
\hline \multirow[t]{5}{*}{ Arco Extradós } & Tipo de arco & Escarzano \\
\hline & № Trazados curvos & 1 \\
\hline & № Trazados rectos & 0 \\
\hline & Luz & 2,05 \\
\hline & Altura máxima & 2,82 \\
\hline Basa & Sin datos & $\begin{array}{c}2 \text { columnillas } \\
\text { ¿heptagonales? }\end{array}$ \\
\hline \multirow[t]{11}{*}{ Jamba } & Molduras del extradós a intradós: & Radio /Longitud \\
\hline & ¿Caveto? & -- \\
\hline & Baqueta o columnilla & -- \\
\hline & ¿Filete o caveto? & $3,2 \mathrm{~cm}$ \\
\hline & ¿Caveto semicircular? & -- \\
\hline & ¿Filete o caveto? & -- \\
\hline & Baqueta o columnilla & $2,7 \mathrm{~cm}$ \\
\hline & ¿Caveto? & -- \\
\hline & Profundidad jamba & $9,7 \mathrm{~cm}$ \\
\hline & Ancho jamba & $26 \mathrm{~cm}$ \\
\hline & Ángulo jamba & -- \\
\hline Capitel & sí & 2 por jamba \\
\hline
\end{tabular}




\section{Portada Escalera de Honor}

La documentación gráfica disponible de esta portada es la siguiente:

- Álbum Fotográfico Grande. Disponemos de dos fotografías de la portada: Fot. 52 y Fot. $53^{400}$ (ver Fig. 271). Las dimensiones de las fotografías son $8 \times 11 \mathrm{~cm}$ y en ellas podemos ver dos vistas de la portada. En la primera se observa una vista lateral de la misma desde la galería sur del Patio de Armas y la segunda es una vista frontal de la misma tomada desde la galería este del Patio de Armas. En base a ellas podemos observar las características de la portada. El tipo de arco es angrelado/mixtilíneo enmarcado en un alfiz perimetral, en las enjuntas hay dos grandes medallones en relieve que representan dos bustos. Dispone de basas de las que parten dos pequeñas basas poligonales (posiblemente heptagonales) de las que, a su vez, nacen los cavetos o columnillas. En cuanto a las molduras, no disponemos de información de las mismas, aunque del grafismo del alzado se deduce que corresponde con un tipo de portada de trazado gótico con dos baquetas de distinto diámetro y caveto semicircular entre ellas, completando la jamba otros cavetos o filetes sin determinar. Tiene 3 parejas de capiteles que enrasan superiormente con la línea de impostas. Dos de ellos apoyan en las columnillas y el tercero nace del lienzo del muro y sobre él arranca el alfiz que enmarca el extradós del arco. Los capiteles tienen decoración vegetal (los pequeños) y formas zooformes los dos exteriores, de mayor tamaño. Dispone de carpintería sencilla de cuarterones, que presumiblemente no es la original. Tiene delante una barandilla sencilla de barrotes verticales formando un balcón y, bajo ella, un alero de teja. Esta portada formaba parte de un conjunto de dos dispuestas simétricamente formando un ángulo de 90ㅇ, siendo el acceso principal a la planta noble desde la escalera de honor del palacio. Esta portada accedía a la Sala 20, y su gemela a la sala que delimitaba el Patio de Armas en su lado sur, y que fue demolido para abrir la calle y parcelar el Palacio. Este conjunto era similar al que podemos contemplar en el patio de la Generalitat Valenciana a la subida de su escalera de honor, con dos arcos flamígeros labrados en piedra enmarcados en alfices y con medallones en sus enjuntas.

- Álbum Fotográfico Pequeño. En él encontramos la fotografía $53^{401}$. Las dimensiones de la fotografía son $9 \times 15 \mathrm{~cm}$ y tiene márgenes en blanco. Se trata de la misma toma de la Fot. 53 del Álbum Grande. Sobre el lateral derecho está rotulado el número de la foto y en la parte inferior "C 1:50" (Escala 1:50). Sobre la fotografía se han acotado el hueco de paso y las medidas totales (ver Fig. 271 derecha), así como el despiece de las distintas piezas de cantería que componen la portada, numeradas de la 1 a la 31 . Las piezas 1 a 9 corresponden al alfiz y enjuntas, y de la 11 a la 31 al resto de piezas que componen la portada comenzando por la basa izquierda y finalizando por la derecha.

\footnotetext{
${ }^{400}$ Fischer, E. (1917-1920). Álbum Fotos Grande. Oliva, Valencia: Museo Municipal de Oliva, Archivo Público Documental, Palacio Condal. pp. 12R.

${ }^{401}$ Fischer, E. (1917-1920). Álbum Fotos Pequeño. Oliva, Valencia: Museo Municipal de Oliva, Archivo Público Documental, Palacio Condal. pp. 9 R.
} 


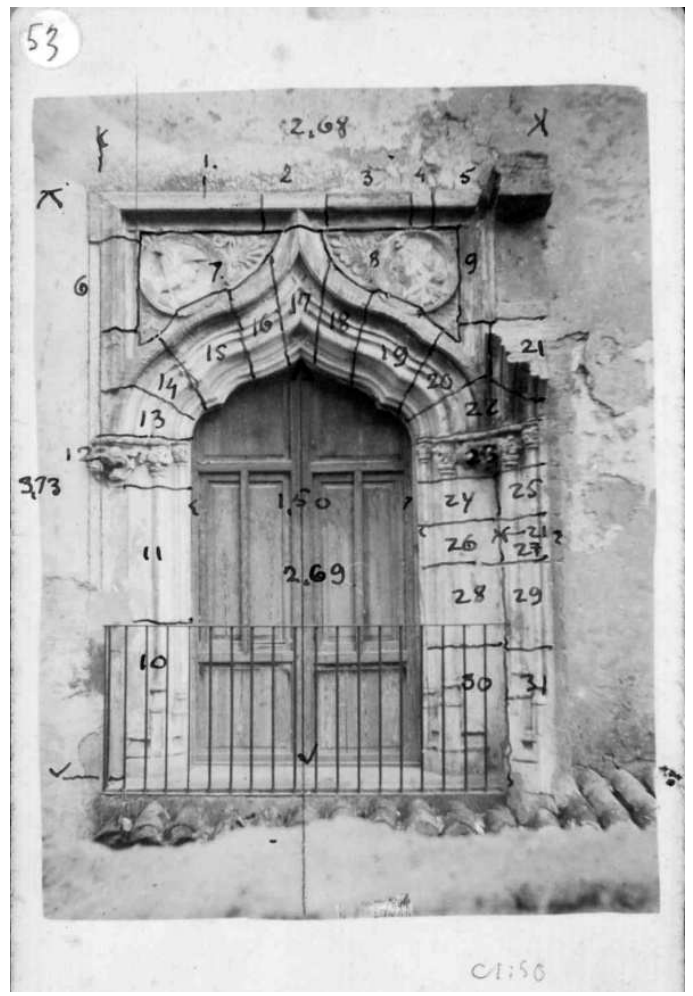


Tabla 42. Ficha Portada Escalera Honor.

\begin{tabular}{|c|c|c|}
\hline Ficha 34 & \multicolumn{2}{|l|}{ Portada Escalera Honor } \\
\hline Localización & \multicolumn{2}{|l|}{ Patio de Armas } \\
\hline \multirow{3}{*}{$\begin{array}{l}\text { Documentación } \\
\text { existente }\end{array}$} & Planos & NO \\
\hline & Álbum Fotográfico Grande & 52 y 53. Pág.12R \\
\hline & Álbum Fotográfico Pequeño & 53. Pág.9R \\
\hline \multirow[t]{5}{*}{ Arco Intradós } & Tipo & Variación del flamígero \\
\hline & № Trazados curvos & 8 \\
\hline & № Trazados rectos & 0 \\
\hline & Luz & 1,5 \\
\hline & Altura libre & 2,69 \\
\hline \multirow[t]{5}{*}{ Arco Extradós } & Tipo de arco & Variación del Flamígero \\
\hline & № Trazados curvos & 8 \\
\hline & № Trazados rectos & 0 \\
\hline & Luz & 2,68 \\
\hline & Altura máxima & 3,73 \\
\hline Basa & Sin datos & $\begin{array}{c}2 \text { columnillas } \\
\text { ¿heptagonales? }\end{array}$ \\
\hline \multirow[t]{11}{*}{ Jamba } & Molduras del extradós a intradós: & Radio / Longitud \\
\hline & ¿Caveto? & -- \\
\hline & Baqueta o columnilla & -- \\
\hline & ¿Filete o caveto? & $3,0 \mathrm{~cm}$ \\
\hline & ¿Caveto semicircular? & -- \\
\hline & ¿Filete o caveto? & -- \\
\hline & Baqueta o columnilla & $2,0 \mathrm{~cm}$ \\
\hline & ¿Caveto? & -- \\
\hline & Profundidad jamba & --- \\
\hline & Ancho jamba & -- \\
\hline & Ángulo jamba & -- \\
\hline Capitel & sí & 3 por jamba \\
\hline
\end{tabular}




\section{TIPOS DE ARCOS}

En este apartado analizaremos los distintos tipos de arcos existentes en las portadas documentadas por Fischer y Lauritzen; estos son muy variados, encontrándonos con todo un catálogo de trazados, que van desde el más sencillo arco escarzano de un solo centro a los trazados más complejos: variación del flamígero de 10 centros (portada sin identificar LA1136) o mixtilíneo/variación del flamígero de 16 centros y 4 tramos rectos (Portada 15). Todos ellos tienen trazados normalizados mediante trazos rectos y arcos de circunferencia que se unen entre sí mediante puntos de tangencia o de corte. Los tipos de arco documentados en portadas son las siguientes: escarzano, carpanel, flamígero aquillado, mixtilíneo variación del flamígero, inflexo en talón roto, variación del flamígero, mixtilíneo cortinado, adintelado, mixtilíneo carpanel; trilobulado rebajado, flamígero aquillado mixtilíneo, angrelado, angrelado mixtilíneo, trilobulado carpanel mixtilíneo, polilobulado rebajado, polilobulado mixtilíneo rebajado, cortinado escarzano, rebajado e inflexo en talón mixtilíneo. En las 33 portadas documentadas por Egil Fischer y Vilhelm Lauritzen encontramos 18 tipos de arcos distintos, si bien geométricamente no existen dos arcos iguales. En algunos de ellos el tipo y la morfología del arco varía desde el intradós al extradós del mismo, produciéndose una metamorfosis de dichos trazados en las diferentes molduras que componen su sección.

Los trazados de los arcos evidencian que se trata de un estilo gótico tardío (flamígeros aquillados, cortinados, mixtilíneos), así como sus influencias mudéjares (polilobulados).

Dentro de la clasificación de las portadas según las características de los arcos estableceremos dos grupos: en el primer grupo incluiremos las portadas de arcos uniformes y en el segundo, relacionaremos todos aquellos arcos que sufren una transformación en su trazado desde el intradós hasta el extradós.

Para identificar y nombrar cada uno de los arcos se han utilizado varias clasificaciones ${ }^{402}$. En el caso de arcos complejos se le ha dado un nombre que identifique todas sus características geométricas; siempre que en su trazado se inserten tramos rectos se le ha añadido el calificativo de "mixtilíneo", independientemente del tipo de arco principal.

En esta clasificación se incluirán la totalidad de las portadas grafiadas en la documentación de Fischer y Lauritzen.

\subsection{Portadas de arcos uniformes}

En este primer grupo clasificaremos las portadas que mantienen su trazado geométrico en todas las molduras que componen su arco, desde su intradós hasta su extradós, según su trazado geométrico:

\footnotetext{
402 Sánchez, N. (2011). Geometría de los arcos. Guía para la construcción y trazado de arcos. Murcia: Región de Murcia. Consejería de Educación, Formación y Empleo, Moreno García, F. (2004). Arcos y bóvedas. Barcelona: Ediciones CEAC. 99. 14-39 y Rodríguez de Abajo, F.J. y Álvarez Bengoa, V. (1987). Curso de dibujo geométrico y de croquización. Alcoy, Alicante: Editorial Marfil, S.A. pp. 165-175.
} 
- Arco adintelado: se trata de un trazado lineal. Aunque en las portadas no se aprecia un despiece de dovelas, consideramos su trazado como un arco adintelado e incluiremos dentro de este grupo la Portada 11 . Tiene la peculiaridad de ser una portada en esquina cuyas jambas y dintel forman $90^{\circ}$ con un eje de simetría a $45^{\circ}$ (ver Fig. 272 izq.).

- Arco escarzano: se trata de un arco rebajado de un solo centro cuyo arco de circunferencia son $60^{\circ}$ o próximo a este valor de ángulo. Se trata del trazado geométrico curvo más sencillo y a él pertenecen un total de 9 portadas: 1, 9, 14, $16,17,19,21$, y las portadas sin numerar de las láminas LA1191 y LA 1192 (ver Fig. 272 dcha.). En el arco de la portada 1, por debajo del arco adintelado, se forma un nuevo arco carpanel en una moldura que no es sino una especie de batiente sobre el que hace tope la hoja de carpintería.

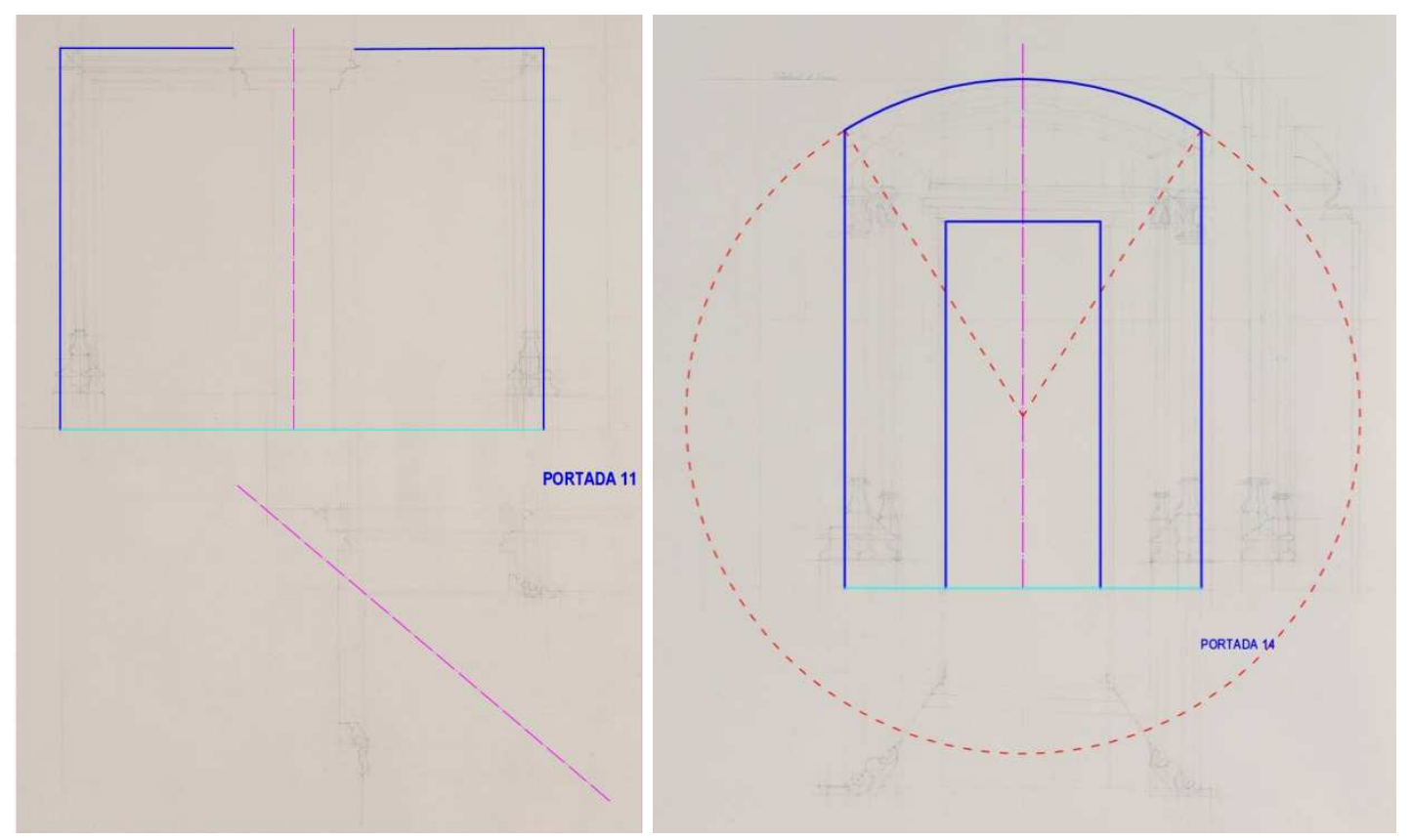

Figura 272. Izquierda: Arco Adintelado. Portada 11. Derecha: Arco Escarzano. Portada 14.

- Arco carpanel: Se trata de un arco rebajado formado por un número impar de arcos de circunferencia ( 3 o más) tangentes entre sí. Los arcos extremos tienen su centro en la línea de impostas. En nuestro caso se trata de arcos de cinco centros y podemos incluir en este grupo las portadas 10.2 y 10.3 (la Portada 10 son en realidad 3 portadas unidas mediante un distribuidor que une las Salas 7 y 11) (ver Fig. 273). 


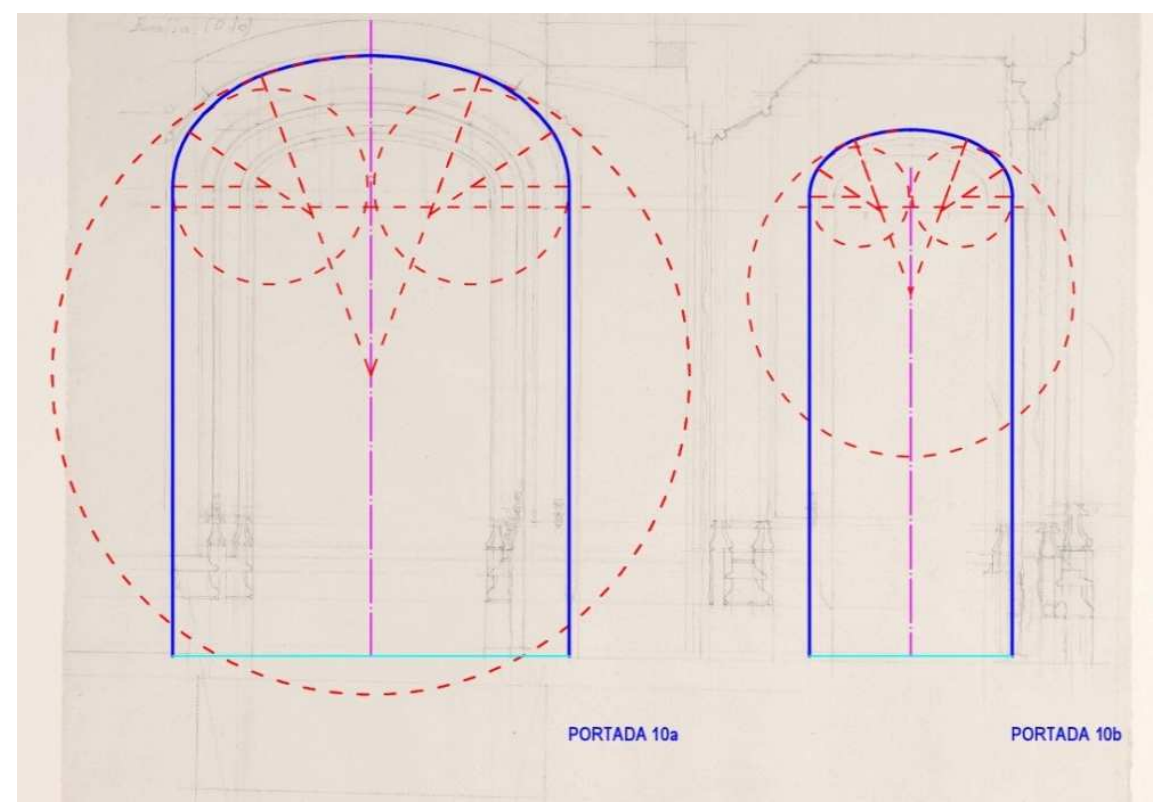

Figura 273. Arcos carpaneles. Portadas 10 a y 10 b.

- Arco trilobulado rebajado: hemos denominado de este modo el arco de la Portada 13 por tratarse de un arco rebajado formado por tres arcos de circunferencia que intersectan entre sí formando dos aristas vivas. Se trata, por tanto, de un arco de tres centros (ver Fig. 274 izq.).

- Arco flamígero aquillado: dentro de este tipo podemos encuadrar el arco de la Portada 20. Se trata de un arco flamígero o conopial de 6 centros (ver Fig. 274 dcha.).

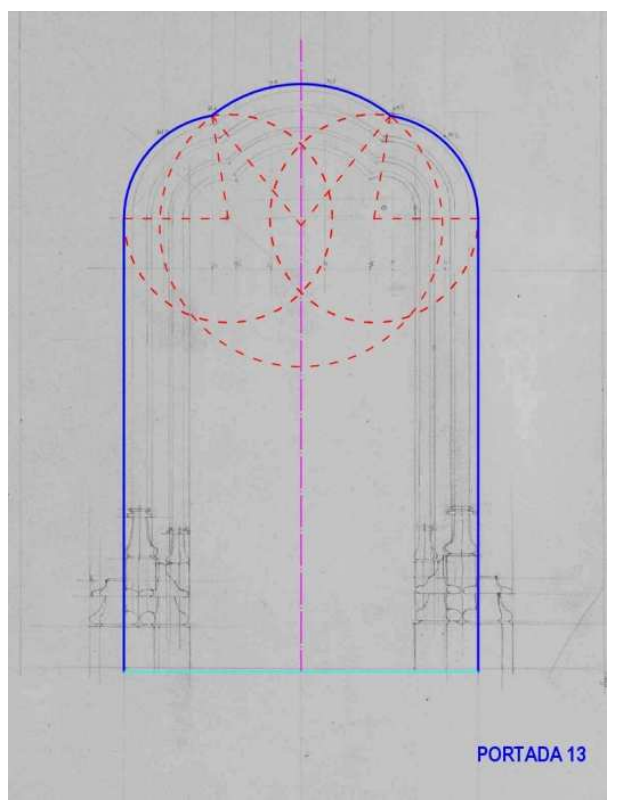

Figura 274. Izquierda: arco trilobulado. Portada 13. Derecha: arco flamígero aquillado. Portada 20. 
- Arco flamígero aquillado mixtilíneo: se trata de un tipo de arco flamígero o conopial de 4 centros en el cual se han insertado dos tramos rectos verticales en el punto de tangencia de sus arcos laterales. Los arcos de las portadas 6 y 18 podemos incluirlos dentro de este grupo. En el caso de la Portada 6 son 4 los tramos rectos, ya que en el arranque del arco se insertan dos tramos rectos más en este caso horizontales (Fig. 275).
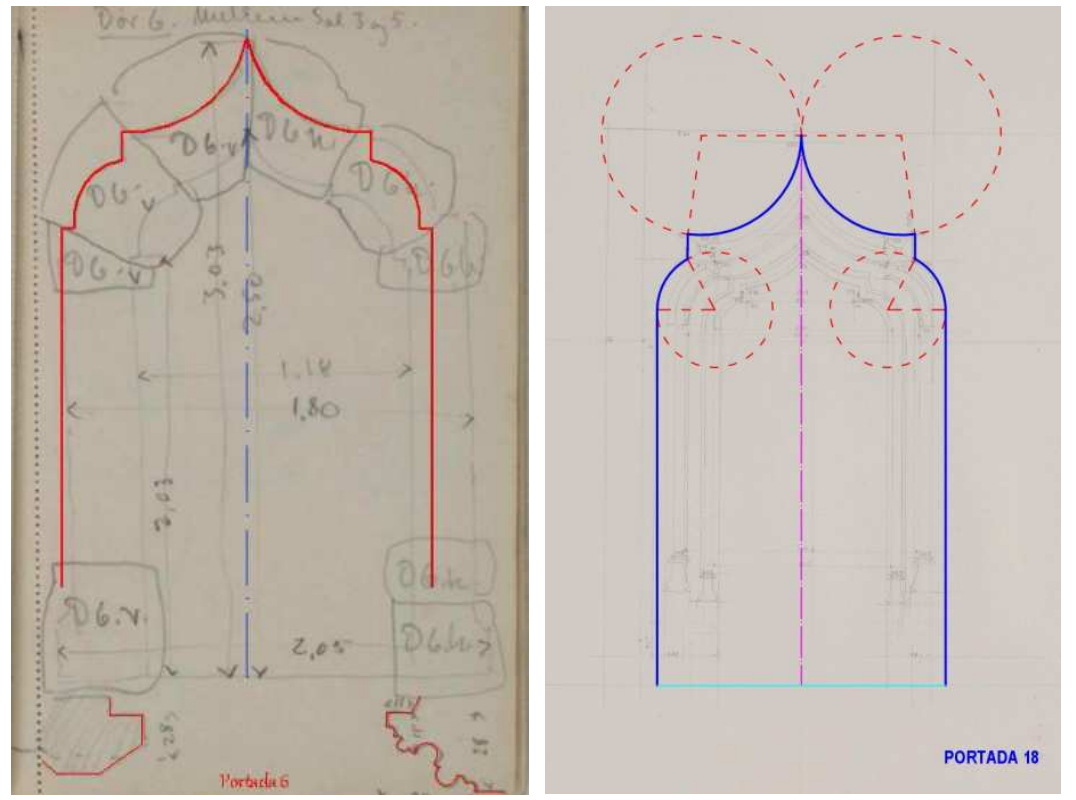

Figura 275. Flamígero aquillado mixtilíneo. Izquierda: Portada 6. Derecha: Portada 18.

- Arco inflexo de talón roto: dentro de este tipo podemos encuadrar el arco de la Portada 4. Se trata de un arco de 5 centros. Arranca con dos arcos de circunferencia cóncavos desde la línea de impostas. Estos arcos se unen a dos arcos convexos mediante un punto de tangencia y estos últimos, a su vez, intersectan con el arco de circunferencia convexo situado en la clave, formando dos aristas en el extradós del arco (Fig. 276). 


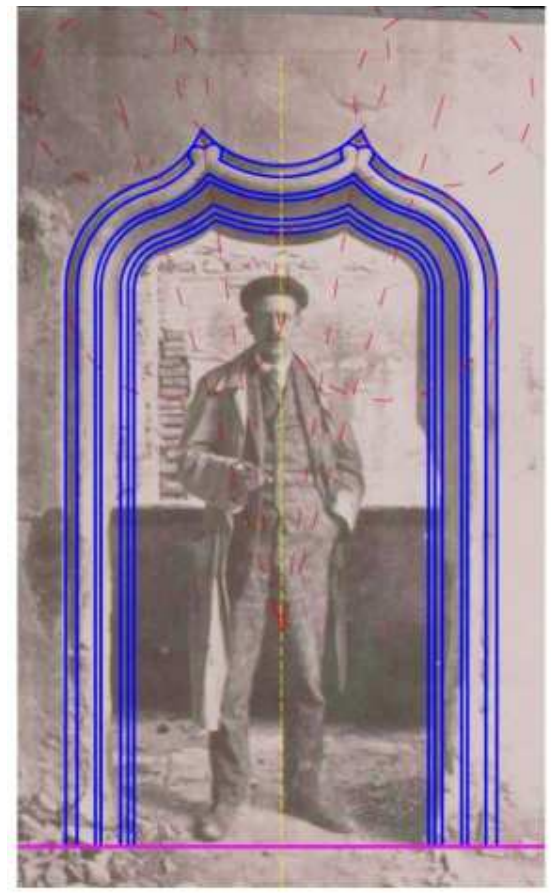

Figura 276. Arco inflexo de talón roto. Portada 4.

- Variación del flamígero: se trata de un arco con un número par de centros formados por arcos de circunferencia unidos mediante tangencia o arista que tienen como denominador común el unirse en arista en la clave y arrancar siempre con sendos arcos cóncavos desde la línea de impostas. En este grupo podemos incluir los arcos de las portadas 5 y 22, formado por 6 arcos de circunferencia con uniones tangente y en arista desde los arranques y la Portada 10.1, con 8 arcos de circunferencia unidos mediante tangencias, salvo en la clave (ver Fig. 277 izq.).

- Variación del flamígero mixtilíneo: se trata de una variación del anterior donde se intercalan segmentos rectos entre los puntos de unión de algunos arcos de circunferencia. Dentro de este tipo podemos incluir la Portada $7^{403}$, formada por 6 centros y dos tramos rectos; la Portada 3, formada por 8 arcos de circunferencia y 2 trazados rectos; y la 15 , con 10 centros en su cara interior que se transforman en 16 centros en su cara exterior y 4 trazados rectos (este arco se ha optado por clasificarlo dentro del grupo de los arcos uniformes, ya que si bien sus trazados curvos se trasforman pasando de un centro en su trazado interior a dos en su trazado exterior, el número de tazados curvos y rectos y el tipo de arco se mantienen en el intradós y en el extradós) (ver Fig. 277 dcha.).

403 Aunque en el croquis del Notebook II y en la fotografía 61, la Portada 7 aparece con una decoración puramente renacentista, la Lámina LA1182 y la fotografía 69 del Álbum Grande (página 15 R), así como la sección de la jamba del croquis del Notebook II, evidencian que una vez desmontado el revestimiento renacentista se descubrió que éste se había colocado sobre una portada anterior neogótica. En la presente clasificación de las portadas nos hemos basado en el arco tardogótico dibujado por Fischer sobre la fotografía 69 para identificar el arco primitivo. 

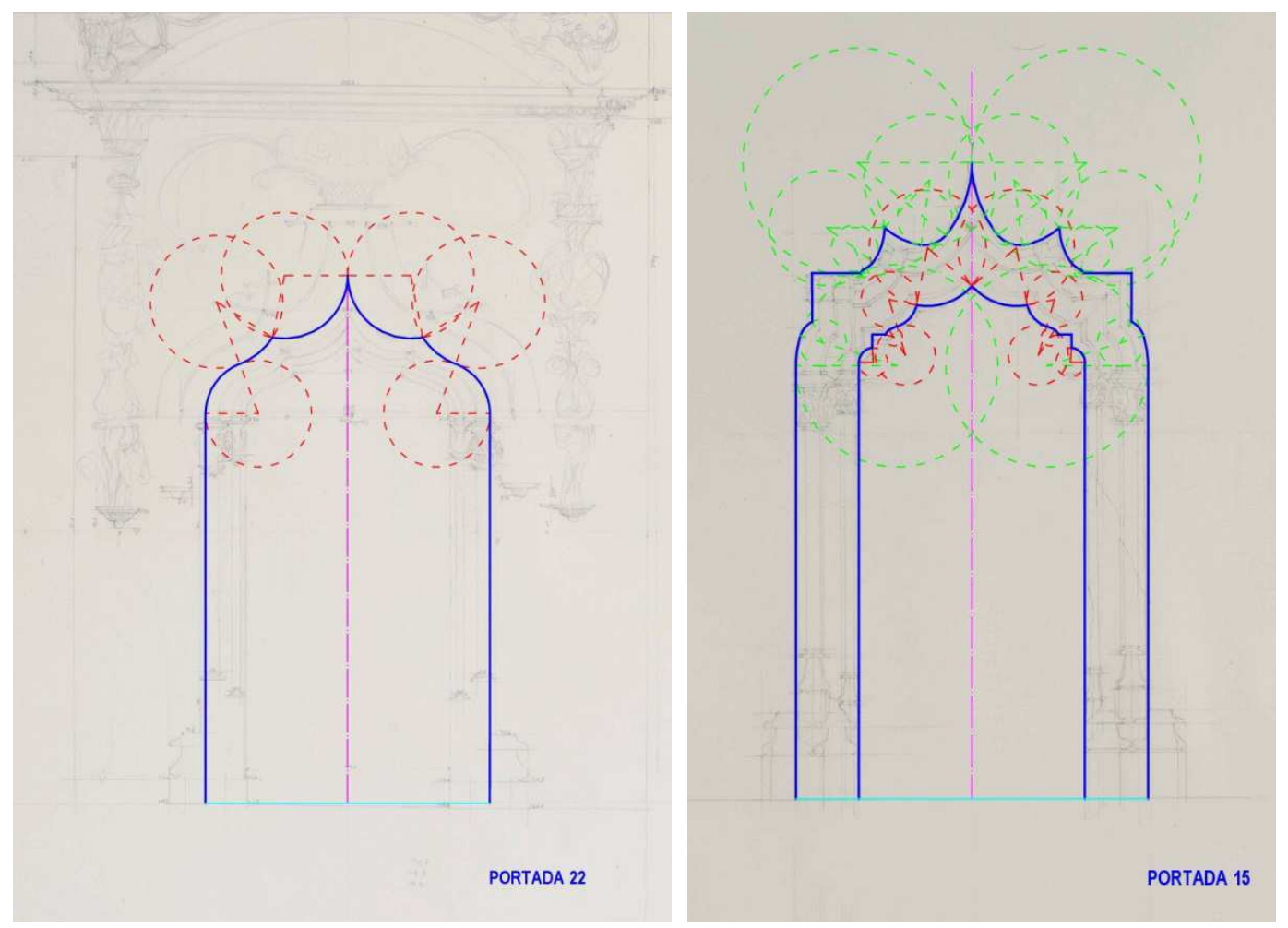

Figura 277. Izquierda: variación del flamígero. Portada 22. Derecha: variación del flamígero mixtilíneo. Portada 15.

- Arco angrelado: si bien puede incluirse como una variación del flamígero, denominaremos "arco angrelado" a un arco flamígero de 6 trazados curvos que arrancan desde la línea de impostas con dos arcos cóncavos y, a diferencia que en la variación del flamígero, los siguientes arcos de circunferencia son también cóncavos, cortando con los anteriores en arista hacia el intradós. Estos, a su vez, enlazan con dos últimos trazados curvos convexos que unen con los anteriores mediante tangencia $y$, entre ellos, en arista hacia el extradós con la forma conopial característica. Incluimos dentro de este grupo los arcos de las Portadas 25 y 26 . En el caso de la Portada 26 los dos últimos trazados curvos están formados por dos arcos de circunferencia, por lo que tiene un total de 8 centros, mientras que en la Portada 25 son arcos sencillos con un total de 6 centros (ver Fig. 278). 


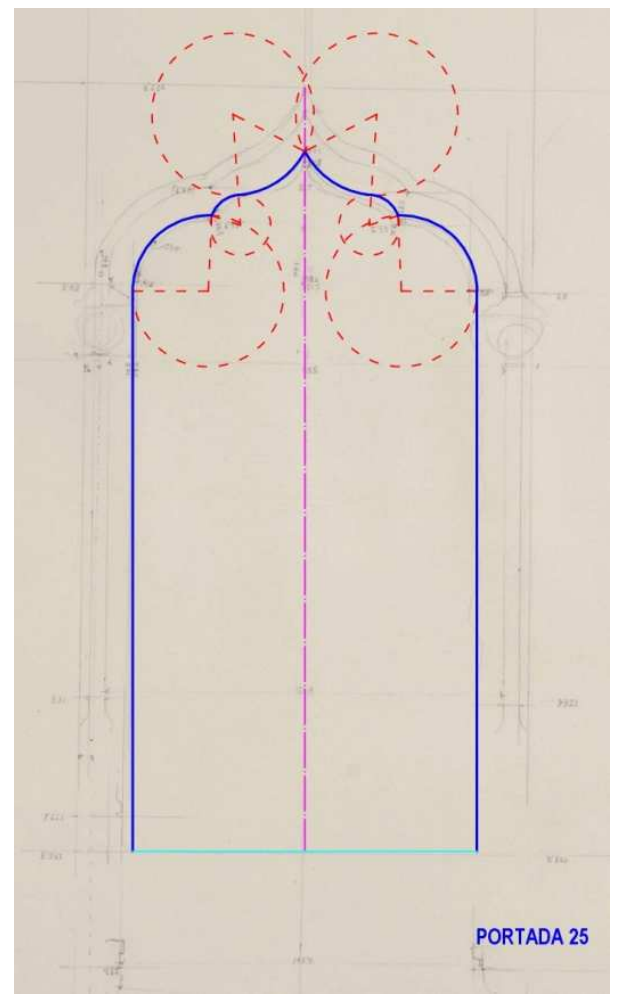

Figura 278. Arco angrelado. Izquierda: Portada 25. Derecha: Portada 26.

- Arco angrelado mixtilíneo: se trata de una variante dentro del tipo anterior en la cual se insertan tramos rectos entre la unión de algunos de sus trazados curvos. Podemos incluir en este grupo el arco de la portada sin numerar de la lámina LA1177, que arranca con dos trazados rectos horizontales desde la línea de impostas (ver Fig. 279 izq.).

- Arco cortinado mixtilíneo variación del flamígero: dentro de esta definición podemos encajar el arco correspondiente a la Portada 8 con 6 centros y dos trazados rectos. Los primeros trazados desde la línea de impostas son arcos convexos, como corresponde a un arco cortinado, y continúan dos trazados rectos horizontales en la unión con los siguientes arcos de circunferencia cóncavos. Completan el trazado dos arcos convexos tangentes a los anteriores y que cortan en una arista en el extradós del arco, forma característica de los arcos flamígeros o conopiales (ver Fig. 279 dcha.). 


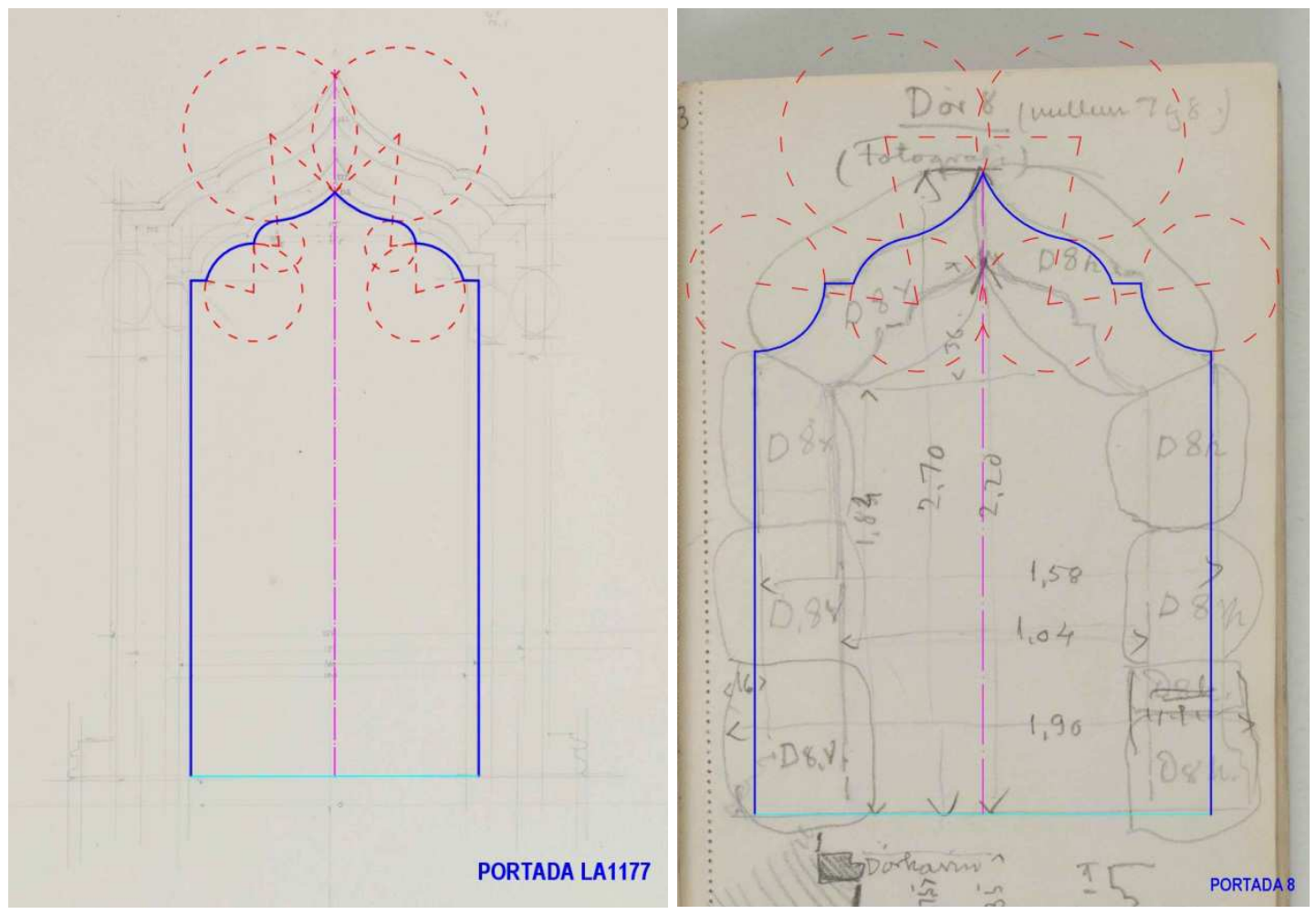

Figura 279. Izquierda: arco angrelado mixtilíneo Portada LA1177. Derecha: arco cortinado mixtilíneo variación del flamígero. Portada 8.

\subsection{Portadas de arcos múltiples}

En algunas portadas la forma geométrica del arco inferior o intradós difiere de la forma del arco superior o extradós, produciéndose una transformación del mismo en las diferentes molduras que lo componen: cavetos, listeles, columnillas y gorgueras. La transformación más común se produce en la clave, pasando de un tipo de arco a otro. Procedemos a describir cada una de las distintas transformaciones que encontramos en las portadas objeto de nuestro estudio. Enumeraremos, en primer lugar, el arco en la cara inferior o intradós de la portada:

- Arco adintelado a arco escarzano: en este grupo el arco se transforma desde un dintel recto a un arco escarzano. Los encontramos en la Portada 14. En este caso la transformación desde el arco adintelado se realiza en el abocinamiento del muro, donde se ubica la portada; el resto de molduras que conforman la portada (gorguera, columnillas, cavetos y listeles) adoptan el trazado curvo del arco escarzano (ver Fig. 280 izq.). Hemos diferenciado este tipo de arco del escarzano simple, ya que en este caso el dintel se encuentra decorado y moldurado, por lo que lo distinguimos de los arcos escarzanos sencillos porque la transición se realiza del arco directamente al dintel de la puerta.

- Arco escarzano a arco cortinado escarzano: corresponde a este tipo el arco de la Portada 28. En ellas las primeras molduras del intradós de la jamba (cavetos, 
columnilla, listel y gorguera) adoptan un trazado de arco escarzano. La gorguera, por su parte, se divide en dos formando un segundo arco con un trazado cortinado o festonado que continúan el resto de molduras que parten de la jamba (listel, columnilla y caveto). En el triángulo que se origina entre los dos trazados se forma una pirámide invertida. Al trazado exterior le hemos denominado "cortinado escarzano", ya que los trazados convexos no entregan directamente sobre la línea de impostas, sino mediante tangencia a un arco escarzano inferior (ver Fig. 280 dcha.).

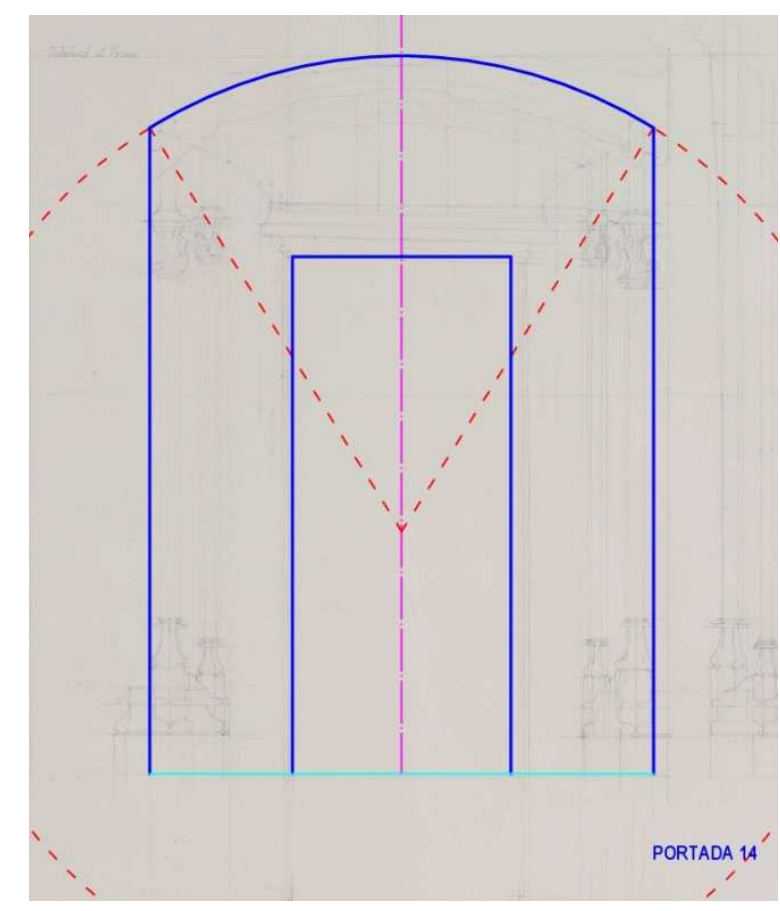

Figura 280. Izquierda: arco adintelado a arco escarzano. Portada 14. Derecha: arco escarzano a arco cortinado escarzano. Portada 28.

- Arco escarzano a arco angrelado: dentro de esta transformación podemos definir el arco de la Portada 23, en el cual las molduras que parten de las jambas forman un arco escarzano. A la altura de los capiteles, otro par de capiteles surgen del propio lienzo del muro del que, a su vez, arranca un segundo arco superpuesto al anterior con trazado angrelado de 6 centros (ver Fig. 281 izq.).

- Arco carpanel a arco flamígero aquillado: esta transformación la encontramos en el arco de la Portada 2. Aunque en el croquis de la página 15 del Notebook // no se detalla cómo se produce la transformación de las distintas molduras que componen el arco, sí podemos observar cómo en trazado de su intradós corresponde a un arco carpanel de 3 centros y en su trasdós éste se ha transformado en un arco flamígero aquillado o conopial de 4 centros (ver Fig. 281 dcha.). 


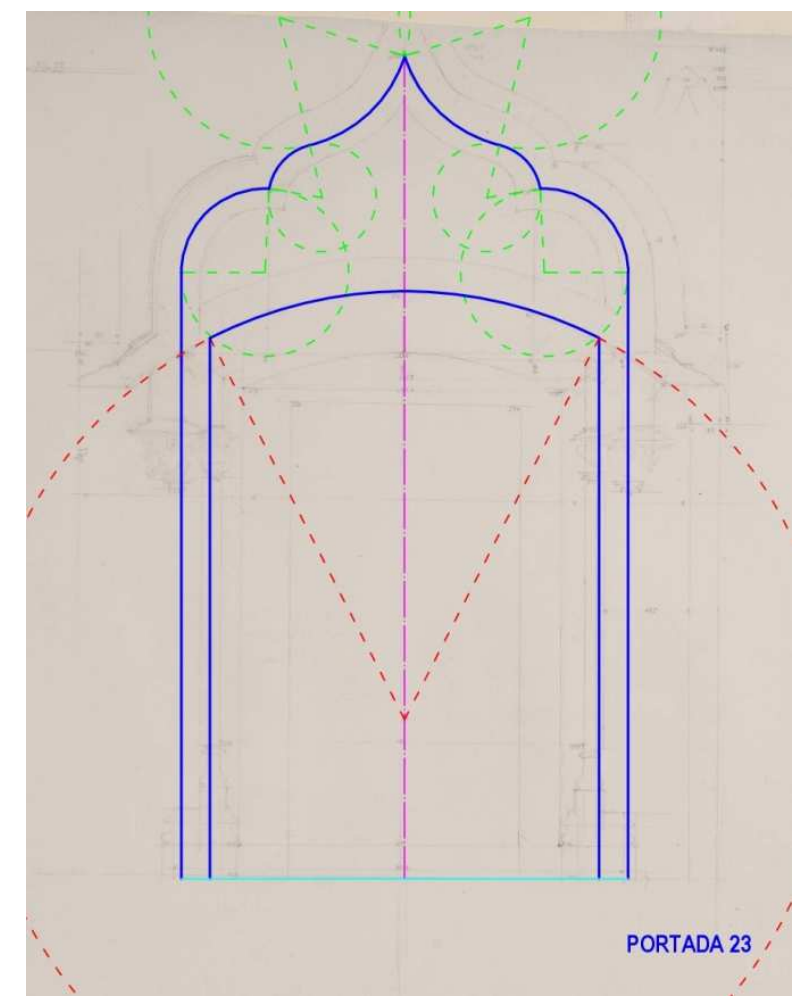

Figura 281. Izquierda: arco escarzano a arco angrelado. Portada 23. Derecha: arco carpanel a arco flamígero aquillado. Portada 2.

- Arco inflexo en talón mixtilíneo a arco rebajado: esta transformación corresponde al arco de la portada sin numerar de la lámina LA1176. En ella las molduras principales que forman la portada están compuestas por un arco inflexo en talón de 5 centros mixtilíneo con trazado cóncavo en los arranques, trazados curvos tangente superiores, trazados rectos horizontales y trazado curvo central de medio punto en el intradós. Este arco se encuentra enmarcado en su extradós por un arco circular rebajado cuya generatriz forma $90^{\circ}$ con el lienzo del muro (ver Fig. 282 izq.).

- Arco polilobulado rebajado mixtilíneo a arco polilobulado rebajado: el arco interior arranca con dos arcos de un cuarto de circunferencia que intersectan con dos trazados rectos verticales. Estos continúan con dos trazados rectos horizontales y cierran con un arco carpanel rebajado de tres centros. En el caso del exterior se trata de un arco rebajado polilobulado de 5 centros de circunferencia que intersectan entre sí formando 4 aristas con un eje de simetría central. A este tipo de arco corresponde la Portada 27 (ver Fig. 282 dcha.). 


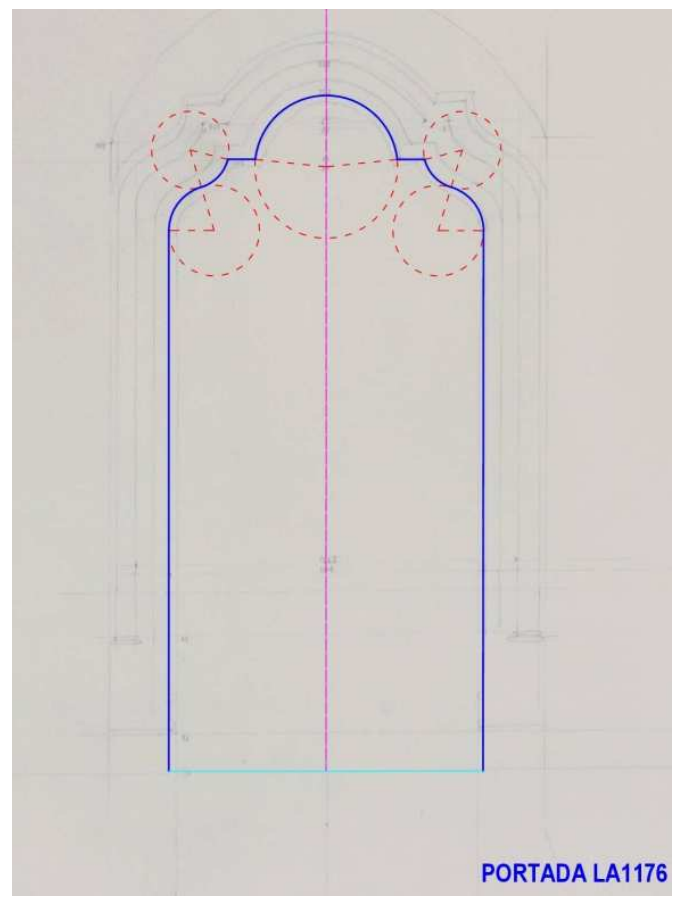

Figura 282. Izquierda: inflexo en talón mixtilíneo a arco rebajado. Portada LA1176. Derecha: arco polilobulado rebajado mixtilíneo a arco polilobulado rebajado. Portada 27.

- Arco trilobulado carpanel mixtilíneo a arco angrelado mixtilíneo: esta es la definición que podemos atribuirle al arco de la Portada 24 (ver Fig. 283 izq.). El trazado del intradós está formado por 5 arcos de circunferencia y 4 trazados rectos. Inician el arco dos trazados cóncavos de un cuarto de circunferencia, continúan a cada lado un trazo recto vertical seguido de otro trazo recto horizontal, cerrando el arco con un trazado carpanel de 3 centros. Este trazado lo forman la columna del intradós y sus molduras adyacentes, así como la gorguera, que, a su vez, se divide en dos para transformarse el arco carpanel central en un arco flamígero aquillado de 4 centros. Esta forma la continúan la columna exterior de la jamba y sus molduras adyacentes. A la altura de los capiteles surge del lienzo del muro un tercer capitel y sobre este nuevas molduras, que continúan con el trazado del extradós.

- Arco variación del inflexo a arco variación del flamígero: el arco correspondiente a la portada sin identificar de la lámina LA1136 (ver Fig. 283 dcha.). El trazado del intradós, de nueve centros, arranca desde la línea de impostas con dos trazados de arco de circunferencia convexos, a los que siguen otros dos arcos cóncavos que se unen con los anteriores en un punto de tangencia. Continúan dos nuevos arcos convexos que intersectan con los anteriores formando una arista hacia el exterior, seguidos de dos nuevos arcos cóncavos unidos a los anteriores mediante tangencia, y cierra el arco un trazado curvo cóncavo sobre la clave tangente a los anteriores. En el trazado del extradós, el último arco de circunferencia se sustituye por dos arcos convexos que se unen con los anteriores mediante 
tangencia, y entre ellos formando una arista hacia el trasdós, forma característica de los arcos flamígeros. Al no existir una sección que nos defina exactamente las molduras que componen la portada no disponemos de información sobre cómo se produce la transformación, si bien podría producirse de manera similar a los casos de las Portadas 28 y 24.
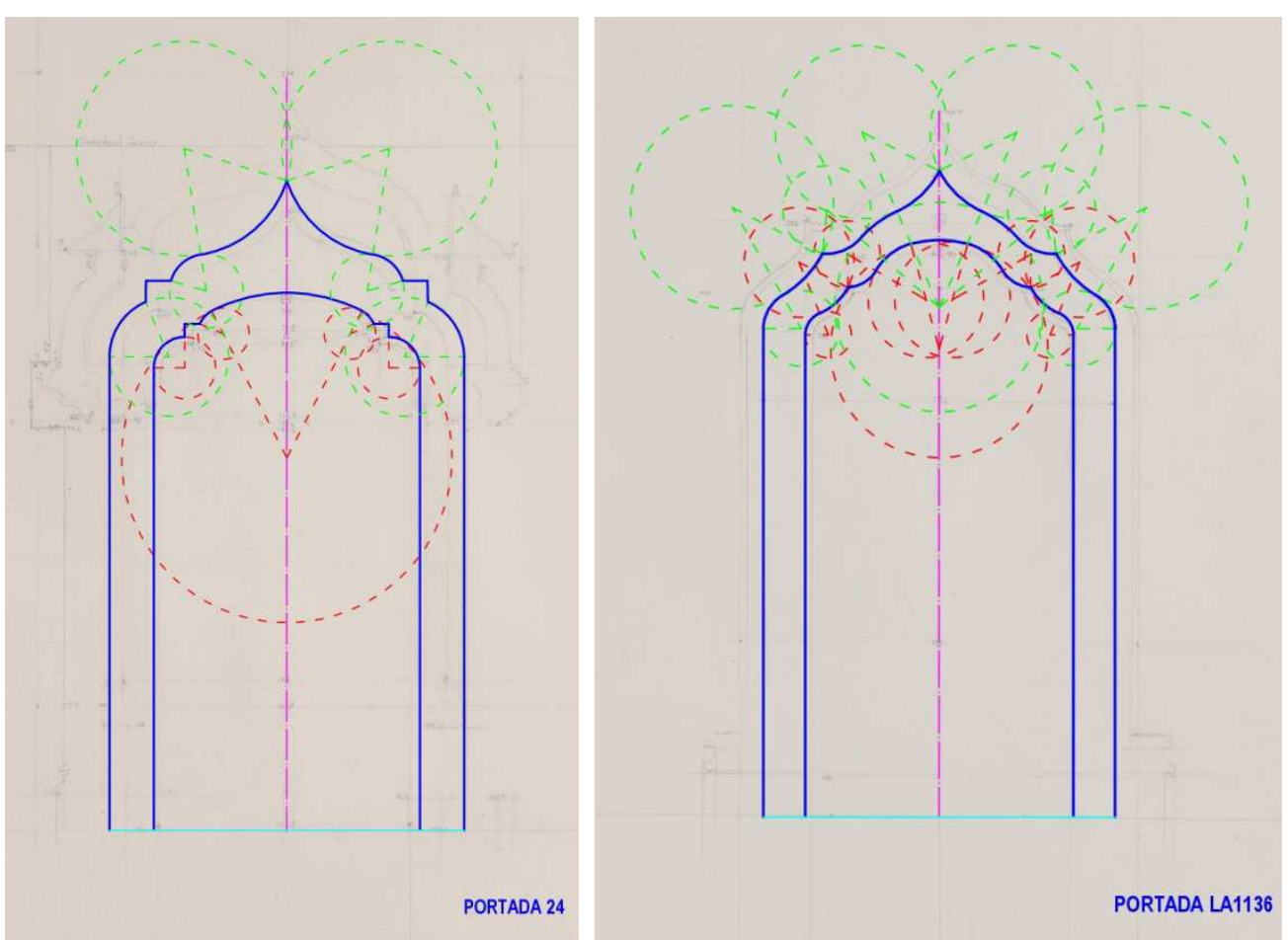

Figura 283. Izquierda: arco trilobulado carpanel mixtilíneo a arco angrelado mixtilíneo. Portada 24. Derecha: arco variación del inflexo a arco variación del flamígero. Portada LA1136.

- Arco variación del inflexo en talón mixtilíneo a arco variación del flamígero mixtilíneo: esta definición corresponde al arco de la Portada 12 (ver Fig. 284). El trazado de su intradós, de 7 centros y 4 trazados rectos, arranca desde la línea de impostas con dos trazados rectos, continúa con dos arcos de circunferencia convexos, seguidos de otros dos cóncavos unidos a los anteriores mediante tangencia y, a continuación, de dos nuevos trazados rectos. Cierra el arco un arco carpanel de tres centros. Este trazado lo forman los dos cavetos del intradós, la columnilla interior, el listel del intradós y la gorguera. El listel, la columnilla y el caveto del extradós modifican su trazado final sustituyendo el arco carpanel por dos arcos de circunferencia cóncavos más dos convexos unidos mediante tangencia con los anteriores y formando entre sí un vértice en el extradós sobre el eje de simetría, forma característica de los arcos flamígeros. 


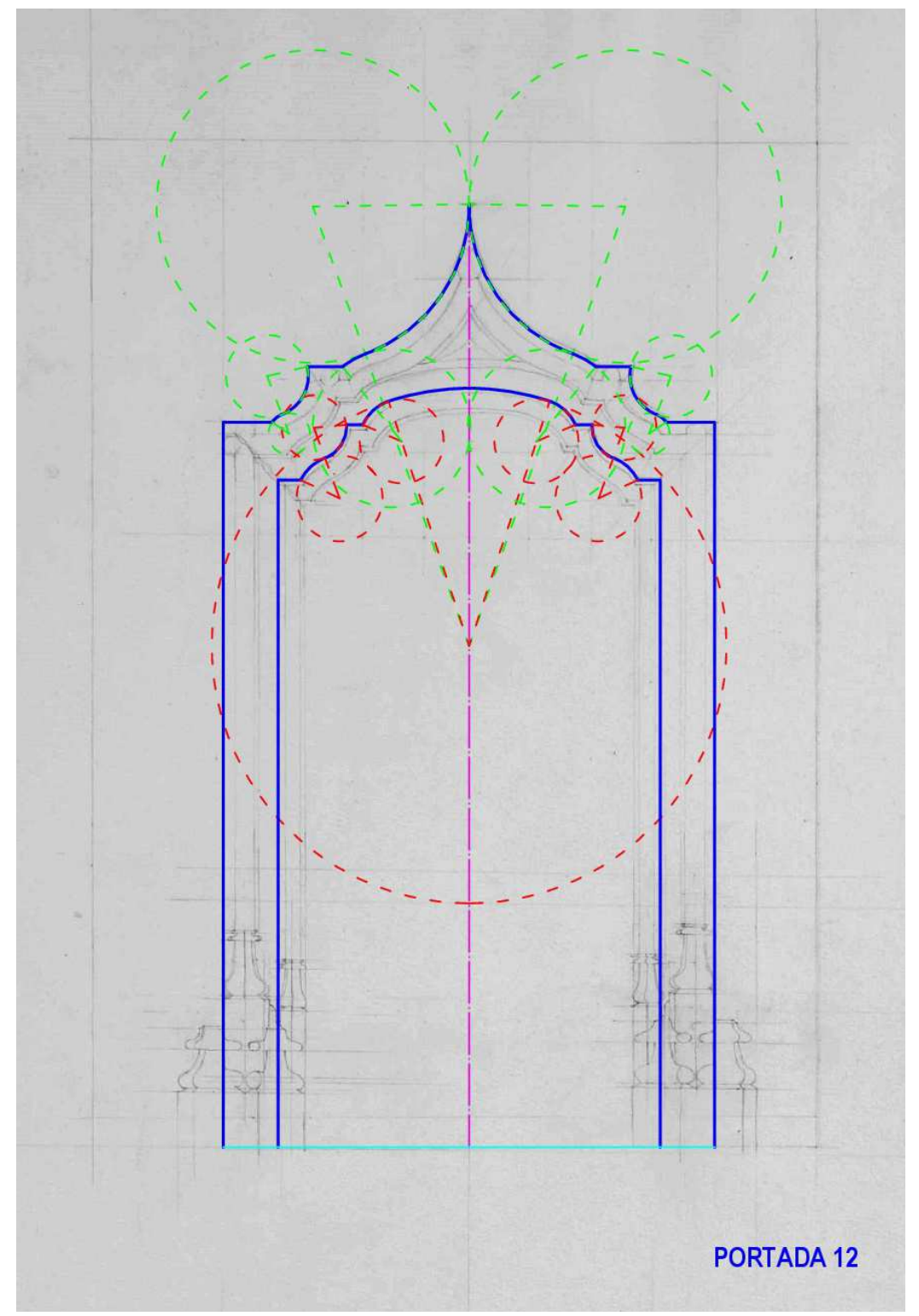

Figura 284. Arco variación del inflexo en talón mixtilíneo a arco variación del flamígero mixtilíneo. Portada 12. 
Tabla 43. Portadas del Palacio de Oliva con numeración, localización y clasificación de sus arcos. Tabla 1 de 2.

\begin{tabular}{|c|c|c|c|c|c|c|c|}
\hline \multirow[b]{2}{*}{ Portada/Dör } & \multirow[b]{2}{*}{$\begin{array}{l}\text { Sala / } \\
\text { Rum }\end{array}$} & \multicolumn{3}{|c|}{ Arco Extradós } & \multicolumn{3}{|c|}{ Arco Intradós } \\
\hline & & Tipo de arco & $\begin{array}{c}\text { no } \\
\text { Centr } \\
\text { os }\end{array}$ & $\begin{array}{c}\text { Tram } \\
\text { os } \\
\text { rectos }\end{array}$ & Tipo de arco & $\begin{array}{c}\text { no } \\
\text { Centr } \\
\text { os }\end{array}$ & $\begin{array}{c}\text { Tram } \\
\text { os } \\
\text { rectos }\end{array}$ \\
\hline Dör 1 & 1 & Escarzano & 1 & NO & Carpanel & 3 & NO \\
\hline Dör 2 & Escalera & Flamígero aquillado & 4 & NO & Carpanel & 3 & NO \\
\hline Dör 3 & $\begin{array}{c}\text { Torre } \\
\text { Palomar }\end{array}$ & $\begin{array}{l}\text { Mixtilíneo/Variación del } \\
\text { flamígero }\end{array}$ & 8 & 2 & $\begin{array}{l}\text { Mixtilíneo/Variación del } \\
\text { flamígero }\end{array}$ & 8 & 2 \\
\hline Dör 4 & 4 & Inflexo en talón roto & 5 & NO & Inflexo en talón roto & 5 & NO \\
\hline Dör 5 & 3 & Variación del Flamígero & 6 & NO & Variación del Flamígero & 6 & NO \\
\hline Dör 6 & 3 & $\begin{array}{l}\text { Mixtilíneo/Variación del } \\
\text { flamígero }\end{array}$ & 4 & 4 & $\begin{array}{l}\text { Mixtilíneo/Variación del } \\
\text { flamígero }\end{array}$ & 4 & 4 \\
\hline Dör 7 & 7 & & & & $\begin{array}{c}\text { Mixtilíneo/Variación del } \\
\text { flamígero }\end{array}$ & 6 & 2 \\
\hline Dör 8 & 7 & $\begin{array}{l}\text { Mixtilíneo/Cortinado/V } \\
\text { ariación del flamígero }\end{array}$ & 6 & 2 & $\begin{array}{l}\text { Mixtilíneo/Cortinado/Vari } \\
\text { ación del flamígero }\end{array}$ & 6 & 2 \\
\hline Dör 9 & 8 & Escarzano & 1 & NO & Escarzano & 1 & NO \\
\hline Dör 10 & 11 & $\begin{array}{l}\text { Variación del Flamígero } \\
\text { + Carpanel+ Carpanel }\end{array}$ & $\begin{array}{l}8 \\
5 \\
5\end{array}$ & $\begin{array}{l}\text { NO } \\
\text { NO } \\
\text { NO }\end{array}$ & $\begin{array}{c}\text { Variación del Flamígero + } \\
\text { Carpanel+ Carpanel }\end{array}$ & $\begin{array}{l}8 \\
5 \\
5\end{array}$ & $\begin{array}{l}\text { NO } \\
\text { NO } \\
\text { NO }\end{array}$ \\
\hline Dör 11 & 11 & Adintelado & 0 & 1 & Adintelado & 0 & 1 \\
\hline Dör 12 & 12 & $\begin{array}{c}\text { Mixtilíneo/Variación del } \\
\text { flamígero }\end{array}$ & 8 & 4 & Mixtilíneo/carpanel & 7 & 4 \\
\hline Dör 13 & 12 & Trilobulado/Rebajado & 3 & 0 & Trilobulado/Rebajado & 3 & 0 \\
\hline Dör 14 & 13 & Escarzano & 1 & 0 & Adintelado & 0 & 1 \\
\hline Dör 15 & 13 & $\begin{array}{l}\text { Mixtilíneo/Variación del } \\
\text { flamígero }\end{array}$ & 16 & 4 & $\begin{array}{c}\text { Mixtilíneo/Variación del } \\
\text { flamígero }\end{array}$ & 10 & 4 \\
\hline Dör 16 & 14 & Adintelado & 1 & 0 & Escarzano & 1 & 0 \\
\hline Dör 17 & 15 & Adintelado & 1 & 0 & Escarzano & 0 & 1 \\
\hline
\end{tabular}


Tabla 44. Portadas del Palacio de Oliva con numeración, localización y clasificación de sus arcos. Tabla 2 de 2.

\begin{tabular}{|c|c|c|c|c|c|c|c|}
\hline \multirow[b]{2}{*}{ Portada/Dör } & \multirow[b]{2}{*}{$\begin{array}{l}\text { Sala/ } \\
\text { Rum }\end{array}$} & \multicolumn{3}{|c|}{ Arco Extradós } & \multicolumn{3}{|c|}{ Arco Intradós } \\
\hline & & Tipo de arco & $\begin{array}{c}\text { no } \\
\text { Centro } \\
\mathrm{s}\end{array}$ & $\begin{array}{l}\text { Tramo } \\
\mathrm{s} \\
\text { rectos }\end{array}$ & Tipo de arco & $\begin{array}{c}\text { no } \\
\text { Centro } \\
\mathrm{s}\end{array}$ & $\begin{array}{l}\text { Tramo } \\
\mathrm{s} \\
\text { rectos }\end{array}$ \\
\hline Dör 17 & 15 & Adintelado & 1 & 0 & Escarzano & 0 & 1 \\
\hline Dör 18 & 16 & $\begin{array}{c}\text { Flamígero } \\
\text { aquillado/Mixtilíneo }\end{array}$ & 4 & 2 & $\begin{array}{c}\text { Flamígero } \\
\text { aquillado/Mixtilíneo }\end{array}$ & 4 & 2 \\
\hline Dör 19 & 16 & Adintelado & 1 & 0 & Escarzano & 1 & 0 \\
\hline Dör 20 & 17 & Flamígero aquillado & 6 & 0 & Flamígero aquillado & 6 & 0 \\
\hline Dör 21 & 17 & Adintelado & 1 & 0 & Escarzano & 0 & 1 \\
\hline Dör 22 & 18 & $\begin{array}{c}\text { Variación del } \\
\text { flamígero }\end{array}$ & 6 & 0 & $\begin{array}{c}\text { Variación del } \\
\text { flamígero }\end{array}$ & 6 & 0 \\
\hline Dör 23 & 18 & Angrelado & 6 & 0 & Escarzano & 1 & 0 \\
\hline Dör 24 & 19 & $\begin{array}{c}\text { Angrelado/Mixtilíne } \\
\text { o }\end{array}$ & 6 & 4 & $\begin{array}{c}\text { Trilobulado/Carpanel/ } \\
\text { mixtilíneo } \\
\end{array}$ & 5 & 4 \\
\hline Dör 25 & 19 & Angrelado & 6 & 0 & Angrelado & 6 & 0 \\
\hline Dör 26 & 20 & Angrelado & 8 & 0 & Angrelado & 8 & 0 \\
\hline Dör 27 & 20 & $\begin{array}{l}\text { Polilobulado/Rebaja } \\
\text { do }\end{array}$ & 7 & 0 & $\begin{array}{c}\text { Polilobulado/Rebajad } \\
\text { o Mixtilíneo }\end{array}$ & 5 & 4 \\
\hline Dör 28 & 12 & Cortinado/Escarzano & 3 & 0 & Escarzano & 1 & 0 \\
\hline LA1136 & $\begin{array}{c}\text { Sin } \\
\text { localizar }\end{array}$ & $\begin{array}{l}\text { Variación del } \\
\text { Flamígero }\end{array}$ & 10 & NO & $\begin{array}{c}\text { Variación del inflexo } \\
\text { en talón }\end{array}$ & 9 & NO \\
\hline LA1176 & $\begin{array}{c}\text { Sin } \\
\text { localizar }\end{array}$ & $\begin{array}{l}\text { Inflexo en talón/ } \\
\text { Mixtilíneo }\end{array}$ & 5 & 2 & $\begin{array}{l}\text { Inflexo en talón/ } \\
\text { Mixtilíneo }\end{array}$ & 5 & 2 \\
\hline LA1177 & $\begin{array}{c}\text { Sin } \\
\text { localizar }\end{array}$ & $\begin{array}{c}\text { Angrelado/Mixtilíne } \\
\text { o }\end{array}$ & 6 & 2 & Angrelado/Mixtilíneo & 6 & 2 \\
\hline LA1191 & $\begin{array}{c}\text { Sin } \\
\text { localizar }\end{array}$ & Escarzano & 1 & 0 & Escarzano & 1 & 0 \\
\hline LA1192 & $\begin{array}{c}\text { Sin } \\
\text { localizar }\end{array}$ & Escarzano & 1 & 0 & Escarzano & 1 & 0 \\
\hline Escalera Honor & Patio & $\begin{array}{l}\text { Variación del } \\
\text { Flamígero }\end{array}$ & 8 & 0 & $\begin{array}{l}\text { Variación del } \\
\text { Flamígero }\end{array}$ & 8 & 0 \\
\hline
\end{tabular}




\section{BASAS}

Uno de los elementos más característicos y comunes a la totalidad de las portadas son sus basas. Dichas basas, de trazado claramente gótico, arrancan desde el nivel del pavimento con un prisma rectangular a modo de zócalo cuya planta está formada por un octógono irregular que intersecta con el lienzo del muro. Sobre este prisma, cuya altura varía según las portadas, se desarrollan una serie de molduras cóncavas y convexas hasta encontrarse con el lienzo del muro. La disposición de las molduras sigue el siguiente patrón partiendo desde el zócalo: pequeño caveto, forma cóncavo convexa formada por baqueta seguida de caveto, filete horizontal, nueva forma cóncavo convexa de menor altura y, por último, pequeño caveto que entrega sobre el muro (estas formas varían en altura y profundidad según las portadas). De estas molduras curvas emergen las basas prismáticas de las columnillas que intersectan con dichas molduras. Estos prismas tienen planta de polígono regular de 7 u 8 lados según las portadas y lados curvados con un arco de circunferencia. Sobre ellos se forman nuevas basas de planta poligonal regular y lados en arco de circunferencia. Su sección vertical más característica está formada por un pequeño caveto, a continuación una moldura de forma cóncavo convexa formada por baqueta seguida de caveto, posteriormente un filete horizontal, de nuevo de forma cóncavo convexa de menor altura y, por último, un pequeño bocel. Sobre esta base arrancan las columnillas que, salvo alguna excepción, son de sección circular (ver Fig. 285).

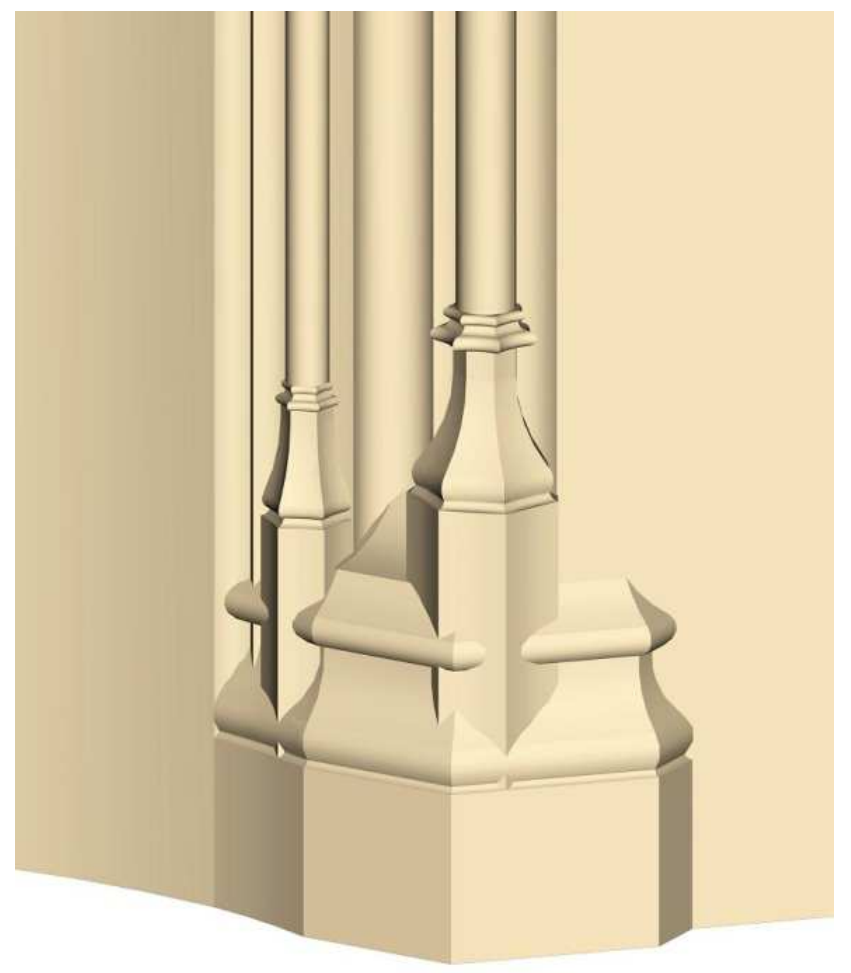

Figura 285. Basa derecha portada 28. Reconstrucción virtual. 
Nos encontramos con basas de una sola columnilla, de dos columnillas, lo más común entre las portadas (en este caso la columnilla exterior es siempre de mayor sección que la interior) y portadas más complejas que pueden tener hasta 5 columnillas de distintos tamaños en cada una de sus basas, con sus correspondientes baquetas o columnillas. Este tipo de basas es característico del gótico mediterráneo y podemos encontrarlas en muchas portadas de edificios coetáneos en el antiguo Reino de Valencia ${ }^{404}$.

De las 34 portadas documentadas por Fischer y Lauritzen, 11 tienen una sola columnilla, 19 poseen 2, 3 cuentan con tres, y 1 con 5. Los dos últimos tipos corresponden a las portadas más complejas, como son la 10, la 20, la 26 y la 27 . Por su parte, el caso de una sola columnilla normalmente se corresponde, salvo excepciones, con la cara posterior de una portada que se resuelve con un sencillo arco escarzano. Por lo tanto, el tipo más característico y que, como veremos, más se repite también en otras portadas de estas características es la formada por dos baquetones o columnillas. Estableceremos, por tanto, dos casos de estudio: las basas formadas por dos columnillas y las basas formadas por 1 columnilla.

Para analizar las características geométricas de las basas, se han introducido en una tabla los datos geométricos más característicos de las mismas, que se detallan en la figura 67 para su posterior análisis:

- L Lado de la basa paralelo al muro de la portada.

- $\quad \boldsymbol{\beta}$ Ángulo de la basa principal respecto del muro de la portada.

- A Altura del zócalo de la basa principal.

- B Altura de la parte moldurada de la basa principal.

- C Altura de la basa prismática de la columnilla pequeña desde el pavimento.

- D Altura de la basa prismática de la columnilla grande desde el pavimento.

- H1 Altura de la basa moldurada de la columnilla grande.

- H2 Altura de la basa moldurada de la columnilla pequeña.

- R1 Altura de la basa moldurada de la columnilla grande.

- $\quad$ R2 Altura de la basa moldurada de la columnilla pequeña.

En el caso de las basas de 1 columnilla, sus medidas se identificarán como los de la columnilla grande (D, H1 y R1).

${ }^{404}$ Zaragozá Catalán, A. (2000). Arquitectura Gótica Valenciana. Siglos XIII-XV Valencia: Generalitat Valenciana. Conselleria de Cultura i Educació. pp. 186-188. 


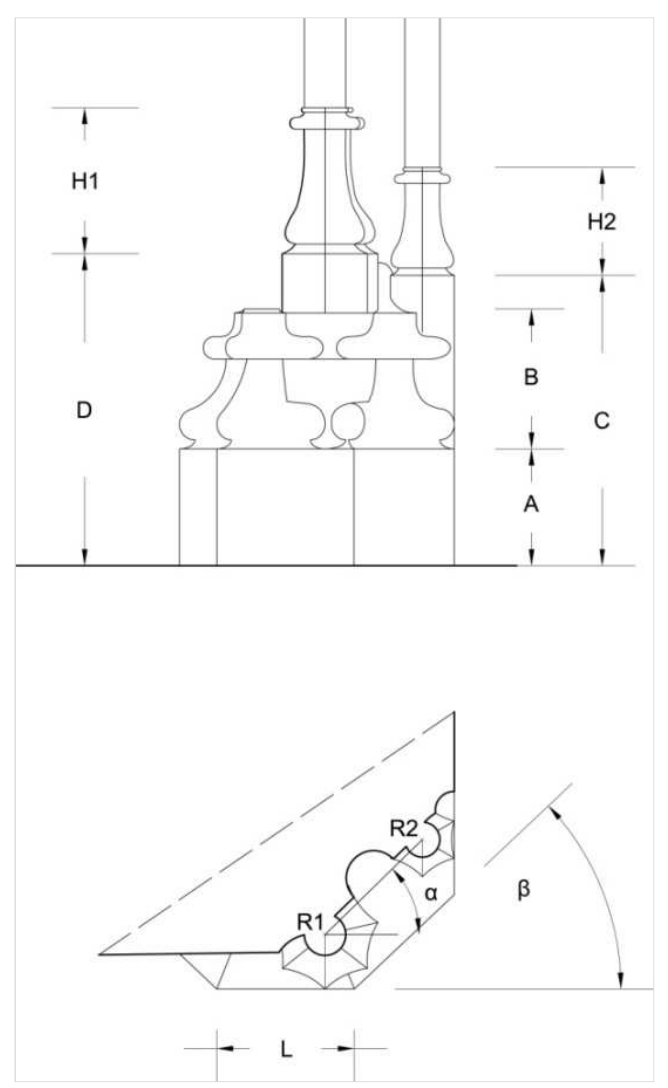

Figura 286. Esquema de identificación de los datos de las basas.

\subsection{Basas de dos columnillas}

En este apartado se presentan los datos obtenidos de los planos de Lauritzen y Fischer. Se han eliminado de la tabla las portadas LA1191, LA1192 y la Portada del Patio Central por carecer de datos, así como las portadas 1 a 9 por haberse obtenido los datos a través de una reconstrucción gráfica, y no a partir de una medición, directa o indirecta, por lo que la muestra resultante es de 10 casos. Otro de los datos incluido en la tabla es el número de lados de las basas menores de las columnillas, aunque en este caso el número de datos es menor, ya que no todas las basas están grafiadas en planta y el alzado o las fotografías son insuficientes para poder concretar este dato.

Una vez completada la tabla, se han obtenido los siguientes datos estadísticos para cada uno de los valores geométricos:

- Valor máximo de la serie.

- Valor mínimo de la serie.

- Media geométrica de la serie.

- Mediana o número central de la serie.

- Moda o valor más frecuente de la serie ${ }^{405}$.

\footnotetext{
${ }^{405}$ El dato de la moda, finalmente, no se ha incluido en la tabla ya que la muestra no es lo suficiente amplia para obtener un valor.
} 
Todos estos datos han sido recogidos también en la tabla 45 para su posterior análisis.

Tabla 45. Datos geométricos de las basas. Portadas de 2 columnillas. Datos en $\mathrm{cm}$.

\begin{tabular}{|c|c|c|c|c|c|c|c|c|c|c|c|}
\hline & \multicolumn{5}{|c|}{ Basa } & \multicolumn{3}{|c|}{ Columnilla Grande } & \multicolumn{3}{|c|}{ Columnilla Pequeña } \\
\hline $\begin{array}{c}\text { Portada/ } \\
\text { Dör }\end{array}$ & A & B & L & $\begin{array}{c}\text { Ángulo } \beta \\
\text { ( } \beta\end{array}$ & $\begin{array}{c}\text { № Lados } \\
\text { basas } \\
\text { colum. }\end{array}$ & $\begin{array}{c}\text { Radio } \\
\text { R1 }\end{array}$ & D & H1 & $\begin{array}{c}\text { Radio } \\
\text { R2 }\end{array}$ & C & H2 \\
\hline Dör 12 & 19,2 & 19,9 & 20,9 & 43 & 7 & 8,3 & 47,5 & 22,3 & 5,6 & 44,2 & 16,5 \\
\hline Dör 13 & 17,9 & 18,8 & 22,5 & 45 & 7 & 8,3 & 44,9 & 20,6 & 4,9 & 42,7 & 15,1 \\
\hline Dör 14 & 18 & 18,8 & 28,6 & 55 & 7 & 9,1 & 46,2 & 20,8 & 6,3 & 42,9 & 15,2 \\
\hline Dör 15 & 20,5 & 20,6 & 25,1 & 41 & 7 & 8,3 & 49,9 & 20,4 & 4,7 & 44,6 & 14,9 \\
\hline Dör 18 & 14 & 16,6 & 17,2 & 49 & ¿? & -- & 44,7 & 16,8 & -- & 39,9 & 13,3 \\
\hline Dör 24 & 16,2 & 15,9 & 28,1 & 44 & ¿? & -- & 46,8 & 20,2 & -- & -- & -- \\
\hline Dör 28 & 18,3 & 19,2 & 22,9 & 48 & 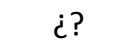 & 8,4 & 48,4 & 20,1 & 5,2 & 43,3 & 14,8 \\
\hline LA1136 & 16,1 & 15,8 & 22,6 & 45 & ¿? & -- & -- & -- & -- & -- & -- \\
\hline LA1176 & 12,2 & 15,9 & 12,3 & 53 & $\dot{ } \dot{?}$ & -- & 28,1 & 16,7 & -- & -- & -- \\
\hline LA1177 & 10,2 & 14,2 & 21,1 & 45 & ¿? & -- & -- & -- & -- & -- & -- \\
\hline Máximo & 20,5 & 20,60 & 28,60 & 55,00 & 7 & 9,10 & 49,90 & 22,30 & 6,30 & 44,60 & 16,50 \\
\hline Mínimo & 10,2 & 14,20 & 12,30 & 41,00 & 7 & 8,30 & 28,10 & 16,70 & 4,70 & 39,90 & 13,30 \\
\hline $\begin{array}{c}\text { Media } \\
\text { geométrica }\end{array}$ & 15,9 & 17,45 & 21,58 & 46,62 & 7 & 8,47 & 43,98 & 19,65 & 5,31 & 42,91 & 14,94 \\
\hline Mediana & 17,05 & 17,70 & 22,55 & 45,00 & 7 & 8,30 & 46,50 & 20,30 & 5,20 & 43,10 & 15,00 \\
\hline
\end{tabular}


Sobre la tabla se han marcado en azul los datos que coinciden (o más se aproximan) a la mediana.

\subsection{Basas de una columnilla}

En el caso de las portadas de una columnilla la muestra obtenida es de 6 casos, ya que además de las portadas 1 a 9, se han omitido las portadas 22 y 23 por carecer de datos sobre las basas en sus láminas. Todos los datos se recogen en la tabla 46.

Tabla 46. Datos geométricos de las basas. Portadas de 1 columnilla. Datos en $\mathrm{cm}$.

\begin{tabular}{|c|c|c|c|c|c|c|c|c|}
\hline \multirow[b]{2}{*}{ Portada/Dör } & \multicolumn{5}{|l|}{ Basa } & \multicolumn{3}{|c|}{ Columnilla } \\
\hline & $A$ & B & $L$ & $\begin{array}{l}\text { Ángulo } \\
\beta\left({ }^{\circ}\right)\end{array}$ & $\begin{array}{l}\text { № Lados basa } \\
\text { columnilla }\end{array}$ & Radio & D & H1 \\
\hline Dör 11 & 20,7 & 17,8 & 19,1 & 31 & 7 & 7,5 & 46,3 & 17,7 \\
\hline Dör 16 & 27,3 & 23,6 & 19,6 & 45 & 7 & 8,9 & 54,8 & 19,3 \\
\hline Dör 17 & 10,8 & 18,2 & 13,9 & 36 & 7 & 7,2 & 36,8 & 18,2 \\
\hline Dör 19 & 9,9 & 20,5 & 22,1 & 51 & ¿? & |-- & 37,2 & 18,1 \\
\hline Dör 21 & 19,4 & 24,2 & 26,8 & 56 & ¿? & -- & -- & -- \\
\hline Dör 25 & 14,3 & 18,4 & 12,6 & 70 & 8 & -- & 48,2 & 13,2 \\
\hline Máximo & 27,3 & 24,2 & 26,8 & 70 & 8 & 8,9 & 54,8 & 19,3 \\
\hline Mínimo & 9,9 & 17,8 & 12,6 & 31 & 7 & 7,2 & 36,8 & 13,2 \\
\hline $\begin{array}{l}\text { Media } \\
\text { geométrica }\end{array}$ & 16,0 & 20,3 & 18,4 & 46,4 & 7,2 & 7,8 & 44,1 & 17,2 \\
\hline Mediana & 16,85 & 19,45 & 19,35 & 48 & 7 & 7,5 & 46,3 & 18,1 \\
\hline
\end{tabular}




\section{SECCIÓN DE JAMBAS Y ARCOS}

La sección de los arcos tiene un trazado genuinamente gótico y sus formas principales son las columnillas circulares, acompañadas de otras molduras como cavetos y listeles, destacando siempre entre cada par de columnillas una moldura convexa de radio circular de gran tamaño (su radio es siempre mayor a la columnilla de mayor diámetro). La sección de esta tipología de jambas tiene su origen en el trazado de las molduras de los nervios de las bóvedas góticas, y, más concretamente, en los nervios con molduras cóncavoconvexas, de acuerdo con la clasificación realizada por el profesor Navarro ${ }^{406}$. Por su parte, Villard de Honecourt, en dos de las láminas de su manuscrito, dibuja varias monteas de nervios de traza triangular con baquetones en cabeza, algunas con listel y remate con bocel ${ }^{407}$.

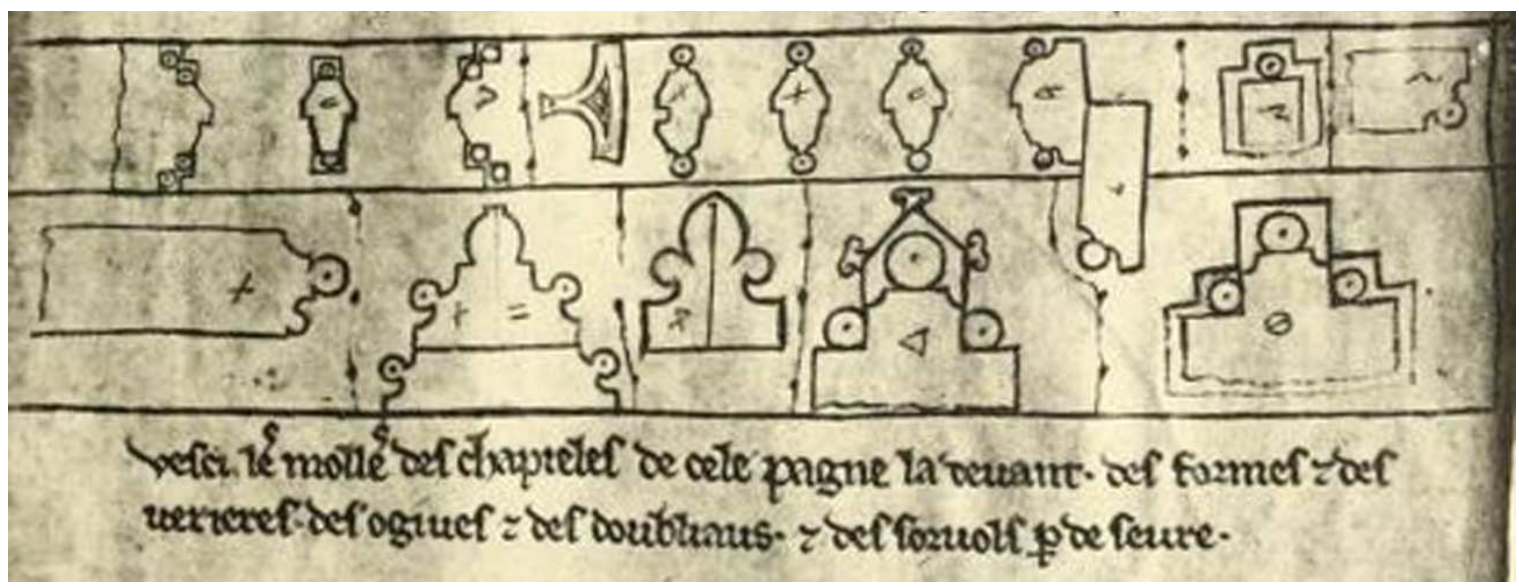

Figura 287. Detalle de la lámina LLXIII de Villard de Honecourt con distintas monteas de nervios de bóvedas. Fuente: Álbum de Villard de Honnecourt.

Si analizamos algunos de estos perfiles, podemos ver la sección tipo de las portadas que encontramos en el Palacio de Oliva. El resto de portadas de este periodo coinciden con la mitad de la montea, tal y como sucede con la montea en un arco perpiaño, donde la intersección del nervio con el muro por su eje de simetría hace que sólo se genere la mitad del nervio (ver Fig. 288).

\footnotetext{
${ }^{406}$ Navarro Fajardo, J. C. (2004). Bóvedas valencianas de crucería de los siglos XIV al XVI. Traza y montea. (Tesis Doctoral publicada). Valencia: Universitat de València. Servei de Publicacions. pp. 137-144.

${ }^{407}$ Honnecourt, V. (1927). Álbum de Villard de Honnecourt. Architecte du XIII Siècle (Reproducción del manuscrito). Paris: Bibliotèque Nationale. pp. LXI y LXIII.
} 


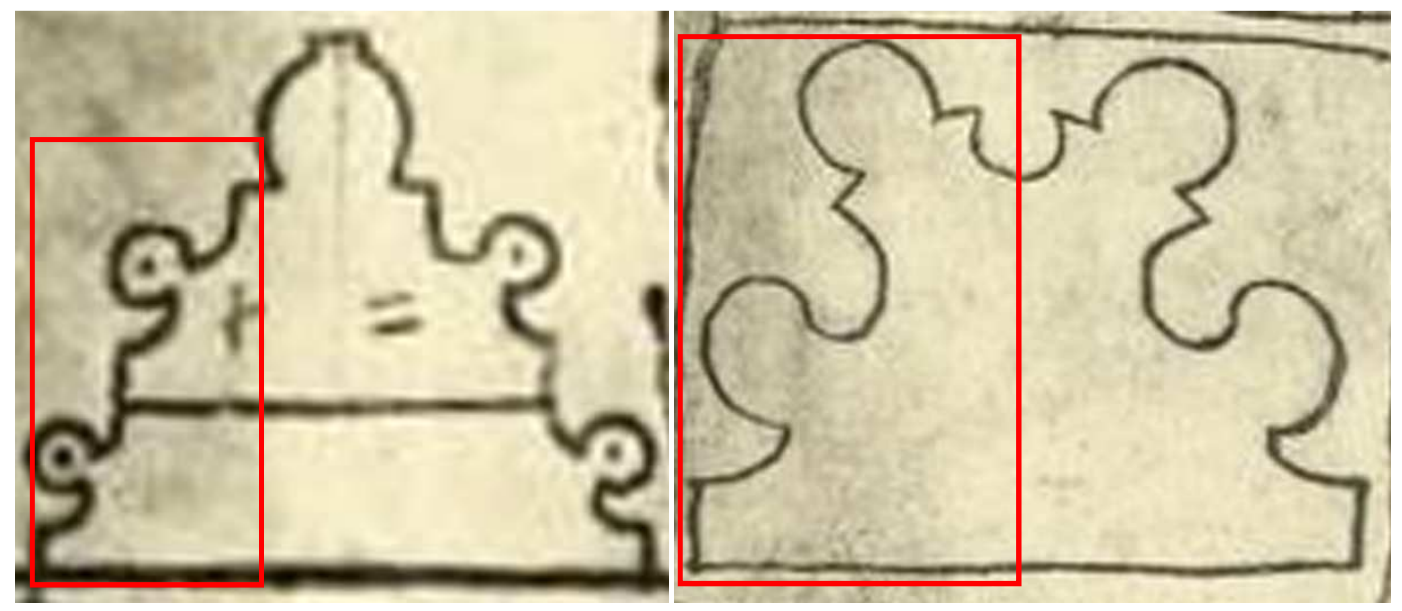

Figura 288. Detalle de monteas de nervaduras de las láminas LXIII (izq.) y LXI (dcha.) de Villard de Honnecourt. Recuadro en rojo: perfil hipotético de una jamba trazada con dicha montea. Fuente: Álbum de Villard de Honnecourt.

Las baquetas o columnillas, tal y como se han descrito en las basas, son generalmente de base circular. Como excepciones tenemos una de las columnillas de la Portada 20 y otra en la Portada 26, en las que el baquetón de mayor diámetro tiene un perfil apuntado, finalizando en un filete.

Por su parte, la columnilla más exterior de la Portada 20 tiene un perfil mixtilíneo. Su sección está formada por cuatro circunferencias de igual diámetro inscritas en un cuadrado, tangentes cada una de ellas a dos de sus lados, y un cuadrado inscrito en el anterior cuyos vértices intersectan con el punto medio de los lados del primer cuadrado, creando una sección mixta formada por un prisma cuadrangular de lados cóncavos girados 45 으 respecto al lienzo del muro, de cada uno de los cuales parte un baquetón (ver Fig. 289).

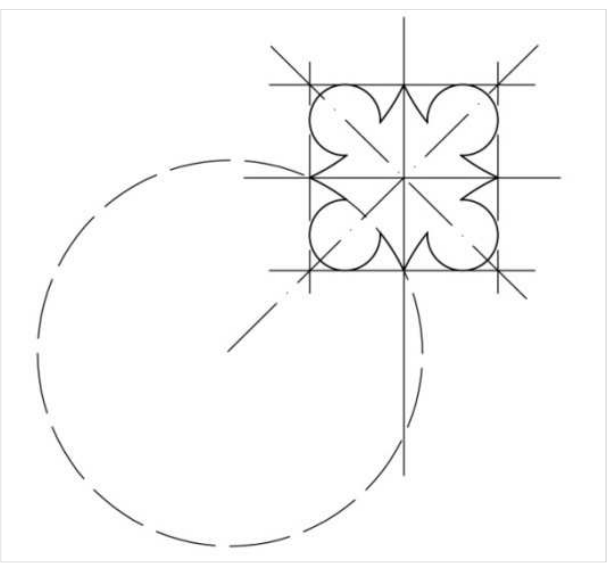

Figura 289. Trazado columnilla mixtilínea. Portada 20.

Esta pilastra tiene la peculiaridad de no formar parte del arco de la portada, sino de transformarse en un pináculo gótico, por lo que su base se ha trazado utilizando la red ad cuadratum, es decir, un cuadrado inscrito en otro girado $45^{\circ}$ y cuyas aristas son tangentes al punto medio de los lados del primero. Este esquema de diseño lo podemos observar en 
los dibujos de Matthäus Roriczer para los pináculos de la catedral de Ratisbona (ver Fig. $290)^{408}$.
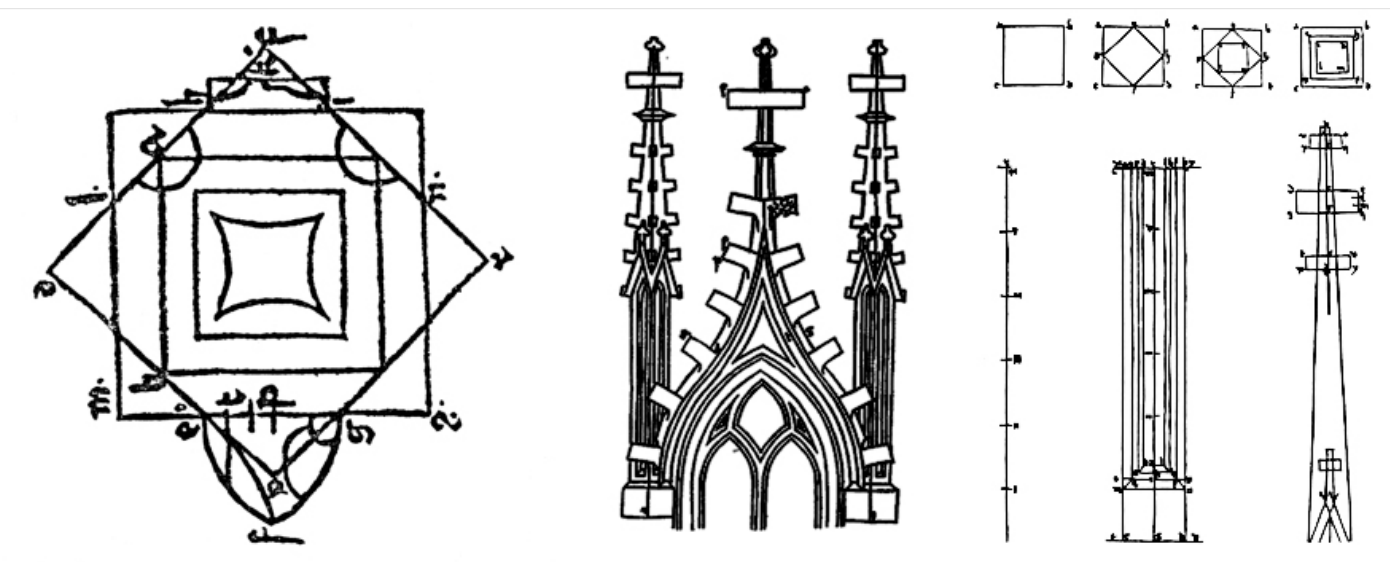

Figura 290. Diseño de los pináculos de la catedral de Ratisbona por Matthäus Roriczer utilizando la red ad quadratum.

En la parte posterior esta pilastra intersecta con el muro en el lado derecho, y en el lado izquierdo, con el caveto que continúa la forma de la jamba perdiendo parte de su perfil (ver Fig. 291).

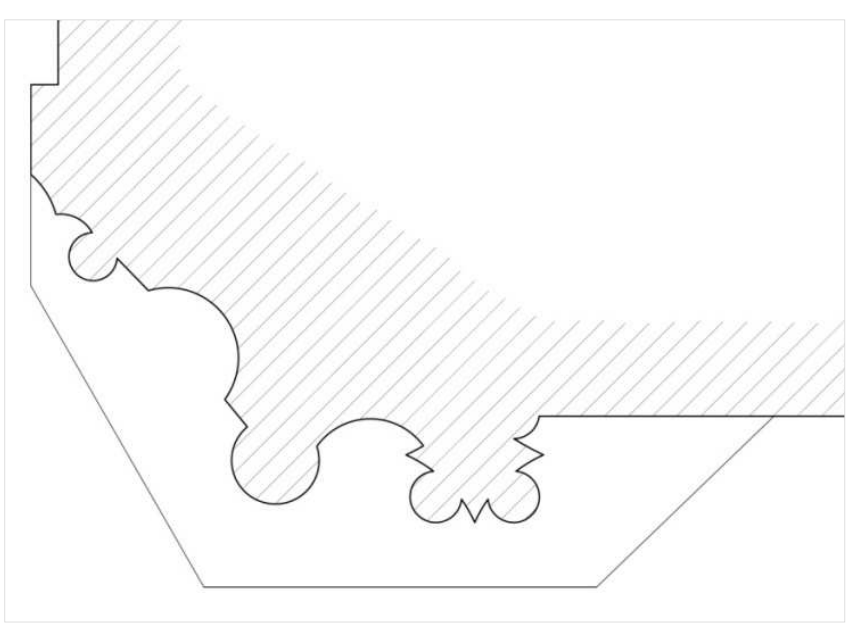

Figura 291. Sección derecha basa. Portada 20.

Procedemos a describir a modo de ejemplo la sección de la jamba izquierda de la Portada 8, por tener estas características: desde el lienzo del muro arranca dicha jamba con un caveto hacia el interior del muro (a), continúa con la columnilla mayor o baqueta (b), se sigue un caveto (c) y una moldura semicircular convexa (d), después, un nuevo caveto (e) y una columnilla o baqueta pequeña (f) tras dos cavetos que forman una arista entre sí ( $g$ y h).

\footnotetext{
${ }^{408}$ Ruiz de la Rosa, J. A. (1987). Óp. cit. y Zaragozá Catalán, A. y Gómez-Ferrer, M. (2007). Óp. cit. pp. 90-96.
} 
Finalmente, se origina una pequeña jamba recta (ver Fig. 292). Esta es la disposición más repetitiva, pudiendo variar el tipo y la situación de las molduras menores, y repitiéndose su serie en el caso de portadas con más de dos columnillas. En el caso de esta Portada, la sección continúa con una jamba abocinada de forma convexa, filete perpendicular al eje del muro seguido de otro a $90^{\circ}$, donde se alojaba el batiente de la carpintería de madera ${ }^{409}$.

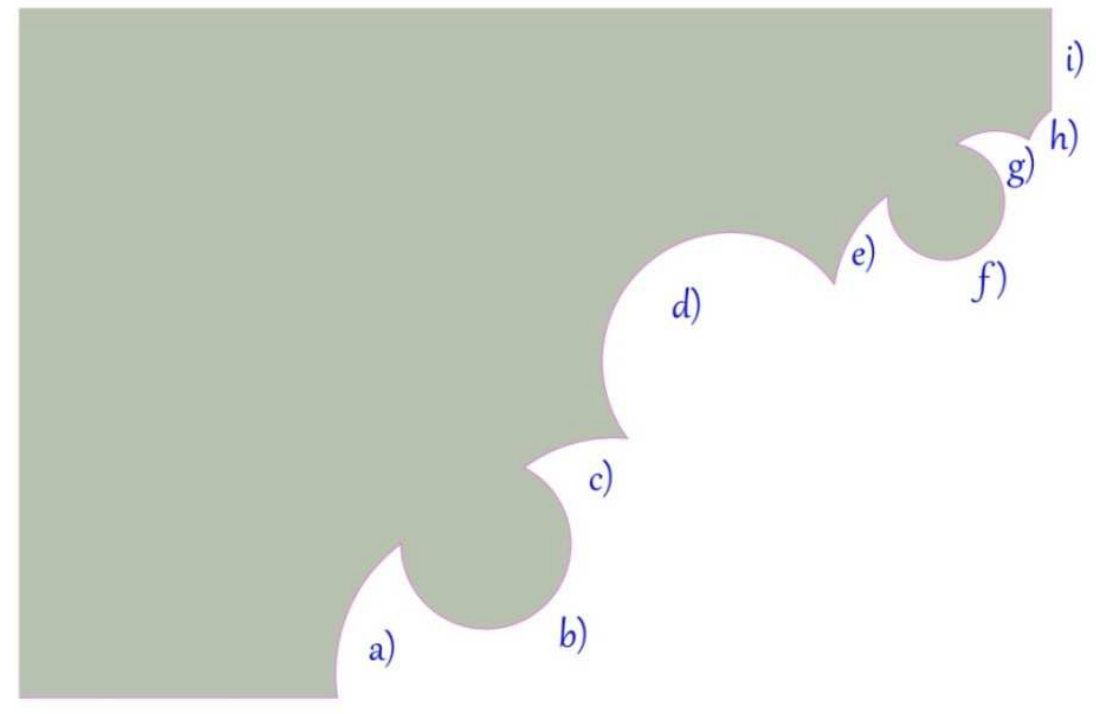

Figura 292. Esquema de identificación de los datos de las jambas.

Como en el caso de las basas, procederemos a analizar los datos geométricos más característicos de las jambas de las portadas, estableciendo el mismo criterio de clasificación según el número de columnillas que las componen. La sección de los arcos, como regla general, es idéntica a la de los arcos, aunque en algunas portadas el baquetón de mayor diámetro transforma su perfil circular en un perfil mixtilíneo en forma de tetón. Esta transformación sólo se produce en portadas con capiteles, produciéndose esta transición en los mismos.

\subsection{Sección de jambas de dos columnillas}

En este apartado analizaremos los datos geométricos de las jambas de portadas formadas por dos columnillas. Los datos analizados son los siguientes:

- a Ancho de la jamba.

- p Profundidad de la jamba.

${ }^{409}$ Fischer, E. y Lauritzen V. (1919-1920). Óp. cit. LA1143 y LA1144. 
- $\quad \boldsymbol{\alpha}$ Ángulo de la jamba: este dato se toma uniendo los centros de las dos columnillas y referenciándolo respecto al lienzo del muro.

- r1 Radio de la columnilla mayor.

- r2 Radio de la columnilla menor.

- r3 Radio del caveto central semicircular.

En la figura 72 se muestra un ejemplo indicando todos estos datos:

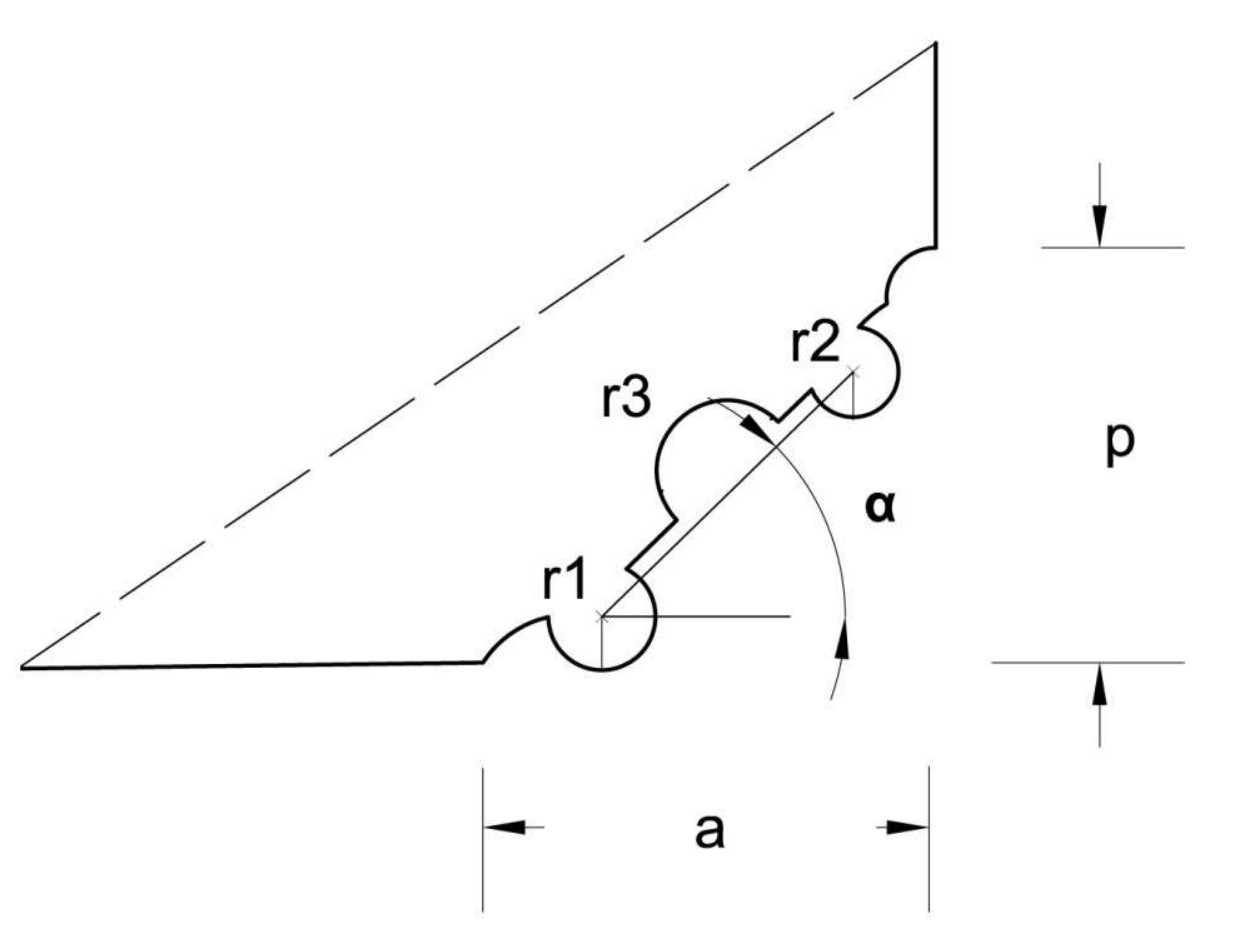

Figura 293. Esquema de identificación de los datos de las jambas de 2 columnillas.

En este tipo de jambas se ha establecido como directriz principal la línea que une los centros de los dos baquetones o columnillas. En un trazado ideal, el centro del caveto semicircular estaría alineado también en esta recta, formando parte fundamental en el trazado de la montea de las jambas y arcos de las portadas.

Una vez más, estos datos han sido introducidos en una tabla y, en el caso de las basas (ver tabla 47), se han marcado en azul los que coinciden o se aproximan más a la mediana. 
Tabla 47. Datos estadísticos de las jambas. Portadas 2 columnillas.

\begin{tabular}{|c|c|c|c|c|c|c|}
\hline Portada / Dör & Ancho a & Profundidad $p$ & $\begin{array}{c}\text { Radio } \\
\text { Columnilla } \\
\text { grande } r 1\end{array}$ & $\begin{array}{l}\text { Radio caveto } \\
\text { semicircular r3 }\end{array}$ & $\begin{array}{c}\text { Radio Columnilla } \\
\text { pequeña } \\
\text { r2 }\end{array}$ & Ángulo Jamba $\left({ }^{\circ}\right)$ \\
\hline Dör 12 & 26,8 & 24,5 & 3,1 & 4,2 & 2,6 & 44,00 \\
\hline Dör 13 & 27 & 22,8 & 3,1 & 4,4 & 2,3 & 39,00 \\
\hline Dör 14 & 33,3 & 26,7 & 3,3 & 5,6 & 2,4 & 40,00 \\
\hline Dör 15 & 29,4 & 22,9 & 3,3 & 5 & 2,3 & 36,00 \\
\hline Dör 18 & 29,9 & 37.3 & 2,9 & 7,5 & 2 & 60,00 \\
\hline Dör 24 & 20,9 & 10 & -- & -- & -- & -- \\
\hline Dör 28 & 31,4 & 21,3 & 3,2 & 4,5 & 2,4 & 38,00 \\
\hline LA1136 & 29,1 & 10,3 & 3,2 & -- & -- & -- \\
\hline LA1176 & 22,5 & -- & 3 & -- & 2,5 & -- \\
\hline LA1177 & 28,6 & 13,3 & 3,2 & -- & 2,3 & -- \\
\hline Máximo & 33,3 & 26,7 & 3,3 & 7,5 & 2,6 & 60 \\
\hline Mínimo & 20,9 & 10 & 2,9 & 4,2 & 2 & 36 \\
\hline $\begin{array}{c}\text { Media } \\
\text { Geométrica }\end{array}$ & 27,6 & 17,8 & 3,1 & 5,1 & 2,3 & 42,2 \\
\hline Mediana & 28,85 & 22,05 & 3,2 & 4,75 & 2,35 & 39,5 \\
\hline
\end{tabular}




\subsection{Sección de jambas de una columnilla}

En este apartado analizaremos los datos geométricos de las portadas de una columnilla. En este caso el ángulo $\alpha$ lo tomaremos como el ángulo que forma la línea que une el centro de la baqueta o columnilla con el del caveto semicircular o de mayor diámetro por ser estas las molduras principales que forman todas las jambas de este tipo. En la figura 294 se muestra el esquema de los datos geométricos tomados en este tipo de portadas.

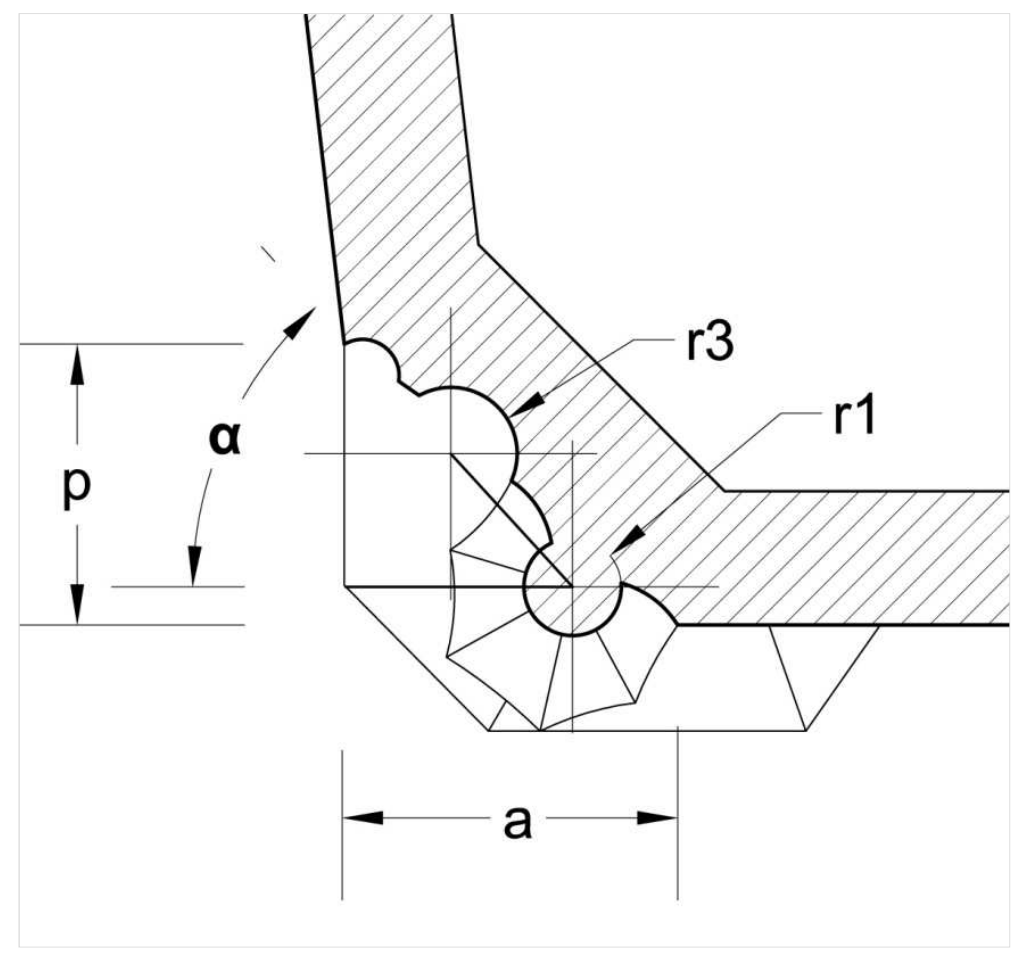

Figura 294. Esquema de identificación de los datos de las jambas de 1 columnilla.

Para mantener el criterio tomado en las portadas de una columnilla, la alineación principal de la jamba y, por tanto, su ángulo se ha tomado uniendo el centro de la columnilla con el del caveto semicircular, molduras principales en este tipo de jambas.

Los datos geométricos junto con los estadísticos de las jambas de las portadas de una columnilla o baquetón se recogen en la tabla 48. 
Tabla 48. Datos estadísticos de las jambas. Portadas 1 columnilla.

\begin{tabular}{|c|c|c|c|c|c|}
\hline $\begin{array}{c}\text { Portada/ } \\
\text { Dör }\end{array}$ & Ancho a & $\begin{array}{l}\text { Profundidad } \\
\text { p }\end{array}$ & $\begin{array}{c}\text { Radio } \\
\text { Columnilla } \\
\text { grande r1 }\end{array}$ & $\begin{array}{c}\text { Radio caveto } \\
\text { semicircular } \\
\text { r3 }\end{array}$ & $\begin{array}{c}\text { Ángulo } \\
\text { Jamba } \alpha\left(^{\circ}\right)\end{array}$ \\
\hline Dör 11 & 25,8 & 26,2 & 2,8 & -- & 15 \\
\hline Dör 16 & 20,6 & 17,3 & 3 & 4,1 & 48 \\
\hline Dör 17 & 15,7 & 12,8 & 2,8 & 5,3 & 29 \\
\hline Dör 19 & 19,5 & 13,9 & 3,5 & 4 & 35 \\
\hline Dör 21 & 19,9 & 15,8 & 2,9 & 5,5 & 38 \\
\hline Dör 25 & -- & -- & 3 & -- & -- \\
\hline Máximo & 25,8 & 26,2 & 3,5 & 5,5 & 48 \\
\hline Mínimo & 15,7 & 12,8 & 2,8 & 4 & 15 \\
\hline $\begin{array}{c}\text { Media } \\
\text { Geométrica }\end{array}$ & 20,0 & 16,6 & 3,0 & 4,7 & 30,8 \\
\hline Mediana & 19,9 & 15,8 & 2,95 & 4,7 & 35 \\
\hline
\end{tabular}

\section{CAPITELES}

Solamente las portadas más elaboradas presentan capiteles que delimitan las jambas de las portadas de los arcos. Dicho elemento ornamental parte en la mayor parte de los casos de un trazado geométrico gótico, y sobre él emergen figuras humanas, antropomórficas, zooformes y vegetales muy características de este estilo. En las portadas con decoración renacentista existen asimismo capiteles con ornamentación propia de este estilo. Procederemos a realizar una descripción de los capiteles de cada una de las portadas. 


\section{Portada 14}

En esta portada, formada por dos columnillas y arco escarzano, encontramos capiteles sencillos en cada una de sus cuatro columnillas que conforman las jambas. Se encuentran al mismo nivel que el dintel inferior que forma la portada y a un nivel inferior del arranque del arco. Los capiteles tienen planta octogonal regular, recuperando esta geometría de las basas, de las columnillas, y sección curva con un trazado principal cóncavo convexo. Sobrepuestos a estas formas geométricas se encuentran esculpidas formas vegetales y antropomórficas. En la fotografía 61 del Álbum de Fotografías Grande puede visualizarse la portada in-situ con los capiteles, así como en las láminas de ésta portada ${ }^{410}$.

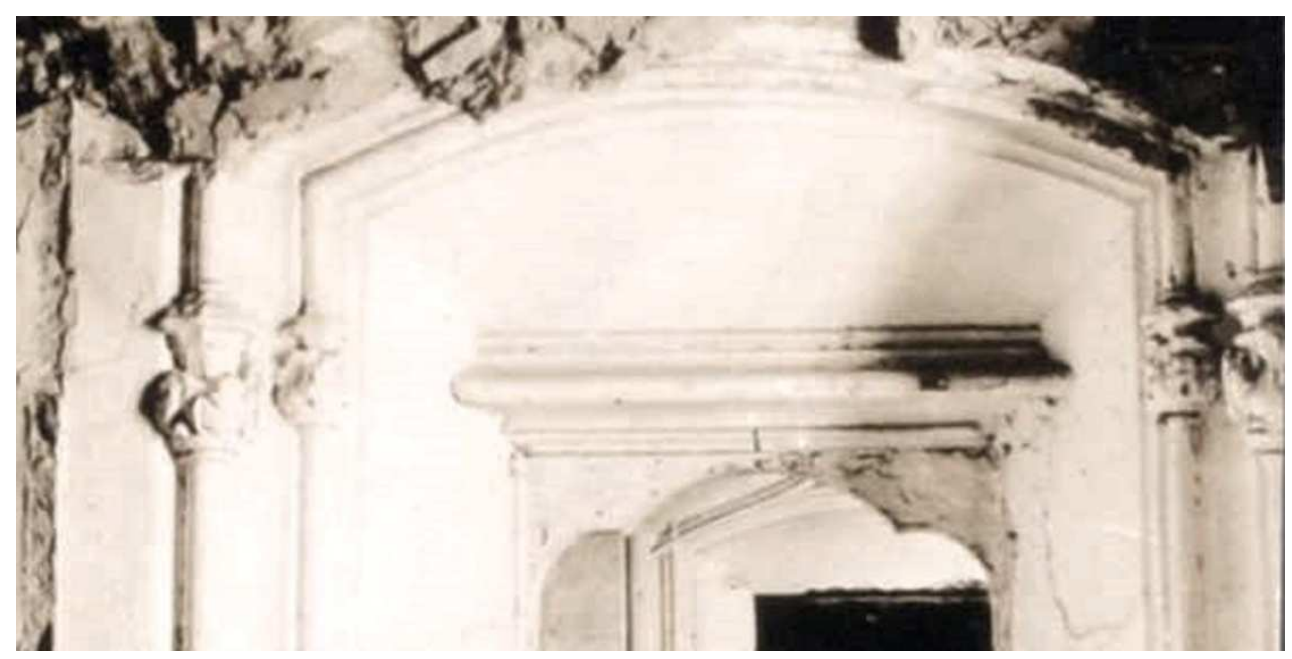

Figura 295. Detalle Portada 14-Fot. 61. AFG. Egil Fischer.

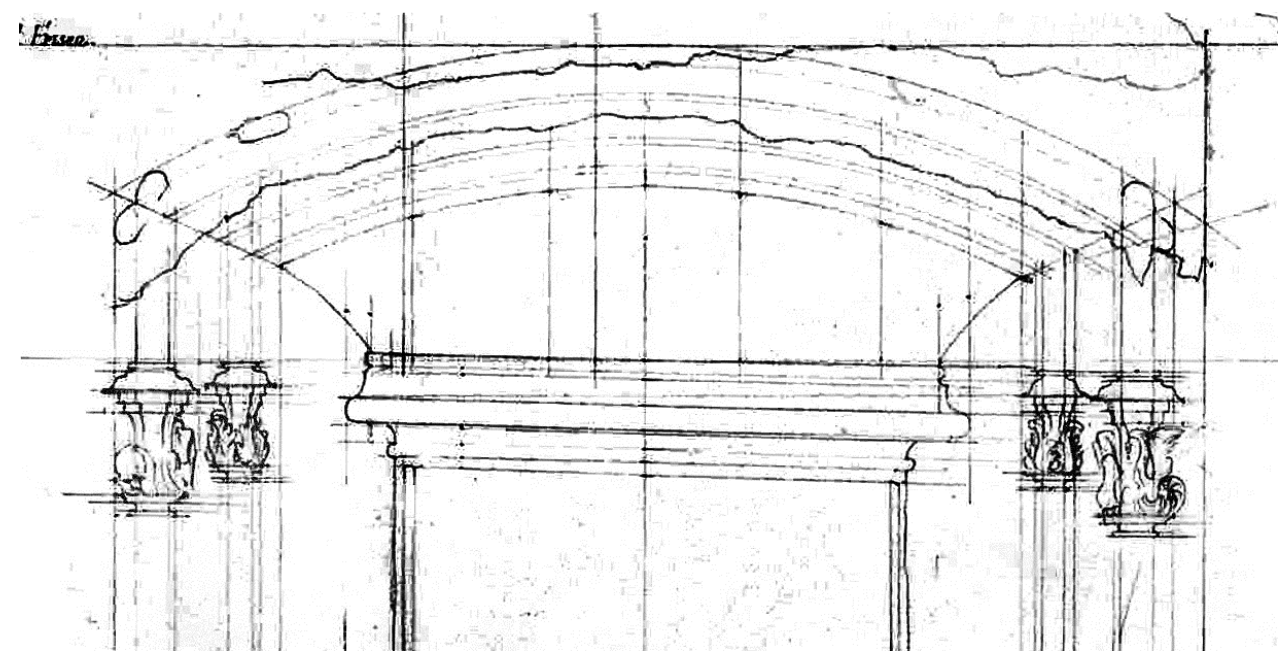

Figura 296. Detalle Portada 14. Plano LA1144. E. Fischer y/o V. Lauritzen

${ }^{410}$ Fischer, E. y Lauritzen V. (1919-1920). Óp. cit. LA1147, LA1148 y Fischer, E. (1917-1920). Óp. cit. pp. 14A. 
Las fotografías 60 y 62 (ver Fig. 297) muestran dos capiteles, derecho e izquierdo respectivamente, desmontados de su posición original. En ellas se puede ver con detalle una figura humana sentada, y un animal comiendo frutos de un árbol en la primera, y una armadura y armas cruzadas en la segunda. En el AFG aparece el mismo texto en danés: "Kæpital fra capellet medtaget og renset"(Capitel de la Capilla incluido y limpio). Aunque aparecen en la misma página del álbum situados a la derecha e izquierda de la portada, una vez analizados, vemos que el situado a la derecha corresponde por su molduras a una jamba izquierda. Al analizar en detalle las formas antropomórficas y zooformes de los mismos nos damos cuenta de que no se corresponden con las de la fotografía 61 (aunque esta es de mala calidad), ni con las representadas a modo de boceto en las láminas LA1147 y LA1148. Asimismo, se han analizado los planos de la ventana $V 5^{411}$ situada en la misma sala y vemos que la ventana tenía capiteles y un rotulo en danés que nos dice: "de to smaa Kapital ens"(De los dos capiteles pequeños uno). Esta descripción correspondería con lo observado en estas dos fotografías, donde vemos que el capitel izquierdo, aunque oculto por otra pieza, conserva los dos capiteles y la derecha solamente el capitel grande, por lo que una hipótesis sería que estos capiteles correspondan a la ventana V5, si bien se observa que la forma de la moldura superior es diferente en cada uno de ellos.

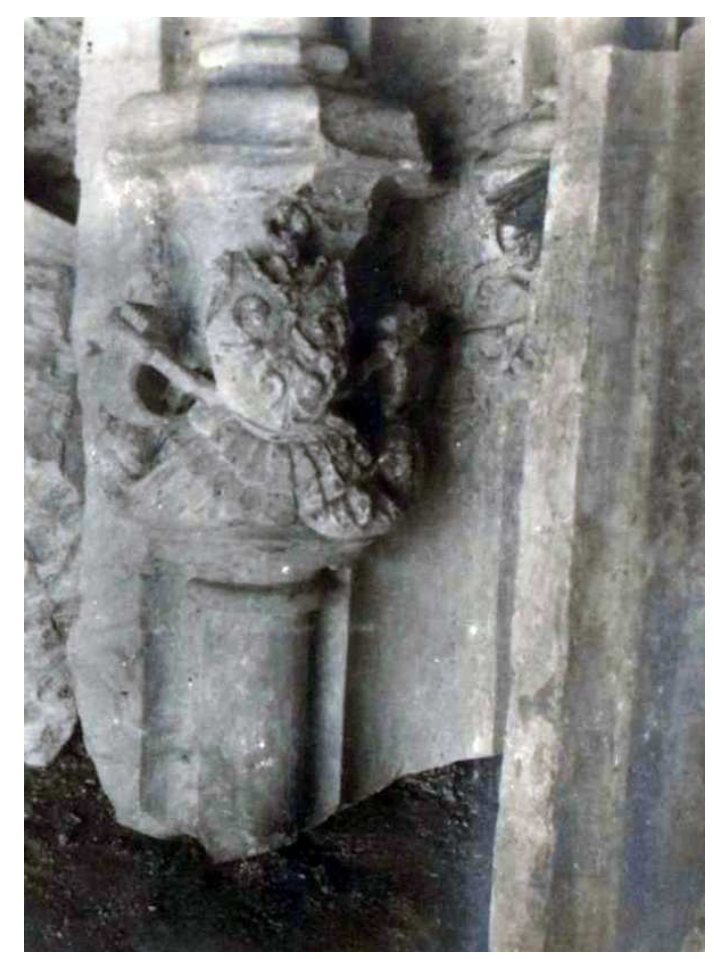

Figura 297. Capiteles de la Capilla desmontados. Izquierda: Fot. 62. Derecha: Fot. 60.

${ }^{411}$ Fischer, E. y Lauritzen V. (1919-1920). Óp. Cit. LA1198 y LA1199. 


\section{Portada 15}

Esta portada, descrita en el apartado de arcos, es la más sofisticada en cuanto al trazado geométrico de su arco. En ella encontramos cuatro capiteles sobre sus cuatro columnillas situadas sobre las jambas de la portada y justo por debajo del nivel de arranque del arco. Sus formas generales podemos intuirlas a través de la fotografía y láminas existentes, pero no disponemos de fotografías que nos permitan definirla con exactitud ${ }^{412}$ (ver Fig. 298 y 299).

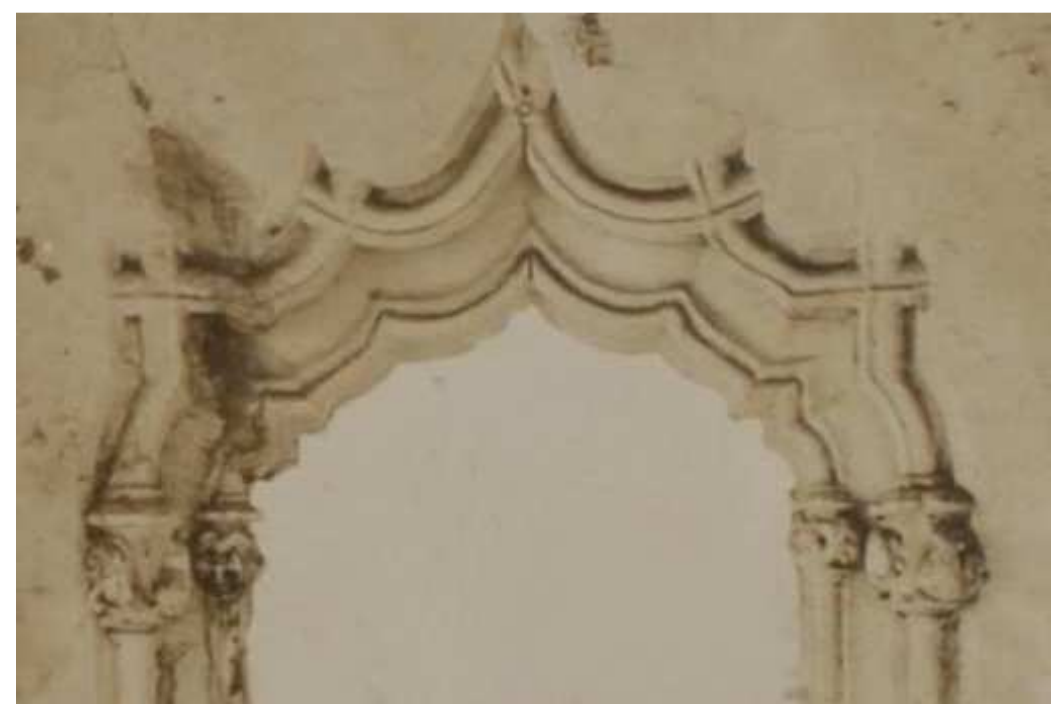

Figura 298. Detalle Portada 15. Fot. 65. AFG. E. Fischer

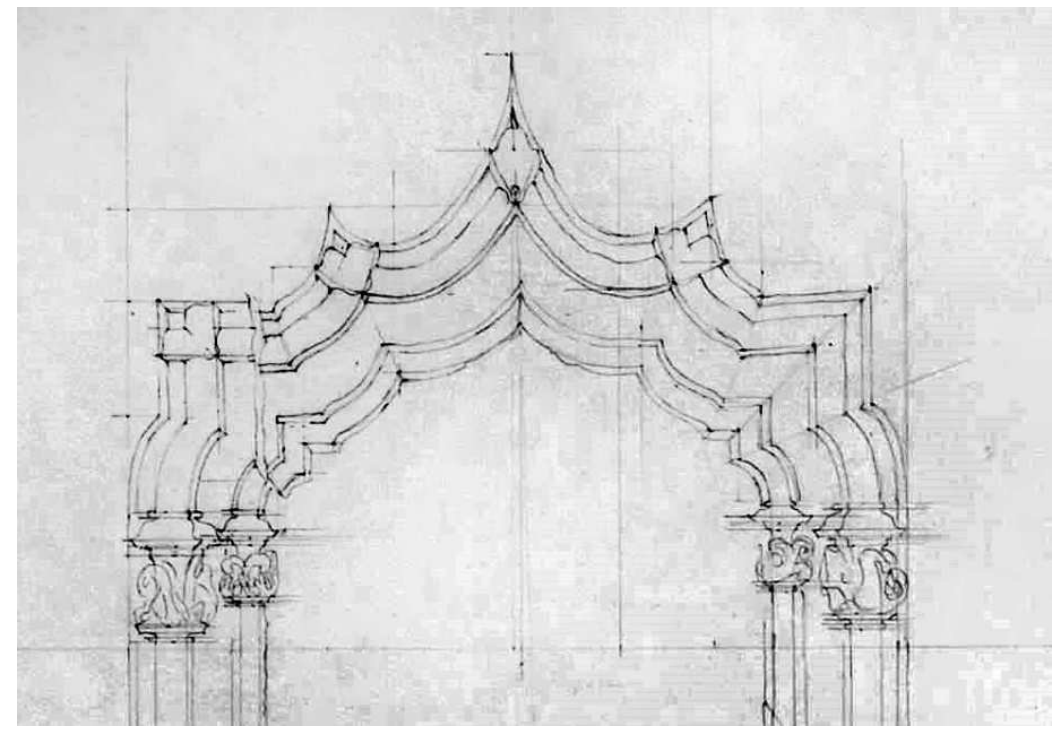

Figura 299. Detalle Portada 15. Plano LA1150. E. Fischer y/o V. Lauritzen.

${ }^{412}$ Fischer, E. (1917-1920). AFG. Óp. cit. pp. 9 A. 


\section{Portada 20}

Esta portada es mucho más compleja que las anteriores. En cuanto a sus capiteles, encontramos dos parejas con trazado y ornamentación gótica y formas orgánicas situadas sobre las columnillas. Asimismo, dos capiteles laterales surgen del lienzo del muro a modo de ménsulas y representan animales con grandes alas. Los capiteles interiores se encuentran enrasados por su parte superior, mientras que los dos exteriores no guardan ningún tipo de alineación con los primeros ${ }^{413}$. Sobre los capiteles exteriores se sustenta el alfiz que enmarca el arco y, entre estos capiteles y los anteriores, emerge un pináculo en cada lado del arco, con rica ornamentación, que queda enmarcado dentro del alfiz (ver Fig. 300 y 301).

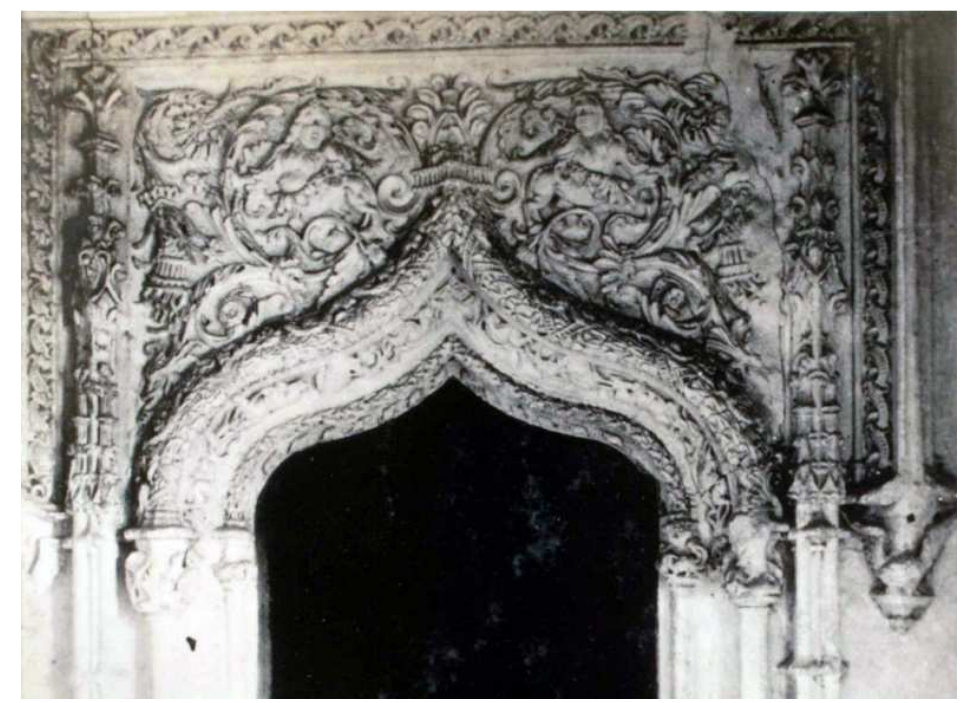

Figura 300. Detalle Portada 20. Fot. 32. AFG. E. Fischer

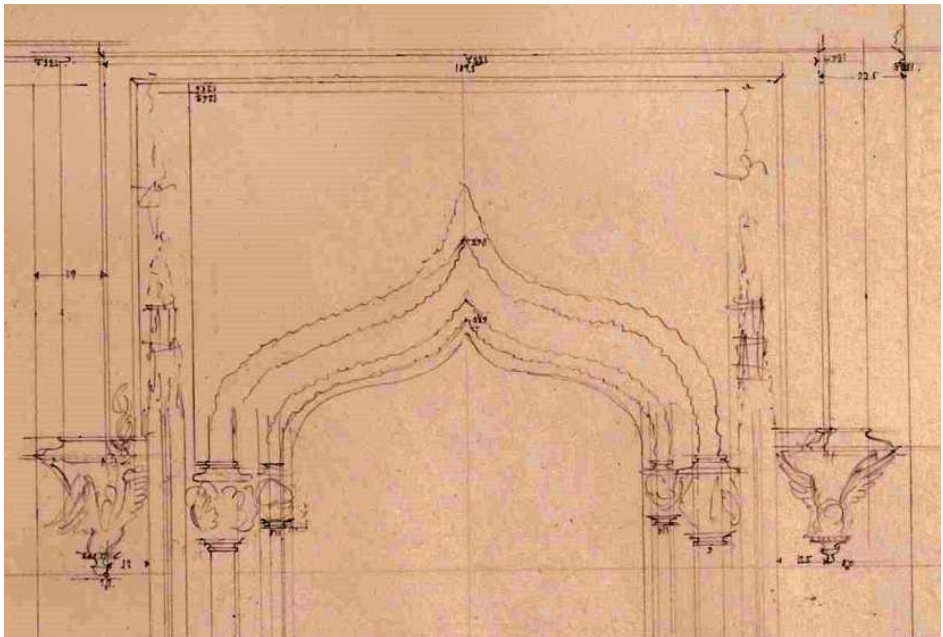

Figura 301. Detalle Portada 20. Plano LA1160. E. Fischer y/o V. Lauritzen.

${ }^{413}$ Fischer, E. y Lauritzen V. (1919-1920). Óp. Cit. LA1159 y LA1160 y Fischer, E. (1917-1920). AFG. Óp. cit. pp. 14R. 


\section{Portada 22}

Contiene cuatro parejas de capiteles; las dos interiores de carácter gótico (situados sobre las columnillas) y las dos exteriores de características claramente renacentistas, que parten directamente del muro: la primera con decoración vegetal, y la segunda formada por puttis con guirnaldas que sustentan la decoración a candilieri, que forma el alfiz del arco. En esta portada dos de los capiteles, independientemente de su estilo, se encuentran alineados por su trazado superior. Su análisis se ha realizado a partir de las fotografías y láminas generales existentes ${ }^{414}$ (ver Fig. 302 y 303 ).

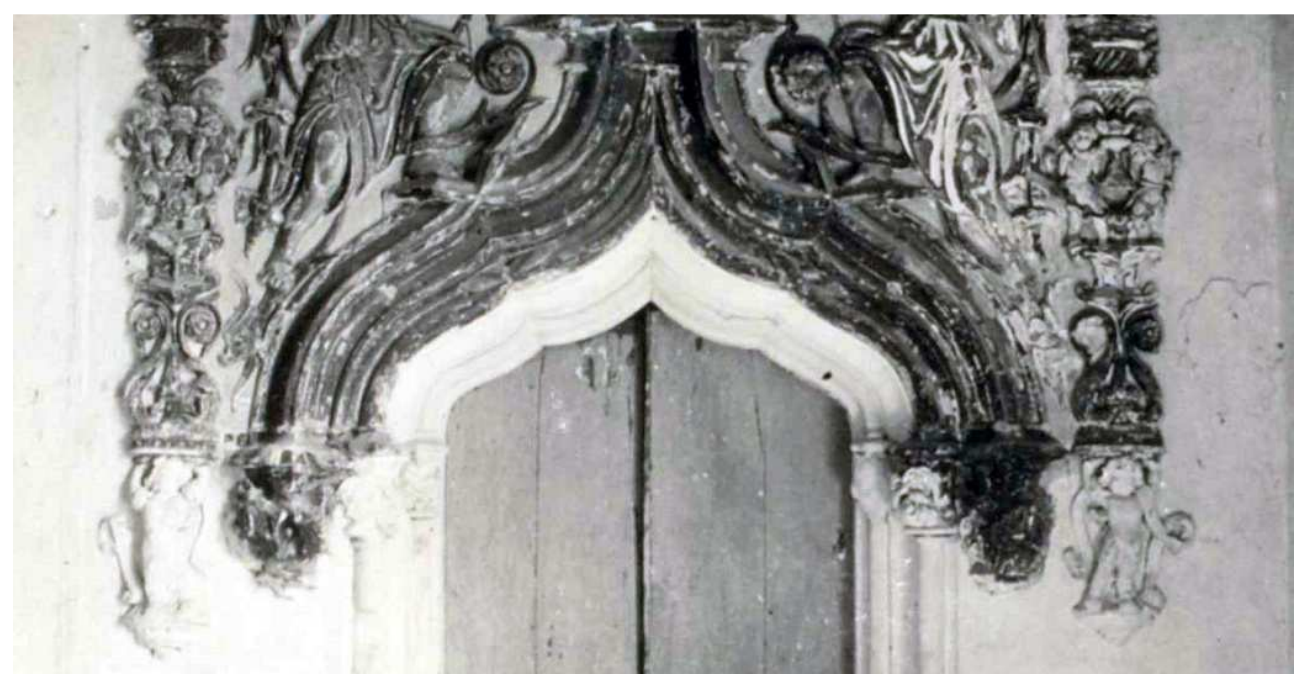

Figura 302. Detalle Portada 22. Fot. 28. AFG. E. Fischer.

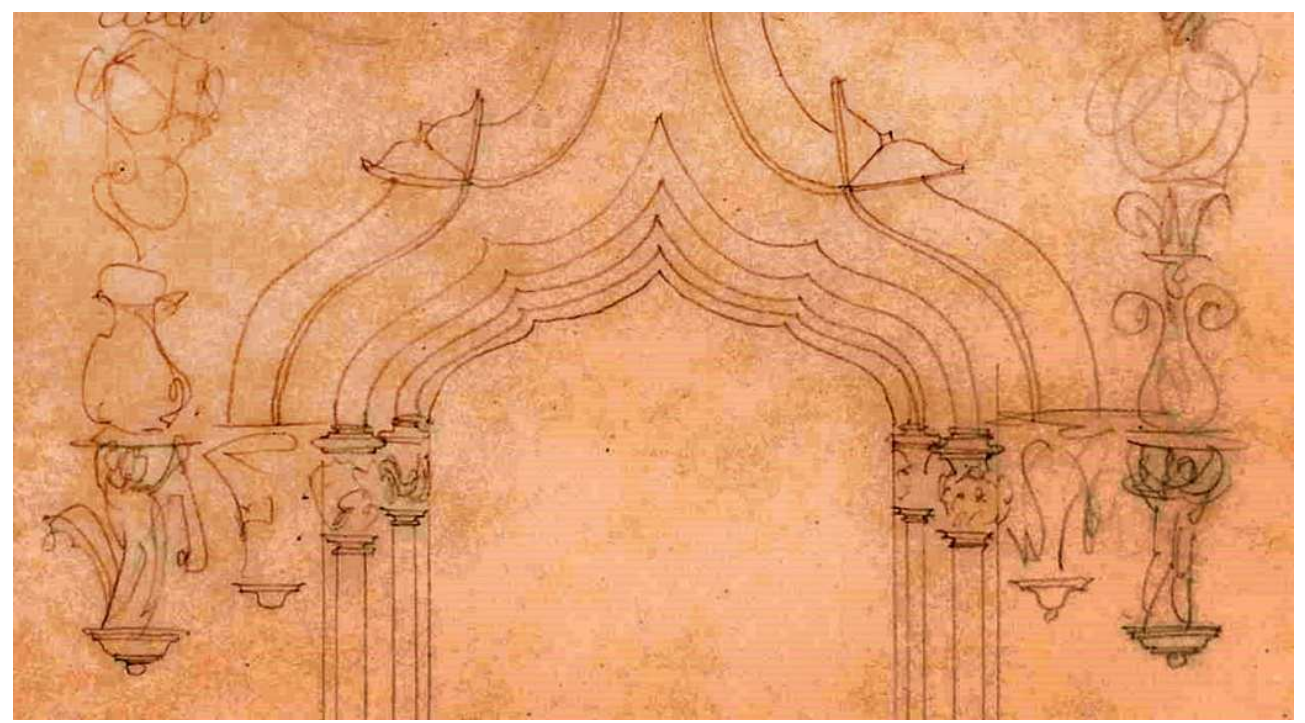

Figura 303. Detalle Portada 22. Plano LA1164. E. Fischer y/o V. Lauritzen.

${ }^{414}$ Fischer, E. y Lauritzen V. (1919-1920). Óp. Cit. LA1163 y LA1164, Fischer, E. (1917-1920). AFG. Óp. cit. 8A y Fischer, E. (1917-1920). Álbum Fotográfico Pequeño 7A. 


\section{Portada 23}

Esta portada dispone de cuatro capiteles, dos de ellos sobre las dos columnillas que sustentan el arco interior escarzano y dos exteriores, de donde parte el arco superior angrelado. Todas ellas tienen una geometría gótica y ornamentación vegetal y antropomórfica, y se encuentran alineadas superiormente como se observa en los documentos gráficos ${ }^{415}$. El hecho de estar policromadas en colores oscuros, y su contraste con el fondo blanco al haberse jabelgado de cal el resto de la sala, hace que en las fotografías en blanco y negro no puedan apreciarse bien las formas de estos capiteles (Fot. $77)^{416}$. Asimismo, el dibujo de los capiteles de las láminas LA1165 y LA1166 es bastante esquemático (ver Fig. 304 y 305).

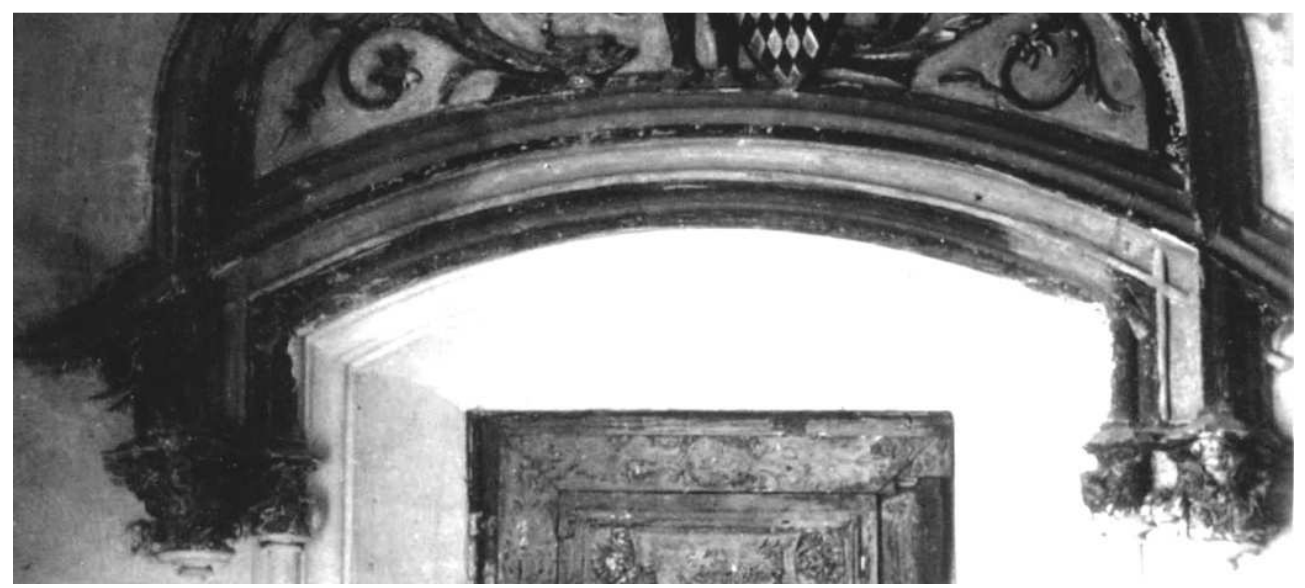

Figura 304. Detalle Portada 23. Fot. 31. AFG. E. Fischer.

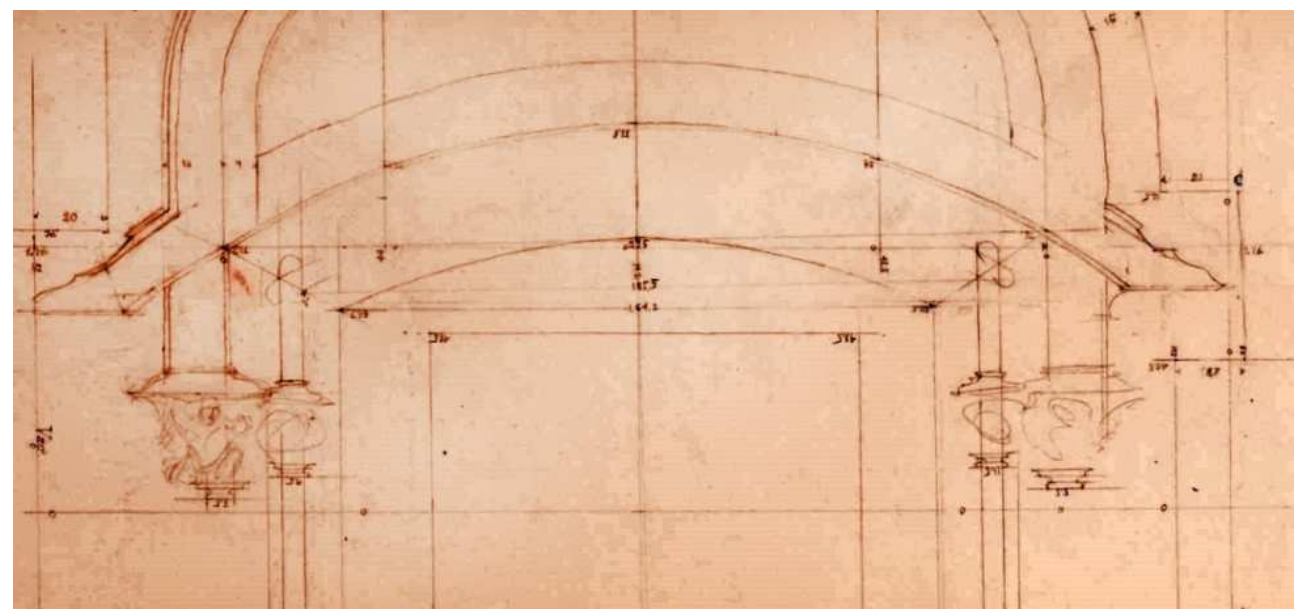

Figura 305. Detalle Portada 23. Plano LA1166. E. Fischer y/o V. Lauritzen.

\footnotetext{
${ }^{415}$ Fischer, E. y Lauritzen V. (1919-1920). Óp. Cit. LA1165 y LA1166 y Fischer, E. (1917-1920). AFG Óp. cit. pp. 7R.

${ }^{416}$ Arciniega García, L. (2001). La Memoria del ducat de Gandia i els seus títols annexos. Redactada per Basilio Sebastián per al duc d'Osuna (1851-1852). Gandia: CEIC Alfonso el Vell. pp. 221.
} 


\section{Portada 24}

En ella encontramos seis parejas de capiteles, cuatro de ellos sobre las columnillas que componen la portada y dos exteriores que, partiendo del muro, sustentan las molduras más exteriores del arco. Todas ellas son de estilo, gótico con ornamentación de formas orgánicas. Los capiteles interiores son más esbeltos, mientras que los exteriores resultan menos proporcionados, como ocurre en el resto de portadas de este tipo ${ }^{417}$ (ver Fig. 306 y 307).

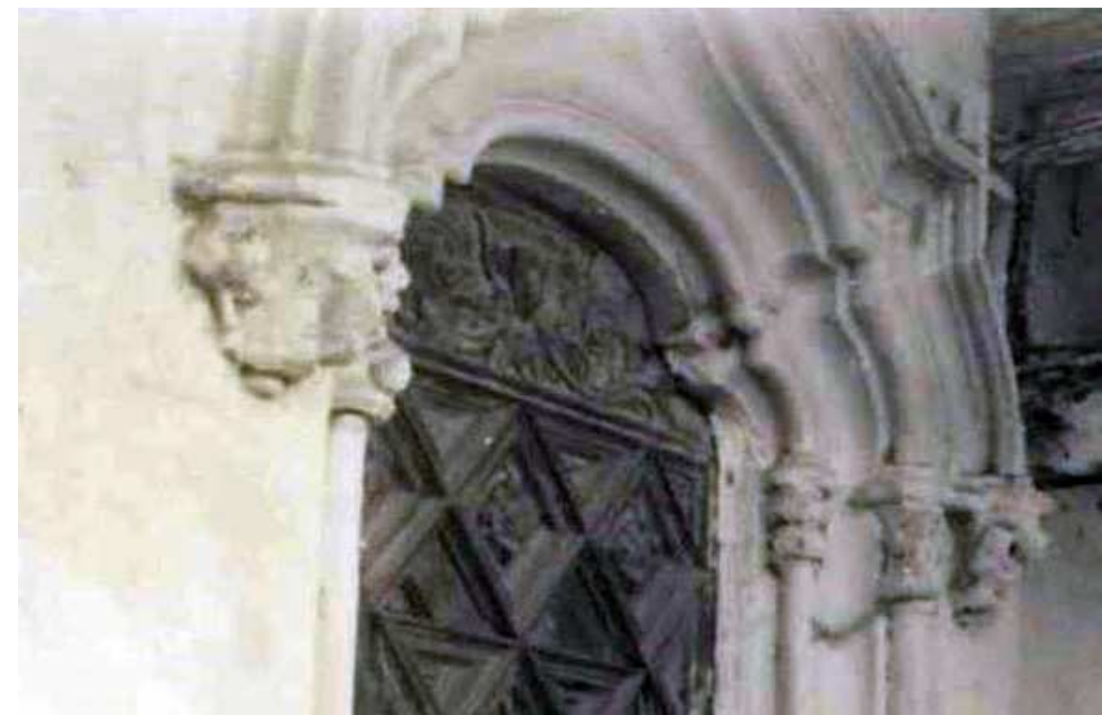

Figura 306. Detalle Portada 24. Fot. 29. AFG. E. Fischer.

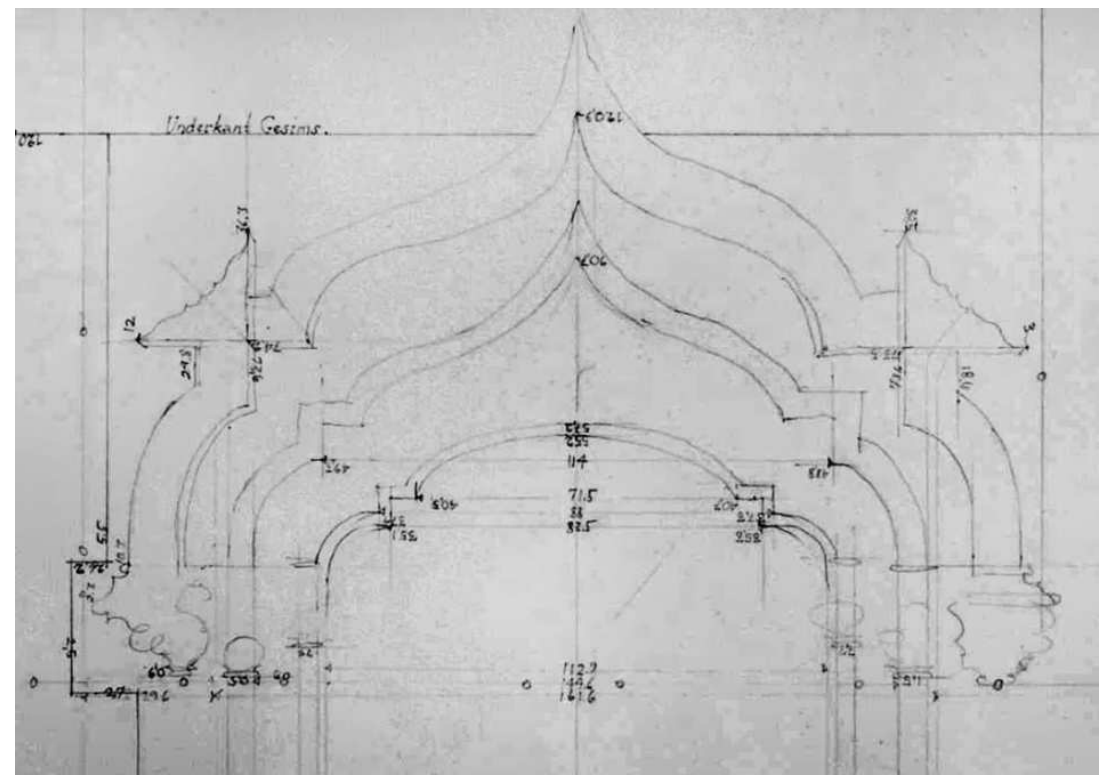

Figura 307. Detalle Portada 24. Plano LA1168. E. Fischer y/o V. Lauritzen.

${ }^{417}$ Fischer, E. y Lauritzen V. (1919-1920). Óp. Cit. LA1167 y LA1168, Fischer, E. (1917-1920). AFG Óp. cit. pp. 8R y Fischer, E. (1917-1920). AFP. Óp. cit. pp. 6A. 


\section{Portada 26 o de los Borja}

Esta portada dispone de cuatro pares de capiteles: tres de ellos descansan sobre las columnillas que forman el arco y el cuarto emerge del muro como una ménsula. Todos ellos son de geometría gótica con figuras humanas, animales y formas vegetales como decoración. Los capiteles se encuentran enrasados por su cara superior y su altura es proporcional al diámetro de la columna sobre la que apoyan (o molduras que sustentan, como es el último caso), encontrándose ordenados de mayor a menor tamaño desde el extradós al intradós de la portada. En este caso, disponemos de una fotografía con mayor detalle de los capiteles de la jamba izquierda y otra de esa misma pieza una vez desmontada (ver Fig. 308) que nos permiten identificar con mayor detalle las figuras representadas: en el capitel mayor podemos ver un ángel en posición frontal con rostro de animal, vistiendo una túnica y en posición sentada; en el segundo capitel podemos ver otra figura humana sentada, en este caso de perfil junto a lo que parece ser una hoguera; y en el tercero, una figura humana inclinada con una pierna avanzada en una posición de trabajo o esfuerzo físico ${ }^{418}$. No están representados los capiteles en los planos; tan sólo están grafiadas y acotadas las molduras de arranque de los mismos.

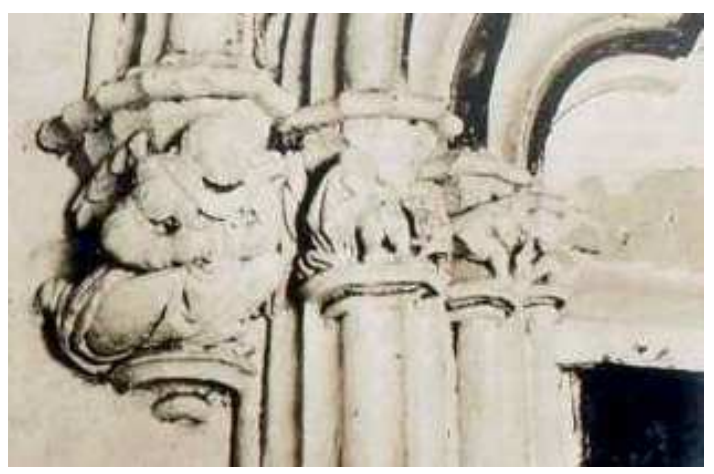

Figura 308. Capiteles jamba izquierda Portada 26. Izquierda: Detalle. Fot. 40. Derecha: Pieza desmontada. Fot. 41. AFG. E. Fischer.

\section{Portada 27}

Esta portada contiene 5 pares de capiteles sobre sendas columnillas que sustentan los arcos. En este caso disponemos de fotografías de detalle de las dos secciones de la portada que contienen los capiteles, fotografiadas una vez desmontadas. Los dos capiteles interiores se encuentran alineados superiormente entre sí, siendo de trazado gótico con elementos decorativos vegetales en el caso del ubicado en el intradós y zooformes las correspondientes a las segundas columnillas. El tercer par de capiteles, de unas dimensiones inferiores, está situado un nivel superior a los anteriores; su decoración contiene motivos vegetales (parecen hojas de acanto que surgen de un cordón entrelazado inferior, lo que denota un estilo más renacentista). La cuarta pareja de capiteles es la de mayor dimensión. A través de su geometría variable, la columnilla sección circular donde

\footnotetext{
${ }^{418}$ Fischer, E. y Lauritzen V. (1919-1920). Óp. Cit. LA1172 y LA1173 y Fischer, E. (1917-1920). AFG Óp. cit. pp. 10R.
} 
apoya se transforma en una sección rectangular achaflanada mediante dos cavetos en sus esquinas. Están situados a un nivel intermedio entre el segundo y tercer par de capiteles. Aunque sus trazados geométricos son de carácter gótico, en su ornamentación apreciamos elementos claramente renacentistas como es el caso de una concha en el caso del capitel derecho, situada entre dos figuras humanas y dos putti en el capitel izquierdo. Por último, los capiteles más exteriores, de tamaño similar al par tres, se encuentran enrasados superiormente $y$, aunque no aparecen en las fotografías de detalle, podemos apreciar en las fotografías generales su ornamentación vegetal ${ }^{419}$ (ver Fig. 309).
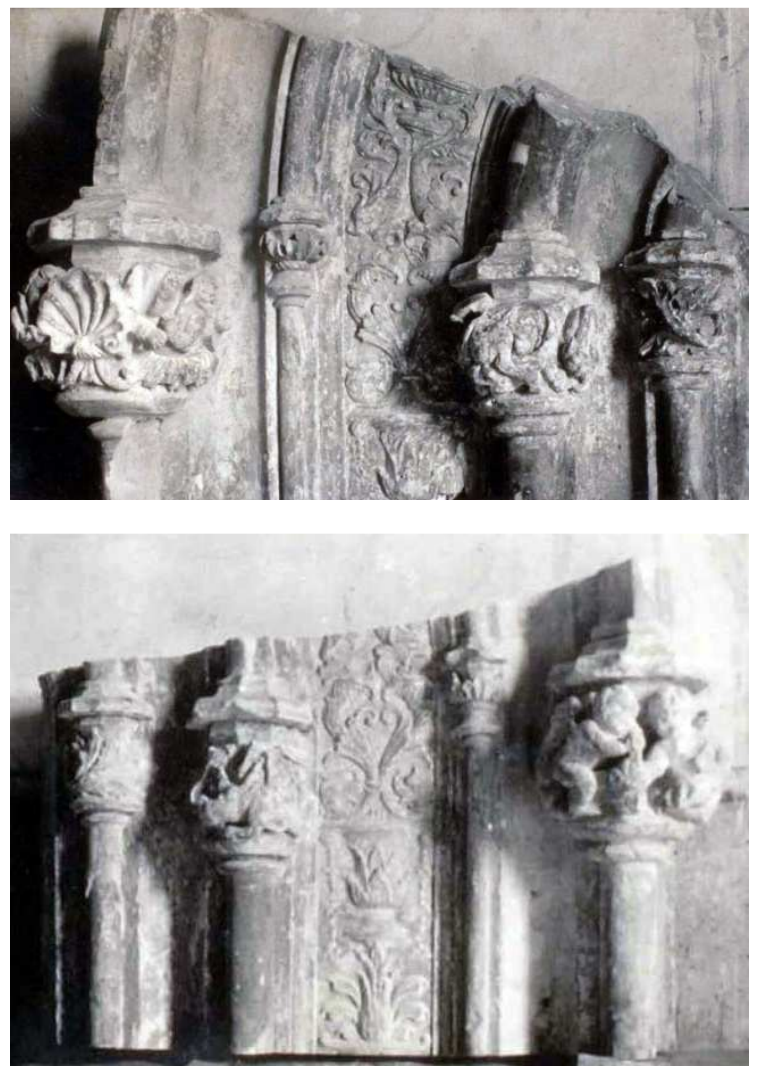

Figura 309. Capiteles desmontados Portada 27. Izquierda: Capiteles jamba izq. Fot. 36. Derecha: Capiteles jamba der. Fot. 38. AFG. E. Fischer

\section{Portadas 19, 21, 25}

Estas portadas están formadas por un sencillo arco escarzano (caso de las portadas 19 y 21) y arco angrelado (caso de la portada 25). Todas ellas disponen de una sola columnilla en cada una de sus jambas, y sobre estas y a un nivel inferior del arranque del arco, se sitúan

\footnotetext{
${ }^{419}$ Fischer, E. y Lauritzen V. (1919-1920). Óp. Cit. LA1124 y LA1125 y Fischer, E. (1917-1920). AFG Óp. cit. pp. 9R y $10 \mathrm{~A}$.
} 
sendos capiteles decorados con formas vegetales y/o antropomórficas que se pueden intuir a través de los dibujos de las láminas ${ }^{420}$, ya que no hay fotografías (ver Fig. 310).

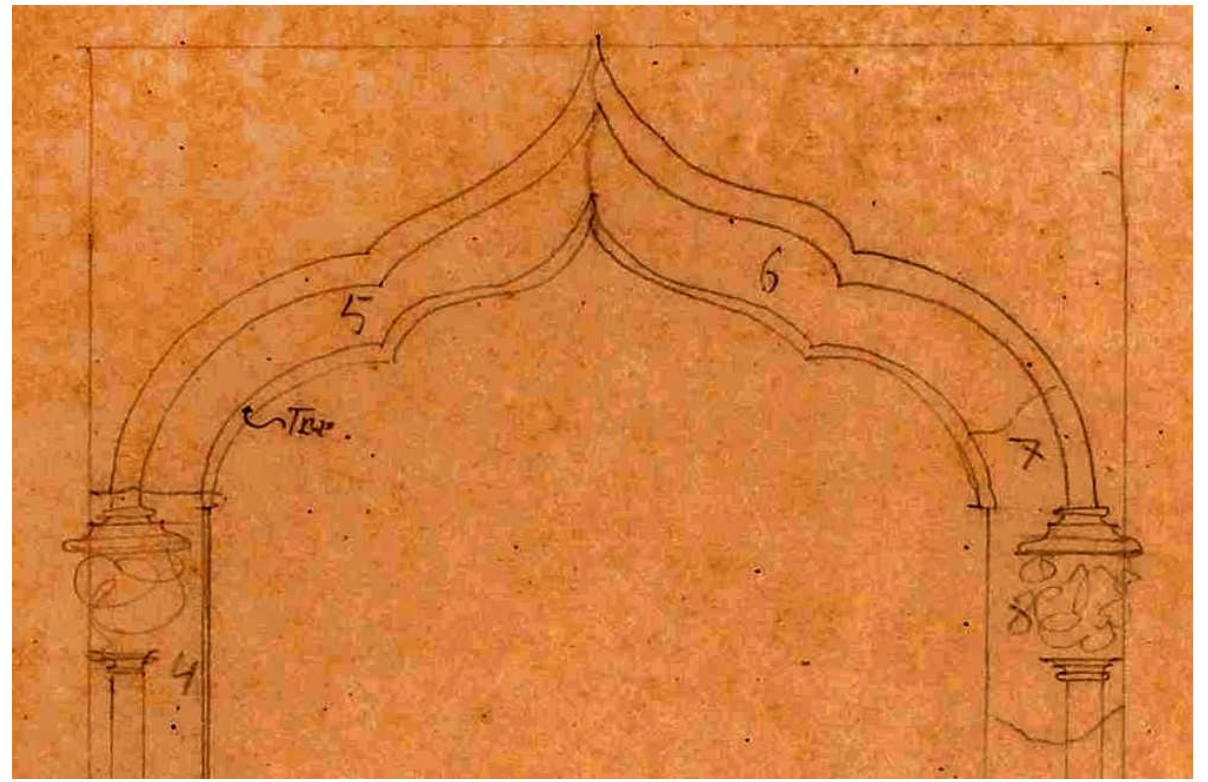

Figura 310. Detalle Portada 25. Plano LA1170. E. Fischer y/o V. Lauritzen.

\section{ORNAMENTACIÓN RENACENTISTA}

Al igual que en el caso de los capiteles, la ornamentación renacentista la encontramos en el caso de las portadas más singulares que dan acceso a las salas más nobles del palacio. En la mayoría de ellas la ornamentación renacentista se encuentra sobrepuesta en el lienzo del muro sobre el arco que conforma las portadas de trazado gótico, enmarcadas en un alfiz, tratándose aparentemente de una decoración sobrepuesta a las portadas originales ${ }^{421}$.

Existen un total de 6 portadas con ornamentación puramente renacentista que procederemos a describir y detallar:

${ }^{420}$ Fischer, E. y Lauritzen V. (1919-1920). Óp. Cit. LA1157, LA1158, LA1161, LA1162 y LA1169 a LA1171.

${ }^{421}$ E. Muller, P. (1997). El Palau d'Oliva dels Centelles. En A. Esteve i Blai, Antoni (Ed). El Palau dels Centelles d'Oliva. Recull gràfic y documental. Oliva (pp. 87-138) Oliva, España: L'Associació Cultural Centelles i Riu-Sec. pp. 108. 


\section{Portada 7}

Esta portada es un caso particular dentro de las portadas con ornamentación renacentista ya que, a pesar de no ser una de las de mayor interés desde el punto formal y arquitectónico, nos da la clave de cómo el palacio experimenta una renovación estilística con la llegada del Renacimiento. Esta portada aparece documentada en el croquis del Notebook II, las fotografías 61,69 y 70 y en la LA1182 ${ }^{422}$. Se trata de una portada con una decoración puramente renacentista: jambas rectangulares con decoración vegetal, capiteles decorados con elementos vegetales y putti alados, dintel recto, friso dentado y tímpano superior triangular rematado con jarras ornamentales. Esta ornamentación fue producida en serie ya que se han encontrado elementos idénticos en la Capilla de Todos los Santos de la Cartuja de Portaceli ${ }^{423}$. Si analizamos la Lámina LA1182, la fotografía 69 y la sección de la jamba del croquis del Notebook II observamos que, una vez desmontado el revestimiento renacentista por parte del equipo de Fischer, se descubrió que este se había colocado sobre una portada anterior de trazado tardogótico, tal y como se refleja en el dibujo realizado sobre la fotografía 69 (ver Fig. 311) y la sección de la jamba gótica dibujada en el Notebook II.

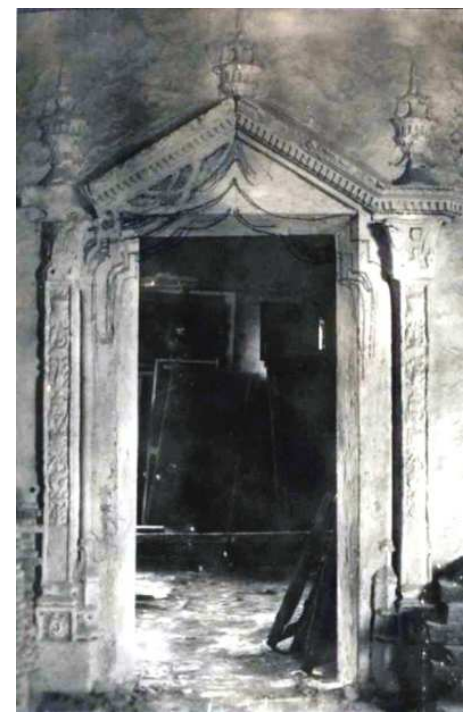

Figura 311. Portada 7.Izquierda: vista frontal D7, sobre dibujadas molduras góticas. Fot. 69. Derecha: Piezas desmontadas de la portada. Fot. 70. AFG. E. Fischer.

\section{Portada 20}

Se trata de una de las portadas donde mejor se entrelazan y conviven la composición gótica y la renacentista. Las molduras del arco, de trazado conopial (baquetones y caveto central),

${ }^{422}$ Fischer, E. (1919-1920). Notebook II. Oliva, Valencia: Museo Municipal de Oliva, Archivo Público Documental, Palacio Condal. pp.20A, Fischer, E. y Lauritzen V. (1919-1920). Óp. Cit. LA1182, Fischer, E. (1917-1920). AFG. Óp. cit. pp. 15R y Fischer, E. (1917-1920). AFP Óp. cit. pp. 9R.

${ }^{423}$ Gavara Prior, J. y E. Muller, P. (2013). El Palacio Condal de Oliva. Catálogo de los planos de Egil Fischer y Vilhelm Lauritzen. Oliva, Valencia: Ajuntament de Oliva. pp. 26-27. 
se transforman, incorporando ornamentación vegetal en forma de guirnaldas y diferenciándose, así, de las molduras idénticas que conforman las jambas, y que son totalmente lisas. A la altura de los capiteles del arco surgen del lienzo del muro dos nuevos capiteles sobre los que se apoya un alfiz que enmarca la totalidad del arco. En la cara interior de este marco aparece decoración vegetal entrelazada y dispuesta geométricamente. El interior del mismo está decorado con grutescos: dos figuras mitológicas, mitad humana mitad animal, una masculina y otra femenina que se sitúan enfrentadas; se encuentran enmarcadas a modo de medallones en elementos vegetales y rodeadas, a su vez, por hojas de acanto y elementos vegetales, formando una composición decorativa claramente renacentista. Como contraste estilístico emergen verticalmente entre el marco perimetral y los grutescos dos pináculos decorados con elementos geométricos y vegetales con un marcado estilo gótico. La cara interior del alfil está decorada con elementos vegetales encadenados. No se aprecia policromía en la fotografía, si bien pudo haber estado pintada como otras portadas de las que sí tenemos evidencias. Para el análisis de esta portada hemos partido de los planos y fotografía existentes ${ }^{424}$ (ver Fig. 312).

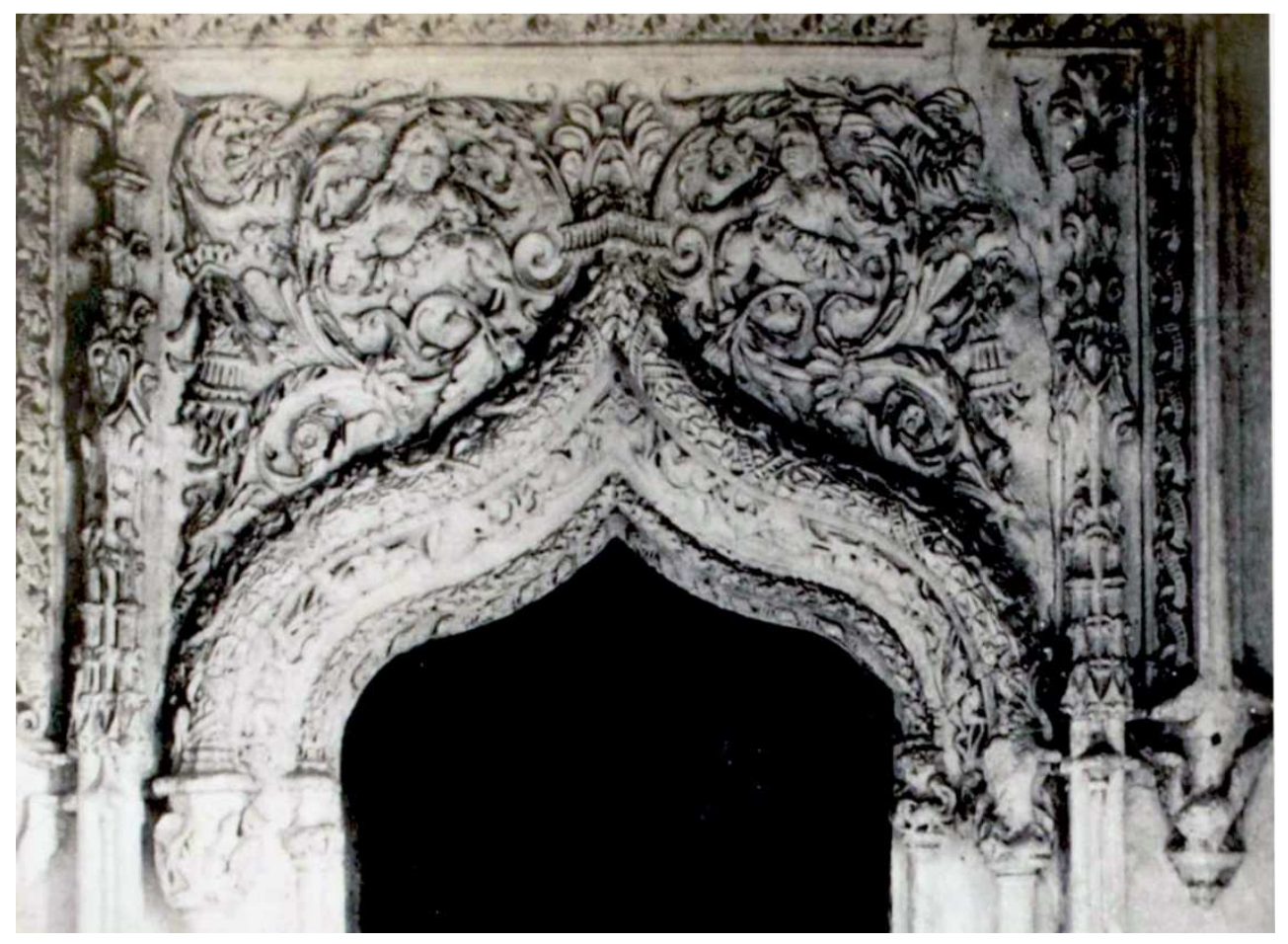

Figura 312. Detalle ornamentación Portada 20. Fot. 32. AFG. E. Fischer.

Muller define su decoración del siguiente modo: "...rico trabajo de relieve que decoraba su arco conopial, el marco y alfiz de su dintel (...) los tímpanos) muestran -en un alarde de horror vacui- una pareja de fabulosos centauros y criaturas asirenadas en un medio de

${ }^{424}$ Fischer, E. y Lauritzen V. (1919-1920). Óp. Cit. LA1159 y LA1160 y Fischer, E. (1917-1920). AFG. Óp. cit. pp. 14R. 
abundante vegetación y frutos, cuya ejecución en relieve definía y acentuaba formas, líneas, luces y sombras". Muller realiza un paralelismo entre la decoración de esta portada y el gótico tardío europeo presente en Castilla entre 1480 y 1510, poniendo como ejemplo el Patio del Colegio de San Gregorio en Valladolid ${ }^{425}$ (ver Fig. 313). Si bien es cierto que existen similitudes ornamentales, en este caso se ha producido una perfecta simbiosis entre la ornamentación renacentista y la gótica, con una portada característica del tardogótico mediterráneo, que incluyen elementos del gótico centro europeo como son los pináculos. Estos mismos elementos los podemos encontrar en portadas exteriores como la del Convento de la Trinidad en Valencia, pero son inusuales en una portada interior y esculpida en yeso.

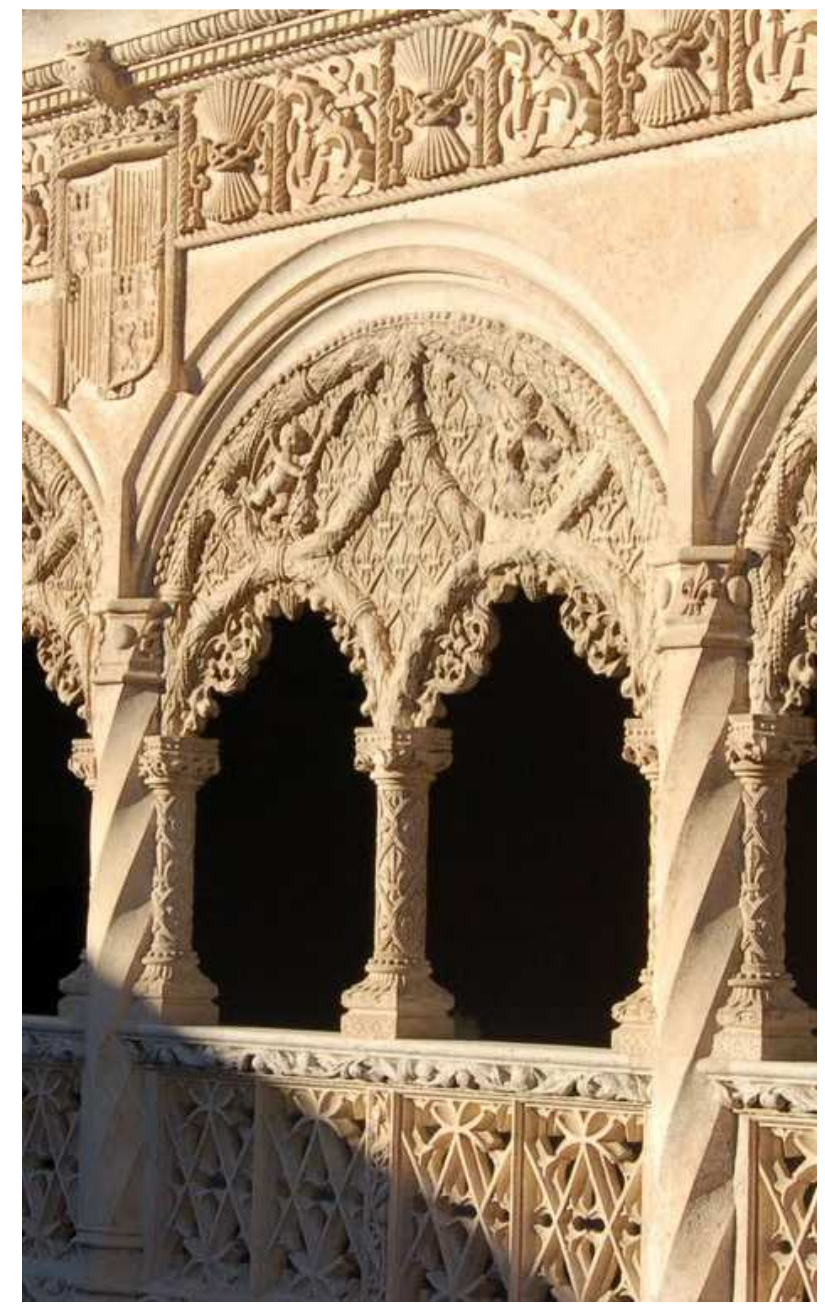

Figura 313. Galería superior patio Colegio San Gregorio. Valladolid. Fuente: Centro Vasco de Arquitectura. Recuperada webhttp://intranet.pogmacva.com/.

${ }^{425}$ Gavara Prior, J. y E. Muller, P. (2013). El Palacio Condal de Oliva. Catálogo de los planos de Egil Fischer y Vilhelm Lauritzen. Oliva, Valencia: Ajuntament de Oliva. pp. 50. 


\section{Portada 22}

Esta portada dispone de una rica ornamentación de claro corte renacentista. Sobre la clave del arco se forma una moldura horizontal sobre la que emerge un centro de vegetal con frutos. De él parten dos grandes hojas de acanto dispuestas simétricamente, que son sustentadas por dos grandes figuras humanas vestidas con túnica y dispuestas simétricamente que apoyan en cada uno de los lados del arco. Lateralmente se sitúan dos ristras a candilieri, apoyadas sobre dos figuras humanas (hombre y mujer) situadas sobre el lienzo del muro a la altura de los capiteles que forman los laterales del alfiz del arco. Sobre este conjunto, una cornisa dentada de corte clásico cierra el alfiz, y sobre esta un arco rebajado moldurado. En el tímpano central se puede observar una decoración en forma de concha. Encima del friso se sitúan zarcillos, dispuestos simétricamente, y dos figuras mitológicas aladas situadas a ambos lados. Se evidencian restos de policromía en las fotografías existentes ${ }^{426}$ (ver Fig. 314).

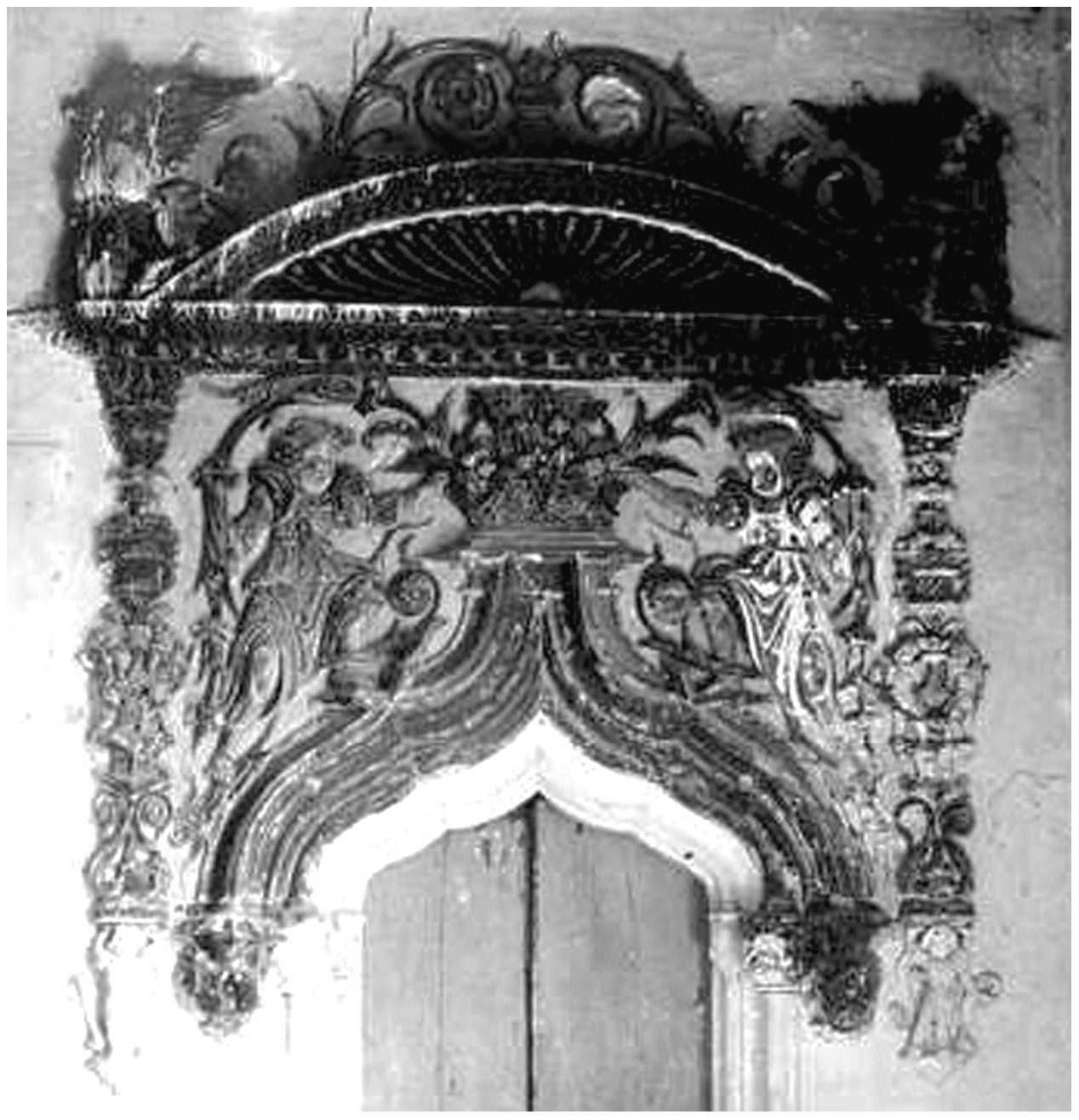

Figura 314. Detalle ornamentación Portada 22. Fot. 28. AFG. E. Fischer.

\footnotetext{
${ }^{426}$ Fischer, E. y Lauritzen V. (1919-1920). Óp. Cit. LA1163 y LA1164, Fischer, E. (1917-1920). AFG. Óp. cit. pp. 8A y Fischer, E. (1917-1920). AFP. Óp. Cit. pp. 7A.
} 
Muller define de esta portada de la siguiente forma: "...contaba inicialmente con un modesto arco conopial contracurvado (...). Sin embargo, por encima, los sobrios bordes del arco fueron repetidos de forma recargada en un remate sin columna policromado que se elevaba hacia arriba cortándose abruptamente para acomodar una ménsula. En ella había una naturaleza muerta de flores en cesta cuyos zarcillos eran sostenidos por dos adolescentes de atuendo clásico, cada uno situado en los tímpanos cuyas verticales con ornamentación vegetal descansaban sobre dos hercúleos querubines situados, como los capiteles del remate ornamental sin columna, aproximadamente al nivel de la imposta del arco interior. El exceso de ornamentación en alabastro pintado y dorado que contrasta en gran manera con la simple puerta sobre la que asienta, continúa hacia arriba hasta rematarse en un gablete ${ }^{427}$ en forma de concha de inspiración clásica, sobre cuyo arco caen todavía más zarcillos en el centro. Unas esfinges de grandes alas sientan sobre los acroteiros $^{428}$ a cada lado ${ }^{1429}$.

Muller(2013) considera que la ornamentación renacentista de la Portada 22 fue superpuesta sobre una portada de trazado originalmente gótico por la falta de proporción del conjunto y por las marcadas diferencias ornamentales entre unos y otros elementos. Asimismo evidencia lo recargada que resulta esta decoración con una superposición de distintos elementos. El nuevo gusto "a la romana" provocó esta superposición de estilos en un mismo elemento arquitectónico.

\section{Portada 23}

Esta portada se encontraba en la Sala 18 o Sala de Armas y está formada por un arco inferior escarzano y un arco superior angrelado. En el tímpano formado entre ambos arcos se representa la figura de un guerrero con casco, escudo y zarcillos con hojas de acanto dispuestas de modo asimétrico. La decoración se encontraba policromada. El guerrero presenta tonos azules y ocres y el escudo, con la cota de armas de los Centelles, está formado por rombos blancos y rojos dispuestos en juego de damas. Las hojas de acanto estaban policromadas en rojo y azul. En este caso disponemos de la información cromática, ya que además de las láminas y de la fotografía originales ${ }^{430}$, disponemos de la figura del guerrero que fue recuperada y se encuentra restaurada y expuesta en el Museo Arqueológico de Oliva (ver Fig. 315 y 316).

\footnotetext{
${ }^{427}$ Gablete: Arq.: Remate formado por dos líneas rectas y ápice agudo, que se ponía en los edificios de estilo ojival. RAE. Recuperado en: http://dle.rae.es.

${ }^{428}$ Acroteiro Arq.: Cada uno de los pedestales que sirven de remate en los frontones, y sobre los cuales suelen colocarse estatuas, macetones u otros adornos. RAE. Recuperado en: http://dle.rae.es. ${ }^{429}$ Gavara Prior, J. y E. Muller, P. (2013). Óp. cit. pp. 40-41.

${ }^{430}$ Fischer, E. y Lauritzen V. (1919-1920). Óp. Cit. LA1165 y LA1166 y Fischer, E. (1917-1920). AFG Óp. cit. pp. 7R.
} 


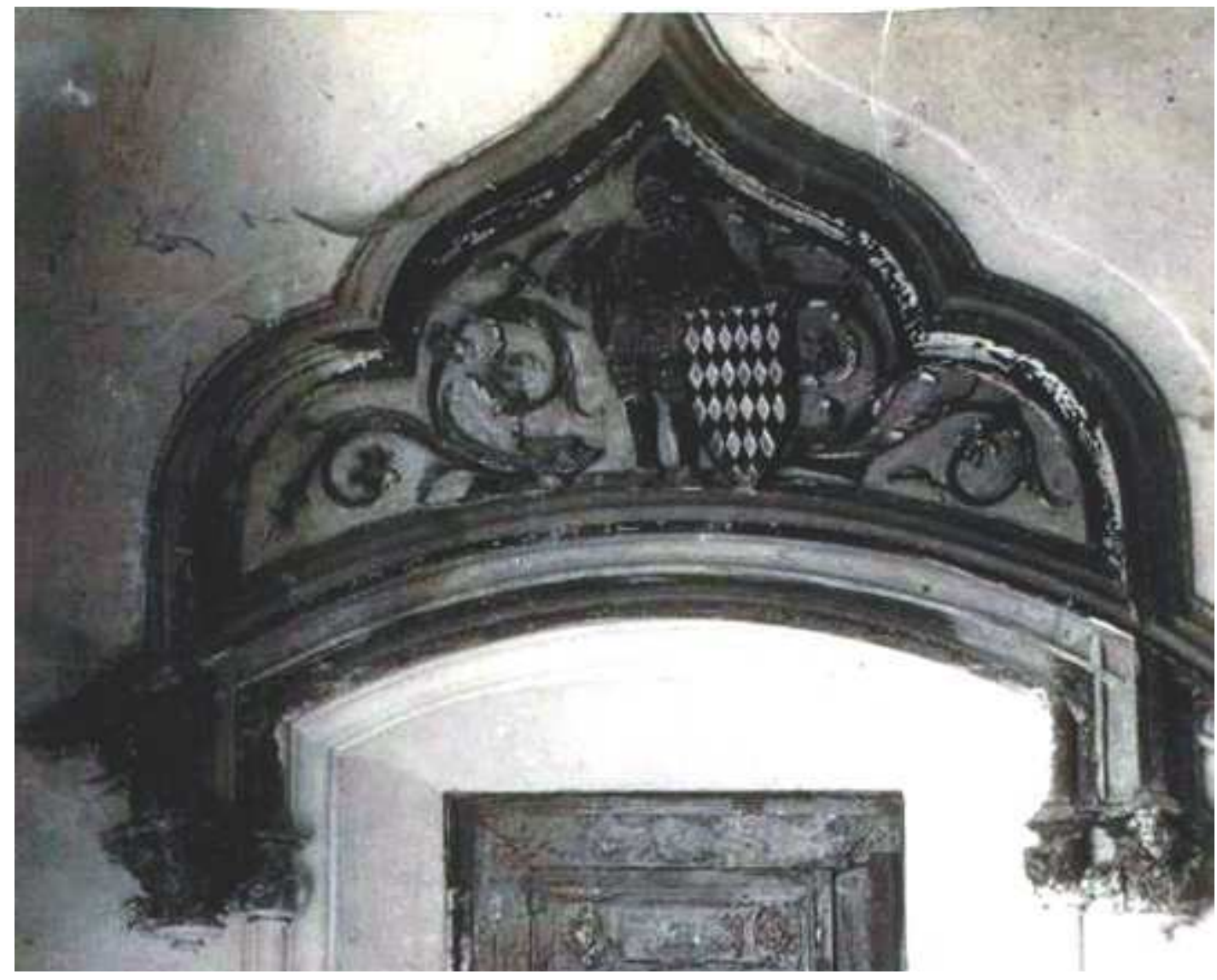

Figura 315. Detalle ornamentación Portada 23. Fot. 31. AFG. E. Fischer.

Muller hace la siguiente definición sobre su decoración: "La ornamentación de la Puerta 23 (...) era menos exuberante. Su dintel coronaba también un marco relativamente simple con arco carpanel poco pronunciado soportado por unas columnillas adosadas que terminaban en modestos capiteles y bases esculpidos. El dintel en sí, con su base siguiendo las líneas del arco bajo él, era claramente gótico, aunque con un modificado arco conopial muy pronunciado. En el centro del dintel y en medio de una decoración no demasiado densa de zarcillos, podía contemplarse el bajorrelieve policromado de un joven de pie y en armadura presentando un escudo con la cota de armas de los Centelles". Según Muller el guerrero podría representar a Gilabert de Centelles y Riu-Sec, Señor De Nules y Oliva y abuelo de Francesc Gilabert, primer Conde de Oliva. Para la investigadora, en esta portada se ven perpetuadas formas góticas, pero introduciendo en su diseño elegantes zarcillos que, poco a poco, irán sustituyendo los troncos y decoración de hojas, característicos del gótico a partir de principios del siglo $\mathrm{XVI}^{431}$ :

${ }^{431}$ Gavara Prior, J. y E. Muller, P. (2013). Óp. cit. pp. 41-42. 


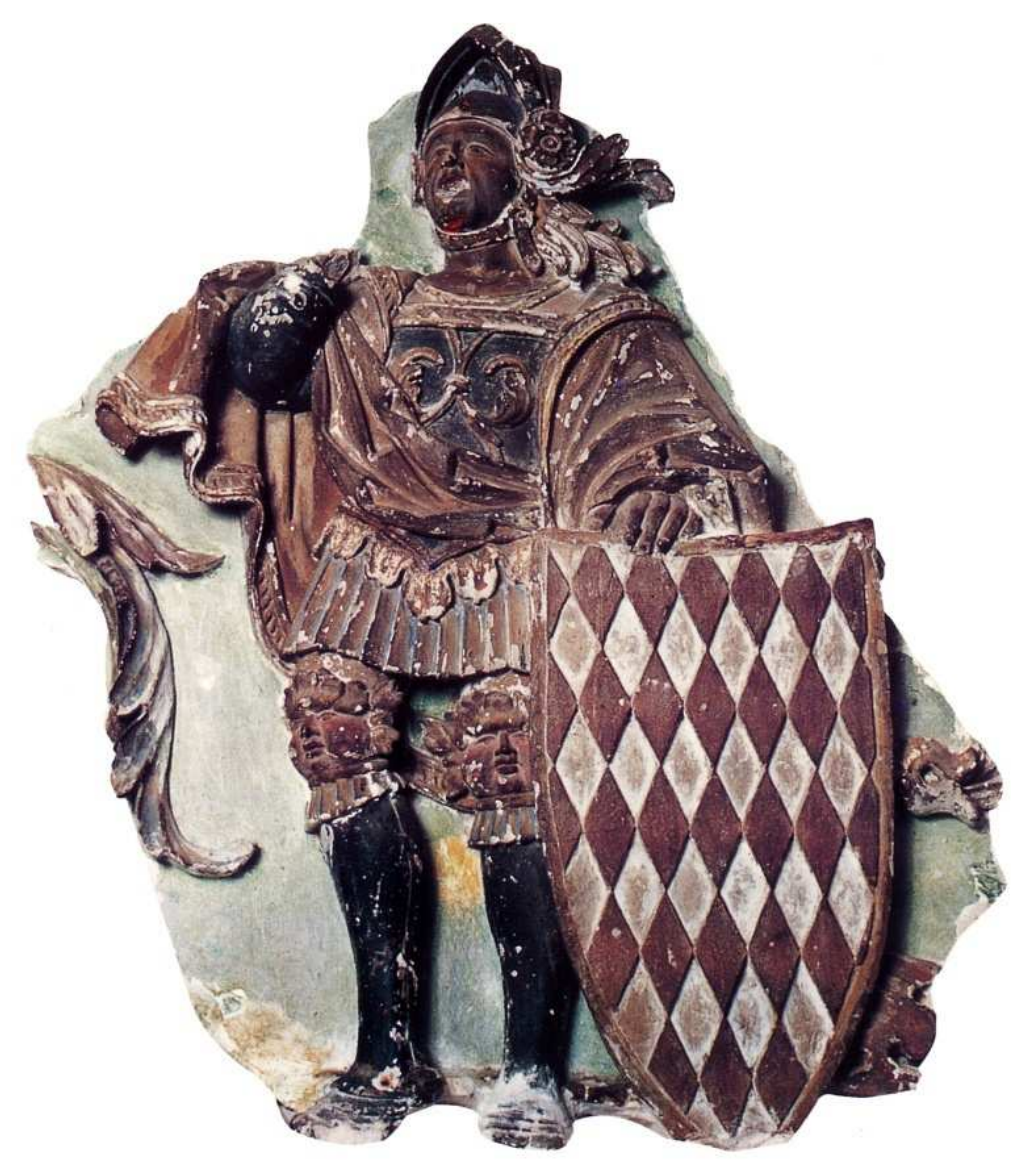

Figura 316. Guerrero en altorrelieve Portada 23. MAO. Salvador Mañó i Fenollar.

\section{Portada 26 o de los Borja}

Esta portada, Ilamada también "de los Borja", se encuentra situada en la Sala 20. Enmarcando el arco angrelado que la forma, se sitúan las molduras verticales que arrancan de dos capiteles exteriores que surgen directamente del muro. Dichas molduras intersectan con una cornisa situada a un nivel muy superior al del arco. "Dos grifos, en posición enfrentada, se encontraban colgados sobre zarcillos habitados por putti en la excepcionalmente alta albanega sobre su arco y dentro de las molduras de alfiz, con sus patas delanteras reposando sobre un escudo central, sus alas hacia arriba y estrechándose en su parte inferior para encontrar el punto del arco" ${ }^{\prime 32}$. El escudo de armas que apoya directamente sobre la clave del arco corresponde al de los Centelles en la parte derecha y al de los Borja y Oria en la izquierda. La portada se encontraba policromada. La documentación gráfica que disponemos se compone de dos láminas y tres fotografías originales $^{433}$.

\footnotetext{
${ }^{432}$ Gavara Prior, J. y E. Muller, P. (2013). Óp. cit. pp. 42.

${ }^{433}$ Fischer, E. y Lauritzen V. (1919-1920). Óp. Cit. LA1172 y LA1173 y Fischer, E. (1917-1920). AFG Óp. cit. pp. 10R.
} 


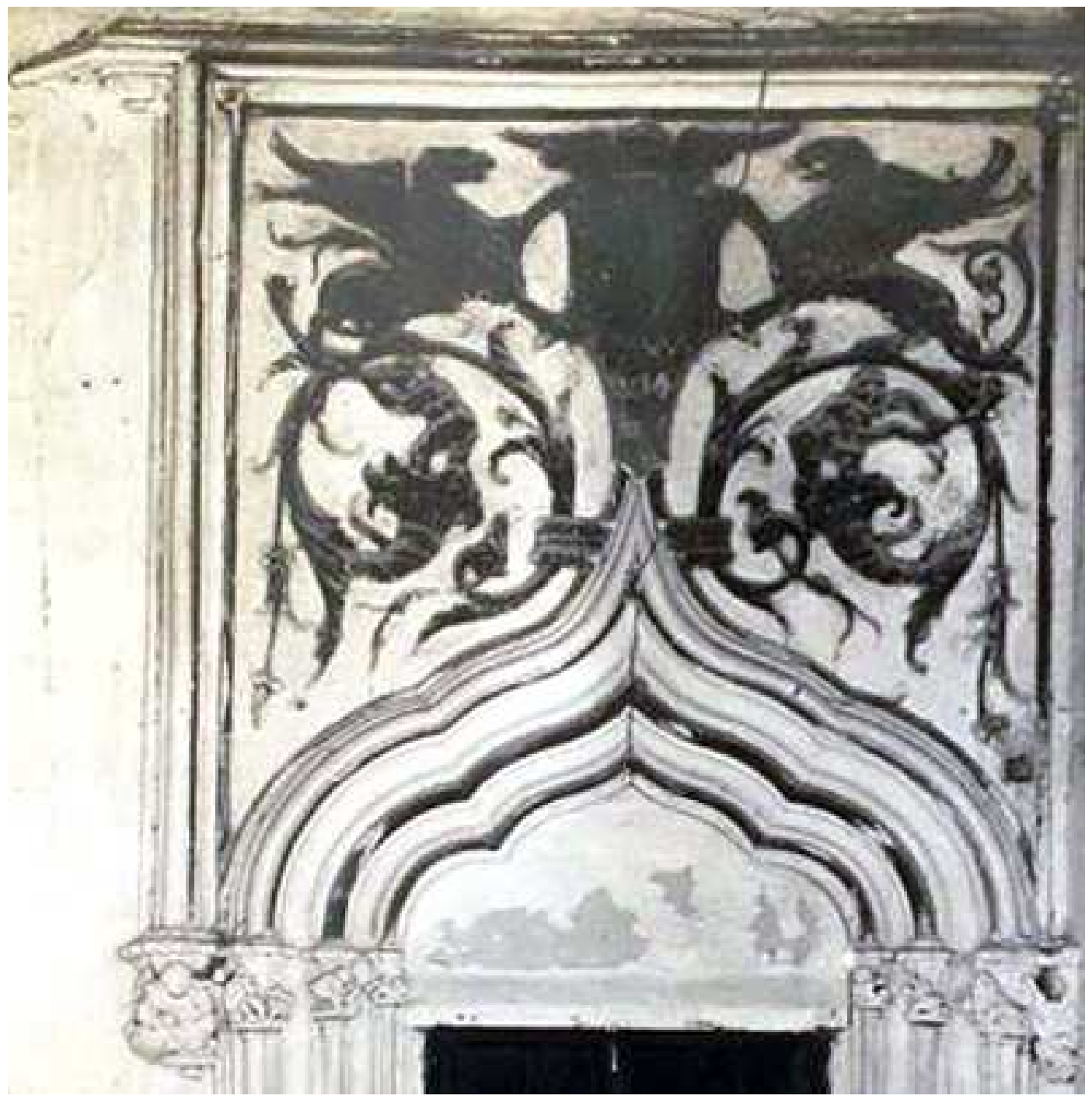

Figura 317. Detalle alfiz Portada 26. Fot. 39. AFG. E. Fischer.

Muller la define de la siguiente forma: "Dos grifos en posición enfrentada, se encontraban colgados sobre los zarcillos habitados por putti en la excepcionalmente alta albanega ${ }^{434}$ sobre su arco y dentro de las molduras de alfiz, con sus patas delanteras reposando sobre el escudo central, sus alas hacia arriba y estrechándose en su parte inferior para encontrar el punto del arco. Con el escudo de armas de los Centelles en la parte derecha del escudo y de los Borja y Oria en la superior e inferior izquierda, los grifos jugarían el papel de temibles y poderosos protectores de esas familias de la nobleza". La portada es mucho anterior a la unión de las casas Borja y Centelles, por lo que el escudo debió de ser modificado tras el enlace de Magdalena de Centelles y Carlos de Borja en 1548. Muller compara el dintel de

434 Albanega: Arq.: Espacio triangular comprendido entre la rosca de un arco y el alfiz. RAE. Recuperado en: http://dle.rae.es. 
esta portada con los de la Generalitat Valenciana y pone de relieve cómo el estilo gótico se "resiste" a abandonar los gustos ornamentales durante el primer tercio del siglo $\mathrm{XVI}^{435}$.

\section{Portada 27}

Esta portada está situada también en la Sala 20, a la izquierda de la Portada de los Borja. Sobre su arco polilobulado rebajado surgen dos enormes volutas en espiral helicoidal que forman, a su vez, un arco con forma conopial. Dichas espirales intersectan volumétricamente con el resto de molduras que forman el arco. El caveto aparece entre la segunda y la tercera columna y, desde el intradós del arco, presenta decoración renacentista a candilieri ${ }^{436}$.

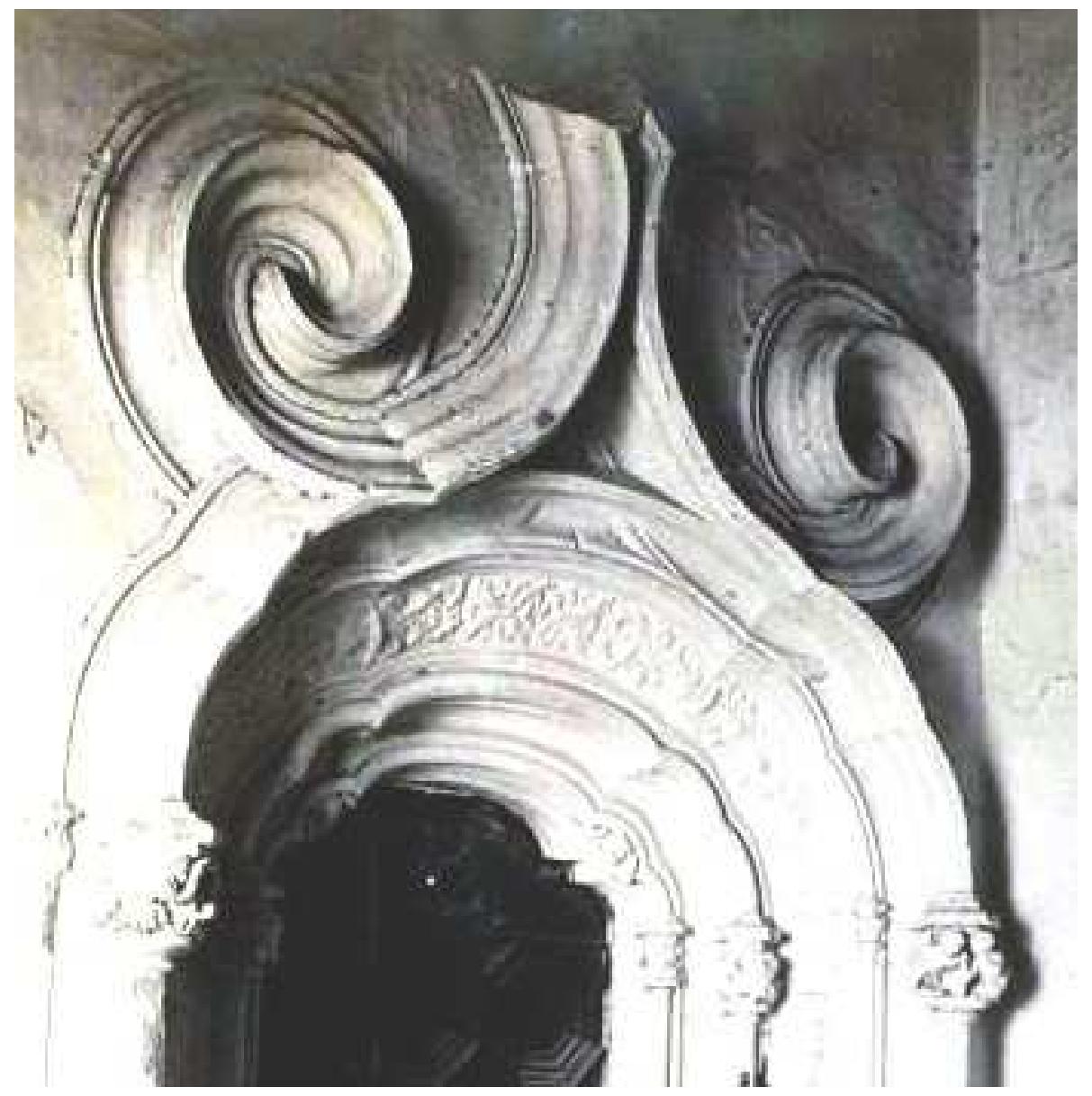

Figura 318. Detalle Portada 27. Fot. 33. AFG. E. Fischer.

${ }^{435}$ Gavara Prior, J. y E. Muller, P. (2013). Óp. cit. pp. 42-43.

${ }^{436}$ Fischer, E. y Lauritzen V. (1919-1920). Óp. Cit. LA1124 y LA1125 y Fischer, E. (1917-1920). AFG Óp. cit. pp. $9 R$ y $10 A$. 
"Este extraordinario marco cuya monumentalidad se sustenta en las colosales volutas superpuestas, no tiene parangón. Las enormes volutas que se curvan hacia un punto de pronunciado énfasis, repiten y refuerzan -de una manera que podría considerarse casi extravagante- las líneas por otro lado casi imperceptibles, del arco ojival que arranca del molde superior del arco de medio punto ${ }^{437}$ bajo el. Al empequeñecer el marco inferior, la impresión global confiere a la puerta gran importancia y una sensación de altura extrema, aunque en realidad, esta es menor a la del vecino dintel Borja". Con esta definición se refiere Muller a la Portada 27, siendo sin duda la que más impresiona a la investigadora por su voluptuosidad. En cuanto a los relieves de la portada los define así: "...el marco de puerta con arco de medio punto con puntilla, capiteles profundamente esculpidos, ornamentación de relieves del primer Renacimiento de jarras simétricas, peces, esfinges, cornucopias y motivos vegetales centrados entre columnas que daban profundidad a la puerta...". A pesar de que las volutas superiores no tienen un referente en otro tipo de portadas, la autora defiende, frente a otros autores, que no se trata de un añadido posterior dada su simbiosis con el resto de los elementos de la portada y por la ausencia de modificaciones estilísticas posteriores en el Palacio, y pone como antecedente las volutas de la fachada de Santa María Novella de Florencia iniciada en $1458^{438}$.

\section{MÉTRICA Y PROPORCIONES GEOMÉTRICAS}

En este apartado tratamos de analizar el sistema metrológico y las proporciones geométricas con las que fueron trazadas las portadas. Para ello, nos apoyaremos en los planos elaborados a partir de la toma de datos llevada a cabo por Egil Fischer y Vilhelm Lauritzen entre 1917 y 1920.

\subsection{Métrica}

Desde la antigüedad los sistemas de medidas se basaban en las proporciones humanas, siendo por tanto sistemas antropométricos ${ }^{439}$. Estos sistemas tenían sus orígenes en el sistema metrológico romano, de carácter antropométrico, con múltiplos y submúltiplos del pie según el sistema sexagesimal (heredado de la cultura oriental de Siria). Tras la disgregación del imperio romano, se pierde su unidad metrológica y aparecen variantes regionales o locales. La vara adquiere gran protagonismo suplantando en buena parte al

\footnotetext{
437 Aunque la percepción general es que se trata de un arco de medio punto, su trazado es polilobular de 5 centros.

${ }^{438}$ Gavara Prior, J. y E. Muller, P. (2013). Óp. cit. pp. 43-44.

${ }^{439}$ García Valldecabres, J. (2010). La métrica y las trazas en la iglesia de San Juan del Hospital de Valencia. (Tesis doctoral). Valencia: Universitat Politècnica de València. pp. 229-248 y Máñez Pitarch, M. J. (2014). Óp. cit. pp. 221.
} 
pie. Ésta tiene una dimensión cómoda para ser utilizada por constructores y comerciantes $^{440}$.

Tras la reconquista del Reino de Valencia, el rey Jaume I, en el siglo XIII, otorgó los fueros a sus pobladores. En ellos instauraba un sistema de medidas y pesos que debía ser igual en la ciudad de Valencia y en todas las villas, castillos y demás lugares del Reino. En este sistema de medidas foral valenciano se fijó como medida de longitud la alna o vara ${ }^{441}$, y como submúltiplo de esta el palmo. Una vara o alna equivalía a 4 palmos.

El sistema era de base duodecimal, principalmente por el alto número de divisiones elementales $2,3,4$ y 6 , que evita el uso de quebrados ${ }^{442}$.

La equivalencia del palmo valenciano respecto del sistema métrico decimal se establece en 22,65 cm según algunos autores (Soler-Verdú y Soler Estrela, 2015; Zaragozá y Marín, 2015) y $23 \mathrm{~cm}^{443}$ según otros (López-Bueno y García-Valldecabres, 2014; Máñez, 2014). Se ha realizado un estudio de todas las portadas aplicando ambas metrologías, tanto en anchura como en altura. En la mayoría de las portadas la métrica que más encaja es la de $23 \mathrm{~cm}$, si bien no todas las portadas encajan de manera exacta en el palmo de $23 \mathrm{~cm}$. Debemos tener en cuenta que, al tratarse de elementos relativamente pequeños, no necesariamente se modularían en palmos enteros. Por otra parte, existe una acumulación de errores que pueden provocar diferencias entre la traza original y los planos realizados. Procedemos a enumerar estos errores:

- Errores de ejecución: en todos los procesos constructivos se cometen una serie de errores de ejecución, produciéndose pequeñas diferencias métricas entre el objeto diseñado y el resultado final. Si tenemos en cuenta que las portadas se ejecutaron con medios manuales con las herramientas propias del siglo XVI, es comprensible que puedan existir pequeños errores entre la traza original y el elemento construido.

- Errores de medición: en 1919, cuando se realizaron los planos, las herramientas de medición eran manuales y, por tanto, las cotas del objeto obtenidas se tomaron mediante comprobación visual sobre la cinta métrica, por lo que se pueden producir errores a la hora de visualizar y anotar las medidas si éstas no se toman con el suficiente rigor y con un criterio científico. En este caso, se pueden acumular los errores propios de la tolerancia dimensional de la herramienta de medida y el posible deterioro o deformación del elemento desde la fecha en que fue construido, en este caso, hacía tres siglos.

- Errores de escalado y rectificación: no en todas las láminas originales disponemos de cotas numéricas, por lo que se ha procedido al escalado y rectificación de las imágenes digitales, según la escala gráfica de referencia y las medidas totales de

\footnotetext{
440 López González, C., García Valldecabres, J. Una metodología para el análisis de los trazados reguladores clásicos de la Arquitectura. APEGA. EGE. 2002, no 7, pp. 110 y Máñez Pitarch, M. J. (2014). Óp. cit. pp. 221.

${ }^{441}$ García Valldecabres, J. Óp. cit. pp. 255-267 y Máñez Pitarch, M. J. (2014). Óp. cit. pp. 221.

${ }^{442}$ Máñez Pitarch, M. J. (2014). Óp. cit. pp. 222.

${ }^{443}$ Máñez Pitarch, M. J. (2014). Óp. cit. pp. 460.
} 
las láminas. Esto hace que se produzcan también errores en este proceso de tratamiento digital que pueden afectar a las medidas finales obtenidas de las portadas.

Otro factor a tener en cuenta en las alturas es la cota de pavimento. Es posible que, a la hora de trazar las portadas, no se tuviera en cuenta la cota definitiva del pavimento, o bien que este se modificara posteriormente, por lo que podrían existir diferencias de $+/-6 \mathrm{~cm}$ en las cotas de altura atribuibles a esta causa.

Sin embargo, una vez analizadas todas las portadas, se han detectado numerosas coincidencias o aproximaciones con esta modulación de palmos de $23 \mathrm{~cm}$. Estas coincidencias se han producido en distintas medidas de elementos singulares de las portadas, como en la luz de paso, la altura libre, la anchura total, la altura total y la línea de impostas. En la tabla 49 se analiza la anchura y altura total por ser las medidas en las que se han encontrado más coincidencias. En la siguiente tabla se han marcado en azul las diferencias menores o iguales a $3 \mathrm{~cm}$, tanto en positivo como en negativo, respecto al número de palmos enteros o fracción de los mismos. En este caso se ha considerado sólo $1 / 2$ y $1 / 3$ de palmo. En el caso de las portadas con decoración sobre las enjuntas del arco, estas no se han considerado en la modulación (portadas 20,22, 26 y 27). En las siguientes figuras se incluyen las modulaciones en palmos valencianos de algunas de las portadas que más se ajustan a este módulo.

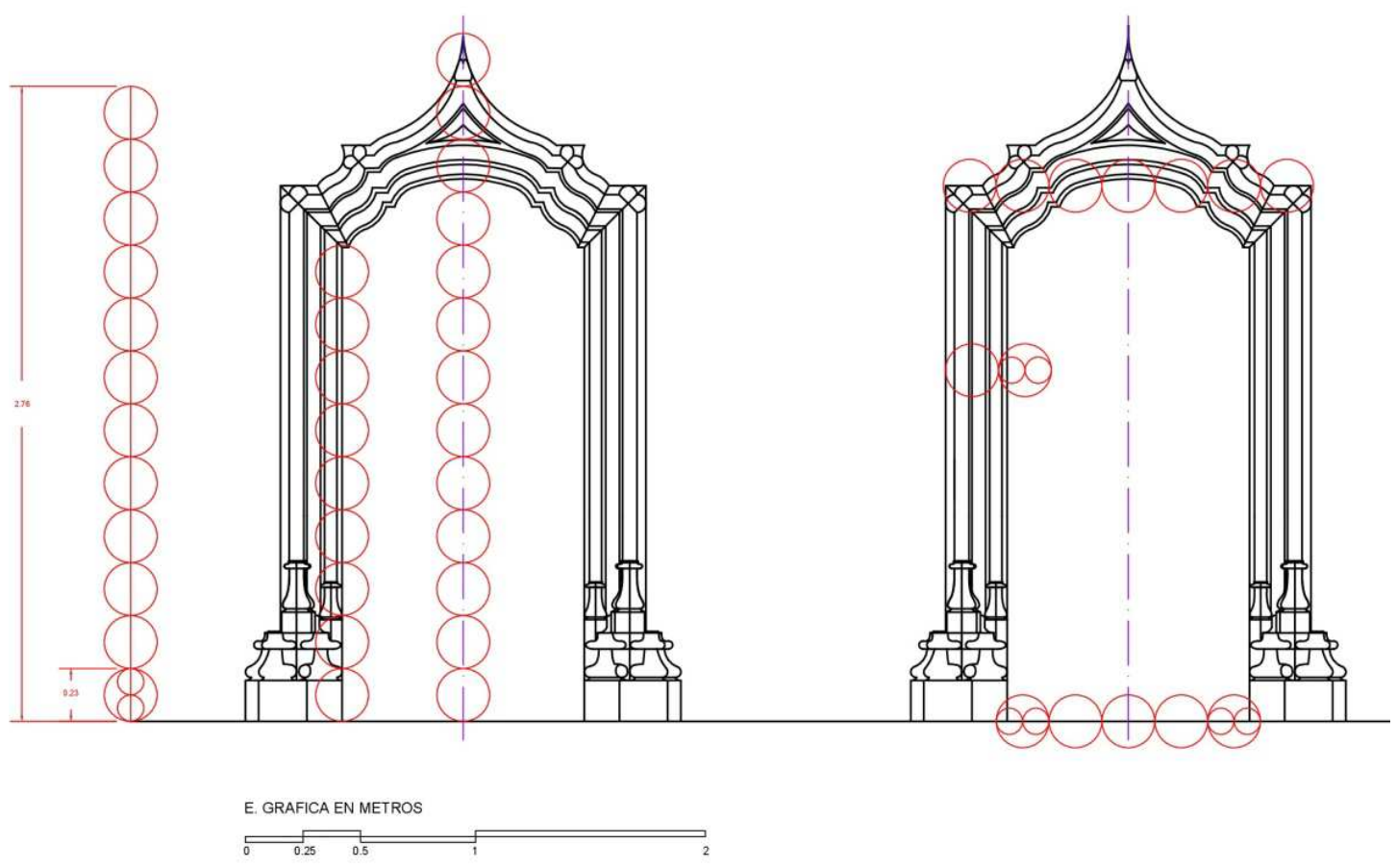

Figura 319. Alzado portada 12. Modulación en palmos valencianos. 

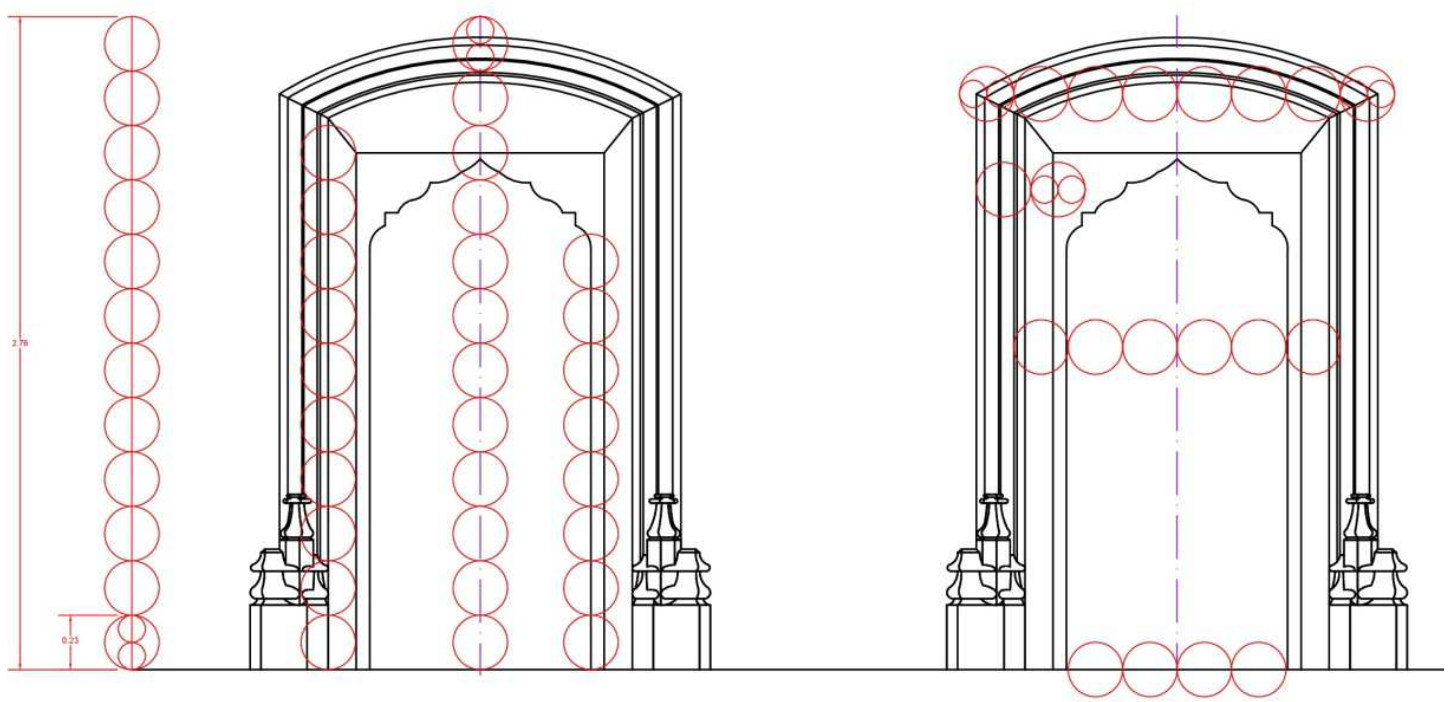

E. GRAFICA EN METROS

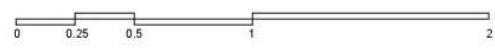

Figura 320. Alzado portada 16. Modulación en palmos valencianos.

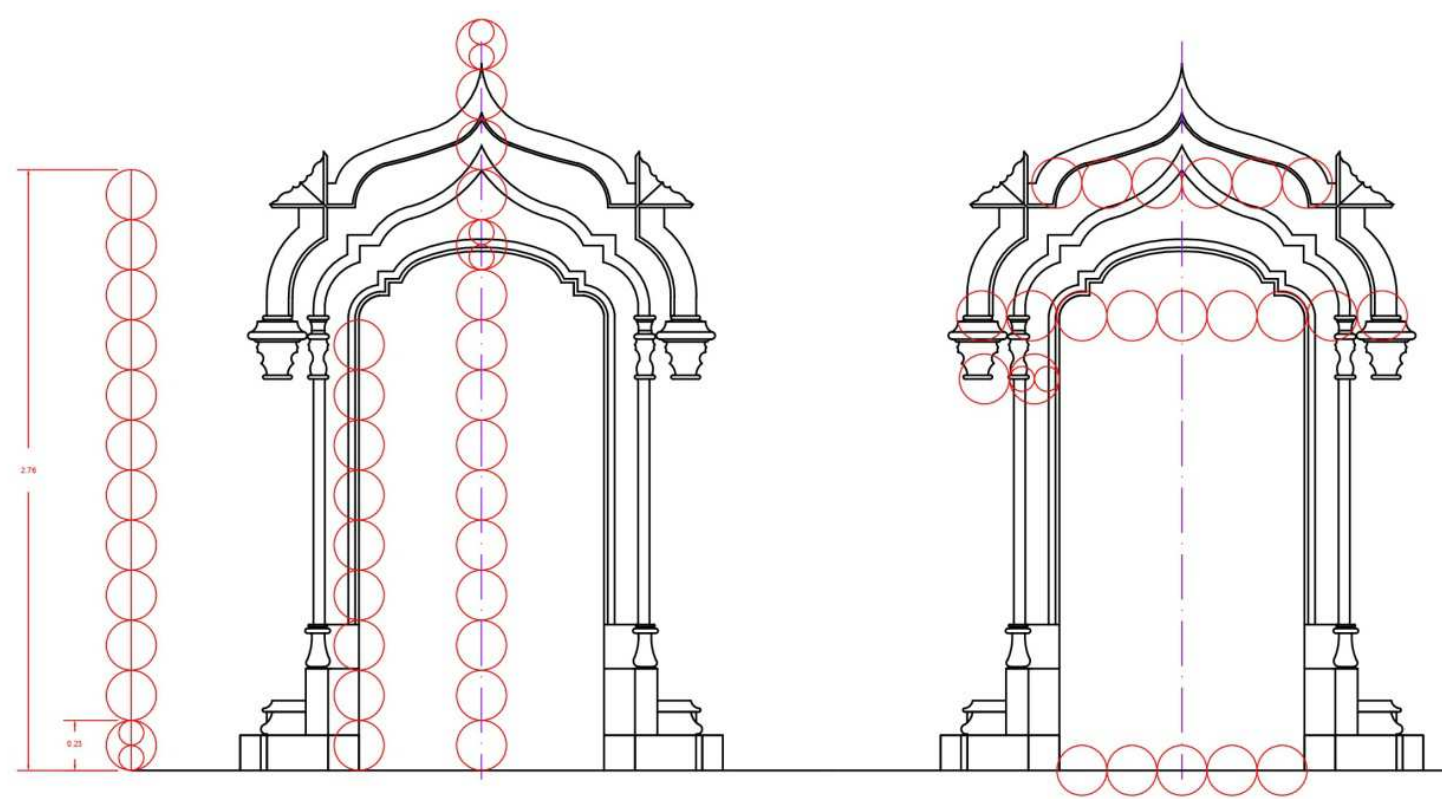

E GRAFICA EN METROS

Figura 321. Alzado portada 24. Modulación en palmos valencianos. 


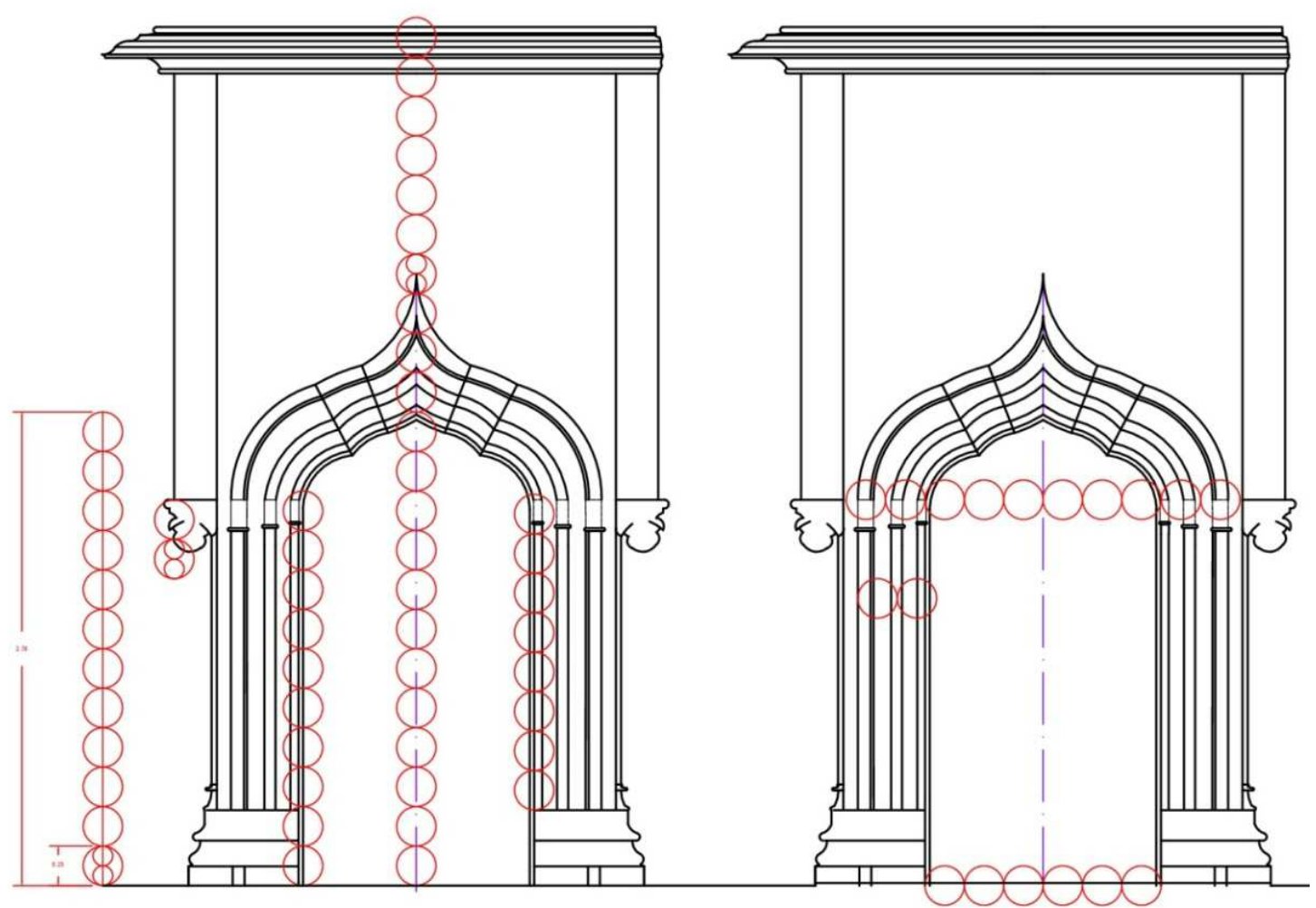

E Graficaen Metros

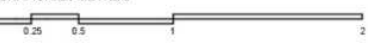

Figura 322. Alzado portada 26. Modulación en palmos valencianos.

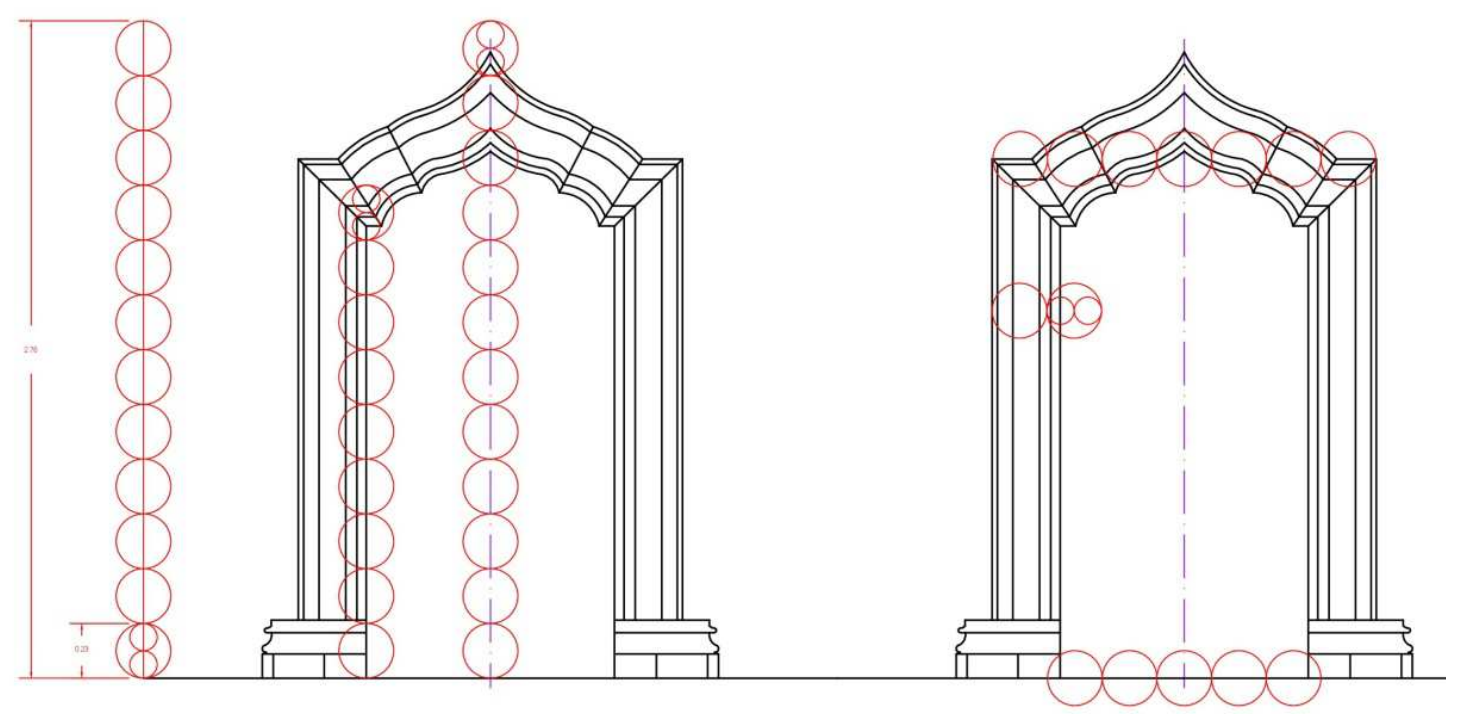

E. GRAFICA EN METROS

Figura 323. Alzado portada LA1177. Modulación en palmos valencianos. 
Tabla 49. Modulaciones en palmos de las portadas. Altura y anchura total.

\begin{tabular}{|c|c|c|c|c|}
\hline Portada & $\begin{array}{c}\text { Altura } \\
\text { Total } \\
\text { (palmos) }\end{array}$ & $\begin{array}{c}\text { Diferencia } \\
\text { anchura } \\
\text { modulación } \\
\text { palmos }\end{array}$ & $\begin{array}{c}\text { Anchura } \\
\text { Total } \\
\text { (palmos) }\end{array}$ & $\begin{array}{c}\text { Diferencia } \\
\text { altura } \\
\text { modulación } \\
\text { palmos }\end{array}$ \\
\hline D-1 & 13 & $+6,0 \mathrm{~cm}$ & 10 & $+1,9 \mathrm{~cm}$ \\
\hline D-2 & 13 & $-5,8 \mathrm{~cm}$ & 7 & $+5,4 \mathrm{~cm}$ \\
\hline D-4 & 13 & $-1,0 \mathrm{~cm}$ & 8 & $-4,2 \mathrm{~cm}$ \\
\hline D-5 & 13 & $-6,0 \mathrm{~cm}$ & 8 & $+4,0 \mathrm{~cm}$ \\
\hline D-6 & 13 & $+4,0 \mathrm{~cm}$ & 8 & $-6,0 \mathrm{~cm}$ \\
\hline$D-8$ & 11 y $1 / 2$ & $+7,0 \mathrm{~cm}$ & 8 & $+0,5 \mathrm{~cm}$ \\
\hline D-9 & 11 y $1 / 2$ & $+7,2 \mathrm{~cm}$ & 8 & $+0,5 \mathrm{~cm}$ \\
\hline D-10b & 11 & $+2,5 \mathrm{~cm}$ & 7 & $+1,2 \mathrm{~cm}$ \\
\hline D-11 & 11 & $+3,5 \mathrm{~cm}$ & 6 & $+2,7 \mathrm{~cm}$ \\
\hline D-12 & 13 & $+3,0 \mathrm{~cm}$ & 7 & $-2,0 \mathrm{~cm}$ \\
\hline D-13 & 10 y $1 / 2$ & $-0,4 \mathrm{~cm}$ & 6 & $+6,2 \mathrm{~cm}$ \\
\hline D-14 & 13 y $1 / 4$ & $-0,5 \mathrm{~cm}$ & 9 & $+5,4 \mathrm{~cm}$ \\
\hline D-15 & 13 & $+2,8 \mathrm{~cm}$ & 7 & $+5,0 \mathrm{~cm}$ \\
\hline D-16 & 11 y $1 / 2$ & $+2,8 \mathrm{~cm}$ & 7 y $1 / 2$ & $-2,7 \mathrm{~cm}$ \\
\hline D-17 & 10 y $1 / 2$ & $-4,0 \mathrm{~cm}$ & 5 y $1 / 2$ & $-2,5 \mathrm{~cm}$ \\
\hline D-18 & 11 & $+1,9 \mathrm{~cm}$ & 6 & $+3,6 \mathrm{~cm}$ \\
\hline D-19 & 11 & $+4,8 \mathrm{~cm}$ & 7 & $-5,6 \mathrm{~cm}$ \\
\hline D-20 & 11 & $-4,9 \mathrm{~cm}$ & 6 & $-0,8 \mathrm{~cm}$ \\
\hline D-21 & 11 y $1 / 2$ & $+4,6 \mathrm{~cm}$ & 7 y $1 / 2$ & $+0,5 \mathrm{~cm}$ \\
\hline D-22 & 10 y $1 / 2$ & $-2,0 \mathrm{~cm}$ & 6 & $-6,2 \mathrm{~cm}$ \\
\hline D-23 & 13 y $1 / 2$ & $-1,8 \mathrm{~cm}$ & 11 & $+/-0,0 \mathrm{~cm}$ \\
\hline D-24 & 14 & $+2,8 \mathrm{~cm}$ & 8 y $1 / 2$ & $+1,8 \mathrm{~cm}$ \\
\hline D-25 & 13 & $+5,8 \mathrm{~cm}$ & 7 & $+6,0 \mathrm{~cm}$ \\
\hline D-26 & 15 y $1 / 2$ & $+/-0,0 \mathrm{~cm}$ & 9 y $1 / 2$ & $-2,2 \mathrm{~cm}$ \\
\hline D-27 & 13 & $-1,3 \mathrm{~cm}$ & 10 & $-7,2 \mathrm{~cm}$ \\
\hline D-28 & 17 & $+0,4 \mathrm{~cm}$ & 10 & $+4,5 \mathrm{~cm}$ \\
\hline D-LA1136 & 12 & $-2,9 \mathrm{~cm}$ & 7 & $-7,6 \mathrm{~cm}$ \\
\hline D-LA1176 & 10 y $1 / 2$ & $+2,5 \mathrm{~cm}$ & 6 & $+6,4 \mathrm{~cm}$ \\
\hline D-LA1177 & 11 y $1 / 2$ & $-1,5 \mathrm{~cm}$ & 7 & $+0,6 \mathrm{~cm}$ \\
\hline D. Escalera & 19 & $+4,2 \mathrm{~cm}$ & 12 & $+0,5 \mathrm{~cm}$ \\
\hline
\end{tabular}

Si analizamos la tabla 49, observamos que, de las 30 portadas analizadas, 15 tienen una diferencia de altura menos de $3 \mathrm{~cm}$ sobre el módulo del palmo o fracción. La altura que más se repite es la de 13 palmos;8 de las portadas se ajustan o aproximan a esta medida. La segunda medida más repetida es la de 11 palmos y $1 / 2$ que, junto a la de 11 palmos, se repite en 5 portadas. 
En cuanto a la anchura, 15 de las portadas se ajustan al módulo del palmo o fracción con esta horquilla de tolerancia establecida de $3 \mathrm{~cm}$. En este caso, la medida que más se repite es la de 7 palmos, que la encontramos en 9 de las portadas. Por otra parte, la medida de $6 \mathrm{y}$ 8 palmos se repite en 5 de las portadas.

Otra de las comprobaciones métricas que se han realizado ha sido con los radios y la altura del centro respecto a la línea de pavimento en los arcos rebajados y escarzanos, dada su sencillez, con el fin de tratar de determinar su trazado y las unidades utilizadas en el mismo. El radio considerado es el del trasdós del arco. En la siguiente tabla recogemos estos datos y su equivalencia en pies.

Tabla 50. Radios y altura de centro en arcos escarzanos.

\begin{tabular}{|c|c|c|c|c|}
\hline Portada & Radio $(\mathbf{m})$ & $\begin{array}{c}\text { Altura } \\
\text { centro }(\mathbf{m})\end{array}$ & Radio $(\mathbf{p})$ & $\begin{array}{c}\text { Altura } \\
\text { centro } \mathbf{( p )}\end{array}$ \\
\hline D-1 & 1,98 & 1,03 & 8,6 & 4,5 \\
\hline D-9 & 2,35 & 0,30 & 10,2 & 1,3 \\
\hline D-14 & 2,03 & 1,03 & 8,8 & 4,5 \\
\hline D-16 & 1,57 & 1,03 & 6,8 & 4,5 \\
\hline D-17 & 1,62 & 1,01 & 7,0 & 4,4 \\
\hline D-19 & 1,57 & 1,05 & 6,8 & 4,6 \\
\hline D-21 & 1,42 & 1,26 & 6,2 & 5,5 \\
\hline
\end{tabular}

No se han detectado coincidencias en los radios de los arcos, aunque sí en la localización de los centros. De las 7 portadas con esta tipología de arco, en 3 la altura del centro es idéntica $y$ en dos hay una diferencia de $2 \mathrm{~cm}$ respecto a la primera, una en positivo y otra en negativo, diferencia mínima tratándose de una cota sobre pavimento cuyo nivel puede variar ligeramente. Si transformamos esta medida de $1,03 \mathrm{~m}$. a palmos valencianos obtenemos que cuadra casi exactamente con 4,5 palmos valencianos, lo que corrobora nuestra hipótesis de que el edificio pudo ser trazado con esta unidad metrológica.

\subsection{Proporciones geométricas}

Cuando se remodeló el Palacio Condal de Oliva, a principios del siglo XVI, el Renacimiento comenzaba a introducirse tímidamente en la arquitectura valenciana, fundamentalmente en sus elementos decorativos. Así, durante el Renacimiento resurgen los antiguos ideales clásicos de belleza que se habían utilizado en Roma y Grecia, considerándose que la belleza estaba relacionada con la proporcionalidad. En esta época aparecen también los primeros tratados de arquitectura en los que se introducen los cocientes racionales en las proporciones de los edificios. El tratado de Alberti De Re Aedificatoria, impreso en Florencia en 1485 , en su capítulo $V$ del libro IX, menciona las relaciones dupla $(2 / 1)$, sesquiáltera $(3 / 2)$ 
y sesquitercia $(4 / 3)^{444}$. Sebastiano Serlio, en 1545 , publica en París sus libros primero y segundo sobre la Geometría y la Perspectiva de su obra general sobre la Arquitectura. En ellos plasma mediante ilustraciones las diferentes proporciones: $5 / 4,4 / 3,3 / 2,5 / 3$ y dupla $2 / 1$, además de la relación irracional $\sqrt{ } 2^{445}$.

Desconocemos si a las manos de los maestros que trazaron las portadas del Palacio de Oliva habían llegado alguno de los tratados de Arquitectura de la época, y cuáles eran las reglas con las que diseñaban el trazado de las portadas. Con el fin de intentare determinar cuáles eran los cánones que seguían las composición de las portadas, se han analizado las siguientes proporciones: triángulo de oro, proporción $3 / 2^{446}$, sección áurea y proporción V3. Para estudiar todas estas proporciones se ha cogido el perímetro exterior de las portadas: el ancho de las jambas y la altura hasta la clave en el extradós. En el caso del triángulo de oro se ha comprobado también el ancho de la portada de las basas inferiores.

Todos estos datos se han incluido en la tabla 51 con el fin de poder analizarlos. En esta tabla se indican las diferencias en altura en $\mathrm{cm}$ entre cada una de las proporciones y la altura máxima de la portada. En el caso de superar la portada la altura de la proporción, la diferencia se expresa con signo positivo; en caso contrario, con signo negativo. Las diferencias menores o iguales a $6 \mathrm{~cm}$ se han marcado en tono azul, en este caso se considera que hay coincidencia; las que tienen un valor entre 6 y $15 \mathrm{~cm}$ se han marcado en tono azul más oscuro porque se considera que existe una aproximación a esta proporción. Por su parte, las diferencias mayores a 15 centímetros se han considerado como no coincidentes.

Otra de las proporciones que se han analizado es la de 2/1. En este caso se ha aplicado en el intradós o hueco de paso de las portadas. Se ha utilizado el mismo criterio que en las proporciones anteriores para determinar el grado de coincidencia. En este caso, al tratarse del intradós de la portada, estas coincidencias o aproximaciones entre las proporciones y los arcos se han establecido respecto a puntos singulares de los mismos (arranque, trazados rectos intermedios o clave).

\footnotetext{
${ }^{444}$ Vitrubio Polion, M. (1787). Los diez libros de architectura. Joseph Ortiz y Sanz (comentarios y traducción del latín). Madrid: Imprenta real. pp. 59.

${ }^{445}$ Serlio, S. (1545). Le premier libre d'architecture... Le second libre de perspective... París: J. Barbé pp. 21.

${ }^{446}$ El estudio de estas dos proporciones se ha basado en el trabajo : Pisu, C. (2013). Survey methodoly and geometrical analysis of late Gothic acchitecture in Sarninia. IJRET. International Journal of Research in Engineering and Technology. Volume: 02. pp. 407-4016.
} 
Tabla 51. Tabla proporciones geométricas de las portadas.

\begin{tabular}{|c|c|c|c|c|c|c|c|c|}
\hline Portada & $\begin{array}{c}\text { Triáng. } \\
\text { Oro } \\
\text { Jamba }\end{array}$ & $\begin{array}{c}\text { Triáng. Oro } \\
\text { basa }\end{array}$ & Próp. $3 / 2$ & $\begin{array}{c}\text { Sección } \\
\text { Áurea }\end{array}$ & Próp. $\sqrt{3}$ & $\begin{array}{c}\text { Rectáng. } \\
2 / 1 \\
\text { (hueco) }\end{array}$ & $\begin{array}{c}\text { Referencia } \\
\text { Rectángulo } \\
2 / 1 \\
\end{array}$ & Capialzado \\
\hline D-1 & NO & -- & NO & NO & -- & $+2,0 \mathrm{~cm}$ & Clave & $\mathrm{SI}$ \\
\hline D-2 & NO & -- & NO & NO & $-13 \mathrm{~cm}$ & NO » & & NO \\
\hline D-4 & NO & NO & NO & $+6,0 \mathrm{~cm}$ & -- & $-7,4 \mathrm{~cm}$ & Clave & NO \\
\hline D-5 & NO & -- & NO & $+0,3 \mathrm{~cm}$ & -- & $+3,0 \mathrm{~cm}$ & Clave & NO \\
\hline D-6 & NO & $-8,6 \mathrm{~cm}$ & NO & NO & -- & $+1,6 \mathrm{~cm}$ & Clave & NO \\
\hline D-8 & NO & $-5,4 \mathrm{~cm}$ & NO & $+14 \mathrm{~cm}$ & -- & $-14,0 \mathrm{~cm}$ & Clave & NO \\
\hline D-9 & NO & NO & NO & NO & -- & NO & & $\mathrm{SI}$ \\
\hline D-10b & NO & NO & NO & $-7,0 \mathrm{~cm}$ & -- & $-2,8 \mathrm{~cm}$ & Arranque & NO \\
\hline D-11 & $+3,4 \mathrm{~cm}$ & NO & $+6,6 \mathrm{~cm}$ & NO & -- & $-3,0 \mathrm{~cm}$ & Dintel & NO \\
\hline D-12 & NO & $+14,6$ & NO & NO & $-15,5 \mathrm{~cm}$ & $-4,7 \mathrm{~cm}$ & Arranque & NO \\
\hline D-13 & NO & NO & NO & $+7,7 \mathrm{~cm}$ & -- & $+6,0 \mathrm{~cm}$ & Arranque & NO \\
\hline D-14 & NO & NO & $-14,0 \mathrm{~cm}$ & NO & $+8,7 \mathrm{~cm}$ & NO & & $\mathrm{SI}$ \\
\hline D-15 & NO & $-0,1 \mathrm{~cm}$ & NO & NO & NO & $+/-0,0 \mathrm{~cm}$ & $\begin{array}{l}\text { Tramo recto } \\
\text { arco }\end{array}$ & NO \\
\hline D-16 & NO & NO & NO & $+7,5 \mathrm{~cm}$ & NO & $+8,6 \mathrm{~cm}$ & Dintel & $\mathrm{SI}$ \\
\hline D-17 & NO & NO & NO & NO & $+9,8 \mathrm{~cm}$ & $-0,9 \mathrm{~cm}$ & Dintel & $\mathrm{SI}$ \\
\hline D-18 & NO & NO & NO & NO & $-4,6 \mathrm{~cm}$ & $+5,0 \mathrm{~cm}$ & Arranque & NO \\
\hline D-19 & NO & NO & NO & NO & $+9,8 \mathrm{~cm}$ & $+6,1 \mathrm{~cm}$ & Clave & $\mathrm{SI}$ \\
\hline D-20 & NO & NO & NO & NO & NO & $+15,9 \mathrm{~cm}$ & Arranque & NO \\
\hline D-21 & $+6,1 \mathrm{~cm}$ & NO & $+9,6 \mathrm{~cm}$ & $-10,8 \mathrm{~cm}$ & NO & NO & & $\mathrm{SI}$ \\
\hline D-22 & NO & $+9,3 \mathrm{~cm}$ & NO & NO & $+3,8 \mathrm{~cm}$ & $-9,6 \mathrm{~cm}$ & Arranque & NO \\
\hline D-23 & NO & NO & NO & NO & NO & $+3,0 \mathrm{~cm}$ & Dintel & NO \\
\hline D-24 & NO & $-12,6 \mathrm{~cm}$ & NO & $+5,5 \mathrm{~cm}$ & NO & $-1,0 \mathrm{~cm}$ & $\begin{array}{l}\text { Tramo recto } \\
\text { arco }\end{array}$ & NO \\
\hline D-25 & NO & NO & NO & NO & $+13,0 \mathrm{~cm}$ & NO & & NO \\
\hline D-26 & NO & NO & NO & $+6,5 \mathrm{~cm}$ & NO & $+6,8 \mathrm{~cm}$ & Clave & NO \\
\hline D-27 & NO & NO & NO & NO & NO & $-1,0 \mathrm{~cm}$ & $\begin{array}{l}\text { Tramo recto } \\
\text { arco }\end{array}$ & NO \\
\hline D-28 & NO & $-13,0 \mathrm{~cm}$ & NO & $+9,6 \mathrm{~cm}$ & $-15,0 \mathrm{~cm}$ & $+0,6 \mathrm{~cm}$ & Dintel & NO \\
\hline D-LA1136 & NO & $-0,8 \mathrm{~cm}$ & NO & NO & $+7,6 \mathrm{~cm}$ & $+3,5 \mathrm{~cm}$ & Arranque & NO \\
\hline D-LA1176 & NO & -- & NO & NO & $-6,2 \mathrm{~cm}$ & $-1,5 \mathrm{~cm}$ & $\begin{array}{l}\text { Tramo recto } \\
\text { arco }\end{array}$ & NO \\
\hline D-LA1177 & NO & NO & NO & $+1,4 \mathrm{~cm}$ & NO & $+12,4 \mathrm{~cm}$ & Clave & NO \\
\hline Escalera & NO & NO & NO & NO & $+5,7 \mathrm{~cm}$ & NO & & NO \\
\hline
\end{tabular}

Las coincidencias y aproximaciones para cada una de las proporciones analizadas son las siguientes: 
- Triángulo de oro respecto a las jambas: para esta proporción sólo encontramos coincidencia en la D-11 y, aproximación, en la D-21, de un total de 31 portadas analizadas.

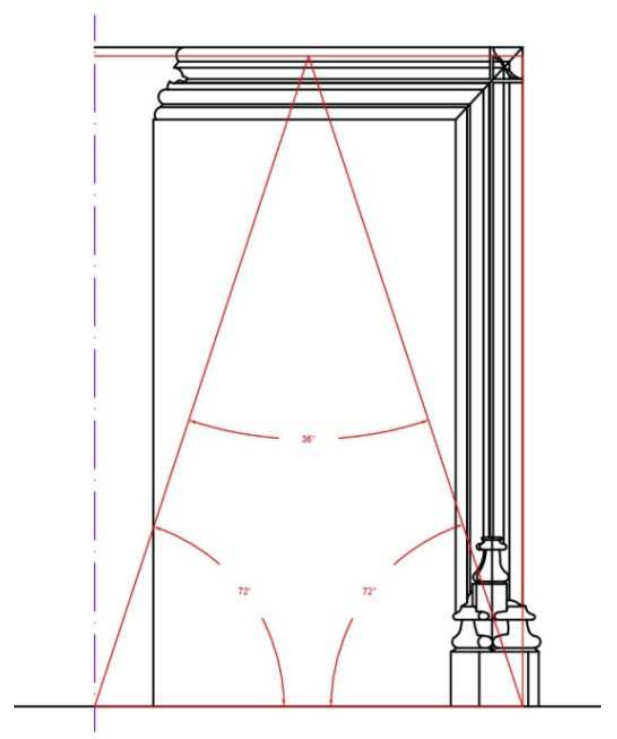

Figura 324. Alzado portada 11. Proporción con triángulo de oro respecto a la jamba.

- Triángulo de oro respecto a las basas: para esta proporción encontramos tres coincidencias, la portada 8, la 15 y la LA1136, y un total de cinco aproximaciones. En este caso se han analizado 27 portadas, por no tener datos sobre las basas en algunos de ellas o por no tratarse de basas exentas que permitan aplicar la modulación de una manera clara.

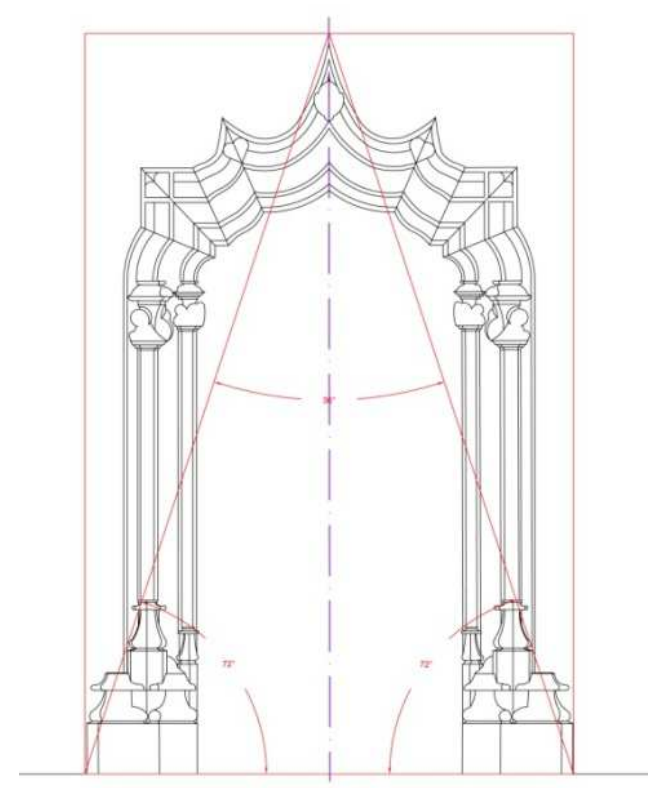

Figura 325. Alzado portada 15. Proporción con triángulo de oro respecto a la basa. 
- Proporción 3/2: en este caso sólo se han encontrado 3 aproximaciones con una diferencia menor de $15 \mathrm{~cm}$ entre todas las portadas.

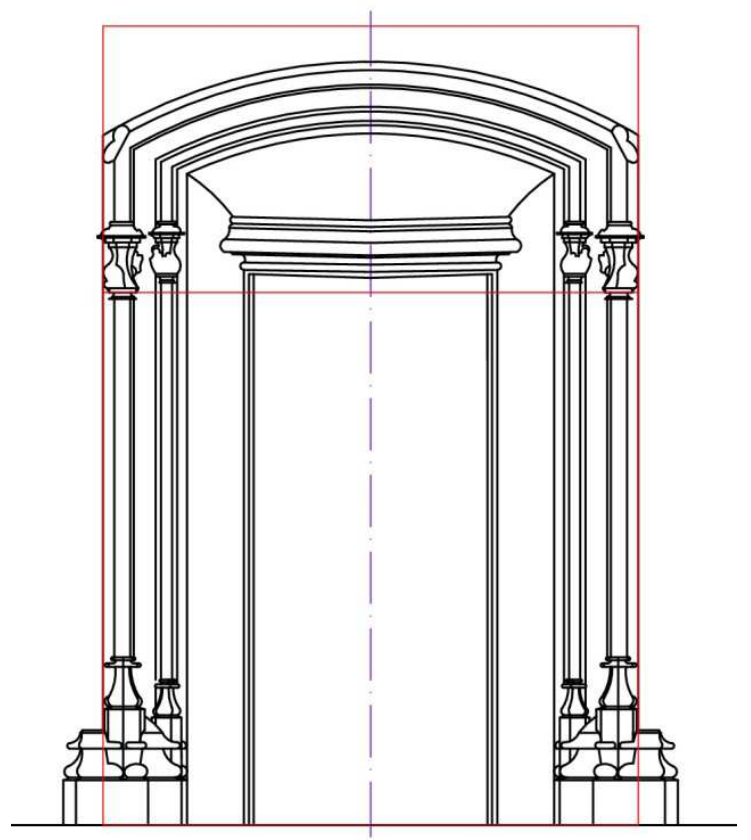

Figura 326. Alzado portada 14. Proporción 3/2 o sesquiáltera.

- Sección áurea: se han encontrado 3 portadas que cumplen esta proporción dentro de la tolerancia establecida (D-4, D-5 y D-24), y un total de 7 aproximaciones.

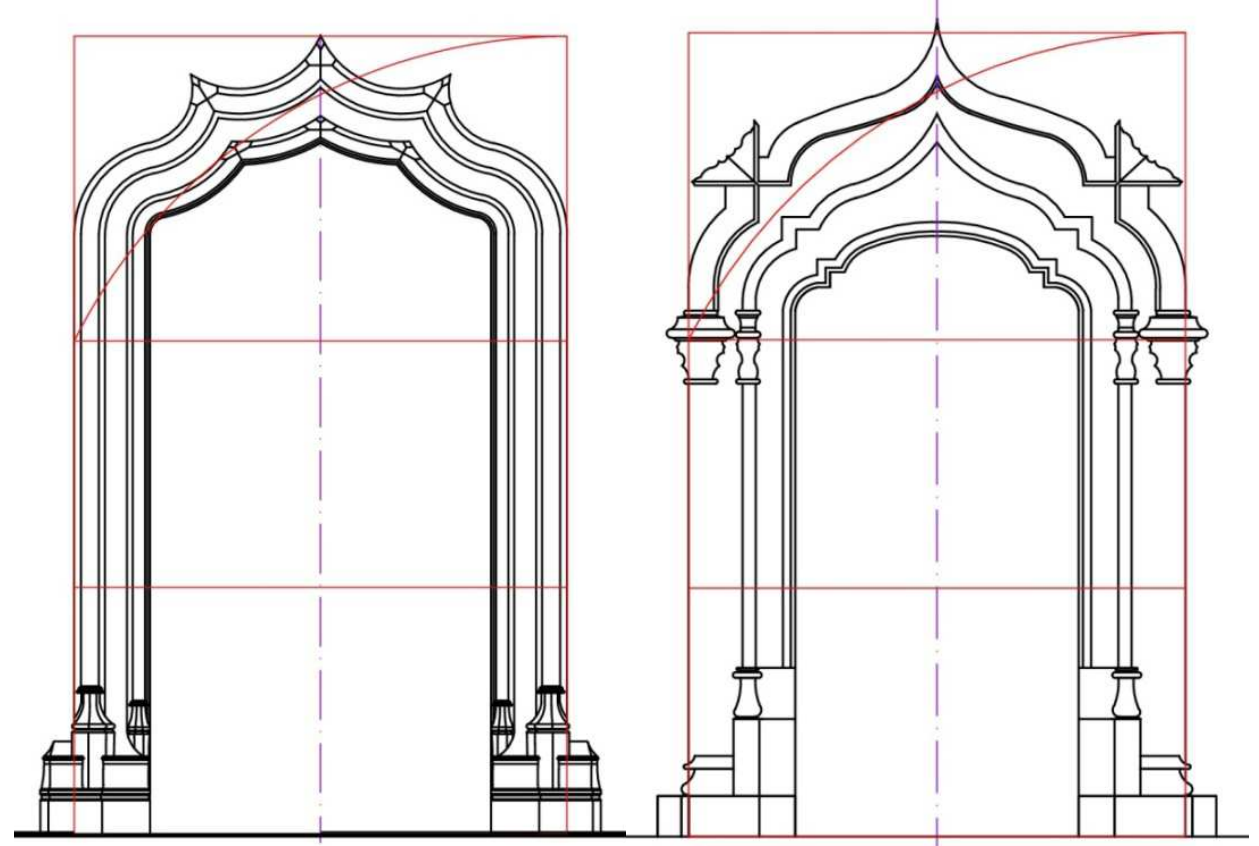

Figura 327. Proporción áurea. Izquierda: Portada 8. Derecha: Portada 24. 
- Proporción $\sqrt{3}$ : esta proporción se cumple sensiblemente en las portadas D-18 y D-22 y se aproxima en un total de 8 portadas. Sólo se ha comprobado en aquellos casos en los que la portada superase sensiblemente la sección áurea.

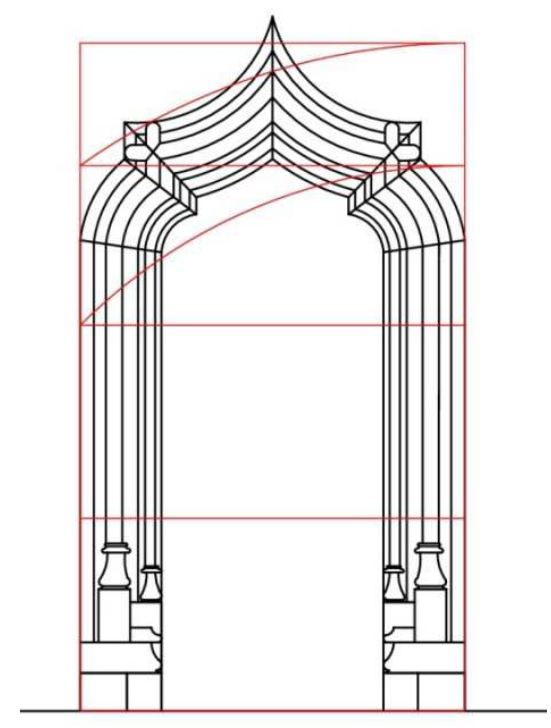

Figura 328. Alzado Portada 18. Proporción $\sqrt{ } 3$.

- Proporción 2/1: en este caso hemos encontrado un total de 17 coincidencias y 8 aproximaciones. En cuanto a las coincidencias: 4 son en la clave, 5 en la línea de impostas o arranque del arco, 4 en el dintel (en el caso de capialzados o arcos adintelados) y 4 en los tramos rectos intermedios para el caso de arcos mixtilíneos.

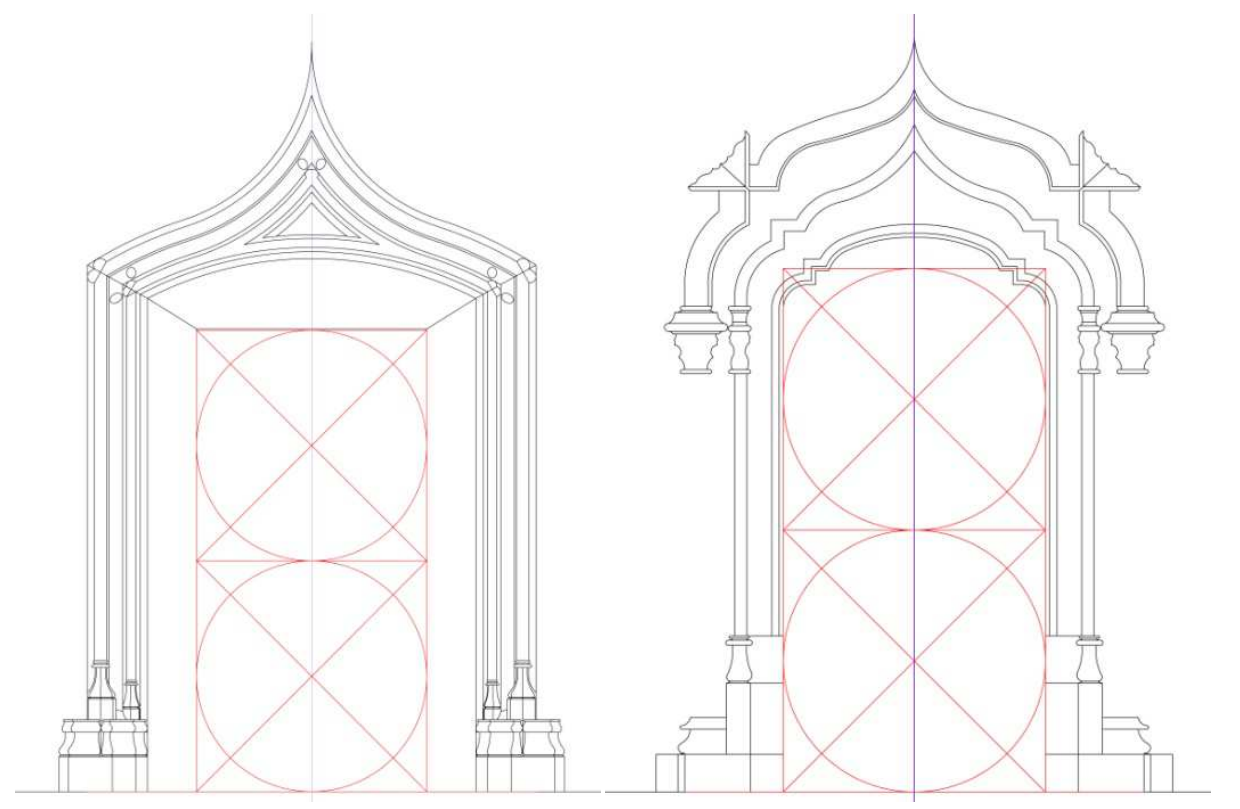

Figura 329. Proporción 2/1 hueco de paso. Izquierda: Portada 28. Derecha: Portada 24. 


\section{Portadas de decoración renacentista}

En el caso de las portadas con decoración superpuesta mediante alfices o volutas, como es el caso de la portada 27, además del análisis de la composición del arco se ha analizado la proporción de todo el conjunto. Procedemos a comentar los resultados obtenidos:

- Portada 20: en el caso de la portada 20 se cumple casi a la perfección la proporción áurea entre el ancho de las portadas y la cara inferior del alfiz.

- Portada 22: en el caso de la portada 22 la proporción que más se aproxima es la $\sqrt{ } 2$, considerando en anchura la decoración a candilieri, y en altura la cara superior del friso, excluyendo el tímpano superior.

- Portada 23: en el caso de la portada 23 no se ha encontrado ninguna proporción para el conjunto de la portada

- Portada 26: en esta portada, si consideramos el contorno del alfiz, encontramos una aproximación a la proporción dupla (2/1).

- Portada 27: en el caso de esta portada, si consideramos el contorno total de la portada con las volutas superiores, su contorno se aproxima mucho a la sección áurea, existiendo una diferencia de $7,8 \mathrm{~cm}$ que, tratándose de una cota de altura y de una portada de estas dimensiones, no resulta excesivo.

- Portada Escalera de Honor: en esta portada la sección áurea cuadra casi a la perfección sobre el contorno del alfiz que enmarca el arco.

\section{OTRAS PORTADAS}

En este apartado se documentarán otras portadas de la misma época que comparten con las Portadas del Palacio de Oliva similitudes formales y tipológicas, y que nos ayudan a entender la importancia que tuvieron estos elementos arquitectónicos en la arquitectura tardogótica valenciana, tanto en la construcción civil como en la religiosa, y a profundizar en su estudio. Dentro de esta selección encontraremos portadas exteriores y portadas interiores, sí como portadas fabricadas en piedra y en yeso.

Dada la imposibilidad de datarlas cronológicamente con exactitud en su mayoría, y el hecho de utilizarse, indistintamente, en exterior e interior, así como la utilización de uno u otro material, se ha optado por ordenarlas alfabéticamente según el nombre de la localidad donde se localizan o se localizaban; ya que algunas de ellas han corrido idéntica suerte que las del Palacio Condal de Oliva.

\subsection{Castillo-Palacio de los Aguilar o de las Cuatro Torres (Alaquás)}

El Castillo de Alaquàs es el resultado de un gran proyecto constructivo datado a principios del siglo XVI y llevado a cabo por la familia Aguilar, señores de Alaquás en esa época. Fue mandado construir por Luis Prado de la Casta, primer Conde de Alaquàs en 1582. Fue 
declarado Monumento Histórico y Artístico el 26 de abril de 1918 y Bien de Interés Cultural el 1 de diciembre de 1999. Actualmente, es de titularidad pública y fue restaurado en $2007^{447}$. En él encontramos elementos característicos del último gótico y del primer renacimiento, entre los que encontramos una portada de arco conopial.

- Portada de acceso biblioteca: se trata de una portada de arco conopial contracurvado esculpido en yeso. Sus jambas están formadas por tres pares de columnillas con dos cavetos semicirculares y otros cavetos menores. Las baquetas que forman el arco se entrecruzan en las inflexiones del arco. Cada una de estas columnillas finaliza en un capitel decorado con formas vegetalizadas. Exteriormente a estos capiteles, un par de ménsulas parten de lienzo del muro con formas antropomórficas de las que, a su vez, nacen nuevas molduras en el arco. Sobre las enjuntas del arco dos animales esculpidos completan la decoración de la portada.

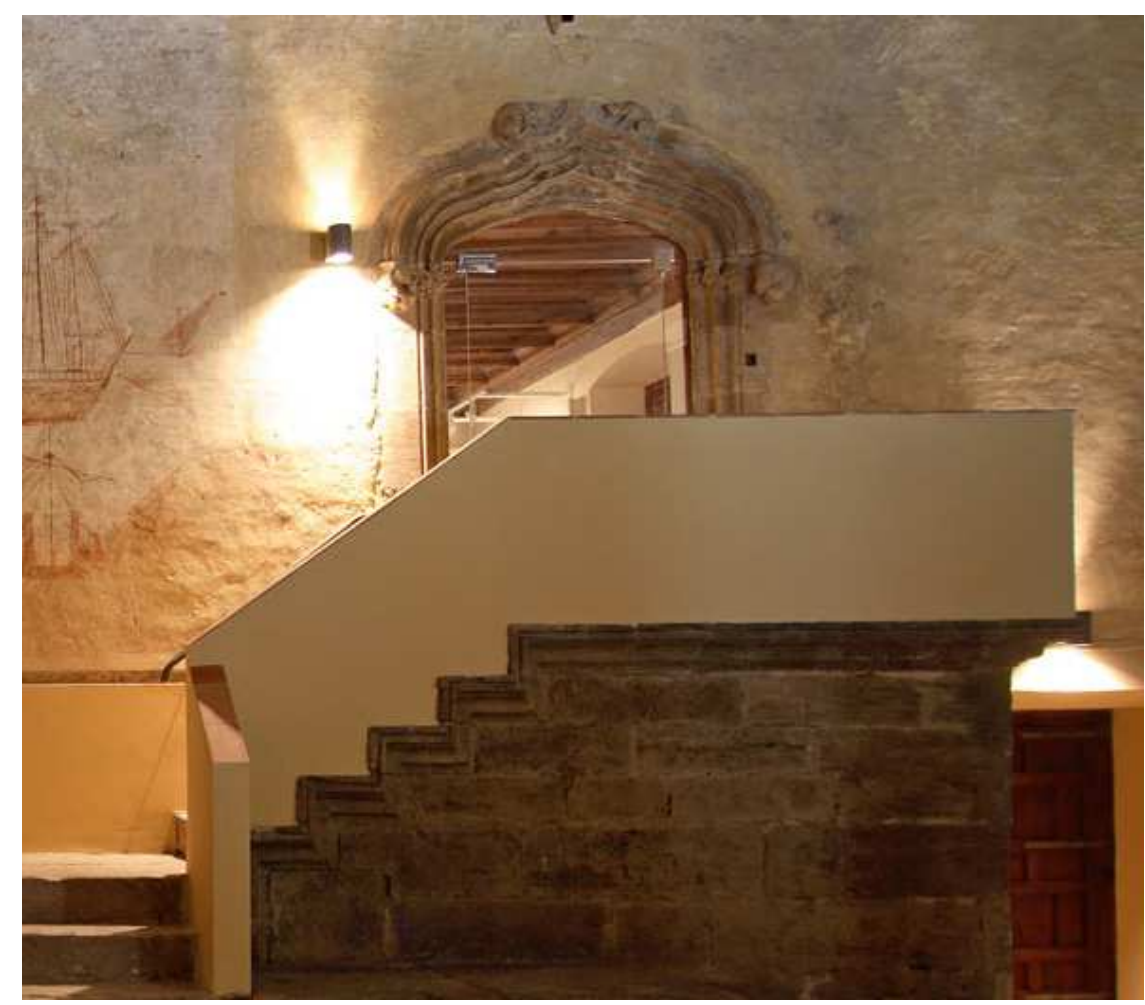

Figura 330. Portada acceso biblioteca. Castillo-Palacio de los Aguilar. Alaquás. Fotografía: www.castell.alaquas.org.

\subsection{Palacio de Albalat dels Sorells}

En 1480, Tomás Sorell y Sagarriga, Mosén Sorell, hijo de Bernardo Tomás Sorell, señor de Xeldo y Sot de Ferrer, compra el Señorío de Albalat a Lluís Aguiló de Codinats, y construye el Palacio de Albalat, datado entre 1481 y 1508. En 1626, Felipe IV instituye el condado de Albalat y Jaime Sorell i Boil será el primer conde de Albalat. Fue declarado BIC con categoría

${ }^{447}$ Castillo de Alaquàs. Recuperado de: http://castell.alaquas.org/esp/monumento.php. 
de monumento en $1999^{448}$. En él se encontraban algunas portadas tardogóticas hoy desaparecidas:

- Portada Patio de Armas: a través de una fotografía de 1920, atribuida a Cabedo, podemos observar una de las portadas originales situadas en el Patio de Armas. En la fotografía antigua podemos observar una portada cuyo arco tiene en su intradós un trazado carpanel y, en su extradós, un trazado cortinado rebajado formado por 6 trazados curvos contracurvados con un perfil rebajado. Se intuyen capiteles con decoración. Actualmente, tras los trabajos de restauración del Palacio, ha sido sustituida por una portada en piedra de arco conopial (ver fig. 331).

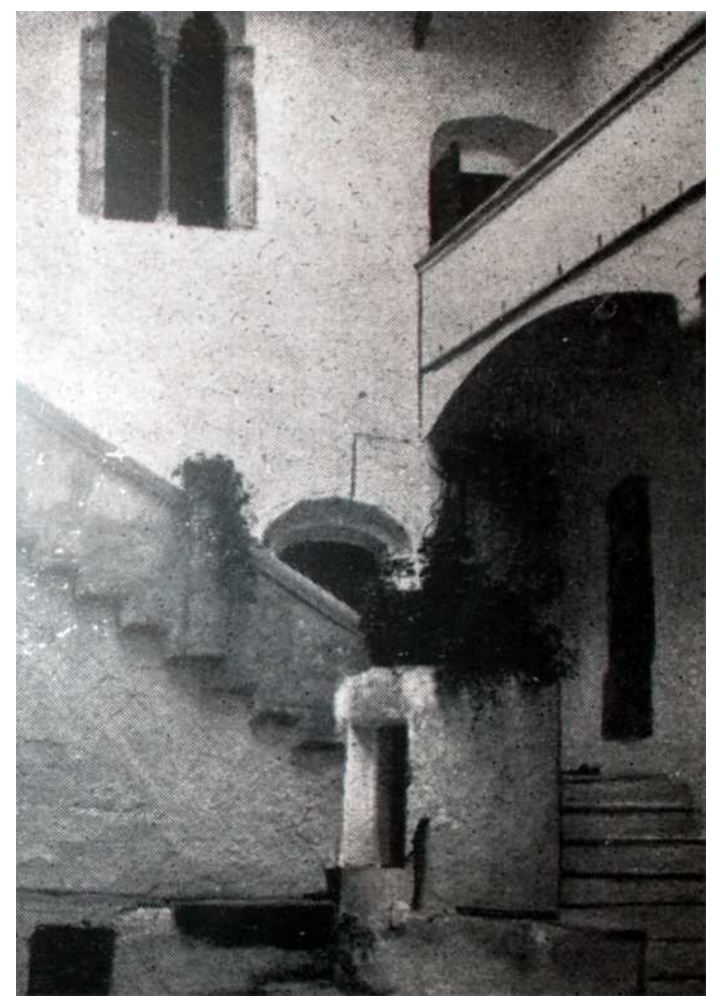

Figura 331. Patio de Armas del Palacio de Albalat dels Sorells con portada en el entresuelo. Izquierda: Fotografía de Cabedo, 1920. Derecha: Fotografía actual.

\subsection{Castillo Palacio de Ceyt Abu Ceyt o del Marqués de Monistrol (Argelita)}

Argelita fue conquistada por Jaume I a los árabes en 1238, refugiándose éstos en el castillo del Buey Negro, próximo a la localidad. A principio del siglo XIII perteneció a los dominios de Ceyt Abu Ceyt, rey moro convertido al catolicismo con el nombre de Vicente Belvis. Por venta pasó a la familia Zapata, y el16 de febrero de 1611, después de la expulsión de los

448 Inventario de Bienes Inmuebles de la Comunidad Valenciana. Óp. cit. Palacio de Albalat dels Sorells. 
moriscos, su señor Pedro Escrivá Zapata le otorgó nueva carta puebla. La baronía de Argelita perteneció posteriormente al marqués de Monistrol. El palacio fue demolido en 1942 quedando actualmente en pie sólo dos de sus torres defensivas, declaradas BIC en $2003^{449}$ Este palacio tenía portadas de trazado gótico labradas en yeso ${ }^{450}$.

- Portada de acceso al piso principal (Patio): a través de la fotografía C24523 ${ }^{451}$, tomada en 1919, podemos observar una de las portadas originales situada en el Patio de Armas, en el acceso a la planta principal. En la fotografía antigua podemos observar una portada con arco conopial y jambas abocinadas características de este tipo de portadas góticas, fabricada en yeso (ver fig. 332).

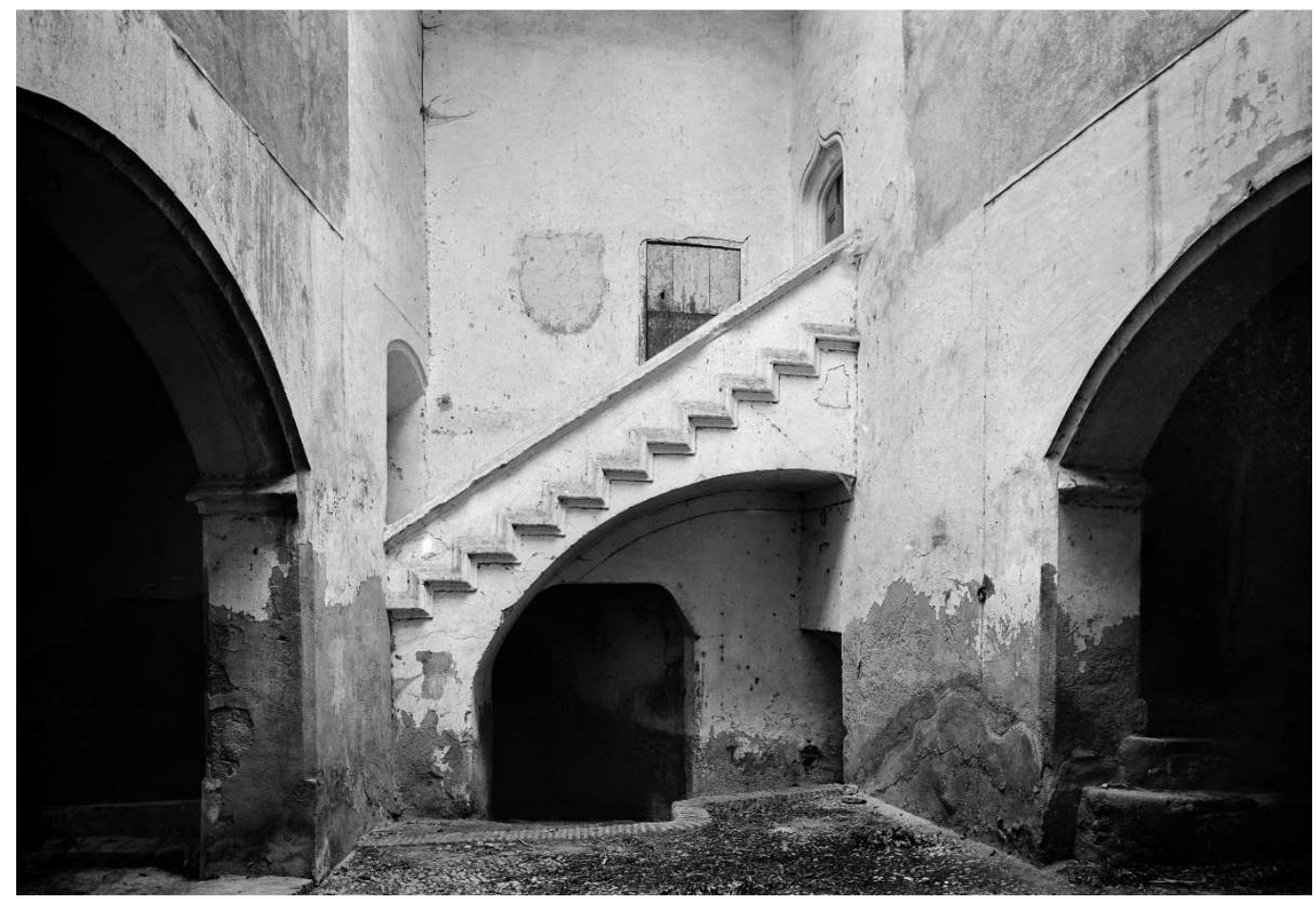

( 2016. Institut Amatller d'Art Hispànic. foto Mas C-24523 (1918)-im. 05402010

Figura 332. Patio Palacio Marqués de Monistrol, Argelita. Sobre la escalera portada con arco conopial. Fotografía: Arxiu Mas, 1919.

${ }^{449}$ Pérez Olagüe, C. (¿ं). Castillo Palacio de Ceyt Abu Ceyt. Inventario de Bienes Inmuebles de la Comunidad Valenciana. Recuperado de: http://www.ceice.gva.es/web/patrimonio-cultural-ymuseos/bics.

${ }^{450}$ Zaragozá Catalán, A. (2000). Arquitectura Gótica Valenciana. Siglos XIII-XV Valencia: Generalitat Valenciana. Conselleria de Cultura i Educació. pp. 186.

${ }^{451}$ Anónimo, (1919). Fotografías Palacio del Marqués de Monistrol Instituto Amatller d'Art Hispanic. Foto Mas. Fot. C24523. 
- Portadas interiores: a través de la fotografía C24524 452 podemos observar dos de las portadas originales situadas en el interior del Palacio. En primer plano observamos una portada de arco conopial contracurvado mixtilíneo. La portada disponía de basas en buen estado de conservación, con una basa prismática de la que partía el baquetón o columnilla; la jamba y molduras del arco las completaban un gran caveto semicircular junto con otros cavetos y filetes de menor dimensión. El baquetón se entrecruza formando una cruz en las enjuntas del arco. La portada que vemos alineada con la primera a través de su hueco de puerta está formada por un arco polilobulado rebajado mixtilíneo; la composición de las jambas y basas es idéntica a la de la primera portada (ver fig. 333).

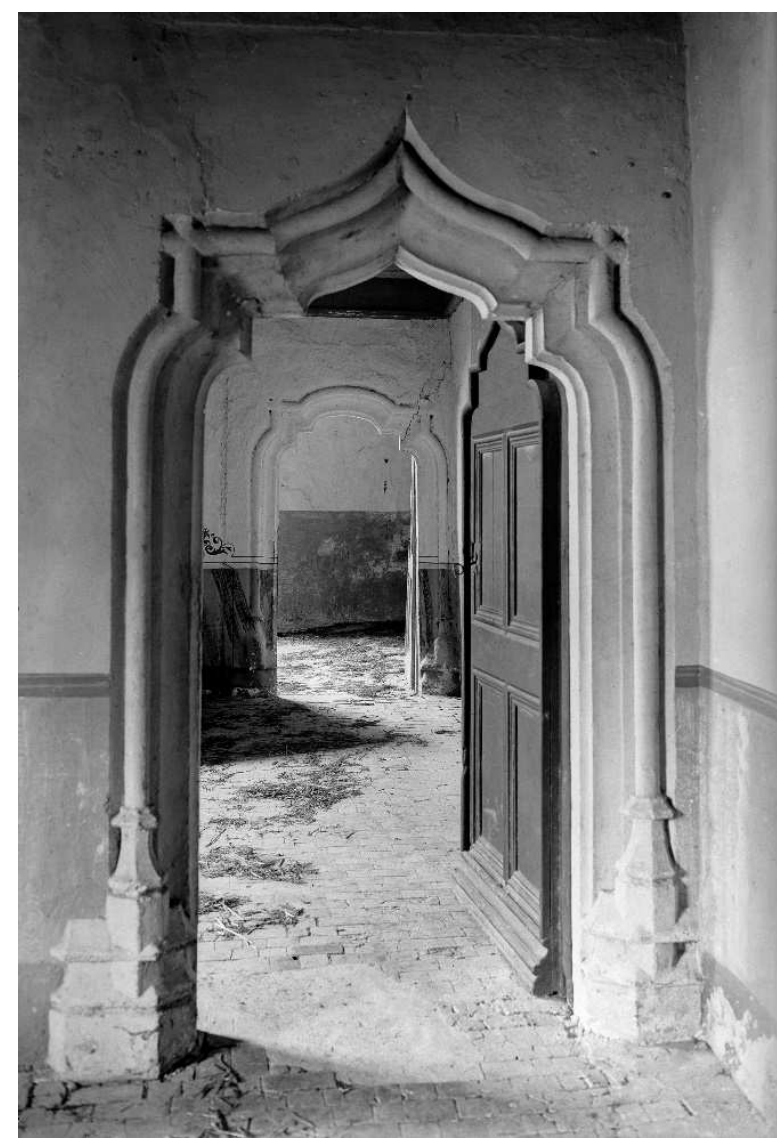

Figura 333. Portadas mixtilíneas. Patio Palacio Marqués de Monistrol, Argelita. Fotografía: Arxiu Mas, 1919.

\subsection{Castillo de Benisanó}

Fue mandado construir por Luis Vilarasa de Cabanilles, copero de Juan II, en 1467. Tiene numerosos elementos originales como ventanas geminadas, artesonados y portadas,

\footnotetext{
452 Anónimo, (1919). Fotografías Palacio del Marqués de Monistroll Instituto Amatller d'Art Hispanic. Foto Mas. Fot. C24524.
} 
aunque también tiene elementos añadidos de $1900^{453}$. Analizaremos una de sus portadas en yeso originales.

- Portada de la Capilla: se trata de una de las portadas originales del Palacio, realizada en yeso. Está formada por un arco cortinado con seis trazados curvos y dos trazados rectos. Dispone de una basa sencilla de la que parte una columnilla, y varios cavetos y filetes. Se encuentra pintada en color marrón oscuro, de manera impropia (ver Fig. 334).

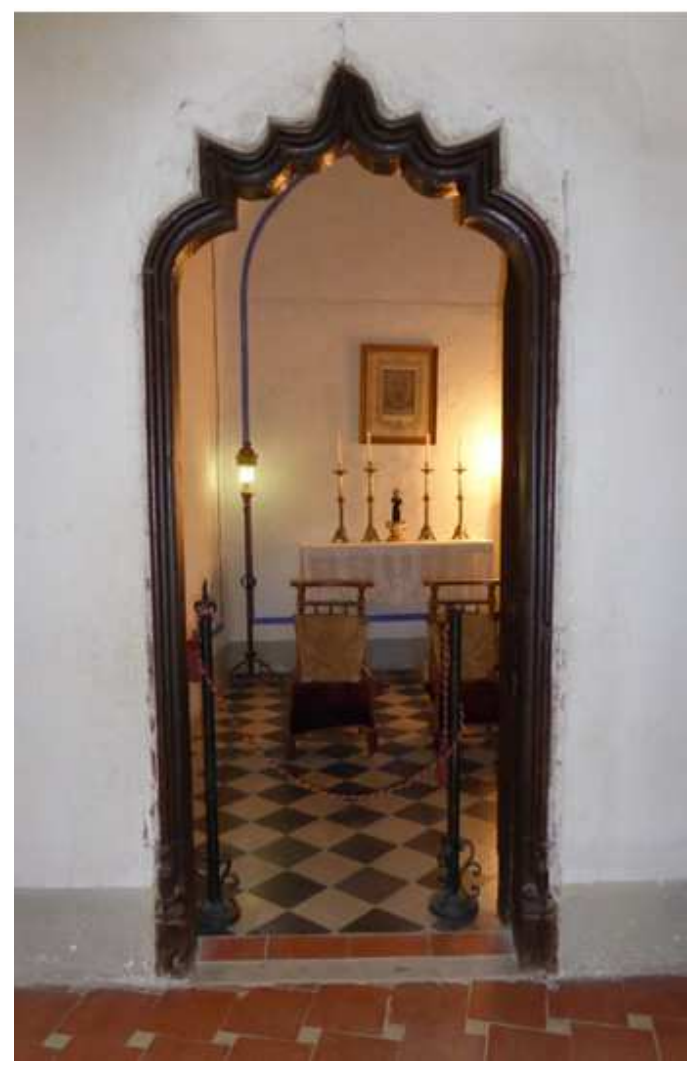

Figura 334. Portada Capilla. Castillo de Benisanó.

\subsection{Castillo de Bolbaite}

Los primeros datos documentales del castillo datan del año 1394, constando como propiedad de Pascual Maçana. Posteriormente pasó a manos de la familia Marrades. En esta época Bolbaite era la cabeza de la baronía. Durante el siglo XVI fue castillo del Señor de Alaquás, Pardo de La Casta, quien lo mandó reconstruir. En años posteriores pasaría a familias tales como los Condes de Priego o los Manfredi. Fue derruido a finales del siglo XIX

453 Inventario de Bienes Inmuebles de la Comunidad Valenciana. Óp. cit. Castillo de Benisanó. 
para aprovechar sus materiales. Actualmente sólo quedan de él restos que han sido consolidados recientemente. Fue declarado BIC en $2002^{454}$.

- Portada y ventana acceso planta principal: entre los restos del palacio encontramos restos de portadas y ventanas de características tardogóticas ejecutadas en yeso ${ }^{455}$. El acceso a la planta principal desde la escalera de honor se realizaba a través de una portada de arco variación del flamígero mixtilíneo formado por seis trazados curvos y cuatro rectos. Las molduras de la portada, por su parte, eran dos baquetones con un caveto semicircular intermedio, y otros cavetos y filetes de menor dimensión. Dispone de capiteles decorados con elementos vegetales situados por debajo de la línea de arranque y restos de las basas características. El baquetón exterior, de mayor diámetro, se entrecruza en las aristas del arco. La ventana es adintelada y dispone de las mismas molduras y basas, aunque carece de capiteles (ver Fig. 335).

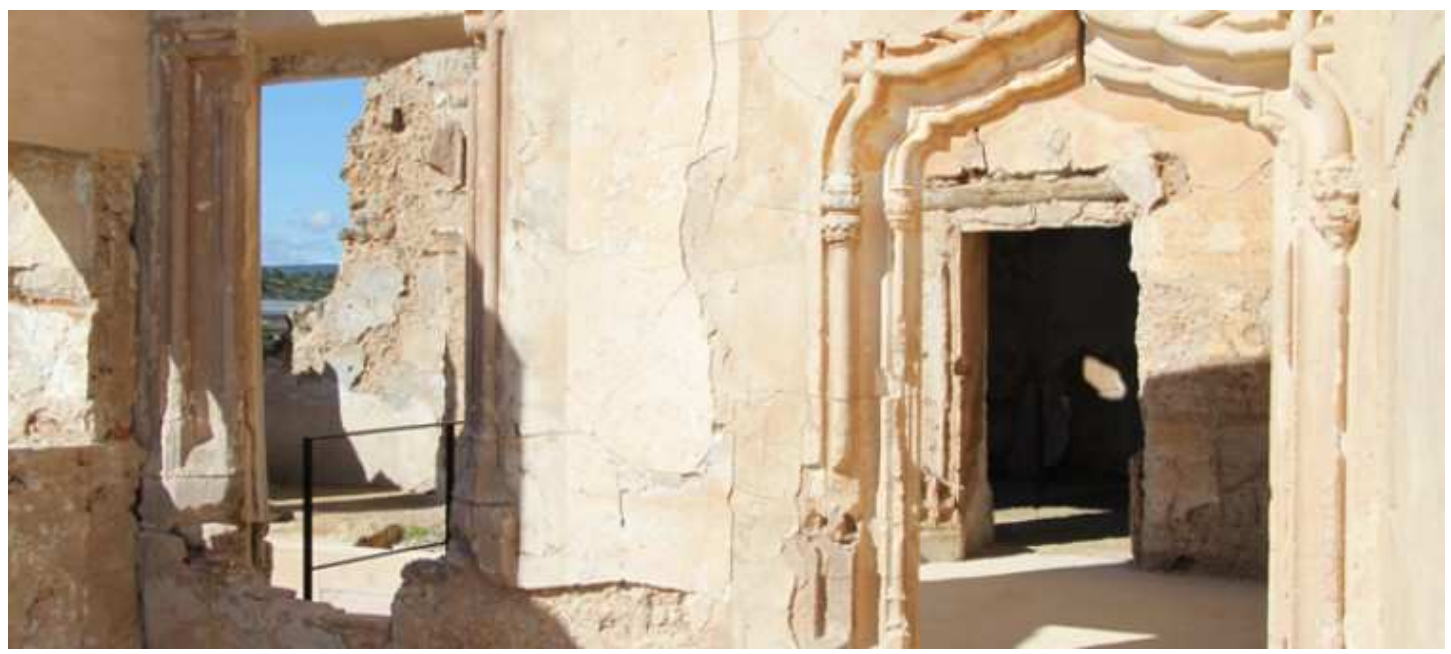

Figura 335. Portada y ventana Castillo de Bolbaite. Fotografía: www.valenciaturisme.org.

\subsection{Monasterio de Cotalba}

Es uno de los monasterios más notables y mejor conservados de la Comunidad Valenciana. Tiene una gran diversidad de estilos, con una primitiva estructura gótica del siglo XIV, y desarrollado, fundamentalmente, entre los siglos XVI al XVIII.

Su construcción data 1388 y contiene importantes elementos mudéjares, góticos, barrocos y neoclásicos, entre los que encontramos gran cantidad de portadas y ventanas de trazado

\footnotetext{
${ }^{454}$ Pérez Olagüe, C. (¿ं). Castillo de Bolbaite. Óp. cit.

455 Marín Sánchez, R. (2014). Uso estructural de prefabricados de yeso en la arquitectura levantina de los siglos XV y XVI [Tesis doctoral no publicada]. Universitat Politècnica de València. pp. 118.
} 
tardogótico. En el pasado perteneció a la orden de los Jerónimos, y pasó a manos privadas tras la desamortización de Mendizábal. Fue declarado BIC en $1994^{456}$.

En adelante, analizaremos algunas de sus portadas:

- Portada 1. Acceso planta baja: esta sencilla portada se encuentra en el acceso al antiguo monasterio. Formada por un arco conopial contracurvado mixtilíneo, las basas están muy deterioradas, así como también las jambas y las molduras del arco baquetón, un caveto semicircular, y otros cavetos y filetes de menor dimensión. Las sucesivas capas de cal impiden poder visualizar perfectamente su perfil. Presumiblemente está construida en yeso como las demás portadas del monasterio (ver Fig. 336).

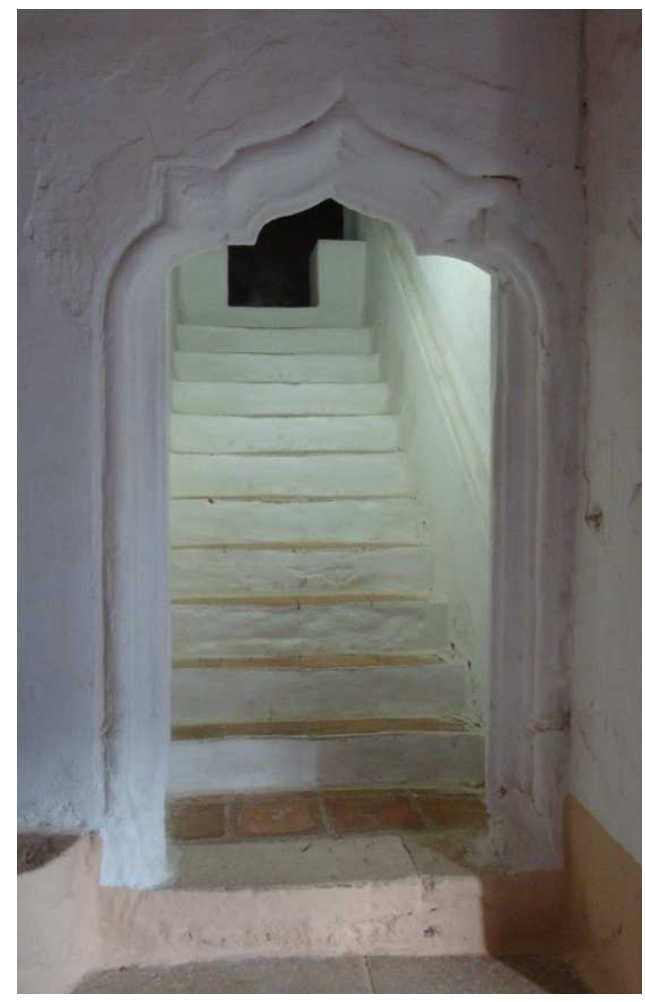

Figura 336. Portada 1 en acceso. Monasterio de Cotalba.

- Portada 2. Escalera planta baja: ésta sencilla portada se encuentra en el claustro, en la escalera que comunica la planta baja con la primera. Está formada por un arco carpanel que apoya en su parte izquierda sobre los capiteles decorados de la jamba y en la derecha sobre una ménsula. La jamba está formada por dos baquetones, un caveto semicircular, y otros cavetos menores y filetes. Dispone de basa, aunque se encuentre muy deteriorada. Está pintada de manera impropia (ver Fig. 337).

${ }^{456}$ Monasterio de Sant Jeroni de Cotalba. Recuperado de: http://www.cotalba.es/cast/index.html. 


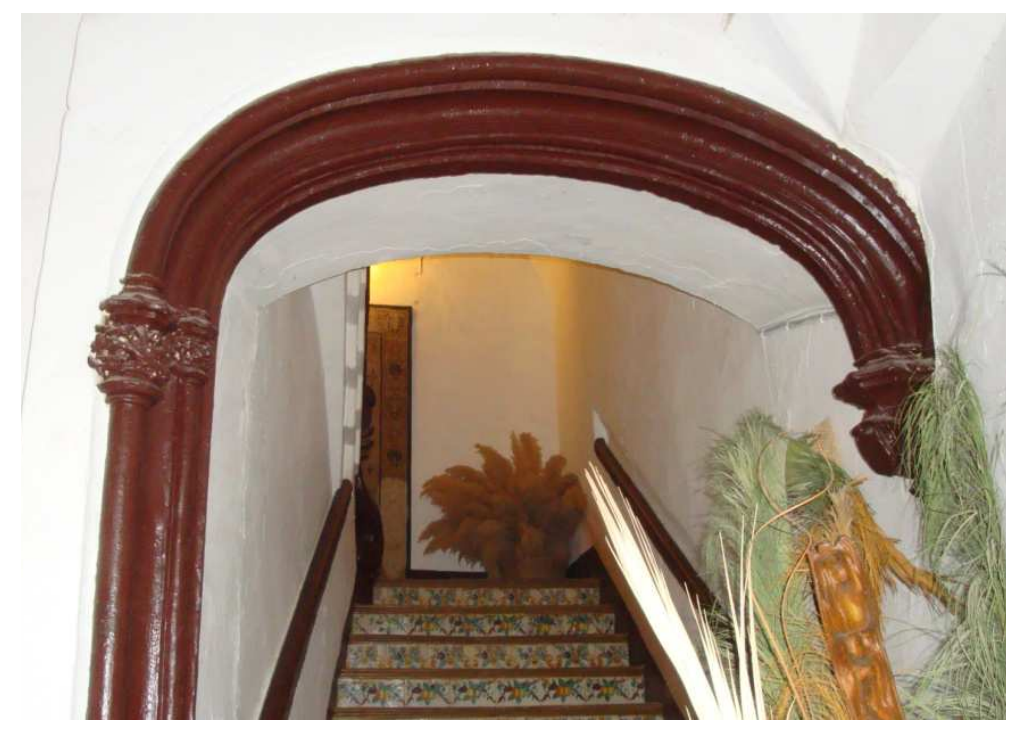

Figura 337. Portada 2. Escalera PB. Monasterio de Cotalba.

- Portada 3. Claustro(1 1 - planta): se encuentra en la planta primera del claustro, dando acceso al actual despacho. Está formada por un arco carpanel en el intradós que se transforma en un arco conopial sencillo a través de las molduras que lo forman. La jamba está formada por un gran baquetón y un caveto semicircular, y otros cavetos menores y filetes. Dispone de basa, encontrándose en muy buen estado de conservación (ver Fig. 338).

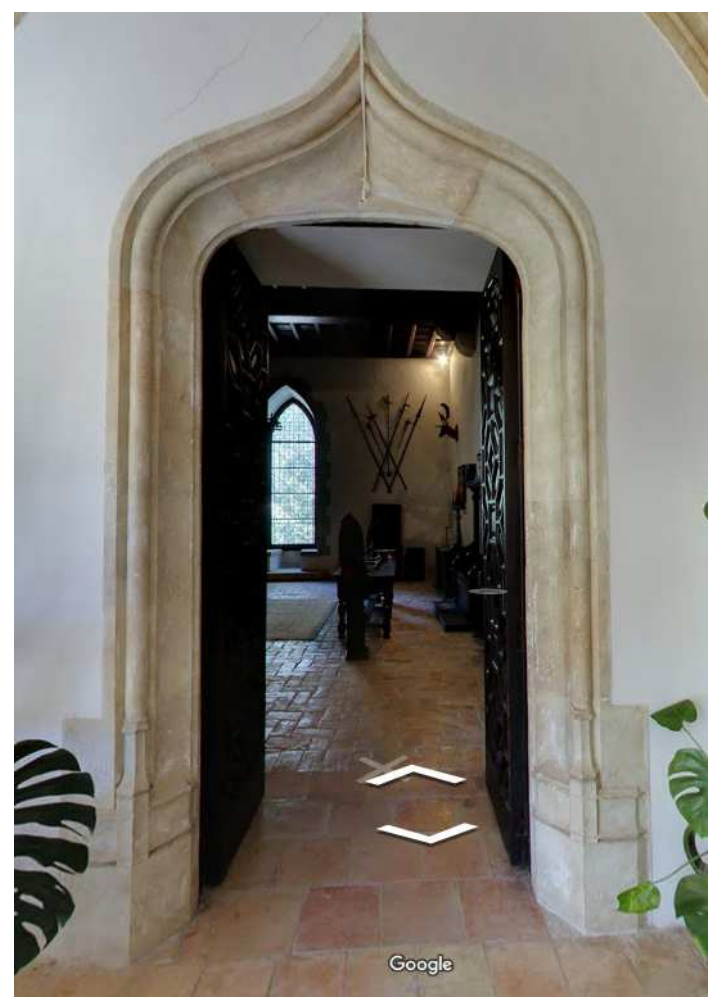

Figura 338. Portada 3. P. 1a Claustro. Monasterio de Cotalba. Fotografía: Google Maps. 
- Portada 4. Claustro (1a planta): está formada por un arco angrelado multilobulado. A su vez, la jamba está formada por dos grandes baquetones, un caveto semicircular y otras molduras menores (cavetos y filetes). Dispone de basa, con dos basas octogonales menores de las que parten las columnillas o baquetones. Se encuentra en perfecto estado de conservación (ver Fig. 339).

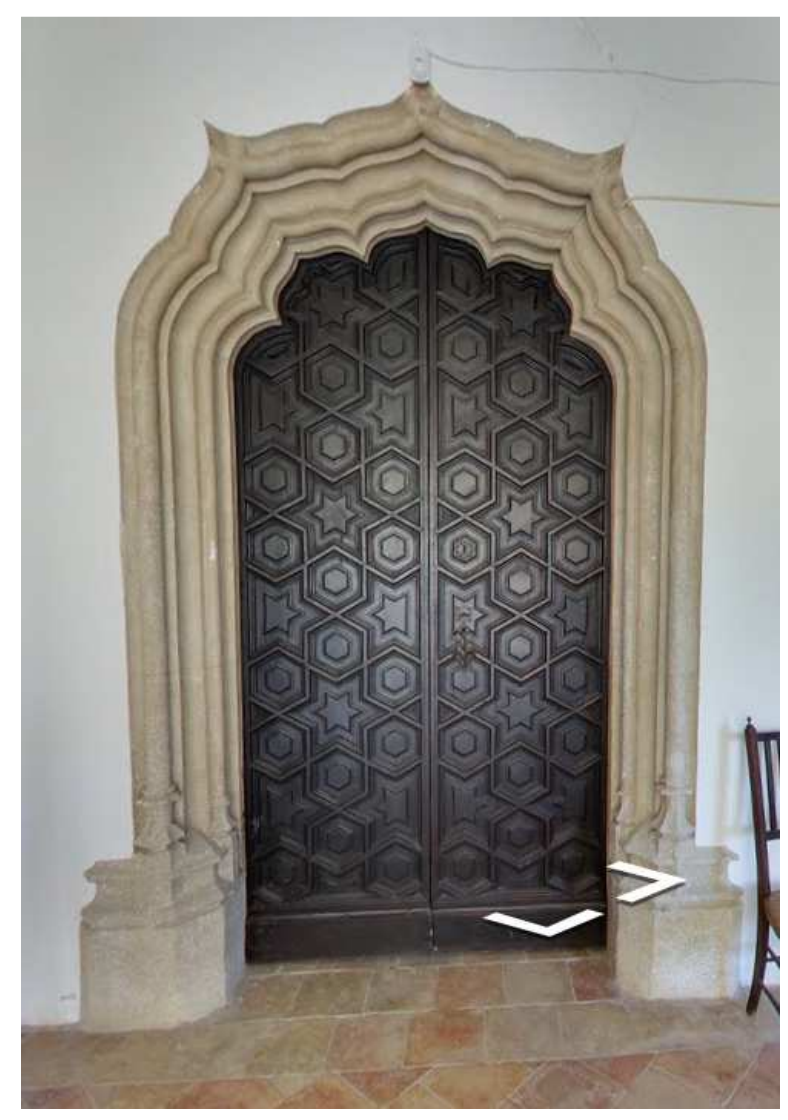

Figura 339. Portada 4. P. 1a Claustro. Monasterio de Cotalba. Fotografía: Google Maps.

- Puerta de los leones: esta singular portada se encuentra en la planta primera del claustro. Está formada por dos arcos simétricos de tipo variación del flamígero en su intradós y 6 centros en su intradós que se transforman en complejos arcos mixtilíneos en el trasdós. Los arcos apoyan lateralmente sobre las mismas ménsulas que las bóvedas de arista del claustro y en el centro, sobre una columna entorchada, se disponen las jambas centrales de los arcos formadas por dos grandes baquetones, un caveto semicircular y otros cavetos y filetes que parten de sendas basas que se unen a la de la columna formando una única pieza. Estas jambas tienen capiteles decorados con formas vegetales. En el centro, sobre las enjuntas de los dos arcos, aparece un ángel en relieve que sostiene el escudo de armas de los duques de Gandía. A ambos lados de la portada dos pedestales entorchados sustentan sendos leones con escudos dispuestos simétricamente (ver Fig. 340). 


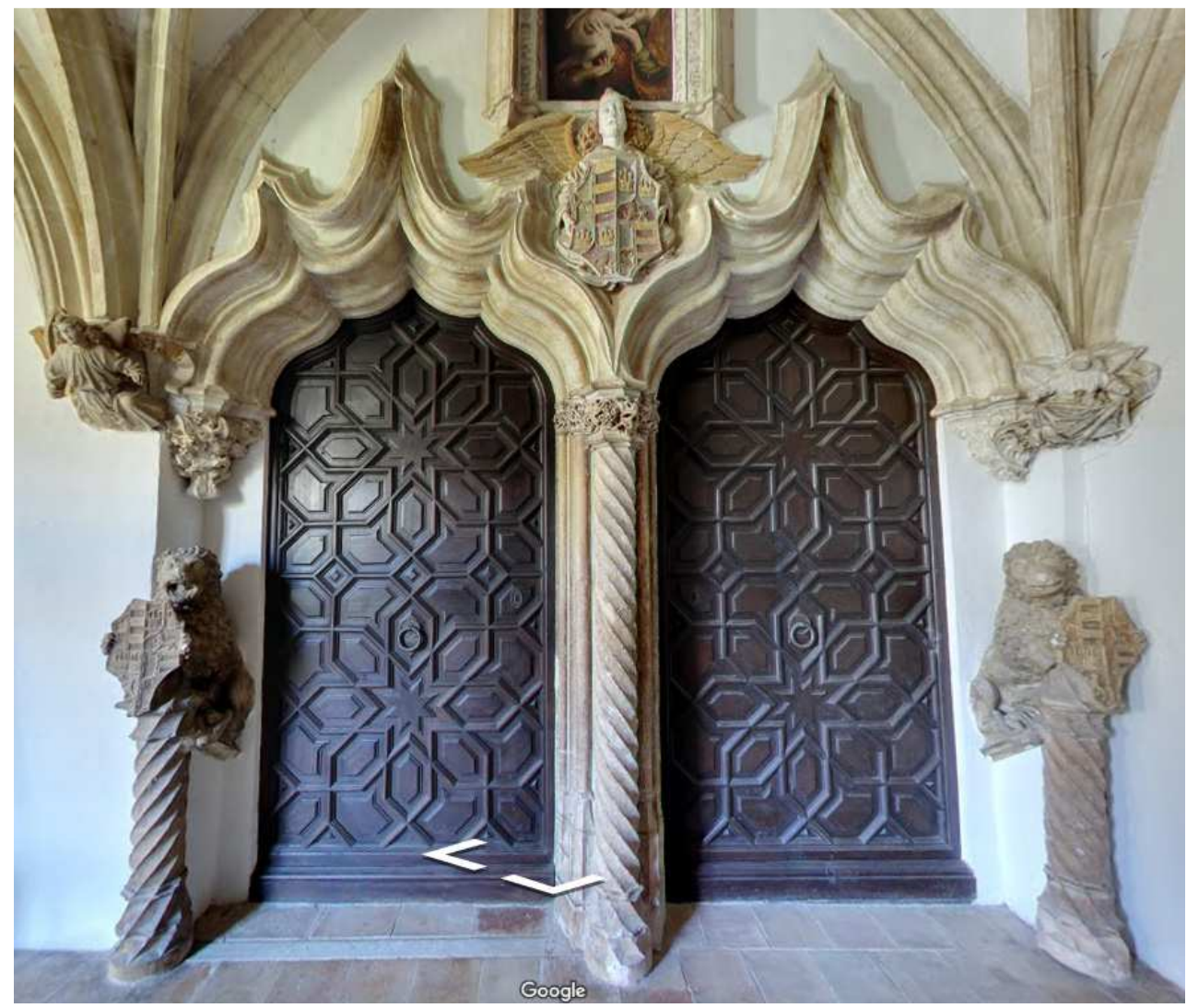

Figura 340. Puerta de los leones. Monasterio de Cotalba. Fotografía: Google Maps.

\subsection{Castillo Palacio de los Duques de Medinaceli (Geldo)}

Este castillo-palacio fue construido entre los siglos XIV y XV. El palacio perteneció a varias familias diferentes: Valterra, Sorell, Folch de Cardona hasta el siglo XVII, que pasó a la Casa de Medinaceli. Actualmente, es de titularidad pública y fue declarado patrimonio cultural en $1985^{457}$. Se encuentra sin restaurar en su interior, donde se encontraron restos de portadas tardogóticas y bóvedas realizadas en yeso.

- Portada 1: está situada en la planta principal del palacio. Está formada por un arco carpanel en el intradós que se transforma en un arco conopial sencillo a través de las molduras que lo forman. La jamba está compuesta por dos baquetones, caveto semicircular y otros cavetos menores y filetes. Dispone de basas, encontrándose estas muy deterioradas (ver Fig. 341 izq.).

- Portada 2: se encuentra en la planta principal del palacio. Está formada por un arco mixtilíneo variación del flamígero. Las jambas, muy deterioradas, al igual que las basas presentan las mismas molduras que la portada 1, (ver Fig. 341 der.).

${ }^{457}$ Pérez Olagüe, C. (¿?). Castillo Palacio de Geldo. Óp. cit. 


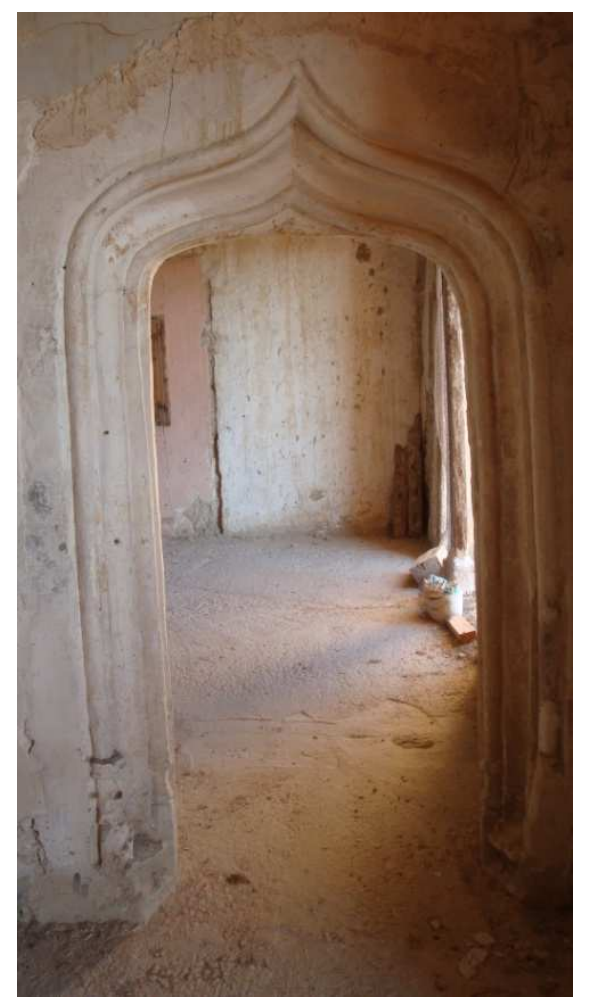

Figura 341. Portadas 1 y 2. Palacio de los Duques de Medinaceli, Geldo.

\subsection{Iglesia del Corpus Christi (Lluxent)}

La Iglesia del Corpus Christi está situada en el lado norte del claustro del monasterio del mismo nombre. Sus orígenes se remontan al siglo XIV sobre una primitiva ermita. En el siglo XVIII se procedió a su renovación tras el incendio en la guerra de Sucesión. Fue declarada BIC con categoría de monumento en el año $2007^{458}$.

En la portada de acceso encontramos una portada sencilla tallada en piedra de características góticas. Está formada por un arco de sillería de medio punto que en su intradós se transforma en un arco flamígero decorado con molduras características góticas, formadas por una baqueta o columnilla y diversos cavetos. La columnilla está rematada con capiteles góticos sencillos por debajo de la línea de impostas. En la parte inferior de las jambas se disponen basas molduradas que han sido reparadas con no mucho acierto (ver Fig. 342).

458 Inventario de Bienes Inmuebles de la Comunidad Valenciana. Generalitat Valenciana. Conselleria de Cultura i Esport. Direcció General de Patrimoni Cultural Valencià. Recuperado de: www.cult.gva.es/dgpa. 


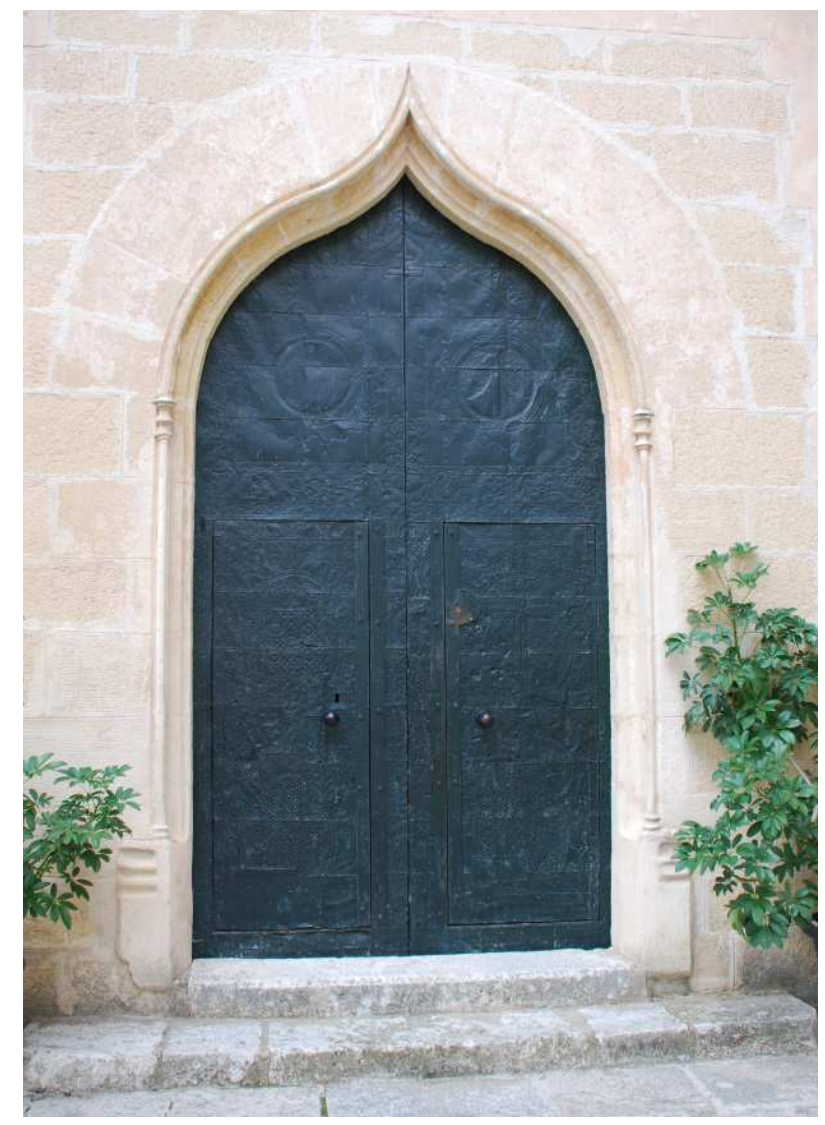

Figura 342. Portada arco flamígero. Iglesia Monasterio Corpus Christi. Lluxent.

\subsection{Palacio de Luxent}

En 1277 el rey Jaume I donó el señorío de Lluxent a Juan de Próxita, cuyos sucesores levantaron el castillo-palacio. La fecha de su levantamiento es desconocida, aunque se estima que su construcción se realizó durante el siglo XIV, con posteriores intervenciones. En 1487 fue comprado por Pedro Maza de Lizana, el cual procedió a su remodelación. Se trató de una reforma importante que modificó sustancialmente el aspecto interior del edificio, añadiendo nuevas estancias e incorporando nuevos elementos decorativos acordes con los gustos de la época ${ }^{459}$.

En su interior encontramos portadas y restos de restos de varias portadas realizadas en yeso $^{460}$ con molduras y trazados góticos. Documentaremos algunas de las mejor conservadas.

\footnotetext{
459 Inventario de Bienes Inmuebles de la Comunidad Valenciana. Óp. cit.

${ }^{460}$ García Giner, M. I. (2007). El yeso en la arquitectura tardogótica valenciana. En: Actas de Quinto Congreso Nacional de Historia de la Construcción, Instituto Juan de Herrera. pp. 411-422. Burgos, España.
} 
- Portada 1 Galería del Patio de Armas. Se trata de una portada sencilla de arco carpanel en su intradós que se transforma en un arco conopial en el extradós. De las basas principales arrancan dos pequeñas basas prismáticas, muy deterioradas, de las que parten las dos columnillas o baquetas. La jamba está formada por dos baquetones, un caveto semicircular y otros cavetos menores y filetes (ver Fig. 343).

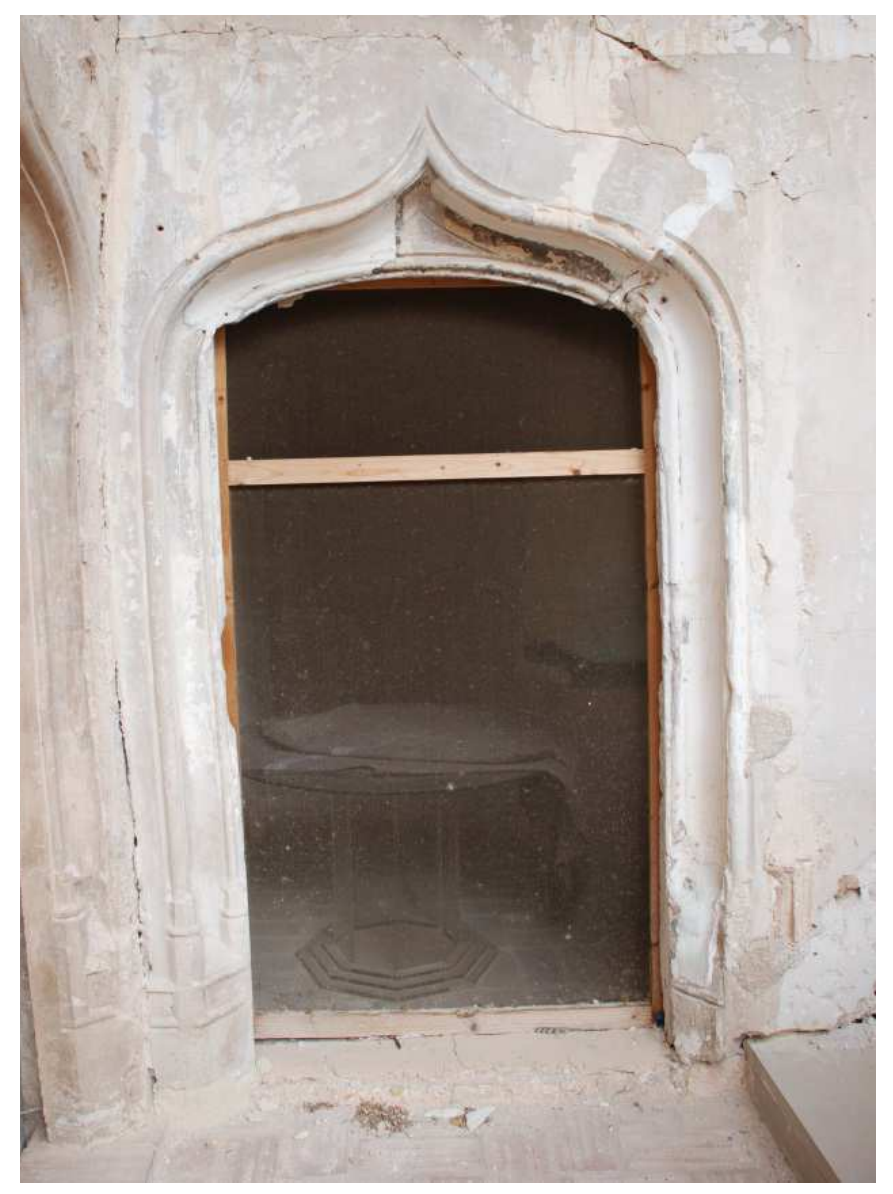

Figura 343. Portada arco conopial. Castillo Palacio de los Próxita. Lluxent.

- Portada 2: se encuentra en la planta principal del palacio formando una hornacina en uno de los muros. Está formada por un arco doble cortinado en su intradós con tracería calada que se transforma en un sencillo arco conopial en el extradós. Las jambas y el arco están formados por una columnilla o baqueta y varios cavetos. Presenta basa que ha sido restaurada con poco acierto, (ver Fig. 344 izq.).

- Portada 3: se encuentra también en la planta principal del palacio. Está formada por un sencillo arco carpanel. Las jambas y el arco están formados por dos columnillas o baquetas, un caveto central semicircular y varios cavetos y filetes. Tanto las basas como las jambas se encuentran en muy mal estado de conservación (ver Fig. 344 dcha.). 


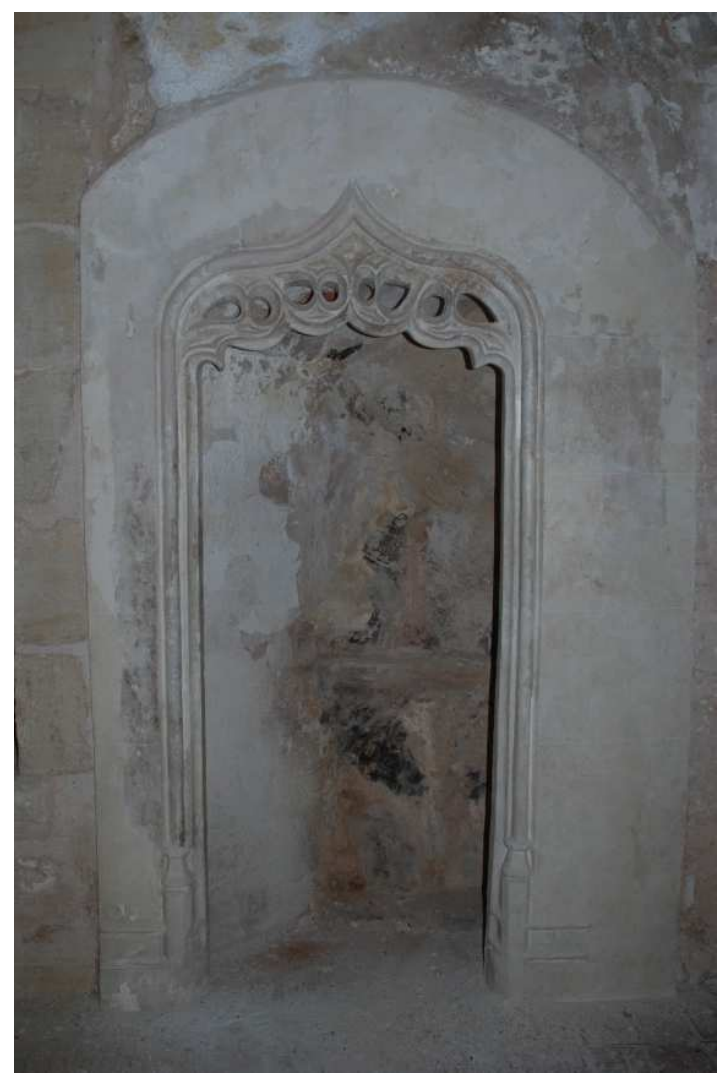

Figura 344. Izquierda: Portada arco conopial. Derecha: Portada arco carpanel. Castillo Palacio de los Próxita. Lluxent.

\subsection{Castillo de Ortells}

Ortells es una pequeña pedanía de Morella, en la Comarca de Els Ports. El Castillo de Ortells se construyó en el siglo XIII como una fortificación sobre la atalaya árabe ya existente. Posteriormente fue objeto de transformaciones en estilo gótico y renacentista, encontrándose en su interior revoltones de yeso con decoración renacentista y una portada trabajada en yeso:

- Portada interior: se trata de una portada sencilla con un arco mixtilíneo del tipo variación del flamígero. En este caso su jamba está constituida por un sencillo caveto que forma la jamba rematado con un filete que, a su vez, arranca con una rudimentaria base desde el pavimento (ver Fig. 345). Aunque dista mucho de la configuración de las portadas del Palacio de Oliva, resulta significativo el uso de las portadas de yeso con arcos conopiales en las casas señoriales valencianas a finales del siglo XV y principios del XVI. 


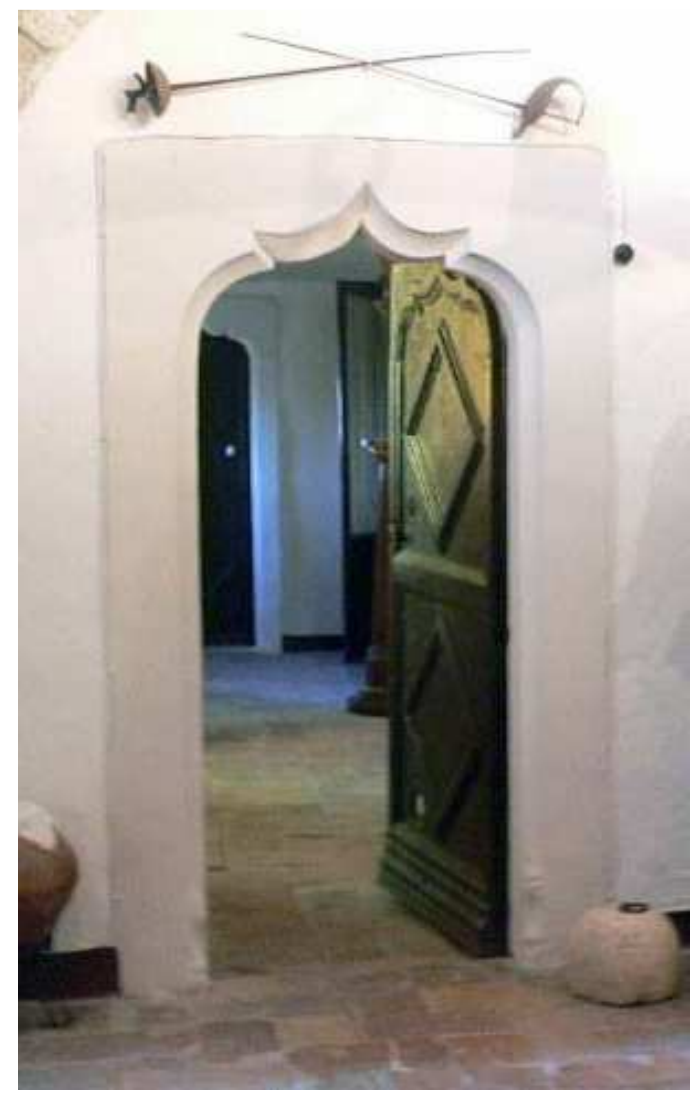

Figura 345. Portada interior Castillo de Ortells. Fotografía: Familia Pastor Eixarch.

\subsection{Palacio de Sot de Ferrer}

Se trata de un castillo-palacio medieval, con una doble utilidad: residencial-factoría y uso defensivo militar. Es un edificio de tapial con elementos de cantería góticos de finales del siglo XIII y otros de los siglos XIV y XV. Es de titularidad privada ${ }^{461}$. En su interior tiene portadas y ventanas característicamente góticas realizadas en yeso ${ }^{462}$. Hemos localizado algunos de estos elementos en fotografías históricas del Arxiu Mas datadas en $1919^{463}$. Aunque en este apartado nos hemos centrado en portadas, hemos incluido éstas dos ventanas por compartir el mismo lenguaje constructivo y formal.

- Portada interior: se trata de una portada sencilla con un arco carpanel en el intradós que se transforma en un arco conopial en el resto de molduras. Tanto las jambas como el arco están formados por dos baquetones de distinto diámetro, un

${ }^{461}$ Inventario de Bienes Inmuebles de la Comunidad Valenciana. Óp. cit.

${ }^{462}$ García Giner, M. I. (2007) El yeso en la arquitectura tardogótica valenciana. En: Actas de Quinto Congreso Nacional de Historia de la Construcción, Instituto Juan de Herrera. pp. 411-422. Burgos, España.

463 Anónimo, (1919). Fotografías Antiguo palacio del Conde de Santa Coloma. Barcelona: Instituto Amatller d'Art Hispanic. Foto Mas. Fot. C27227 y C27228. 
gran caveto central y otras molduras menores. Aunque en mal estado, tiene las basas características de estas portadas (ver Fig. 346).

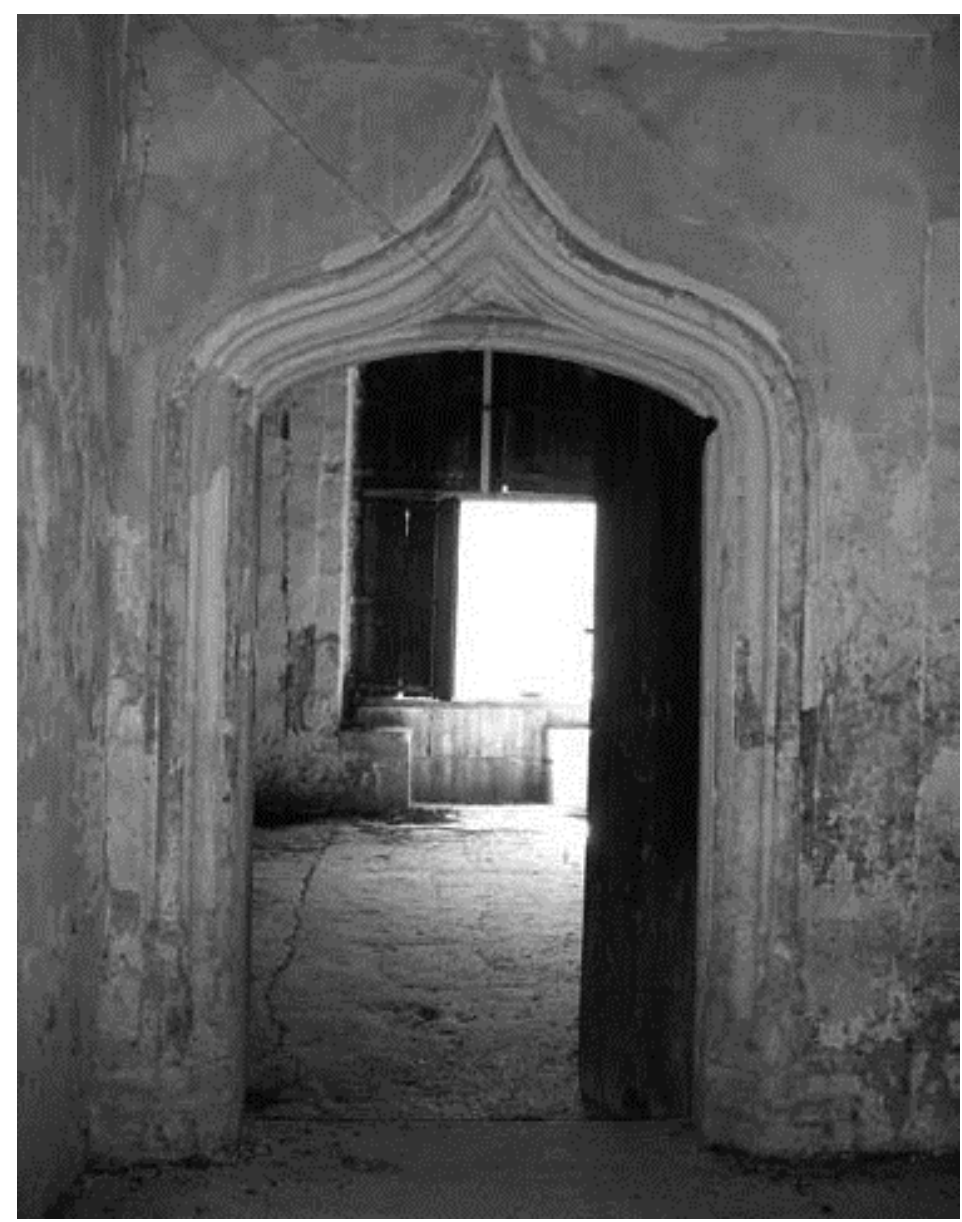

Figura 346. Portada. Antiguo Palacio del Conde de Santa Coloma. Fotografía: Giner, M.I. (2007).

- Ventanas: en el palacio encontramos también ventanas realizadas con la misma técnica de yeso que, al estar situadas en el exterior, se encuentran bastante deterioradas en su parte inferior. La ventana de la fotografía C27227 está formada por un arco festoneado angrelado polilobulado en su interior, que se transforma en un arco conopial contracurvado en el extradós. Tanto las jambas como el arco están formados por dos baquetones de distinto diámetro, un gran caveto central y otras molduras menores. Tiene la basa característica con dos bases menores octogonales. La portada de la Fot. C27228 está formada también por un arco festoneado angrelado polilobulado en su interior que se transforma en un arco conopial sencillo en el extradós. Tanto las jambas como el arco están formados por un baquetón, un gran caveto en el exterior y otras molduras; tenía basa, aunque se encuentra muy deteriorada en la imagen (ver Fig. 347). 


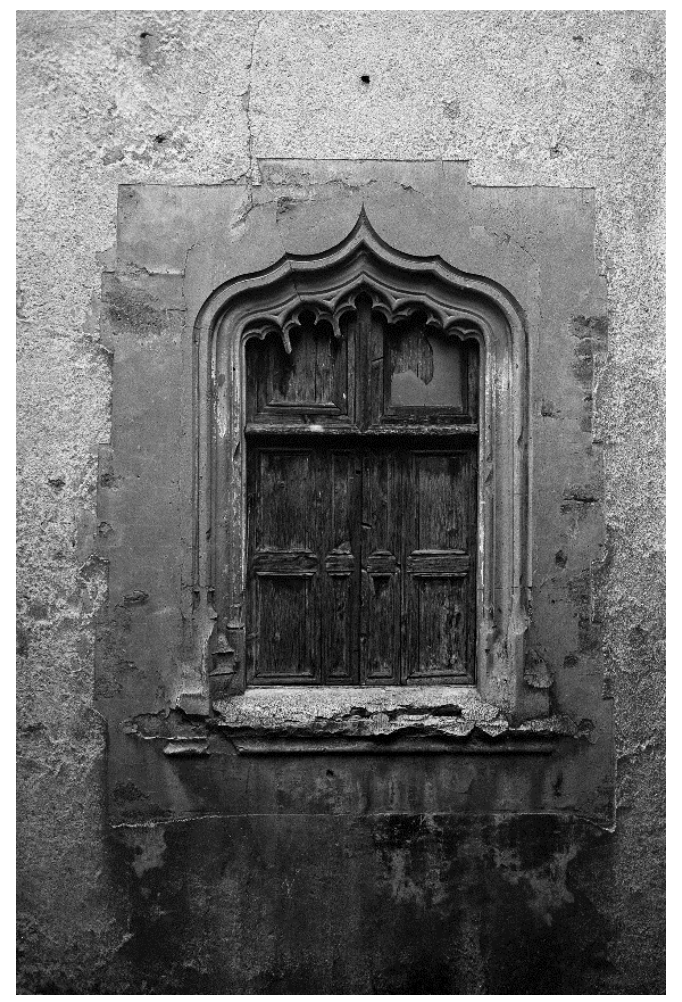

Figura 347. Ventanas. Antiguo Palacio del Conde de Santa Coloma. Fotografía: Arxiu Mas (1919).

\subsection{Catedral de Valencia}

A la muerte de Francesc Baldomar, Pere Compte fue nombrado maestro de obras de la Seo, encargándose de finalizar la Arcada Nova (1487). Entre 1494 y 1056 trabajó en las capillas que unen el Aula Capitular con la Catedral, en la Capilla de los Pertusas ${ }^{464}$ y en la Sacristía nueva. En 1497 el escultor Johan de Kassel labraba una salutació de alabastro para las enjutas del arco de la sala Capitular que daba acceso a la antigua librería (Gómez-Ferrer y Zaragozá, 2007). Este artista trabajó también en la Lonja.

- Portada antigua librería: esta portada, realizada a finales del siglo XV bajo la dirección de Pere Compte y con ornamentación del maestro Kassel, contiene un arco conopial contracurvado (variación del flamígero). Está, a su vez, formada por seis arcos de circunferencia. Las jambas se componen (de extradós a intradós) de un caveto, una baqueta $(\varnothing 4 \mathrm{~cm})$, un filete, un caveto semicircular $(\varnothing 12 \mathrm{~cm})$, un filete, una baqueta $(\varnothing 3 \mathrm{~cm}$ ) y un caveto. Las basas de las columnillas son de planta octangular con los lados convexos y con una de sus caras alineada con la basa principal en el caso de la pequeña y dos en el caso de la grande. Las columnillas entregan en el arco a través de columnillas de forma geométrica con decoración vegetal superpuesta. Al mismo nivel parten del muro dos ménsulas de las que arranca el alfiz del arco que es tangente a la clave. Este está formado por diversos

${ }^{464}$ Zaragozá Catalán, A. y Gómez Ferrer, M. (2007). Pere Copmte Arquitecto. Valencia: Consorci de Museus de la Comunitat Valenciana. pp. 113-115. 
cavetos y filetes. La portada está tallada en piedra caliza gris y en las enjuntas hay decoración en alabastro que representa la Anunciación de la Virgen (ver Fig. 348).

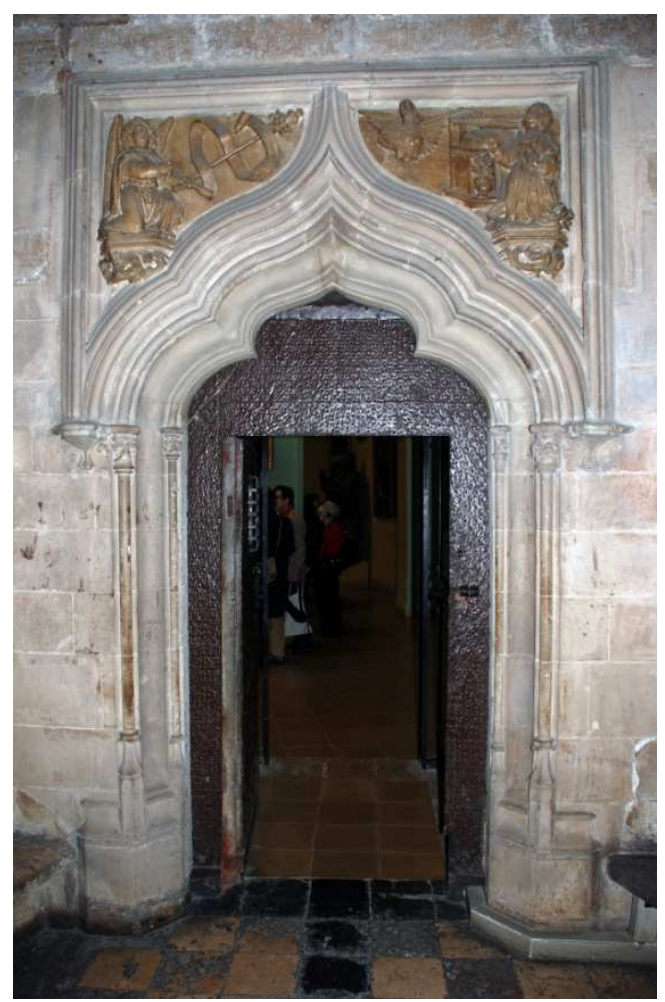

Figura 348. Izquierda: Portada antigua biblioteca. Derecha: detalle basa izquierda. Aula Capitular. Catedral de Valencia.

\subsection{Palacio de los Escrivá (Valencia)}

Este palacio perteneció a Guillem Escrivà en el siglo XV; en el XVI Juan Escrivà emparentó con Jerónima Boíl y, posteriormente, pasó a la familia Verdes de Montenegro. El palacio, de estructura gótica, se organiza a través de un patio central con escalera. Al final de la misma se abre una portada con arco conopial. En la actualidad es propiedad privada. Fue declarado BIC en 1966.

- Portada escalera: es una portada de arco variación del flamígero mixtilíneo formado por seis arcos de circunferencia y cuatro trazados rectos. Las jambas están formadas por dos columnillas que finalizan en capiteles decorados. Junto a la jamba derecha, al mismo nivel de los capiteles, surge una ménsula decorada de la que parte el alfiz del arco, tangente a la clave. En la jamba izquierda, el alfiz desaparece al existir un muro perpendicular. En las enjuntas del arco están esculpidos los escudos de las familias Escrivà y Boíl, del siglo XVI (ver Fig. 349). 


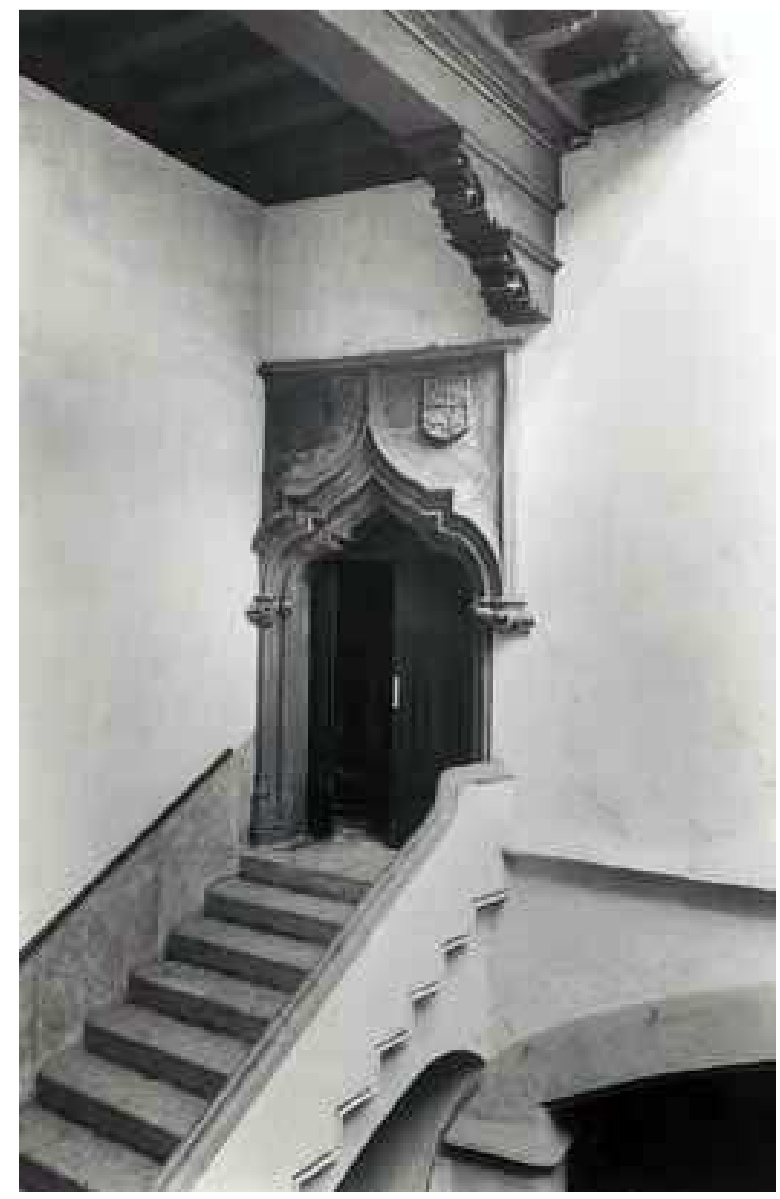

Figura 349. Portada escalera. Palacio de los Escrivá. Fotografía: Arxiu Mas.

\subsection{Palacio de la Generalitat (Valencia)}

En 1418 los diputados de la Generalitat decidieron buscar un lugar fijo para reunirse. Cuatro años más tarde, en 1422, compraron un edificio en la calle Caballeros y, a partir de ese momento, comenzaron las primeras obras. Los trabajos de construcción del actual Palacio se desarrollaron en varias fases y se extendieron hasta finales del siglo XVI. En la obra intervinieron grandes maestros de la época como Pere Compte y Joan Ibarra. En 1494 se incorporó a los trabajos el experimentado cantero Joan Corbera, que realizó las portadas de piedra del estudio y la escribanía, y en 1504 la del archivo con arcos mixtilíneos de influencia castellana ${ }^{465}$. Fue declarado monumento nacional en 1931.

- Portada acceso a la Sala Dorada Grande: da acceso a la sala desde el patio central. Es una portada de arco mixtilíneo polilobulado rebajado formado por siete arcos de circunferencia en su intradós que pasan a tres en su extradós; en ambos casos tiene 4 trazados rectos. Las jambas están formadas por dos columnillas que finalizan en

\footnotetext{
${ }^{465}$ Aldana, S. (1995). El Palau de la Generalitat Valenciana. València: Generalitat Valenciana, Consell Valencià de Cultura.
} 
capiteles decorados, caveto semicircular central y otros cavetos y filetes de menor dimensión. En el lienzo del muro, a la altura de los capiteles, se sitúan dos ménsulas decoradas con animales fantásticos de las que parten nuevas molduras que complementan el arco y que se prolongan verticalmente formando su alfiz. Las enjuntas del arco no están decoradas (ver Fig. 350).

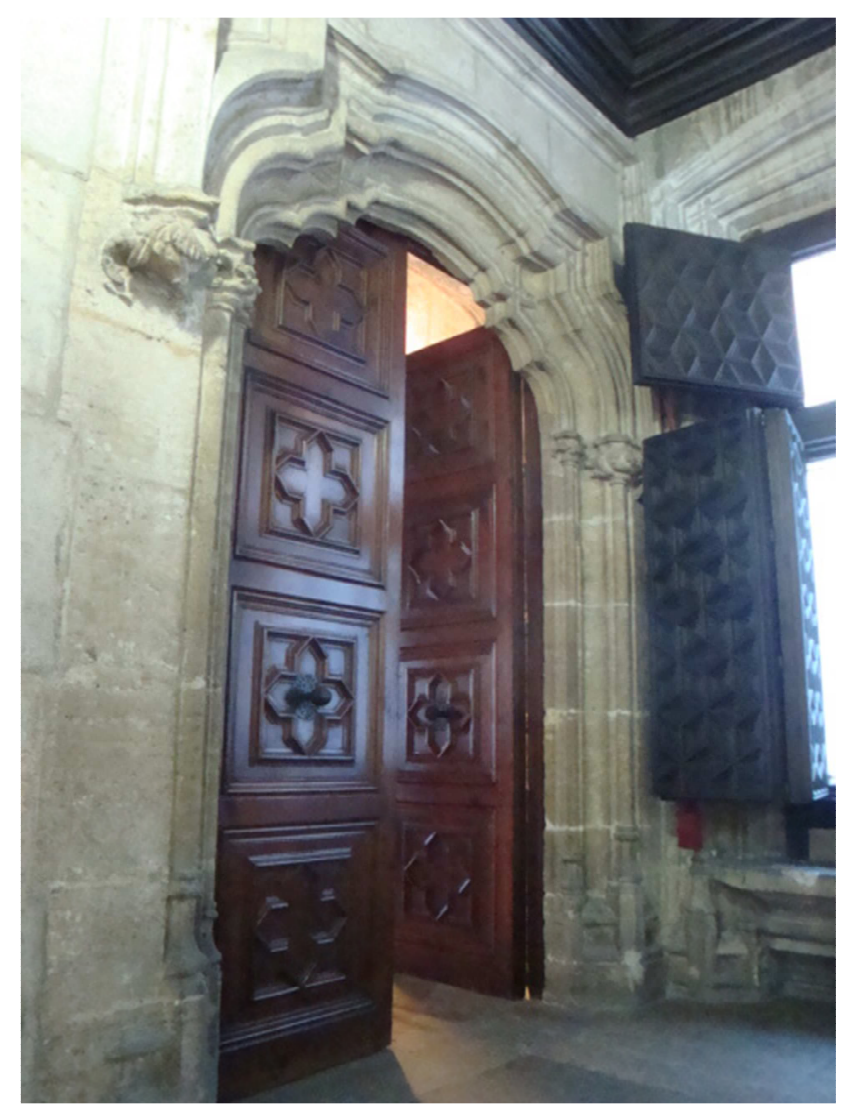

Figura 350. Portada acceso Sala Dorada Grande. Palacio de la Generalitat.

- Portada acceso a la Sala Dorada Pequeña: da acceso a la sala desde el patio central. Es una portada de arco mixtilíneo variación del flamígero formado por 6 arcos de circunferencia y 6 trazos rectos. Las jambas están formadas por dos columnillas que finalizan en capiteles decorados, caveto semicircular central y otros cavetos, baquetas y filetes de menor dimensión. Los cavetos se cruzan en las aristas. En el lienzo del muro, a la altura de los capiteles, se sitúan dos ménsulas decoradas con animales fantásticos de las que parten nuevas molduras que complementan el arco y que se prolongan verticalmente formando su alfiz. Las enjuntas del arco no están decoradas (ver Fig. 351). 


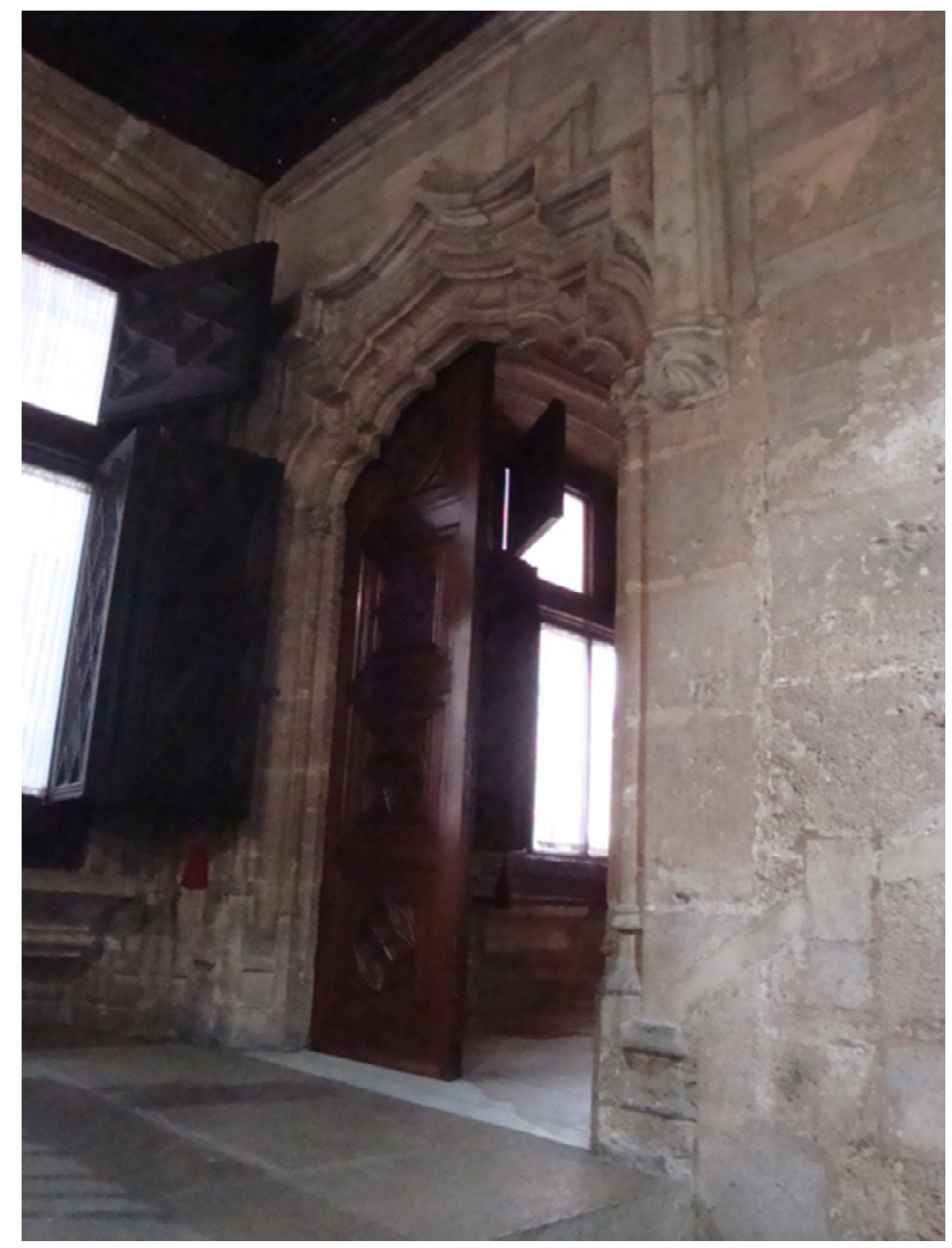

Figura 351. Portada acceso Sala Dorada Pequeña. Palacio de la Generalitat.

- Portadas acceso Sala Dorada Pequeña: se trata de dos portadas situadas a los lados de la Sala Dorada Grande que dan acceso a la Sala Dorada Pequeña. Son dos portadas gemelas con diferencias en su parte escultórica. Sus arcos son tipo variación del flamígero mixtilíneo, formadas por seis arcos de circunferencia y cuatro trazados curvos. Las jambas poseen dos columnillas (que finalizan en capiteles decorados), un caveto semicircular central, y otros cavetos y filetes de menor dimensión. Las columnillas exteriores tienen forma de tetón y se prolongan sobre los capiteles formando sus molduras el alfiz del arco. Las enjuntas del arco están decoradas en relieve representando dos centauros enfrentados (ver Fig. 352). 


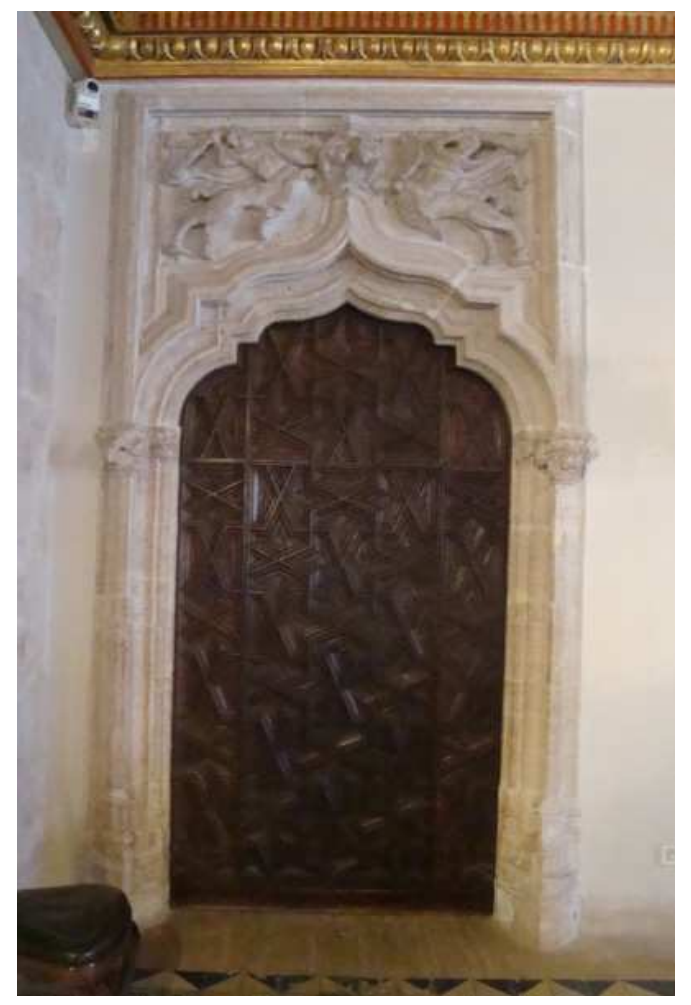

Figura 352. Portadas acceso Sala Dorada Pequeña. Palacio de la Generalitat.

- Portada del antiguo Studi: es una portada de arco variación del flamígero mixtilíneo formada por seis arcos de circunferencia y cuatro trazados rectos. Las jambas están formadas por tres columnillas que finalizan en capiteles decorados, un caveto semicircular central, y otros cavetos y filetes de menor dimensión. Las columnillas centrales tienen forma de tetón y se prolongan sobre los capiteles formando sus molduras el alfiz del arco. La basa se dispone en "V", en cuyo vértice se sitúa la columnilla de mayor diámetro. Las enjuntas del arco están decoradas en relieve, representando dos putti alados con cintas. Son obra de Joan Corbera y la parte escultórica de Jaume Vicent (1494) ${ }^{466}$ (ver Fig. 353).

\footnotetext{
${ }^{466}$ Aldana, S. (1995). El Palau de la Generalitat Valenciana. València: Generalitat Valenciana, Consell Valencià de Cultura. pp. 177.
} 


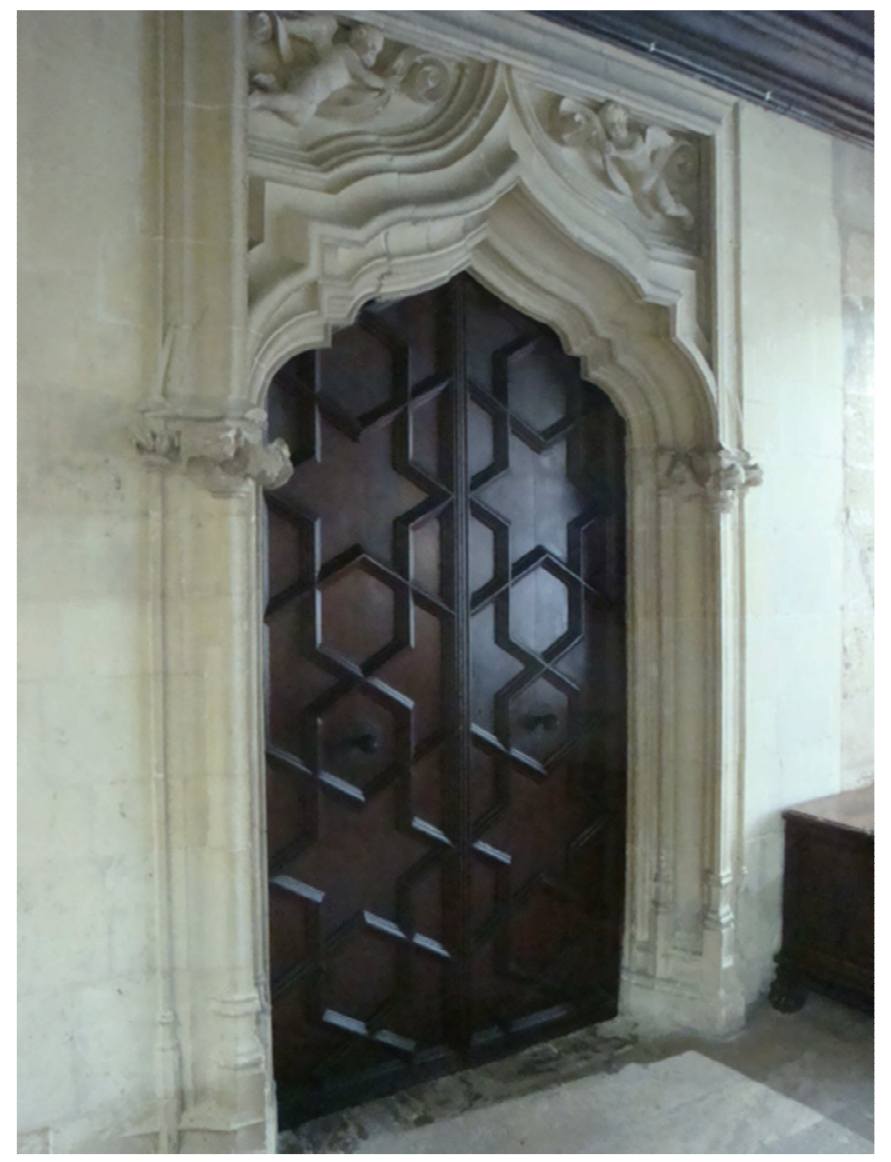

Figura 353. Portada acceso al antiguo Studi. Palacio de la Generalitat.

- Portadas sobre escalera: se trata de dos portadas sobre la escalera de patio que forman $90^{\circ}$, con un eje de simetría a $45^{\circ}$. Son dos portadas gemelas con diferencias en su parte escultórica. La portada izquierda da acceso a la Sala de Reyes y la derecha al Vestíbulo de Ingreso. Sus arcos son tipo variación del flamígero mixtilíneo, formado por seis arcos de circunferencia y cuatro trazados curvos. Las jambas están formadas por dos columnillas, que finalizan en capiteles decorados, un caveto semicircular central, y otros cavetos y filetes de menor dimensión. Dos ménsulas, una en cada arco, se sitúan al nivel de los capiteles, y de ellas parten nuevas molduras que completan los arcos y se prolongan verticalmente para formar los alfices de ambos arcos que se encuentran en el eje de simetría de las dos portadas. Sobre la clave del arco se forma un dintel que, junto con el alfiz, enmarcan la decoración escultórica de las portadas. Sobre la portada izquierda están representados los tres brazos que formaban la antigua Generalitat y sobre la de la derecha dos medallones de estilo clásico con un busto femenino y otro masculino (ver Fig. 354 y 355). Fueron realizadas por el Maestro Joan Corbera en 1516. Por su parte, la decoración fue realizada por Luis Muñoz en $1517^{467}$.

${ }^{467}$ Aldana, S. (1995). Óp. cit. pp.78-81. 


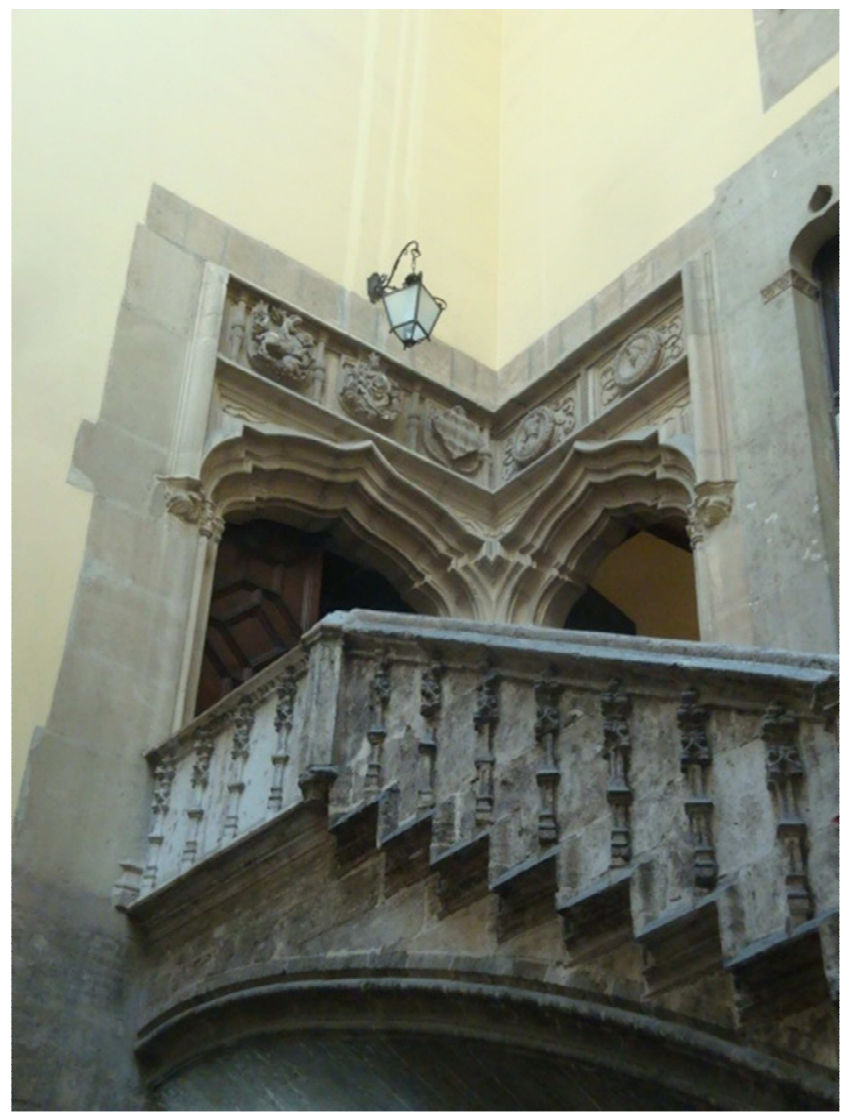

Figura 354. Portadas sobre Escalera. Palacio de la Generalitat.

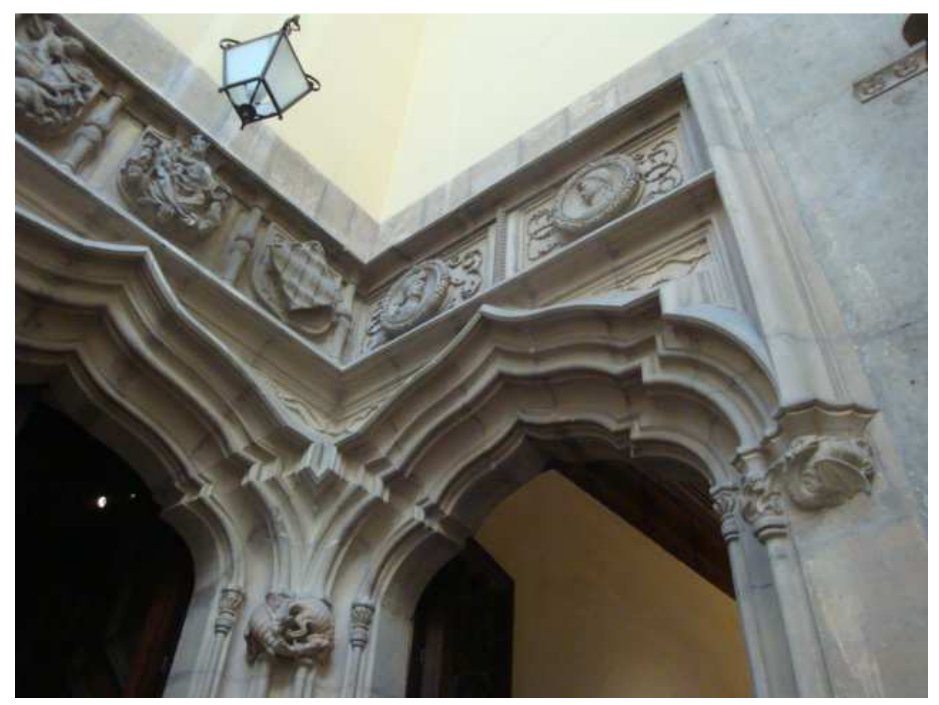

Figura 355. Detalle portadas Sobre Escalera. Palacio de la Generalitat. 


\subsection{Lonja de Valencia}

Las obras se encargaron a Pere Compte y Joan Ibarra y se iniciaron en 1483, levantándose en primer lugar la Sala de Contratación. A la muerte de Ibarra (1486), el primero asumió la dirección de la obra. En 1498 se finalizan las obras de la Sala de Contratación y se iniciaron las del Consulado del Mar, que fueron dirigidas por el maestro Compte hasta su muerte en 1506, continuando su labor el maestro Joan Corbera ${ }^{468}$ y finalizándose hacia $1533^{469}$. Fue declarada monumento en 1931 y Patrimonio de la Humanidad en $1996^{470}$. Analizaremos algunas de las portadas tardogóticas de La Lonja, eligiendo las de menor escala, por compartir un lenguaje formal con las del Palacio de Oliva.

- Portada Escalera de Caracol: esta portada da acceso a la escalera de caracol desde la Sala de Contratación. Está formada por un arco deprimido en su intradós que se transforma en arco conopial en el extradós. Las jambas están formadas por un caveto, un baquetón, un filete, y un caveto. Cada columnilla entrega al arco con capiteles decorados con elementos vegetales. Los cavetos se entrecruzan en la clave del arco. Sobre las ménsulas laterales decoradas con formas vegetales a la izquierda, y un putti alado montado sobre un reptil, la derecha, arrancan nuevas molduras que completan el perfil del arco. El pequeño tímpano que se forma en la transición entre los dos tipos de arcos está decorado con un ángel con túnica que porta una cinta y el escudo de Valencia. Las basas están formadas por una pequeña basa de planta octogonal que emerge de las molduras de la basa principal. El trasdós del arco está decorado con elementos vegetales y putti, y sobre la clave, una cruz formada por elementos vegetales de idéntica composición a los de las portadas de la fachada (ver Fig. 356).
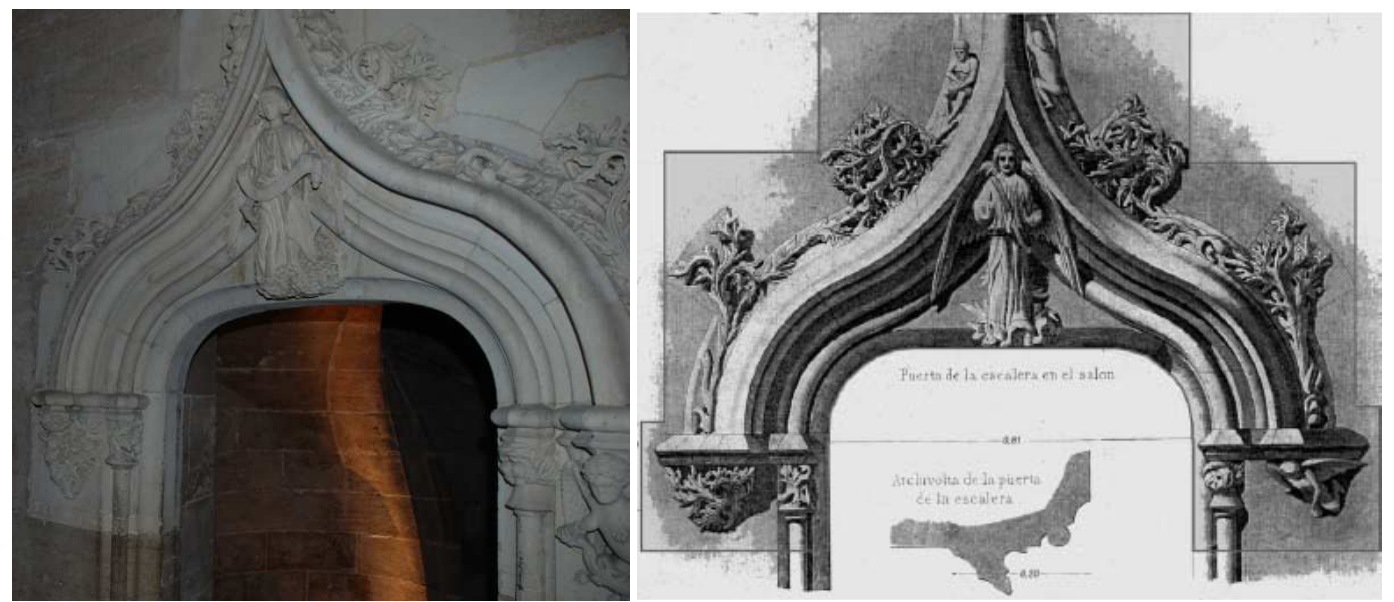

Figura 356.Izquierda: fotografía Portada Escalera Caracol. Sala de Contratación. Arco. Derecha: alzado y sección del arco dibujada por R.M. Jiménez en 1876. Fuente: Ramírez Blanco, MJ. (2013).

\footnotetext{
468 Zaragozá Catalán, A. y Gómez Ferrer, M. (2007). Pere Copmte Arquitecto. Valencia: Consorci de Museus de la Comunitat Valenciana. pp. 76-102.

${ }^{469}$ Ramírez Blanco, M. J. (2013). La Lonja de Valencia y su conjunto monumental, origen y desarrollo constructivo (Tesis doctoral). Editorial Universitat Politècnica de València. pp. 98.

${ }^{470}$ Inventario de Bienes Inmuebles de la Comunidad Valenciana. Óp. cit. La Lonja de la Seda.
} 
- Portada Planta Baja Consulado del Mar: es una portada de arco deprimido en su intradós que se transforma en arco conopial en el extradós. Las jambas están formadas por caveto, baquetón, filete, caveto semicircular, filete, baqueta y caveto. Cada columnilla entrega al arco con capiteles decorados con elementos vegetales. Los cavetos se entrecruzan en la clave del arco. Sobre ménsulas laterales decoradas con figuras zooformes arrancan nuevas molduras que completan el perfil del arco. El pequeño tímpano que se forma en la transición entre los dos tipos de arcos está decorado con el escudo de Valencia con la corona real. Las basas están formadas, a su vez, por dos pequeñas basas de planta octogonal que emergen de las molduras de la basa principal (ver Fig. 357). Este hueco que no forma parte de la obra original, se fue abierto por el maestro Miquel Joan Porcar en $1546^{471}$.

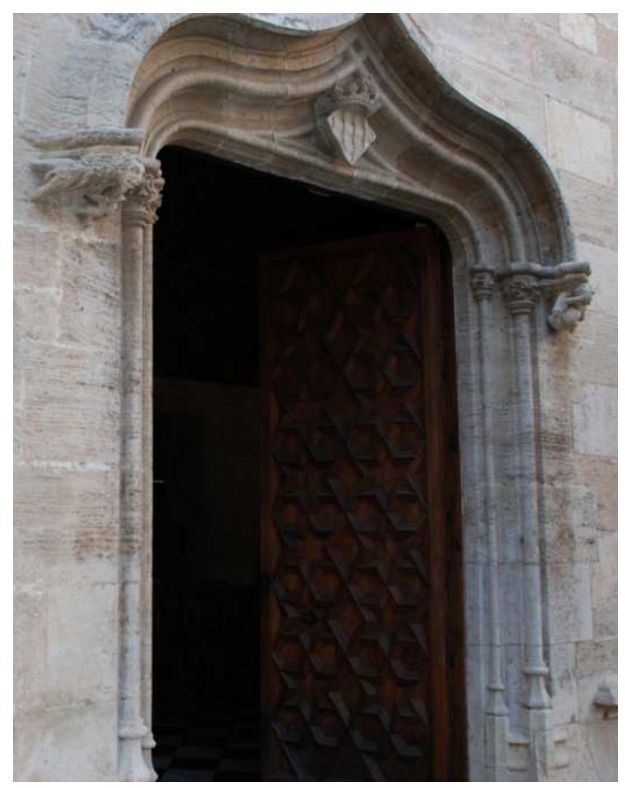

Figura 357. Portada planta baja Consulado del Mar. Vista general y detalle de la basa derecha.
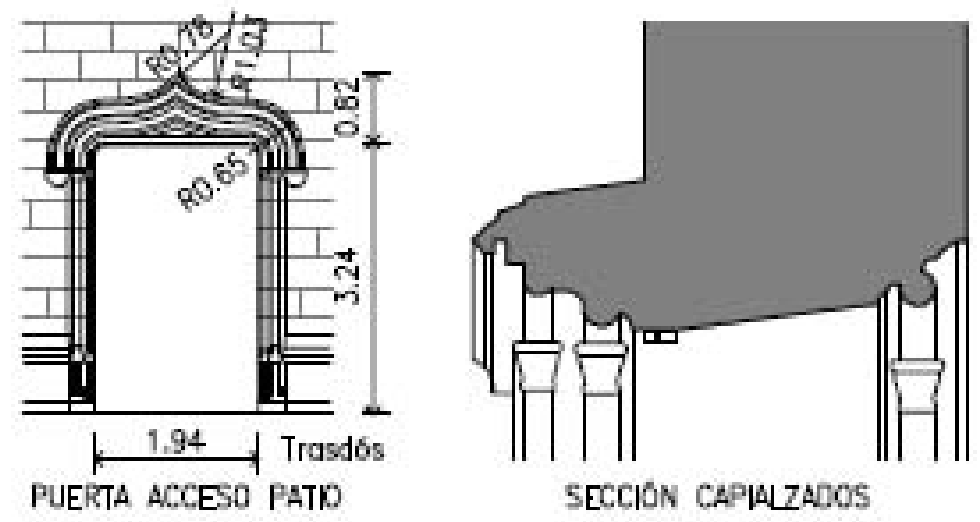

Figura 358. Portada planta baja Consulado del Mar. Alzado y sección del capialzado. Fuente: Ramírez Blanco, M. J. (2013).

${ }^{471}$ Ramírez Blanco, M. J. (2013). Óp. cit. pp.110. 
- Portada Planta Principal Consulado del Mar: es una portada de arco variación del flamígero o conopial contracurvado. Las jambas están formadas por caveto, baquetón, filete, caveto semicircular, filete, baqueta y caveto. Cada columnilla entrega al arco con capiteles decorados con elementos vegetales. El caveto exterior se entrecruza en las aristas del arco. Sobre las ménsulas laterales, decoradas con figuras zooformes y antropomórficas, arrancan nuevas molduras que completan el perfil del arco y se prolongan verticalmente formando el alfiz, que es tangente a la clave. Las enjuntas están decoradas con elementos vegetales geometrizados. Las basas están formadas por dos pequeñas basas de planta octogonal que emergen de las molduras de la basa principal (ver Fig. 359). Las obras de la planta primera fueron finalizadas por el Maestro Corbera en 1510, aunque no hay constancia de quién ejecutó la portada ${ }^{472}$.

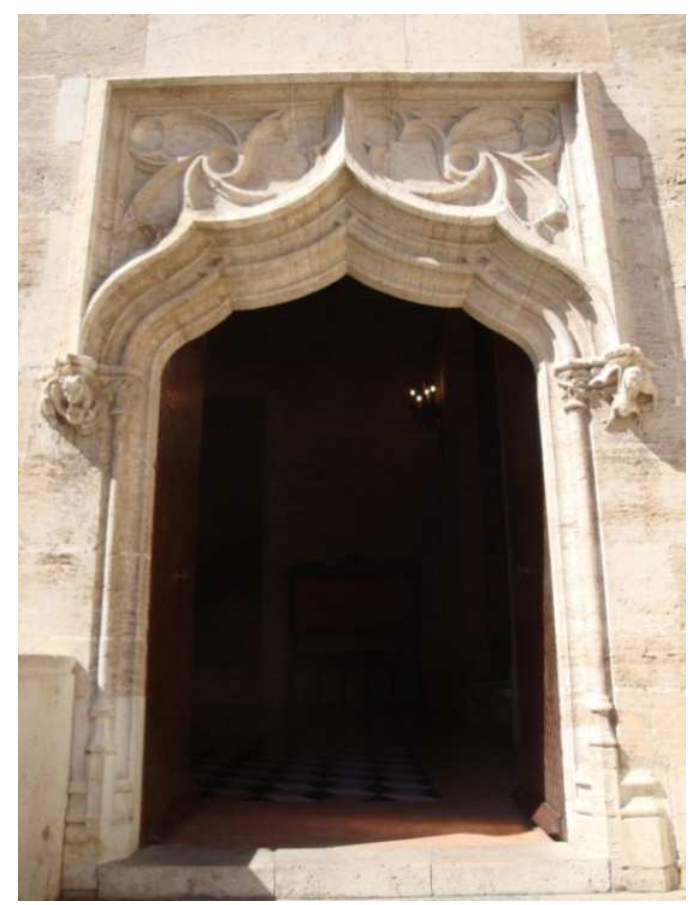

Figura 359. Portada planta principal. Consulado del Mar. Vista general y detalle de la basa izquierda.

${ }^{472}$ Ramírez Blanco, M. J. (2013). Óp. cit. pp.122. 


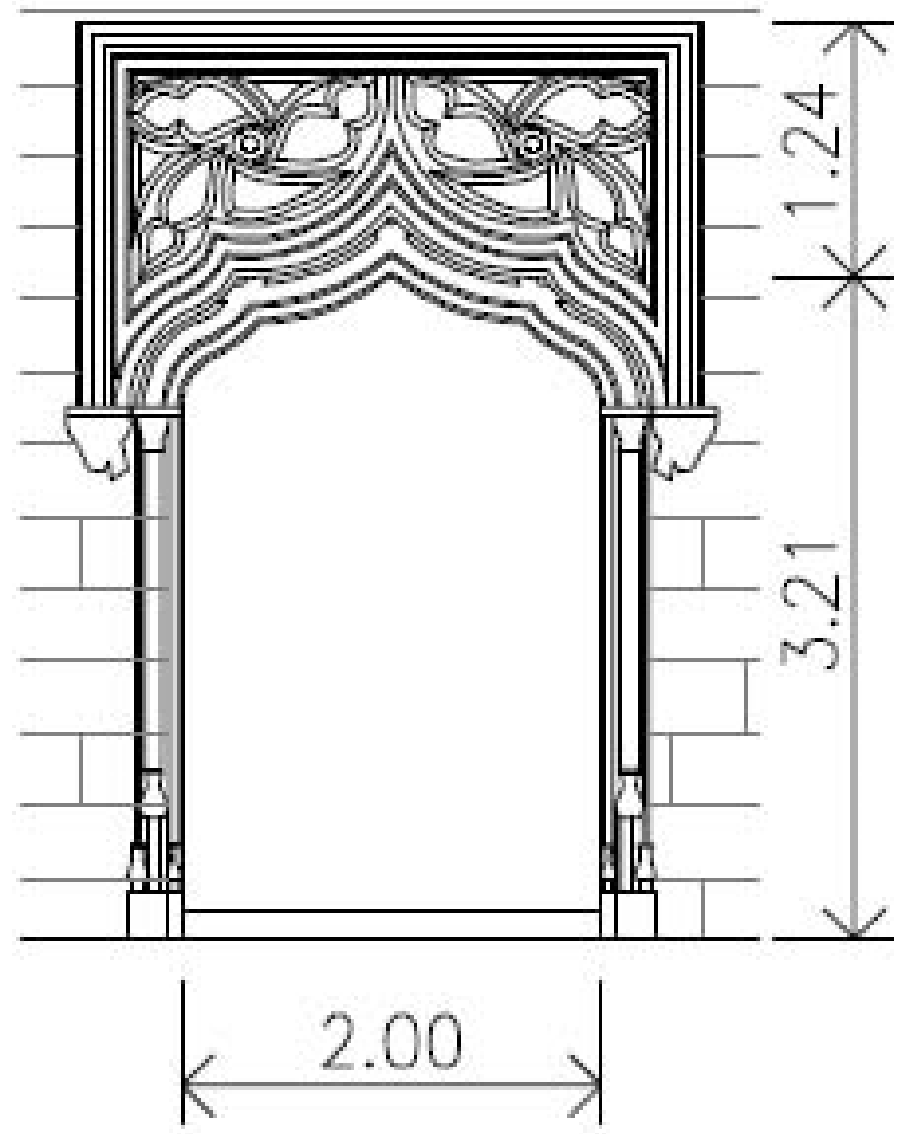

Figura 360. Portada planta principal. Consulado del Mar. Alzado. Fuente: Ramírez Blanco, MJ. (2013).

\subsection{Monasterio de la Santísima Trinidad (Valencia)}

Este monasterio del siglo XV se comenzó a construir en 1445 a instancia de la reina Doña María de Castilla, esposa de Alfonso $\mathrm{V}$ el Magnánimo. Está formado por el claustro, la iglesia y el resto de dependencias conventuales: refectorio, sala capitular, celdas, cocina y huerto. Fue declarado BIC en $1982^{473}$.

- Portada lateral Iglesia: es una portada de arco ojival. Las jambas están formadas por caveto, baquetón, filete, caveto semicircular, filete, columnilla con tetón, filete, caveto, baqueta y caveto. Un capitel sencillo envuelve toda la jamba y sobre él arranca el arco que, en su cara interior, sigue las molduras de las jambas y, en su trasdós, dos grandes dovelas forman un arco de medio punto enrasado con el resto del lienzo de la fachada. Las basas están formadas por dos pequeñas basas de planta octogonal que emergen de las molduras de la basa principal (ver Fig. 361).

473 Inventario de Bienes Inmuebles de la Comunidad Valenciana. Óp. cit. La Lonja de la Seda. 


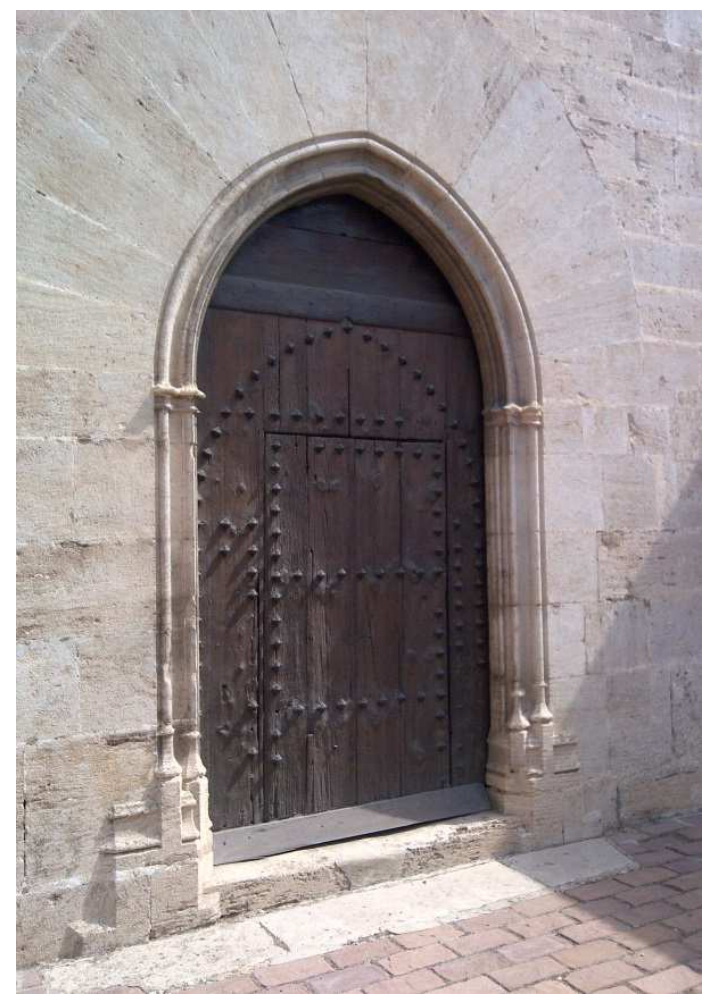

Figura 361. Portada lateral. Monasterio de la Trinidad. Vista general y detalle de la basa derecha.

\subsection{Palacio Mosén Sorell (Valencia)}

El Palacio Mosén Sorell, hoy desaparecido, fue uno de los más importantes palacios medievales de la ciudad de Valencia. Se localizaba en la actual calle Corona, donde hoy se encuentra el mercado de Mosén Sorell. Se construyó entre 1455 y 1460 por Tomás Sorell Sagarriga († 15-11-1485) en estilo gótico predominante en esta época. En 1878 sufrió un incendio que lo destruyó casi por completo y fue demolido completamente en 1882. Algunas de sus piezas fueron vendidas, conservándose 3 de sus portadas.

- Portada acceso principal: se encuentra desde 1924 en la fachada de la Galería Parmeggiani en Reggio Emilia (Italia). Se trata de una puerta gótico flamígera con el escudo de los Sorell-Aguiló y, sobre él, un yelmo. La portada se compone de un arco carpanel y sobre montado otro conopial; todo el conjunto bordeado por un guardapolvos a modo de alfiz que arranca de dos ménsulas situadas al nivel de los capiteles. Los arcos apoyan en columnas sencillas. Entre los dos arcos de la portada se encuentra el escudo de armas de la familia Sorell-Aguiló. En las enjutas del arco dos haces de trigo y una leyenda con caracteres góticos que dice: "Lo que tenemos fallece y el bien obrar no fenece". 


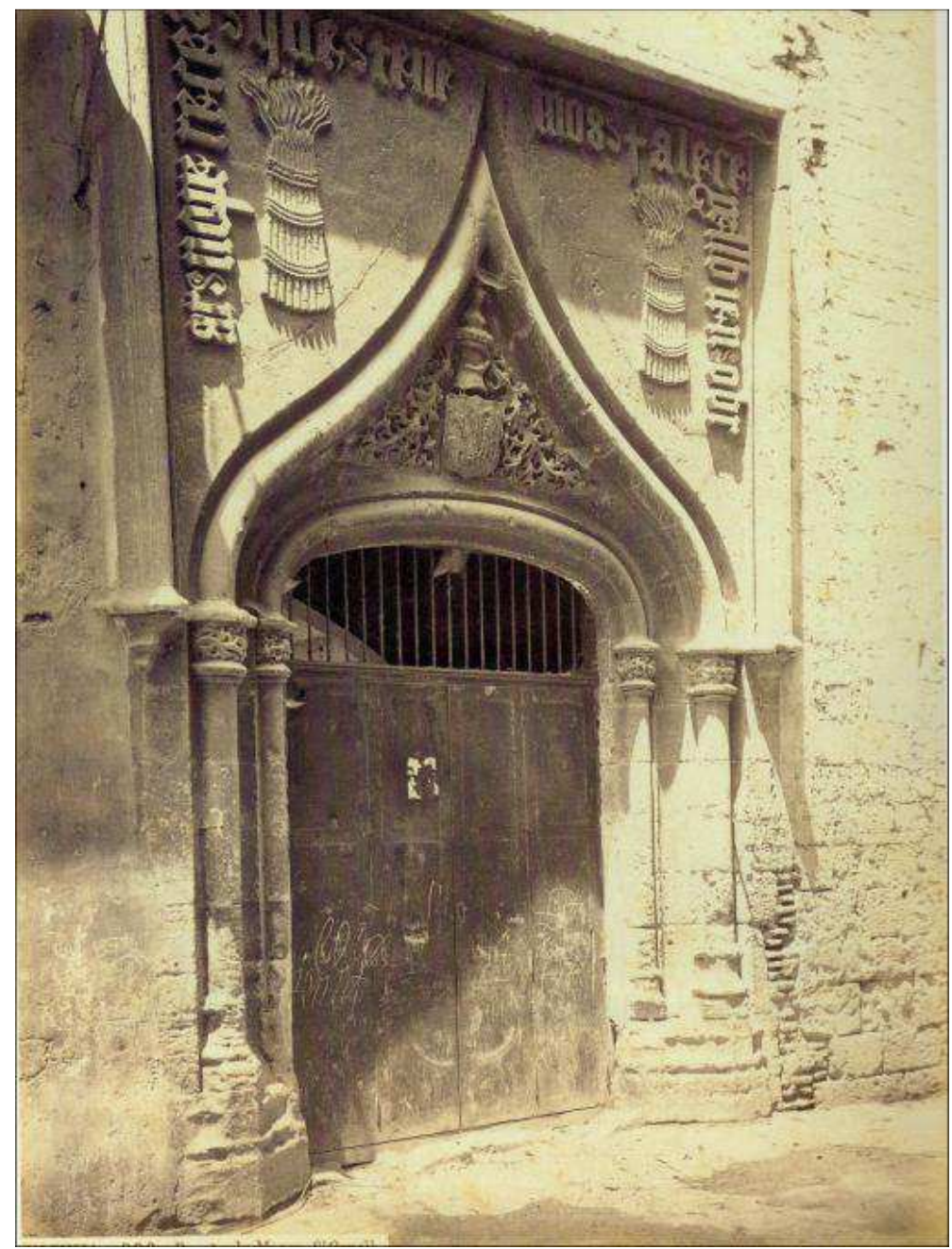

Figura 362. Portada principal Palacio Mosén Sorell. Fotografía: Federico Iborra Bernard. Fuente:www.jdiezarnal.com.

- Puerta de la capilla: fue adquirida por el Gobierno francés en 1883. En la actualidad se encuentra en el Museo del Louvre. En la clave del arco destaca el busto de lo que parece ser un clérigo. En la parte superior se muestra una escena correspondiente a la Anunciación, el arcángel San Gabriel a la izquierda, una gran cruz floreada en el centro y a la derecha la Virgen María. Se atribuye esta portada a Pere Compte, y se considera que es de finales del siglo XV. Realizada en piedra calcárea, conserva trazas de policromía. En las dos filacterias que podemos observar en la portada podemos leer la siguiente frase: "Ipsa me consolata sunt" ("Ellos me consuelan"). Flanquean la portada dos pináculos adornados que se alzan hasta lo alto de la misma. 


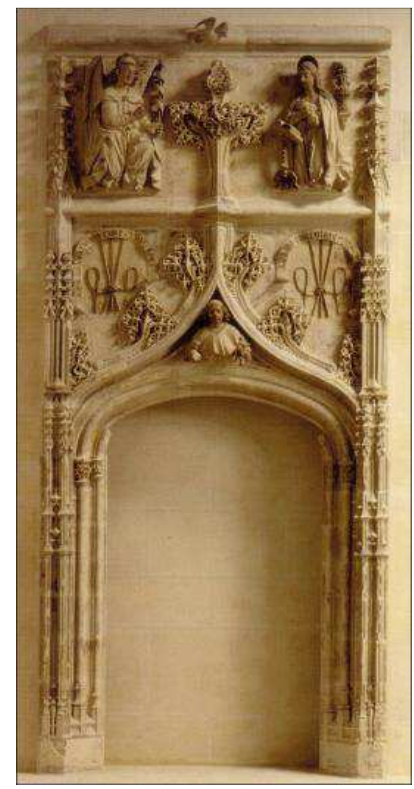

Figura 363. Puerta de la Capilla. Palacio Mosén Sorell. Fotografía: Federico Iborra Bernard. Fuente:www.jdiezarnal.com

- Puerta salón principal: en la actualidad se encuentra en el Museo de Cerámica de Manises, ya que fue adquirida por José Sanchís Pertegás para colocarla en su domicilio que, con el tiempo, se convirtió en Museo de Cerámica. Se compone de un arco carpanel y sobre montado otro conopial que hace funciones de guardapolvos. Su jamba se compone de dos baquetas y caveto central. Tiene capiteles decorados con elementos vegetales. Sobre el extradós posee también decoración con elementos vegetales y sobre la clave emerge una gran cruz floreada.

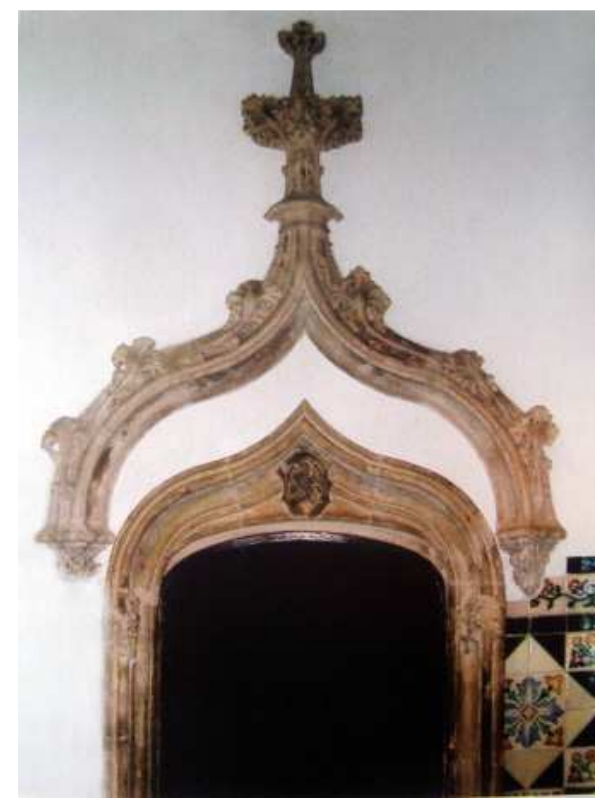

Figura 364. Puerta Salón principal. Palacio Mosén Sorell. Fotografía: P. Alcántara. 


\subsection{Palacio de los Almirantes de Aragón (Valencia)}

Es de uno de los mejores ejemplos de palacios góticos valencianos. Su construcción data del último tercio del siglo XV, sufriendo transformaciones posteriores. Perteneció a los barones de Villalonga y Castilnovo, pasando luego a la familia de los Cardona, Almirantes de Aragón ${ }^{474}$. En él encontramos algunas portadas de marcado carácter gótico que presentan cierto paralelismo con las portadas del Palacio Condal de Oliva.

- Portada acceso entresuelo: se trata de una portada de arco conopial contracurvado mixtilíneo o variación del flamígero mixtilíneo, esculpida en yeso El resto de la construcción original estaba formada por seis trazados curvos y cuatro trazados rectos. Sus molduras principales son dos baquetones de distinto diámetro y un gran caveto central que, junto con otros cavetos menores y filetes, forman el hueco abocinado. La basa tiene forma prismática y muestra el escudo de Valencia tallado, aunque no se corresponde con la original que, presumiblemente, sería similar a las existentes en las ventanas del entresuelo, hoy restituidas a partir de los vestigios encontrados de las ventanas originales ${ }^{475}$.

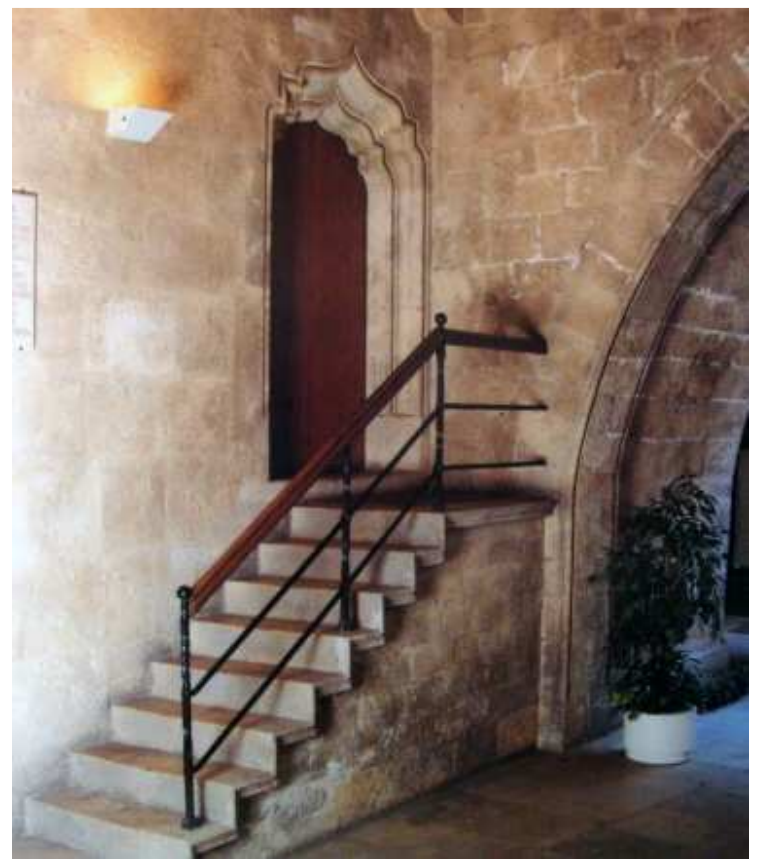

Figura 365. Portada acceso entresuelo. Palacio de los Almirantes de Aragón. Fotografía: Enrique Carrazoni.

- Portada interior: se trata de una portada de arco variación del flamígero mixtilíneo original, formada por seis trazados curvos y cuatro trazados rectos. Sus molduras principales son dos baquetones de distinto diámetro y un gran caveto central que,

474 Roselló M., Teixidor V, Zaragozá Catalán, A. et al. (1991). Palau del Almirall. Valencia: Generalitat Valenciana, Conselleria de Economía y Hacienda. pp. 81,99 y 100.

${ }^{475}$ Roselló, M, Teixidor, V. Zaragozá Catalán, A. et al. (1991). Óp. cit. pp. 107, 154 y 155. 
junto con otros cavetos menores y filetes, forman el hueco abocinado. Las baquetas se entrecruzan en las aristas del arco. Las basas originales se han perdido, siendo sustituida por unas prismáticas.

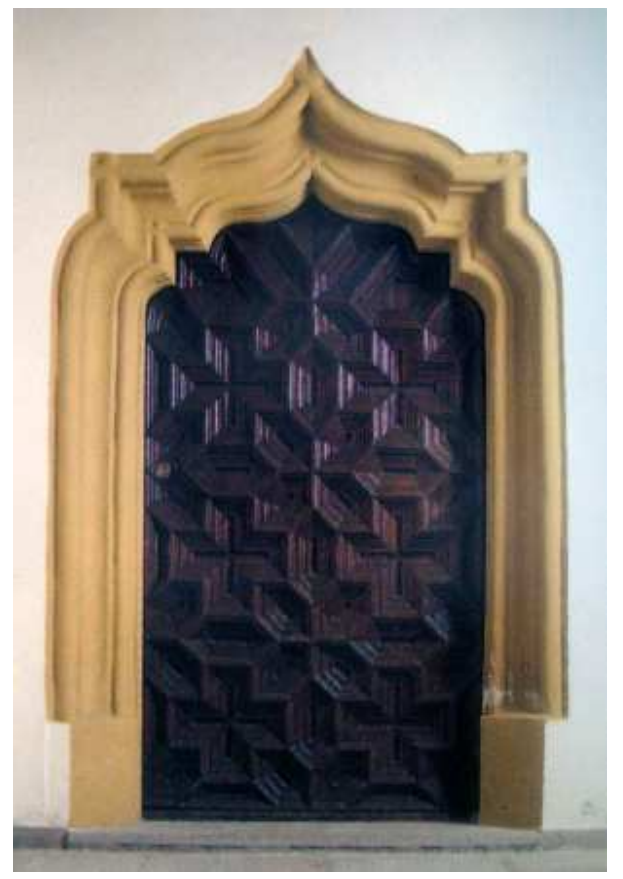

Figura 366. Portada interior. Palacio de los Almirantes de Aragón. Fotografía: Enrique Carrazoni. 
Capítulo 6.Las portadas 
CAPITULO VII

\section{DESARROLLO GRÁFICO}

\section{INTRODUCCIÓN}

El objetivo principal de este capítulo es desarrollar algunos de los elementos arquitectónicos del Palacio Condal de Oliva a partir de la documentación gráfica recuperada: planos, croquis y fotografías. Una vez ordenada y clasificada esta información se procederá a su análisis. Asimismo, nos apoyaremos en referencias bibliográficas históricas y en modelos físicos similares que nos ayuden a interpretar y definir dichos elementos desde un punto de vista formal y estilístico.

En los resultados de este trabajo se propone otro doble objetivo: por una lado, su difusión científica en medios especializados para su futuro estudio por parte de otros investigadores $y$, por otro, la difusión cultural de este monumento nacional, hoy desaparecido, a través de recreaciones virtuales. Además, se realizará una posterior elaboración de maquetas que permitan visualizar de manera efectiva ciertos elementos del edifico para poder ser entendidos por todo tipo de usuarios. Otro de los objetivos es permitir la adaptabilidad de ciertos elementos con el propósito de permitir a personas con diversidad funcional y falta de percepción visual disfrutar de este patrimonio a través del sentido del tacto. Asimismo, este trabajo puede servir como punto de partida para futuras investigaciones relacionadas con el edificio o con otros casos de estudio de características similares.

El trabajo tiene como punto de partida el material gráfico elaborado por los arquitectos daneses Fischer y Lauritzen, actualmente depositado en el Museo Arqueológico de Oliva: Planos, Notebooks y Álbumes de Fotografías (AFG y AFP). Una vez analizada la documentación gráfica existente de cada uno de los elementos arquitectónicos, se procede a la rectificación y escalado de sus planos y fotografías para poder dimensionar aquellos elementos no acotados en los planos, y proceder al grafiado de las piezas siguiendo la metodología ya utilizada en otros elementos arquitectónicos. Para la rectificación tanto de las fotografías como de las láminas se ha utilizado software de rectificación fotogramétrica. Una vez rectificadas las imágenes y planos, se han escalado en una herramienta CAD ayudándonos de las cotas de los planos y croquis originales. 


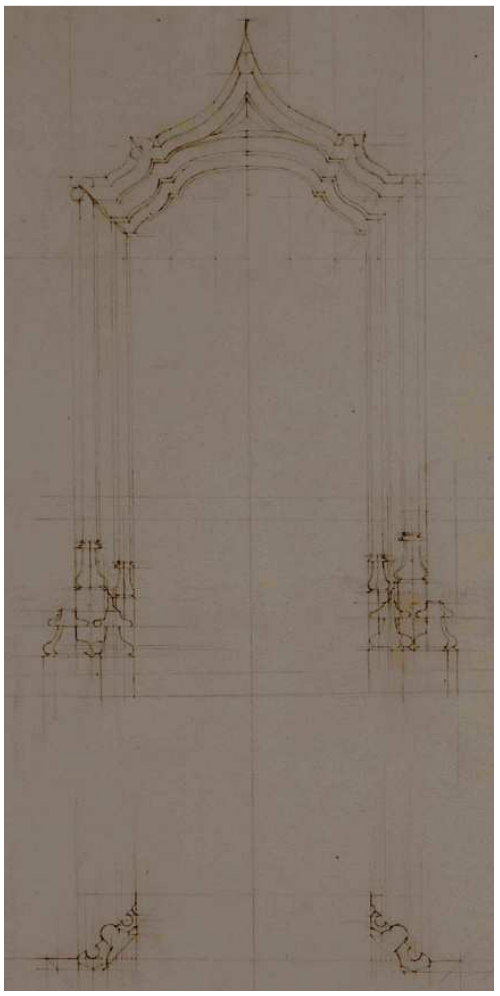

Figura 367. Lámina LA1139. Portada 12. Fischer y Lauritzen 1919-20.

\section{PLANOS 2D}

La mayor parte de los elementos restituidos gráficamente han sido portadas y ventanas, por lo que explicaremos el proceso para este tipo de elementos. En el caso de los forjados, al tratarse también de piezas donde predominan dos de las tres dimensiones, el proceso es idéntico. Sin embargo, en el caso de las bóvedas el proceso ha sido diferente por tratarse de piezas volumétricas.

A partir de la documentación de partida se realiza un proceso gráfico con el fin de obtener vistas de la pieza en proyección diédrica: alzado y sección horizontal, así como detalles de las los elementos singulares (basas), utilizando para ello una herramienta del entorno CAD.

En cuanto a la documentación de partida, nos encontramos con cuatro casos:

- Croquis.

- Croquis y fotografía.

- Lámina a escala.

- Lámina a escala y fotografía.

Además de estos casos en los que partimos de la documentación gráfica elaborada por Fischer y Lauritzen, contamos con la ventana de la calle Palau número 7. En este caso no disponemos de documentación previa, aunque sí del elemento físico. 
En adelante explicaremos el proceso utilizado para cada uno de los casos.

\subsection{Croquis}

Este caso lo encontramos en algunas de las portadas del grupo 1 a 9, las cuales fueron representadas en el cuaderno de notas ${ }^{476}$, y de las que no disponemos de fotografías. En este grupo estarían las portadas D1, D2 y D9.

En el caso de estas tres portadas el proceso seguido ha sido dibujar el alzado y la sección según las cotas generales que aparecen en el croquis. La sección de la jamba se ha dibujado a partir de las distintas molduras y proporción de las mismas de acuerdo con el croquis y basándonos en los criterios de alineación de las molduras obtenidos de otras portadas de las que disponíamos de más información. En el caso de las D1 y D2 sólo se ha representado el alzado y la sección de las jambas; en el caso de la D9, además se ha dibujado una hipótesis de sus basas a partir de información obtenida de otras portadas de características similares.

\subsection{Croquis y fotografía}

Cuando disponíamos de una fotografía frontal además del croquis acotado, esto nos aportaba una información fundamental que nos permitió una restitución de la pieza con una mayor precisión. Este caso se presenta en las portadas D3 a D8. Se explicará el proceso basándonos en la restitución de la portada D5.

\section{Fotografía rectificada del alzado}

Para el levantamiento del alzado en primer lugar establecemos una retícula con las cotas generales obtenidas del croquis del Notebook II. Posteriormente, rectificamos la fotografía $72^{477}$ mediante el programa de rectificación fotogramétrica ASRix. Para ello, nos apoyaremos en las cotas del croquis y en la medida de la vara de medir que aparece acotada en la fotografía. La primera operación consiste en realizar un primer ajuste de la fotografía utilizando el software PTlens. La función de este software será eliminar el efecto "barrilete" de la imagen e incorporar los parámetros de la cámara fotográfica (en este caso de la cámara con la que se ha digitalizado la imagen analógica antigua), para que el software ASRix los reconozca y permita realizar el proceso de rectificación.

Una vez tratada la imagen con el primer software, determinamos que las imágenes se han digitalizado empleando una cámara con las siguientes características: marca Nikon SRL, modelo D200, objetivo 18-135 mm f/3.5-5.66 IF-ED AF-S DX, longitud focal 44.000.

\footnotetext{
${ }^{476}$ Fischer, E. (1917-1920.). Notebook II. Óp. cit. pp. 11A-22A.

${ }^{477}$ Fischer, E. (1917-1920). Álbum Fotos Grande. Óp. cit. pp. 16A.
} 
A continuación se ha rectificado la fotografía sobre el contorno interior de la portada utilizando los siguientes puntos:

- Origen (O 01): intersección de la jamba derecha con el plano del pavimento. Coordenadas: $(x=0, y=0)$.

- Horizontal (H 02): intersección de la jamba izquierda con el pavimento. coordenadas: $(x=0, y=1,29)$.

- Vertical (V 03): punto en la vertical de 001 situado a una altura de 1,00 m. (dicha altura se ha proporcionado sobre la fotografía utilizando la referencia de la vara de medir que aparece en la fotografía acotada en 1,00 m. Coordenadas: $(x=0, y=1,0)$.

- Neutro (04): punto en la vertical de V 02 situado a una altura de 1,00 m. (dicha altura se ha proporcionado sobre la fotografía siguiendo la misma metodología utilizada en V 03. Coordenadas: $(x=1,29, y=1,0)$.

El resultado conseguido es una imagen rectificada en el plano del intradós de la portada.

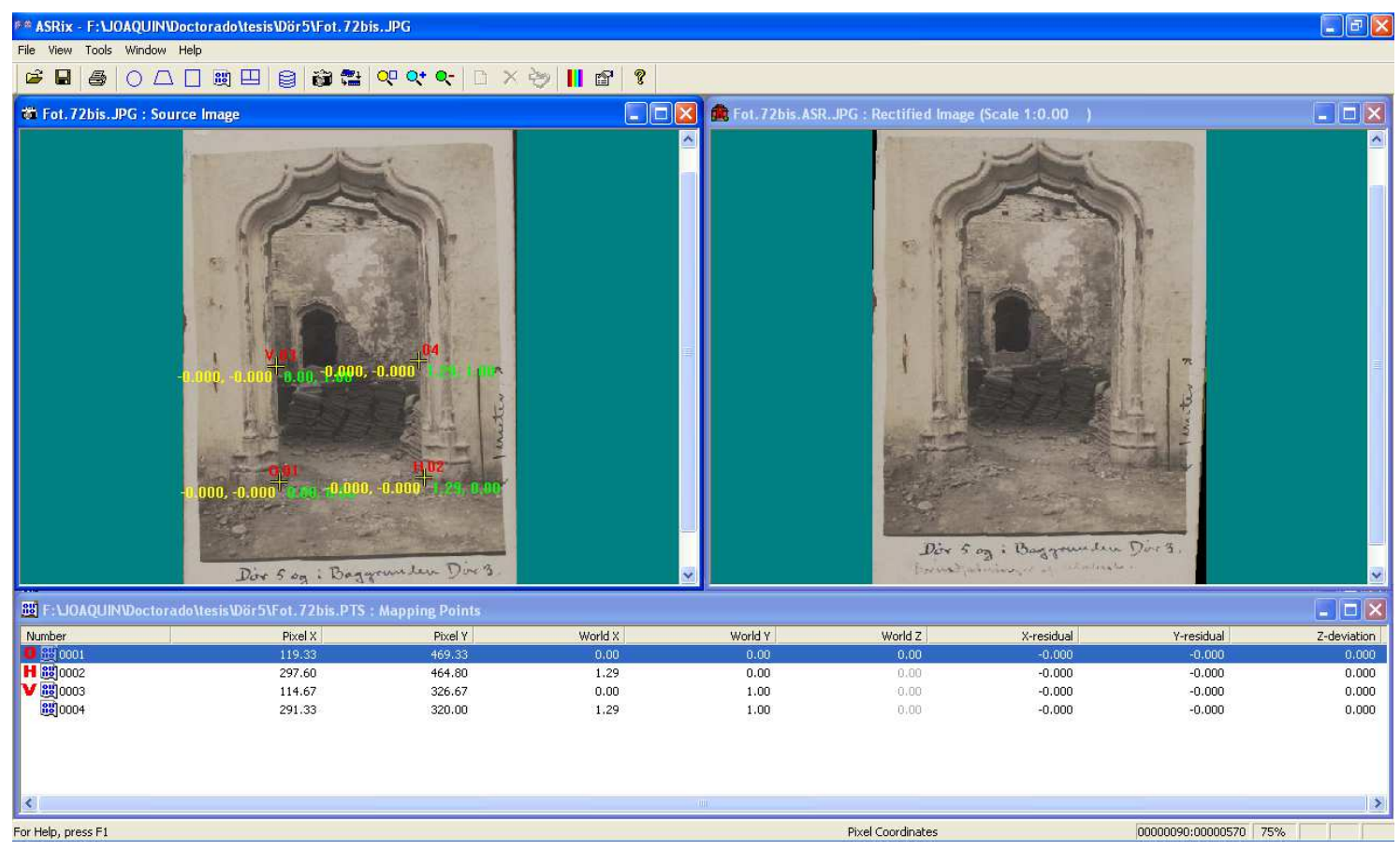

Figura 368. Proceso de rectificación de la fotografía 72 mediante herramienta ASRix: a la izquierda fotografía sin rectificar con los cuatro puntos utilizados para la rectificación. A la derecha fotografía rectificada.

Posteriormente, trataremos esta fotografía rectificada con la herramienta Photoshop con la finalidad de aumentar el contraste de la misma y poder visualizar mejor las distintas aristas. Después insertaremos esta imagen en nuestro archivo CAD y escalaremos dicha fotografía mediante las cotas generales obtenidas del croquis del Notebook $1 I^{478}$.

${ }^{478}$ Fischer, E. (1917-1920.). Notebook II. Oliva, Valencia: Museo Municipal de Oliva, Archivo Público Documental, Palacio Condal. pp. 21A. 
Dada la escasa profundidad de los elementos, y puesto que la fotografía es suficientemente frontal despreciaremos el error de medida entre los distintos planos que conforman la portada y mediremos directamente sobre la imagen escalada, como si de una proyección vertical se tratase.

\section{Los trazados del alzado}

Sobre esta imagen rectificada dibujaremos el alzado del arco buscando tanto las líneas rectas que conforman las jambas como los distintos trazados de circunferencia que forman la geometría del arco (la jamba derecha contiene información sobre el eje de la basa y otras medidas que pueden añadir información). La definición de los trazados proporciona una información muy valiosa para establecer los parámetros estilísticos y cronológicos de su arquitectura.

A partir de estas líneas auxiliares obtenidas y de la retícula de cotas generales del Notebook Il trazaremos la proyección vertical de las jambas y el alzado de la portada. El procedimiento anterior es suficientemente aproximado en todo el alzado salvo en el zócalo inferior. Las molduras de las basas no se proyectan en su verdadera magnitud, por lo que para definir su geometría, es mejor seguir otros procedimientos a partir del conocimiento de sus trazados y leyes reguladoras del estilo gótico.

\section{Las molduras: sección de la jamba}

Para el trazado de la sección horizontal de la jamba partimos del croquis de la misma que tenemos dibujado en la página $21 \mathrm{~A}$ del Notebook II. Sobre dicho croquis se realiza una primera lectura a partir del conocimiento de los trazados góticos y de la geometría de las molduras. Superpondremos las líneas rectas o las de arco de circunferencia buscando los centros y radios que se ajustan a la geometría del croquis. En la sección de las molduras no se detalla las cotas individualizadas de cada una de ellas; sólo disponemos de sus cotas generales: ancho $28 \mathrm{~cm}$. y profundidad $27 \mathrm{~cm}$., por lo que a partir de ellas escalamos la plantilla que hemos conseguido redibujando sobre el croquis, obteniendo así una aproximación a su geometría real.

Al no tener la certeza de que el croquis esté bien proporcionado, puesto que se trata de una toma de datos cuya intención tan sólo es definir las formas, procederemos a proporcionar las distintas aristas de la jamba en su cara frontal, apoyándonos en las líneas auxiliares que aparecen en la fotografía rectificada y escalada (ver Fig. 369 izquierda). Estas líneas auxiliares son las líneas de la capa azul oscuro de la Fig. 369 derecha que nos permiten modular los elementos de la jamba en sentido horizontal. 


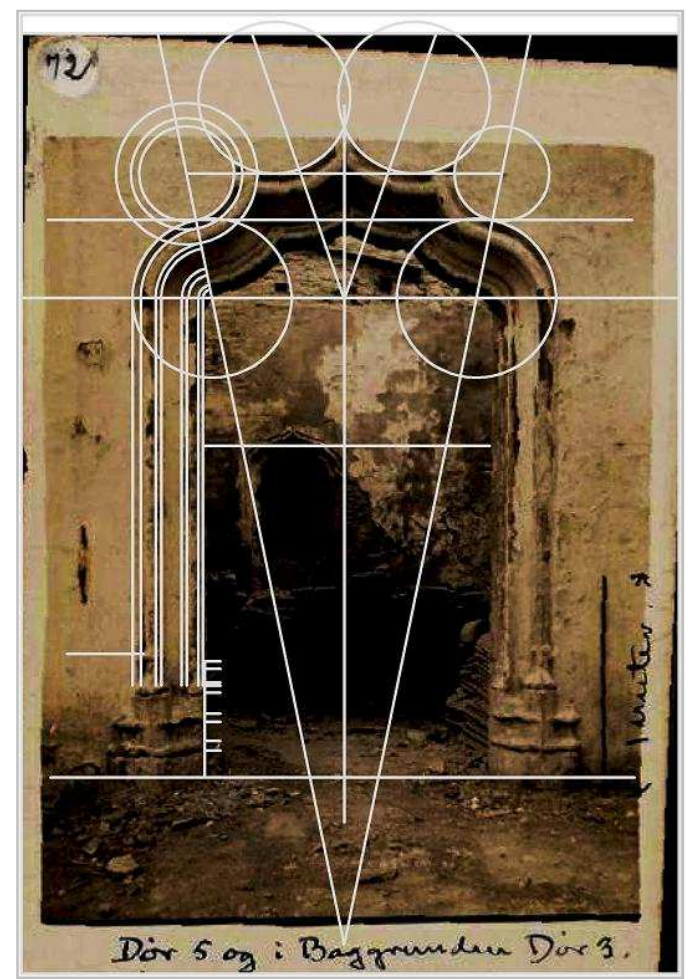

Figura 369. Izquierda: Trazados arcos, proyección de molduras y alturas de basa a partir de la ortofoto. Derecha: trazado de la basa de la Portada 5 con líneas auxiliares: alzado frontal y sección horizontal.

En el sentido transversal nos basaremos en la cota general, las proporciones del croquis, así como en la existencia de un trazado ideal en el que los tres círculos principales (columna grande, columna pequeña y moldura cóncava) se encuentran alineados por sus centros.

\section{Las basas. Planta y alzados}

La falta de detalle en la documentación sobre el zócalo inferior de la Portada 5 aconseja apoyarse en la información existente de otras portadas similares para llevar a cabo su restitución. De este modo, para definir la planta de la basa, partimos de la sección de la jamba, y ayudándonos de la fotografía, dibujamos la sección horizontal a nivel del pavimento, formada por un octógono irregular. Posteriormente, dibujamos la base de planta octogonal de las dos columnillas, basándonos en la geometría de otras portadas de idéntica tipología de basa y de las cuales disponemos de planos escalados (p. ej. D12, D15 y D18). Asimismo, teniendo en cuenta la fotografía rectificada y escalada (Fig. 369 izq.), se han dibujado las líneas horizontales que conforman las alturas de la base principal (líneas auxiliares horizontales capa azul marino Fig. 369 dcha.), así como las bases prismáticas y molduras curvas del arranque de las dos columnas que arrancan de cada una de las bases. 
Por otra parte, para el trazado de las curvas que conforman la sección vertical de la basa nos guiaremos por los trazados obtenidos de un detalle de la lámina LA $1135^{479}$ de Fischer/Lauritzen que, a pesar de tratarse de la moldura de la base de las pilastras de la Galería de la Torre Grande, tiene un perfil idéntico al de las basas de las columnillas (ver Fig. 370). En este caso se debe tener en cuenta que hay que abatir las secciones en verdadera magnitud y volverlas a abatir para cada una de las aristas que conforman según el ángulo de las mismas.

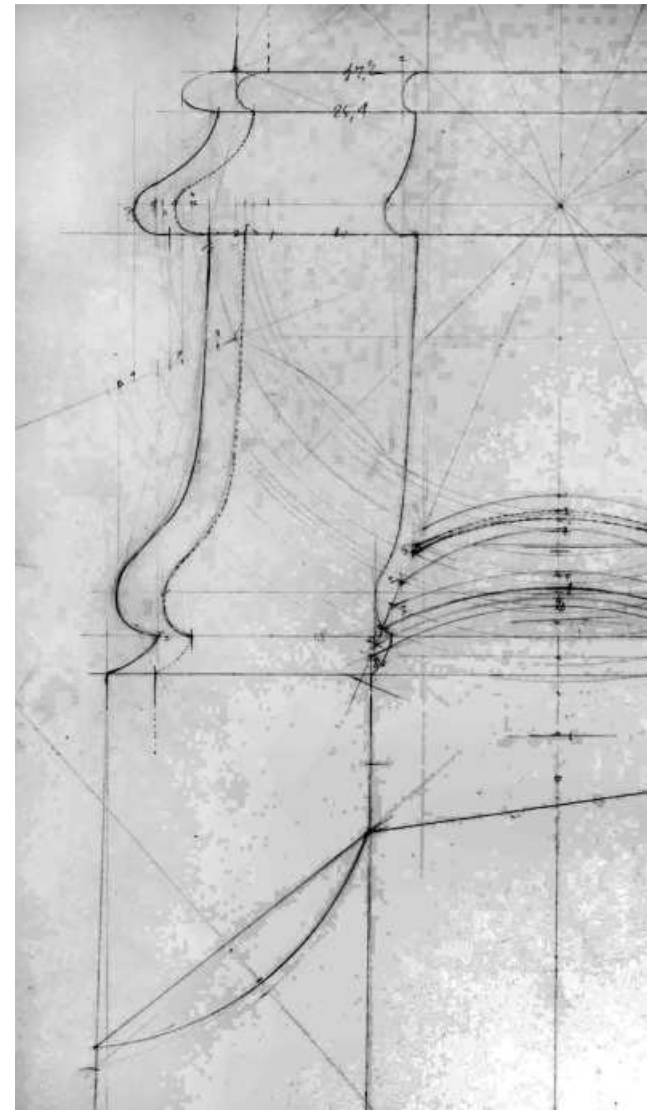

Figura 370. Detalle molduras verticales pilastra Galería Torre Grande. LA1135 E. Fischer y/o V. Lauritzen.

Una vez finalizado todo el proceso, obtenemos las vistas de la portada en proyección diédrica y se procede a elaborar una presentación que contenga toda la información necesaria, pudiéndose medir y acotar cada uno de sus elementos, tanto en planta como en altura. El resultado final es la presentación que se muestra en la Fig. 371.

${ }^{479}$ Fischer, E. y/o Lauritzen V. (1919-1920). Planos. Óp. cit. pp. LA1135. 

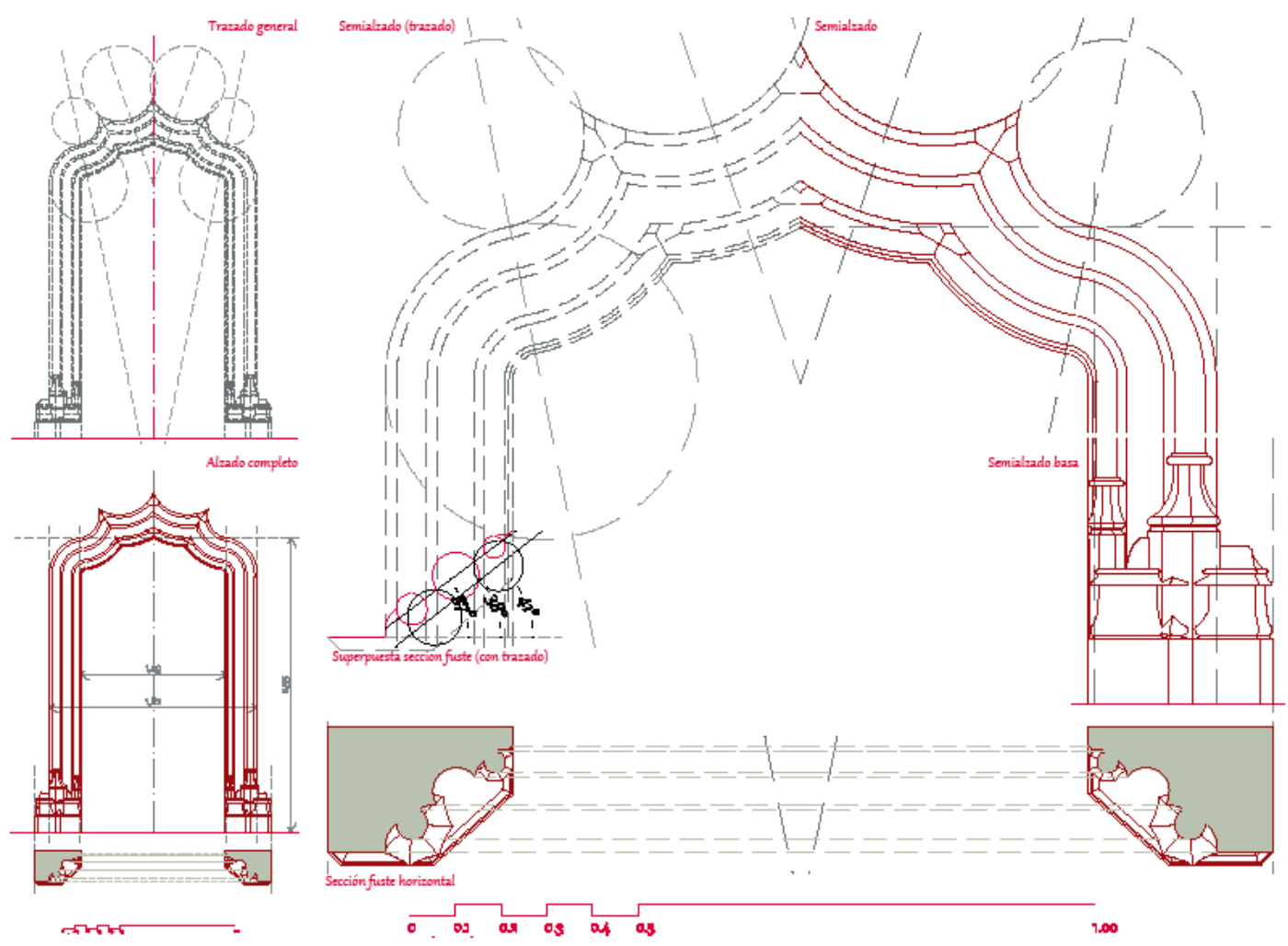

Figura 371.Lámina de presentación de la Portada 5 (Dör 5): alzado, sección horizontal y trazados de jamba y arco.

Este mismo proceso se ha seguido para las portadas $4,5,6$ y $8^{480}$. La portada 3 no se ha restituido ya que, debido a su pésimo estado de conservación, sólo existe la parte superior del arco y no se dispone de la sección de las molduras. Por su parte, la portada 7 no se ha restituido por ser la única totalmente renacentista y no disponer de la suficiente información. Su modulación se ha realizado a partir de su fotografía rectificada.

\subsection{Lámina a escala}

Este es el caso de las portadas D16, D17, D19, D21, D25, LA1136, LA1176, LA1177, LA1191 y LA1192 y de las ventanas V5, V6, V7, V8 y V9. En cuanto a las portadas, se trata en su mayoría de portadas sencillas de arco escarzano.

${ }^{480}$ Este proceso de restitución gráfica a partir de un croquis y una fotografía ha sido publicado por el autor en: Martínez Moya, J. A., Soler Estrela, A. (2014). Metodología de recuperación gráfica de las portadas de Palacio Condal de Oliva. Revista de Expresión Gráfica de la Edificación. Núm. 8. pp. 4351. 
En cuanto a las láminas, nos encontramos con dos casos: aquellas que disponen de cotas y las que carecen de las mismas; en ambos casos se trata de planos a escala 1:10; esto se ha comprobado en las láminas acotadas y también a través del plano de planta del edificio LA1109. En adelante describiremos el proceso de restitución llevado a cabo.

Dado que las láminas han sido digitalizadas mediante captura fotográfica, la primera operación ha consistido en rectificar la fotografía. El proceso es idéntico al expuesto para el caso de las imágenes de las portadas, utilizando cuatro puntos del elemento, definidos mediante cotas, o a través de las esquinas de la lámina en el caso de no estar acotado dicho elemento. Una vez rectificada la imagen, se inserta en una herramienta CAD, procediéndose a su escalado y orientando la verticalidad de la lámina a través de su eje principal (eje de simetría).A partir de ahí se procede a redibujar la portada en la herramienta CAD buscando la correspondencia diédrica de las vistas. Los vacíos de información se completan a partir de la información obtenida de otras portadas o ventanas de características similares. De este grupo no se ha realizado la restitución de las portadas LA1191 y LA1192 ya que sólo se dispone de información de los trazados de los arcos (escarzanos) y del contorno de la basa y de las ventanas V6 y V9 porque éstas se encontraban incompletas (carecen de arco).

El resultado final es la obtención de unas vistas ortogonales de las piezas en proyección vertical y sección horizontal.

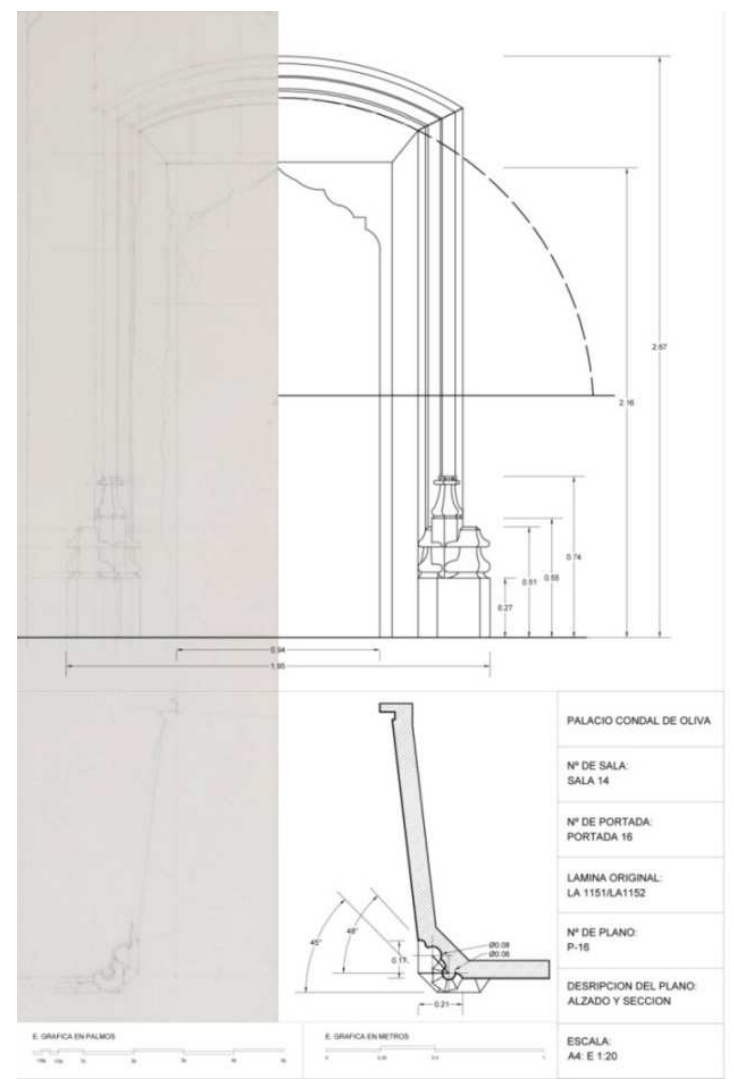

Figura 372. Lámina de presentación de la Portada 16 (Dör 16): alzado y sección horizontal. 


\subsection{Lámina a escala y fotografía}

Este es el caso más generalizado, el de las portadas D10 a D15, D18, D20, D22 a D24 y D26 a D28, así como el de las ventanas V3, V4, V6, V7 y V10. El proceso es idéntico al anterior en cuanto al tratamiento de las láminas. En este caso las fotografías complementan los vacíos de información, fundamentalmente en el caso de las basas y portadas que, en el caso de algunas láminas, no se encuentran detalladas, para lo que se realiza la rectificación de la fotografía con las cotas o medidas tomadas de las láminas a escala.

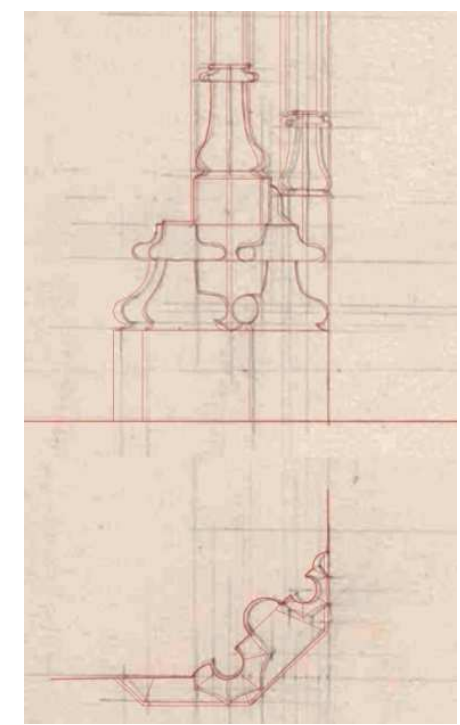

Figura 373.Detalle basa portada 12, alzado frontal y sección. Trazado sobre lámina original LA1139.

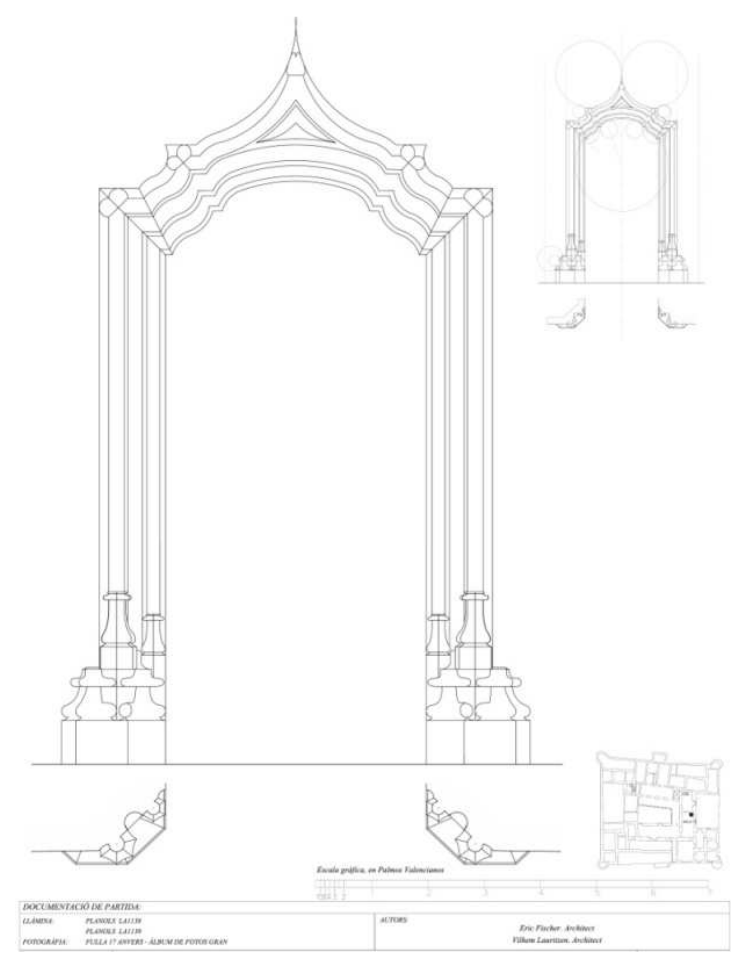

Figura 374.Presentación portada 12, alzado frontal y sección horizontal. 


\section{Artesonado Sala 12}

Este mismo proceso se ha seguido para llevar a cabo la restitución del artesonado de la Sala 12. Así, en la lámina $L A 1114^{481}$ se representa una planta cenital del artesonado, enumerándose perfectamente cada una de las piezas que componen los casetones mediante un código formado por un número, una letra y un número romano. Por su parte, las vigas diagonales están numeradas mediante un número romano y las molduras perimetrales mediante un número de tres cifras.

En la LA1116 ${ }^{482}$ se representa la planta cenital y sección longitudinal a escala de la sala donde se detalla perfectamente el artesonado. Se grafían asimismo unos pequeños rosetones que aparecen en los cruces de los nervios del artesonado; al igual que en la LA1114 se representa una franja sin casetones.

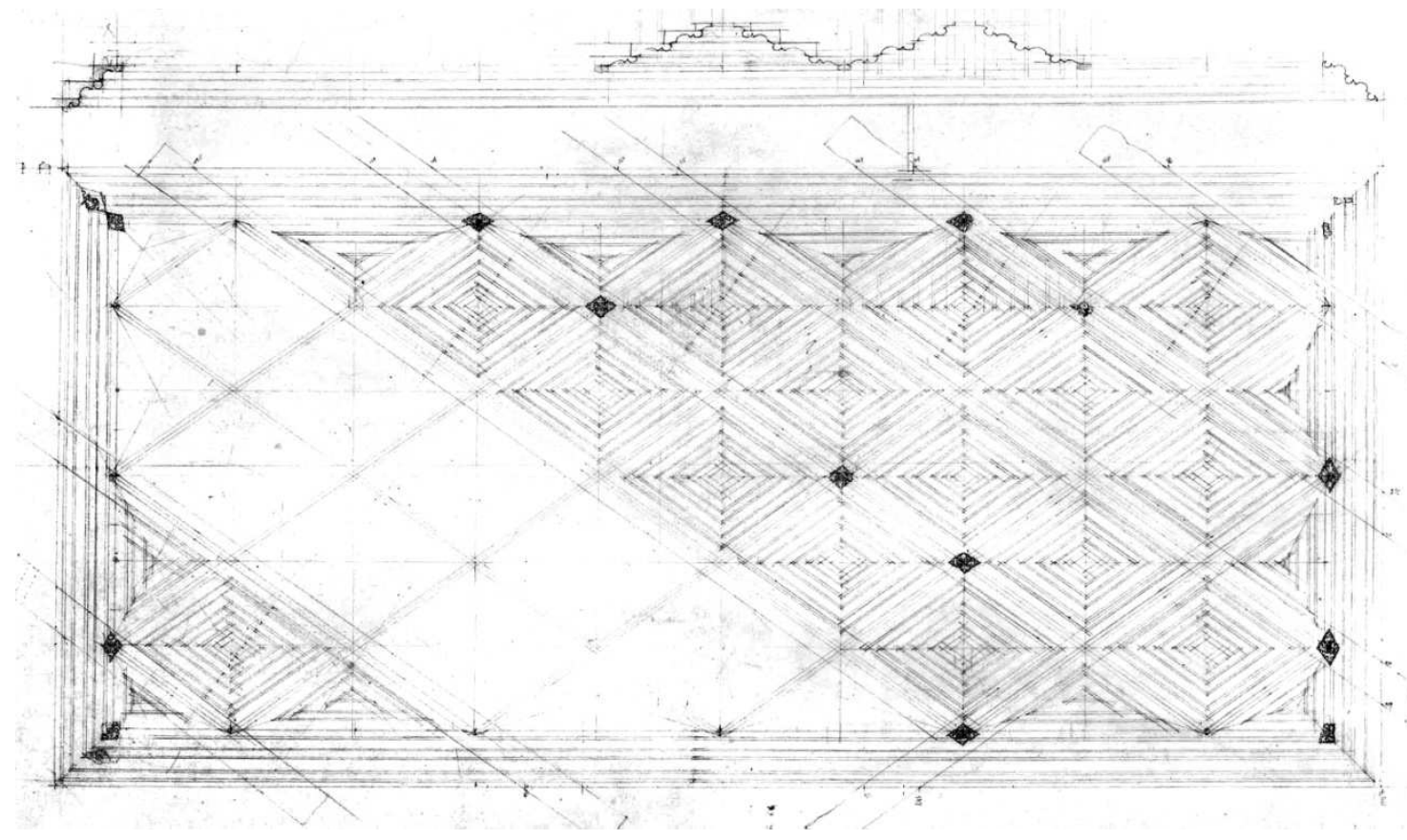

Figura 375. LA116. Planta y sección del artesonado. Fischer y Lauritzen 1919-20.

Se dispone asimismo de la fotografía $48^{483}$, aunque en este caso no aporta información adicional, ya que en las láminas el elemento se encuentra perfectamente definido.

\footnotetext{
${ }^{481}$ Fischer, E. y/o Lauritzen V. (1919-1920). Planos. Óp. cit. pp. LA1114.

${ }^{482}$ Fischer, E. y/o Lauritzen V. (1919-1920). Planos. Óp. cit. pp. LA1116.

${ }^{483}$ Fischer, E. (1917-1920). AFG. Óp. cit. pp. 12A
} 


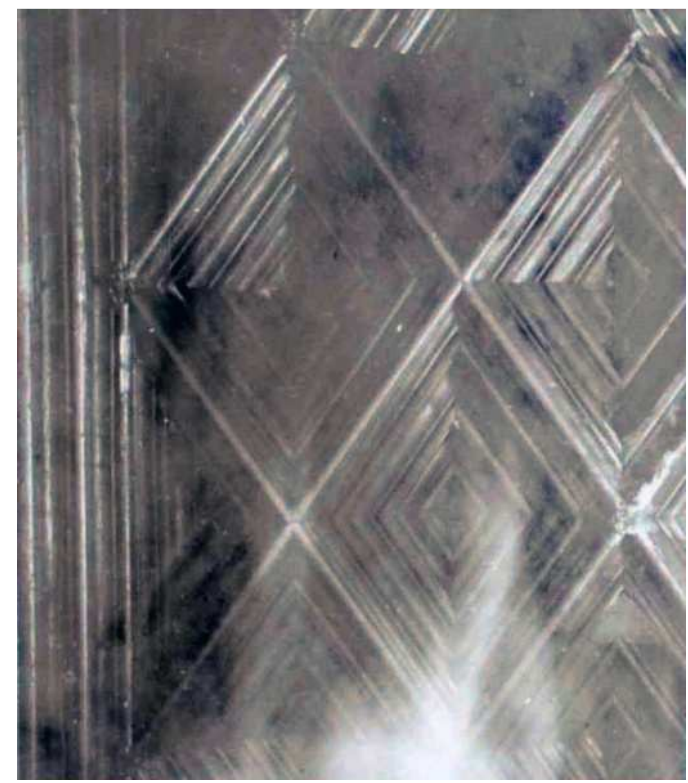

Figura 376. Fot. 48. Vista cenital artesonado Sala 12.

A partir de la documentación gráfica de partida se han elaborado las vistas ortogonales en la herramienta CAD que nos permite tener perfectamente definido el elemento arquitectónico.

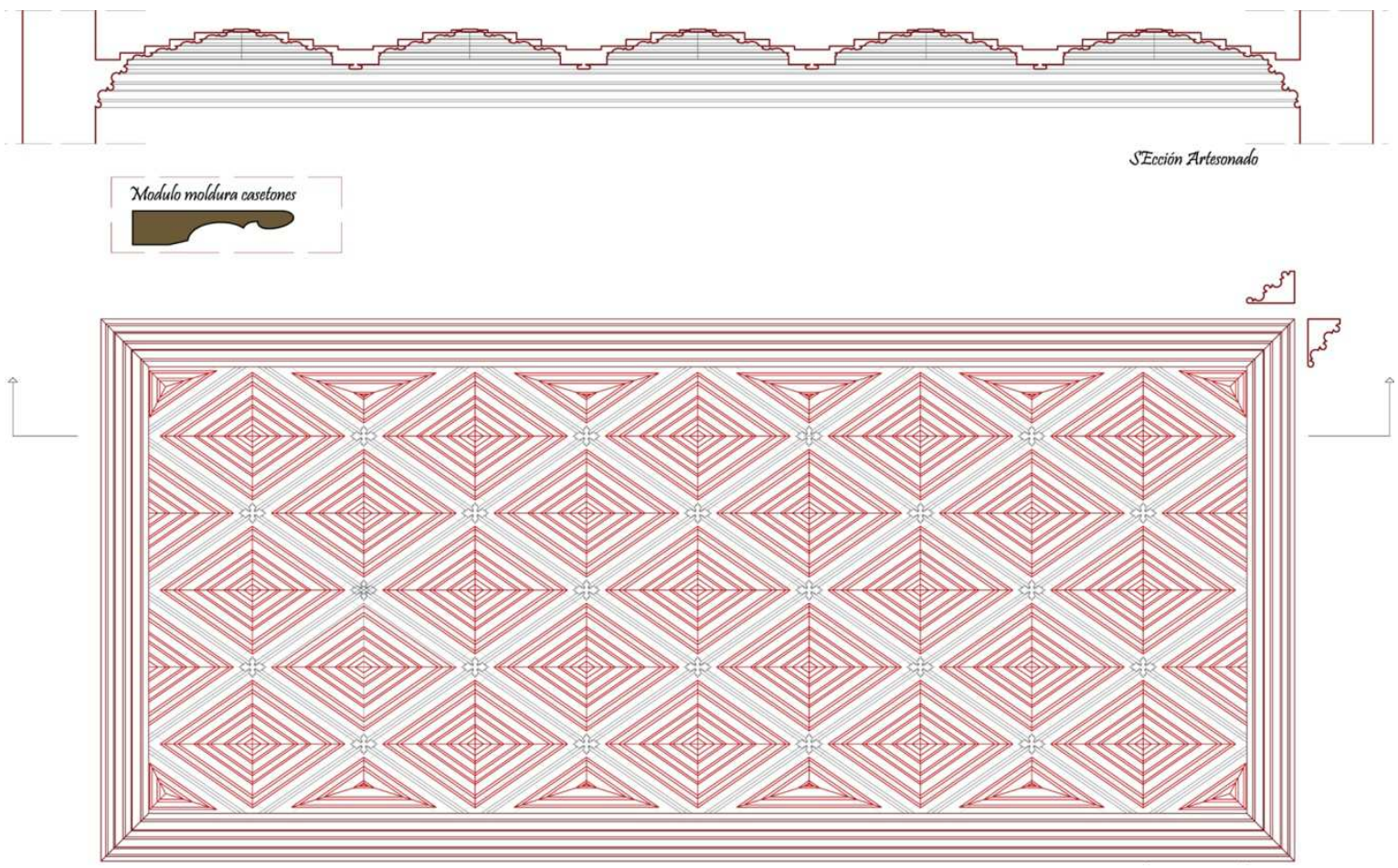

Figura 377. Artesonado Sala 12. Planta cenital y sección longitudinal. 


\subsection{Ventana calle Palau no 7}

Se trata de una ventana de arco escarzano y jamba formada por dos columnillas y baqueta central similar a las ventanas V3 a V10, aunque de menor dimensión. Está ejecutada en yeso como las anteriores. Su levantamiento se ha realizado utilizando tanto técnicas de fotogrametría como mediante escaneo 3D.

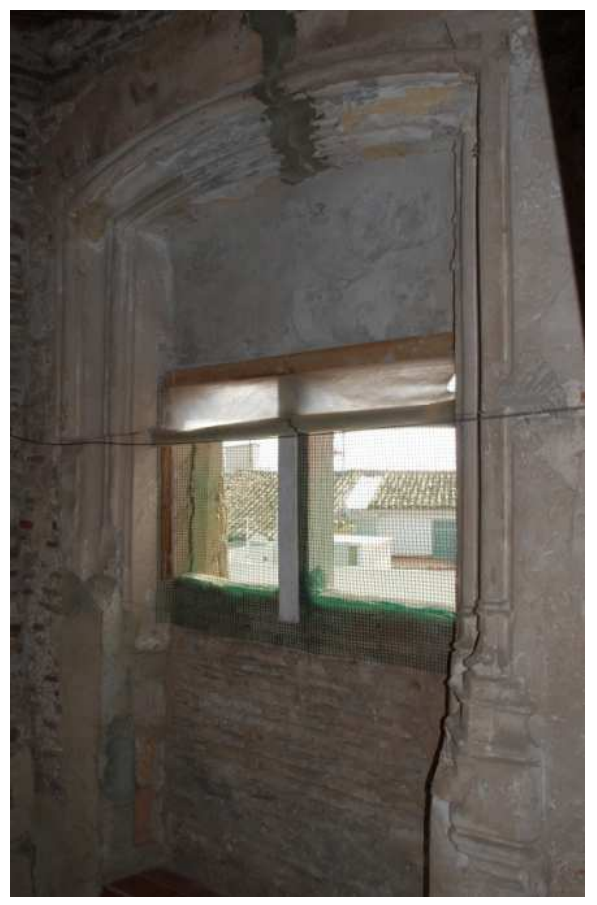

Figura 378.Ventana calle Palau no 7. Vista general y detalle de jamba derecha.

Se ha realizado un levantamiento fotogramétrico mediante la técnica de structure from motion $^{484}$. A partir de este levantamiento se han realizado una serie de Ortofotos, tanto frontales como de secciones horizontales y verticales, que nos han servido de base para realizar la restitución gráfica del elemento en su estado original. A partir de la sección horizontal de las basas se ha comprobado que éstas son de planta heptagonal y que el ángulo que forman las dos columnillas con el lienzo de la pared es de $45^{\circ}$. El ángulo de la basa respecto al muro es de $52^{\circ}$.

${ }^{484}$ Amoruso, G. (01-12-16). Gli strumenti geometrici, proiettivi e visuali per il progetto, nell'era del digitale. En: XIII Congreso Internacional de Expresión Gráfica aplicada a la Edificación, APEGA 2016. pp. 21-42. Valencia, España. y Amoruso, G., Sdegno, A. y Riavis, V. (01-12-16). Ricostruzione virtuale di uno spazio illusorio. La prospettiva solida di Giovanni Maria da Bitonto a Bologna. En: XIII Congreso Internacional de Expresión Gráfica aplicada a la Edificación, APEGA 2016. pp. 453-466. Valencia, España. 

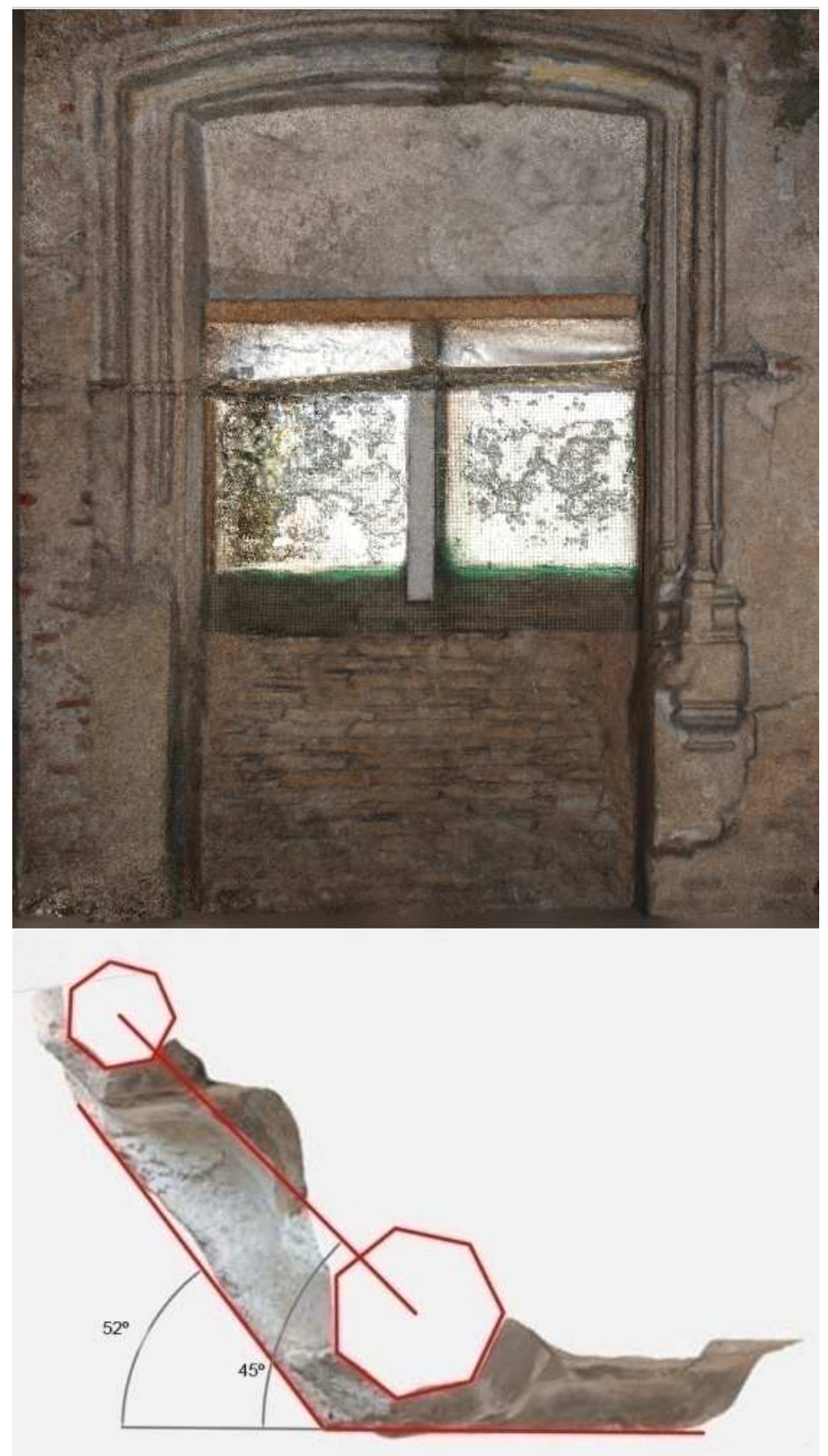

Figura 379.Ortofotos ventana calle Palau no 7. Superior: vista frontal. Inferior: sección horizontal. Trazado de basas de columnillas y ángulos de jamba y basa.

Mediante la nube de puntos obtenida a partir del escaneo tridimensional se han obtenido una serie de medidas que nos han permitido escalar las imágenes conseguidas para poder restituir el elemento: la ventana tiene una anchura total en su intradós de $141,7 \mathrm{~cm}$; el diámetro de la columnilla grande es de $6,5 \mathrm{~cm}$; el de la columnilla pequeña, $4,6 \mathrm{~cm}$; y la cuerda del caveto central $9,2 \mathrm{~cm}$. 


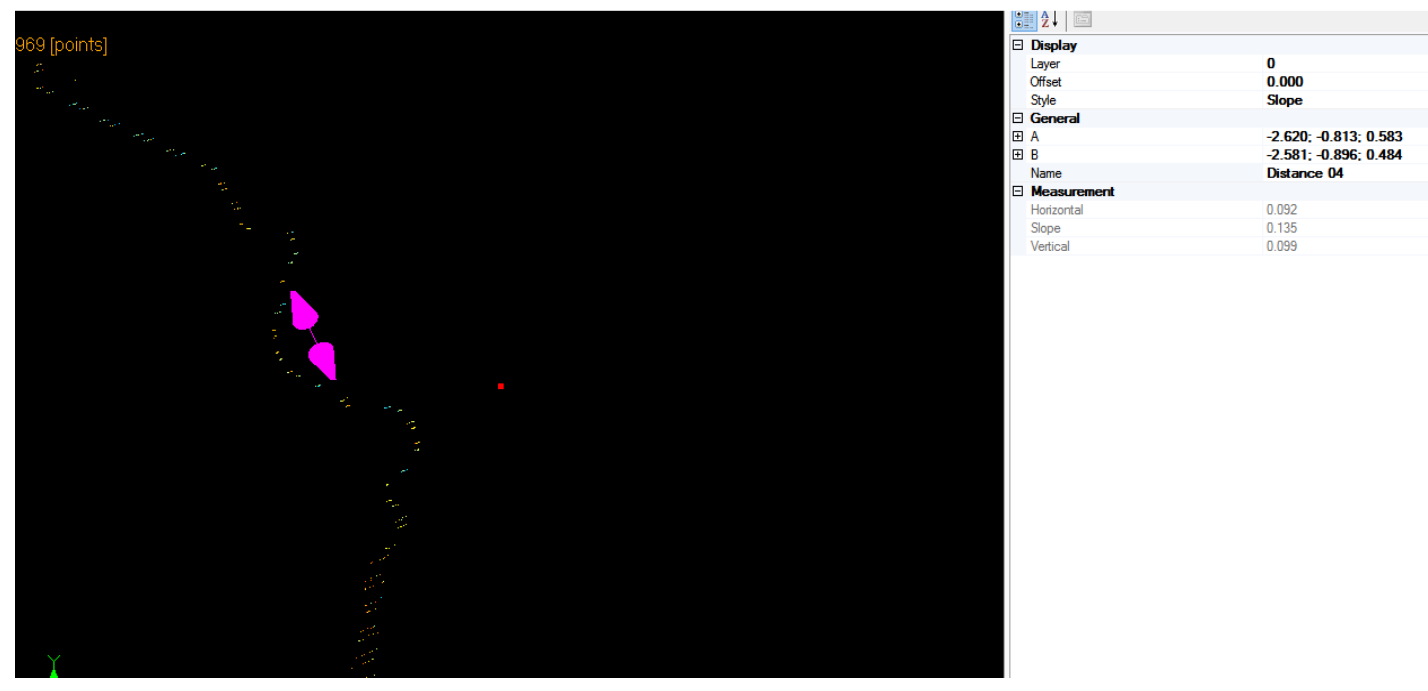

Figura 380.Nube de puntos Ventana calle Palau no 7, sección horizontal. Cota del caveto central $(9,2 \mathrm{~cm})$.

A partir de todos estos datos se han elaborado las vistas ortogonales de la ventana de las que podemos obtener toda la información métrica y geométrica.

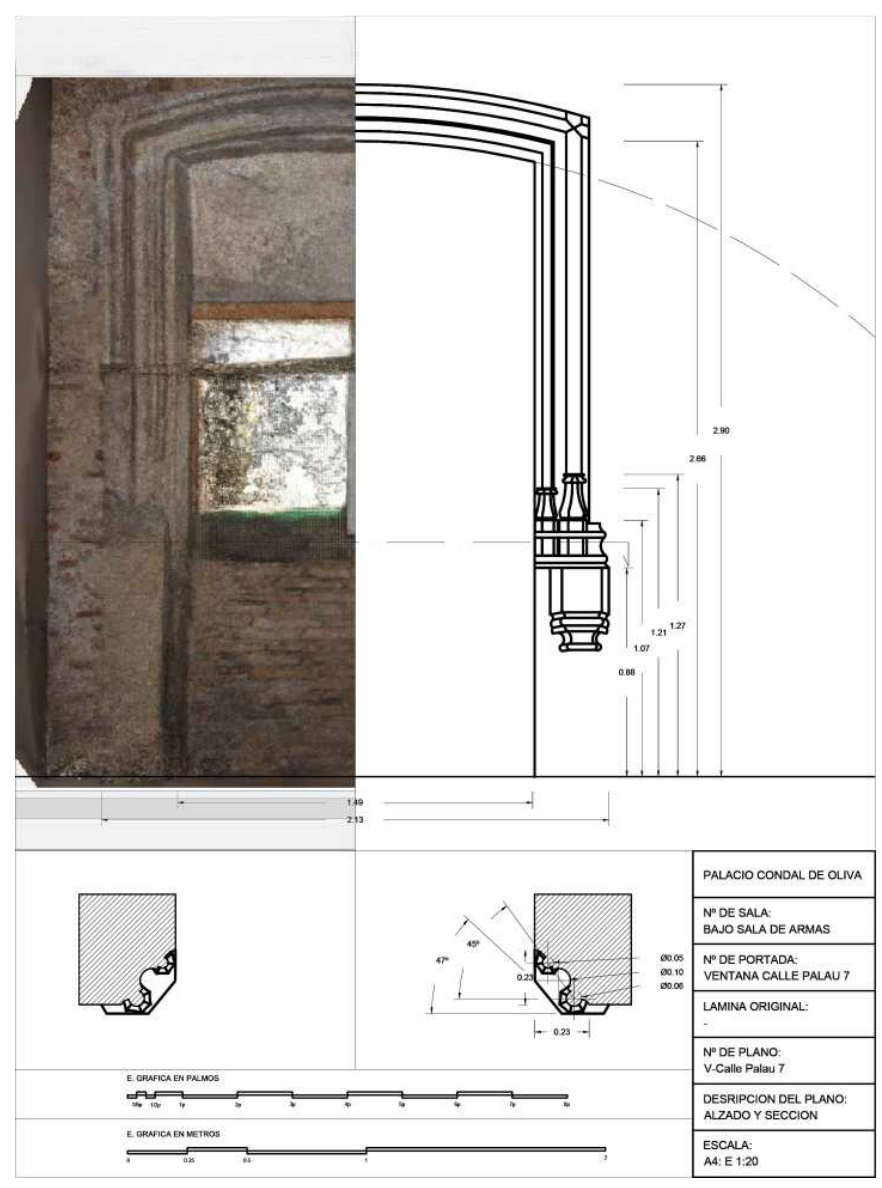

Figura 381.Presentación ventana calle Palau no 7. Alzado y sección horizontal. 


\section{PIEZAS en 3D}

Dada la complejidad geométrica de las piezas y con el objetivo de poderlas definir perfectamente se ha procedido al modelado tridimensional de algunas de ellas. Este trabajo se ha realizado gracias a una herramienta $C A D$, partiendo de las vistas ortogonales de las piezas mediante la extrusión y revolución de los distintos elementos y molduras que forman la pieza de manera individual, y su posterior unión e intersección, obteniendo el sólido común. Se trata de un proceso complejo debido a la gran cantidad de elementos que forman cada una de las piezas.
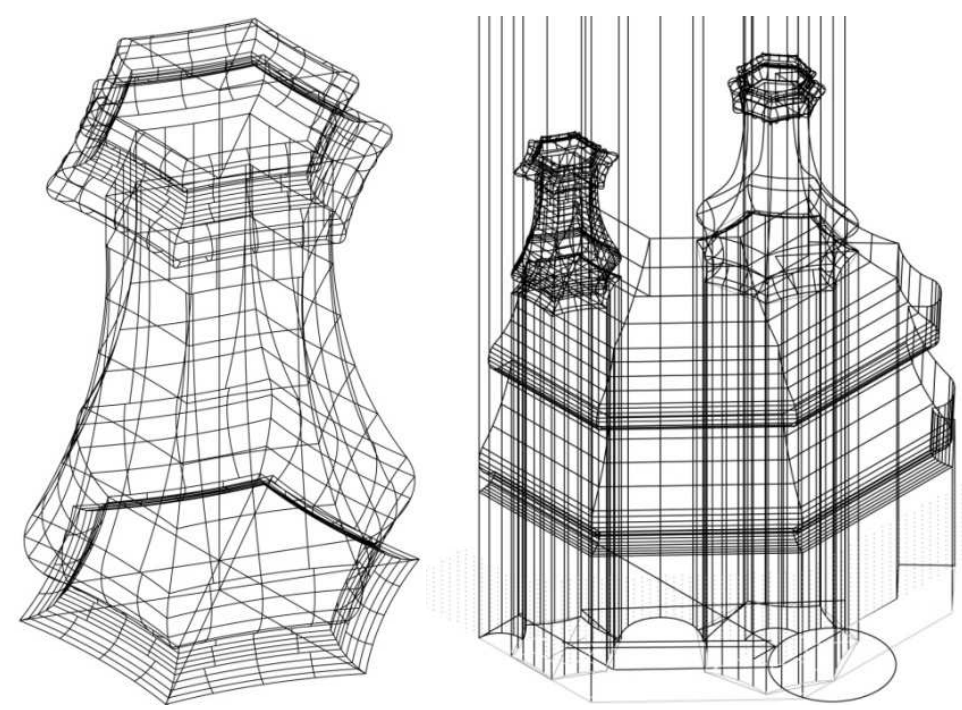

Figura 382.Estructura alámbrica 3D. Modelado Portada 12. Izquierda: Detalle basa columnilla pequeña. Derecha: basa derecha.

Una vez obtenido el modelo 3D se consigue una superficie del conjunto al que se le aplica una textura para su posterior renderizado.

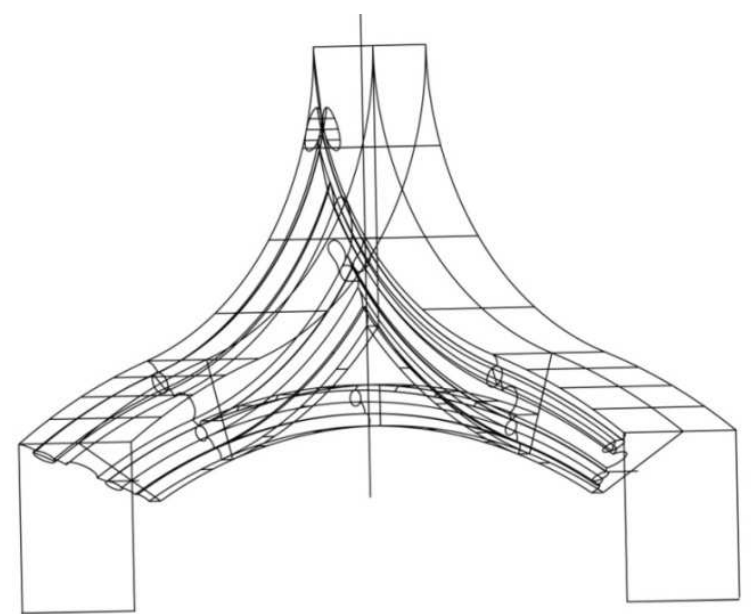

Figura 383.Estructura alámbrica 3D. Modelado arco Portada 28. 


\subsection{Portadas}

Este proceso se ha llevado a cabo en las portadas D12, D13 y D28, pertenecientes todas ellas a la Sala 12 del Palacio, también denominada "Sala de los Linajes".

\section{Portada 12}

La Portada 12 está compuesta por un arco mixtilíneo carpanel en su intradós que se transforma en arco mixtilíneo variación del flamígero en su trasdós. En este caso la moldura convexa (caveto central) no sigue un trazado regular cuando forma al arco, transformándose su diámetro a lo largo de su trazado, lo que ha supuesto una dificultad añadida, y pudiéndose definir gracias a su trazado en 3D. La transformación de la parte central del arco de carpanel a conopial es, junto con la basa, la parte más compleja de modelar tridimensionalmente.

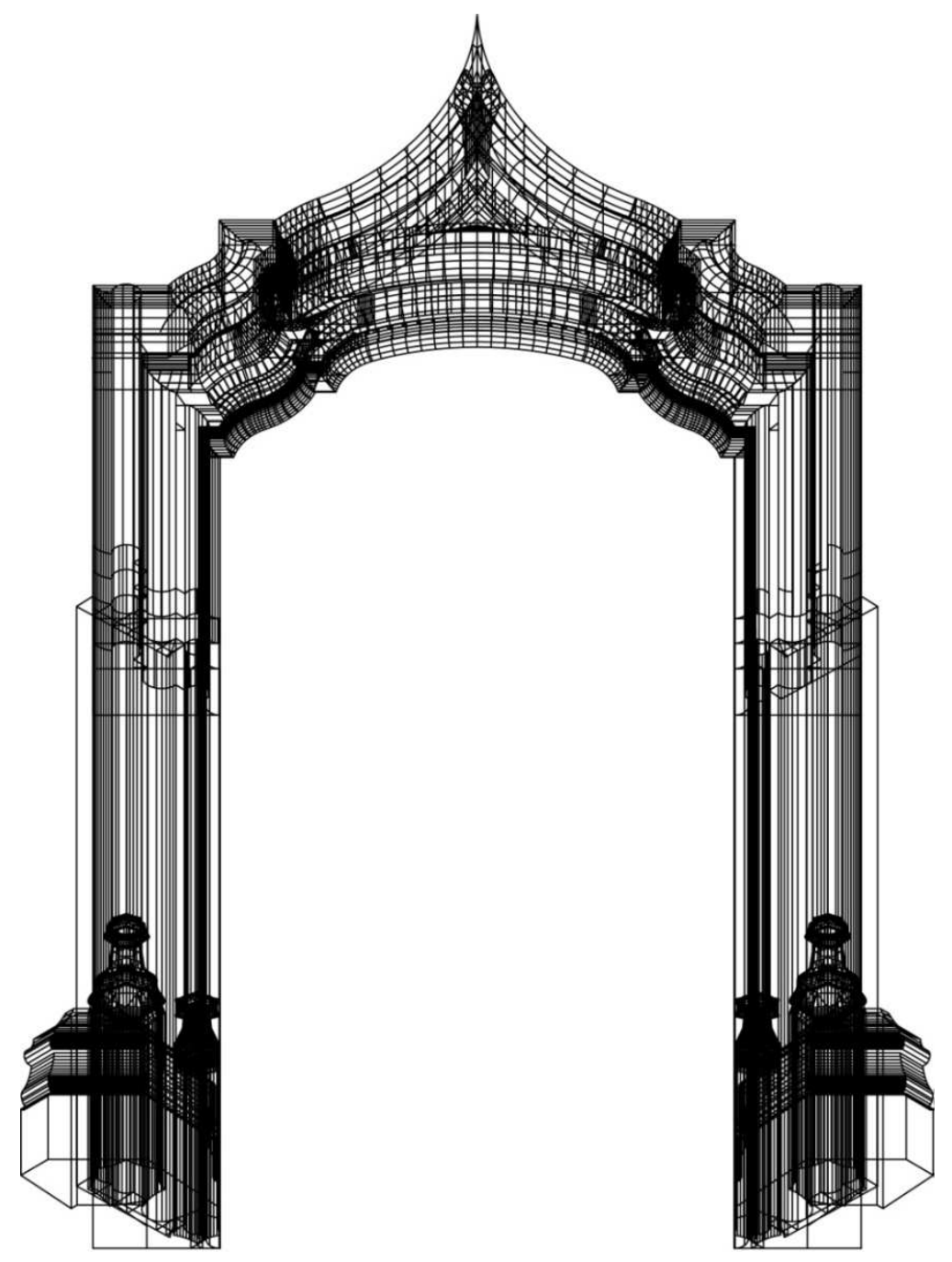

Figura 384.Portada 12.Estructura alámbrica 3D. 
Se ha elaborado una nueva lámina de presentación de la Portada 12 incorporando las vistas ortogonales tanto de la restitución 2D, como de la 3D, para mejorar la visualización y comprensión de la pieza, así como un render de la misma.
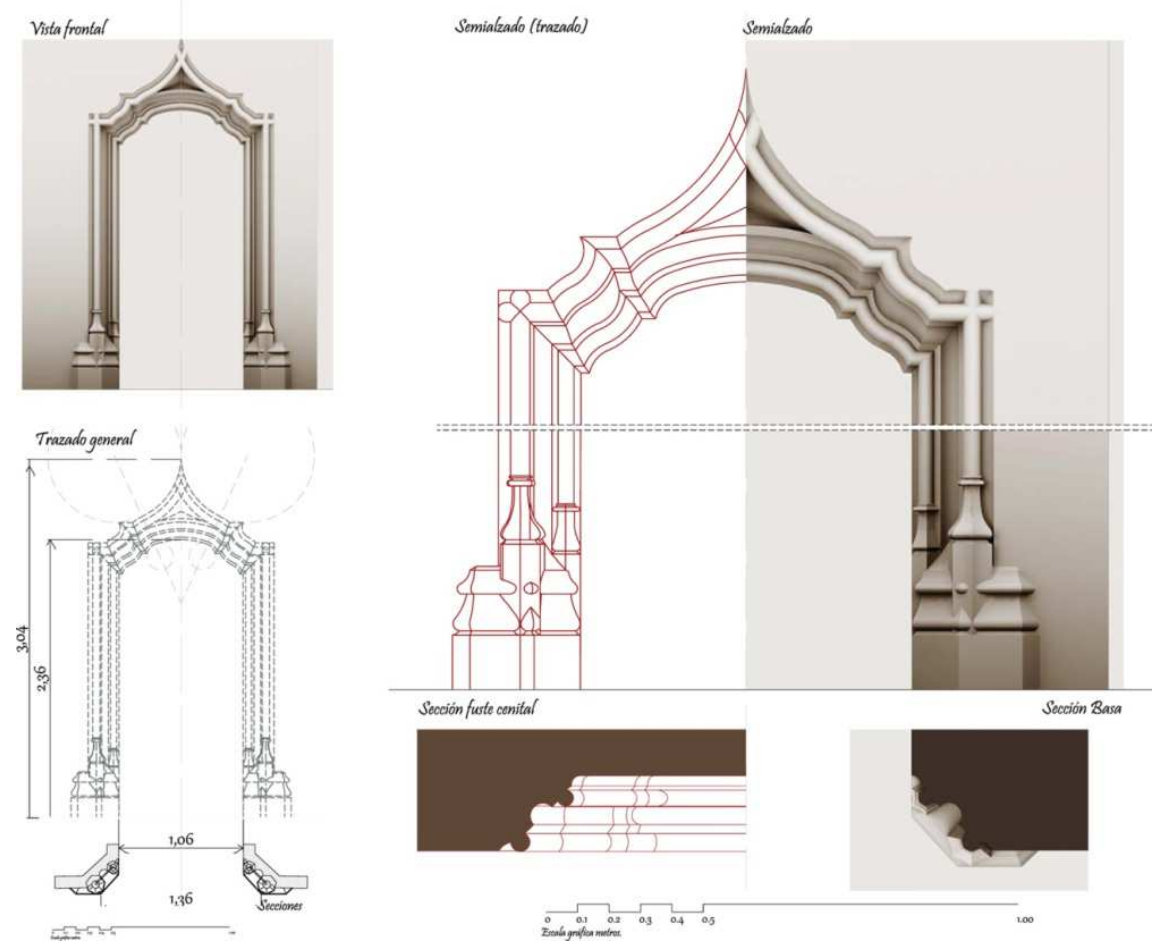

Figura 385. Lámina de la Portada D12. Alzado, secciones horizontales y trazado utilizando restitución $2 \mathrm{D}$ y $3 \mathrm{D}$.

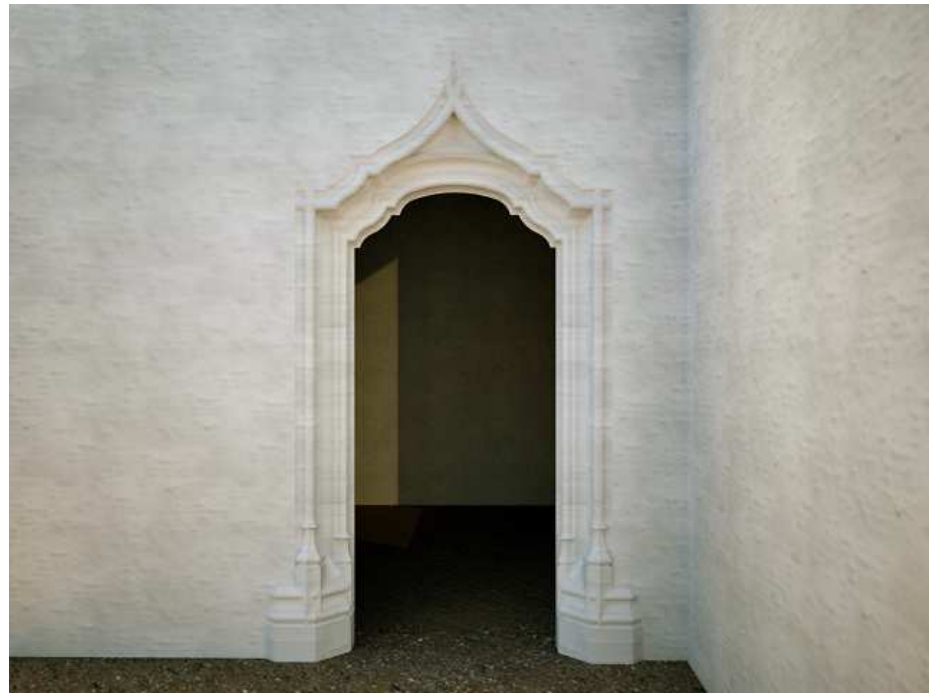

Figura 386. Render de la portada D12 en la Sala 12. 


\section{Portada 13}

La Portada 13 está formada por un arco trilobulado rebajado y la Portada 28 por un arco escarzano en su intradós que se transforma en arco cortinado escarzano en su trasdós; en este caso la sección se prolonga mediante una jamba abocinada. El modelado de este arco ha resultado más sencillo, ya que se trata de tres arcos que cortan en dos aristas y las molduras son todas concéntricas. La dificultad de esta pieza radica, como en todas las portadas y ventanas, en la modelización de su basa formada por diversos elementos, algunos de ellos complejos: zócalo recto, zócalo moldurado, basas poliédricas de lados cóncavos y basas molduradas, así como la intersección de la basa con las molduras que forman la jamba.

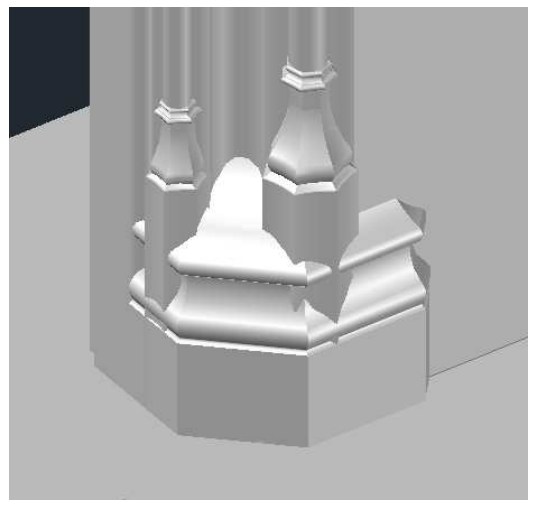

Figura 387. Detalle basa derecha portada D13. Vista axonométrica volumen 3 D con superficie.

Como en el caso de la portada anterior, se ha elaborado una nueva lámina de presentación de la Portada 13, incorporando las vistas ortogonales tanto de la restitución 2D, como de la 3D, así como un render de la misma en su ubicación en la Sala 12.
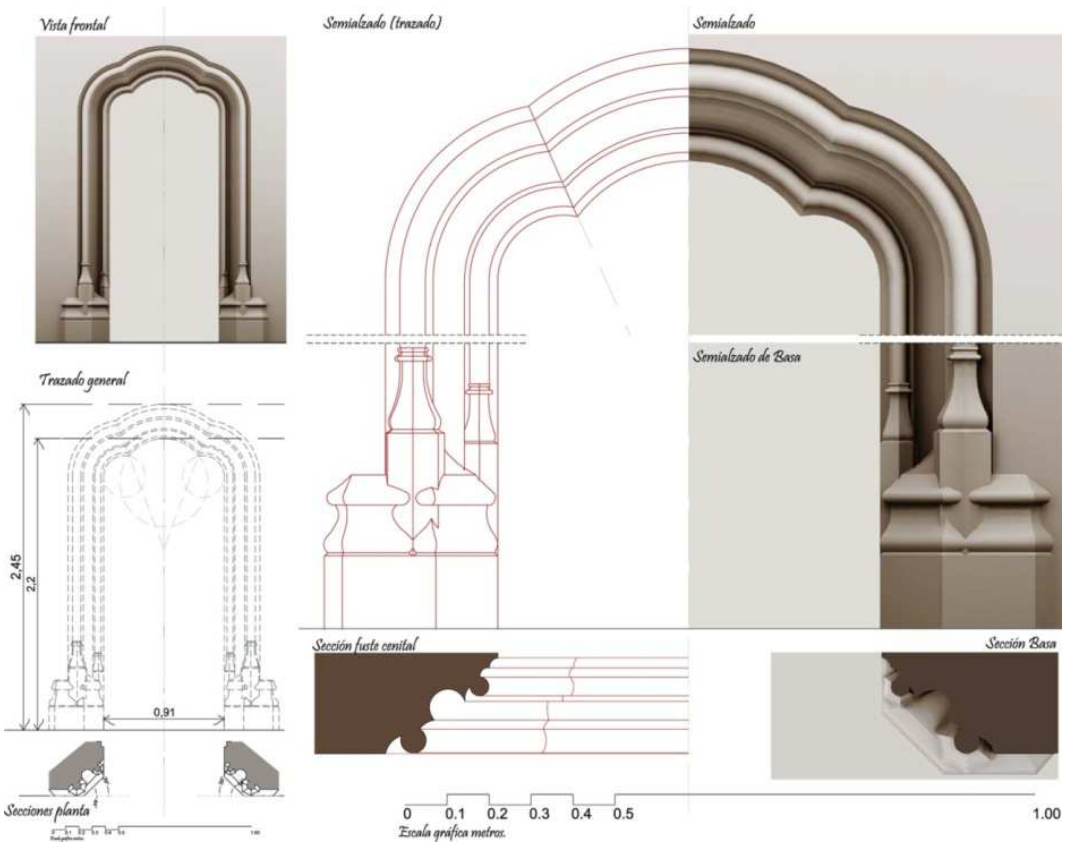

Figura 388. Lámina de la Portada D13. Alzado, secciones y trazado utilizando restitución 2D y 3D. 


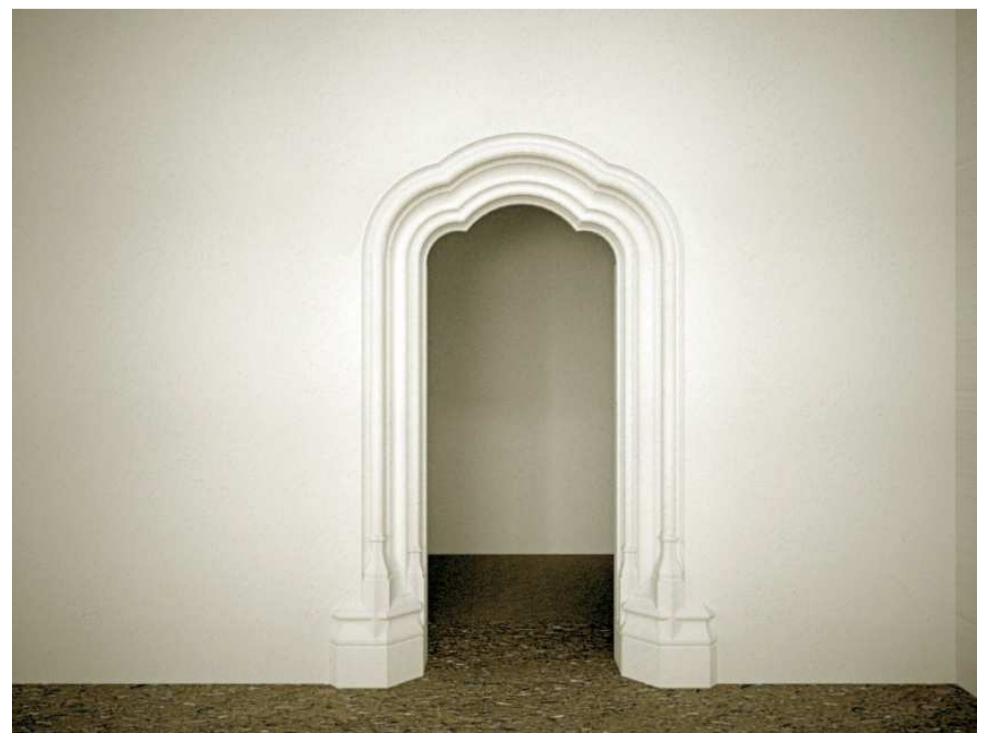

Figura 389. Render de la portada D13 en la Sala 12.

\section{Portada 28}

La Portada 28 posee un arco escarzano en su intradós que se transforma en arco cortinado escarzano en su trasdós. En este caso toda la sección de las jambas se prolonga por la directriz del arco exterior. Por su parte, el arco inferior lo forman sólo las molduras situadas en su intradós (dos cavetos, columnilla pequeña y filete). En el triángulo existente entre los dos arcos se forma una pirámide invertida. La dificultad del modelado 3D de esta pieza radica en la diversificación de la directriz del arco y en el modelado de la basa, como en el resto de piezas.

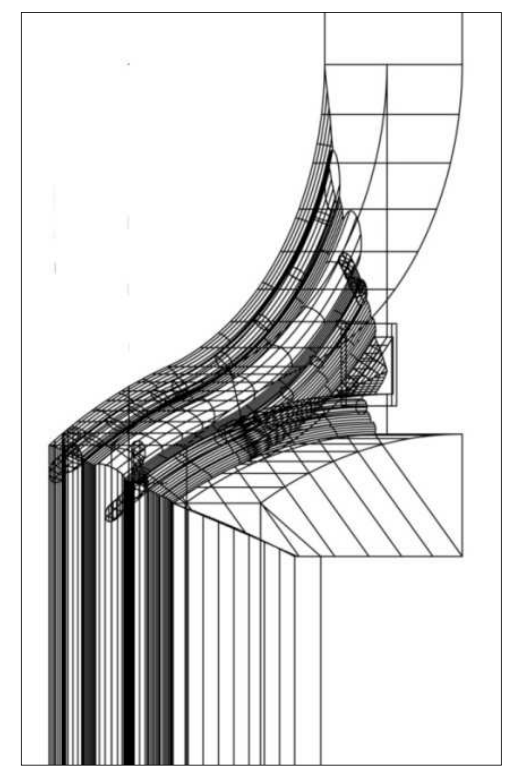

Figura 390. Estructura alámbrica semiarco y jamba izquierdos. Portada D28. 


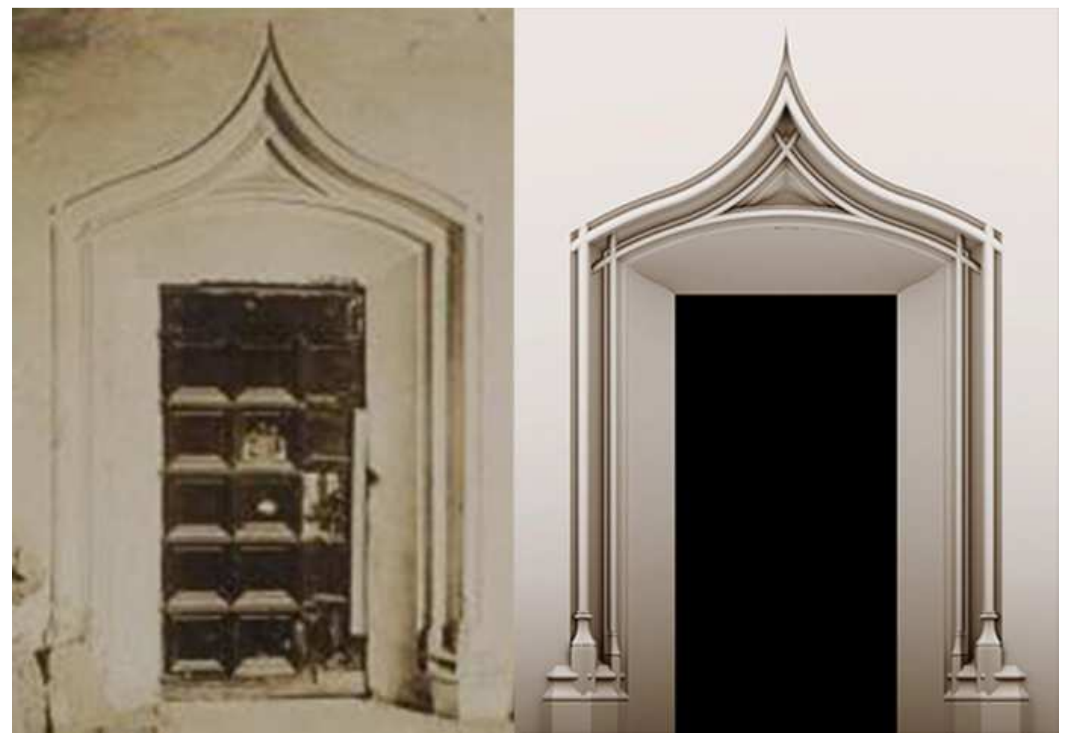

Figura 391. Portada 28: Izquierda: Fot. 64 AFG. Fischer. Derecha: Alzado. Restitución gráfica 3D.

Como en las anteriores portadas, se ha elaborado una nueva lámina de presentación de la Portada 28 con sus vistas ortogonales tanto de la restitución 2D, como de la 3D, así como un render de la misma en su ubicación en la Sala 12.
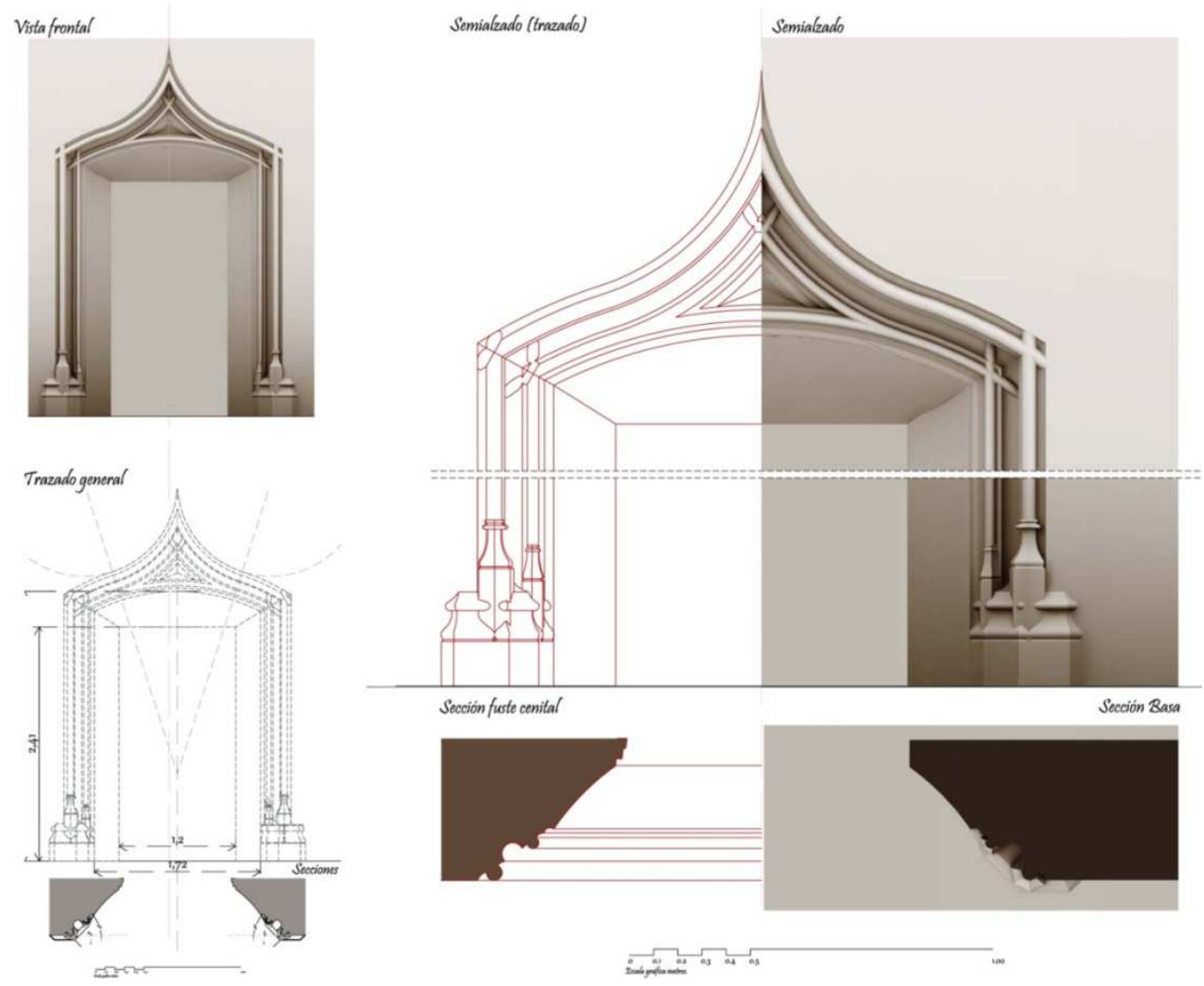

Figura 392. Lámina de la Portada 28. Alzado, secciones y trazado utilizando restitución 2D y 3D 


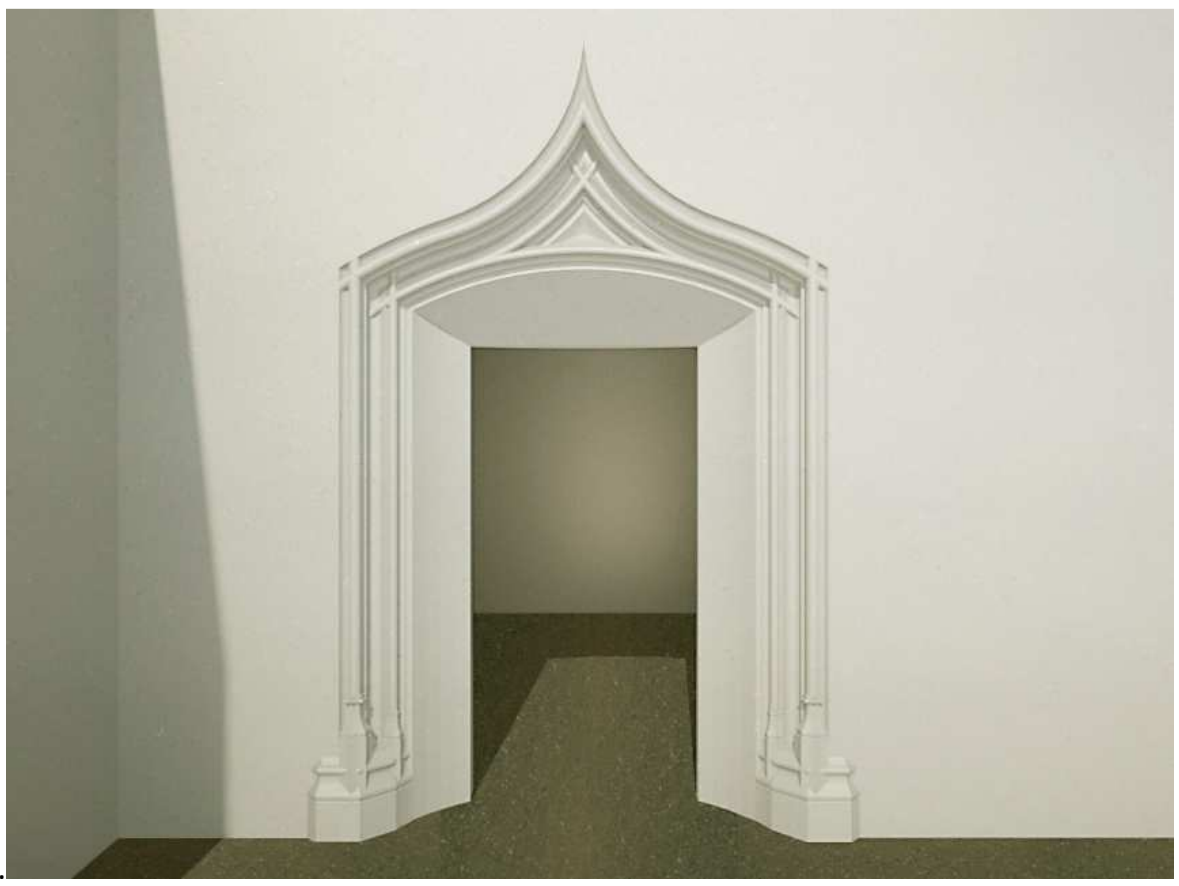

Figura 393. Render de la portada D28 en la Sala 12.

\subsection{Ventanas}

El proceso de restitución gráfica tridimensional se ha llevado a cabo en la venta V4 perteneciente a la Sala 12 de la planta noble del palacio.

\section{Ventana V4}

El proceso de elaboración es idéntico al seguido en las portadas. En la documentación de Fischer y Lauritzen existen dos láminas correspondientes a la ventana V4: LA1196 y LA $1197^{485}$; siendo la primera un calco donde se indican los despieces a realizar. A diferencia de las portadas, donde como regla general sólo se representa el alzado y una sección horizontal de las mismas, en este caso se ha representado también una sección vertical sobrepuesta al alzado. Esta vista resultaba imprescindible para poder definir completamente el elemento arquitectónico en cuestión.

En primer lugar, cabe destacar que tiene una altura mucho mayor que las portadas; que está formada por un arco escarzano; y que sus molduras principales son idénticas a las de las portadas. Otra diferencia es que las basas no parten del pavimento, sino que arrancan del lienzo del muro, apoyándose en una moldura con forma de peana. En este caso las columnillas disponen de capiteles con decoración vegetal y zoomórfica, pero sin duda uno de los elementos más característicos de esta ventana son sus festejadors ${ }^{486}$, característicos

\footnotetext{
${ }^{485}$ Fischer, E. y/o Lauritzen V. (1919-1920). Planos. Óp. cit. pp. LA1196 y LA1197.

${ }^{486}$ Festejador (Valenciano): asiento dispuesto a cada lado de una ventana gótica por su parte interior, destinados a utilizarse para charlar o hacer labores necesitadas de luz.
} 
en las ventanas del gótico mediterráneo como se ha comentado anteriormente. Esta ventana se ve también parcialmente en la fotografía $77^{487}$.

En el caso de la ventana se ha modelizado todo el conjunto salvo los capiteles, por tratarse de un elemento escultórico y no arquitectónico y, por tanto, su restitución correspondería a la disciplina de las Bellas Artes. Como elementos novedosos respecto a las portadas nos encontramos con los festejadors y con las peanas o ménsulas, sobre las que se apoyan las basas de la ventana.

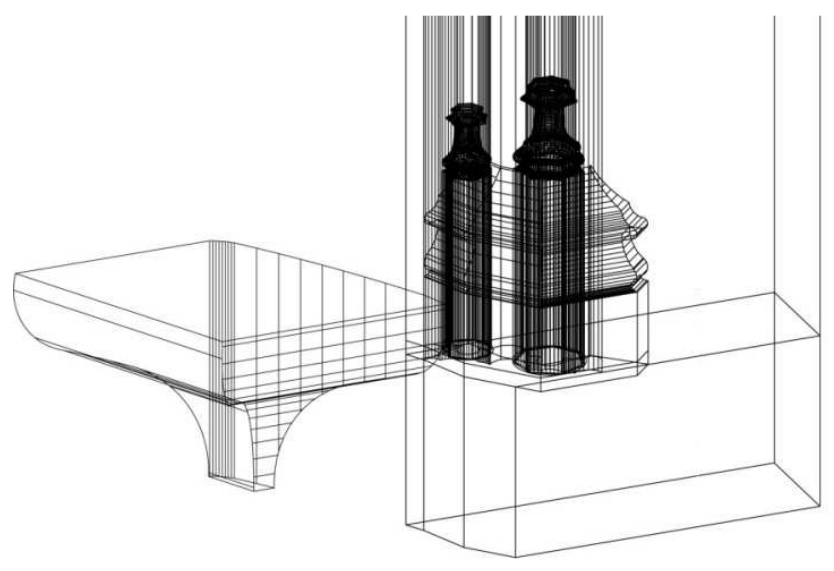

Figura 394. Ventana V4. Proceso de modelizado 3D. Estructura alámbrica.

Como en el caso de las portadas, se ha elaborado una nueva lámina de presentación de la ventana V4 con sus vistas ortogonales tanto de la restitución 2D, como de la 3D, así como un render de la misma en su ubicación en la Sala 12.
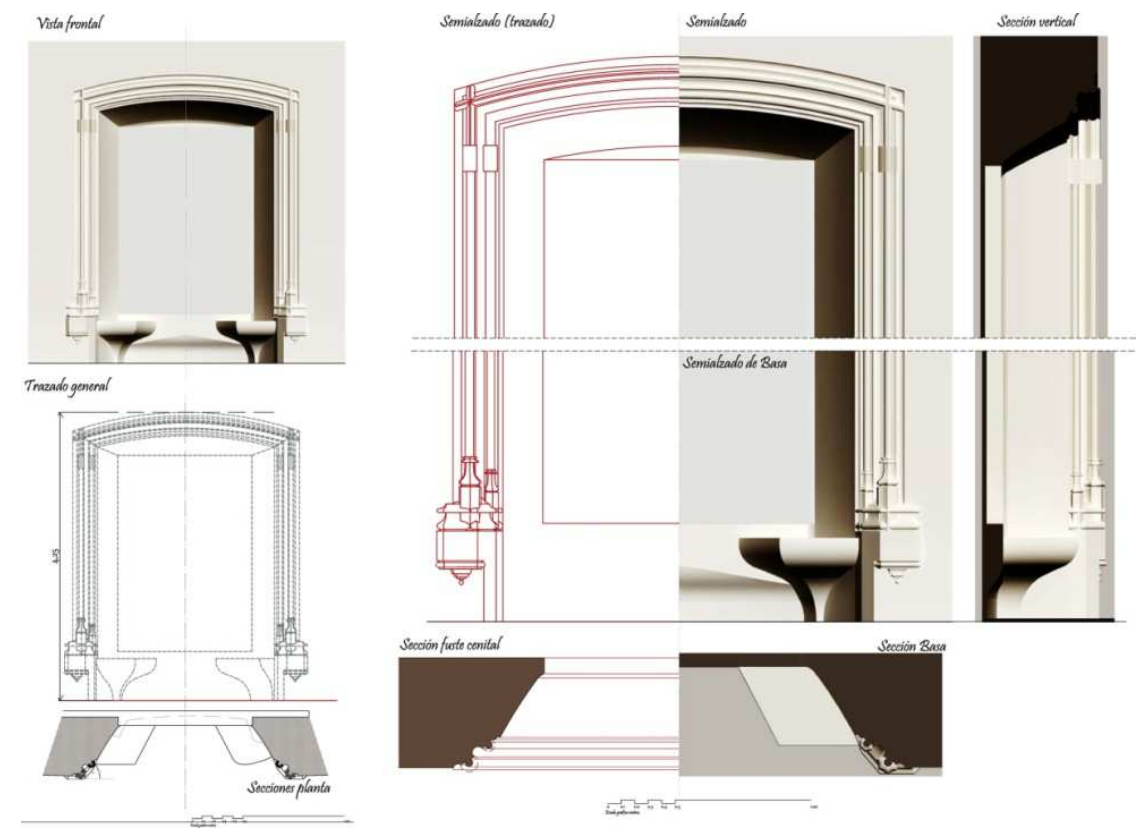

Figura 395. Lámina ventana V-4. Alzado y secciones utilizando restitución 2D y 3D.

${ }^{487}$ Fischer, E. (1917-1920). AFG. Óp. cit. pp. 17A. 


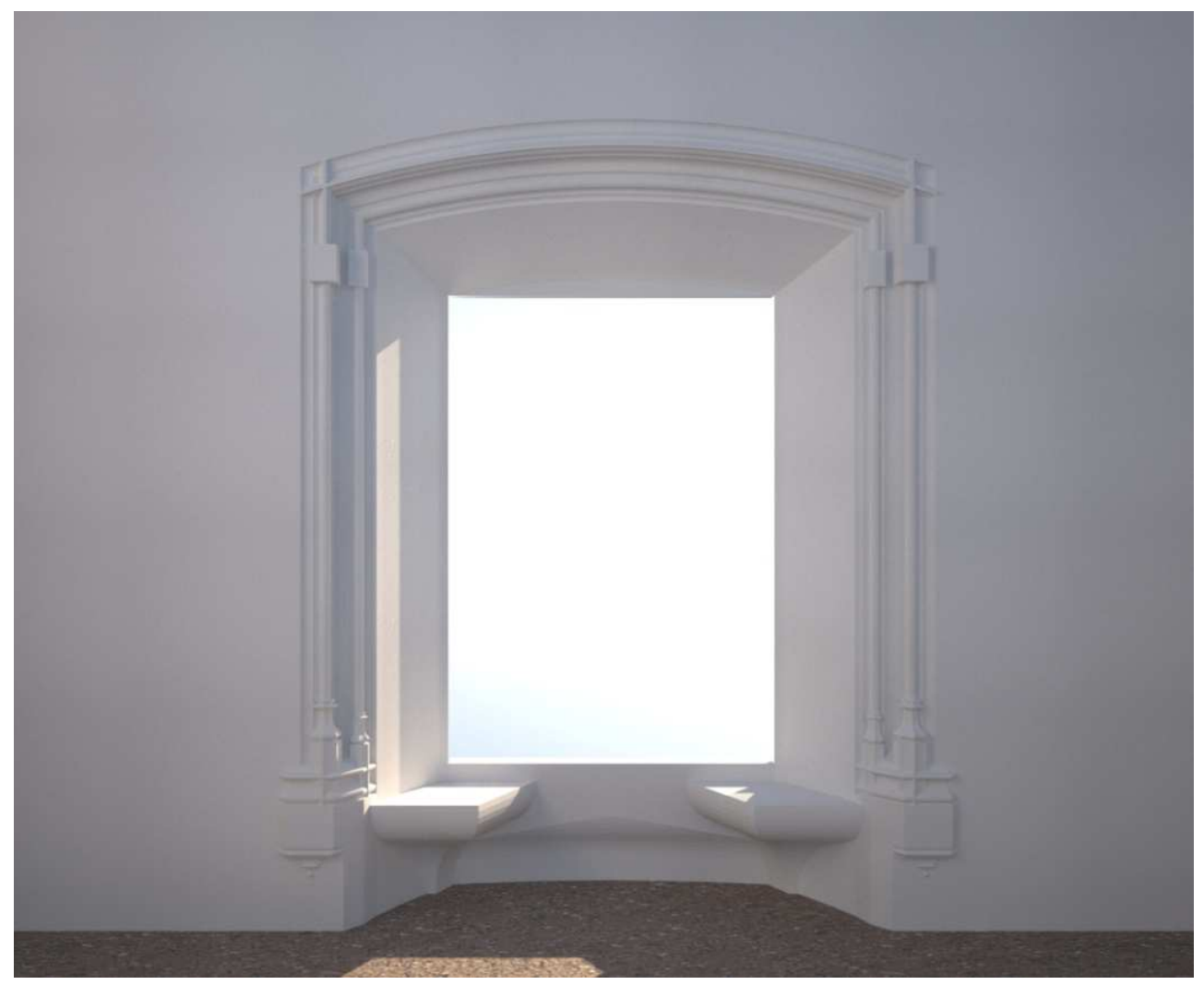

Figura 396. Render de la ventana V4 en la Sala 12.

\subsection{Forjados y artesonados}

La documentación gráfica más completa y detallada corresponde a los artesonados de las salas 11 y 12, ya que el hecho de tratarse de elementos complejos, que se pretendían desmontar y volver a montar pieza a pieza, obligó a los arquitectos daneses a que elaboraran unos minuciosos planos y enumeraran cada una de las piezas, desde las de mayor dimensión a las más minúsculas con un con un código alfanumérico. En el caso de los forjados dibujaron tan sólo planos de planta a escala o croquis acotados y secciones esquemáticas con las secciones de las vigas y molduras.

\section{Artesonado sala 12}

Partiendo de las vistas ortogonales bidimensionales se ha elaborado este elemento en tres dimensiones mediante la extrusión de cada una de las molduras y listones que lo conforman, situándolas tridimensionalmente e interseccionándolas correctamente para obtener una volumetría del conjunto. 


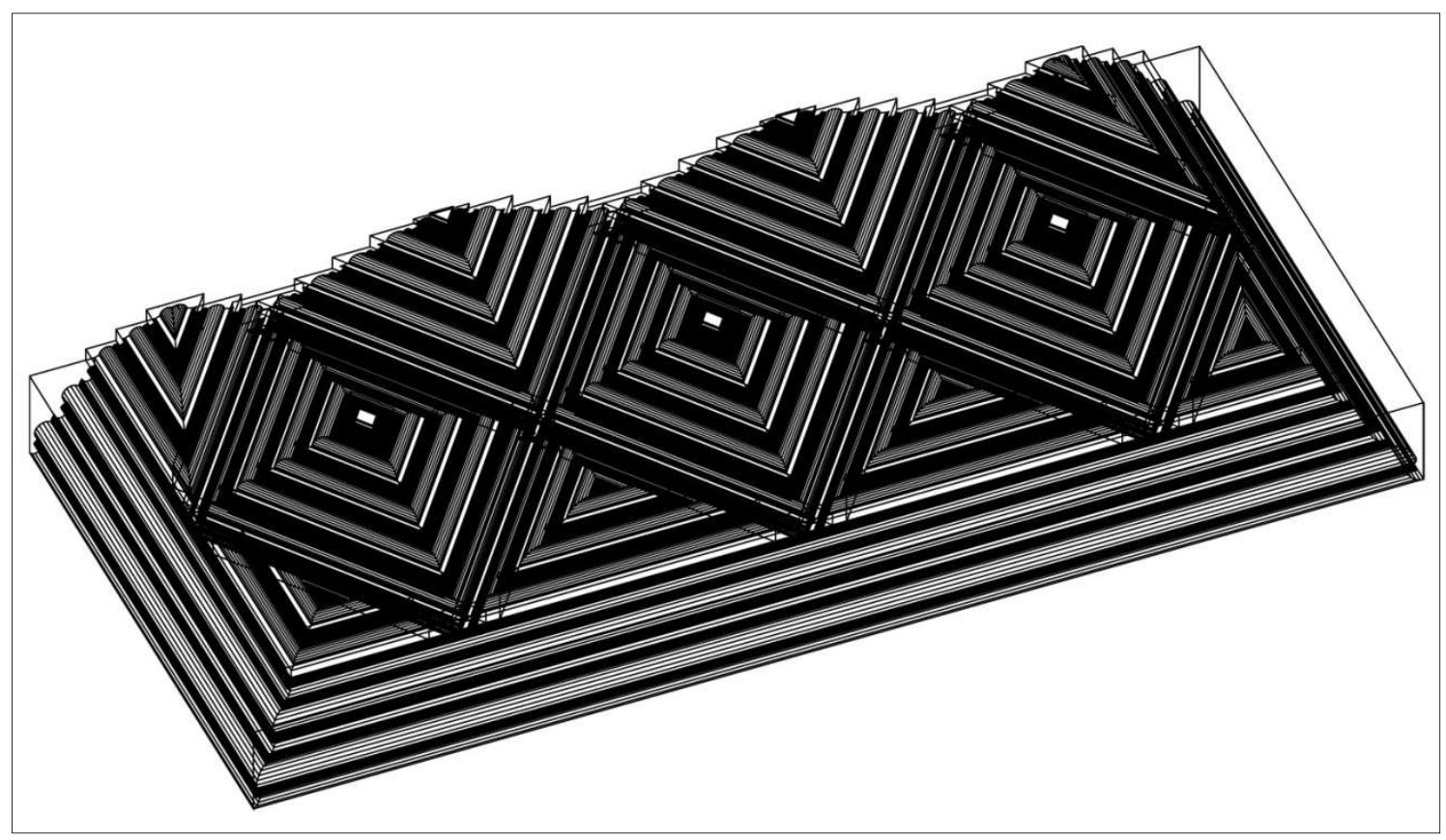

Figura 397. Artesonado Sala 12. Axonometría seccionada. Estructura alámbrica.

\subsection{Bóvedas}

En el caso de las bóvedas el proceso de restitución es diferente; varía según la bóveda a restituir, siendo diferente en una bóveda de cañón, formada por casetones, que en una de arista o una estrellada. En cualquier caso, se ha escogido como caso de estudio la bóveda de la Sala 17 por ser la de mayor interés por su trazado.

\section{Bóveda estrellada Sala 17}

Para la restitución de la bóveda se ha partido del plano LA1124 ${ }^{488}$, donde están dibujadas a escala 1:20 todas las vistas de la bóveda: planta cenital, secciones longitudinal y transversal y alzados de todos los arcos formeros, además del perfil del arco crucero y la posición de todas las claves acotadas, por lo que se pueden obtener también los terceletes. El plano está acotado tanto en planta como en altura, tratándose de una autentica traza y montea de la bóveda realizada a escala. Las cotas en altura tienen como cota 0 de referencia en un plano horizontal situado por encima de la cara superior de la cornisa. Se trata de una bóveda estrellada de 5 claves de terceletes y rampante curvo $^{489}$. La planta es rectangular de lados irregulares; el trazado del arco crucero (radio 2,78 m) corresponde prácticamente con

${ }^{488}$ Fischer, E. y/o Lauritzen V. (1919-1920). Planos. Óp. cit. pp. LA1196 y LA1197.

${ }^{489}$ Navarro Fajardo, J.C. (2004). Bóvedas valencianas de crucería de los siglos XIV al XVI. Traza y montea. (Tesis Doctoral). Valencia: Universitat de València. Servei de Publicacions. pp.81-85. y García Gómez, N. (2012) Trazado de las bóvedas de nervaduras mexicanas del siglo XVI. Revista de Arquitectura. Vol. 14. Núm.1. pp. 106-115. 
la distancia desde la clave al vértice $1(2,75 \mathrm{~m})$, y coincide prácticamente con los 12 palmos valencianos $(2,76 \mathrm{~m})$. Los arcos formeros son apuntados, salvo el del lado 3-4 que es rebajado. Los arcos apuntados están trazados dividiendo el ancho de la luz en 12 partes y tomando la primera desde el centro hasta cada uno de sus lados. La altura máxima de la bóveda medida en la plementería, desde la cota 0 de referencia, es de 2,12 m. Tanto los arcos formeros como los terceletes tienen distintas alturas para adaptarse a la geometría irregular de la sala.

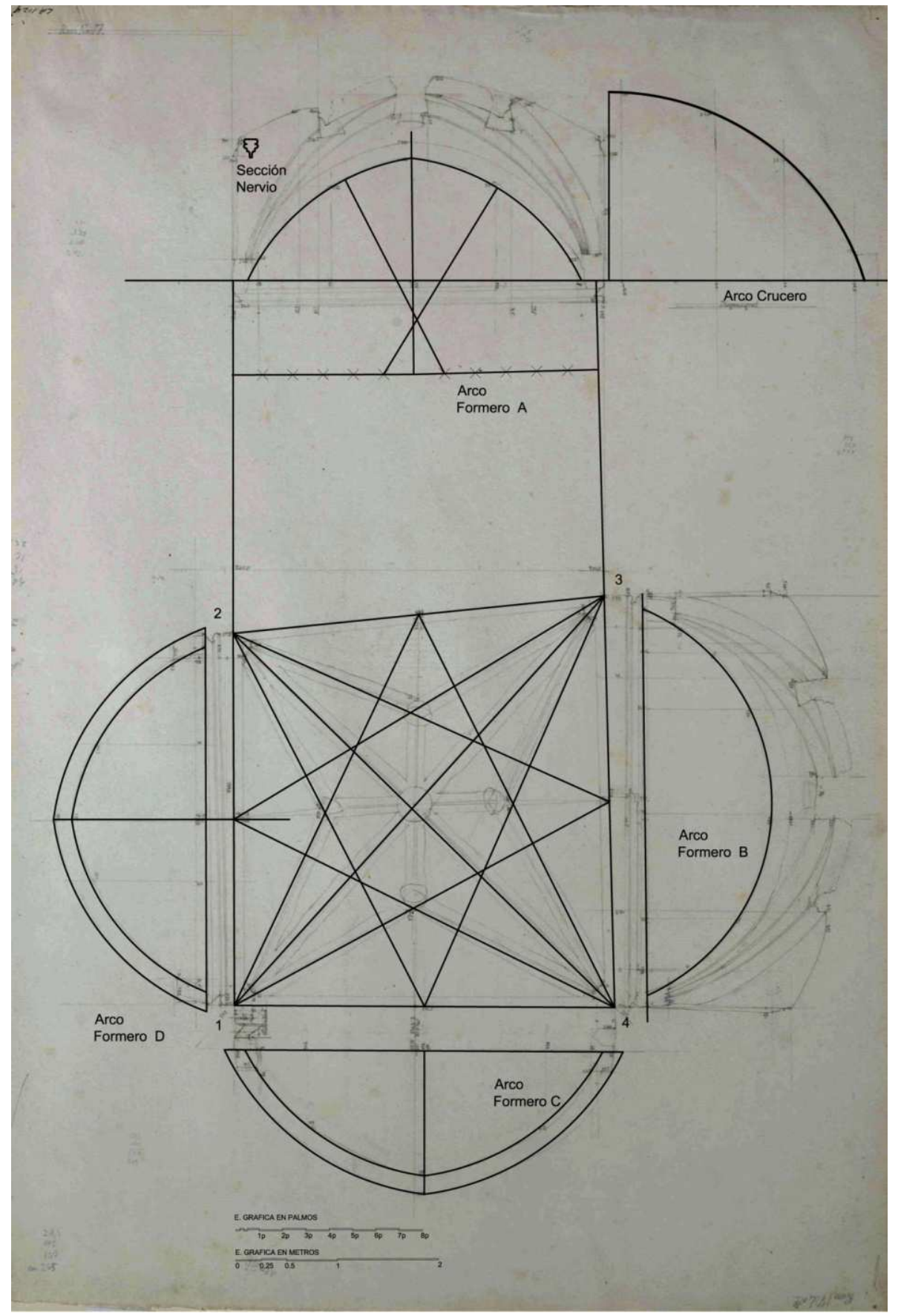

Figura 398. Lámina LA1124. Bóveda Sala 17. Traza, monteas y secciones de la bóveda. 


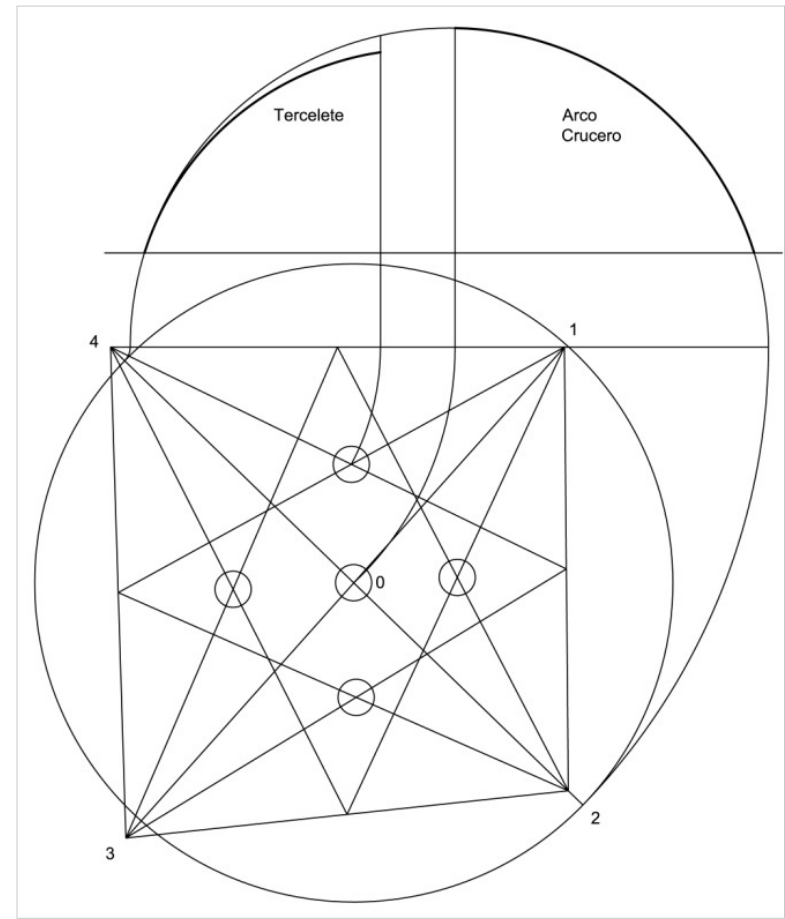

Figura 399. Traza de la bóveda 17 y montea del arco crucero y del tercelete del arco formero 1-4.

El proceso para obtener la traza y las monteas a partir de la lámina LA1124 ha sido idéntico al descrito para el caso de las portadas y las ventanas. Una vez obtenidos estos datos geométricos de la bóveda, se ha procedido a modelarla tridimensionalmente. Se ha optado por tomar como referencia la cara superior de los arcos, obteniéndose así la superficie de la plementería de la bóveda.

Figura 400. Bóveda sala 17. Izquierda: estructura alámbrica. Planta. Derecha: perspectiva de la superficie de la plementería. 


\section{RESTITUCIÓN GRÁFICA SALA 12}

Se ha elegido la Sala 12 como caso de estudio por sus grandes dimensiones, por la singularidad de su artesonado, y por tener una de las portadas de arco conopial contracurvado mixtilíneo más características del Palacio, la D12. El desarrollo de este trabajo nos permitirá poder visualizar, analizar y comprender este espacio arquitectónico en su conjunto de manera virtual a partir de su estudio.

Como se ha comentado anteriormente, la Sala 12 se encontraba situada, al igual que el resto de salas nobles del palacio, en la planta primera o principal. Con sus grandes dimensiones, sus portadas tardogóticas y su artesonado romboidal era, sin duda, junto con la Sala de Armas, una de las más singulares del palacio. Por ello, fue documentada casi en su totalidad por los arquitectos daneses.

La sala tenía unas dimensiones en planta de 13,38 x 8,03 m. Su paramento noroeste recaía en el patio con la misma orientación (Pati del Portalet o Patio de Armas), del que recibía luz natural a través de la ventana V4. Asimismo, delimitaba con la Sala 13, también denominada "Capilla", con la que se comunicaba a través de la Portada 13. Su muro sureste la separaba de la Sala 16 o Sala de Armas. A su vez, el muro suroeste la separaba de la Sala 20, con la cual se comunicaba a través de la Portada 28 y con la Sala 10 o Galería Inferior, con la que no tenía comunicación directa. Su paramento noroeste delimitaba con la Sala 11, con la que se comunicaba a través de la Portada 12 (ver Fig. 401).

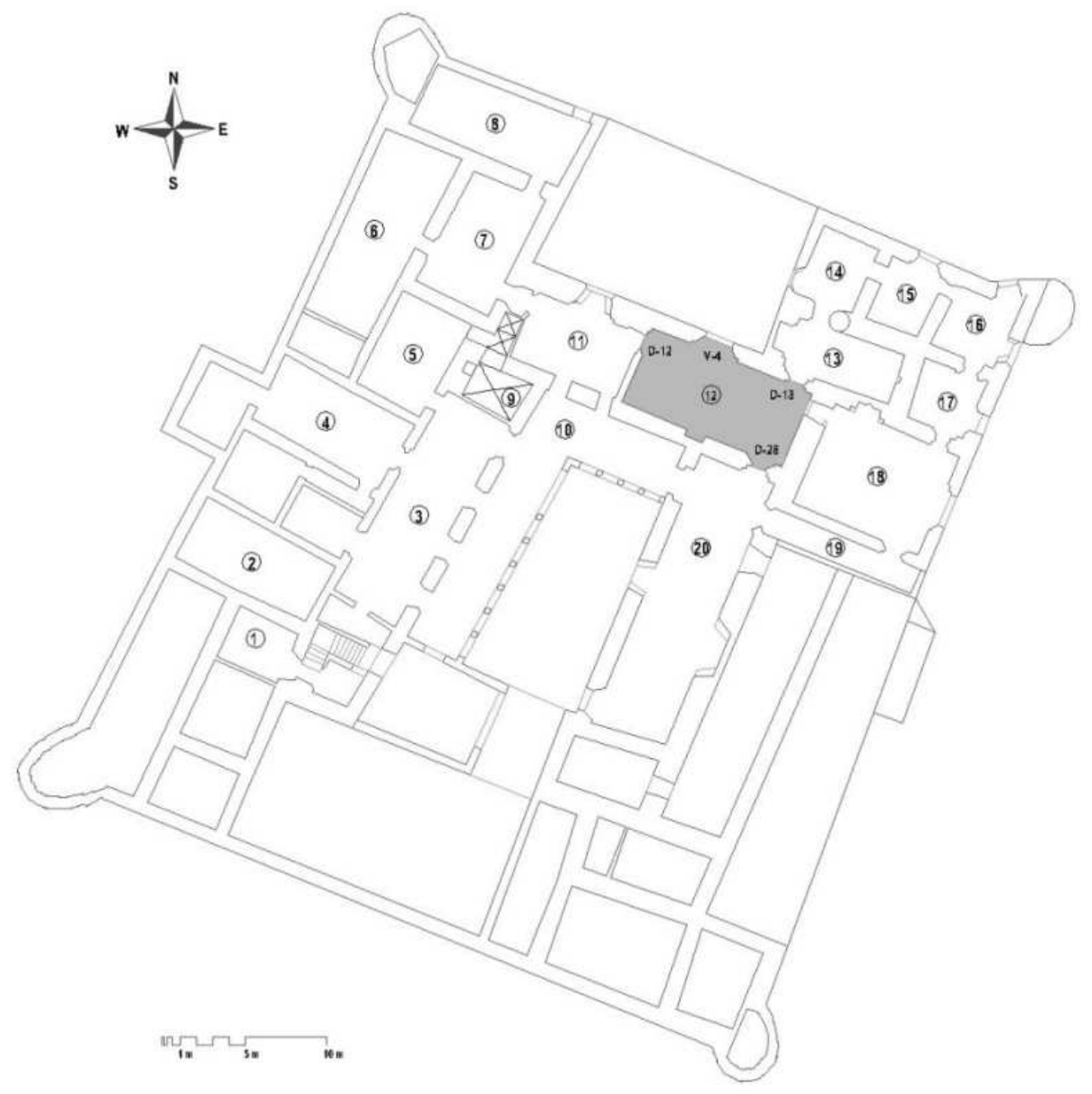

Figura 401. Planta 1ạ del Palacio. Plano general. Localización Sala 12. 
Como se ha comentado, se ha elegido esta sala por sus grandes dimensiones, pudiéndose fijar puntos de vista que permiten obtener vistas generales con un ángulo lo suficientemente amplio. Otra de las razones es la peculiaridad de su artesonado romboidal, y el hecho de que sus tres portadas se puedan restituir completamente con elementos geométricos, ya que la herramienta CAD no permite hacer lo mismo con los escultóricos.

Esta sala era una de las de mayor dimensión del Palacio y en ella colgaban los cuadros de los ilustres antepasados de las familias Carrós y Centelles, por lo que Sebastián Castellanos la denomina "Sala de Linajes" ${ }^{490}$. El hecho de que a dicha sala se accediera directamente desde la galería de la planta principal, y que a través de ella se llegara a la Sala de Armas, a la Capilla y a la Sala 11, nos indica que tenía uso público dentro del Palacio, donde se realizarían actos de recepción o sociales con otros nobles o personalidades de la época. En 1851 el Palacio ya había sido despojado de sus bienes muebles, aunque conservaba las poleas de donde, en su día, colgaban tapices que cubrían sus altas paredes. Sebastián Castellanos describe su artesonado como de color oscuro y dorado, por lo que esta sala se correspondería con uno de los studis daurats a los que se refiere el inventario de $1550^{491}$. El nombre de "estudi daurat" se debía a la decoración con pan de oro o pintura dorada de sus techos, como sucede en el Palacio de la Generalitat de Valencia. Otro de los salones dorados era, sin duda, la Sala de Armas, donde tanto las vigas como el friso y los revoltones se encontraban decorados con pinturas con tonos dorados.

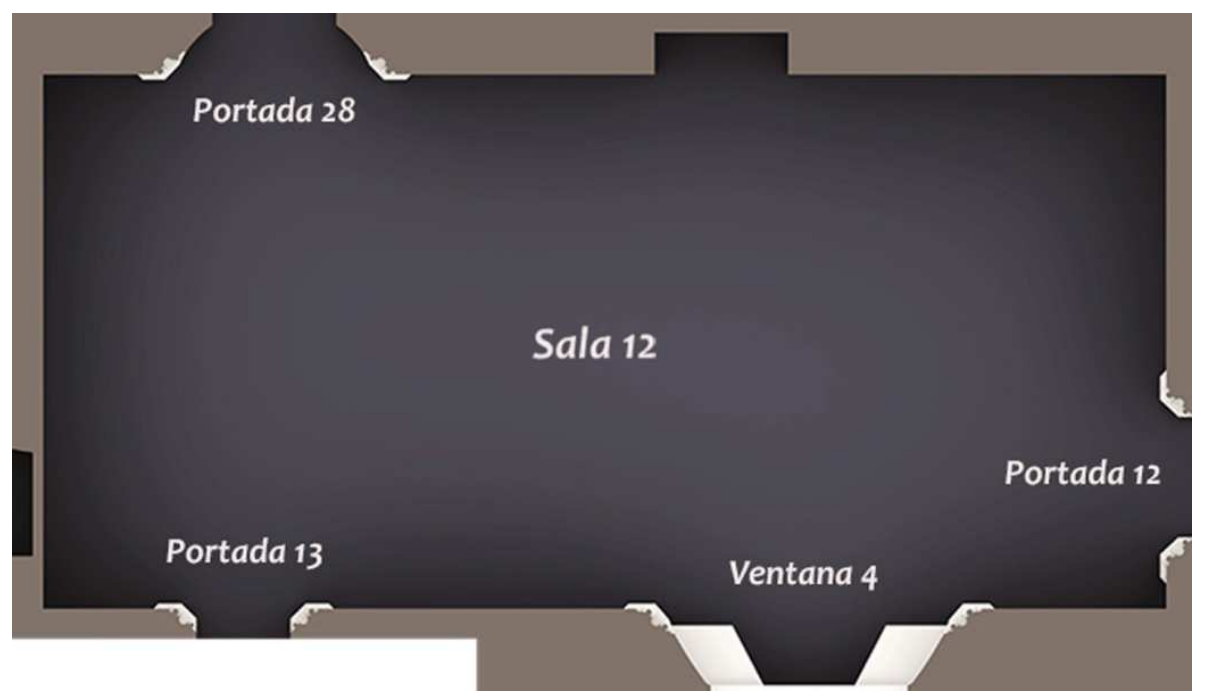

Figura 402. Planta Sala 12.

Aunque Fischer dibujó y documentó algunos de los pavimentos del Palacio, estos no corresponden a las salas nobles. Este hecho nos lleva a pensar que estos elementos fueron retirados con anterioridad a su llegada al Palacio. De este modo, si observamos la fotografía 77, el pavimento es una simple mancha gris, lo que da a entender que estamos viendo la capa de compresión del forjado; pero si la analizamos con detenimiento, observamos en la parte inferior de la ventana $\mathrm{V} 4$ lo que parece ser restos de las baldosas del pavimento en el perímetro de la sala. Sin embargo, no disponemos de suficiente información que nos

${ }^{490}$ Arciniega García, L. (2001). Óp. cit. pp.78 y 224.

${ }^{491}$ Felip Sempere, V. (2001). Óp. cit. pp. 301-368. 
permita restituir con exactitud el pavimento, si bien por analogía con los documentados este debía de estar compuesto por cerámica vidriada y decorada, cubriendo toda la sala o intercalada con baldosas rojas de barro cocido como en los pavimentos detallados por Fischer en el Notebook I. $^{492}$

Los elementos arquitectónicos que componían la Sala 12 son las portadas D12, D13 y D28, la ventana V4 y el artesonado 12. En el plano de planta se observa un hueco en el centro del muro suroeste que, probablemente, albergaría una chimenea ornamental desmontada antes de la llegada de Fischer al Palacio. Como se ha expuesto anteriormente, cada uno de los elementos que componen esta sala se han modelado en 3D mediante herramienta CAD. Para interpretar algunas de las formas y molduras, insuficientemente detalladas en esta documentación, se han usado como referencia otros elementos arquitectónicos similares localizados en edificios de la época, como son La Lonja y el Palacio de la Generalitat en Valencia, el Palacio de los Próxita en Lluxent o el Palacio de los duques de Medinaceli en Geldo.

Una vez dibujado cada uno los elementos en tres dimensiones se ha procedido a ubicarlos, generando un archivo CAD que contiene tanto las dimensiones tridimensionales de la sala como todos los elementos tridimensionales en su posición. Las dimensiones de la sala se han obtenido contrastando las láminas a escala del artesonado, con el plano de cubiertas LA1106, donde aparece una escala gráfica. Para la posición de las portadas y ventana hemos partido de su posición en el plano de distribución de la $\operatorname{LA} 1109^{493}$. La altura de la sala la hemos determinado proporcionando la altura de la Portada 12 con la altura total de la sala partiendo de la Fot. $77^{494}$, obteniendo una altura del muro de 5,60 m.

Posteriormente, se han aplicado las texturas: a los muros y sus elementos ornamentales se les ha aplicado una textura lisa en color blanco roto, que se ha obtenido directamente del encalado que se aprecia en las fotografías; al artesonado una textura dorada, ya que si bien las fotografías no permiten determinar los colores originales, esta sala se identifica como uno de los estudis daurats del Palacio ${ }^{495}$; en cuanto al pavimento se ha optado por colocar una textura grisácea que emula la capa de mortero, tal y como aparece en las fotografías 63,65 y $77^{496}$. No se ha representado la carpintería por no disponer de datos concretos de la misma, por lo que las imágenes reflejan un espacio arquitectónico diáfano sin carpinterías. Para la obtención de las imágenes se ha iluminado la sala con luz natural a través de la ventana V4. Una vez aplicadas las texturas, colocadas las luces y posicionadas las cámaras, se ha procedido al renderizado de las imágenes mediante los software 3D Studio y Maxwell Studio, obteniendo tanto imágenes ortogonales de cada una de las piezas como perspectivas cónicas de la sala. Las perspectivas obtenidas nos permiten visualizar la Sala 12 en su conjunto, así como analizar y entender este espacio arquitectónico: su escala, volumen y proporción, y la relación entre los distintos elementos que la componen. La restitución virtual de este espacio puede servir para futuros estudios, así como para su difusión tanto en el ámbito científico como en el cultural y patrimonial.

\footnotetext{
${ }^{492}$ Fischer, E. (1917-1920.). Notebook I. Óp. cit. pp. 10, 11, 35, 36, 37, 63, 65, 71 y 73.

${ }^{493}$ Fischer, E. y/o Lauritzen V. (1919-1920). Planos. Óp. cit. pp. LA1106 y LA1109.

${ }^{494}$ Fischer, E. (1917-1920.). AFG. Óp. cit. pp. 17A.

${ }^{495}$ Felip Sempere, V. (2001). Óp. cit. pp. 301-368.

${ }^{496}$ Fischer, E. (1917-1920.). AFG. Óp. cit. pp. 14R y 17A
} 
Así, se ha intentado recrear la Sala 12, tal y como la percibieron Fischer y Vilhelm en 1919. En la figura 403 se ha colocado el punto de vista a una altura de 1,65 m. Esta era la altura del punto de vista de Egil Fischer, obtenida escalando su figura a partir de la Fotografía $73^{497}$, donde aparece él fotografiado bajo el arco de la portada D4. En la figura 404 se muestra una comparativa entre la imagen virtual de la Figura 403 y la fotografía 77, tomada por Fischer. La figura 405 se ha tomado colocando el punto de vista a una altura de 1,20 m y situando la cámara sobre el festejador izquierdo de la ventana V4, tal y como vería la sala el arquitecto sentado sobre él. ${ }^{498}$

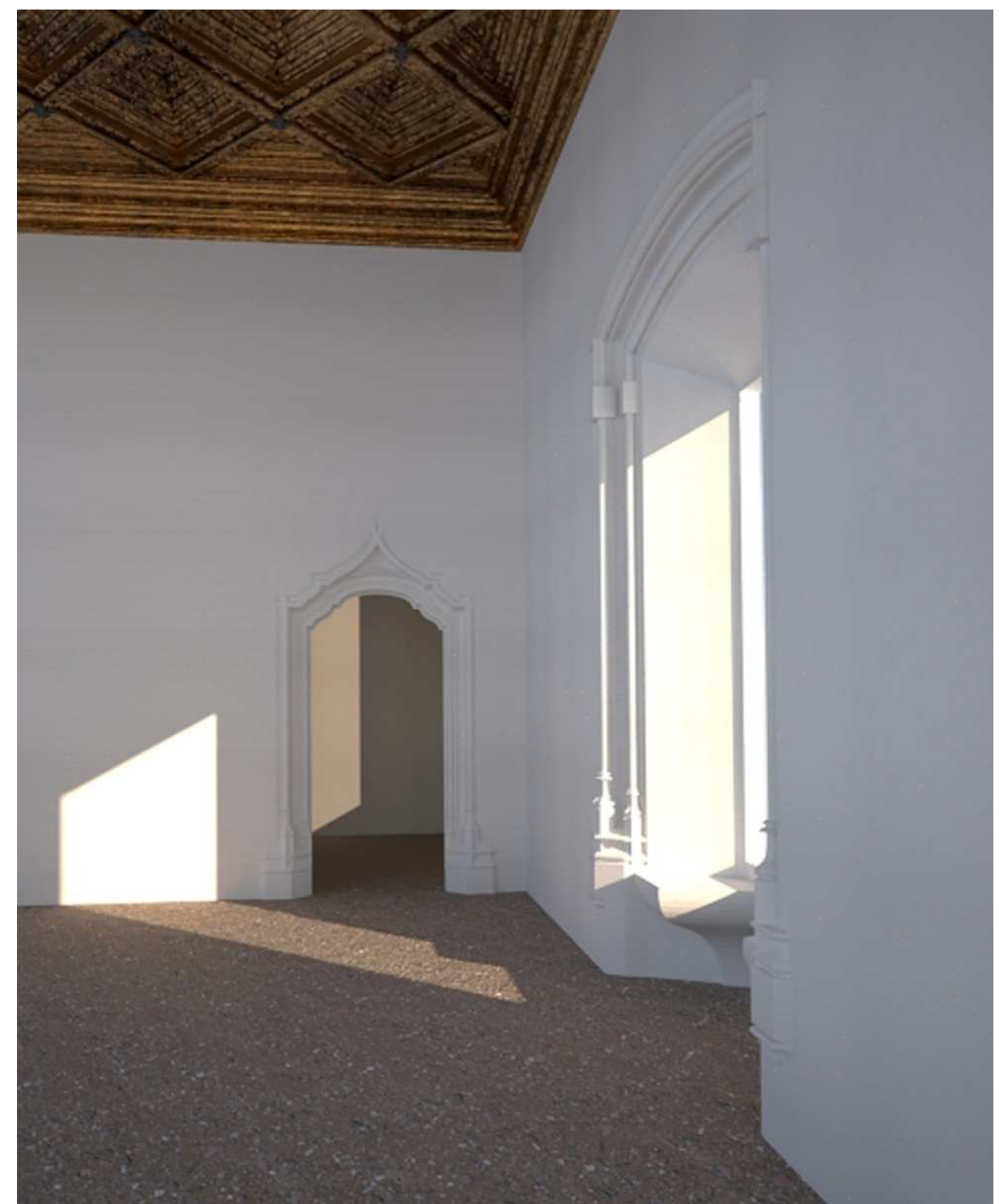

Figura 403. Perspectiva de la Sala 12 con la Portada D12 al fondo y la ventana V4 a la derecha.

\footnotetext{
${ }^{497}$ Fischer, E. (1917-1920.). AFG. Óp. cit. pp. 16A.

${ }^{498}$ Este trabajo ha sido publicado por el autor en: Martínez Moya, J. (2016). Restitución gráfica de la sala 12 del Palacio Condal de Oliva a partir del legado gráfico de Fischer y Lauritzen. EGA. Revista de expresión gráfica arquitectónica, Vol. 21. Núm. 28. pp. 60-69.
} 


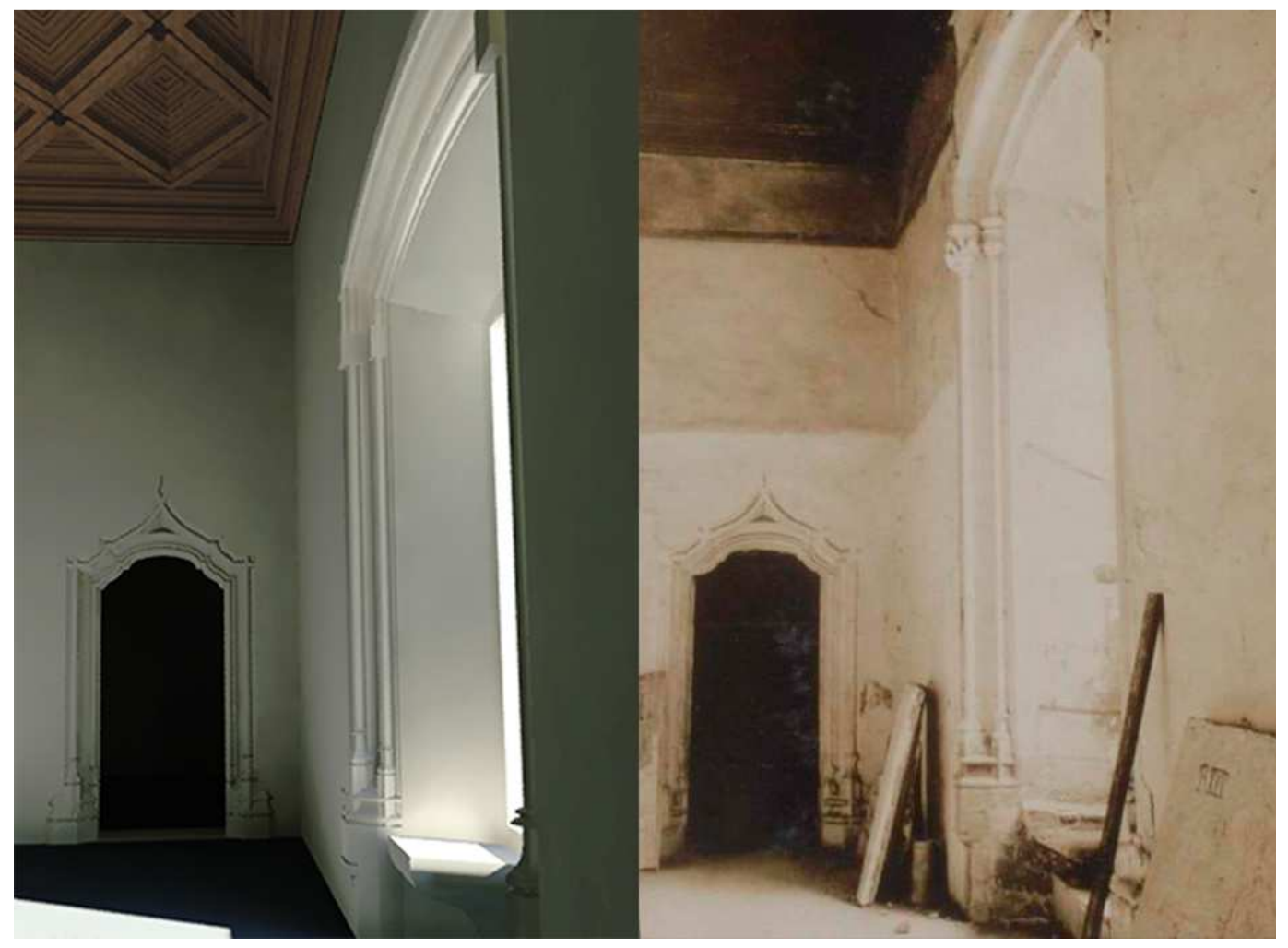

Figura 404. Comparación entre imagen virtual de la Sala 12 y Fot.77 con un punto de vista similar.

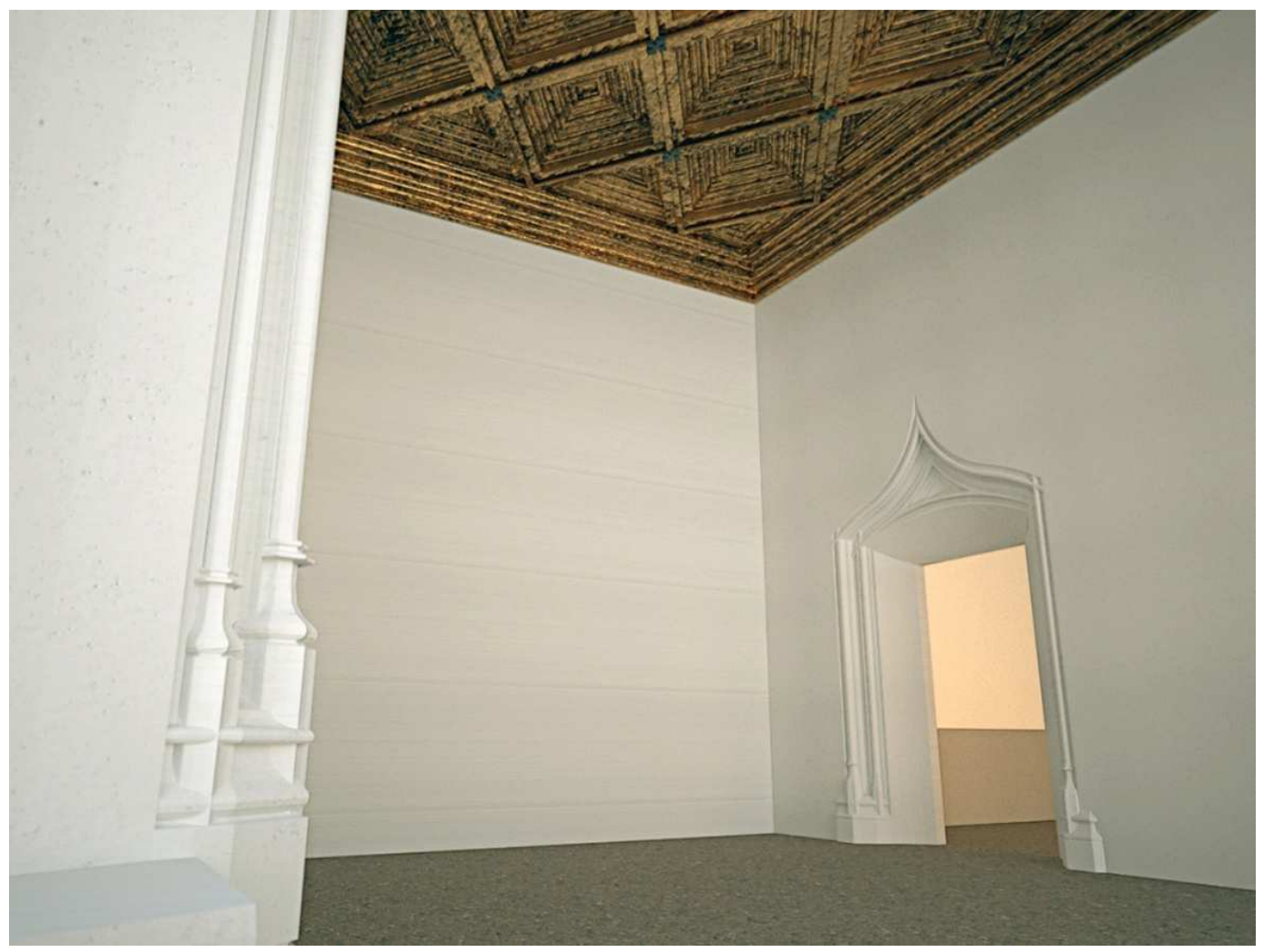

Figura 405. Perspectiva de la Sala 12 desde el festejador de la ventana. 
Aunque no disponemos de información concreta sobre el diseño del pavimento, sabemos que la sala estaba revestida con azulejos blancos y azules. A partir de esta información y con el objetivo de obtener una idea de cómo sería la sala originariamente, se han realizado dos hipótesis derestitución gráfica colocando en ella el pavimento localizado en la Torre de la Comare y expuesto en el Museo Arqueológico de Oliva: la hipótesis 1 corresponde con el despiece original tal y como se encontraba en esta localización y la hipótesis 2 realizando un nuevo despiece con estas mismas piezas emulando los pavimentos de las Salas Doradas del a Generalitat Valenciana. Además de insertar las imágenes rectificadas del pavimento, este se ha texturizando para darle el aspecto irregular característico de este tipo de pavimentos realizados a mano.

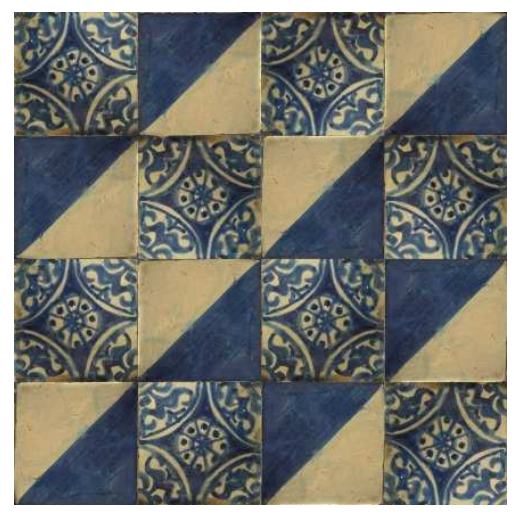

Figura 406. Pavimento azulejos decorados en blanco y azul procedentes de la Torre de la Comare. MAO. Izquierda: hipótesis 1 disposición original. Derecha: hipoteis 2 disposición similar a los Salones Dorados de la Generalitat Valenciana.

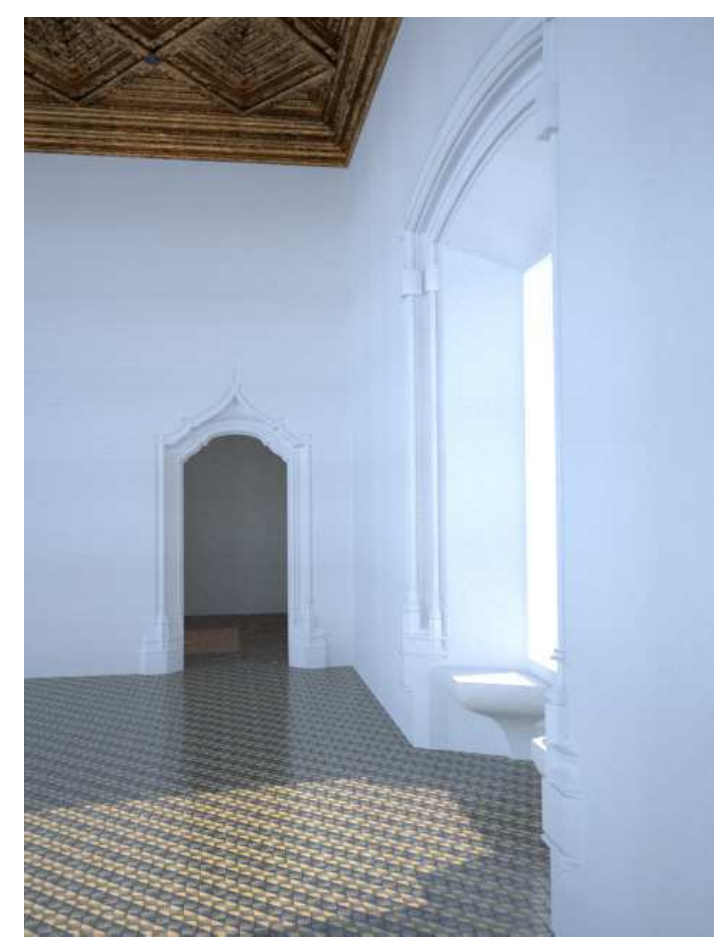

Figura 407. Renderizado de la Sala 12 con pavimento en blanco y azul. Izquierda: hipótesis 1. Derecha: hipótesis 2. 
Figura 408. Renderizado de la Sala 12. Detalle de la hipótesis 1 de pavimento junto a la D13.

Figura 409. Renderizado de la Sala 12. Detalle de la hipótesis 2 de pavimento junto a la V4. 


\section{ANAGLIFOS}

Los anaglifos son imágenes bidimensionales que tienen la capacidad de crear un efecto tridimensional cuando se ven con lentes especiales. Se basan en el fenómeno de síntesis de la visión binocular que fue patentado por Louis Ducos du Haroneen el 1891. Las imágenes de anaglifo se componen de dos capas de color, superpuestas pero movidas ligeramente una respecto a la otra con la finalidad de producir el efecto de profundidad. La imagen anaglifa contiene dos imágenes que están filtradas por color, una para cada ojo. Cuando se ve a través de las gafas, se visualiza una imagen tridimensional. La corteza visual del cerebro fusiona esta información percibiendo un objeto o escena con profundidad.

A pesar de su antigüedad estas imágenes vuelven a despertar interés debido a la presentación de imágenes y vídeos en Internet, así como videojuegos, películas de cine y DVD que han utilizado anaglifos para crear efecto de ficción tridimensional. También se han elaborado imágenes tridimensionales con esta técnica para su uso en la ciencia y el diseño, donde la percepción de profundidad es muy útil.

Para crear un anaglifo se necesitan dos fotografías tomadas en el mismo momento, con el objetivo de que tengan iguales condiciones de luz y escenografía. Además, las dos fotografías deben enfocar el mismo objeto, moviendo lateralmente la cámara entre 3 y 5 $\mathrm{cm}$ para realizar la segunda fotografía (la distancia entre los dos ojos).

En el caso de las fotografías tomadas por Fischer, tenemos una única fotografía de casi todos los elementos; sólo en algunos casos contamos con dos del mismo elemento tomadas con un punto de vista similar, por lo que se ha intentado obtener imágenes de anaglifo a partir de estos pares de imágenes. Para ello se ha utilizado la herramienta Anaglyph Maker.

\section{Portada 20}

De la portada 20 disponemos de dos fotografías con un punto de vista similar: fotografía $32^{499}$ y fotografía $1695^{500}$. La 32 se ha cortado a la misma altura que la 1695 y se les ha dado a ambas la misma dimensión y resolución mediante un software de retoque fotográfico.

\footnotetext{
${ }^{499}$ Fischer, E. (1917-1920.). AFG. Óp. cit. pp. 9 A.

${ }^{500}$ Sarthou, C. (1919-1920) Fotografías Palacio de Oliva. (1639, 1642-1644 y 1670-1698). Valencia: AGFDV.
} 


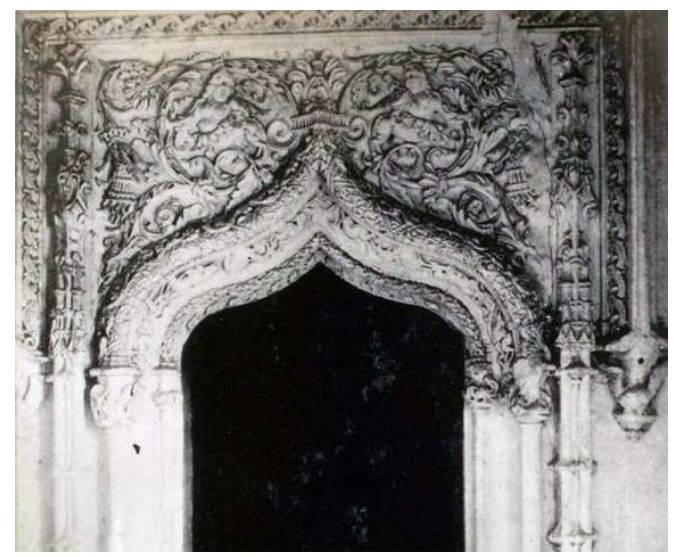

Figura 410. Izquierda: Fot. 32. AFG. Derecha: Fot. 1695. Sarthou, C. (1919-1920).

A partir de estas dos imágenes se ha obtenido la imagen Fot. 32 anaglifo.

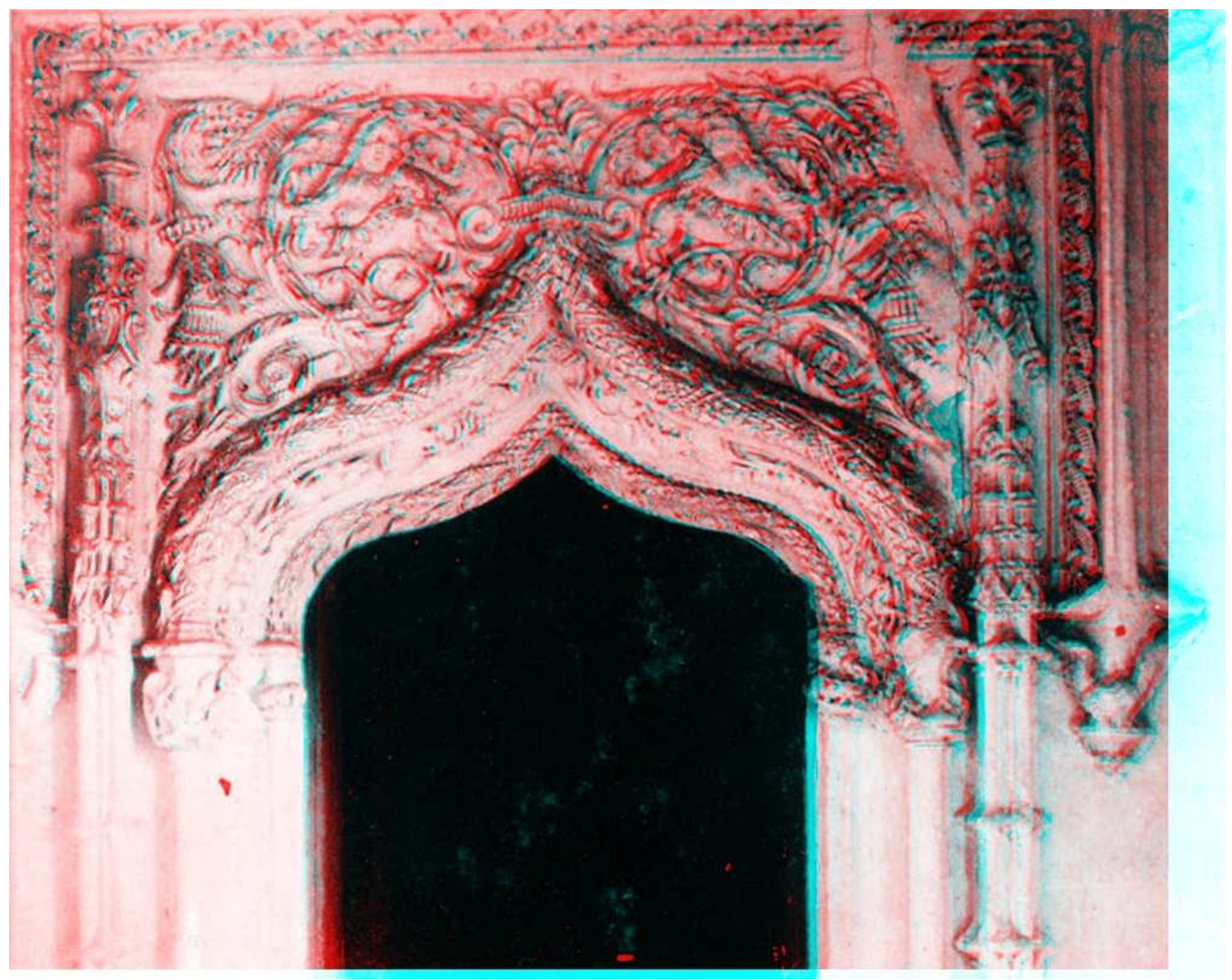

Figura 411. Fotografía 32 Anaglifo. Portada 20. Obtenida a partir de las fotografías 32 y 1695. 


\section{Portada 22}

En el caso de la Portada 22 disponemos de dos fotografías con un punto de vista similar: Fot. $28^{501}$ y Fot. $28 \mathrm{P}^{502}$. Se detectó que se trataba de dos tomas diferentes debido a que en la primera las puertas están cerradas y en la segunda abiertas, ya que el punto de vista es muy similar.

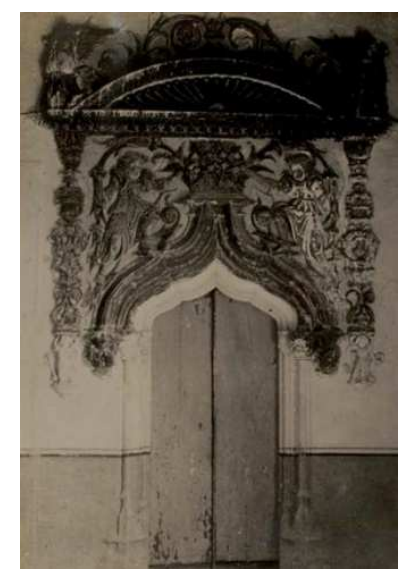

Figura 412. Izquierda: Fot. 28. AFG. Dcha.: Fot. 28P. AFP. Egil Fischer (1917-1920).

Estas imágenes se han optimizado mediante la herramienta Photoshop y se ha igualado su tamaño antes de introducirlas en el sotfware para crear la imagen anaglifo. Además, se han realizado diversas pruebas, obteniéndose la imagen Fot. 28 anaglifo. Al tratarse de fotografías antiguas y muy oscuras, el resultado no es óptimo, pero sí se consigue una imagen tridimensional pudiéndose apreciar la volumetría de la decoración de la portada.

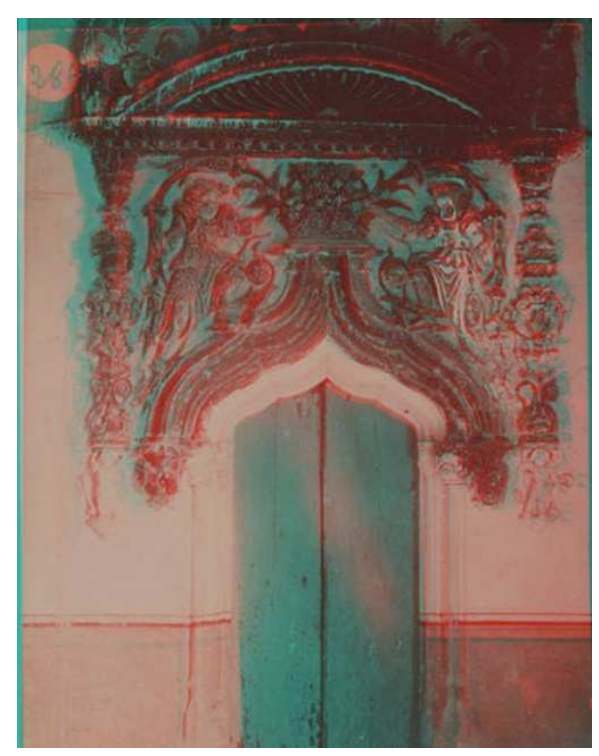

Figura 413. Fotografía 28 Anaglifo. Portada 22. Obtenida a partir de las fotografías 28 y $28 \mathrm{P}$.

\footnotetext{
${ }^{501}$ Fischer, E. (1917-1920.). AFG. Óp. cit. pp. 8A.

${ }^{502}$ Fischer, E. (1917-1920.). AFP. Óp. cit. pp. 7A.
} 


\section{Portada 24}

En el caso de la Portada 24 disponemos de dos fotografías con un punto de vista similar: Fot. $29^{503}$ y Fot. $29.1^{504}$. El punto de vista es muy similar, aunque en la primera sólo se encuentra la puerta, y en la segunda hay un grupo de personas fotografiadas frente a la portada (aparentemente se trata de Vilhelm Lauritzen con gente de Oliva).

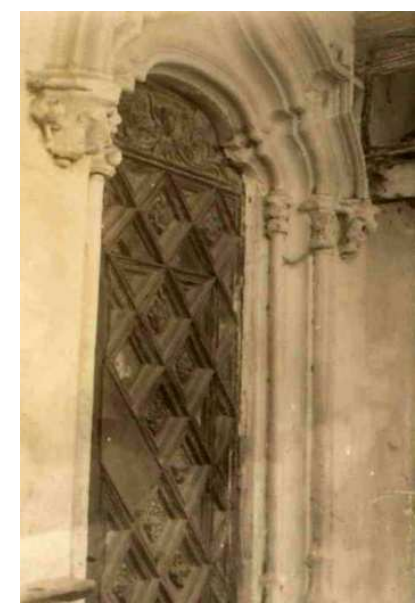

Figura 414. Izquierda: Fot. 29. AFG. Dcha.: Fot. 29.1. AFP. Egil Fischer (1917-1920).

En esta ocasión se ha igualado el tamaño de las fotografías, y en el caso de la Fot. 29.1 se ha "pegado" digitalmente ya que la imagen analógica se encontraba rota. Después de este proceso se ha obtenido la fotografía 29 anaglifo.

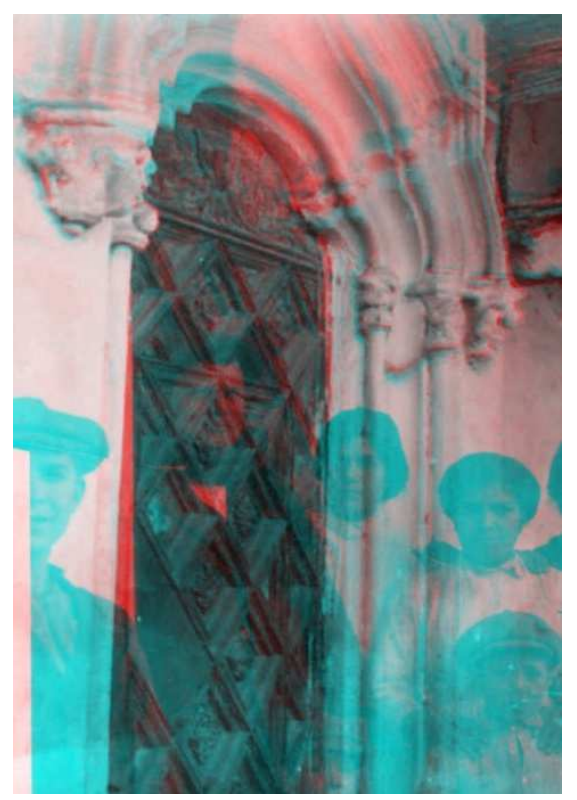

Figura 415. Fotografía 29 anaglifo. Portada 24. Obtenida a partir de las fotografías 29 y 29.1.

${ }^{503}$ Fischer, E. (1917-1920.). AFG. Óp. cit. pp. 8A

${ }^{504}$ Fischer, E. (1917-1920.). AFP. Óp. cit. pp. 6A. 


\section{Galería Patio}

En la galería del patio disponemos de dos fotografías con un punto de vista similar: Fot. 10 y Fot. $16^{505}$. En el caso de la primera existe un muro que tapa la parte inferior de la arcada, y en la segunda ya se ha retirado.

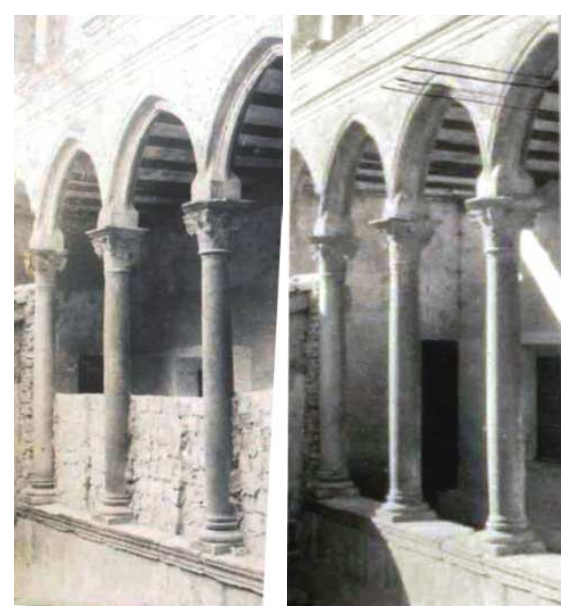

Figura 416. Izquierda: Fot. 10. AFG. Derecha: Fot. 29.1. AFP. Egil Fischer (1917-1920).

Asimismo, se han realizado diversos ajustes de tamaño, encuadre y orientación con la finalidad de ajustar al máximo dos fotografías y poder conseguir el objetivo deseado. Finalmente, se ha obtenido una nueva imagen anaglifo denominada "Galería Patio Anaglifo".

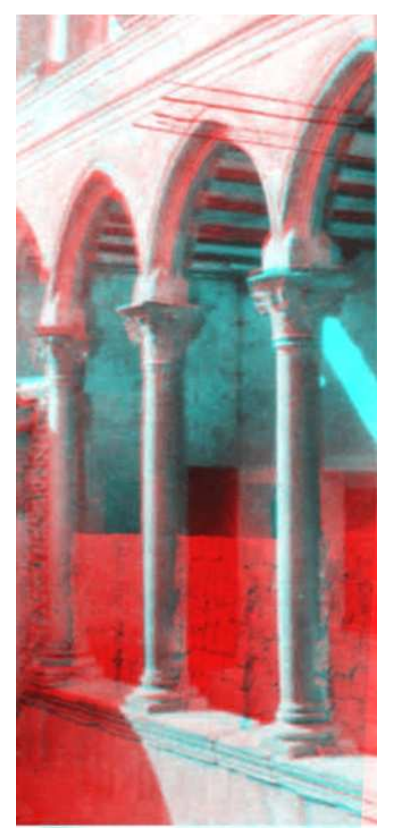

Figura 417. Galería Patio Anaglifo. Obtenida a partir de las fotografías 10 y 16

${ }^{505}$ Fischer, E. (1917-1920.). AFP. Óp. cit. pp. 2R y 3R. 


\section{MAQUETAS}

\subsection{Maquetas físicas}

La impresión en 3D se ha convertido en los últimos tiempos en una potente herramienta, y no sólo para la visualización y concepción espacial; su potencial va más allá, permitiendo la creación de prototipos de una manera rápida y efectiva, e incluso facilitando la fabricación de piezas o elementos únicos a un coste razonable. Así, su campo de aplicación es muy amplio: la creación artística, el diseño industrial, la ingeniería, la arquitectura, la arqueología y la biomedicina, por citar algunos de los campos más relevantes.

Otra de las funciones de las maquetas es servir de instrumento perceptivo para que personas con problemas de visión puedan acceder a la información de carácter gráfico y visual. Además, en el ámbito del patrimonio arquitectónico existe numerosa documentación de carácter visual que es, prácticamente, inaccesible para una persona invidente. Por ello, las maquetas, utilizadas como herramienta de percepción táctil, permiten que este conjunto de personas con discapacidad visual puedan obtener este tipo de información mediante el sentido del tacto.

En el campo del patrimonio arquitectónico y la museología existen numerosos enfoques de estudio dedicados al desarrollo de dispositivos orientados a personas con ceguera o deficiencia visual. Estos dispositivos táctiles son utilizados como instrumentos didácticos de apoyo a la visita en museos y espacios de divulgación de la cultura. Podemos establecer los siguientes tipos ${ }^{506}$ :

- Láminas en relieve, dibujos y diagramas táctiles.

- Maquetas y planos en relieve.

- Modelos.

En los últimos años se han desarrollado determinadas técnicas para la fabricación rápida de prototipos, en concreto de fabricación aditiva, comúnmente conocidas como "impresión en $3 D^{\prime \prime}$, que han posibilitado la realización de estas maquetas de una manera muy efectiva ${ }^{507}$.

En el campo de la arquitectura se han realizado diversos estudios sobre el uso de las maquetas táctiles arquitectónicas producidas mediante impresión 3D como el llevado a cabo por Voigt y Martens (2006). Así, a partir de la gran cantidad de edificios digitalizados pertenecientes al patrimonio arquitectónico, es posible desarrollar maquetas táctiles orientadas a todos los públicos y especialmente a las personas con discapacidad visual. A

\footnotetext{
${ }^{506}$ Consuegra Cano, B. (1997). La visita al museo de alumnos ciegos y deficientes visuales. Integración, Revista sobre discapacidad visual, (24), 47-50.

${ }^{507}$ Gual, J., Serrano, J., y Máñez, M. J. (2015). Aplicación de la fabricación aditiva en la obtención de moldes para termoconformar gráficos tangibles orientados a personas con discapacidad visual. Tangible graphics using rapid prototyping techniques: volume as a design constituent. The Spanish Digital Journal on Blindness and Visual Impairment, 66.
} 
través de estas maquetas se facilita la comprensión del espacio arquitectónico construido ${ }^{508}$.

A escala nacional existen también experiencias destacables como la llevada a cabo desde la Universitat Jaume I, en colaboración con la Universitat Politècnica de València y la Universitat Politècnica de Catalunya, con diversas experiencias positivas en el campo de los planos táctiles producidos mediante impresión $3 D^{509}$. Asimismo, a escala local también se han desarrollado proyectos que tienen como objetivo el desarrollo de maquetas y planos táctiles que permiten la difusión del patrimonio arquitectónico entre las personas con problemas visuales y el público en general ${ }^{510}$.

En nuestro caso en particular, a partir del modelado tridimensional realizado de algunos de los elementos del palacio, se han creado los sólidos de las piezas y se han exportado a un archivo LST para poder realizar una impresión tridimensional de las mismas.

La creación de los modelos físicos o maquetas se ha realizado mediante distintas técnicas de prototipado rápido, concretamente mediante el método de Fabricación Aditiva (Additive Manufacturing, AM). Durante el proceso de fabricación o construcción de las piezas el material se deposita lentamente, de manera que se crea, capa a capa y progresivamente, la geometría de la pieza. Esta herramienta también se conoce como "técnicas de fabricación en capas" ${ }^{\prime 11}$. Para la realización de nuestro proyecto se han utilizado tres técnicas de impresión: deposición de hilo de plástico (FDM), esterolitografía (SLA) y con polvo (3DP). Para la impresión con hilo se ha utilizado una impresora WANHAO Duplicator 3Plus con una velocidad de impresión de $50-250 \mathrm{~mm}$ y un espesor de capa de $0.1 \mathrm{~mm}$ con filamento de $1.75 \mathrm{~mm}$. La dimensión máxima de impresión es 200 × 200 × 200 mm. El material empleado ha sido plástico PLA de color verde.

Por su parte, para la impresión en resina se ha utilizado una impresora 3D XYZprinting Nobel 1.0A con tecnología de estereolitografía (SLA). El tamaño máximo del área de impresión es de $128 \times 128 \times 200 \mathrm{~mm}$ y el material utilizado ha sido resina acrílica fotosensible transparente. Se ha empleado un espesor de capa de $0.05 \mathrm{~mm}$.

\footnotetext{
${ }^{508}$ Voigt, A., y Martens, B. (2006). Development of 3D tactile models for the partially sighted to facilitate spatial orientation. En: Communicating Space(s): 24th eCAADe Conference Proceedings, pp. 366-370. Volos (Grecia): University of Thessaly.

${ }^{509}$ Gual, J., Puyuelo, M., y Lloveras, J. (2014). Three-dimensional tactile symbols produced by 3D printing: improving the process of memorizing a tactile map key. British Journal of Visual Impairment, 32 (3), 263-278, Gual, J., Puyuelo, M., \& Lloveras, J. (2015a). Improving tactile map usability through 3D printing techniques: An experiment with new tactile symbols. The Cartographic Journal, 52, 51-57, Gual, J., Puyuelo, M., y Lloveras, J. (2015). The effect of volumetric (3D) tactile symbols within inclusive tactile maps. Applied Ergonomics, 48, 1-10 y Gual, J., Puyuelo, M., Lloveras, J., y Merino, L. (2012). Visual impairment and urban orientation: pilot study with tactile maps produced through 3D printing. Psychology: Ambiental-Bilingual Journal of Environmental Psychology, 3 (2), 239-250.

${ }^{510}$ Máñez Pitarch, M.J., Gual Ortí, J. Garfella Rubio, J.T. y Martínez Moya, J.A. (2016). RenaissanceStyle Architecture in El Maestrazgo: From Virtual to Tactile Models. En Giuseppe Amoruso (Ed.), Handbook of Research on Visual Computing and Emerging Geometrical Design Tools. Hershey, Pensilvania: IGI Global.

511 Máñez Pitarch, M J., Gual Ortí, J. Garfella Rubio, J. T. y Martínez Moya, J. A. (2016). Óp. cit. pp.187.
} 
Por último se ha utilizado la impresora 3D Mod Z Printer 310. En este caso el material es polvo especial de impresiónzp ${ }^{\circledR} 150$ y aglutinante ZBR 60 . La medida máxima de impresión es de $280 \times 220 \times 200 \mathrm{~mm}$. El espesor de capa es de $0.1 \mathrm{~mm}$. En los dos primeros casos los resultados son aceptables, si bien la textura de los materiales no es la óptima para este tipo de piezas arquitectónicas, existiendo asimismo una gran limitación en el tamaño de impresión. La ventaja de estos materiales es su dureza y resistencia a golpes y caídas.

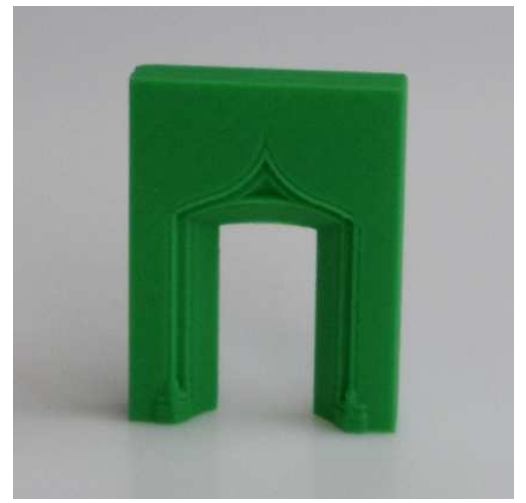

Figura 418. Maqueta portada D28. Izquierda: impresión con hilo PLA. Derecha: impresión en resina fotosensible.

En el tercer caso se han realizado dos pruebas de impresión de la portada D28 a escala 1:20 y la basa izquierda de la portada D28 a escala 1:7,5. En esta ocasión se ha obtenido un acabado más arquitectónico, con una textura similar a los modelos originales (portadas de yeso). El inconveniente de estas maquetas, sin embargo, es su fragilidad, aunque se pueden tratar con un consolidante, si bien pierden su textura y color original.
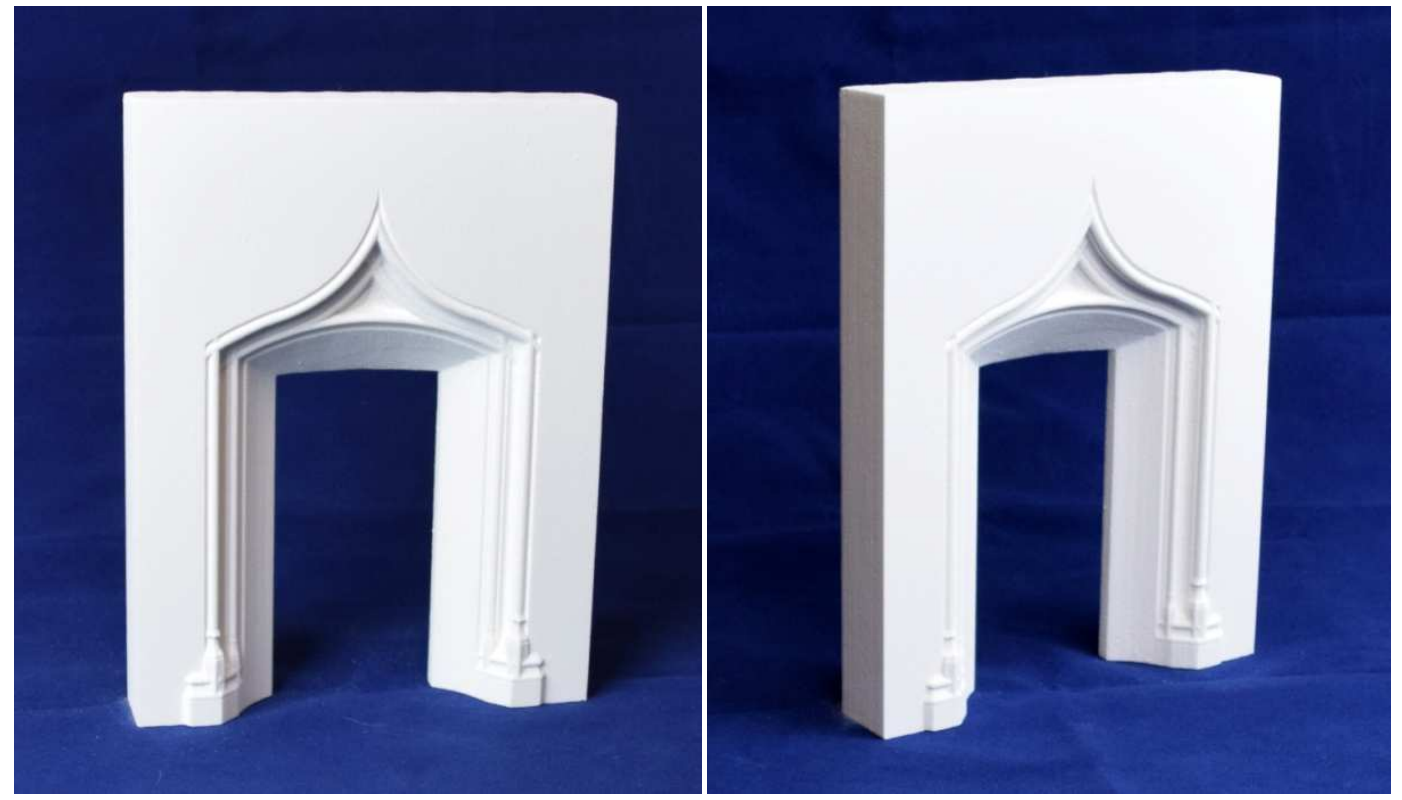

Figura 419. Maqueta portada D28. Impresión con impresora Z Printer 310. Material: $\mathrm{zp}^{\circledR} 150$ y aglutinante $z b^{\circledR} 60$. 

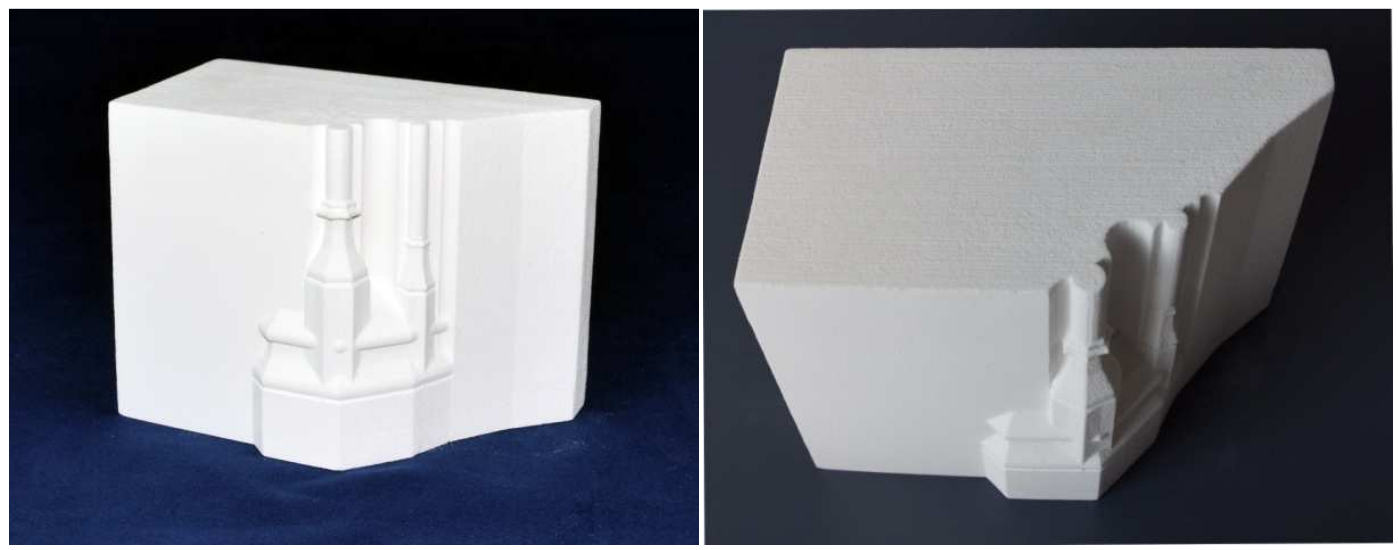

Figura 420. Maqueta basa izquierda portada D28. Impresión con impresora Z Printer 310. Material: $z p^{\circledR} 150$ y aglutinante $z b^{\circledR} 60$.

\subsection{Maquetas virtuales}

Los métodos de representación han evolucionado a lo largo de los siglos, si bien la irrupción de la informática ha revolucionado exponencialmente tanto los métodos de generación y representación gráfica como la propia generación y desarrollo de ideas y proyectos, permitiéndonos una comunicación exhaustiva y detallada de las características del proyecto o elemento representado, y una visualización próxima a la realidad del elemento proyectado $^{512}$.

En el campo del patrimonio arquitectónico las posibilidades del uso de maquetas virtuales como herramienta de proyecto y difusión de contenidos son múltiples, tanto en la fase de toma de datos, como en la gestión de la documentación, y en la de modelado, permitiendo una mejor visualización del modelo desde las primeras fases del proyecto. Esta herramienta facilita en todo momento la corrección de los modelos 3D generados, así como la correcta visualización de las restituciones gráficas, y propuestas de restauración y conservación a nivel compositivo y cromático, etc.

En el caso de edificios históricos donde una parte delos mismos ha desaparecido o ha sido dañada, esta puede ser restituida virtualmente y visualizada de una manera efectiva mediante esta herramienta, permitiéndonos realizar una visualización efectiva, próxima a la realidad al aplicar distintas texturas y buscar puntos de vista similares a una visión real, que aproximen el espacio virtual representado al espacio arquitectónico original de una manera efectiva y sostenible ${ }^{513}$. Este tipo de restitución gráfica puede aplicarse no sólo a un edificio aislado, sino a todo su entorno urbano o paisajístico ${ }^{514}$, lo que nos permite, por ejemplo,

512 Gaiani, M. (2008). Architectorum delineamenta, ovvero le interfacce di lavoro dell'architetto, En: Abitare virtuale significa rappresentare, Roma, Edizioni Kappa, pp. 74-119.

513 Ceconello, M., y Paquet, E. (18-04-07). Virtual urban design. En: $9^{\text {th }}$ Virtual Reality International Conference. pp. 26-31. Laval, Francia.

514 Ceconello, M. y Sallazzo, D. (06-10-08). Virtual Reality for enhanced Urban Design. En: $5^{\text {th }}$ INTUITION International Conference; Virtual Reality in Industry and Society: From Research to Application. pp. 66. Turín, Italia. 
situar el Palacio de Oliva de manera virtual en el entorno urbano actual y analizar el resultado desde un punto de vista urbanístico y paisajístico.

De este modo, partiendo de estas premisas y del material gráfico existente (planos de distribución del palacio, planos de cubiertas, croquis de plantas y fachadas, las fotografías generales y de detalle del exterior, así como de los testimonios escritos que nos definen algunos de sus elementos) se ha levantado una maqueta virtual del exterior del palacio, intentando dar una visión de cómo era en $1917^{515}$, cuando Fischer lo visitó por primera vez. No se trata de una maqueta rigurosamente científica, ya que carecemos de muchos datos, aunque también en este caso se han tratado de completar con información complementaria disponible. El resultado del trabajo es una primera maqueta virtual conceptual que permita entender este gran Palacio en su conjunto.

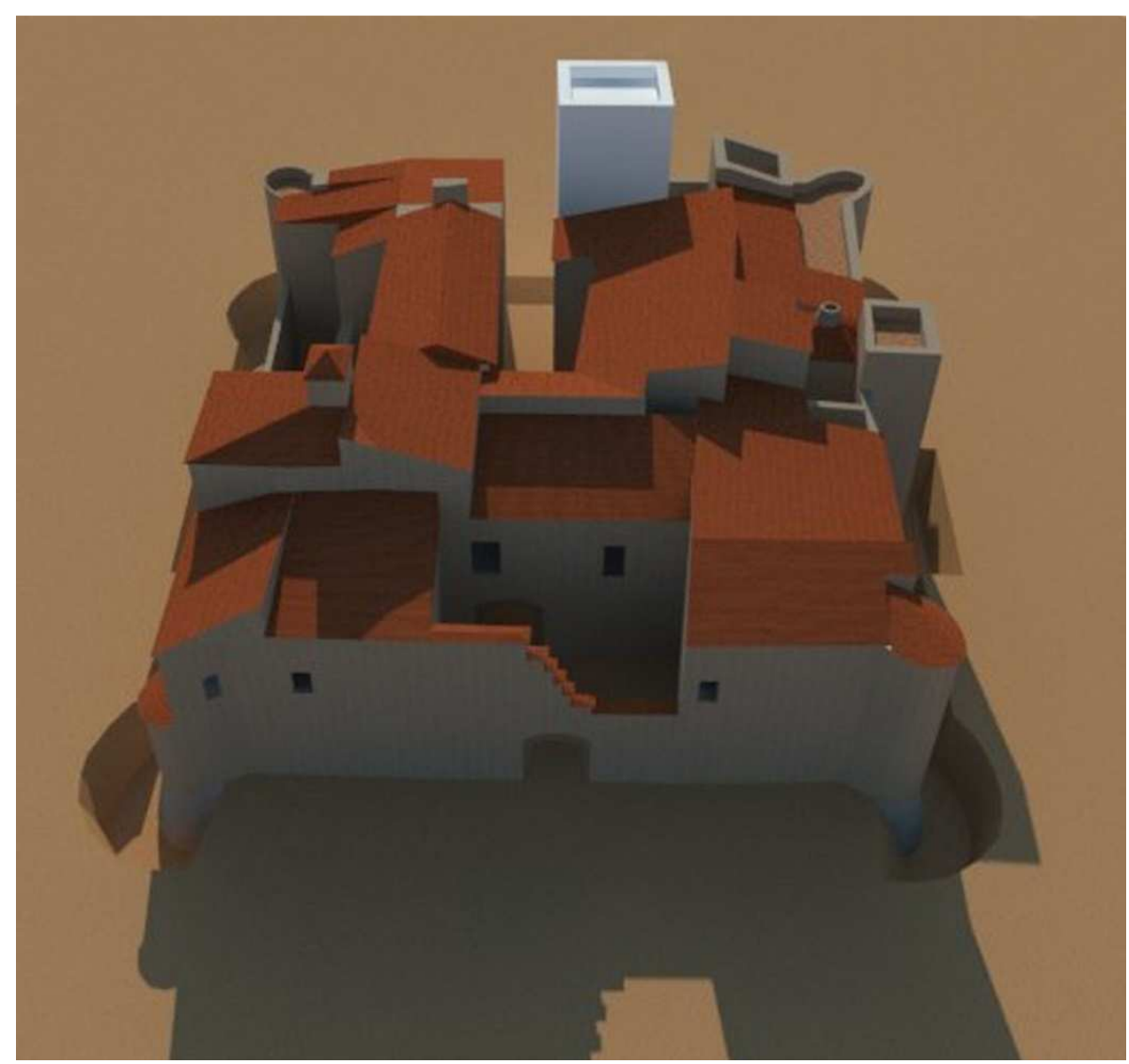

Figura 421. Maqueta virtual del palacio. Vista axonométrica desde la fachada NE.

515 En esta restitución se ha añadido la Torre Maestra dado su carácter icónico en el conjunto del Palacio, aunque no se ha texturizado para diferenciarla del resto que sí se encontraba en pie en 1917. 


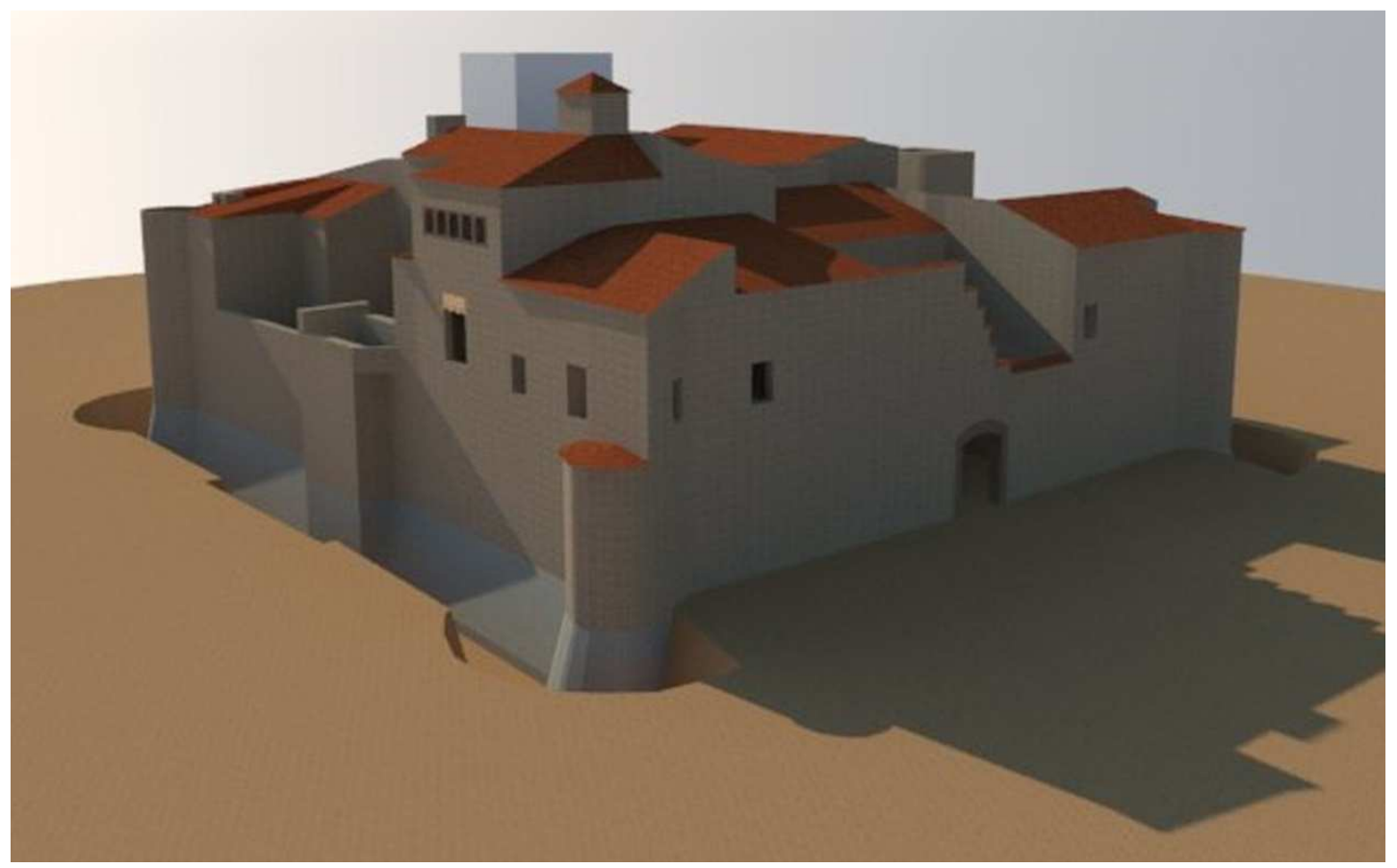

Figura 422. Maqueta virtual del palacio. Vista axonométrica. Fachadas NE y SE. 



\section{CAPITULO VIII}

\section{CONCLUSIONES}

\section{EL EDIFICIO}

El Castillo-palacio de Oliva fue, por sus dimensiones y por su riqueza arquitectónica y ornamental, único en todo el Reino de Valencia; siendo, asimismo, un laboratorio donde se experimentaron nuevas formas arquitectónicas "a la romana" sobre los sólidos muros de una fortaleza de impronta gótica.

Todos los viajeros e historiadores que tuvieron la oportunidad de visitarlo cuando todavía estaba en pie quedaron impresionados por la singularidad y riqueza de sus elementos arquitectónicos. Así, Gaspar Escolano, Sebastián Castellanos, Llorente, García Simancas, Tormo y Sarthou, entre otros, han sabido trasmitirnos con sus palabras la singularidad del edificio.

\subsection{Enclave}

El palacio se fue construyendo a los pies de la gran Torre Maestra, mandada edificar por Jaume I tras la Reconquista. La torre era de planta rectangular y tenía unas medidas aproximadas de $36 \times 23$ palmos $(8,28 \times 7,36 \mathrm{~m})$. Su altura era de 120 pies $(27,6 \mathrm{~m})$. Dado que la altitud aproximada en su base era de $30 \mathrm{msnm}$ y la de la torre de $57 \mathrm{msnm}$ aproximadamente, posibilitaba tener una visibilidad desde esta cota de prácticamente toda la Conca de la Safor, desde Gandía hasta Denia, divisándose desde ella los Castillos de Rebollet Palma y Bayrén. No cabe duda de que su localización en la falda de la montaña de Santa Ana era un lugar estratégico tanto para la comunicación a pie (se encontraba en la vía que unía Valencia con Denia), por mar (estaba próximo a la costa y disponía de puerto), como para la comunicación por señales a través de las torres vigía (estaba localizado en un lugar privilegiado en la falda de una pequeña montaña muy próxima a la costa). El crecimiento del edificio se produjo en dirección SO-NE, manteniendo sus alineaciones principales paralelas a las de la primitiva torre.

\subsection{Datación}

Aunque hay constancia de la existencia de un castillo en esta ubicación desde el siglo XIV, en tiempos de los Carrós, la gran transformación en palacio tuvo lugar durante los siglos XV y XVI. Tradicionalmente se ha atribuido a Serafín de Centelles su gran renovación al introducir el nuevo gusto "a la romana" debido a su papel de humanista y protector de las artes. Esta reforma tuvo lugar entre 1511 y 1515. Tras la ocupación del palacio por parte de los agermanados se produjo una nueva intervención en 1921; obras que finalizarían en $1531^{516}$. Se atribuye a su sobrino Francesc Gilabert la gran fortificación del palacio,

\footnotetext{
${ }^{516}$ Esta fecha viene sugerida por la inscripción que se encontraba en el escudo de armas situada sobre la puerta de acceso.
} 
convirtiéndolo en un alcázar, cuyos trabajos finalizarían en 1546-1546 $6^{517}$. Sin embargo, hay dos datos que debemos tener en cuenta: el primero de ellos es el lema que, de forma casi encriptada, estaba pintado en la moldura del friso de la Sala de Armas. Su mensaje nos lleva a pensar que la decoración de esta sala se finalizó posteriormente a la ocupación del palacio por parte de los agermanados ${ }^{518}$; y por otro lado, la información contenida en el inventario de $1550^{519}$, según la cual en esa fecha se encontraba acopiado en diversos habitáculos gran parte del material para la construcción de la galería del Patio Central, por lo que las obras, al menos de este elemento o parte del mismo, se realizarían posteriormente a la muerte de Francesc Gilabert.

\subsection{Magnitud}

El edificio era de planta casi cuadrangular con 4 torres circulares en sus esquinas y dos torres rectangulares. Sus dimensiones aproximadas eran de 58 varas $\times 46$ varas y dos palmos $(53,5 \times 46,5 \mathrm{~m})$ y cubría una superficie de $2.250 \mathrm{~m}^{2}$, el equivalente a 2,7 fanegadas. El cuerpo cuadrangular del edificio se inscribe en una circunferencia de $50,20 \mathrm{~m}$ (54 v y 2 p); y el inmueble, incluidas las torres, se inscribe en un círculo de $70 \mathrm{~m}$ (76 v). El ángulo que forma el eje principal con la alineación NS es de $22^{\circ}$. Por sus dimensiones en planta se puede comparar con los Palacios de Cocentaina (56,5 x 59,3 m) y Gandía (49 x 52 m el cuerpo original), lo que nos permite afirmar que se trató de uno de los mayores castillospalacio del Reino de Valencia de principios del siglo XVI.

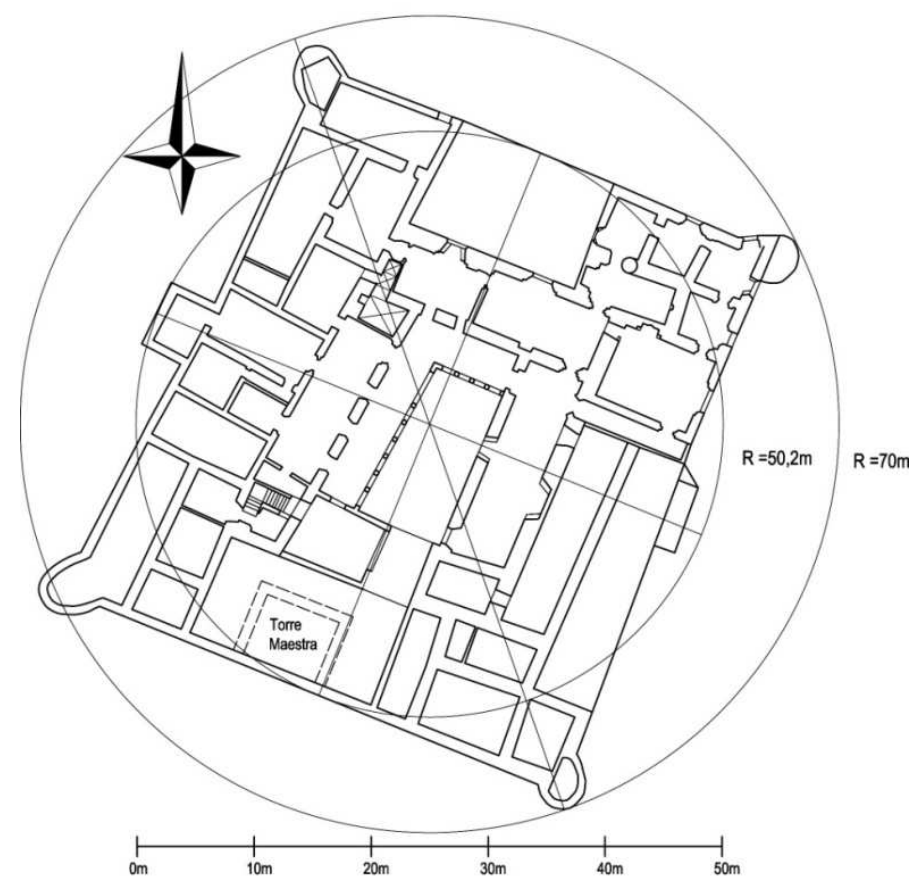

Figura 423. Plano general de planta. Orientación y círculos circunscritos.

\footnotetext{
${ }^{517}$ Así lo describen las lápidas conmemorativas que se encontraban en la antesala Condal transcritas por Sebastián Castellanos en su ubicación original.

${ }^{518}$ Arciniega, L. (2001). Óp. cit. pp. 77.

${ }^{519}$ Felip Sempere, V. (2001). Óp. cit. pp. 309-310 y 347-348.
} 


\subsection{Tipología constructiva}

el Palacio cumple escrupulosamente todas y cada una de las características de los castillospalacios valencianos ${ }^{520}$ : muros de las plantas bajas en talud, patio central descubierto; cuatro plantas (planta baja, entresuelo, planta noble y andana); escalera de la planta noble situada en un ángulo del patio ${ }^{521}$; edificio aislado de otras construcciones; fachada principal más cuidada con una gran portada de acceso; entresuelo con ventanas rectangulares; planta noble con ventanas ajimezadas; logia en la andana para ventilar; gran alero con vigas labradas ${ }^{522}$; fachadas sin ningún tipo de simetría; pozo en el patio; planta baja destinaba a dependencias de servicio, establos y bodega; escalera de acceso al entresuelo desde el vestíbulo; planta noble abierta al patio interior mediante ventanas o galería de arcos donde se localizan las estancias de los señores, con techos muy altos formados por alfarjes tallados y policromados; andana con acceso por escaleras interiores, donde vivían los criados y se guardaban alimentos y otros enseres; y huerto-jardín ${ }^{523}$.

Su estructura vertical estaba formada por gruesos muros realizados por fábricas de mampostería en sus arranques y algunos de sus muros, fábricas de tapial con hiladas de ladrillo y muros de fábrica de ladrillo tomados con mortero de cal. En la planta baja se abrían grandes huecos en los muros formados por arcos apuntados de fábrica de ladrillo. Los elementos de cantería se reservaban a los huecos de los portones de entrada y a los grandes arcos en la planta baja del patio central; esto es debido a que el edificio está enclavado en una zona donde predominan los materiales terrosos frente a la piedra ${ }^{524}$.

En cuanto a la estructura horizontal encontramos los siguientes elementos constructivos: bóvedas de cañón construidas con fábrica de ladrillo, bóvedas tabicadas en arista de fábrica de ladrillo, forjados de madera y revoltón de ladrillo y yeso, y artesonados de madera. Los dos primeros tipos se utilizarían predominantemente en la planta baja, aunque también como soporte de la planta principal (cocina) o incluso para cubrir las salas 13, 15, 17 y 19. Los artesonados de madera los encontramos en las grandes salas (11 y 12) y los forjados con revoltón de ladrillo y revestidos de yeso son los más utilizados para cubrir la planta entresuelo y principal, existiendo desde sencillos revoltones de yeso a revoltones decorados en relieves y otros decorados con pinturas de gran belleza y sofisticación como es el caso de la Sala de Armas.

\footnotetext{
${ }^{520}$ Zaragozá Catalán, A. (2000). Arquitectura Gótica Valenciana. Siglos XIII-XV Valencia: Generalitat Valenciana. Conselleria de Cultura i Educació. pp. 206-218.

${ }^{521}$ El uso de estas escaleras exteriores se extendieron en los reinos de Valencia y Mallorca a partir del S.XIII. Según Federico Iborra provienen de oriente y llegaron a España a través de Italia. Iborra Bernar, F. (2013). Óp. cit. pp. 471.

${ }^{522}$ Arciniega, L. (2001) Óp. cit. pp. 74.

${ }^{523}$ En el inventario de 1550 se hacer referencia a la torre llamada de "I'Ort de Savall". En Felip Sempere, V. (2201). Óp. cit. pp. 343.

${ }^{524}$ Zaragozá Catalán, A. y Gómez Ferrer, M. (2008) Lenguajes, fábricas y oficios en la arquitectura valenciana del tránsito entre la Edad Media y la Edad Moderna. (1450-1550) en Artigrama, núm. 23. pp. 122.
} 
En cuanto a la decoración de huecos de puertas y ventanas, así como bóvedas se utilizó fundamentalmente el yeso modelado o tallado (basas y capiteles) y aterrajado (jambas y arcos), y en la decoración de forjados el yeso moldeado. En el caso de las bóvedas pudieron usarse tanto el modelado (nervios y claves) como el moldeado (cornisas, casetones y frontones). Estas técnicas tienen una clara influencia andalusi ${ }^{255}$.

\subsection{Sus constructores}

Desgraciadamente, no se disponen de los protocolos notariales que permitan poder confirmar quiénes fueron los autores de este gran palacio, aunque sí podemos afirmar en base a su gran variedad formal que en ella intervinieron numerosos mestres de obra, menestrals, entalladors, mestres de obra d'algeps, etc.

En cuanto a los elementos de cantería del palacio, se emplearon los siguientes: arcos escarzanos del patio, escalera exterior y puerta de acceso a la planta noble y ventanas ajimezadas con interior capialzado y capiteles decorados. En esta ocasión la referencia es claramente el maestro de obra Joan Corbera, quien realizaría elementos de similar factura en el Palacio de la Generalitat entre 1497 y $1527^{526}$ y en el Consulado del Mar entre 1506 y $1533^{527}$ a quien, además, se le encargarían unas ventanas en el Palacio de la Generalitat "como las del Palacio del Conde de Oliva", lo que nos da a entender que el maestro trabajó para el Conde de Oliva, si no en éste, en alguno de sus palacios valencianos ${ }^{528}$. Otra referencia podría ser Miguel de Maganya, maestro de obra muy activo en esa época junto con Corbera ${ }^{529}$.

En cuanto a la ornamentación renacentista en yeso, la referencia es Lluís Muñoz, quien con toda probabilidad trabajó en el Palacio de Oliva. A él se le atribuye la obra de la capilla de Todos los Santos de Portaceli, y muchas de las yeserías del Palacio de Oliva se realizaron con los mismos moldes ${ }^{530}$. El maestro Muñoz trabajó también en la Capilla de la Generalitat siendo Serafín Centelles contador de la institución.

\footnotetext{
${ }^{525}$ Giner García, M.I. (2007). 'Óp. cit. pp. 416-418, Marín Sánchez, R. (2014). pp. 99-129 y Marín Sánchez, R. (26-12-11). Bóvedas de crucería con nervios prefabricados de yeso y de ladrillo aplantillado. En: Actas del Séptimo Congreso Nacional de Historia de la Construcción. (pp. 841-850). Santiago de Compostela, España.

${ }^{526}$ Gavara Prior, J. y E. Muller, P. (2013). pp. 23.

${ }^{527}$ Ramírez Blanco, MJ. (2013)..Óp. cit. pp. 98-135.

${ }^{528}$ Según el inventario de 1550 , los condes de Oliva tenían tres casas en Valencia. Felip Sempere (2001). Óp. cit. pp. 308.

${ }^{529}$ Gavara Prior, J. y E. Muller, P. (2013). pp. 24 y Gómez Ferrer, M. y Corbalán, J. (2004). La casa del obispo de Tortosa, Alfonso de Aragón. Un Palacio valenciano en la encrucijada de los siglos (XV-XVI). Ars Longa. Num. 13. pp. 11-13.

${ }^{530}$ Gavara Prior, J. y E. Muller, P. (2013). pp. 24.
} 


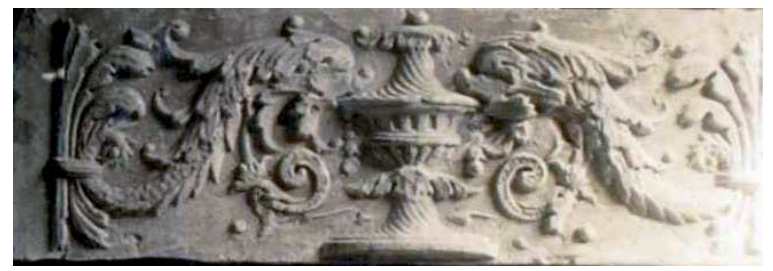

Figura 424. Izquierda: Fot. 44. Pieza de yeso con decoración en relieve. Bóveda portada D10. Derecha: Decoración del friso de la Capilla de Todos los Santos. Monasterio de Portaceli.

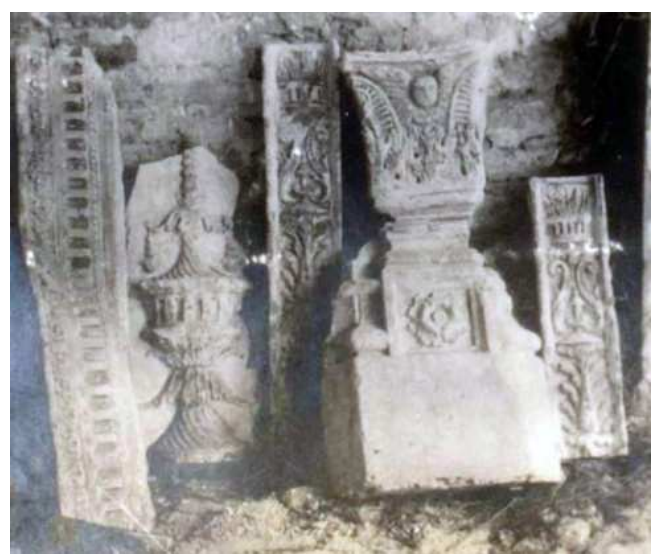

Figura 425. Izquierda: Piezas desmontadas portada D7. Fot. 4. Egil Fischer. Centro y derecha: cornisa y elemento en jarra. Decoración de la Capilla de Todos los Santos. Monasterio de Portaceli.

También los nervios de la bóveda de la sala 15 guardan un gran parecido formal con los nervios de la bóveda de la Capilla de Todos los Santos, aunque estos elementos se debieron de realizar con la técnica del modelado (tallado).

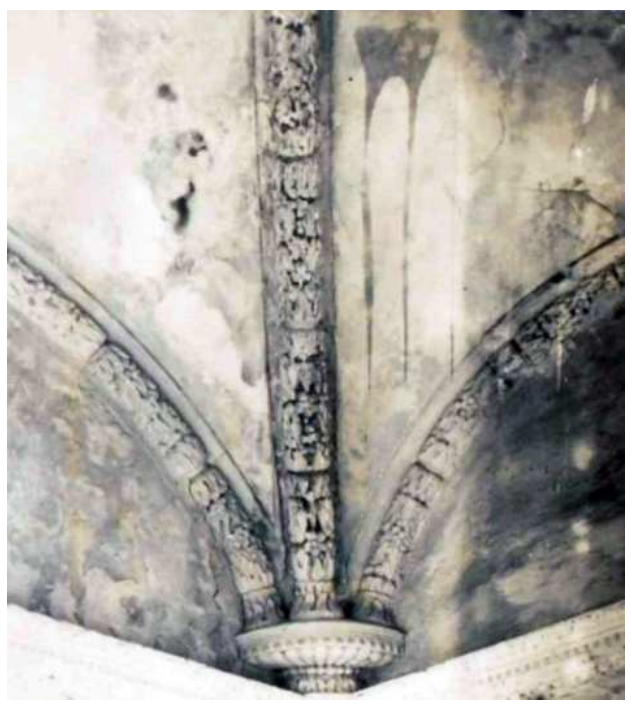

Figura 426. Nervios bóveda crucería Sala 15. Izquierda: Fot. 51. Egil Fischer. Derecha: Nervios bóveda Capilla de Todos los Santos. Monasterio de Portaceli. 
Lluís Muñoz es definido como mestre de la obra de talla axi de fusta com de algeps de pedra ${ }^{531}$.Trabajó en los artesonados de la Generalitat, por lo que podría haber participado también en los artesonados de los casetones de las Salas 11 y 12, también dorados como los de la Generalitat; aunque sin ornamentación en relieve ${ }^{532}$ Trabajó también en los elementos decorativos de los portales y ventanas de la Generalitat, junto con el maestro Corbera. Algunas de estas portadas guardan muchos paralelismos con las del Palacio de Oliva; como la decoración en ángulo de acceso a los studis de la planta principal, cuyos medallones tallados guardan gran similitud con los de la portada de la escalera de Oliva. Sabemos también por los libros de la Generalitat que los diputados enviaron al maestro en 1519 a las canteras propiedad del Conde de Oliva, recientemente descubiertas, para comprobar la idoneidad del material para ser usado en los studis ${ }^{533}$.

Otro de los maestros que pudo tomar parte de la obra del Palacio es Jaume Vicent, quien trabajó junto con Muñoz en el órgano de la Catedral y asumió en 1517 el encargo de la Capilla de la Casa de la Ciudad, realizada "a la romana", y en la que trabajaría también Muñoz.

Independientemente de su autoría, en la portada D20, enmarcada entre dos pináculos de estilo gótico flamígero o "pilares recambiados", encontramos la estela del maestro Pere Compte y de su círculo; quien utilizó este tipo de elementos para enmarcar muchas de sus portadas, como la de la capilla del Palacio de Mosén Sorell, aunque en este caso se sustituye la decoración gótico-flamígera de las enjuntas del arco por decoración "a la romana" ${ }^{1534}$.

\section{LEGADO GRÁFICO}

El estudio de la documentación disponible confirma el inmenso valor del legado gráfico de este destacado palacio, a caballo entre el último gótico y el primer renacimiento, adquiriendo mayor relevancia tras su casi total desaparición. Uno de sus elementos arquitectónicos más representativos son, sin duda, sus portadas; siendo, probablemente, las de mayor interés y complejidad para su análisis gráfico; por lo que el grueso del trabajo se ha centrado en las mismas, dedicándoles un capítulo independiente.

El material elaborado por E. Fisher y V. Lauritzen supone una toma de datos del estado real del edificio llevado a cabo en una vasta zona del mismo entre los años 1917-1920; aportándonos una gran colección de croquis, planos a escala y fotografías. Es un material gráfico valiosísimo para la historia de la arquitectura y la construcción, y ha sido poco estudiado hasta el momento. Pese a su gran interés, en algunos casos la información existente está incompleta. También los levantamientos gráficos tienen sus límites, puesto que es casi imposible reflejar los diversos parámetros de la arquitectura de los elementos

\footnotetext{
${ }^{531}$ Aldana, S. (1995). Óp. cit., vol. I. pp. 198-200.

${ }^{532}$ Gavara Prior, J. y E. Muller, P. (2013). pp. 25-26.

${ }^{533}$ Gavara Prior, J. y E. Muller, P. (2013). pp. 25-26 y 35 y Aldana, S (1992). Óp. cit. pp. 208-209.

${ }^{534}$ Zaragozá Catalán, A. y Gómez Ferrer, M. Óp. cit. pp. 90-97.
} 
representados, ni de la compleja geometría de los motivos decorativos. La presente investigación ha tratado de analizar críticamente estos vacíos de información.

En adelante trataremos de dar respuesta a algunas cuestiones referidas a la documentación gráfica elaborada por los arquitectos daneses.

\subsection{Datación de los documentos}

El 20 de enero de 1917 Fischer compró mediante escritura notarial ${ }^{535} 7$ sectores entre todos en los que se había parcelado el palacio tras su venta por parte de la casa de Osuna. En 1918 regresó a Oliva para iniciar unas pruebas del proceso de desmontaje de las piezas. Finalmente, la "brigada danesa" llegó a Oliva el 15 de noviembre de 1919 para iniciar las labores de documentación y desmontaje de los elementos del palacio ${ }^{536}$. Por las cartas que Lauritzen envía a Fischer cuando este ya está de vuelta en Dinamarca, sabemos que Fischer debió abandonar Oliva aproximadamente en marzo de 1920 y que Lauritzen permaneció en la localidad al menos hasta mayo de 1920 , retornando posteriormente. ${ }^{537}$ Por lo tanto, el grueso de la documentación se elaboró entre noviembre de 1919 y mayo de 1920. No descartamos que Fischer en sus primeras visitas al palacio ya tomara algunas de las fotografías del mismo, ya que en los dos álbumes vemos que estas se han realizado en diferentes fechas. Este hecho se observa sobre todo en las fotografías de la Galería del Patio, en las que se pueden ver distintas fases del desmontaje: desde el vaciado de las fábricas que la cerraban, hasta el desmontaje de la galería del piso superior. Por otro lado, Fischer, en los planos que elabora para el Museo Español en Dinamarca, dibuja esquemáticamente muchas de las portadas así como la arcada del patio, por lo que debió basarse en fotografías, ya que los planos todavía no se habían elaborado. En la página 68 del Notebook I hay un recibo por el alquiler de una casa a E. Fischer, datado el 7 de marzo de 1917. No se ha localizado ninguna otra fecha en el resto de la documentación gráfica.

A partir de esta información podemos establecer la siguiente datación de los documentos:

- Notebook I y Notebook II: están numerados correlativamente, por lo que el II es posterior al I. No podemos determinar en qué fecha Fischer dejó de escribir en este cuaderno, en el que quedan varias páginas en blanco. Con el fin de abarcar todo el periodo en el que Fischer viajó a Oliva, podemos datarlos entre 1917-1920.

- Láminas: según todos los indicios, quien elaboró la mayoría de las láminas originales fue el entonces estudiante de arquitectura Vilhelm Lauritzen, por lo tanto estas láminas se deben datar entre 1919-1920, ya que tenemos constancia de que

\footnotetext{
${ }^{535}$ Delicado Martínez, J. (1999). El Palacio de los Condes de Oliva. En Aldana Fernández, S. (Ed.). Monumentos desaparecidos de la Comunidad Valenciana. I Valencia. (pp. 411-414). Valencia: Consell Valencià de Cultura.

${ }^{536}$ Lauritzen, V (1997). Relación sobre el Palacio, Oliva, Valencia. En Esteve i Blai, Antoni (Ed.). EI Palau dels Centelles d'Oliva. Recull gràfic y documental. Oliva, España: L'Associació Cultural Centelles i Riu-Sec. pp. 142.

${ }^{537}$ Lauritzen, V. (1920). Cartas de V. Lauritzen a E. Fischer. Documentación Palacio de Oliva. FA68 y FA69. Søborg, Dinamarca: Archivo DKS.
} 
llegó a Oliva en noviembre de 1919, y permaneció en la localidad hasta mediados de mayo de 1920, volviendo posteriormente ${ }^{538}$.

- Planos Museo Español en Dinamarca: el plano el LA-E1 está fechado en enero de 1919, y el resto de planos de las dos propuestas entre el 12 y el 22 de febrero de 1919; por lo que podemos datar cada uno de ellos con su fecha concreta y el conjunto como enero/febrero de 1919. El plano LA $1108^{539}$ corresponde a una variación de la propuesta II para el proyecto del museo, por lo que su fecha de elaboración es posterior; se propone mantener la datación del resto de láminas: 1919-1920.

- Álbum de Fotografías Grande: en la portada está rotulado el título en inglés: "Photografies and Notebooks from Fischer-Lauritzen Campaing at Oliva, ca. 19171920". Este título, pegado sobre las tapas, debió de incorporarse cuando el material fue adquirido por la HSA. Las fotos, sin duda, pertenecen a ese periodo; desconocemos si el montaje de álbum y las anotaciones manuales se realizaron posteriormente en Dinamarca, pero daremos por buenas estas fechas, ya que el documento fotográfico corresponde a este periodo.

- Álbum Fotográfico Pequeño: en este caso no hay referencia de fechas, pero las imágenes que contiene son en su mayoría las mismas que en el álbum grande. Las dos últimas corresponden a los terrenos en Frederiksberg, a las afueras de Copenhague, donde Fischer quería construir el museo; desconocemos en qué fecha fueron tomadas. Por analogía con el AFG, lo dataremos también entre 1917-1920.

\subsection{Autoría de los documentos}

No cabe duda de que el autor intelectual de todo el trabajo fue el arquitecto Egil Fischer, que fue quien lo ideó y dirigió el equipo de trabajo. Como se sabe, en cualquier proyecto de arquitectura intervienen diversos técnicos y personal de apoyo en su redacción, pero la autoría intelectual es de aquel o aquellos que, finalmente, firman el proyecto. En este caso Fischer sólo firmó los planos que se presentaron a algún organismo para su supervisión. Así, fue él quien firmó los planos de los dos proyectos del Museo Español en Dinamarca para que fueran entregados a la Real Academia de Bellas Artes danesa, y el plano de cubrición del Palacio de Oliva, para presentarlo a las autoridades locales del municipio. No hay ningún plano firmado por V. Lauritzen. De hecho, Priscila E. Muller, en su Catálogo ${ }^{540}$, asigna todos los planos de planta a E. Fischer, casi todo el resto de planos sobre papel opaco a V.

\footnotetext{
${ }^{538}$ Lauritzen escribió 4 cartas a Fischer las dos primeras están fechadas en Oliva el 8 de abril y el 3 de mayo de 1920, la tercera está fechada el 15 de mayo de 1920 en Barcelona y la cuarta, de nuevo desde Oliva. En estas cartas le informa de la situación de los trabajos y relación las autoridades en Oliva. Óp. cit. Lauritzen, V. (1920).

${ }^{539}$ Este plano está titulado en el Catálogo de P.E. Muller (Gavara Prior, J. y E. Muller, P. (2013). EI Palacio Condal de Oliva. Catálogo de los planos de Egil Fischer y Vilhelm Lauritzen. Oliva, Valencia: Ajuntament de Oliva.) como "Palacio, secciones del sudoeste, niveles superiores, planos de plantas", tratándose de un error ya que el plano en realidad es una variación sobre el plano LA-E4 y LA-E5.

${ }^{540}$ Gavara Prior, J. y E. Muller, P. (2013). Óp. cit. pp. 65-179.
} 
Lauritzen y casi todos los planos en papel de calco a V. Lauritzen y/o E. Fischer, a partir de un estudio comparativo de las anotaciones realizadas en las láminas ${ }^{541}$. Es posible que puntualmente participaran otras personas como ayudantes o colaboradores para la elaboración del material ${ }^{542}$.

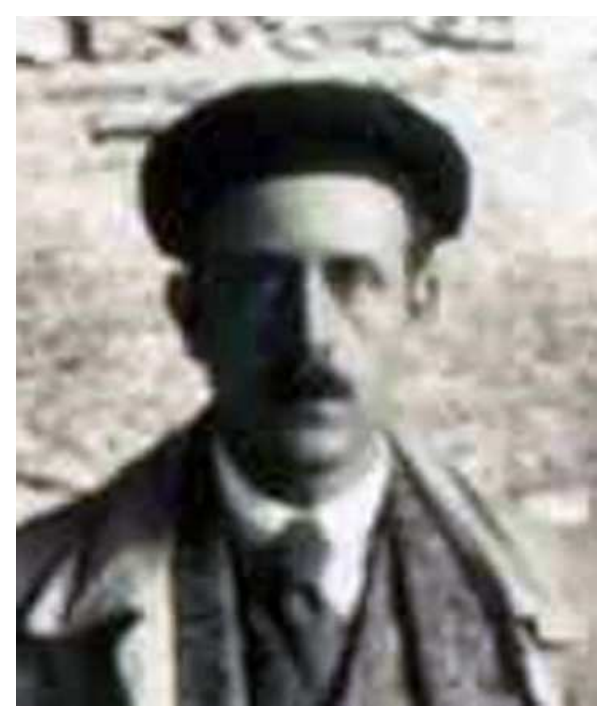

Figura 427. Izquierda: Fotografía de E. Fischer bajo la D4. Fot. 73. AFG. Derecha: Fotografía de V. Lauritzen delante de la D24. Fot. 29.1 AFP.

A partir de la información disponible podemos establecer la siguiente autoría de los documentos:

- Notebook I y Notebook II: la autoría de estos documentos es claramente del arquitecto $\mathrm{E}$. Fischer, aunque en su interior hay algunas anotaciones que no son suyas, como el recibo de alquiler mencionado en el apartado anterior.

- Láminas: en estos documentos quedan algunas dudas sobre la autoría de los planos. Dado el rigor mostrado por la investigadora americana, Priscilla E. Muller en su trabajo sobre el palacio, no podemos sino sumarnos a su criterio para otorgar la autoría de las láminas a Vilhelm Lauritzen. Sin embargo, a la hora de citar el conjunto de planos lo más correcto sería referirse a ellos cono de E. Fischer y $\mathrm{V}$. Lauritzen, ya que se trató de un trabajo de equipo donde el papel del discípulo fue tan importante como el del maestro.

- Planos Museo Español en Dinamarca: la autoría recae en E. Fischer, que es quien los firma. Estos planos se elaboraron con anterioridad a la incorporación de Lauritzen al proyecto.

\footnotetext{
${ }^{541}$ E. Muller, P. (1997). Óp. cit. pp. 133-134 Nota 18.

${ }^{542}$ EI plano LA1106 está rotulado en castellano con una letra diferente al resto, es posible que el propio Vicente Arnal, amigo de los arquitectos daneses les ayudara a rotularlo o contrataran a algún delineante local para elaborarlo.
} 
- Álbum de Fotografías Grande: desconocemos quién tomó realmente las fotografías, pero estas pertenecieron al arquitecto Egil Fischer y los textos que las describen están manuscritos por él, por lo que consideramos que la autoría debe atribuírsele en exclusiva a Fischer.

- Álbum Fotográfico Pequeño: al igual que en el caso del AFG, se considera que la autoría debe atribuírsele a Fischer.

\subsection{El valor de los documentos}

Los documentos elaborados por Fischer y Lauritzen fueron realizados con la finalidad de recuperar el edificio, pero no en el sentido que otorgamos hoy en día a este concepto. En la actualidad realizaríamos un levantamiento gráfico del edificio con el fin último de recuperarlo mediante una restauración, reconstrucción o consolidación del mismo en su localización original.

Para algunos autores (Merino y Aguilar, 1997) el caso del Palacio de Oliva es un ejemplo de expolio del patrimonio arquitectónicos y de "elginismo" llevado a cabo en España hasta bien entrado el siglo $X X^{543}$. No en vano el edificio engrosa el catálogo de los monumentos desaparecidos de la Comunidad Valenciana ${ }^{544}$.

Sin embargo, Fischer estaba convencido de que la única forma de salvar aquel viejo palacio, vendido por sus dueños, dividido en trozos y del que se habían arrancado gran parte de sus tesoros, era desmontarlo pieza a pieza y reconstruir parte de sus salas en un nuevo inmueble en Dinamarca. Todo ello con el doble objetivo de salvar los elementos arquitectónicos de gran valor que aún se conservaban en él y permitir que los estudiantes de arquitectura daneses pudieran estudiar la arquitectura española sin necesidad de cruzar la frontera ${ }^{545}$.

Paradójicamente, el tiempo ha dado la razón a Fischer, ya que a pesar de su catalogación como Monumento Nacional en 1920, las autoridades de la época no hicieron lo posible por conservar lo que quedaba del edificio, y este finalmente ha desaparecido casi por completo.

Si analizamos lo que dice la Carta del levantamiento Arquitectónico, nos damos cuenta de que los arquitectos daneses realizaron un auténtico "Levantamiento Arquitectónico" del palacio con los medios técnicos de la época, y no sólo eso, Fischer se preocupó de buscar documentación bibliográfica con el fin de poderlo contextualizarlo ${ }^{546}$. La documentación elaborada por E. Fischer y V. Lauritzen nos permite poder conocer, estudiar, difundir y disfrutar de este monumento, e incluso restituir algunas partes del mismo, por lo que

\footnotetext{
${ }^{543}$ Aguilar Civera, I. (1997). Pròleg. En A. Esteve i Blai, Antoni (Ed.). El Palau dels Centelles d'Oliva. Recull gràfic y documental. Oliva (pp. 31-40) Oliva, España: L'Associació Cultural Centelles i Riu-Sec.

${ }^{545}$ Fischer, E. (1919). Documento 7. Documentación Palacio de Oliva. FA68 y FA69. Søborg, Dinamarca: Archivo DKS.

${ }^{546}$ Fischer, E. (1917-1920.). Notebook II. Óp. Cit. pp. 1-10 y Fischer, E. (1917-1920.). Notebook I. Óp. Cit. pp. 52.
} 
podemos afirmar que realmente consiguieron conservar gran parte de este magnífico palacio gracias a su labor de documentación, no en el sentido físico, pero sí documentalmente.

La documentación gráfica se centra en dos grandes zonas del Palacio: las áreas de Sanchis y Miguel y las salas de la 10 a la 20.

\subsection{Los elementos arquitectónicos}

En este apartado trataremos de realizar una síntesis de cada uno de los elementos arquitectónicos estudiados:

\section{Las ventanas}

La mayoría de las ventanas documentadas son interiores de arco escarzano, y una o dos columnillas con capiteles decorados, jambas abocinadas y capialzado y bancos o festejadors (V3 a V10). Estaban realizadas en yeso. Esta tipología de ventanas es idéntica a las que encontramos en el Palacio de la Generalitat o en la Lonja de Valencia, aunque en este caso fueron realizadas en obra de cantería. Joan Corbera hizo muchas de las ventanas del Palacio de la Generalitat, y en 1510 recibió un encargo para realizar unas ventanas como las del Palacio del Conde de Oliva, aunque aparentemente se trataba de uno de los palacios que Serafín Centelles tenía en la Calle Caballeros, en Valencia ${ }^{547}$.

Además de las ventanas interiores, existe documentación en los planos y fotografías de algunas ventanas exteriores; entre ellas encontramos algunas elaboradas en piedra, otras en yeso e incluso en ladrillo. En cuanto a su tipología podemos establecer tres grupos: las ventanas sencillas de tipología defensiva (ventanas de la torre del palomar LA1185 y LA1186), las ventanas de entresuelo (LA1193, LA1179, LA1193) y las ventanas de la planta noble (LA1187, Fot. 79, Fot. 83 y Fot. 84). Estas dos últimas tipologías las documentó Concepción López (1996) en su trabajo sobre los palacios góticos en la ciudad de Valencia $^{548}$.

\footnotetext{
${ }^{547}$ Aldana, S. (1995) El Palau de la Generalitat Valenciana. Tomo I. València: Generalitat Valenciana, Consell Valencià de Cultura. pp. 179.

${ }^{548}$ López González, C. (1996). Análisis Gráfico de las fachadas de los edificios señoriales construidos durante los siglos XIV y XV en la ciudad de Valencia. Revista de Expresión Gráfica de la Edificación. Núm. 4. pp.186-190.
} 

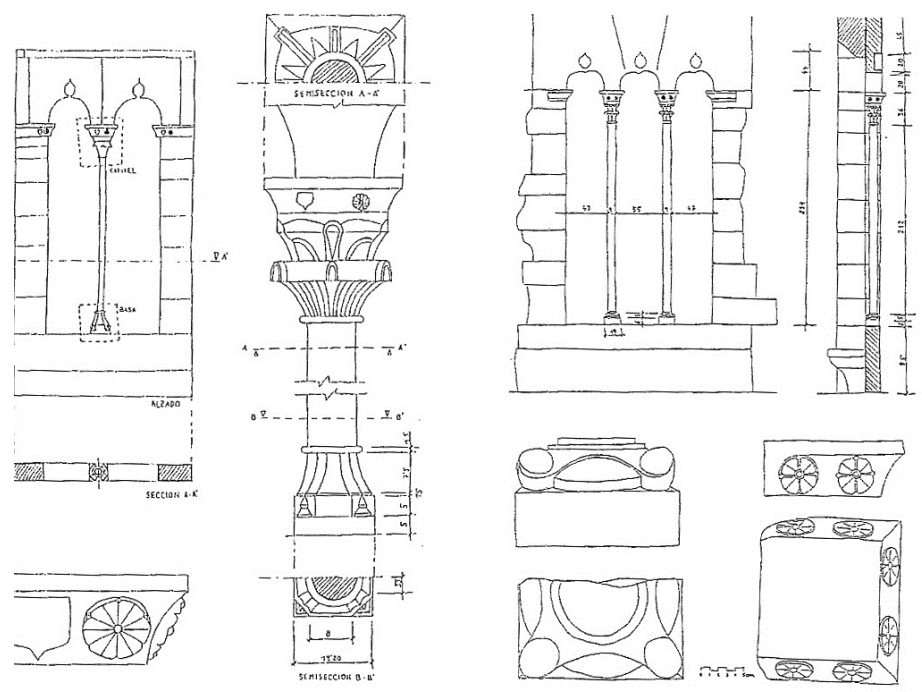

Figura 428. Superior: lámina de ventanas ajimezadas pertenecientes a la planta noble en los palacios góticos valencianos. Concepción López. Inferior: Imágenes ventanas ajimezadas del Palacio de Oliva. Fuente: AFG. E. Fischer y propia.

\section{Los forjados y artesonados}

Entre los forjados documentados encontramos tres tipologías:

- Artesonados: Fischer y Lauritzen documentaron dos artesonados ${ }^{549}$ de casetones localizados en dos de las salas de mayores dimensiones del palacio, las salas $11 \mathrm{y}$ 12. El primero de ellos está formado por casetones cuadrados y el segundo

\footnotetext{
${ }^{549}$ Aunque el aspecto exterior es el de artesonados de casetones, por su sistema constructivo sería más correcto llamarles alfarjes, ya que la estructura portante es lineal, no existiendo piezas de acodalamiento transversal. Ver: Soler Estrela, A. y Soler Verdú, R. (13-10-15). Carpintería de armar: alfarjes medievales. Metodología de estudio. En: Actas del Noveno Congreso Nacional y Primer Congreso Internacional Hispanoamericano de Historia de la Construcción. Segovia, España.
} 
romboidales. En ambos casos se trata de artesonados de tipo italiano. Sabemos que al menos el de la sala 12 era dorado. El primero tiene cierta similitud con el artesonado de casetones cuadrados del Palacio de los duques de Medinaceli en Segorbe; y un artesonado de casetones romboidales similar al 12 se encuentra en el Palacio de la Alfajería de Zaragoza.

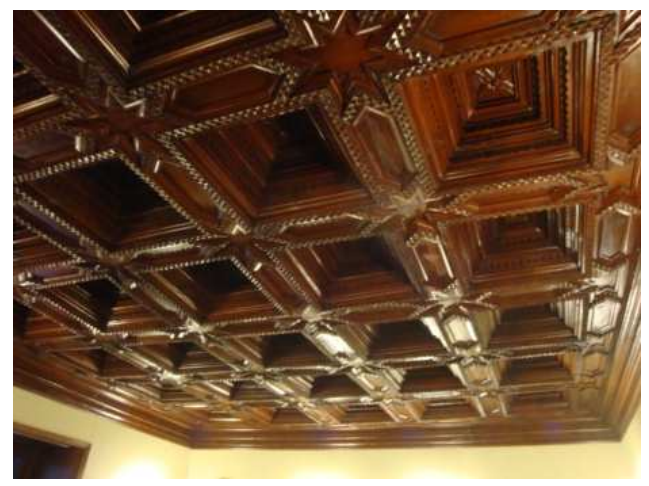

Figura 429. Izquierda: Artesonado casetones cuadrados. Palacio de los duques de Medinaceli. Segorbe. Derecha: Artesonado romboidal. Palacio de la Alfajería. Zaragoza. Fuente: Juan Mora Insa. Gobierno de Aragón.

- Forjados de vigas de madera y revoltones de ladrillo y yeso en relieve: las vigas de madera se encuentran perfiladas y labradas en sus esquinas, y el entrevigado está formado por piezas prefabricadas de yeso realizadas con un molde con ornamentación renacentista en relieve. A este tipo pertenecen los forjados Loft $A$ (Fot. 47) y Loft B (Fot. 48). Este tipo de forjado, denominado "revoltons de algeps e rajolla revellats al roma", fue rechazado por los diputados para cubrir algunas las salas del Palacio de la Generalitat por considerar que "la obra de fusta" (artesonados) era de mayor calidad ${ }^{550}$.

- Forjados de vigas de madera y revoltones de ladrillo y yeso pintados: a este grupo pertenecen los forjados de la Sala 16 y de la Sala 18 o Sala de Armas. Los revoltones son lisos y están decorados con ricas pinturas: medallones con bustos, elementos en jarra, amorcillos, cornucopias y otros elementos característicos de la decoración "a la romana"

\section{Las bóvedas}

En la documentación de Fischer aparecen documentadas 4 bóvedas correspondientes a la planta noble, si bien tenemos constancia de la existencia de otras en la planta entresuelo. Corresponden a 4 tipos diferentes de bóvedas:

- Bóveda de cañón: a este tipo pertenece la bóveda de la sala 13 o capilla. Estaba teselada mediante casetones tronco piramidales de piezas de escayola; en realidad

${ }^{550}$ Gavara Prior, J. y E. Muller, P. (2013). Óp. Cit. pp. 24-25.
${ }^{551}$ Gavara Prior, J. y E. Muller, P. (2013). Óp. Cit. pp.51-52. 
esta era una falsa bóveda que se sustentaba de una bóveda apuntada de fábrica de ladrillo, tal y como se observa en la fotografía 58 de Fischer.

- Bóveda cuatripartita o de crucería simple ${ }^{552}$ : a este tipo pertenece la bóveda de la Sala 15. Está formada por dos arcos cruceros rebajados que se cruzan en una gran clave central, por lo que podemos denominarla también "escarzana". Tanto estos como los arcos formeros, también rebajados, están formados por dovelas, que con toda seguridad serían de yeso, y estaban labradas con decoración renacentista en macolla. Los nervios arrancaban de cuatro ménsulas situadas en las esquinas de la sala.

- Bóveda de crucería estrellada: se incluye aquí la bóveda de la sala 17. Se trata de una bóveda de crucería de 5 pendolones y rampante curvo. Tres de sus arcos formeros son apuntados y uno rebajado. Los arcos cruceros eran rebajados. Sus nervios tenían un perfil gótico de forma triangular con extremo agudo ${ }^{553}$ finalizado en filete, seguido de dos cavetos y dos boceles.

- Bóveda de crucería con arcos combados: a este tipo pertenece la pequeña bóveda de la Sala 19. Se trata de una bóveda escarzana formada por dos arcos cruceros principales y dos arcos combados o pies de gallo que parten de las claves de los arcos formeros ${ }^{554}$ y se encuentran en 4 claves situadas en el centro de los arcos cruceros. Los nervios tienen un perfil sogueado.

Además de estas bóvedas de la planta noble, Fischer documentó la bóveda octopartita que formaba la campana de la cocina, y en los restos del edificio quedan vestigios de otras bóvedas de cañón y tabicadas en arista que han sido documentas en el capítulo IV.

Por su cronología, y a partir de los restos existentes, las bóvedas de crucería 15, 17 y 19 del palacio estarían construidas como bóvedas tabicadas.

\section{Las galerías}

Hay documentadas tres galerías en el palacio:

- Galería del Patio Central: estas galerías de arcos apuntados las encontramos en otros palacios del gótico Mediterráneo como la del Palacio de los Marqueses de la Scala o el Palacio de la Generalitat de Cataluña, aunque en este caso la singularidad se encuentra en la sustitución de los pilares de factura gótica por columnas de orden compuesto en mármol blanco sobre las que descansa una arcada apuntada de perfil gótico, con una pieza intermedia de pizarra negra. Sobre la arcada apoya un friso tripartito, también de mármol blanco, rematado por una balaustrada del mismo material. Sabemos que los mármoles se trajeron de Génova, y al menos parte del material se encontraba acopiado en el palacio en $1550^{555}$.

\footnotetext{
${ }^{552}$ Navarro Fajardo, J.C. (2004). Óp. cit. pp. 70-71.

${ }^{553}$ Navarro Fajardo, J.C. (2004). Óp. cit. pp. 70, 81-85 y 141-144.

${ }^{554}$ Este tipo de bóveda no es frecuente en el tardogótico valenciano. Navarro documenta una en una capilla de la iglesia de Utiel. Navarro Fajardo, J.C. (2004) Óp. cit. pp. 75-76.

${ }^{555}$ Felip Sempre, V (2001). Óp. cit. pp. 309-301 y 347-348.
} 
- Galería Torre Grande: Fischer la denomina así aunque en realidad se trata de una logia formada por arcos rebajados apoyados sobre pilastras octogonales con basas y capiteles con complejas molduras de perfil gótico. Esta logia es similar a las existentes en palacios como el Palacio Ducal de Gandía o el de los Borja en Valencia, aunque en el caso del Palacio de Oliva su composición es mucho más compleja.

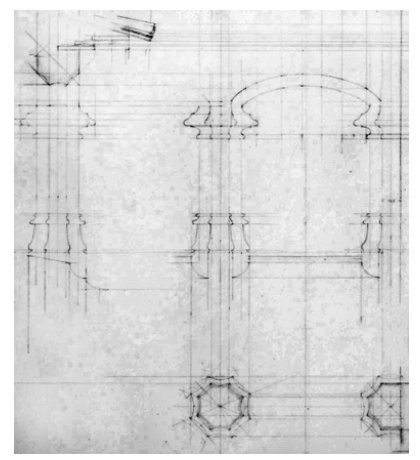

Figura 430. Izquierda: Detalle Galería Torre Grande. Palacio de Oliva. LA1127. E. Fischer. Derecha: Logia Palacio Ducal de Gandía.

- Galería Inferior Torre Grande: con este nombre denominaron Fischer y Lauritzen a los restos de una antigua galería cuya columna aparece embebida en el muro de la Sala de Armas. Hay cierta ambigüedad en la documentación gráfica, pero todo indica que corresponde a una intervención anterior a la gran renovación del palacio llevada a cabo por Serafín de Centelles. Se trata de un arco de medio punto moldurado apoyado sobre columnas entorchadas formadas por cuatro baquetas $y$ rematadas lateralmente por dos filetes y cavetos en cuarto de circunferencia, cuyo eje de simetría forma $45^{\circ}$ con el de las baquetas. Existen restos de columnillas entorchadas, en este caso en arista, en la jamba de la ventana V10. En esta tipología de columnas vemos sin duda la estela de Pere Compte y su círculo, a quien se le atribuye también la Colegiata de Gandía ${ }^{556}$.

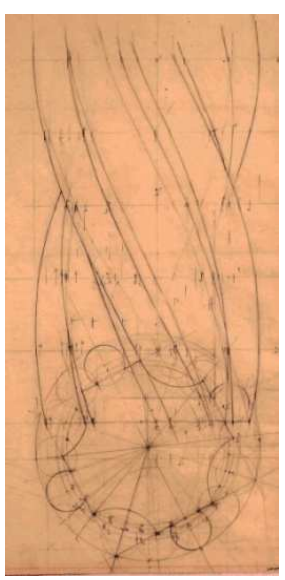

Figura 431. Izquierda: Columna entorchada perteneciente a la galería inferior de la Torre Grande. LA1189. V. Lauritzen. Centro: Columna entrochada del salón columnario de la Lonja de Valencia. Derecha: Nervio entorchado. Colegiata de Gandía.

${ }^{556}$ Zaragozá Catalán, A. y Gómez Ferrer, M. (2007). Óp. cit. pp. 98-102. 


\subsection{Els studis blanchs ${ }^{557}$}

Esta área comprende las salas numeradas por Fischer como 1 a 9 en el plano. La LA1109 corresponde a la planta noble del palacio, situada en el ala noroeste del mismo. En esta zona se encuentran localizadas las portadas 1 a 9 , de las que sólo existen croquis en el Notebook $\| I^{558}$ y algunas fotografías, portadas 3, 4, 5, 7 y $8^{559}$. En el plano de planta LA1109 aparecen numeradas las ventanas 1 y 2 , aunque no existen los planos de detalles de las mismas. De esta zona hay documentados varios techos codificados con letras $A, B, C, y E^{560}$, cuyas dimensiones no coinciden con el plano de panta principal. Sabemos por Sebastián Castellanos (1851) que en la planta en el entresuelo del palacio, tanto a la derecha como a la izquierda, habían forjados decorados por, lo que cabría situarlos en esta planta; y algunos de ellos recaerían en esta área del Palacio situada a la derecha del zaguán: "A la derecha de este zaguán o ingreso se ve una escalerilla y puerta gótica que da ingreso al entresuelo de este lado, en cuyas habitaciones que dan al torreón de la derecha entrando, se ven portadas góticas sencillas. En la ventana del muro de al lado de la puerta del foso hay una sala con tirantes labrados, en cuyos espacios se ven lindos relieves de estuco cuyos dibujos se componen de sirenas aladas con canastillos en los medios y cornucopias vertiendo frutos. ${ }^{1561}$. Esta descripción podría corresponder al forjado A, en cuyos casetones aparece rotulado en danés kvinder overkrop (torso femenino). Con toda seguridad, algunas de las ventanas y portadas sin numerar corresponden también a ésta área del palacio.

Fischer no pretendía restituir esta área en su nuevo proyecto, por lo que no detalló de manera fidedigna todos los elementos sobre un plano (salvo las portadas), sino que los documentó de manera aislada, ya que su objetivo era utilizarlos para completar ciertas necesidades de su proyecto o bien para otros fines. De la documentación de esta zona se encargó fundamentalmente Fischer ${ }^{562}$, recogiendo en sus cuadernos de notas croquis con cotas generales, anotaciones y detalles de algunas de sus piezas. Desconocemos si algunas de las láminas de Lauritzen sin localizar corresponden también a esta área del palacio.

Por todo ello, no es posible realizar una restitución fidedigna y completa de la zona, pero sí podemos situar algunos de sus elementos y recrear parcialmente la planta principal, situando las portadas 1 a 9 . En el caso del entresuelo no disponemos de suficientes datos para poder restituir ninguna de sus salas completamente, tan sólo podemos tratar los elementos individualmente o establecer hipótesis sobre cómo serían algunas de sus salas, colocando en ellas portadas, ventanas y pavimentos documentados para crear una idea de conjunto.

\footnotetext{
557 Esta denominación está sacada del inventario de 1550. Felip Sempre, V (2001) Óp. cit. pp. 305368.

${ }^{558}$ Fischer, E. (1917-1920.). Notebook II. Óp. cit. pp. 13 y 14-22.

${ }^{559}$ Fischer, E. (1917-1920). Álbum Fotos Grande. Óp. cit. pp.15A, 15R y $16 \mathrm{~A}$.

${ }^{560}$ Fischer, E. (1917-1920.). Notebook I. Óp. cit. pp. 3-5, 13, 16-17 y 53-55.

${ }^{561}$ Arciniega García, L. (2001). Óp. cit. pp. 218.

${ }^{562}$ Gavara Prior, J. y E. Muller, P. (2013). Óp. cit. pp. 37-39.
} 


\subsection{Els studis daurats ${ }^{563}$}

En esta área del palacio se encontraban los elementos arquitectónicos cruciales para el proyecto de reconstrucción que Fischer planteaba y, por tanto, fue la que con mayor detalle y minuciosidad fue documentada. Esta labor correspondió casi exclusivamente a Lauritzen, quien fue el encargado de elaborar las láminas originales con gran profesionalidad y minuciosidad ${ }^{564}$.

Así, Lauritzen elaboró los planos de cada uno de los elementos (portadas, ventanas, forjados, artesonados, bóvedas y arcadas principalmente) a grafito, utilizando como soporte láminas de papel sin marca (filigrana de Vda. de Romaní) ${ }^{565}$. La dimensión de la mayoría de ellas era de $680 \times 470 \mathrm{~mm}$. Las láminas están representadas a escala 1:10, salvo excepciones, como los artesonados, las bóvedas y algunos detalles. Aunque no está rotulada, se ha comprobado mediante las cotas existentes en muchas de las láminas.

Lauritzen utiliza dos tipos de acotación, las cotas lineales y las cotas a origen. Las primeras las emplea fundamentalmente para dimensionar los elementos horizontalmente (por ejemplo, las anchuras de puertas y ventanas) y las segundas para acotar en altura. En este segundo caso establece un nivel 0 de referencia a partir del cual acota los elementos tanto hacia arriba como hacia abajo. Este sistema lo utiliza en las portadas y ventanas fundamentalmente y también en las bóvedas para determinar alturas. En el caso de las bóvedas esta cota $+/-0,00$ coincide, aproximadamente, con la cara superior de la cornisa que bordea la sala, estableciendo un nivel horizontal, independientemente de las deformaciones de las piezas. En el caso de las portadas y ventanas establece una cota arbitraria, aunque en algunos casos coincide con la cara superior de los capiteles. Este nivel de referencia le permite establecer no sólo las cotas de los elementos, sino los desniveles del pavimento, o los desniveles entre piedras simétricas ocasionados por movimientos del edificio.

Aunque no son objeto de este trabajo, queremos resaltar el hecho de que no sólo se grafíen los elementos en cuanto a su geometría y morfología, sino también las patologías que presentaban, como desconchados o grietas, algunas de ellas de considerable anchura, lo que nos hace ver el grado de deterioro que presentaba el palacio a principios del siglo XX.

Llama sin embargo la atención que no se documentara ninguno de los pavimentos de estas salas. La primera hipótesis nos lleva a pensar que cuando Fischer llegó al Palacio muchos de éstos ya habían sido desmantelados como otros muchos elementos de valor, tal y como nos relata Teodoro Llorente ${ }^{566}$. En la mayoría de las fotografías de esta zona en las que se ve el

563 Esta denominación está sacada del inventario de 1550. Felip Sempre, V (2001) Óp. cit. pp. 305368.

${ }^{564}$ Gavara Prior, J. y E. Muller, P. (2013). p. 37.

${ }^{565}$ La investigadora P.E. Muller en su Catálogo identifica así el soporte. Ramón Romaní i Puigdengolas (1846-1898) fue un importante empresario papelero catalán. Ver Gutiérrez i Poch, M. (2014). Ramón Romaní i Puigdengolas (1846-1898): paperer, empresari i historiador. Miscellanea Aqualatensia. Núm.: 1. Recerques sobre la comarca de l'Anoia. pp.135-183.

${ }^{566}$ Llorente, Teodoro (1889). Valencia. Colección "España: sus monumentos y sus artes - su naturaleza é historia». Barcelona: Editorial de Daniel Cortezo y C. pp. 708-709. 
pavimento sólo se puede distinguir una capa gris que se asemeja más bien a la capa de compresión del forjado. En la fotografía 75 de la Sala 12 vemos restos de pavimento junto a la pared, lo que indica que se habían desmontado las piezas enteras del centro y se habían dejado las piezas cortadas del perímetro. En la única sala en la que se puede ver un despiece de pavimento es en la Sala de Armas. Así, en las fotografías 28 y 94 se puede apreciar un despiece de baldosas cuadradas de pequeño formato (unos $10 \times 10 \mathrm{~cm}$, aproximadamente) colocados a cartabón y bastante deterioradas que podrían corresponder al pavimento original, si bien su suciedad y la calidad de las fotografías no permiten identificar su diseño.

En cuanto a las láminas en papel traslúcido, están dibujadas en su mayoría a grafito de diferentes medidas (aparentemente se ha cortado de un rollo y por sus lados irregulares en algunos casos). En las láminas se representa sólo una copia de la vista principal o alzado en el caso de las portadas y ventanas de la lámina original. Sobre esta copia se han siglado las piezas del elemento, tal y como se han desmontado. Los cortes nos indican que existía un plan de desmontaje, pero en algunos casos las piezas debían de romperse durante este proceso, ya que en ocasiones aparecen piezas pequeñas y de contornos irregulares. En otros casos las líneas de despiece vienen condicionadas por grietas previas existentes en el soporte que han fracturado el elemento a desmontar.

A partir de la documentación existente de esta zona se podría realizar una reconstrucción casi total de ella, con algunas lagunas que relacionaremos, además del despiece y diseño del pavimento del que no tenemos datos de ninguna de las salas.

- Sala 10: en realidad esta sala corresponde con el tramo corto de la galería porticada del Patio de Armas. Este espacio está perfectamente documentado a través de los planos elaborados por Lauritzen y de los numerosos croquis y fotografías que detallan perfectamente la arcada, el arco de acceso a la sala 20, e incluso la escalera tabicada de comunicación con la galería superior que se ve perfectamente en la fotografía 14.

- Sala 11: de esta sala tenemos documentados el artesonado (Rum 11 Loft), las portadas (D10 y D11) y la ventana (V3). En el plano de planta existen dos huecos en el muro que separa esta sala de la sala 10 , un hueco de paso que no parece original y del que no hay ninguna referencia, y lo que parece ser un hueco de chimenea. Por lo tanto se podría realizar una restitución de esta sala, existiendo las siguientes lagunas para ello, además del pavimento: el exterior de la ventana que suponemos ajimezada, y de la que no disponemos información; y el diseño de la chimenea y la decoración de los capiteles, que pese a estar fotografiados, no tenemos suficiente detalle como para poderlos reproducir fielmente.

- Sala 12: de esta sala disponemos igualmente de los planos del artesonado (Rum 12 Loft), las portadas (D12, D13 y D28) y la ventana (V4). Disponemos de dos fotografías (76 y 78) donde están fotografiados los capiteles de la ventana V4, en las que se pueden ver con suficiente detalle como para poderlos reproducirlos. En esta sala existe un hueco impropio en el muro que separa la sala con la Sala de Armas y un hueco, posiblemente de una chimenea en el muro, que limita con las 
salas 10 y 20. Las lagunas de documentación son el pavimento, la chimenea y el exterior de la ventana.

- Sala 13: de esta sala, denominada también "Capilla", disponemos de información de las portadas (D14 y D15), de la ventana (V5) y de la bóveda de cañón (Rum 13 Loft). A pesar del mal estado de conservación de la bóveda en el momento de su documentación, disponemos de suficiente información para poderla restituirla. La ventana carecía de arco y prácticamente de capiteles. En cuanto al arco, no sería problema restituirlo ya que todos los de las ventanas eran escarzanos y se carece de información fidedigna de los capiteles de la ventana. Esta laguna se sumaría a la del pavimento y el exterior de la ventana (según el plano de planta LA1109 esta se encontraba cegada en 1919). De los capiteles de las portadas podrían recuperarse sus volumetrías generales, pero no sus detalles debido a la calidad de las fotografías.

- Sala 14: disponemos de información de la portada (D16), pero no de la ventana, que no está numerada en el plano de Fischer ${ }^{567}$, ni del forjado. En este caso la restitución pasaría por recrear una ventana de la misma tipología que el resto, adecuada al ancho de hueco. En cuanto al forjado cabría realizar una hipótesis con un forjado similar al de la Sala 16, con armadura de madera y entrevigado de escayola, aunque no tendríamos suficiente información para hacer una propuesta de decoración del mismo. Los elementos de mayor interés de esta sala son, sin duda, sus portadas.

- Sala 15: de esta sala disponemos de datos de la portada (D17), la ventana (V6) y la bóveda de crucería que la cerraba (Rum 15 Loft). En el plano de planta LA1109 existe un hueco en el muro que la separa de la Sala 14. Podría tratarse de un hueco impropio o el hueco de una antigua chimenea. En este caso, como en la mayoría de las salas, las lagunas estarían en el pavimento y en la ornamentación de los capiteles de la ventana. El elemento de mayor interés es su bóveda de crucería simple y con los nervios decorados con ornamentación renacentista en macolla. Disponemos de una fotografía que ayudaría a su redecoración.

- Sala 16: de esta sala disponemos láminas de sus dos portadas (D18 y D 19), de las dos ventanas (V7 y V8) y del forjado (Rum 16 Loft). Poseemos, por tanto, toda la información necesaria, salvo la referida al pavimento, el arco y capiteles de la ventana. No tenemos fotografías de la decoración de los capiteles de la V8 y la D19, tan sólo su volumetría general dibujada en las láminas. Del forjado, además de los planos de planta, disponemos de una fotografía que, aunque en blanco y negro, nos ayudaría a poder recuperar la decoración renacentista de los casetones.

- Sala 17: de esta sala existen láminas de sus dos portadas (D20 y D 21), de la ventana (V9) y de la bóveda (Rum 17 Loft). De esta sala disponemos de toda la información salvo del pavimento, el exterior de la ventana (posiblemente ajimezada) y el arco y capiteles de la ventana interior (V9), incompletos en la

\footnotetext{
${ }^{567}$ A pesar de estar grafiada la ventana en el plano de planta LA1109, incluso los festejaors, ésta es la única ventana de la zona noble del Palacio sin numerar. La explicación creemos que es que carecía de toda ornamentación original en sus jambas y dintel.
} 
lámina. No tenemos fotografías de la decoración de los capiteles de la D21 y de la portada D20. La fotografía 32 no nos permite ver con detalle los capiteles, aunque sí la decoración de las enjuntas del arco y los pináculos. Se disponen de planos detallados y fotografías de la bóveda estrellada. Con esta información es posible recrear la arquitectura de la sala salvando algunas lagunas de información con otros elementos similares del palacio.

- Sala 18: de la sala 18 o Sala de Armas existen láminas de sus dos portadas (D22 y D 23), de la ventana (V10) y del forjado (Rum 18 Loft). De esta sala disponemos de toda la información salvo del pavimento (aunque en las fotografías se intuye su tamaño cuadrado de pequeño formato y a cartabón). La información sobre el hueco que aparece en el plano LA1109 en el muro que separa esta sala de la Sala 13 (podría tratarse de una chimenea o una hornacina) y del hueco impropio que comunicaba esta sala con la 12, no tiene interés ya que no es original. De la ventana tenemos suficiente información para recrear la parte exterior ajimezada y formada por tres arquillos trilobulados con decoración renacentista en relieve y columnillas entorchadas que hacían de parteluz. Del forjado o armadura disponemos de suficiente documentación para recrearlo a nivel arquitectónico, decorativo y pictórico. Aunque no es nuestro campo, entendemos que hay suficientes imágenes y de calidad aceptable para recrear parcialmente algunas zonas. Igual ocurriría con el friso, del que existen varias fotografías. En el caso de la Sala de Armas disponemos de algunas piezas originales tanto en el HSA como en el MAO que ayudarían en estas labores, permitiendo identificar pigmentos y colores originales.

- Sala 19: de esta sala, que en realidad es una galería abierta que da acceso a la Sala de Armas, disponemos de información tanto gráfica como fotográfica de las dos portadas (D24 y D25) y de la bóveda estrellada que cubría parte de su superficie (Rum 19 Loft). Además, tenemos documentación sobre un arco perpiaño y frontón original de la bóveda que, aunque se encuentra en una colección privada, se podría escanear en 3 dimensiones para su reproducción. Disponemos también de una fotografía de una de las columnas entorchadas como las que en su día formaban la galería (Fot. $85 \mathrm{AFG}$ ) y de un detalle de la antigua arcada dibujado por Lauritzen en el plano LA1132. A partir de esta información se puede realizar una reconstrucción parcial de la galería, quedando como lagunas de qué manera se puede completar el resto de la cubrición y su pavimento. Asimismo, deberíamos lanzar una hipótesis sobre la arcada de esta galería y su posición, corroborando o modificando la que hicieron Carlos Martínez y José García en su maqueta del palacio ${ }^{568}$.

- Sala 20: de esta sala poseemos información completa de las portadas (D26 y D27), así como de los planos (aunque no se detallan las basas y jambas), fotografías generales y fotografías de detalle de los capiteles. Disponemos asimismo de una fotografía acotada de la portada exterior de acceso (puerta de la Escalera de Honor) y de dos fotografías de las ventanas que recaen en la fachada SE. Sin embargo, no se dispone de información del interior de estas ventanas ni del interior de la

${ }^{568}$ Carlos Martínez y José García realizaron una maqueta a escala 1:50 del Palacio de Oliva en el año 1999 en la que se se representa una reconstrucción de esta galería con las columnas entorchadas. La maqueta se encuentra en el MAO. 
portada de la Escalera de Honor, ni del forjado o el pavimento. Tampoco tenemos documentación del resto de huecos que conforman la sala (dos ventanas recayentes en el Patio de Armas y la puerta que comunica con la galería porticada, Sala 10). Por la descripción que realiza Sebastián Castellanos (1851), que la denomina "Antecámara Condal", sabemos que el forjado era de madera con tirantes labrados sobre ménsulas y que, de los seis huecos, dos eran grandes ventanas góticas jambeadas con columnillas y bancos de piedra. Cada una de estas ventanas recaía en cada uno de los dos patios ${ }^{569}$. Se podría hacer una reconstrucción parcial de la sala, dado que se dispone de información de los elementos más singulares, las portadas 26 y 27, pudiendo así aventurar una hipótesis de cómo serían el resto de huecos de la sala, el pavimento y el forjado, a partir de la información que se dispone de otros elementos similares del palacio.

En resumen, podemos concluir que es posible restituir esta zona del palacio de una forma bastante fidedigna, si bien se requiere de un equipo multidisciplinar que incluya la arquitectura, la historia, la arqueología, la escultura, y la pintura, entre otros, cubriendo las lagunas de información existentes.

\subsection{El proyecto de Pile Allé}

Fischer redactó la Propuesta I del proyecto del Museo Español con fecha de enero (plano general) y 12 de febrero de 1919, y la Propuesta II, con fecha 21,22 y 23 de febrero de 1919, a partir de las notas que tomó en los cuadernos Notebooks I y Notebook II, y entendemos que con la ayuda de las fotografías tomadas en sus viajes a Oliva en 1917 y 1919.

Por su parte, el plano LA1108 que Priscilla E. Muller identifica como un plano de planta del palacio es, en realidad, una variante de la Propuesta II de "El Palacio" (así es como rotula Fischer sus propuestas para el Museo Español). Este plano fue, sin duda, elaborado con la información obtenida tras la campaña de 1919-1920, ya que en este plano está rotulada la posición de las portadas de la 1 a la 28 y las ventanas de la 3 a la 10, numeradas en el plano LA1109 del palacio. En este plano las salas están numeradas con números romanos del I al XIV, existiendo otras salas sin numerar. Se ha analizado el grafismo y las medidas de los forjados y bóvedas del palacio documentados por Fischer y Lauritzen en los planos y croquis de los Notebooks y se ha comprobado que coinciden algunos de los representados en el plano LA1108, aunque en este caso, se numeran de acuerdo con la nueva organización del proyecto. En otros casos se crean nuevas distribuciones de forjados a partir de vigas recuperadas de manera independiente; entendemos que a partir del material inventariado en la página 26 del Notebook I (vigas molduradas). En este plano la arcada de la galería porticada del patio se representa con el mismo ángulo que estaba en el Palacio $\left(96^{\circ}\right)$ para poder acoplar los sillares del zócalo y esquina, a diferencia de los planos LAE1, LAE2, LAE3 y LAE4, donde se representa en ángulo recto. Podemos identificar en él también la escalera representada en las páginas $10 \mathrm{R}$ a $13 \mathrm{~A}$ del Notebook /l y la galería de arcos de la logia de Torre Grande situada sobre la Sala de Armas.

${ }^{569}$ Arciniega García, L. (2001). Óp. cit. pp. 216-225. 
En estos planos Fischer, lejos de hacer una restitución fidedigna de la zona noble del palacio, se limita a recrear un rompecabezas del mismo con las piezas desmontadas, adaptándolas a su nuevo plan de necesidades, pero sin intentar conservar la planta ni la distribución original; ni siquiera asigna a cada portada la otra cara del muro que le correspondía en el palacio. La única excepción la hace con la Sala de Armas, donde mantiene la distribución en planta y la disposición de los tres huecos de la misma (D22, D23 y V10) en la misma posición original. Aun así, la portada exterior sólo corresponde con el palacio en el caso de la D23, que mantiene la portada 24 en su cara exterior. En el caso de la Portada 22, en el exterior se ha sustituido la D21 por la D1.

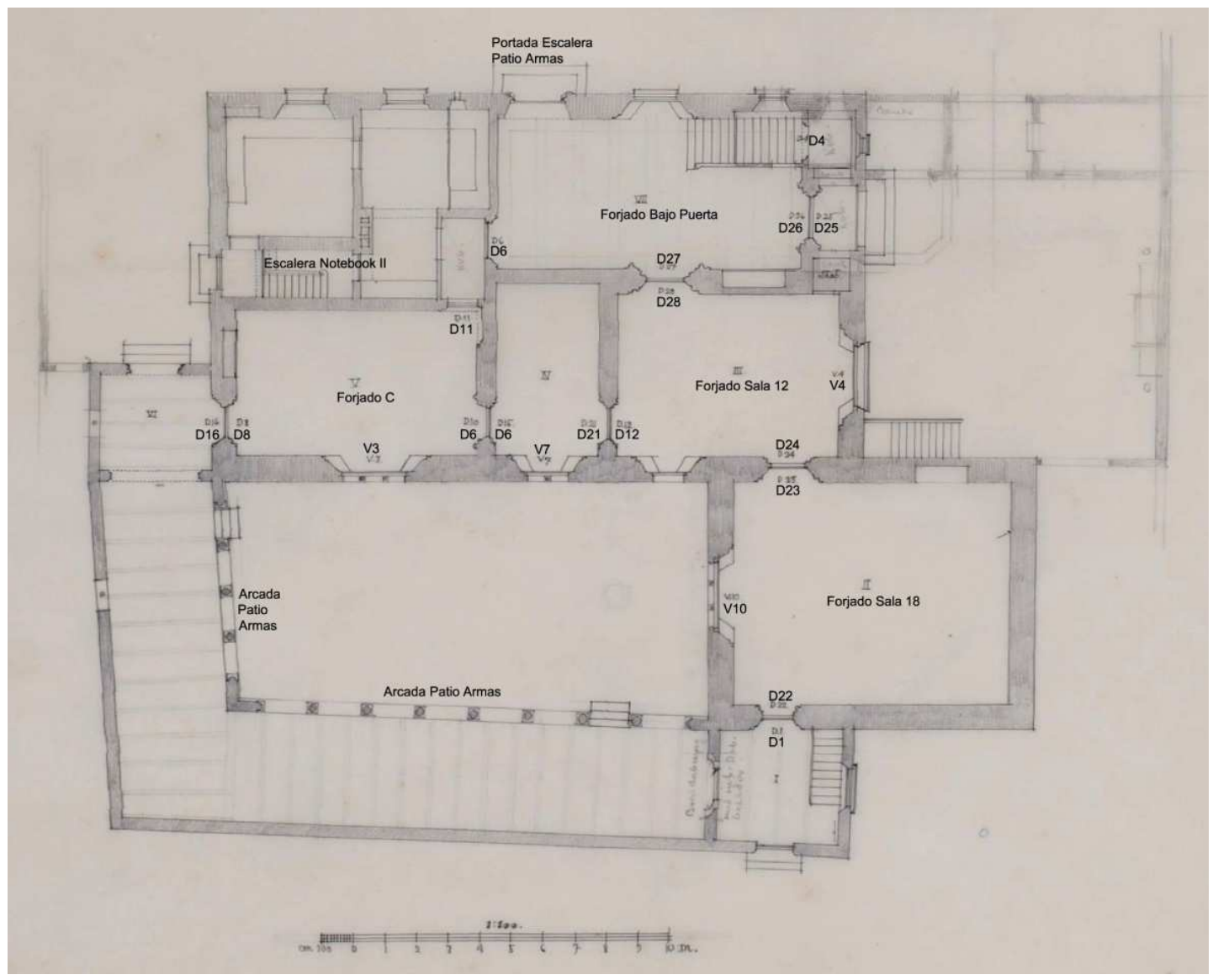

Figura 432. Plano LA1108. Proyecto Pile Allé. Planta Baja. Egil Fischer. Identificación de elementos del Palacio.

\section{LAS PORTADAS}

Las portadas del Palacio Condal de Oliva son, por la cantidad y calidad de los textos, el elemento arquitectónico mejor documentado por Egil Fischer y Vilhelm Lauritzen. A pesar de ello, quedan vacíos de información, que se han tratado de cubrir en este trabajo estudiando otras portadas de similar tipología y época de construcción. 
Una simple inspección ocular de la documentación gráfica sirve para vislumbrar la variedad y riqueza formal de las portadas del Palacio Condal de Oliva, pero sólo un análisis meticuloso y en profundidad nos puede ayudar a entender que nos encontramos ante un auténtico tratado en cuanto al trazado de arcos se refiere, por su amplia variedad formal y tipológica. El trabajo aporta una clasificación inédita de las portadas y de su tipo de arcos, y ayuda a entender el complejo proceso de composición formal de las mismas.

\subsection{Clasificación}

Son diversas las clasificaciones que se pueden establecer de las portadas atendiendo a diversos criterios, pudiéndose enmarcar una misma portada dentro de distintas categorías.

\section{Por su material}

Las portadas documentadas estaban realizadas en fábrica de yeso, salvo la portada de la Escalera de Honor que era de cantería.

\section{Por su decoración}

Dentro de las portadas encontramos dos grandes grupos: las portadas sencillas de factura gótica y las portadas con decoración renacentista. En el segundo grupo podemos englobar las portadas 7, 20, 22, 23, 26, 27 y la de la Escalera de Honor. A su vez, dentro del segundo grupo podemos distinguir tres tipos diferenciados: por un lado está la portada 7, en la que se ha realizado una composición completamente renacentista en jambas, capiteles y frontón superior; el segundo grupo lo integran las portadas 22 y 23 , en las que claramente se ha incorporado una ornamentación superior de carácter renacentista sobre portadas sencillas de factura gótica ${ }^{570}$; el tercer grupo estaría formado por las portadas 20, 26, 27 y Portada de la Escalera de Honor (EH), en las que la ornamentación arquitectónica forma parte del diseño original.

En el primer grupo estarían todas las demás portadas numeradas, así como las portadas no numeradas dibujadas por los arquitectos daneses: D1 a D6, D8 a D19, D21, D24, D25, D28, LA1136, LA1176, LA1177, LA1191 y LA1192.

Dentro de este apartado cabría otro nivel de clasificación, que sería la presencia o no de capiteles. Así, ninguna de las portadas del área de Miguel y Sanchis disponía de capiteles; en las salas 10 a 20 encontramos portadas que carecen de ellos y otras que sí disponen de los mismos, y esto se da independientemente de la sencillez o complejidad de los arcos. Entre las 5 portadas sin numerar ni localizar también encontramos algunas con y $\sin$ capiteles.

\footnotetext{
${ }^{570}$ Gavara Prior, J. y E. Muller, P. (2013). Óp. cit. pp. 40-41.
} 


\section{Por su tipo de jambas}

Por su tipo de jambas se pueden establecer tres grandes grupos: las portadas con una columnilla, las portadas con dos columnillas y las portadas complejas con más de tres columnillas. En el primer grupo están incluidas la D1, D2, D4, D10c, D11, D16, D17, D19, D21 y D25; en el segundo, la D3, D5 a D9, 10b, D12 a D15, D18, D24, D28, LA1136, LA1176, LA1777, LA1191, LA1192 y EH; y en el tercero la 10a, 2026 y 27.

Otro criterio de clasificación de las portadas es según si disponen, o no, de jamba abocinada entre la parte moldurada y la posición de la carpintería. Las portadas con capialzado tienen la función de resolver arquitectónicamente la apertura de huecos en fábricas de gran espesor, facilitando la entrada de luz, alojando las carpinterías en las jambas abocinadas y dando una sensación de mayor amplitud tanto al hueco como a las estancias. Las portadas con jambas abocinadas y capialzado son siempre la cara menos noble, en cuya parte principal encontramos una portada con un arco de mayor complejidad. Las primeras se suelen resolver con un arco escarzano, salvo en algún caso (portada 28), en el que este arco se transforma en su extradós en un arco cortinado, o la portada 23, en la que el arco escarzano se transforma en el extradós en un arco angrelado. Esta solución se aplica también al intradós de las ventanas, aunque en este caso las basas parten de una ménsula desde el muro, y no desde el pavimento.

\section{Por su tipo de arco}

Como vimos en el Capítulo VI, una clasificación de los arcos sería considerado si se trata de un arco que mantiene su tipo a lo largo de todas las molduras o si, por el contrario, existe una transformación a través de las distintas molduras que lo componen. Esta clasificación y la definición pormenorizada de cada arco se han desarrollado en el capítulo VI.

Entre los tipos de arcos que más se repiten, se encuentran los escarzanos con capialzado que, como hemos visto en el apartado anterior, tienen la función de resolver la cara "b" de los arcos de mayor relevancia, junto con los arcos mixtilíneos variación del flamígero que Muller define, de manera genérica, como "arcos conopiales contracurvados" ${ }^{\text {"711. }}$.

Una de las características que distinguen las portadas del Palacio de Oliva respecto de otros edificios, incluido el Palacio de la Generalitat, es la cantidad y diversidad de arcos; no se encuentran dos arcos idénticos en su trazado y llegan a un nivel de complejidad tal encontradas en ninguna de las portadas localizadas en edificios coetáneos.

\subsection{Las basas}

En la clasificación de las basas se ha establecido el mismo criterio que en la clasificación de las portadas según el número de columnillas de las jambas, ya que ambos elementos van unidos intrínsecamente.

${ }^{571}$ Gavara Prior, J. y E. Muller, P. (2013). Óp. cit. p. 40. 
Las conclusiones que hemos obtenidos del análisis de las mismas son las siguientes:

La altura del zócalo recto (A) varía tanto en las portadas de una columnilla como en las de 2 columnillas entre $9,9 \mathrm{~cm}$ y $27,3 \mathrm{~cm}$ (sólo en un caso excede de 1 palmo). La mediana es de $17,05 \mathrm{~cm}$ para las basas de dos columnillas y $16,85 \mathrm{~cm}$ para las basas de una columnilla. Por tanto, un criterio para trazar nuevas portadas o restituir aquellas de las que carecemos de información sería establecer una altura de $3 / 4$ de palmo o lo que es lo mismo, $17,25 \mathrm{~cm}$, ya que es la fracción en palmos que más se aproxima a la mediana en ambos tipos.

En cuanto a la altura del zócalo moldurado (B), ésta varía entre 12, $20 \mathrm{~cm}$ y $24,20 \mathrm{~cm}$ (sólo en dos casos exceden de 1 palmo). La mediana es de 17,70 cm para las basas de dos columnillas y $19,45 \mathrm{~cm}$. en las portadas de una columnilla. Esta altura es algo superior a la medida del zócalo (A), si bien esto puede deberse a variaciones en el nivel del pavimento. En las basas de una columnilla no detectamos una tendencia clara, existiendo variaciones importantes de altura entre ambas molduras, tanto en un sentido como en el otro. Basándonos en un sistema metrológico en palmos, podríamos establecer como "medida" estándar $3 / 4$ de palmo para las portadas de 2 columnillas y 10/12 de palmo (10 dedos) para las de una columnilla $(17,25 \mathrm{~cm}$ y $19,17 \mathrm{~cm}$, respectivamente).

Si analizamos la medida del lado frontal de la base (L) vemos que la mediana es de $22,55 \mathrm{~cm}$ en las de dos columnillas y de $19,35 \mathrm{~cm}$ en las de una columnilla. Para el primer grupo se podría estandarizar esta medida en 1 palmo para la primera y 10 dedos para la segunda.

En cuanto al ángulo de la basa ( $\beta$ ) en el caso de las portadas de dos columnillas, este se podría estandarizar en $45^{\circ}$, y también para las portadas de una columnillas, aunque en este caso encontramos una gran divergencia de datos.

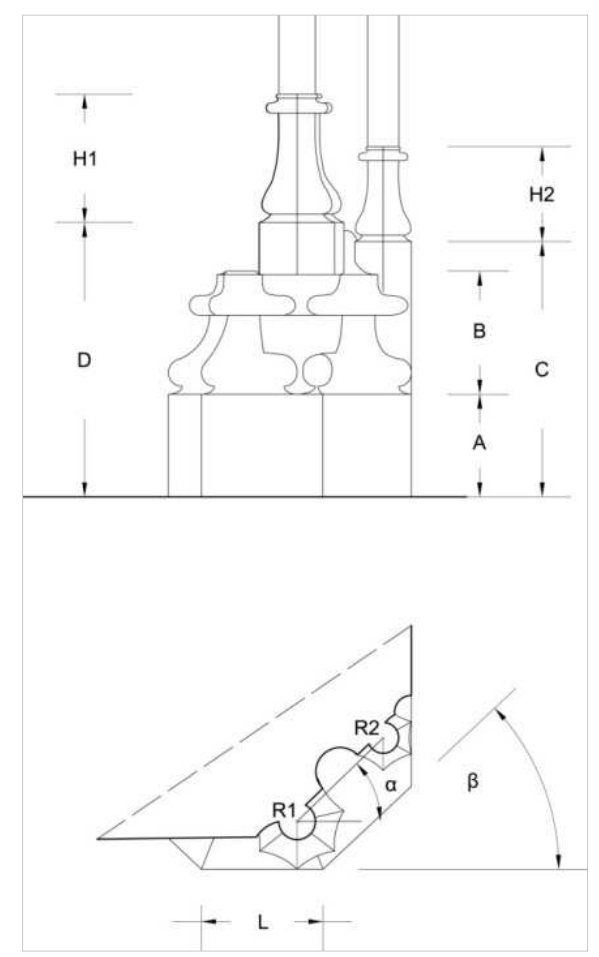

Figura 433. Esquema de identificación de los datos de las basas. 
En cuanto al polígono que forman las basas de las columnillas, este es heptagonal en todas las basas dibujadas por Lauritzen. Con el fin de ampliar la muestra, se han analizado las tres ventanas que tienen representada la base de las columnillas. En cuanto a las ventanas, es octogonal en la V3, heptagonal en la V4 y hexagonal en la V6. En algunos de los dibujos hemos tenido dudas a la hora de asignar uno u otro polígono, realizándose la comprobación sobre las dos jambas y sobre las distintas columnillas para comprobar cuál fue el polígono trazado por Lauritzen. La existencia de diferentes criterios pensamos que se puede deber a la intervención de diversos maestros con diferentes planteamientos de traza.

La discrepancia con otros casos de estudio como las portadas de la Lonja, la Catedral o el Monasterio de la Trinidad, donde los trazados de las basas son hexagonales u octagonales nos hizo pensar que la representación de Lauritzen (en el que la mayoría de las basas representadas son heptagonales) de debiera a un problema de interpretación de las mismas dado que no se pueden visualizar completamente por interseccionar con el muro y por la falta de medios técnicos en la época para poder comprobar correctamente su trazado. Sin embargo, el levantamiento de la única pieza de estas características que se conserva in-situ, la ventana gótica de la vivienda no 7 de la calle Palacio, nos ha permitido verificar que las basas eran heptagonales.

En cuanto a los radios de las basas de las columnillas, la de mayor diámetro (R1) es la medida que más se repite y coincide con la mediana $(8,3 \mathrm{~cm})$, aunque esta medida no cuadra exactamente con una fracción del palmo $(1 / 3 p=7,67 \mathrm{~cm}$ y $5 / 12 p=9,58 \mathrm{~cm})$. En cuanto al radio de la columnilla pequeña (R2), la mediana nos da $5,2 \mathrm{~cm}$, aproximándose esta medida a $1 / 4 p=5,75 \mathrm{~cm}$. En las basas de una columnilla la medida del radio de su basa se aproxima a la de las columnillas grandes de las basas dobles, siendo sus medidas más próximas a $1 / 3$ de palmo, por lo que podríamos estandarizar esta medida en ambos casos.

En cuanto a las alturas de las columnillas en el caso de las bases dobles para la mayor (H1) tenemos una mediana de $20,3 \mathrm{~cm}$, y si lo expresamos en fracciones duodecimales de palmo, se aproximaría a 10 dedos $(19,2 \mathrm{~cm})$. Para el caso de la pequeña $(\mathrm{H} 2)$, la mediana es de $15,00 \mathrm{~cm}$ que, expresada en palmos, sería $2 / 3 \mathrm{p}(15,33 \mathrm{~cm})$. Para las de una columnilla donde la mediana es $18,1 \mathrm{~cm}$ se podría establecer como medida estándar 9 o 10 dedos $(17,25$ ó $19,2 \mathrm{~cm})$.

\subsection{Sección de jambas y arcos}

El perfil tipo de las jambas y los arcos, como hemos visto en el Capítulo VI, tiene su origen en los nervios de los arcos de las bóvedas góticas de crucería. Estos perfiles fueron evolucionando desde formas rectangulares ochavadas a perfiles esbeltos en $\mathrm{V}$ de gran inercia $^{572}$.

\footnotetext{
572 Viollet le Duc, E. (1996) La construcción Medieval. Madrid: Instituto Juan de Herrera, CEHOPU y CEDEX (Edición a cargo de Rabasa Díaz, E. y Huerta Hernández, S.). pp. 85-87.
} 


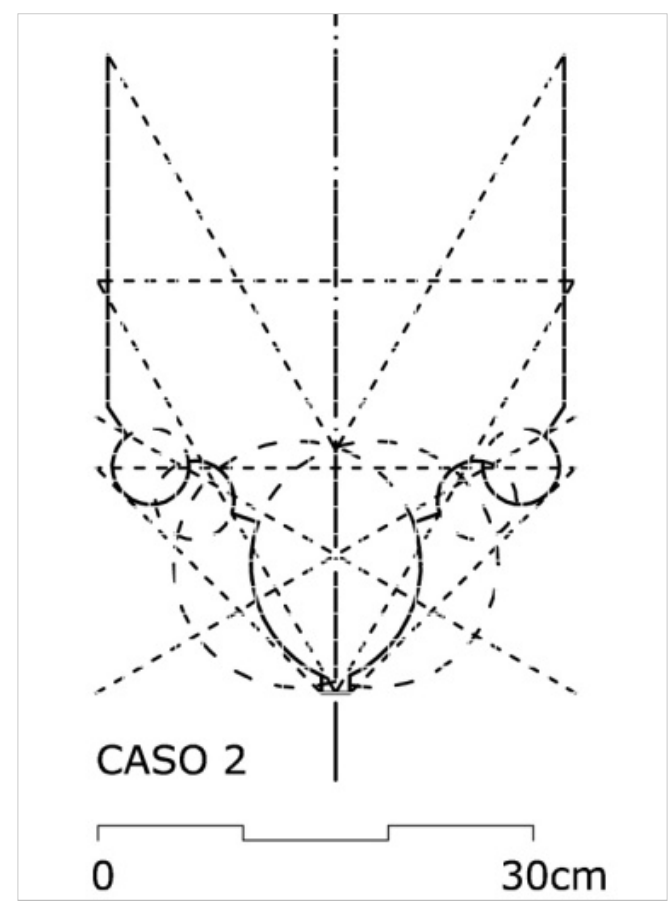

Figura 434. Izquierda: Plantilla nervio de la Iglesia de S. Mateu. Sección: bocel apuntado rematado en filete flanqueado por baquetas laterales separadas mediante listel y caveto. Fuente: A. Soler y M. Cabeza. Derecha: Evolución de las secciones de los nervios. La construcción Medieval. Viollet le Duc.

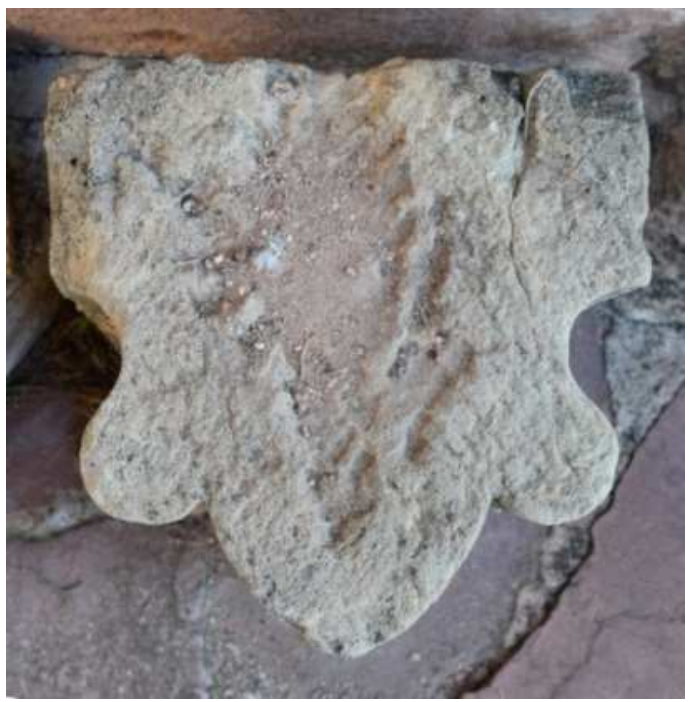

Figura 435.Izquierda: Dovela arco bóveda de crucería. Sección: bocel apuntado flanqueado por dos baquetas y rematado con dos cavetos (Monasterio de Portaceli). Derecha: nervio de la Iglesia de S. Mateu. Sección: bocel apuntado rematado en filete flanqueado por baquetas, cavetos semicirculares, baquetas y finalmente cavetos.

Las secciones de una sola columnilla corresponderían con los trazados moldurados más sencillos, y los de dos columnillas con trazados de dovelas de mayor inercia. En el caso de 
portadas complejas con más columnillas se trata de una variación compositiva de los anteriores modelos.

Las molduras que componen las jambas se limitan a tres: baquetas o columnillas, cavetos y filetes. Esta terminología se ha basado en la utilizada por Viollet le Duc: baqueta para baguette, caveto para cavet, y filete para filet ${ }^{573}$.

En nuestro caso se ha utilizado también el término "columnilla" para denominar a las baquetas o baquetones dado que esta moldura dispone siempre de una basa de planta poligonal y en muchos casos está rematada por un capitel, formando esbeltas columnas dentro del perfil de las jambas. En la sección del arco sería más correcto denominar a esta moldura "baqueta".

Aunque la mayoría de las columnillas están formadas por baquetas, encontramos algunas excepciones como la columnilla de planta mixtilínea de la portada 20 , que es realmente un pináculo, o la columnilla de mayor diámetro de la Portada D26 con perfil apuntado y rematado en filete.

En cuanto al análisis metrológico de las jambas, se han obtenido las siguientes conclusiones para el caso de las molduras con dos baquetas o columnillas: el ancho lo podemos estandarizar en 1 y $1 / 4$ de palmo $(28,75 \mathrm{~cm}$ frente a 28,85 de la mediana) y la profundidad la podríamos estandarizar en 1 palmo (frente a los $22,05 \mathrm{~cm}$ de la mediana). En cuanto a los radios de las columnillas las medidas más repetidas y que coinciden con la mediana son 3,2 $\mathrm{cm}^{574} \mathrm{~cm}$ para el mayor y $2,3 \mathrm{~cm}^{575}$ para el pequeño. Estas medidas no se corresponden con la fracción del palmo o dedo, aproximándose más a un sistema de medición en pulgadas. Así, la columnilla pequeña se aproxima a una pulgada $(2,55 \mathrm{~cm})$ y la grande a 1 y $1 / 4$ pulgadas $(3,19 \mathrm{~cm})$. En el caso del caveto central existen más disparidad de medidas, aunque este se aproxima a 2 pulgadas $(5,10 \mathrm{~cm})$. En cuanto a los ángulos, la escasa muestra y diversidad de datos no nos permite obtener una regla clara, a esto hay que añadirle la dificultad de tomar este ángulo in-situ en 1919 sin las herramientas adecuadas. Sí observamos, no obstante, que en algunos casos coinciden con ángulos fácilmente trazables con un compás $\left(30^{\circ}, 45^{\circ}\right.$ y $\left.60^{\circ}\right)$. En la comprobación realizada en la jamba de la ventana de la calle Palau no 7, el ángulo obtenido es exactamente de $45^{\circ}$.

En cuanto a las jambas con una columnilla, el ancho de jamba se puede asimilar a 10 dedos y la profundidad a $2 / 3$ de palmo (las medianas son $19,9 \mathrm{~cm}$ y $15,8 \mathrm{~cm}$, respectivamente). El radio de la columnilla se aproxima al de las columnillas grandes de las jambas dobles $(2,95$ $\mathrm{cm}$ la mediana), por lo que se podría asimilar a 1 y $1 / 4$ pulgadas y el del caveto principal a dos pulgadas, como en el caso anterior ( $4,7 \mathrm{~cm}$ de mediana). También como en el caso anterior, los ángulos podrían asimilarse a ángulos sencillos $\left(15^{\circ}, 30^{\circ}\right.$ y $\left.45^{\circ}\right)$.

\footnotetext{
${ }^{573}$ Viollete-le-Duc, E. (1854-1868) Diccionario razonado de la arquitectura francesa del S. XI al XVI. 10V. Tome septième. París: A. Morel Éditer. Palabra profil. Pp .483-532.

${ }^{574}$ La mediana prácticamente coincide con la medida de la columnilla grande de la ventana existente en la calle Palau, $7(3,23 \mathrm{~cm})$.

${ }^{575}$ La mediana coincide exactamente con la medida de la columnilla pequeña de la ventana existente en la calle Palau, $7(2,3 \mathrm{~cm})$.
} 


\subsection{Capiteles y ménsulas}

Los capiteles son un elemento decorativo que forma una parte importante en la composición de las portadas, aunque no imprescindible. Estos se sitúan en las zonas más nobles del palacio, no encontrándole ninguno en las portadas documentadas en las áreas de Miguel y Sanchis. Tampoco aparecen capiteles en las portadas de las salas 11 y 12, a pesar de ser éstas de gran relevancia por su tamaño y por los artesonados que las cubrían.

Los capiteles tienen planta poligonal, al igual que las basas, y su sección vertical está compuesta por varios trazados rectos y curvos que le dan su perfil característicamente gótico. Sobre estas formas geométricas surge la parte escultórica en su parte central. En los capiteles pequeños las formas son principalmente vegetales, y en los de mayor tamaño éstas se combinan con formas zooformes y antropomórficas, según el caso. Normalmente se sitúan justo debajo de la línea de impostas, aunque a veces las columnillas se prolongan por encima de los capiteles, interseccionando directamente las baquetas del arco.

Por su parte, las ménsulas se sitúan al mismo nivel que los capiteles y sobre ellas nacen nuevas molduras que completan el arco o las molduras que conforman el alfiz. Las encontramos en las portadas 20, 22, 23, 24, 26, 27 y en la Portada de la Escalera de Honor. Salvo la Portada 24, todas estas portadas tienen también decoración renacentista sobre las enjuntas $y$, aunque parten de una base geométrica gótica, encontramos nuevas formas "a la romana" como conchas o querubines.

Es importante también tener en cuenta que no se trataba de un edificio de nueva planta, sino que los elementos arquitectónicos se adaptaron a un edificio ya construido por lo que las preexistencias pudieron condicionar su diseño y afectar tanto a su trazado como a la métrica utilizada.

\subsection{La métrica}

Una vez realizado el análisis métrico de todas las portadas tanto en palmos de 22,65 como de $23 \mathrm{~cm}$, se han obtenido mayores coincidencias con la segunda métrica, estableciéndose este módulo para posteriores comprobaciones. El hecho de que en 5 de las 7 portadas con arco escarzano el centro se situara exactamente a 4,5 palmos de $23 \mathrm{~cm}$ parece indicar que esta fue la métrica original utilizada para trazar las portadas. Se ha comprobado asimismo la coincidencia de esta métrica tanto en el intradós como en el trasdós de los arcos, encontrándose mayores aproximaciones en el trasdós. Llama, sin embargo, la atención que la medida más común en altura sea 13 palmos, seguido de 11 palmos y $1 / 2$ y 11 palmos, siendo siempre un número impar, y que en anchura sea también un número impar el más repetido, 7, seguido de 6 y 8 palmos. Esta diferencia de medidas se sebe a la variedad y complejidad de los arcos y a las distintas jerarquías de los mismos. Si analizamos las portadas de la 1 a la 9 (salvo la 7, cuyo trazado gótico estaba oculto), de las 8 portadas, 6 tienen una altura aproximada de 13 palmos y otras 6 de ellas una anchura aproximada de 8 palmos. Se observa, por tanto, que en el caso de este grupo de portadas más sencillas hay una cierta uniformidad. Por su parte, en el grupo de portadas de la 10 a la 28 las alturas son muy variables (entre 10 palmos y medio y 17 palmos, y las anchuras entre 6 y 11 palmos). 
Aunque en las cotas generales de las portadas la métrica del palmo encaja de manera aproximada, no encontrábamos explicación a que las medidas de un elemento tan característico y repetitivo como son las columnillas de las portadas no se correspondieran de manera aproximada con el submúltiplo del palmo, el dedo. El hecho más que probable de que las portadas y ventanas fueran realizadas con mano de obra morisca, nos ha hecho replantearnos que las plantillas de las portadas pudieran haberse trazado con el sistema métrico utilizado por ellos, en lugar de con el palmo valenciano.

La medida oficial de la España musulmana era el codo mediano morisco o codo raššāšší, que se dividía en 32 dedos y equivalía a 0,55727 metros $^{576}$. Una columnilla con un diámetro de 2 dedos moriscos de radio equivaldría a $3,48 \mathrm{~cm}$, aproximándose a los $3,2 \mathrm{~cm}$ de la mediana. En cuanto a la columnilla pequeña, 1,5 dedos moriscos de radio ( 3 de diámetro) equivaldrían a $2,61 \mathrm{~cm}$, aproximándose a los $2,3 \mathrm{~cm}$ de la mediana. El ancho del intradós de la ventana de la calle Palau es de $1,417 \mathrm{~m}$, esto equivale prácticamente a 2,5 codos moriscos $(1,39 \mathrm{~m})$. Si comprobamos el ancho de las portadas, vemos que en muchas de las portadas sencillas el ancho de paso corresponde o se aproxima, como hemos visto, a 4 palmos valencianos $(92 \mathrm{~cm})$; sin embargo, hay otro grupo de portadas en las que el ancho se aproxima mucho a los dos codos moriscos $(111 \mathrm{~cm})$. Este dato nos hace plantearnos que, aunque las trazas de los elementos más singulares fueran realizadas por mestres de obra y estos trabajaran en palmos valencianos, las portadas, y sobre todo las más sencillas, así como sus plantillas pudieran haber sido trazadas por mestrals, y que estos utilizaran indistintamente el metro valenciano o el codo mediano morisco, según su procedencia.

\subsection{Las proporciones geométricas}

Con el fin de tratar de definir las proporciones geométricas con las que se trazaron las portadas, se han comprobado las siguientes proporciones respecto del extradós de las mismas: triángulo de oro, triángulo de oro respecto de la base, proporción $3 / 2^{577}$, sección áurea, proporción $\sqrt{3} / 1$. Se ha establecido un criterio de $+/-6 \mathrm{~cm}$ para considerar que existe coincidencia con una de las proporciones; y de entre 6 y $16 \mathrm{~cm}$ para considerar que existe aproximación a la misma. Teniendo en cuenta estos criterios, podemos afirmar que las portadas analizadas no cumplen en su conjunto con ninguna de estas proporciones, si bien sí encontramos cierto sentido de la proporcionalidad en algunas de ellas:

- La proporción en la que hemos encontrado un mayor índice de coincidencia y/o aproximación es la áurea, con un $13 \%$ de coincidencia y un $23 \%$ de aproximación, con lo que podemos concluir que un $36 \%$ cumple o se aproxima a esta proporción.

- La segunda proporción que más se aproxima es la $\sqrt{3} / 1$, con un $6 \%$ de coincidencia y un $26 \%$ de aproximaciones, con un índice total de coincidencia y/o aproximación del $32 \%$.

\footnotetext{
${ }^{576}$ Vallvé Bermejo, J. (1976). Notas de metrología hispano-árabe. El codo en la España musulmana. Al-Andalus: revista de las Escuelas de Estudios Árabes de Madrid y Granada, 41 (2). pp. 339-354.

577 Se realizaron estas comprobaciones apoyándonos en el estudio de la profesora Claudia Pisu en portadas góticas de Cerdeña. Ver: Pisu, C. (2013). Survey methodology and geometrical analysis of late Gothic architecture in Sardinia. IJRET: International Journal of Research in Engineering and Technology. Volume: 02. Issue: 12. pp. 407-416.
} 
- La proporción del triángulo de oro trazado desde el ancho de la basa tiene un índice global de coincidencia y/o aproximación del $26 \%$ (10\% y $16 \%$, respectivamente).

- Las coincidencias y/o aproximaciones para el caso de las otras dos proporciones son anecdóticas.

- Con el fin de tratar de buscar nuevas proporciones que se ajustaran al trazado de las portadas, se ha probado con la proporción 2/1. En este caso, la mayor aproximación se he producido en el intradós del arco.

- En este estudio se ha obtenido un índice total de coincidencia y/o aproximación del $81 \%$ ( $55 \%$ y $26 \%$ ), si bien estas coincidencia y aproximaciones se producen en distintos puntos singulares del arco: arranque y tramos rectos intermedios, dintel (capialzados y arco adintelado) y clave; con unos coeficientes globales del $23 \%$, $13 \%, 16 \%$ y $29 \%$, respectivamente. Se puede afirmar, por tanto, que las portadas cumplen de manera general la proporción $2 / 1$ en el intradós o hueco de paso, ajustándose esta proporción a los puntos singulares del arco, arranque, clave, trazos intermedios en caso de arcos mixtilíneos y dintel en las portadas con capialzado $o$ adinteladas.

\subsection{Paralelismos con otras portadas}

Se han analizado en este trabajo 37 portadas pertenecientes a 18 edificios de tipología y época similar pertenecientes a palacios y castillos señoriales (20), monasterios y edificios religiosos (8) y otros edificios de uso civil (9). En la tabla 52 se enumeran todas las portadas analizadas en este trabajo.

Este tipo de portadas, denomina "portadas de cortina o de pabellón", se sitúan en el último gótico junto con los abovedamientos aristados y los nervios sogueados. Normalmente estaban encuadradas en un guardapolvo a modo de alfiz y los arcos eran mixtilíneos con variados segmentos de curvas y contracurvas ${ }^{578}$. La primera de estas portadas documentada por Zaragozá (2000) es la de la antigua librería de la Catedral, cuyas enjuntas labró el escultor Johan de Kassel en 1497.

En cuanto a las similitudes entre las portadas del Palacio Condal de Oliva con el resto de portadas analizadas encontramos los siguientes paralelismos:

- Portadas D1 a D9, D10b, D10C, D11, D12, D13, D15, D16, D17, D21, D28, LA1136, LA1176, LA1177, LA1191 y LA1192: este grupo de portadas de trazado sencillo formadas por arcos escarzanos, carpaneles o conopiales sencillos $y$, en algunos casos, mixtilíneos, sin capiteles y ejecutadas en obra de yeso son muy similares a las portadas que encontramos en los Palacios de Geldo, Sot de Ferrer o de Lluxent, el Castillo de Benisanó y también a las del Palacio de los Almirantes de Aragón, las portadas sencillas del monasterio de Cotalba o a las que existían en el CastilloPalacio de Argelita.

- Portadas sencillas pero con capiteles góticos (D14, D15, D19 y D25): este grupo de portadas tienen semejanzas con las portadas del Castillo de Bolbaite o algunas de

${ }^{578}$ Zaragozá Catalán, A. (2000). Óp. cit. pp. 186-187. 
las portadas del Monasterio de Cotalba, donde encontramos portadas de idénticas características realizadas también en obra de yeso y con capiteles góticos.

Tabla 52. Listado de otras portadas analizadas en este trabajo.

\begin{tabular}{|c|c|c|c|}
\hline Edificio & Localización & Uso & $\begin{array}{l}\text { No } \\
\text { Portadas }\end{array}$ \\
\hline Castillo-Palacio de los Aguilar & Alaquás & Señorial & 1 \\
\hline Palacio de Albalat dels Sorells & Albalat dels Sorells & Señorial & 1 \\
\hline Castillo-Palacio de Ceyt Abu Ceyt & Argelita & Señorial & 3 \\
\hline Castillo de Benisanó & Benisanó & Señorial & 1 \\
\hline Castillo de Bolbaite & Bolbaite & Señorial & 1 \\
\hline Monasterio de Cotalba & Alfahuir & Religioso & 5 \\
\hline $\begin{array}{l}\text { Castillo-Palacio de los duques de } \\
\text { Medinaceli }\end{array}$ & Geldo & Señorial & 2 \\
\hline Iglesia del Corpus Christi & Lluxent & Religioso & 1 \\
\hline Palacio de Lluxent & Lluxent & Señorial & 3 \\
\hline Castillo de Ortells & Morella & Señorial & 1 \\
\hline Palacio de Sot de Ferrer & Sot de Ferrer & Señorial & 1 \\
\hline Catedral & Valencia & Religioso & 1 \\
\hline Palacio de los Escrivá & Valencia & Señorial & 1 \\
\hline Palacio de la Generalitat & Valencia & Civil & 6 \\
\hline Lonja & Valencia & Civil & 3 \\
\hline Convento de la Trinidad & Valencia & Religioso & 1 \\
\hline Palacio Mosén Sorell & Valencia & Señorial & 3 \\
\hline Palacio de los Almirantes de Aragón & Valencia & Señorial & 2 \\
\hline
\end{tabular}

- Portadas con capiteles y guardapolvo sobre ménsulas (D22, D23 y D24): Esta característica la encontramos en las portada de acceso a la escalera de caracol y la portada de la planta baja del Consulado del Mar de la Lonja de Valencia y en la portada del salón principal del Palacio de Mosén Sorell, hoy en el Museo de Cerámica de Manises, aunque éstas están ejecutadas en fábrica de cantería. 
- Portadas con capiteles y alfiz sobre ménsulas (D26, D27 y Portada Escalera Honor): Estas portadas guardan similitudes con las portadas de la planta primera del Consulado del Mar de la Lonja, con las portadas del Palacio de la Generalitat, la de la antigua biblioteca de la Catedral de Valencia, la portada principal del Palacio de Mosén Sorell o la del Palacio de los Escrivá en Valencia. La portada doble de la Escalera de Honor, esculpida por Lluís Muñoz, guardaba una gran similitud con la portada doble en esquina de acceso a la planta principal de la Generalitat. En esta última las enjuntas de la portada derecha están decoradas con dos medallones de estilo renacentista y con dos bustos en relieve ${ }^{579}$. En el Palacio de Oliva en la portada izquierda, que pudo fotografiar Fischer, aparecen igualmente dos medallones: el de la izquierda representa un guerrero, que podría ser uno de los condes de Oliva, y el de la derecha representa probablemente a un emperador romano. En la portada del Palacio de los Escrivá encontramos una composición similar, con la diferencia de que, en este caso, la escalera entrega en una potada sencilla y la decoración de las enjuntas son los escudos de armas de la familia.

Independientemente de algunos paralelismos formales existentes, en el Palacio Condal de Oliva hay algunas portadas con unas características únicas que no hemos encontrado en ningún otro edificio de todos los estudiados:

- Portada 20: esta portada presenta pináculos góticos, al igual que la portada de la Capilla del Palacio de Mosén Sorell. En ella, como sucede en la D20, parten de la misma basa las molduras que forman las jambas, y del arco de la portada arrancan dos pináculos característicamente góticos que sobrepasan la clave del arco y enmarcan todo el conjunto. La gran diferencia radica en que en el caso de la primera la decoración de las enjuntas es característicamente gótica y en la D20 es de carácter renacentista, con dos grandes sirenas rodeadas de abundante vegetación. La portada 20 incorpora además ornamentación renacentista en macolla en las molduras de sus arcos, sobre unos capiteles característicamente góticos. Esta portada es, sin duda, una de las más complejas y donde la simbiosis de estilos y de ornamentación entre el tardogótico y el renacimiento alcanza su máxima expresión.

- La Portada 15: aunque aparentemente pueda parecer una portada característica de arco conopial, el trazado de su arco hace que sea única entre todas las estudiadas. Su arco mixtilíneo variación del flamígero, con 4 tramos rectos y 10 tramos curvos en su intradós, se transforman en 16 tramos curvos con gran complejidad en su trazado, ya que los arcos se van estilizando y sus curvas se van transformando desde su intradós al extradós. Una transformación similar en los trazados la encontramos en la Portada de los Leones del Monasterio de Cotalba.

- Portadas 22 y 23: inicialmente estas portadas estaban formadas por dos sencillos arcos góticos (conopial contracurvado y escarzano) a los que, posteriormente, se añadieron nuevas molduras sobre ménsulas y una ornamentación renacentista que,

${ }^{579}$ Aldana, S. (1192). Óp. Cit. Tomo II. pp.78-82. 
en el caso de la D22, resulta excesiva y muy recargada ${ }^{580}$. No se han encontrado portadas de características similares entre todas las estudiadas.

- Portadas 26 y 27: estas portadas fueron diseñadas desde su inicio en este estilo híbrido que incorpora elementos de decoración renacentista sobre trazados de factura gótica. En estos dos casos las basas originales son complejas y están formadas por 3 y 5 columnillas para apoyar sobre ellas arcos de grandes dimensiones y con una gran ornamentación en sus enjutas. Aunque la D26 está enmarcada en un alfiz como otras portadas, este es de enormes dimensiones para situar entre la clave apuntada del arco y éste un gran escudo con las armas de los Centelles y los Borja (estos pintados con posterioridad tras la unión de las dos familias). En el caso de la portada 27, una de las molduras que forman las jambas y el arco presentan decoración a candelieri y las grandes volutas que decoran las enjutas del arco intersecan entre las molduras, apareciendo entre las mismas, lo que denota que fue diseñada con esta decoración desde su inicio ${ }^{581}$. Aunque totalmente distintas, el encuentro de las dos volutas formando un arco apuntado en $V$ es similar a las claves de las portadas gemelas de la Puerta de los Leones del Monasterio de Cotalba.

\section{DESARROLLO GRÁFICO}

\subsection{Planos 2D}

La elaboración de planos bidimensionales es el primer paso en el proceso de restitución gráfica de los elementos arquitectónicos, un paso esencial en aquellos elementos como las portadas 1 a la 9, en las que sólo se dispone de un sencillo croquis acotado y, a veces, de una fotografía. Asimismo, permite completar la información en otros elementos.

En el apartado de metodología se ha descrito el proceso, especificando los datos directos y las hipótesis adoptadas para la restitución de las portadas. Además, se ha aplicado a la Portada 5. En la valoración del conjunto se observa la repetición de unos mismos elementos tanto en su sección de detalle como en el trazado de los alzados, pertenecientes al mundo tardogótico con decoraciones renacentistas. La combinación de las diversas formas y elementos da lugar a un variado repertorio de portadas cuya recuperación gráfica permitirá poner en valor la excepcional riqueza arquitectónica de este Palacio Condal.

El estudio incluye la recuperación gráfica de las portadas, mediante la elaboración de una lámina resumen, que supone una documentación objetiva e inédita, indispensable para poder profundizar en aspectos compositivos, cronológicos y estilísticos, y que permitirá que acreditados historiadores puedan realizar investigaciones sobre estos portales desde el punto de vista de la historia de la arquitectura y contrastar los esquemas generales. Este material se podrá difundir en diversos formatos multimedia, con el objetivo de revalorizar el Palacio Condal de Oliva.

\footnotetext{
${ }^{580}$ Gavara Prior, J. y E. Muller, P. (2013). Óp. cit. pp. 40-42.

${ }^{581}$ Gavara Prior, J. y E. Muller, P. (2013). Óp. cit. pp. 42-45.
} 


\subsection{Piezas 3D}

El modelado de elementos arquitectónicos tridimensionales del Palacio ha sido el segundo paso desarrollado en el proceso de restitución gráfica de algunas piezas. Una labor costosa, aunque imprescindible, para poder definir completamente algunos de los elementos de las portadas y ventanas, como son sus complejas basas y los encuentros y transformaciones de sus arcos.

Este modelado nos ha permitido asimismo poder obtener una mejor visualización y comprensión de las piezas, y servir de base para las siguientes fases del proceso de restitución gráfica.

\subsection{Restitución gráfica Sala 12}

Una vez restituidos los elementos arquitectónicos individualmente, el siguiente paso ha sido recrear una sala completa de la que dispusiéramos de toda su información gráfica. Se eligió la Sala 12 por sus grandes dimensiones, la singularidad de sus elementos y por tratarse de elementos con un trazado geométrico, sin apenas parte ornamental.

De este modo, se ha recreado esta sala tal y como la percibieron Fischer y Vilhelm en 1919, con las paredes desnudas, sin pavimento y con el mismo punto de vista, de acuerdo con su altura. También se ha recreado una imagen situando el punto de vista del observador como si estuviese sentado en el festejador izquierdo de la ventana V4.

Finalmente, se ha realizado una hipótesis de pavimento a partir de un despiece original encontrado en los restos del palacio. Para poder ver esta imagen de la sala debemos viajar más atrás en el tiempo, al menos hasta 1851, cuando Sebastián Castellanos visitó el palacio para redactar su memoria al Duque de Osuna.

Las perspectivas obtenidas nos permiten poder visualizar la Sala 12 en su conjunto así como analizar y entender este espacio arquitectónico: su escala, volumen y proporción, y la relación entre los distintos elementos que la componen. La restitución virtual de este espacio puede servir para futuros estudios, así como para su difusión tanto en el ámbito científico como en el cultural y patrimonial.

\subsection{Anaglifos}

Uno de los objetivos principales de este trabajo ha sido el poner en valor el palacio a través de la documentación gráfica elaborada por los arquitectos daneses. Salvo en el caso del forjado de la Sala de Armas y de la Galería del Patio, de la mayoría de elementos disponíamos, aparentemente, de una única fotografía; lo que nos impediría obtener imágenes tridimensionales de los elementos arquitectónicos a partir de las imágenes antiguas. Sin embargo, una vez analizada y clasificada toda la documentación se detectó la existencia de un par de fotografías con similar punto de vista en el caso de las portadas 22 y 
24, así como una de la Galería del Patio, que aunque con diferencias, se podían retocar con el objetivo de poder obtener una imagen de anaglifo.

Tras localizar una nueva toma de la portada 20 en el AGFDP, con un punto de vista similar a la fotografía ya existente, nos encontrábamos ante un nuevo par estereoscópico con la posibilidad de obtener un anaglifo. La técnica de las imágenes estereoscópicas, como se ha visto, es muy antigua. Carlos Sarthou ya utilizó esta técnica y se encuentran muchas imágenes estereoscópicas antiguas sobre edificios tanto en el Archivo General y Fotográfico de la Diputación de Valencia como en el Archivo Fotográfico de la Biblioteca Valenciana ${ }^{582}$. Entendemos que Fischer no utilizó esta técnica ya que su objetivo no era la difusión del palacio, sino su desmontaje y posterior montaje. En el archivo de la Biblioteca Nacional Danesa se pudieron observar algunos clichés de las imágenes de Fischer, siendo estos de tomas sencillas ${ }^{583}$. En cuanto a las fotografías atribuidas a Sarthou, existen dudas sobre la autoría real de las mismas, ya que la mayoría de las tomas son coincidentes con las de Fischer. Por otro lado, el AGFDV sólo dispone de copias en papel de estas fotografías, no los clichés.

A pesar de no haberse realizado fotografías estereoscópicas del Palacio de Oliva, la tecnología actual nos ha permitido obtener algunas imágenes de anaglifo de algunos elementos del palacio con las que podemos tener una visión tridimensional, aunque elemental, de estos elementos arquitectónicos, mejorando su visualización y divulgación.

\subsection{Maquetas}

El uso de maquetas es una herramienta de enorme potencial en el campo del diseño inclusivo para su uso como herramienta de difusión y conocimiento del patrimonio arquitectónico, pudiendo servir como instrumento para acceder a contenidos culturales a personas con discapacidad visual, para las que de otra manera serían inaccesibles. Las nuevas técnicas de prototipado rápido nos permiten obtener modelos tridimensionales de manera fácil y eficiente, permitiendo su uso como herramientas táctiles. El hecho de que el palacio haya desaparecido amplia el potencial de estas herramientas, ya que permiten poder visualizar a escala estos elementos arquitectónicos y poder entender de manera más efectiva sus formas y volumetría.

El modelado tridimensional previo realizado de algunos elementos nos ha facilitado el poder obtener, de una manera sencilla, diversas maquetas tridimensionales que nos permiten visualizar y comprender mejor las distintas molduras que componían las portadas; sus basas, con complicadas formas geométricas, así como los trazados y encuentros de sus complejos arcos.

582 García, A. (1999). Archivo fotográfico de la Diputación de Valencia. AVEI Assosiació Valenciana d'Especialistes en información. En: Métodos de Información: archivos fotográficos. Noviembre 1999, Volumen 6, no34, pp.81-84. y Máñez Pitarch, M. J. (2014). Óp. cit. pp. 569-571.

583 Danmarks Kunstbibliotek Studiesalen (Biblioteca Nacional Danesa del Arte. Sala de estudio) Transformervej, 21b: Søborg, Dinamarca. 
Esta última fase del proceso de restitución tiene un importante papel a la hora de acercar el patrimonio al gran público, especialmente cuando el objeto físico no existe. Asimismo, es una herramienta imprescindible en el campo de la accesibilidad del patrimonio de las personas con problemas visuales, permitiéndoles su comprensión a través del sentido del tacto.

Además, en los edificios históricos que prácticamente han desaparecido, como es el caso del Palacio de Oliva, las maquetas virtuales nos permiten realizar una visualización efectiva, próxima a la realidad, aplicando distintas texturas y buscando puntos de vista similares a una visión real, que aproximen el espacio virtual representado al espacio arquitectónico original de una manera efectiva y sostenible ${ }^{584}$.

\section{SÍNTESIS FINAL}

La gran cantidad de documentación gráfica elaborada por Fischer y Lauritzen entre 1917 y 1920 nos ha permitido estudiar algunos de los elementos más singulares del Palacio Condal de Oliva, acercándonos a tratar de descifrar ciertas claves del edificio, como son su origen, sus autores, su métrica, su traza y su composición arquitectónica.

Con el proceso de restitución gráfica se ha podido demostrar que es posible realizar una reconstrucción rigurosa de algunos de los elementos arquitectónicos del palacio a escala gráfica, posibilitando una hipotética reconstrucción física. La modelización tridimensional de sus elementos posibilita múltiples opciones de visualización y reconstrucción a través de maquetas tanto virtuales como físicas, acercando la arquitectura de este palacio a todo tipo de público y fomentando su difusión no sólo científica, sino también cultural y patrimonial

584 Ceconello, M., y Paquet, E. (18-04-07). Virtual urban design. En: $9^{\text {th }}$ Virtual Reality International Conference. pp. 26-31. Laval, Francia. 



\section{Bibliografía}

\section{LIBROS}

Aldana, S. (1995) El Palau de la Generalitat Valenciana. València: Generalitat Valenciana, Consell Valencià de Cultura.

Almagro Gorbea, A. (2004). Levantamiento arquitectónico. Granada: Universidad de Granada.

Arciniega García, L. (2001). La Memoria del ducat de Gandia i els seus títols annexos. Redactada per Basilio Sebastián per al duc d'Osuna (1851-1852). Gandia: CEIC Alfonso el Vell.

Benito Domenech, F. (2000). El patio del palacio del Embajador Vich. Elementos para su recuperación. Valencia: Museo de Bellas Artes de Valencia.

Berchez Gómez, J. (1983) Catálogo de monumentos y conjuntos de la Comunidad Valenciana I. Valencia: Consellería de Cultura, Educación y Ciencia de la Generalitat Valenciana.

Berchez Gómez, J. y Jarque, F. (1994). Arquitectura Renacentista Valenciana (1500-1570). Valencia: Bancaixa Obra Social.

Beüt Belenguer, E. (1984). Castillos Valencianos. Valencia: José Huguet.

Canga Argüelles, J. (1827) Diccionario de hacienda para el uso de los encargados de la suprema dirección de ella: I L M N O P. Volumen 4. Madrid.

Corachán, J. B. (1719). Arithmetica demonstrada theorico-práctica para lo mathematico y mercantil explicanse las monedas, pesos y medidas de los Hebreos, Griegos y Romanos, y de estos Reynos de España, conferidas entre sí. Barcelona.

Escolano, G. (1611) Segunda parte de la década primera de la historia de la insigne, y coronada ciudad y Reyno de Valencia. Valencia: Pedro Patricio Mey

Espinalt y García, B. (1786). Atlante español o Descripción general de todo el Reino de España. Tomo IX: descripción del Reyno de Valencia. Parte II. Madrid: Imprenta de Hilario Santos Alonso.

Felip Semprere, V. (2001). Recull per a una historia de Nules (Barcelona. 1977 - Nules 2000) Vol. II. Nules, Castellón: Caixa Rural de Sant Josep de Nules.

Gavara Prior, J. y E. Muller, P. (2013). El Palacio Condal de Oliva. Catálogo de los planos de Egil Fischer y Vilhelm Lauritzen. Oliva, Valencia: Ajuntament de Oliva. 
González Simancas, M. (1916). Catálogo monumental y artístico de la provincia de Valencia. Tomo II (Manuscrito). Madrid.

Honnecourt, V. (1927). Álbum de Villard de Honnecourt. Architecte du XIII Siècle (Reproducción del manuscrito). Paris: Bibliotèque Nationale.

José i Pitarch, A (1992). Sobre l'art valencià dels segles XIII-XV. Lluís de Santàngel uno nou home un nou món. Valencia: Presidència de la Generalitat Valenciana.

Llorente, Teodoro (1889). Valencia. Colección «España: sus monumentos y sus artes - su naturaleza é historia». Barcelona: Editorial de Daniel Cortezo y $\mathrm{C}$.

Moreno García, F. (2004). Arcos y bóvedas. Barcelona: Ediciones CEAC.

Navarro Fajardo, J.C. (2004). Bóvedas valencianas de crucería de los siglos XIV al XVI. Traza y montea. (Tesis Doctoral). Valencia: Universitat de València. Servei de Publicacions.

Rabasa Díaz, E. (2011). El manuscrito de cantería de Joseph Gelabert. Palma de Mallorca: Col.legi Oficial d'Arquitectes de les Illes Balears.

Ramírez Blanco, MJ. (2013). La Lonja de Valencia y su conjunto monumental, origen y desarrollo constructivo (Tesis Doctoral). Valencia: Editorial Universitat Politècnica de València.

Rodriguez de Abajo, F.J. y Álvarez Bengoa, V. (1987). Curso de dibujo geométrico y de croquización. Alcoy, Alicante: Editorial Marfil, S.A.

Roselló, V., Teixidor, M. J., Zaragozá Catalán, A. y otros (1991). Palau del Almirall. Valencia: Generalitat Valenciana, Consellería de Economía y Hacienda.

Ruiz de la Rosa, J. A. (1987). Traza y simetría de la Arquitectura. En la Antigüedad y Medievo. Sevilla: Servicio de Publicaciones de la Universidad de Sevilla.

Sarthou y Carreres, C. (1920). Geografía General del Reino de Valencia. Provincia de Valencia. Tomo II. Barcelona: Editorial de Atberto Martín.

Serlio, S. (1545) Le premier libre d'architecture...Le second libre de perspective... Paris: J. Barbé.

Tormo, E (1923) España. Levante. Guías Calpe. Madrid: Calpe.

Vandelvira, A. (1977). El tratado de arquitectura de Alonso de Vandelvira: reproducción facsímil. Albacete: Caja de Ahorros Provincial de Albacete.

Viollete-le-Duc, E. (1854-1868) Diccionario razonado de la arquitectura francesa del S. XI al XVI. 10V. Tome septième. París: A. Morel Éditer. 
Viollet le Duc, E. (1996) La construcción Medieval. Madrid: Instituto Juan de Herrera, CEHOPU y CEDEX (Edición a cargo de Rabasa Díaz, E. y Huerta Hernández, S.).

Vitrubio Polion, M. (1787). Los diez libros de architectura. Joseph Ortíz y Sanz (comentarios y traducción del latín). Madrid: Imprenta real.

VV.AA. Esteve i Blai, A. (1997). El Palau dels Centelles d'Oliva. Recull gràfic y documental. Oliva, Valencia: L'Associació Cultural Centelles i Riu-Sec Oliva.

VV.AA. Cardona Miralles, S. (1988). Iniciación a la Historia de Oliva (2aㅡ.). Oliva, Valencia: Publicaciones del Ayuntamiento de Oliva.

Zaragozá Catalán, A. (2000). Arquitectura Gótica Valenciana. Siglos XIII-XV Valencia: Generalitat Valenciana. Conselleria de Cultura i Educació.

Zaragozá Catalán, A. y Gómez Ferrer, M. (2007). Pere Copmte Arquitecto. Valencia: Consorci de Museus de la Comunitat Valenciana.

\section{CAPÍTULOS DE LIBROS}

Aguilar Civera, I. (1997). Pròleg. En A. Esteve i Blai, Antoni (Ed). El Palau dels Centelles d'Oliva. Recull gràfic y documental. Oliva (pp. 31-40) Oliva, España: L'Associació Cultural Centelles i Riu-Sec Oliva.

Brines Bañó, F. (1988). El rostro de Oliva. En Cardona Miralles, S. (Ed). Iniciación a la Historia de Oliva (2a Ed.). (pp. 17-32). Oliva, Valencia: Publicaciones del Ayuntamiento de Oliva.

Camarena Mahiques, J. (1988) De la historia de oliva y Rebollet. En Cardona Miralles, S. (Ed). Iniciación a la Historia de Oliva (2a Ed.). (pp. 125-243). Oliva, Valencia: Publicaciones del Ayuntamiento de Oliva.

Cardona Miralles, S. (1988) El medio físico. En Cardona Miralles, S. (Ed). Iniciación a la Historia de Oliva (2 $\underline{a}$ Ed.). (pp. 32-86). Oliva, Valencia: Publicaciones del Ayuntamiento de Oliva.

Delicado Martínez, J. (1999). El Palacio de los Condes de Oliva. En Aldana Fernández, S. (Ed). Monumentos desaparecidos de la Comunidad Valenciana. I Valencia. (pp. 411-414). Valencia: Consell Valencià de Cultura.

E. Muller, P. (1997). El Palau d'Oliva dels Centelles. En A. Esteve i Blai, Antoni (Ed). El Palau dels Centelles d'Oliva. Recull gràfic y documental. Oliva (pp. 87-138) Oliva, España: L’Associació Cultural Centelles i Riu-Sec Oliva. 
Garfella Rubio, J.T., Máñez Pitarch, M.J., y Martínez Moya, J.A. (2015). Comparative Study of Graphic Representation Methods on Architectural Heritage. En Stefano Brusaporci (Ed.), Handbook of Research on Emerging Digital Tools for Architectural Surveying, Modeling, and Representation. Hershey, Pensilvania: IGI Global.

Gómez-Ferrer, M. (2009). La arquitectura renacentista en Valencia. En Jorge Hermosilla Pla (Ed.). La ciudad de Valencia: historia, geografía y arte de la ciudad de Valencia. Vol. 2. Valencia: Universitàt de València. pp. 317-323.

Máñez Pitarch, M.J., Gual Ortí, J. Garfella Rubio, J.T. y Martínez Moya, J.A. (2016). Renaissance-Style Architecture in El Maestrazgo: From Virtual to Tactile Models. En Giuseppe Amoruso (Ed.), Handbook of Research on Visual Computing and Emerging Geometrical Design Tools. Hershey, Pensilvania: IGI Global.

Mestre Sanchis, A. (1988). La economía Olivense. En Cardona Miralles, S. (Ed). Iniciación a la Historia de Oliva (2a Ed.). (pp. 273-296). Oliva, Valencia: Publicaciones del Ayuntamiento de Oliva.

Mestre i Pons, F. (1997). Apunts bibliogràfics dels Centelles. En A. Esteve i Blai. El Palau dels Centelles d'Oliva. Recull gràfic y documental (pp. 41-75). Oliva, España: L’Associació Cultural Centelles i Riu-Sec Oliva.

Pons Fuster, F. (1988). Estudio demográfico de Oliva. (Siglos XVI-XX). En Cardona Miralles, S. (Ed). Iniciación a la Historia de Oliva (2a Ed.). (pp. 224-272). Oliva, Valencia: Publicaciones del Ayuntamiento de Oliva.

Plá Ballester, E. (1988). Prehistoria y Protohistoria. En Cardona Miralles, S. (Ed). Iniciación a la Historia de Oliva (2 Ed.). Oliva, Valencia: Publicaciones del Ayuntamiento de Oliva.

Iborra Bernard, F. y Zaragozá Catalán, A. (2003). El Palacio de Mosén Sorell en Valencia. En Mirá, E. y Zaragozá Catalán, A. (Ed). Una arquitectura gótica Mediterránea Vol II. Valencia: Conselleria de Cultura i Educació.

\section{ARTÍCULOS DE REVISTAS}

Carbonell Boria, M.J. (1995).Las Cortes Forales Valencianas. Cortes Valencianas. Corts: Anuario de derecho parlamentario, no 1. pp. 61-78.

Chalmeta Gendrón, P. (2008). El almotacén a través de los "llibre del Mustaçaf". Universidad de Zaragoza, Aragón en la Edad Media. no20. pp. 203-223.

Consuegra Cano, B. (1997). La visita al museo de alumnos ciegos y deficientes visuales. Integración, Revista sobre discapacidad visual, (24). pp. 47-50. 
E. Muller, P. (1996). El Palacio de Oliva de los Centelles. Architectura 18: Arkitekturhistorisk Årsskrift 18, pp. 127-157.

E. Muller, Priscilla. (1999). A la recerca del Palau. Cabdells: Revista d'investigació de I'Associació Cultural Centelles i Riusech, Núm 1. pp. 21-28.

Gaiani, M. (2008). Architectorum delineamenta, ovvero le interfacce di lavoro dell'architetto, En: Abitare virtuale significa rappresentare, ROMA, Edizioni Kappa, pp. $74-119$.

García, A. (1999). Archivo fotográfico de la Diputación de Valencia. AVEI Assosiació valenciana d'especialistas en información. En: Métodos de Información: archivos fotográficos. Noviembre 1999, Volumen 6, no 34, pp. 81-84.

García Gómez, N. (2012) Trazado de las bóvedas de nervaduras mexicanas del siglo XVI. Revista de Arquitectura. Vol. 14. Núm.1. pp. 106-115.

Gómez Ferrer, M. y Corbalán, J. (2004). La casa del obispo de Tortosa, Alfonso de Aragón. Un Palacio valenciano en la encrucijada de los siglos (XV-XVI). Ars Longa. Num. 13. pp. 11-13.

Gual, J., Puyuelo, M., y Lloveras, J. (2014). Three-dimensional tactile symbols produced by 3D printing: improving the process of memorizing a tactile map key. British Journal of Visual Impairment, 32 (3), pp. 263-278.

Gual, J., Puyuelo, M., \& Lloveras, J. (2015a). Improving tactile map usability through 3D printing techniques: An experiment with new tactile symbols. The Cartographic Journal, 52, pp. 51-57.

Gual, J., Puyuelo, M., \& Lloveras, J. (2015).The effect of volumetric (3D) tactile symbols within inclusive tactile maps Applied Ergonomics, 48, pp. 1-10.

Gual, J., Puyuelo, M., Lloveras, J. y Merino, L. (2012). Visual impairment and urban orientation: pilot study with tactile maps produced through 3D printing. Psychology: Ambiental-Bilingual Journal of Environmental Psychology, 3 (2), pp. 239-250.

Gual, J. , Serrano, J., y Máñez, M.J. (2015). Tangible graphics using rapid prototyping techniques: volume as a design constituent. The Spanish Digital Journal on Blindness and Visual Impairment, 65, pp. 1-22.

Gual, J., Serrano, J. y Máñez, M.J. (2015). Aplicación de la fabricación aditiva en la obtención de moldes para termoconformar gráficos tangibles orientados a personas con discapacidad visual. Tangible graphics using rapid prototyping techniques: volume as a design constituent. The Spanish Digital Journal on Blindness and Visual Impairment, 66. pp. 1-31. 
Gutiérrez i Poch, M. (2014). Ramón Romaní i Puigdengolas (1846-1898): paperer, empresari i historiador. Miscellanea Aqualatensia. Núm.: 14 Recerques sobre la comarca de I'Anoia. pp. 135-183.

Iborra Bernard, F. (2013). Corte y cortesanos: evolución tipológica residencial y ecos del palacio del monarca en el Reino de Valencia. Anales de Historia del Arte. Vol. 23 Núm. especial (II). pp. 469-485.

Ivars Pérez, J. (2013). Intervenció a la Torre de la Comare: Palau dels Centelles. Cabdells: Revista d'investigació de I'Associació Cultural Centelles i Riusech, Núm XI. pp. 5-17.

López González, C. (1996). Análisis Gráfico de las fachadas de los edificios señoriales construidos durante los siglos XIV y XV en la ciudad de Valencia. Revista de Expresión Gráfica de la Edificación. Núm. 4. pp. 186-190.

López González, C., García Valldecabres, J. (2002). Una metodología para el análisis de los trazados reguladores clásicos de la Arquitectura. Revista de Expresión Gráfica de la Edificación. Núm. 7. pp. 108-114.

Martínez Moya, J.A., Soler Estrela, A. (2014). Metodología de recuperación gráfica de las portadas de Palacio Condal de Oliva. Revista de Expresión Gráfica de la Edificación. Núm. 8. pp. 43-51.

Martínez Moya, J. (2016). Restitución gráfica de la sala 12 del Palacio Condal de Oliva a partir del legado gráfico de Fischer y Lauritzen. EGA. Revista de expresión gráfica arquitectónica, Vol 21. Núm. 28. pp. 60-69.

Mestre i Pons, F. (2001). Donació de taulletes gòtics del Palau d'Oliva., Núm 3. pp. 146-151.

Olaso i Sendra, V. (2015). Oliva en "Valencia, puerto mediterráneo en el siglo XV (14101525)", de Jaqueline Guiral. Cabdells: Revista d'investigació de l'Associació Cultural Centelles i Riusech, Núm 13. pp. 41-45.

Pisu, C. (2013). Survey methodology and geometrical analysis of late Gothic architecture in Sardinia. IJRET: International Journal of Research in Engineering and Technology. Volume: 02.Issue: 12. pp. 407-416.

Vallvé Bermejo, J. (1976). Notas de metrología hispano-árabe. El codo en la España musulmana. Al-Andalus: revista de las Escuelas de Estudios Árabes de Madrid y Granada, 41 (2). pp. 339-354.

Zaragozá Catalán, A. y Gómez Ferrer, M. (2008) Lenguajes, fábricas y oficios en la arquitectura valenciana del tránsito entre la Edad Media y la Edad Moderna. (14501550) en Artigrama, núm. 23. pp. 149-184. 


\section{PRENSA HISTÓRICA}

Gaceta de Madrid (1920). Orden Real declarando El Palacio Condal de Oliva Monumento Arquitectónico Artístico. Gaceta de Madrid. Num. 215, pp. 423.

Vidal, J.M. (1932) El Palacio de los Condes de Oliva. Semanario científico, literario y de información agrícola Patria Chica № 11.

\section{PRENSA ON LINE}

Batalla, E. (24 febrero, 1999) Oliva recupera la memoria del Palau Comtal en una exposición con motivo de su 550 aniversario. El Pais. Recuperado de: http://elpais.com/diario/1999/02/24/cvalenciana/919887497_850215.html.

\section{ACTAS DE CONGRESOS}

Amoruso, G. (01-12-16). Gli strumenti geometrici, proiettivi e visuali per il progetto, nell'era del digitale. En: XIII Congreso Internacional de Expresión Gráfica aplicada a la Edificación, APEGA 2016. pp. 21-42. Valencia, España.

Amoruso, G., Sdegno, A. y Riavis, V. (01-12-16). Ricostruzione virtuale di uno spazio illusorio. La prospettiva solida di Giovanni Maria da Bitonto a Bologna. En: XIII Congreso Internacional de Expresión Gráfica aplicada a la Edificación, APEGA 2016. pp. 453-466. Valencia, España.

Ceconello, M. y Sallazzo, D. (06-10-08). Virtual Reality for enhanced Urban Design. En: $5^{\text {th }}$ INTUITION International Conference; Virtual Reality in Industry and Society: From Research to Application. P.66. Turín, Italia.

Ceconello, M., y Paquet, E. (18-04-07). Virtual urban design. En: 9th Virtual Reality International Conference. pp. 26-31. Laval, Francia.

García Giner, M.I. (2007) El yeso en la arquitectura tardogótica valenciana. En: Actas de Quinto Congreso Nacional de Historia de la Construcción, Instituto Juan de Herrera. pp. 411-422. Burgos, España.

Marín Sánchez, R. (26-12-11). Bóvedas de crucería con nervios prefabricados de yeso y de ladrillo aplantillado. En: Actas del Séptimo Congreso Nacional de Historia de la Construcción. pp. 841-850. Santiago de Compostela, España. 
Martínez Moya, J.A. (1-12-16). Composición y decoración de las portadas tardogóticas del palacio condal de Oliva. En: XIII Congreso Internacional de Expresión Gráfica aplicada a la Edificación, APEGA 2016. pp. 557-568. Valencia, España

Martínez Moya, J.A. (12-06-14). Classification of the graphic legacy of Disappeared Earl of Oliva's Palace. En: XII Forum Internazionale di Studi Le vie dei Mercanti. Best practices in heritage conservation and management. pp. 604-613. Aversa-Capri, Italia.

Martínez Moya, J.A. (2014). Análisis gráfico de las portadas tardogóticas del Palacio Condal de Oliva a partir del patrimonio gráfico recuperado. En XII Congreso Internacional de Expresión Gráfica Aplicada a la Edificación. Nuevas Técnicas, mismos fundamentos. Vol. II. pp. 465-467. Madrid, España.

Martínez Moya, J.A., Máñez Pitarch, M.J., y Garfella Rubio, J.T. (22-10-2015). Valencian Castle-Palace Route. Ruta de los Castillos-Palacio Góticos Valencianos. En: III Congreso Internacional sobre Documentación, Conservación y Reutilización del Patrimonio Arquitectónico. REUSO 2015. pp. 1708-1715. Valencia, España.

Martínez Moya, J.A., Máñez Pitarch, M.J., y Garfella Rubio, J.T. (11-06-2015). Geldo's Castle Palace, at Castellón Province, Spain. En: Heritage and Technology Mind Knowledge Experience (XIII Forum Internationale Le Vie dei Mercanti). pp. 1820-1827. Aversa, Capri, Italia.

Soler Estrela, A. y Soler Verdú, R. (13-10-15). Carpintería de armar: alfarjes medievales. Metodología de estudio. En: Actas del Noveno Congreso Nacional y Primer Congreso Internacional Hispanoamericano de Historia de la Construcción. pp. 1643-1652. Segovia, España.

Soler Estrela, A., Soler Verdú, R. y Cabeza González, M. (11-06-2015). A pyramidal kitchen vault in a Gothic-Renaissance palace. Oliva, Valencia, Spain. En: Heritage and Technology Mind Knowledge Experience (XIII Forum Internationale Le Vie dei Mercanti). pp. 396-403. Aversa, Capri, Italia.

Soler Estrela, A., Soler Verdú, R. y Cabeza González, M. (22-10-2015). Una bóveda desaparecida en el palacio gótico-renacentista de Oliva, Spain. Análisis de los restos y tipología. En: III Congreso Internacional sobre Documentación, Conservación, y Reutilización del Patrimonio Arquitectónico y Paisajístico. pp. 2315-2322. Valencia, España.

Voigt, A., y Martens, B. (2006). Development of 3D tactile models for the partially sighted to facilitate spatial orientation. En: Communicating Space(s): 24th eCAADe Conference Proceedings, pp. 366-370. Volos (Grecia): University of Thessaly. 


\section{NORMAS}

Normas APA. Recuperado de: www.normasapa.net.

\section{TESIS NO PUBLICADASY TRABAJOS ACACÉMICOS}

García Valldecabres, J. (2010) La métrica y las trazas en la iglesia de San Juan del Hospital de Valencia. (Tesis doctoral no publicada). Universitat Politècnica de València.

Máñez Pitarch, M. J. (2014)La Arquitectura religiosa renacentista en tierras del Maestre: Ia Iglesia de Nuestra Señora de la Asunción de Vistabella del Maestrazgo. (Tesis doctoral no publicada). Universitat Politècnica de València, Valencia, España.

Marín Sánchez, R. (2014). Uso estructural de prefabricados de yeso en la arquitectura levantina de los siglos XV y XVI (Tesis doctoral no publicada). Universitat Politècnica de València.

Perales Vila, D. (2007). Palau dels Centelles d' Oliva, estudio arquitectónico y constructivo a partir de los restos y fuentes documentales existentes, cerramiento exterior, muros y torres. (Trabajo Final de Carrera. Tutora: Alba Soler Estrela). Universitat Politècnica de València.

Valero Martínez, F. (2207).El palau dels Centelles d' Oliva. (Trabajo Final de Carrera. Tutora: Alba Soler Estrela). Universitat Politècnica de València.

\section{PROYECTOS TÉCNICOS DE RESTAURACIÓN}

Ferrant, A. (1946). Proyecto de Obras de Conservación de elementos Decorativos Pertenecientes al Palacio de los Condes de Oliva (Valencia). Archivo IPCE. Madrid.

Ivars Pérez, Josep (1999) Restauració de la torre del Carrer Comare, Palau dels Centelles (Oliva). Castellón: Direcció General del Patrimoni Artistic, Direcció Territorial de Castelló.

Soler Verdú, R. y Soler Estrela, A. (2007). Recuperació de la façana de llevant del Palau dels Centelles d'Oliva. Estudios Previos. Ayuntamiento de Oliva.

\section{DOCUMENTACIÓN ARCHIVOS}

Aguilar, J. V. (1708). Carta al duque de Gandía (Pascual Francisco Borja Centelles Ponce de León). AHN. Osuna. OSUNA,CT.123,D.39. 
Anónimo. Autógrafo de D. Luis de Salazar (¿?). Tabla genealógica de la familia de Centelles, condes de Oliva. Colección Salazar y Castro de la RAH.

Anónimo, (1919). Fotografías Palacio del Marqués de Monistroll. Barcelona: Instituto Amatller d'Art Hispanic. Foto Mas. Fot. C24523 y C24524

Anónimo, (1919). Fotografías Antiguo palacio del conde de Santa Coloma. Barcelona: Instituto Amatller d'Art Hispanic. Foto Mas. Fot. C27227 y C27228.

Ferrant, A. (1946). Proyecto de Obras de Conservación de elementos Decorativos Pertenecientes al Palacio de los Condes de Oliva (Valencia). Archivo IPCE. Madrid.

Fischer, E. y/o Lauritzen V. (1919-1920). Planos. Oliva, Valencia: Museo Municipal de Oliva, Archivo Público Documental, Palacio Condal.

Fischer, E. (1917-1920). Notebook I. Oliva, Valencia: Museo Municipal de Oliva, Archivo Público Documental, Palacio Condal.

Fischer, E. (1917-1920.). Notebook II. Oliva, Valencia: Museo Municipal de Oliva, Archivo Público Documental, Palacio Condal.

Fischer, E.(1917-1920). Álbum Fotos Grande. Oliva, Valencia: Museo Municipal de Oliva, Archivo Público Documental, Palacio Condal.

Fischer, E. (1917-1920). Álbum de Fotos Pequeño. Oliva, Valencia: Museo Municipal de Oliva, Archivo Público Documental, Palacio Condal.

Ivars Pérez, Josep (1999). Restauració de la torre del Carrer Comare, Palau dels Centelles (Oliva). Castellón: Direcció General del Patrimoni Artistic, Direcció Territorial de Castelló, D.L. 1999.

Lauritzen, V. (1920). Cartas de V. Lauritzen a E. Fischer. Documentación Palacio de Oliva. FA68 y FA69. Søborg, Dinamarca: Archivo DKS.

Lauritzen, V (1979). Relación sobre el Palacio. Documentación Palacio de Oliva. FA68 y FA69. Søborg, Dinamarca: Archivo DKS.

Sarthou, C. (1919-1920) Fotografías Palacio de Oliva. (1639, 1642-1644 y 1670-1698). Valencia: AGFDV.

València (Regne). (1548). Corts. Fori Regni Valentiae. Rública XXXVIII. Folio CCLXI. Valencia.

\section{PÁGINAS WEB}

ARKITEKTURBILLEDER. Recuperado de: www.arkitekturbilleder.dk 
Ayuntamiento de La Font d'en Carròs. Recuperado en: http://www.lafontdencarros.es

Castillo de Alaquás. Recuperado de: http://castell.alaquas.org/esp/monumento.php

CERES. Colecciones en Red. Recuperado de: www.ceres.mcu.es

Consellería de Cultura de la Generalitat Valenciana. Recuperado de: www.cult.gva.es

Conselleria de cultura i esport. Generalitat Valenciana. Recuperado de: www.cult.gva.es/dgpa/leydepatrimonio

Institut Cartogràfico Valencià. Recuperado de: www.fototeca.icv.gva.es

Inventario de Bienes Inmuebles de la Comunidad Valenciana. Generalitat Valenciana. Conselleria de Cultura i Esport. Direcció General de Patrimoni Cultural Valencià. Recuperado de: www.cult.gva.es/dgpa

Femmoller Strand. Recuperado de: www.femmoller-strand.dk/egil-fischer

Grundejerforeningen Femmøller Beach. Recuperado en: http://www.gffs.dk/gffs/Historie

Kultur Ministeriet (Ministerio de Cultura Danés). Recuperado de: www.kulturarv.dk

Millech, K y Villadsen, V. (1979-1984). Den Store Danske. Enciclopedia Bibliográfica Danesa. Recuperado de:

www.denstoredanske.dk/Dansk_Biografisk_Leksikon/Kunst_og_kultur/Arkitektur/Ar kitekt/Egil_Fischer

Ministerio de Cultura. Recuperado de: www.mecd.gob.es

Ministerio de Cultura Danés. Recuperado de: www.kulturarv.dk

Monasterio de Sant Jeroni de Cotalba. Recuperado de:

http://www.cotalba.es/cast/index.html

Pérez Olagüe, C. (¿’). Castillo Palacio de Bolbaite. Inventario de Bienes Inmuebles de la Comunidad Valenciana. Recuperado de: http://www.ceice.gva.es/web/patrimoniocultural-y-museos/bics

Pérez Olagüe, C. (¿’). Castillo Palacio de Geldo. Inventario de Bienes Inmuebles de la Comunidad Valenciana. Recuperado de: http://www.ceice.gva.es/web/patrimoniocultural-y-museos/bics

Pérez Olagüe, C. (¿’). Castillo Palacio de Ceyt Abu Ceyt. Inventario de Bienes Inmuebles de la Comunidad Valenciana. Recuperado de: http://www.ceice.gva.es/web/patrimoniocultural-y-museos/bics 
Vilhelm Lauritzen Arkitekter. Recuperado de: www.vla.dk/projekter.html

Villadsen, V. (1979-1984). Den Store Danske. Enciclopedia Bibliográfica Danesa. Recuperado de:

http://denstoredanske.dk/Dansk_Biografisk_Leksikon/Kunst_og_kultur/Arkitektur/Arkitekt /Vilhelm_Lauritzen

Wikipedia. Egil Fischer. Recuperado de: www.da.wikipedia.org/wiki/Egil_Fischer

Wikipedia. Vilhelm Lauritzen. Recuperado de:

www.en.wikipedia.org/wiki/Vilhelm_Lauritzen

\section{MUSEOSY EDIFICIOS HISTÓRICOS VISITADOS}

Archivo General y Fotográfico de la Diputación de Valencia

Castel Nuovo (Napoles, Italia)

Castillo Palacio de Benisanó (Benisanó, Valencia)

Castillo Palacio de Lluxent (Lluxent, Valencia)

Catedral de Valencia

Convento de la Trinidad (Valencia)

Lonja de Valencia

Monasterio de la Cartuja de Portaceli (Serra, Valencia)

Monasterio de Sant Jeroni de Cotalba (Alfahuir, Valencia)

Monasterio de la Santísima Trinidad (Valencia)

Museo Arqueológico de Oliva (Oliva, Valencia)

Museo de Bellas Artes de Valencia (Valencia, España).

Museo de Cerámica y Artes Suntuarias González Martí. (Valencia)

Museo de Cerámica de Manises (Manises, Valencia)

Museo de Diseño y de las Artes Aplicadas de Copenhague (Copenhague, Dinamarca)

Palacio de Albalat dels Sorells (Albalat dels Sorells, Valencia) 
Palacio de los Duques de Gandía (Gandía, Valencia)

Palacio de los Duques de Medinaceli (Geldo, Castellón)

Palacio de la Generalitat (Valencia)

Torre de la Comare (Oliva, Valencia)

\section{BIBLIOTECAS CONSULTADAS}

Biblioteca Universitat Jaume I (Castellón)

Biblioteca Universitat Politècnica de València (Valencia)

Biblioteca Centrale di Architettura - BCA. Politecnico di Milano. (Campus Bonardi) Via Ampère, 2 (Milán, Italia)

Biblioteca Campus Durando - BCD. Politecnico di Milano. (Campus Bobisa). Via Candiani, 72 (Milán, Italia)

Biblioteca Pública del Estado (BPE) Valencia. Calle Hospital, 13 (Valencia)

Biblioteket for Arkitectur Design Konservering \& Scenekunst (The Library of Architecture, Desing Conservation \& Performing Arts) Danneskiold-Samsøes Allé, 50 (Copenhage, Dinamarca)

Danmarks Kunstbibliotek (Biblioteca Nacional Danesa del Arte). Nyhavn, 2 (Copenhague, Dinamarca)

Danmarks Kunstbibliotek Studiesalen (Biblioteca Nacional Danesa del Arte. Sala de estudio) Transformervej, 21b (Søborg, Dinamarca)

Det Kongelige Bibliotek (Biblioteca Real Danesa) Søren Kierkegaards Plads, 1 (Copenhague, Dinamarca)

KADK. Det Kongelige Danske Kunstakademis Skoler for Arkitektur, Design og Konservering (The Royal Danish Academy of Fine Arts Schools of Architecture, Design and Conservation) Philip De Langes Allé, 10 (Copenhague, Dinamarca)

VIA Biblioteker (Biblioteca VIA College University) Chr. M. Østergaards Vej, 4 (Horsens, Dinamarca). 

ANEXO GRÁFICO

“La arquitectura del expoliado Palacio Condal de Oliva a través del legado gráfico”" 



ÍNDICE ANEXO GRÁFICO

Plano

Pág.

Plano de emplazamiento .......................................................................6

Plano de situación ..........................................................................................

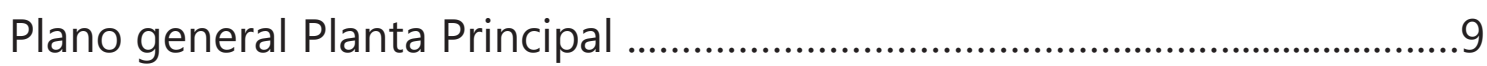

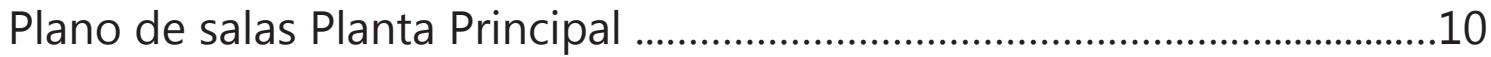

Plano situación portadas y ventanas ............................................................11

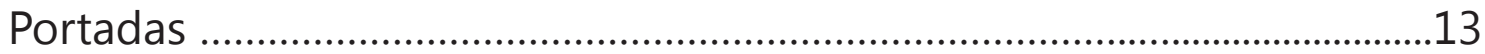

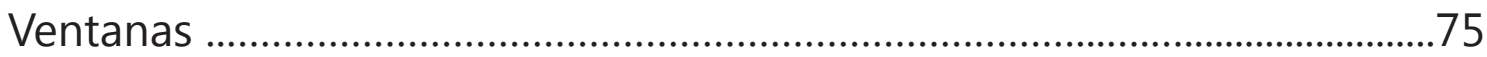

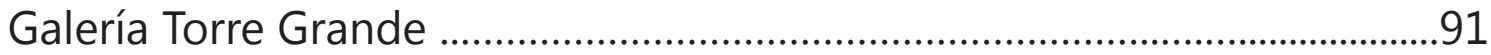

Artesonado y Bóveda ........................................................................................95

Compartiva Proyecto Pile Allé ..................................................................................101

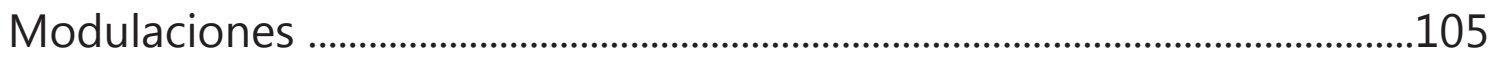

Comparativo Fotografías Carlos Sarthou y Egil Fischer ............................123

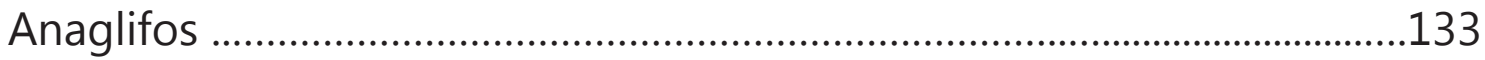

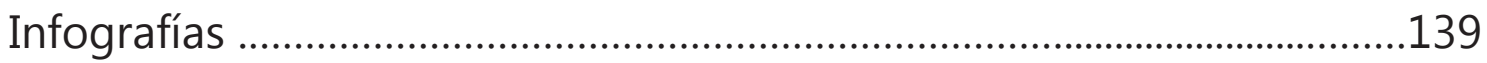

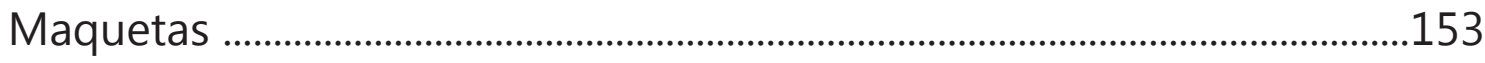




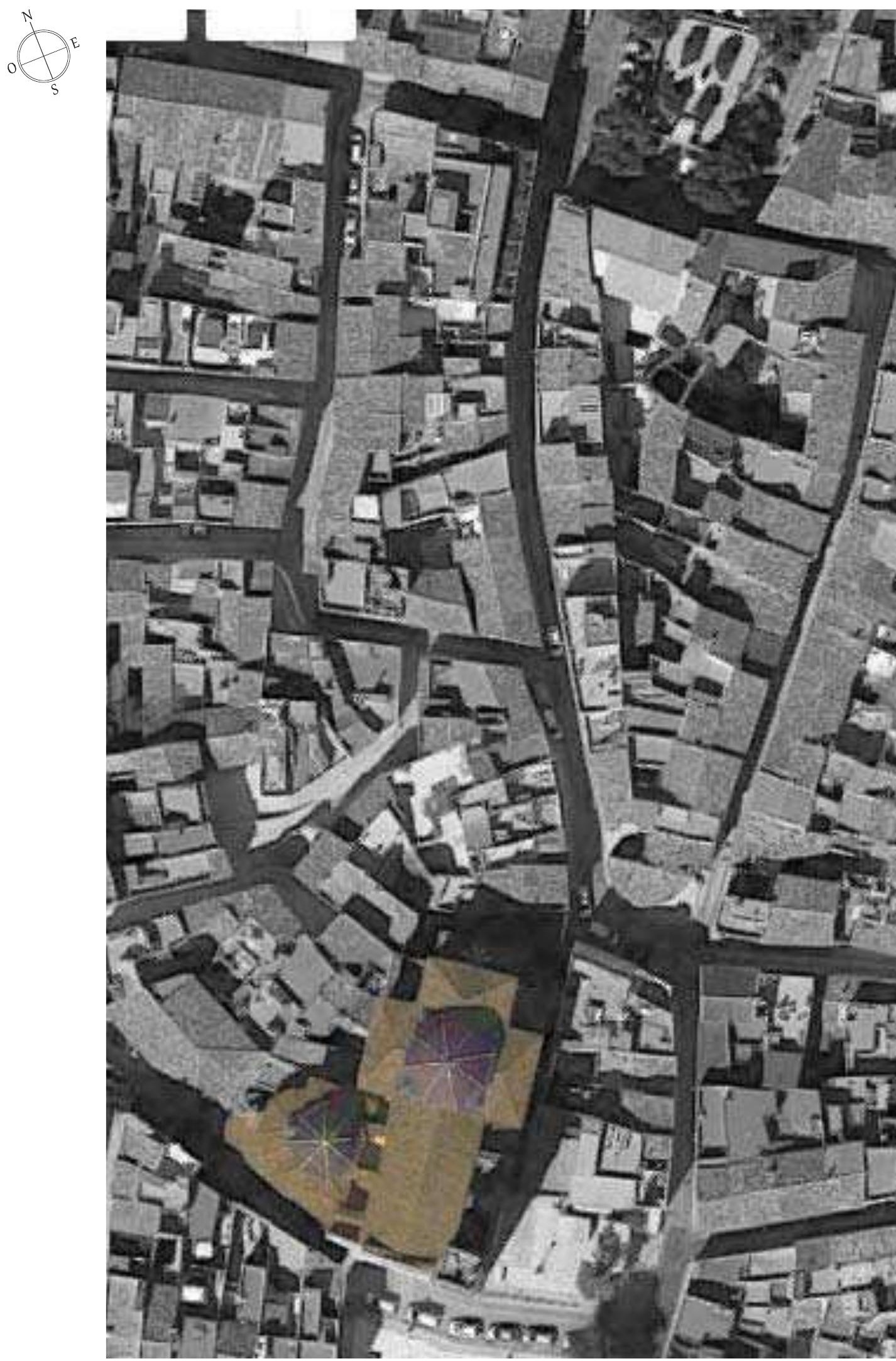




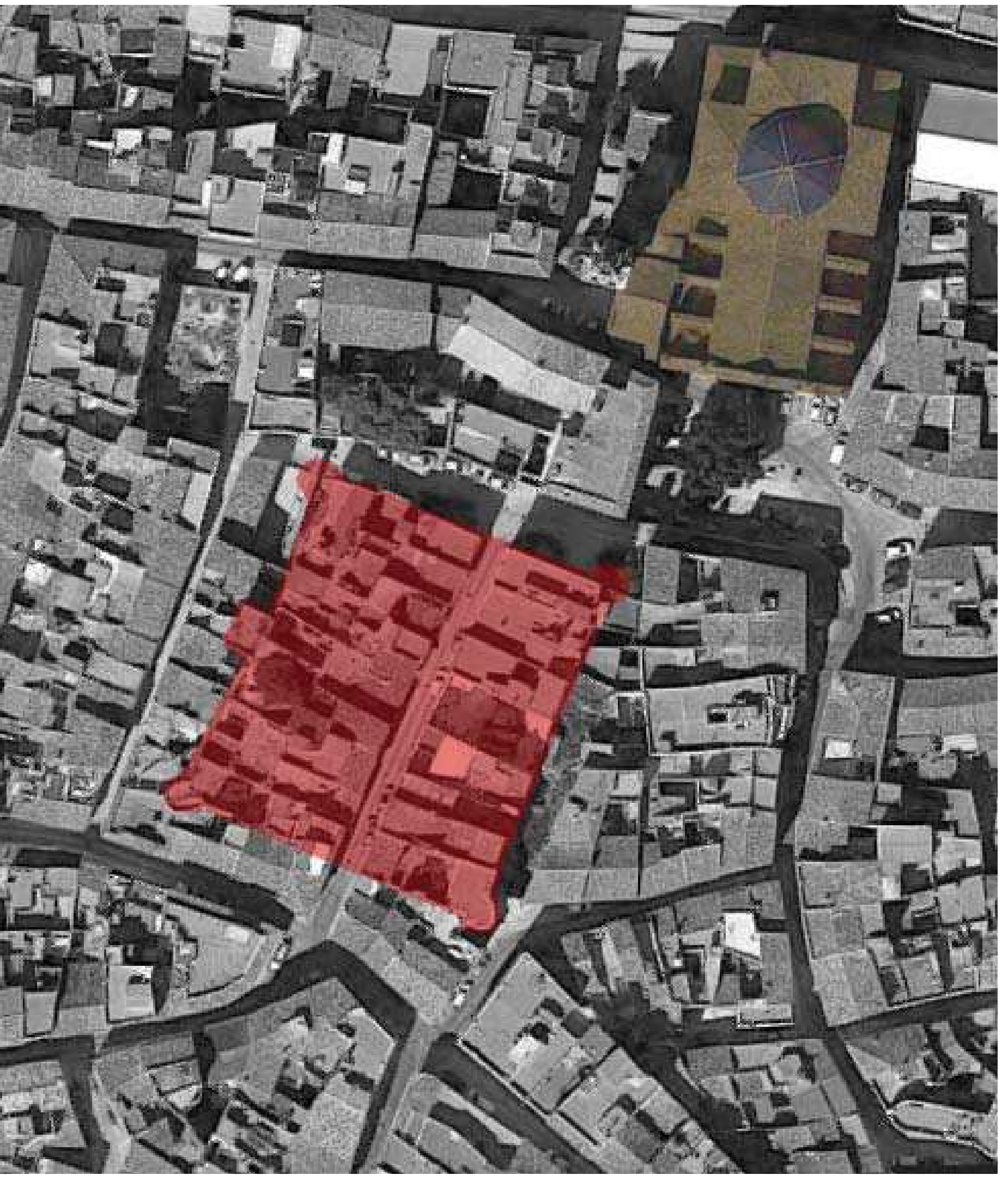

PLANO DE EMPLAZAMIENTO PALACIO CONDAL DE OLIVA 

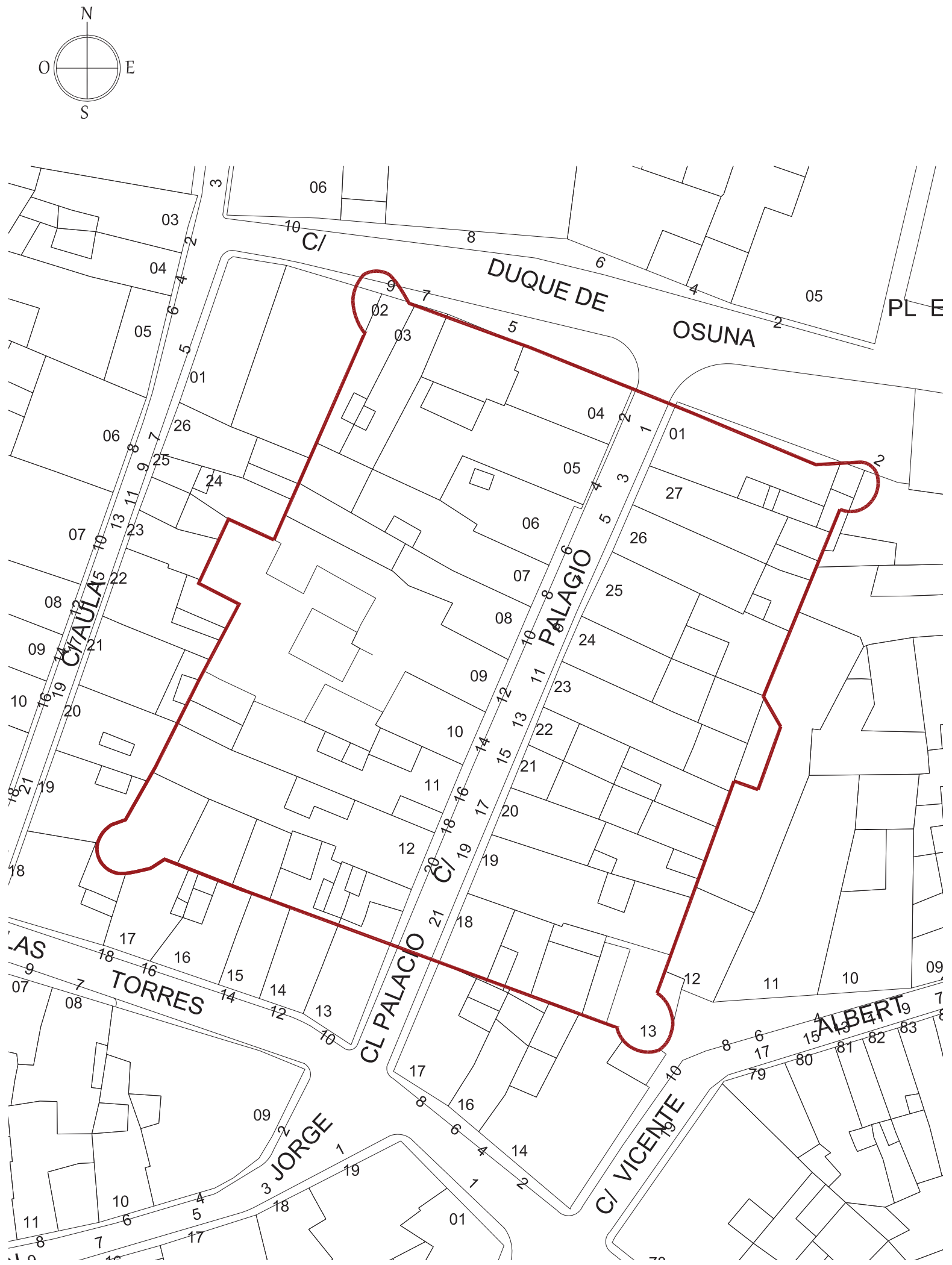

Escala gráfica metros.

$\begin{array}{lllllll}0 & 5 & 10 & 15 & 20 & 30 & 40\end{array}$ 

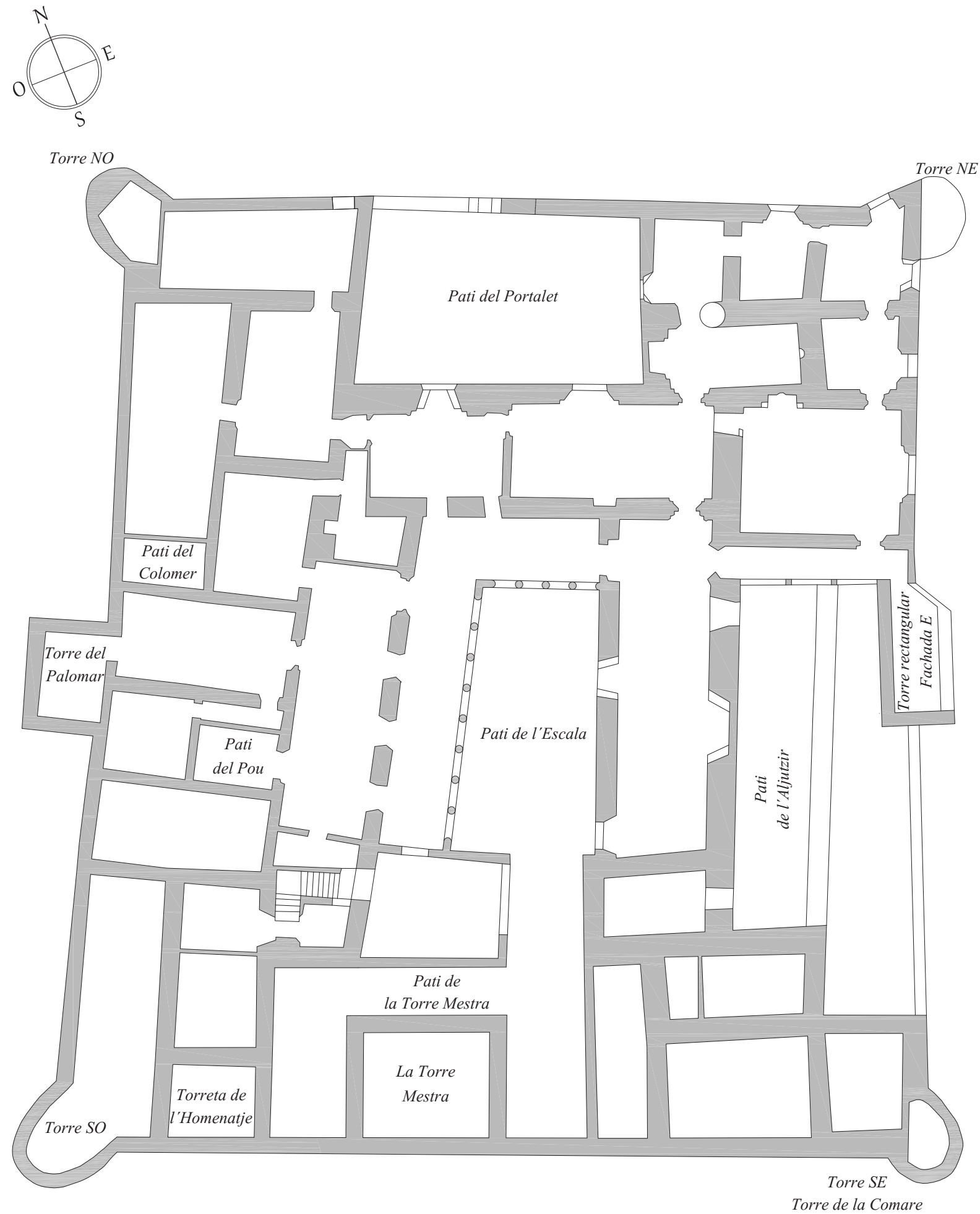

Escala gráfica metros.

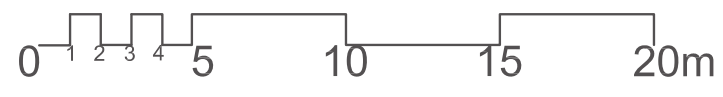


<smiles>CC12CC3CC(CC(C3)C1)C2</smiles>

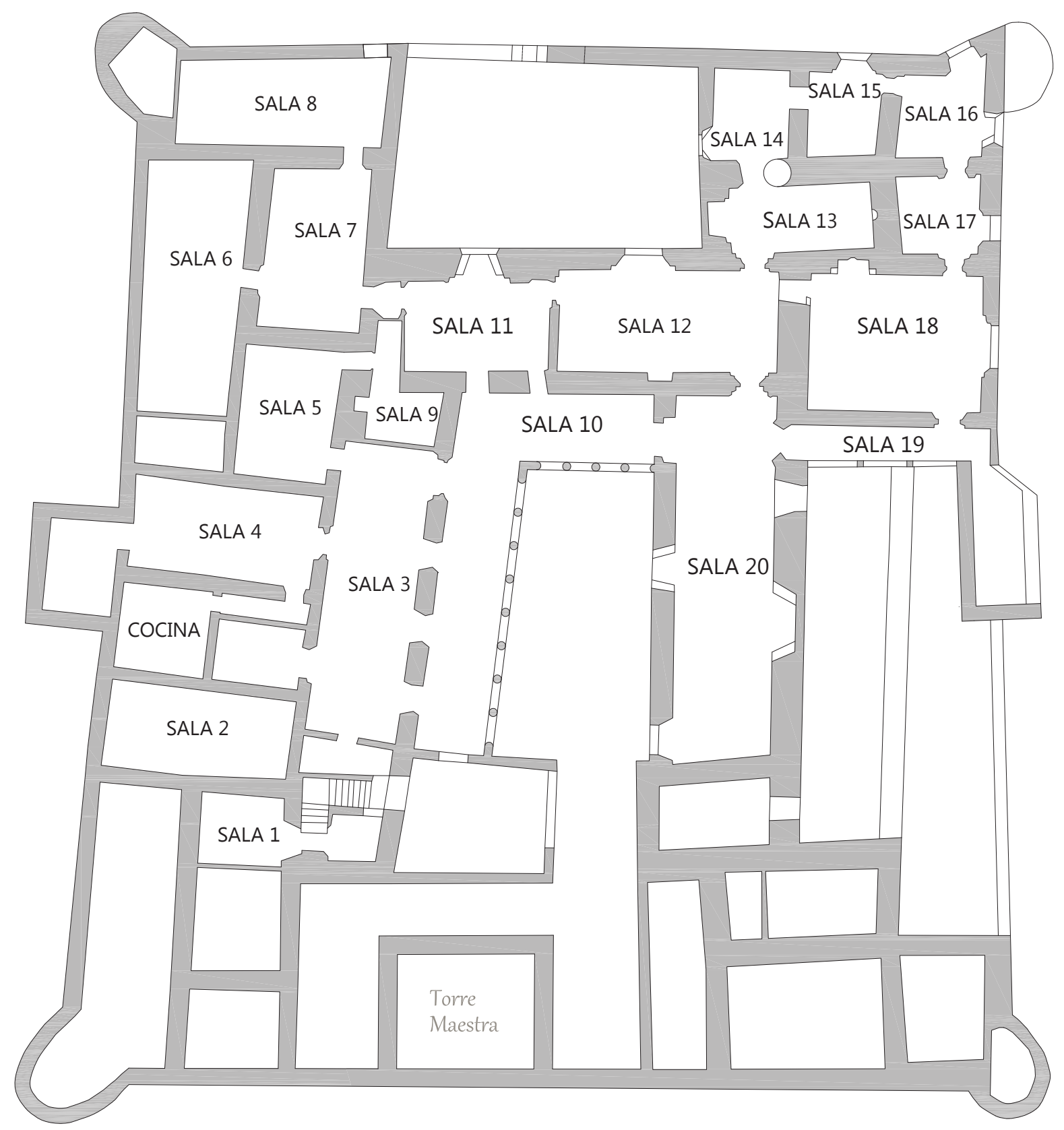

Escala gráfica metros.

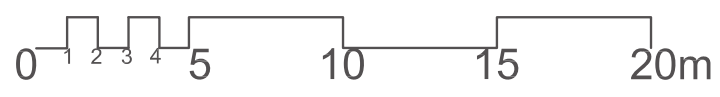


"La arquitectura del expoliado Palacio Condal de Oliva a través del legado gráfico"

PLANO SITUACIÓN PORTADAS Y VENTANAS PALACIO CONDAL DE OLIVA<smiles>CC12CC3CC(CC(C3)C1)C2</smiles>

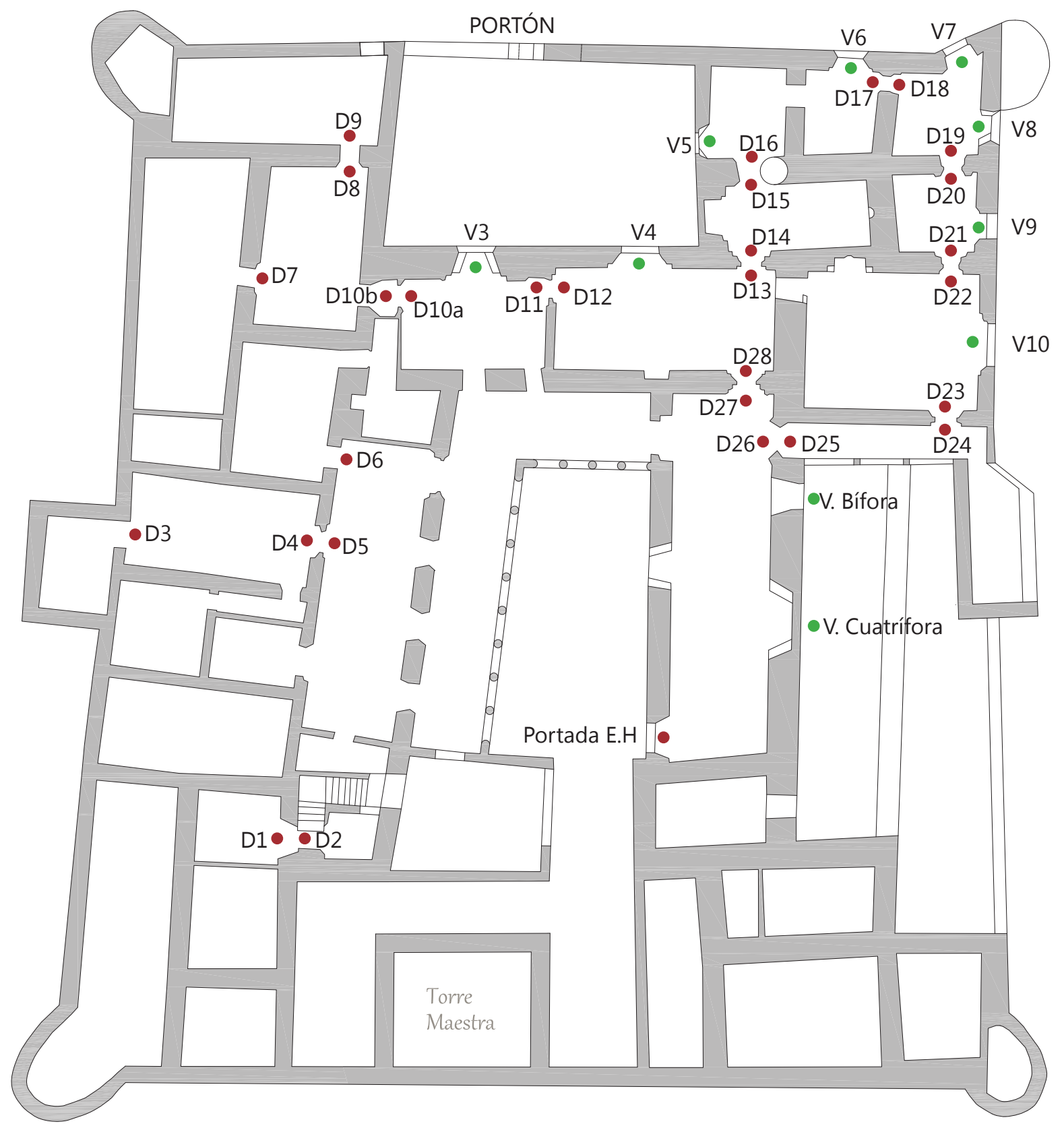

UBICACIÓN VENTANAS

UBICACIÓN PORTADAS

Escala gráfica metros.

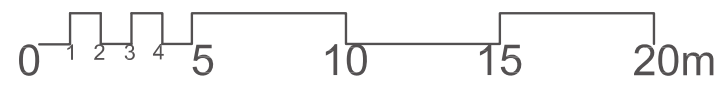





\section{Portadas}

“La arquitectura del expoliado Palacio Condal de Oliva a través del legado gráfico” 

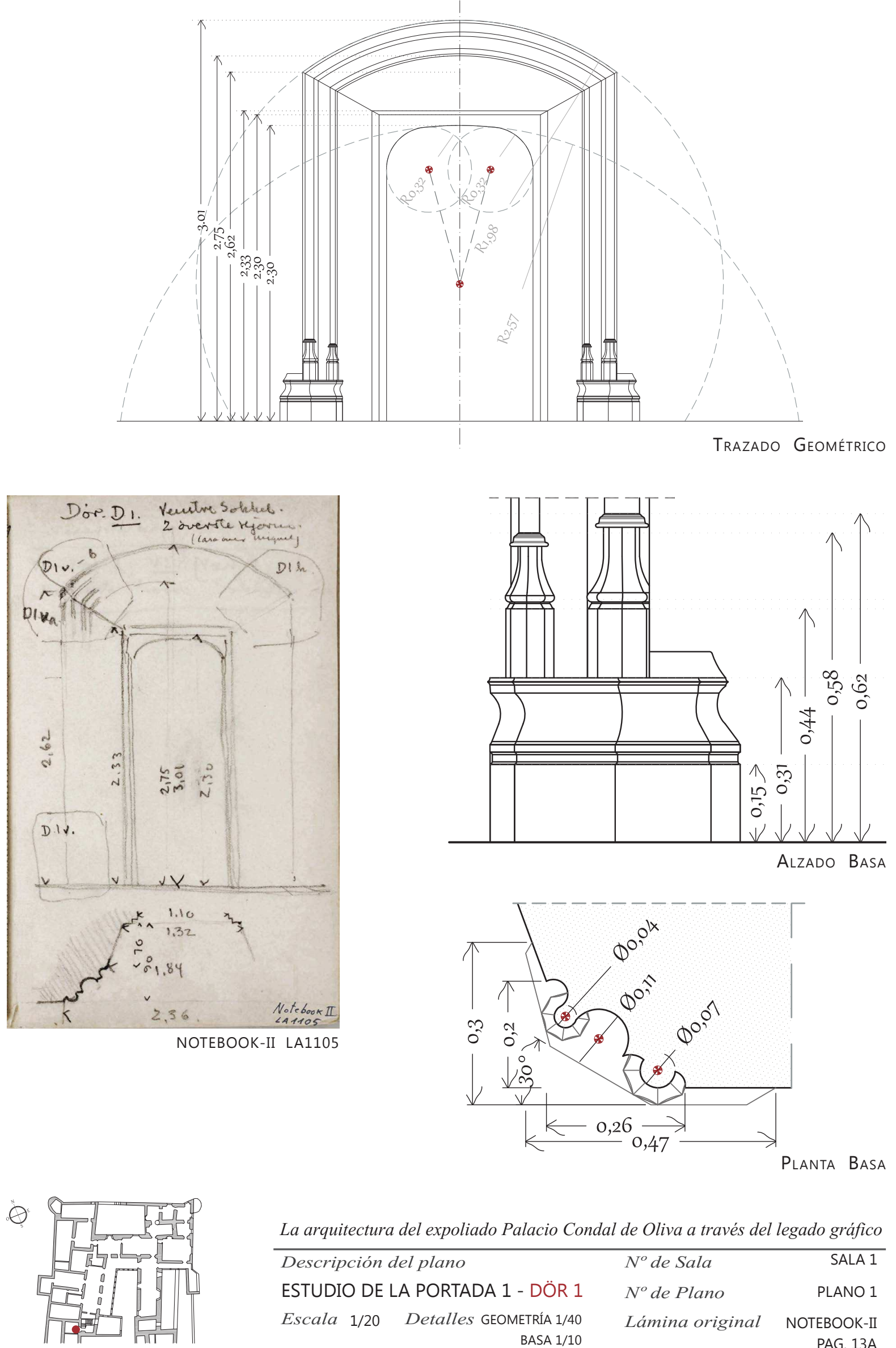

La arquitectura del expoliado Palacio Condal de Oliva a través del legado gráfico

Descripción del plano $N^{\circ}$ de Sala SALA 1

ESTUDIO DE LA PORTADA 1 - DÖR 1

$N^{o}$ de Plano

PLANO 1

Escala 1/20 Detalles GEOMETRÍA 1/40

Lámina original NOTEBOOK-II 

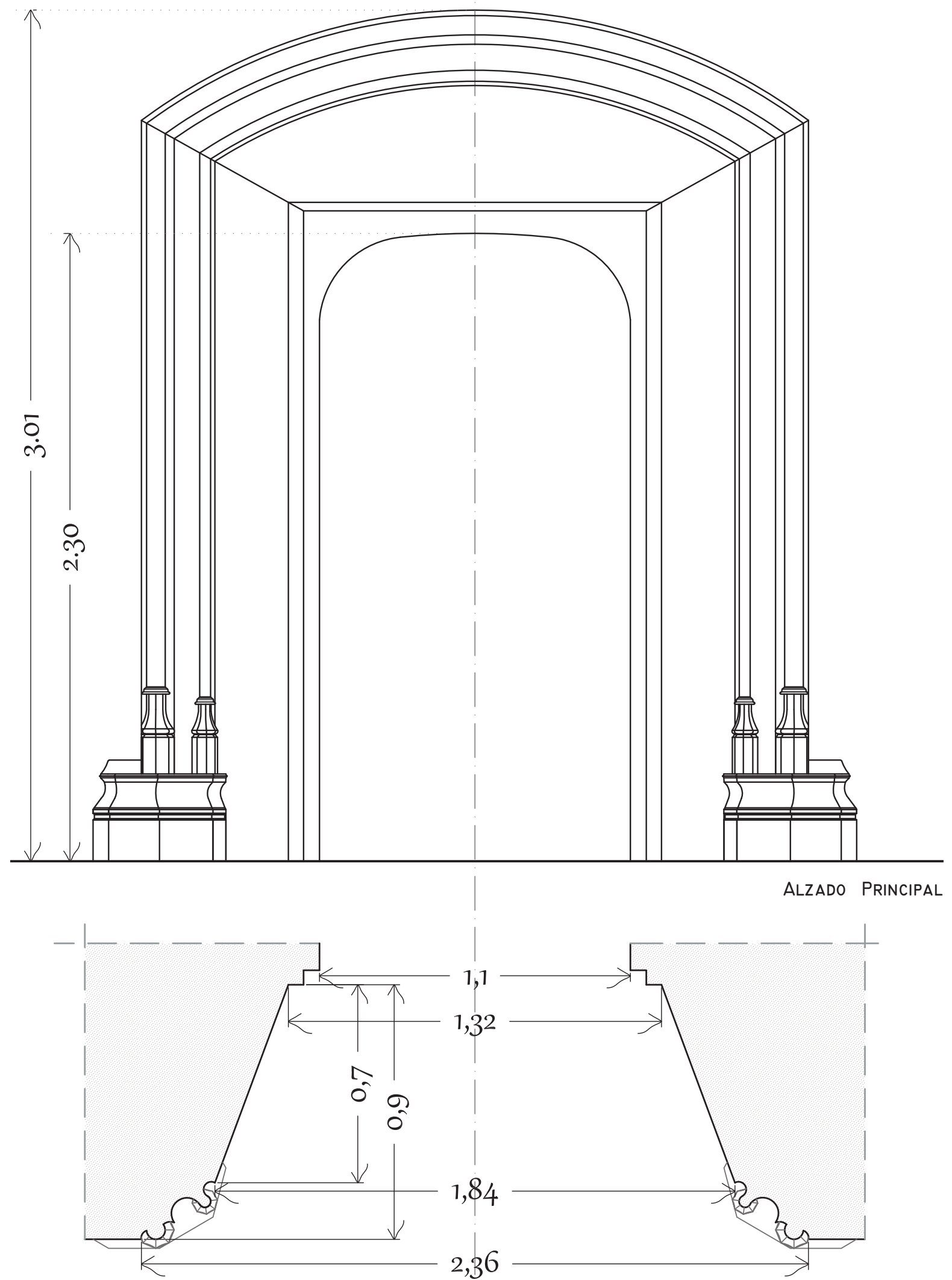

SeCCIÓN JAMBA

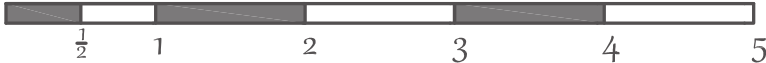

Escala gráfica en palmos valencianos.

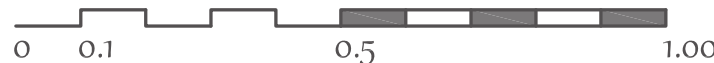

Escala gráfica metros. 

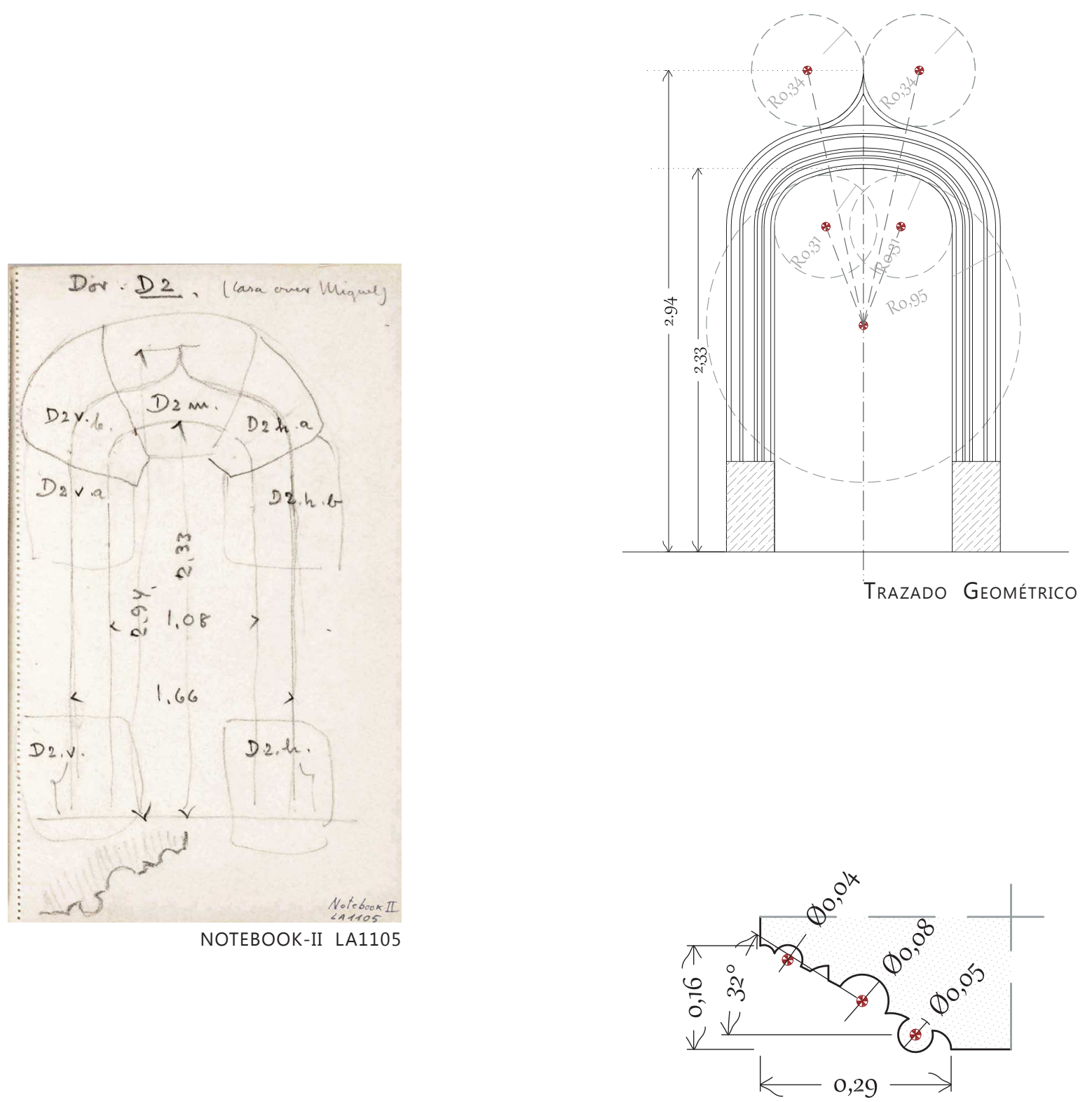

SeCCIÓn JAMBA

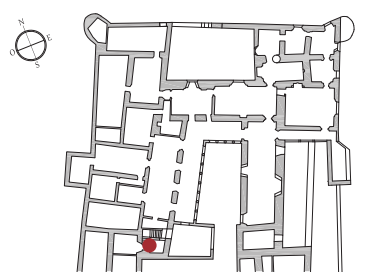

La arquitectura del expoliado Palacio Condal de Oliva a través del legado gráfico

Descripción del plano

$N^{o}$ de Sala

ANEXO A SALA 1

ESTUDIO DE LA PORTADA 2 - DÖR 2

$N^{o}$ de Plano

PLANO 2

Escala 1/20 Detalles GEOMETRÍA 1/40

Lámina original NOTEBOOK-II BASA $1 / 10$ PAG. 15A 

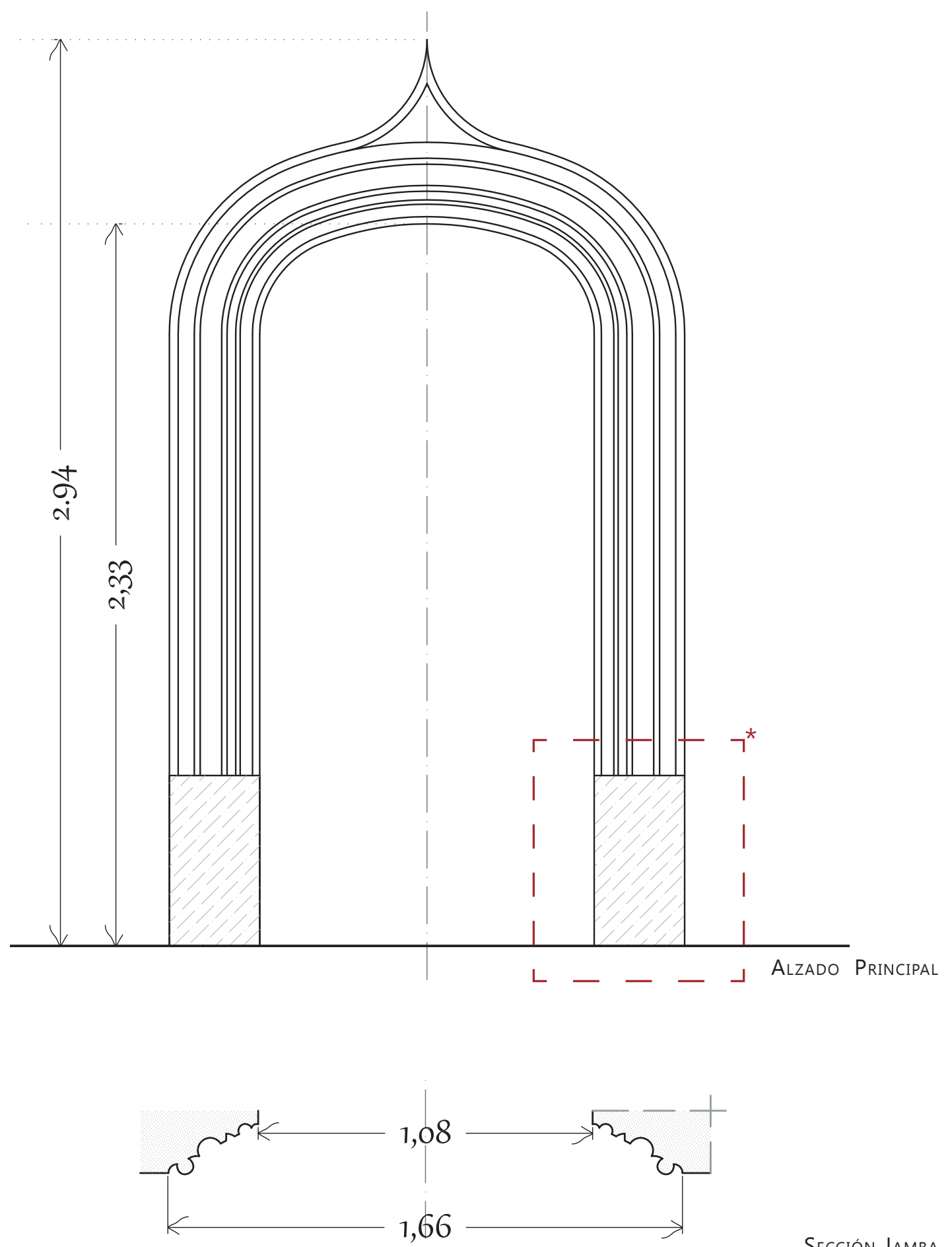

SECCIÓN JAMBA

* Alzado y detalle de basa no delineado por carecer de documentación gráfica y/o fotográfica necesaria.

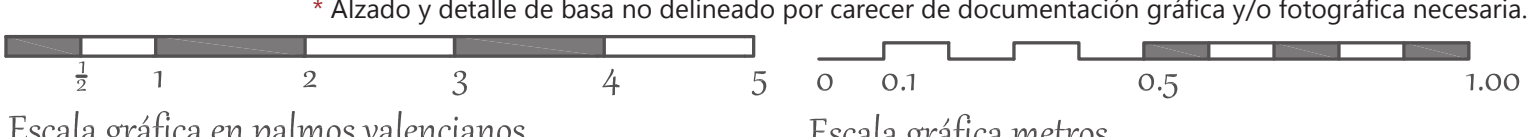

Escala gráfica en palmos valencianos. Escala gráfica metros. 

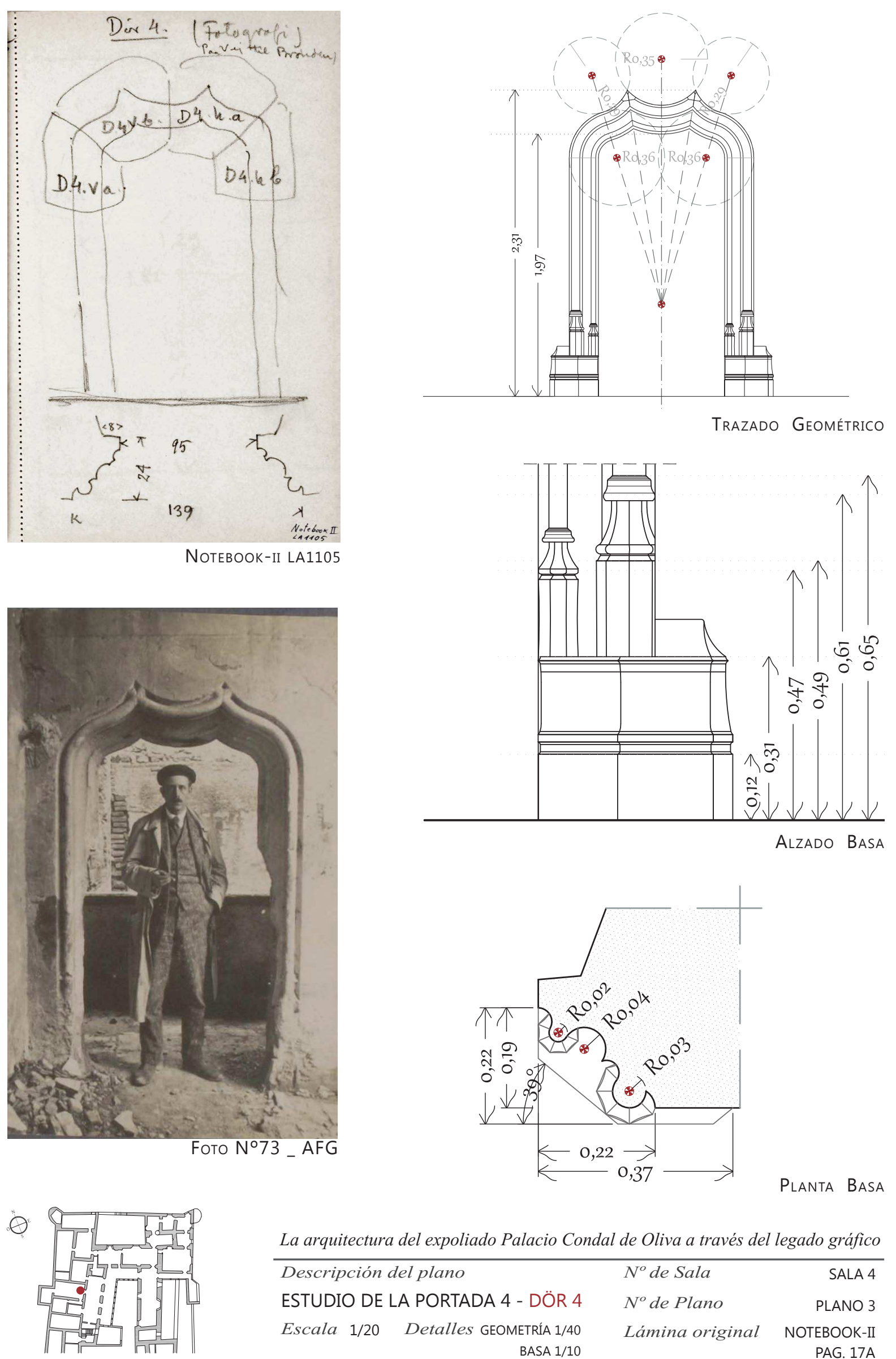

La arquitectura del expoliado Palacio Condal de Oliva a través del legado gráfico

\begin{tabular}{|c|c|c|c|}
\hline Descripción & el plano & $N^{o}$ de Sala & SALA 4 \\
\hline ESTUDIO DE & A PORTADA 4 - DÖR 4 & $N^{o}$ de Plano & PLANO 3 \\
\hline Escala $1 / 20$ & $\begin{array}{r}\text { Detalles GEOMETRÍA } 1 / 40 \\
\text { BASA } 1 / 10 \\
\end{array}$ & Lámina original & $\begin{array}{r}\text { NOTEBOOK-II } \\
\text { PAG. 17A } \\
\end{array}$ \\
\hline
\end{tabular}




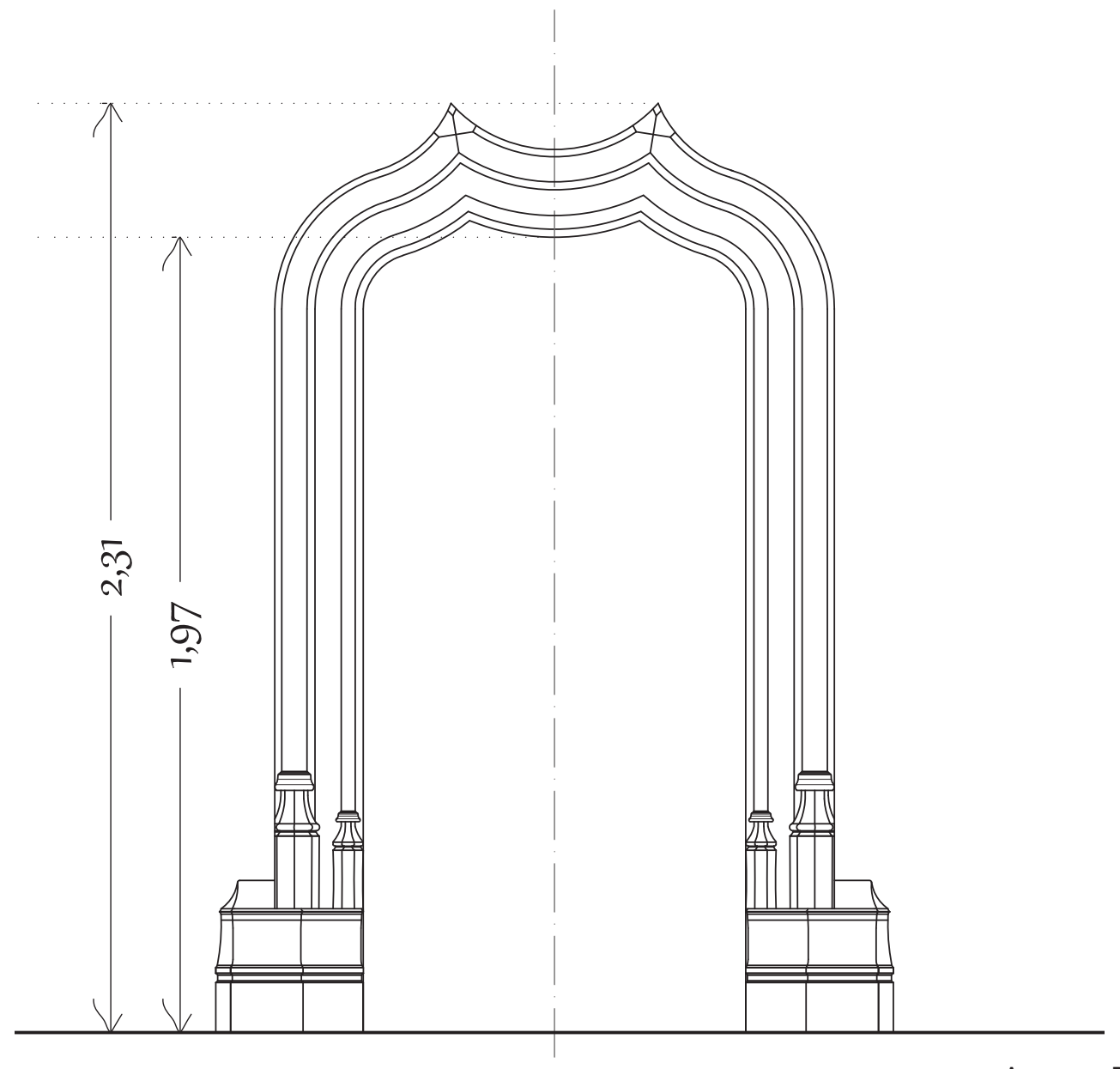

Alzado Principal

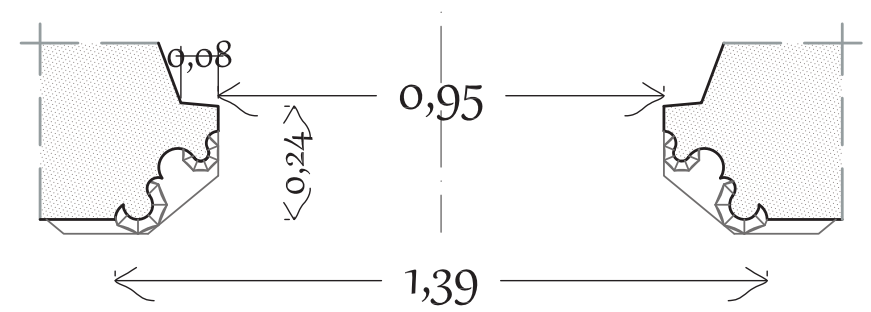

Sección Jamba
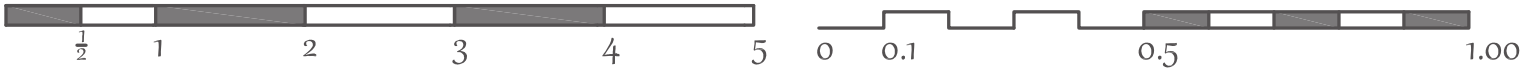

Escala gráfica en palmos valencianos.

Escala gráfica metros. 

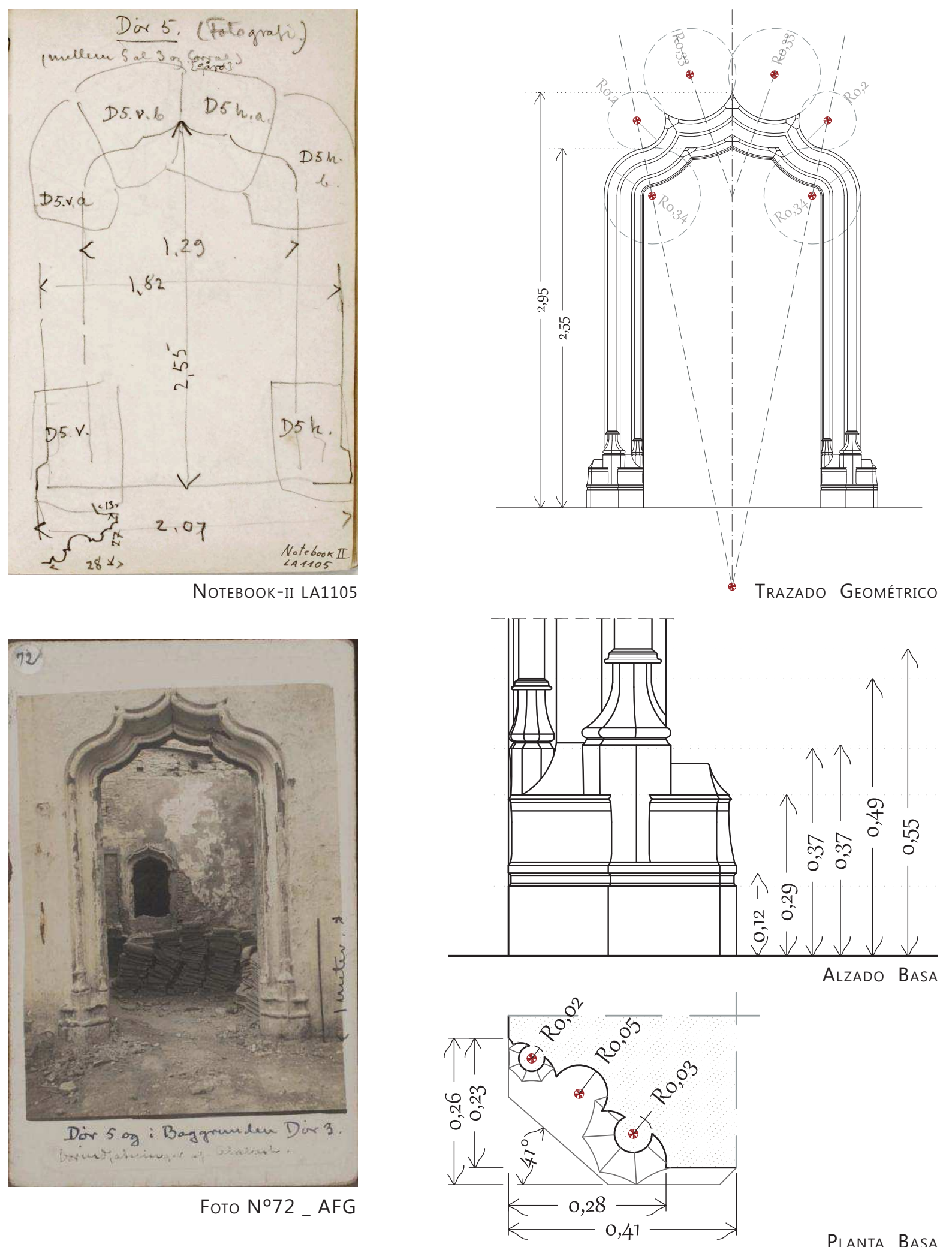

Planta Basa

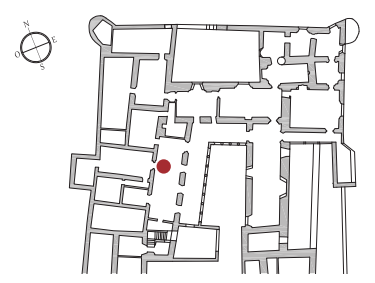

La arquitectura del expoliado Palacio Condal de Oliva a través del legado gráfico

Descripción del plano $N^{\circ}$ de Sala SALA 3

ESTUDIO DE LA PORTADA 5 - DÖR 5

$N^{o}$ de Plano

PLANO 4

Escala 1/20 Detalles GEOMETRÍA 1/40

Lámina original NOTEBOOK-II BASA $1 / 10$ PAG. 18A 


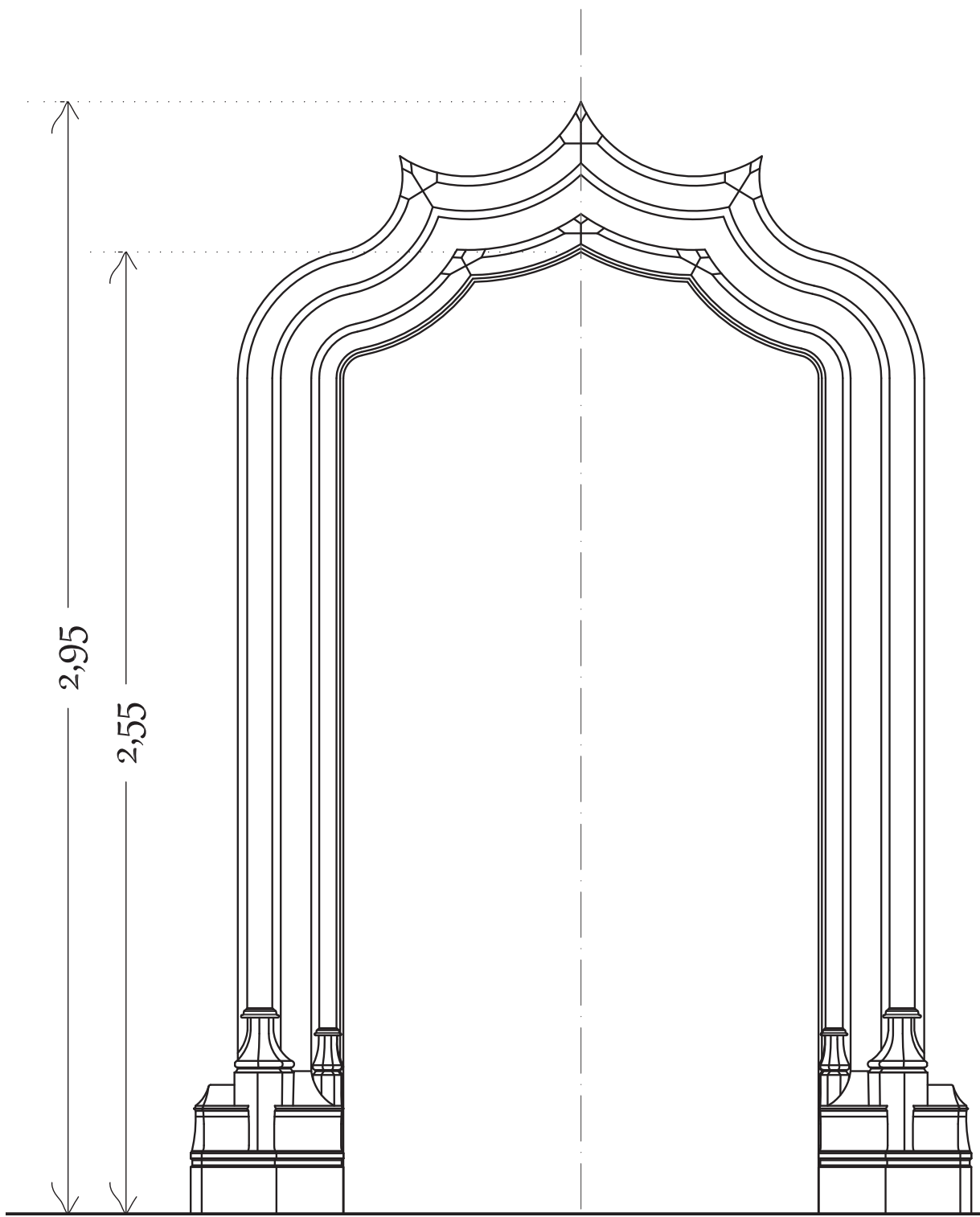

Alzado Principal

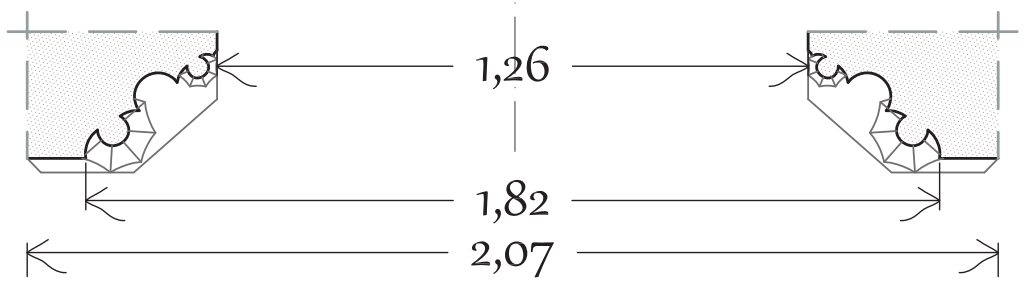

SecCión Jamba

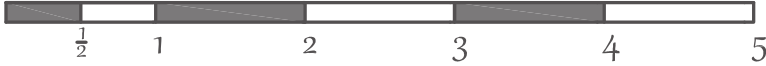

Escala gráfica en palmos valencianos.

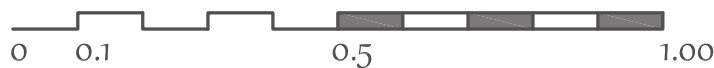

Escala gráfica metros. 

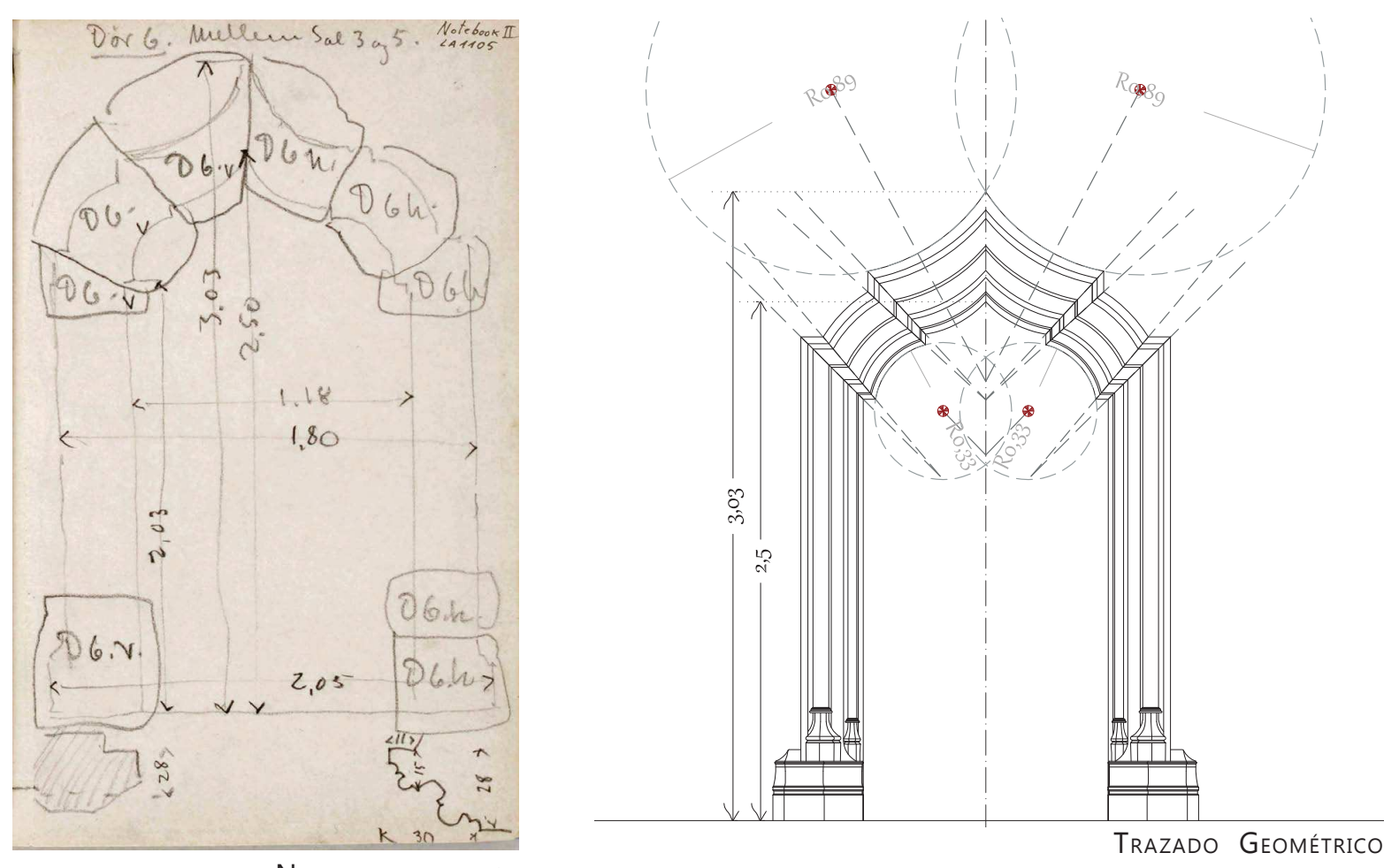

NoteBOOK-II LA1105
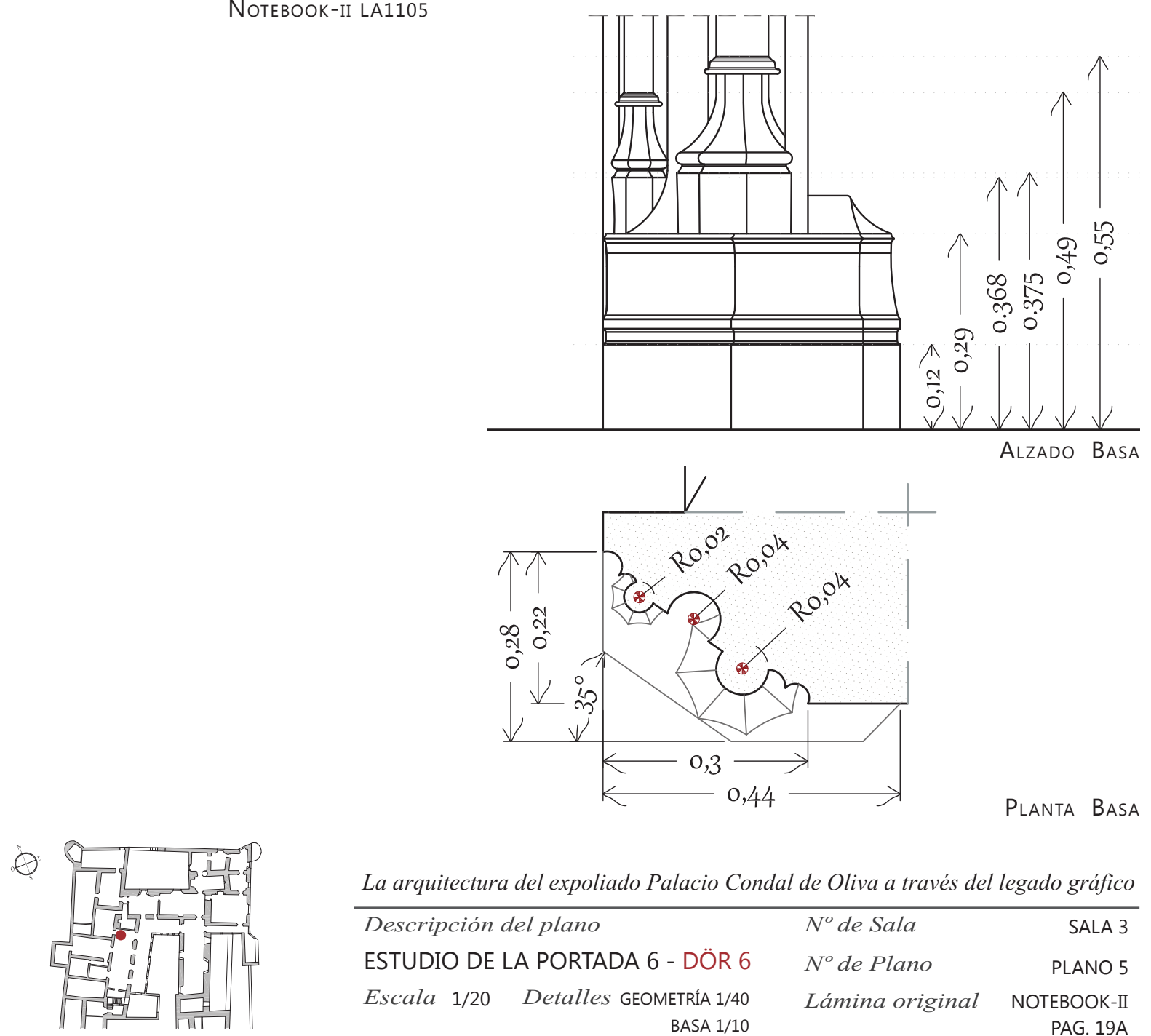

La arquitectura del expoliado Palacio Condal de Oliva a través del legado gráfico

Descripción del plano

ESTUDIO DE LA PORTADA 6 - DÖR 6

Escala $1 / 20$

Detalles GEOMETRÍA 1/40 BASA $1 / 10$

$N^{o}$ de Sala

$N^{o}$ de Plano

SALA 3

Lámina original NOTEBOOK-II PAG. 19A 


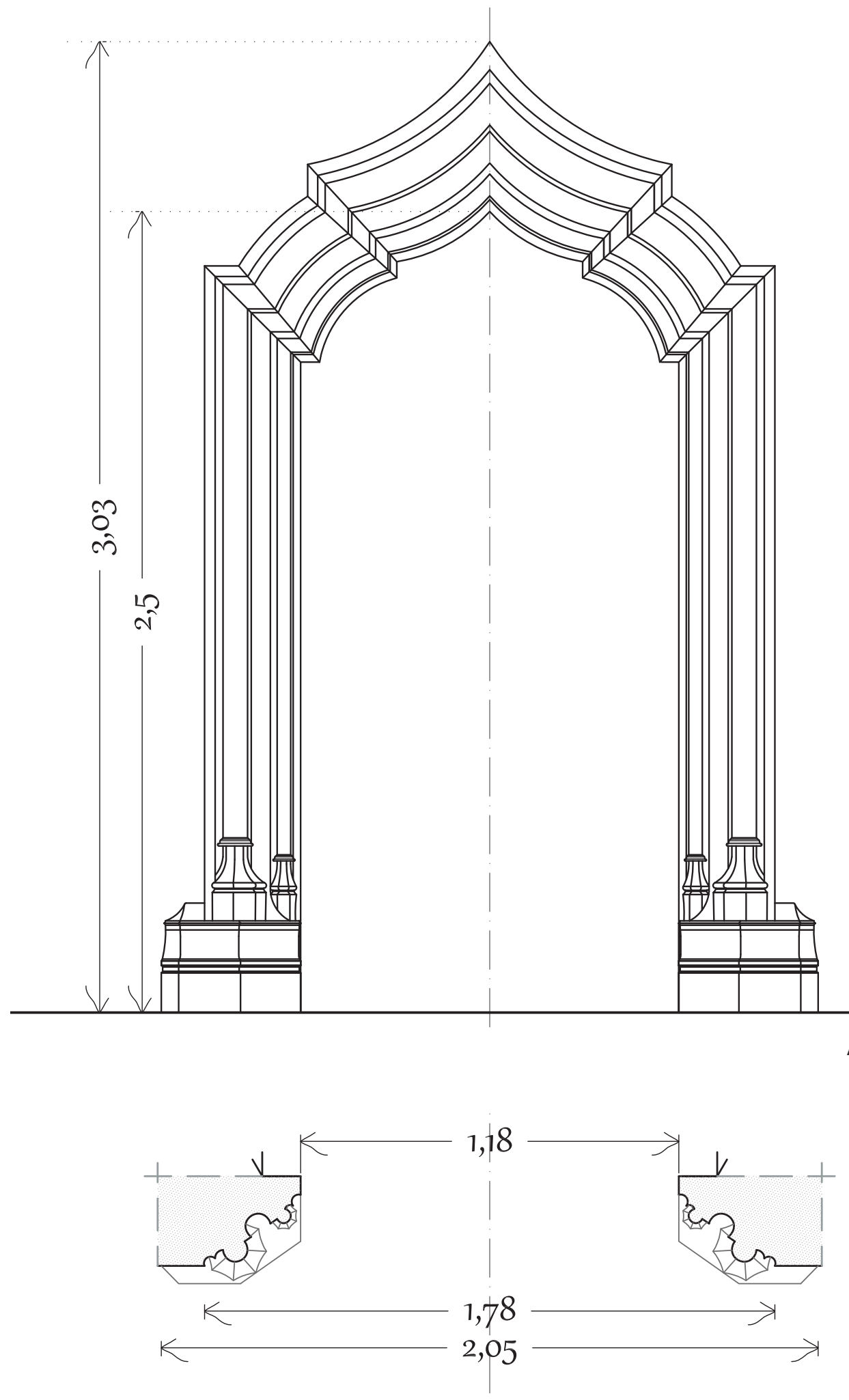

SeCCIÓn Jamba

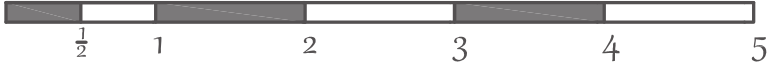

Escala gráfica en palmos valencianos.

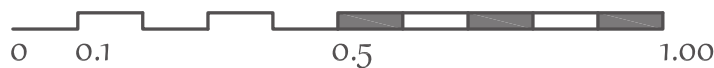

Escala gráfica metros. 

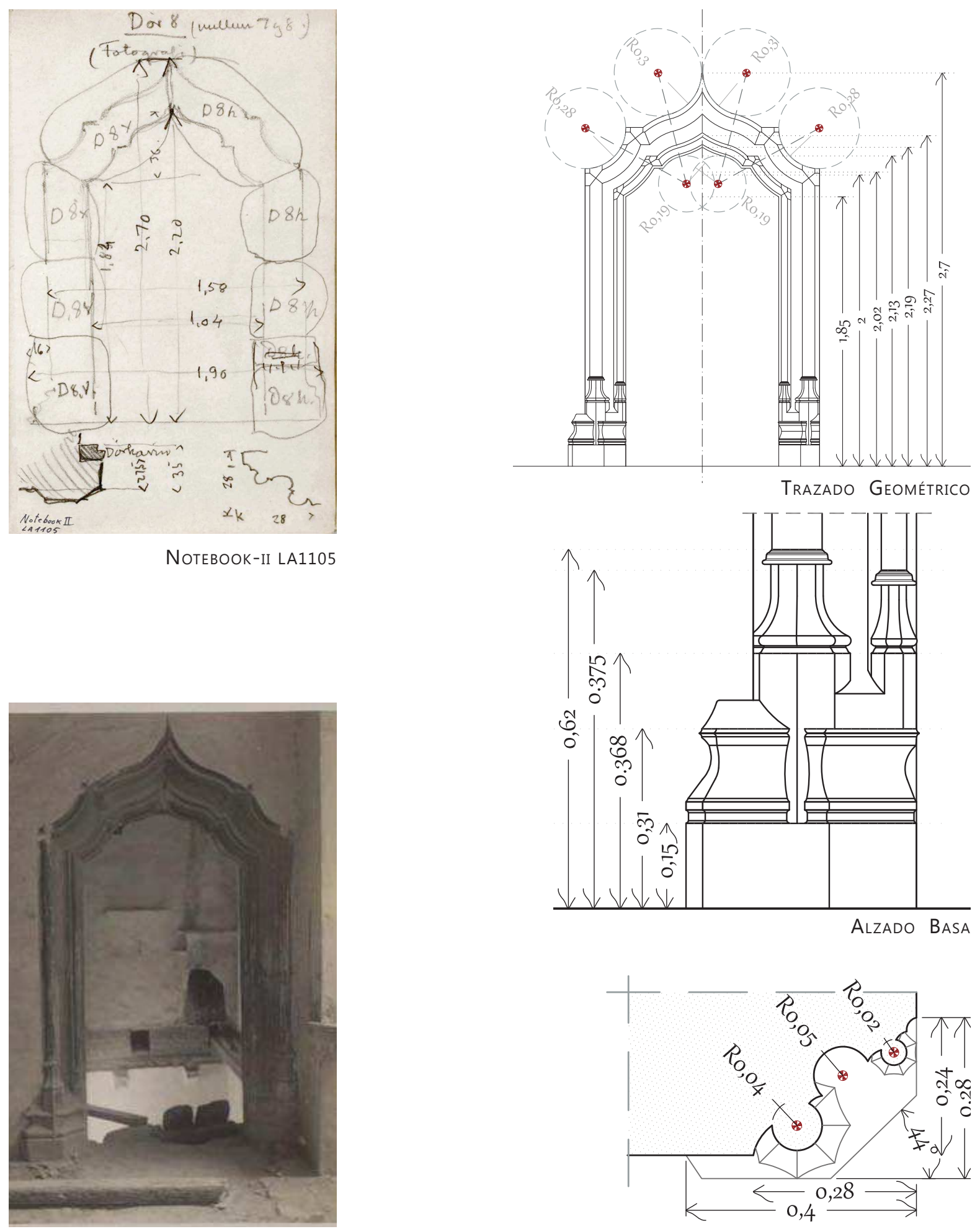

AlzAdo BASA

Fото $\mathrm{N}^{\circ} 68$ _ AFG
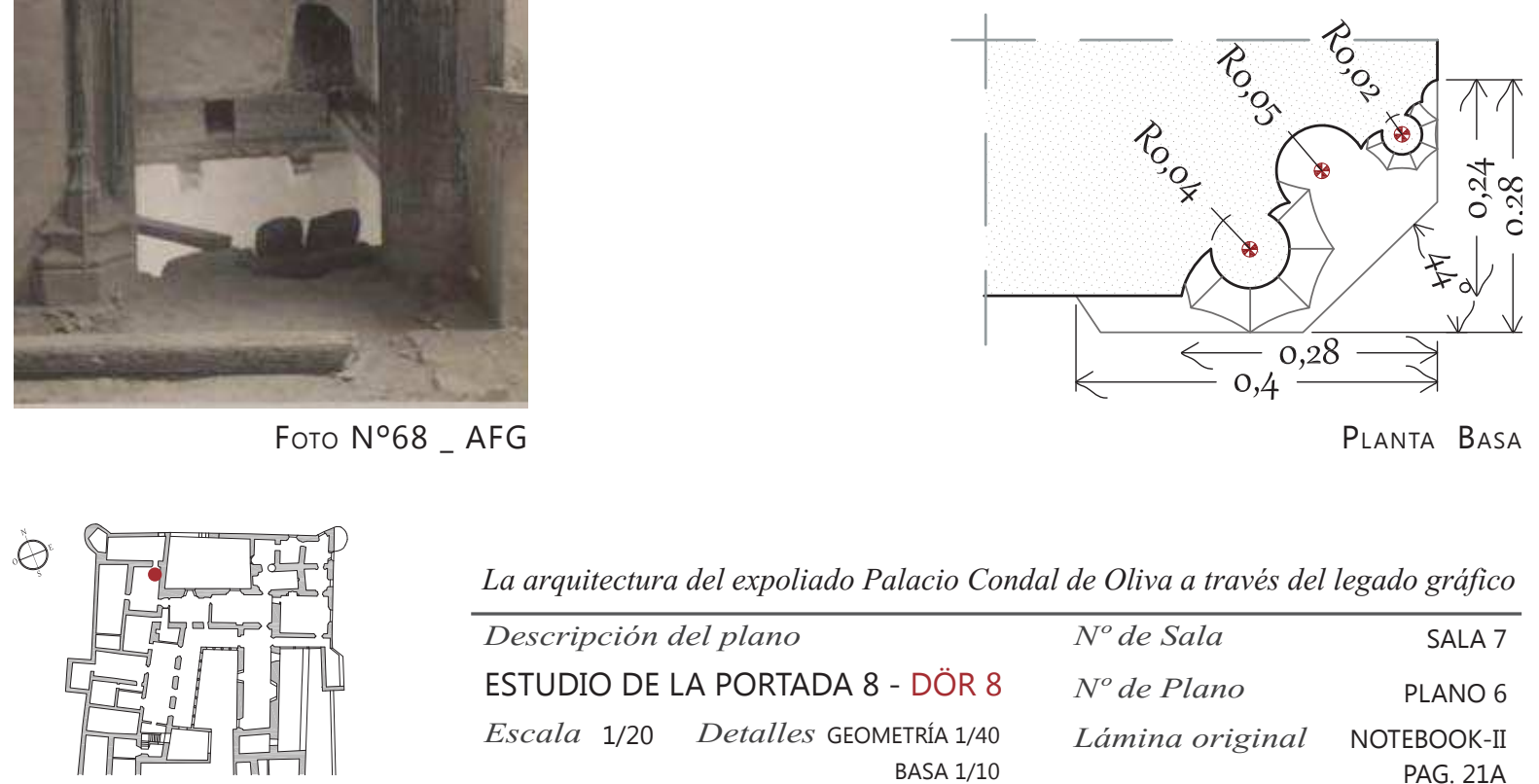

La arquitectura del expoliado Palacio Condal de Oliva a través del legado gráfico

Descripción del plano $N^{\circ}$ de Sala SALA 7

ESTUDIO DE LA PORTADA 8 - DÖR 8

$N^{o}$ de Plano

PLANO 6

Escala $1 / 20$ Detalles GEOMETRÍA 1/40

Lámina original NOTEBOOK-II 

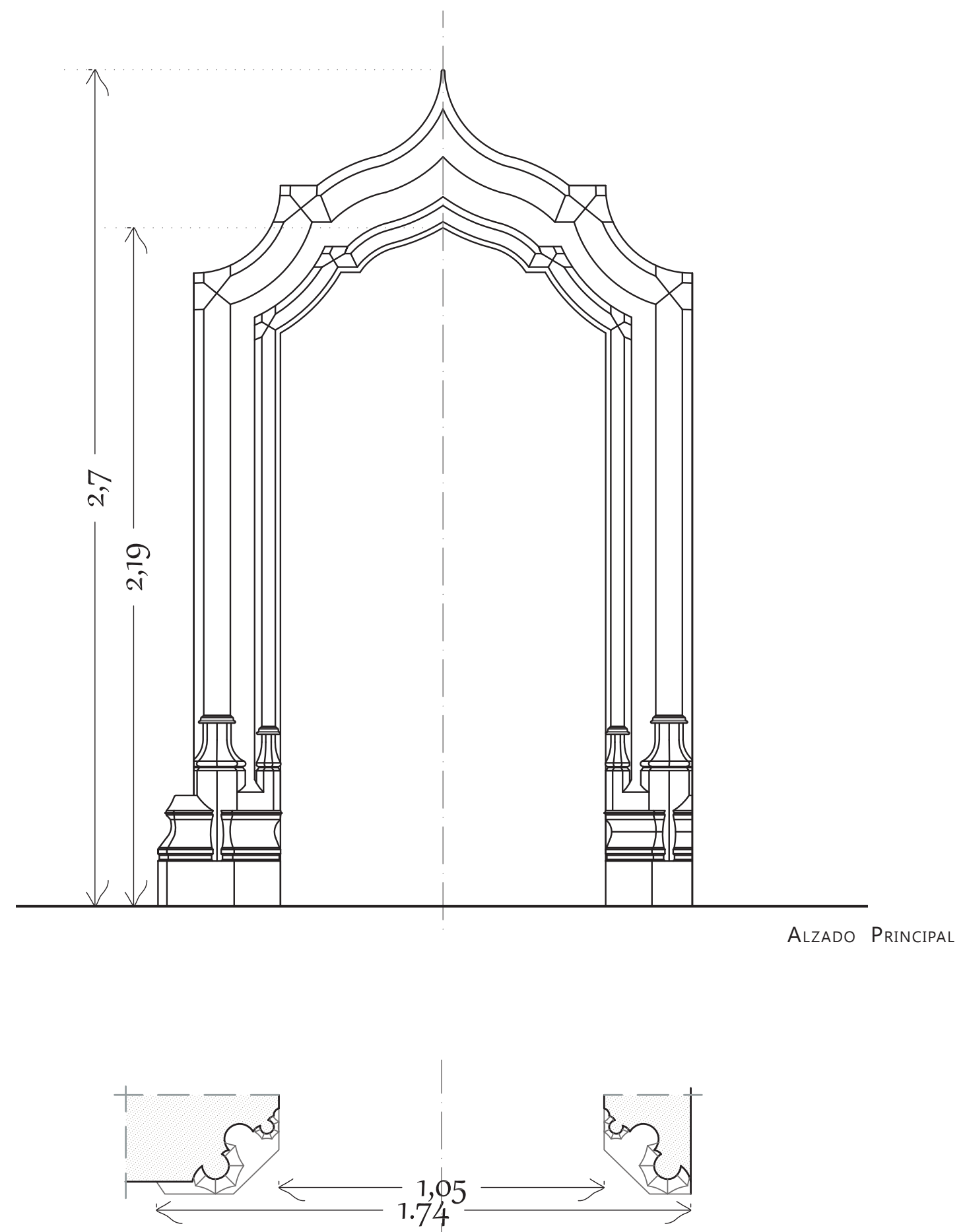

Sección JAMBA

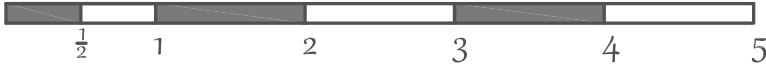

Escala gráfica en palmos valencianos.

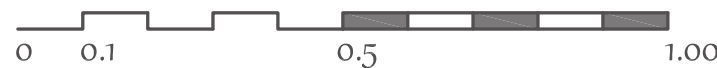

Escala gráfica metros. 

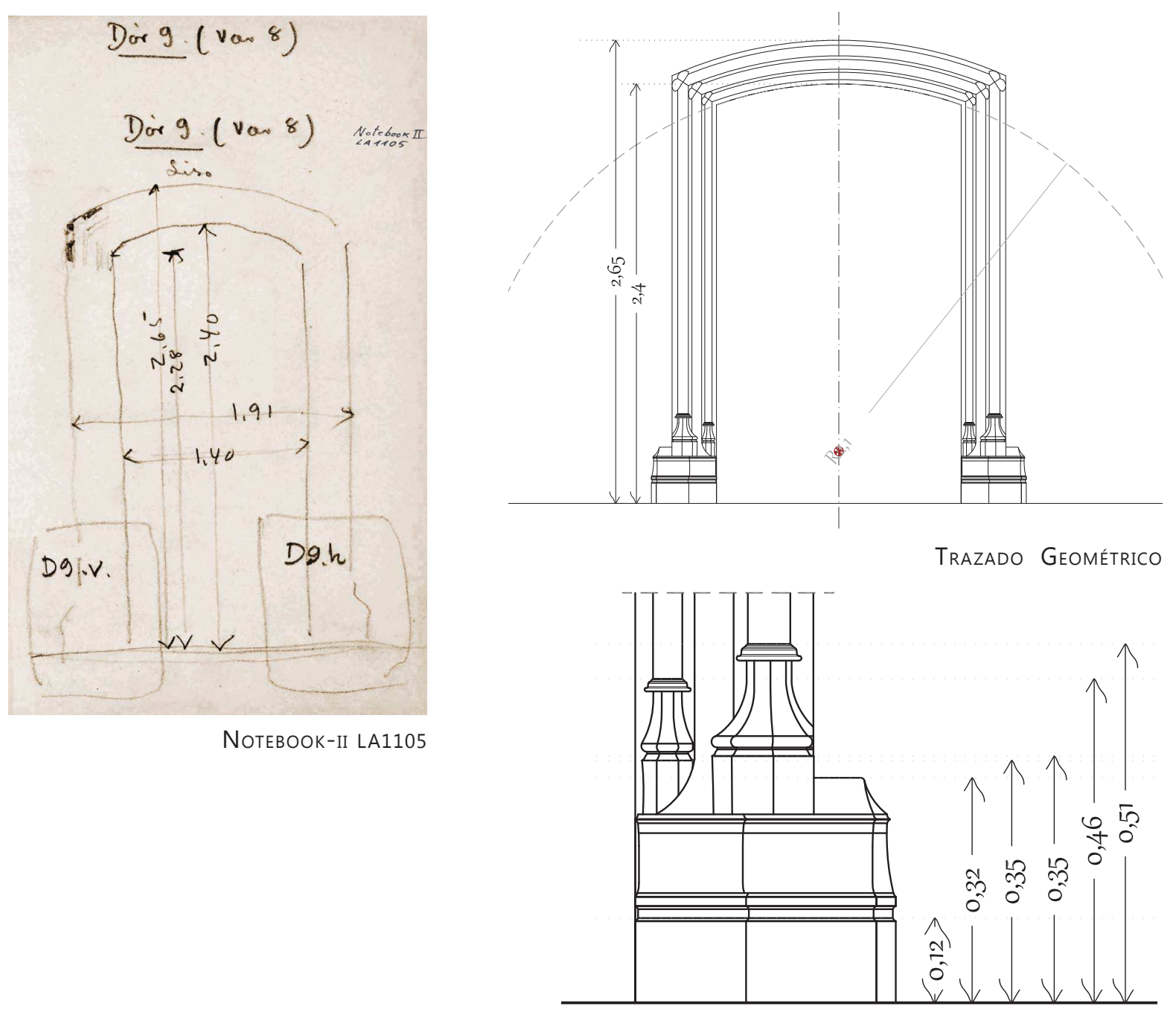

AlzAdO BASA

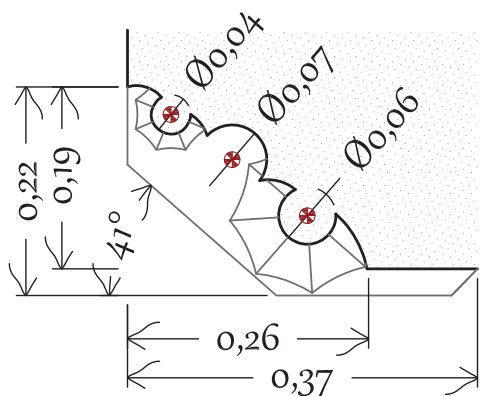

Planta Basa

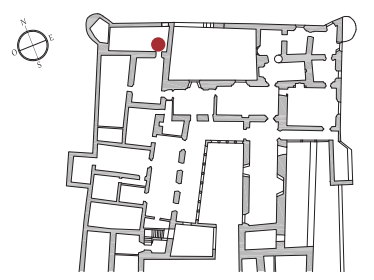

La arquitectura del expoliado Palacio Condal de Oliva a través del legado gráfico

\begin{tabular}{|c|c|c|c|}
\hline Descripción & el plano & $N^{o}$ de Sala & SALA 8 \\
\hline ESTUDIO DE & A PORTADA 9 - DÖR 9 & $N^{o}$ de Plano & PLANO 7 \\
\hline Escala $1 / 20$ & $\begin{array}{r}\text { Detalles GEOMETRÍA } 1 / 40 \\
\text { BASA } 1 / 10\end{array}$ & Lámina original & $\begin{array}{r}\text { NOTEBOOK-II } \\
\text { PAG. 29A }\end{array}$ \\
\hline
\end{tabular}



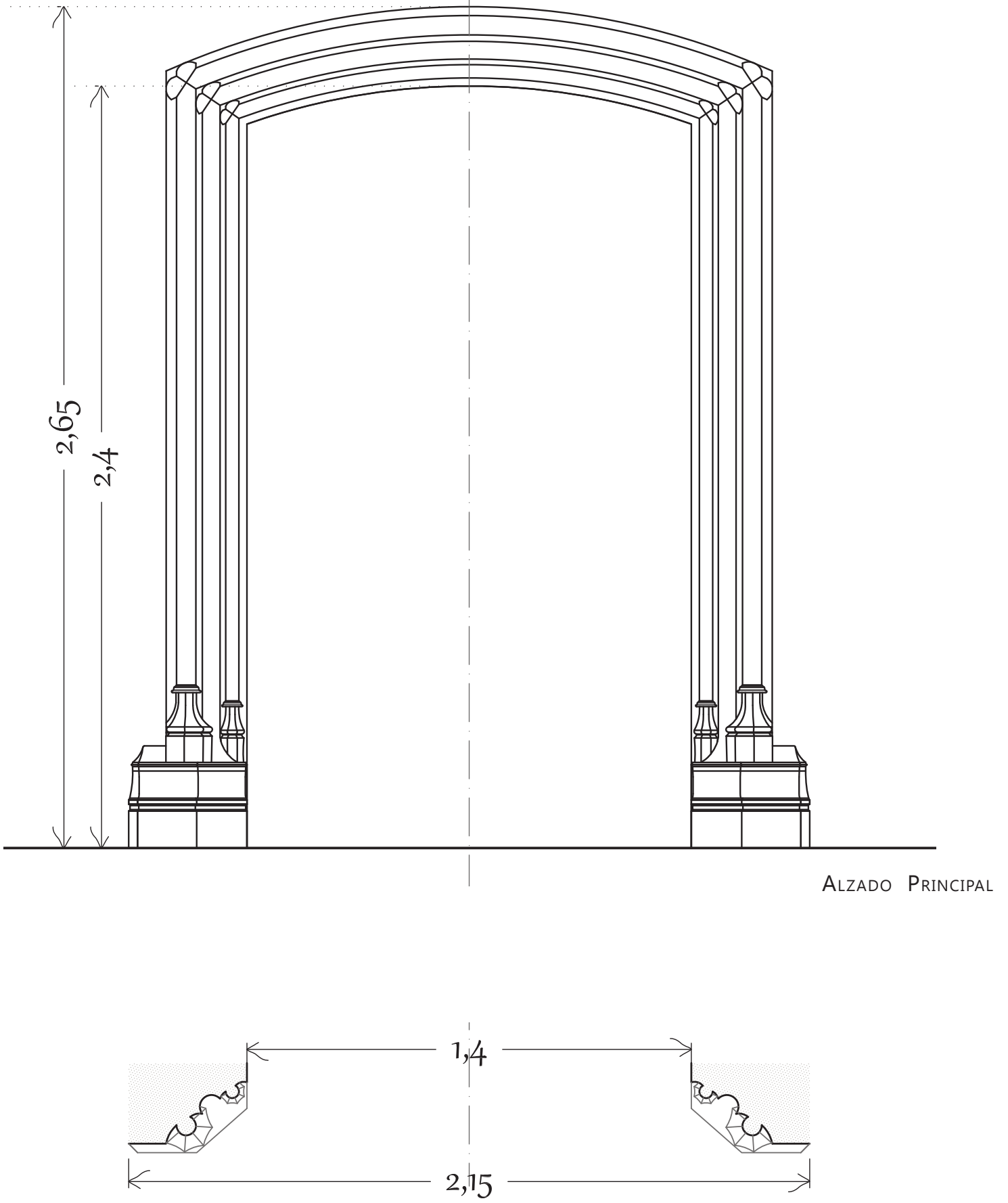

Sección Jamba
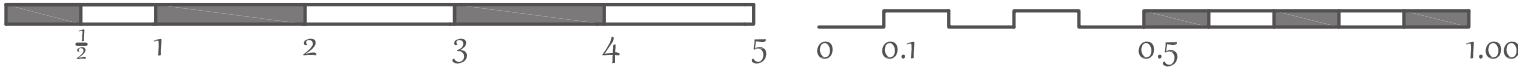

Escala gráfica en palmos valencianos.

Escala gráfica metros. 

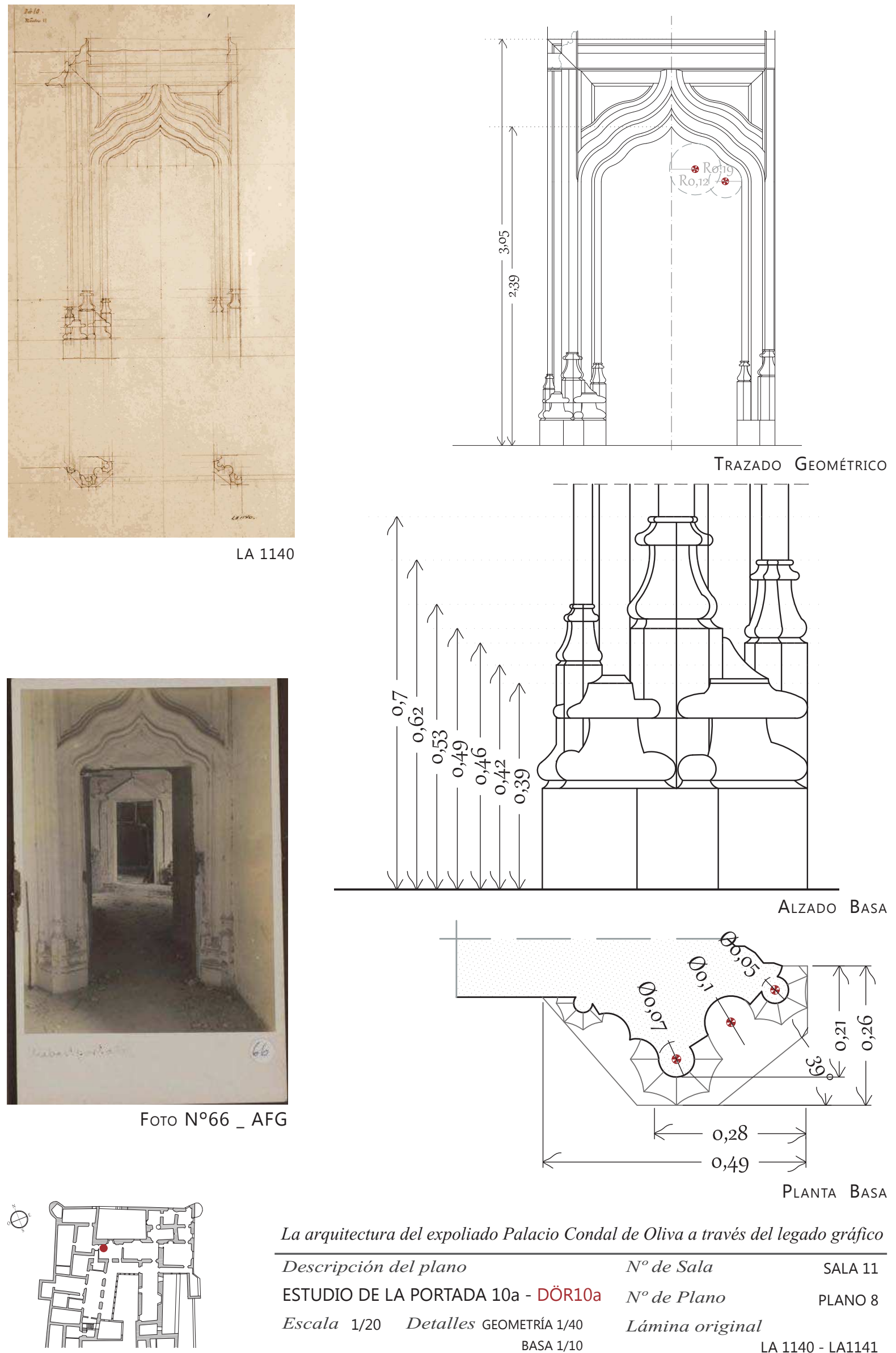

La arquitectura del expoliado Palacio Condal de Oliva a través del legado gráfico

\begin{tabular}{rlrr}
\hline Descripción del plano & $N^{o}$ de Sala & SALA 11 \\
ESTUDIO DE LA PORTADA 10a - DÖR10a & $N^{o}$ de Plano & PLANO 8 \\
Escala $1 / 20 \quad$ Detalles GEOMETRÍA 1/40 & Lámina original \\
BASA 1/10 & LA 1140 - LA1141 \\
\hline
\end{tabular}




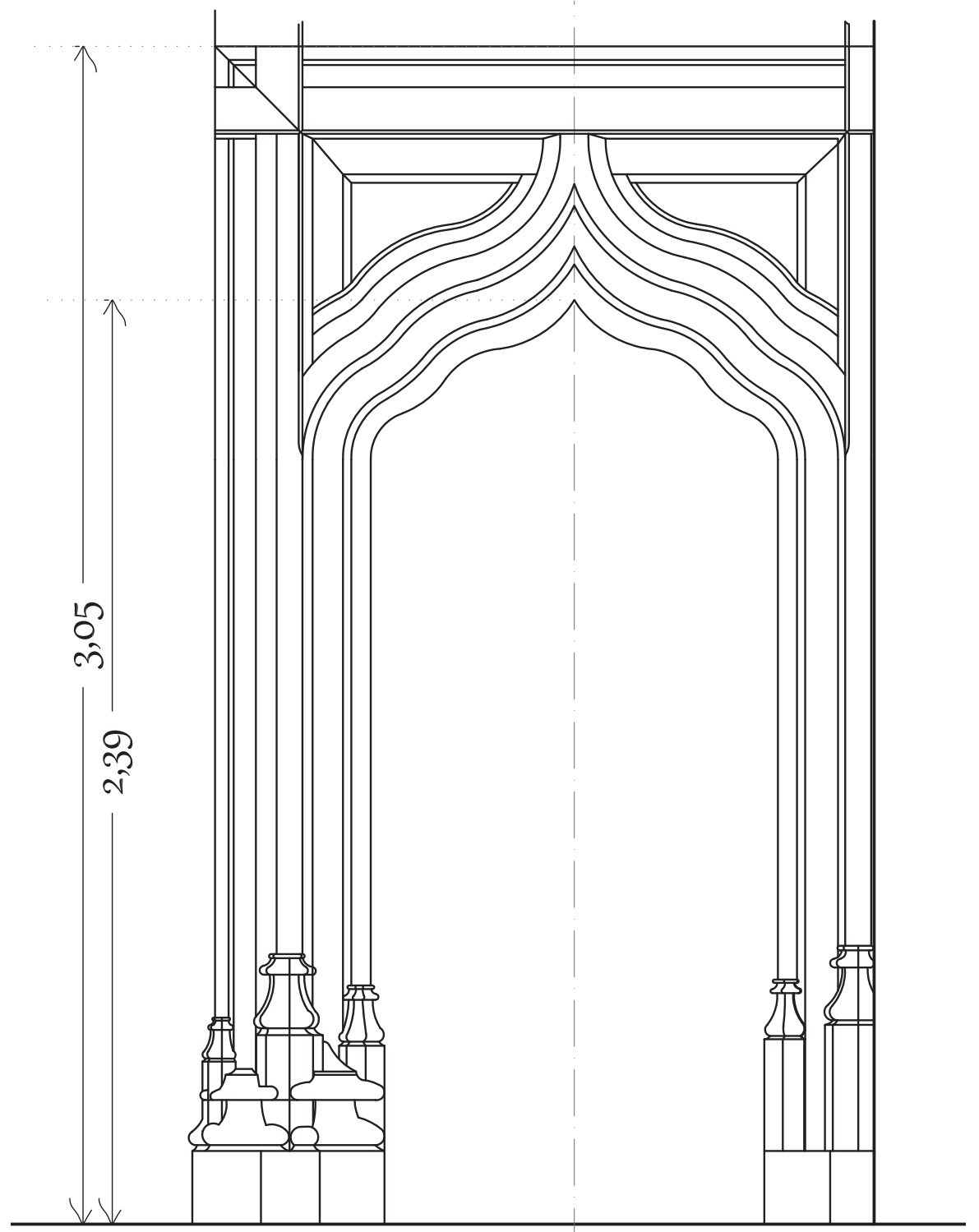

Alzado Principal

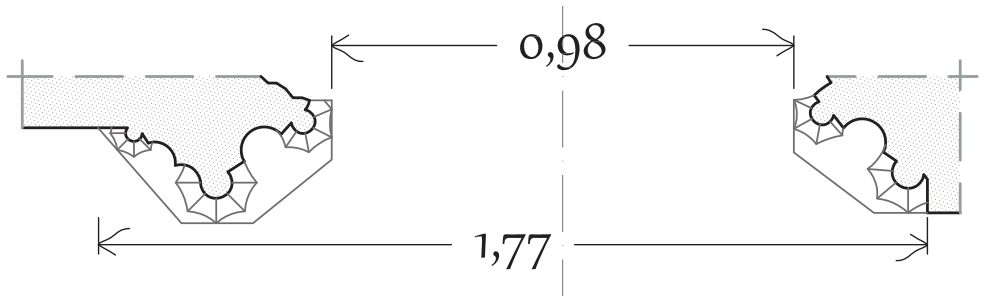

SeCCIÓn JAMBA

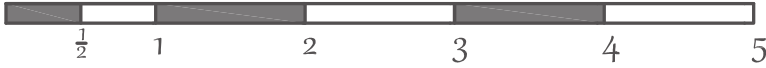

Escala gráfica en palmos valencianos.

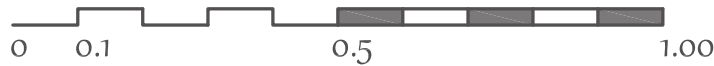

Escala gráfica metros. 

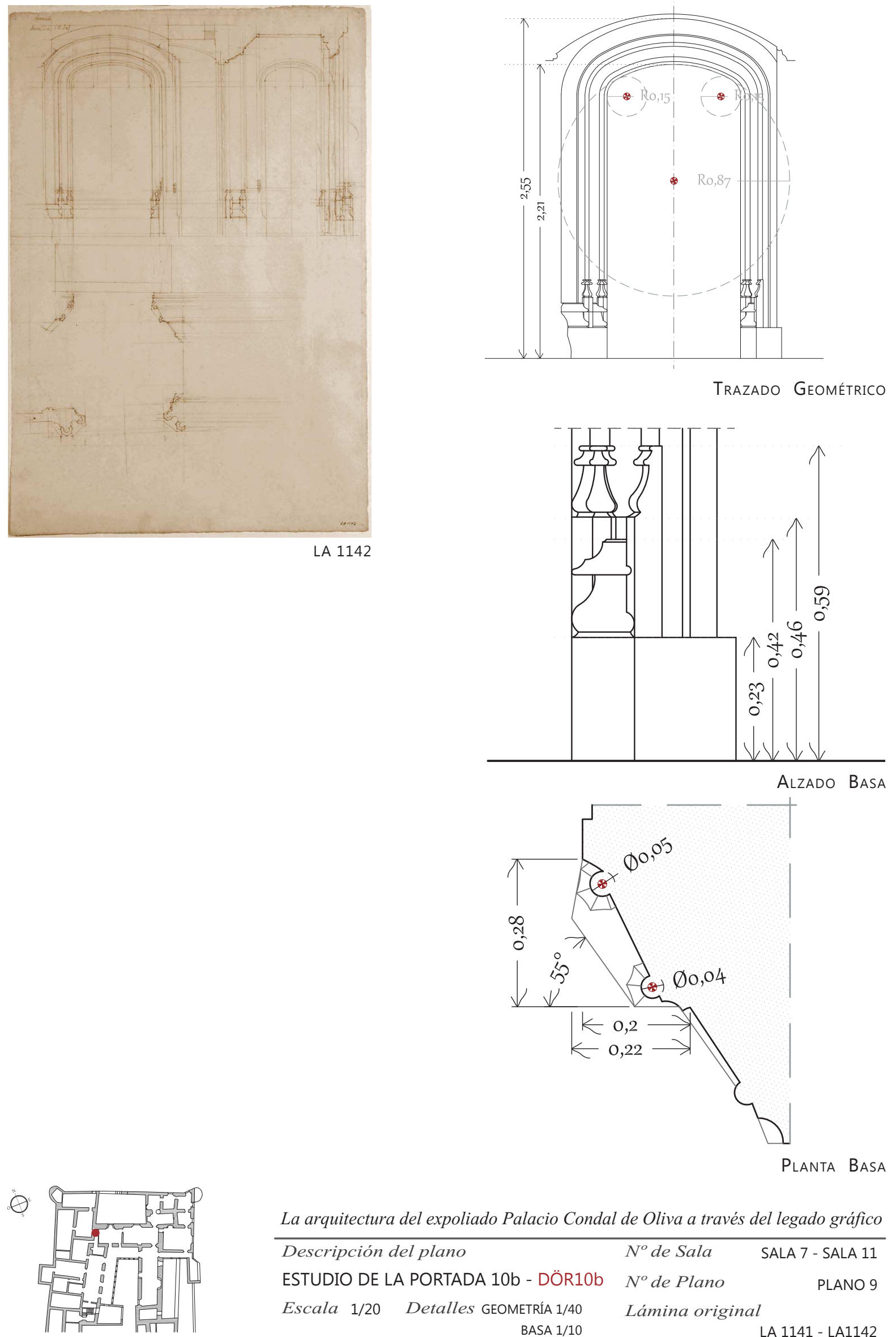

La arquitectura del expoliado Palacio Condal de Oliva a través del legado gráfico Descripción del plano $\quad N^{o}$ de Sala $\quad$ SALA 7 - SALA 11 ESTUDIO DE LA PORTADA 10b - DÖR10b $N^{o}$ de Plano PLANO 9 


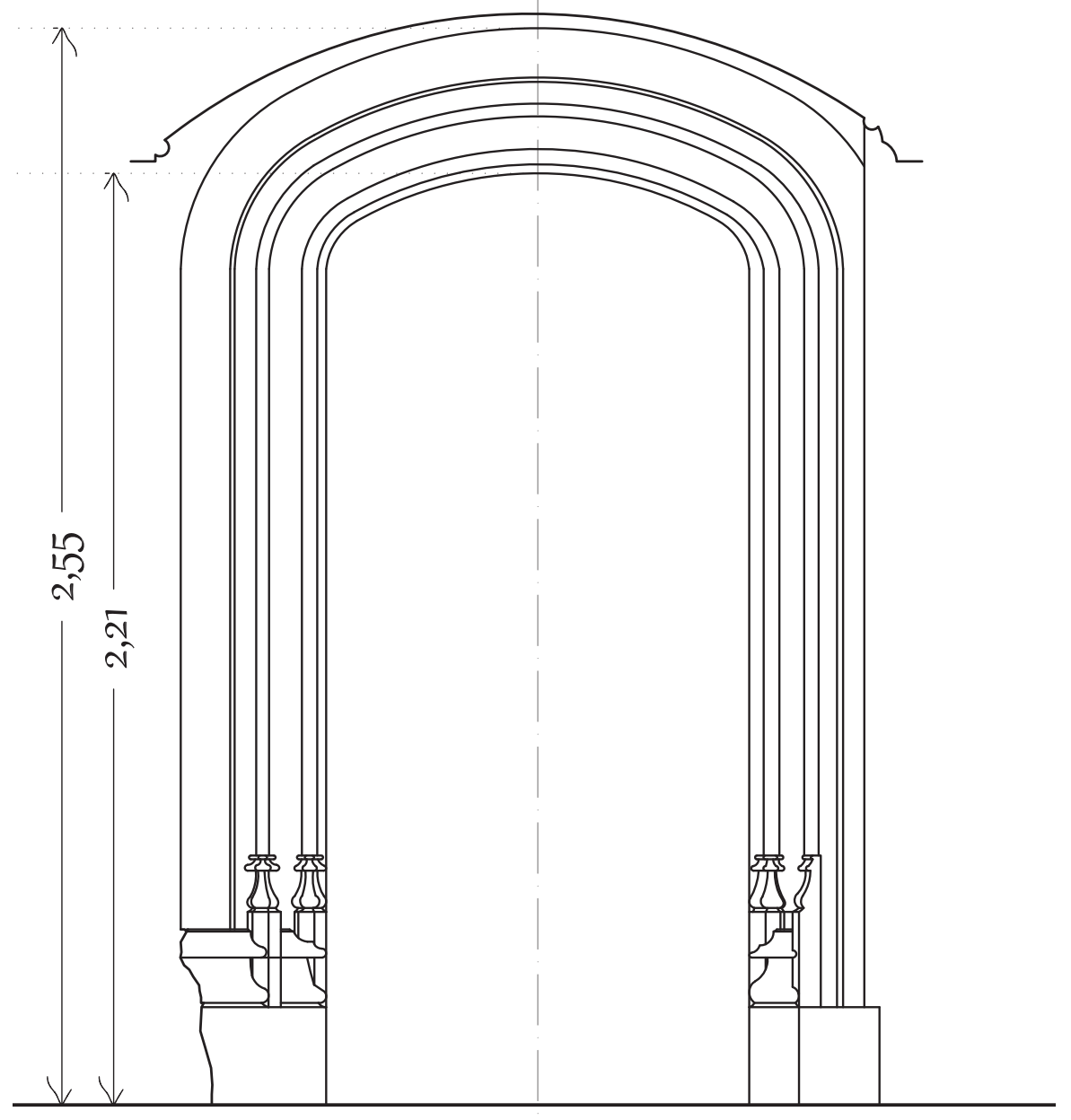

Alzado Principal

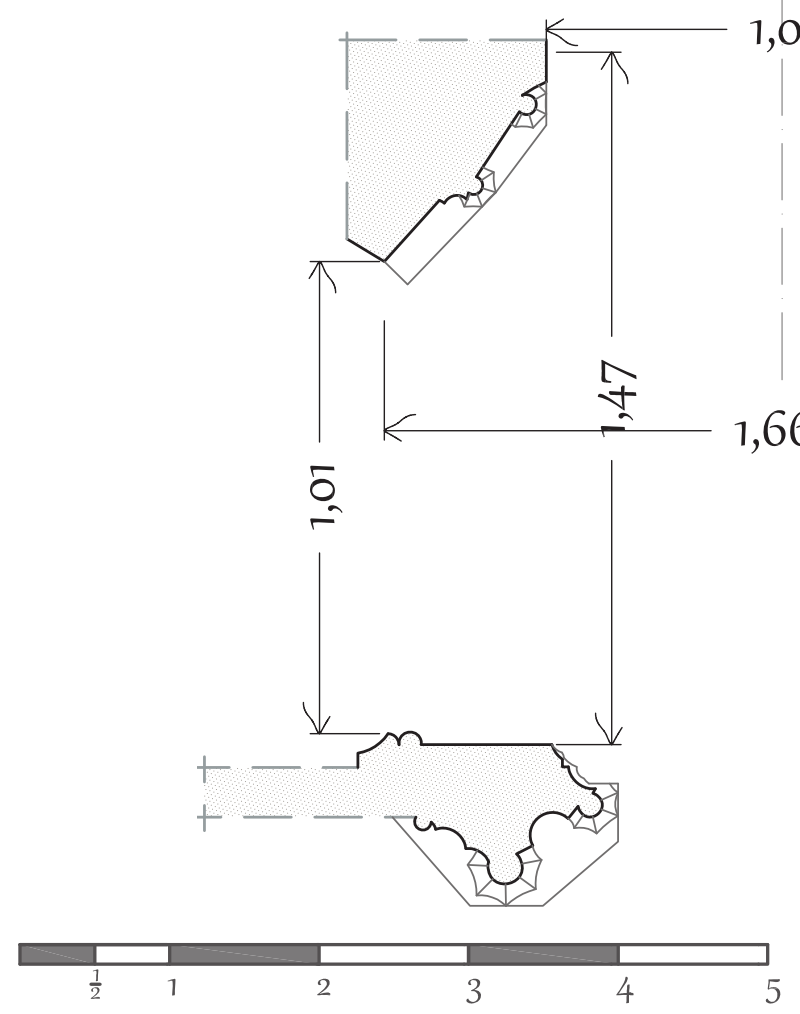

Escala gráfica en palmos valencianos.
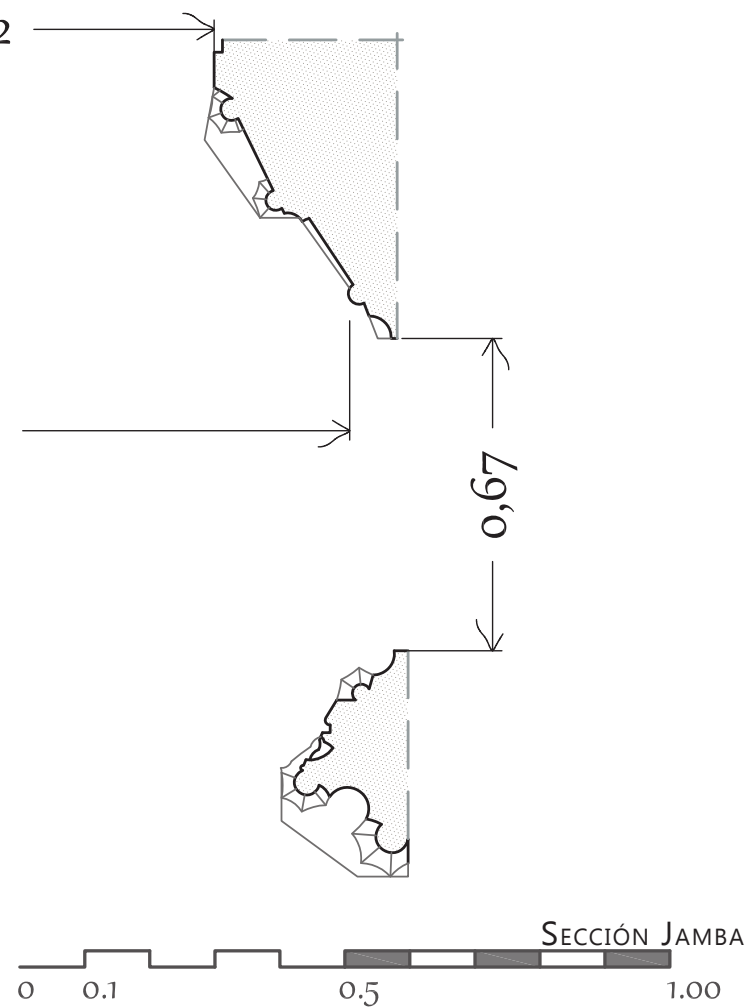

Escala gráfica metros. 

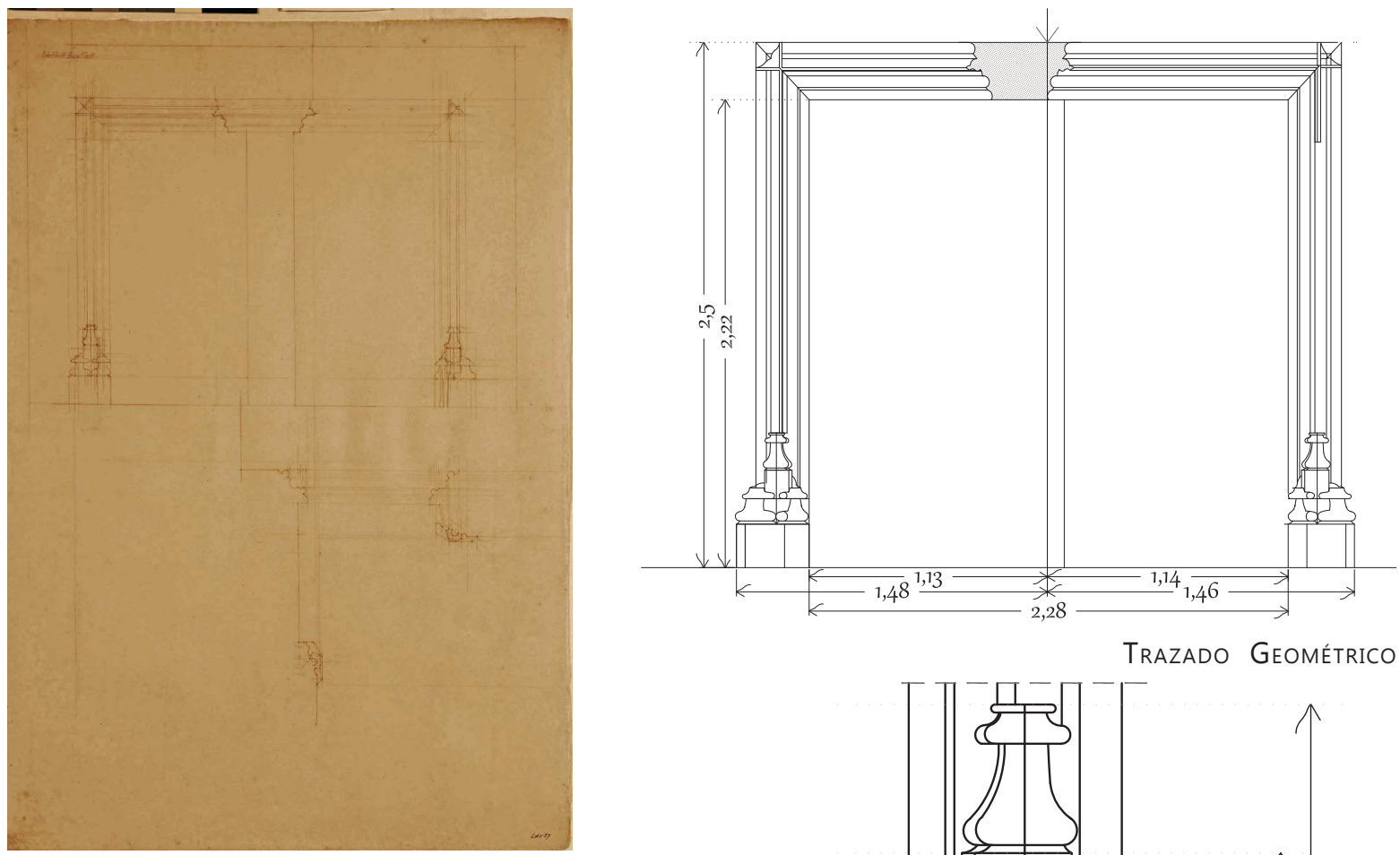

LA 1137
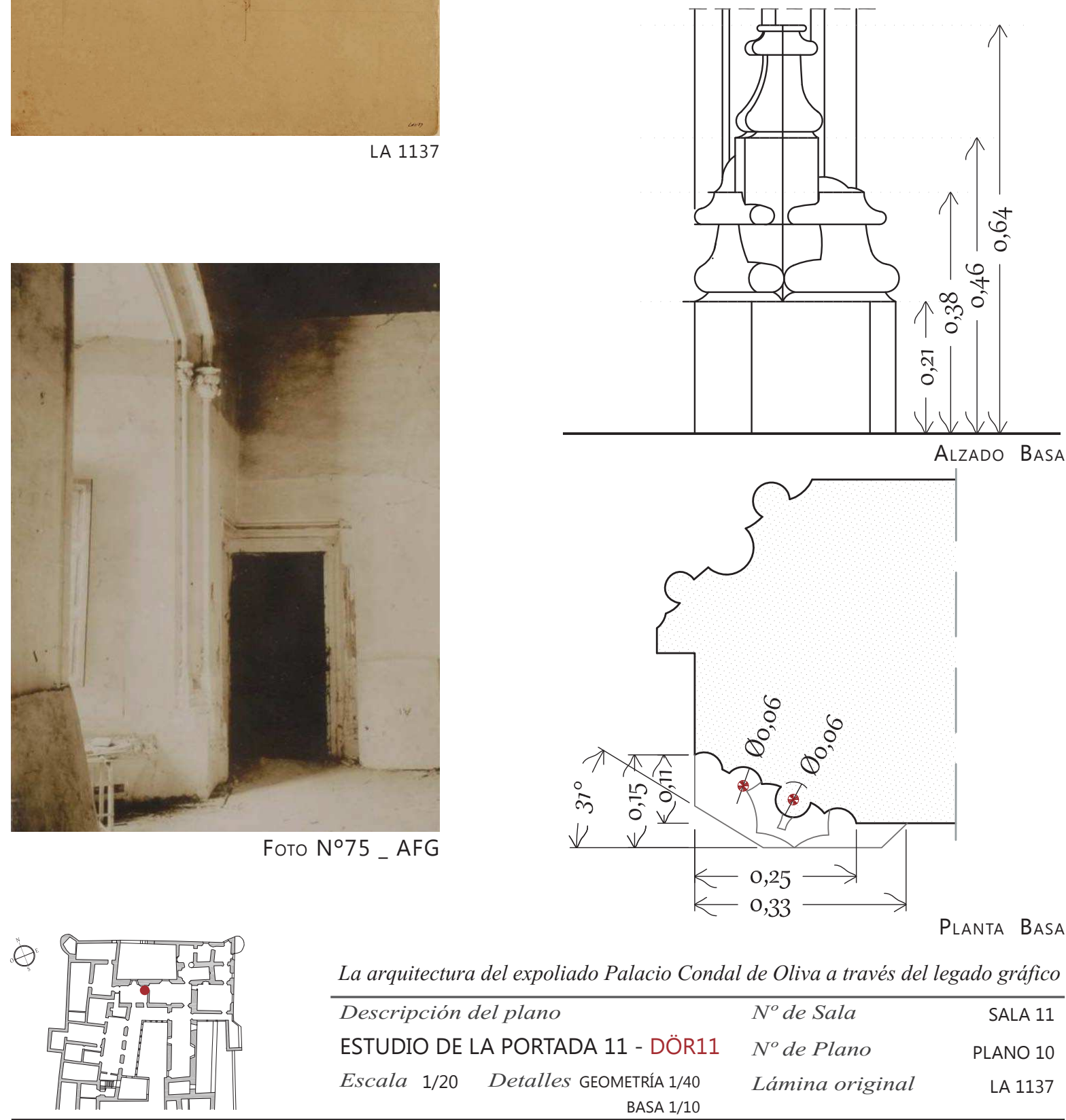

La arquitectura del expoliado Palacio Condal de Oliva a través del legado gráfico

\begin{tabular}{lllr}
\hline Descripción del plano & $N^{o}$ de Sala & SALA 11 \\
ESTUDIO DE LA PORTADA 11 - DÖR11 & $N^{o}$ de Plano & PLANO 10 \\
Escala $1 / 20$ & Detalles GEOMETRÍA 1/40 & Lámina original & LA 1137 \\
\hline
\end{tabular}



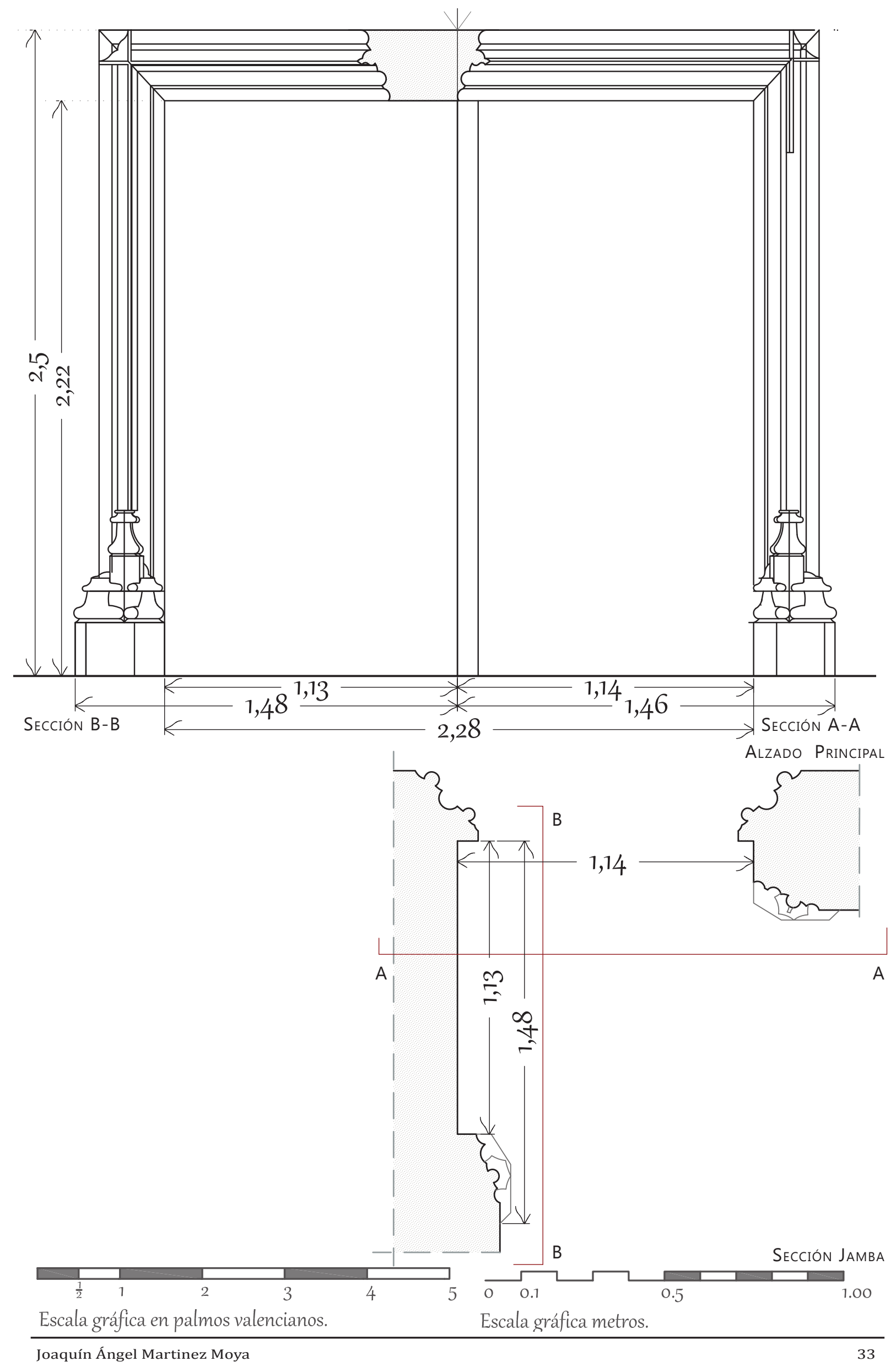

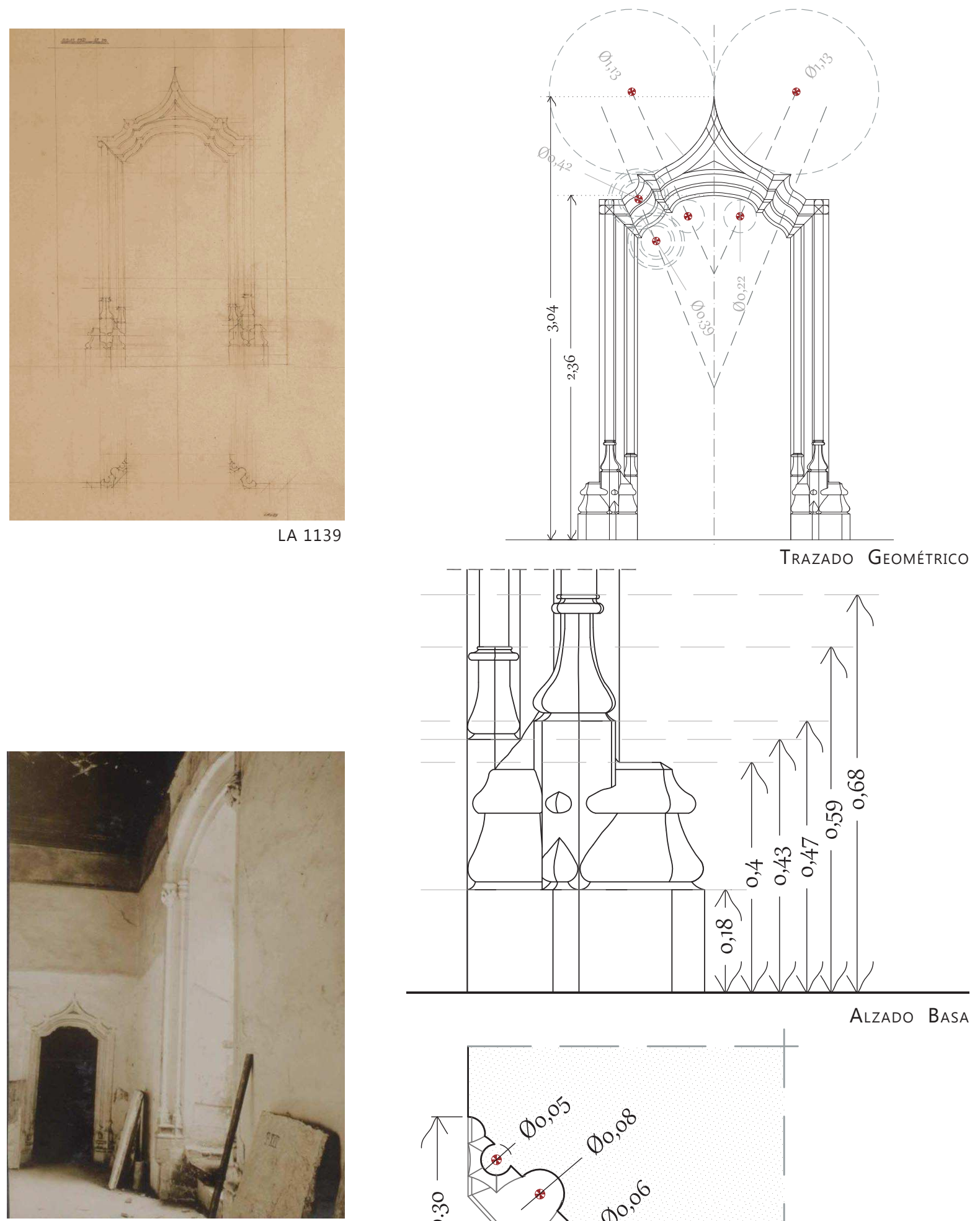

Fото $N^{0} 77$ _ AFG

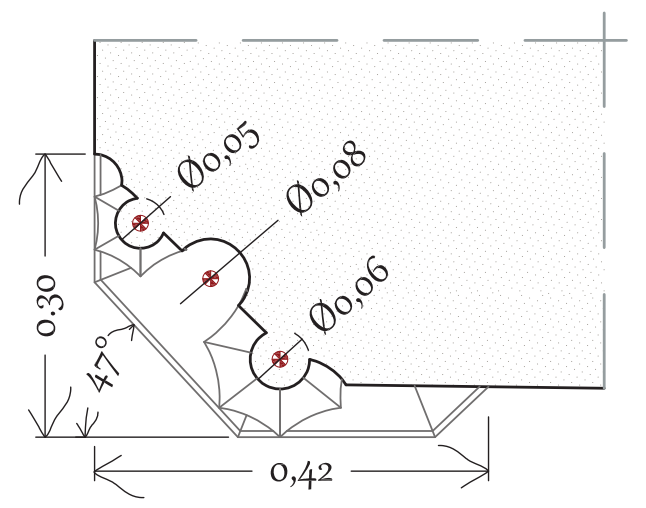

Planta Basa

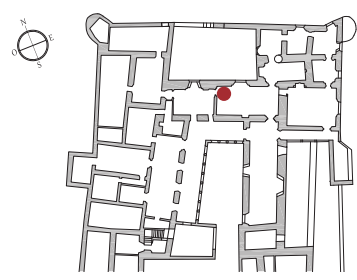

La arquitectura del expoliado Palacio Condal de Oliva a través del legado gráfico

Descripción del plano $N^{o}$ de Sala SALA 12

ESTUDIO DE LA PORTADA 12 - DÖR12

$N^{o}$ de Plano

PLANO 11

Escala 1/20 Detalles GEOMETRÍA 1/40

Lámina original

BASA $1 / 10$

LA 1138 - LA1139 


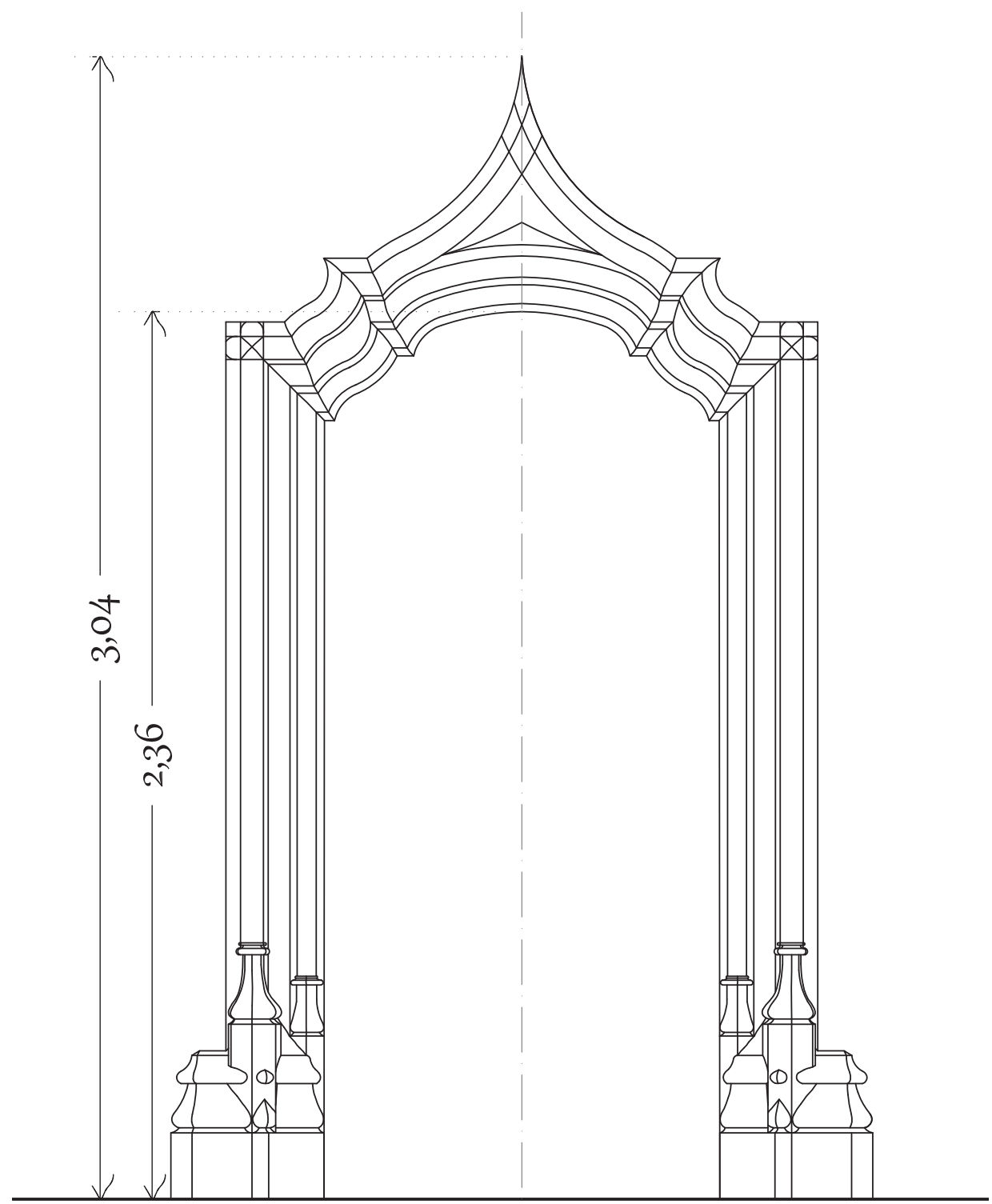

Alzado Principal

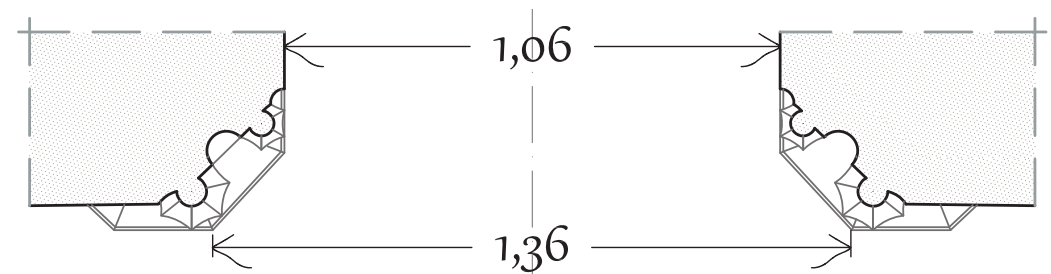

Sección Jamba

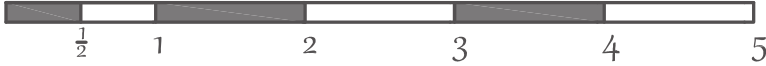

Escala gráfica en palmos valencianos.

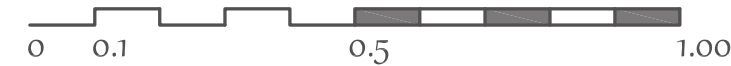

Joaquín Ángel Martinez Moya

Escala gráfica metros. 

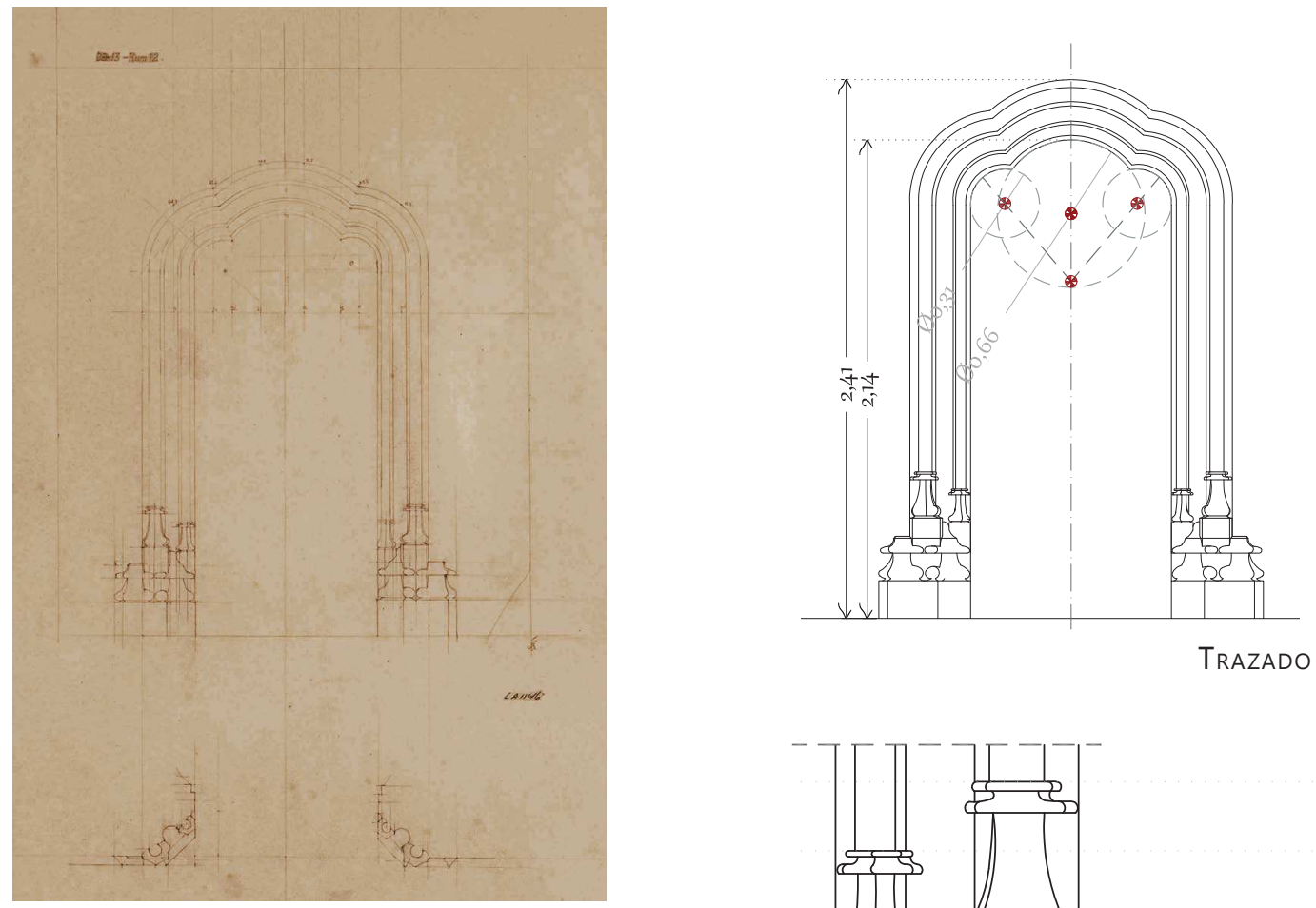

LA 1146

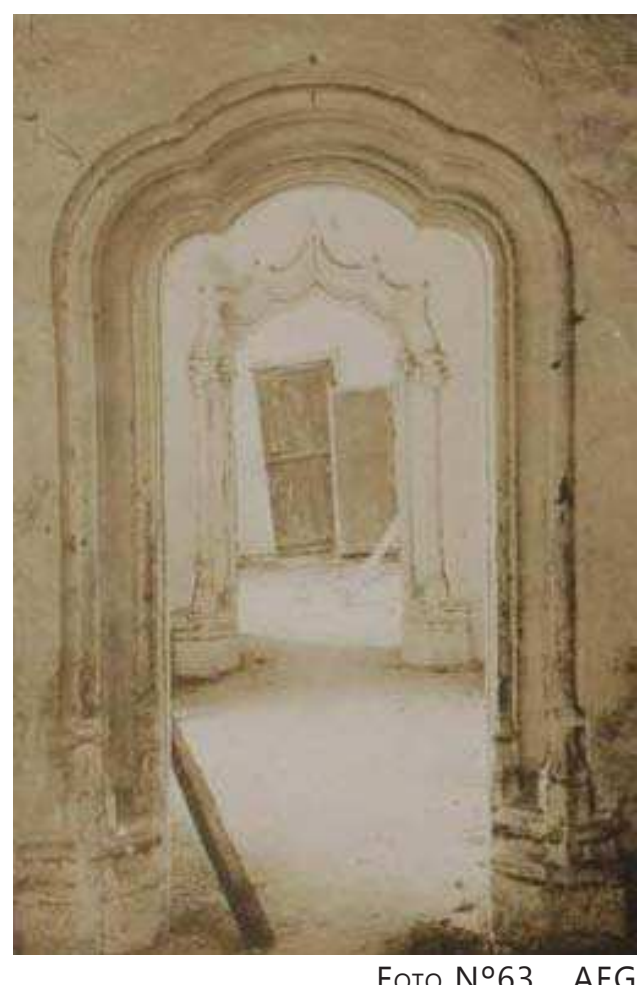

Fото $\mathrm{N}^{\circ} 63$ _ AFG

Trazado Geométrico
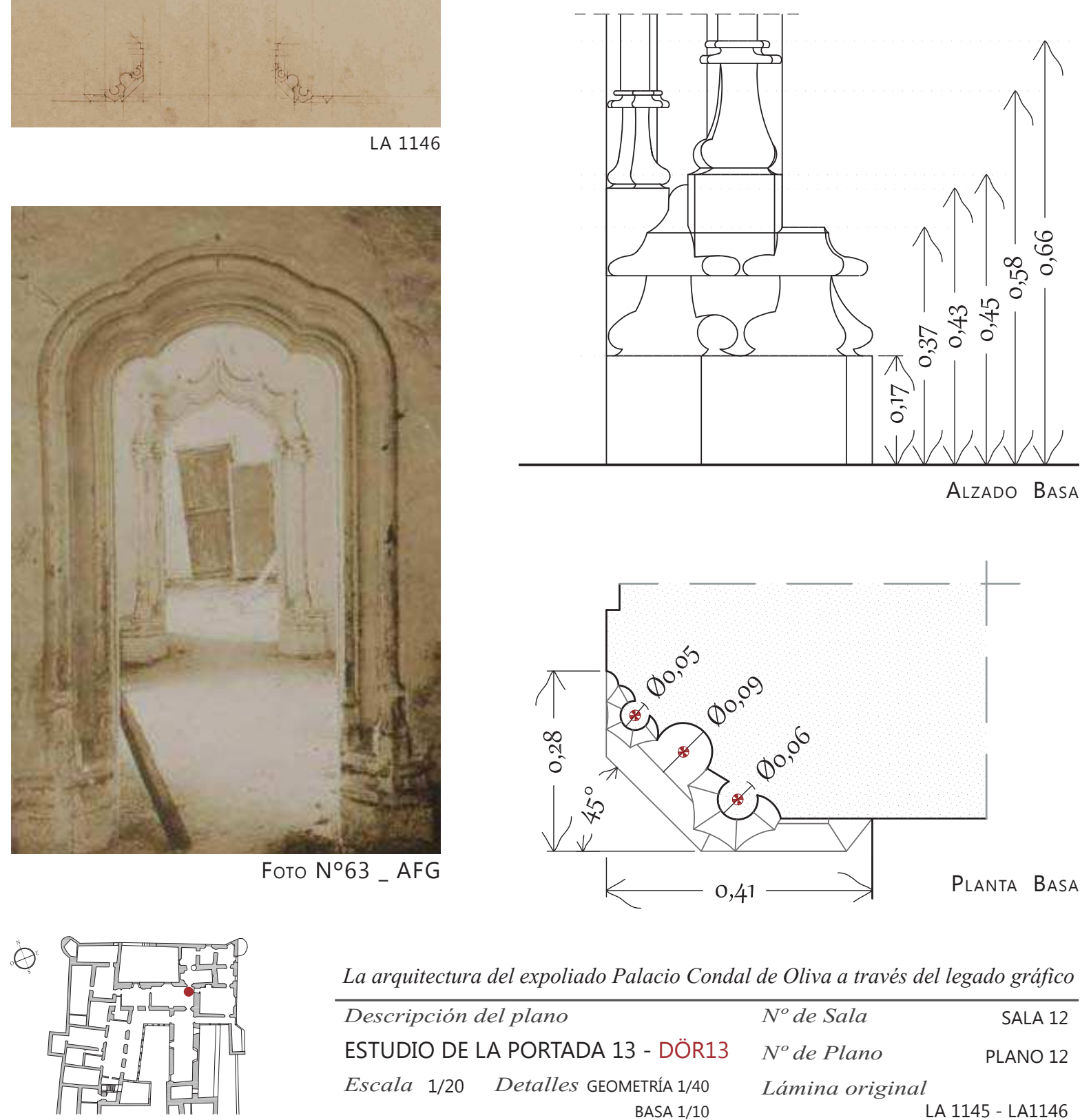

La arquitectura del expoliado Palacio Condal de Oliva a través del legado gráfico

Descripción del plano $N^{o}$ de Sala SALA 12

ESTUDIO DE LA PORTADA 13 - DÖR13

$N^{o}$ de Plano

PLANO 12

Escala $1 / 20$ Detalles GEOMETRÍA $1 / 40$

Lámina original

BASA $1 / 10$

LA 1145 - LA1146 


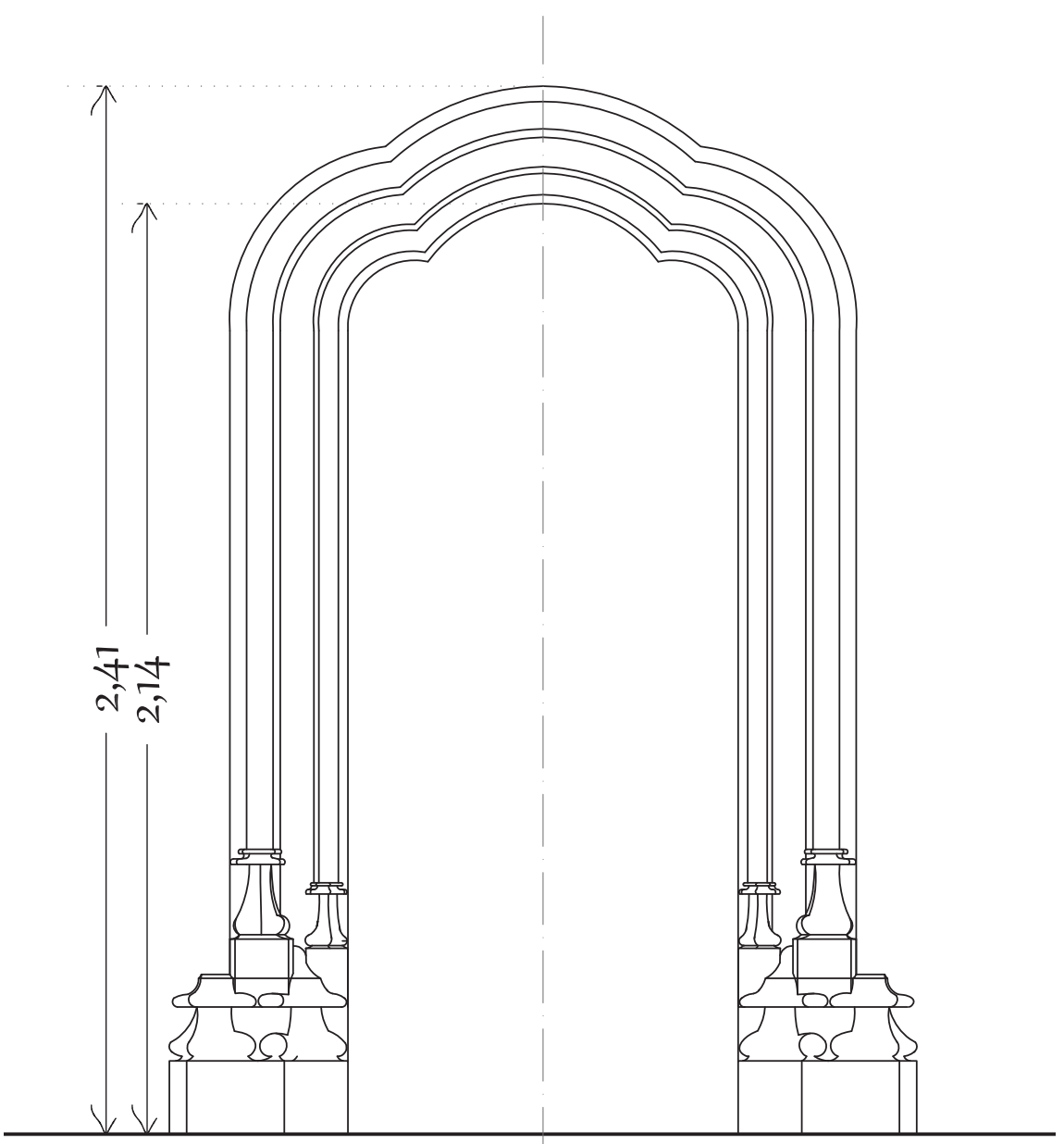

Alzado Principal

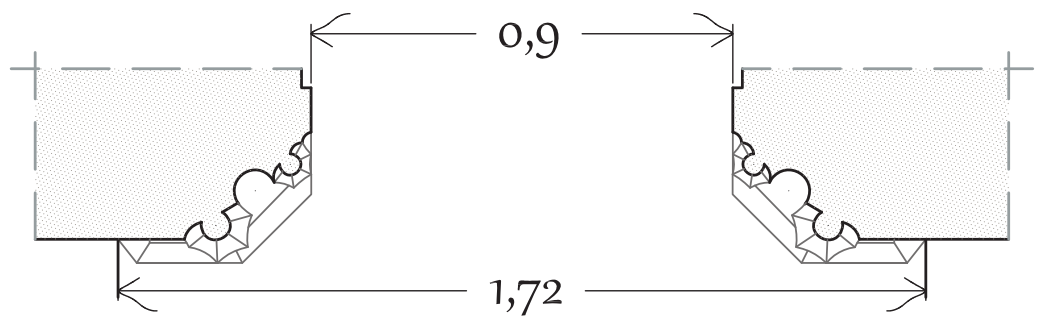

Sección Jamba
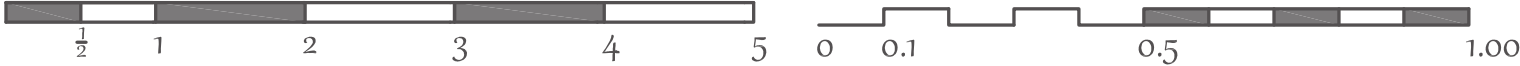

Escala gráfica en palmos valencianos.

Escala gráfica metros. 

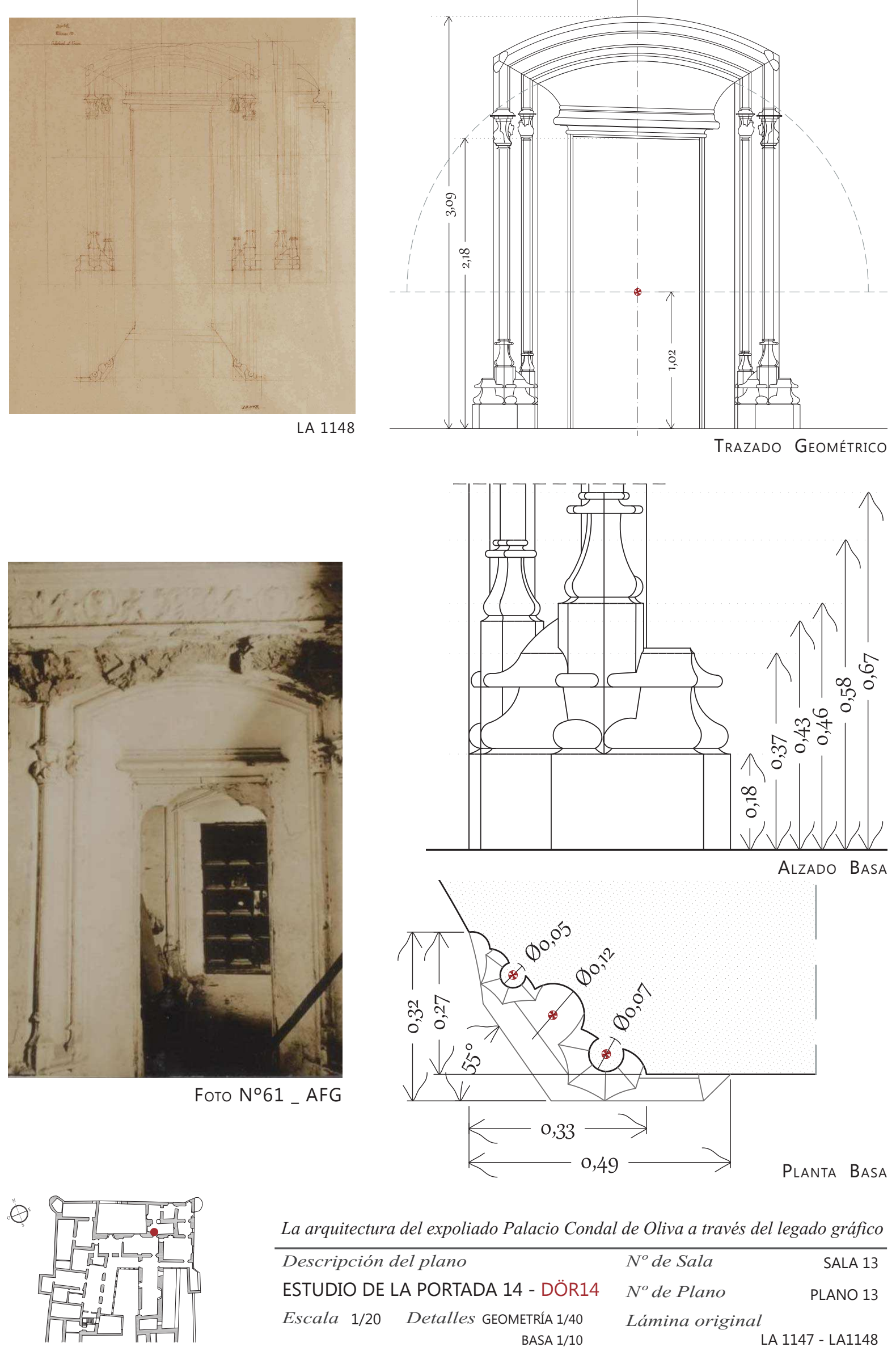

La arquitectura del expoliado Palacio Condal de Oliva a través del legado gráfico Descripción del plano $N^{\circ}$ de Sala SALA 13 ESTUDIO DE LA PORTADA 14 - DÖR14 $N^{o}$ de Plano PLANO 13 Escala 1/20 Detalles GEOMETRÍA 1/40 Lámina original BASA $1 / 10$ 

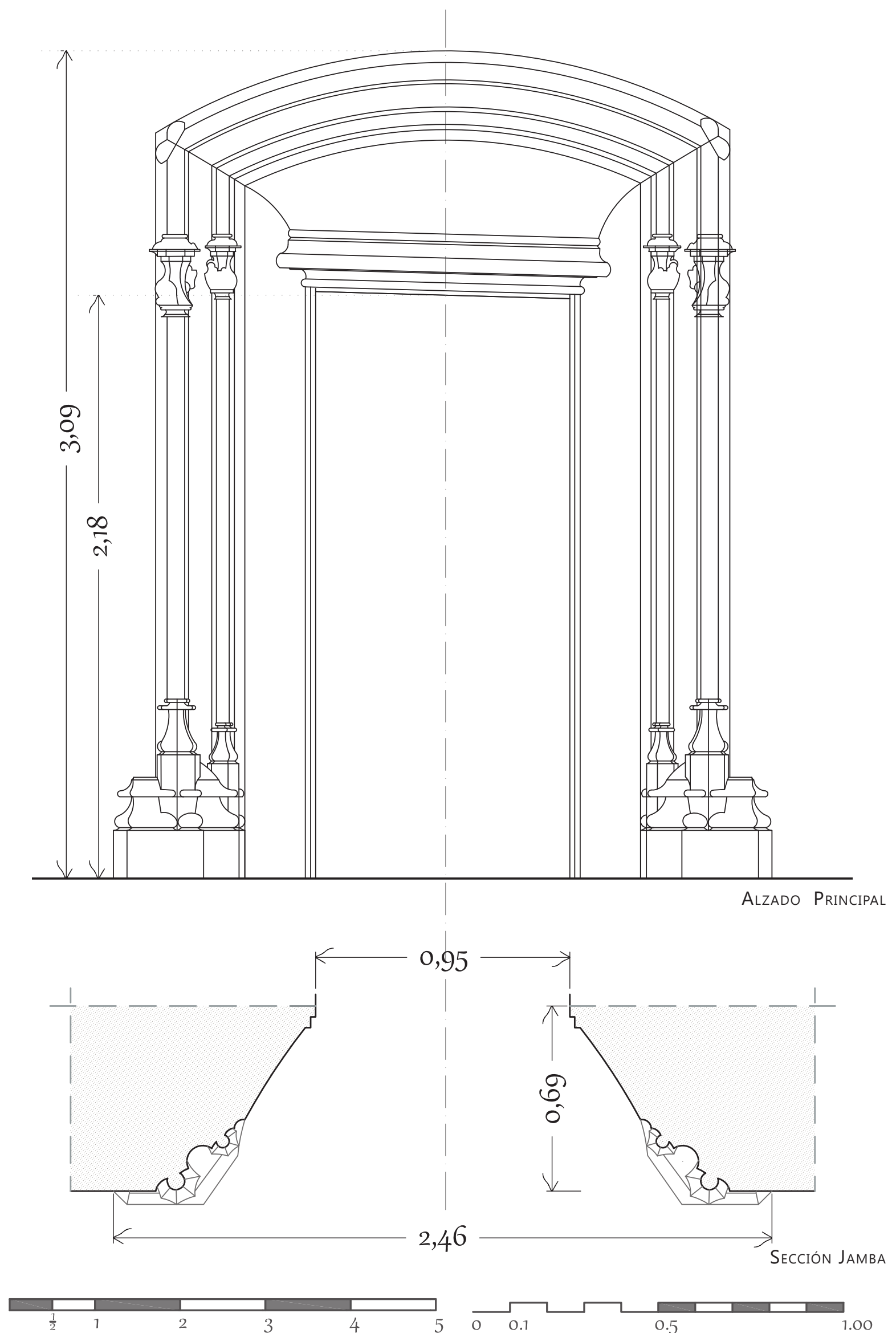

Escala gráfica en palmos valencianos.

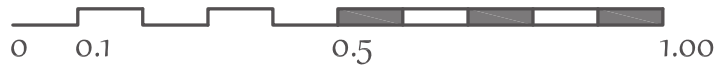

Joaquín Ángel Martinez Moya

Escala gráfica metros. 


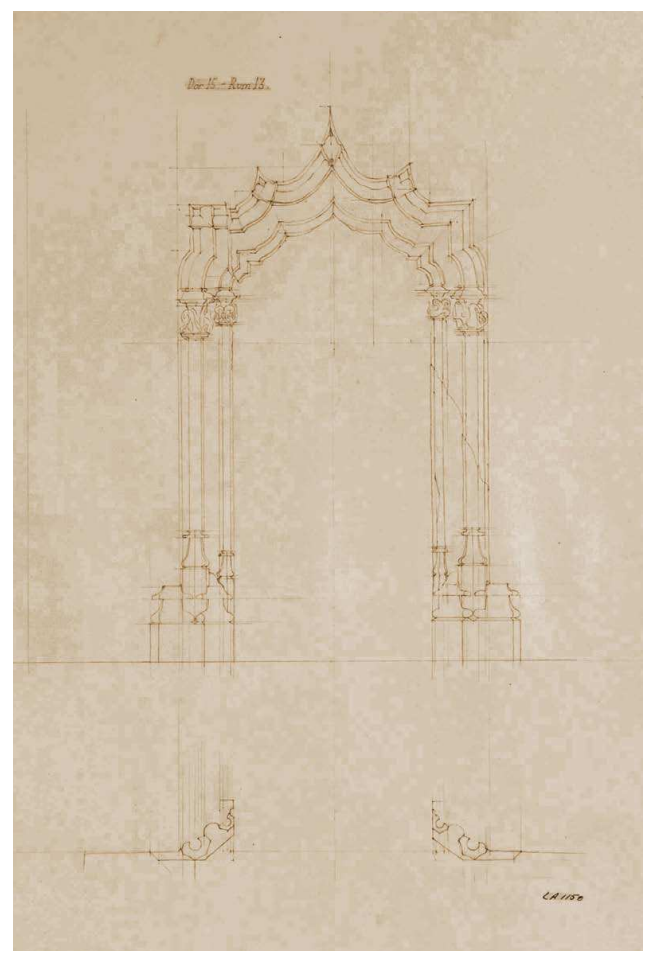

LA 1150

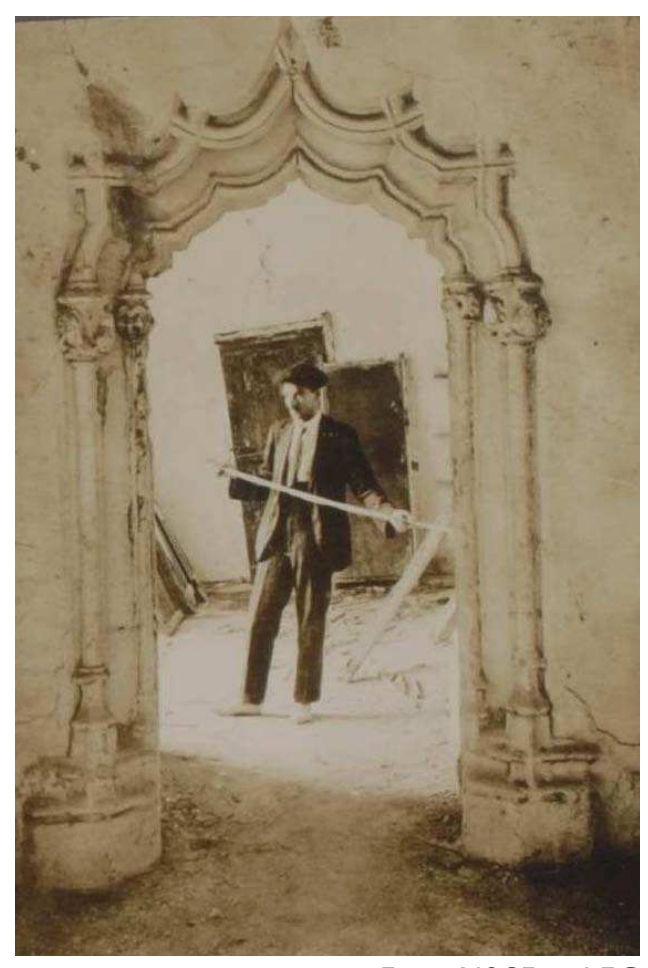

Fото $\mathrm{N}^{\circ} 65$ _ AFG
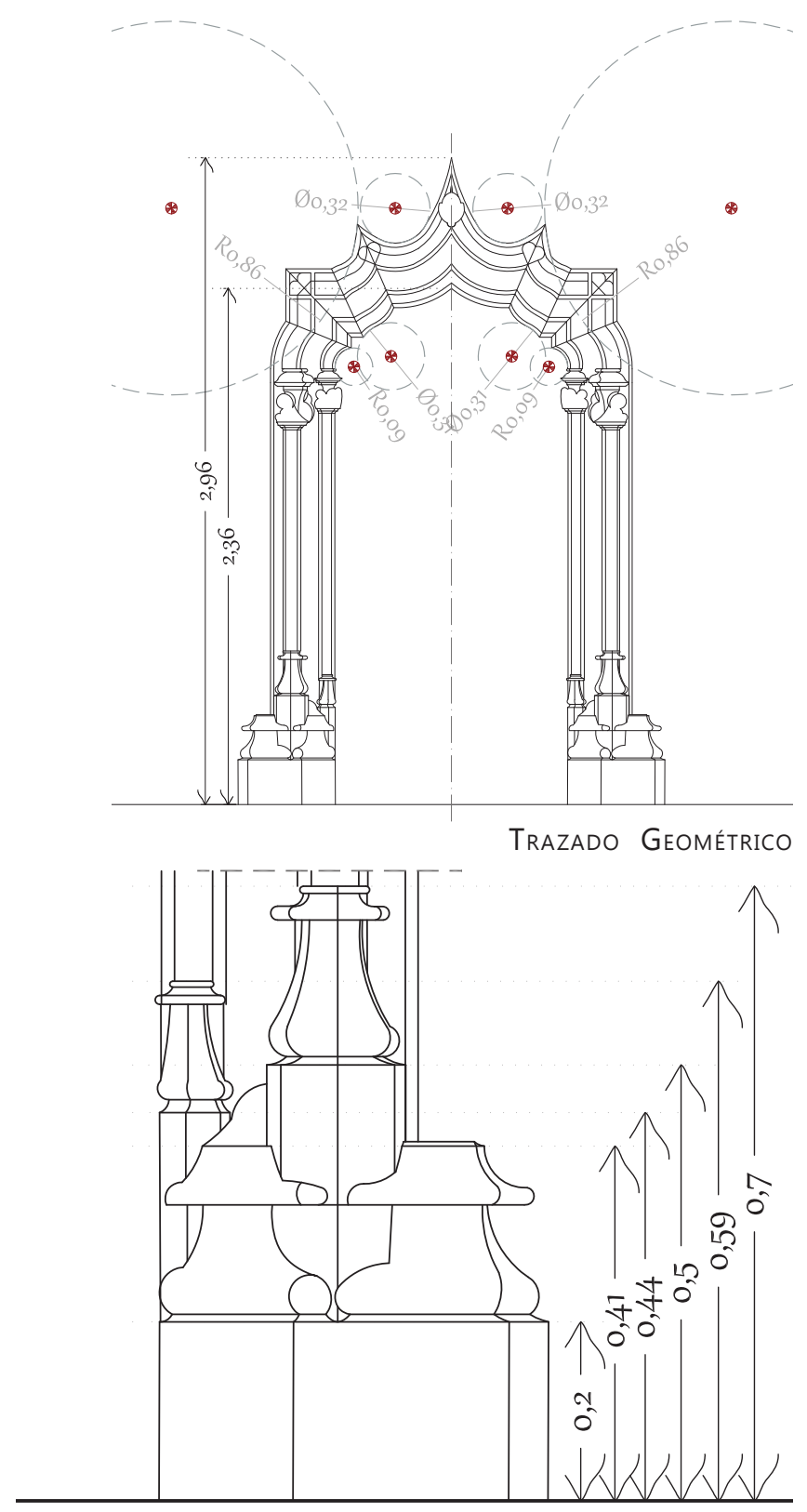

Alzado BASA

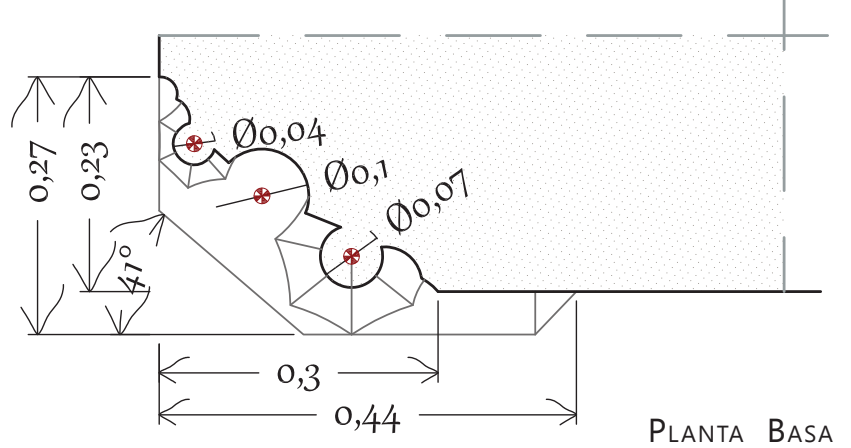

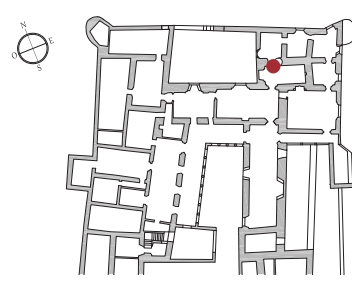

40

La arquitectura del expoliado Palacio Condal de Oliva a través del legado gráfico Descripción del plano $N^{o}$ de Sala SALA 13 ESTUDIO DE LA PORTADA 15 - DÖR15 $\quad N^{o}$ de Plano PLANO 14 Escala $1 / 20$ Detalles GEOMETRÍA 1/40 Lámina original BASA $1 / 10$ 

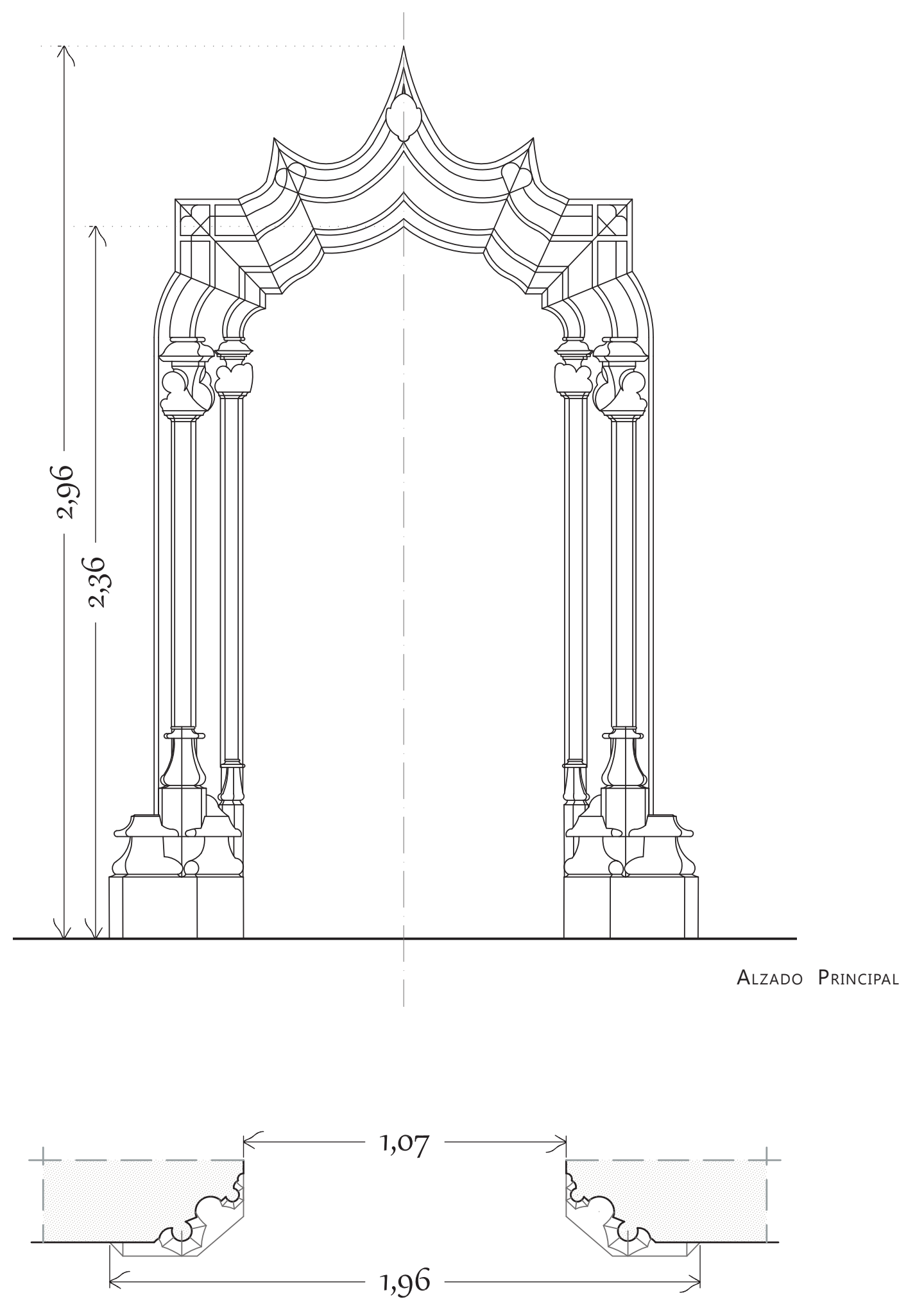

SeCCión Jamba

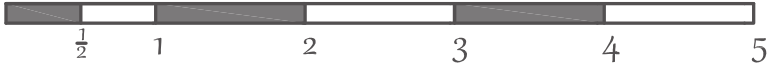

Escala gráfica en palmos valencianos.

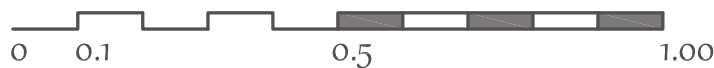

Escala gráfica metros. 

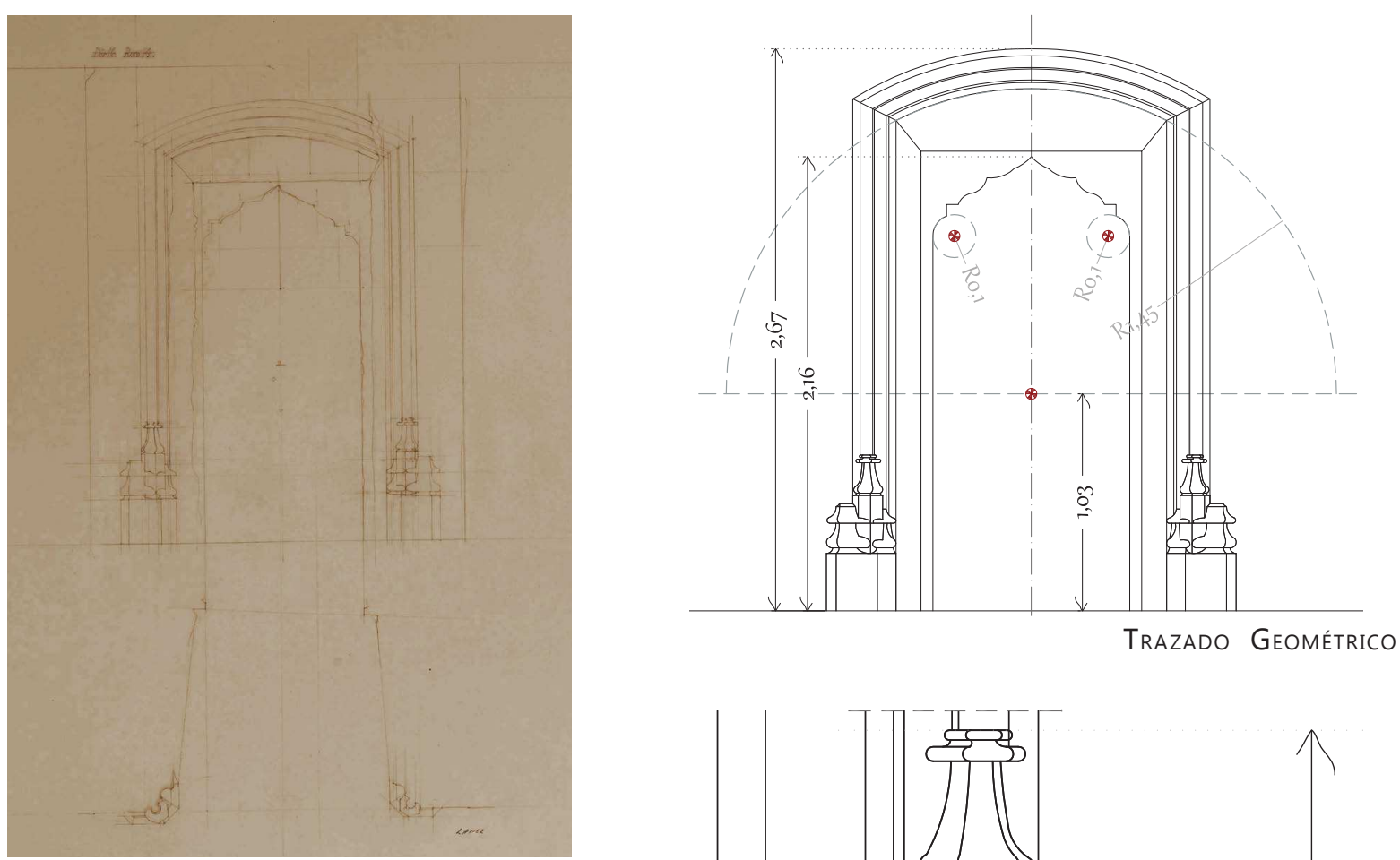

LA 1152
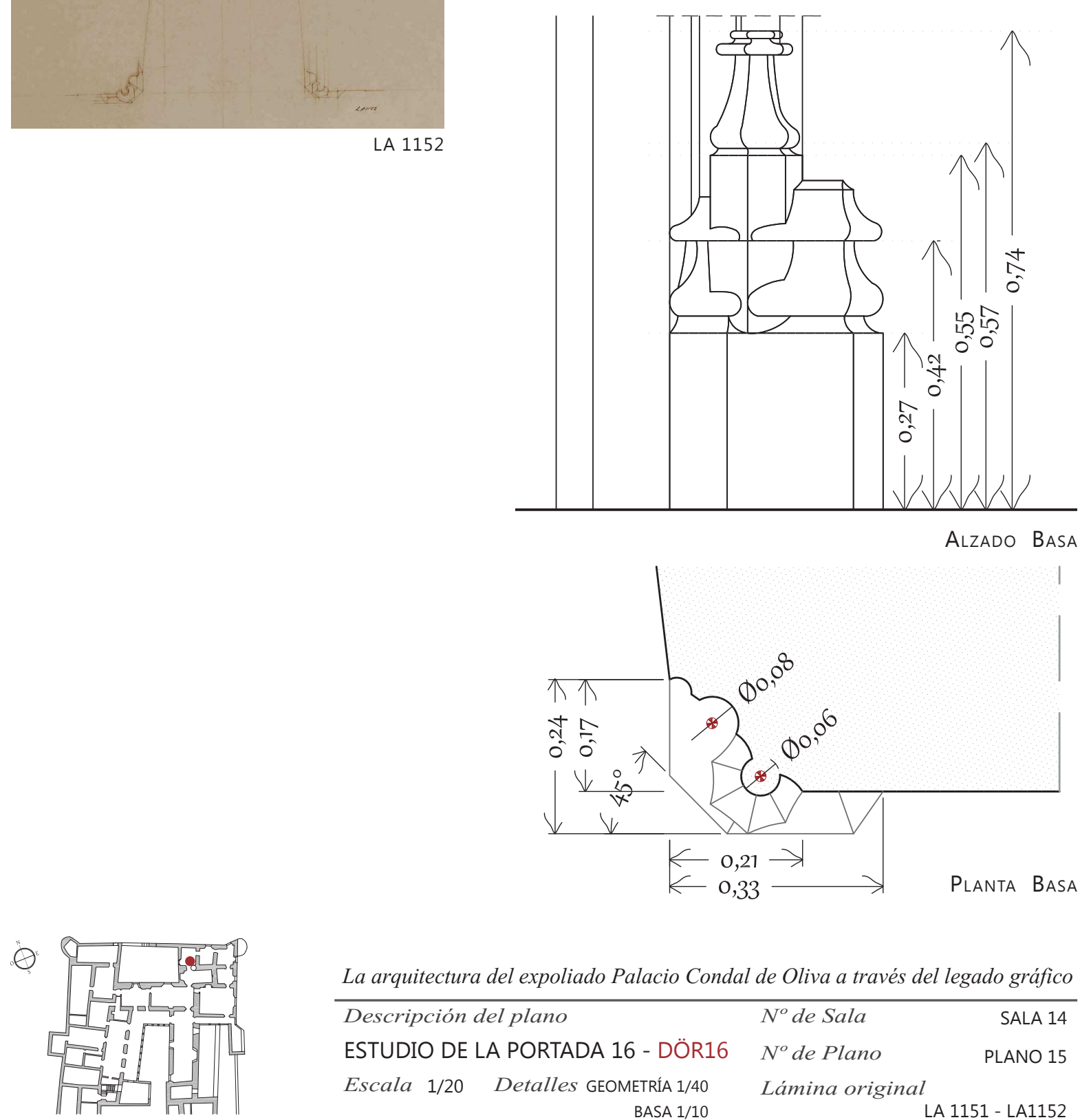

La arquitectura del expoliado Palacio Condal de Oliva a través del legado gráfico

Descripción del plano $N^{o}$ de Sala SALA 14

ESTUDIO DE LA PORTADA 16 - DÖR16

$N^{o}$ de Plano

PLANO 15

Escala $1 / 20$ Detalles GEOMETRÍA $1 / 40$

Lámina original

BASA $1 / 10$

LA 1151 - LA1152 

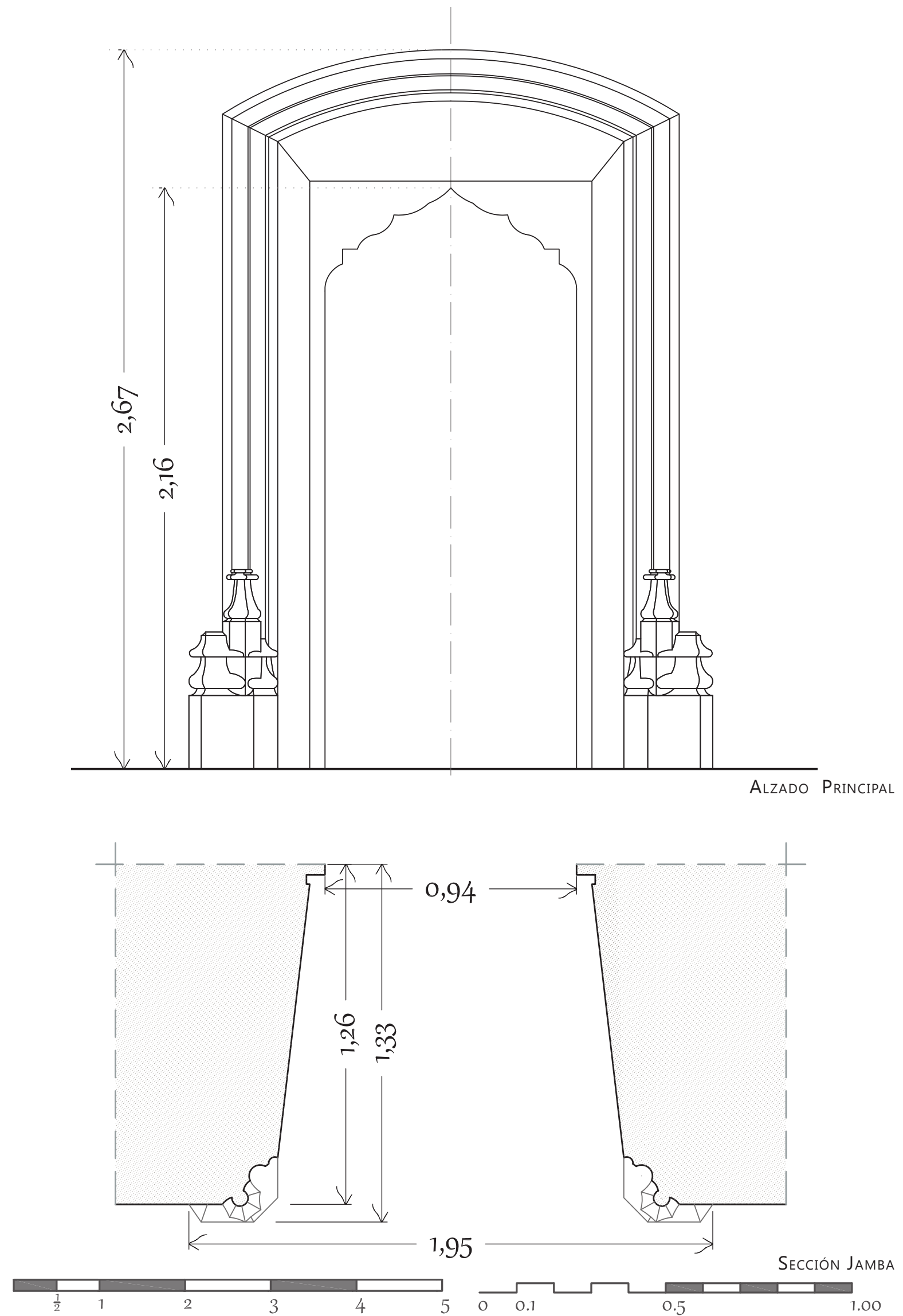

Escala gráfica en palmos valencianos.

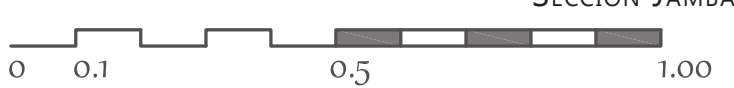

Escala gráfica metros. 

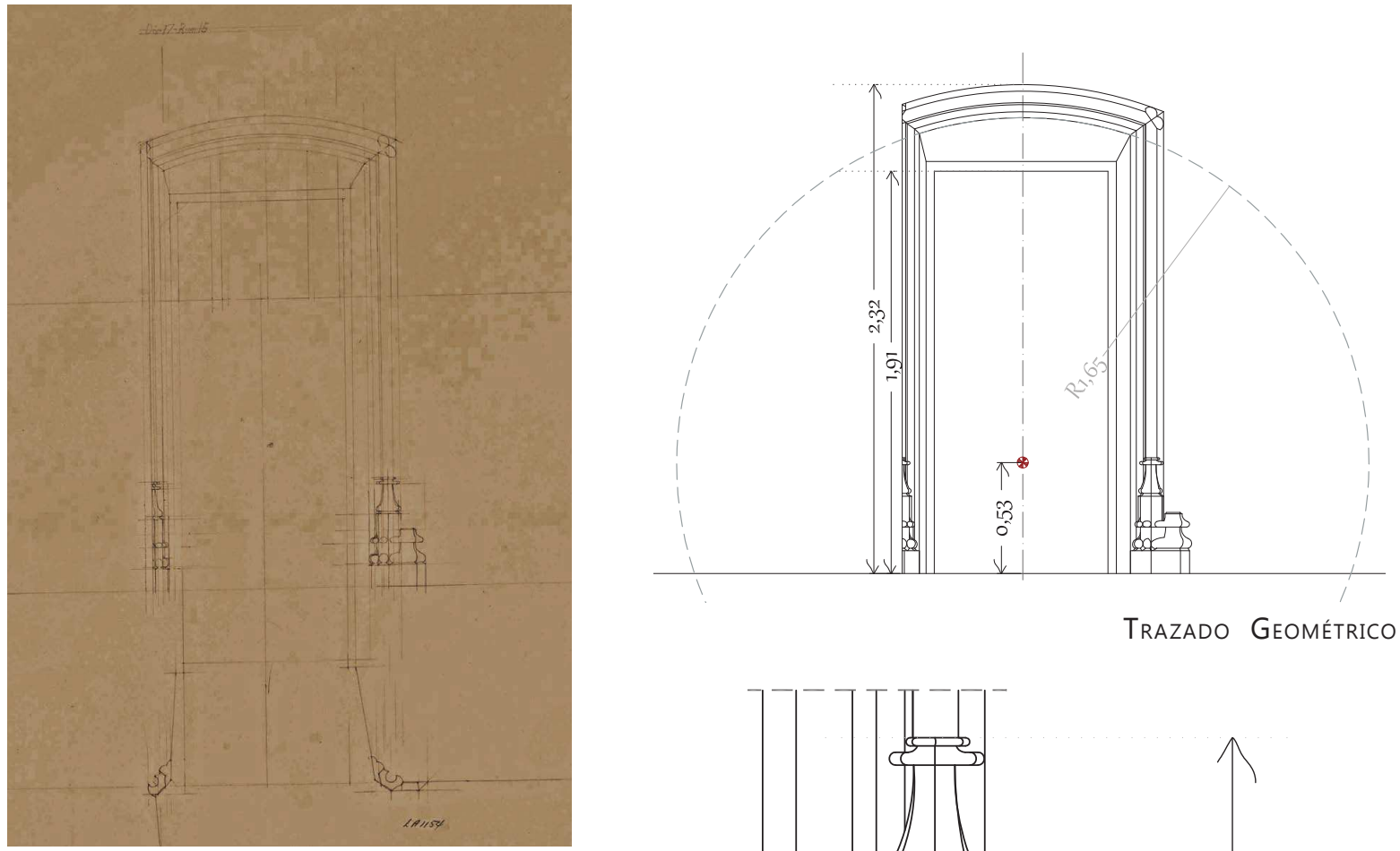

LA 1154

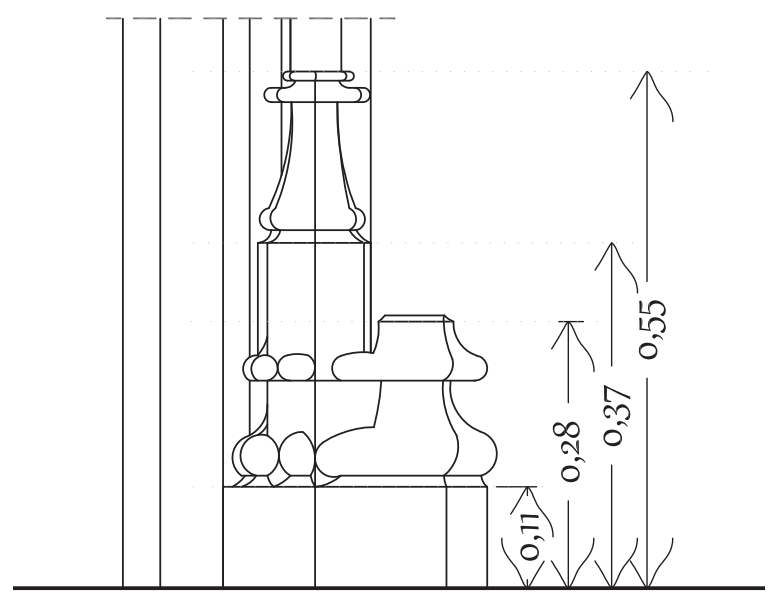

Alzado Basa

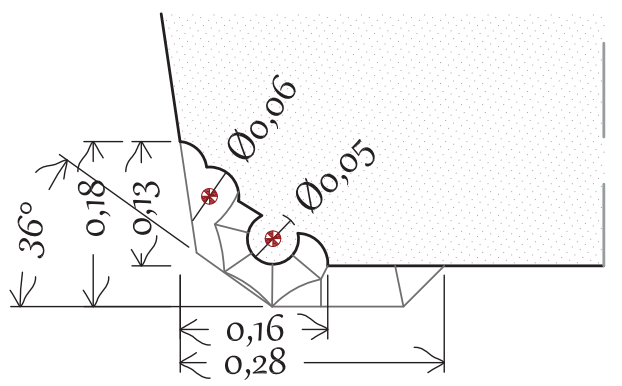

Planta Basa

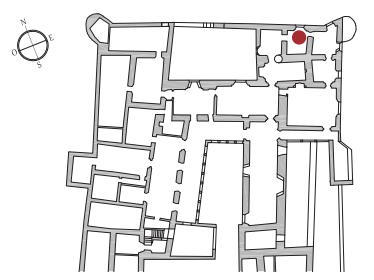

La arquitectura del expoliado Palacio Condal de Oliva a través del legado gráfico Descripción del plano
ESTUDIO DE LA PORTADA ESTUDIO DE LA PORTADA 17 - DÖR17 $N^{o}$ de Sala SALA 15

Escala $1 / 20$ Detalles GEOMETRÍA 1/40 $N^{o}$ de Plano PLANO 16 BASA $1 / 10$ Lámina original 


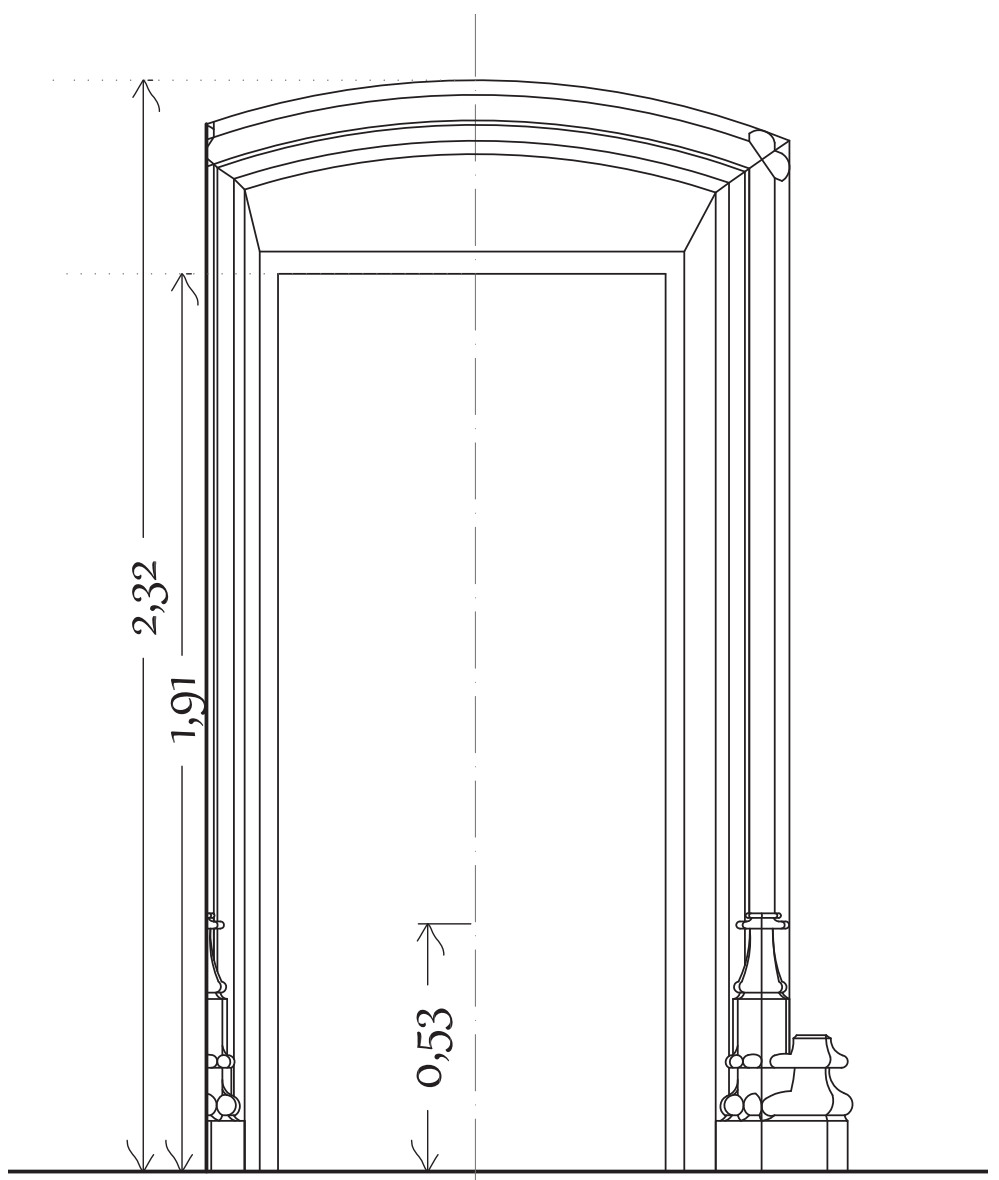

Alzado Principal

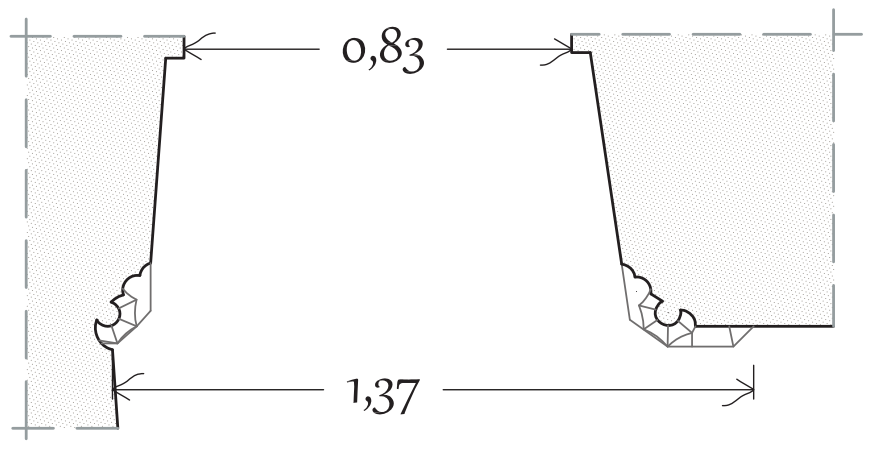

SeCCión JAMBA
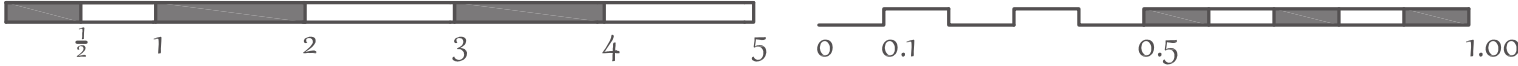

Escala gráfica en palmos valencianos.

Escala gráfica metros. 


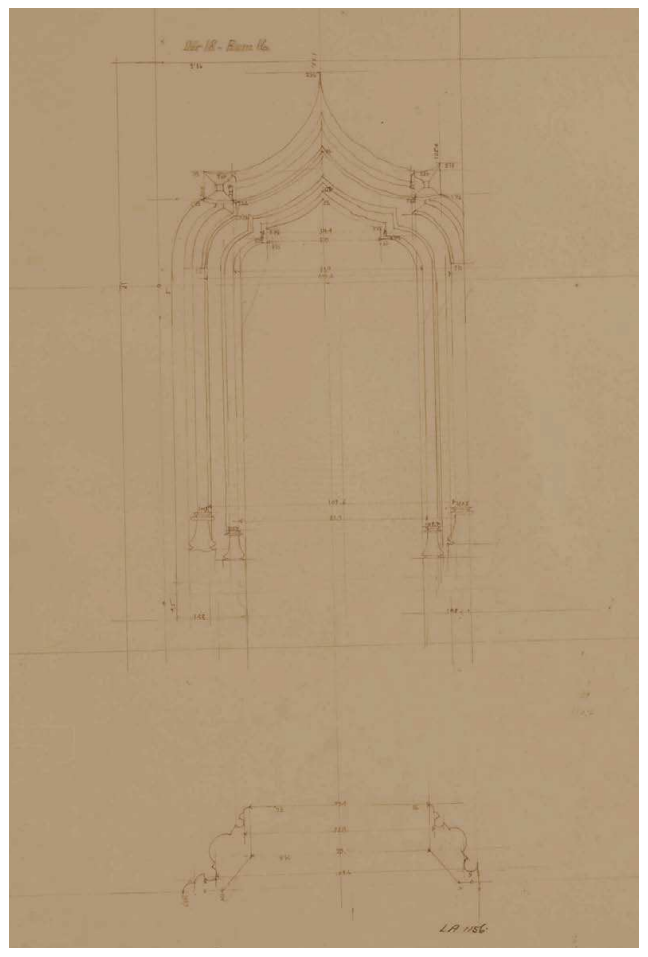

LA 1156

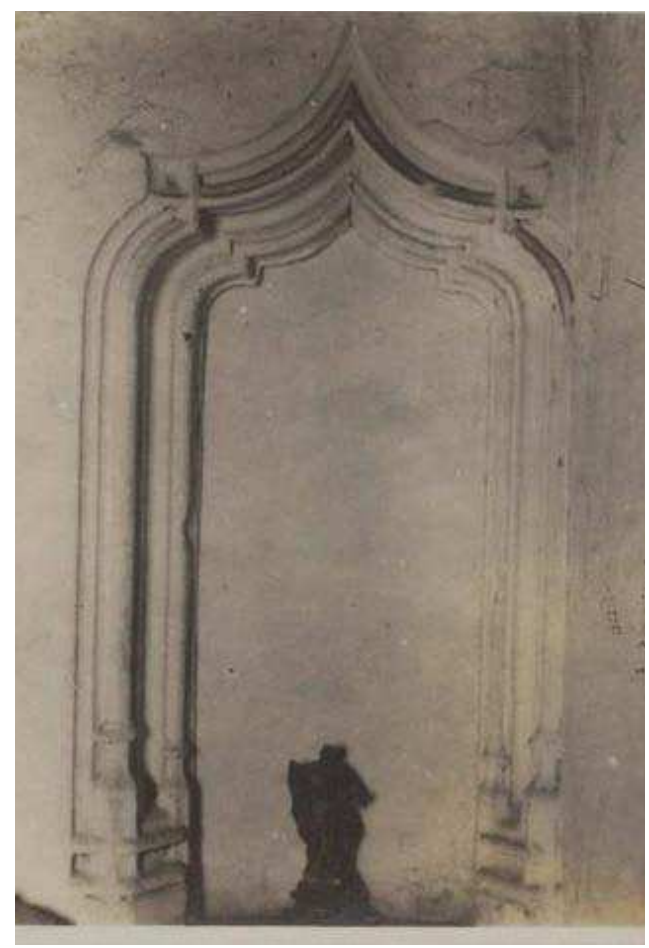

Fото $\mathrm{N}^{\circ} 67$ _ AFG

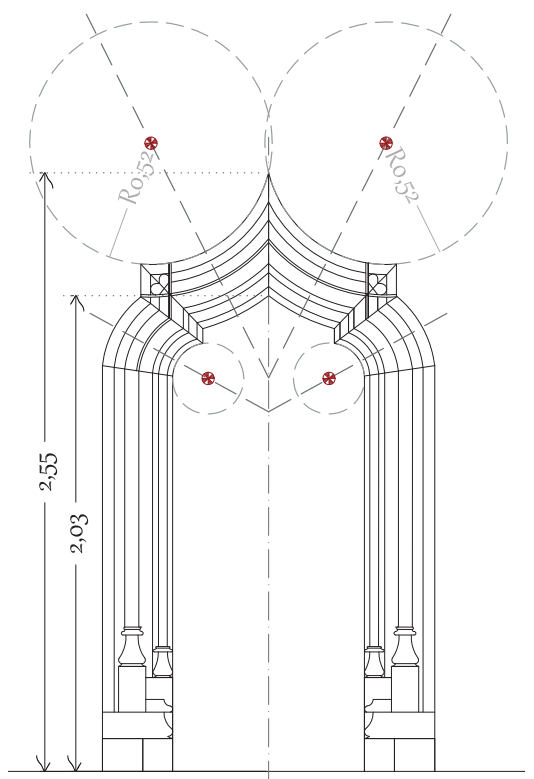

Trazado Geométrico

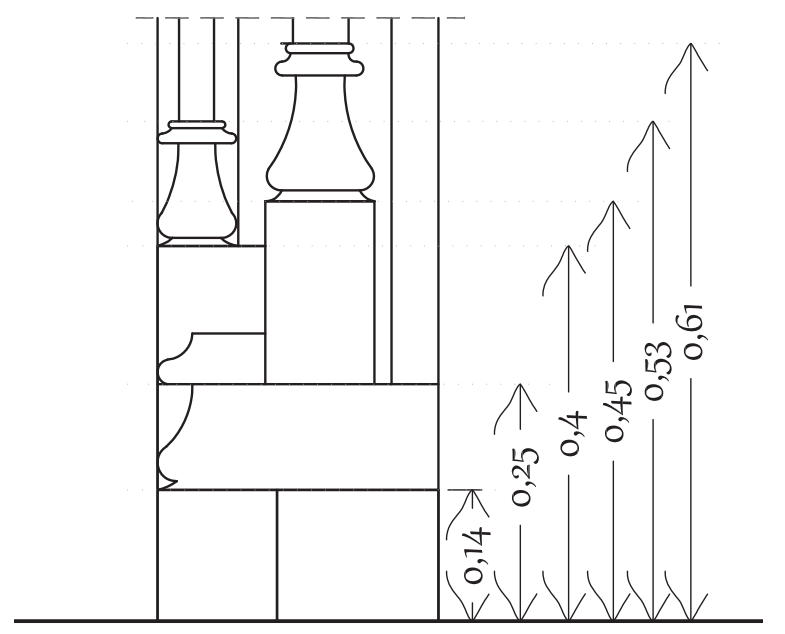

AlzAdo BASA

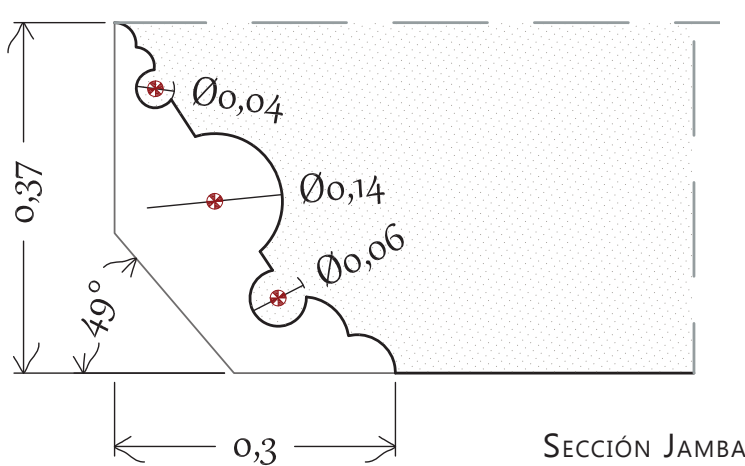

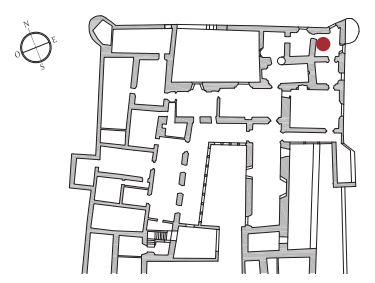

La arquitectura del expoliado Palacio Condal de Oliva a través del legado gráfico

Descripción del plano $N^{\circ}$ de Sala SALA 16

ESTUDIO DE LA PORTADA 18 - DÖR18

$N^{o}$ de Plano

PLANO 17

Escala 1/20 Detalles GEOMETRÍA 1/40

Lámina original

BASA $1 / 10$

LA 1155 - LA1156 

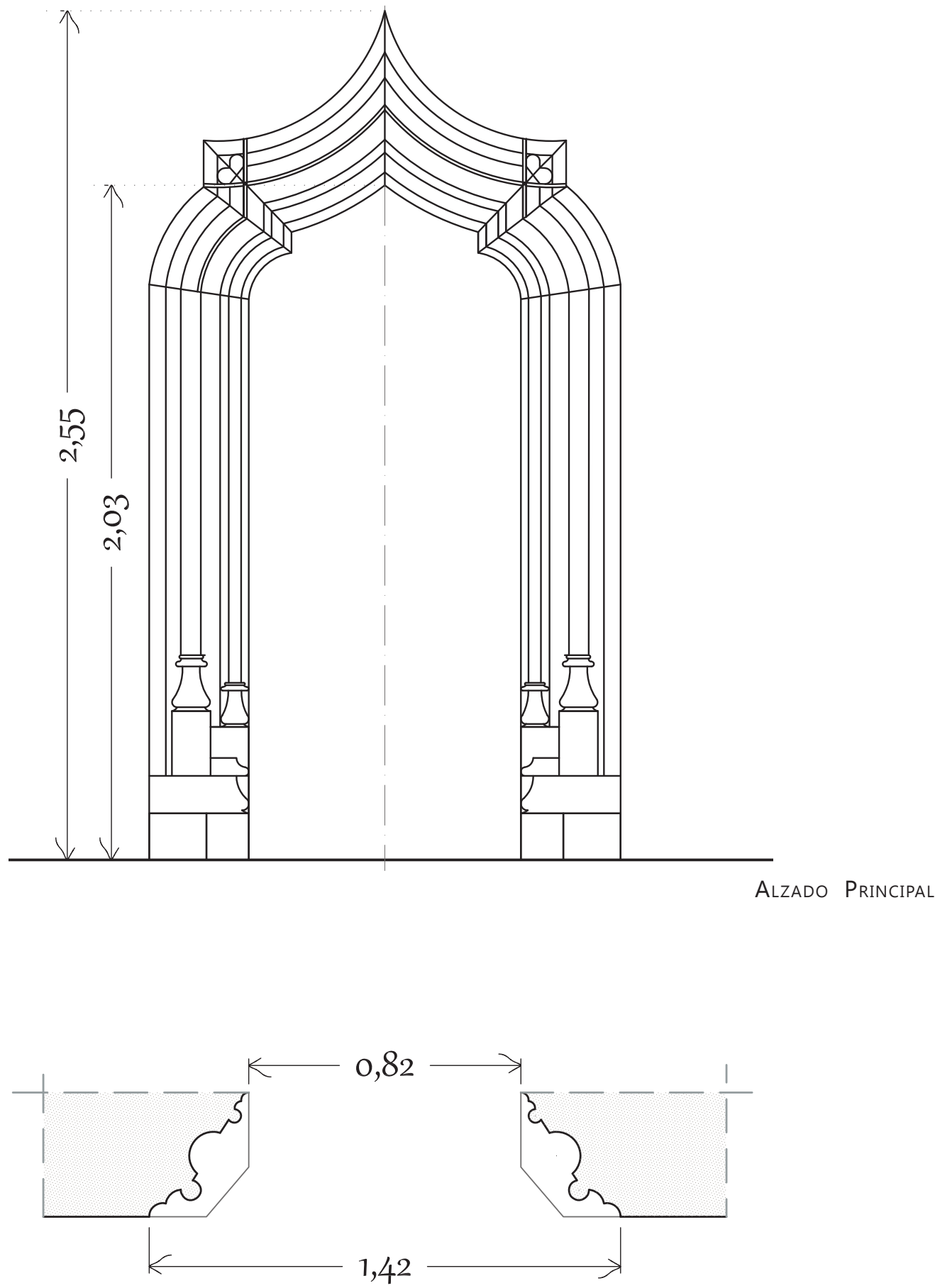

Sección Jamba

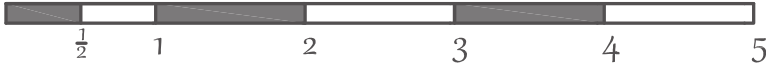

Escala gráfica en palmos valencianos.

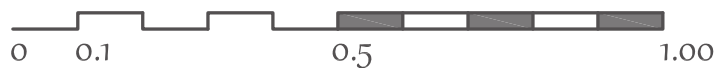

Escala gráfica metros. 

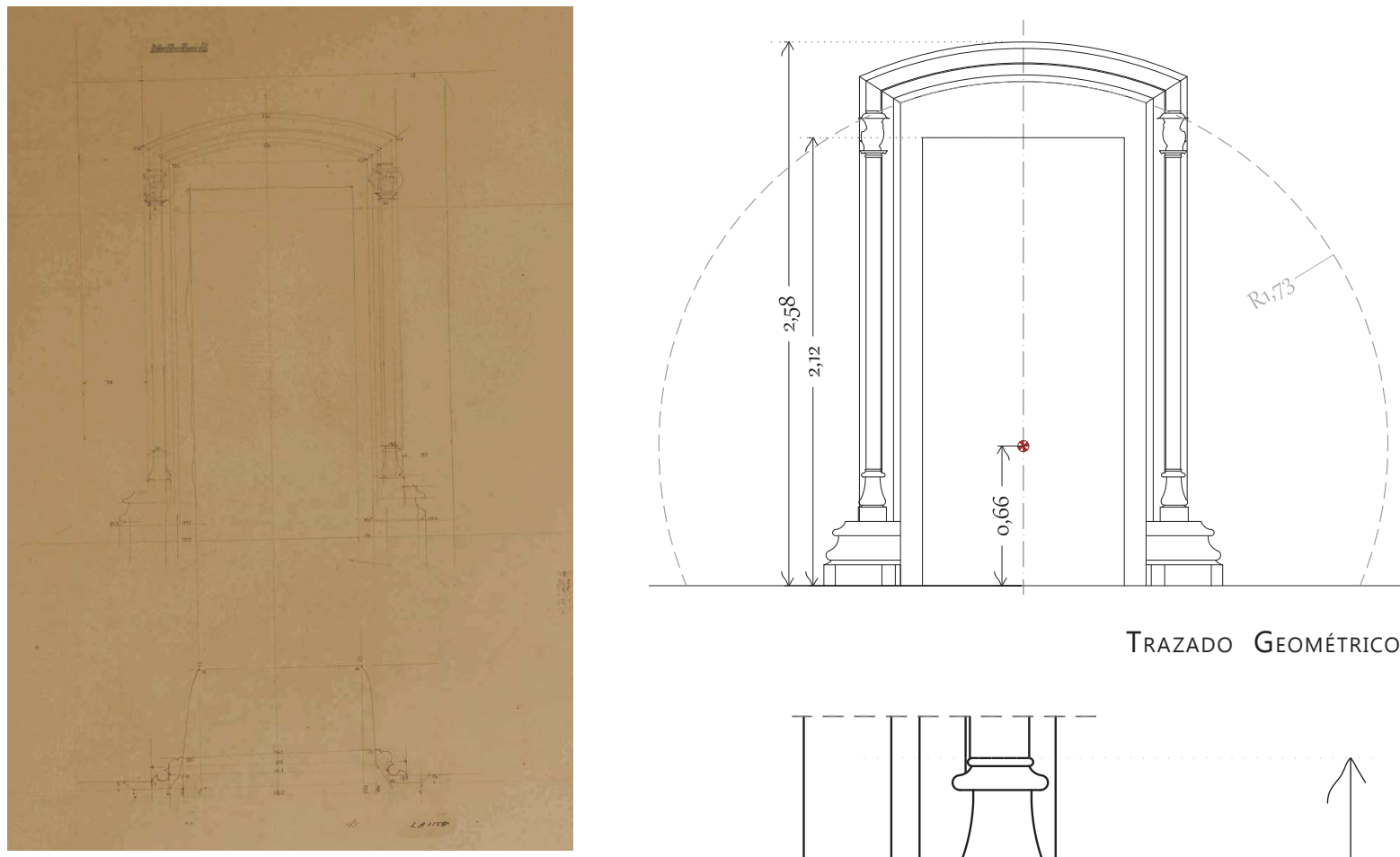

LA 1158

TrazAdo Geométrico
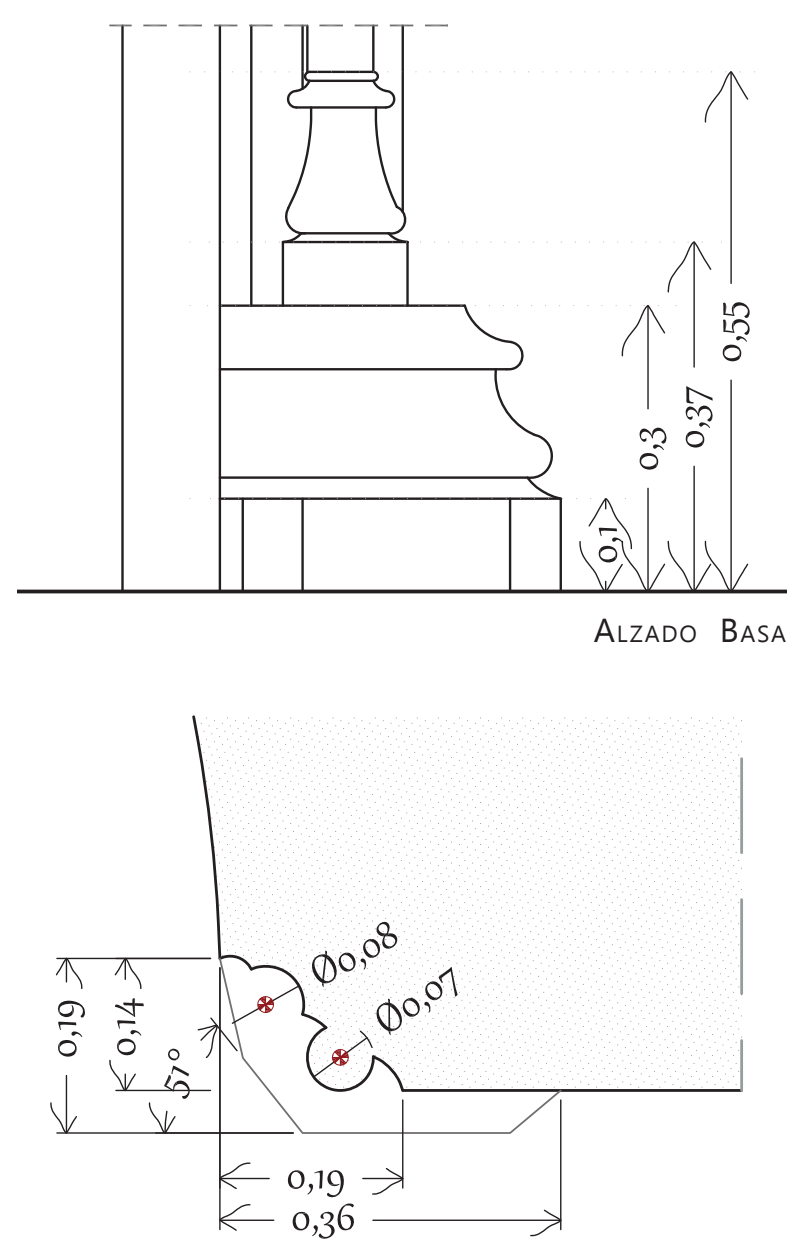

SeCCIÓN JAMBA

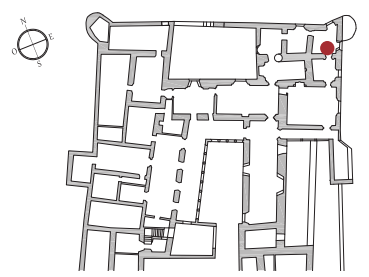

La arquitectura del expoliado Palacio Condal de Oliva a través del legado gráfico

Descripción del plano $N^{\circ}$ de Sala SALA 16

ESTUDIO DE LA PORTADA 19 - DÖR19 $N^{o}$ de Plano

PLANO 18

Escala $1 / 20$ Detalles GEOMETRÍA 1/40

Lámina original

BASA $1 / 10 \quad$ LA 1157 - LA1158



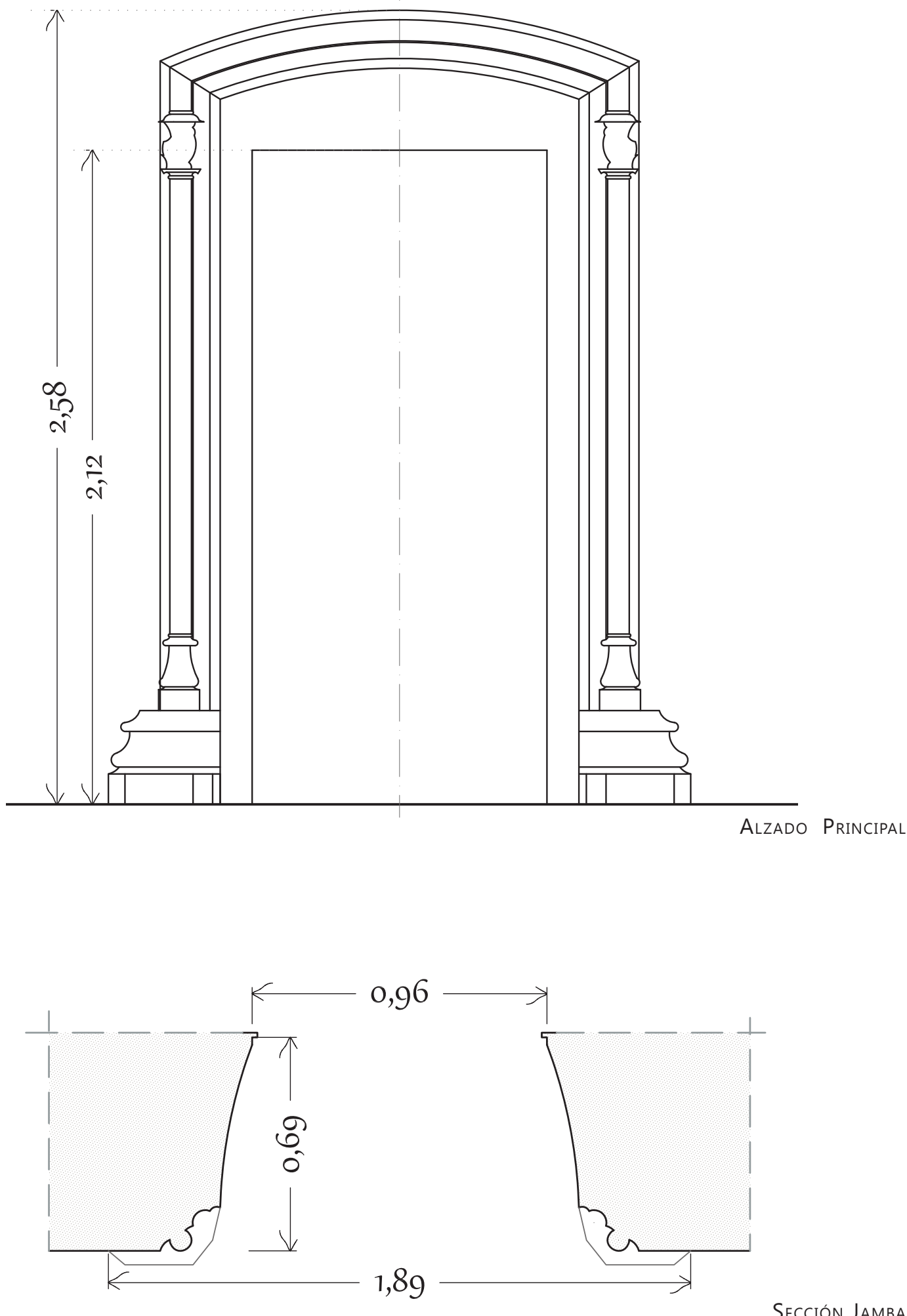

SECCIÓN JAMBA

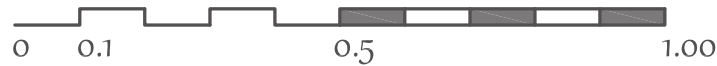



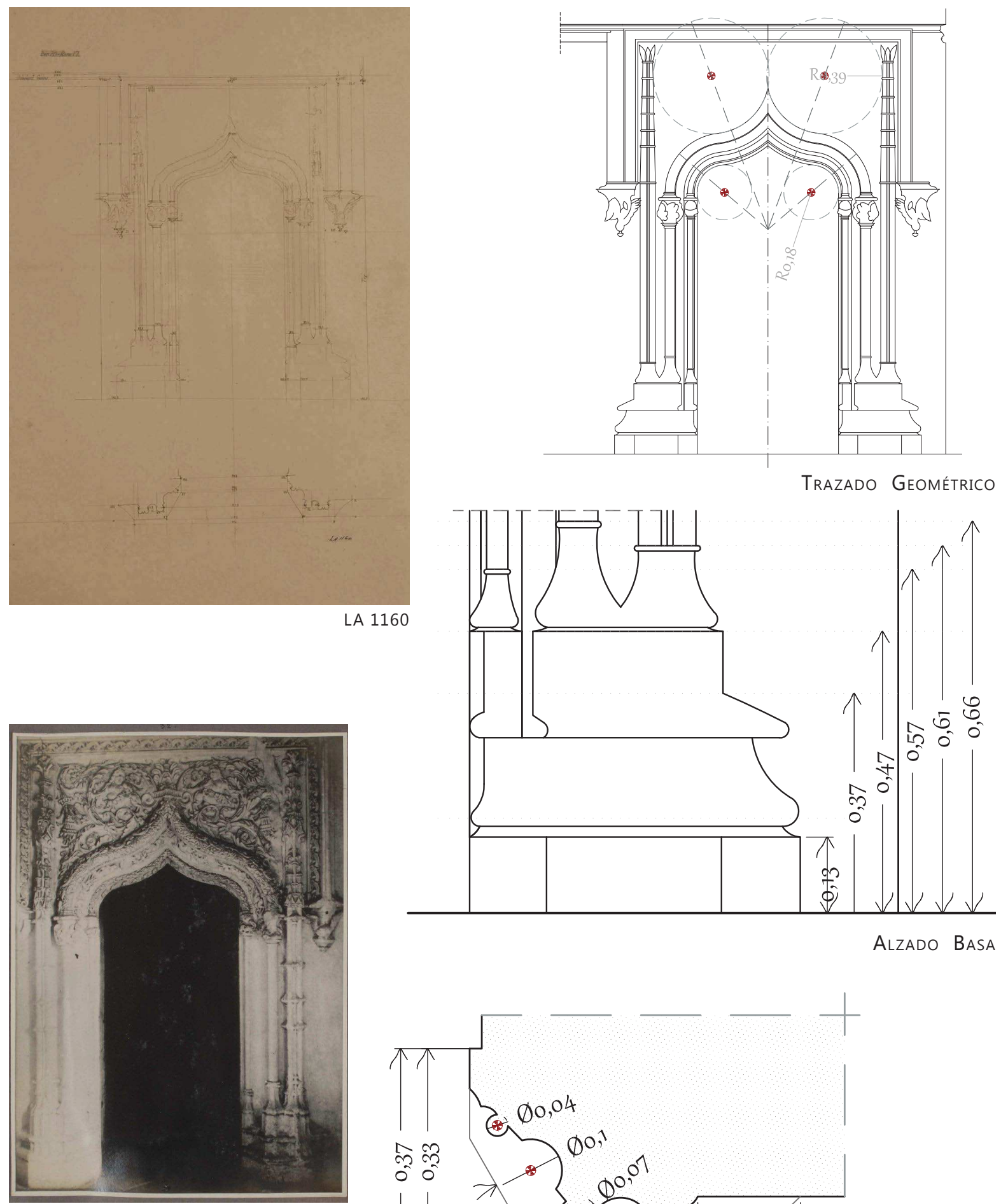

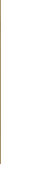

\section{0}
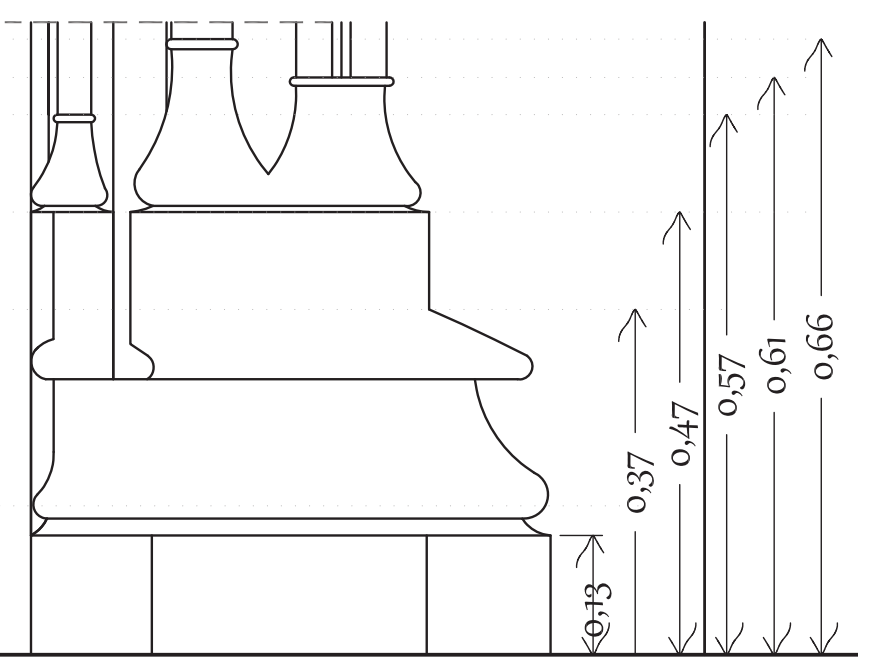

AlzAdo BASA

Fото $\mathrm{N}^{0} 32$ _ AFG
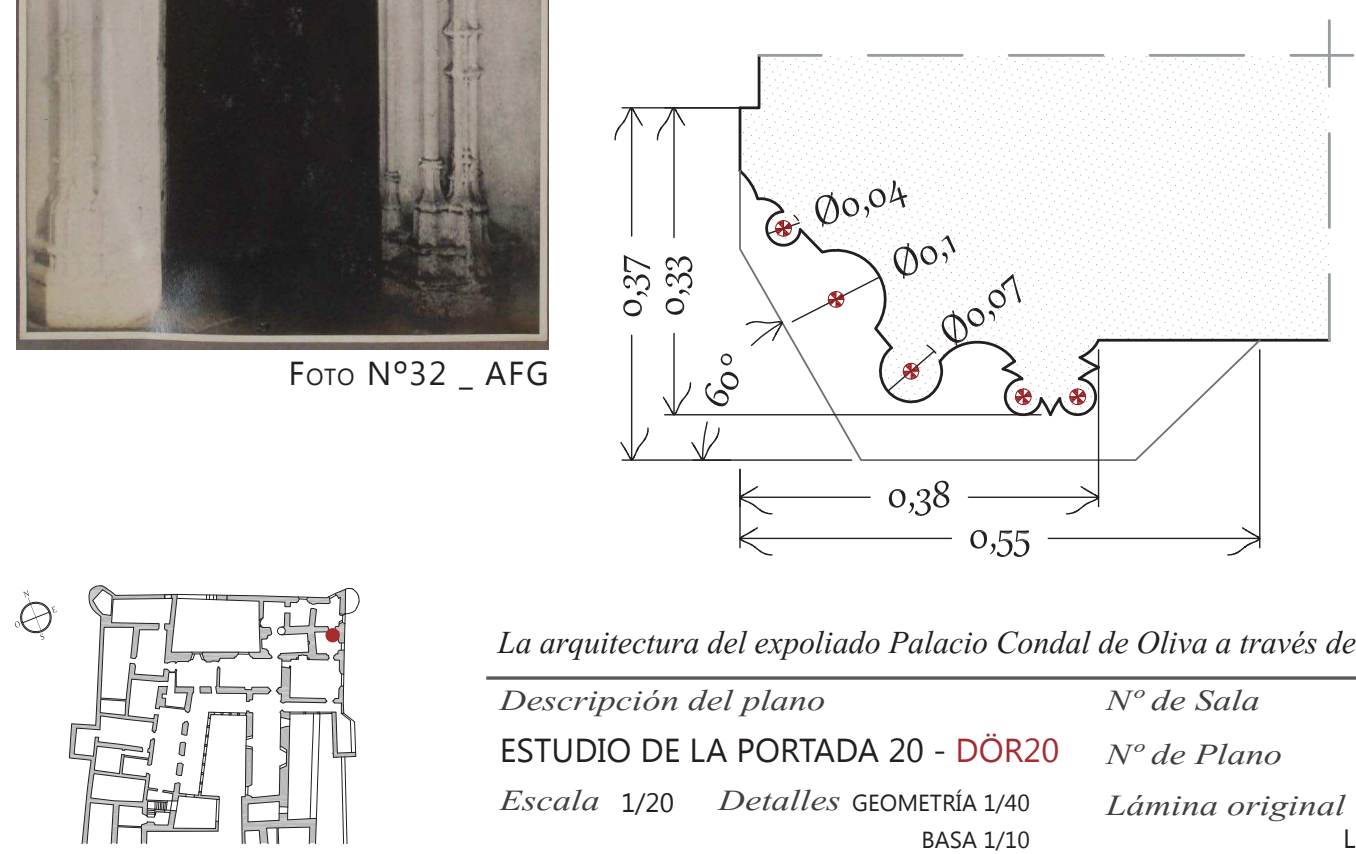

La arquitectura del expoliado Palacio Condal de Oliva a través del legado gráfico

\begin{tabular}{llr}
\hline Descripción del plano & $N^{o}$ de Sala & SALA 17 \\
ESTUDIO DE LA PORTADA 20 - DÖR20 & $N^{o}$ de Plano & PLANO 19 \\
Escala $1 / 20 \quad$ Detalles GEOMETRÍA 1/40 & Lámina original &
\end{tabular}
BASA $1 / 10$

LA 1159 - LA1160 


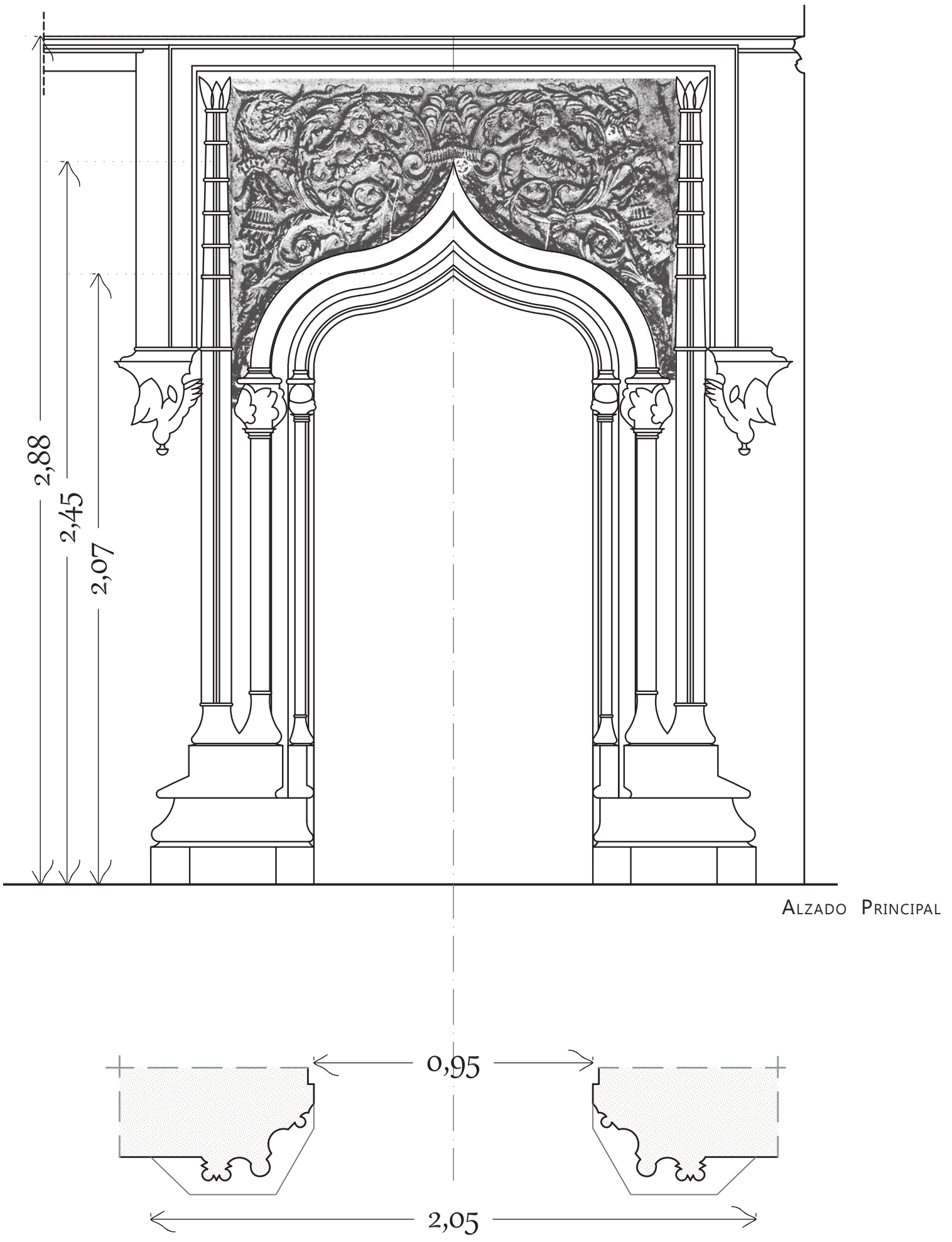

SeCCIÓN JAMBA

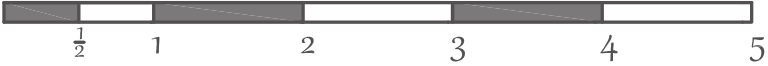

Escala gráfica en palmos valencianos.

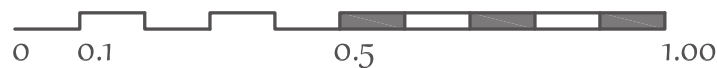

Escala gráfica metros. 

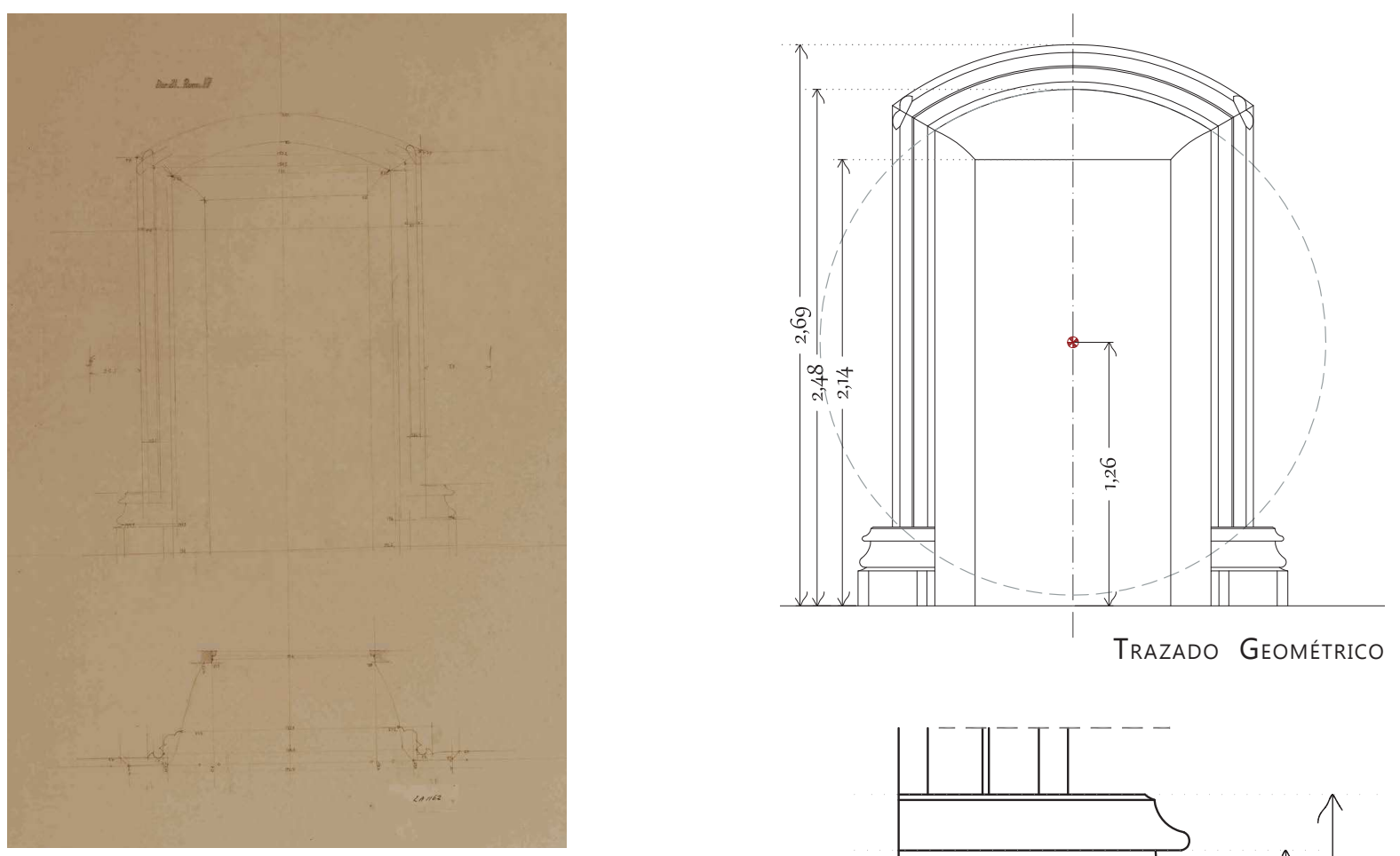

LA 1162
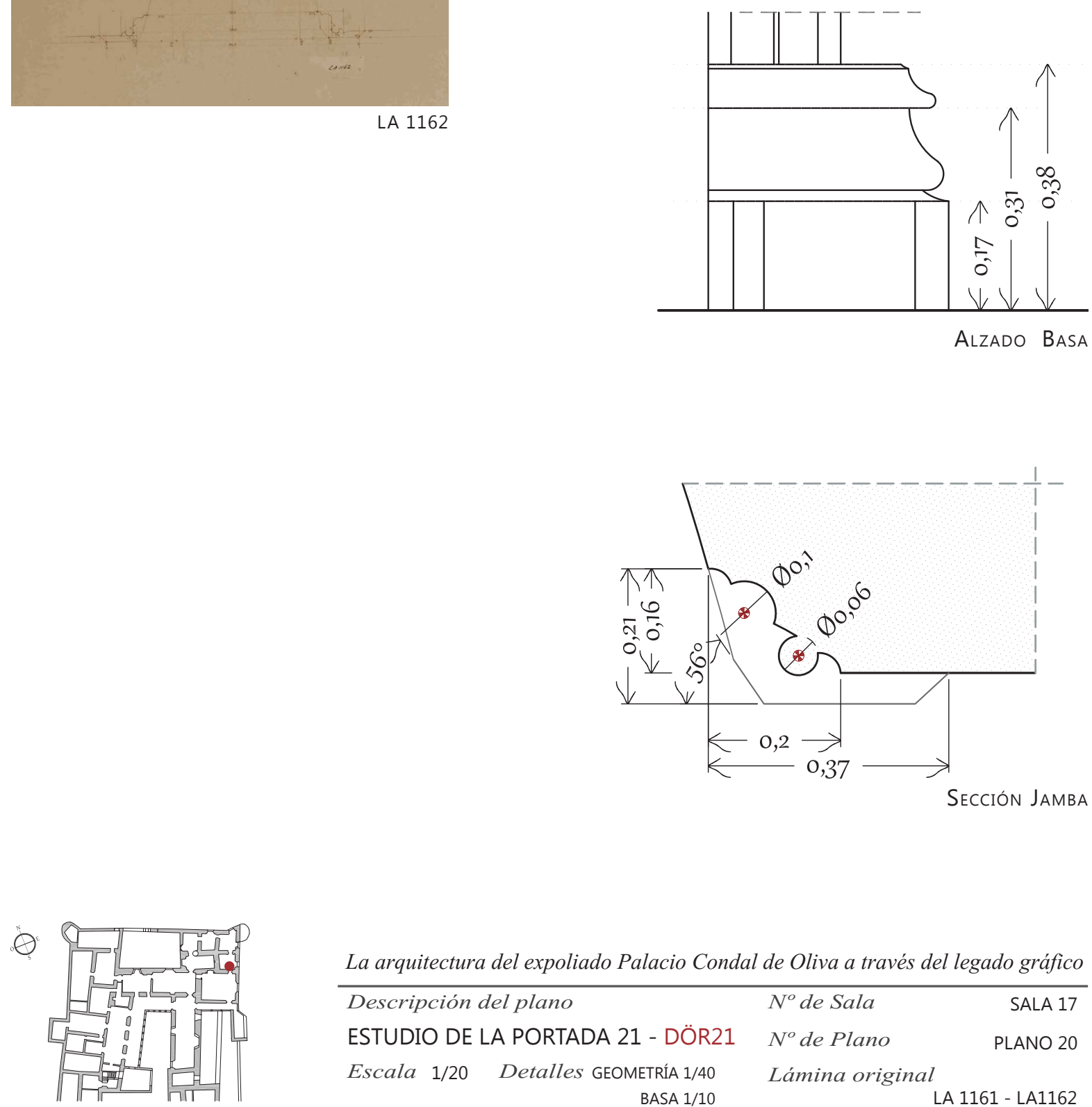

La arquitectura del expoliado Palacio Condal de Oliva a través del legado gráfico

Descripción del plano $N^{\circ}$ de Sala $\quad$ SALA 17

ESTUDIO DE LA PORTADA 21 - DÖR21

$N^{o}$ de Plano

PLANO 20

Escala $1 / 20$ Detalles GEOMETRÍA 1/40

Lámina original

BASA $1 / 10$

LA 1161 - LA1162 

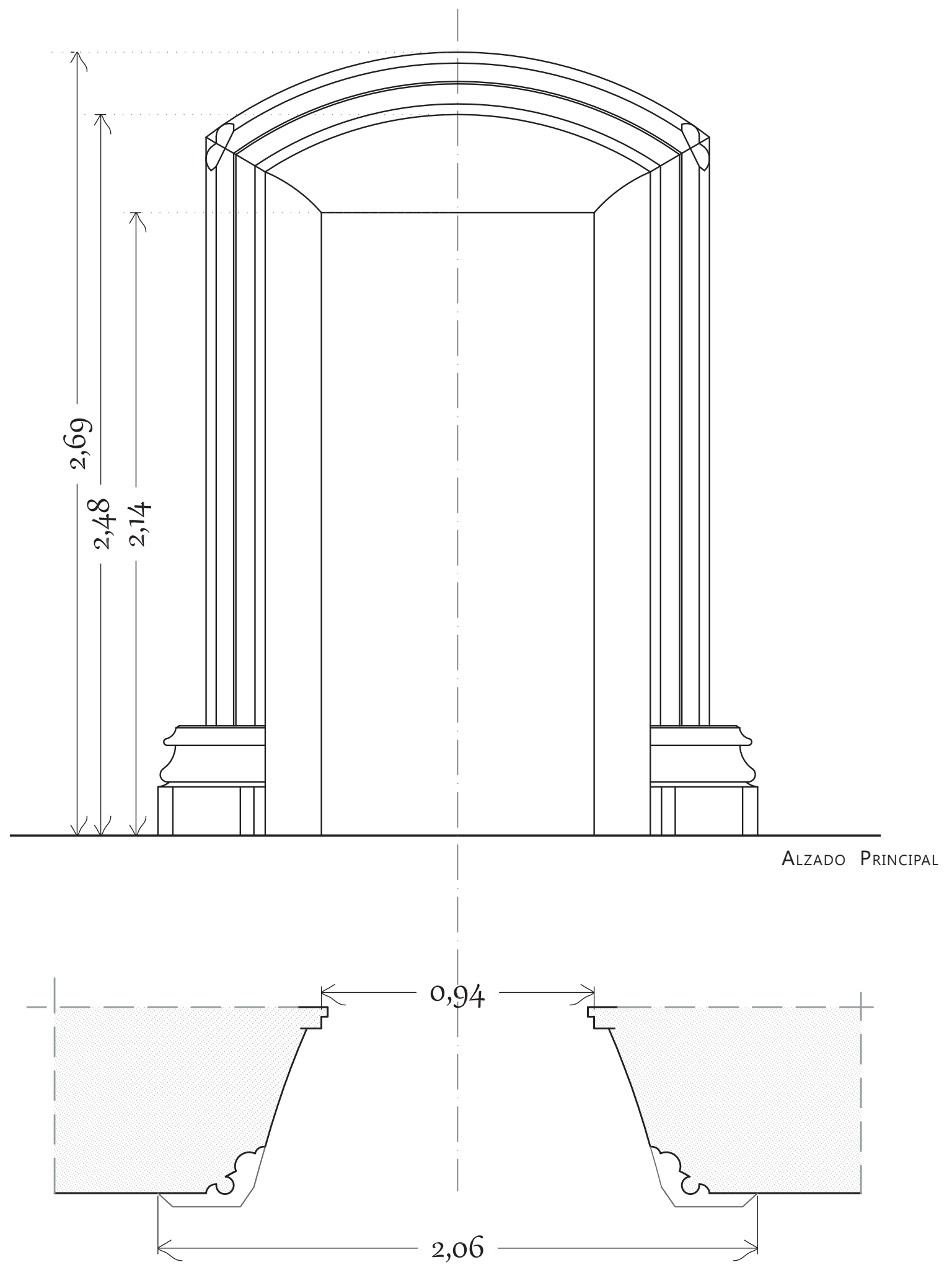

SeCCIÓn JAmba

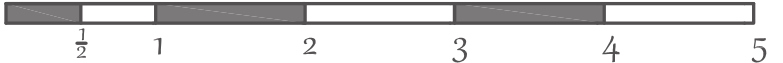

Escala gráfica en palmos valencianos.

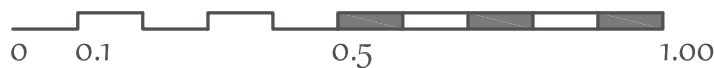




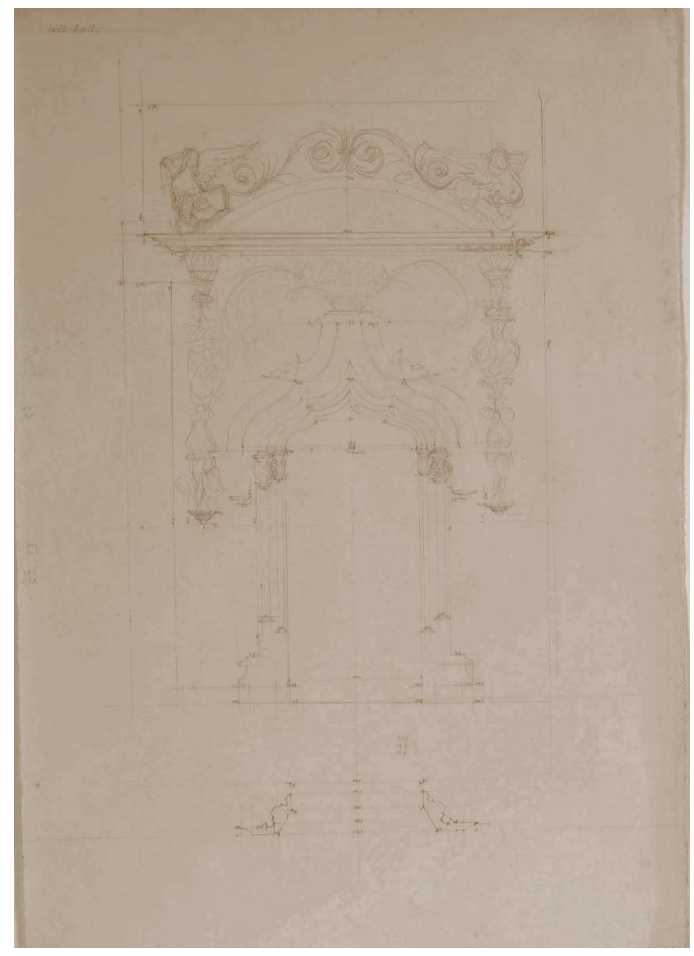

LA 1164

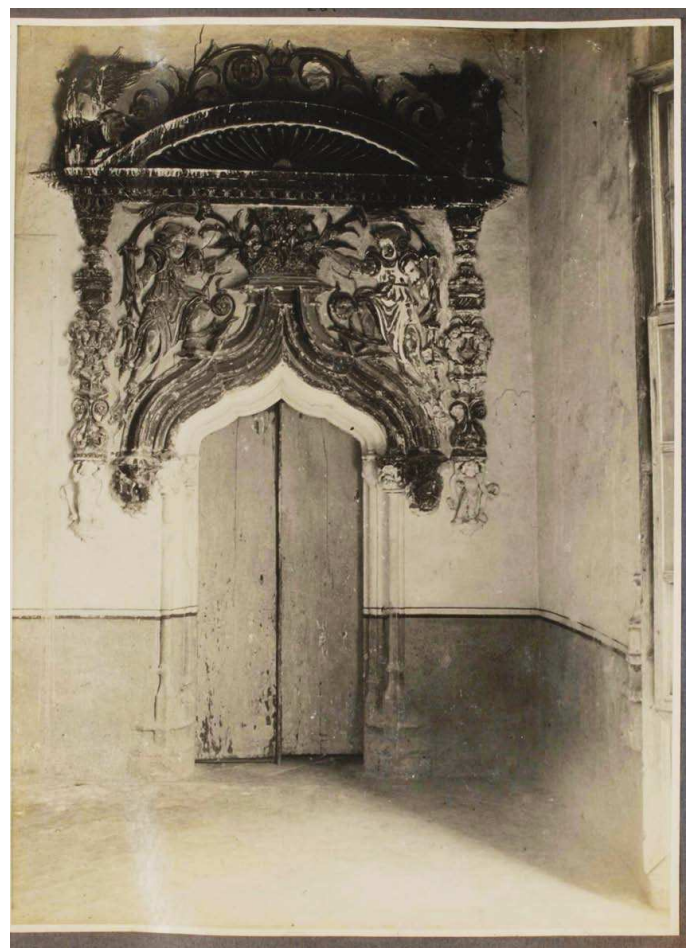

Fото $\mathrm{N}^{\circ} 28$ _ AFG

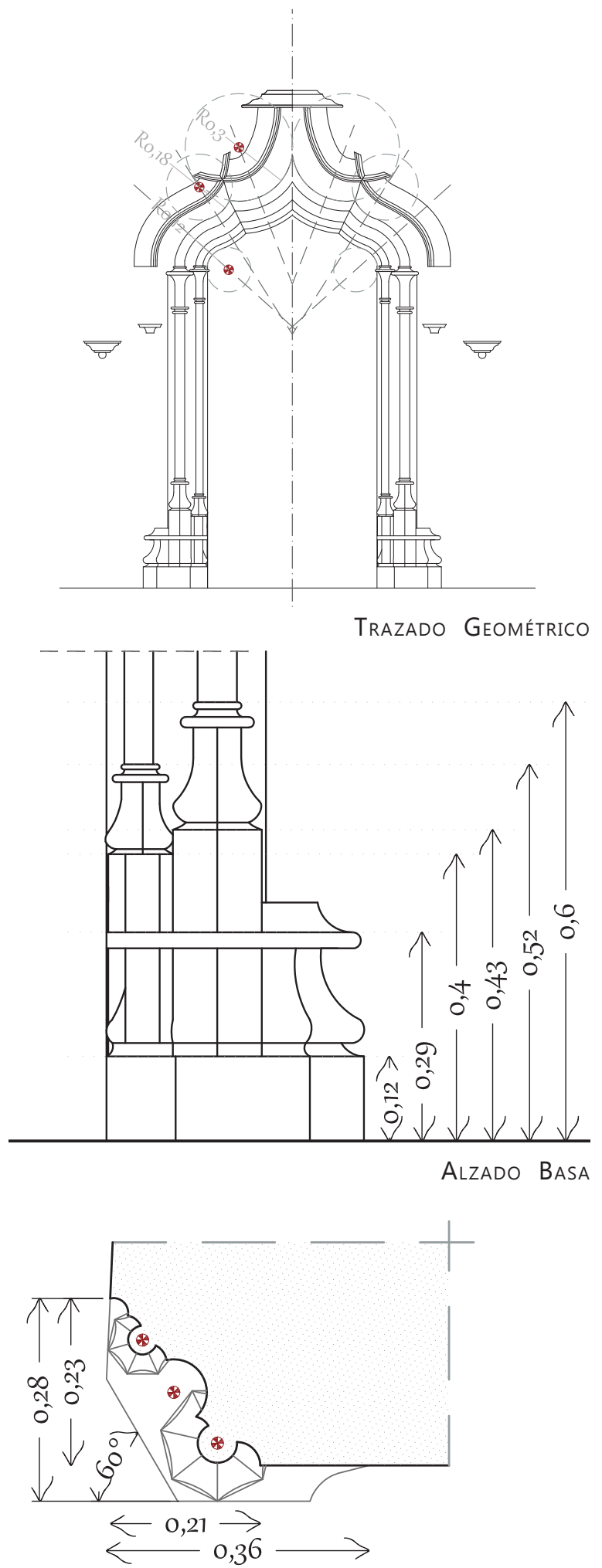

Planta Basa

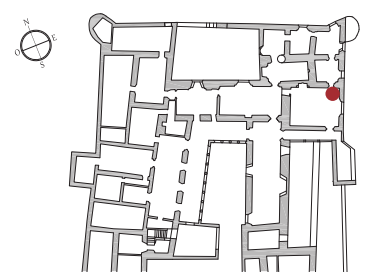

La arquitectura del expoliado Palacio Condal de Oliva a través del legado gráfico

Descripción del plano $N^{\circ}$ de Sala SALA 18

ESTUDIO DE LA PORTADA 22 - DÖR22

$N^{o}$ de Plano

PLANO 21

Escala $1 / 20$ Detalles GEOMETRÍA 1/40

Lámina original

BASA $1 / 10$

LA 1163 - LA1164 
"La arquitectura del expoliado Palacio Condal de Oliva a través del legado gráfico"

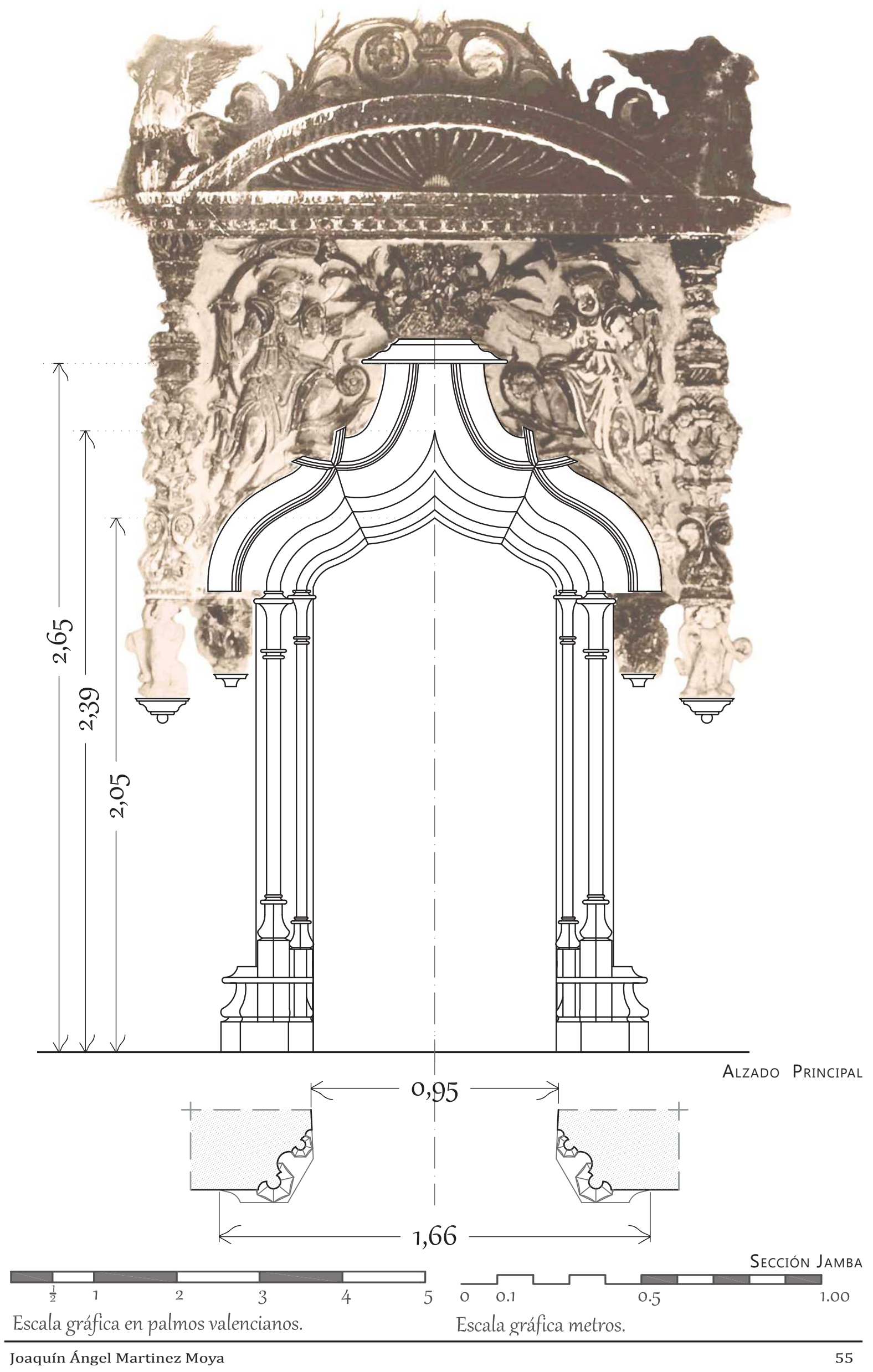




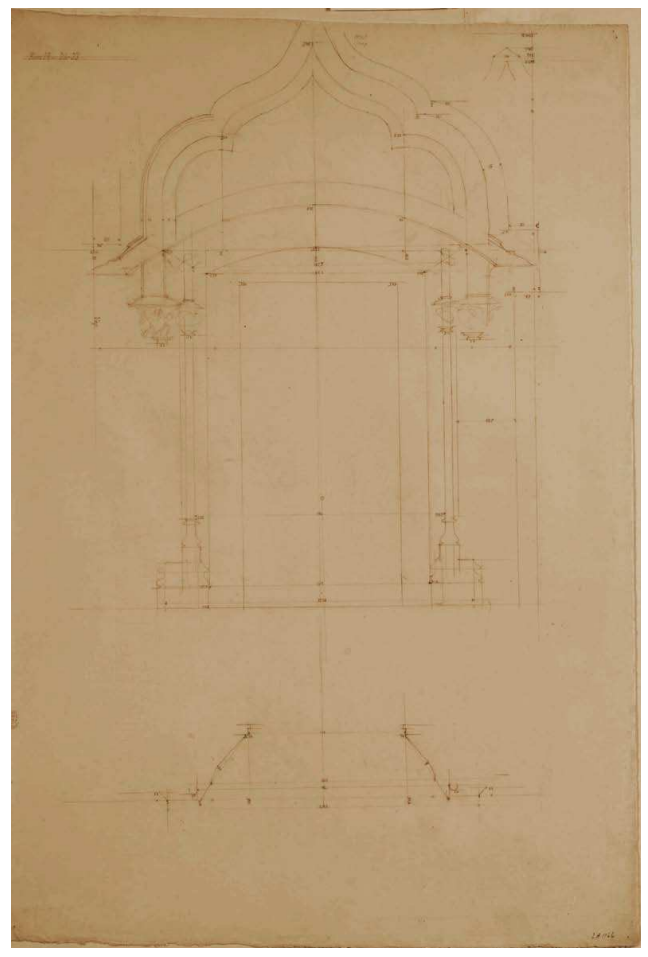

LA 1166

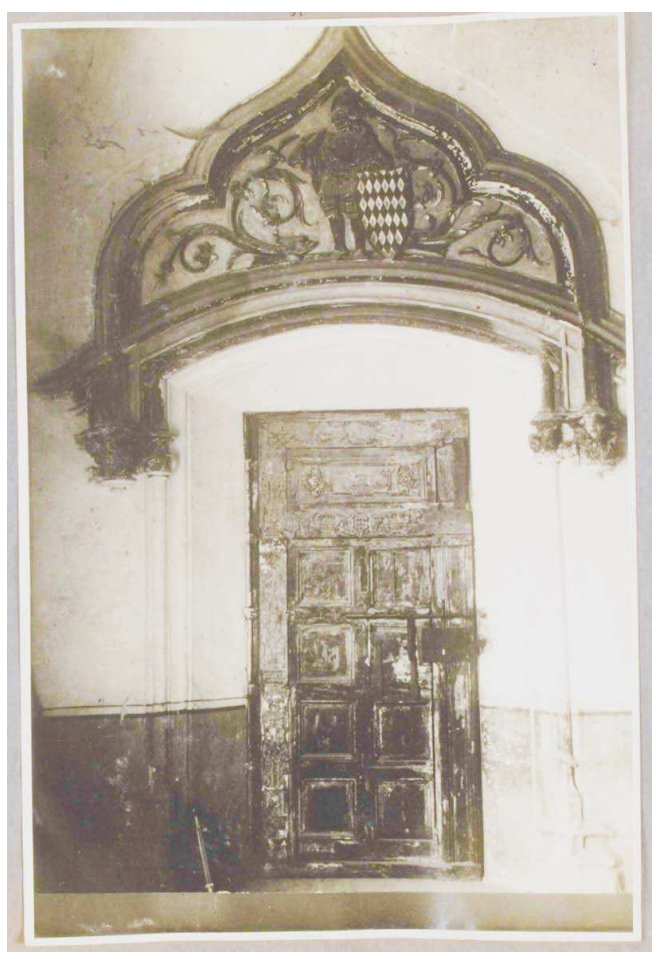

Fото N031_AFG
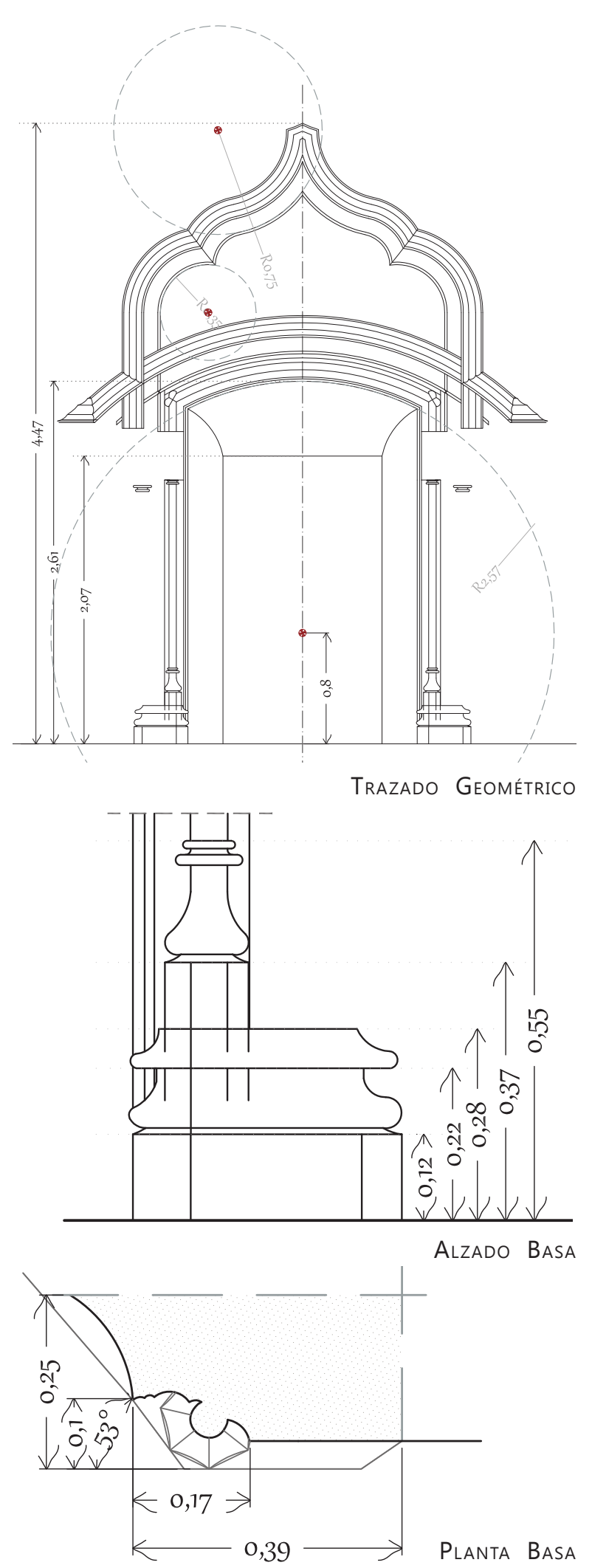

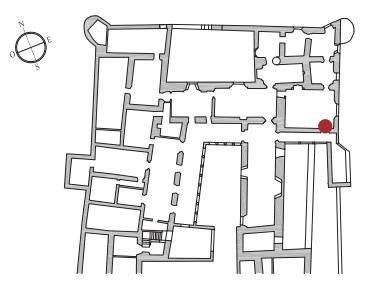

La arquitectura del expoliado Palacio Condal de Oliva a través del legado gráfico

\begin{tabular}{|c|c|c|c|}
\hline \multicolumn{2}{|c|}{ Descripción del plano } & $N^{o}$ de Sala & SALA 18 \\
\hline \multicolumn{2}{|c|}{ ESTUDIO DE LA PORTADA 23 - DÖR23 } & $N^{o}$ de Plano & PLANO 22 \\
\hline Escala $1 / 20$ & $\begin{array}{r}\text { Detalles GEOMETRÍA } 1 / 40 \\
\text { BASA } 1 / 10\end{array}$ & Lámina original & 65 - LA1166 \\
\hline
\end{tabular}



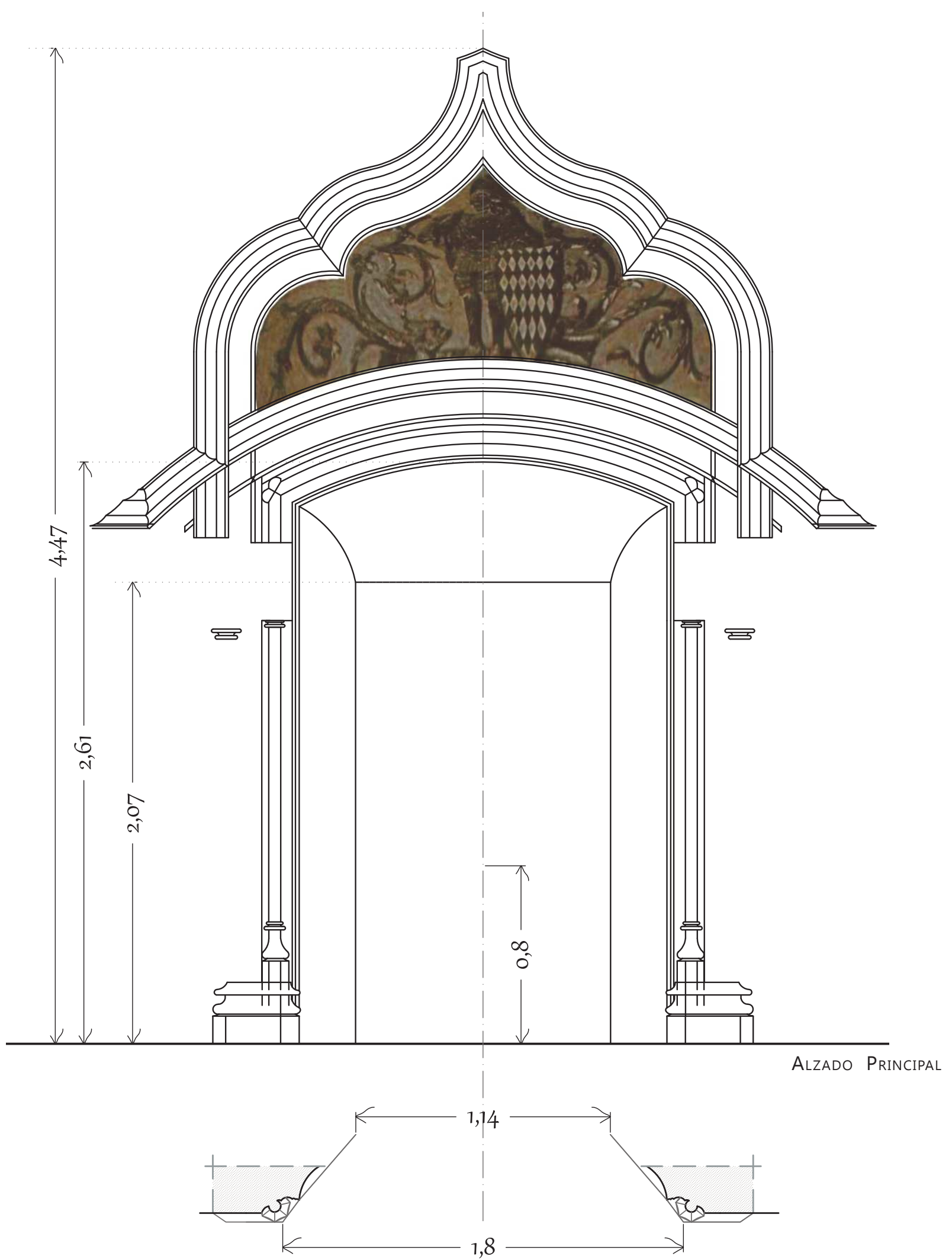

Sección Jamba

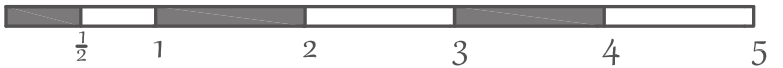

Escala gráfica en palmos valencianos.

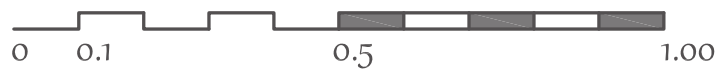

Escala gráfica metros. 

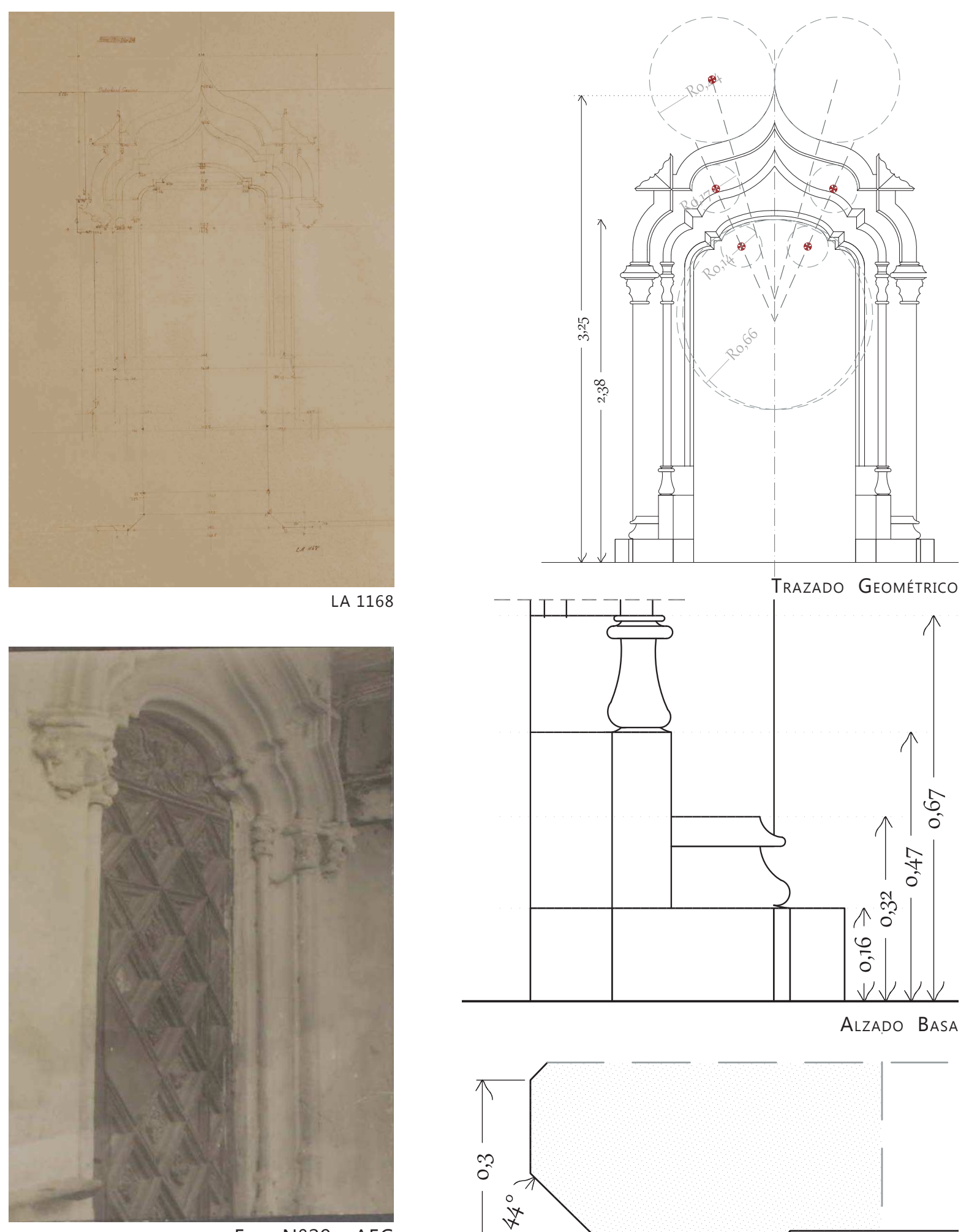

Fото $N^{\circ} 29$ _ AFG
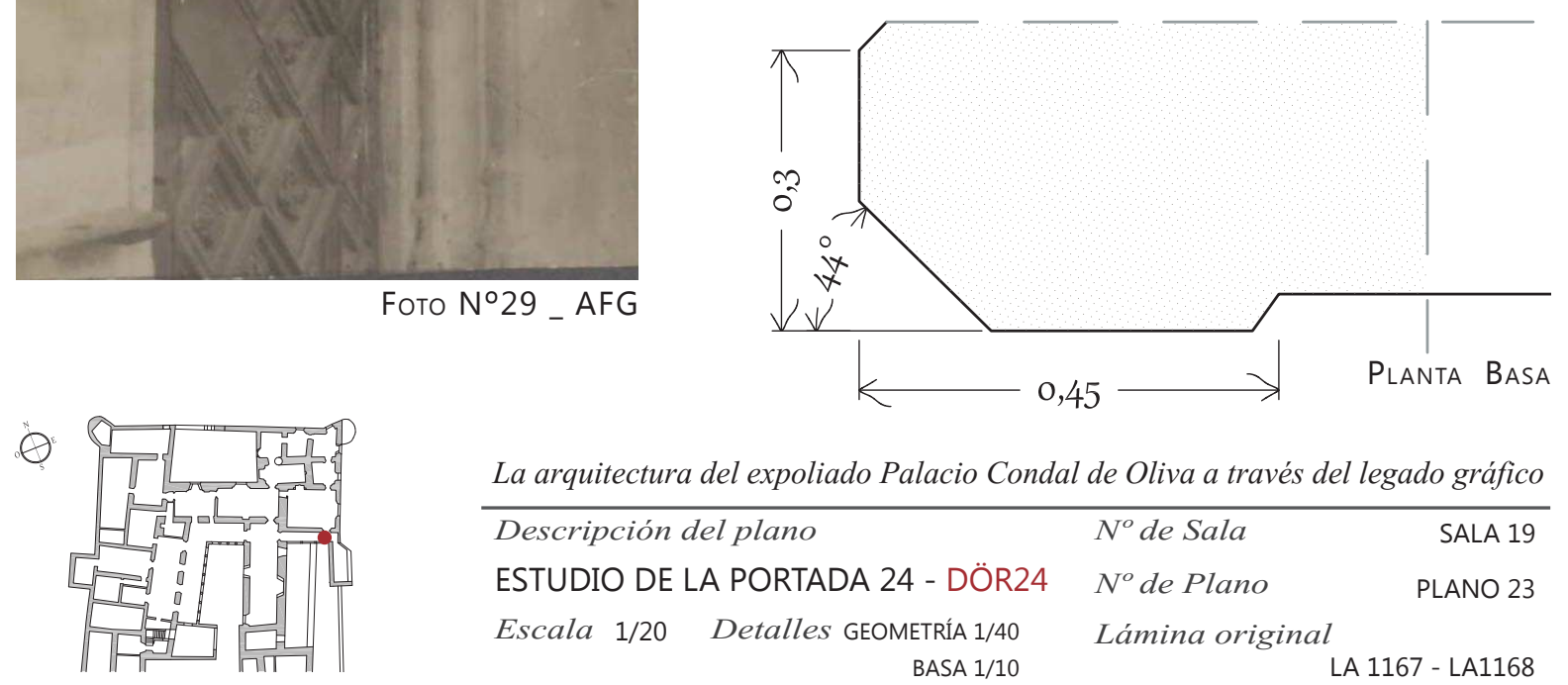

La arquitectura del expoliado Palacio Condal de Oliva a través del legado gráfico

\begin{tabular}{rrrr}
\hline Descripción del plano & $N^{o}$ de Sala & SALA 19 \\
ESTUDIO DE LA PORTADA 24 - DÖR24 & $N^{o}$ de Plano & PLANO 23 \\
Escala $1 / 20$ & Detalles GEOMETRÍA 1/40 & Lámina original \\
BASA 1/10 & \\
LA 1167 - LA1168
\end{tabular}



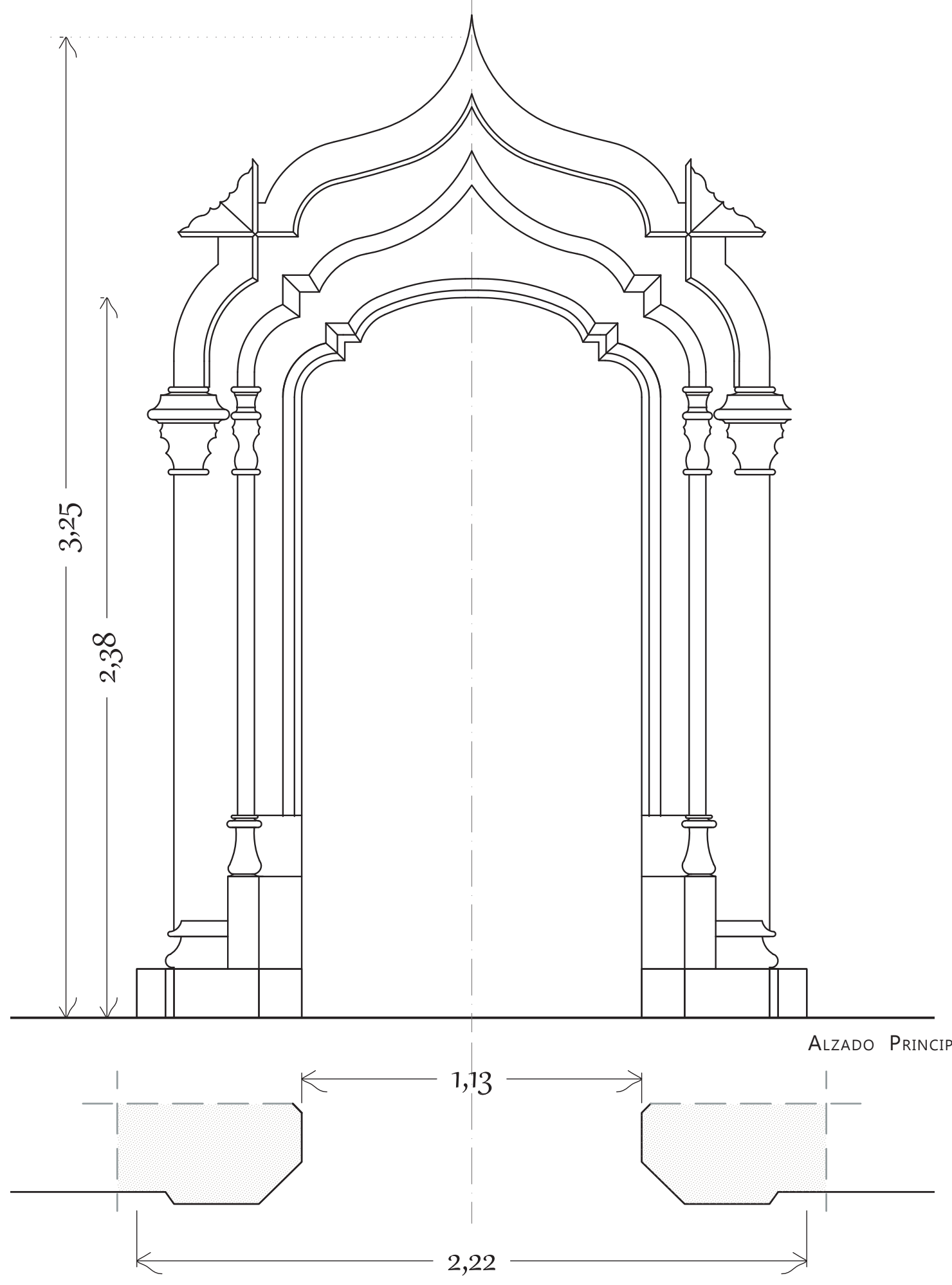

SecCión BASA

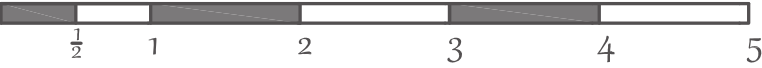

Escala gráfica en palmos valencianos.

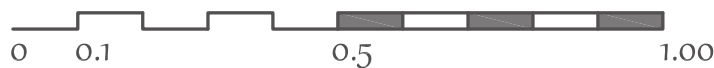

Escala gráfica metros. 

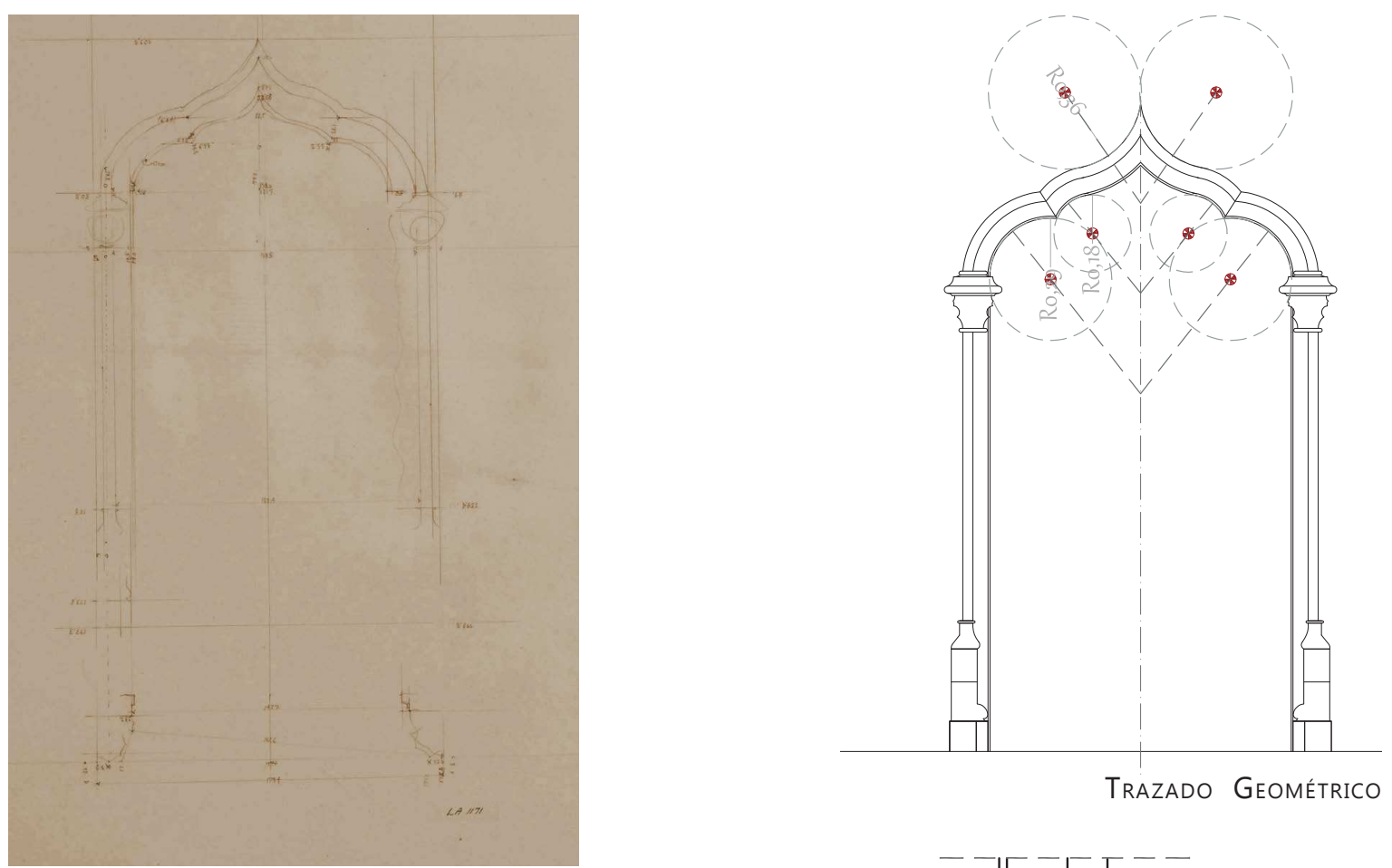

LA 1171
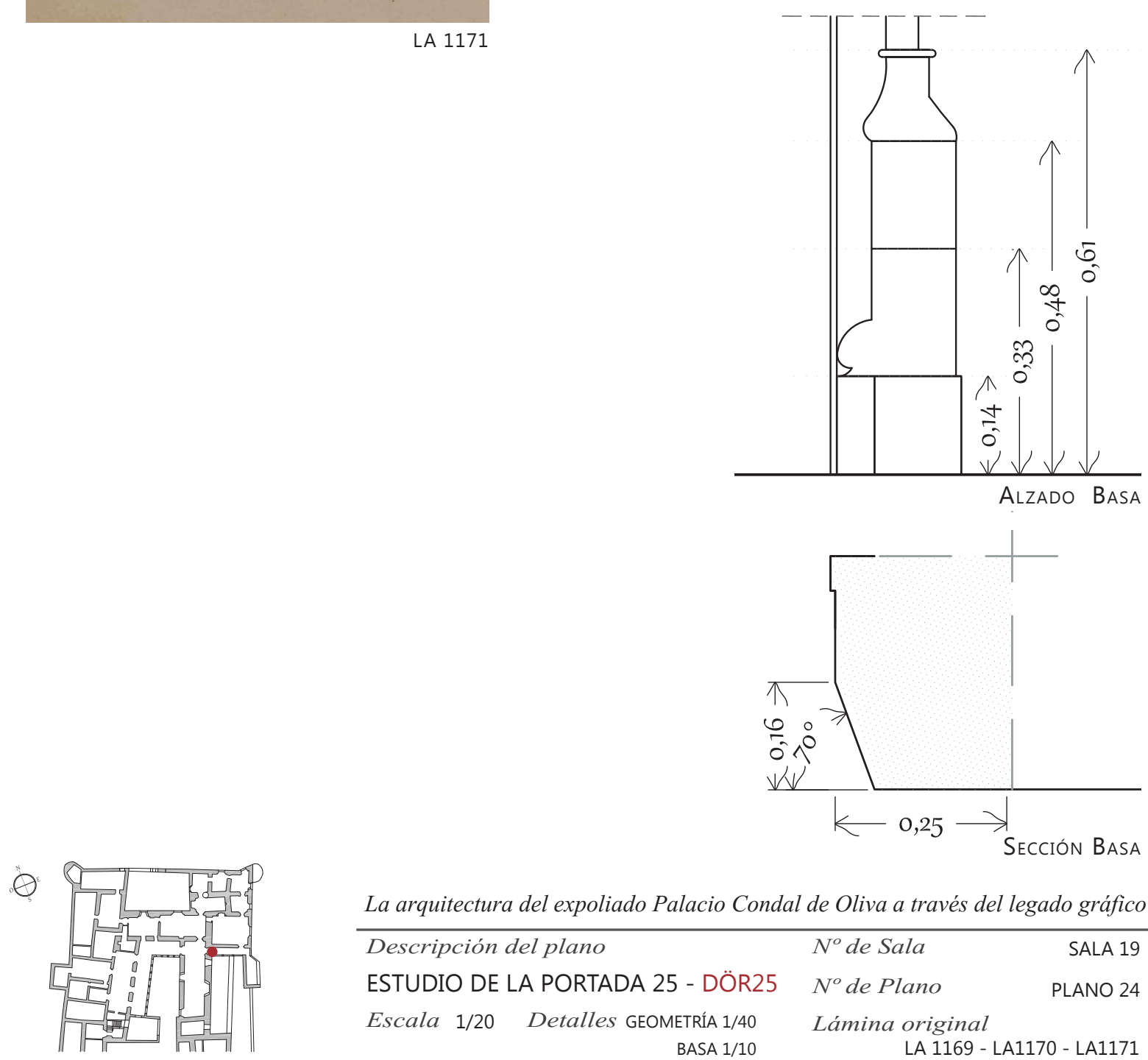

La arquitectura del expoliado Palacio Condal de Oliva a través del legado gráfico

Descripción del plano

ESTUDIO DE LA PORTADA 25 - DÖR25

Escala $1 / 20$

Detalles GEOMETRÍA 1/40

BASA $1 / 10$

\begin{tabular}{lr}
$N^{o}$ de Sala & SALA 19 \\
$N^{o}$ de Plano & PLANO 24 \\
Lámina original & \\
\multicolumn{2}{l}{ LA 1169 - LA1170 - LA1171 }
\end{tabular}

Joaquín Ángel Martinez Moya 


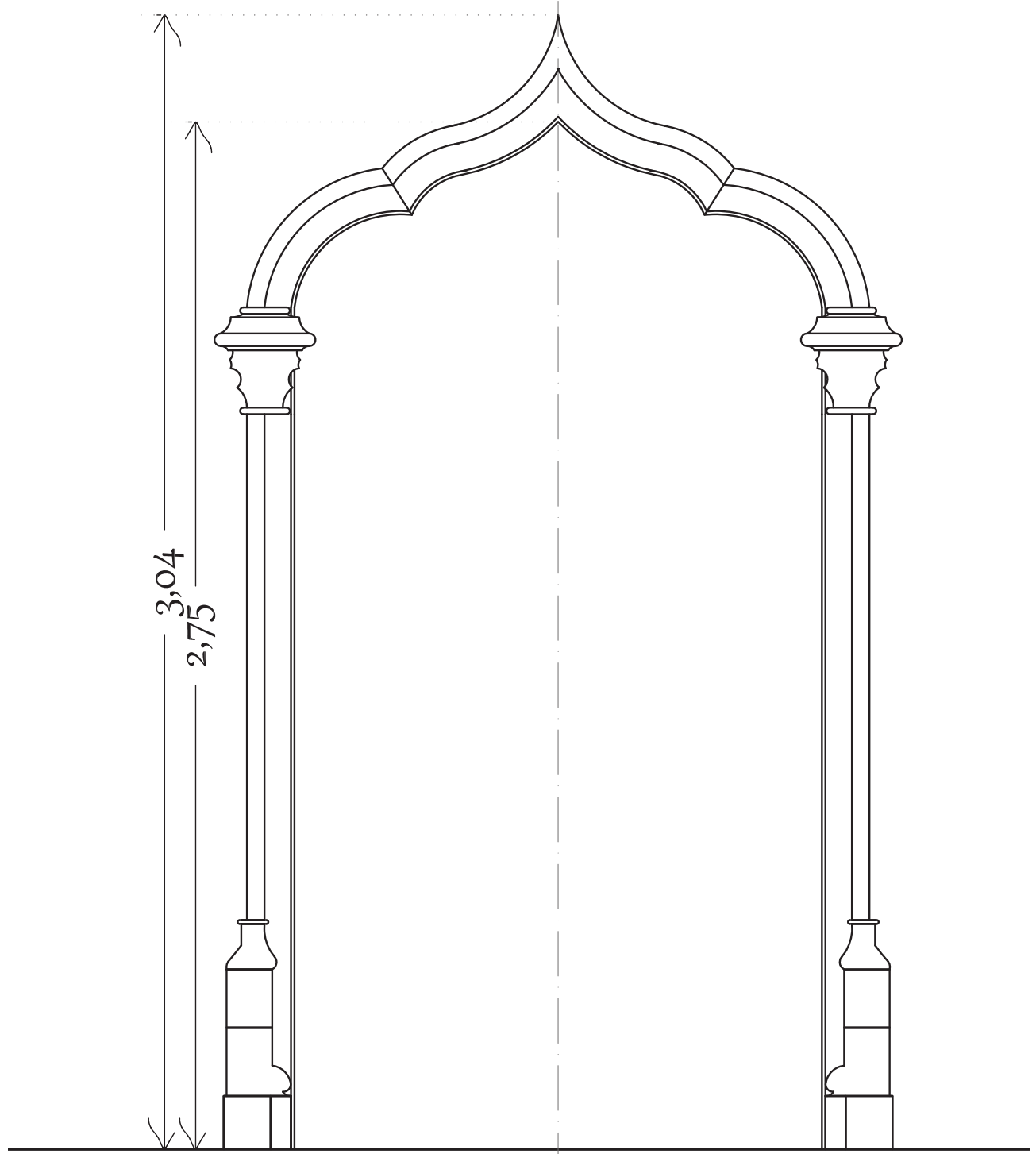

Alzado Principal

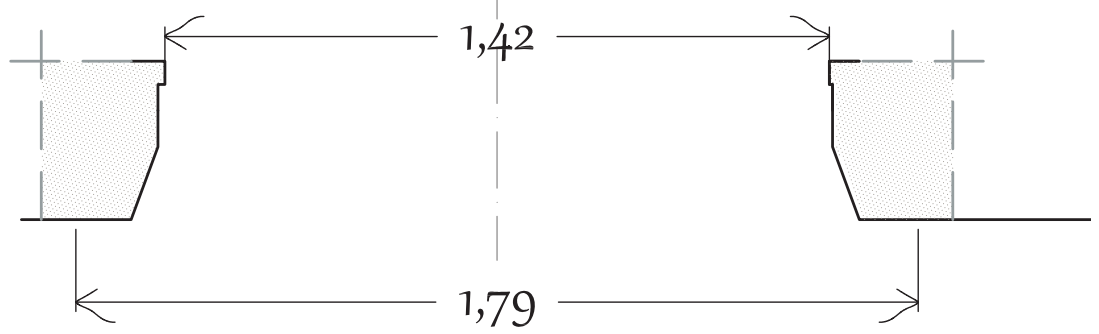

SeCción BASA

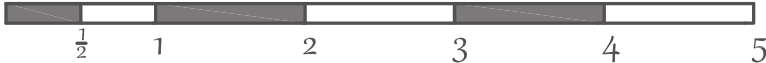

Escala gráfica en palmos valencianos.

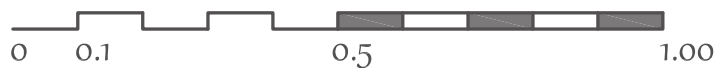

Escala gráfica metros. 

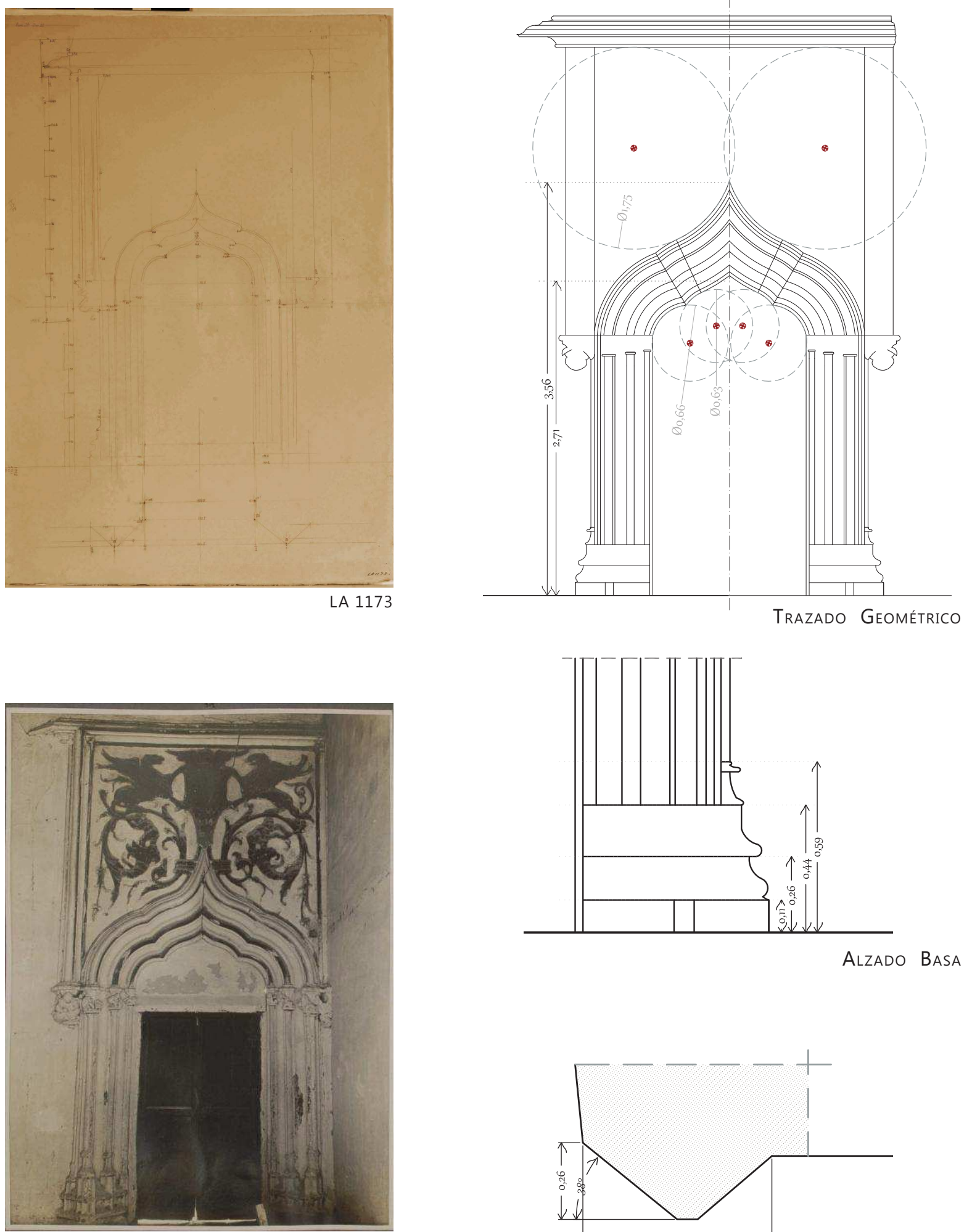

Fото $\mathrm{N}^{0} 39_{\text {_ AFP }}$

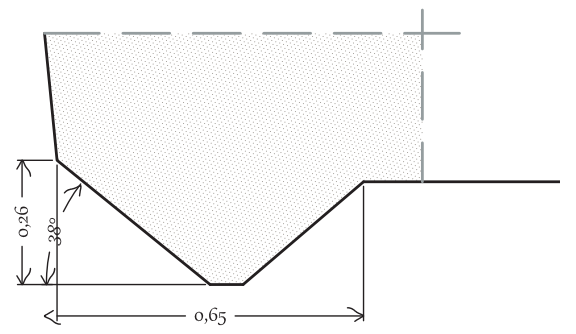

SECCIÓN BASA

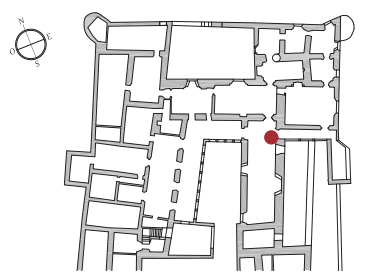

La arquitectura del expoliado Palacio Condal de Oliva a través del legado gráfico

Descripción del plano $N^{\circ}$ de Sala $\quad$ SALA 20
ESTUDIO DE LA PORTADA 26 - DÖR26

Escala $1 / 20$ Detalles GEOMETRÍA 1/40 $N^{o}$ de Plano PLANO 25 BASA $1 / 10$ 


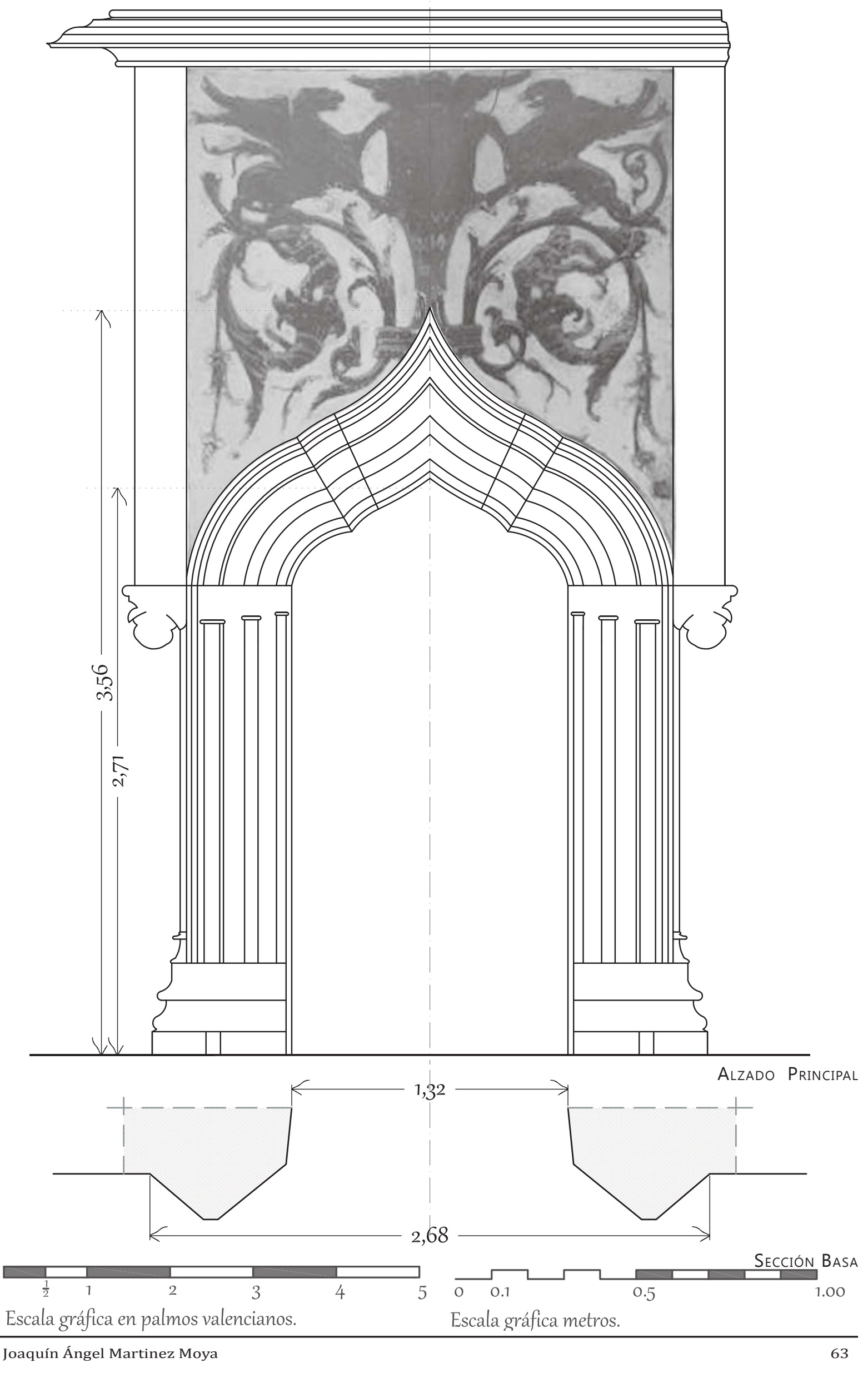



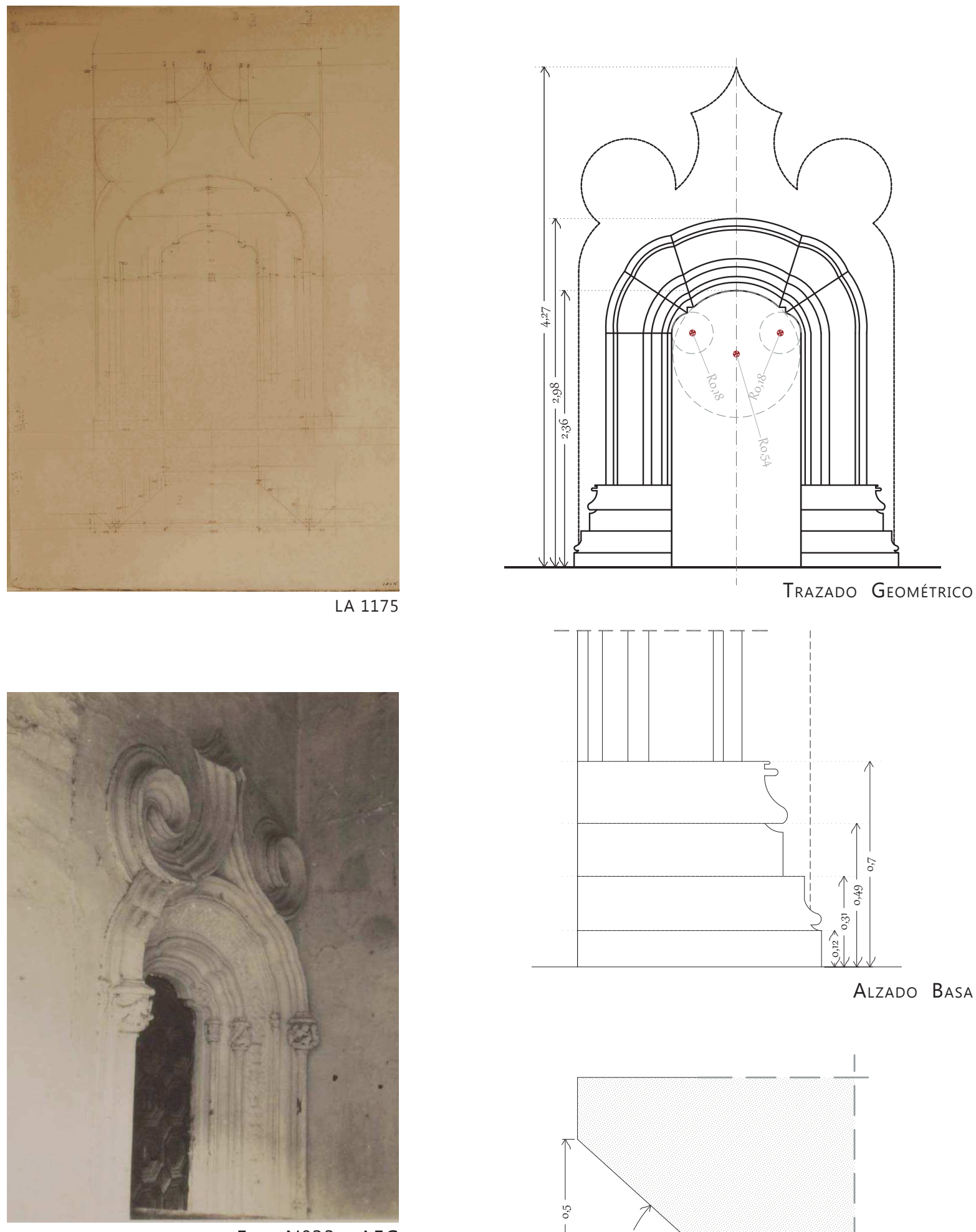

AlzAdo BASA

Fото $\mathrm{N}^{0} 33_{\text {_ }} \mathrm{AFG}$
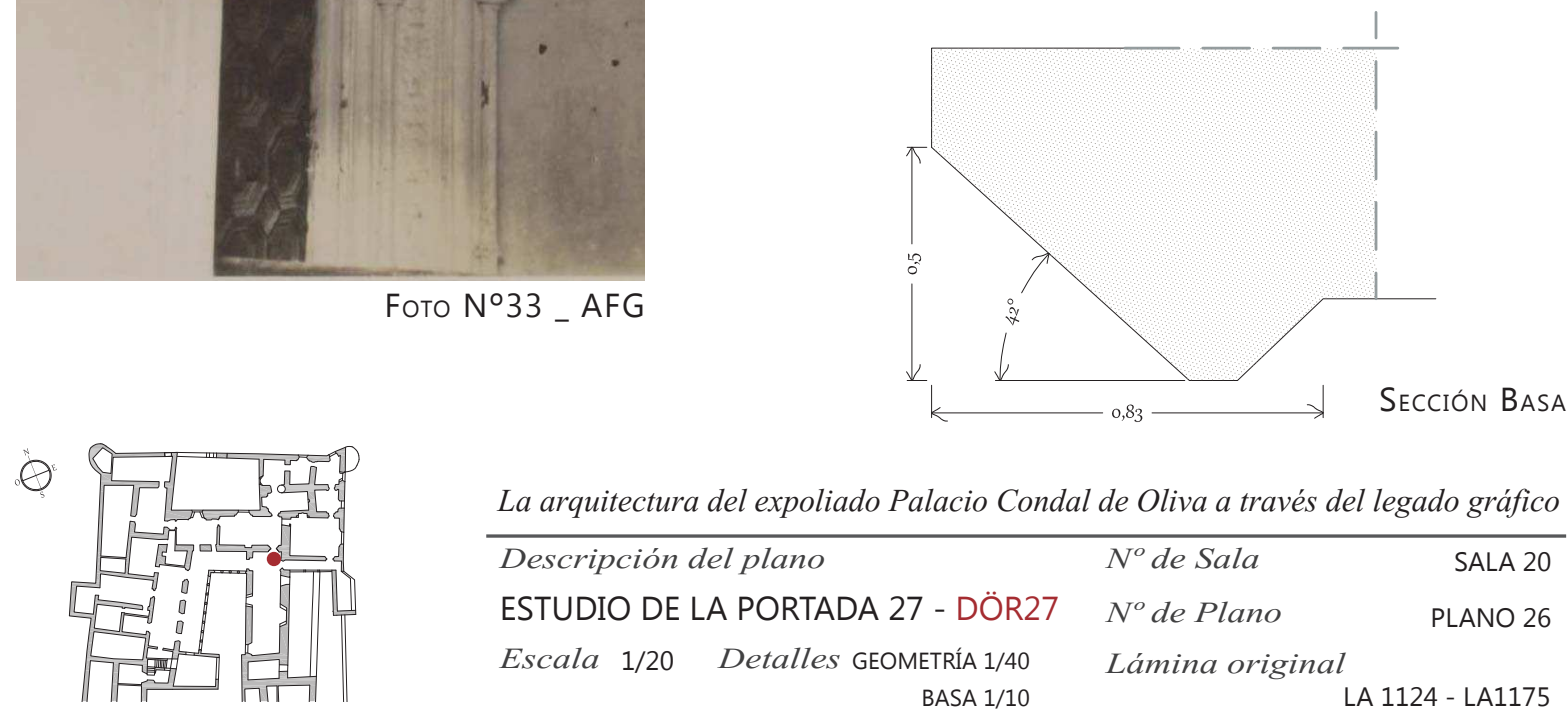

La arquitectura del expoliado Palacio Condal de Oliva a través del legado gráfico

\begin{tabular}{rrrr}
\hline Descripción del plano & $N^{o}$ de Sala & SALA 20 \\
ESTUDIO DE LA PORTADA 27 - DÖR27 & $N^{o}$ de Plano & PLANO 26 \\
Escala $1 / 20$ & Detalles GEOMETRÍA 1/40 & Lámina original \\
BASA 1/10 & LA 1124 - LA1175 \\
\hline
\end{tabular}



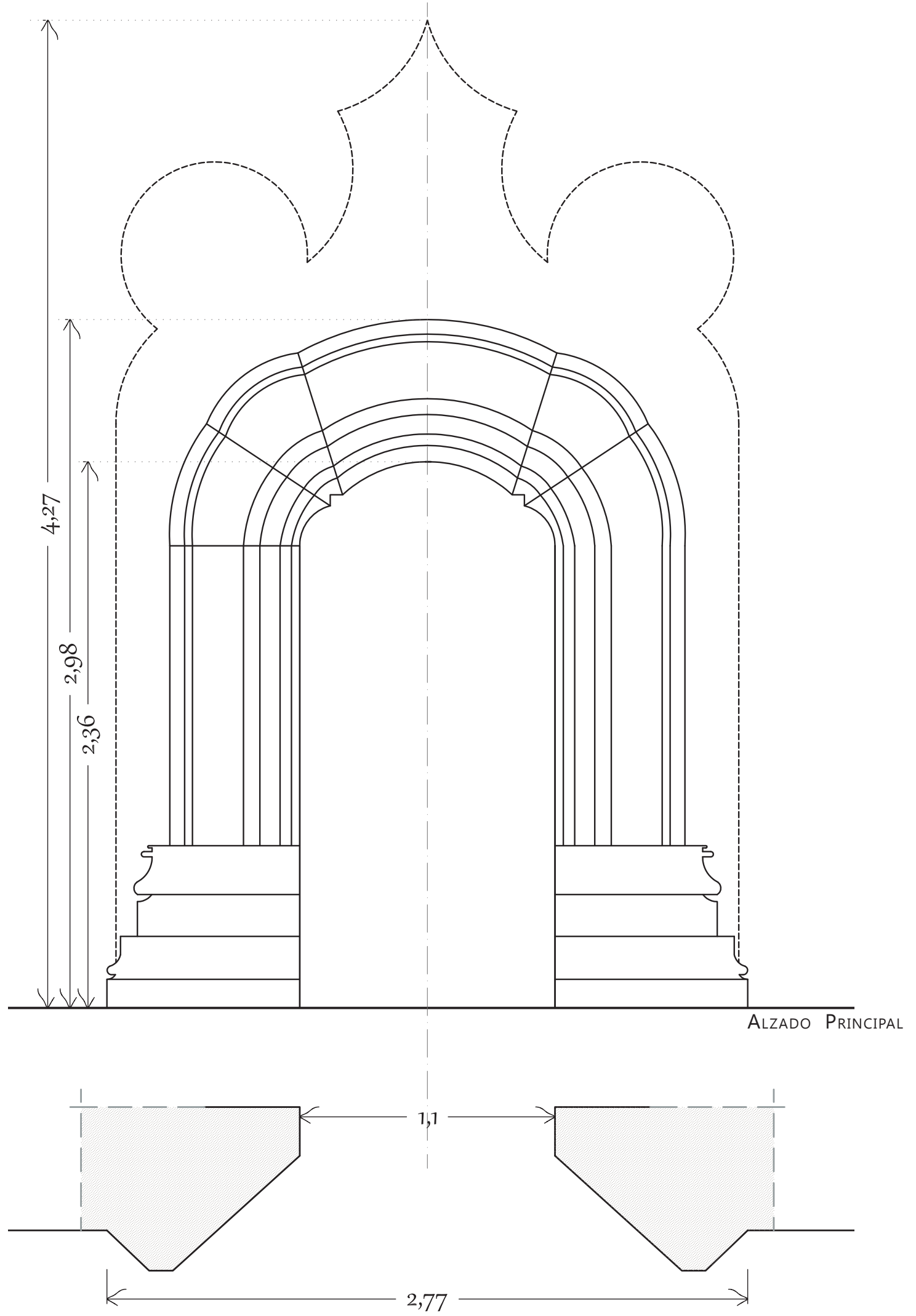

SecCIÓn BASA

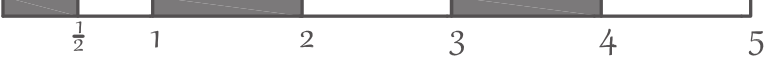

Escala gráfica en palmos valencianos.

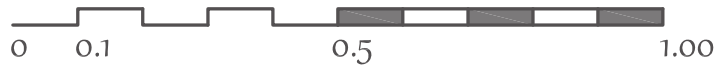

Escala gráfica metros. 


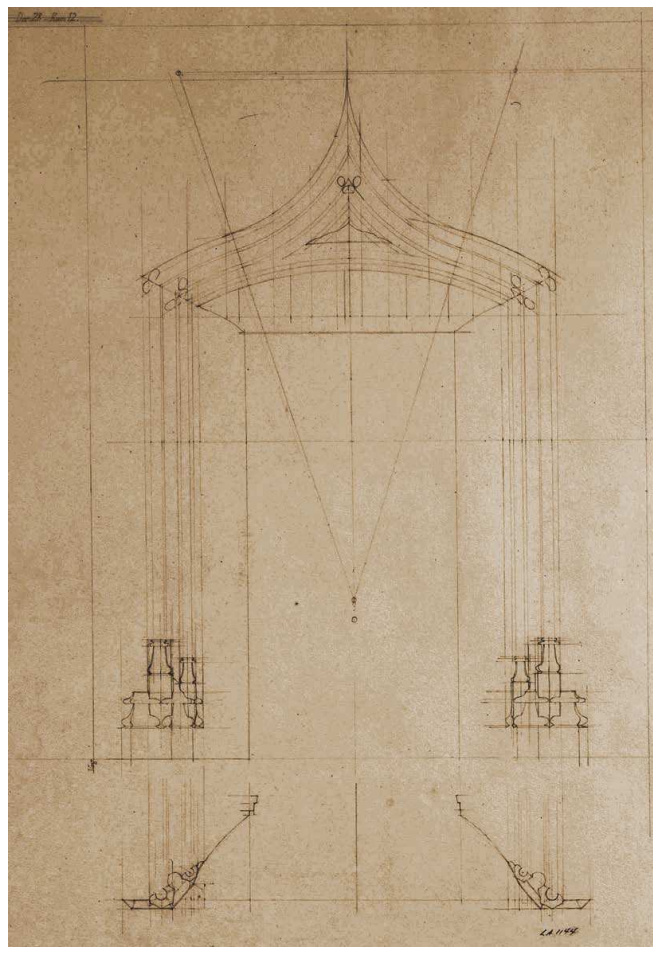

LA 1144

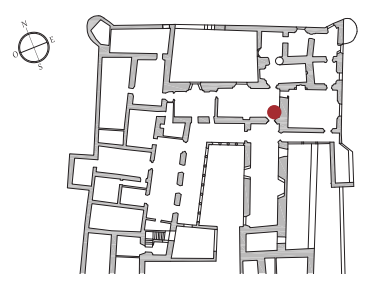

La arquitectura del expoliado Palacio Condal de Oliva a través del legado gráfico

Descripción del plano

ESTUDIO DE LA PORTADA 28 - DÖR28

Escala $1 / 20$
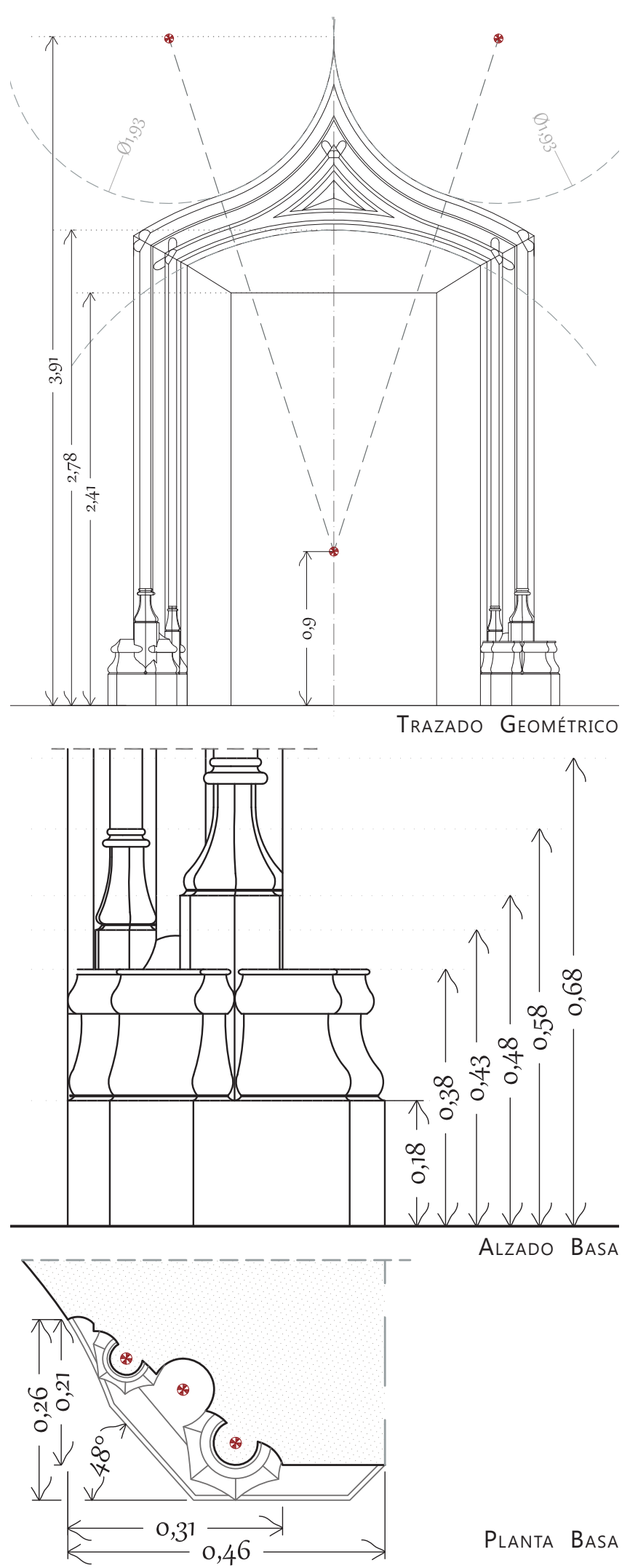
"La arquitectura del expoliado Palacio Condal de Oliva a través del legado gráfico"

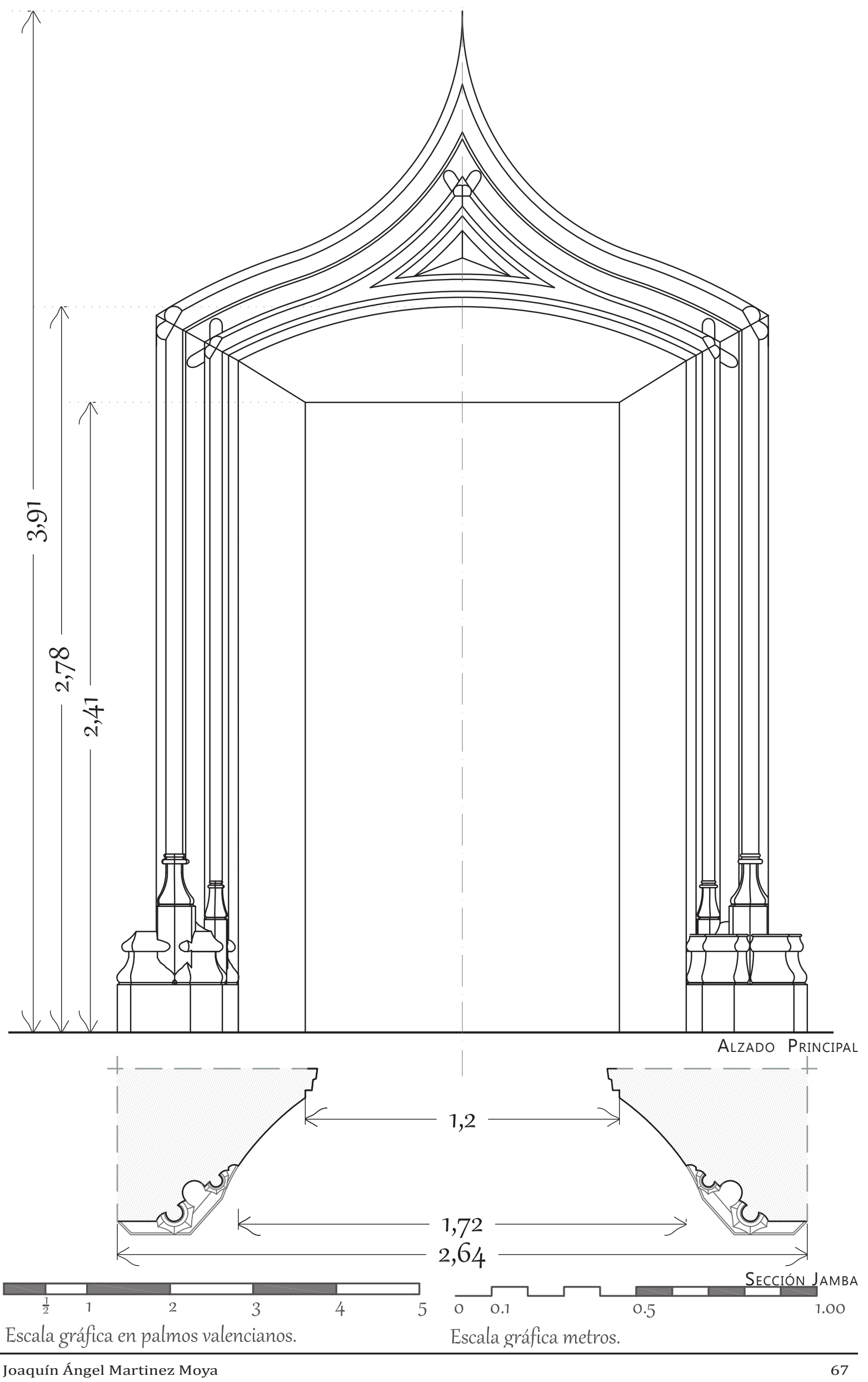



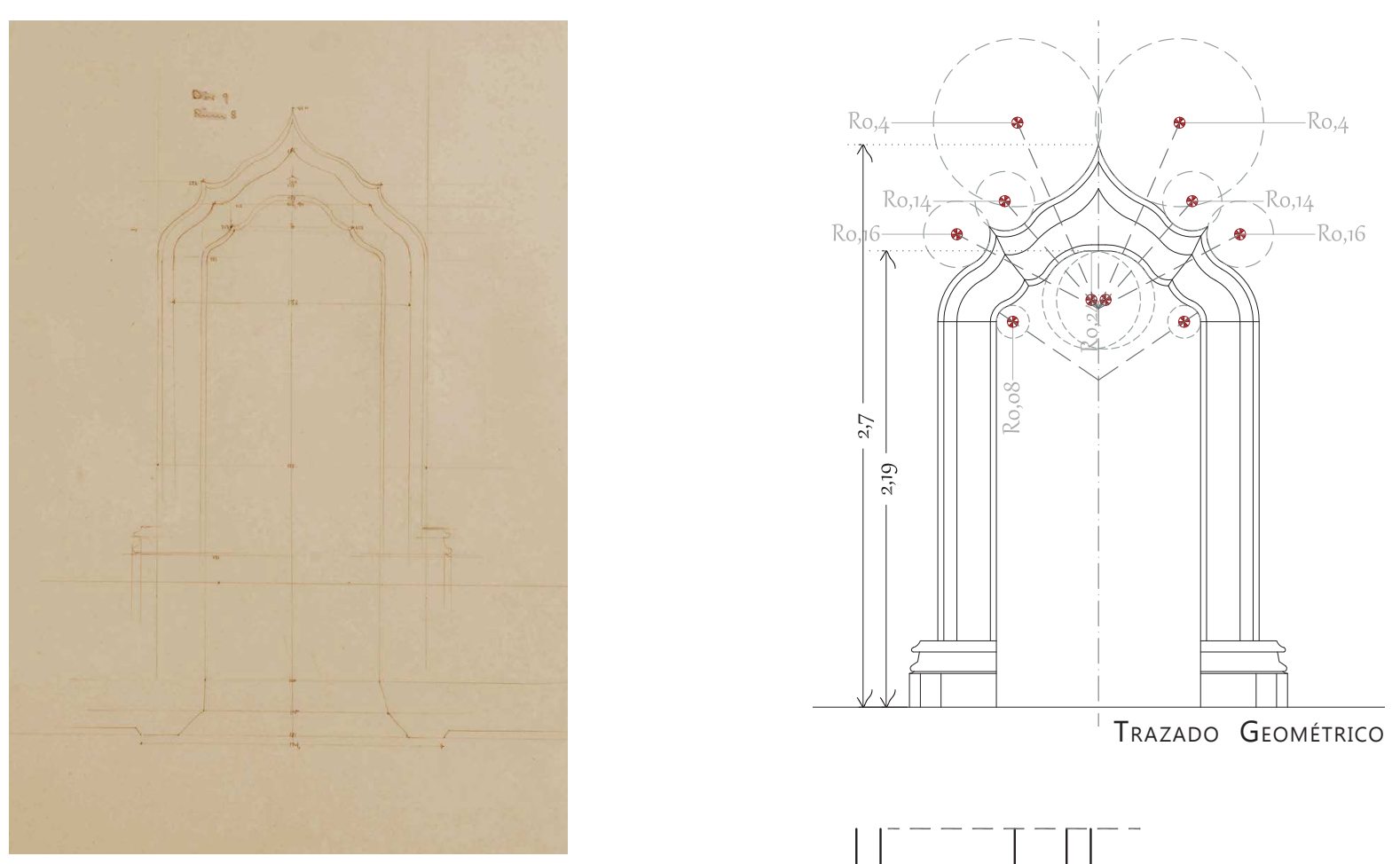

LA 1136
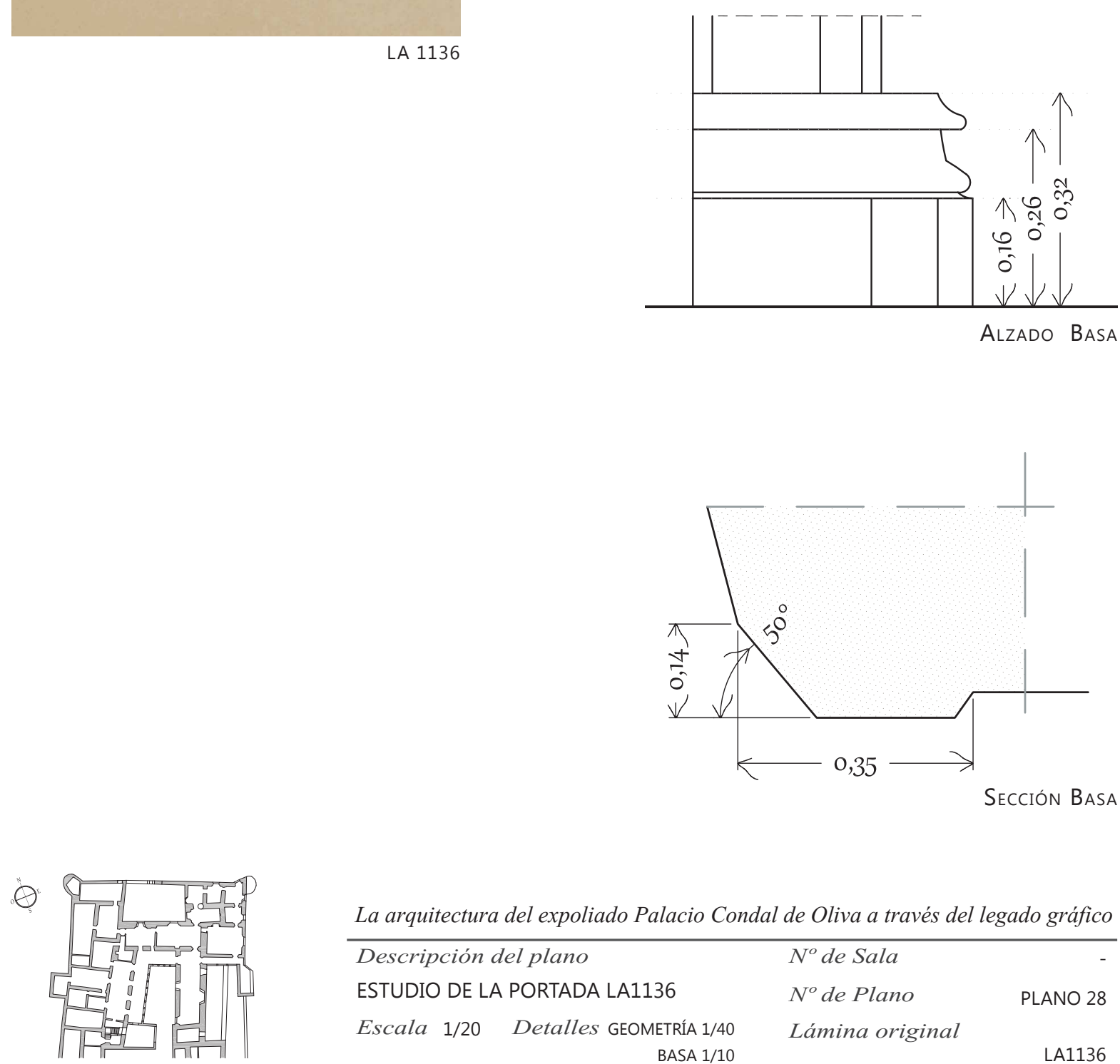

La arquitectura del expoliado Palacio Condal de Oliva a través del legado gráfico

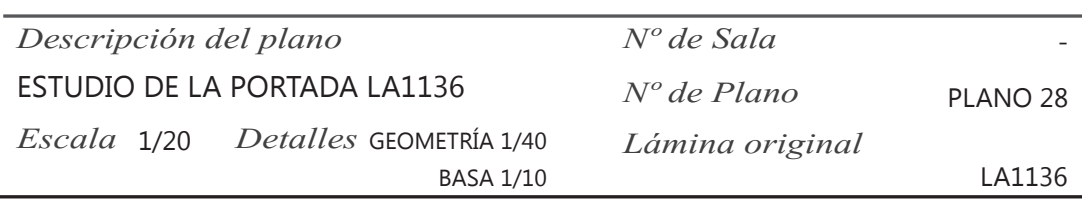




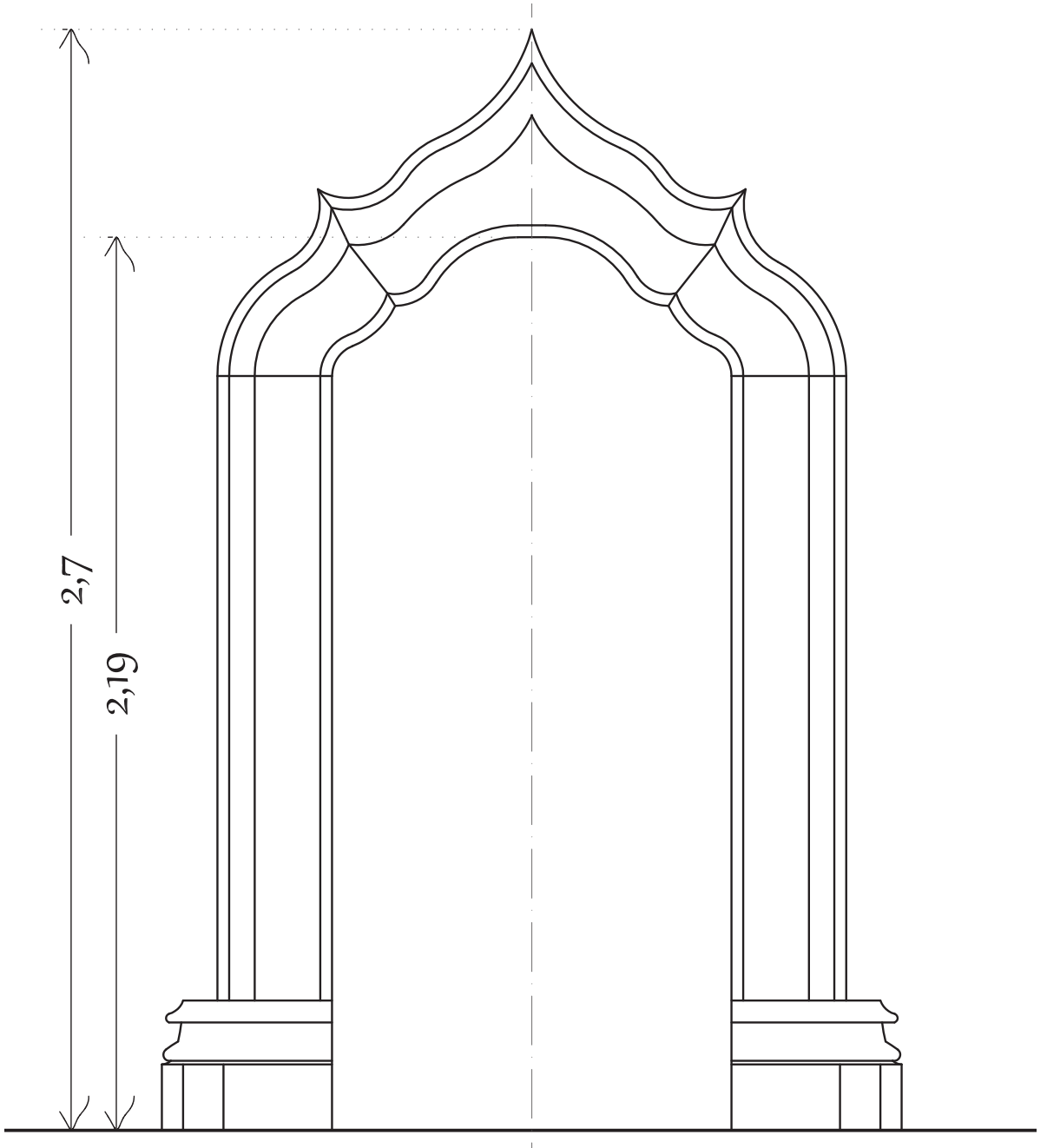

Alzado Principal

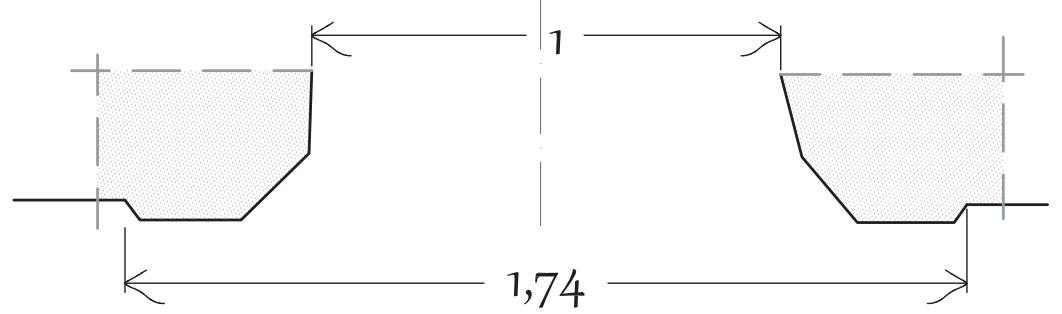

SeCCIÓn BASA

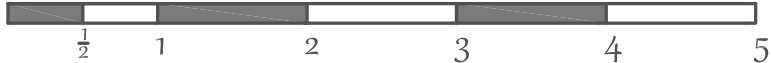

Escala gráfica en palmos valencianos.

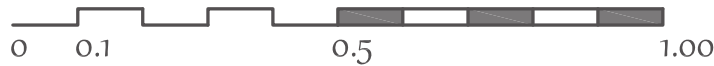



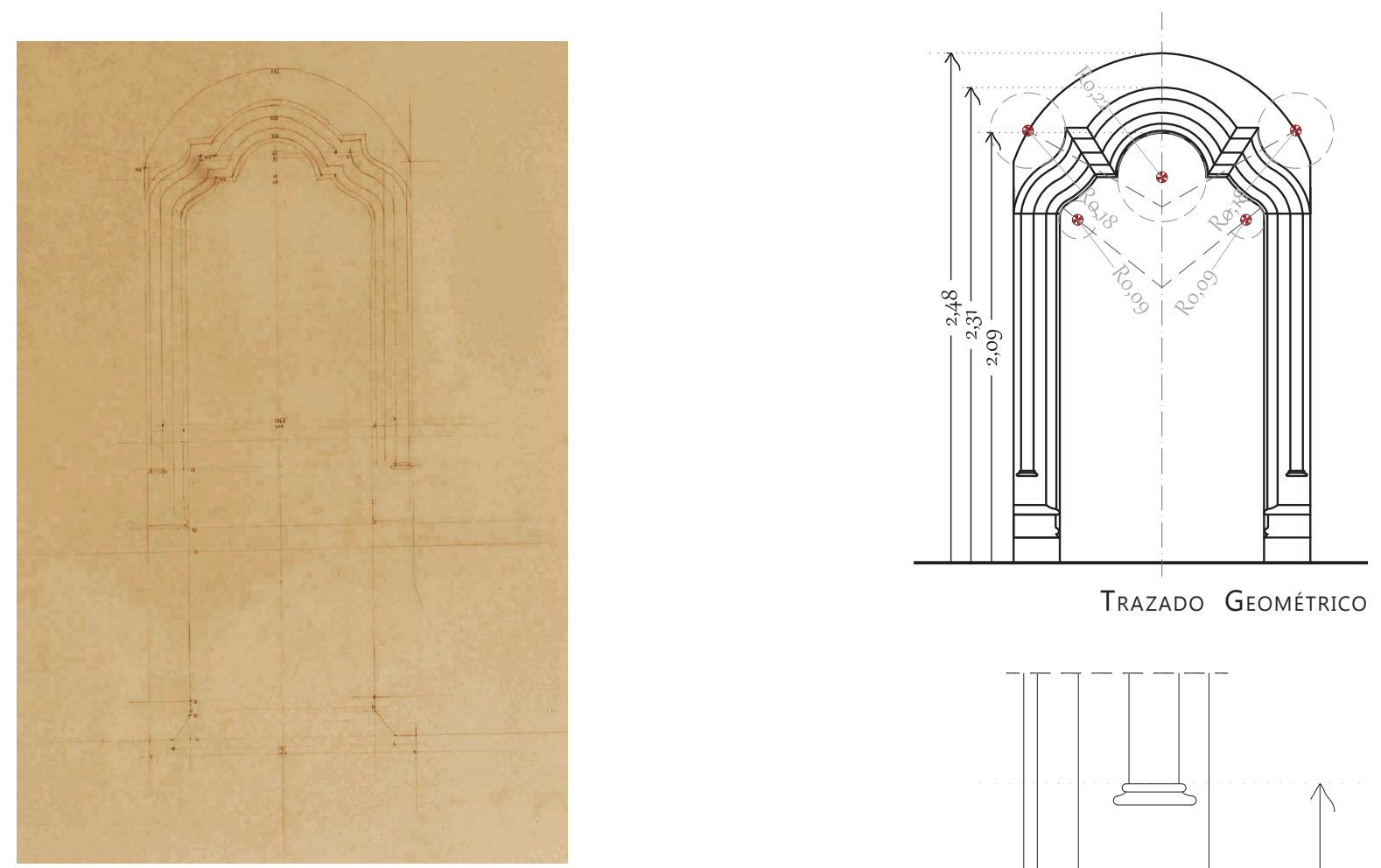

LA 1176
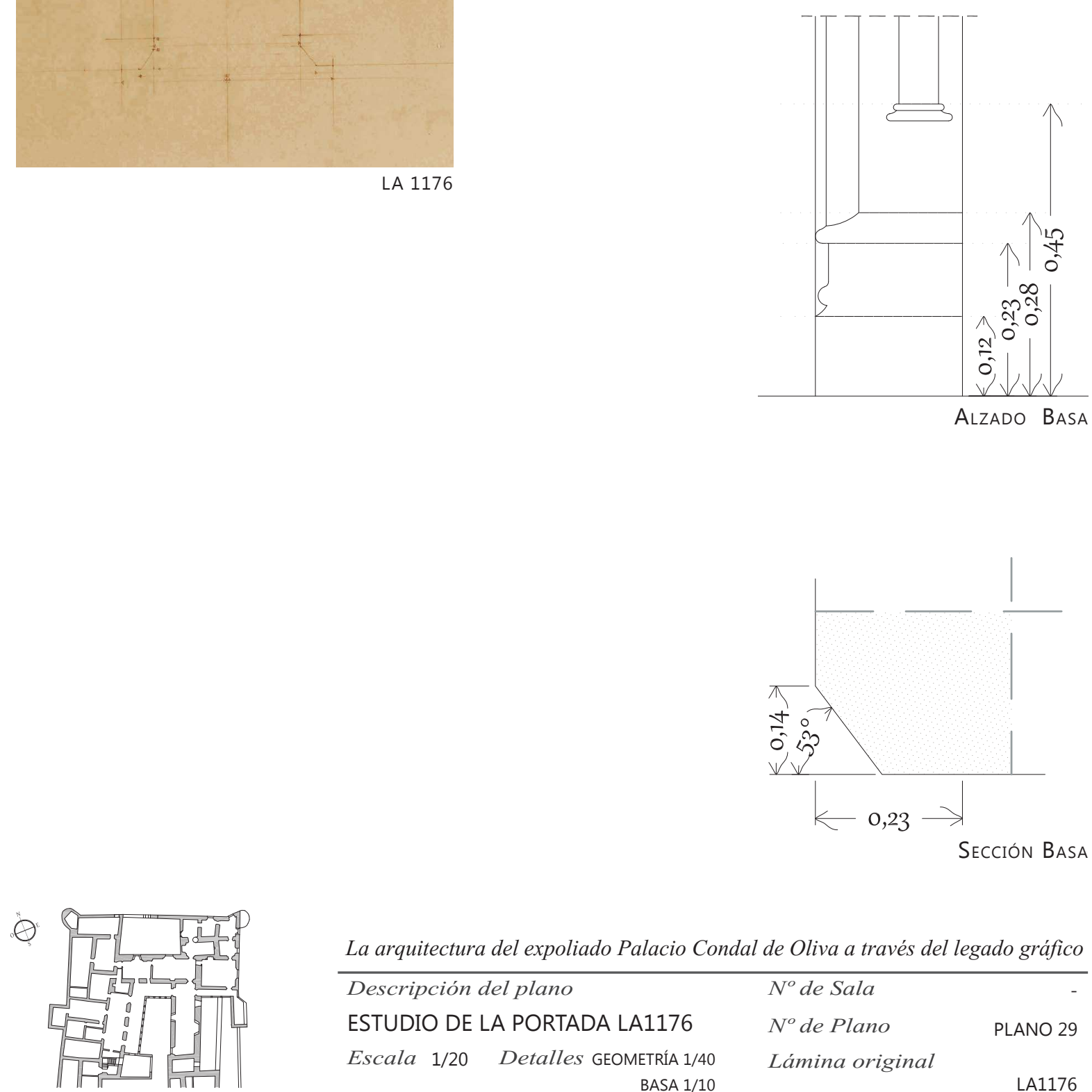

La arquitectura del expoliado Palacio Condal de Oliva a través del legado gráfico

Descripción del plano $\quad N^{o}$ de Sala

ESTUDIO DE LA PORTADA LA1176

$N^{o}$ de Plano

PLANO 29

Escala $1 / 20$ Detalles GEOMETRÍA 1/40

Lámina original

LA1176 


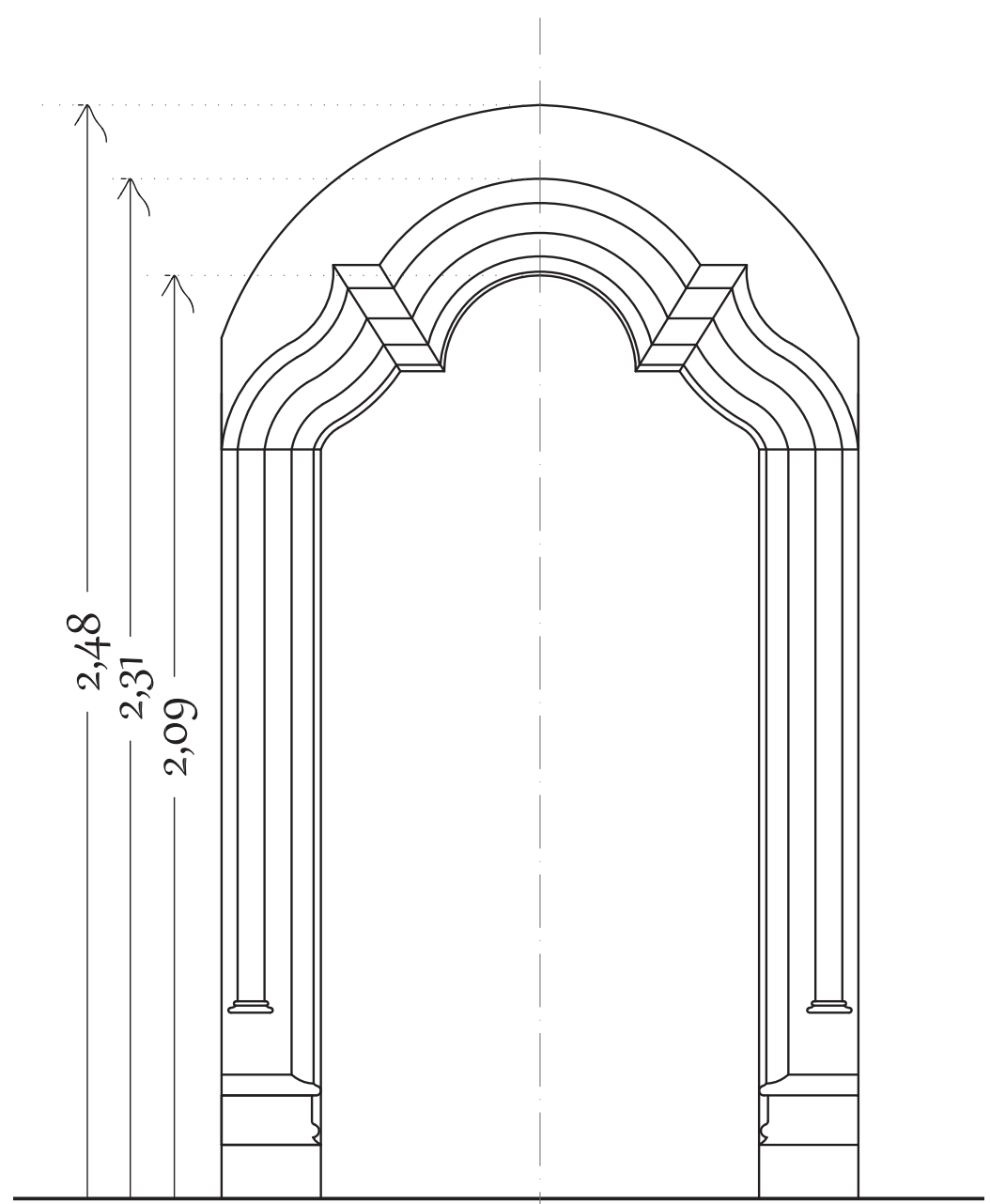

Alzado Principal

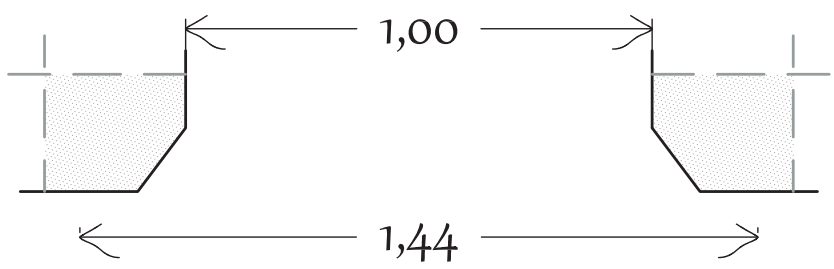

SeCCIÓn BASA

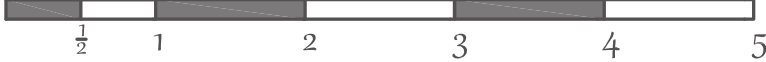

Escala gráfica en palmos valencianos.

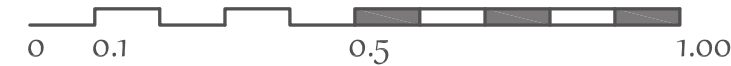



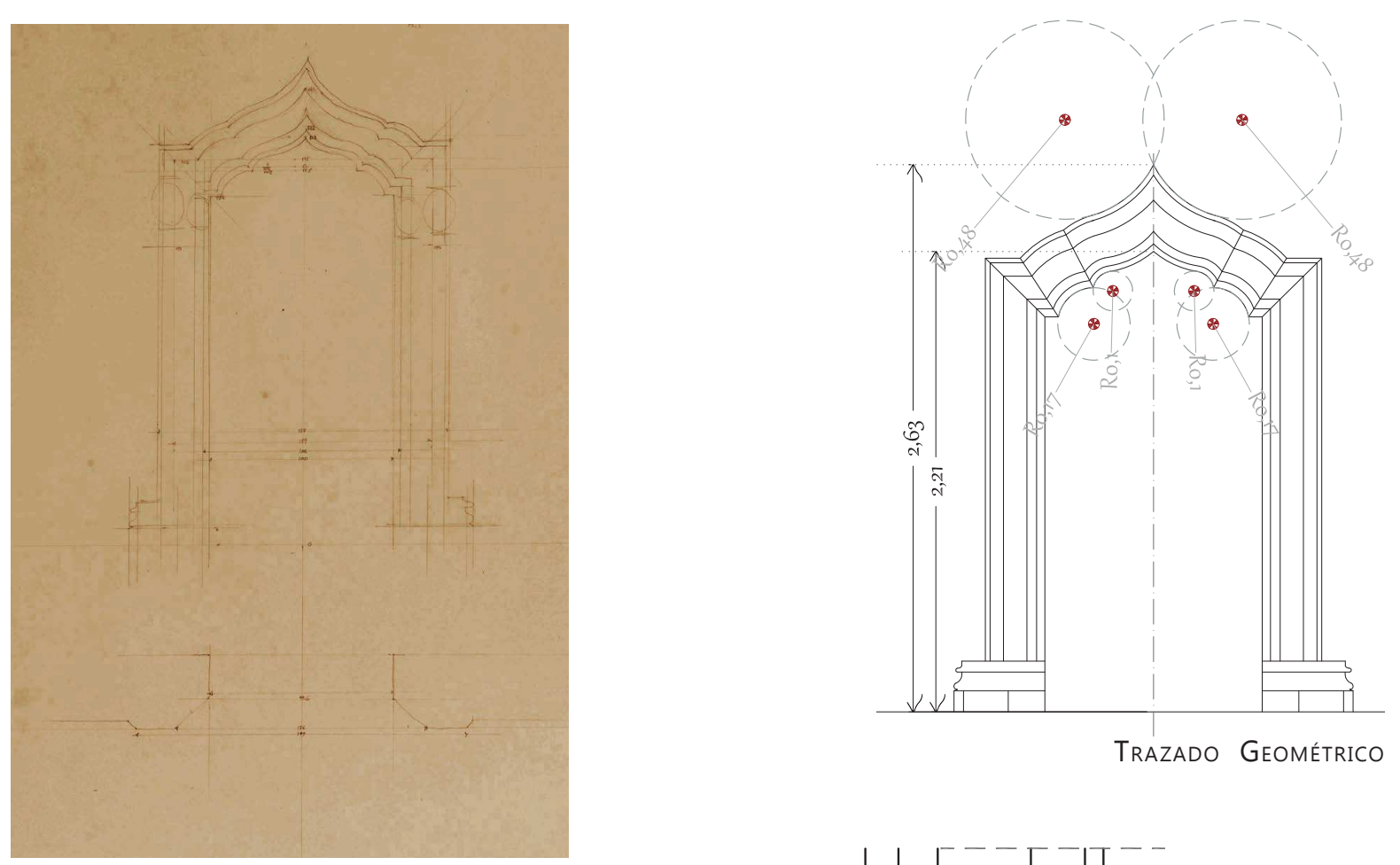

LA 1177

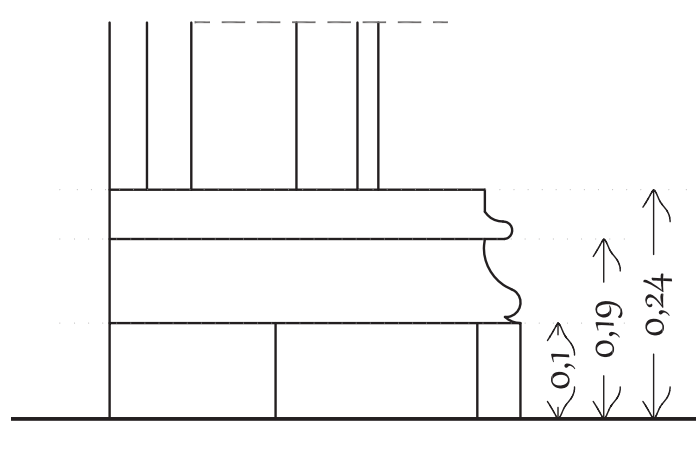

Alzado BASA

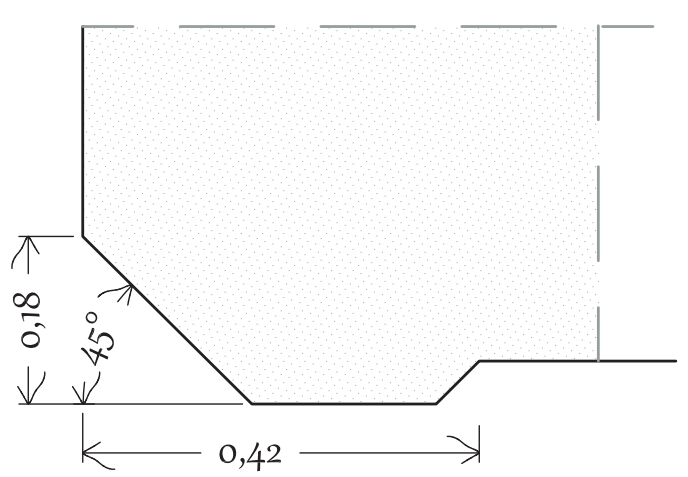

SECCIÓN BASA

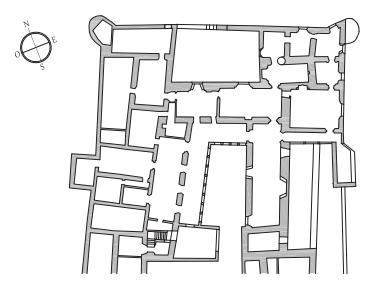

La arquitectura del expoliado Palacio Condal de Oliva a través del legado gráfico

Descripción del plano $\quad N^{o}$ de Sala

ESTUDIO DE LA PORTADA LA1177

$N^{o}$ de Plano

PLANO 30

Escala $1 / 20$ Detalles GEOMETRÍA 1/40

Lámina original

LA 1177 

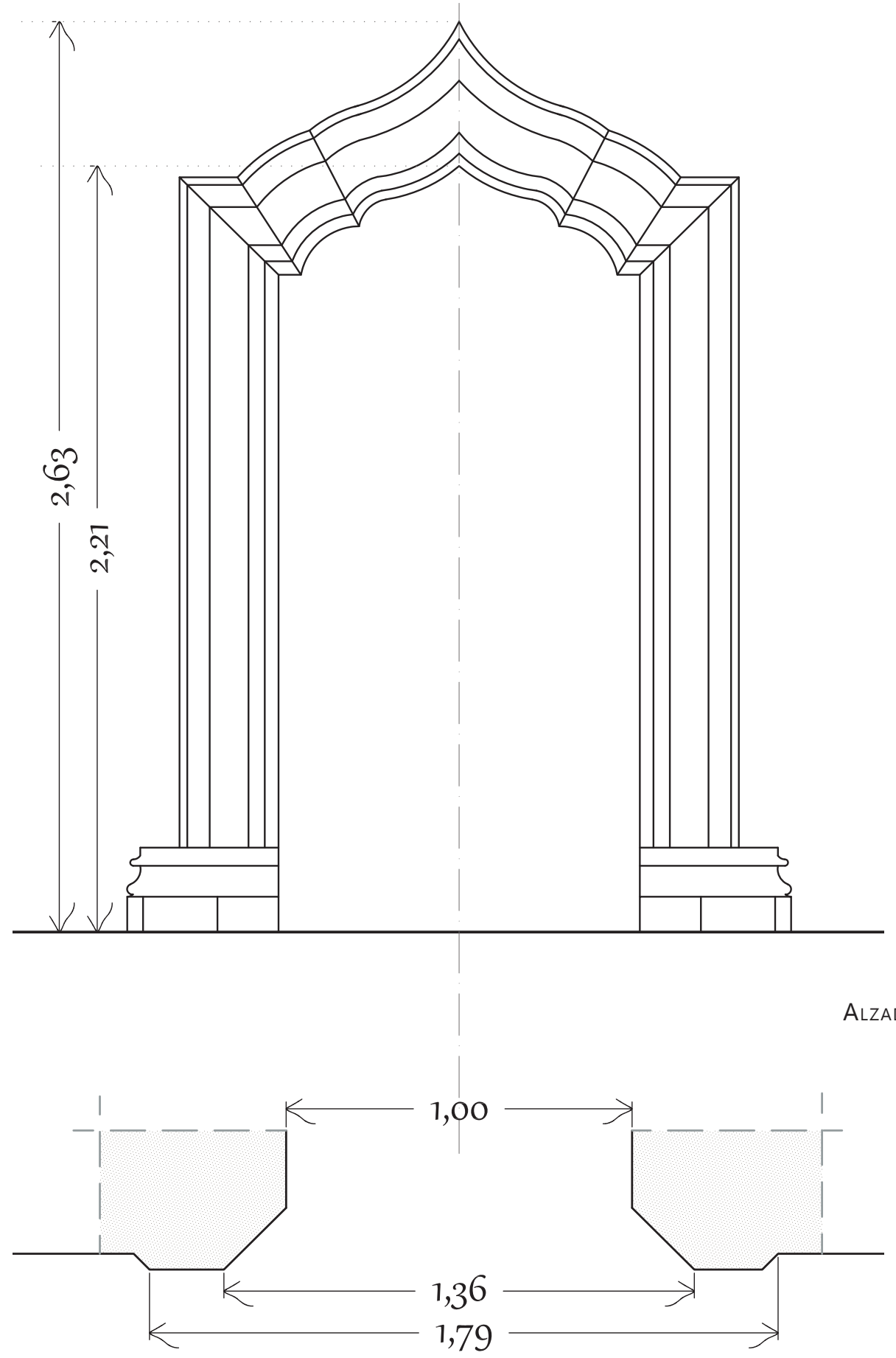

Sección BASA

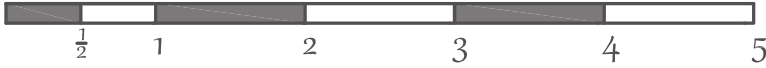

Escala gráfica en palmos valencianos.

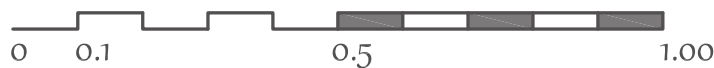

Escala gráfica metros. 



\section{Ventanas}

"La arquitectura del expoliado Palacio Condal de Oliva a través del legado gráfico" 

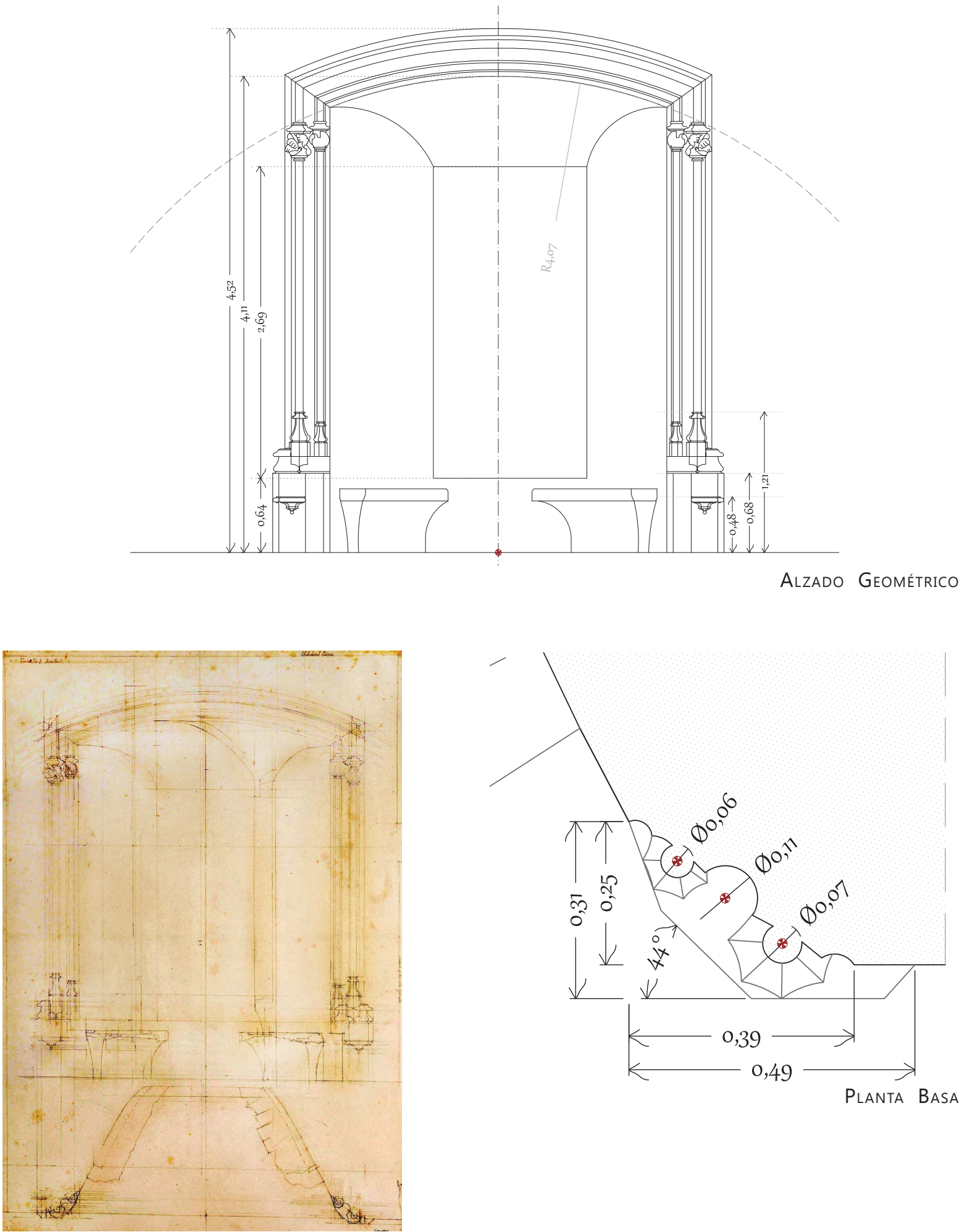

LA 1195

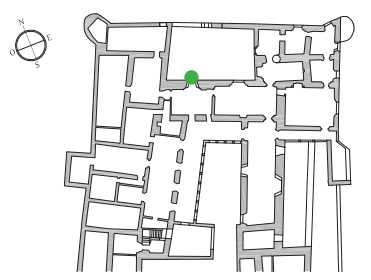

La arquitectura del expoliado Palacio Condal de Oliva a través del legado gráfico

Descripción del plano $N^{\circ}$ de Sala SALA 11

ESTUDIO DE LA VENTANA 3 - VINDRELL3 $N^{o}$ de Plano

PLANO 31

Escala 1/20 Detalles GEOMETRÍA 1/50

Lámina original

BASA $1 / 10 \quad$ LA 1183 - LA 1194 - LA1195



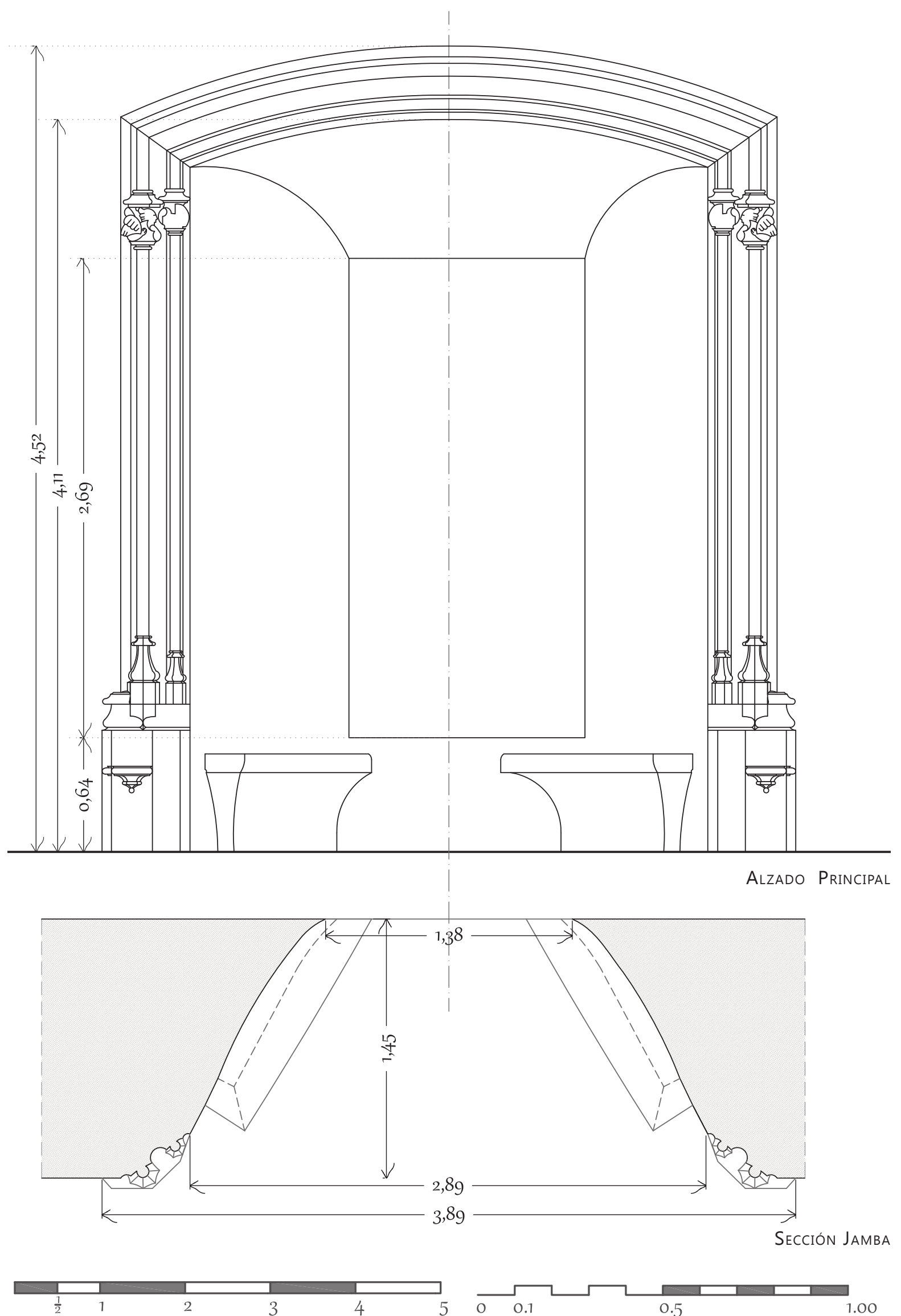

Escala gráfica en palmos valencianos.

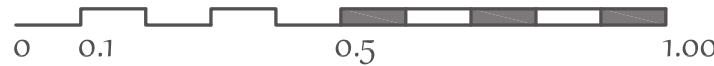

Escala gráfica metros. 

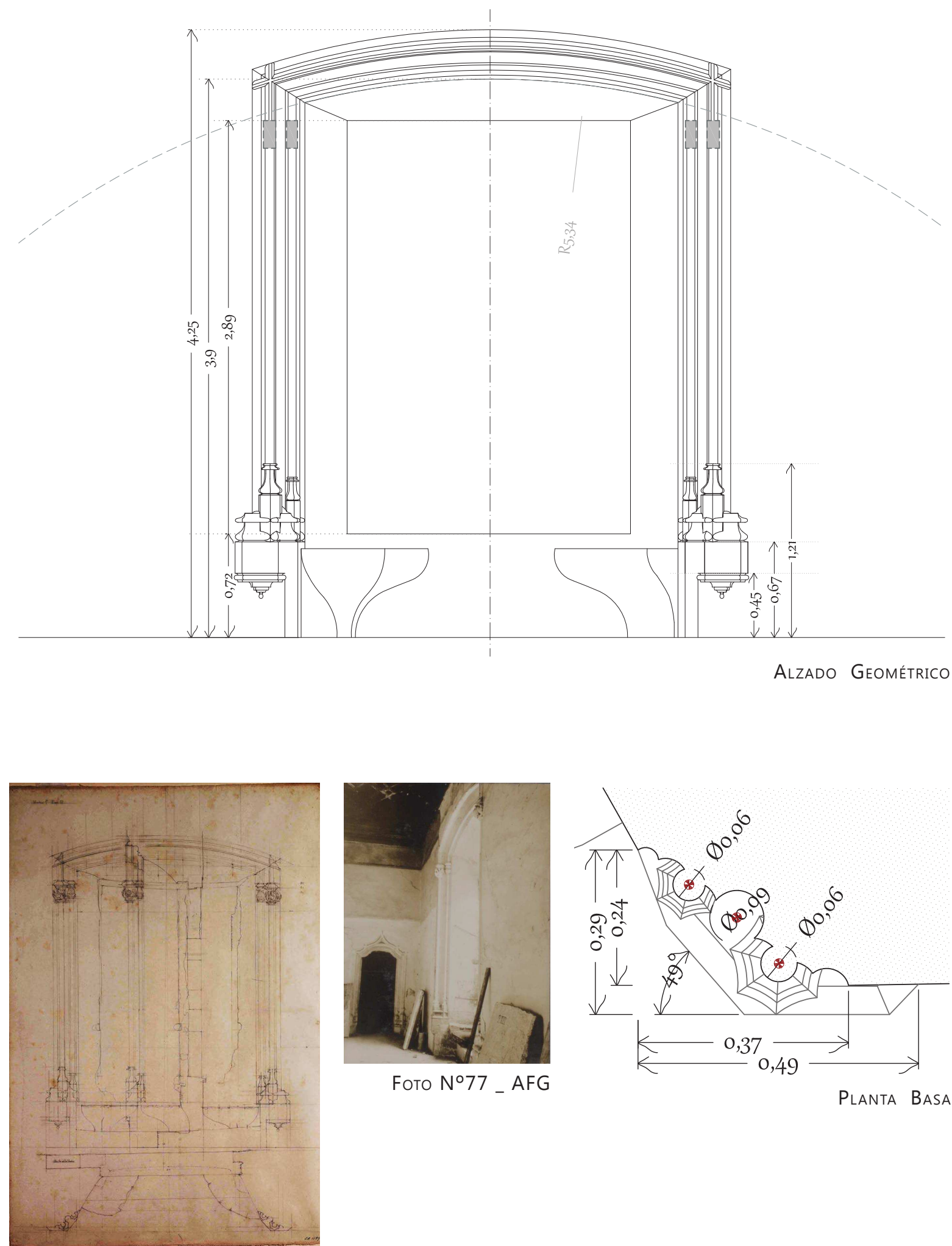

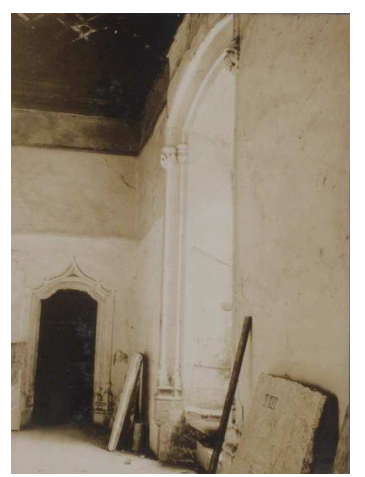

Fото N077 _ AFG
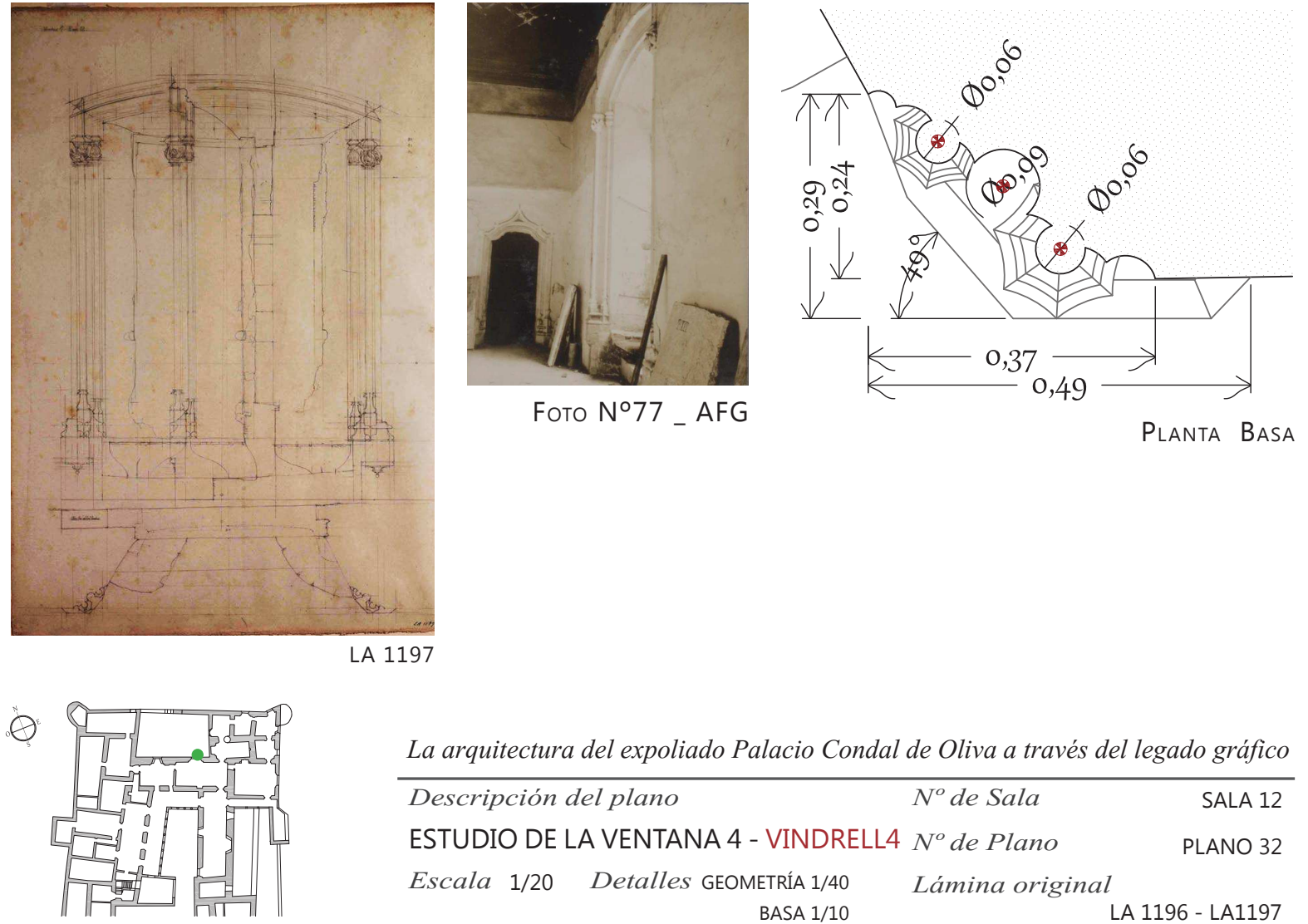

La arquitectura del expoliado Palacio Condal de Oliva a través del legado gráfico

Descripción del plano $N^{o}$ de Sala SALA 12

ESTUDIO DE LA VENTANA 4 - VINDRELL4 $N^{\circ}$ de Plano

PLANO 32

Escala $1 / 20$ Detalles GEOMETRÍA 1/40

Lámina original

BASA $1 / 10$

LA 1196 - LA1197 

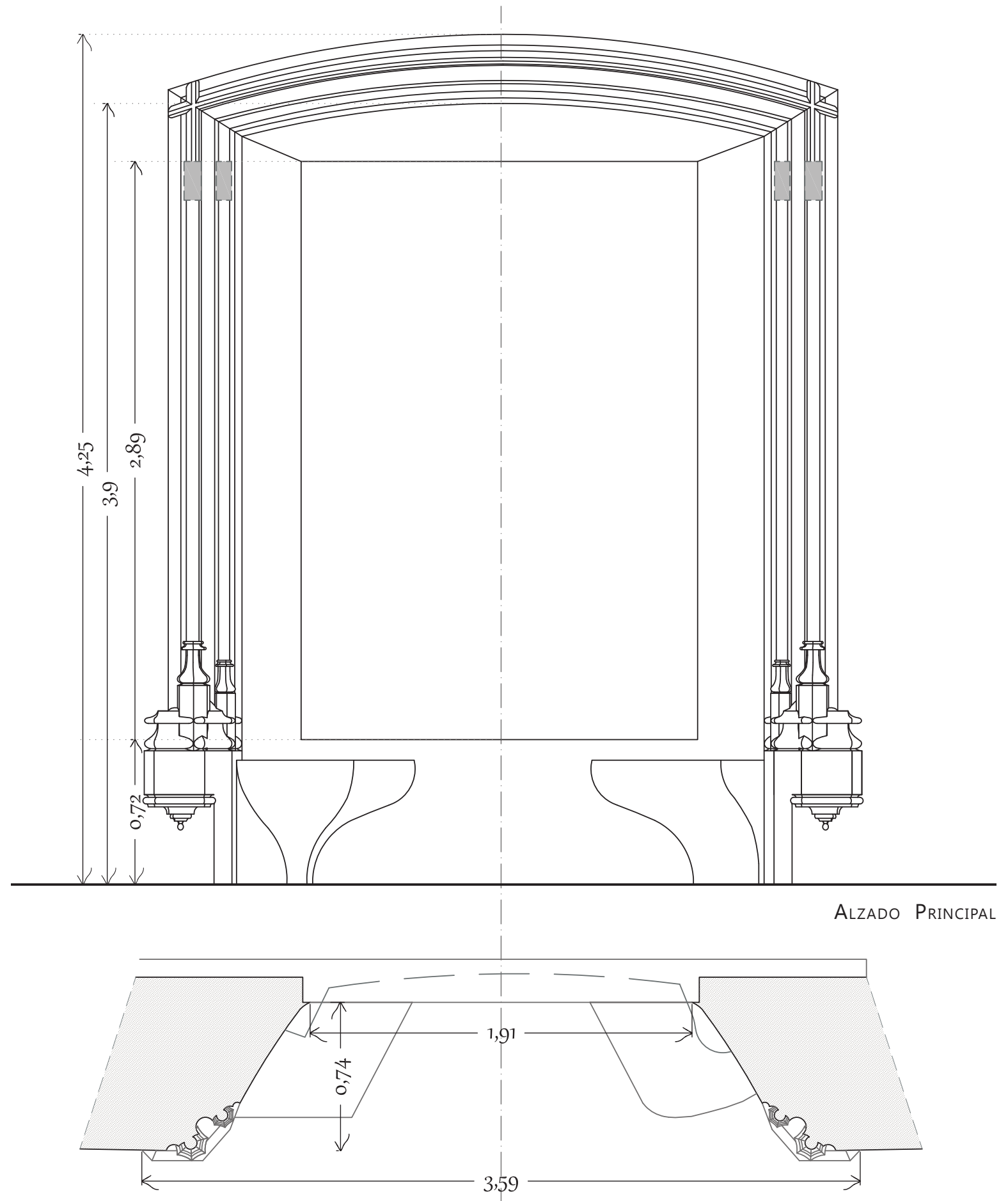

SeCCIÓn JAmba

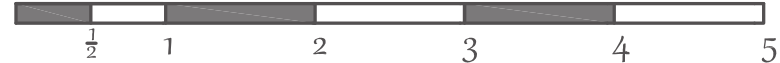

Escala gráfica en palmos valencianos.

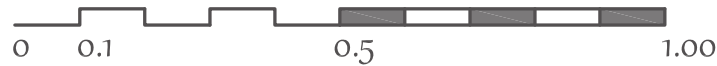

Escala gráfica metros. 

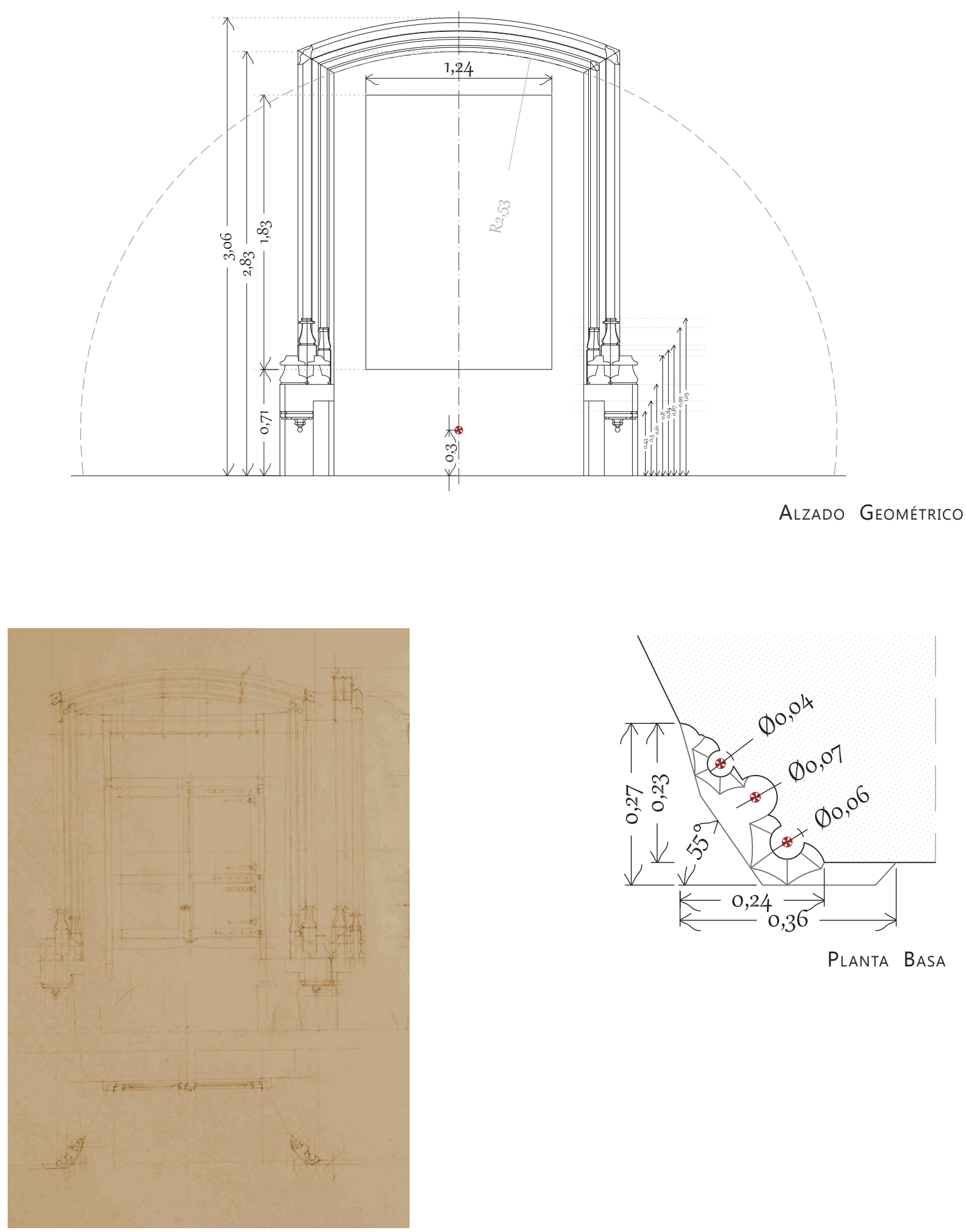

LA 1201

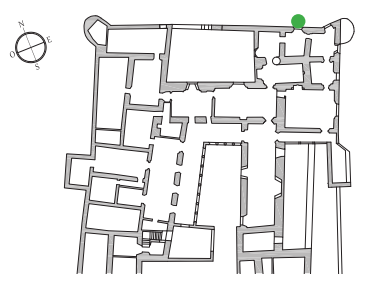

La arquitectura del expoliado Palacio Condal de Oliva a través del legado gráfico

Descripción del plano $N^{\circ}$ de Sala SALA 15

ESTUDIO DE LA VENTANA 6 - VINDRELL6 $N^{\circ}$ de Plano

PLANO 33

Escala $1 / 20$ Detalles GEOMETRÍA $1 / 40$

Lámina original

BASA $1 / 10$

LA 1120 - LA1201 


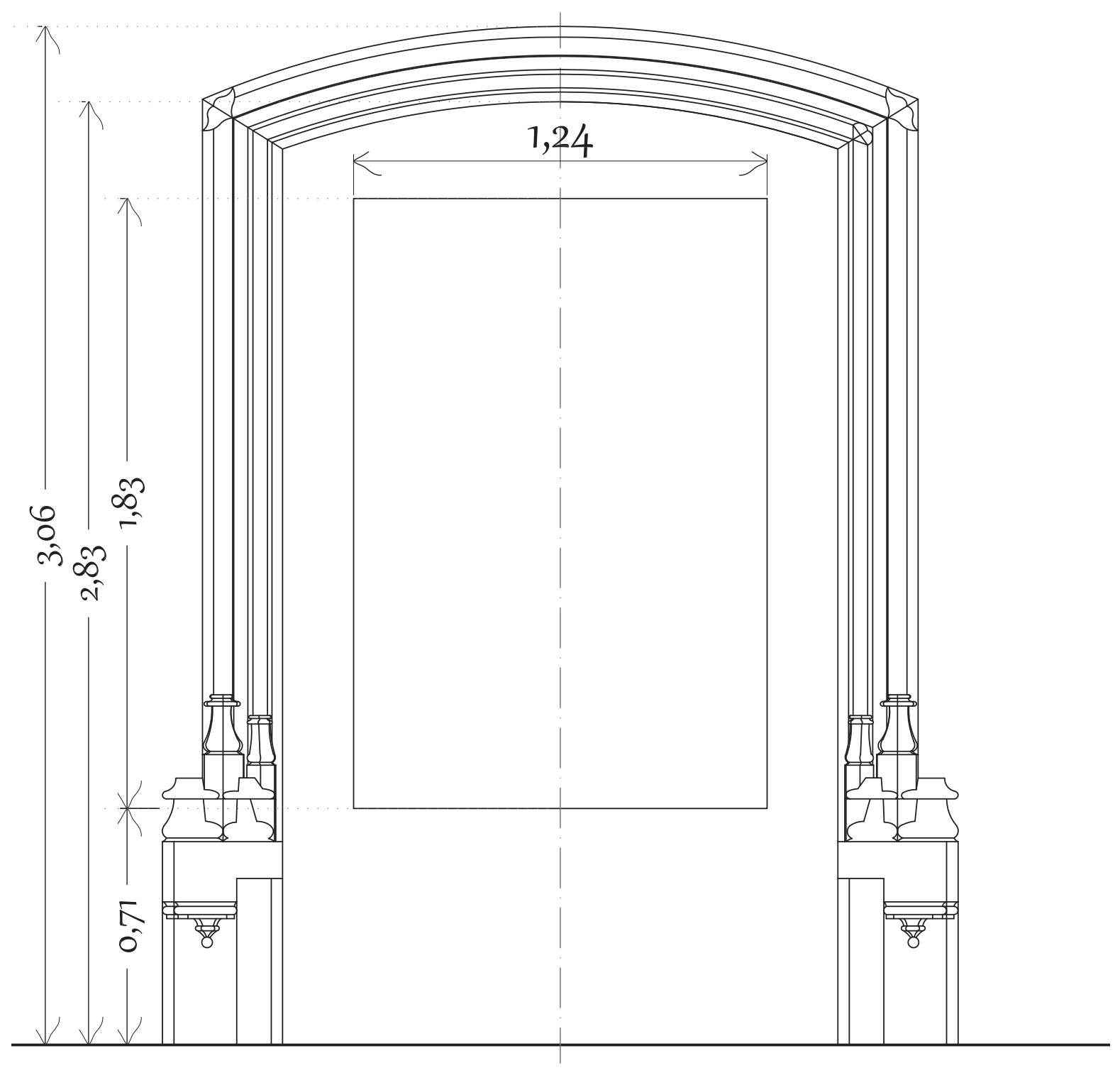

Alzado Principal

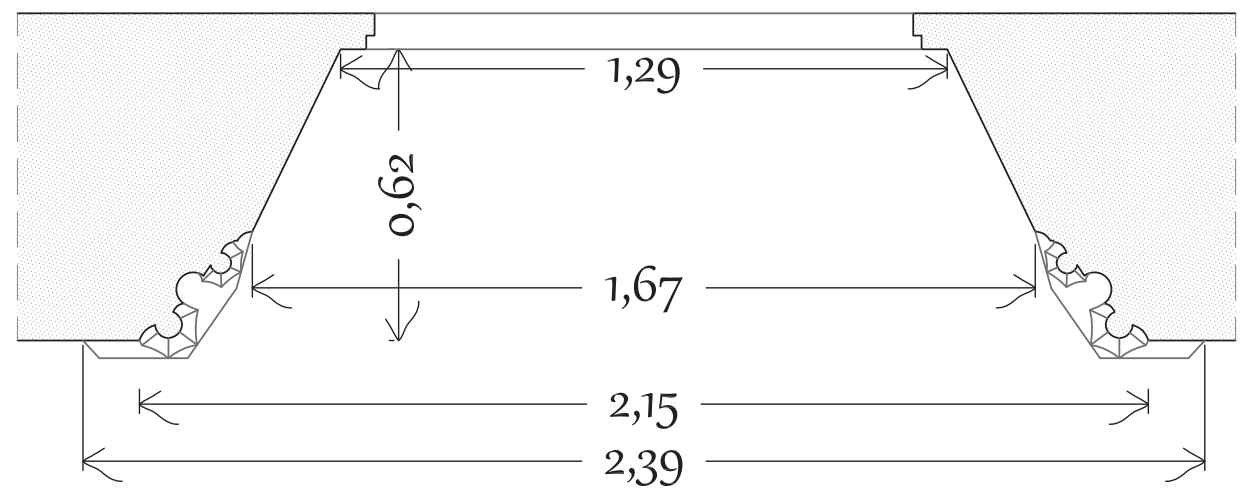

Sección Jamba

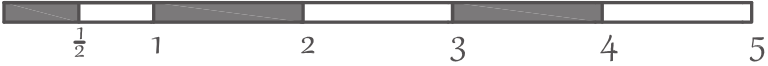

Escala gráfica en palmos valencianos.

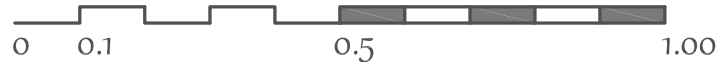

Escala gráfica metros. 


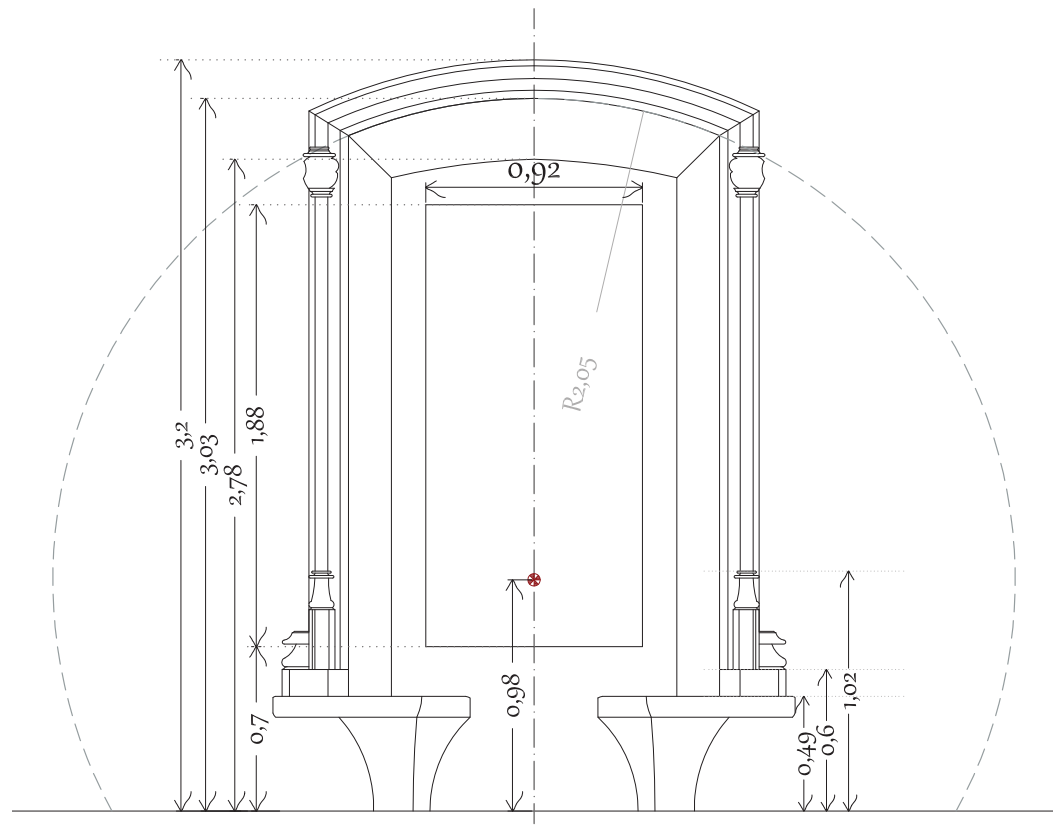

Alzado Geométrico
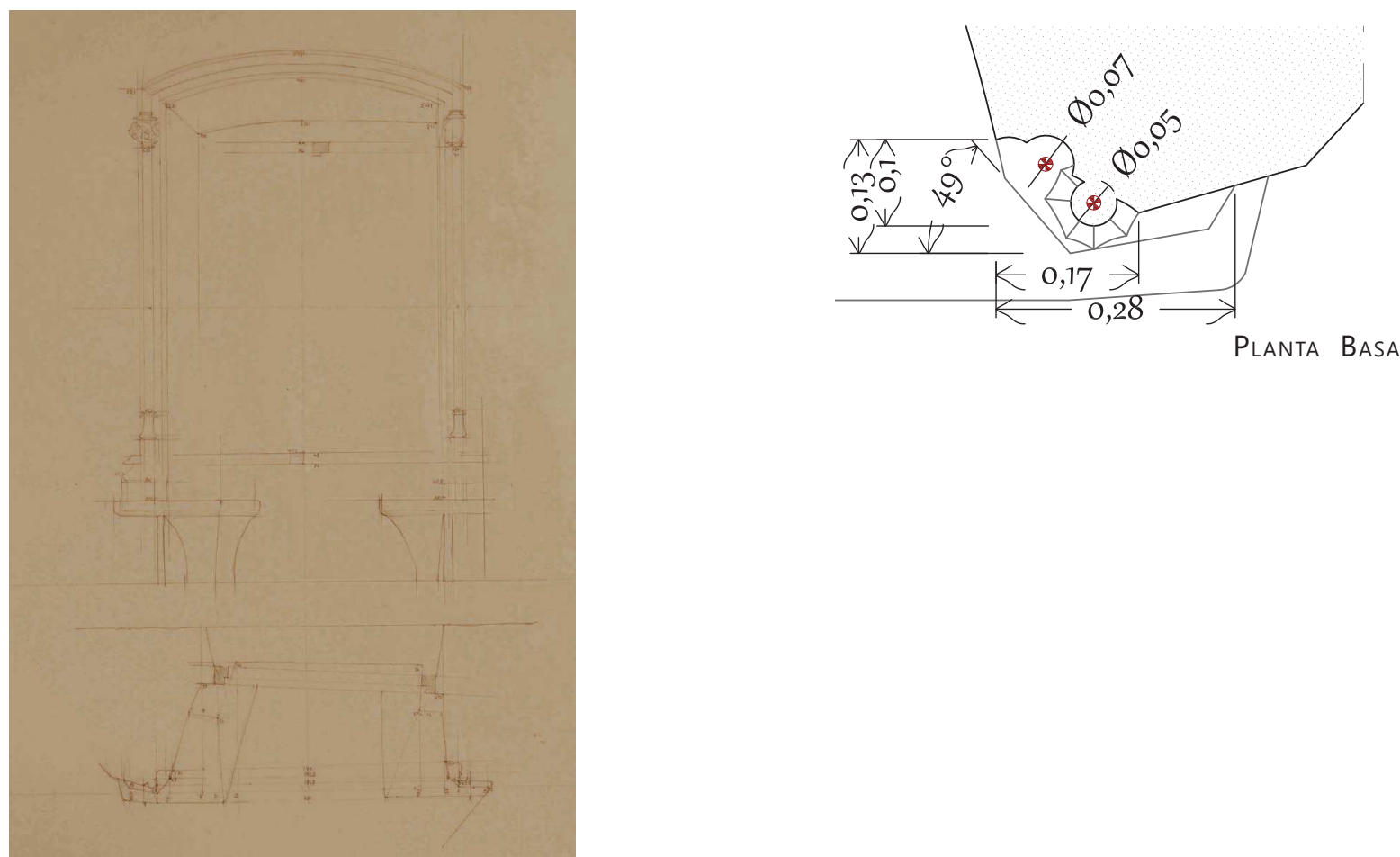

LA 1203

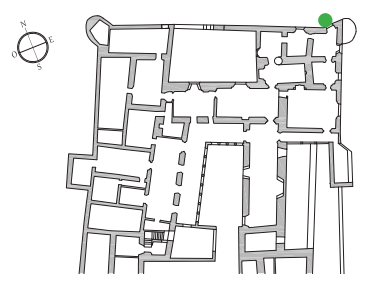

La arquitectura del expoliado Palacio Condal de Oliva a través del legado gráfico

Descripción del plano $N^{\circ}$ de Sala SALA 16

ESTUDIO DE LA VENTANA 7 - VINDRELL7 $N^{o}$ de Plano

PLANO 34

Escala 1/20 Detalles GEOMETRÍA 1/40

Lámina original

BASA $1 / 10 \quad$ LA 1202 - LA 1203



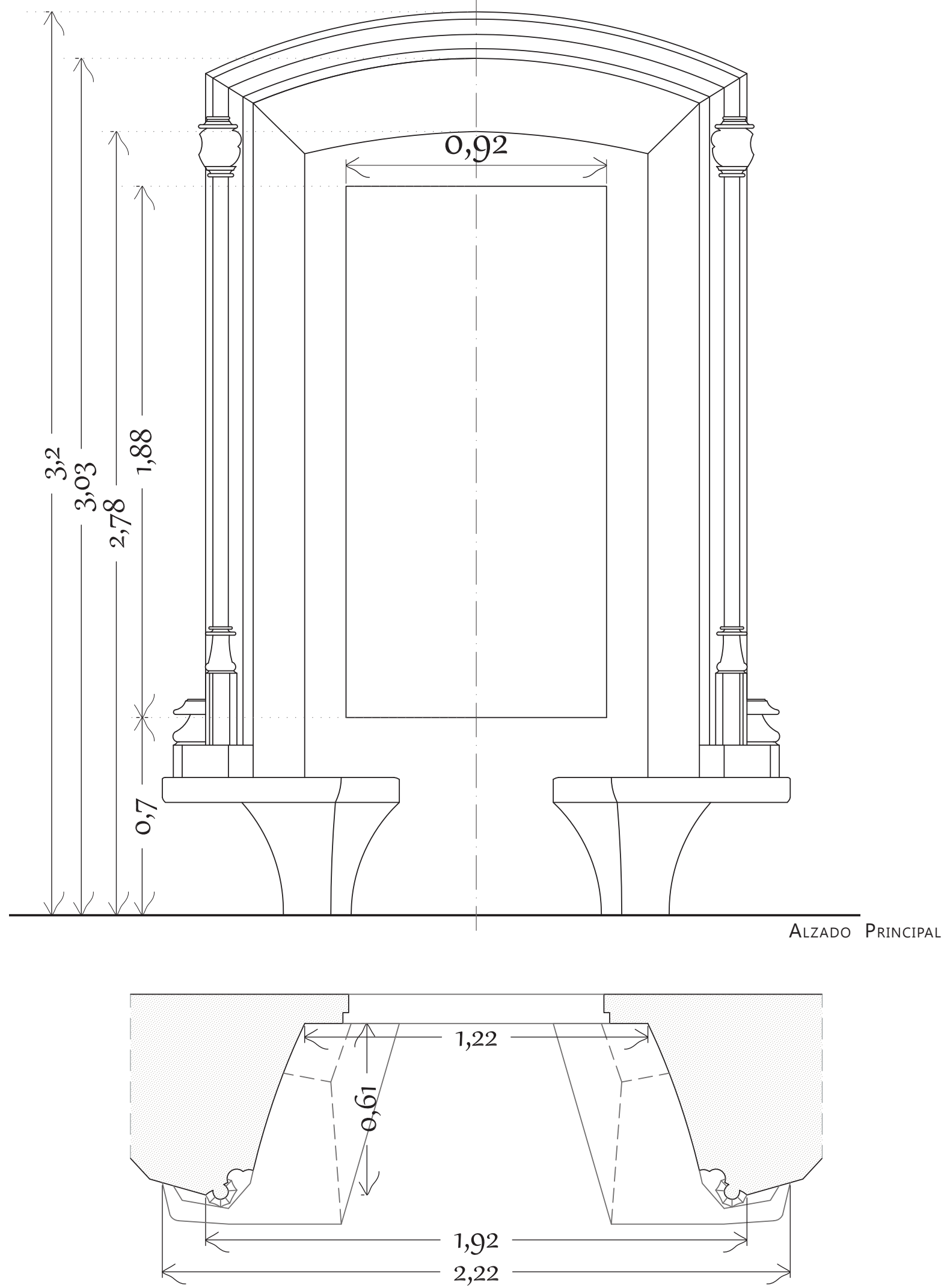

Sección Jamba

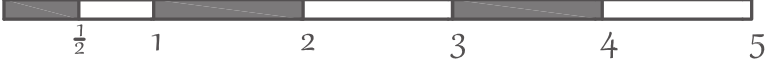

Escala gráfica en palmos valencianos.

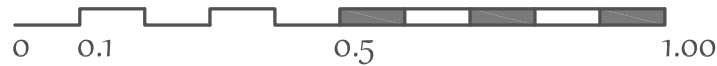

Joaquín Ángel Martinez Moya

Escala gráfica metros. 


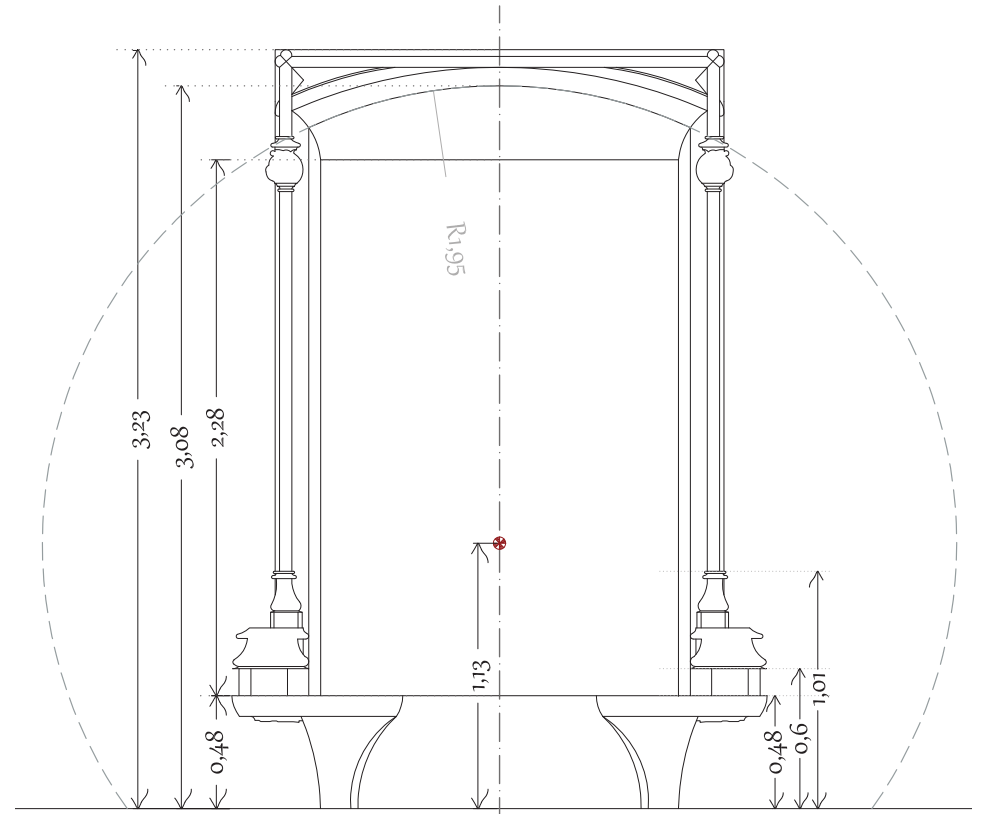

Alzado Geométrico
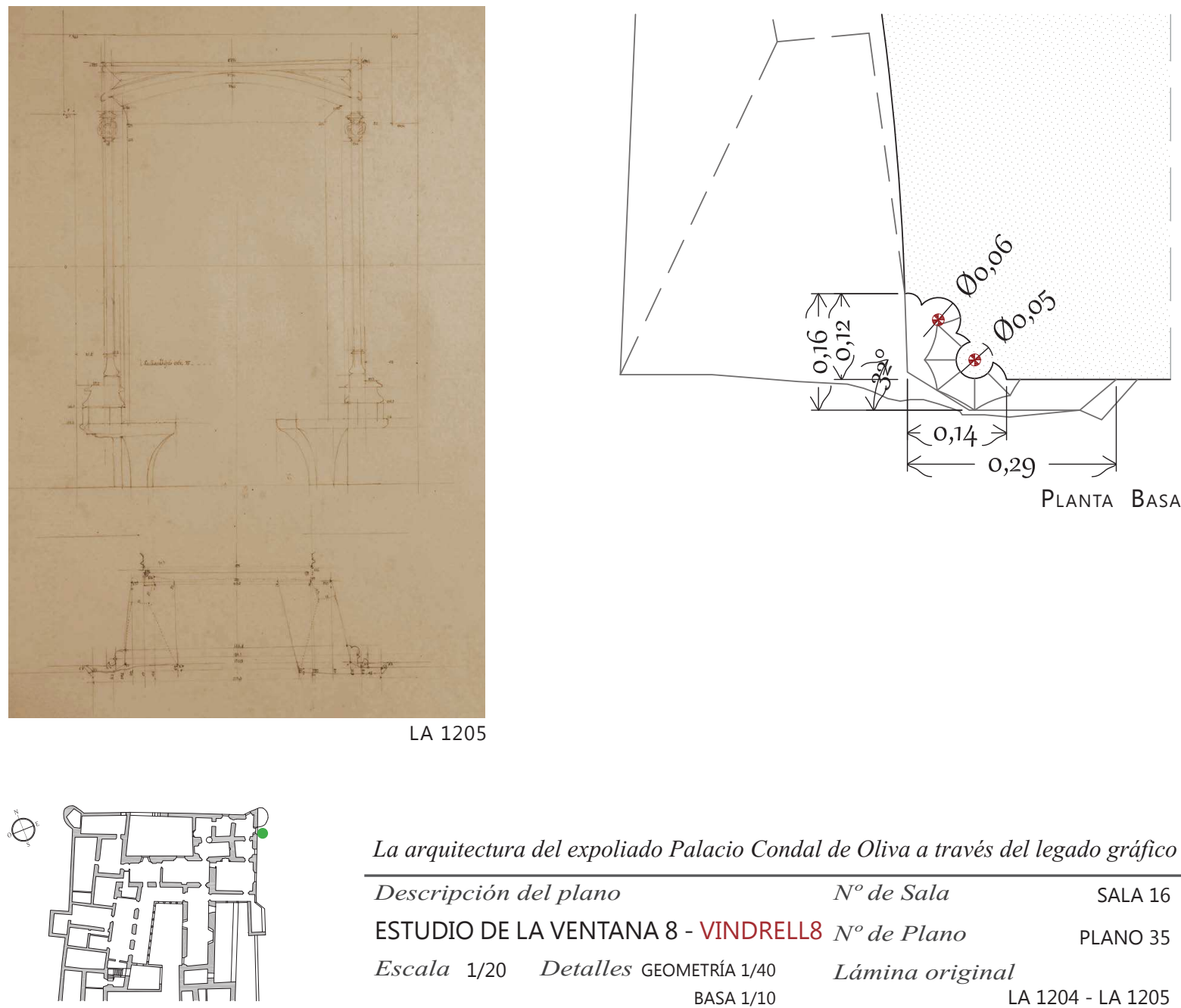

La arquitectura del expoliado Palacio Condal de Oliva a través del legado gráfico

Descripción del plano $N^{\circ}$ de Sala SALA 16

ESTUDIO DE LA VENTANA 8 - VINDRELL8 $N^{\circ}$ de Plano

PLANO 35

Escala 1/20 Detalles GEOMETRÍA 1/40

Lámina original BASA $1 / 10$

LA 1204 - LA 1205



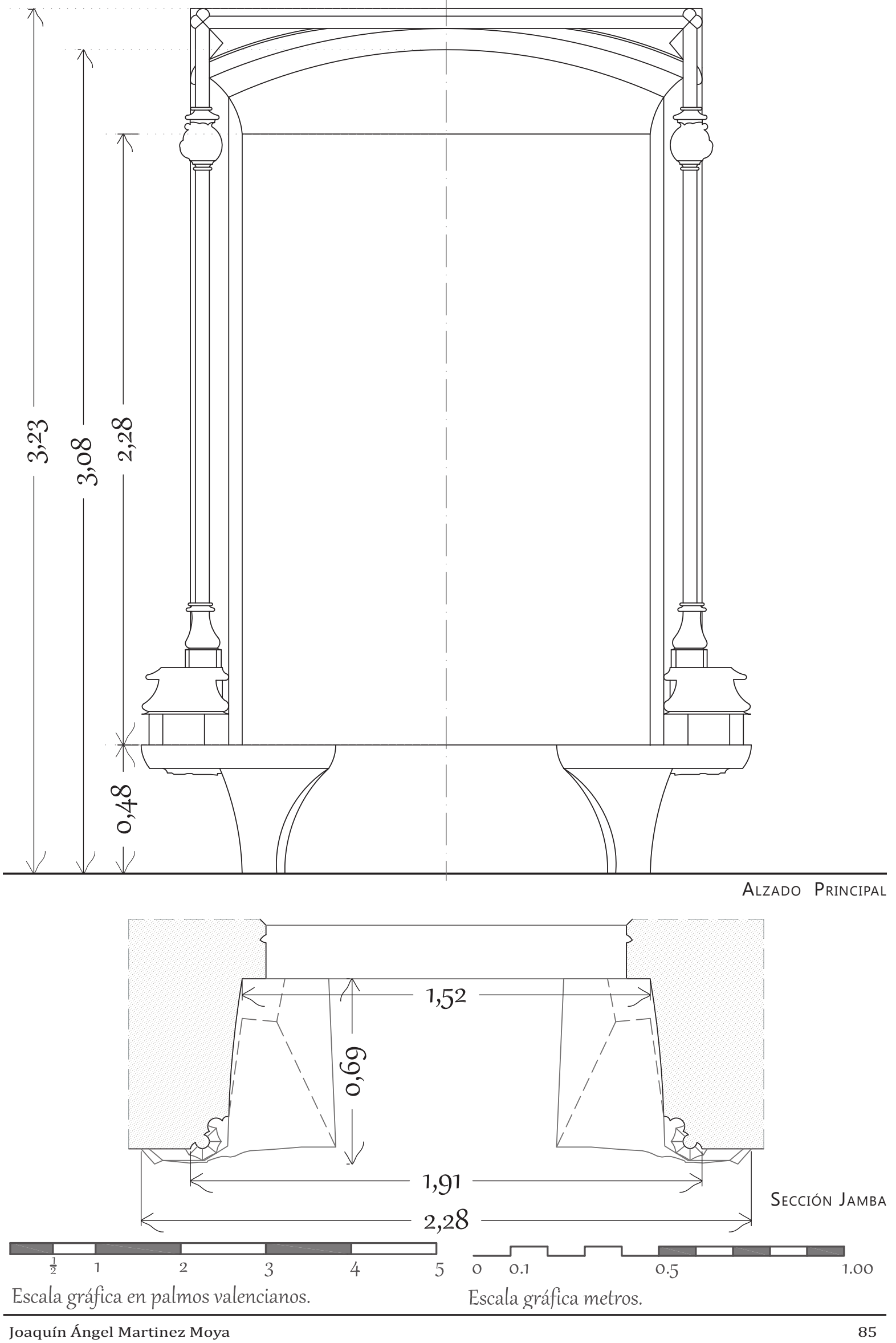


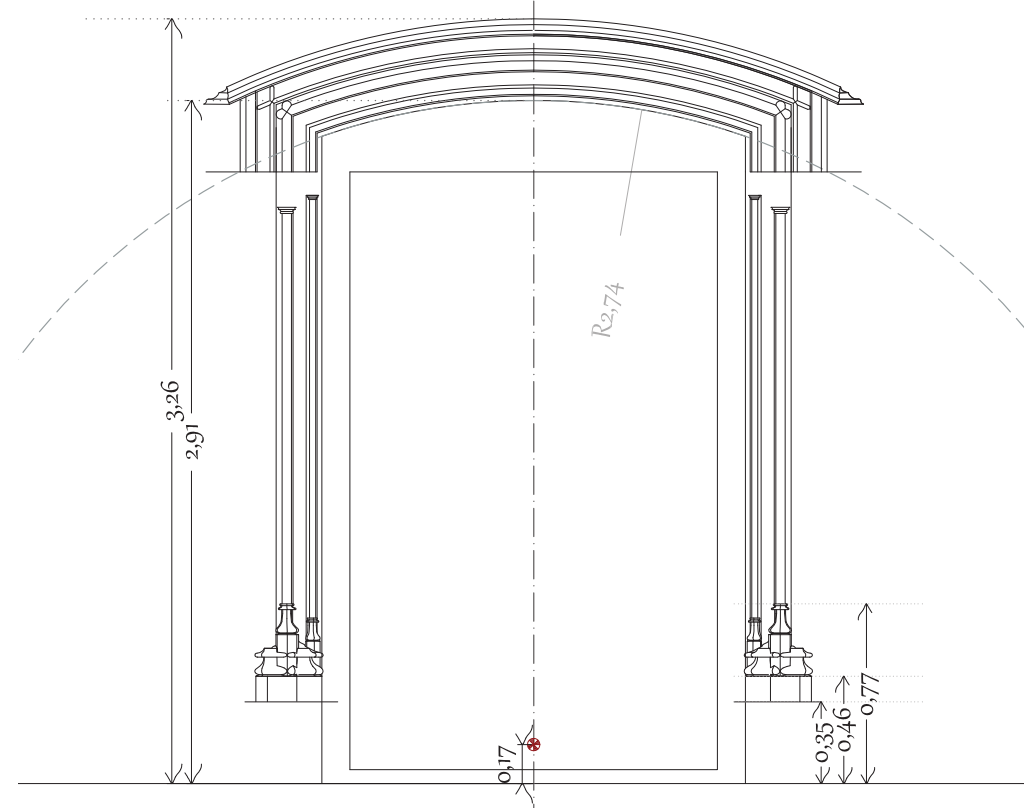

Alzado Geométrico
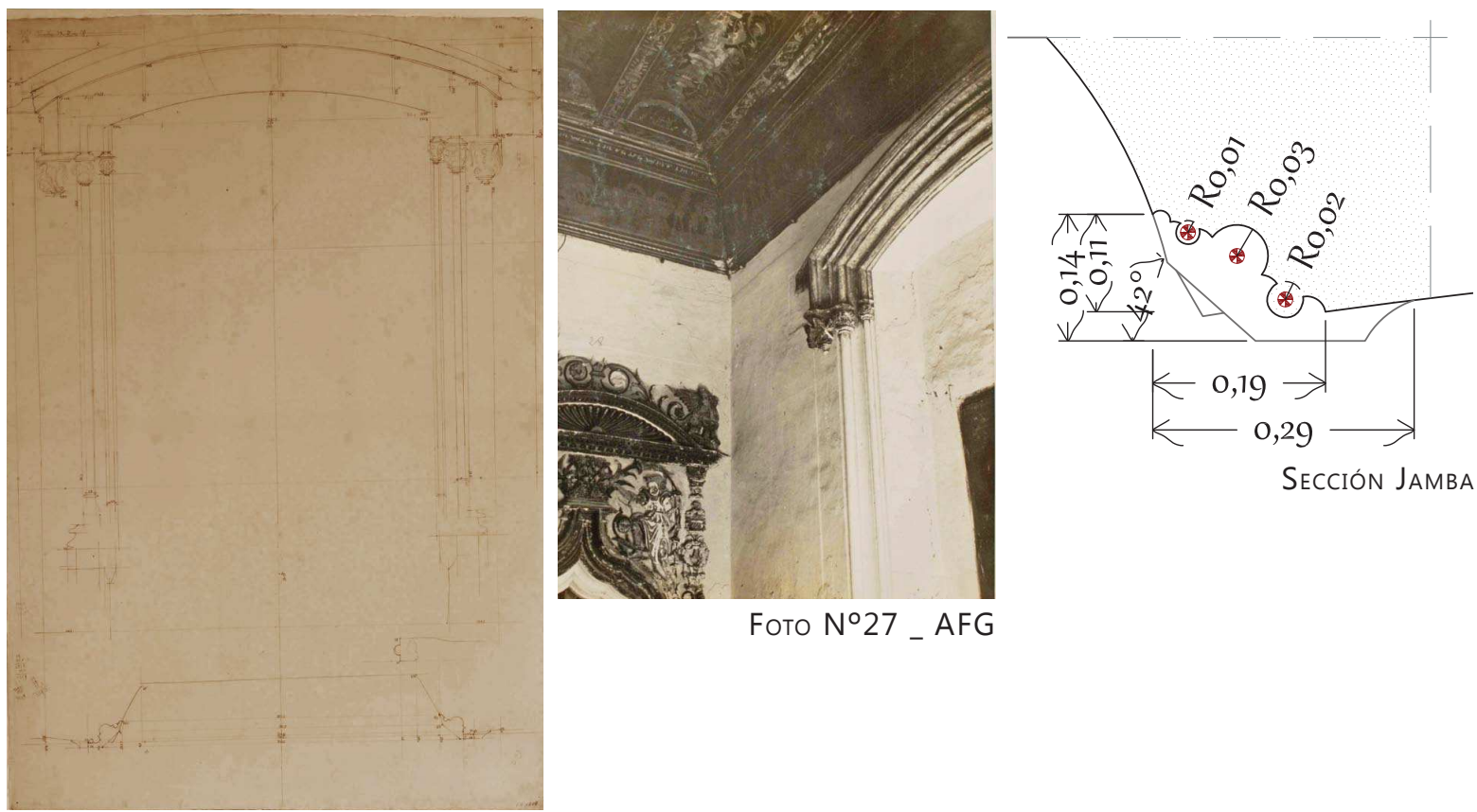

Fото N²7 AFG

LA 1209

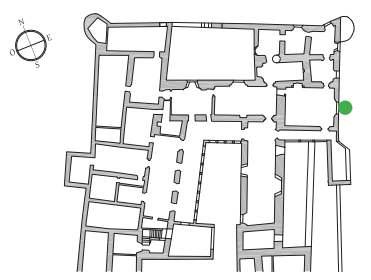

La arquitectura del expoliado Palacio Condal de Oliva a través del legado gráfico

\begin{tabular}{lllr}
\hline Descripción del plano & $N^{o}$ de Sala & SALA 18 \\
ESTUDIO DE LA VENTANA 10 - VINDRELL10 & $N^{o}$ de Plano & PLANO 36 \\
Escala $1 / 20$ & Detalles GEOMETRÍA 1/40 & Lámina original \\
BASA 1/10 & LA 1208 - LA 1209 - LA1210 - LA1211
\end{tabular}



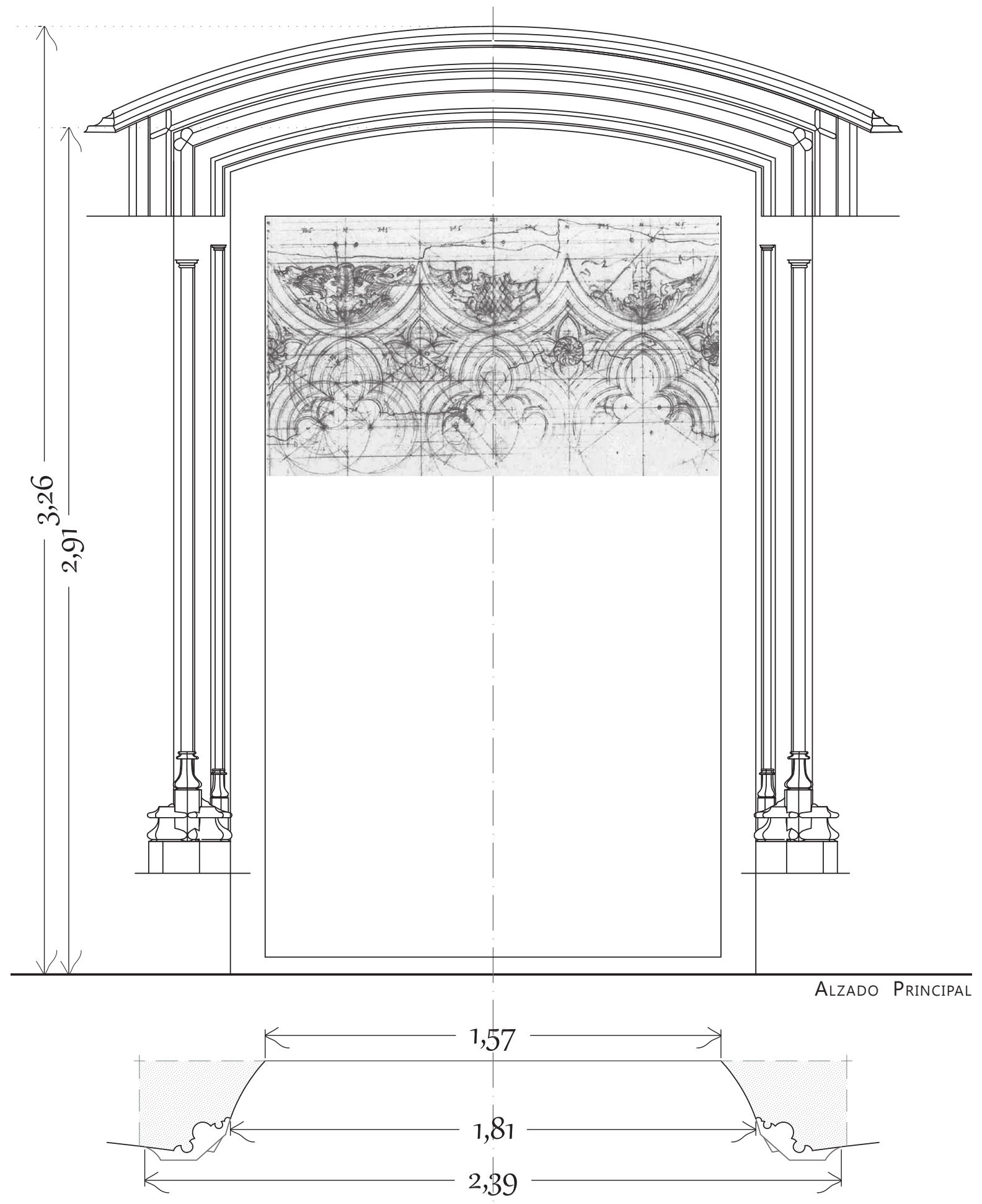

Sección Jamba

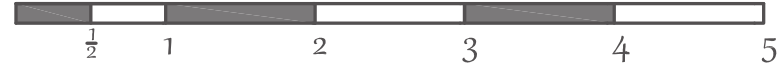

Escala gráfica en palmos valencianos.

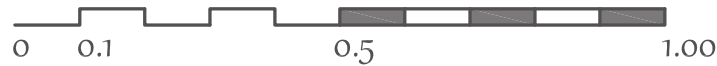

Joaquín Ángel Martinez Moya

Escala gráfica metros. 


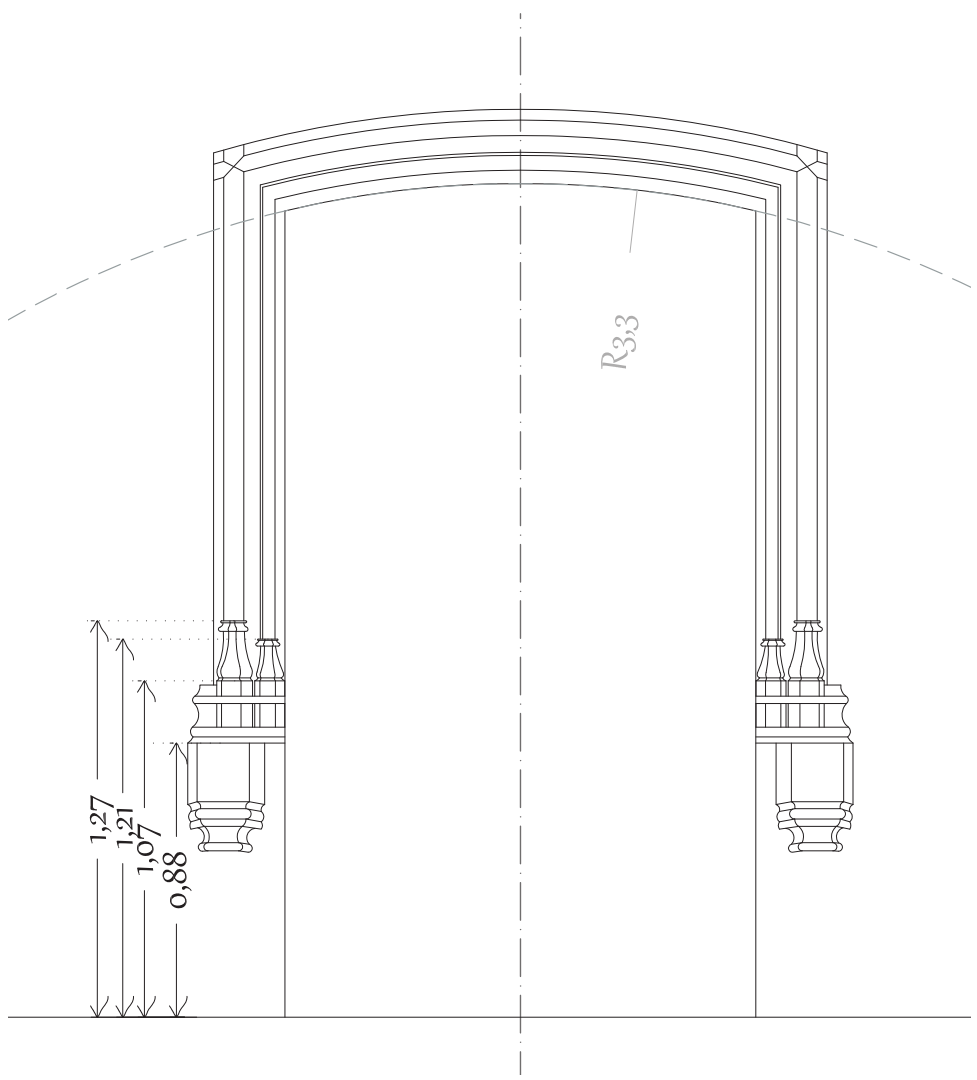

Alzado Geométrico
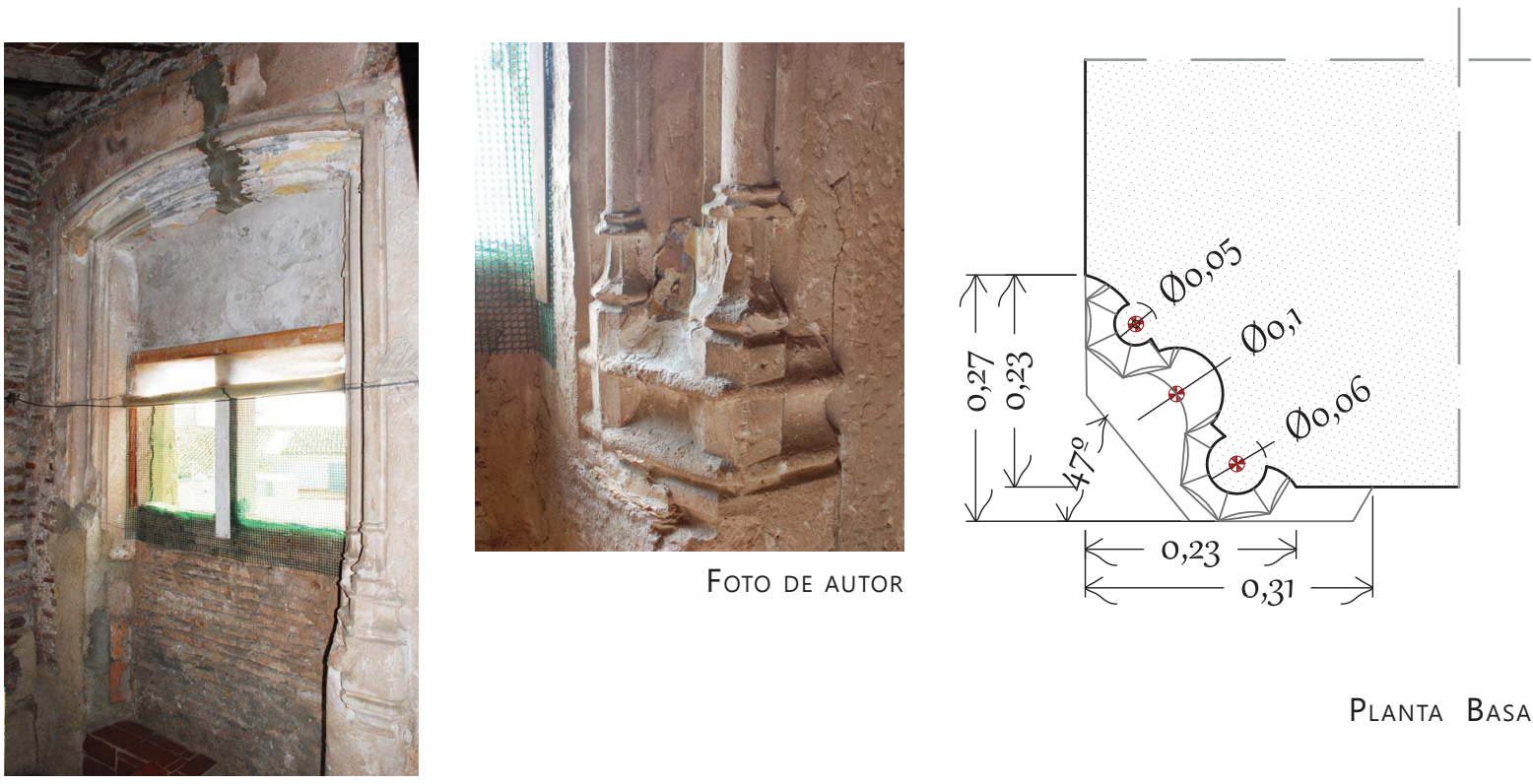

Planta Basa

FOTO DE AUTOR

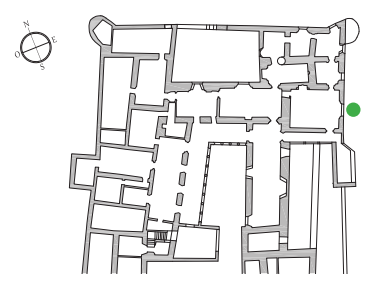

La arquitectura del expoliado Palacio Condal de Oliva a través del legado gráfico

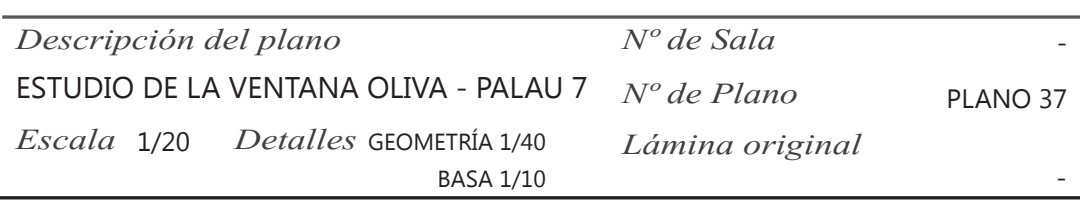




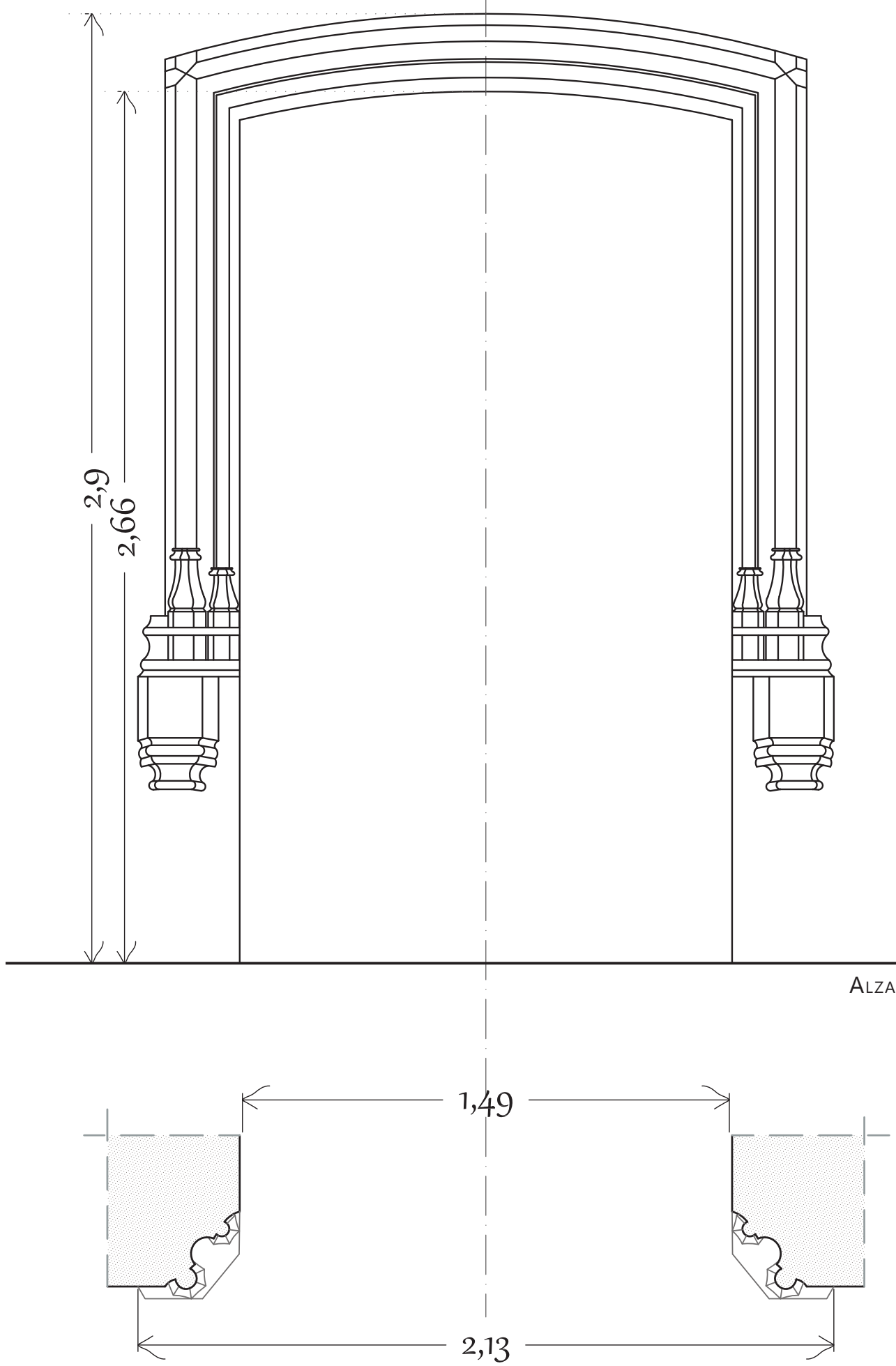

SECCIÓN JAMBA

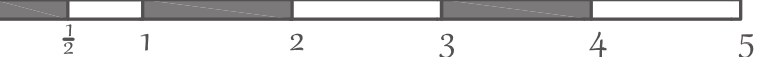

Escala gráfica en palmos valencianos.

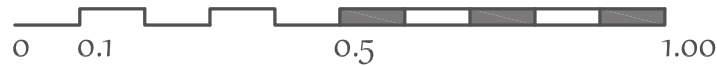

Escala gráfica metros. 



\section{Galería Torre Grande}

"La arquitectura del expoliado Palacio Condal de Oliva a través del legado gráfico" 

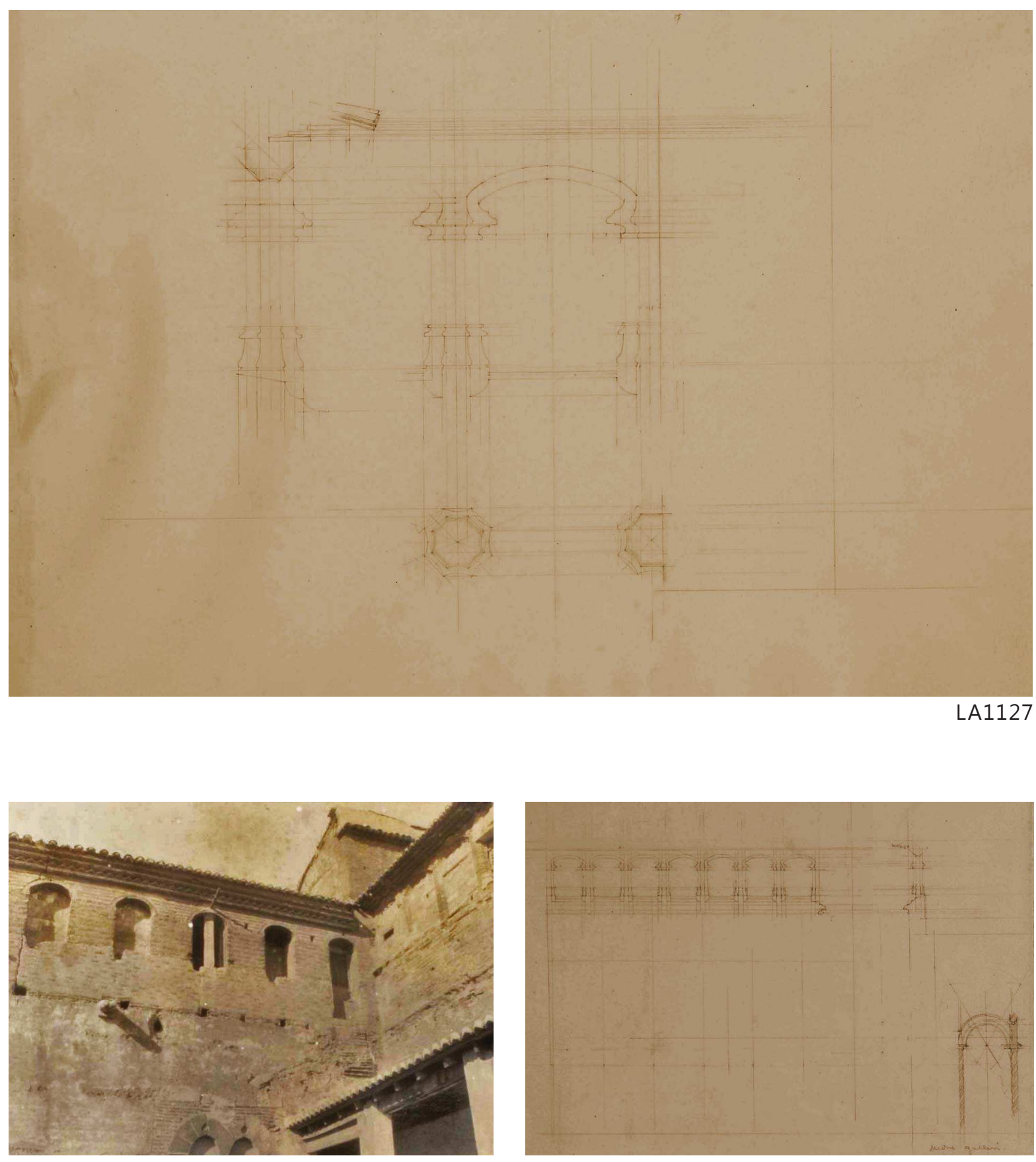

Fото $N^{\circ} 81_{\text {_ }}$ AFG

LA1132

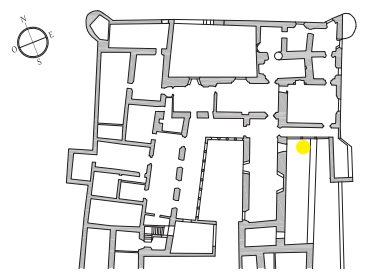

La arquitectura del expoliado Palacio Condal de Oliva a través del legado gráfico

\begin{tabular}{lllr}
\hline Descripción del plano & $N^{o}$ de Sala & PATI DE L’ESCALA \\
ESTUDIO DE LA GALERIA & & $N^{o}$ de Plano & PLANO 38 \\
Escala $1 / 30 \quad$ Detalles & GALERÍA $1 / 15$ & Lámina original &
\end{tabular}



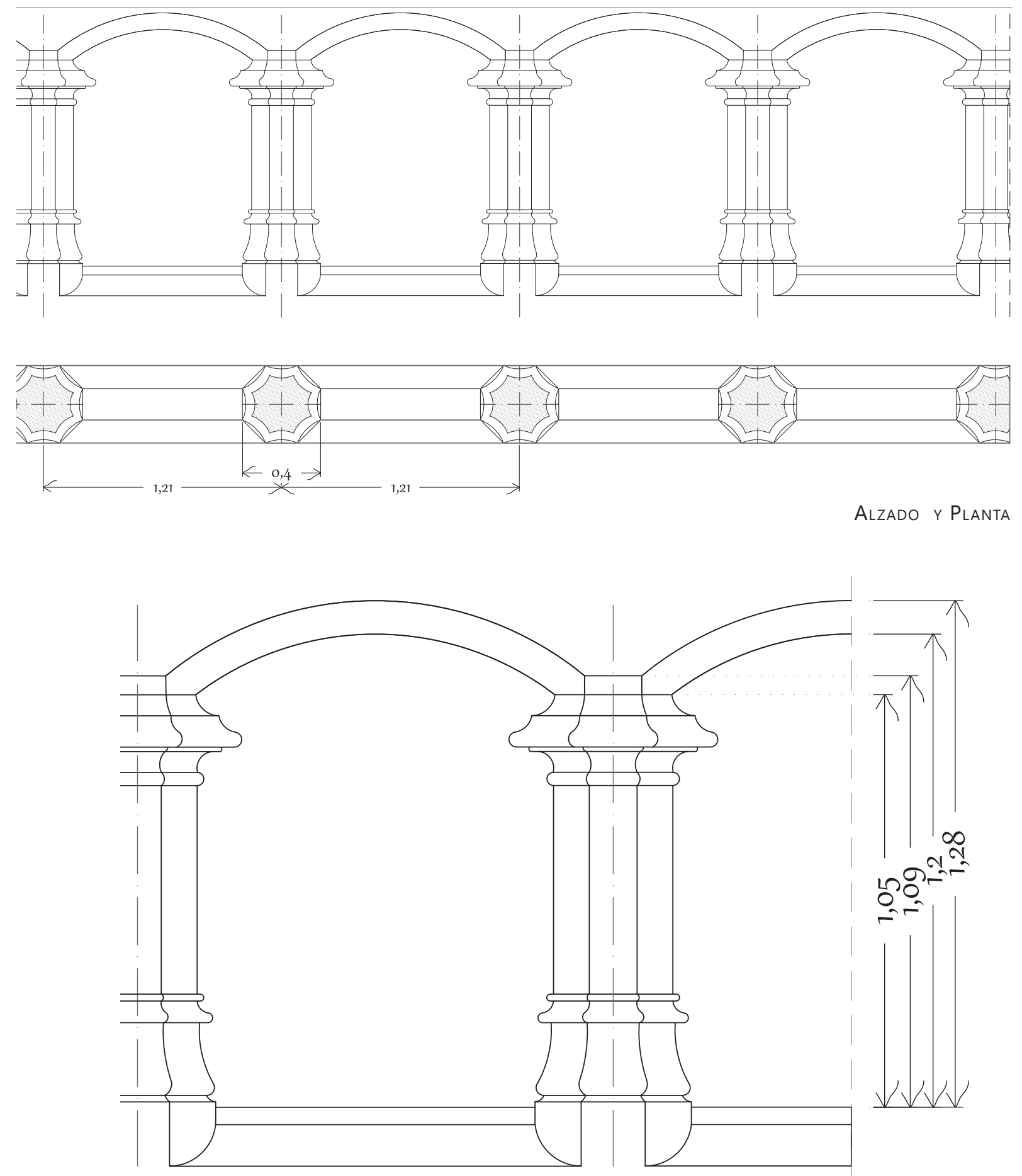

Detalle ARCo DE GALERIA
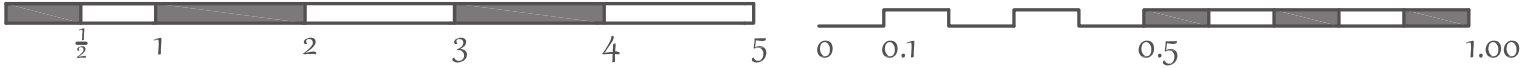

Escala gráfica en palmos valencianos.

Escala gráfica metros. 



\section{Artesonado y Bóveda}

“La arquitectura del expoliado Palacio Condal de Oliva a través del legado gráfico” 
Levantamiento Gráfico Artesonado sala 12
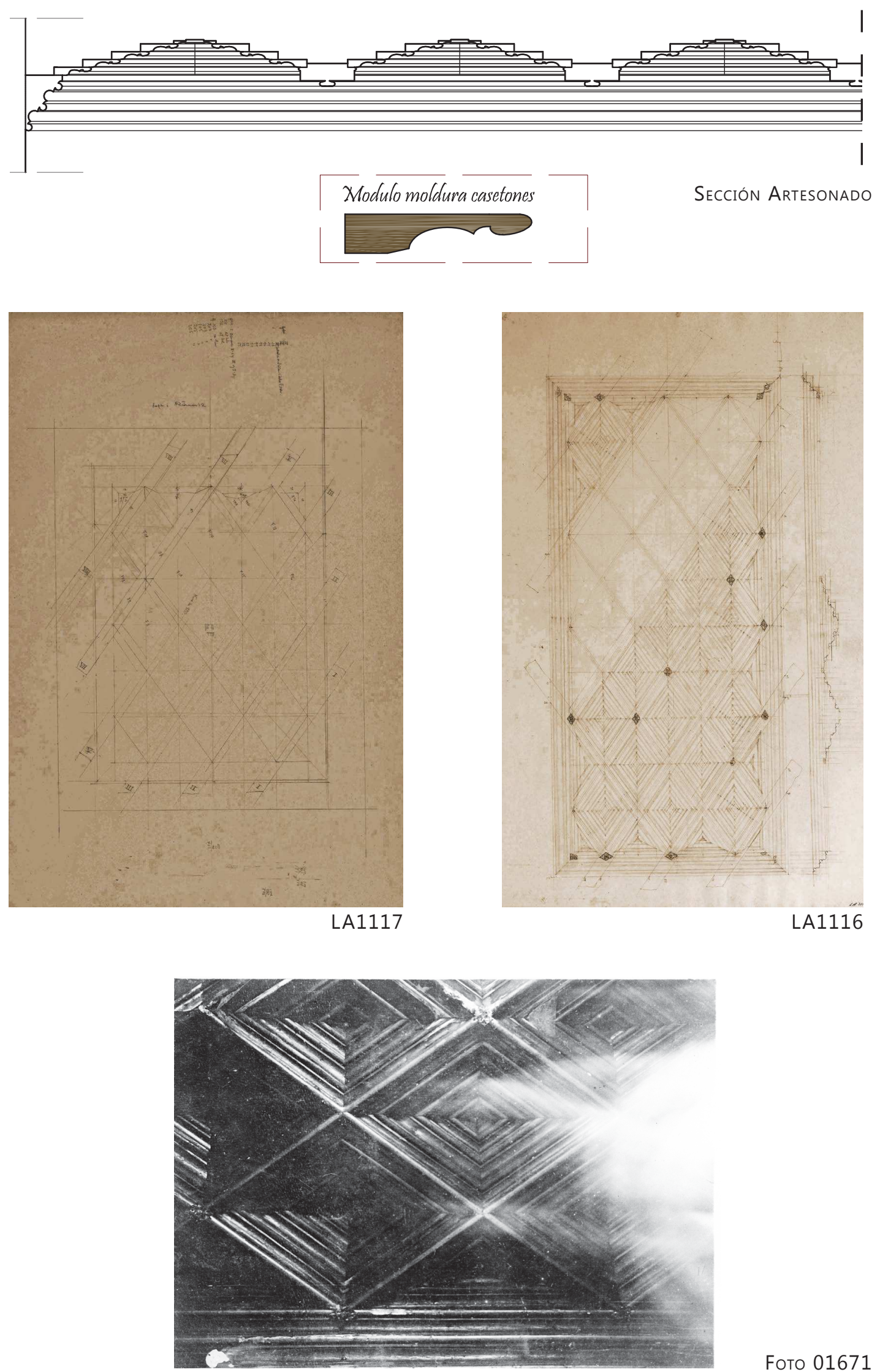

Fото 01671 


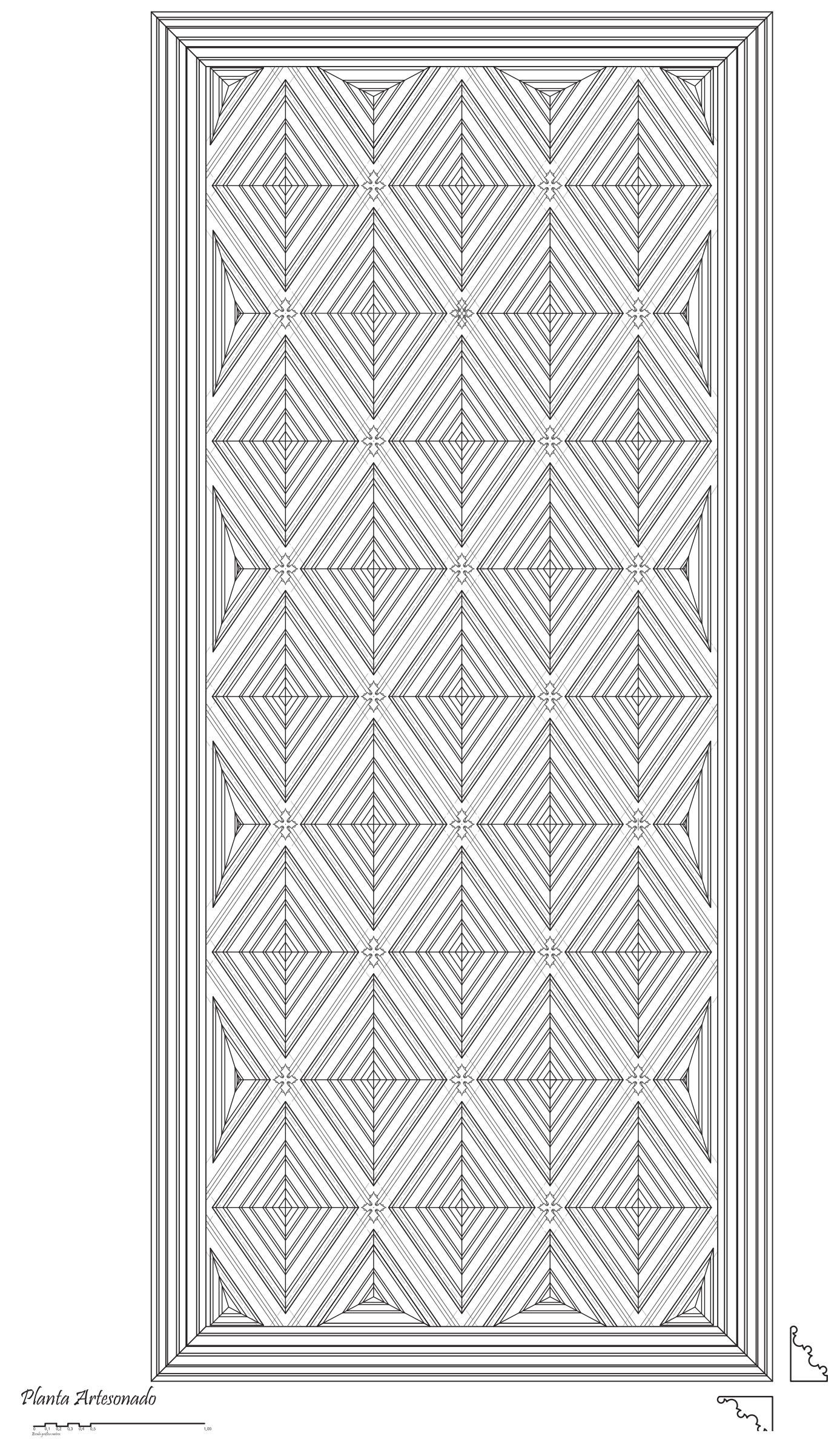


"La arquitectura del expoliado Palacio Condal de Oliva a través del legado gráfico"

Levantamiento Gráfico Bóveda Sala 17

- Trazas y estructura alámbrica de la plementería -
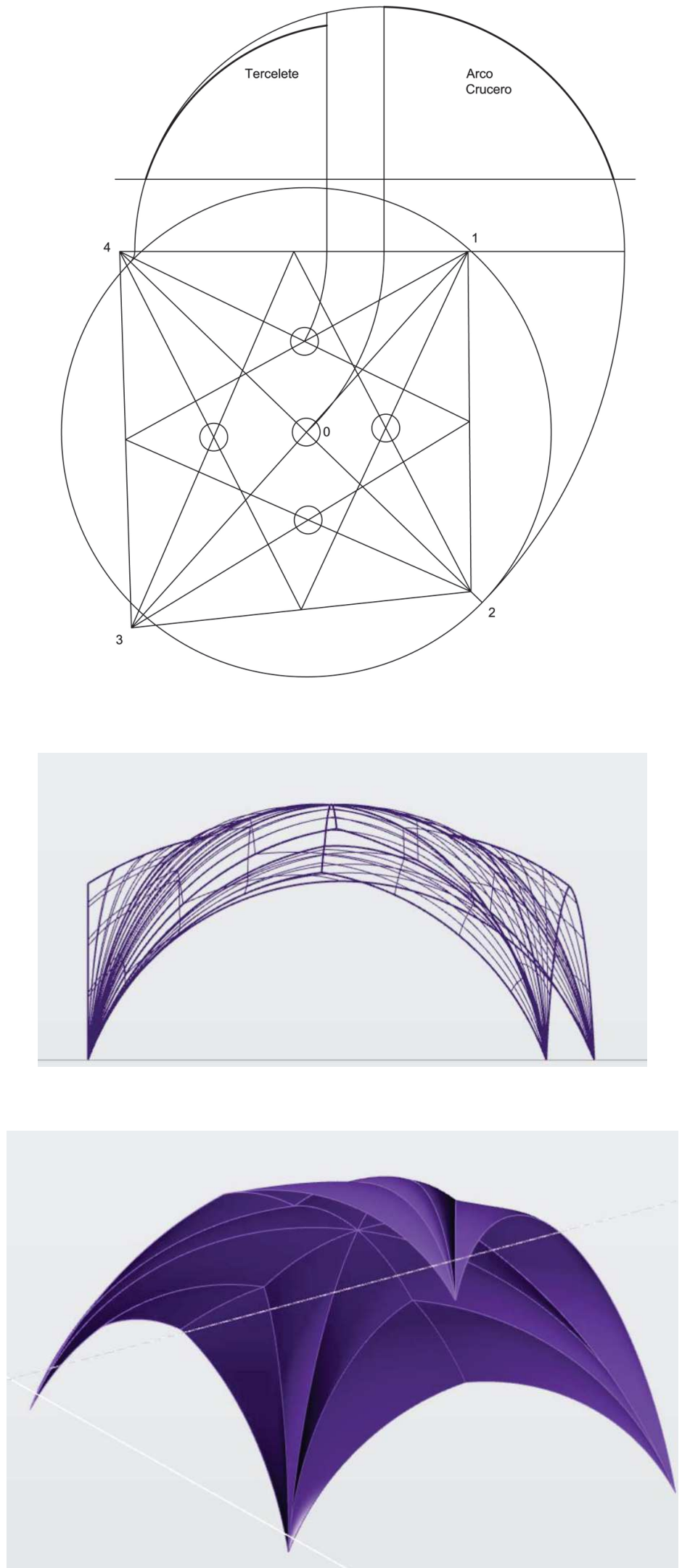
"La arquitectura del expoliado Palacio Condal de Oliva a través del legado gráfico" Levantamiento Gráfico Bóveda Sala 17

- Trazas bóveda 17 SOBre lámina la1124 -

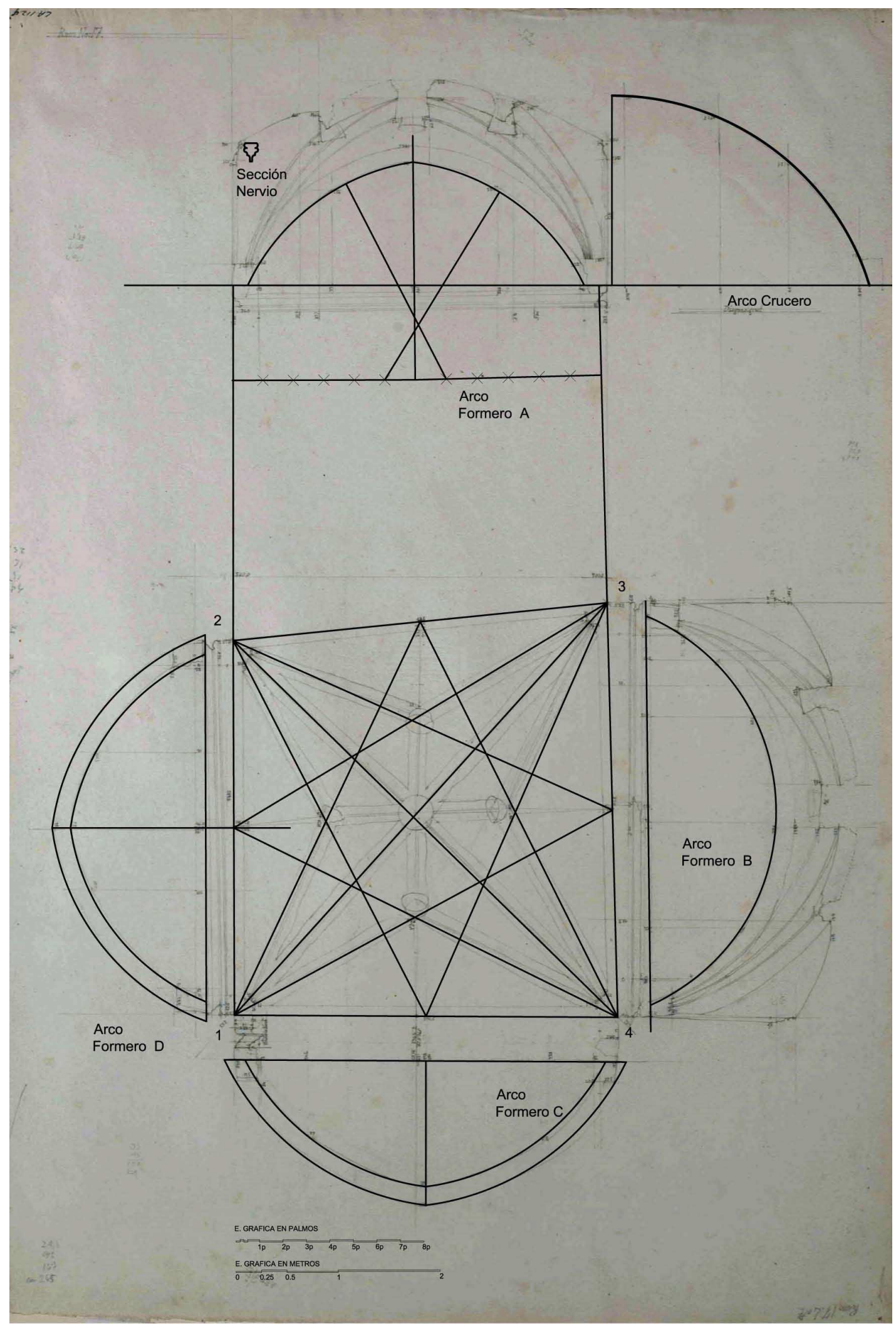





\section{Comparativa Proyecto Pile Allé}

"La arquitectura del expoliado Palacio Condal de Oliva a través del legado gráfico" 

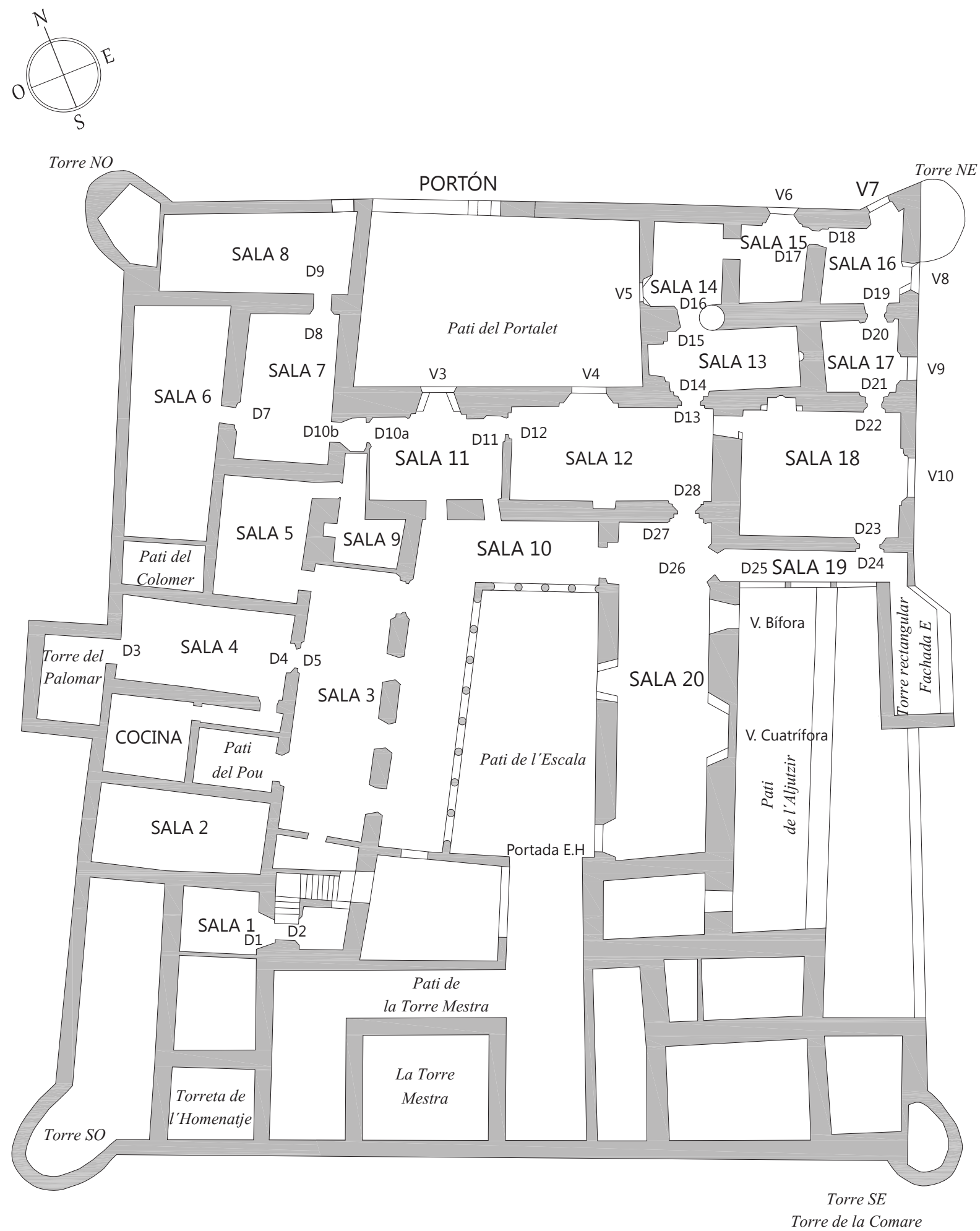

Escala gráfica metros.

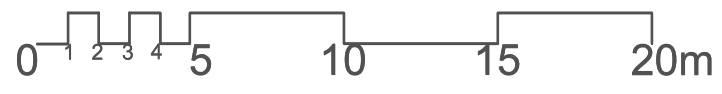


"La arquitectura del expoliado Palacio Condal de Oliva a través del legado gráfico"

PLANO SITUACIÓN DE PORTADAS Y VENTANAS. PROYECTO PILE ALLÉ. LA1138

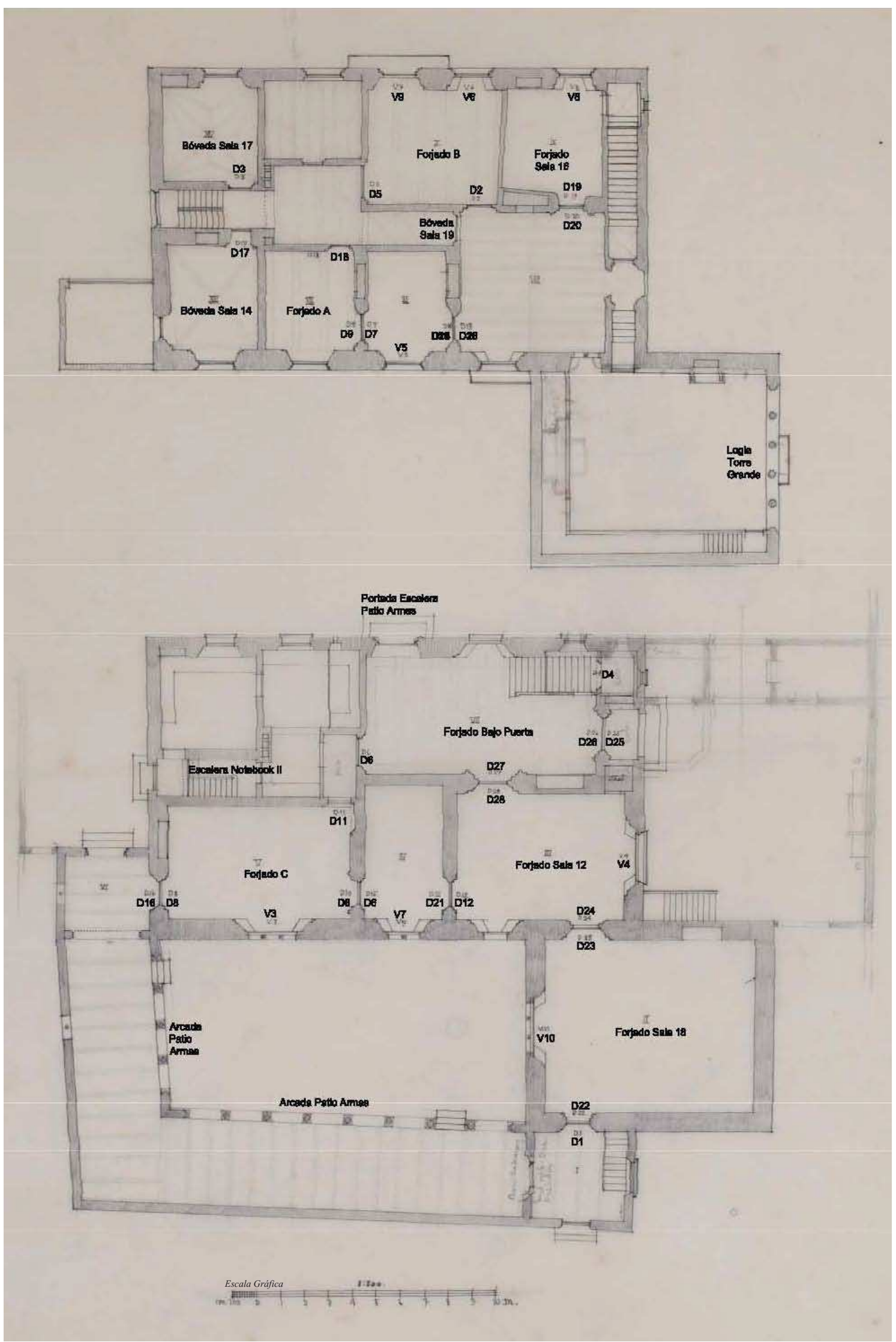





\section{Modulaciones}

"La arquitectura del expoliado Palacio Condal de Oliva a través del legado gráfico" 


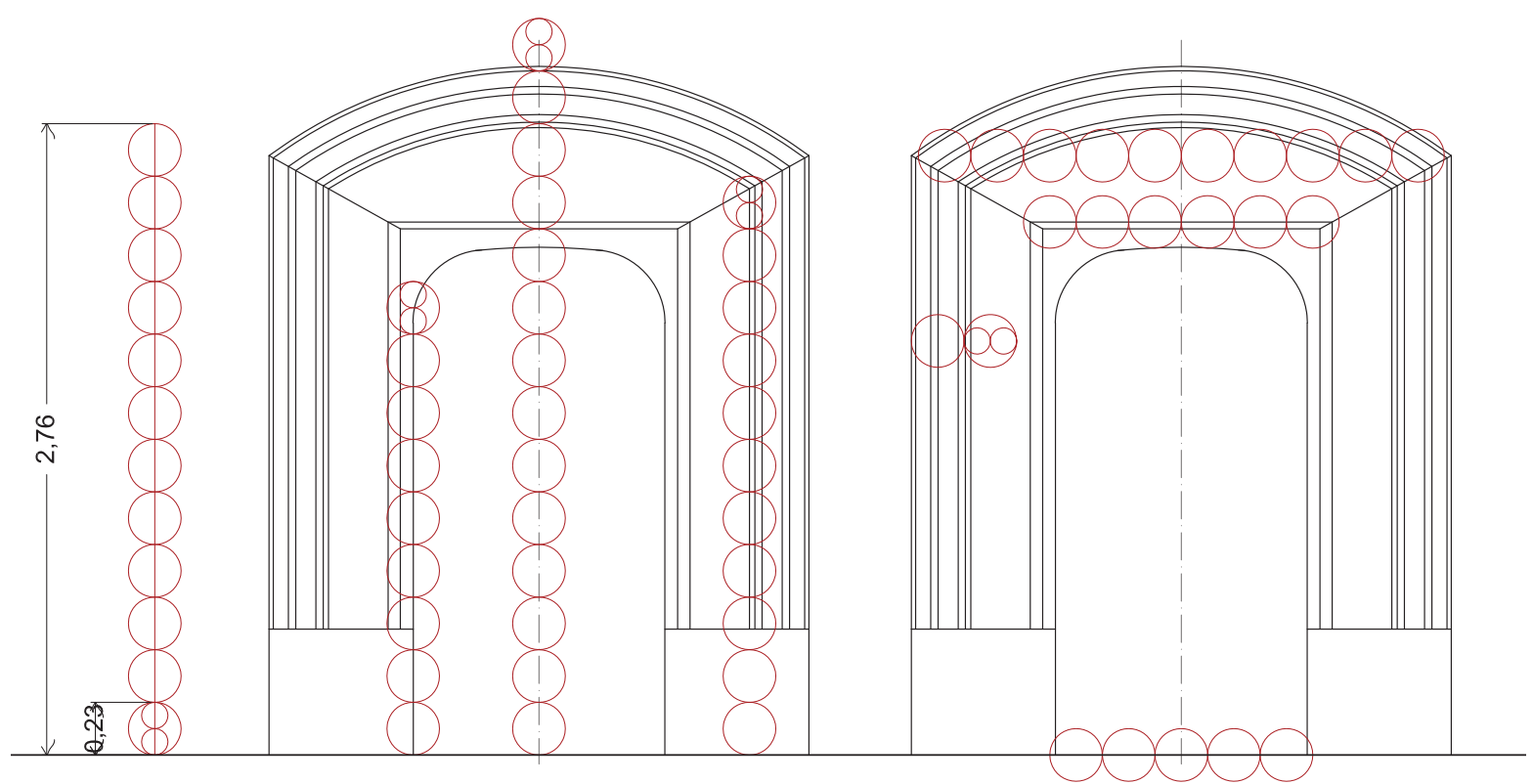

MODULACIÓN PORTADA 1 - DÖR 1

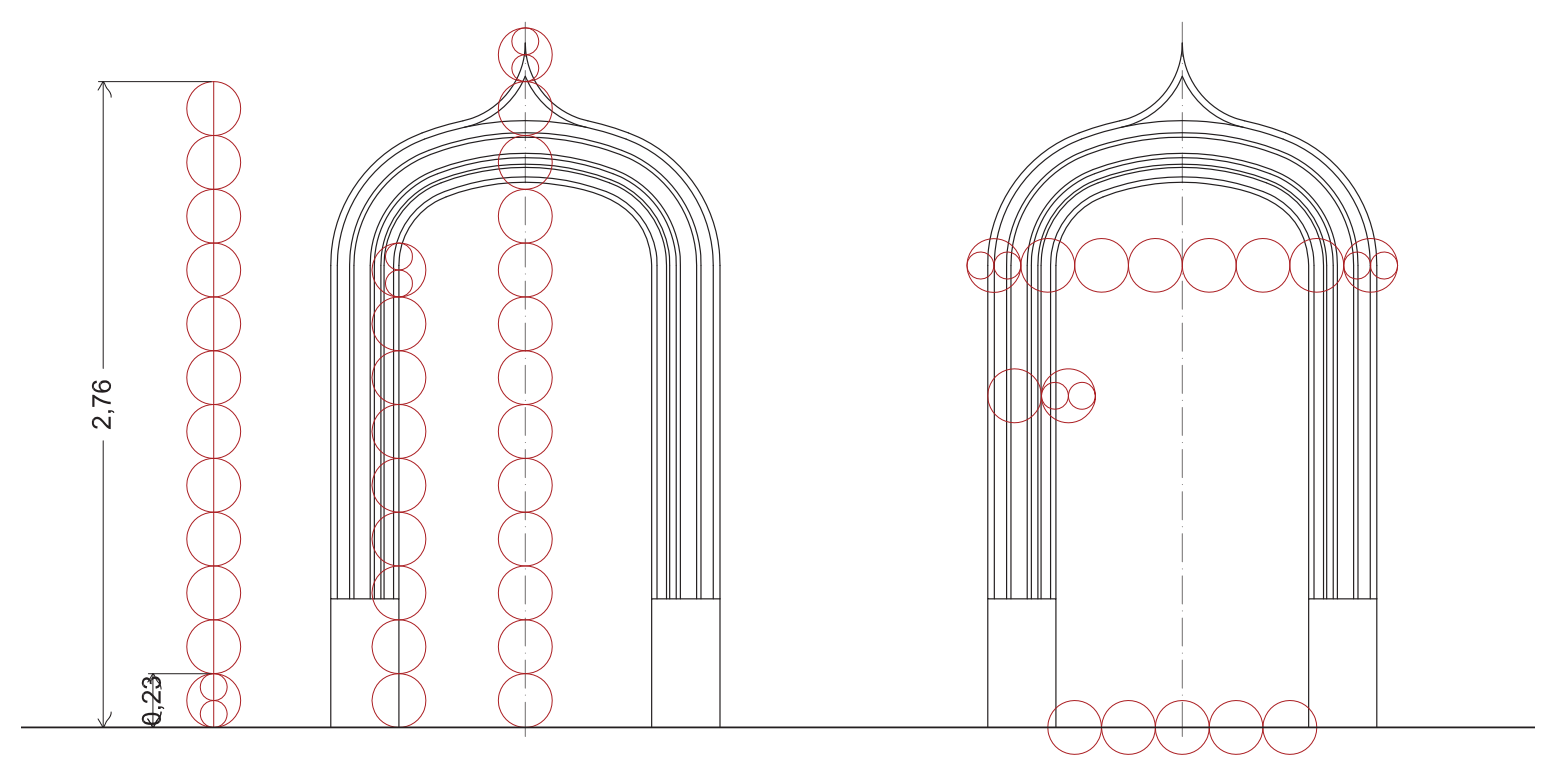

MODULACIÓN PORTADA 2 - DÖR 2 


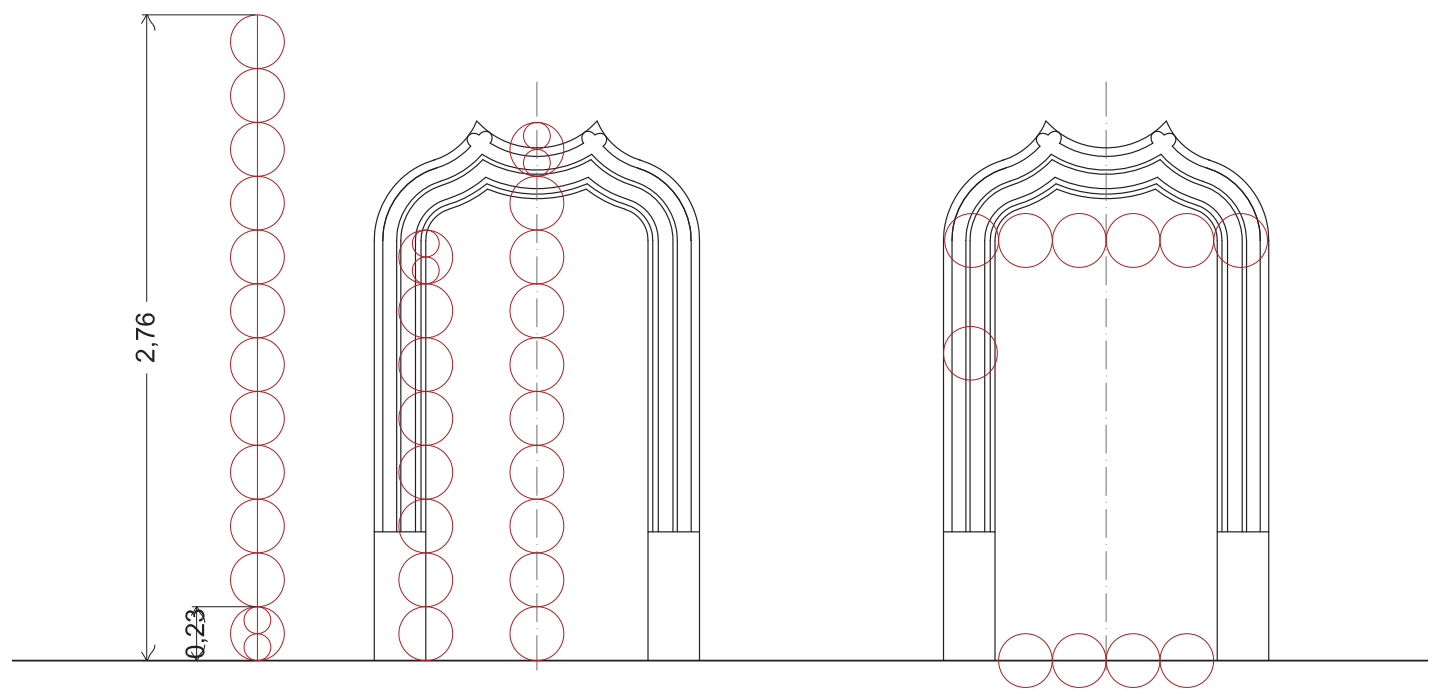

MODULACIÓN PORTADA 4 - DÖR 4

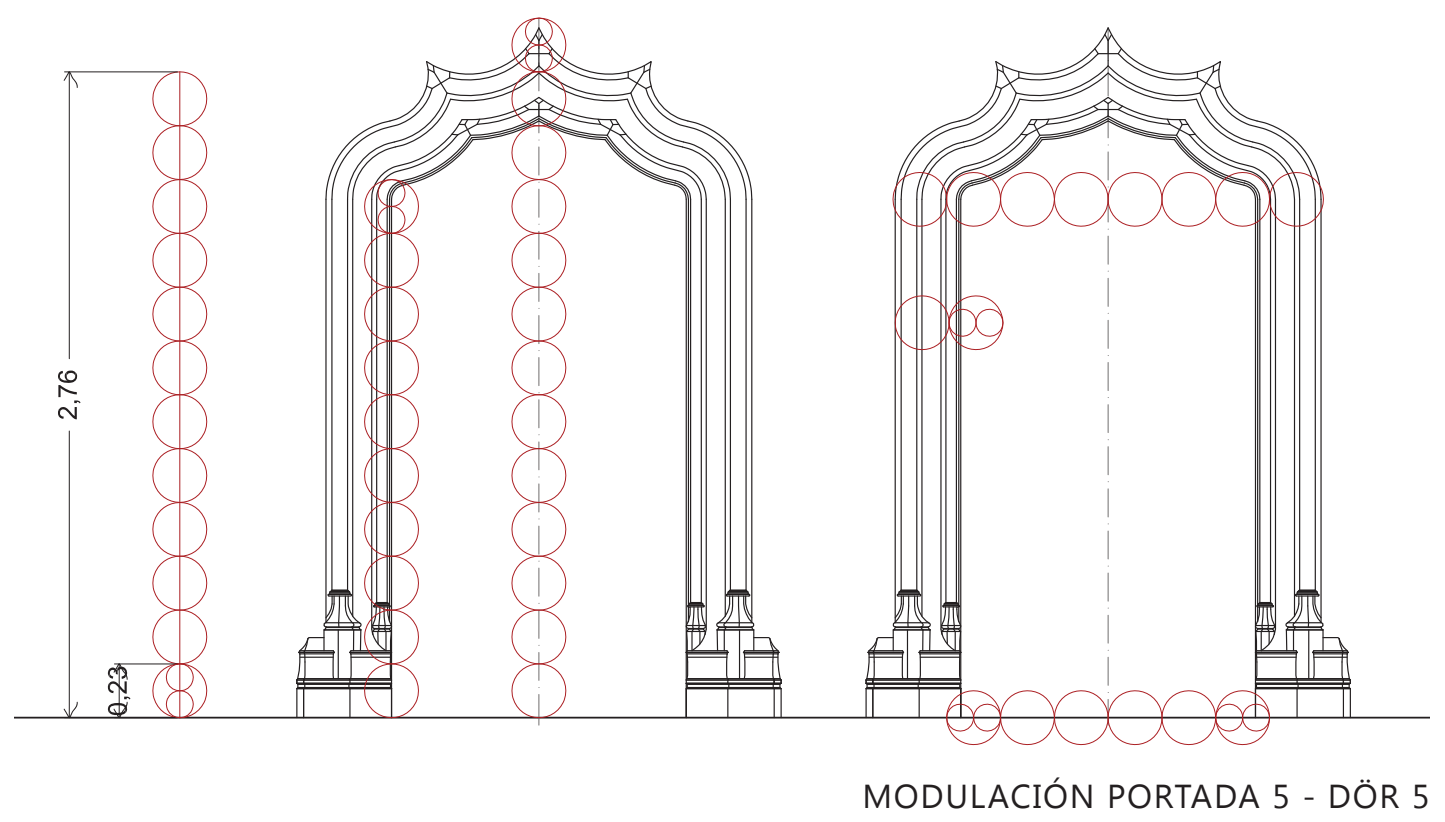



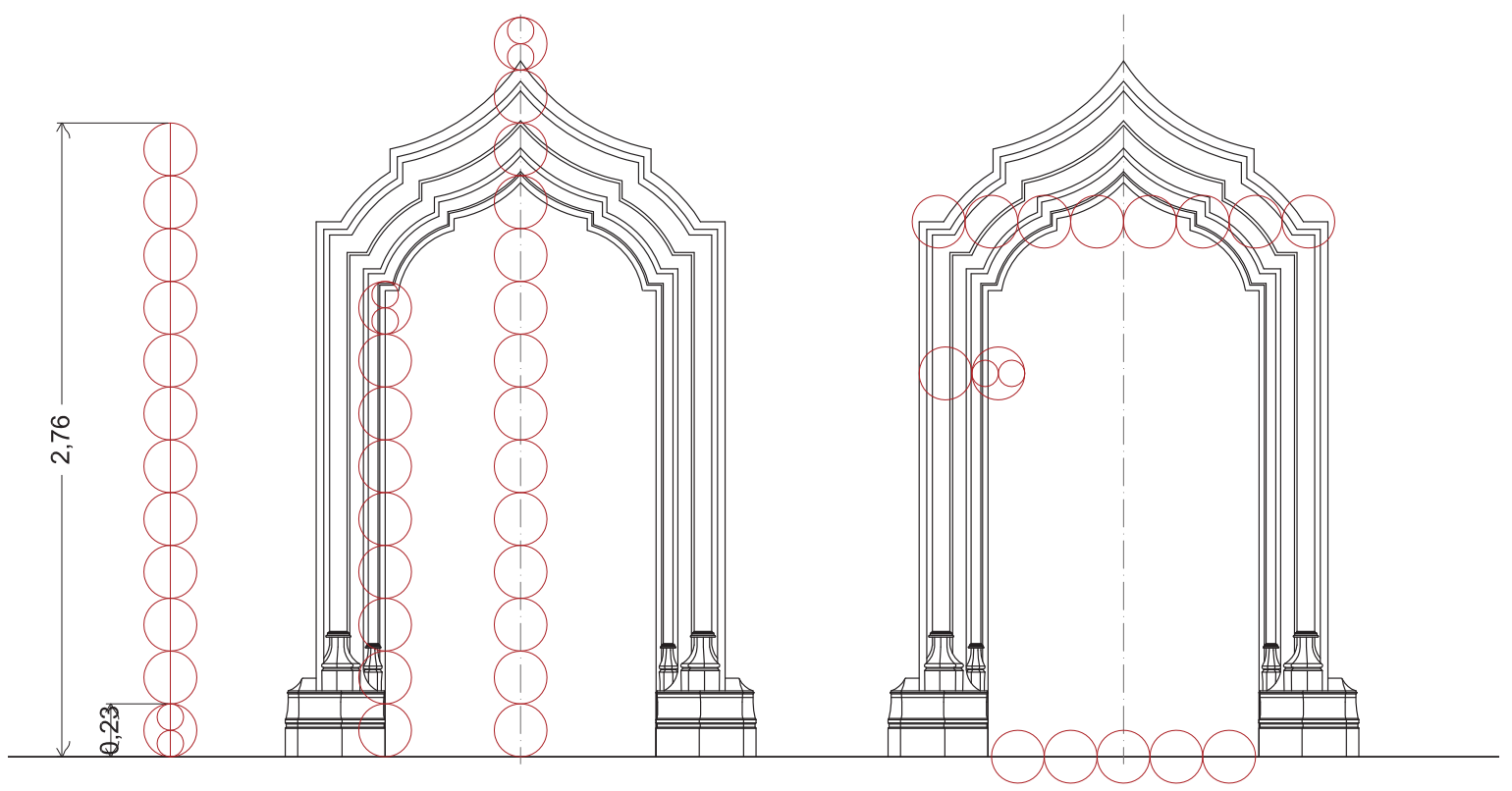

MODULACIÓN PORTADA 6 - DÖR 6
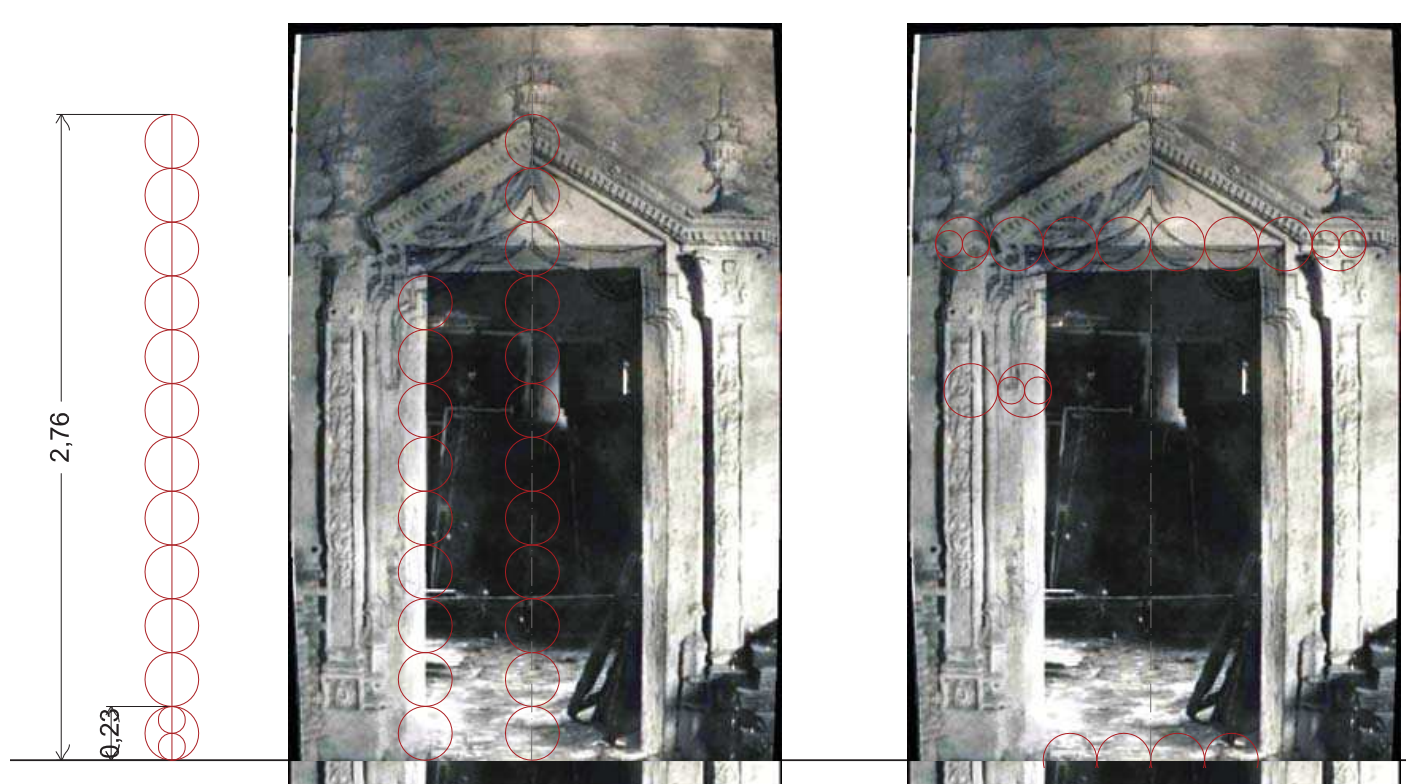

MODULACIÓN PORTADA 7 - DÖR 7 


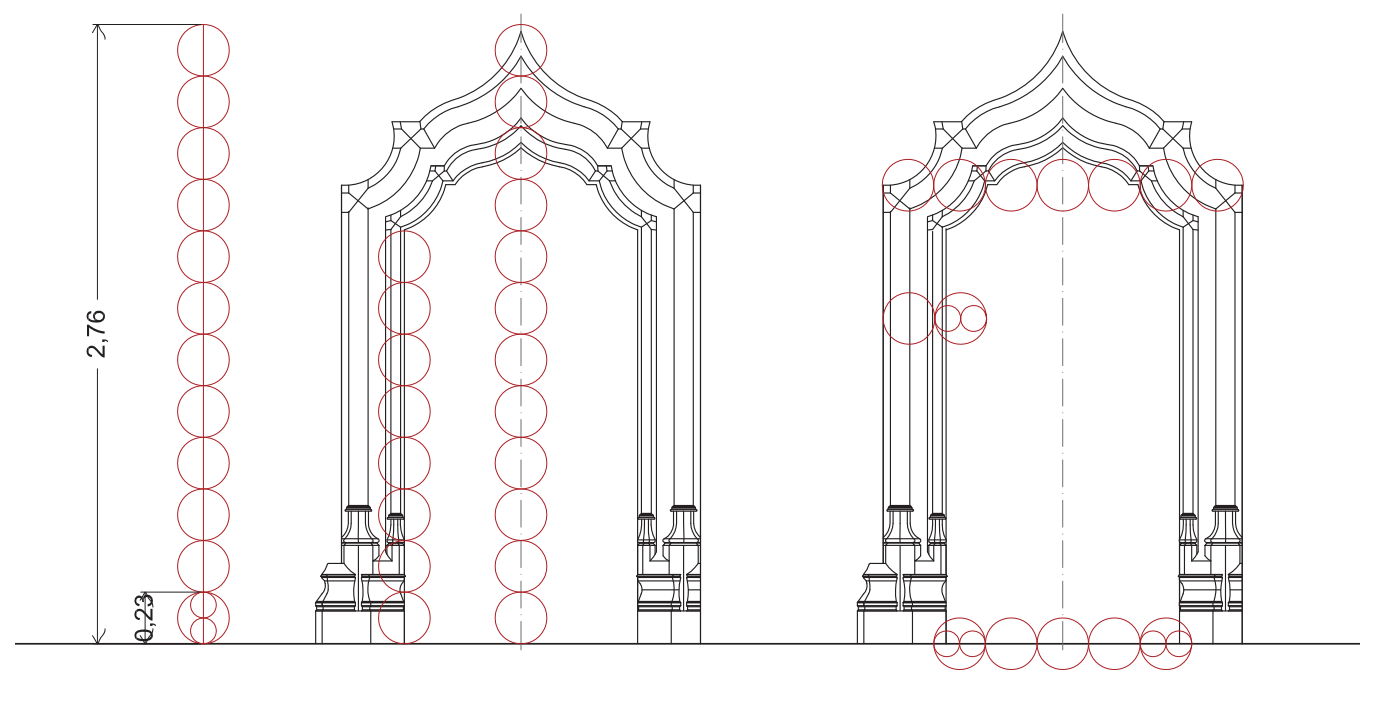

MODULACIÓN PORTADA 8 - DÖR 8

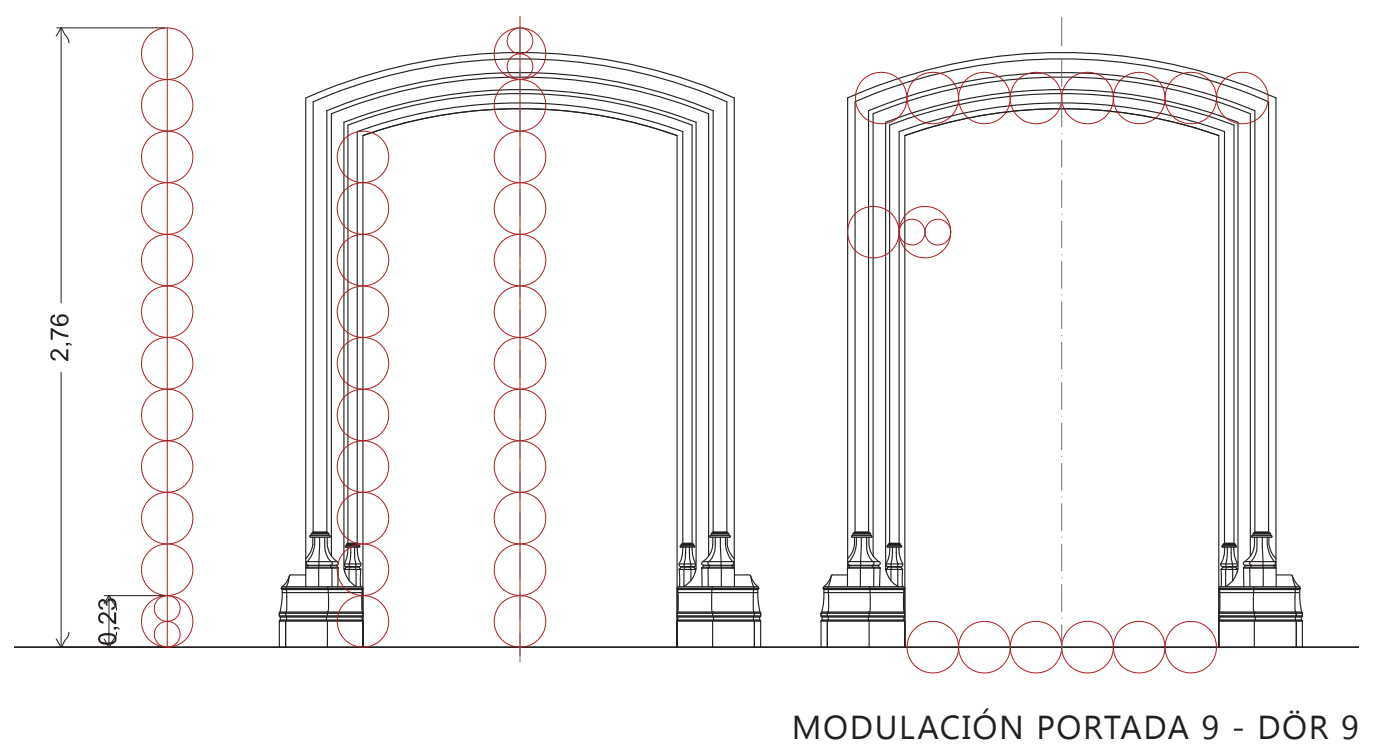




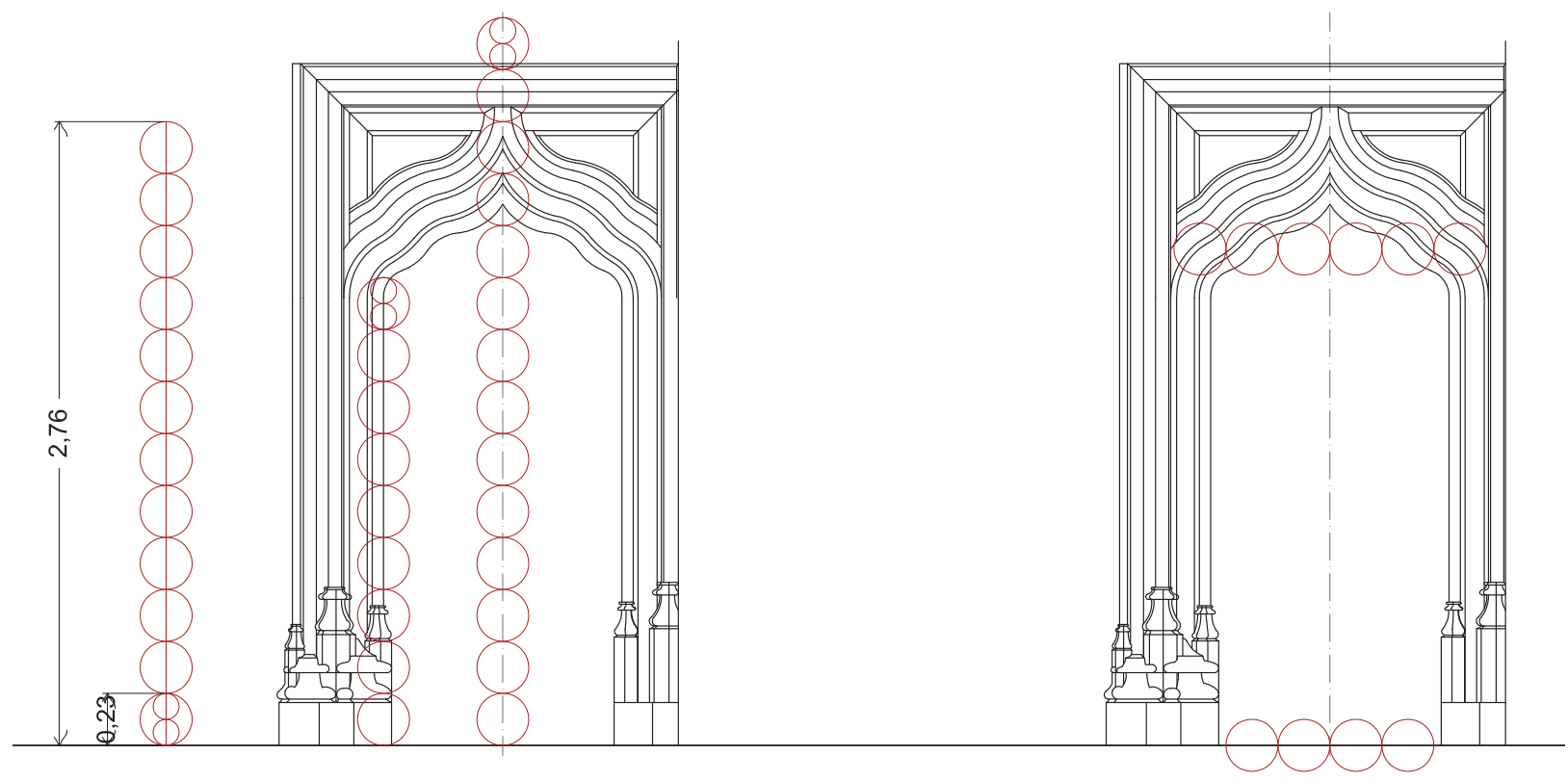

MODULACIÓN PORTADA 10 - DÖR 10

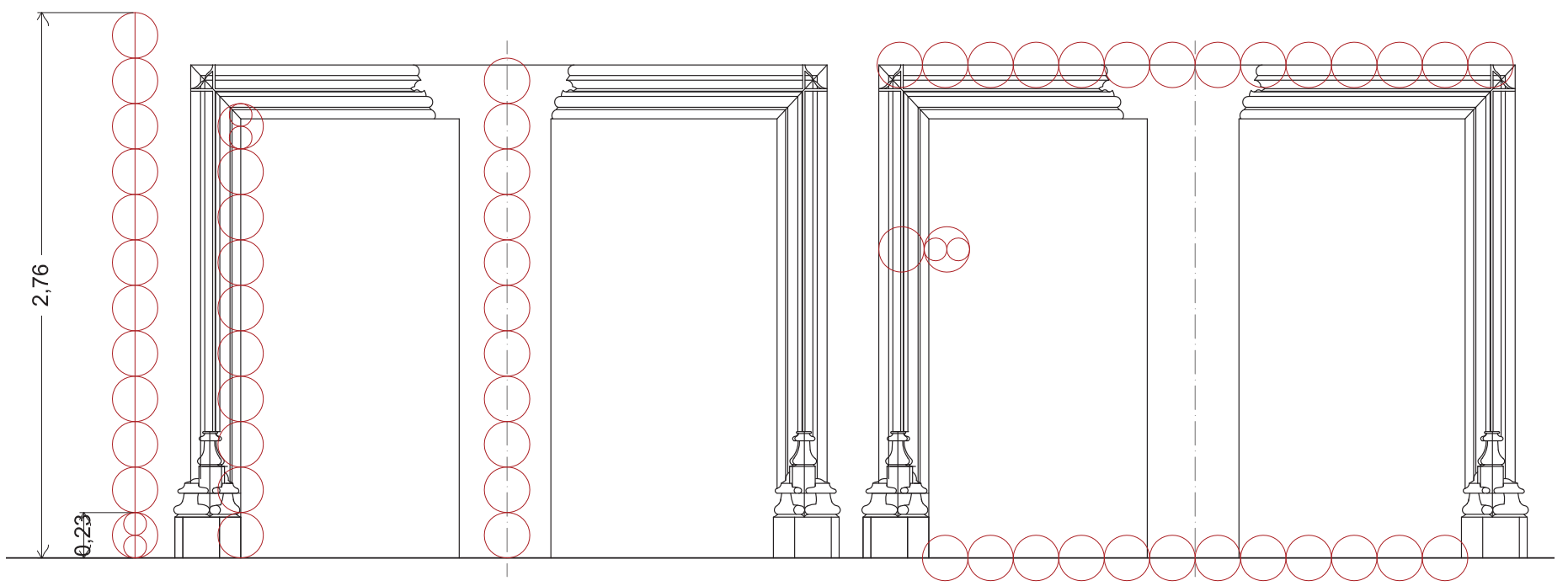

MODULACIÓN PORTADA 11 - DÖR 11 


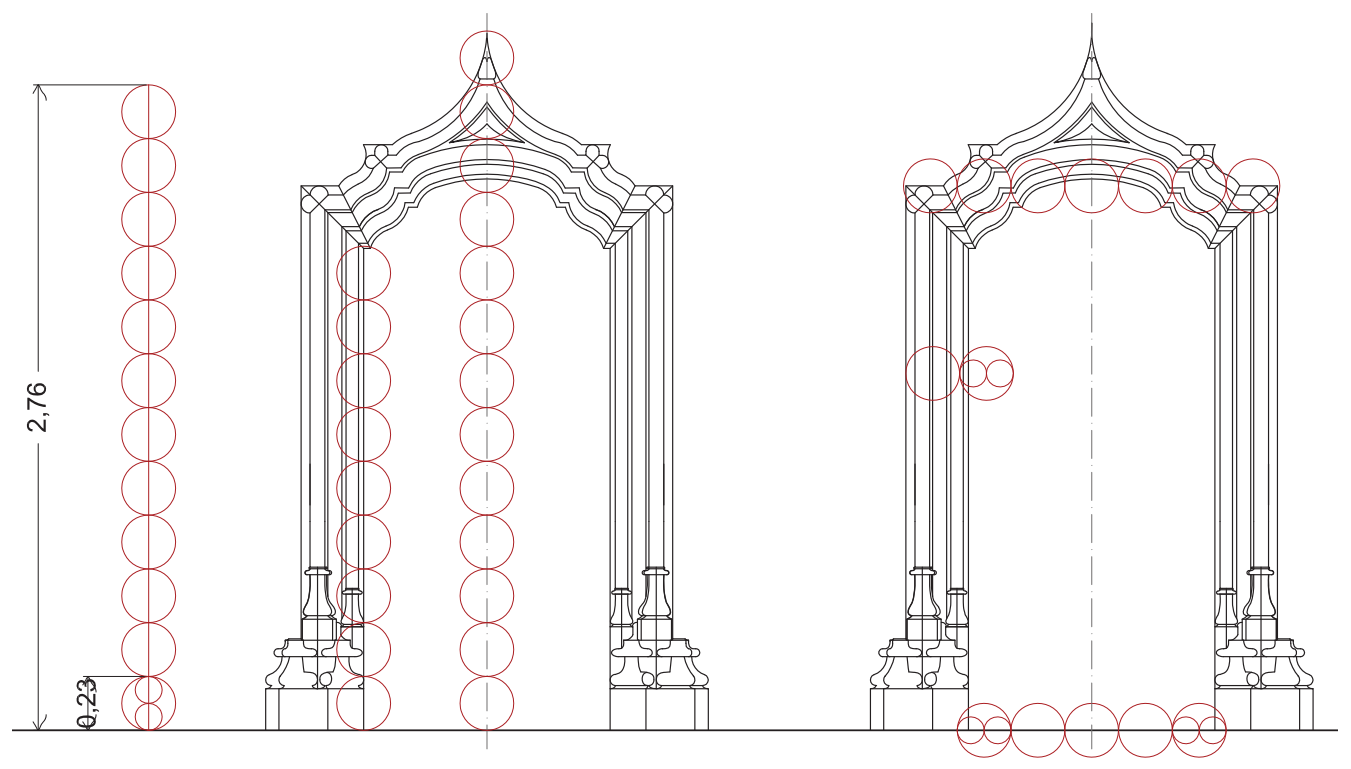

MODULACIÓN PORTADA 12 - DÖR 12

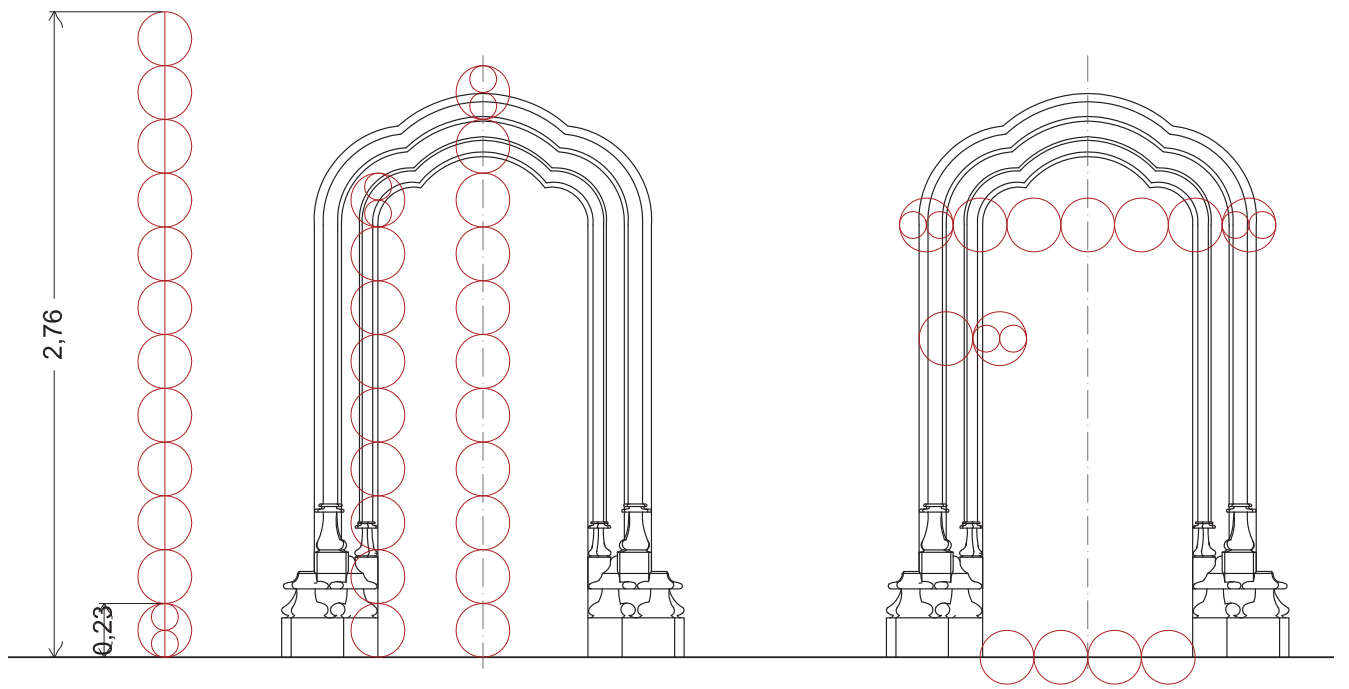

MODULACIÓN PORTADA 13 - DÖR 13 

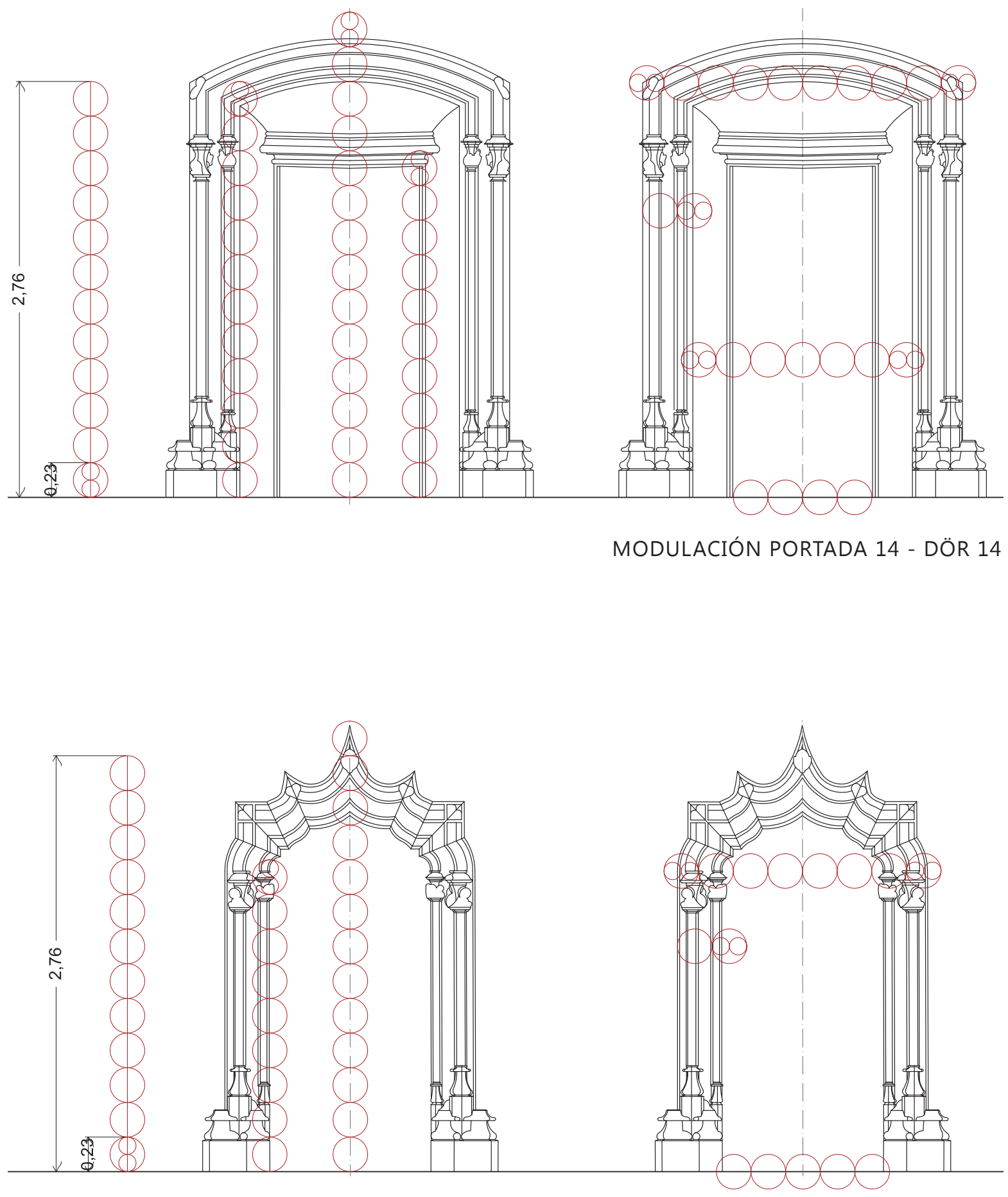

MODULACIÓN PORTADA 15 - DÖR 15 

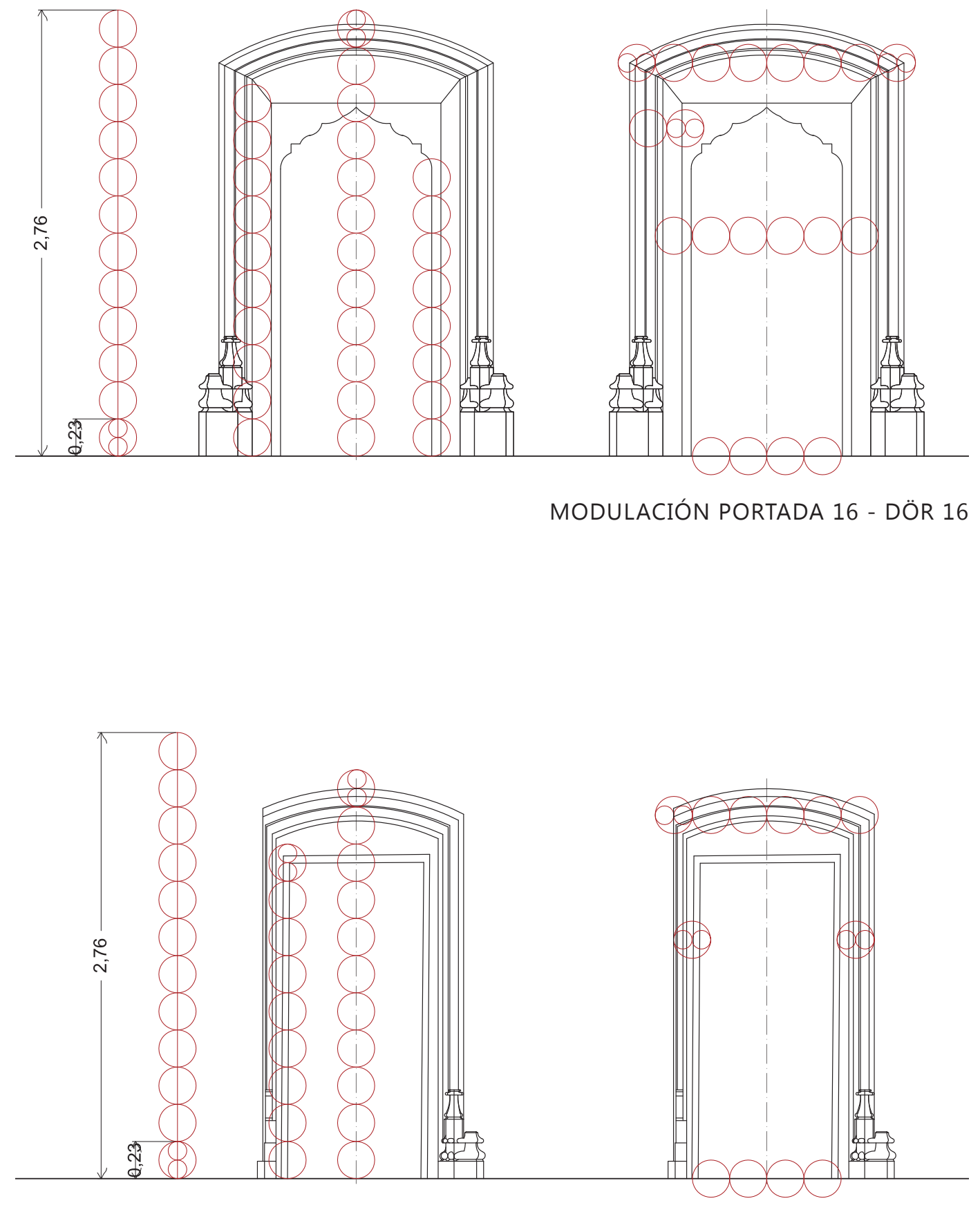

MODULACIÓN PORTADA 17 - DÖR 17 


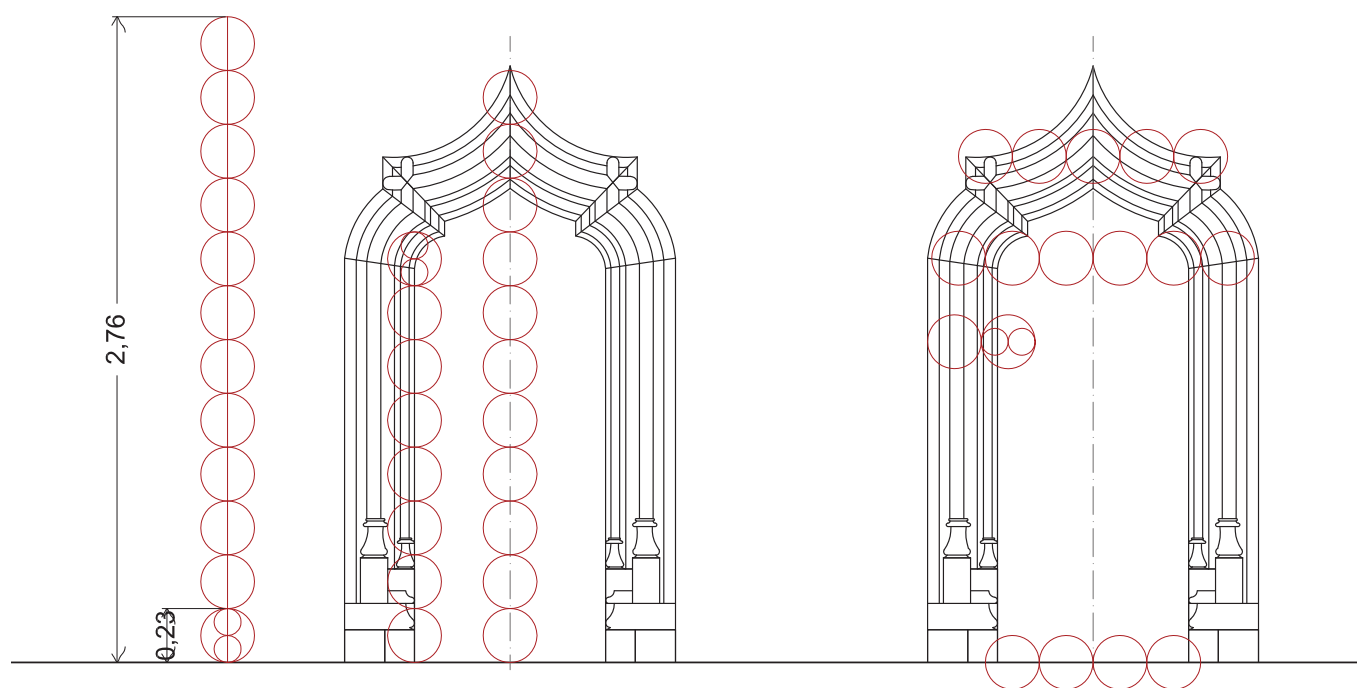

MODULACIÓN PORTADA 18 - DÖR 18

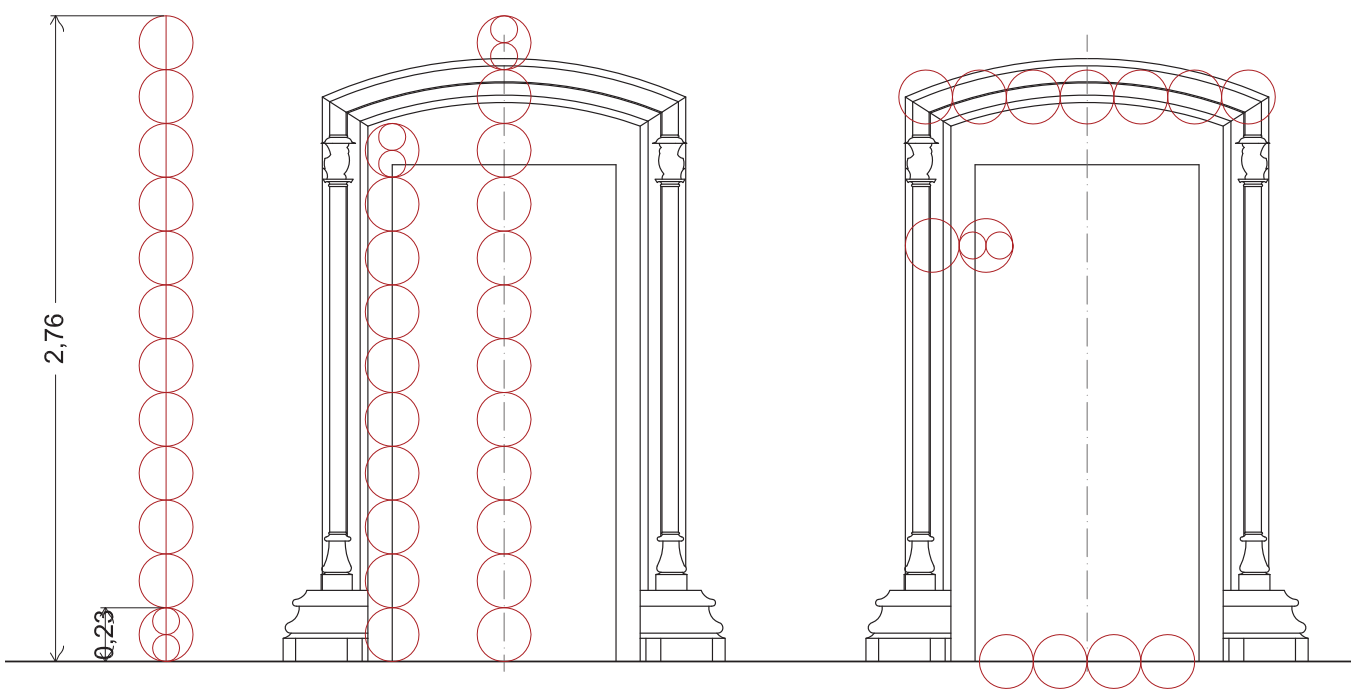

MODULACIÓN PORTADA 19 - DÖR 19 

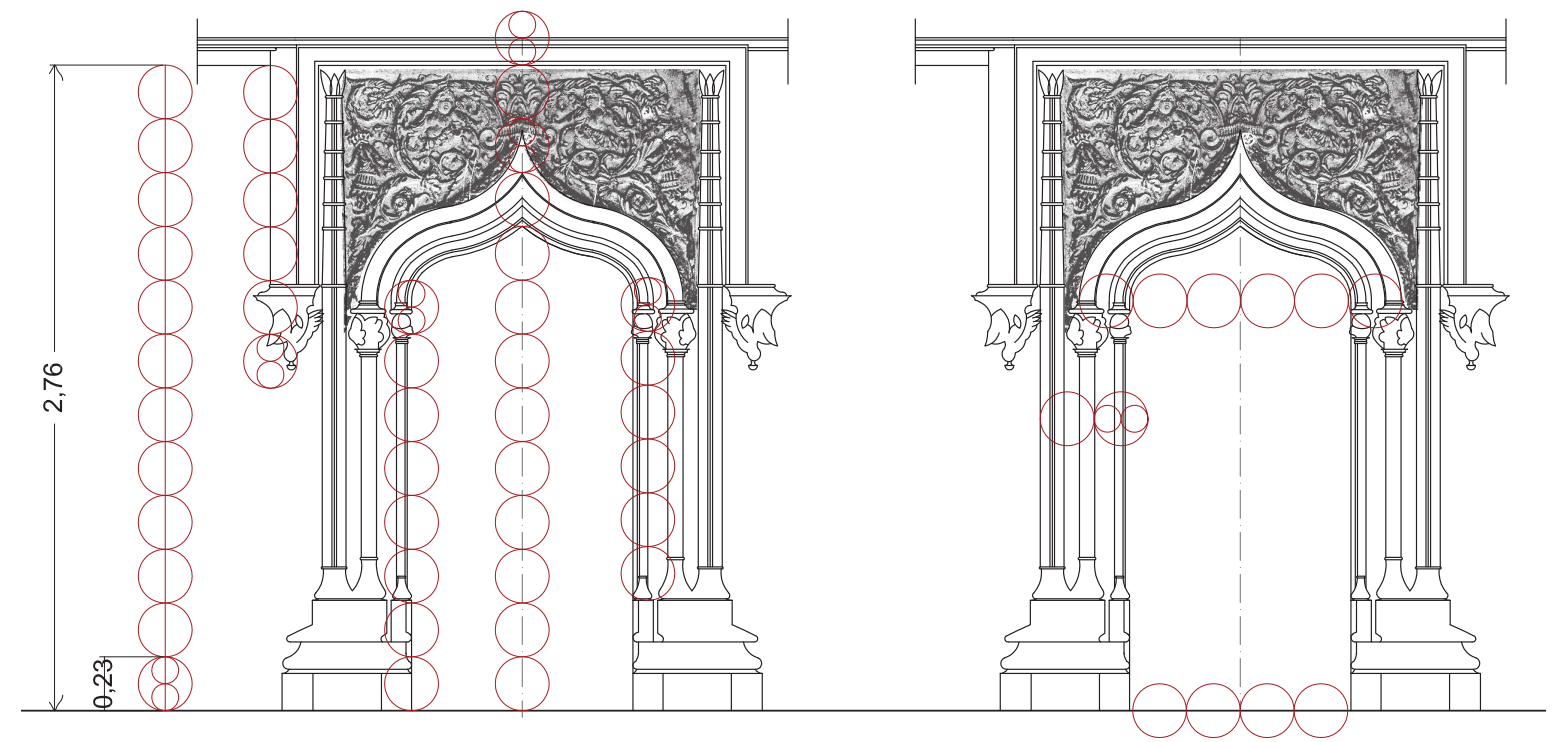

MODULACIÓN PORTADA 20 - DÖR 20

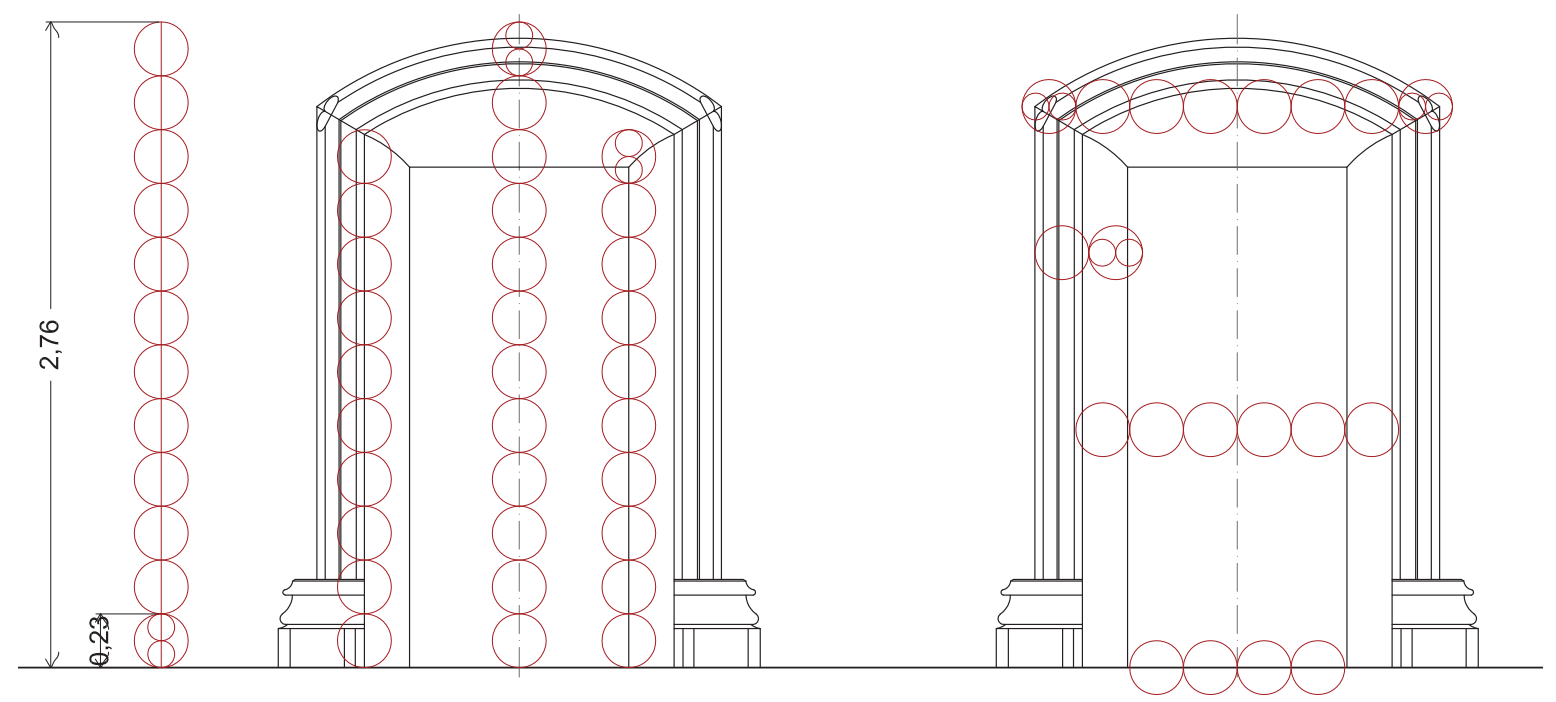

MODULACIÓN PORTADA 21 - DÖR 21 

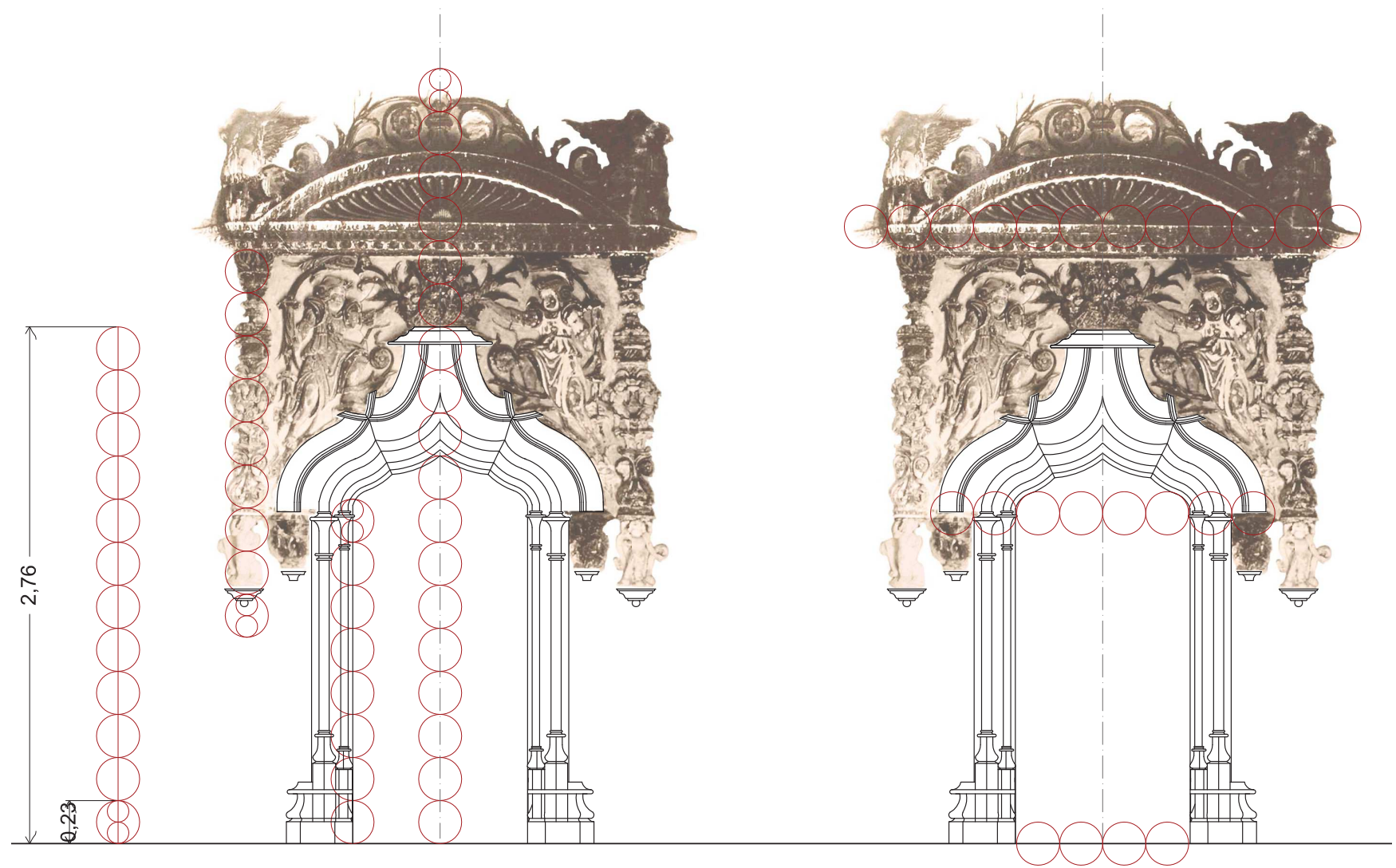

MODULACIÓN PORTADA 22 - DÖR 22

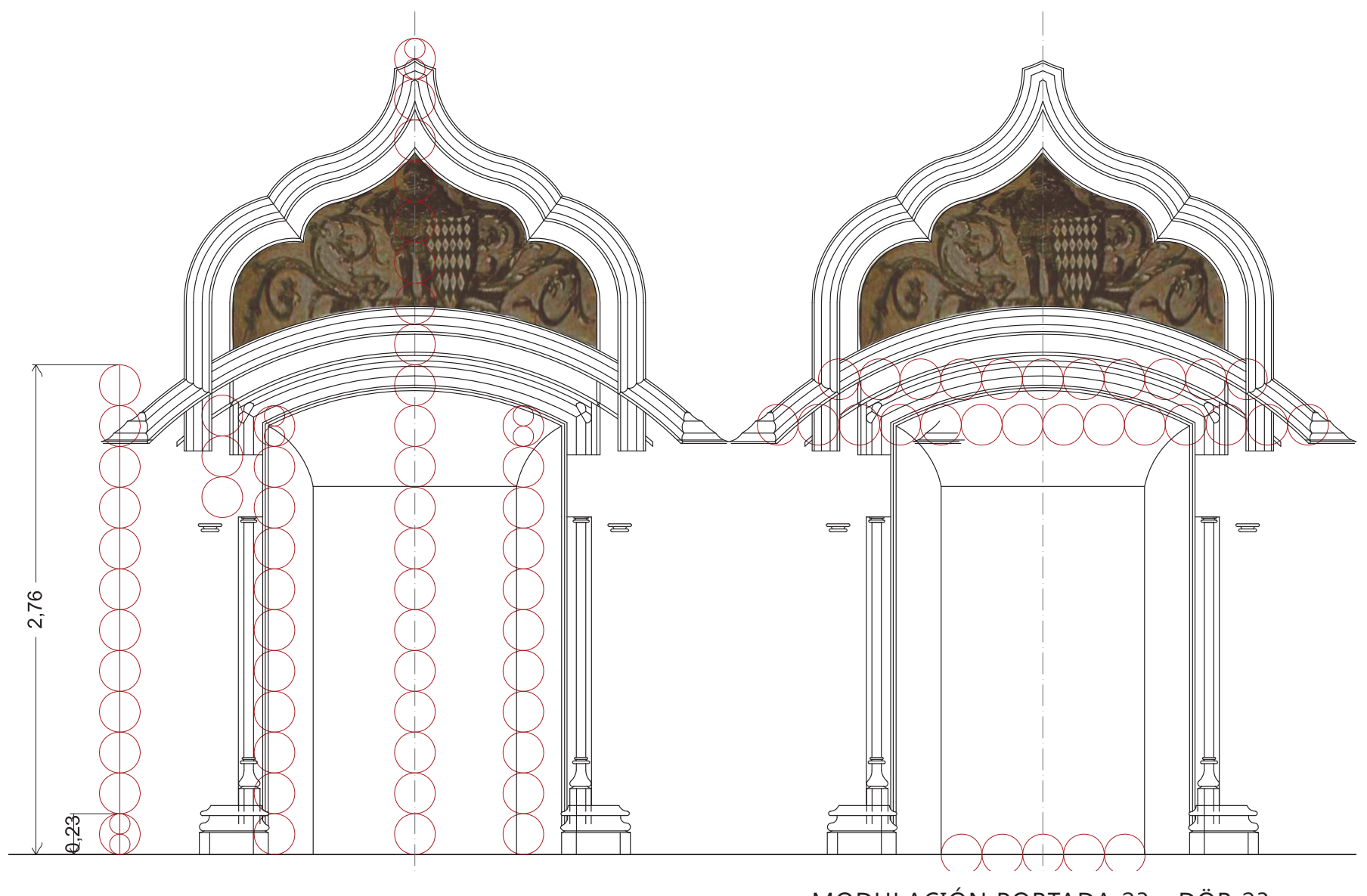

MODULACIÓN PORTADA 23 - DÖR 23 

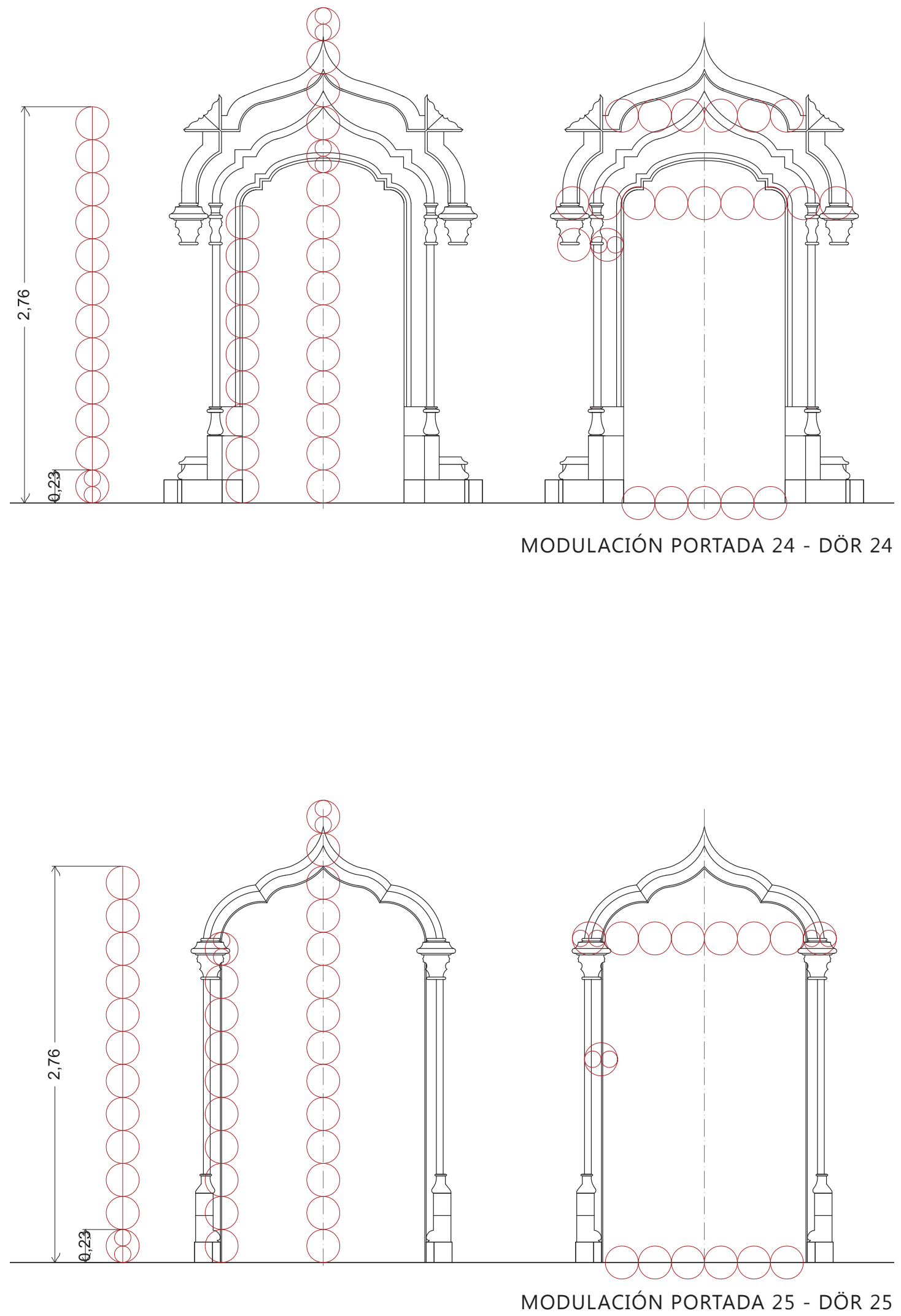

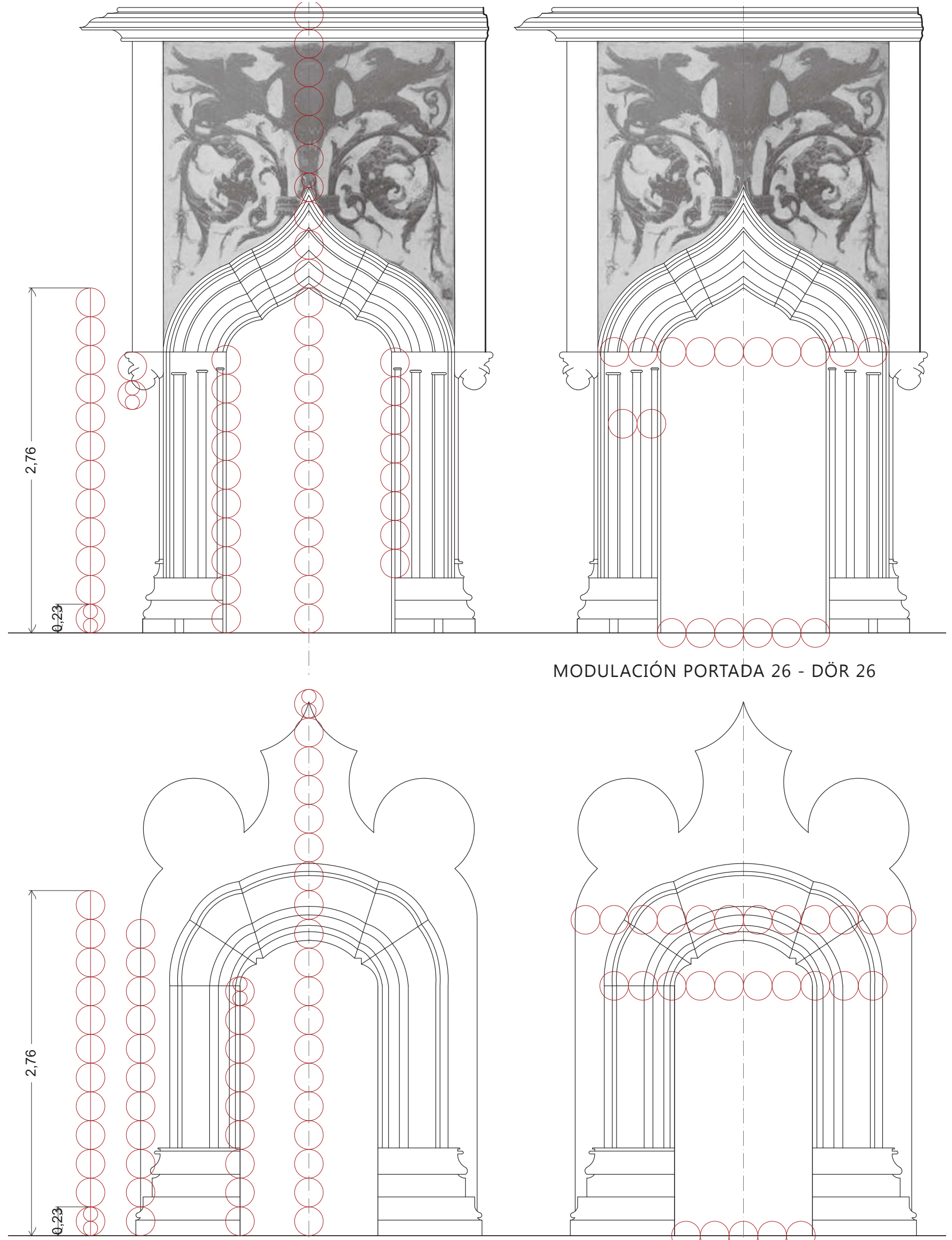

MODULACIÓN PORTADA 26 - DÖR 26

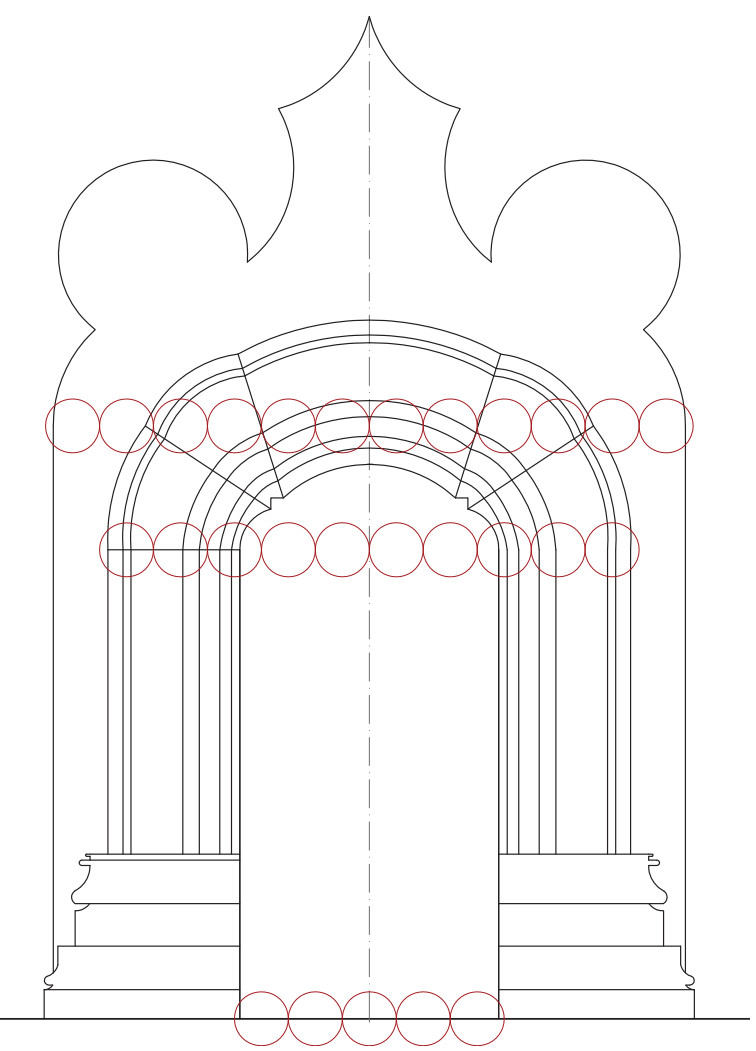

MODULACIÓN PORTADA 27 - DÖR 27 

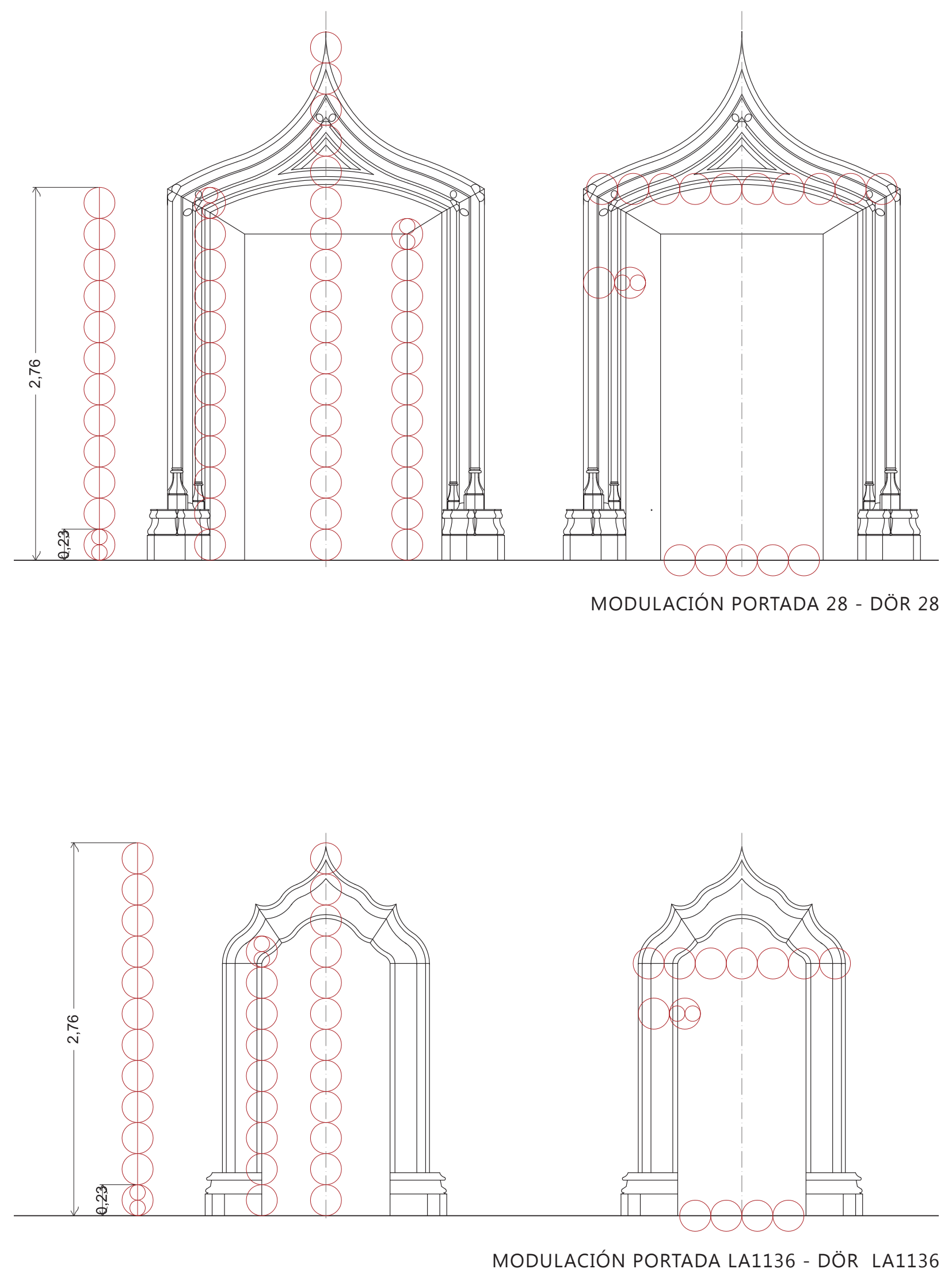

Joaquín Ángel Martinez Moya 


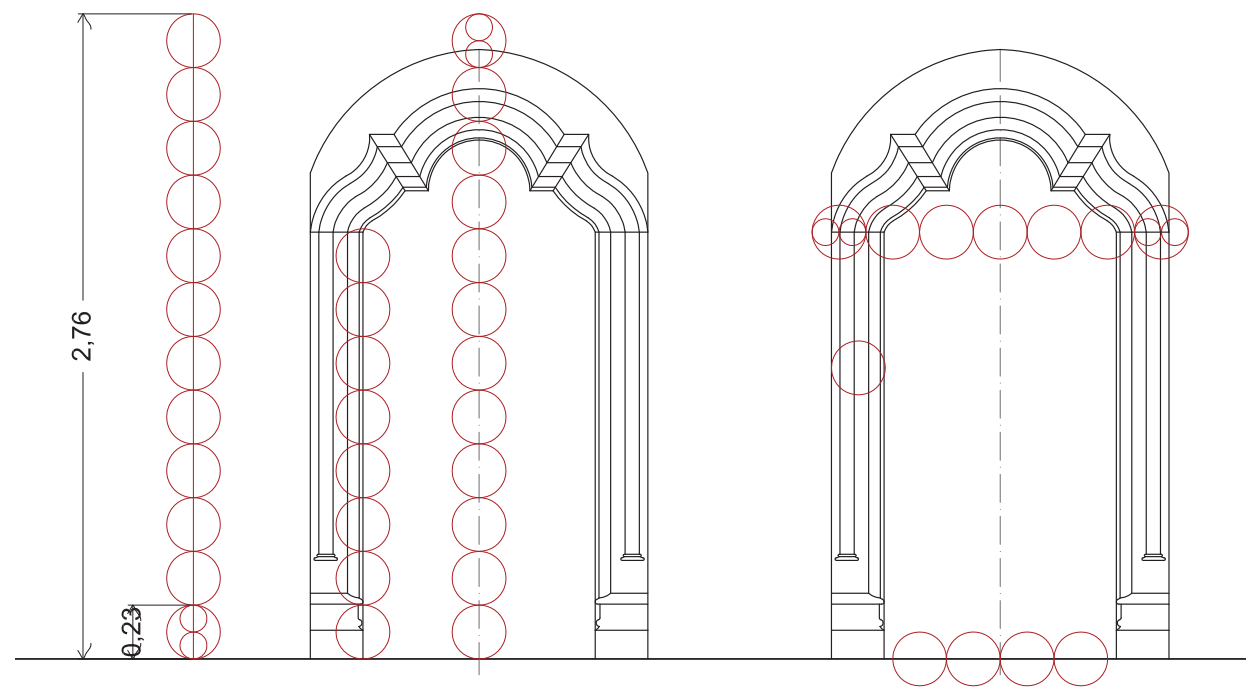

MODULACIÓN PORTADA LA1176 - DÖR LA1176

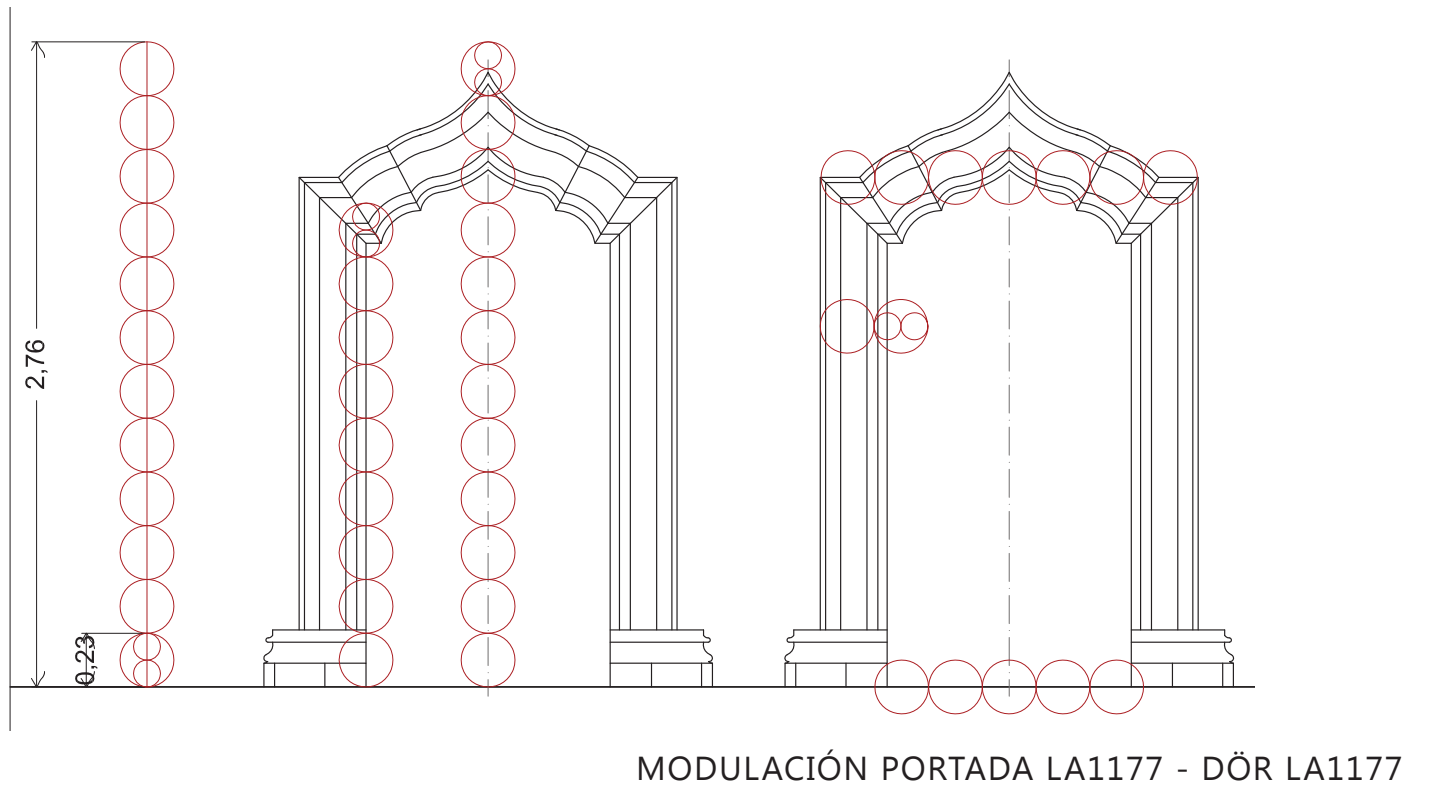




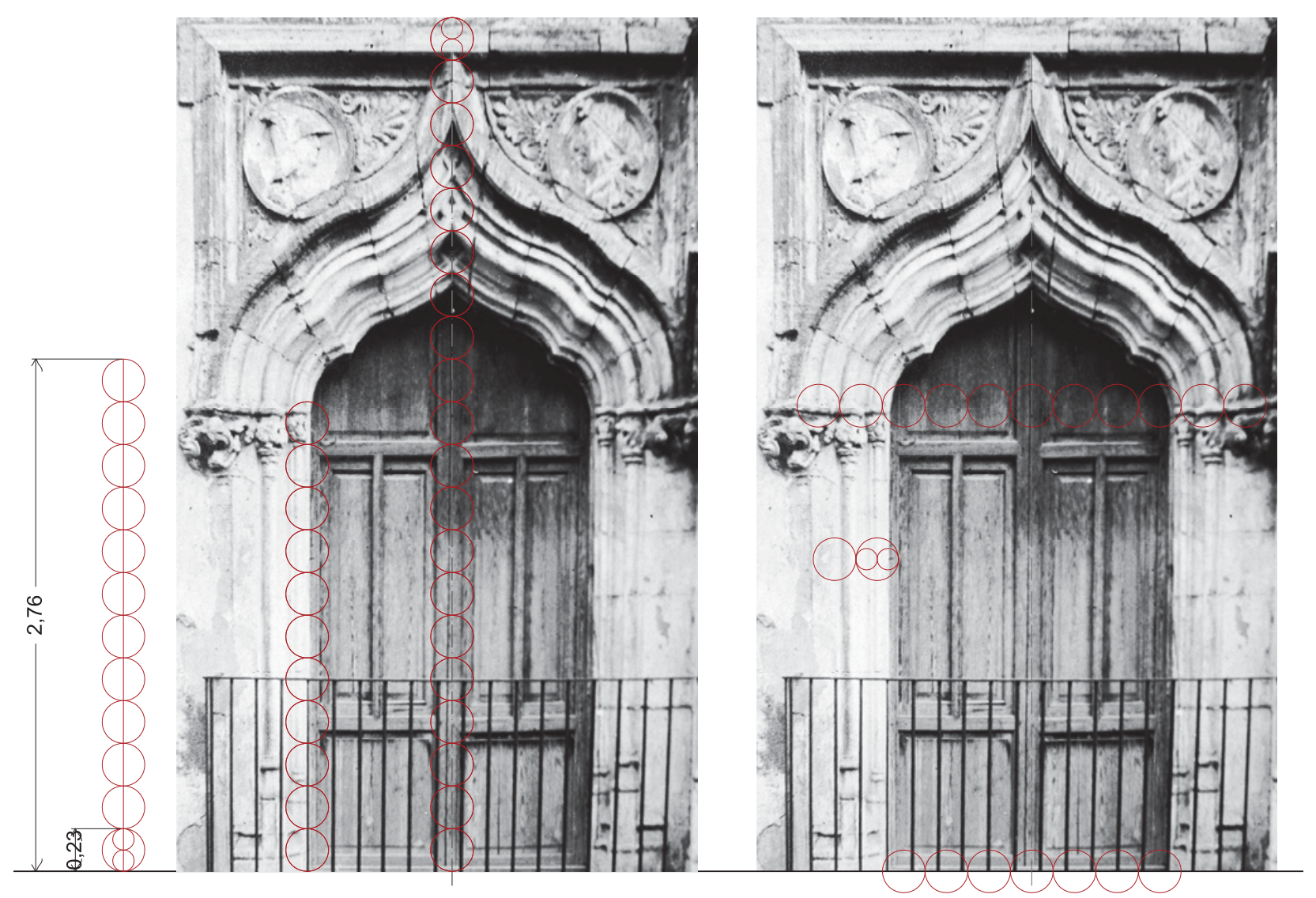

MODULACIÓN PORTADA ESCALERA DE HONOR 



\section{Comparativo Fotografías Carlos Sarthou y Egil Fischer}

"La arquitectura del expoliado Palacio Condal de Oliva a través del legado gráfico" 
COMPARATIVO FOTOGRAFÍAS CARLOS SARTHOU (AGFDV) Y EGIL FISCHER. (AFG).

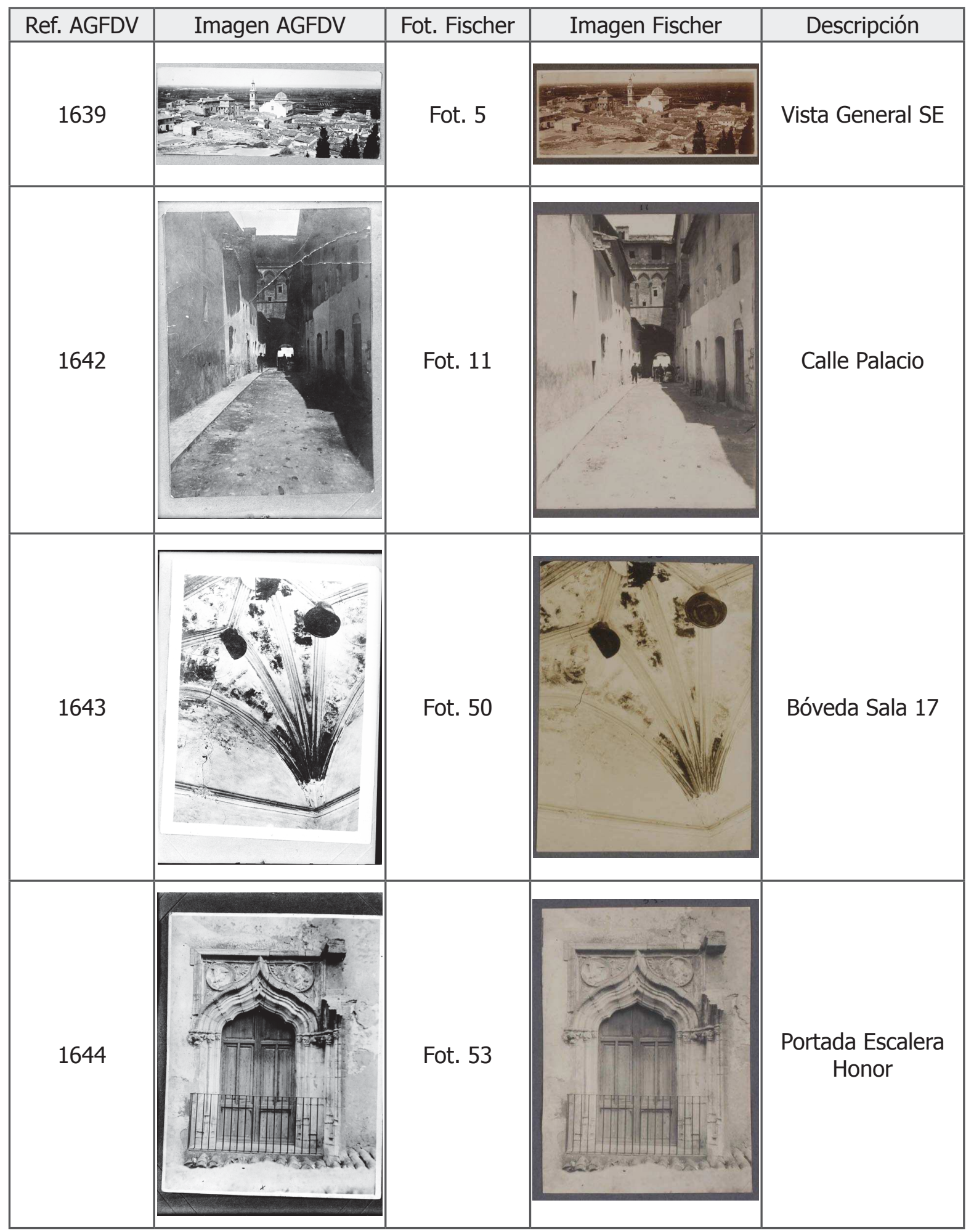




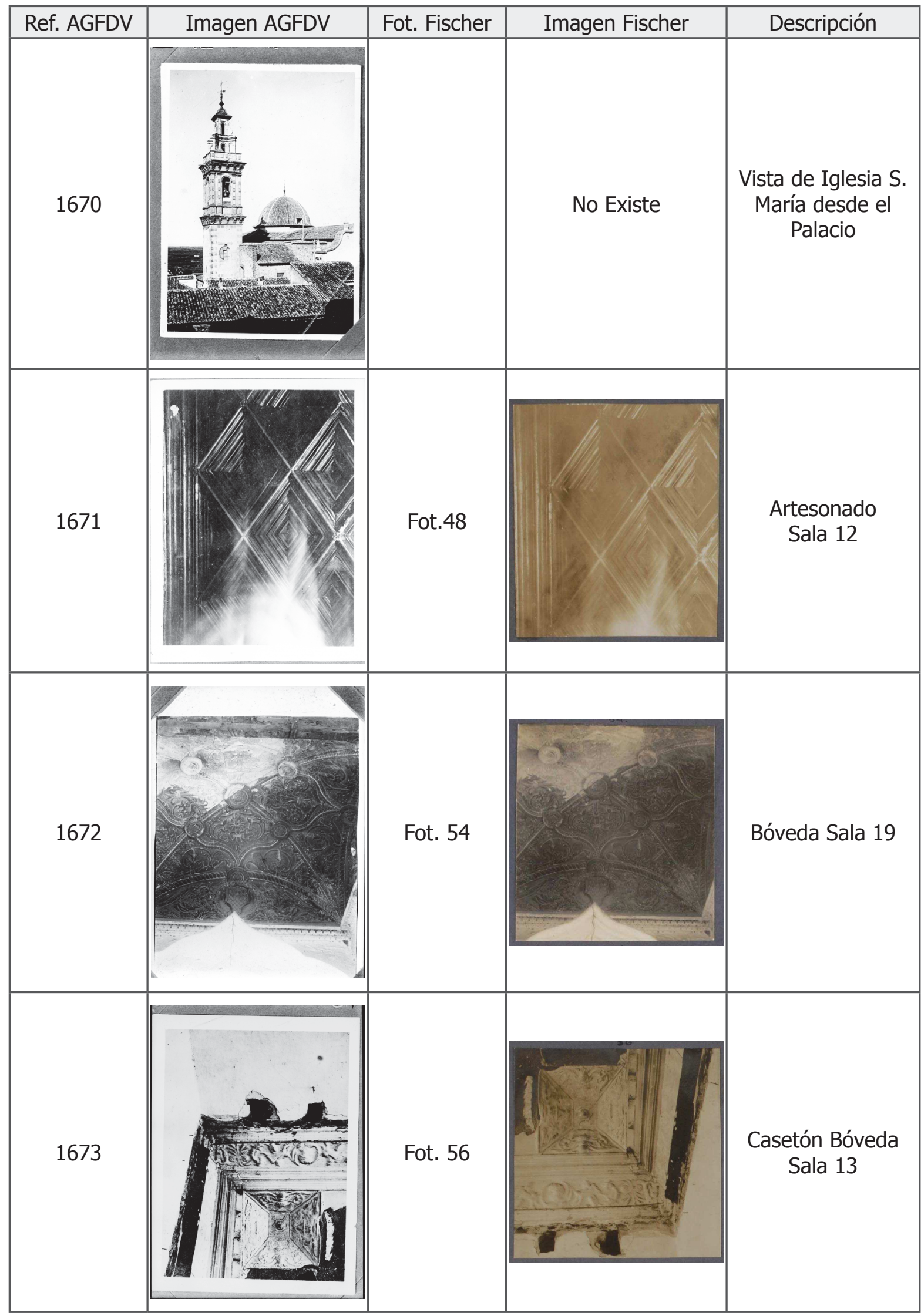




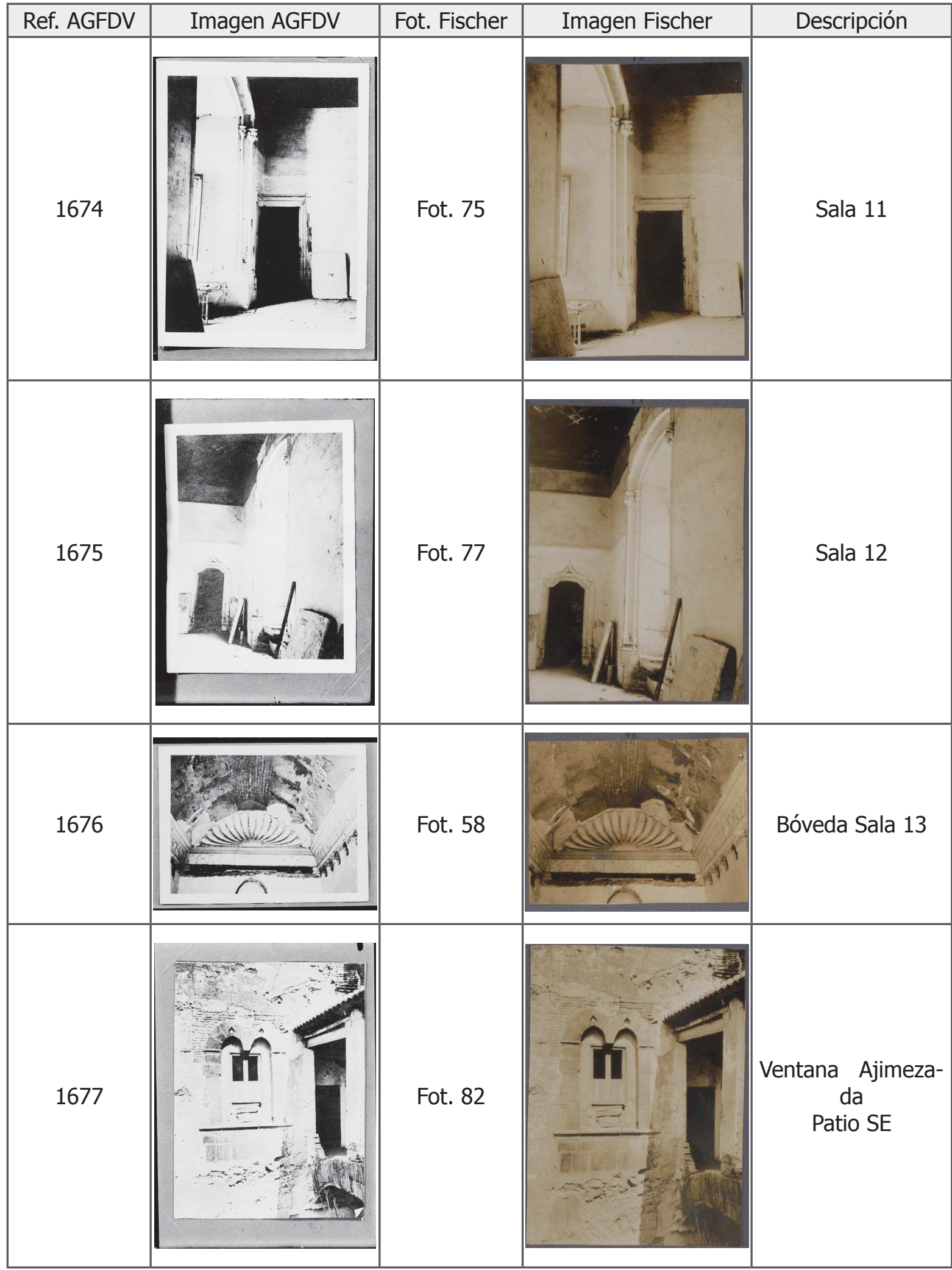




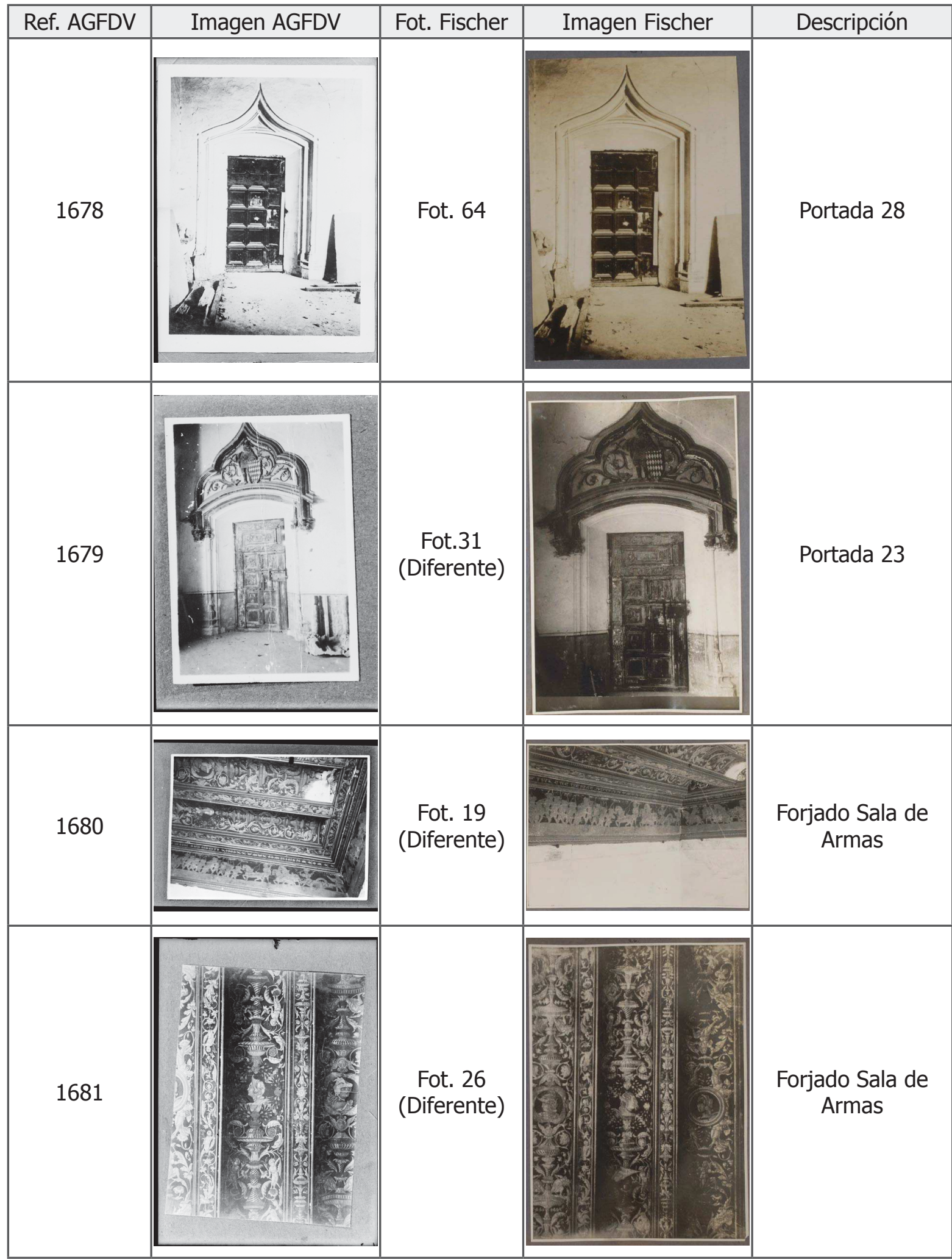




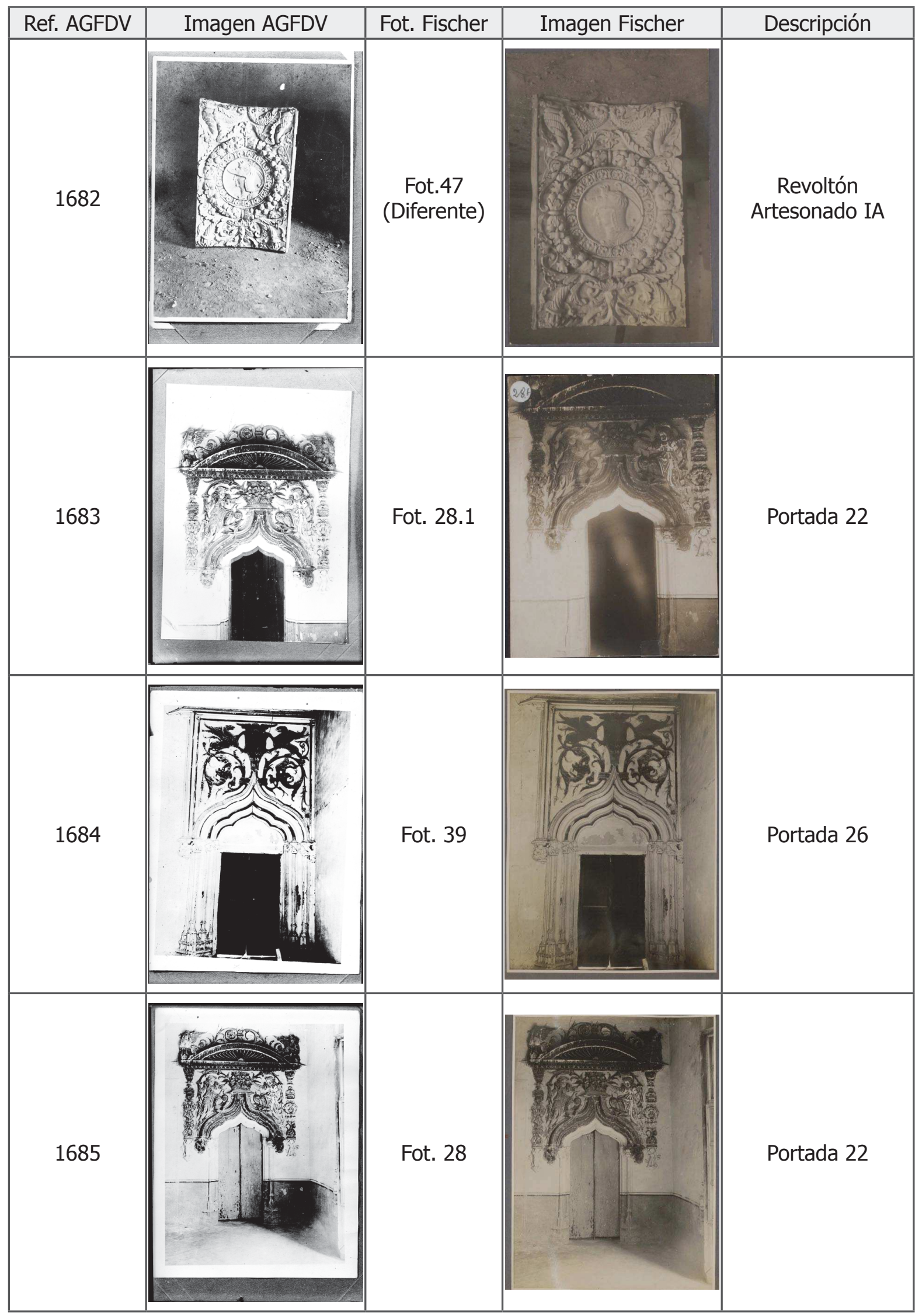




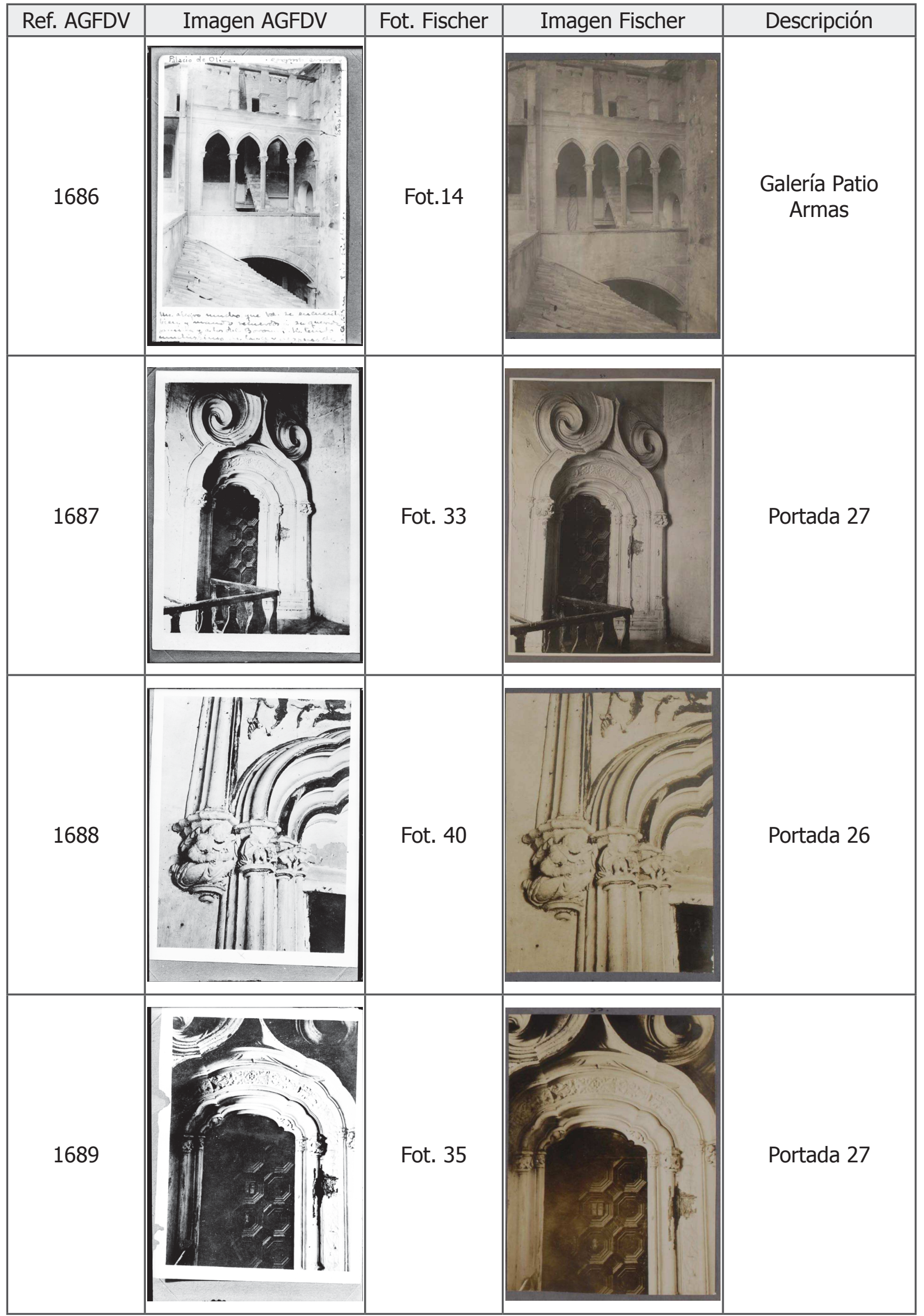




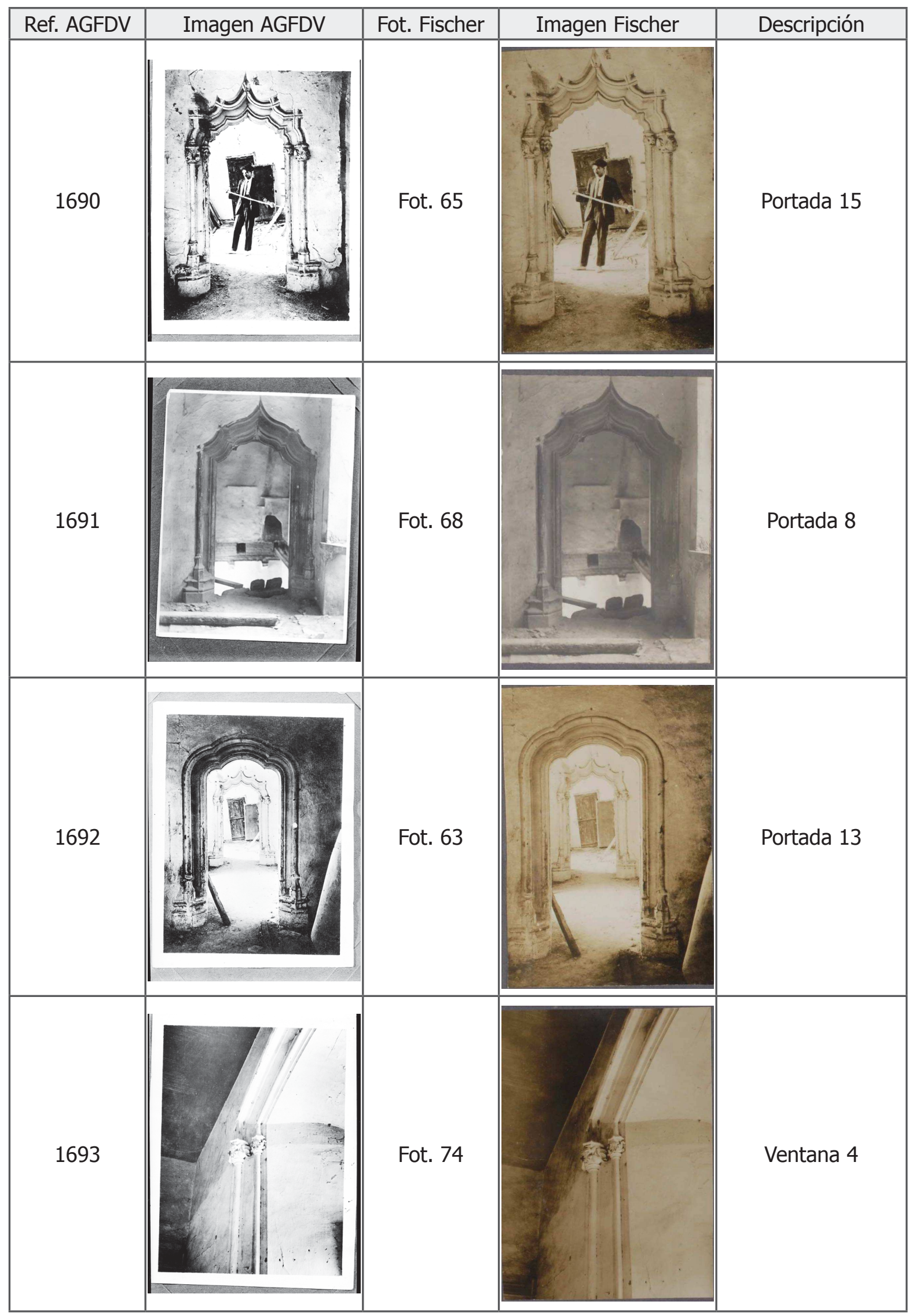


"La arquitectura del expoliado Palacio Condal de Oliva a través del legado gráfico"

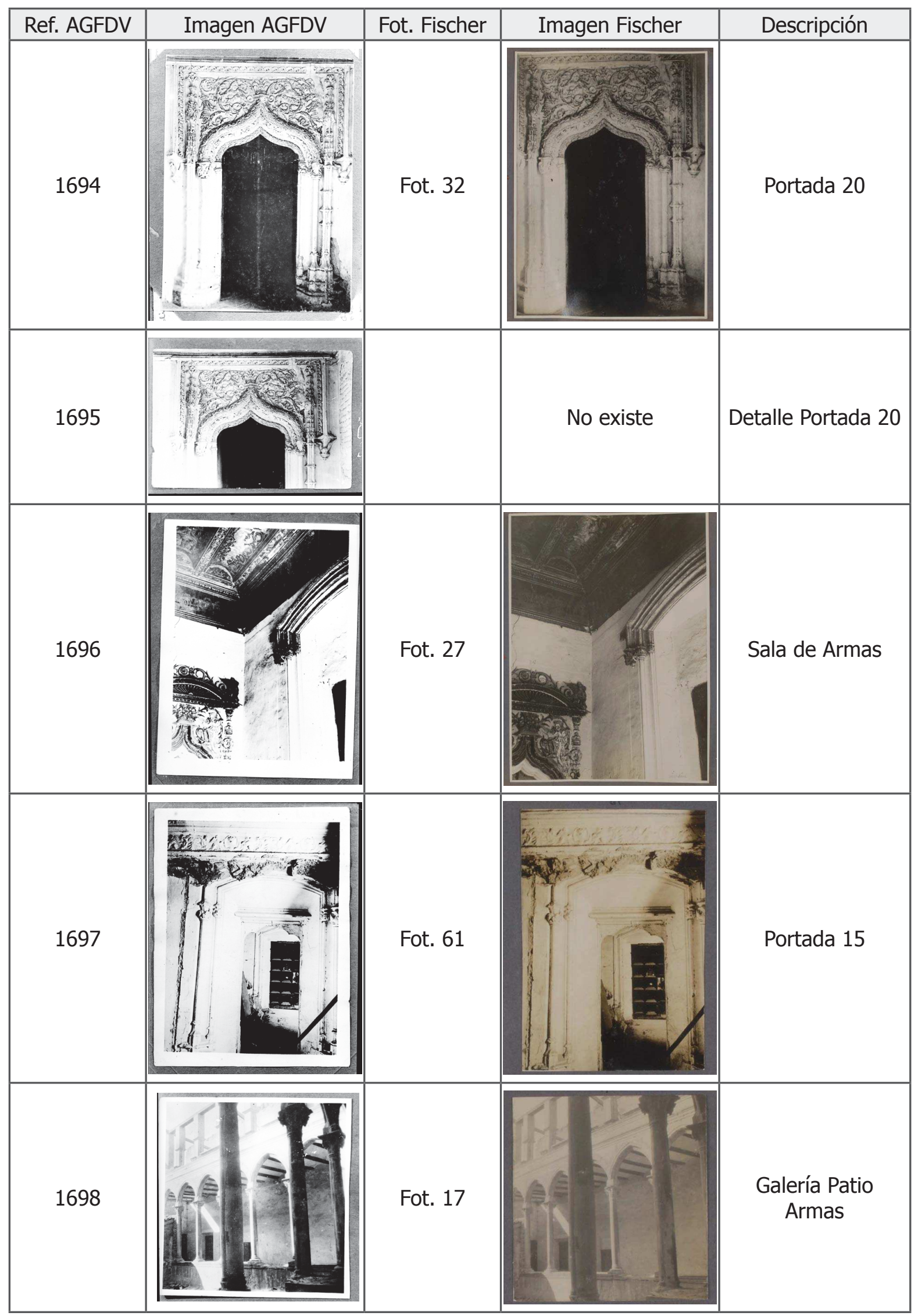





\section{Anaglifos}

“La arquitectura del expoliado Palacio Condal de Oliva a través del legado gráfico” 
"La arquitectura del expoliado Palacio Condal de Oliva a través del legado gráfico"

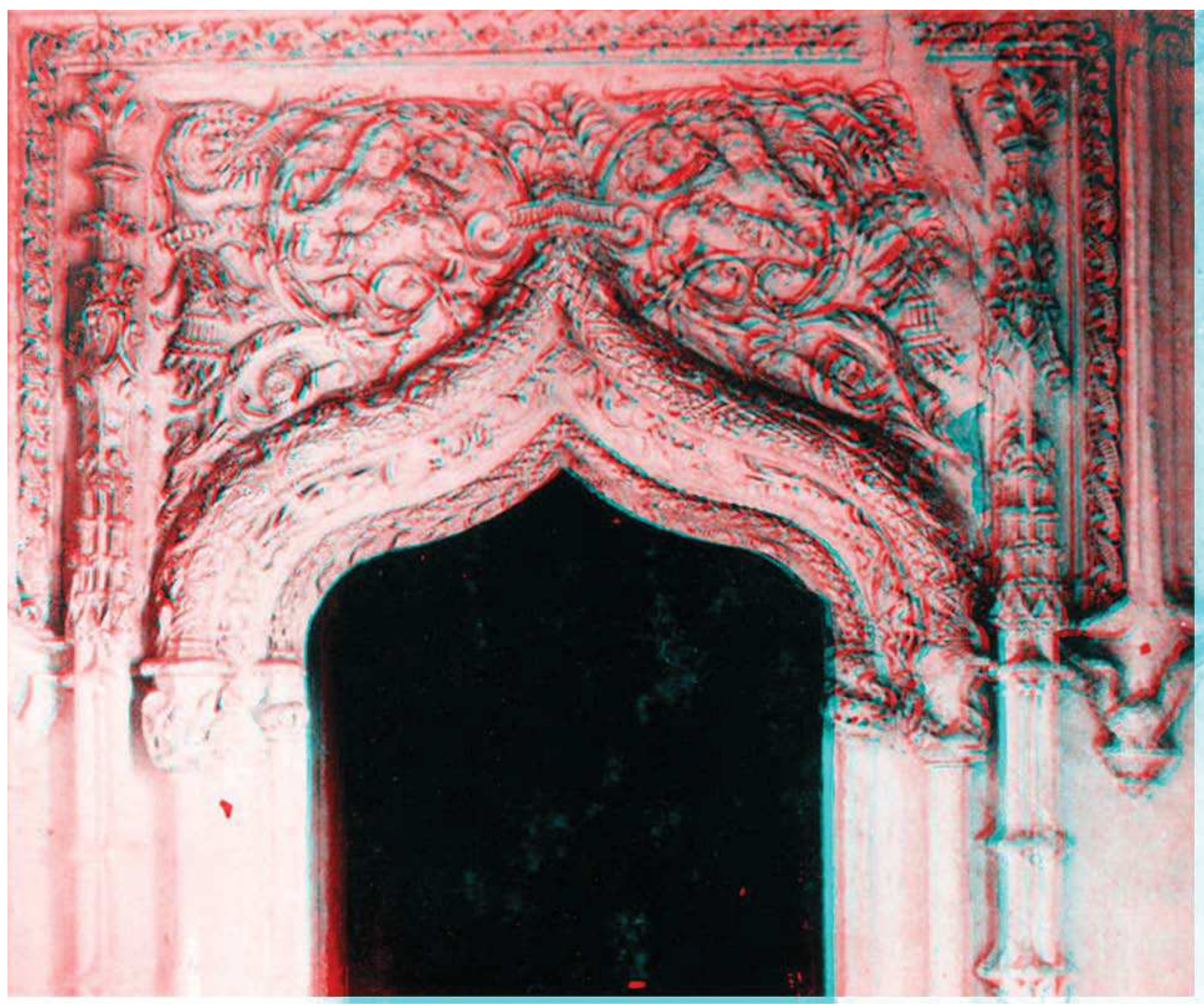

ANAGLIFO PORTADA 20 


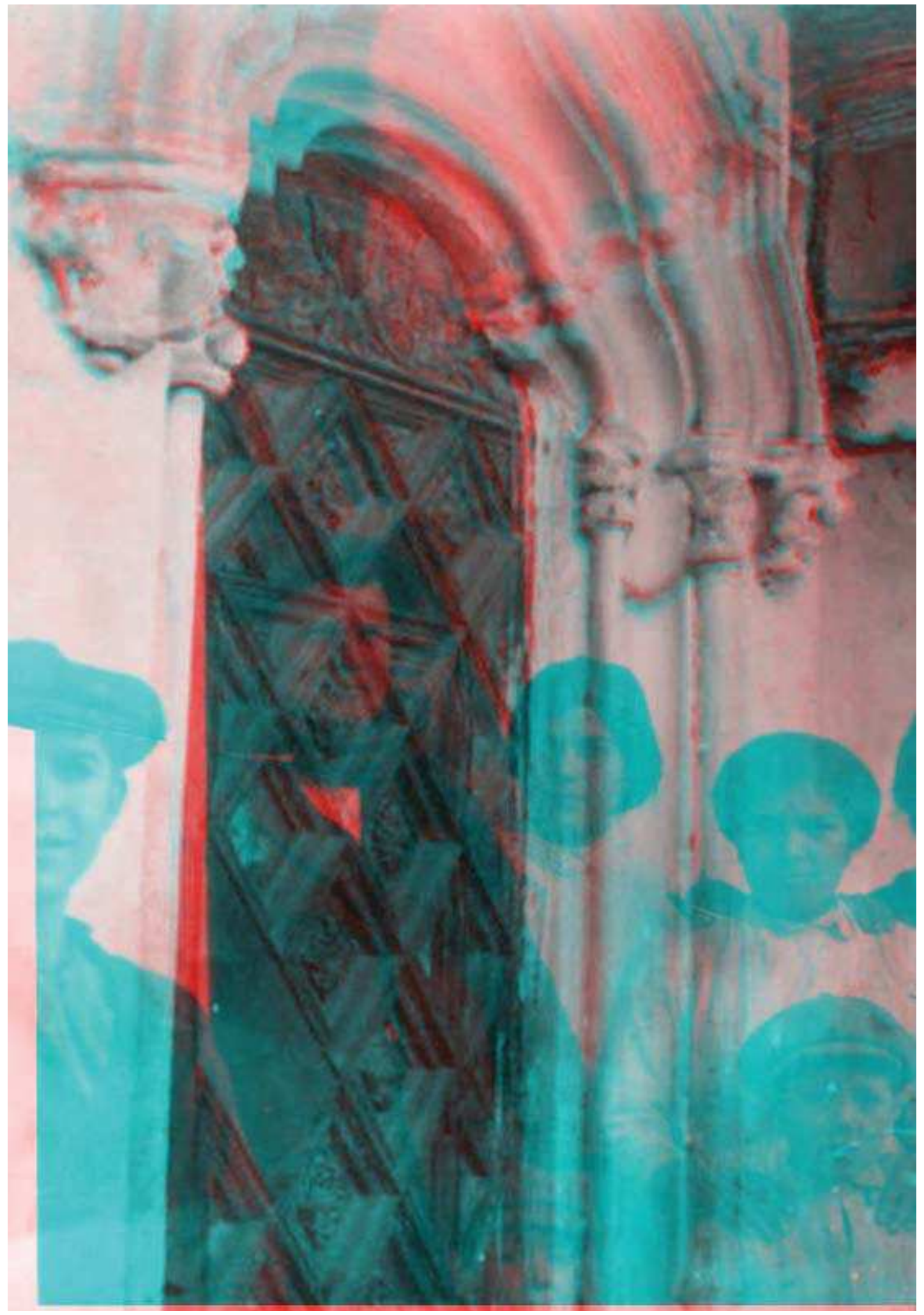

ANAGLIFO PORTADA 24 


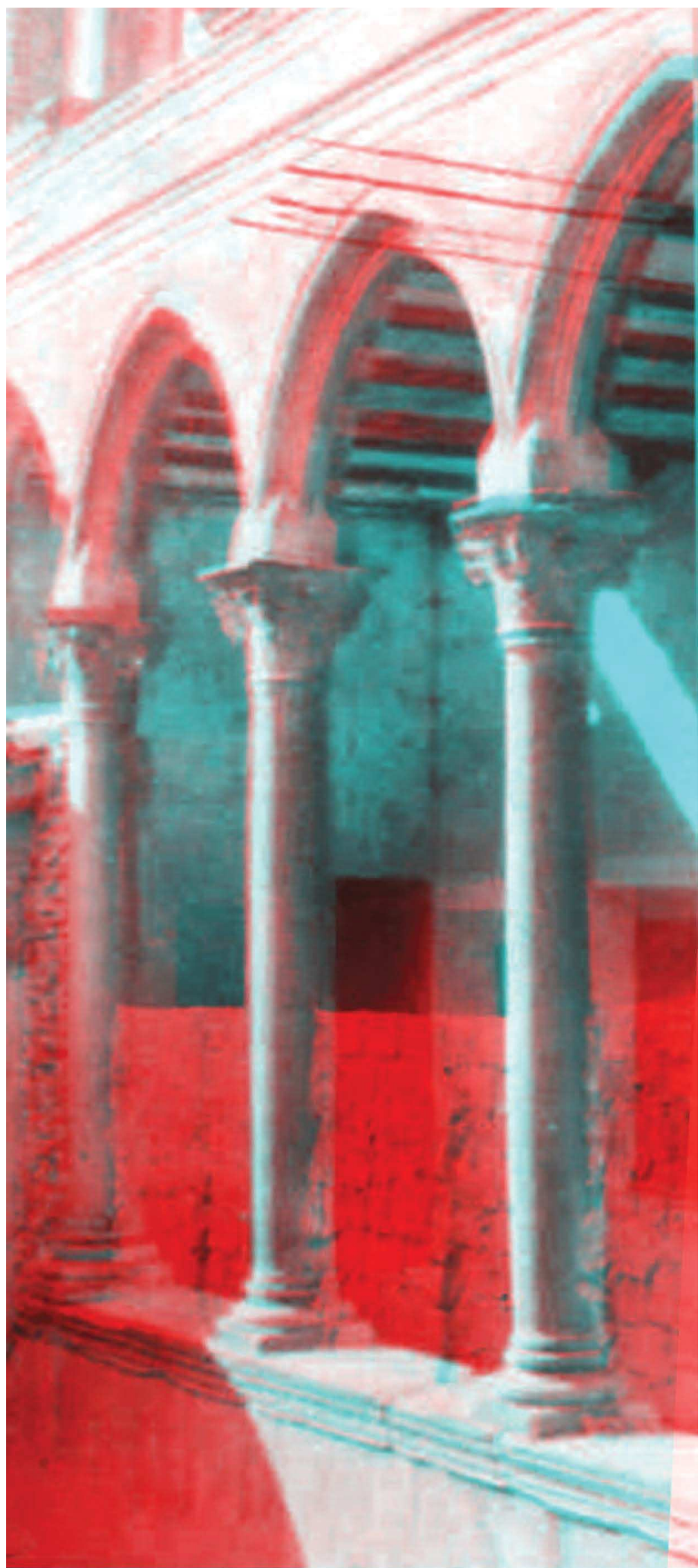

ANAGLIFO GALERÍA

PATI DE L'ESCALA 


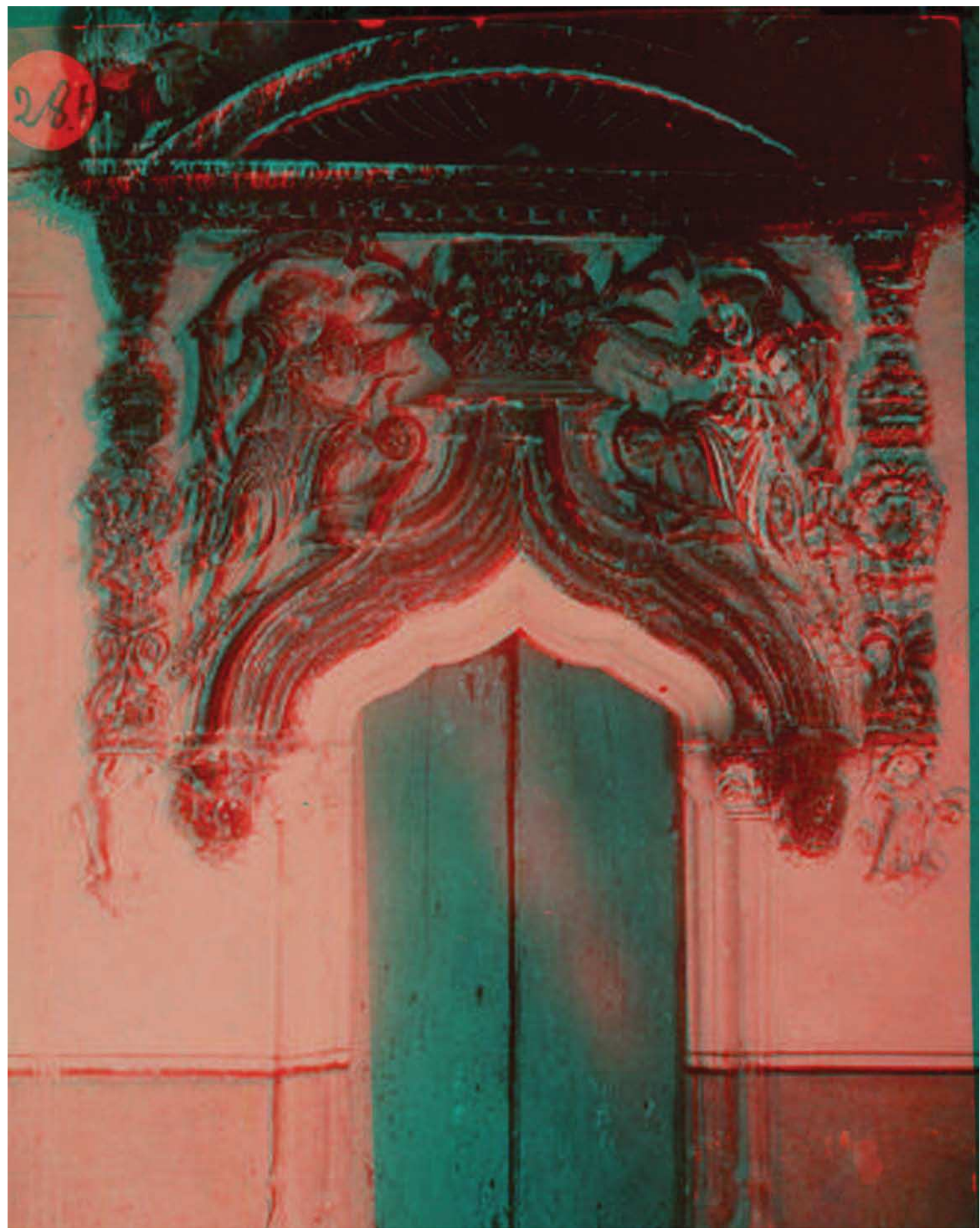

ANAGLIFO PORTADA 22 



\section{Infografías}

“La arquitectura del expoliado Palacio Condal de Oliva a través del legado gráfico” 
"La arquitectura del expoliado Palacio Condal de Oliva a través del legado gráfico"

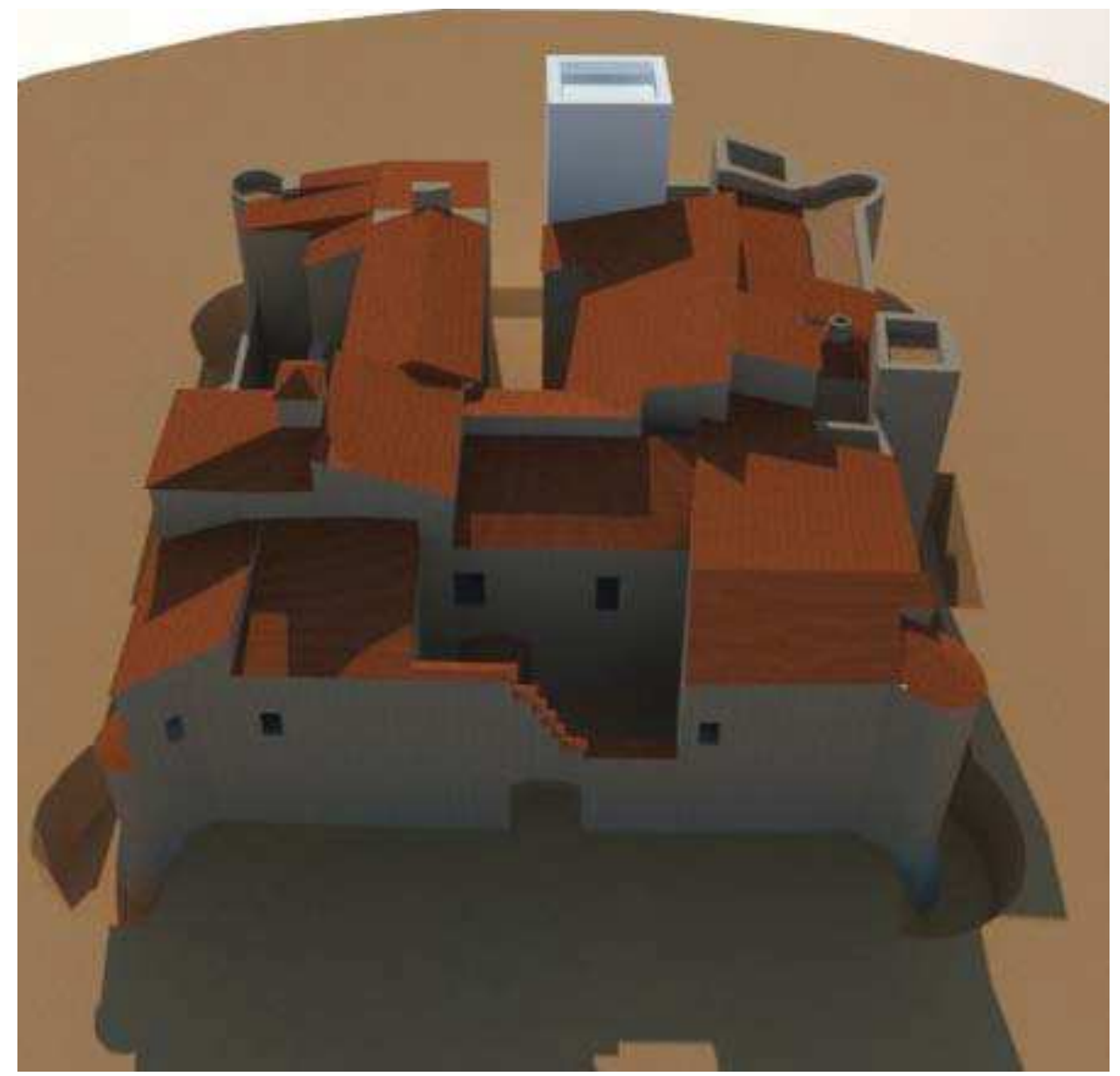

Vista aérea del Palacio Condal de Oliva 


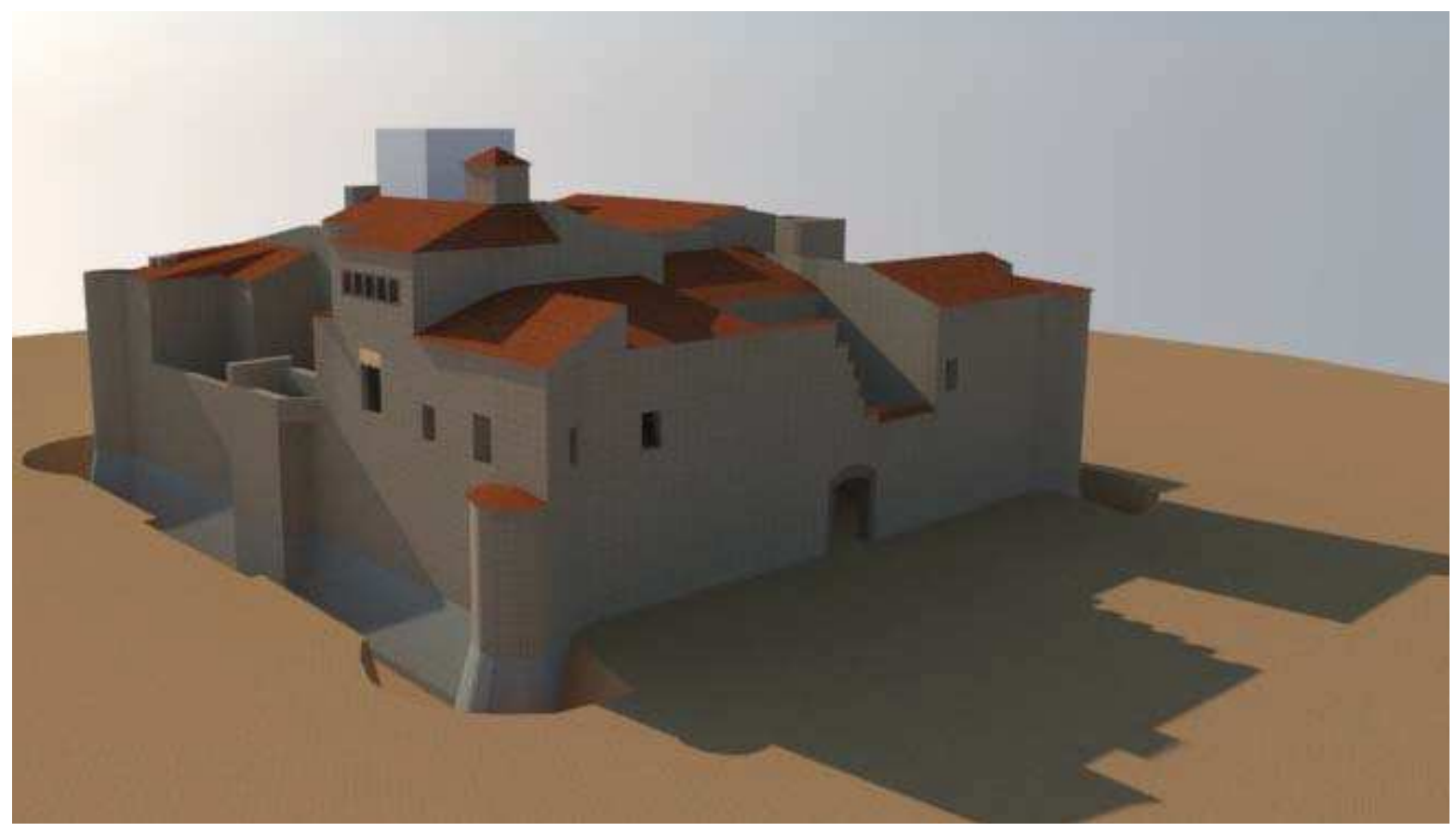

Vista aérea del Palacio Condal de Oliva

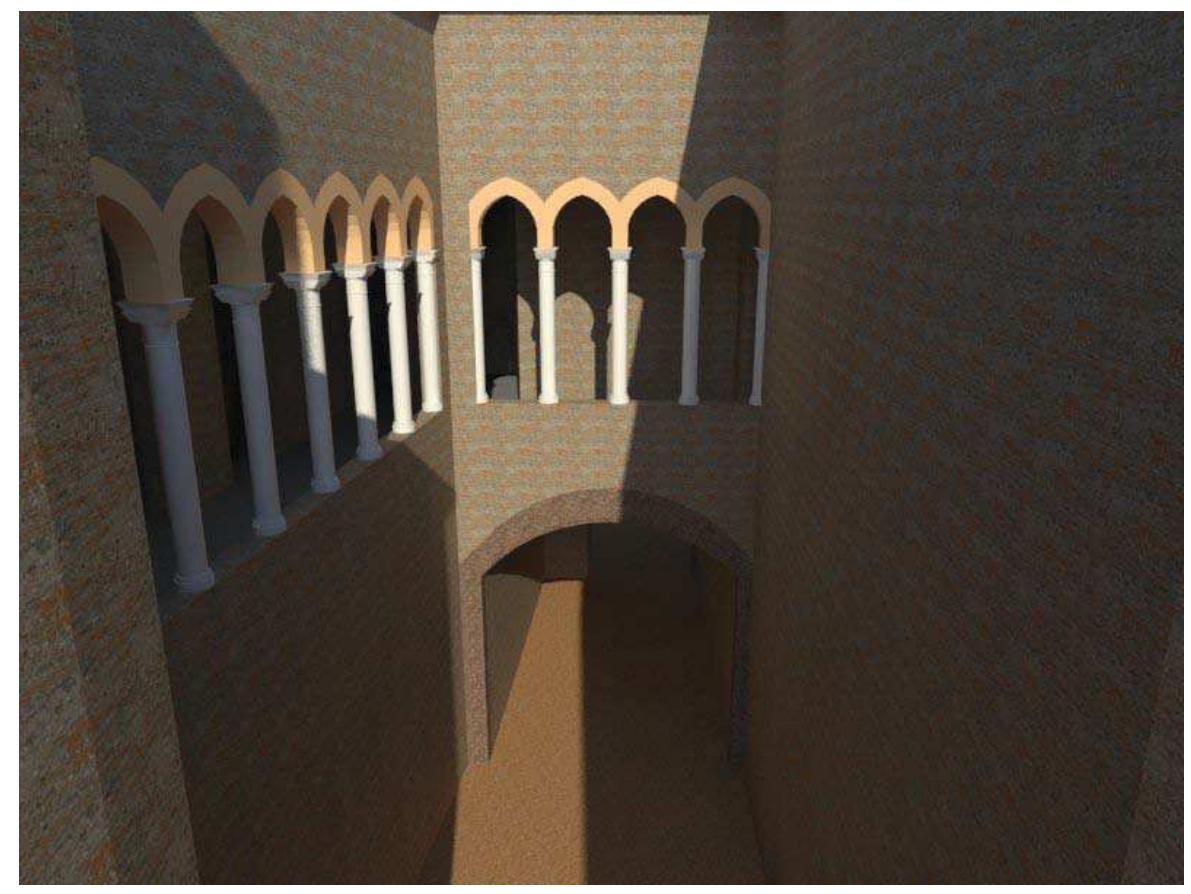

Vista del Pati de L'Escala 


\section{INTERIOR SALA 12}

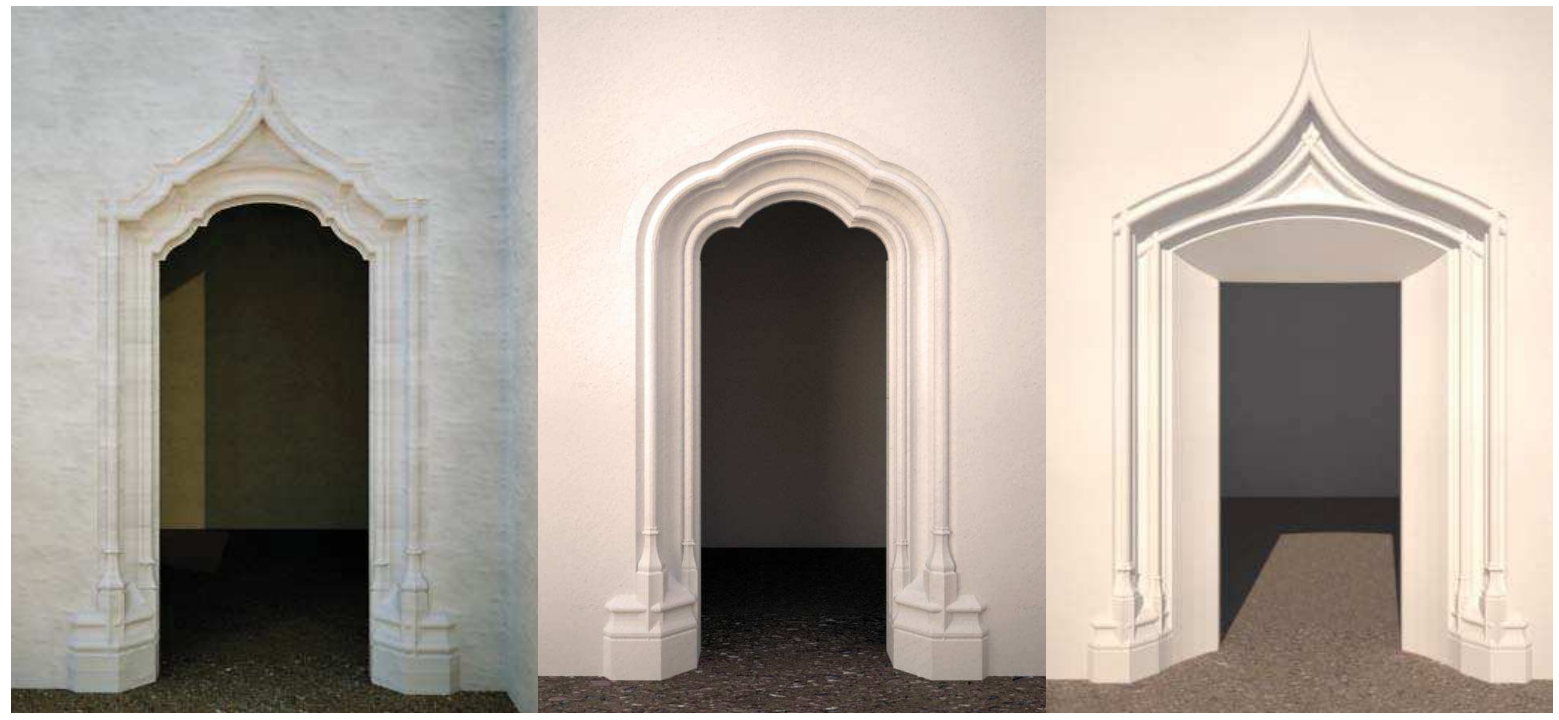

PORTADA 12

PORTADA 13

PORTADA 28

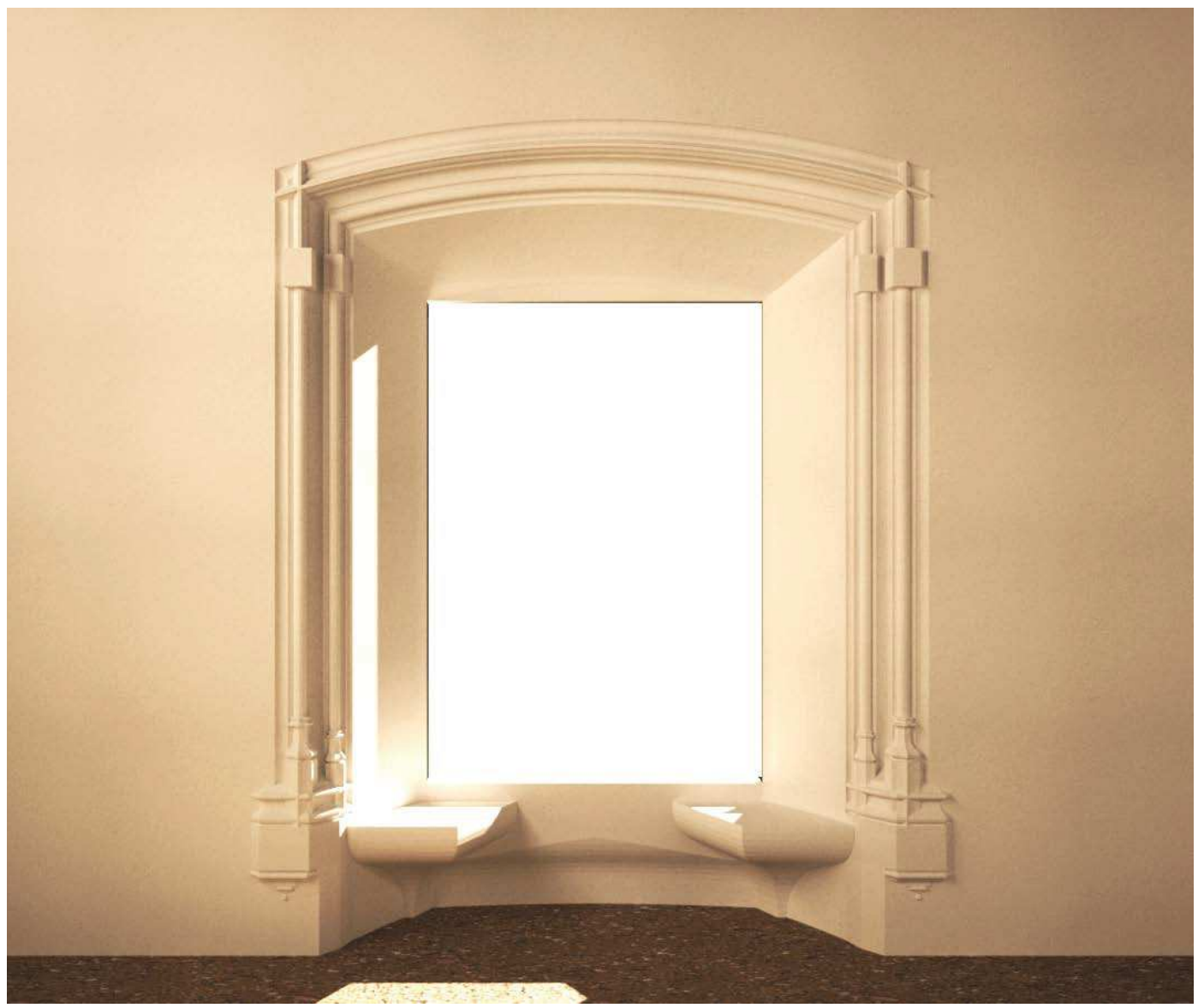

VENTANA 4 
"La arquitectura del expoliado Palacio Condal de Oliva a través del legado gráfico"

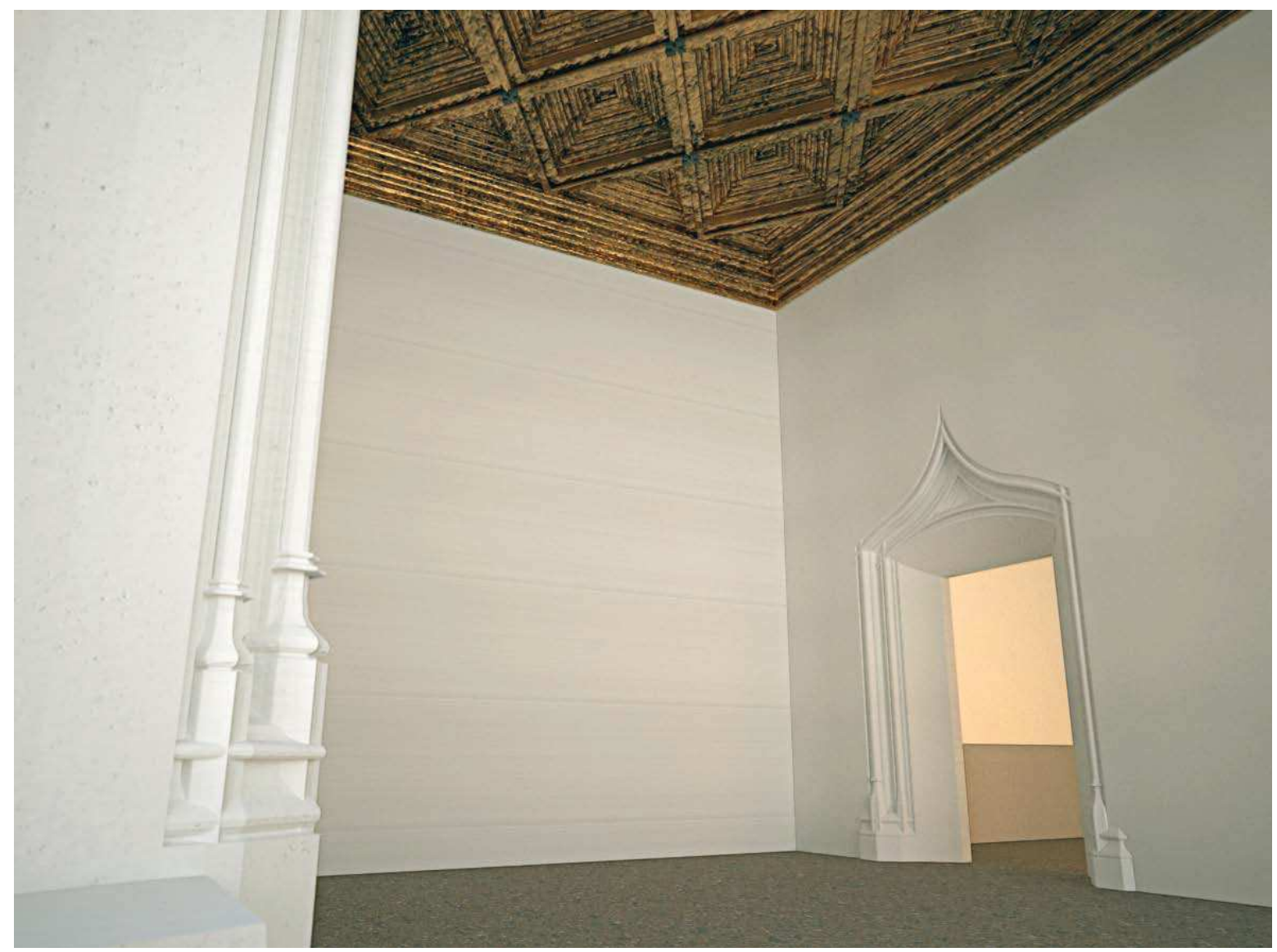

Vista INTERIOR SALA 12 


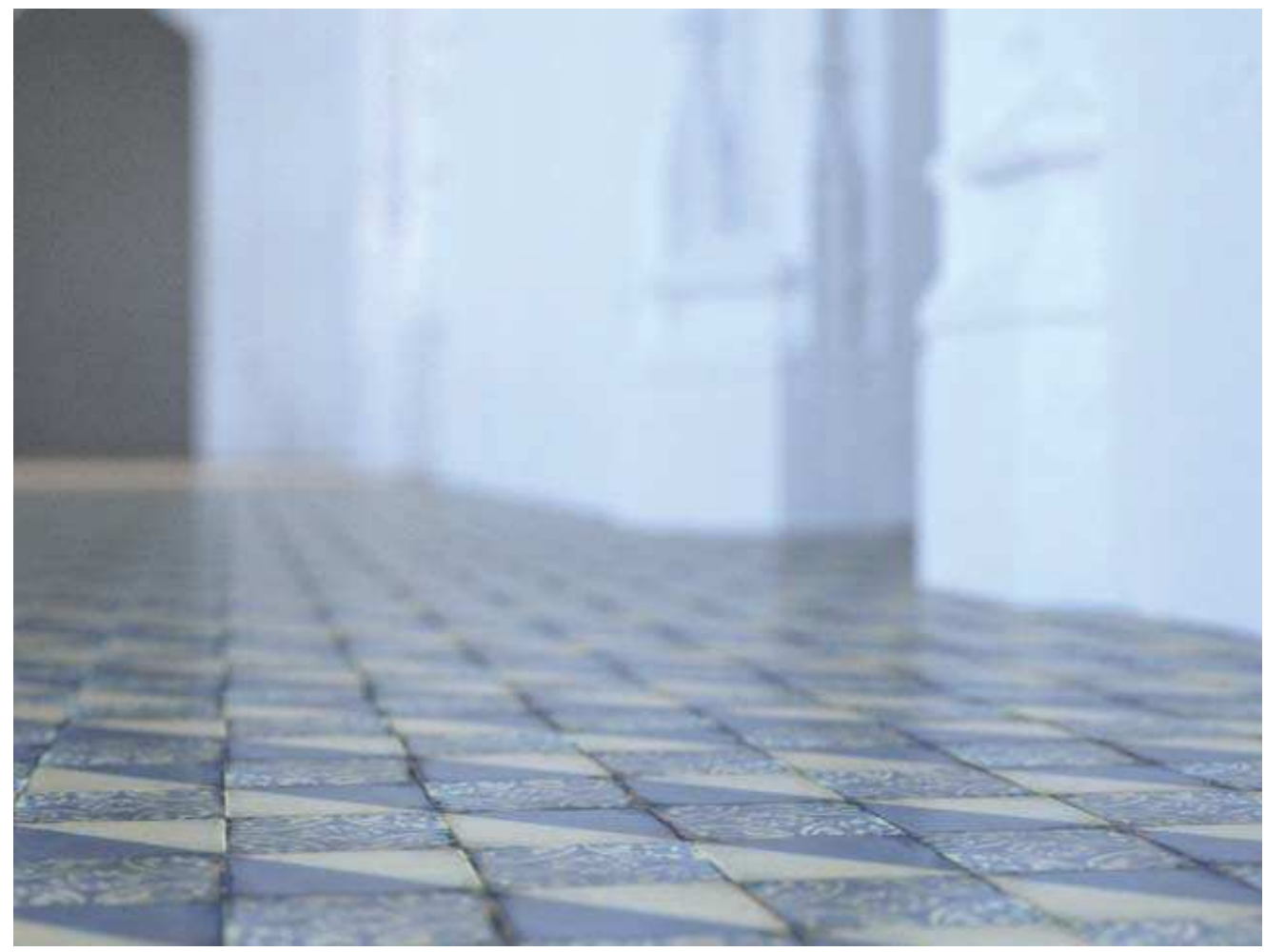

Detalle Pavimento sala 12 - hipótesis 1

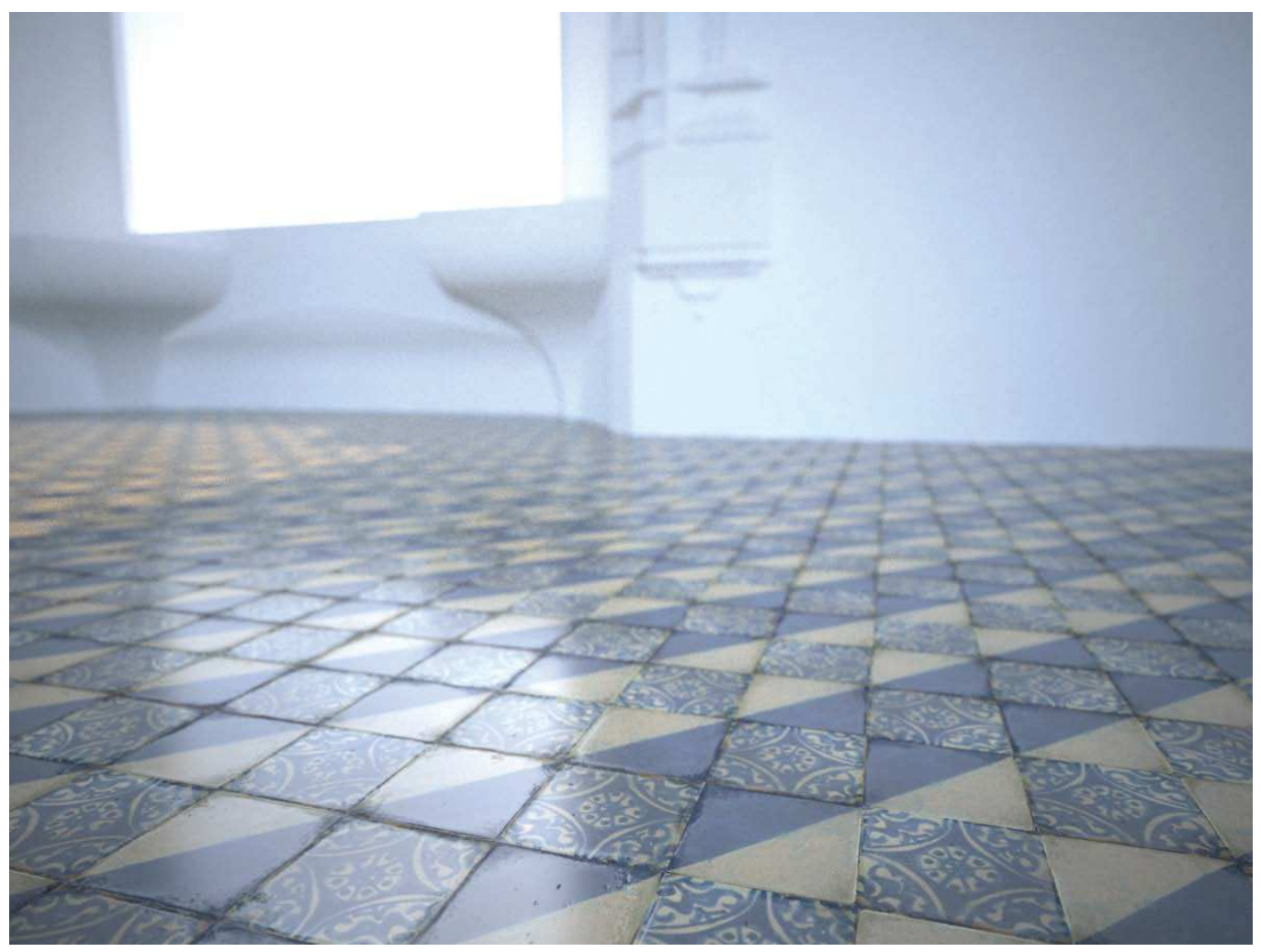

Detalle Pavimento sala 12 - hipótesis 1 


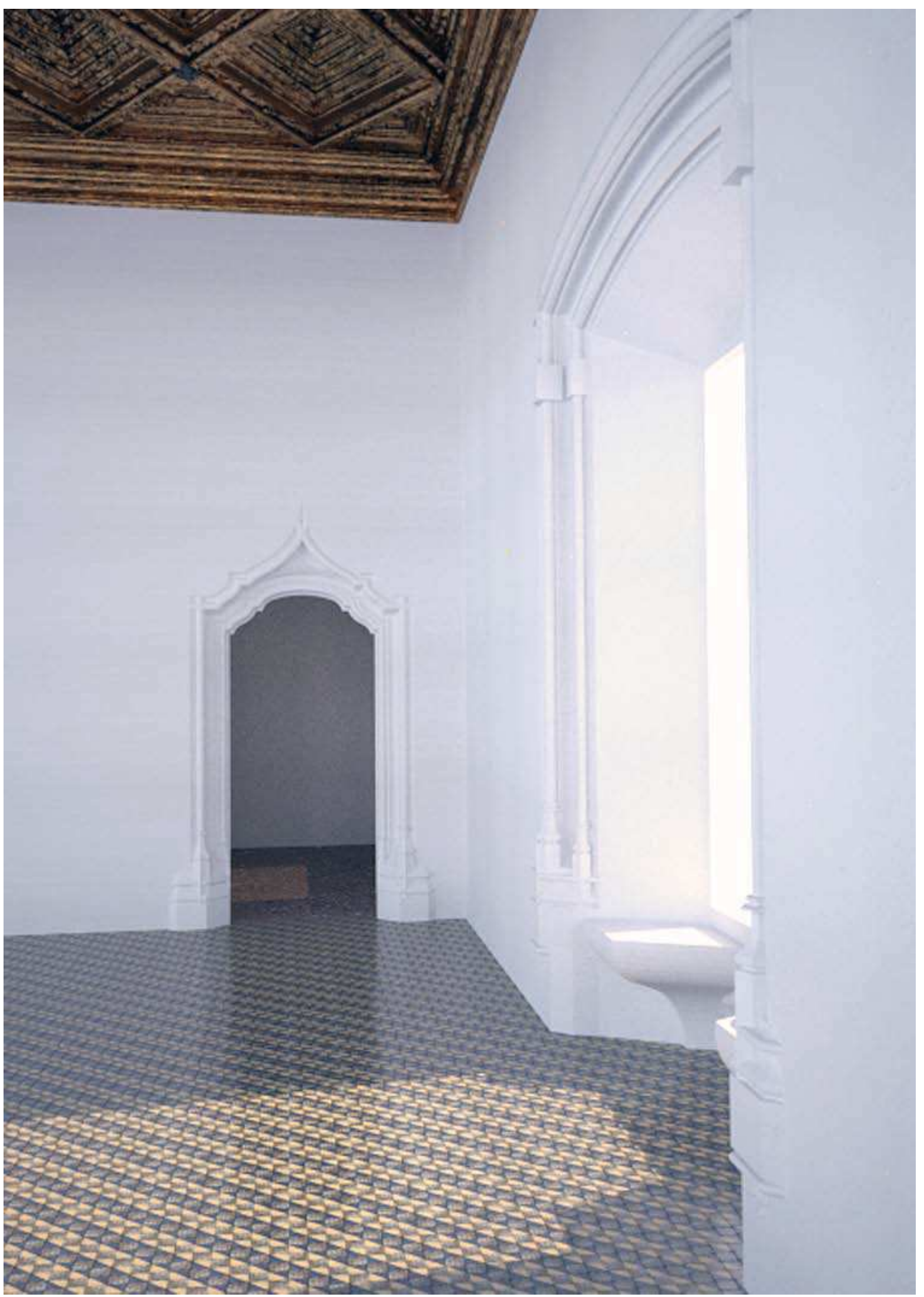

Vista Interior Sala 12 - hipótesis de pavimento 1 
"La arquitectura del expoliado Palacio Condal de Oliva a través del legado gráfico"

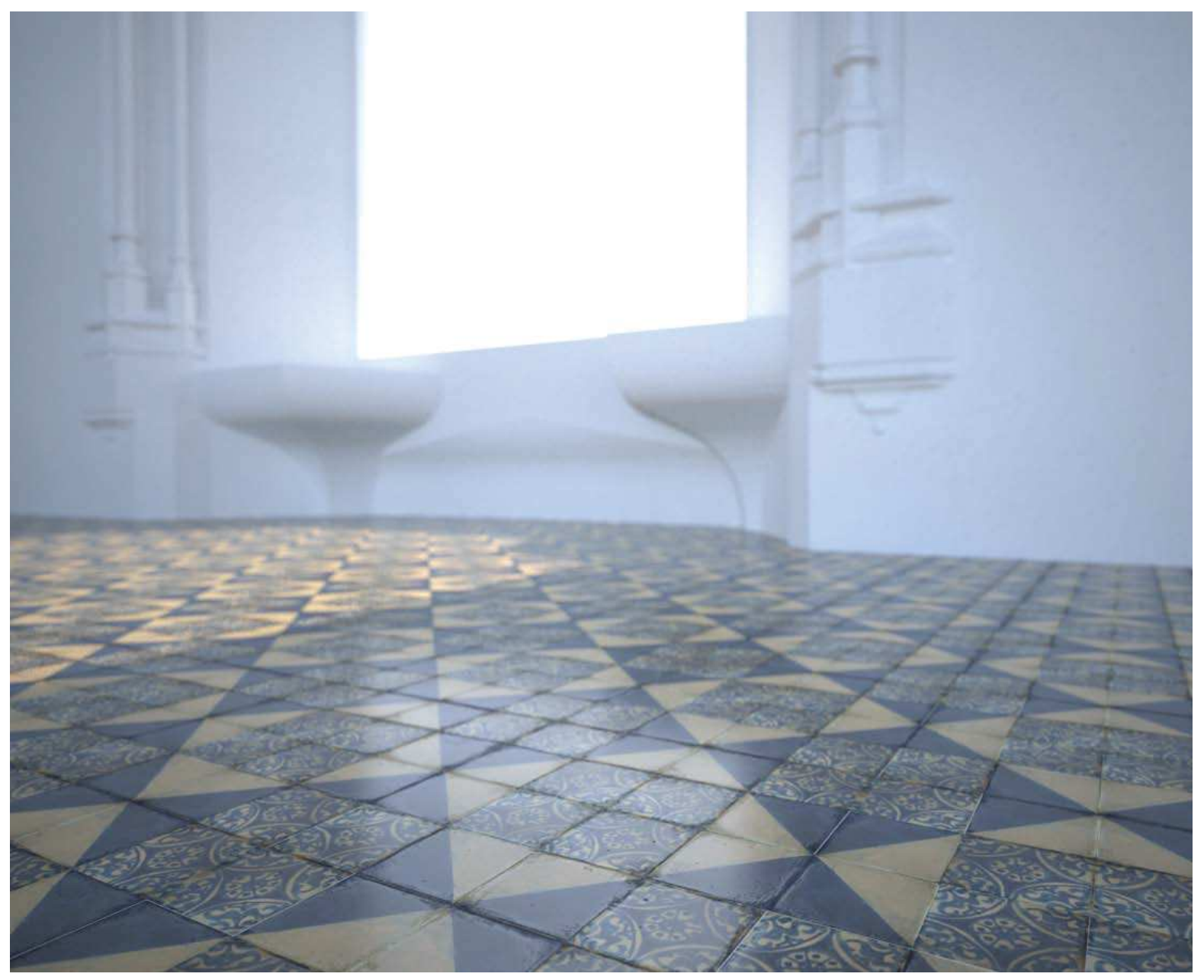

Detalle Pavimento y Basa de ventana 4 - sala 12 - hipótesis 2 


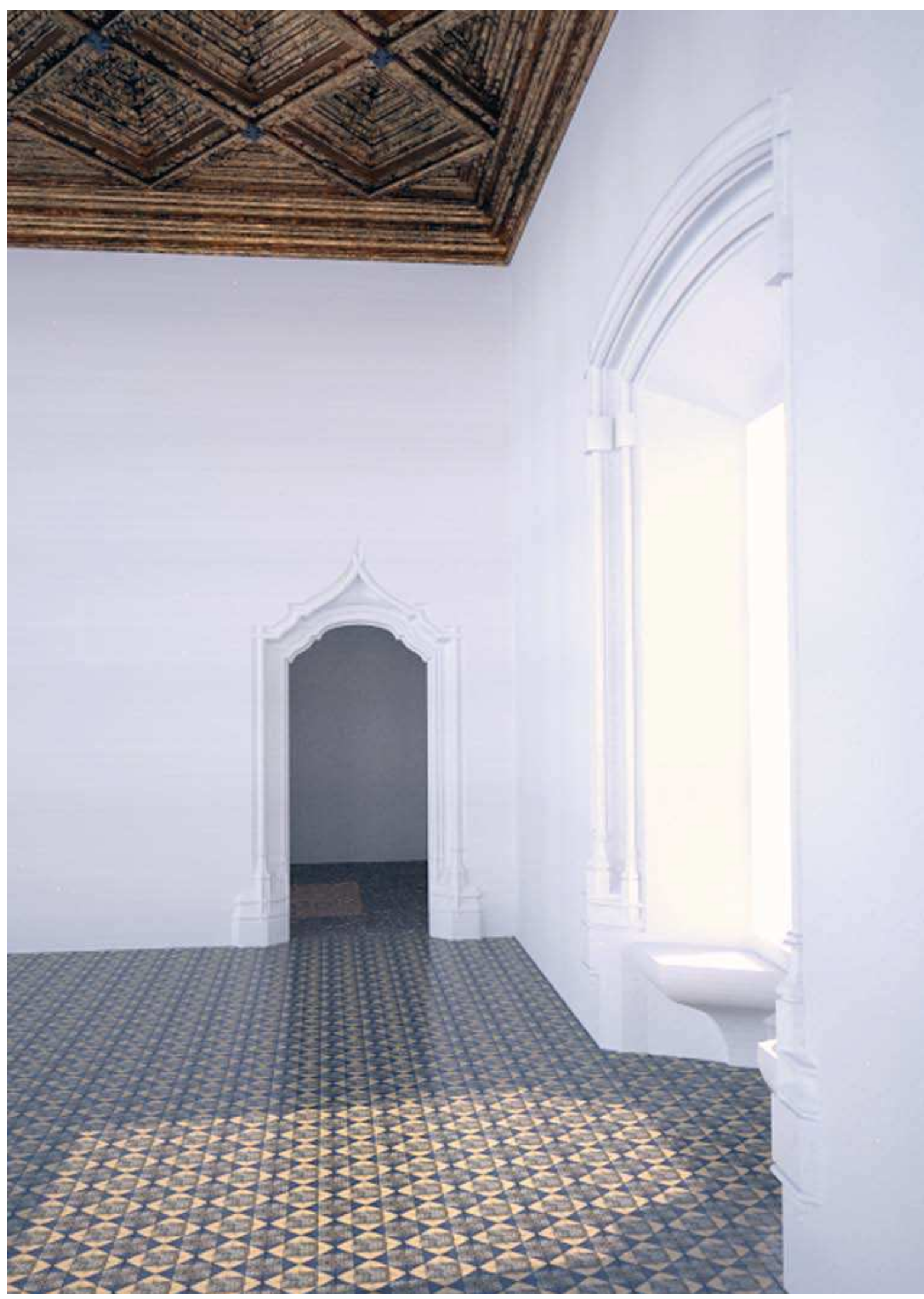

Vista Interior Sala 12 - hipótesis de paVimento 2 
"La arquitectura del expoliado Palacio Condal de Oliva a través del legado gráfico"

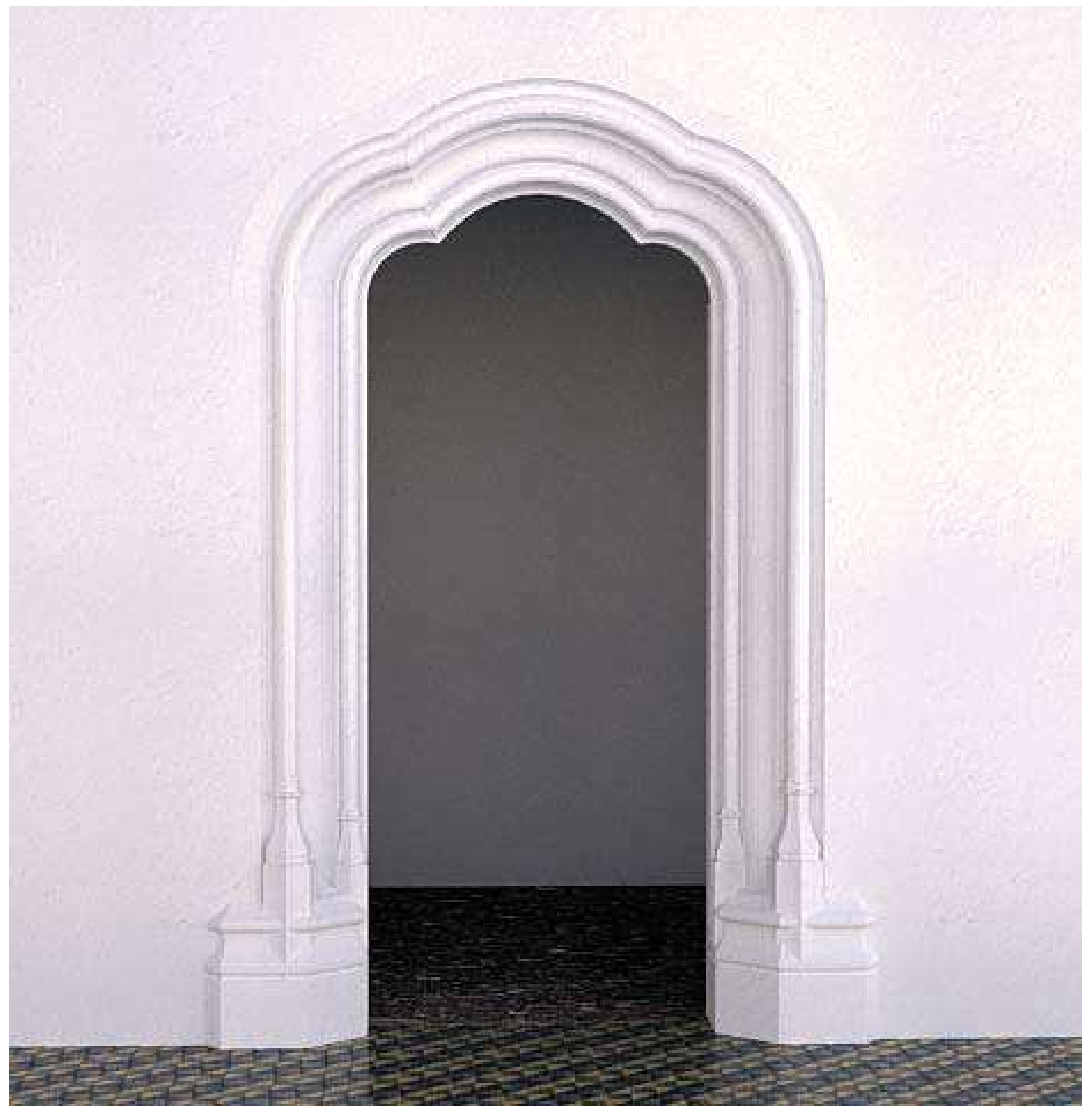

ALZADO 3D PORTADA 13 
"La arquitectura del expoliado Palacio Condal de Oliva a través del legado gráfico"

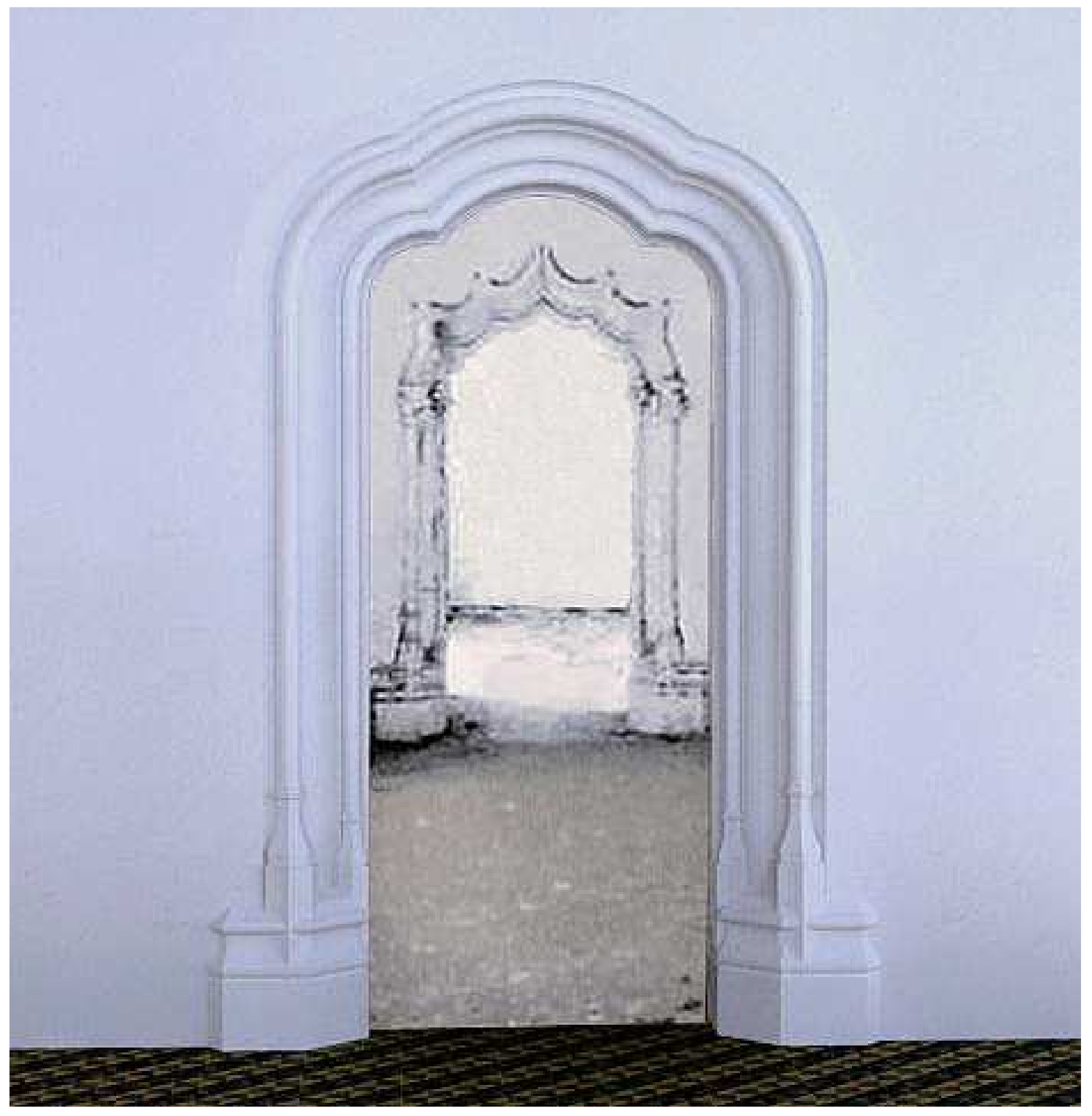

ALZADO 3D PORTADA 13 


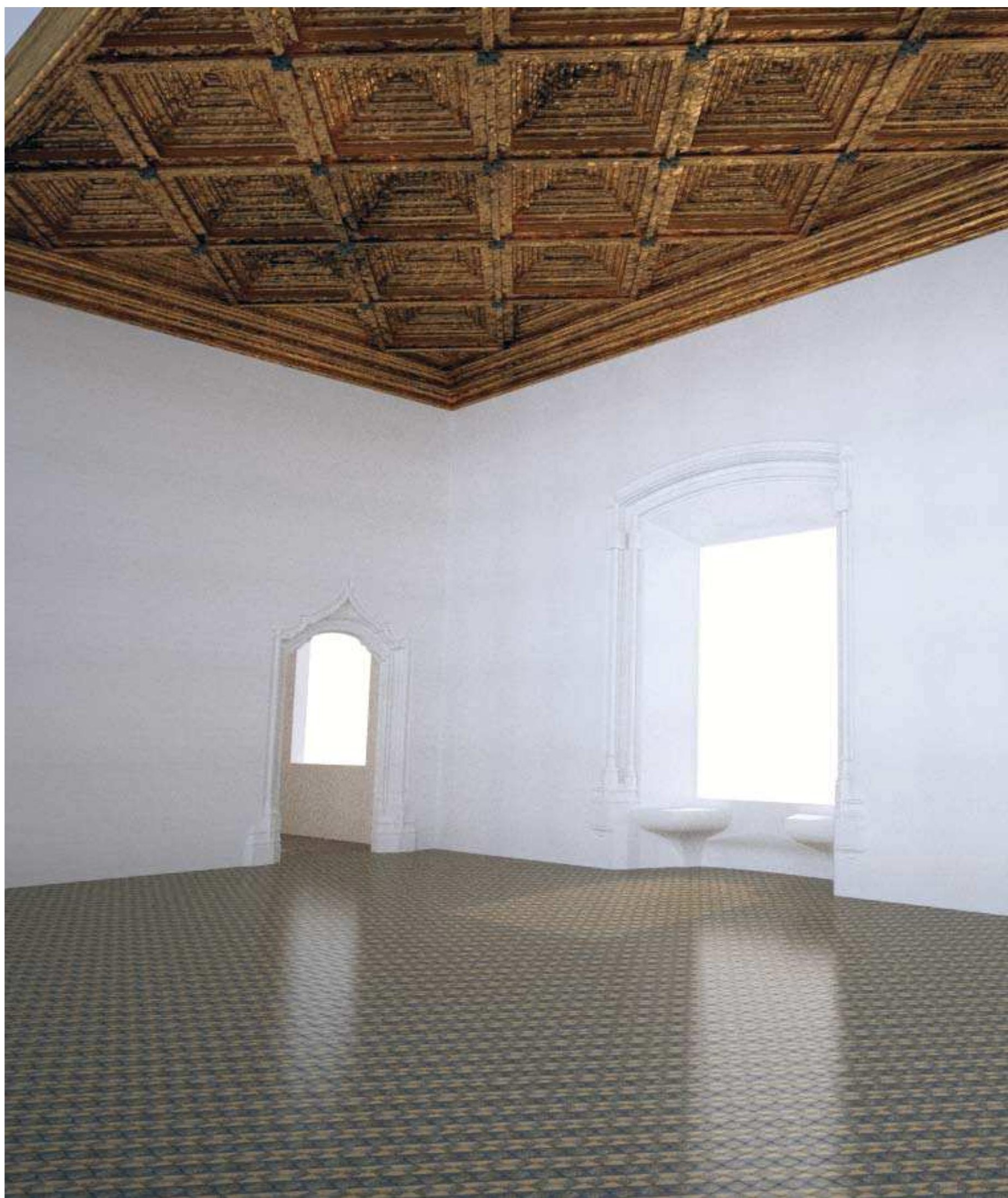





\section{Maquetas}

"La arquitectura del expoliado Palacio Condal de Oliva a través del legado gráfico” 
MAQUETA CONCEPTUAL DE LA LOCALIZACIÓN DEL PALACIO EN LA TRAMA URBANA ACTUAL
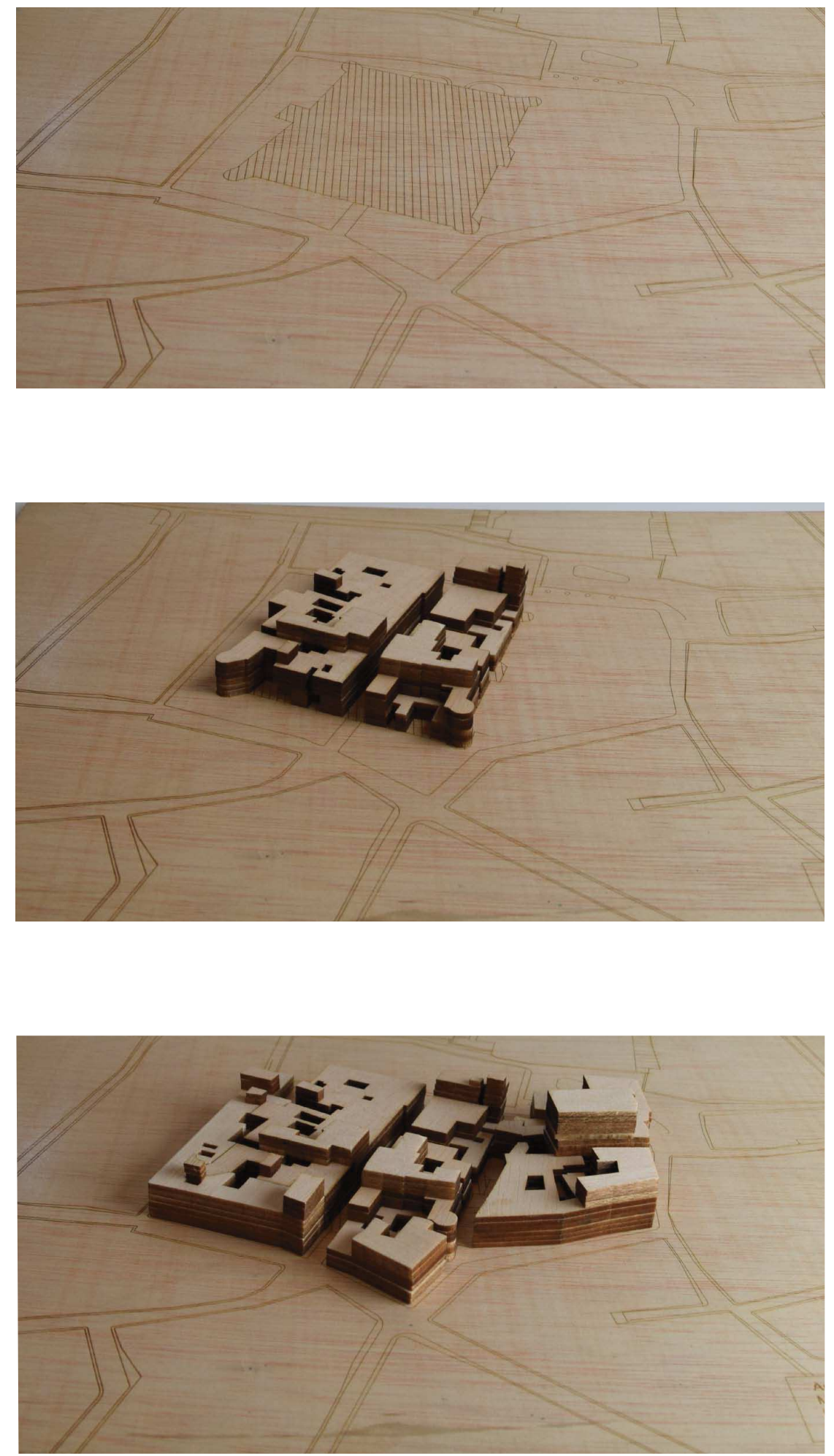
"La arquitectura del expoliado Palacio Condal de Oliva a través del legado gráfico"

ELABORACIÓN DE MAQUETA EN 3D - IMPRESORA DE POLVO
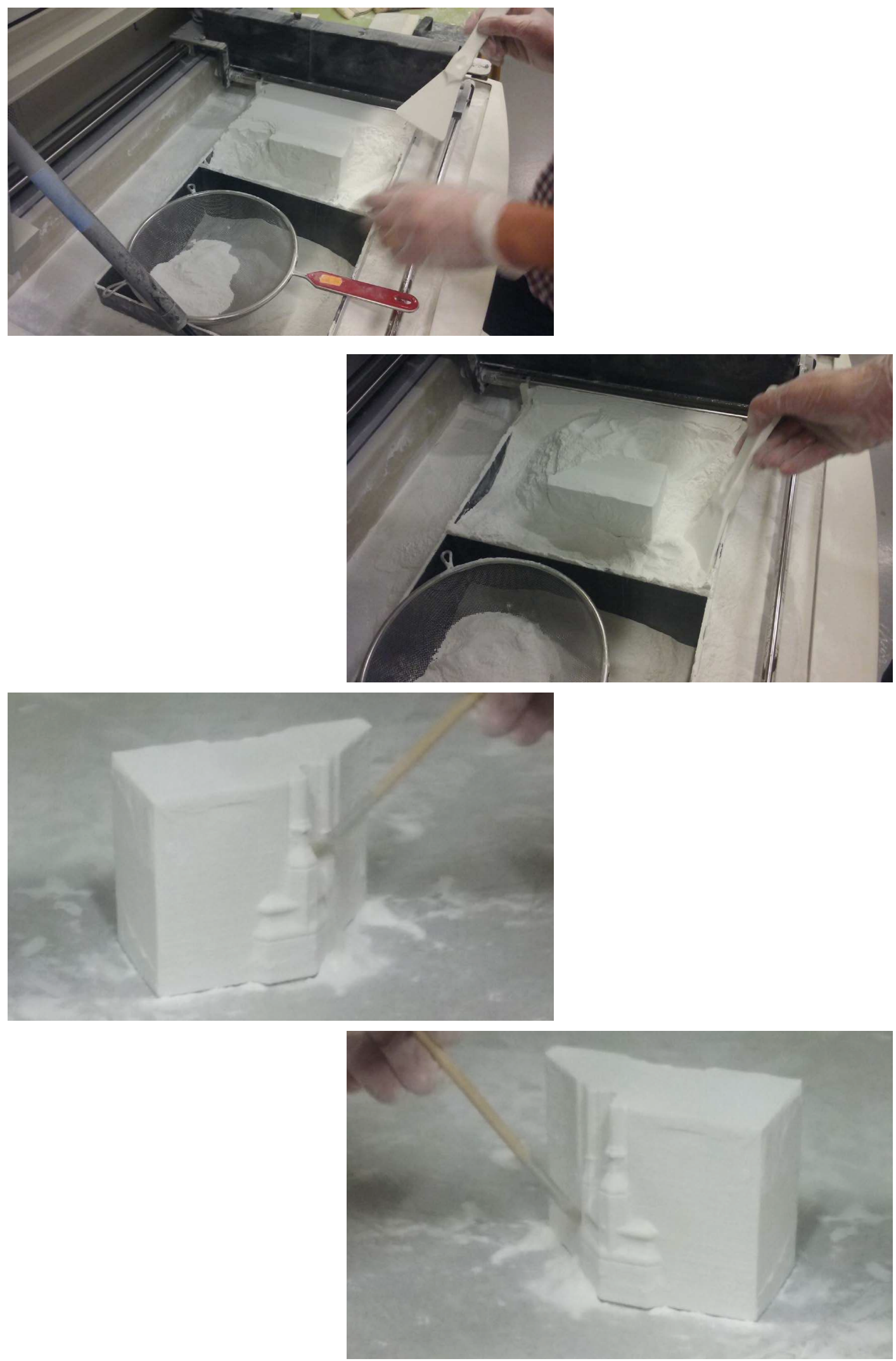

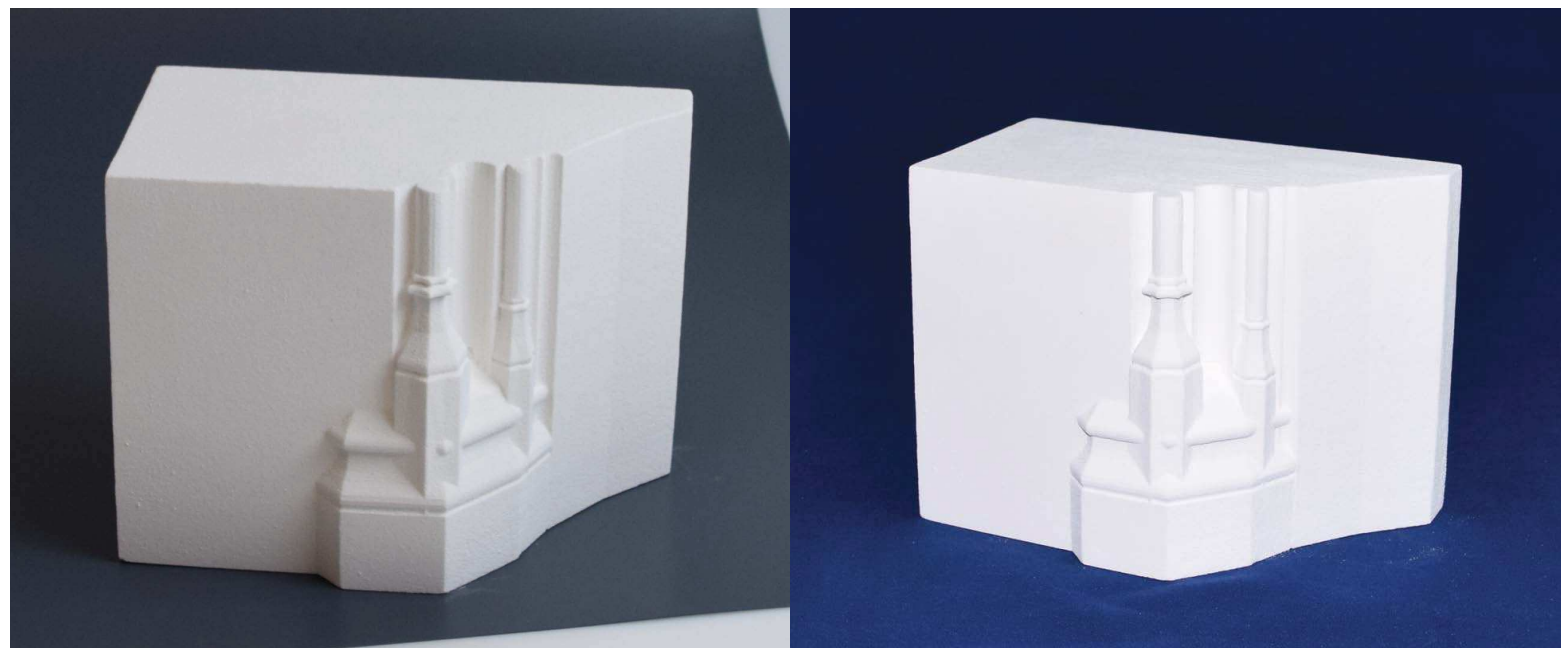

DETALLE BASA - IMPRESIÓN EN POLVO

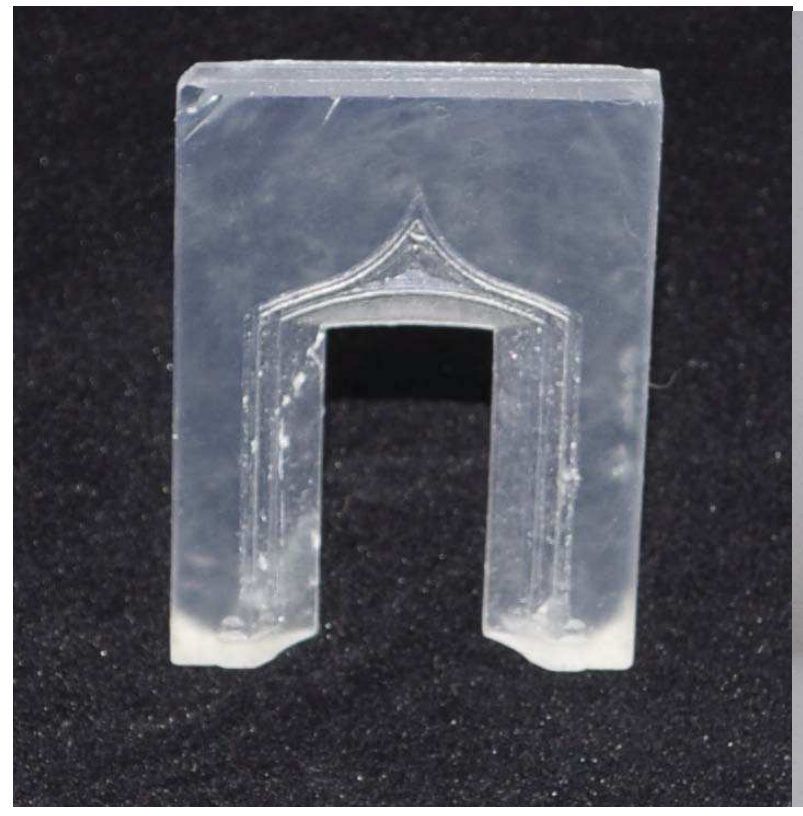

PORTADA 28 - IMPRESIÓN EN RESINA FOTOSENSIBLE

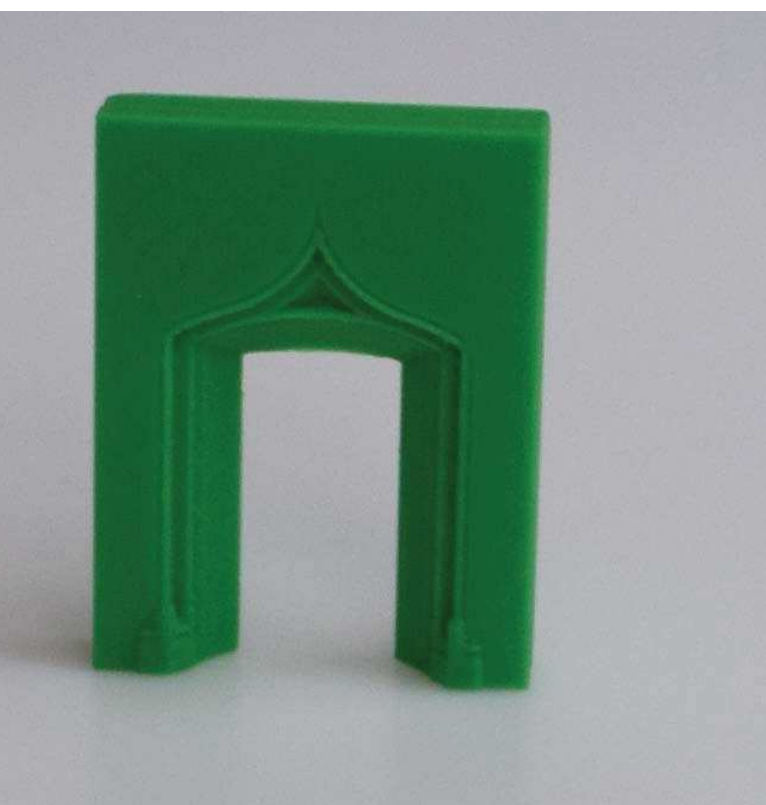

PortAdA 28 - IMPRESIÓN CON PLA 


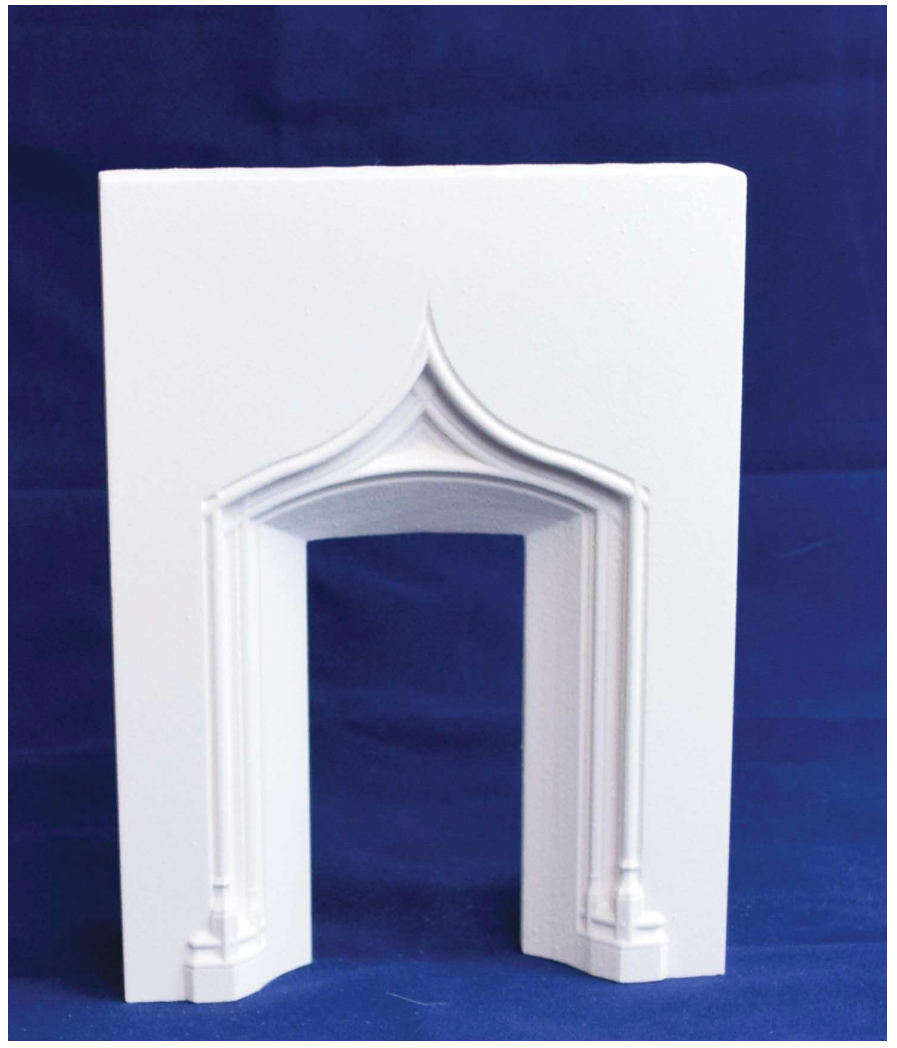

PORTADA 28 - IMPRESIÓN EN POLVO

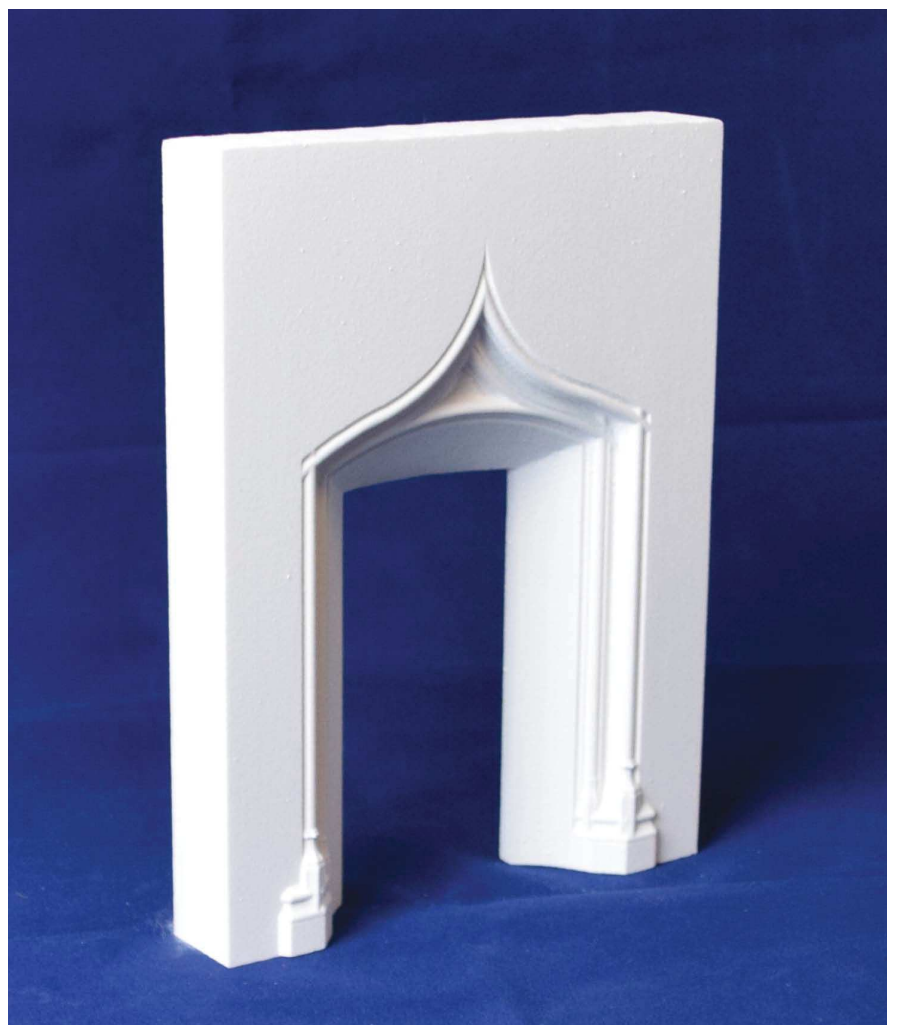

PoRTADA 28 - IMPRESIÓN EN POLVO 

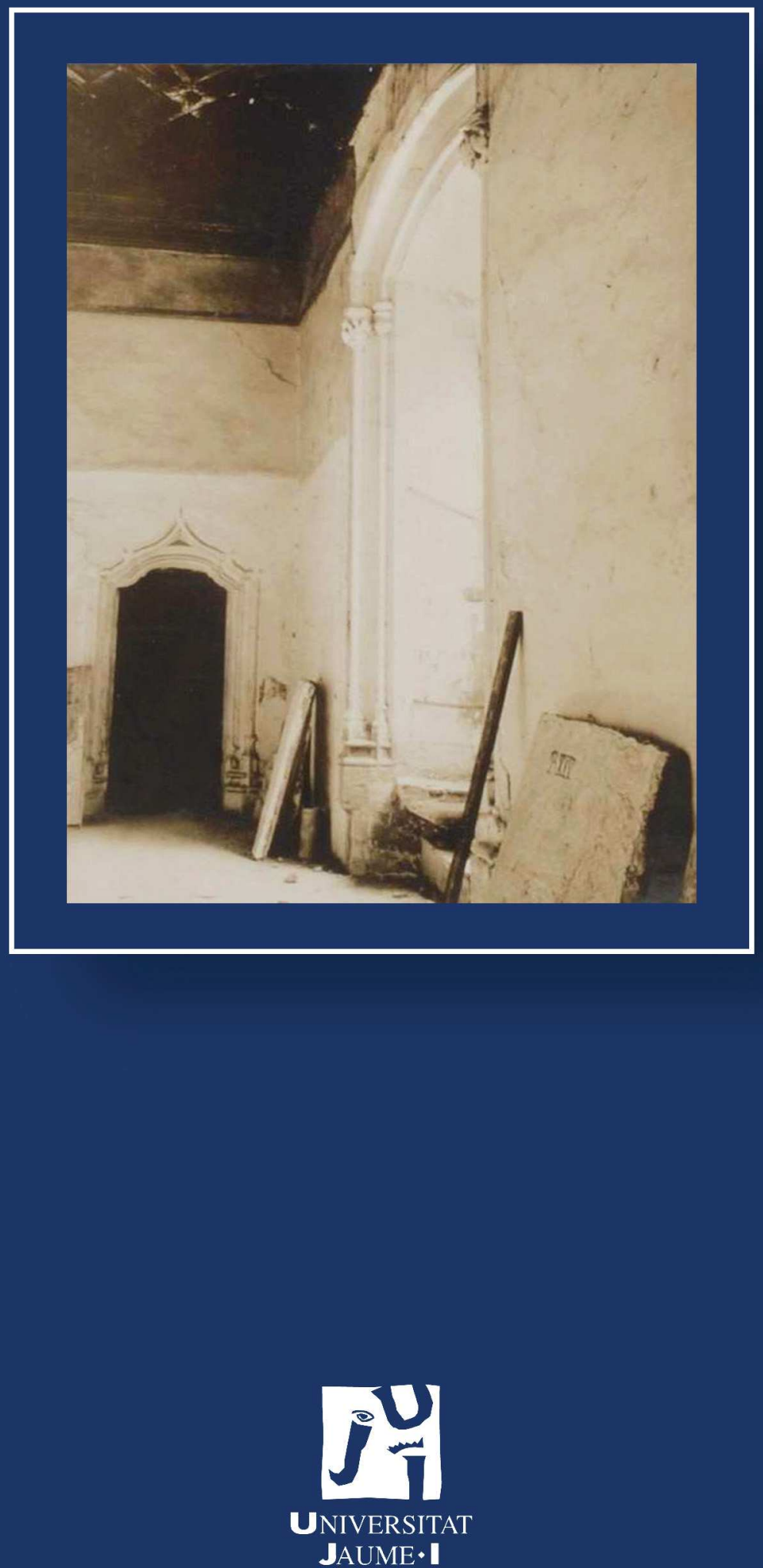